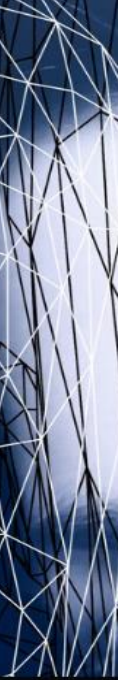

FREDERICO CELESTINO BARBOSA

\title{
DESAFIOS DA
} PSICOIOGIA NO BRASIL

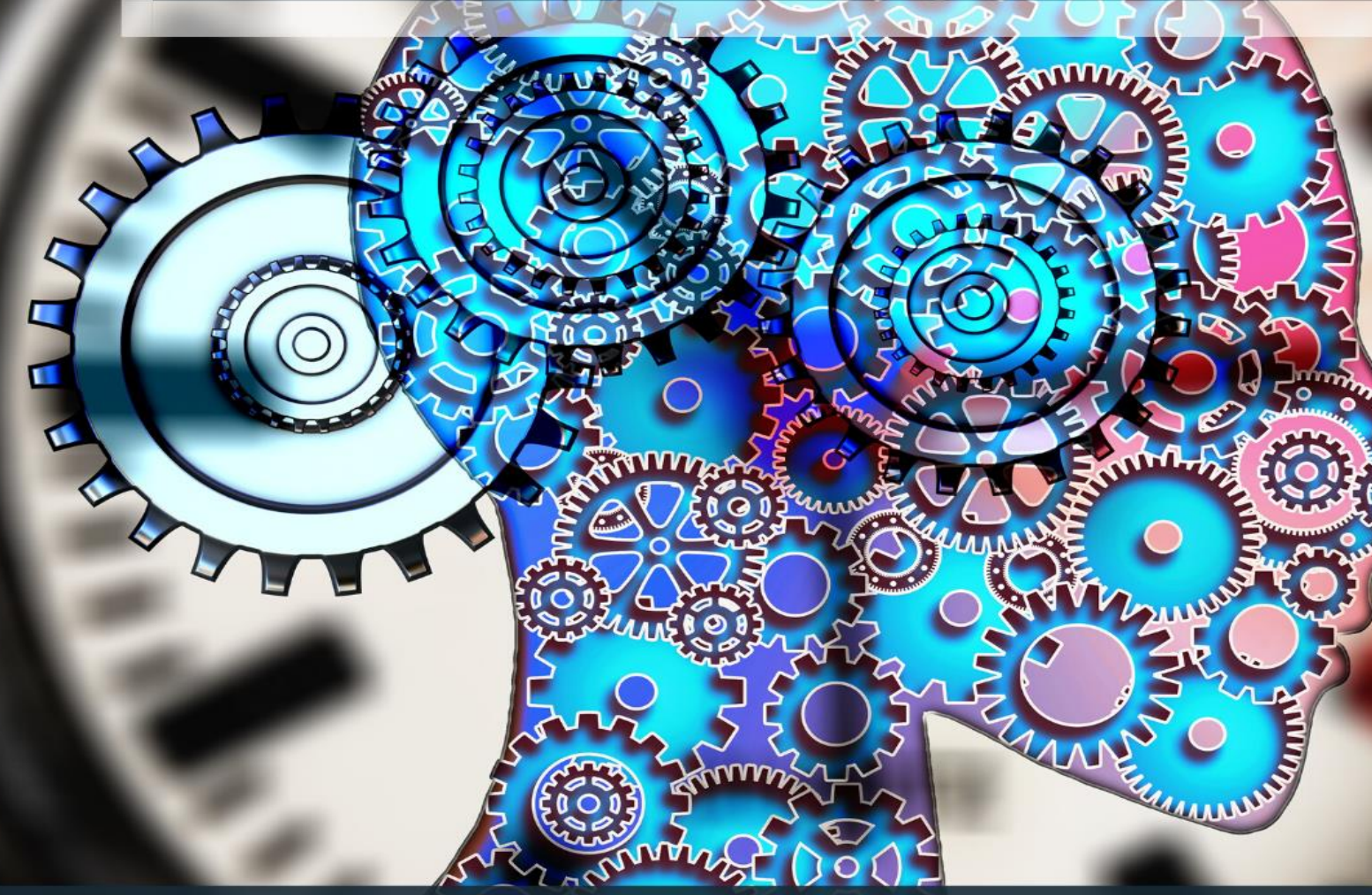

EDITORA CONHECIMENTO LIVRE 
Frederico Celestino Barbosa

Desafios da psicologia no Brasil

1 a ed.

Piracanjuba-GO

Editora Conhecimento Livre

2020 
$1^{\mathrm{a}}$ ed.

Dados Internacionais de Catalogação na Publicação (CIP)

\begin{tabular}{|l} 
Barbosa, Frederico Celestino \\
B238a \\
Desafios da psicologia no Brasil \\
/Frederico Celestino Barbosa - Piracanjuba - GO \\
Editora Conhecimento Livre, 2020 \\
1086 f.: il \\
DOI: 10.37423/2020.a7 \\
ISBN: 978-65-86072-10-5 \\
Modo de acesso: World Wide Web \\
Inclui bibliografia \\
1. Psicologia. 2. Saúde mental. 3. Psicanálise L. 4. Teoria comportamental 5. \\
Terapia. I. Barbosa, Frederico Celestino. I. Título. \\
\end{tabular}

https://doi.org/10.37423/2020.a7

O conteúdo dos artigos e sua correção ortográfica são de responsabilidade exclusiva dos seus respectivos autores. 


\section{EDITORA}

\section{CONHECIMENTO LIVRE}

\section{Conselho Editorial}

$\underline{\text { MSc. Frederico Celestino Barbosa }}$

MSc. Carlos Eduardo de Oliveira Gontijo

MSc. Plínio Ferreira Pires

Editora Conhecimento Livre

Piracanjuba-GO

$\underline{2020}$ 


\section{Desafios da psicologia no Brasil}

\section{Sumário}

CAPÍTULO 1

SABERES E SABORES NO PROCESSO DE APRENDIZAGEM 9 DOI: $10.37423 / 200200147$

CAPÍTULO 2.

JUVENTUDE E TRABALHO NO ÂMBITO DA ATENÇÃO BÁSICA: a experiência do CRAS Mantiqueira 20 DOI: $10.37423 / 200200149$.

CAPÍTULO 3. .34

A ESCOLA E O PROCESSO DE SUBJETIVAÇÃO: UMA INTERVENÇÃO À LUZ DA EDUCAÇÃO PARA AS RELAÇÕES ÉTNICO-RACIAIS

CAPÍTULO 4. .42

PESSOA-COMUNIDADE E INTER-RELAÇÕES NA OBRA DE EDITH STEIN

DOI: $10.37423 / 200200156$

CAPÍTULO 5. .53

CONTRIBUIÇÕES DA LIDERANÇA POSITIVA PARA AS ORGANIZAÇÕES. 50

DOI: $10.37423 / 200200158$ 53

CAPÍTULO 6.

CONHECIMENTO ACERCA DO CLORIDRATO DE METILFENIDATO: UMA ANÁLISE A PARTIR DE PESQUISA COM PAIS DE ALUNOS DE UMA ESCOLA MUNICIPAL DE FORMIGA - MG. 


\section{Desafios da psicologia no Brasil}

Diagnóstico Escolar: um estudo de levantamento de demandas em Psicologia Escolar na rede Municipal de Barbacena 112

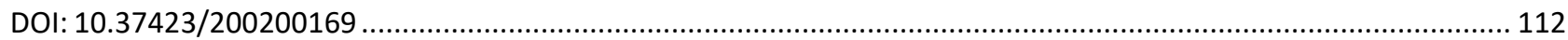

CAPÍTULO 9. .127

CRIANÇA COMO SER DE DIREITOS: IMPLICAÇÕES PARA O LAÇO SOCIAL. .124

DOI: $10.37423 / 200200170$

CAPÍTULO 10 137

A (AUTO) FORMAÇÃO E O DESAFIO DA DOCÊNCIA NUMA PERSPECTIVA (AUTO) BIOGRÁFICA ${ }^{1}$ 137 DOI: $10.37423 / 200200171$ .134

CAPÍTULO 11 .153

CONTRIBUIÇÕES DA PSICOLOGIA DE ORIENTAÇÃO ANALÍTICA NA ESCUTA DO SUJEITO AUTOR DE CRIMES. .150

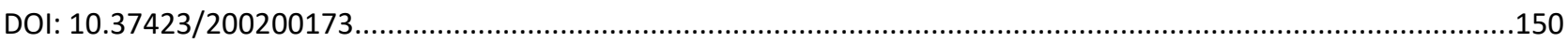

CAPÍTULO 12. .163

AVALIAÇÃO PSICOEDUCACIONAL EM CRIANÇAS ENCAMINHADAS COM DIFICULDADE DE APRENDER. .160

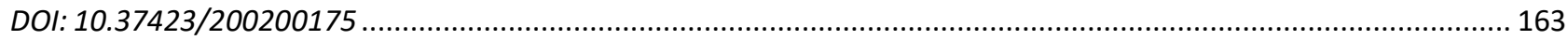

CAPÍTULO 13. .175

A FORMAÇÃO DE PROFESSORES EM EXERCÍCIO NOS ANOS INICIAIS DO ENSINO FUNDAMENTAL

DOI: 10.37423/200200176.

CAPÍTULO 14

INICIAÇÃO ESPORTIVA E ESPECIALIZAÇÃO PRECOCE: O DISCURSO E A PRÁXIS.

DOI: $10.37423 / 200200179$

CAPÍTULO 15

EDUCAÇÃO E INFORMÁTICA NA ÁREA PROJETUAL.

DOI: $10.37423 / 200200183$

CAPÍTULO 16

ATIVIDADES EXTRACURRICULARES NO BRASIL: REVISÃO SISTEMÁTICA DA LITERATURA. 


\section{Desafios da psicologia no Brasil}

REPRESENTAÇÕES SOCIAIS DE PSICÓLOGOS(AS) SOBRE DIFICULDADES E LIMITES EM RELAÇÃO AO CONTEXTO DA

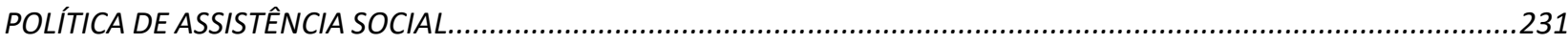

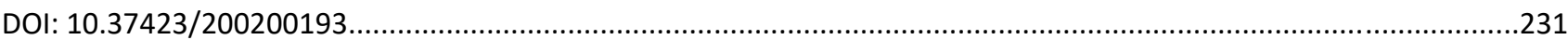

CAPÍTULO 18

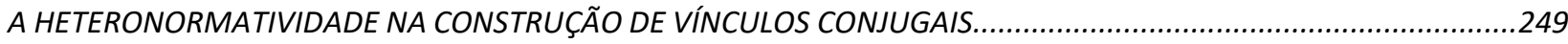

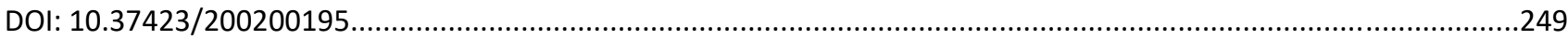

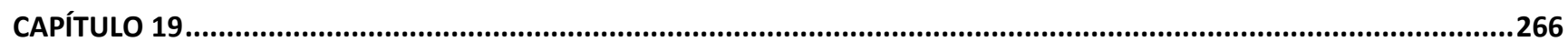

EXERCÍCIOS ESPIRITUAIS DE INÁCIO DE LOYOLA E A PSICANÁLISE: UM DIÁLOGO POSSÍVEL ....................................263

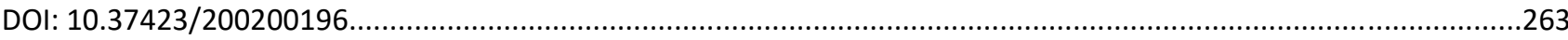

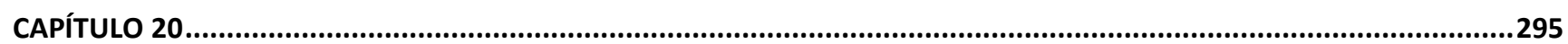

O RECONHECIMENTO HUMANO COMO PRÁTICA EDUCATIVA NA CONSTITUIÇÃO DA SUBJETIVIDADE....................292

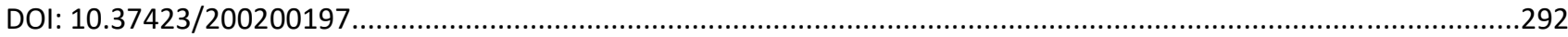

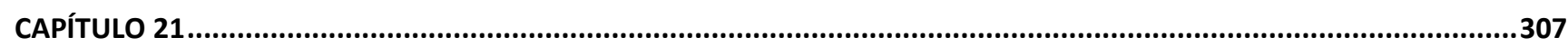

TRANSTORNO DO ESPECTRO AUTISTA E COMORBIDADES: UMA PROBLEMÁTICA POSSÍVEL.....................................304

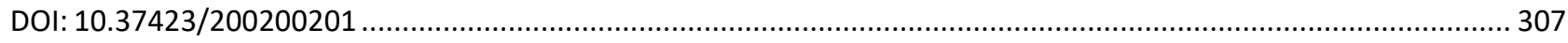

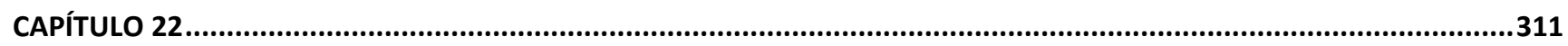

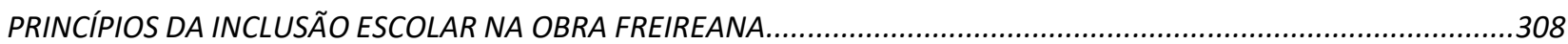

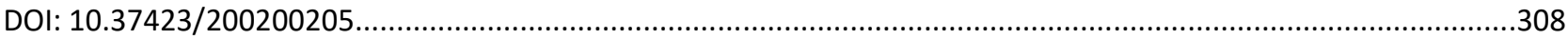

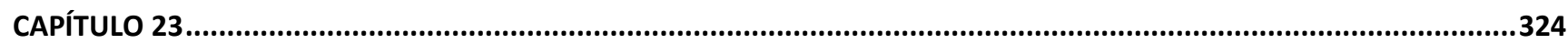

A LINGUAGEM DO VIDEOGAME COMO FERRAMENTA AUXILIAR NO PROCESSO DE ENSINO E APRENDIZAGEM........321

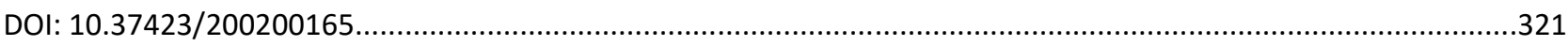

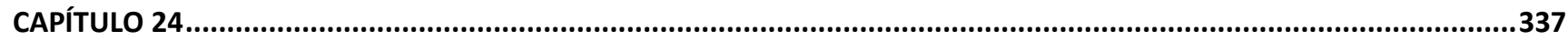

PENSANDO A PESSOA COM DEFICIÊNCIA E AS CONDIÇÕES DE ACESSIBILIDADE NA UEMG - UNIDADE DIVINÓPOLIS: UM RECORTE CONFECCIONADO PELOS DISCENTES DOS CURSOS DE LICENCIATURA.....

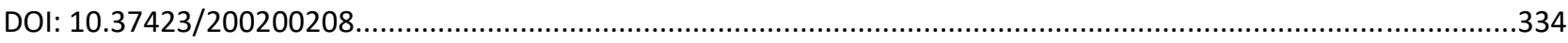

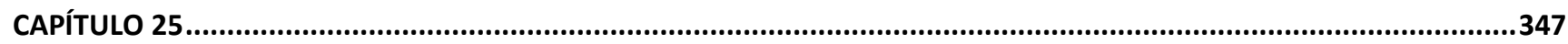

A ECONOMIA SOLIDÁRIA COMO FORMA DE EMPODERAMENTO PARA MULHERES: A EXPERIÊNCIA DE UMA INCUBADORA UNIVERSITÁRIA PARANAENSE

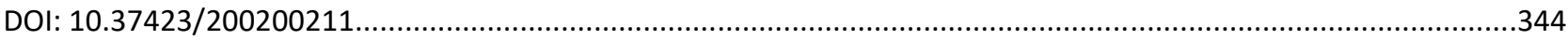




\section{Desafios da psicologia no Brasil}

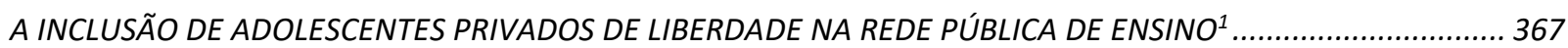

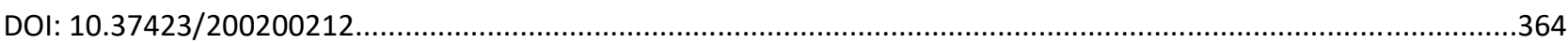

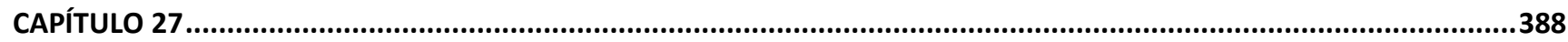

MOTIVAÇÃO PARA A PRÁTICA DE ATIVIDADE FÍSICA EM ACADEMIAS: UMA REVISÃO SISTEMÁTICA....................385

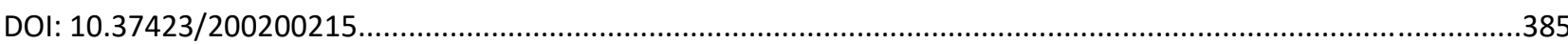

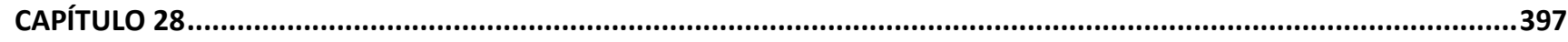

AVALIAÇÃO NEUROPSICOLÓGICA DO TDAH NO BRASIL: REVISÃO SISTEMÁTICA DOS ÚLTIMOS DEZ ANOS........ 397

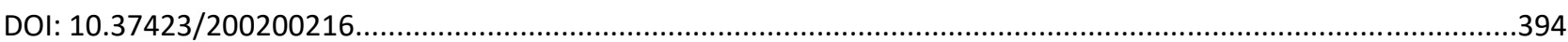

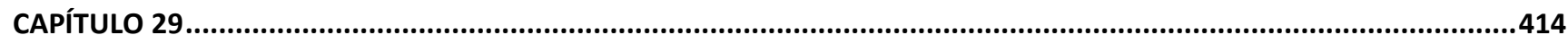

REGULAÇÃO DE ESTADOS AFETIVOS: BENEFÍCIOS DO CONTATO COM A NATUREZA.......................................441

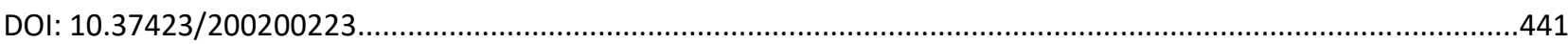

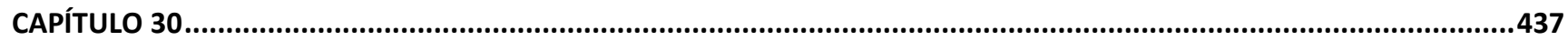

PRÁTICAS NO SERVIÇO DE ATENÇÃO ÀS PESSOAS EM SITUAÇÃO DE VIOLÊNCIA NA REDE MUNICIPAL DE SAÚDE DE VITÓRIA/ES. .434

DOI: $10.37423 / 200200224$ .434

CAPÍTULO 31 445

SAÚDE MENTAL NA UNIVERSIDADE: QUAIS OS ESTILOS DE PENSAMENTOS DOS PROFESSORES? .442

DOI: $10.37423 / 200200225$ 442

CAPÍTULO 32 .479

ATELIESCOLA ACAIA: EXPERIÊNCIA E TRANSMISSÃO EM PSICANÁLISE. 476

DOI: $10.37423 / 200200227$. 476

CAPÍTULO 33 .490

OBESIDADE: UM DESAFIO MULTIFATORIAL .487

DOI: $10.37423 / 200200228$ .487

CAPÍTULO 34 .498

OLHARES SOBRE A MEDIAÇÃO ESCOLAR NO RIO DE JANEIRO... .495 


\section{Desafios da psicologia no Brasil}

CAPÍTULO 35

NEUROPSICOLOGIA E EDUCAÇÃO: UM DIÁLOGO A FAVOR DO PROCESSO DE ENSINO-APRENDIZAGEM.

DOI: $10.37423 / 200200234$

CAPÍTULO 36

ESTRATÉGIA DE INTERVENÇÃO EM PSICANÁLISE: DIAGNÓSTICO PSICOLÓGICO ÉTICO POLÍTICO NA PRODUÇÃO DO LAÇO SOCIAL DOS ADOLESCENTES NO CREAS. 528

DOI: $10.37423 / 200200236$ .528

CAPÍTULO 37 .583

A (DES) CONSTRUÇÃO PSICANALÍTICA DAS FORMULAÇÕES SOBRE O PATOLÓGICO E O NORMAL 583 DOI: $10.37423 / 200200237$.

CAPÍTULO 38 616

Compreendendo a agressividade da criança: observações e intervenções na educação infantil ${ }^{1}$ 616 DOI: $10.37423 / 200200238$.

CAPÍTULO 39 637

DUAS SITUAÇÕES ENVOLVENDO DIVISÃO DE NÚMEROS DECIMAIS ABORDADAS JUNTO A UM GRUPO DE FABRICAÇÃO DE PRODUTOS DE LIMPEZA NO CONTEXTO DA EDUCAÇÃO NÃO FORMAL 637 DOI: $10.37423 / 200200246$.

CAPÍTULO 40

Ecovilas e Cidades em Transição: criando sustentabilidade no meio urbano 652 DOI: $10.37423 / 200200249$.

CAPÍTULO 41 674

A DOCÊNCIA EM AVALIAÇÃO PSICOLÓGICA. 674 DOI: $10.37423 / 200200251$.

O MECANISMO DE PRODUÇÃO, MANUTENÇÃO E LIBERTAÇÃO DA DOR CRÔNICA: REFLEXÕES PARA A PRÁTICA CLÍNICA

A IMPORTÂNCIA DO LÚDICO NO DESENVOLVIMENTO DA AUTOESTIMA DE CRIANÇAS COM PARALISIA CEREBRAL 


\section{Desafios da psicologia no Brasil}

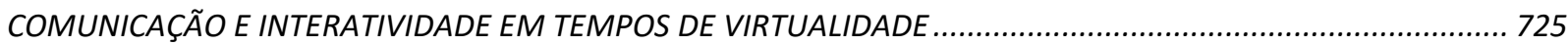

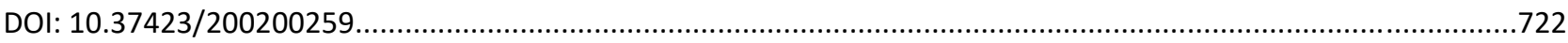

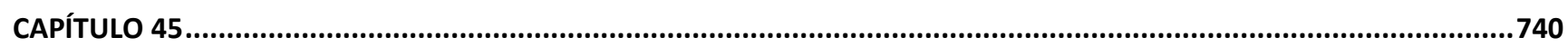

BARBÁRIE NA PSICANÁLISE, CIÊNCIA E CULTURA. UMA INTERSECÇÃO CONCEITUAL ......................................740

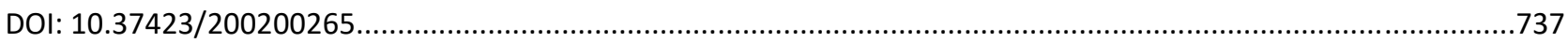

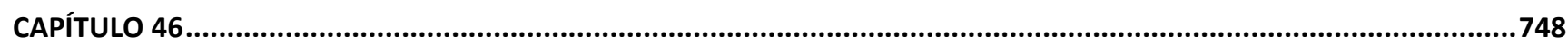

ESSE BECO TEM SAÍDA: DIÁLOGOS INTERSETORIAIS NA INCLUSÃO DO PROJETO TERAPÊUTICO SINGULAR....... 748

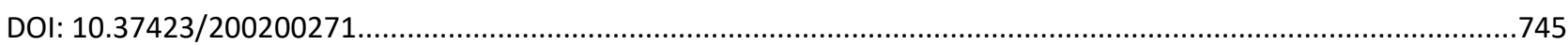

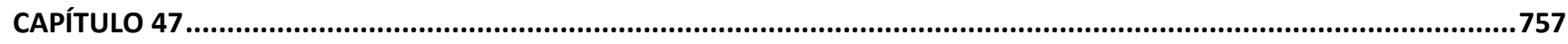

ORIENTAÇÃO à QUEIXA ESCOLAR: REFLEXÕES SOBRE AS PRÁTICAS DO PSICÓLOGO EDUCACIONAL. ................ 757

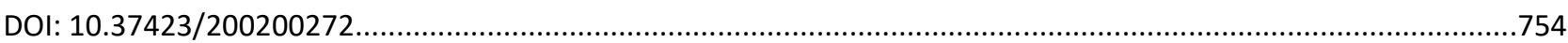

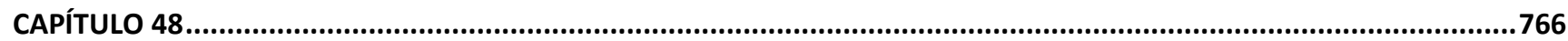

ENTRE A MILITÂNCIA E A CIÊNCIA: A IMPLICAÇÃO DO PESQUISADOR NO PROCESSO DE PESQUISA EM

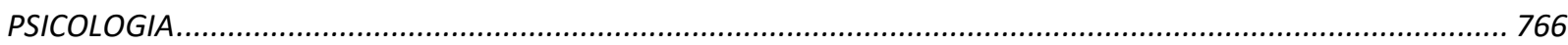

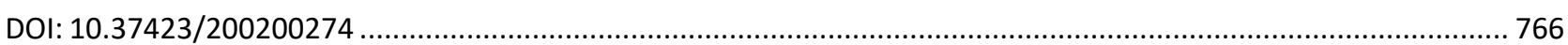

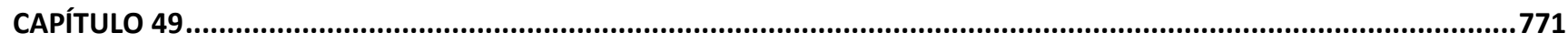

A experiência na Universidade Aberta à Terceira Idade e a formação de estudantes de Psicologia ................... 771

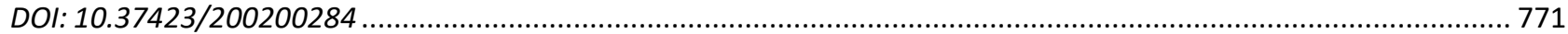

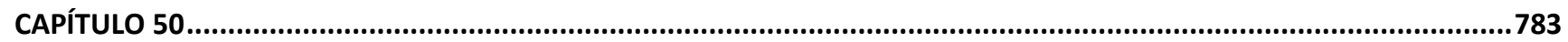

PSICOLOGIA JURÍDICA E VIOLÊNCIA DOMÉSTICA: UMA EXPERIÊNCIA FORMATIVA..........................................780

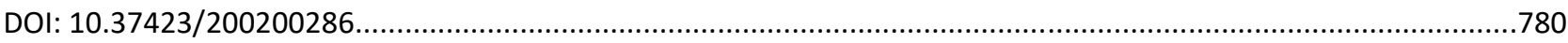

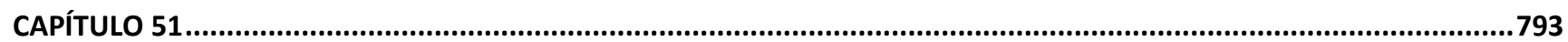

CAPITAL HUMANO E INOVAÇÃO: IMPACTOS DA SAÚDE MENTAL NO DESEMPENHO DAS ORGANIZAÇÕES...............790

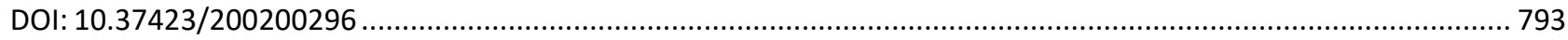

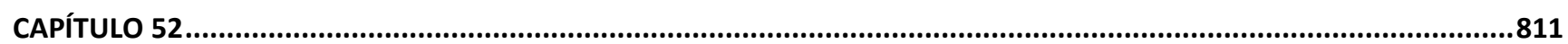

DEFICIÊNCIA MÚLTIPLA NO CONTEXTO DA ESCOLA COMUM: OS DESAFIOS E AS POSSIBILIDADES DA INCLUSÃO.............808

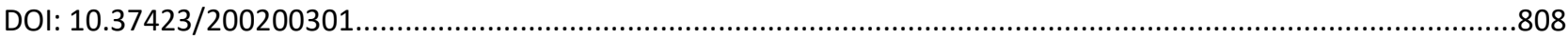

CAPÍTULO 53.

.823

ACOMPANHAMENTO E INTERVENÇÃO PRECOCE COM BEBÊS PREMATUROS TARDIOS: UMA INTERVENÇÃO INTERDISCIPLINAR BASEADA NA PSICANÁLISE. 


\section{Desafios da psicologia no Brasil}

DOI: $10.37423 / 200200304$

CAPÍTULO 54

DOCÊNCIA EM PAUTA: ESTRESSE E BURNOUT SOB O PONTO DE VISTA PSICOLÓGICO

DOI: $10.37423 / 200200306$

CAPÍTULO 55

COORDENADOR PEDAGÓGICO: MEDIADOR NO PROCESSO DE INCLUSÃO DE ALUNOS COM DEFICIÊNCIAS NO ENSINO REGULAR.

DOI: $10.37423 / 200200308$.

CAPÍTULO 56

CONCEPÇÃO E ATUAÇÃO DE PSICÓLOGOS EM SECRETARIAS DE EDUCAÇÃO DE SÃO PAULO. .865

DOI: $10.37423 / 200200310$ .865

CAPÍTULO 57 .883

DESAFIOS DA AVALIAÇÃO PSICOLÓGICA PARA PORTE DE ARMA DE FOGO. 880

DOI: $10.37423 / 200200312$ .880

CAPÍTULO 58 .893

O REBAIXAMENTO COMO FATOR DE PRESTÍGIO SOCIAL 890

DOI: $10.37423 / 200200316$ 893

CAPÍTULO 59 912

A SAÚDE DO TRABALHADOR BANCÁRIO: (DES)VELANDO O RETORNO AO TRABALHO APÓS AFASTAMENTO POR DOENÇA. 909

DOI: $10.37423 / 200200319$ 909

CAPÍTULO 60 925

UMA OBSERVAÇÃO PSICOLÓGICA DOS VÍNCULOS DA EDUCADORA DE CRECHE. 922

DOI: $10.37423 / 200200323$ .922

CAPÍTULO 61 .939

JACAREZINHO-APARECIDA DE BICICLETA: A PRÁTICA DO CICLOTURISMO PARA UMA VIDA SOCIAL COM QUALIDADE. 936

DOI: $10.37423 / 200200325$ .936

CAPÍTULO 62 .957

EFEITO ANTIDEPRESSIVO DA RIPARINA IV EM MODELO DE ESTRESSE CRÔNICO EM CAMUNDONGOS 954 


\section{Desafios da psicologia no Brasil}

DOI: $10.37423 / 200200326$

CAPÍTULO 63 981

MÃO E COGNIÇAO: RETIRADA DOS SUBTESTES EXECUTIVOS/MOTORES NO WISC-IV....... 978

DOI: $10.37423 / 200200327$ .978

CAPÍTULO 64 1005

A ANÁLISE DE ERROS EM MATEMÁTICA: ELEMENTOS PARA A FORMAÇÃO DOCENTE 1005 DOI: $10.37423 / 200200328$. .1002

CAPÍTULO 65 1019

Efeito antidepressivo da Riparina III em camundongos submetidos ao modelo de estresse crônico pela administração de corticosterona 1019

DOI: $10.37423 / 200200332$ 1016

CAPÍTULO 66 1020

TRABALHO PEDAGÓGICO DOS PROFESSORES DE PRIMEIRO ANO DO ENSINO FUNDAMENTAL 1033

DOI: $10.37423 / 200300334$ .1033

CAPÍTULO 67 1020

O USO/ABUSO DE ÁLCOOL ENTRE JOVENS INDÍGENAS: ESTUDO DE UMA COMUNIDADE KAINGANG NO PARANÁ. 1050

DOI: $10.37423 / 200300337$ .1050

CAPÍTULO 68 1020

ALTERAÇÕES NEUROPSICOLÓGICAS CAUSADAS PELA INGESTÃO DO CHÁ DA AYAHUASCA E A OBSERVAÇÃO DO EFEITO EM UM BEBE. 1068 DOI: $10.37423 / 200300380$. .1068 


\section{Capítulo 1}

\section{SABERES E SABORES NO PROCESSO DE APRENDIZAGEM}

DOI: $10.37423 / 200200147$

Rosa Jussara de Bonfim Silva (Doutora em Educação. Coordenadora e professora do Curso de Pedagogia EAD da Faculdade do Noroeste de Minas - FINOM. rosa.jsilva@catolica.edu.br

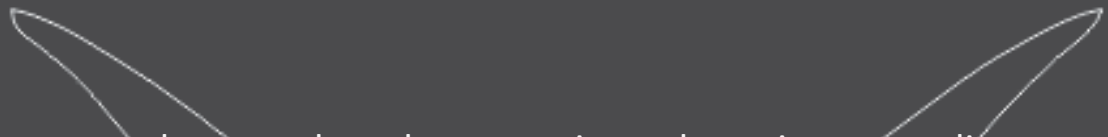

Resumo: O presente-texto busca redesenhar os projetos de ensino-aprendizagem numa perspectiva que conjugue o sabor e) o saber no processo aprendente, de maneira que o contexto escolar compreenda da dinâmica educaciọnal por uma ótica do sabor eda interatividade dos saberes. Pensando dessa maneira, o trabalho foi elaborado sob a luz de autores/que tratám das questốes sobre o processo de aprendizagem, o entendimento de saber e a possibilidade do sabor, com o objetivo-de elucidar a importância de agregar a articulação entre saber e sabor/de maneira interatiya e reflexiva. Nesse texto o sabor é pensado como a possibilidade de todos podérem inferir na realidade circundante por meio de um olhar mais reflexivo e crítico, de maneira que se alie a aquisiçå de novos sabberes à possibilidade de manifestação da grande diversidade de pensamentos no contexto escolar. A temática central do trabalho é investigar como o saber, aliado ao sabor, torna-se um processo de ensino-aprendizagem carregado de significado, de reflexão do real, tạnto para o/estudante, quanto para o professor. Assim,o processo aprendente pode trazer um toque de sabor/por meio da compreensão da alteridade, do diálogo, da autonomia, da identidade, da reflexăd e da ação como fatores propulsorres do processo de ensino. Para tanto, a-trabatho busca-relactonar o processo de saber do sabor-no-projeto de ensinoaprendizagem, tentando-entender como o professor ensina, e como o aluno aprende, de maneira a 


\section{Desafios da psicologia no Brasil}

assim dizer, uma aprendizagem com sabor e uma aprendizagem sem sabor, haja vista que atrelar sabor ao processo de aprendizagem é uma característica do ser humano por meio das interações sociais. Portanto, ao buscarmos entender o percurso de ensino-aprendizagem entre o saber e o sabor, assumimos que em um projeto de aprendizagem deve-se privilegiar a reflexão sobre a prática, de maneira que o professor possa também ao ensinar, aprender, e ao mesmo tempo ser este um processo que desenvolva atitudes e valores, por meio da interatividade entre docente e discente. Partindo dessa premissa, esse trabalho investiga também o processo de aprendizagem que carrega em seu cerne a reflexão da prática, o pensar sobre o espaço social e cultural e a construção de saberes, levando-se em consideração a relação dos saberes e dos sabores no processo aprendente, investigando como estão direcionadas as relações entre as pessoas, as relações sociais e culturais. Nesse sentido, é possível acoplar sabor ao projeto de ensino-aprendizagem de maneira que a relação entre educador e educando seja caracterizada por uma contribuição significativa, tanto por parte do docente, quanto por parte do discente, e que se faça presente o reconhecimento do outro, a participação, a contribuição e valorização de todos os sujeitos. A metodologia de pesquisa utilizada ancorou-se na modalidade qualitativa buscando na revisão de literatura o seu subsídio.A escolha da metodologia citada se deu por entender que a pesquisa qualitativa oferece maiores possibilidades para investigar sabores e saberes na educação.

Palavras-chave: Saber. Sabor. Aprendizagem. 


\section{Desafios da psicologia no Brasil}

\section{INTRODUÇÃO}

O presente trabalho objetiva investigar quaisos fatores que agregam sabor ao projeto de ensinoaprendizagem, estabelecendo o diálogo entre elementos constitutivos da aquisição do conhecimento e o gosto pela aprendizagem no processo de aprender e ensinar. A princípio se faz uma abordagem entre o significado de sabor e de saber no processo aprendente, de maneira que o saber seria o desenvolvimento da capacidade de dialogar com o objeto de estudo, processando as informações de maneira crítica, trazendo o cotidiano como estímulo da aprendizagem, e organizando a diversidade de conhecimentos para a construção de um projeto educativo com um sentido pessoal e social. Dentro deste contexto, o sabor se apresenta como vivência relacionada ao objeto de estudo, inferindo, assim, traços da subjetividade do sujeito no processo de aprendizagem.

A metodologia utilizada nesse trabalho foi a qualitativa, pautando-se na revisão de literatura. De acordo com Gonçalves; Gonçalves e Souza (2012), investigar utilizando esse paradigma de pesquisa possibilita ao cientista compreender os fenômenos que apontem diversos caminhos a serem seguidos na produção de conhecimentos e, consequentemente, os múltiplos olhares para analisá-los. Quando se trata de uma pesquisa que abarque a realidade social em uma determinada conjuntura, essa pesquisa deveria promover a criação e o desenvolvimento de metodologias adequadas ao objeto de estudo, e deveria incluir, como base tática integrada à sensibilidade, com apoio da reflexão crítica e intuitiva, uma investigação mais qualitativa.

Nessa direção segundo Gonçalves; Gonçalves e Souza (2012), o pesquisador deve ancorar as suas práticas em uma postura balizada por princípios éticos e estéticos, tendo em vista que produzir conhecimentos envolve inquietações e responsabilidades com o processo e também com o produto da pesquisa, na direção do respeito à vida e da satisfação de todos os envolvidos na situação.

A escola, segundo Rios (2010), deveria ser o lugar da descoberta, dos risos e dos encantos. Por isso, ensinar com sabor é dar sentido ao processo de aprendizagem, é intervir, mas não se opondo às necessidades e autonomia dos alunos, mas criando oportunidades para que todos façam parte do processo de ensino, buscando compreender as realidades sociais e sua própria existência. Aprender passa, necessariamente, por um processo de ensinar melhor, e este ensino carece de sabor para se tornar saboroso.

Ao nos restringirmos à aquisição de conhecimentos mecânicos e ao que está pré-definido, negligenciando o pensar e o questionar, tornamos o saber empobrecido, e isso nos faz negar que a constituição do saber perpassa por toda historicidade cultural, social, econômica e emocional do sujeito aprendente. É preciso que haja de acordo com Síveres (2006) uma consonância entre 


\section{Desafios da psicologia no Brasil}

conhecimento e sabedoria. Portanto, não há como desassociar o processo de aquisição do conhecimento da constituição do sujeito em sua plenitude, mostrando assim que estímulos exteriores e interiores influenciam de modo positivo ou negativo no caminho da aprendizagem.

A questão da relação entre saber e sabor na aprendizagem escolar pode ser enfocada pelo menos a partir de dois pontos de referência: como o professor ensina e como o aluno aprende. Dessa forma, a perspectiva de saber se amplia e se ampara na sociabilidade da partilha dos saberes por meio da interatividade com o outro. No que tangem a subjetividade, o saber é agregado pela historicidade do sujeito, bem como sua cultura, sua linguagem e seus conceitos.

Conforme Síveres (2006), o processo educativo deve propor situações que propiciem conhecimentos críticos e criativos. Essa perspectiva transforma a visão do papel da escola na relação entre aprendizagem, ensino e saber. Portanto, existiria assim um saber sem sabor e um saber com sabor que mantém uma estreita relação com a identidade do indivíduo, sua cultura e seus saberes. 0 entendimento de sabor é manifestado pela possibilidade de pensar sobre o saber, de inferir no entendimento do conhecimento de maneira mais próxima possível da pessoa, de maneira que a realidade se manifeste no seio do conhecimento, de modo que se perceba o que nos cerca e o que nos move.

Atrelar sabor ao processo de aprendizagem coloca o sujeito e o conhecimento em um mesmo espaço, tendo em vista que a educação tem em sua base as interações sociais que carregam histórias, linguagens, culturas que se interpenetram e se complementam mutuamente. Assim, as diferenças subjetivas que ocorrem no processo de ensino-aprendizagem estão fortemente ligadas aos procedimentos metodológicos de ensinar e aprender.

Para dar um significado interativo a este procedimento, será aprofundada a relação entre os saberes e os sabores no processo de aprendizagem. Embora cada uma destas categorias seja apresentada de forma autônoma, a compreensão das mesmas deverá ser feita de maneira complementar.

\section{OS SABERES NO PROCESSO DE APRENDIZAGEM}

Compreender como acontecem os processos de aprendizagem, implica em entender como se processa e se desenvolve a cognição. Para Vygotsky (2003), o ser humano aprende por meio da interação com o outro, com o meio em que vive. Assim, passamos a fazer escolhas, desenvolvendo um pensamento mais dinâmico e complexo a partir do nosso amadurecimento e contato com as coisas e os fenômenos. Com base neste pressuposto, o processo de aprendizagem se divide em dois aspectos: o primeiro é o aspecto informal, pelo qual aprendemos constantemente sobre tudo que nos rodeia. É neste processo 


\section{Desafios da psicologia no Brasil}

que se manifesta a aprendizagem da cultura, da linguagem, dos pensamentos frente ao meio social, cultural e econômico, que para Libâneo (2011) seria a aprendizagem casual e espontânea.

O conhecimento adquirido ao longo do processo de aprendizagem, que ocorre por meio de falas e gestos que não são necessariamente ensinados, mas observados ao longo da vida, sem haver necessariamente fases, métodos, exercícios que possam afirmar este conhecimento. Isto ocorre porque somos seres sociais, que se relacionam com uma grande capacidade de interagir com o meio em que nos encontramos. O processo de ensino-aprendizagem parte da consequência das diversas interações sociais que surgem nas salas de aula, que Libâneo (2011) chama de mediação pedagógica. O segundo aspecto é a aprendizagem sistemática, que de acordo com Libâneo (2011) é a aprendizagem escolar. Este processo de aprendizagem é organizado e intencional, e segue uma padronização hierárquica, de acordo com os padrões de amadurecimento cognitivo do sujeito, perpassando um conjunto de singularidades de maneira estruturada.

Neste sentido os processos de aprendizagem, tanto sistemático quanto informal, se constroem e reconstroemcontinuamente. Desta forma, segundo Freire (2011), o conhecimento vai se produzindo e superando o conhecimento antigo, de forma que os referenciais vão evoluindo e se recriando, adquirindo uma ótica mais sofisticada. Tendo em vista que, o contato com informações formais e informais provocam no ser humano inquietações que irão conduzir a uma necessidade de aprofundamento em aprender sobre aquilo que está sendo informado.

O conhecimento, neste caso, constrói-se e se sustenta a partir do meio social, cultural em que estamos inseridos. Há pessoas que desenvolvem uma grande capacidade de aprender a lidar com determinados elementos que estão em seu meio cultural, como por exemplo, a natureza e, no entanto, ao buscar aprofundar este conhecimento em nível acadêmico, tornam-se desmotivados e perdem o sabor por aquele conhecimento, entrando numa rotina epistemológica, fato identificado por Freire (2011), como uma "educação bancária". Tal atitude fortalece um procedimento, que de acordo com Síveres (2012), caracteriza os sujeitos que se satisfazem com respostas prontas, deixando de fazer perguntas e de aprender com elas.

De acordo com as linhas de argumentação acima indicadas, pode-se destacar as diferentes formas de aquisição do conhecimento, aventando para a possibilidade de que o ato de ensino-aprendizagem com sabedoria pode redirecionar o pensamento e a visão do sujeito sobre o objeto de estudo. Este caminho pode ser percorrido, conforme proposta de Morin (2011, p. 64), na medida em que "refletir é ensaiar, e uma vez que foi possível contextualizar, compreender, ver qual pode ser o sentido, quais podem ser as perspectivas". A capacidade de mobilizar saberes para dominar situações concretas traz a 


\section{Desafios da psicologia no Brasil}

necessidade de um pensar mais complexo, mais dinâmico e que contribua com o sentido da história pessoal e profissional.

Para efetivar esta proposta é necessário agregar sabedoria na aquisição e sistematização do saber. Este, para ser transformado em conhecimento sólido e significativo, demanda caminhos cognitivos para a aprendizagem, ou seja, possibilita formas diferentes de aprender e de relacionar os conhecimentos com a realidade.

Umas das possibilidades para instaurar um processo de ensino-aprendizagem, segundo Vygotsky (2003), é levar em conta as particularidades individuais do sujeito. Dessa forma a condição humana, por meio de uma aprendizagem com características de sabedoria, pode ser concebida por meio de uma mudança de comportamento, adquirindo e reformulando informações para se transformarem em conhecimento e sabedoria. Portanto, conforme sugestão do autor, o processo de ensino-aprendizagem deve desenvolver a personalidade do sujeito aprendente.

Outra sugestão de Vygotsky (2003), é que o processo de ensino-aprendizagem precisa considerar uma relação marcada pela troca de saberes. Tal atitude desencadeia a percepção e a reflexão do meio no qual o sujeito está inserido, fazendo com que a aprendizagem possa adquirir seu significado realmente humanizado, fato que poderá influenciar nas mudanças de paradigmas. Assim, para a construção do conhecimento se tornar básica e realmente sólida e significativa para o ser humano, o fator da interação com o mundo é fundamental, tendo em vista que temos a necessidade de reconstruir, por meio dos outros e de outras realidades, nossas representações sociais, cognitivas e culturais.

Além da dimensão subjetiva e social do processo de aprendizagem, é oportuno indicar para a possibilidade de ampliação desse panorama. Com base nesta proposta, Ferreiro (1999) afirma que a possibilidade de aprendizagem inicia muito antes da inserção do sujeito na escola. Saber utilizar, portanto, estas manifestações dialógicas com o objetivo de interligar as informações empíricas e científicas com o desenvolvimento cognitivo, é uma função imprescindível do professor, principalmente quando se utiliza de todas as manifestações culturais e sociais para buscar a autonomia, a criatividade e a criticidade nos processos pedagógicos.

Para Piaget (2011), a construção do conhecimento pelo sujeito constitui, por meio da interação com o objeto de estudo, a compreensão desta realidade, podendo suscitar, assim, uma forma ousada de organizar um novo conhecimento. Dessa maneira a construção do conhecimento se torna possível por meio de uma interação mediada pela ação do indivíduo, chegando aos conceitos de assimilação e acomodação. 


\section{Desafios da psicologia no Brasil}

Pensando nessa direção, a interação gera a possibilidade de aproximação dos saberes, agregando assim o conhecimento já consolidado pelo sujeito ao novo conhecimento de forma contextualizada. $\mathrm{O}$ conceito de assimilação, segundo Piaget (2011)seria, por assim dizer, o processo mental que o sujeito utiliza para se aproximar do conhecimento, já acomodação seria o processo mental que modificam os conhecimentos por meio da interação com outros sujeitos e novos conhecimentos.

De acordo com Síveres (2006) e Libâneo (2011), a subjetividade, a sociabilidade e a interatividade são condições necessárias, para se construir um processo de ensino-aprendizagem com características de sabedoria. Isto pode se concretizar a partir do momento em que o projeto pedagógico contemplar a formação e transformação da prática docente e discente, fortalecendo a interatividade da teoria e prática, a integração do ensino e aprendizagem, e a vinculação dos saberes e sabores.

\section{OS SABORES NO PROCESSO DE ENSINO-APRENDIZAGEM}

As palavras saber e sabor tem a mesma origem, originando do verbo latino sapere. Assim, o processo de ensino-aprendizagem deve, ao mesmo tempo, ter o saber que seria o conhecimento aprofundado dos elementos filosóficos, científicos, sociais, culturais e humanos, agregado ao sabor, que seria a afetividade, o desejo e o valor no cotidiano escolar e na dinâmica educativa. Esta vinculação entre o saber e o sabor, contextualizados no projeto pedagógico, de acordo com Castoriadis (2006), seria uma maneira séria e profunda de abordar os conhecimentos de forma libertária, na busca da autonomia e da democracia de maneira participativa e direta.

Na continuidade dessa proposta, para que se desenvolva uma educação com base no saber e no sabor é necessário desenvolver, segundo Castoriadis (2006), três categorias. A primeira é despertar o estudante para que esteja interessado no fato de aprender e demonstrar desejo por aquilo que aprende, a segunda é conscientizar o professor que é preciso gostar de ensinar e adorar as crianças, e em terceiro lugar criar valores e assegurar que os mesmos façam parte da sociedade.

O processo de despertar o interesse no estudante em aprender e ao mesmo tempo ter desejo por aquilo que se aprende, se funda em dar significado e interpretação ao objeto de estudo. Nesse sentido, Castoriadis (2006) defende o conceito de práxis e o define como prática aliada à teoria, argumentando que a construção e consolidação do conhecimento se fazem por meio da complementação entre pensamento e ação.

A conscientização do professor em gostar de ensinar, inicia-se na autonomia e na liberdade de escolha pelo magistério. Deste princípio se evolui para a necessidade de contribuir com a educação, e no cerne 


\section{Desafios da psicologia no Brasil}

desta contribuição, baseia-se a motivação do ensino. Para Castoriadis (2006), a essência sempre precede a existência, assim a motivação do gostar de ensinar está em poder contribuir com a evolução humana.

A escola como promotora de criação de valores na sociedade, deve se basear em um projeto de autonomia na esperança, onde os indivíduos refletem e deliberam de maneira a transformar o contexto social. Tal disposição, de acordo com Castoriadis (2006), elucida o fato de que não basta conhecer a sociedade, mas compreendê-la e articulá-la a um projeto social, humano e democrático.

Com base nestas categorias o processo de ensino-aprendizagem tem em seu cerne o sabor. O tempero essencial no processo saboroso de ensino é a vinculação de todos os sujeitos envolvidos no processo de aprendizagem, de maneira que se trabalhem propostas pedagógicas desafiadoras e que levem os estudantes a pensarem sobre o seu papel no mundo, que segundo Rogers (1984), seria buscar o conhecimento centrado na pessoa. Tal reflexão instiga o processo de ensino-aprendizagem como um vínculo entre as pessoas e em prol de uma educação significativa e em consonância com a realidade.

Dentro da perspectiva do sabor, porém vinculado ao saber, Freire (2008) relaciona três pontos importantes que o educador necessita para proporcionar a interação de saberes em sala de aula, que podem dar um sabor ao processo aprendente. Tais aspectos seriam: perceber o indivíduo como ser único e também perceber a coletividade, construir um encontro entre ideias por meio do diálogo, e gerir o espaço educativo com o objetivo de desenvolver a autonomia dos alunos. Estes pontos, segundo o autor, pode possibilitar a troca e a articulação dos saberes não apenas escolares, mas também sociais e culturais.

O primeiro ponto é a percepção do indivíduo como ser único e também coletivo, parte do pressuposto de conhecer a subjetividade e a singularidade, mas transpondo para a necessidade de entender a sociedade de forma articulada. Este aspecto, segundo Carvalho (2012), seria a condição de pertencimento, de maneira que se possa localizar o sujeito e suas particularidades, inserindo-o no contexto educacional e social.

O segundo ponto é o diálogo, compreendido como objeto de articulação de saberes entre os sujeitos, uma vez que o mesmo é fator mediador das relações humanas. Tal aspecto, de acordo com Freire (2008), seria uma constante autoconstrução por meio da socialização, tendo em vista que no processo educativo o diálogo é a presença viva das manifestações sociais, culturais e ideológicas, e consequentemente, fator relevante para a formação e transformação do conhecimento. 


\section{Desafios da psicologia no Brasil}

O terceiro ponto, parte do princípio de que o desenvolvimento da autonomia dos alunos, seria por assim dizer, inserir nos ambientes educativos o pensamento reflexivo sobre as questões que influenciam toda a sociedade de maneira direta ou indireta. De acordo com Freire (2011), é desenvolver um comprometimento ético, seriedade e cumplicidade no processo de formação, bem como discutir alternativas sociais, econômicas e humanas, de maneira a impulsionar um novo sentido para a existência.

Com base na proposta de Freire (2011) relacionada ao saber, o processo de ensino-aprendizagem deve ser contínuo e articulado com todos os saberes do estudante e do professor, de maneira que haja uma transversalidade e uma transcendência de conhecimentos. Para fortalecer este argumento, Batalloso afirma que, "uma das características essenciais de todo o fenômeno educacional é sua condição complexa, crítica e instável" (2012, p. 152).

Dessa forma, ao se articular as concepções de saber de Freire (2011) e de sabor de Castoriadis (2006), pressupõe-se que todos os sujeitos envolvidos nesse procedimento de ensinagem e de aprendizagem se conscientizem de que o projeto educativo, não é estático, mas dinâmico, e influenciado pelo contexto social, cultural, econômico e humano, podendo proporcionar o saber com sabor à história, e saboreando as potencialidades dessa realidade se construa conhecimentos realmente significativos, proporcionando assim, segundo Síveres (2006), um saber saboroso.

O saber é preponderante na instauração de um novo pensar, de uma nova maneira de entender a sociedade e suas contradições. Conforme Síveres (2006, p. 157) “o saber não se reduz, simplesmente, à ciência e ao conhecimento, mas se reproduz como uma energia transformadora da sociedade". Dessa forma, a aquisição do saber deve ultrapassar os simples conhecimentos e metodologias, unificando as relações, trabalhando o entrelaçamento de pensamentos e atitudes, e propondo uma nova organização social que possa verdadeiramente valorizar o indivíduo e legitimar uma sociedade com mais consciência ética e democrática.

Buscando novamente Síveres (2006), o autor lança mão da necessidade do saber ouvir, bem como saber viver, e saber fazer de maneira entrelaçada e articulada uma consonância com o saber científico. Com base nesta proposta, a educação pode trazer uma maior significância para a sociedade, tornandose parte de todos os sujeitos que buscam um projeto educativo que trabalhe a diversidade e a singularidade, o local e o global, o indivíduo e a comunidade. 


\section{Desafios da psicologia no Brasil}

\section{CONSIDERAÇÕES FINAIS}

O texto procurou mostrar o percurso do ensino e da aprendizagem entre o saber e o sabor, assumindo assim que em um processo de aprendizagem deve privilegiar a reflexão sobre a prática e o partilhamento de saberes como fator de consolidação do ensino. Dessa maneira, o sabor está manifestado em todas as articulações dos saberes, para que assim haja uma troca entre estudante e educador, e que essa troca possa proporcionar, tanto para quem ensina, quanto para quem aprende, uma possibilidade de aprendizagem interativa e saborosa, desenvolvendo atitudes e valores, por meio da colaboração entre o docente e discente.

Nesse contexto, o princípio do sabor e do saber no projeto de ensino-aprendizagem perpassa a dimensão da formação e da reflexão, de maneira que o espaço educativo seja construído e considerado por todos os sujeitos educativos. A educação e o conhecimento devem partilhar o mesmo espaço, no qual todos possam correlacionar teorias e práticas em função de um crescimento social, cognitivo, científico e humano.

Relacionar o saber e o sabor, no projeto de ensino-aprendizagem, indica para a superação de uma escola monológica e a proposição de uma educação dialógica; recomenda a minimização de um aluno dependente e a maximização de um estudante criativo; sugere a mudança de um professor informativo para um docente reflexivo. Na medida em que tais aspectos puderem ser consolidados, é possível projetar uma educação pautada em saberes e sabores.

\section{REFERÊNCIAS}

BATALLOSO, Juan Miguel. Educação e condição humana. In: ALMEIDA, Maria da Conceição. MORAIS, Maria Cândida (orgs.). Os sete saberes necessários à educação do presente. Rio de Janeiro: Wak Editora, 2012, p. 149-184.

CARVALHO, Edgard de Assis. Pensamento complexo e trajeto antropológico dos saberes. In: ALMEIDA, Maria da Conceição. MORAIS, Maria Cândida (orgs.). Os sete saberes necessários à educação do presente. Rio de Janeiro: Wak Editora, 2012, p. 93-104.

CASTORIADIS, Cornelius. Uma sociedade à deriva. Entrevistas e debates 1974-1997. Aparecida, SP: Ideias \& Letras, 2006.

DANIELS, Harry. Vygotsky e a pedagogia.Tradução Milton Camargo Mota. São Paulo: Edições Loyola, 2003.

FERREIRO, Emilia. Com Todas as Letras. São Paulo: Cortez, 1999.

FREIRE, Paulo. Pedagogia do compromisso. Indaiatuba, SP: Villa das Letras, 2008. 


\section{Desafios da psicologia no Brasil}

FREIRE, Paulo. Pedagogia da autonomia: saberes necessários à prática educativa. São Paulo: Paz e Terra, 2011.

GONÇALVES, Bábara Donnária da Silva; GONÇALVES, Maria Célia da Silva; SOUZA, Nágila Valinhas de Castro e. O uso da memória na construção do corpus de pesquisa nas ciências sociais e da vida. Direito em Revista. Revista Jurídica do curso de Direito da Faculdade do Noroeste de Minas-FINOM. Paravatu. V.1.n.3, p.105-119, Outubro de 2012.

LIBÂNEO, José Carlos. Adeus professor, adeus professora? novas exigências educacionais e profissão docente. São Paulo: Cortez, 2011.

MORIN, Edgar. Amor, poesia, sabedoria. Tradução Edgard de Assis Carvalho. Rio de Janeiro: Bertrand Brasil, 2011.

PIAGET, Jean. Para onde vai a educação? Tradução Ivette Braga. Rio de Janeiro, José Olympio, 2011.

PINTO, Cabral Fernando. A Formação Humana no Projecto da Modernidade. Lisboa: Instituto Piaget, 1996.

RIOS, Terezinha Azerêdo. Compreender e ensinar: por uma docência da melhor qualidade. São Paulo: Cortez, 2010.

ROGERS, Carl. Tornar-se Pessoa. Lisboa: Moraes Editores, 1984.

SÍVERES, Luiz. Universidade: torre ou sino? Brasília, Universa, 2006.

SÍVERES, Luiz. Perspectivas de aprendizagem na extensão universitária. In: SíVERES, Luiz. (org.) Processos de aprendizagem na extensão universitária. Goiânia, GO: Ed. PUC Goiás, 2012, p. 15-31. 


\section{Capitulo 2}

\section{JUVENTUDE E TRABALHO NO ÂMBITO DA ATENÇÃO BÁSICA: A EXPERIÊNCIA DO CRAS MANTIQUEIRA}

DOI: $10.37423 / 200200149$

Fernanda Reis Alves de Oliveira Pedo

fernandafumec@hotmail.com

RESUMO: O objetivo desse artigo é levantar uma discussão acerca da demanda de inclusão produtiva comum no cotidiano do trabalho da Atenção Básica do Sistema UUnico de Assistência Social (\$UAS). Neste contexto, pretende relatar a experiência do CRAS Mantiqueira que consistiu ha realização de duas oficinas reflexivas com/jovens entre 14 è 21 anos de idade, tendo como temática Trabalho e Identidade. Visa discutir a função-psicológica do trabatho, considerando seu papel para além do mero emprego formal, sobretudo para jovens em situação de vulnerabilidade social. Nesse sẹntido, se por um lado o trábalho possui esse papel fundamental para a formação da identidade humana por outrolado pode servir às falácias do capitalismo ou ter uma função diş्iplinadora, ou ainda servir para esconder outrò problemas sociais e comunitários. A experiência do CRAS Mantiqueipa fez ressaltar a relevância de tratar a temática permanentemente no âmbito das intervenções coletivas com os jovens e as famílias do território.

Palavras-chave: Psicotogia.Assistência \$acial./Juventude. Trabatho. Identidade

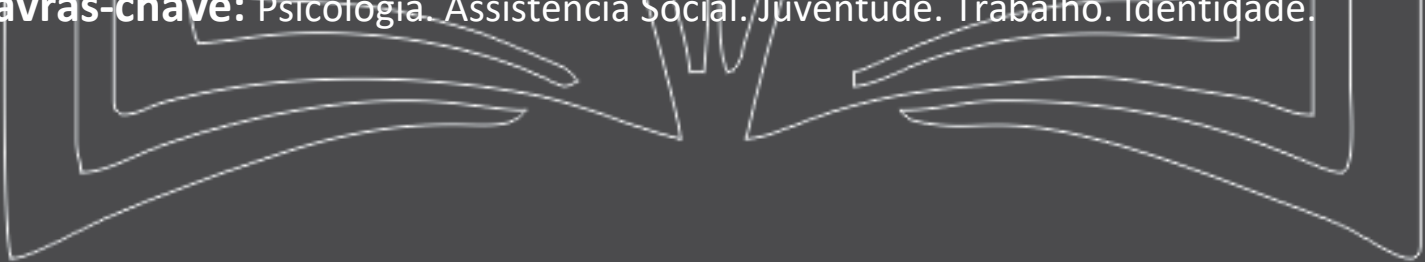




\section{Desafios da psicologia no Brasil}

\section{INTRODUÇÃO}

Enquanto principal unidade e serviço de proteção social básica, o Centro de Referência de Assistência Social (CRAS) tem como foco o trabalho social com famílias de um determinado território, mapeado com alto índice de vulnerabilidade e risco social. De acordo com o Sistema Único de Assistência Social (SUAS), o principal serviço ofertado por esse equipamento deve ser a Proteção e Atendimento Integral à Família (PAIF). Com um caráter continuado, preventivo e proativo, esse serviço socioassistencial deve fortalecer os vínculos familiares e comunitários, potencializando a função protetiva da família, seu protagonismo e sua autonomia. Além disso, compete ao PAIF ofertar às famílias acesso ao sistema de garantia de direitos. Considerando o trabalho como um direito social garantido pela Constituição Federal (CF, art 6) a fim de que os indivíduos tenham condições dignas de subsistência, faz parte das ações do PAIF a inclusão produtiva e o apoio para que usuários construam seus projetos pessoais e profissionais (NOB SUAS, 2012, art.6, inciso IX e X).

A demanda de inclusão produtiva para adolescentes é comum no âmbito do atendimento particularizado no CRAS, apresentando um volume grande, o que torna necessário discutir sobre as particularidades desse ciclo vital, considerando o modo como ele é vivido especificamente nesse território, sobre empregabilidade, emprego e trabalho a fim de qualificar o atendimento realizado no âmbito dessa temática. Considerando a alta demanda, verifica-se que o assunto deve ser tratado de maneira cuidadosa, ultrapassando o aspecto individual e voltando-se para intervenções reflexivas e coletivas.

\section{JUVENTUDE POBRE E DEMANDA DE INSERÇÃO PRODUTIVA}

Optamos por conceber os sujeitos desse relato de forma mais abrangente. Buscando uma perspectiva reflexiva, decidimos chamá-los de jovens, tendo como fundamentação os autores que consideram o aspecto da juventude num caráter mais amplo (FEFFERMAN, 2006; LEON, 2004; FRIGOTTO, 2004) , sem desconsiderar, contudo, os aspectos biológicos e psicológicos, porém com primazia para o aspecto social. Concebemos que a fase compreendida entre a infância e a maturidade adulta deve ser vista na sua totalidade social, pois as condições sociais constroem uma determinada experiência de ser jovem. Refere-se, portanto, a uma fase de latência social constituída dentro de um contexto especifico de um povo. Essa diversidade se concretiza nas condições sociais (classes sociais), culturais (etnias, identidades religiosas, valores), de gênero, nas regiões geográficas, dentre outros (FEFFERMAN, 2006 p. 178). 


\section{Desafios da psicologia no Brasil}

Embora não haja, entre os estudiosos da temática, um consenso sobre o que seja juventude (LEON, 2004), compreenderemos esse termo ao mesmo tempo como uma condição social e como um tipo de representação. Nesse sentido, autores como Frigotto (2004) concordam em utilizar o termo contemporâneo juventudes para designar as diferenças sociais que determinam a maneira de se viver esse período da vida: "os sujeitos jovens (ou as juventudes) teimam em ser uma unidade do diverso econômico, cultural, étnico, de gênero, de religião, etc." (p. 181). Para o autor, embora haja uma tentativa de unificar o conceito, vários estudiosos já demonstram que se deve levar em conta esses aspectos singulares ao estudar o tema.

É nesse sentido que o enfoque do presente relato são os jovens de famílias de baixa renda, inseridos em programas de transferência de renda, como o Bolsa Família, moradores de regiões com baixo Índice de Desenvolvimento Humano (IDH) e alto índice de criminalidade no contexto da periferia de um município urbano de Minas Gerais.

A escassez de recursos para a subsistência, faz com que a demanda por inserção produtiva seja recorrente no cotidiano de atendimento particularizado nos Centros de Referências de Assistência Social; ao mesmo tempo em que a Política de Assistência Social entende que o trabalho e a proteção no trabalho são direitos sociais, garantido pela Constituição Federal.

Martins (2005) afirma que os direitos sociais passaram a ser agregados às constituições, normatizando e assegurando ao trabalhador as garantias mínimas do seu exercício laboral. Segundo o autor, "foram inseridos preceitos relativos à defesa social da pessoa, de normas de interesse social e de garantia de certos direitos fundamentais, incluindo o direito do trabalho." (MARTINS, 2005, p. 42).

Para Silva (2012), a proteção ao trabalho é reafirmada na constituição tanto como direito fundamental quanto como direito social, reconhecendo-se a importância do trabalho como direito e como atividade fundamental à condição humana. Partindo desse pressuposto, o trabalho é entendido pelo legislador como sendo necessário à qualidade de vida dos indivíduos. O direito ao trabalho é vinculado ao direito à igualdade, de acordo com o entendimento jurídico, na medida em que garanti-lo é equalizar situações sociais desiguais, possibilitando melhores condições de vida aos mais vulneráveis economicamente (SILVA, 2012).

É assim que, ao aproximar os direitos da criança e do adolescente dos direitos de toda pessoa humana, o Estatuto da Criança e do Adolescente-ECA traz a profissionalização como uma ação necessária para a inserção dos jovens no mundo do trabalho, considerando-se sua condição especial de pessoa em desenvolvimento. Nesse contexto, a demanda de inserção produtiva para os jovens usuários da 


\section{Desafios da psicologia no Brasil}

Assistência Social é entendida como encaminhamento para o trabalho protegido, considerando a Lei de Aprendizagem Profissional (Lei 10.097/2000).

\section{A FUNÇÃO PSICOLÓGICA DO TRABALHO}

Teóricos clássicos como Marx (1974; 1993) e Lukács (1979), e outros autores contemporâneos como Lima (2007), Jacques (1997) e Toni (2003), defendem a relevância da categoria trabalho no processo de construção humana. Trabalho, de modo geral, é toda atividade desenvolvida pelo homem no contato com a natureza, geralmente com a ajuda de instrumentos, com a finalidade de produzir bens e serviços. Também outros seres transformam a natureza e obtêm aquilo que necessitam. No entanto, o trabalho propriamente dito, entendido como um processo consciente entre a natureza e o homem, é exclusivamente humano. Como afirma Marx (1993), ao final do processo do trabalho humano, surge um resultado que antes do início do processo já existia na mente do homem.

O trabalho é, em primeiro lugar, um processo de que participam igualmente o homem e a natureza, e no qual o homem espontaneamente inicia, regula e controla as relações materiais entre si próprio e a natureza. Ele se opõe à natureza como uma de suas próprias forças, pondo em movimento braços e pernas, as forças naturais de seu corpo, a fim de apropriar-se das produções da natureza de forma ajustada a suas próprias necessidades. Pois, atuando assim sobre o mundo exterior e modificando-o, ao mesmo tempo ele modifica a sua própria natureza (Marx, 1993, p. 197).

Para Marx (1993), o homem é o primeiro ser que conquistou certa liberdade de movimentos em face da natureza. Através dos instintos e das forças naturais em geral, a natureza dita aos animais o comportamento que eles devem ter para sobreviver. O homem, entretanto, graças ao seu trabalho, conseguiu dominar em parte, as forças da natureza, colocando-as a seu serviço. $\mathrm{O}$ trabalho realizado pelo homem visa alterar o estado natural dos materiais na natureza e melhorar sua utilidade. Ele pensa, planeja e produz. Deste modo, se reconhece como parte do gênero humano, é reconhecido pelo outro. Sendo assim, não é possível precisar o período de surgimento do trabalho na história da humanidade, já que ele coincide com a origem do próprio homem. Aprofundando as reflexões acerca da atividade humana, Marx (1993) criticou teorias que desconsideram o homem concreto que se constrói através da sua relação com o mundo objetivo, defendendo que é impossível compreender a subjetividade fora das relações produtivas. Para ele, é através do trabalho que o homem se constitui, transformando-se e transformando a natureza. Apropriando-se do meio de um modo peculiar, o homem desenvolve suas potencialidades e diferencia-se dos outros animais. 


\title{
Desafios da psicologia no Brasil
}

Apoiado no pensamento marxiano, Lukács também defendia o sentido ontológico do trabalho na constituição do homem. Em seus estudos sobre esse filósofo, Lessa (2007) identifica que Lukács não elegia o trabalho como única categoria na definição do humano, mas advertiu que "sem o trabalho, porém, as inúmeras e variadas formas de atividade humano-social não podem sequer existir." (LUKÁCS apud LESSA, 2007, p. 36). Tomando por base as reflexões do filósofo húngaro, Lessa (2007) explica que o homem é o único animal que é capaz de "prévia-ideação", abstraindo e planejando suas ações antes de executá-las. E que, ao exteriorizar as estratégias de ação, confronta seus conhecimentos e habilidades:

\begin{abstract}
A exteriorização é esse momento do trabalho pelo qual a subjetividade, com seus conhecimentos e habilidades, é confrontada com a objetividade a ela externa, à causalidade e, por meio deste confronto, pode não apenas verificar a validade do que conhece e de suas habilidades, como também pode desenvolver novos conhecimentos e habilidades que não possuía anteriormente. (LESSA, 2007, p. 39)
\end{abstract}

$\mathrm{Na}$ atualidade, alguns autores chamam a atenção para a permanência da centralidade do trabalho na sociedade contemporânea. Ao propor uma função psicológica do trabalho, Clot (2006) ressalta que não pretende construir "uma religião do trabalho", mas sim afirmar sua inegável contribuição para o desenvolvimento pessoal e a saúde dos indivíduos. Segundo ele, pelo trabalho, o indivíduo se vê como alguém que participa da construção do mundo ao qual pertence, permitindo seu engajamento num sentido mais amplo e global: "a função psicológica do trabalho residiria ao mesmo tempo no patrimônio que ele fixa e na atividade (conjunta e dividida) exigida pela conservação e pela renovação desse patrimônio." (CLOT, 2006. p. 80).

Jacques (1997) aponta que a articulação entre identidade e trabalho é indispensável. Para ela, essas duas dimensões humanas "pressupõem a reciprocidade, a interdependência e a interação entre os aspectos psicológicos e os aspectos estruturais fundantes de um determinado contexto social." (p. 21). A autora discorre também sobre a importância da interação, característica inerente ao trabalho, pois através dela os indivíduos exercitam o pensamento, a consciência e a linguagem.

Discutindo acerca da polêmica em torno da perda da centralidade do trabalho no contexto da reestruturação produtiva contemporânea, Lima (2007) constata uma confusão entre as noções de emprego e trabalho, dizendo que este último vai além do emprego meramente formal. Ela conclui que as novas demandas do mercado, ditadas pela economia vigente, alteram a organização do trabalho, 


\section{Desafios da psicologia no Brasil}

mas jamais retiraram dessa atividade seu sentido ontológico e essencial na construção das identidades.

Para Toni (2003), embora haja novas formas de organização e reinserção do trabalho, provocadas pela reestruturação produtiva, este se mantém como um vetor que organiza a vida das sociedades e sua apreensão nos possibilita a reflexão a respeito da transformação social. Portanto, para esses autores, a revolução científica e tecnológica não alterou o papel estruturante e primordial do trabalho na vida dos indivíduos.

Considerando o trabalho como princípio educativo e essencial na construção da subjetividade humana, estudiosos do tema aplicado à juventude afirmam que especificamente para essa fase de desenvolvimento psicológico, essa atividade pode ter um sentido transformador. Historicamente atrelado às classes populares que precisavam trabalhar para ajudar na renda familiar, o sentido do trabalho não perdeu o caráter de organizador da identidade juvenil, como discutem Rizzo \& Chamon (2010-2011).

Apesar de estar submetido ao controle que os superiores exercem sobre suas atividades laborais, o adolescente também tem a oportunidade de conviver com iguais e aprender a ordenar suas formas de sociabilidade e suas representações, o que amplia suas experiências e contribui para o processo de amadurecimento psicológico e intelectual. Aumento da autoestima e do sentimento de responsabilidade são aspectos positivos e benéficos da entrada precoce do adolescente no mercado de trabalho (RIZZO \& CHAMON, 2010-2011. p. 410).

Ao apresentar dados da sua pesquisa sobre os sentidos e significados do trabalho para 3.501 jovens brasileiros de 198 municípios, Guimarães (2004) concluiu que o trabalho é uma categoria-chave no imaginário juvenil. Em seus achados, ela discorre sobre a dimensão material e simbólica da representação social do trabalho para os jovens:

[. . .] o lócus da produção de ideias, de representações e simbolizações que informam, vale dizer, são condição de possibilidade, ao darem forma concreta à maneira de se organizar socialmente a produção de bens e serviços. Mais ainda, tal produção simbólica está, ela mesma, enraizada na vida social que transcorre dentro e fora dos espaços onde se tecem as relações sociais de trabalho. (GUIMARÃES, 2004, p. 4)

Jacobina \& Costa (2007) analisam que, embora haja contradições a serem observadas nessa forma de inserção produtiva, "sem dúvida o trabalho pode ser visto como um dos elementos de uma rede social, 


\section{Desafios da psicologia no Brasil}

que se constrói ao redor do adolescente e que tem importante participação na integração do jovem no processo socializador." (p. 98). Reimann (apud JACOBINA, 2006) observa ainda que, ao inserir um jovem num trabalho formal, há uma dimensão de conquistas legais adquiridas historicamente que inaugura sua cidadania. Nesse sentido, "nenhuma outra forma jurídica ou relação social adquiriu a importância que o trabalho tem na construção deste tipo de cidadania:

[. . .] além do trabalho ser um modo de sustento individual e familiar para os jovens, pais e educadores de contextos desfavorecidos, a inserção no mundo precoce do trabalho constitui uma forma de atingir a independência financeira necessária para manter a autoestima e o respeito na comunidade, uma possibilidade de maior autonomia perante os familiares e uma forma de manter o corpo e a mente ocupados. (JACOBINA, 2010, p. 10)

\section{A EXPERIÊNCIA DO CRAS MANTIQUEIRA}

O CRAS Mantiqueira, localizado na regional Venda Nova no município de Belo Horizonte, é um equipamento da Atenção Básica que atende cerca de 2264 famílias dos bairros Mantiqueira, Jardim Leblon, Piratininga e Maria Helena.

Verificando a ausência de ações coletivas voltadas para jovens com idade de 14 a 21 anos do território, a equipe do PAIF decide inserir no Plano de Ação do ano de 2018 a oferta de oficinas reflexivas voltadas para esse público.

Observou-se que a maior parte da entrada desse público no equipamento era, normalmente, acompanhado pela referência familiar e com demanda de inserção produtiva. Aproveitando a chegada das oficinas do ACESSUAS ${ }^{1}$ esses jovens foram convidados a participar de dois encontros reflexivos, encontros estes conduzidos por uma das psicólogas da equipe técnica. Os encontros antecederam as oficinas do ACESSUAS tendo como objetivo aproximar a juventude do território, incentivando-a a se apropriar desse espaço de convivência. Além disso, objetivou discutir sobre Trabalho e Identidade para além da questão de inserção no mero emprego formal e refletir sobre autoestima, empoderamento e protagonismo juvenil.

Foram mobilizados 22 jovens, sendo que, compareceram 18 jovens no primeiro encontro. Tímidos e desconfiados, pareciam atentos a todas as informações. Durante um jogo de mitos e verdades sobre a Política de Assistência Social e do trabalho do CRAS, o grupo demonstrou um desconhecimento 


\section{Desafios da psicologia no Brasil}

significativo sobre seus direitos e a oferta de programas, serviços e projetos ofertados naquele equipamento. Para eles, competia ao CRAS apenas concessão de documentação civil e de tarifa social. Durante o primeiro debate, os participantes não conseguiram associar o trabalho à identidade. Trabalhar está associado ao emprego formal, ao aprendizado de uma habilidade técnica que gere uma recompensa monetária ao final de cada mês. A atividade laborativa em si não é pensada: "Quero conseguir um serviço...Pode ser qualquer coisa".

Na dinâmica de grupo sobre autoconhecimento e escolhas, foi possível refletir sobre os critérios que um indivíduo elege para fazer uma escolha profissional: status, conhecimento, identificação, falta de escolha, coerção, etc. Nesse momento, foi possível constatar que os participantes apresentavam dificuldades para reconhecer características positivas em si e de avaliar seu modo de agir no mundo. Muitos se desqualificavam, reproduzindo uma fala que dizem ouvir de familiares, professores, vizinhos e amigos.

Durante a dinâmica de grupo de encerramento do primeiro encontro, foram apreendidos pelo jogo que exigia concentração e tomada de decisão. Concluíram que podiam exercitar a liderança e mudar de lugar de objeto para um lugar de sujeito autônomo, portador de características positivas e que buscam desenvolvimento pessoal.

A expectativa para o segundo encontro esteve alta. As relações entre os participantes se estreitaram e foi possível observar que conversavam e brincavam entre si. O pacto de respeito proporcionou um ambiente propicio à livre expressão e ao debate, considerando a diversidade do grupo. O formato em círculo, com os jovens sentados em tatames, permitiu o bate papo fluido sobre o vídeo comentado. Discutiu-se sobre o papel das redes sociais na autoestima e sobre sentimentos que ascendem e sentimentos que trazem dor ou violência.

Se no primeiro encontro a questão da baixa autoestima a questão mais marcante. No segundo encontro, apareceu a dificuldade de expressão de sentimentos que não nomeados dificultam a comunicação e, consequentemente, as relações interpessoais. A inabilidade em lidar com questões intrapessoais acabam por culminar com uma comunicação violenta, sobretudo com os familiares. Esse dado ficou claro na dinâmica de grupo "Dentro e Fora do Coração" onde deviam colocar no centro da ilustração de um grande coração, os sentimentos bons que têm e que gostariam de preservar e, fora da ilustração, os sentimentos ruins que reconheciam ter e gostariam de transformar. 


\section{Desafios da psicologia no Brasil}

Discutiram na atividade de vídeo comentado sobre autoestima e redes sociais. Apareceram no debate questões como "ser e parecer ser", "ter e parecer ter", angústia diante de uma vida perfeita exposta nas redes sociais, necessidade de reconhecimento e "curtida" dos outros. E sobre valorização de pequenas conquistas na construção de uma vida. Reconheceram que, na era do celular, as pessoas não se olham ou usam o aparelho para fugir do contato com os outros.

A partir disso, foi realizada uma atividade em pé e em círculos onde deviam "exercitar o olhar" entre os colegas ao som de uma música suave. A princípio, ficaram desconcertados e risonhos, mas foram convidados a se desafiarem, se empoderarem com coragem para fitar uns aos outros. Foi o momento mais rico do encontro. As risadas foram trocadas por um silêncio. Concentrados, se miravam com coragem e no momento de partilha, relataram da dificuldade, superação e de olhares que os marcaram mais ou menos, transmitindo sentimentos.

Os jovens conseguiram iniciar uma reflexão sobre a importância de se apropriarem de si, contribuindo para sua qualidade de vida e apropriação dos diversos espaços sociais, como família e no trabalho. Sobre o empoderamento que viabiliza uma consciência crítica da sua condição socioeconômica e participação comunitária. E que essa mudança de posição, facilitará a experimentação do trabalho para além do emprego.

Isso é mostrado na avaliação anônima dos encontros onde foram colocadas as seguintes avaliações:

"Essa oficina me fez pensar e me fez sentir..."

"Que eu tenho que melhorar minha escuta"

"Que é importante o autoconhecimento. Me senti bem comigo mesma conversando

e me socializando"

"Pensei no meu potencial, competência e nas minhas limitações. Me senti motivado e com esperança" "O quanto é bom compartilhar umas coisas que você pensa e guardaria só pra você. Perder a timidez. Me senti livre, comunicativa e amigável"

"Como posso dar o melhor de mim. Me senti bem, pois descobri mais um pouco de mim e o que eu posso melhorar também"

"Me fez enxergar algumas coisas simples em mim que faz total diferença" 


\section{Desafios da psicologia no Brasil}

\section{DISCUSSÃO}

As observações durante as oficinas e a análise dos relatos, nos fizeram pensar sobre a importância desses trabalhos grupais como importante ação do PAIF para promover o protagonismo juvenil e, sobretudo, como cerne de uma reflexão sobre inserção produtiva para discutir o trabalho em sua acepção mais ampla de fundante do ser. Trata-se de um espaço rico para que os técnicos do PAIF conheçam os jovens do território, compreendendo quais são suas reais demandas. A partir dessa experiência, podemos colocar os seguintes questionamentos: os jovens querem mesmo trabalho quando nos procuram? Encaminhá-los para qualquer emprego é uma solução eficiente? O que desejam realmente os familiares quando demandam para o jovem a inclusão produtiva?

Nesse sentido, recordamos a fala de muitas mães que pedem "arruma um serviço para esse menino" deixando claro que o trabalho formal funciona como um disciplinador de problemas que, normalmente, estão no âmbito das relações intrafamiliares. Essa demanda frequente nos faz pensar à luz de Foucault (2013) e seus estudos sobre as relações de poder onde o trabalho aparece como um mecanismo de controle social para obter corpos dóceis e disciplinados. Assim, as famílias introjetam no âmbito doméstico mecanismos macrossociais de punição e controle.

Segundo Sampaio \& Meneghetti (2016) a disciplina funciona como elemento constitutivo do modo de produção capitalista. E ao atender essa demanda, coadunamos com mecanismos de supressão do sujeito social

A formação profissional e o trabalho podem conter um caráter danoso para o indivíduo quando os métodos de educação e inserção profissional servem para atender as falácias do capitalismo (KUENZER, 2002; FRIGOTTO, 2004). Kuenzer observa que educar pelo trabalho é uma verdadeira atividade pedagógica, porém educar para o trabalho pode servir a mecanismos de dominação de acordo com os interesses econômicos:

Em uma sociedade dividida em classes, onde as relações sociais são de exploração, ele (o trabalho pedagógico) desempenhará a função de desenvolver subjetividades tais como são demandadas pelo projeto hegemônico, neste caso, o capital. Nesse sentido, pode-se afirmar que a finalidade do trabalho pedagógico, articulado ao processo de trabalho capitalista, é o disciplinamento para a vida social e produtiva, em conformidade com as especificidades que os processos de produção, em decorrência do desenvolvimento das forças produtivas, vão assumindo. (KUENZER, 2002)

Essa autora traz importantes elementos para se refletir a respeito das contradições contidas em um projeto de inserção produtiva que se pretende inclusivo. Para ela, vão na contramão das estratégias 


\section{Desafios da psicologia no Brasil}

voltadas para inclusão através do trabalho, que não permitem a formação de identidade autônomas e que, ao contrário, acabam por contribuir de forma sutil, com o processo de desfiliação social.

\section{CONSIDERAÇÕES FINAIS}

A rápida e intensa experiência de realizar oficinas do PAIF sobre a temática Identidade e Trabalho, bem como com seus temas transversais, não pretende esgotar o assunto, nem relatar uma experiência extraordinária. Mesmo porque, outros equipamentos da regional Venda Nova e de outras regionais do município possuem relatos semelhantes. Assim, esse texto pretende discutir sobre a relevância em problematizar de forma menos superficial a questão do trabalho para além do mero emprego formal. E pensar como o tema pode ser uma ferramenta rica para atuação da equipe do PAIF, pensando na função psicológica do trabalho retratada por Clot (2006). Além disso, pretende propor uma discussão para a equipe técnica da Atenção Básica como amortecer o conflito inevitável entre capital-trabalho ao tentar atender as necessidades de geração de renda, sem perder de vista a subjetividade dos sujeitos na sua relação/transformação do mundo concreto.

O relato dos dois encontros com os jovens, nos permite concluir que se trata de opção de aproximação dos jovens do território, viabilizando espaço de escuta individual e coletiva onde evita que corremos o risco de adivinhar o que querem os jovens. Permite traçar de forma mais segura e menos intuitiva, sobre alternativas menos engessadas de inclusão, pela via do trabalho. Ao mesmo tempo que aumenta o rol de possibilidades juvenis. Além disso, nos faz pensar sobre a escassa rede de inserção produtiva e seu efetivo acolhimento e encaminhamento dos jovens atendidos pela assistência social. E de outras alternativas, quando identificamos que para aquele jovem especifico não é hora de trabalho protegido e sim, de outros projetos que possam desenvolver a autonomia ou ainda que têm, primeiro demandas mais emergentes, como acesso à saúde ou educação.

\section{REFERÊNCIAS}

BELO HORIZONTE. Prefeitura Municipal de Belo Horizonte. Secretaria Municipal Adjunta de Assistência Social. Serviço de Proteção Integral à Família - A tradução do direito à proteção básica: uma contribuição de BH. Org. Aidê Almeida Cançado. Belo Horizonte: PBH/ASCOM, 2013.

CLOT, Y. A Função Psicológica do trabalho. Tradução de Adail Sobral. Petrópolis, RJ: Vozes, 2006.

Constituição Federal do Brasil de 1988. (1988, 5 de outubro). Brasília.

FEFFERMANN, M. Vidas arriscadas: o cotidiano dos jovens trabalhadores do tráfico. Petrópolis, RJ: Vozes, 2006. 


\section{Desafios da psicologia no Brasil}

FOUCALT, M. Vigiar e Punir: nascimento da prisão. Tradução de Raquel Ramalhete. Petrópolis/RJ: Vozes, 2013.

FRIGOTTO, G. Juventude, trabalho e educação no Brasil: perplexidade, desafios e perspectivas. In: VANNUCHI, P. \& NOVAES, R. (Orgs.). Juventude e sociedade: trabalho, educação, cultura e participação. São Paulo: Fundação Perseu Ramos, 2004, p. 180-213.

GUIMARÃES, N. A. Trabalho: uma categoria-chave no imaginário juvenil. In: ABRAMO, H. W. \& MARTONI, P. P. (Orgs.). Retratos da juventude brasileira. São Paulo: Instituto Cidadania e Editora da Fundação Perseu Abramo, 2004.

JACOBINA, O. M. P. \& COSTA, L. F. "Para não ser bandido": adolescentes em conflito com a lei e trabalho. Cadernos de Psicologia Social do Trabalho, 10(2), p. 95-110, dez. 2007.

JACQUES, M. G. C. Identidade e Trabalho: uma articulação indispensável. In: TAMAYO, A.; BORGESANDRADE, J.; CODO, W. (Orgs.). Trabalho, Organização e Cultura. São Paulo, 1997, p. 41-49.

KUENZER, A. Z. Exclusão includente e inclusão excludente: a nova forma de dualidade estrutural que objetiva as novas relações entre educação e trabalho. In: LOMBARDI, J. C.; SAVIANI, D., SANFELICE, J. L. (Orgs.). Capitalismo, trabalho e educação. Campinas: Autores Associados; HISTEDBR, 2002.

LE GUILLANT, L. O caso de Marie L. In: LIMA, M. E. A. (Org.). Escritos de Louis Le Guillant: da ergoterapia à psicopatologia do trabalho. São Paulo: Vozes, 2006.

Lei federal no 8069 de 13 de julho de 1990. (1990, 16 de julho). Estatuto da criança e do adolescente. Diário Oficial da União, Brasília.

LEON, O. D. Adolescência e juventude: das noções às abordagens. In: FREITAS, M. R. de (Org.). Juventude e adolescência no Brasil: referências conceituais. São Paulo: Ação Educativa, 2004.

LESSA, S. Trabalho e proletariado no capitalismo contemporâneo. São Paulo: Ed. Cortez, 2007.

LIMA, M.E.A. Trabalho e identidade: uma reflexão à luz do debate sobre a centralidade do trabalho na sociedade contemporânea. Educação\&Tecnologia, v.12, n.3, 2007.

LUKÁCS, G. Ontologia do ser social: os princípios ontológicos fundamentais de Marx. Tradução de Carlos Nelson Coutinho. Ciências Humanas. São Paulo, 1979.

MARTINS, S. P. Direito do trabalho. São Paulo, Atlas, 2005.

MARX, K. Manuscritos econômicos-filosóficos. Lisboa: Ed. 70, 1993.

MARX, K. Manuscritos econômicos-filosóficos e outros textos escolhidos. Tradução de José Carlos Bruni. São Paulo: Abril Cultural, 1974.

MISSE, M. Crime, sujeito e sujeição criminal: aspectos de uma contribuição analítica sobre a categoria "bandido". Lua Nova, 79, p. 15-38, 2010.

MISSE, M. Mercados ilegais, redes de proteção e organização local do crime no Rio de Janeiro. Estudos Avançados, 21(61), p. 139-157, 2007. 


\section{Desafios da psicologia no Brasil}

RIZZO, C. B. S. \& CHAMON, E. M. Q. O. O sentido do trabalho para o adolescente trabalhador. Trab. Educ. Saúde, Rio de Janeiro, 8(3), p. 407-417, nov. 2010/fev. 2011.

SAMPAIO, S. S. \& MENEGHETTI, G. A disciplina como elemento constitutivo do modo de produção capitalista. Katálysis, Florianópolis, 19(1), p. 135-142, jan./jun. 2016.

SILVA, C. C. M. A proteção ao trabalho na Constituição Federal de 1988 e a adoção do permissivo flexibilizante da legislação trabalhista no Brasil. Constituição, Economia e Desenvolvimento: Revista da Academia Brasileira de Direito Constitucional, 4(7), p. 274-301, jul./dez. 2012.

TONI, M. Visões sobre o trabalho em transformação. In: Sociologias, Porto Alegre. 


\section{Desafios da psicologia no Brasil}

\section{NOTAS}

\section{Nota 1}

Programa de Promoção do Acesso ao Mundo do Trabalho (Acessuas Trabalho) de gestão do Ministério do Desenvolvimento Social e parceria com os municípios. 


\section{Capitulo 3}

\section{A ESCOLA E O PROCESSO DE SUBJETIVAÇÃO: UMA INTERVENÇÃO À LUZ DA EDUCAÇÃO PARA AS RELAÇÕES ÉTNICO-RACIAIS}

DOI: $10.37423 / 200200153$

Adelina M. B. Nunes (Mestranda em Educação pela UFOP/MG, Graduada em Psicologia-FAR especialista em Políticas Públicas com ênfase em Gênero e Relações Etnoxraciais pela UFOP/MG e Micropolíticas e Gestão do trabalho em Saúde pela UFF/RJ) abn.psi@gmail.com

Isabela Perucci E. Fagundes (Mestranda em Educação pela UFOR/MG, Graduada em DireitołUFOP/MG, especialista em Direito Processual Civil pela Uninter. isabela@ufop.edu.br
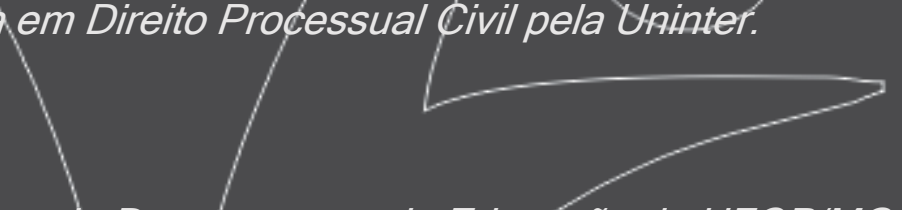

Margareth Diniz (Professora Adjunta do Departamento de Edueação da UFOP/MG, Psicanalista, Dontora em Educação pela UFMG/MG.

dinizmargareth@gmail.com

Resumo: Esse trabalho é fruto de um projeto de/intervenção, "Criança faz cultura: promovendo a igualdade racial na escolạ" desenvolvildo em uma escola da educação básica na Rede Municipal de Educação de Mariana-MG. Com/a justificativa de conhecer e combater o racismo estrutural que permeia a sociedade brasjlęira, essa ação teve como objetivo trabalhar a identidade negra, ofertando materiał simbólico positibo e valerizando as-contriby iç̧é los locais dos/das lafficanos/as e seus descentes para a região através de oficinas, histórias, filmes, desenhos, dinâmicas e outras atividades as mediadoras das atividades se propuseram a promover um deslocamento das categorias "negro" e "África". 


\section{Desafios da psicologia no Brasil}

Facilitando reflexões sobre as diversidades étnico-raciais, as diferenças e as desigualdades, entendendo-as como produzidas socioculturalmente. As atividades desenvolvidas conseguiram ganhar a atenção e interesse dos (as) participantes, e fomentaram a discussão da temática junto a outros integrantes da comunidade escolar.

Palavras chaves: Identidade racial; subjetividade; educação. 


\section{Desafios da psicologia no Brasil}

\section{INTRODUÇÃO}

No século XIX a categoria raça transita da biologia para a cultura, assentando-se no que caracteriza sua função, o de viabilizar uma "hierarquização social" em substituição ao sistema escravocrata, a cor passa a ser um tipo de código para raça (GUIMARÃES, 1995), escala social cromática tradutora das desigualdades produzidas pelo período da economia escravista como um "problema do negro". O que é ser negro, o que é ser branco ou indígena? A educação para as relações étnico-raciais passa por essa questão primária: a tempos os estudos raciais vem se debruçando sobre o Outro. Mas esse processo de diferenciação (o "Eu" e o "Outro") identitária racial, para uma equação completa, precisa dar contornos também ao "Eu", de modo que todos e todas presentes na trama reflitam sobre sua posição e assim possam se conscientizar (sem defesas) dos comportamentos que colaboram com a manutenção ou ruptura do status quo racial vigente.

A cultura racialista não é um aspecto à parte, ela é transmitida como quaisquer outros aspectos culturais naturalizado, o grupo familiar é para os/as bebês a primeira fonte, por assim dizer, através da qual a criança fará contato com a teia de significações estabelecida na cultura previamente a sua chegada ao mundo. E por conseguinte os adultos/as e outras pessoas com que estabelecerem laços contribuirão na sua assimilação do "mundo", até que aquele desenvolva as possibilidades cognitivas e sociais de estabelecer suas próprias significações. Esse processo não se dá apenas na relação de interação humana, a televisão, os desenhos, os livros, as músicas, e mais recentemente, a internet, são meios de transmissão da cultura, o que Ihes confere também uma dimensão pedagógica, somando-a à função educativa dos familiares, e da escola entre outros. O que nos ajuda a compreender parte dos desafios de uma educação para as relações étnico-raciais, ainda hoje. Qual imaginário vem sendo reificado das mulheres e homens negros, dos/das brancos/as e dos "indígenas" na mídia, nos livros didáticos, na arte? (SILVA, 2011), (GOMES, 2012). Que reflexos tais signos impactam a subjetividade? (FANON, 2008; SOUZA, 1983)

Apesar de compreendermos que o sistema de aprendizado do "ethos racial", transpõe as instituições, reconhecemos que também estão presentes nela, e às vezes podem ser meios de produção de novas desigualdades, e as escolas não estão alheias a esse processo. Neste trabalho apresentaremos um projeto de intervenção realizado na Rede de Educação de Mariana- MG, em uma escola que atende a Educação Infantil, Fundamental I e II. O cenário das políticas afirmativas, de reparação simbólica destacamos aqui a Lei de no 10.639/2003 (BRASIL, 2003), que torna obrigatório o Ensino da Histórica da Cultura Afrobrasileira - colocou-nos diante de um desses impasses do racismo, que demanda uma 


\section{Desafios da psicologia no Brasil}

legislação específica para que sejam reconhecido o legado cultural e a importância da contribuição africana para o Brasil. Conforme demonstra o estudo de Nilma Lino Gomes e Rodrigo Ednilson de Jesus (2013) a implementação ainda não pode considerada realizada, tais iniciativas ainda se localizam em professores e disciplinas específicos, e são tratadas pontualmente. A dificuldade expressa na pesquisa de âmbito nacional e as experiências trocadas durante o planejamento do projeto ${ }^{1}$ e de contatos prévios com a escola foram cruciais para a construção dessa proposta de intervenção e escolha da metodologia, viabilizando o objetivo principal de trabalhar a identidade negra, oferecendo material simbólico positivo desse grupo racial e valorizando as contribuições dos/das africanos/as e seus descendentes para a região.

\section{DESENVOLVIMENTO}

A educação é um campo de conhecimento que se articula com as diferentes áreas dos quais ressaltamos a contribuição neste trabalho, que foram: a sociologia, a história e a psicologia. Áreas que a um tempo vêm construindo novos paradigmas em torno do racismo brasileiro ampliando as possibilidades de uma maior consciência racial. O percurso de estudo realizado no desenvolvimento desse projeto também teve contribuições da psicanálise, da antropologia, da medicina e do direito, campos que influenciaram, ao longo da formação do Brasil as políticas educacionais, bem como o modo com que o tema "raça" foi abordado na esfera das pesquisas e logo nas instituições. Ao demonstrar a interdisciplinaridade dos estudos realizados, já posicionamos nosso argumento em defesa de que o racismo está presente de forma estrutural na sociedade brasileira, afeta a subjetividade, agrava desigualdades, impactando diferentes dimensões da vida do sujeito ${ }^{2}$, fazendo parte de um repertório de "aprendizado social" e como tal pode ser desconstruído.

Para fins desta intervenção, iniciamos dividindo os/ as discentes em três grupos, conforme a faixa etária; grupo 1: os que tinham entre 4 e 6 anos (matriculados no 1ำ período, 2o período e 1음 ano do ensino fundamental), grupo 2: os de 7 a 10 anos (alunos do 2ㅇo ao ano do ensino fundamental) e grupo 3: os 11 a 15 anos de idade (aqueles que cursavam entre o 6 e o 9 ano do ensino fundamental). Isso permitiu adequar as atividades, a linguagem e a abordagem a cada grupo. Com o primeiro e segundo grupos foram realizadas três atividades e como terceiro grupo, quatro atividades. Todas as atividades contaram com pelo menos duas mediadoras, que apresentavam a proposta aos alunos e conduziam os trabalhos. 


\section{Desafios da psicologia no Brasil}

a) Bonecas: Nessa atividade as crianças foram estimuladas a criarem uma história e interagir com as bonecas (onde moram, o que serão quando crescer, etc) sendo estas em tudo idênticas, exceto na cor - uma preta e outra branca. Essa atividade teve por objetivo identificar construtos racistas promovendo uma mediação que possibilitasse a ressignificação estereótipos preconceituosos, extensivos também à perspectiva do gênero.

b) Cineminha: A partir da exibição do desenho "Menina Bonita do Laço de Fita"3" foi iniciado um diálogo com os/as alunos/as em torno dos recursos apontados na animação; as mediadoras conduziram a atividade na direção da valorização da beleza negra na perspectiva da afetividade, dando ênfase ao fenótipo com herança ancestral.

c) Contação de história: Com a leitura do livro "A cor de Coraline"(RAMPAZO, 2017) foi proposto o debate sobre a percepção da cor da pele de cada pessoa, sendo na sequência os/as alunos/as convidados/as a desenharem a si próprios, utilizando giz de cera com diversos tons de pele ${ }^{4}$.

\section{Interações realizadas com o Grupo 2:}

a) Contação de história: Contando a história de "Chico Rei", rei africano em sua nação que é trazido para o Brasil, escravizado e lidera um movimento de luta pela liberdade, as mediadoras propuseram uma reflexão sobre a tensão entre violência e resistência que marcam a trajetória da população negra no Brasil.

b) Pensar brincando: Através de uma brincadeira onde as crianças alternam posições de dar e receber ordens, as mediadoras de atividade pediram ao final que as crianças discutissem como se sentiram em cada um desses lugares, introduzindo, a partir das respostas, a violência do período escravocrata brasileiro.

c) Que cor é a minha cor? Aqui as crianças foram convidadas a selecionar em jornais e revistas pessoas que parecem e que não parecem com ela, construindo um mural das semelhanças e diferenças. Através do debate e da observação, os mediadores puderam verificar se havia a necessidade de desenvolver outras atividades que auxiliem na construção de uma identidade positiva.

\section{Interações realizadas com o Grupo 3:}

a) Somos todos iguais? A partir da apresentação do clipe "Minha Rapunzel tem Dread" os alunos foram chamados a debater sobre a diferença fenotípicas, a semelhança como herança ancestral, a construção e desconstrução das desigualdades articuladas as diferenças raciais. 


\section{Desafios da psicologia no Brasil}

b) Preconceito, onde você guarda o seu? Instados a descrever imagens de negros e brancos e como cada grupo racial é representado pelas mídias, os alunos, através das provocações das mediadoras discutiram as diferentes formas que o racismo assume.

c) Jogo das diferenças: Os/as alunos/as foram convidados a dar um passo atrás ou à frente conforme sua resposta às indagações das mediadoras sobre como sentimentos e percepções raciais da sua vivência (ex.: se você já quis ter um cabelo diferente, dê um passo à frente), de forma a "visualizar" a própria trajetória e dos colegas.

d) Cine Black: O racismo no cotidiano escolar foi discutido após a grupo assistir o vídeo "Vista minha pele ${ }^{6 \prime \prime}$, no diálogo as mediadoras introduziram conceitos essenciais para a temática (como racismo e injúria racial) e apresentaram medidas de prevenção e combate à discriminação (como o Estatuto da Igualdade Racial e a Lei no 10.639/2003 que estabelece a obrigatoriedade do ensino da História e Cultura Afro-brasileira e Indígena na educação básica).

Assim diversos recursos foram mobilizados e várias interações foram provocadas, convidando os/as alunos/as a refletir sobre o racismo: o que é, como se manifesta, quais consequências produz na vida de todas as pessoas e, sendo um construto social, como é possível também desconstruí-lo.

\section{CONSIDERAÇÕES FINAIS}

Para o objetivo ser alcançado mostrou-se importantíssimo que o espaço das oficinas não fosse um ambiente de "certo ou errado", mas que todos pudessem se expressar tal como se sentiam. Coube às facilitadoras, ao identificar comportamentos racistas, falas estereotipadas, intolerâncias às diversidades realizarem prontamente a ponte semântica e simbólica de desconstrução diante do ocorrido, de forma horizontal, com todos/as os/as participantes. Conclui-se que promover a igualdade racial é possível, através do deslocamento das próprias percepções e condutas. Dessa intervenção resultou ainda a elaboração de uma cartilha com sugestões de atividades para a abordagem das relações étnico-raciais na escola7.

\section{REFERÊNCIAS}

BRASIL. Lei no 10.639, de 09 de janeiro de 2003. Disponível

em <http://www.planalto.gov.br/ccivil_03/leis/2003/l10.639.htm>. Acesso em 10 jun. 2019.

FANON, Franz. Pele negra, máscaras brancas. Tradução de Renato da Silveira. Salvador: EDUFBA, 2008. 


\section{Desafios da psicologia no Brasil}

GOMES, Nilma Lino. Corpo e cabelo como símbolos de identidade negra. Disponível em <http://www.acaoeducativa.org.br/fdh/wp-content/uploads/2012/10/Corpo-e-cabelo-como s\%C3\%Admbolos-da-identidade-negra.pdf $>$. Acesso em 02 set. 2018.

GOMES; Nilma Lino; JESUS, Rodrigo Ednilson de. As práticas pedagógicas de trabalho com relações étnico-raciais na escola na perspectiva da Lei no 10.639: desafios para a política educacional e indagações para a pesquisa. Educar em Revista, Curitiba, Brasil, n.47, p.19-33, mar. 2013. Disponível em:<http://www.scielo.br/scielo.php?script=sci_arttext\&pid=S010440602013000100003\&lng=en\&n rm=iso $>$. Acesso em 10 jun. 2019.

GUIMARÃES, Antônio Sérgio Alfredo. Racismo e anti-racismo no Brasil. Novos Estudos, n. 43, p. 2644, nov. 1995.

RAMPAZO, Alexandre. A cor de Coraline. Belo Horizonte: Rocco, 2017.

SILVA, Ana Célia da. A representação social do negro no livro didático: o que mudou ? por que mudou? / Ana Célia da Silva. - Salvador : EDUFBA, 2011. 182 p. 


\section{Desafios da psicologia no Brasil}

\section{NOTAS}

\section{Notas 1}

Esse projeto início na disciplina "Constituição do Sujeito e/ou identidades culturais", ofertada pelo programa de Pós Graduação em Educação da UFOP em 2017/1. Sua execução foi vinculado ao Grupo de Pesquisa Caleidoscópio, coordenado pela professora da disciplina Drä.Margareth Diniz.

\section{Nota 2}

Para compreensão mais ampla da tese ver: ALMEIDA, Silva. O que é racismo estrutural?.Belo Horizonte (MG) Letramento,2018.

\section{Nota 3}

Disponível em: https://www.youtube.com/watch?v=UhR8SXhQv6s. Acesso em 25 jan. 2019.

\section{Nota 4}

O giz utilizado foi produzido em uma parceria com um curso de aperfeiçoamento da UNIAFRO/UFRGS, em Política de Promoção da Igualdade Racial na Escola e a Pintkor. Atualmente já é possível encontrar também algumas opções de lápis de cor.

\section{Nota 5}

Disponível em: https://www.youtube.com/watch?v=b1Uf6_SV5_8. Acesso em 25 jan. 2019.

\section{Nota 6}

Disponível em: https://www.youtube.com/watch?v=LWBodKwuHCM. Acesso em 25 jan. 2019.

\section{Nota 7}

Foi produzido uma cartilha a partir desse projeto que está disponível virtualmente e pode ser solicitada pelo e-mail igualdaderacialnaescola@gmail.com.br. 


\title{
Capítulo 4
}

\section{PESSOA-COMUNIDADE E INTER-RELAÇÕES NA OBRA DE EDITH STEIN}

\author{
DOI: $10.37423 / 200200156$
}

Clélia Peretti (Doutora em Teologia pela Escola Superior de Teologia de São Leopoldo, RS. Membro da Academia Internacional de Teologia Prática (IAPT). Professora Aijiunta do Programa de Pós-Graduação e Bacharelado em Teologia da PUCPR).

clelia.peretti@pucpk.br.

RESUMO: O presente artigd toma como texto base o capítulo oitavo da obra a Estrutura della persona umana. Corso de antropologia filosofica de/Edith Stein intitulado O ser social da pessoa. O motivo da escolha deve-se a grande ênfase na conceituação da pessea humana e suas relações sociais o que possui relaçõos diretas com a empatia e com a ética. A sociabilidade humana é discutida a partir dos quatro aspectos apresentados por Edtih Stein: atos sociais, relações sociais, formações sociais e tipos sociais. Com o objetive-de apresentar as contribuições de Edith Stein a anaálise do texto consiste nos seguintes passos: introdução do conteúdo, análise do ser social da pessoa, comunidade povo e implicaçôes para avivência ética.

Palavras-chave: Pessoa; Comunidade; Relapões/intra e interpessoais.

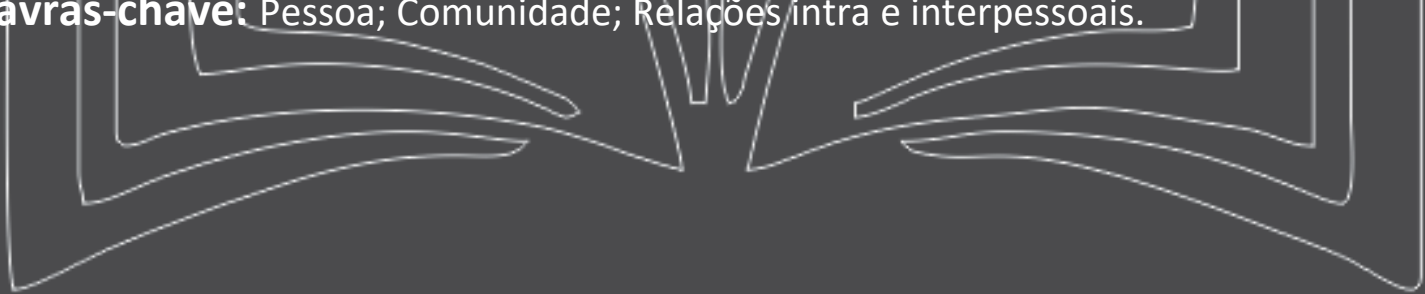




\section{Desafios da psicologia no Brasil}

\section{INTRODUÇÃO}

Edith Stein, ainda jovem estudante, se interessa pelo tema da pessoa humana e, encontra no método fenomenológico de Edmund Husserl o fio condutor de toda sua produção intelectual. A compreensão da empatia, qual é a essência desse ato, como ele é possível e o que nele está implícito, leva a uma profunda análise antropológica, fazendo da investigação sobre a intersubjetividade um caminho para conhecer a essência da pessoa humana. Assim, a partir da análise da empatia a filósofa compreende que a dimensão social e a dimensão intersubjetiva são constitutivas da pessoa humana. Contudo, a pessoa não é absorvida na vida da comunidade, sua particularidade não só é preservada, mas é necessária para a configuração da identidade pessoal. Mesmo identificando traços tipicamente comunitários na pessoa, traços de caráter semelhante aos demais membros da comunidade, ainda assim a pessoa preserva sua peculiar individualidade. Assim, pessoa e comunidade nos escritos steinianos são termos ontologicamente interdependentes.

A comunidade é considerada em analogia à pessoa humana, sendo essencial para sua definição e para a apreensão de seus aspectos originais, para o reconhecimento e o posicionamento das pessoas. A relação comunitária é apresentada como elemento essencial para o processo de formação pessoal. A relação pessoa-comunidade é essencialmente uma relação de interdependência constitutiva, onde os aspectos - ativo e passivo - da pessoa e da comunidade são necessários no processo de tornarem-se si mesmas, o que só pode acontecer a partir de uma abertura recíproca (STEIN, 1996).

A comunidade é identificada objetivamente como uma forma de agrupamento social como são as famílias, os povos, as comunidades científicas, religiosas, etc. A comunidade é observada no seu aspecto objetivo como forma social, mas é olhada por dentro a partir dos seus aspectos constitutivos formados pelas experiências dos seus membros. Edith Stein sustenta que a fundamento de todas as comunidades, da mais ampla até a mais restrita, existe uma comunidade universal por ela denominada de humanidade.

Suas contribuições são valiosas ferramentas para discutir os aspectos essenciais do ser pessoa e do ser comunidade e, ao mesmo tempo, sugerem pistas para o desenvolvimento e a ampliação de uma filosofia social e política da sociabilidade.

Tomamos como texto base para o estudo da sociabilidade humana o capítulo oitavo da Estrutura da pessoa humana dedicado a análise das relações sociais fundamentada em quatro aspectos, a saber: atos sociais, relações sociais, formações sociais e tipos sociais. Ninguém nega que, do ponto de vista 


\section{Desafios da psicologia no Brasil}

biológico, todos os seres pertencem a uma espécie. Ainda, ninguém nega que linguisticamente ou conceitualmente se possa admitir que exista um gênero ou um tipo natural que definimos humano. Mas, afirmar que existe uma comunidade humana é problemático porque essa implica necessariamente uma particular relação entre os seres humanos. Contudo, sabemos que muitos pensadores colocaram em dúvida essa possibilidade, afirmando sua contingência histórica ou a dependência do poder. Mas quando examinamos os discursos sobre os direitos humanos que giram ao redor das questões dos direitos inalienáveis, da violência, das graves violações da dignidade humana, logo invocamos as afirmações steinianas de uma comunidade humana como também a inviolabilidade das pessoas humanas. Num mundo globalizado marcado pela lógica do individualismo e da indiferença qual é o sentido do "nós", da comunidade humana? Quem é o outro? Quais são os critérios para fundamentar nosso agir, querer, pensar e crer a tolerância, a acolhida, a divisão, a solidariedade, o conflito ou a relação? O ato empático possibilita colher no outro um existir como o meu, "é um ato que funda o agir solidário, educa para os valores éticos e civis, testemunha a comunidade como relação personalista do ser" (MANGANARO, 2014, p. 11).

Sob essa perspectiva a comunidade não é apenas compreendida como agrupamento humano, mas estruturalmente é um tipo de relação interpessoal, marcada pelo posicionamento da pessoa a partir do uso de sua razão e liberdade. È na solidariedade, no agir ético que se encontram os elementos constitutivos da abertura para os outros, na eficácia positiva de cada ação ou intervenção recíproca, na unidade ou globalidade dessas relações. A solidariedade é a manifestação da força vital comunitária e, a empatia não é somente um ato intencional, mas formativo e performativo, porque coloca em movimento a relação e, por sua vez, a testemunha e a preserva.

\section{O SER SOCIAL DA PESSOA HUMANA: GERME EMBRIONAL DE COMUNIDADE}

O capítulo VIII da Estrutura da Pessoa humana (2013), dedicado às relações pessoais contém valiosas páginas para compreender a intencionalidade e a performatividade dos atos sociais. Edith Stein inicia o capítulo de forma dramática com a seguinte afirmação:

Considerar um indivíduo ilhado é fazer uma abstração. A existência de um homem é existência em um mundo, sua vida é vida em comunidade. E essas não são relações exteriores que se dão a um ser existente em si mesmo e para si; o estar inserido como membro em uma totalidade mais ampla já faz parte da estrutura do ser humano (STEIN, 2013, p. 185).

Compreendemos imediatamente que ser uma pessoa humana significa viver em um mundo social, estar em comunidade. O conceito de pessoa humana de Edith Stein, entendida como unidade de 


\section{Desafios da psicologia no Brasil}

corpo, psique e espirito, é fundamental e perpassa o conjunto de suas obras filosóficas. Desde o início de sua investigação a pessoa humana possui uma essência fenomenológica e constitui a base de todas as ciências, porque é a pessoa humana que faz progredir as ciências, tanto para aprender a se conhecer quanto para aprender a conhecer a realidade em que vive. Edith Stein nos fornece neste capítulo uma "imagem" do ser social do humano como um ser que realiza atos sociais; vive relações sociais; é um membro das estruturas sociais e é um tipo social.

Sabemos que o conceito de comunidade humana emerge na última parte da reflexão de Edith Stein. Neste capítulo Edith Stein apresenta a ideia embrionária de comunidade universal humana universal, definida por ela de humanidade. O conceito de comunidade não se encontra, nem no seu tratado sobre a empatia, nem nos escritos de 1936 e de 1938 e, menos ainda na Introdução à filosofia (1998). Os germes de um sentido mais amplo de comunidade encontram-se na obra Una ricerca sullo Stato (1993), onde a filósofa afirma que o estado é um tipo de comunidade que se coloca entre as formas mais restritas de comunidade, a família, a igreja e o povo. Nosso objetivo é, portanto, mostrar a origem da ideia de comunidade esboçada nas aulas sobre antropologia filosófica de Münster, um conceito que Edith Stein desenvolverá na sua obra magna, Ser finito e Ser eterno (1988).

Analisaremos a seguir os quatro aspectos que caracterizam o ser social da pessoa humana apresentados no capitulo oitavo da obra A estrutura da pessoa humana (STEIN,2013, p. 185-199).

Edith Stein, entende por atos sociais, os atos do eu, ou seja, os atos que se entrelaçam com a competência performativa do humano. Trata-se dos atos pelos quais uma pessoa se dirige a outra pessoa por meio de perguntas, pedidos e ordens. Todos esses atos são ditados pela vontade de motivar a outra pessoa a assumir um determinado comportamento. As pessoas, juntas, dão vida a um contexto supraindividual que inclui entre ambas as pessoas. Os atos sociais podem se expressar no interior de um contexto axiológico, que inclui o amor, o respeito e a admiração. Edith Stein considera que no caso dos atos de valorização pessoal, embora os valores não possam ser compartilhados e reconhecidos, é possível ainda reconhecer estes atos como sociais, porque envolvem mais de uma pessoa, embora esta última possa não estar envolvida diretamente na ação. De acordo com Edith Stein existe uma terceira categoria de atos sociais constituída por aqueles que possuem a força de produzir ou anular uma determinada realidade objetiva no mundo social:

(...) assim, uma promessa produz o direito de exigir sua realização: este direito não se cumpre por si só mediante o cumprimento da promessa, ou só através da renúncia a sua satisfação pela pessoa a quem a compromisso foi realizado. . Todo o direito positivo possui este caráter. Todos os atos sociais já pressupõem 


\section{Desafios da psicologia no Brasil}

existente um consenso acerca dos acordos entre as pessoas (STEIN, 2013, p 187).

Para as relações sociais, Edith Stein sustenta que essas pressupõem um contexto de conhecimento compartilhado entre as pessoas, fazendo assim emergir a centralidade do eu-tu: as relações sociais não são somente ações de, mas ações entre pessoas. Tratase de uma gramática fenomenológica da relação não simplesmente teorizada, mas "vivida" e ilustra esta vivência da seguinte forma:

\footnotetext{
Até que eu vivo sentimentos de amizade em relação a alguém sem que o outro tenha consciência e lhes retribua, não existe ainda amizade entre nós. Somente quando dois seres humanos expressam reciprocamente seus sentimentos, apenas quando um conhece as ações do outro e lhes retribui, ocorrerá uma relação de amizade. As pessoas nesta relação, são amigas. A partir desse momento, esta relação faz parte do seu ser pessoal e contribui para determinar sua vida [/136]. (STEIN, 2013, p. 187).
}

Aqui se coloca a clássica visão steiniana das experiências comunitárias: a solidariedade que caracteriza as relações sociais pode ser alcançada somente quando as pessoas compreendem ou são conscientes do sentido construtivo do que significa viver na experiência do outro.

A pessoa é membro da estrutura social. Edith Stein ressalta neste terceiro aspecto que a comunidade é a mais alta forma de sociabilidade e revela uma estrutura unitária onde convergem tanto as relações quanto os atos. Enfatiza a relação entre as partes e o todo, e mais especificamente a relação eu-outro, eu-nós. Contudo, as comunidades não são pessoas, mas são semelhantes a estas. Edith Stein diz que "é possível falar de comunidade num sentido mais amplo não somente onde existem relações recíprocas entre as pessoas, mas onde as pessoas se apresentam também como unidades, no interior das quais essas se ligam a um nós" (STEIN, 2013, p. 188). Os temas que emergem aqui são aqueles de história, espírito e valores relacionados com a ideia de humanitas: "na base de cada comunidade humana, tanto daquelas efêmeras como daquelas "de natureza substancial", há uma comunidade universal que abraça todas: é a humanidade". Assim, o homem é desde sempre um ser social inserido numa comunidade, mesmo que não esteja consciente disso. Porém, o que dá dignidade e consistência a humanidade, em última instância, é o fato de ela ser partícipe da vida do "homem-Deus", ou seja, sua unidade está fundada em Deus (STEIN, 2013, p. 189).

Mas qual é a relação entre a constituição essencial do ser humano e os laços comunitários? Para avançar no aprofundamento desta temática as fontes mencionadas por Stein são: D. von Hildebrand, Metafísica da comunidade (1930) e F. Tönnies, Comunidade e Sociedade (1887). Stein também fez referência a esta última no ensaio de 1922, Psicologia e ciências do espírito. Contribuições para uma base filosófica, mais precisamente na introdução do capítulo Indivíduo e comunidade. Assim como a 


\section{Desafios da psicologia no Brasil}

unidade do "nós", a com-unidade é perpassada pelas ideias de alteridade e de espírito, o nós é para Edith Stein fundado teologicamente; e, em nota, faz referência ao Corpus Christi Mysticum. Lê-se:

É possível falar de comunidade em sentido amplo, não só onde há relações recíprocas entre as pessoas, mas lá onde essas pessoas também se apresentam como unidade, dentro da qual estão ligadas a um nós. Essas estruturas podem ser transitórias e temporárias; podem, contudo, ter uma consistência que vai além do atual estar junto de pessoas; falo da comunidade no sentido estrito do termo quando há uma comunidade de vida permanente entre pessoas, que atinge até as profundezas, e Ihe atribui uma marca duradoura; uma comunidade que não se funda somente sobre relações passageiras ligadas ao presente, mas também sobre laços objetivos supraindividuais, que possui sua própria lei de formação segundo o que se realiza e se desenvolve, da mesma forma que uma pessoa humana individual (STEIN, 2013, p. 188-189).

Chegamos ao último aspecto o da sociabilidade, isto é, ao tipo social. O síngulo ser humano compreendido como membro de uma comunidade é também um tipo. Edith Stein observa que um indivíduo pode possuir no seu ser algo em comum com os outros no interior de uma comunidade, mas existem também diferenças que o distingue dos outros. Ela exemplifica com dois distintos tipos de alemães: Suábia e Bavarian. Uma pessoa pode pertencer a diferentes comunidades e podem existir numerosos tipos que convivem em uma comunidade particular. Edith Stein quer mostrar, dessa forma que existem diversos tipos de seres humanos e que são pessoas. Todos pertencem a comunidade humana universal que ela chama de humanidade.

Analisa a etimologia grega da palavra tipo, fazendo notar que nos encontramos diante de um território ontológico, porque typos significa "aquilo que é formado como um todo configurado":

Typos em grego significa, em primeiro lugar, golpe, colisão, e depois aquilo que é formado, que se configura de certa maneira em virtude de uma manipulação externa. Neste sentido, é utilizado tanto em referência à técnica de escultura quanto em referência ao caráter [...]. Não é possível designar o ser humano como tipo em sua particularidade se esta característica é considerada como irrepetível.

Se se define um tipo como um todo configurado (Gestaltganzes) que pode se apresentar em uma multiplicidade de exemplares, de tal modo se poderia resumir o que é indicado pelo significado da palavra de acordo com o uso linguístico atual (STEIN, 2013, p. 192).

O fundamento interior do tipo social implica a possibilidade de uma transformação do que já é formado: pode assim surgir um elemento que não se sobrepõe nem se justapõe, mas gera o novo. Mas, na formação da pessoa é necessário considerar algo para além do contexto social em que está inserido e do qual assume inúmeras características. Se, na fé, assume-se Deus enquanto o criador, e 


\section{Desafios da psicologia no Brasil}

deste crê-se na alma, reconhece-se o ser humano enquanto portador de um todo "corporal-anímico", sendo a alma o que lhe há de mais próprio (STEIN, 2013, p. 172-176).

\section{COMUNIDADE POVO}

Quanto ao conceito de Povo, Stein (2013, p. 199-218) aponta que este é formado por indivíduos, tem uma história e um local geográfico, e suas ações são determinadas pelos seus membros, dos quais há aqueles que possuem a mentalidade ou consciência do todo e se dedicam a ele. Também o povo tem relações internas e externas, a segunda se dá com outros povos e a primeira no âmbito interior de formação, organização e linguagem, ou seja, em sua cultura. Assim, um povo possui laços de sangue (mas não somente), se baseia em uma comunidade espiritual, e tem em seu horizonte a possibilidade de organizar-se em Estado.

Para Stein, nascer em um povo, mais do que receber dimensões deste e assumi-las na medida em que se desenvolve, é também agir dentro do povo. O modo de ser de um povo está afinado a sua cultura e ao seu sentido, que mesmo que o povo desapareça pode permanecer, com isso se encontra uma realidade para além do tempo. E a grande importância do conceito de povo para a humanidade se funda no "homem-Deus" que tem importância para toda a humanidade por ser o redentor, o qual fez parte de um determinado povo e a partir dele agiu para a humanidade (STEIN, 2013, p. 207-210).

Contudo, a relevância da vida está para além da ação para o povo, ela está dada por ser vida humana e relacional e, portanto, amorosa, uma vez que o amor embasa a existência da comunidade, assim a vida é movida por um valor e com isso está participando do eterno. Pois, "amar uma pessoa implica dar uma resposta ao seu valor pessoal e participar deste valor; ainda mais: é preciso protegê-lo e conservá-lo" (Stein, 2013, p. 212). Assim, o valor de uma comunidade se mede pela densidade de seus valores.

Do bom e do belo que circundam o humano provém a noção de um ser supremo o qual o homem quer servir, pois nele se encontra no eterno, e a vida valiosa possui sentido. E aí, se vê um modo positivo do perder-se de um povo, ao deixar o povo que está caminhando para a perdição, um novo povo pode surgir. E todo aquele que está consciente de pertencer a um povo possui responsabilidades para com ele, o que pressupõe uma determinada estatura espiritual. Enfim, a formação do ser humano tem muito a ver com seu povo, mas se deve, em última instância a Deus, a quem deve seu ser diretamente e indiretamente - por meio de seu povo e da humanidade. Assim, Deus é quem determina a importância das comunidades e as funções do homem dentro delas, e o cumprimento das mesmas 


\section{Desafios da psicologia no Brasil}

está sob a responsabilidade e liberdade humanas. E dentro do homem há uma esfera livre de toda a sua transitoriedade e que responde somente a Deus. Deste modo, o valor do homem está em ouvir o chamado de Deus (STEIN, 2013, p. 212-213).

Edith Stein demonstra que tanto a pessoa humana quanto o povo possuem relações sociais, as quais em última análise sempre ocorrem entre indivíduos, contudo são indivíduos culturalmente marcados por determinado povo, e com isso sempre as relações são entre representantes de povos. Além disso, é marcante a iniciativa de fundar tanto a pessoa humana quanto o povo em algo para além das pessoas, do tempo, e da história - Deus. Ao ver na constituição do ser humano um ser corporalanímico ${ }^{1}$ ao mesmo tempo percebe que também o povo possui uma esfera espiritual e que a história do mesmo é feita por aqueles que atingiram uma determinada maturidade de consciência coletiva.

Uma grande conclusão do texto analisado pode ser a seguinte - Deus é o fundamento e sentido último de toda e qualquer relação social, seja ela do indivíduo ou do povo. Dessa forma, Stein fala de um sentido que ultrapassa as últimas realidades da existência, assegurando que o ponto de partida para a compreensão do ser humano não se finde nele mesmo enquanto finito, mas abre-o ao infinito. 0 que, automaticamente, gera uma implicação ética, a de reconhecer o infinito no outro, seja o outro indivíduo ou povo.

Este reconhecimento do infinito do outro embasado no infinito do outro fundante (Deus) e em relação com o infinito do eu, traça por si só um caminho comunitário em que o eu e o outro se encontram no outro fundante que é eterno. Assim, o ser social da pessoa é lançado em uma relação eterna por estar entrelaçada por Deus.

É importante destacar que Stein fala do "homem-Deus" que escolheu integrar um determinado povo para agir de forma redentora. Ao dizer isso, acende a possibilidade de uma outra questão ética, abrindo o ser humano ao referencial último da existência.

Sabendo de sua conversão ao catolicismo se pode afirmar que este "homem-Deus" é Jesus Cristo, o qual serve de referencial ético de duas formas - totalmente homem e totalmente Deus. Assim, além de fundar a vida, Deus é também aquele que a realiza e a vive humanamente, podendo mover todos os seres por meio da relação com Ele. Apesar de não estar explícito neste texto, também é necessário lembrar que o Deus cristão é Trindade, ou seja, é em si mesmo comunidade que já engloba a humanidade. 


\section{Desafios da psicologia no Brasil}

\section{CONSIDERAÇÕES FINAIS}

As contribuições de Edith Stein são fundamentais para compreender o problema da dicotomia pessoacomunidade que enfrentamos em nossas sociedades. O pensamento de Edith Stein possui conotações éticas, uma vez que se entende a ética como base da dimensão relacional da pessoa humana. Nesse sentido, a abordagem de Edith Stein, ao tratar do ser humano e dessas relações, faz com que se pense na perspectiva não somente da ética do indivíduo, mas da ética do povo ou da comunidade como um todo.

De fato, a estrutura da pessoa humana e da comunidade em Edith Stein se dá por meio desta síntese filosófico-teológica que reconhece a dignidade humana a partir de sua humanidade, sendo que sua humanidade já é em si digna por estar fundada em Deus.

Embora não se tenha tratado deste tópico especificamente no texto analisado sabe-se da grande importância dada por Edith Stein a empatia. Com a empatia conhecemos nós mesmos e reconhecemos os outros como semelhantes a nós, outros eus, em reciproca doação de sentido. A empatia nos leva a reconhecer que o outro não é o diferente. $\mathrm{O}$ ato empático cura qualquer tipo de indiferença. As relações sociais devem se dar a partir da empatia, pois este é o mecanismo que permite uma relação social ética. A empatia, enquanto este sentir dentro do outro já é em si carregada de alteridade, e, portanto, elemento basilar para se pensar e fazer ética. Assim, empatia e mística são duas dimensões das relações éticas do homem, pois dizem respeito ao relacionamento com o outro e com Deus. Para Edith Stein empatia diz relação intra e interpessoal, manifesta a relação entre o próprio e o estranho, entre aquilo que me envolve em primeira pessoa e aquilo que se dá no contexto do meu viver (MANGANARO, 2014). Compreender a essência do seu pensamento crítico e coerente, especialmente sobre a empatia, se constitui um dos meios mais completos para uma fecunda atuação da fenomenologia do direito, para a compreensão da passagem da consideração filosófica da pessoa humana àquela teológica.

Enfim, a abordagem de Edith Stein sobre a pessoa e a comunidade possui na sua formulação teórica um caráter relacional ontológico e oferecer respostas aos diversos tipos de dicotomias presentes em nossa cultura. A perspectiva de fundar uma ética em Deus é válida e urgente, do contrário, apesar de enriquecida pela perspectiva do outro, a ética enquanto relação mística seria aniquilada, e a pessoa humana estaria condenada a não desenvolver sua vida e suas relações ao nível mais alto da existência humana, que é a relação com Deus. Não importa se somos chamados a agir numa comunidade mais 


\section{Desafios da psicologia no Brasil}

restrita ou mais ampla, mas sim, importa a consciência de que o nosso agir numa comunidade será fecundo também para a comunidade maior. Resumindo o pensamento de Edith Stein e tendo em consideração o conjunto de suas obras, podemos dizer que a comunidade se coloca no nível espiritual, na esfera dos valores onde o conceito comunidade se entrelaça com o de com-unidade. A comunidade

é considerada uma personalidade de ordem superior, que não elimina a singularidade, mas a potencializa ao multiplicá-la. Não a relativiza, não absolutiza, mas a compreende num conjunto, num todo mais amplo, fundado sobre uma gramática fenomenológica da relação.

\section{REFERÊNCIAS}

MANGANARO, P. Empatia. Padova: Ed. Messaggero di Padova, 2014.

STEIN, E. Essere finito e Essere eterno. Per una elevazione al senso dell'essere. Roma:Città Nuova,1988.

STEIN, E. Il problema dell'empatia. Roma: Studium, 1998.

STEIN, E. Introduzione alla filosofia. Roma: Città Nuova, 1998.

STEIN, E. La struttura della persona umana. Corso di antropologia filosofica. Roma:Città Nuova-OCD, 2013.

STEIN, E. Psicologia e scienze dello spirito. Contributi per una fondazione filosofica.Roma: Città Nuova,1996. 


\section{Desafios da psicologia no Brasil}

\section{NOTAS}

Nota 1

A esta formulação fica o interesse de relacionar a concepção de corpo-anímico de Stein ao conceito de soma-pneumatikon de Paulo. Teria ela se baseado no autor da Carta aos Coríntios? 


\section{Capítulo 5}

\section{CONTRIBUIÇÕES DA LIDERANÇA POSITIVA PARA AS ORGANIZAÇÕES}

DOI: $10.37423 / 200200158$

TOMAZ, Washington Luiz Tomaz (UNESP) - witomaz18@gmail.com OLIVEIRA, Fernanda Serotini Gordono de (UNESP) -fernandagordono@hotmail.com CANDIDO, Fermanda Raqueli (FAAG) - fernandaraqueli@yahoo.com.tp PIRES, Rafaela Amèlia (UNESP) - raphaellapires@gmail.com COSTA, Tiago Francisco Giorgetti (FGV) - transportadorariacho@lphet.com.br

RESUMO: Este trabalho tem como pbjetivo analisar os estilos/de liderança, bem como a liderança positiva. Para tanto, foi realiżado uma pesquisa bibliográfica relacionada ao papel do líder no âmbito organizacional e verificar a /iderança positiva na atualidade e sua importância para o crescimento da organiżação e de seus stakeholders, mostrando ainda que as empresas do mundo também a utilizam como/uma ferramenta estratégica, pois adotando esse método, ảs chances de insurcesso são menores e o nivel de satisfação dos funcionários que nelas trabalham aumentará. As prganizações reconhecem que líderes bem preparados, geram contribuições positivas, maiok produtividadé e aumento na lucratividade das empresas. Também foram classificados ós principais tipos de liderança e foi possível averiguar que não existe um líder específico para o sucesso/de uma empresa, o sucesso vem de acordo com o líder que a empresa necessita. O presente estudo também identifica por meio de uma pesquisa qualitativa como-três lieteres de empresas de grande-porte da- cidade de Lençóis Paulista - SP percebem sua gestão e como vêem a liderança positiva àtravés de sua experiência profissional.

Palavras-chaves: Estilo de Liderança. Liderança. Liderança positiva. 


\section{Desafios da psicologia no Brasil}

\section{INTRODUÇÃO}

A liderança é com certeza um dos temas mais importantes no campo gerencial atual, por ser uma característica que os líderes devem contemplar em seu arsenal de habilidades para o estímulo da eficácia de um determinado grupo e de uma organização.

As empresas estão percebendo a importância de um ambiente de trabalho saudável e como esse contribui para alcançar seus objetivos. Para uma organização ter resultados positivos é necessária uma liderança eficiente que motive e desenvolva talentos.

É fundamental para a organização que seus líderes desenvolvam as competências necessárias para o sucesso do seu negócio, que participem ativamente, assumam responsabilidades e riscos, sejam eternos aprendizes e mestres, tenham senso inovador e visão de negócio. Este perfil de liderança torna-se, cada vez mais, fator indispensável para pessoas que assumem postos chaves nas empresas.

Sabendo que os líderes são responsáveis pelo sucesso ou fracasso da organização, pode-se dizer que não é uma tarefa simples, pois a liderança exige muitas habilidades complementares, tais como: disciplina, respeito, ética, compromisso, postura, entusiasmo, etc. Afinal, a organização é composta por colaboradores com diversas personalidades e é exatamente o ponto que entra a liderança transacional e situacional.

Liderança é o ato de conduzir pessoas, profissionais, grupos e equipes a alcançarem os objetivos propostos pelas organizações. De acordo com Jullier (2011, p. 01):

Demanda-se, hoje, uma liderança que procure entender e acelerar o processo de aprendizado organizacional, permitindo e incentivando o pensamento e a ação integradora em todos os níveis. Sai o chefe que assegura o cumprimento de metas quantitativas de produção, entra o condutor de pessoas, capaz de tirar delas o que têm de melhor, em benefício delas próprias, na medida em que realizam seus potenciais, e da organização com que colaboram.

Um dos maiores problemas na liderança é a desmotivação. Aquele líder que não motiva sua equipe acaba afundando com todos os objetivos propostos, pois não conseguem trabalhar em conjunto, ou seja, em equipe. O líder que motiva sua equipe, tem muitas chances positivas de concluir com êxito os objetivos a serem alcançados. 


\section{OBJETIVOS:}

Compreender o estilo da liderança positiva e analisar como três líderes que trabalham em empresas de grande porte da cidade de Lençóis Paulista desenvolvem e trabalham com suas equipes.

\section{RESULTADOS}

Para a realização do trabalho foi utilizado a pesquisa qualitativa, através de uma entrevista que foi realizada no dia 25 de junho de 2014, onde foi aplicado um questionário com 10 perguntas abertas. Através dessa pesquisa foi possível verificar a percepção sobre a sua liderança e como vêem a liderança positiva.

A escolha dos líderes se deu devido às empresas serem de grande porte e com grande expressividade na cidade e o aceite foi imediato.

As empresas não foram mencionadas, devido a não autorização dos gestores das empresas quanto à divulgação dos seus dados. De acordo com as respostas dos entrevistados, conforme mostra na tabela 1, foi possível averiguar que:

TABELA 1 - Classificação das empresas segundo seu porte

\begin{tabular}{|c|c|}
\hline $\begin{array}{c}\text { Líderes } \\
\text { entrevistados }\end{array}$ & Descrição \\
\hline Líder 1 & 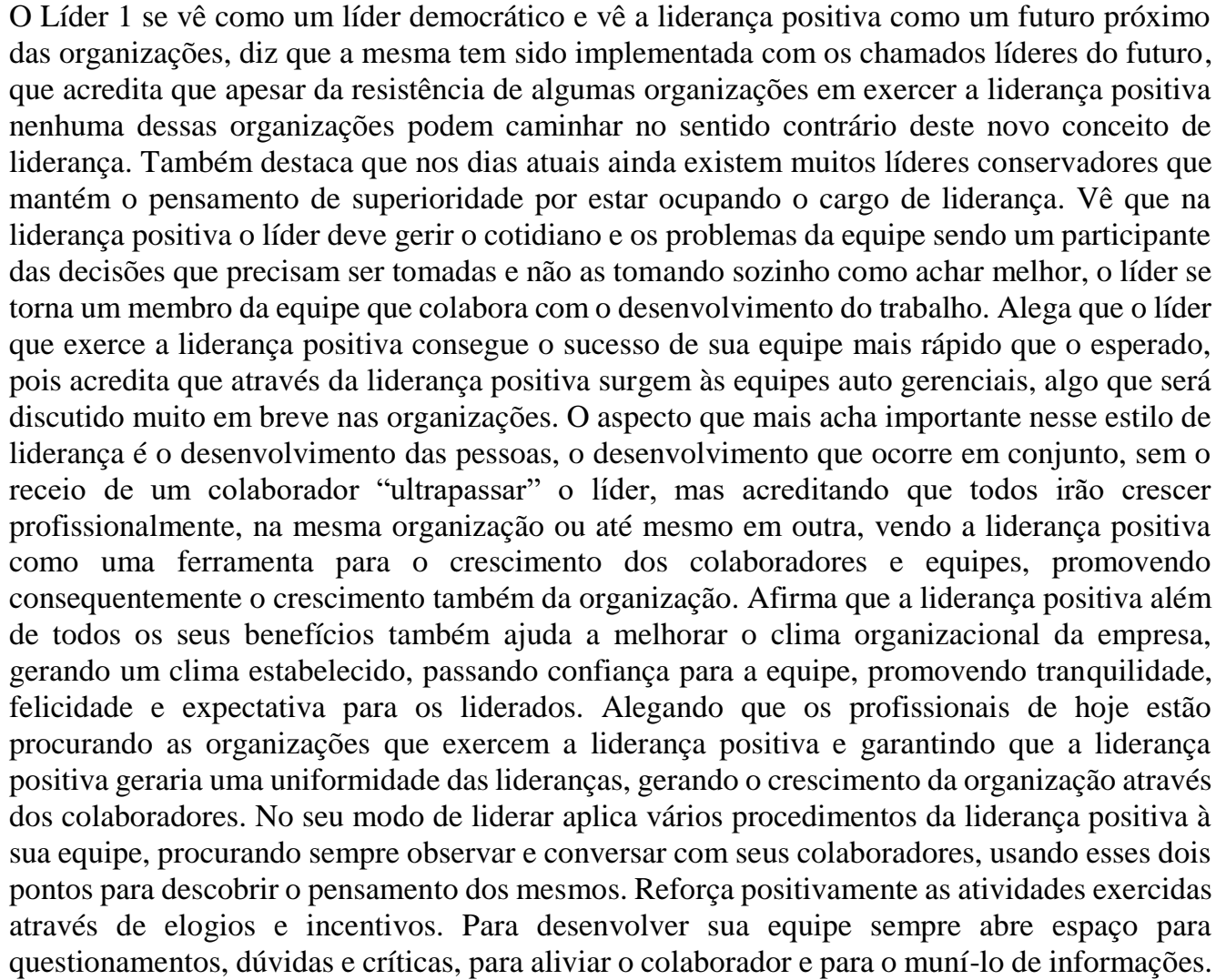 \\
\hline
\end{tabular}




\section{Desafios da psicologia no Brasil}

\begin{tabular}{|c|c|}
\hline & $\begin{array}{l}\text { Através dos procedimentos que aplica à sua equipe pode receber um retorno muito positivo, } \\
\text { onde vê que os colaboradores têm um comprometimento muito maior com os resultados e } \\
\text { produção, vendo nos colaboradores certa esperança no futuro da empresa e do departamento, } \\
\text { acreditando que isso só é possível pela forma de liderar e da liderança positiva. E para encerrar } \\
\text { ele fala um pouco dos programas do grupo, os quais contribuem para o desenvolvimento e } \\
\text { aplicação da liderança positiva, pois há uma preocupação com as pessoas e não somente com os } \\
\text { profissionais. Afirma que ainda estão caminhando para o estabelecimento completo de uma } \\
\text { equipe positiva através da liderança positiva, e que isso se torna mais fácil quando se trabalha } \\
\text { em uma organização que facilita esse estilo de trabalho. }\end{array}$ \\
\hline Líder 2 & $\begin{array}{l}\text { O Líder } 2 \text { vê sua liderança como democrática e as vezes liberal, percebe a liderança positiva } \\
\text { como uma credibilidade com o colaborador para que alcance objetivos propostos pela empresa } \\
\text { com rapidez e eficiência, pois o mais importante dessa liderança é o respeito, comunicação e a } \\
\text { colaboração. Sendo assim o clima organizacional da empresa fica harmonioso e consegue-se um } \\
\text { melhor resultado e valores no mercado. Seguido de uma boa liderança onde a participação do } \\
\text { líder é fundamental para que seus colaboradores tenham um exemplo a seguir, onde toda equipe } \\
\text { é bem unida. }\end{array}$ \\
\hline Líder 3 & $\begin{array}{l}\text { O Líder } 3 \text { se identifica com a liderança democrática e vê a liderança positiva como base para se } \\
\text { ter uma boa equipe, pois valoriza o rendimento e como consequência disso se obtém bons } \\
\text { resultados. Considerando promover sempre os pontos fortes como mais importantes, pois é nos } \\
\text { pontos fortes que se têm resultados. O mesmo acredita que um líder que valoriza seus } \\
\text { funcionários faz com que eles se sintam satisfeitos, fazendo com que tenham comprometimento. } \\
\text { A liderança positiva interfere diretamente no clima organizacional, pois o líder é visto como um } \\
\text { exemplo dentro da empresa, logo tudo o que o líder faz dentro da organização significa que os } \\
\text { funcionários podem fazer também. Um procedimento bem fácil que o líder } 3 \text { faz é reconhecer e } \\
\text { tratar todos os seus liderados de forma igual, sempre valorizando seus pontos fortes e também } \\
\text { sempre estar dando incentivo para que melhorem seus pontos fracos, pois assim depois de um } \\
\text { determinado tempo, você terá um colaborador inteiramente aplicado e formado dentro da } \\
\text { organização. É ótimo quando a equipe tem um líder positivo como ferramenta estratégica, pois } \\
\text { um líder "negativo" sempre tem decadências, nunca tem resultados positivos, de forma que } \\
\text { tendo uma boa liderança os índices de rotatividade diminuem e consequentemente diminui } \\
\text { custos para a empresa. Os funcionários veem esse tipo de liderança ótima, porque sempre que } \\
\text { aparecem problemas tentam resolver da melhor forma, um colaborando com o outro, sempre } \\
\text { dedicando um espaço para novas ideias e opiniões de cada um. O resultado de ter uma liderança } \\
\text { positiva é ter colaboradores totalmente dedicados e motivados querendo sempre se superar em } \\
\text { busca dos objetivos propostos. }\end{array}$ \\
\hline
\end{tabular}

Fonte: Os autores

\section{DISCUSSÃO DOS RESULTADOS}

Ao contrário do que muitos pensam a liderança não é exclusiva, ou pessoas que já nasceram assim, mas sim uma habilidade que pode ser aprendida e desenvolvida por todas as pessoas, com maior ou menor grau, dependendo da disposição e vontade da pessoa (JULLIER, 2011). E na análise de resultados, podemos observar isso nitidamente, visto que os três líderes aprenderam e buscaram aprimorar a liderança mediante suas jornadas profissionais.

Boas e Andrade (2009) definem liderança como "a capacidade de influenciar um grupo para alcançar metas". Para Chiavenato (2010), a liderança é um fenômeno tipicamente social que ocorre exclusivamente em grupos sociais. Pode-se defini-la como uma influência interpessoal exercida numa dada situação e dirigida através do processo de comunicação humana para a consecução de um ou 


\section{Desafios da psicologia no Brasil}

mais objetivos específicos. A influência pode ocorrer através de diversas formas, desde as mais violentas imposições, até as formas mais suaves de convencimento. Dentre os tipos de influência é possível destacar algumas causas, conforme mostra a tabela 2.

TABELA 2 - Tipos de Influência

\begin{tabular}{|c|l|}
\hline \multicolumn{2}{|c|}{ Tipos de Influência } \\
\hline Como influenciar & \multicolumn{1}{c|}{ Atitudes } \\
\hline Coação & $\bullet$ Impor, mandar, forçar a fazer algo sem aceitação. \\
\hline Pressão & $\bullet$ Reprimir, ameaçar, forçar a aceitação. \\
\hline Persuasão & $\bullet$ Manipular, prevalecer sempre seu conselho, indução. \\
\hline Sugestão & $\bullet$ Propor algo sem forçar a aceitação. \\
\hline Emulação & $\bullet$ É espontâneo, imitar com vigor para igualar ou ultrapassar \\
\hline
\end{tabular}

Fonte: Adaptado de Chiavenato (2010)

Assim, a liderança é necessária em todos os tipos de organizações e sua influência positiva é essencial para todas as funções, uma vez que é o procedimento pelo qual uma pessoa consegue influenciar outras a seguirem suas ideias e/ou ações numa determinada situação. Interessante destacar que os três líderes citaram a importância da liderança positiva e o auto exemplo para o sucesso da equipe. $\mathrm{E}$ por pensarem em sua equipe, adotam estilos democráticos e colocam metas e objetivos, onde todos possam alcançar.

\subsection{ESTILOS DE LIDERANÇA}

É muito importante conhecer os tipos de líderes para entender o sucesso de uma organização. Seja na vida pessoal ou profissional, a questão da liderança esta envolvida em todas as situações, uma vez que é a habilidade de influenciar pessoas para trabalharem entusiasticamente visando atingir aos objetivos identificados como sendo para o bem comum (HUNTER, 2004).

Não se define um líder apenas pelas as suas características pessoais ou pela sua personalidade, mas também pela situação em que ele se encontra. Um bom líder sabe se ajustar a todo tipo de situação, a qualquer situação que a empresa esteja ou necessite.

Para Chiavenato (2010, p. 18-19) a liderança "é essencial em todas as funções da Administração: o administrador precisa conhecer a natureza humana e saber conduzir as pessoas, isto é, liderar". Segundo Milton (2012) existem três principais teorias sobre a liderança e entre elas estão os estilos de liderança:

Liderança autocrática: É a liderança onde o líder impõe suas opiniões e decisões sobre seus liderados, sem participação nenhuma destes. O líder pensa somente em si e esquece que o trabalho em equipe 


\section{Desafios da psicologia no Brasil}

é fundamental, é o líder dominador e que tudo esta unicamente em suas responsabilidades. A sua característica principal é de dar uma visão mais ampla para as pessoas, mostrando o seu principal objetivo. $O$ estilo autocrático pode também se transformar no autoritarismo.

- Liderança democrática: Nesse estilo de liderança a decisão de poder esta nas mãos da equipe, pois o líder não expõe muito a sua opinião, ele apenas auxilia a equipe caso seja realmente necessário. Ou seja, quanto mais às decisões forem influenciadas nas opiniões da equipe mais o comportamento do líder será considerado democrático. Estilo de liderança esta fortemente apontado pelos três líderes entrevistados.

- Liderança liberal: Nessa liderança, o líder não toma nenhum tipo de decisão, deixa completamente todas as decisões por conta da equipe, deixando-os completamente à vontade, correndo o grande risco de passar varias falhas e erros.

Em todos os casos a liderança para ser eficaz é necessário que ela seja positiva evidenciando e potencializando os pontos fortes de cada liderado.

\subsection{LIDERANÇA POSITIVA}

A liderança positiva refere à aplicação de princípios que são amplamente estudados pela psicologia positiva, é um conceito que foi introduzido no mercado de trabalho pelo estudioso Kim Cameron no ano de 2008, através do seu livro Positive Leardship, onde se destaca a necessidade de trabalhar e potencializar os pontos fortes dos profissionais (CUNHA; REGO; LOPES, 2013).

O foco esta em desvios positivos de desempenho, os resultados são bem melhores onde existe uma liderança positiva. Uma liderança que troca o pessimismo pelo otimismo, uma liderança que reforce os pontos fortes ao invés dos pontos fracos, onde a comunicação apoia e não critica. Uma liderança onde foque no potencial das pessoas e na melhor condição humana.

Se quiser estimular uma forma construtiva no ambiente corporativo, deve-se incentivar as virtudes, os pontos fortes, os talentos, a empatia e a cooperação para criarmos um ambiente de confiança. $\mathrm{E}$ todos estes aspectos são trabalhados durante o processo da liderança positiva, juntamente com as competências emocionais (CUNHA; REGO; LOPES, 2013).

Quando se fala em desenvolvimento da liderança positiva, precisa ter em mente que são necessários aspectos fundamentais: clima, relacionamentos, comunicação e significados positivos, onde é preciso interagir estes aspectos com as bases das competências emocionais: autoconhecimento, 


\section{Desafios da psicologia no Brasil}

autogerenciamento, automotivação, empatias e habilidades sociais, onde o que mais precisa ter um foco principal é o autoconhecimento, pois ele é essencial para que obtenha um autodesenvolvimento positivo (BOHLANDER; SNELL, 2013), evidenciado na coleta de dados do Líder 1, onde ressalta a mudança e contribuição de melhoria do clima organizacional.

Ainda segundo os autores, a liderança positiva agrega valor para as metodologias que estão sendo usadas dentro das organizações. O terceiro pilar que sustenta o conceito da psicologia positiva são as instituições positivas. Onde sua função é contribuir com as organizações, trazendo elementos essenciais da liderança positiva tais como: pontos fortes, talentos, coragem, esperança, otimismo, resiliência, cooperação, criatividade, emoções positivas, empatia e, principalmente, o significado e o sentido positivo do trabalho, uma ferramenta de extremo valor e importância, pois traz excelência no desenvolvimento organizacional.

Atualmente todos os gestores e líderes devem estar ligados a essa prática de liderança positiva, pois quando é colocada empatia no ambiente de trabalho toda a comunicação e relações interpessoais são impactados positivamente, e consequentemente todos os resultados dentro da organização irão passar a ser positivos.

Ao se trabalhar com os aspectos do autoconhecimento e da automotivação presentes nas competências emocionais a organização estará possuindo a possibilidade de agregar valor nos diferentes estágios que a organização encontra-se. As organizações estão mais preocupadas e se esforçando cada vez mais para criar um clima organizacional positivo, visando o bem-estar dos colaboradores, treinando líderes para a busca da liderança positiva. A liderança positiva desenvolve ferramentas que contribuem e agregam valores para as estratégias organizacionais e para a sustentabilidade das relações.

Para Sheehy (2010) os líderes positivos buscam interações com suas equipes como possibilidades de aumentar o potencial de cada trabalho, maior compromisso e melhor performance.

\section{CONSIDERAÇÕES FINAIS}

As empresas de hoje em dia precisam muito de líderes positivos, uma vez que estão ligadas a melhora do ambiente organizacional e a satisfação do colaborador. Liderar o ambiente é ajustar os objetivos da organização aos objetivos pessoais dos talentos que a compõem.

A liderança já é um tema antigo, mais precisamente por volta de 4.000 a.C e desde daquela época já existia uma pessoa que comandava um grupo de pessoas. E conforme a revolução humana surgiu a 


\section{Desafios da psicologia no Brasil}

necessidade de se ter um representante, devido a esta necessidade, surgiram as equipes e um líder para guiá-los. Porém nas antigas organizações, o líder era visto como autoritário onde os subordinados deviam obedecê-lo sem cogitar. Com o passar do tempo este estilo de liderança se modificou e os líderes hoje já são mais sociáveis, dividem as responsabilidades e são vistos como companheiros.

Atualmente as organizações valorizam muito o trabalho do líder, tendo como chave principal, e reconhecendo que sem ele as organizações bem como os subordinados não conseguiram alcançar os resultados. Pois o líder não é mais aquele que manda e sim, comanda a equipe para decidir quais os melhores procedimentos seguir na busca de objetivos alcançados e a satisfação de todos na organização.

Cabe ao líder mostrar o caminho comum entre os anseios da empresa e dos indivíduos, gerando comprometimento e trazendo resultados. Portanto, resumidamente pode-se dizer que a liderança é: ter capacidade de influenciar pessoas positivamente para que se envolvam voluntariamente em tarefas para a concretização de objetivos comuns; ter capacidade para promover a ação coordenada, com vista ao alcance dos objetivos organizacionais; é um fenômeno de influência interpessoal exercida em determinada situação através do processo de comunicação humana, com vista à comunicação de determinados objetivos e envolve duas dimensões: a primeira é a capacidade presumida de motivar as pessoas a fazerem aquilo que precisa ser feito. A segunda é a tendência dos seguidores de seguirem aqueles que eles percebem como instrumentais para satisfazerem os seus próprios objetivos pessoais e necessidades.

Na pesquisa aplicada aos três líderes foi possível verificar que todos buscam se integrar com a sua equipe, dividir informações em vez de serem centralizadores. Veem a equipe como uma base sólida e que todos podem ter crescimento pessoal e profissional juntos. E consequentemente, eles como líderes crescem também e são reconhecidos pelo seu estilo de liderança. Além do mais, estes tipos de líderes visualizam o futuro das organizações com o estilo da liderança positiva e acreditam que em um futuro próximo, esse estilo predominará os estilos de lideranças nas equipes.

A liderança positiva vem ganhando cada vez mais seu espaço nas organizações e mostra que o antigo conceito de liderança onde o líder exercia poder através da coerção está perdendo espaço para os líderes que exercem a liderança através de seus exemplos positivos. Liderar positivamente é o que faz todo o diferencial nas organizações, se o líder souber agir da maneira certa levará sua equipe ao sucesso. Não existe a liderança perfeita, nem uma melhor que a outra, o que difere a liderança de outra é a capacidade de orientar e guiar pessoas, trabalhar o melhor de cada um de seus subordinados, 


\section{Desafios da psicologia no Brasil}

levando-os a serem competentes e motivados para desempenhar com eficiência e eficácia suas funções.

\section{REFERÊNCIAS}

BOAS, Ana Alice Vilas; ANDRADE, Rui Otávio Bernardes. Gestão estratégica de pessoas. Rio de Janeiro: Elsevier, 2009.

BOHLANDER, George; SNELL, Scott. Administração de recursos humanos. $14^{\circ}$ ed. São Paulo: Cengage Learning, 2013.

CHIAVENATO, I. Gestão de Pessoas: o novo papel dos recursos humanos nas organizações. Rio de Janeiro: Campus, 2010.

CUNHA, Miguel Pina; REGO, Arménio; LOPES, Miguel Pereira. Comportamento organizacional positivo. Análise psicológica, Portugal, v. 31, n. 4, p. 313-328, jan./abr. 2013.

HUNTER, James C.. O monge e o executivo. Uma historia sobre a essência da liderança. Ed.Sextante. Rio de Janeiro, 2004.

JULLIER, Michael. A evolução do pensamento sobre a liderança. 2011. Disponível em: <http://www.administradores.com.br/artigos/marketing/a-evolucao-do-pensamento-sobre-alideranca/57335/>. Acesso em: 14 mar. 2014.

MILTON, Ulisses. Estilos de liderança. 2012. Disponível

em:<http://www.administradores.com.br/artigos/administracao-e-negocios/estilos-de lideranca/67683/>. Acesso em: 12 mar. 2014

SHEEHY, Gail. Liderança positiva- ultrapassando a fronteira da conformidade. Disponivel em:<https://maisrh.wordpress.com/artigos/hugo-nisembaum/lideranca-positiva-\%E2\%80\%93ultrapassando-a-fronteira-da-conformidade/> Acesso em: 21 abr. 2014. 


\section{Capítulo 6}

\section{CONHECIMENTO ACERCA DO CLORIDRATO DE METILFENIDATO: UMA ANÁLISE A PARTIR DE PESQUISA COM PAIS DE ALUNOS DE UMA ESCOLA MUNICIPAL DE FORMIGA - MG}

DOI: $10.37423 / 200200163$

Autores:

Amanda Rodrigues (Alunos/as do $7^{\circ}$ período do curso de Psicologia das Faculdades Pitágoras Divinópolis).

Giaslan Rodrigues (Alunos/as do $7^{\circ}$ período do curso de Psicologla das Faculdades Pitágoras Divinópolis).

Geovanna Souza (Alunoslas do $7^{\circ}$ período do curso de Psicologia das Faculdades Pitágoras Divinópolis).

Gustavo Rilque (Alunos/as do 7 período do curso de Psicologia das Faculdaldes Pitágoras Divinópolis).

lanca Machado (Attnoslas do $7^{\circ}$ período do curso de Psicologia das Faculdades. Pitágoras Diyinópolis).

lara Rayla (Alunostas do $7^{\circ}$ período do curso de Psicologia das Faculdades Pitágoras Divinópolis).

Maria do Carmo da Silva (Alunos/as do $7^{\circ}$ período do curso de Psic Faculdades-Ritágoras Divinópolis)

Renata Vargas (Alunos/as do 70 período do curso de Psicologia das Faculdades Pitágoras Divinópolis).

Co-autora: Juliana Marçal (Psicóloga, psicanalista, professora do curs de Psicologia das Faculdades Pitágoras Divinópolis)

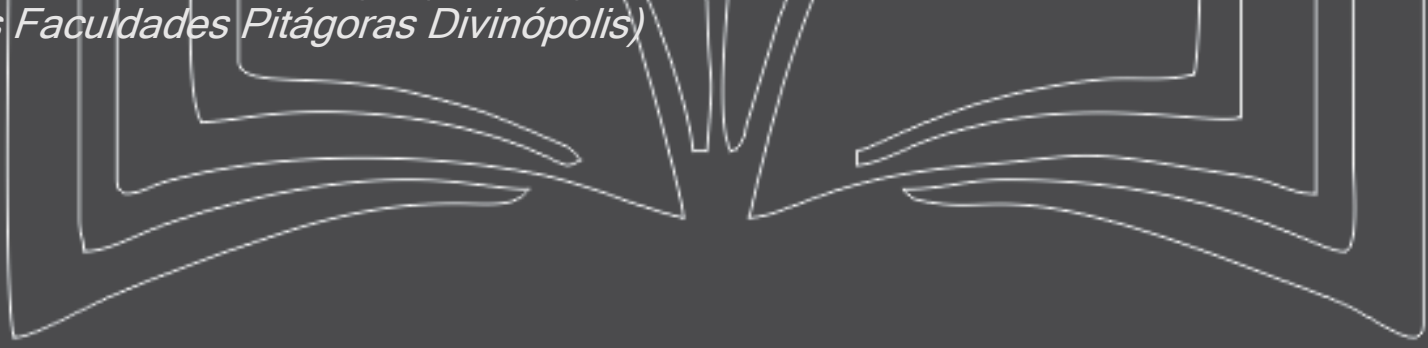




\section{Desafios da psicologia no Brasil}

Resumo: O Cloridrato de Metilfenidato é um estimulante do sistema nervoso central utilizado para aumento da atenção, redução da impulsividade e hiperatividade (NOVARTIS, 2017) e sua principal indicação terapêutica na atualidade é para Transtorno do Déficit de Atenção e Hiperatividade (TDAH). É um dos fármacos psicoestimulantes mais consumidos no mundo, porém estudos indicam que sua prescrição tem sido inadequada, podendo causar graves efeitos quando o uso é inconsequente e acompanhamento clínico médico (CFP, 2014). De acordo com pesquisa feita pelo instituto de medicina social da UERJ, no ano de 2003 foram comercializados no Brasil aproximadamente 94 quilos de Cloridrato de Metilfenidato. Em 2012 este número subiu para 875, o que representa um crescimento de 775\% (SILVA, 2014). Considera-se a importância de analisar tais dados à luz do que COLLARES \& MOYSÉS (2010) denominam medicalização, ou a transformação artificial de questões não-médicas em problemas médicos. Verifica-se que as empresas farmacêuticas investem maciçamente na popularização dos aspectos positivos do uso da medicação, mas não se verifica o mesmo com relação à orientação de usuários e/ou responsáveis acerca dos efeitos adversos causados pela medicação. A presente pesquisa investigou o envolvimento dos pais dos pacientes na prescrição do medicamento em uma escola municipal da cidade de Formiga - MG. Permitiu apurar, dentre outros dados, que a maior parte dos pais de crianças medicadas desconhece os efeitos colaterais que o medicamento pode causar o que nos aponta para a importância de abordagem desta questão por parte de profissionais da saúde e educação.

Palavras chave: Cloridrato de Metilfenidato; TDAH; Medicalização. 


\section{Desafios da psicologia no Brasil}

\section{INTRODUÇÃO}

O Cloridrato de Metilfenidato é um tipo de anfetamina ${ }^{1}$ que atua no sistema nervoso central mantendo o estado de alerta e pode ser encontrado em forma de comprimidos ou cápsulas. É indicado para o tratamento do transtorno de déficit de atenção e hiperatividade.

Auxilia a criança ficar mais atenta, concentrada e sustentar o foco por mais tempo, melhorando seu rendimento intelectual e reduzindo a inquietude física e mental. Entre os efeitos colaterais estão incluídos desconforto abdominal, náusea, azia, nervosismo e insônia no início do tratamento, diminuição de apetite que pode resultar em perda de peso ou atraso de crescimento em crianças, dor de cabeça, sonolência, tontura, alterações nos batimentos cardíacos, febre e reações alérgicas (NOVARTIS, 2017).

Prescrição do Cloridrato de Metilfenidato tem aumentado de forma significativa no Brasil. De acordo com pesquisa feita pelo instituto de medicina social da UERJ, no ano de 2003 foram comercializados no Brasil aproximadamente 94 quilos de Cloridrato de Metilfenidato. Em 2012 este número subiu para 875 , o que representa um crescimento de $775 \%$ (SILVA, 2014). Se o metilfenidato é o fármaco que combate o TDAH seria esperado que a prevalência do transtorno diminuísse com a descoberta de um tratamento eficaz. Porém, com o passar dos anos, com as mudanças nos critérios diagnósticos e a difusão da informação sobre o transtorno, o número de crianças diagnosticadas e o consumo do metilfenidato vem aumentando. Além disso, o TDAH hoje é considerado uma condição crônica, que persiste na vida adulta em cerca de $70 \%$ a $80 \%$ dos casos (ROHDE \& HALPERN, 2004).

Este trabalho foi originado de um projeto de pesquisa que buscou investigar o conhecimento dos pais sobre o cloridrato de metilfenidato prescrito aos seus filhos/as matriculados/as em uma escola municipal de Formiga - MG. O cloridrato de metilfenidato é um estimulante do sistema nervoso central indicado para aumentar a atenção e reduzir impulsividade e hiperatividade em pacientes com o Transtorno de Déficit de Atenção e Hiperatividade, o TDAH (SILVA, 2014). O Conselho Federal de Psicologia aponta, no entanto, que o Brasil vive um processo crescente de medicalização baseado em concepções basicamente organicistas que desconsideram a complexidade de fatores que interferem na vida humana (CFP, 2010). Questiona-se, aqui, o envolvimento dos pais dos pacientes na prescrição do medicamento e esclarecimento acerca de seus possíveis efeitos colaterais. Isto se mostra mais relevante quando se considera que o público-alvo do cloridrato de metilfenidato seja crianças em idade escolar. 


\section{Desafios da psicologia no Brasil}

A perspectiva deste trabalho não visa a negar a existência de crianças e adolescentes com transtorno do déficit de atenção e hiperatividade. Porém, sustenta-se aqui o questionamento sobre o crescente aumento nos encaminhamentos, diagnósticos e, consequentemente, a produção dos novos medicamentos visando a abordagem deste problema. Acompanhamos TAVERNA (2011) em seu questionamento: “Mas, será a maioria,

dado o crescente aumento de encaminhamentos e crianças usuárias de medicação, tendo por justificativa o avanço da produção de novos fármacos?" (TAVERNA, 2011; p. 3) Neste sentido consideramos inicialmente a problemática no escopo da relação entre medicalização e educação.

\section{MEDICALIZAÇÃO E EDUCAÇÃO}

Em um dos trabalhos pioneiros sobre as estratégias mercadológicas da indústria farmacêutica, BARROS (1983) já apontava o processo de medicalização, definindo-o como:

[...] a ampliação crescente do trabalho de intervenção da medicina na vida das pessoas, passando para a alçada médica, inclusive, problemas claramente determinados pela forma de ser da sociedade, no interesse de se manter o status quo - por exemplo, escamoteando os conflitos inerentes à relação capital - trabalho. (BARROS, 1983; p. 378).

medicalização se pauta na necessidade de justificar incoerências e conflitos sociais advindos de uma desigualdade social e uma falsa ilusão de inclusão. De acordo com COLLARES \& MOYSES (2010), há um contexto social na atualidade que privilegia a individualização de um problema de ordem social em que a responsabilidade fica centrada nos seres mais vulneráveis perante a sociedade e sinaliza que há um desajustamento comportamental a ser corrigido o quanto antes.

Assim, é por meio do discurso moralizador da medicalização da vida, das pessoas que esse processo adentra também na instituição escolar, adquirindo características e nomes diferentes, que, à primeira vista, não são percebidos como uma forma de controle social.

Assim, a medicalização da vida torna-se presente em várias situações da vida, como a familiar, a escolar, do trabalho e a da cultura. (LEONARDO \& SUZUKI, 2016).

O processo de medicalização refere-se à transformação das questões da vida cotidiana em objetos da medicina ou, ainda, à capacidade do saber médico de se apropriar dos problemas cotidianos e dar explicações a esses problemas por meio de conhecimentos da medicina. A medicalização seria uma forma de controle social que normatiza, regula e administra diversos aspectos da vida humana. (idem). 


\section{Desafios da psicologia no Brasil}

Há diversas pesquisas sobre o emprego do metilfenidato como medicamento para melhora na aprendizagem, mas há muito a ser pesquisado, para real entendimento das complicações advindas do uso indiscriminado do medicamento por crianças e adolescentes.

Os efeitos adversos mais comuns são perda de apetite, insônia, irritabilidade, cefaléia e sintomas gastrointestinais (ROHDE; HALPERN, 2004). Além desses efeitos existem ainda alguns aspectos controversos, tais como: interferência do metilfenidato no crescimento; potencial de abuso desse fármaco, já que ele faz parte dos chamados estimulantes do sistema nervoso central, do qual faz parte também a cocaína; desconhecimento dos efeitos da suspensão abrupta do tratamento, como durante finais de semana e/ou férias. Estudos também consideram que existe um potencial para que os estimulantes induzam sintomas psicóticos ou maníacos em crianças e que esse tipo de efeito já tem sido descrito há pelo menos 35 anos (idem).

Neste sentido, a pesquisa descrita a seguir buscou se aproximar do entendimento que os pais de crianças medicadas com cloridrato de metilfenidato têm acerca dos efeitos da medicação de forma a subsidiar possíveis questões e intervenções sobre o tema.

\section{PESQUISA E RESULTADOS}

A pesquisa foi realizada entre setembro e novembro de 2017 em uma escola municipal de Formiga MG, na qual a direção se mostrou preocupada com o número de crianças submetidas à medicação com cloridrato de metilfenidato. Nesta escola estão matriculadas 470 crianças na educação infantil e ensino fundamental. A amostra foi constituída por pais de 20 crianças de 6 a 12 anos de ambos os sexos, usuárias de cloridrato de metilfenidato. Foi utilizado questionário que buscou levantar o perfil sociodemográfico das famílias, grau de conhecimento acerca da prescrição do medicamento, expectativas e efeitos verificados. O questionário apresenta-se como uma técnica bastante viável e pertinente para ser empregada quando se trata de problemas cujos objetos de pesquisa correspondem a questões de cunho empírico, envolvendo opinião, percepção, posicionamento e preferências dos pesquisados (CHAER, DINIZ \& RIBEIRO, 2011).

Dentre os pais respondentes $60 \%$ relatam renda familiar de até dois salários mínimos mensais. Isto nos aproxima dos apontamentos de ROSA \& VICENTIN (2010) sobre os modos hegemônicos de gestão social dos riscos que a juventude pobre coloca à ordem social, ou, mais especialmente, a estratégia da patologização. Segundo as autoras, "esses processos produzem práticas de fragmentação e fixação 


\title{
Desafios da psicologia no Brasil
}

dos adolescentes e jovens a espaços de exclusão e controle na mesma medida da redução das políticas sociais a eles dirigidas." (ROSA \& Vicentin, 2010, p. 109).

Outro dado aponta que $80 \%$ das crianças receberam indicação do medicamento por "agitação". Segundo CERVO \& PINTO (2012) observa-se na atualidade, o movimento da sociedade na busca por diagnósticos e medicamentos que resolvam os problemas de comportamento.

\begin{abstract}
Assim, observamos uma pulverização dos diagnósticos, reforçada pelo modo de organização e produção da sociedade atual. A literatura aponta um movimento de valorização da psiquiatria, onde a procura cada vez maior por esse tipo de atendimento, reforça a ideia de não compreensão e não aceitação do comportamento das crianças e adolescentes diante de determinadas situações. (CERVO \& PINTO, 2012; p. 2-3)
\end{abstract}

$30 \%$ dos pais relatam ter conhecimento dos efeitos colaterais imediatos da medicação, porém desconhecem possíveis efeitos a médio ou longo prazo. Este resultado nos parece aproximar-se dos achados de CRUZ, OKAMOTO \& FERRAZZA (2016) em pesquisa a partir do relato de pais e professores. Estes autores concluem duplamente que a busca por uma solução terapêutica rápida é preponderante diante das dificuldades apresentadas ou notadas nas crianças e a popularização do saber psiquiátrico e exclui o saber parental constitutivo do laço social e afetivo, para reduzi-lo apenas ao saber médico.

De fato, o saber parental e até mesmo popular se enfraquece diante de uma afirmação médica a respeito do comportamento infantil, já que ao longo do tempo a ciência médica se caracterizou como a ciência que ditaria o modo e a maneira correta e saudável de se colocar no mundo. Isto leva pais e professores a buscarem fora de seus domínios a resolução para seus problemas, apoiando se na palavra final do especialista. (CRUZ, OKAMOTO \& FERRAZZA, 2016;p.711).

Espera-se que esta pesquisa contribua para que pesquisadores, profissionais e instituições envolvidos possam vislumbrar a construção de estratégias que considerem uma posição alternativa à lógica medicalizante prevalente na atualidade, posição que também considere a influência de mecanismos políticos e sociais na vida psíquica e nas relações.

\section{REFERÊNCIAS:}

BARROS, J. A. C. Estratégias mercadológicas da indústria farmacêutica e o consumo de medicamentos. Revista de Saúde pública, S. Paulo, n 17: 377 - 386; 1983.

CERVO, M.; PINTO, H. A medicalização da infância e sua relação com a saúde mental: alguns apontamentos. Anais do V Congresso Internacional de Psicologia - Univ. Est. De Maringá. 2012.

CHAER, G.; DINIZ, R.; RIBEIRO, Elisa. A técnica do questionário na pesquisa educacional.

Revista Evidência, Araxá, v. 7, n. 7, p. 251-266, 2011. 


\section{Desafios da psicologia no Brasil}

COLLARES, C. A.; MOYSÉS, M. A. Dislexia e TDAH: uma análise a partir da ciência médica. Em Conselho Regional de Psicologia de São Paulo \& Grupo Interinstitucional de Queixa Escolar (Orgs.). Medicalização de crianças e adolescentes: conflitos silenciados pela redução de questões sociais a doença de indivíduos. São Paulo: Casa do Psicólogo, 2010.

CONSELHO FEDERAL DE PSICOLOGIA. Subsídios para a campanha não à medicalização da vida. CFP, Brasília: 2014.

COSTA, Jacqueline Menezes. Introdução à psicofarmacologia: Fundamentos básicos de psicofarmacologia e classificação de psicofármacos. Editora e Distribuidora Educacional S.A,2017.

CRUZ M.; OKAMOTO M.; FERRAZZA D. O caso Transtorno do Déficit de Atenção e Hiperatividade (TDAH) e a medicalização da educação: uma análise a partir do relato de pais e professores. Revista Interface 20 (58): 703-14 SP, 2016.

LEONARDO, N.; SUZUKI A. Medicalização dos problemas de comportamento na escola: perspectivas de professores. Fractal: Revista de Psicologia, v. 28. Maringá, PR, jan.-abr. 2016; p. 46-54.

NOVARTIS: Comprimidos. Responsável técnico: Flávia Regina Pegorer. Novartis Biociências S.A, 2017. Bula de remédio.

ROHDE, L. A.; HALPERN, R. Transtorno de déficit de atenção/hiperatividade: atualização.

Jornal de Pediatria. Porto Alegre, v. 80, n. 2, supl. p. 61-70, abril de 2004.

ROSA, M.; VICENTIN, M. C. Os intratáveis: o exílio do adolescente do laço social pelas noções de periculosidade e irrecuperalidade. Revista Psicologia e Política, São Paulo, v. 10, n. 19, p. 107-124, jan. 2010.

SILVA, M. J. O uso do cloridrato de metilfenidato em unidade infantil da rede pública de Santos: remediando a desmedida? Dissertação de Mestrado, USP, Santos: 2014.

TAVERNA, C. S. Medicalização de Crianças e Adolescentes. Conselho Regional de Psicologia, Grupo Interinstitucional Queixa Escolar (Orgs.). Medicalização de Crianças e Adolescentes - conflitos silenciados pela redução de questões sociais a doenças de indivíduos.São Paulo: Casa do Psicólogo, 290 p. 2010. 


\section{Desafios da psicologia no Brasil}

\section{NOTAS}

\section{Notas 1}

Estimulantes do sistema nervoso central são amplamente conhecidos como psicoanalépticos, noanalépticos, timolépticos. Esses estimulantes são fármacos que produzem um estado de alerta e aumento da vigília. Fazem com que as pessoas fiquem "ligadas", "elétricas". Segundo a Organização Mundial de Saúde (OMS), esses fármacos produzem alterações de comportamento, humor e cognição, possuindo grande propriedade reforçadora sendo, portanto, passíveis de autoadministração (indivíduos usam para o seu próprio prazer sem indicação médica). Em outras palavras, essas drogas levam à dependência química. Exemplos: anfetamina, cocaína e cafeína. 


\section{Gapítulo 7}

\section{A PSICOLOGIA NO MOVIMENTO DE ECONOMIA}

\section{SOLIDÁRIA}

Sara Gambelli

sara.gambelli@gmail.com

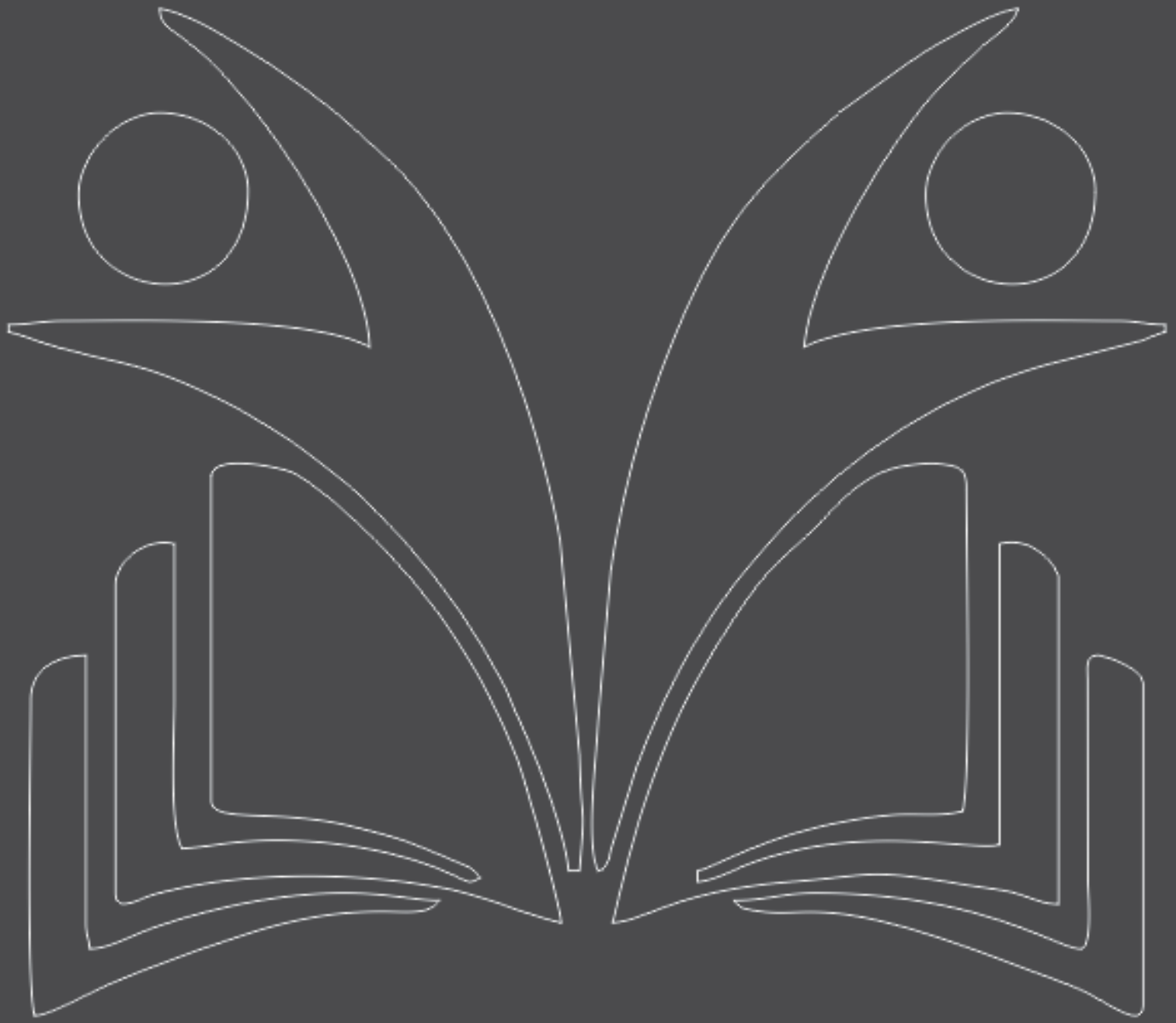




\section{Desafios da psicologia no Brasil}

\section{INTRODUÇÃO}

Por que é preciso trabalhar em grupo? Qual é o valor do trabalho em equipe?

Como gerenciar melhor a dinâmica de grupo e a integração?

Na Economia solidaria o papel de trabalhar em grupo torna-se muito importante!

O trabalho cooperativo, em equipe é muito mais eficiente que o trabalho competitivo, individual, principalmente dentro de uma organização cooperativa. Mas Para um bom trabalho em grupo, não basta juntar várias pessoas num mesmo grupo e deixar os resultados por conta do acaso. Algumas regras devem ser observadas para que o trabalho em conjunto torne-se produtivo e contribua para o desenvolvimento da capacidade da empresa.

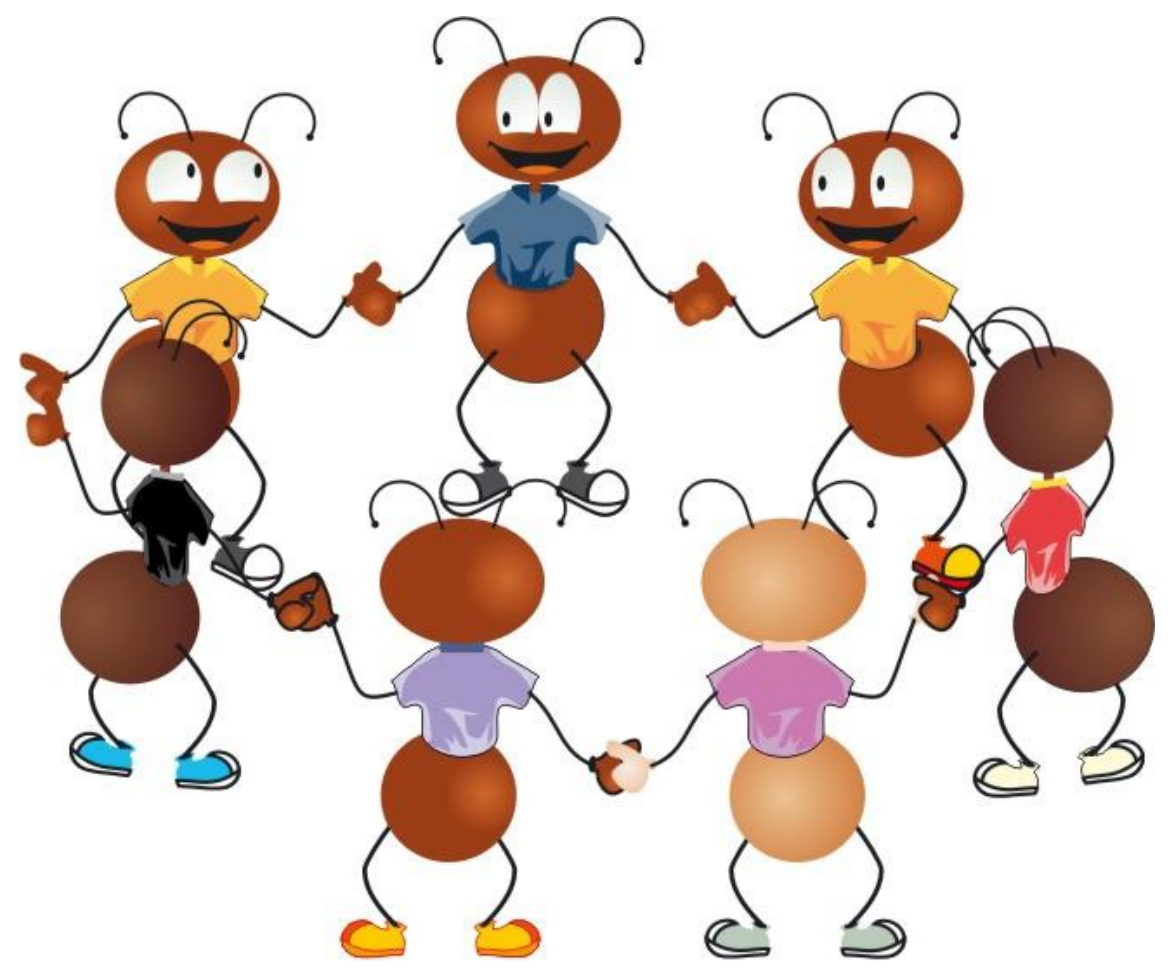

Este livrinho lhe ajudará a entender como.

Com apontamentos práticos que pode usar com sua Equipe de trabalho!

\section{O QUE É UM GRUPO?}

Um grupo é um conjunto de dois ou mais indivíduos que interagem e dependem uns dos outros para alcançar um objetivo comum, compartilhando regras comuns que orientam as suas atividades, funções e desenvolver uma rede de relacionamentos 


\section{Desafios da psicologia no Brasil}
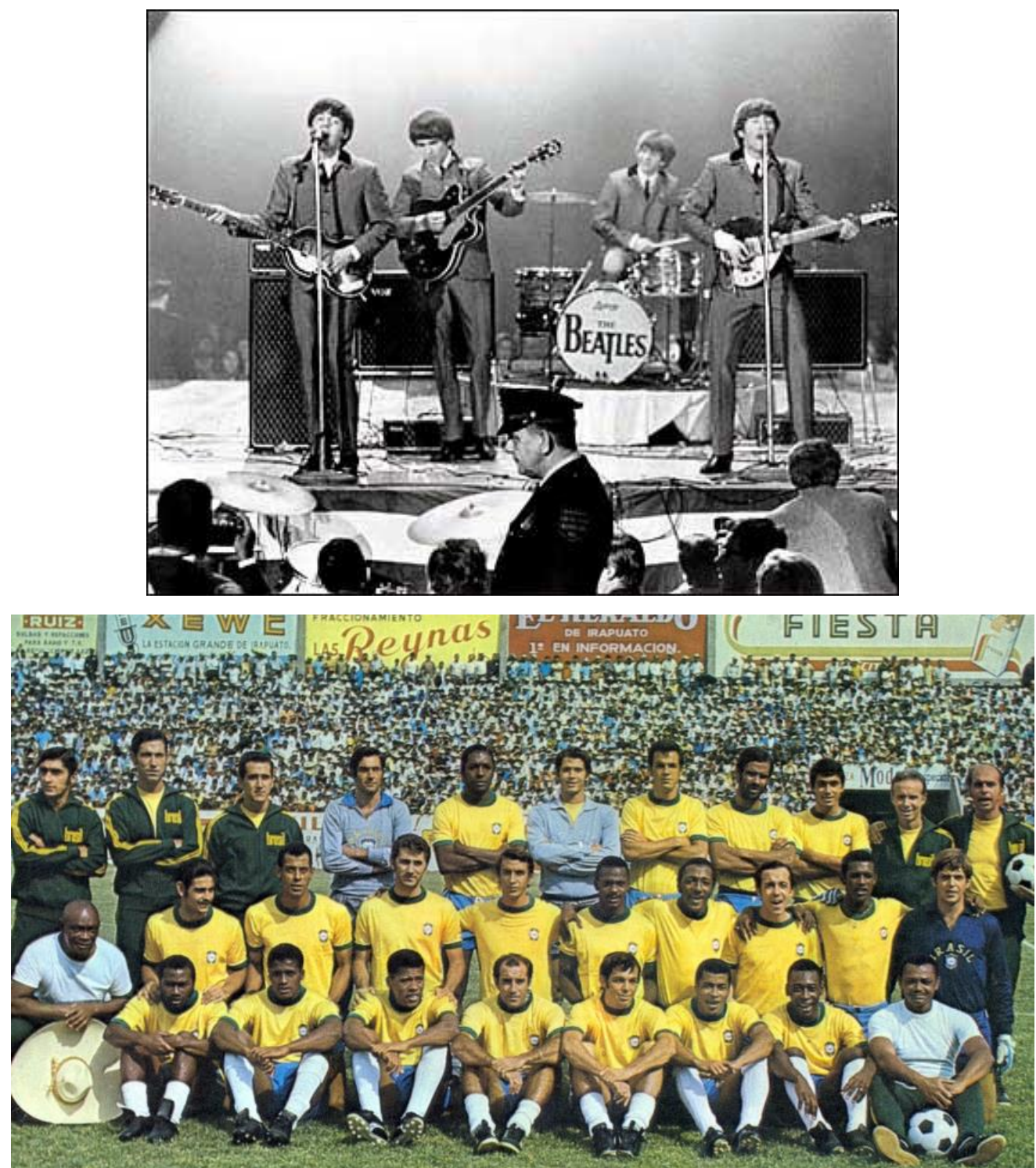

Todos os seres humanos e a maioria das espécies animais pertencem a grupos primários, caracterizados pela interação íntima. São caracterizados por vínculos emocionais da natureza, o sentido de pertença e de lealdade com o grupo, a espontaneidade, a harmonia e a identificação mútua. 


\section{Desafios da psicologia no Brasil}
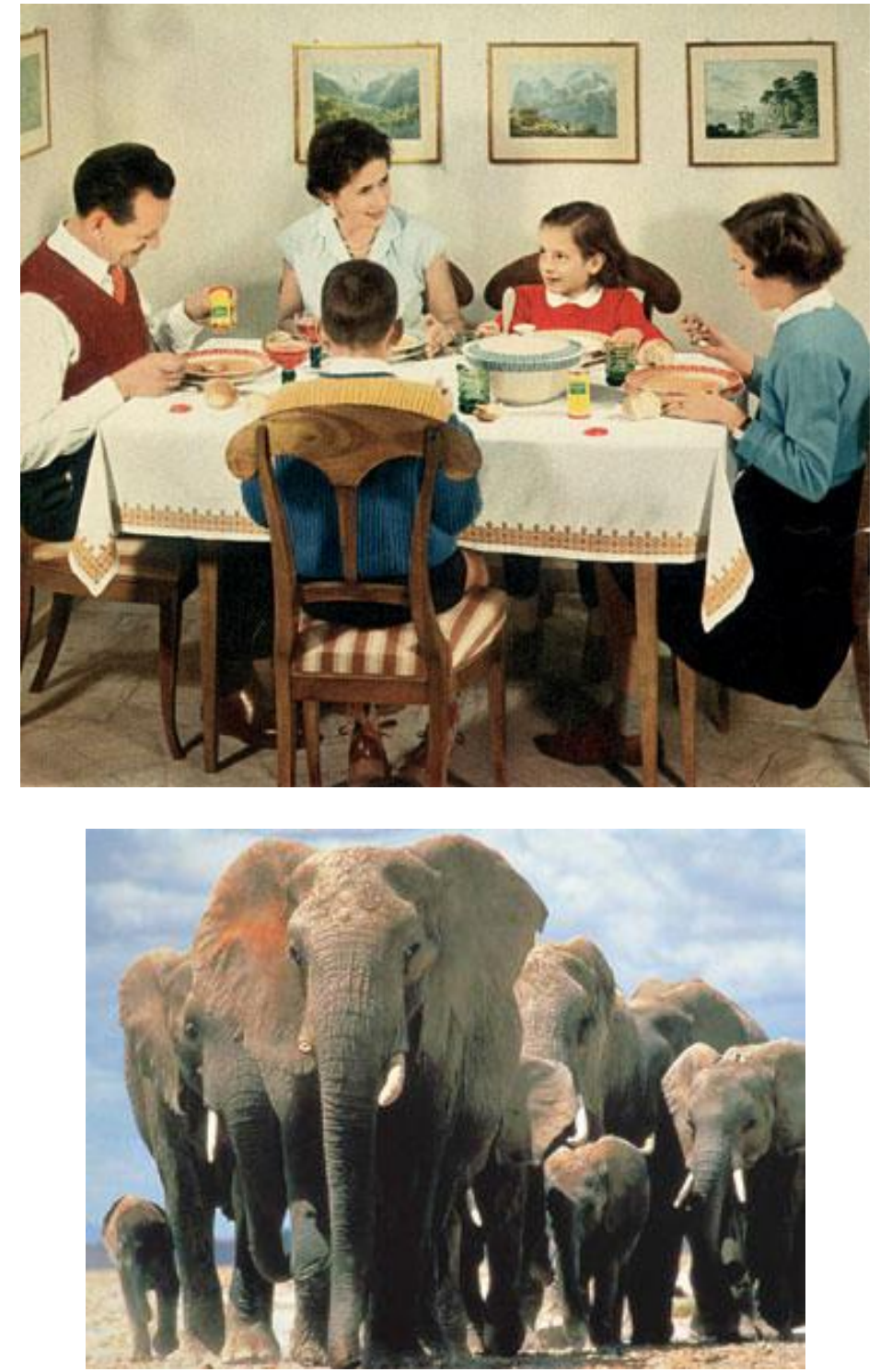

Qualquer sociedade é composta de um conjunto de grupos primários.

Quais são o s grupos na vida de um indivíduo?

O grupo tem uma grande importância na subjetividade de cada pessoa e na influencia sobre esta. A personalidade é baseada na conexão entre: 


\section{Desafios da psicologia no Brasil}

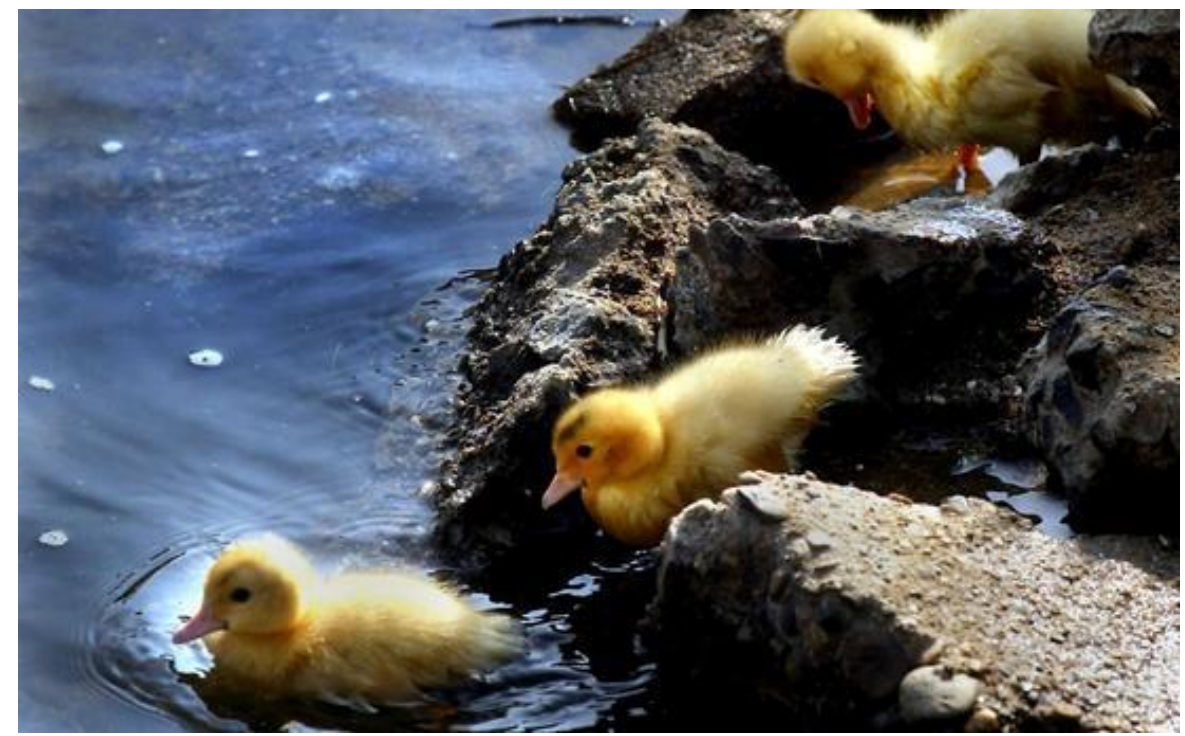

RELACIONAMENTO COM A MÃE

$\hookrightarrow$ GRUPO DA FAMÍLIA

GRUPO DE PARES (AMIGOS, COLEGAS)

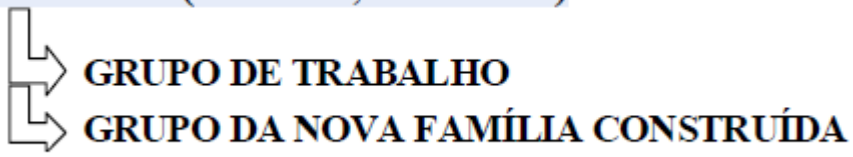

No gráfico tem um exemplo de grupo primário.

O grupo secundário é limitado para o objetivo partilhado por membros do grupo. É um tipo de grupo formal regido por regras. As relações são determinadas por fins práticos a serem alcançados. As relações são uma espécie de contribuição impessoal porque dependem do papel que cada membro pode oferecer.

O grupo secundário pode evoluir para o grupo primário.
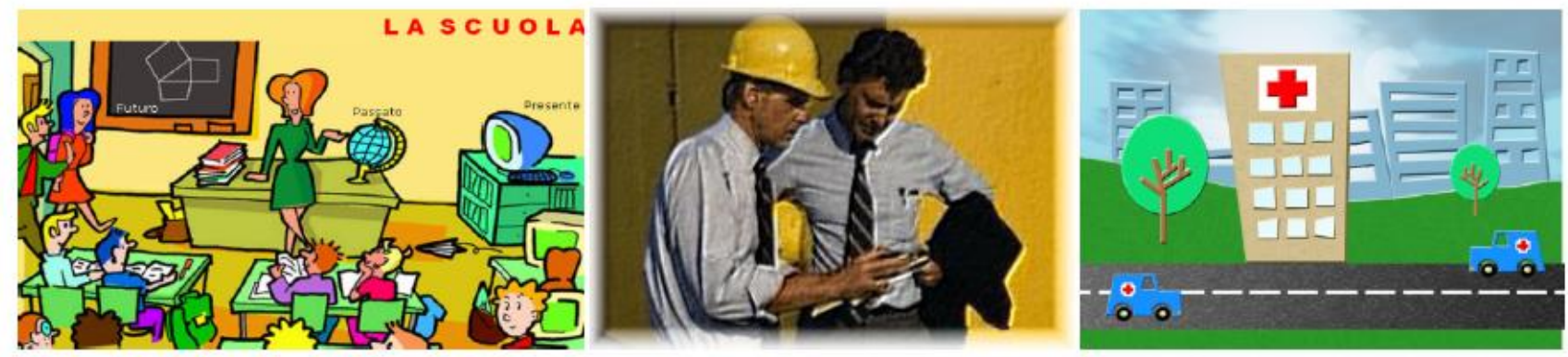


\section{Desafios da psicologia no Brasil}

\section{CARACTERÍSTICAS DE UM GRUPO}

Além das relações particular, emocional que se desenvolvem dentro do grupo e que são "a cola", as características de um grupo são:

1. amplitude;

2. interação prolongada;

3. a percepção do grupo como uma unidade em si mesmo;

4. objetivos;

5. regras;

6. presença de papéis.

\section{RECURSOS DE UM GRUPO}

- Econômica - financeira.

- Numérica (adesão).

- Influência.

- Conhecimentos

técnicos.

- Organizacional.

- identidade simbólica.

- Localização estratégica. 

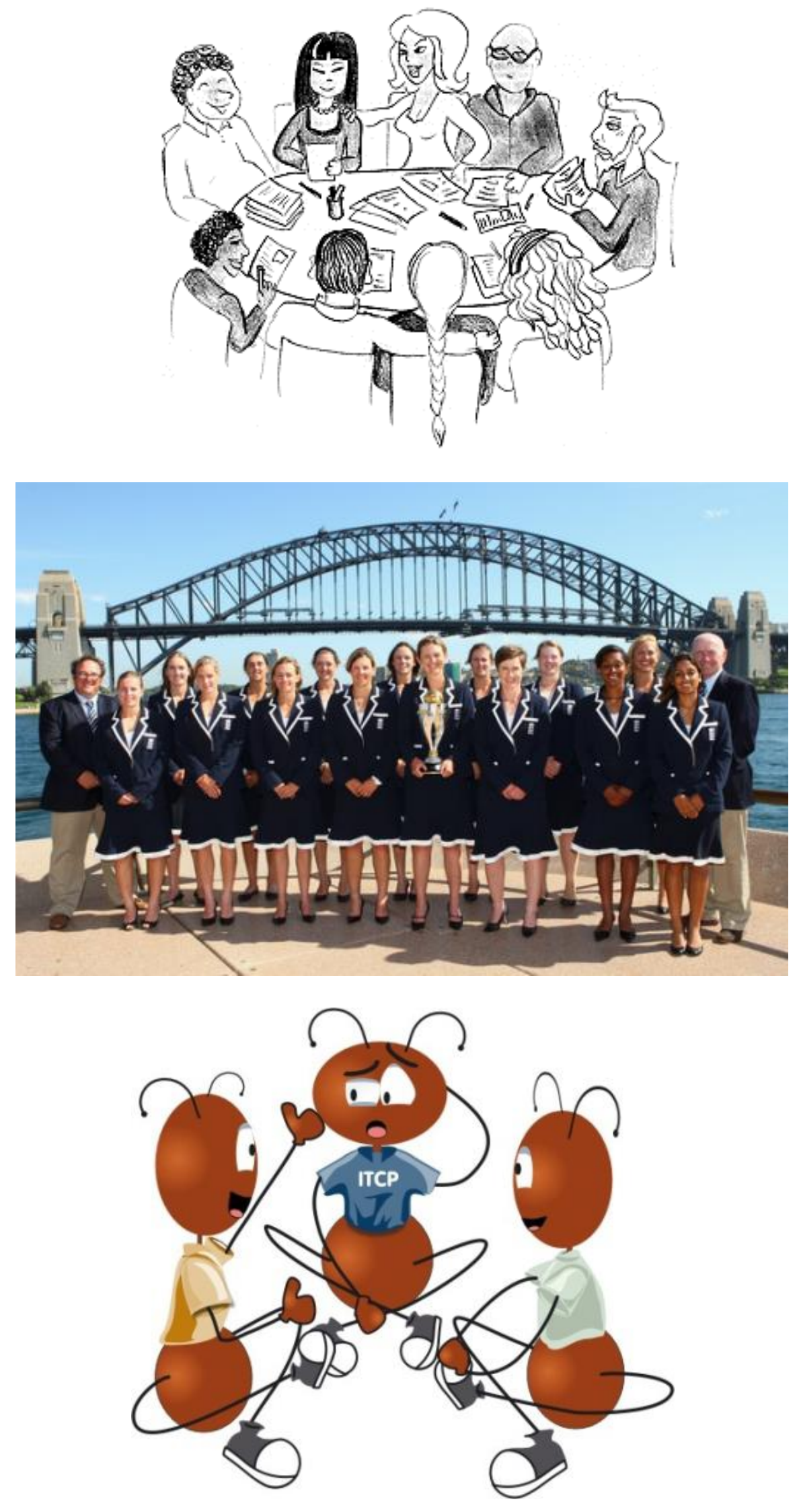


\section{EFEITOS DO GRUPO}

Qual é o valor agregado do grupo? Por que as pessoas trabalham em grupo?

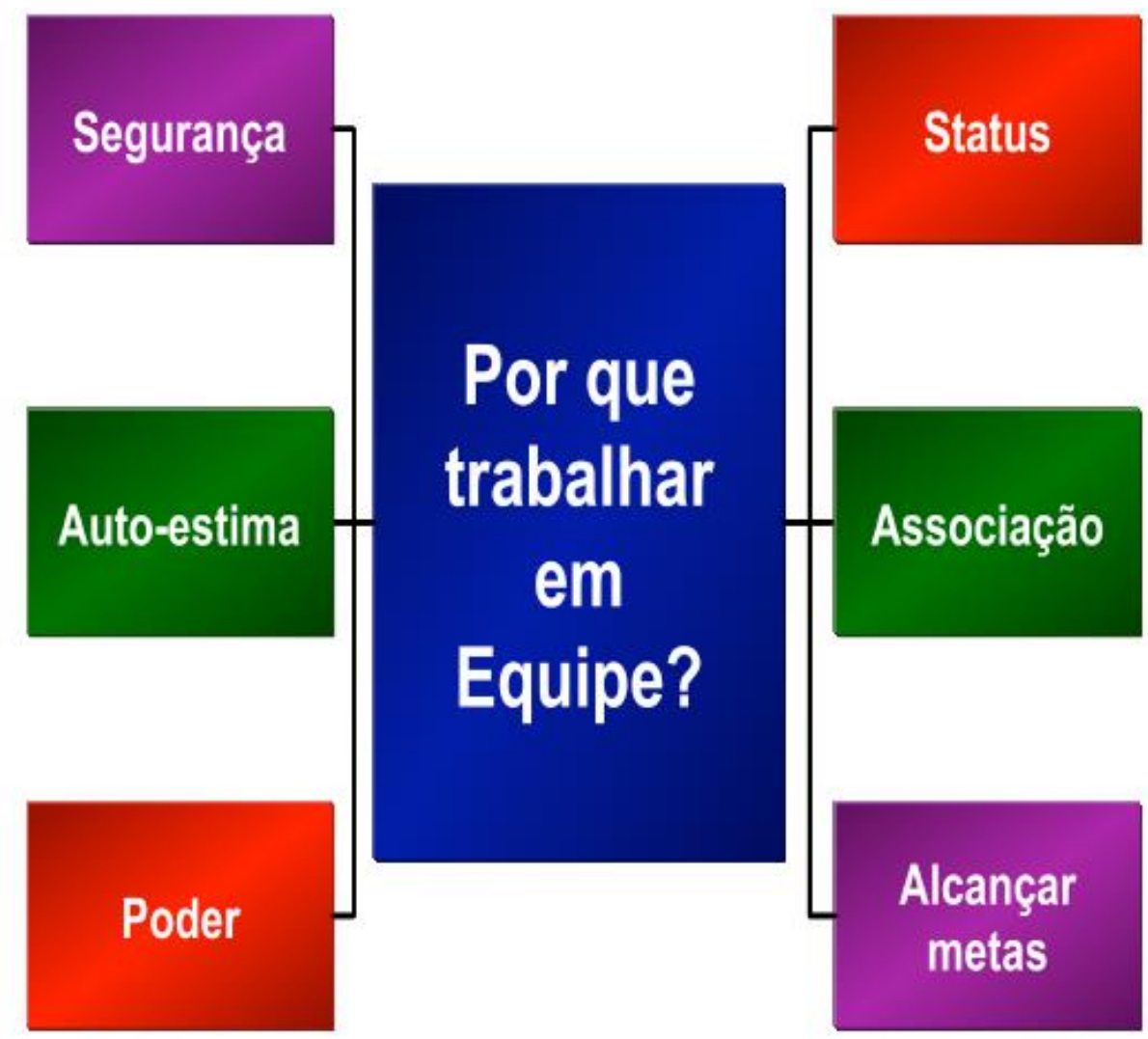

\section{Segurança}

A pessoa não se sente sozinha, mas trabalhando com outros é ainda mais confiante

\section{Status}

A pessoa que pertence a um grupo tem um reconhecimento do Status social.

\section{Auto- Estima}

Reconhecimento de si mesmo e de sua capacidade

\section{Filiação}

A pessoa pode satisfazer as necessidades sociais, tais como a necessidade de pertencer, de amizade, de afeto familiar, de intimidade. Mas também precisa ter auto-estima e ser estimado, se sentir realizado como pessoa em um grupo de colegas, e de superiores. Necessidade de respeito mútuo.

\section{Poder:}




\section{Desafios da psicologia no Brasil}

O grupo é uma entidade onde exercem o seu poder, sua competência, sua moralidade.

\section{Cumprimento de metas:}

Um esforço de grupo significa treinar os talentos. No grupo a pessoa pode expressar uma criatividade que não é evidente no trabalho individual, como também a capacidade de resolver problemas que se baseia em contribuições de todos.
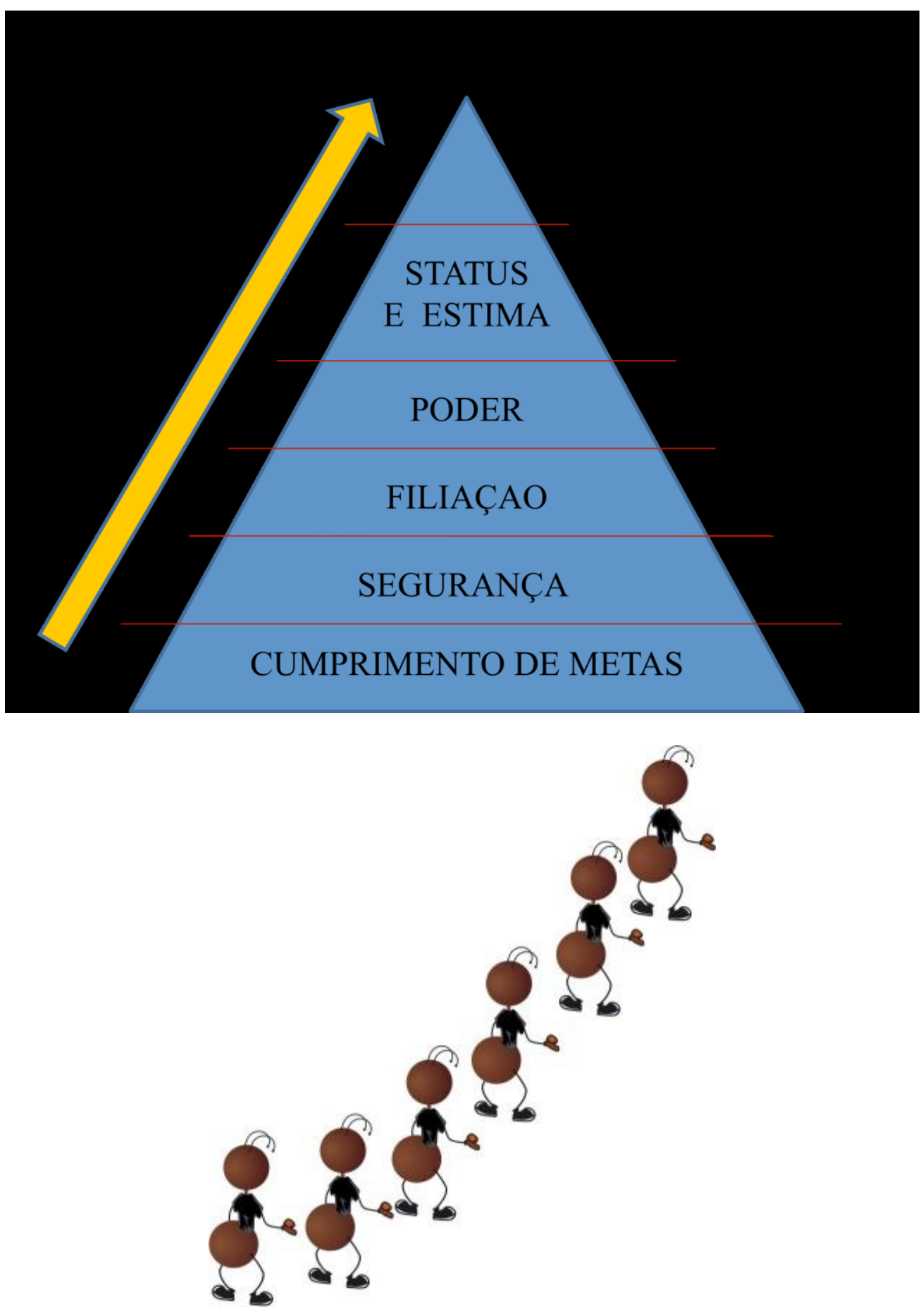


\section{Desafios da psicologia no Brasil}

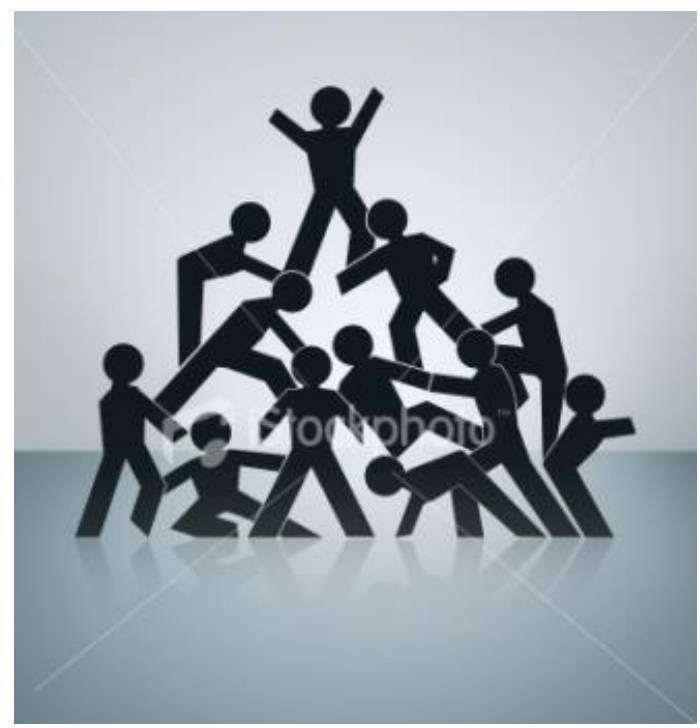

"O grupo é mais" do que a soma dos seus membros ... "

\section{Kurt Lewin}

\section{DO GRUPO PARA “EQUIPE DE TRABALHO”}

Um Grupo são todas as pessoas que vão ao cinema para assistir ao mesmo filme. Elas não se conhecem, não interagem entre si, mas o objetivo é o mesmo: assistir ao filme. Já equipe pode ser o elenco do filme: Todos trabalham juntos para atingir uma meta específica, que é fazer um bom trabalho, um bom filme.

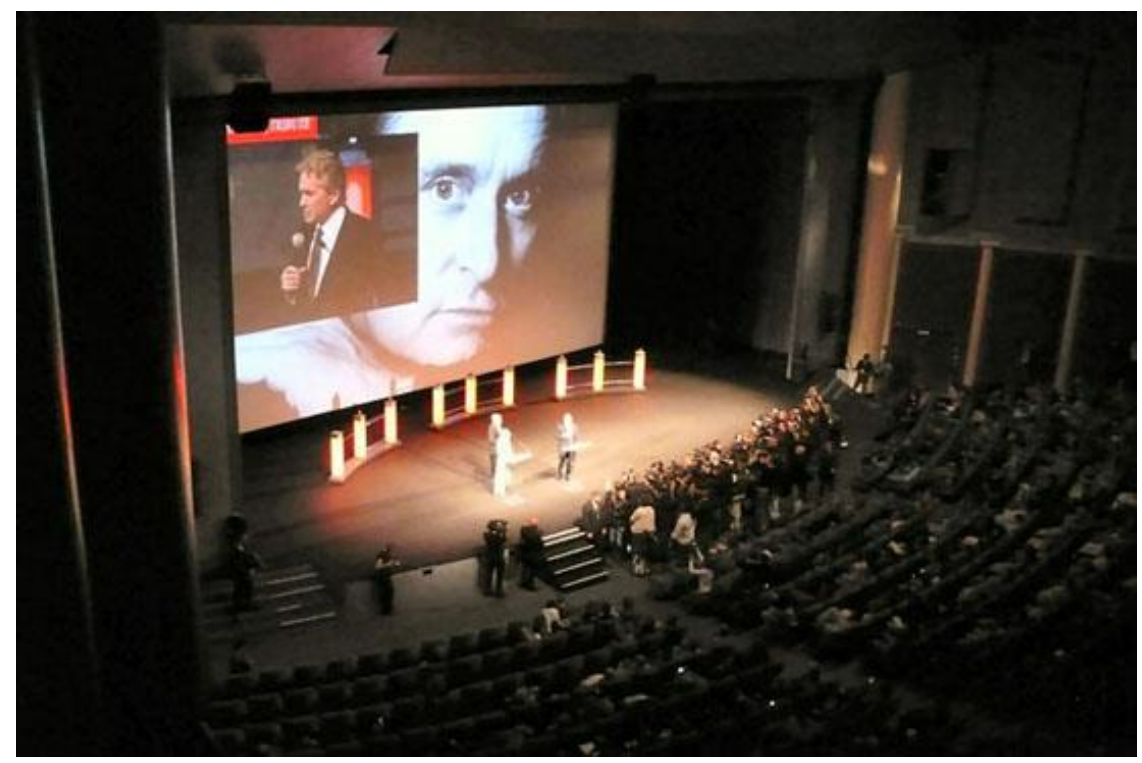

A vida de cada equipe de trabalho é o resultado da interação entre 


\section{Desafios da psicologia no Brasil}
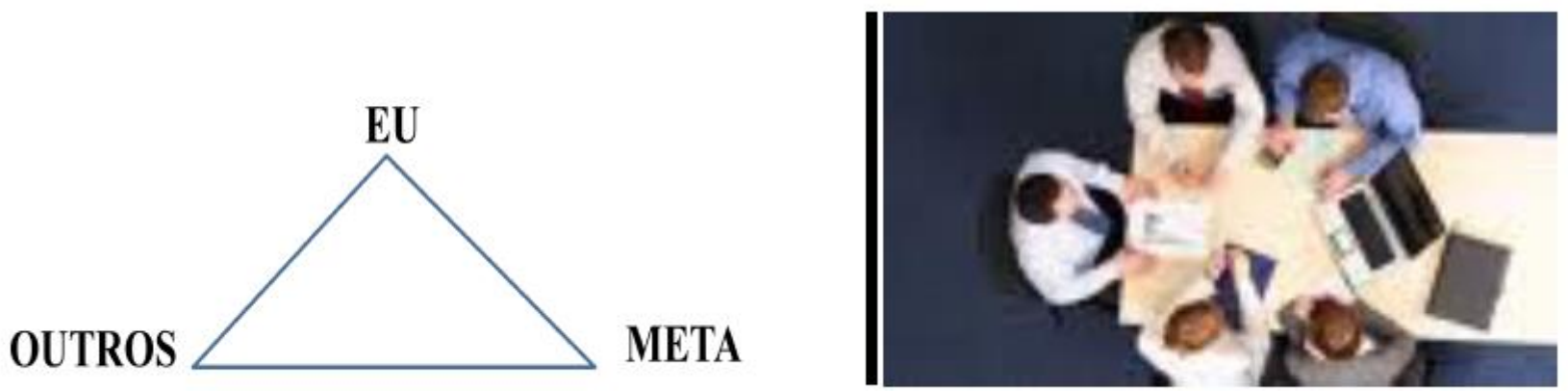

No contexto organizacional.

\section{QUANDO UM GRUPO TEM POTENCIAL PARA TORNAR-SE EQUIPE DE TRABALHO?}

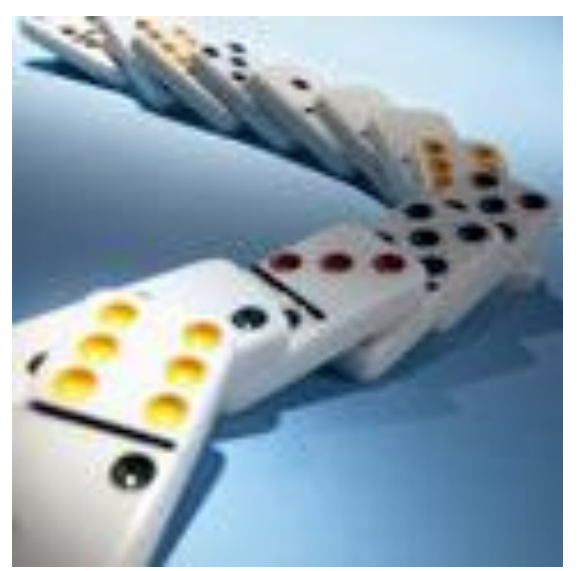

Um grupo tem potencial para tornar-se equipe de trabalho quando existe qualquer forma de interdependência entre as pessoas. Ela tem consciência de depender uns dos outros, porem permanecem em sua própria individualidade e diferenciação.

A integração, por sua vez, desenvolve a colaboração, ou seja, as atividades conjuntas que requerem a participação ativa de indivíduos em cada grupo. 


\section{Desafios da psicologia no Brasil}

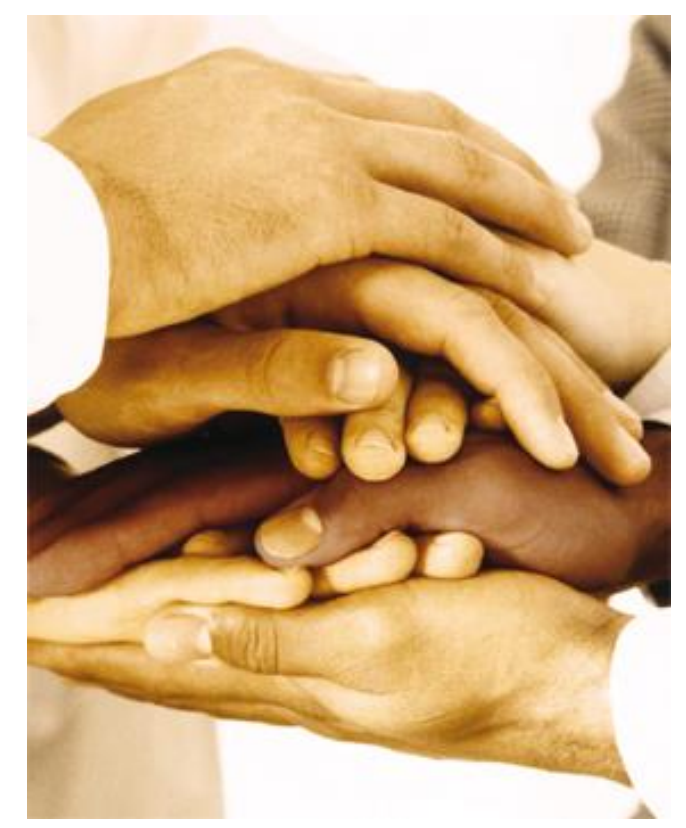

A colaboração é baseada na confiança mútua, na negociação contínua de objetivos, métodos, papéis de liderança e partilha de decisões e dos resultados do trabalho.

A negociação torna-se então o ponto central para a colaboração: significa que cada pessoa tem que identificar o seu ponto de vista, em comparação com o dos outros, para ser capaz de combinar as idéias dos outros com a nossa.

Isto possibilita "ampliar a perspectiva", estar aberto a várias possibilidades, ajudar no crescimento do grupo, levando em conta as diferenças entre indivíduos, e não eliminá-los.
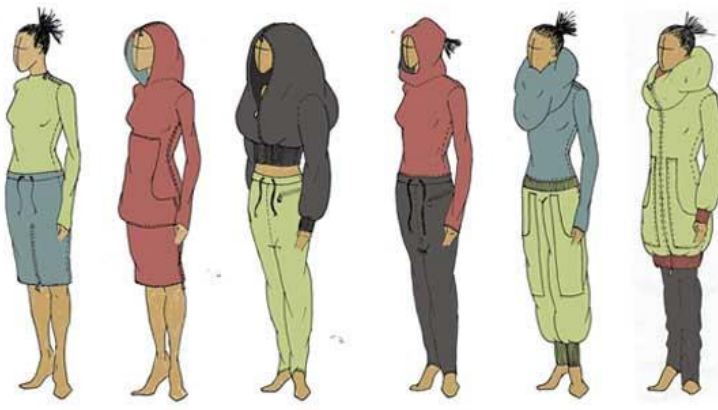

O grupo é uma soma de cérebros e forças (diferentes competências, atitudes, comportamentos, métodos de trabalho) que operam em conjunto, interagem, influenciam e, portanto, ultrapassam os limites individuais.

Para a pessoa é como vestir-se com roupas novas, que nunca teve em mente comprar! 


\section{Desafios da psicologia no Brasil}

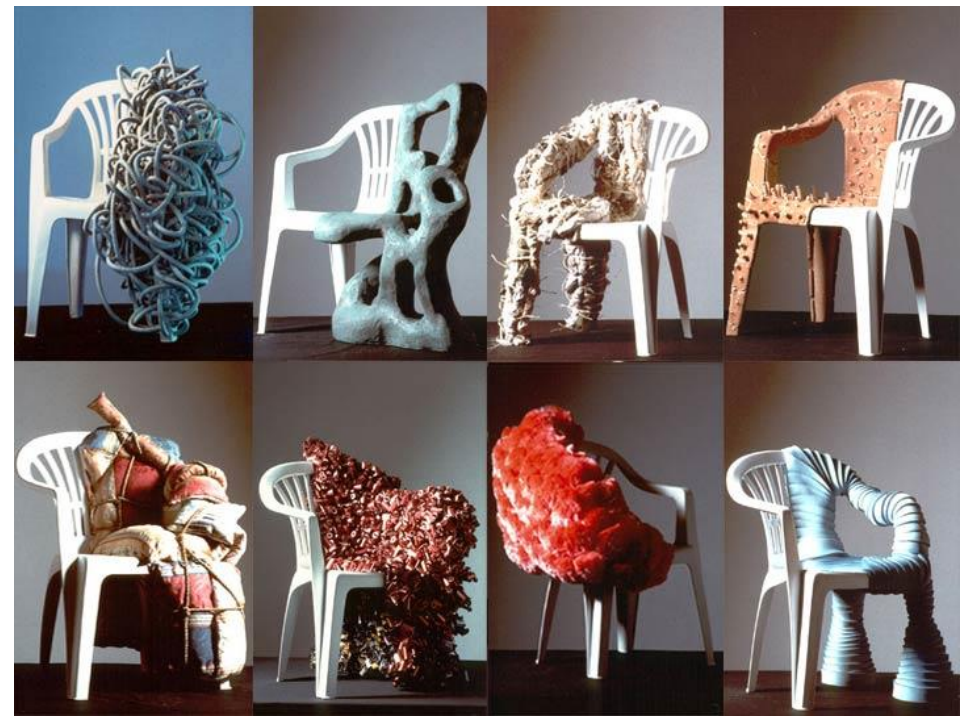

É como uma contaminação de conhecimentos que é competências mais da soma das partes!

Desta forma é possível criar, descobrir novo conhecimento, resolver problemas que as pessoas sozinhas não conseguiriam lidar!

\section{A DIFERENÇA ENRIQUECE!}

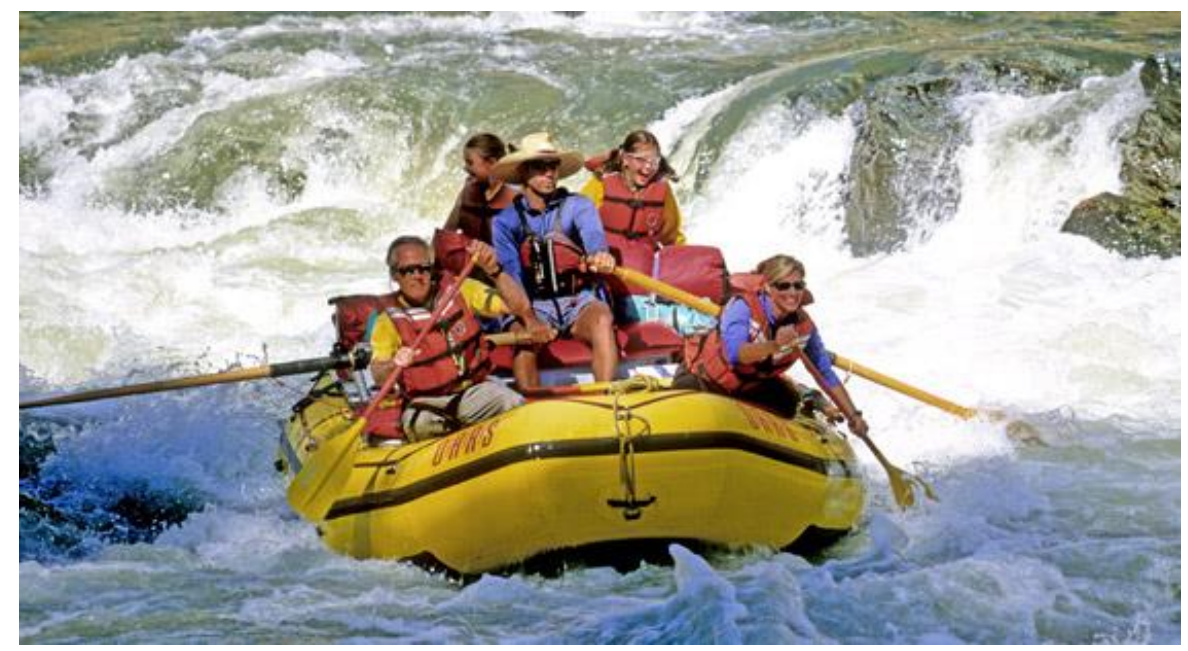

A Interação desenvolve na equipe um fenômeno chamado de coesão que é o surgimento de igualdades, mas que tem o reconhecimento do grupo com sua própria entidade. Coesão pode ser expressa em sentimentos negativos e um forte conflito, ou pode tornar-se aprendizado e melhoria na qualidade do trabalho e da vida das pessoas. 


\section{Desafios da psicologia no Brasil}

\section{GRUPO DE TRABALHO É ENTENDIDO COMO UMA “PLURALIDADE EM INTEGRAÇÃO”}

Equipe

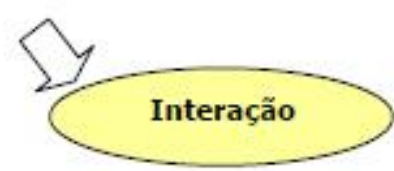

uniformidade
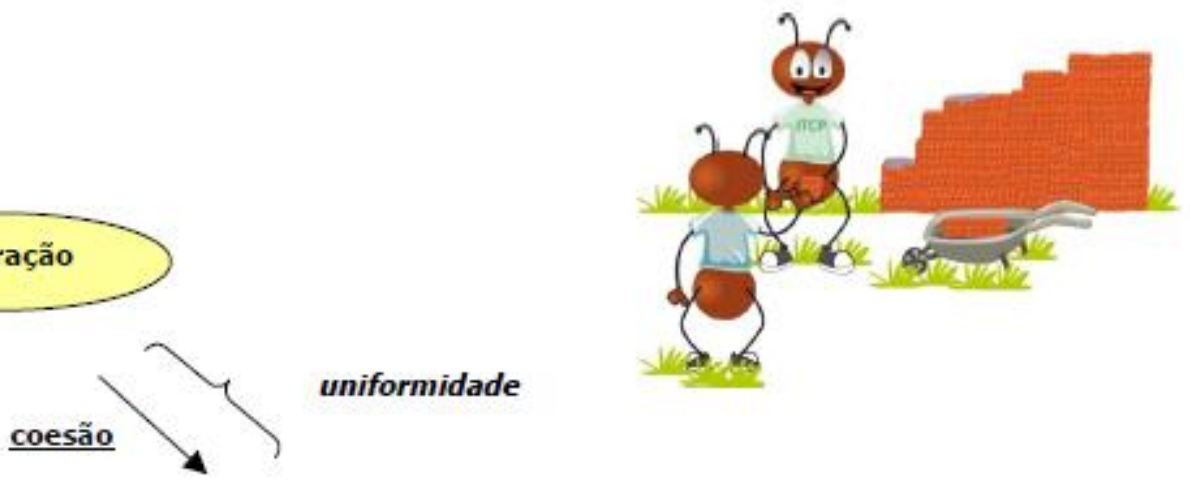

interdependência
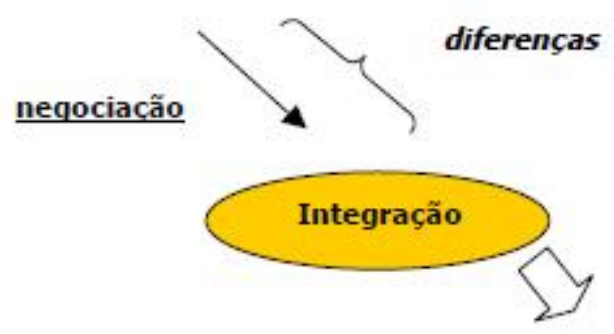

Equipe de trabalho

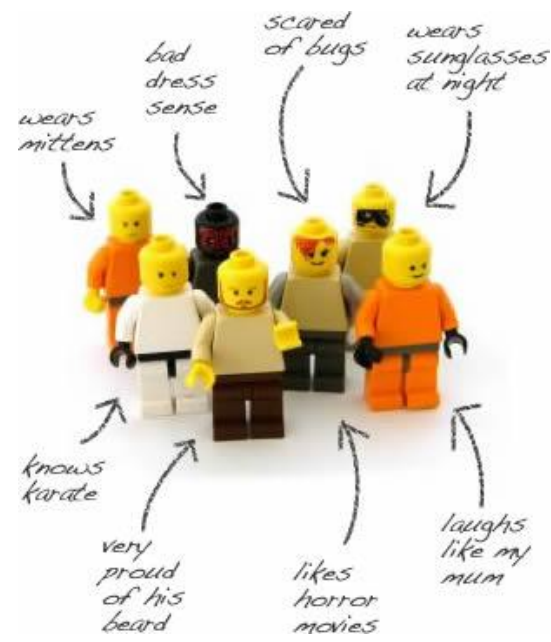

CRIAR UMA EQUIPE DE TRABALHO?

1. Primeira etapa: formação do grupo.

2. Segunda etapa: conflitos e emergência de líderes. 


\section{Desafios da psicologia no Brasil}

3. Terceira etapa: estabelecimento de normas do grupo.

4. Quarta etapa: ação do grupo.

5. Quinta etapa: atualização.

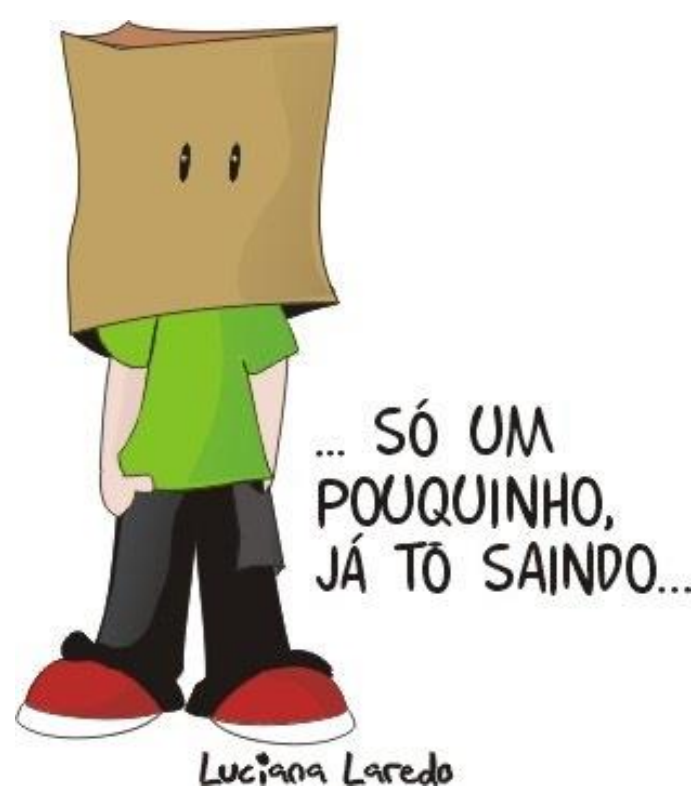

\section{Forming (Formação)}

É a fase de formação de uma equipe.

Tipicamente, é o momento do encantamento e da descoberta, durante o qual as pessoas ainda estão a conhecer-se

- Os papéis e responsabilidades de cada um ainda não são muito claros.

- Reina o otimismo, o orgulho por pertencer ao projeto e a cortesia por ainda não existir grande proximidade entre os elementos.

- É nesta fase que se começa a definir as tarefas e as regras e em que são feitos muitos testes. Perdese muito tempo com discussões abstratas.

- Os líderes costumam ser muito diretivos, desempenham um importante papel de orientadores.

- Esta fase tende a ser curta, podendo até passar por uma única reunião. 


\section{Desafios da psicologia no Brasil}
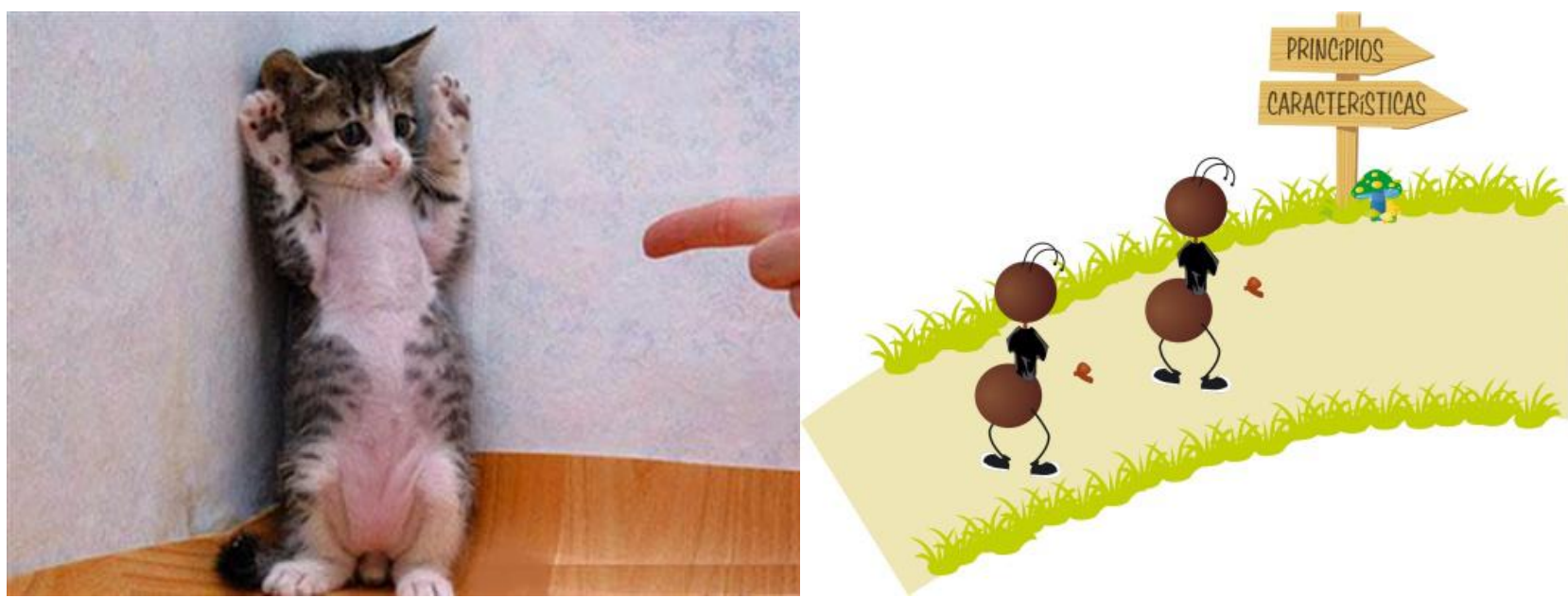

\section{Storming (perturbação)}

É a fase da perturbação. As pessoas começam a conhecer-se e a personalidade de cada um a revelarse. Começam a surgir as diferenças de opinião e, com elas, os desentendimentos e as dúvidas sobre o funcionamento do grupo.

- Estágio dominado por discussões, competição, resistência e tensão.

Se gasta muita energia em questões que não estão relacionadas com o projeto.

- Com os conflitos começa a existir uma certa polarização. As pessoas têm de escolher um lado e a equipe pode dividir-se em facções.

- As decisões não são tomadas com facilidade. Torna-se quase impossível conseguir um consenso.

- Apesar de o líder ter ainda um papel bastante diretivo, começa a mostrar se mais acessível. Cabe-lhe estabelecer os processos e a estrutura, para minimizar os conflitos. Deve também apoiar os elementos que demonstrem maior insegurança.

- Apesar das dificuldades, esta é uma fase imprescindível, durante a qual surgem bons desenvolvimentos que serão ponto de partida para as fases seguintes.

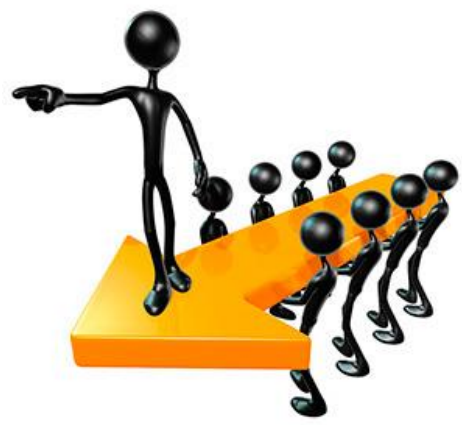




\section{Desafios da psicologia no Brasil}

\section{Norming (normatização)}

As pessoas começam a ajustar-se e a trabalhar melhor em conjunto.

Os elementos da equipe já sabem com o que podem contar dos outros, conhecem as suas forças e fraquezas e são capazes de lidar com isso de forma positiva.

- A coesão do grupo começa a fazer-se notar.

Os conflitos são evitados e as discussões já são construtivas, gerando resultados.

- Surge o risco de perda de criatividade. A aproximação da equipe pode dar origem ao chamado "pensamento de grupo".

- O líder tende a ser mais participativo. A hierarquia já está claramente estabelecida.

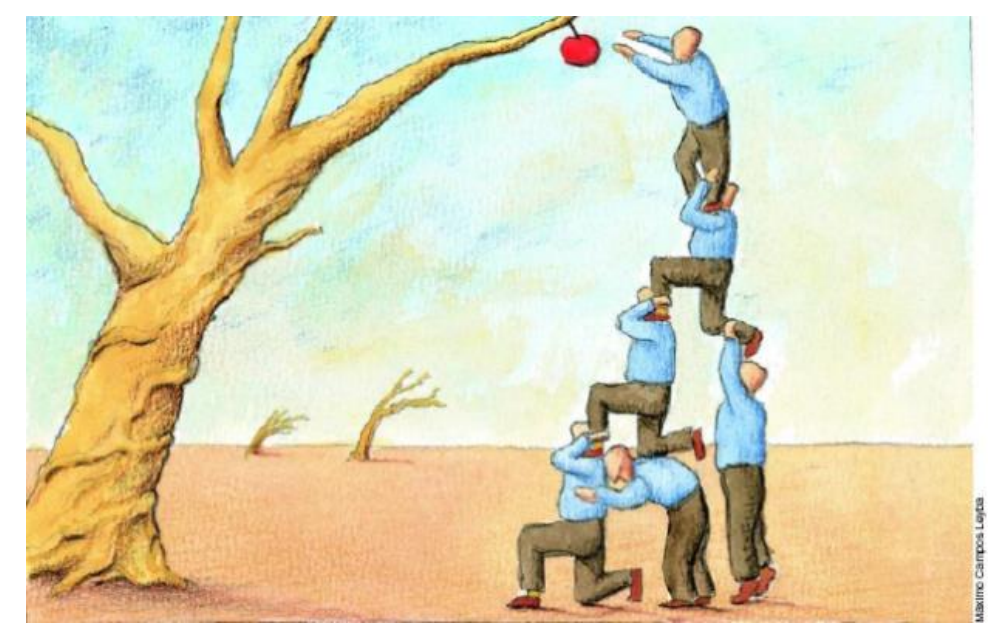

\section{Performing (desempenho)}

- Fase de elevada performance. Este é o momento em que a equipe é mais eficaz e tem um melhor desempenho.

- A equipe consegue concluir novas tarefas e projetos com sucesso.

- Nesta fase, a equipe é capaz de integrar um ou dois novos membros, sem correr o risco de regressar a um dos estágios anteriores.

- O líder já é capaz de delegar a maior parte do trabalho e concentrar-se no desenvolvimento dos membros da equipe.

- Na maioria das organizações, uma equipe leva pelo menos 6 meses para chegar a esta fase 


\section{Desafios da psicologia no Brasil}

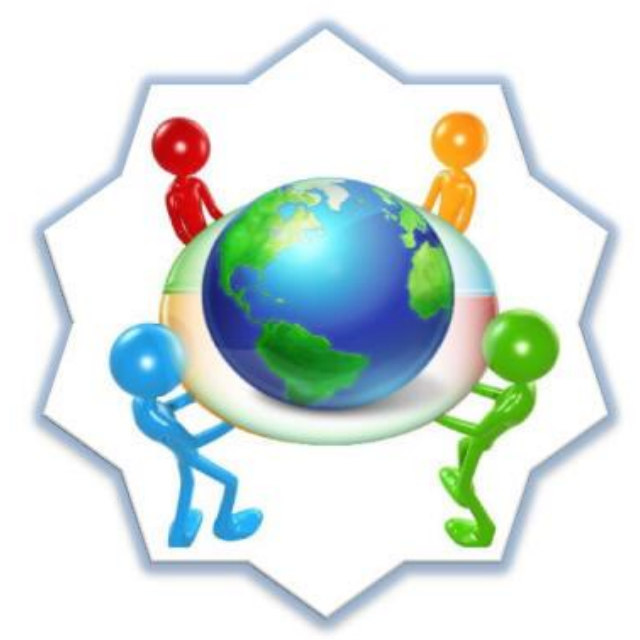

\section{Adjourning (atualização)}

Fase de ajustamento, em que a equipe é separada ou reestruturada.

- Algumas pessoas começam a sair do projeto ou a manifestar algum desinteresse e saturação pelo trabalho.

- Esta fase pode ser particularmente dura para os elementos da equipe, já habituados a uma determinada rotina de trabalho e com uma relação próxima entre si.

- Antes da equipe ser efetivamente separada, é importante reconhecer e celebrar os seus feitos.

- As relações dos elementos tendem a continuar, apesar do grupo ter sido dissolvido.
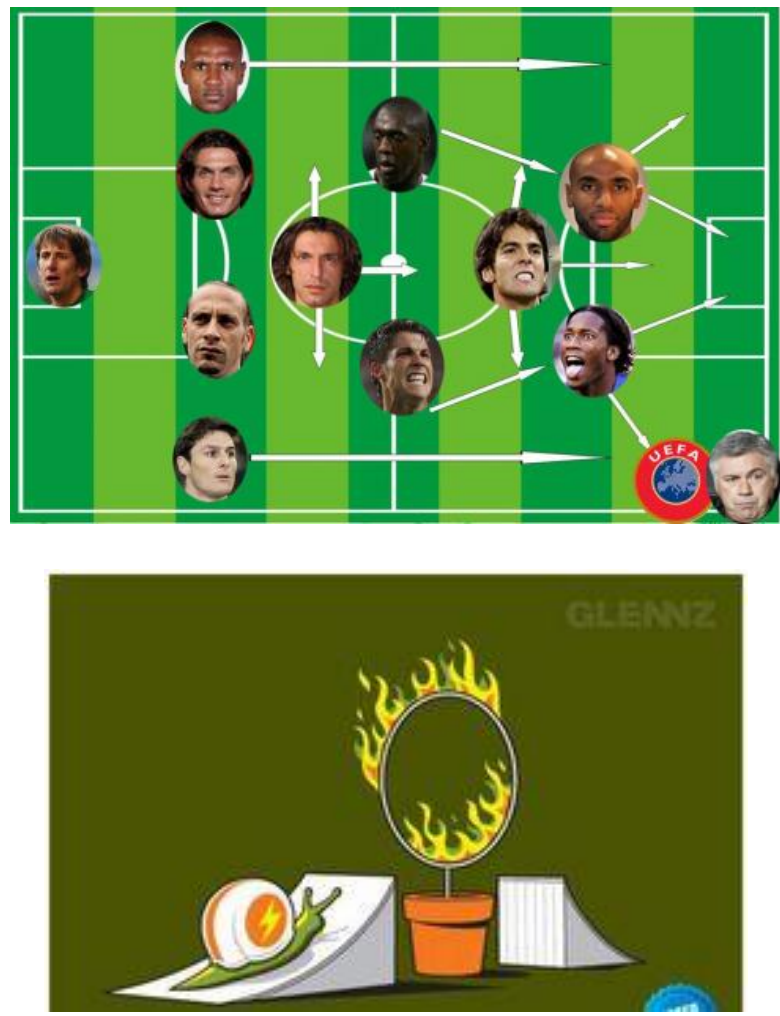


\section{Desafios da psicologia no Brasil}

\section{COMO CONSTRUIR UM (BOM) GRUPO TRABALHO?}

Quais são os ingredientes para uma equipe vencedora e satisfeita, onde os membros se respetam e tem confiança uns nos outros? Onde todos sabem qual é o seu papel e sabe a contribuir ativamente para alcançar a meta comum?
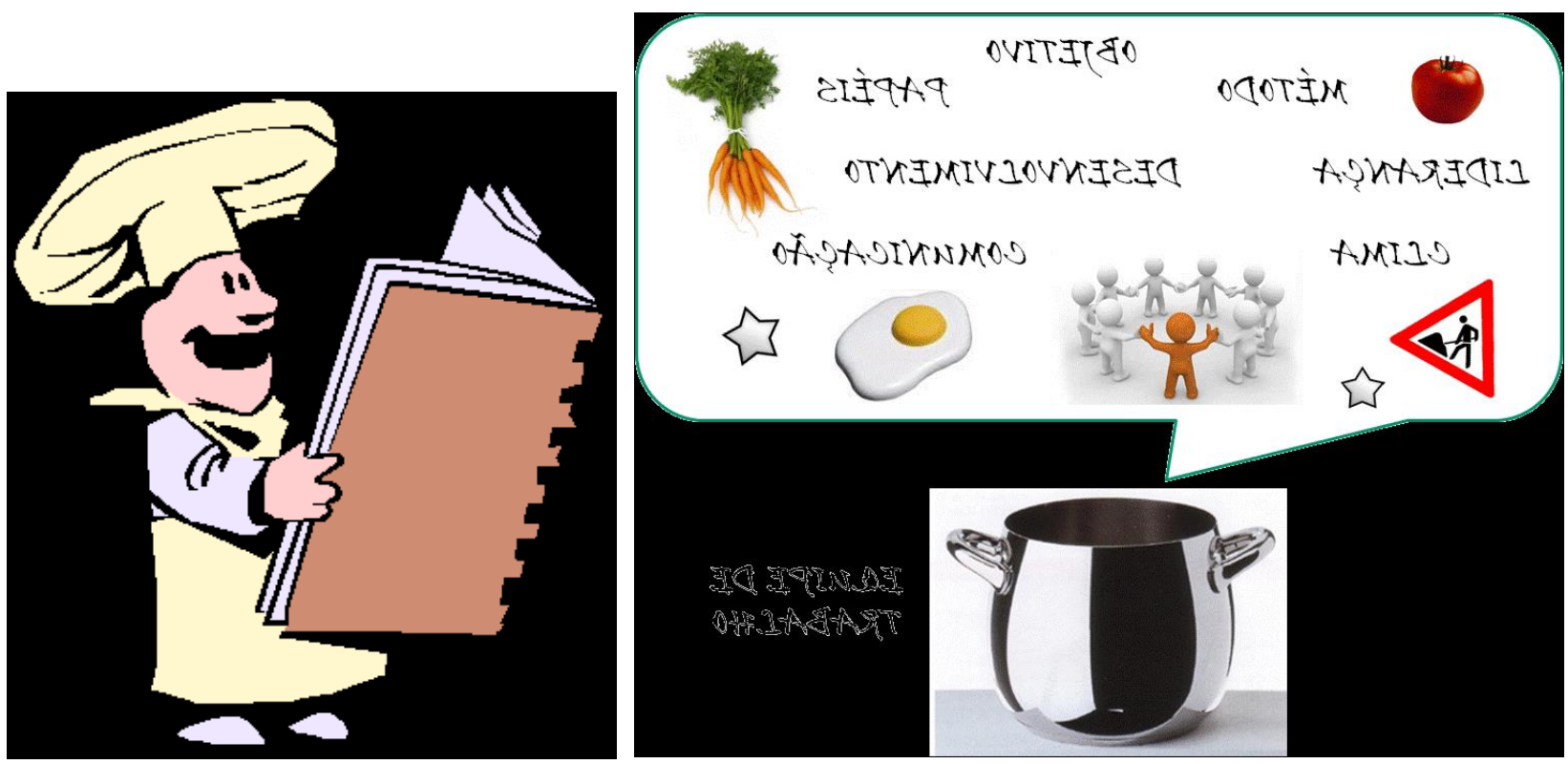

\section{OBJETIVO}

Definir claramente as metas e objetivos da equipe. Todos têm de saber qual o objetivo do trabalho, para que o esforço seja feito na mesma direção. A comunicação clara é fundamental para alcançar esse objetivo. Características das boas metas:

\section{Eles são teus}

\section{Eles são escritos}

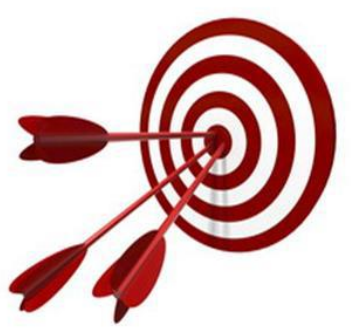

\section{Eles são compatíveis}

\section{Eles são "EMARO" :}

Específico - dividido em tarefas, não demais geral e abstrato

Mensurável - baseado em dados observáveis, em recursos disponíveis, tributável

Atingíveis - que pode ser alcançado

Realístico - baseado em fatos

Oportuno - razoável, útil pelas metas ultimas do trabalho 


\section{Desafios da psicologia no Brasil}

\section{COMO DESENVOLVER OBJETIVOS COMPARTILHADOS?}

A mais importante estratégia é organizar reuniões da Equipe para facilitar o intercâmbio de idéias e a comunicação entre os membros. Depois é preciso organizar sessões de trabalho "amostra" para fazer um planejamento estratégico do trabalho e tentar um método para alcançar as novas metas.

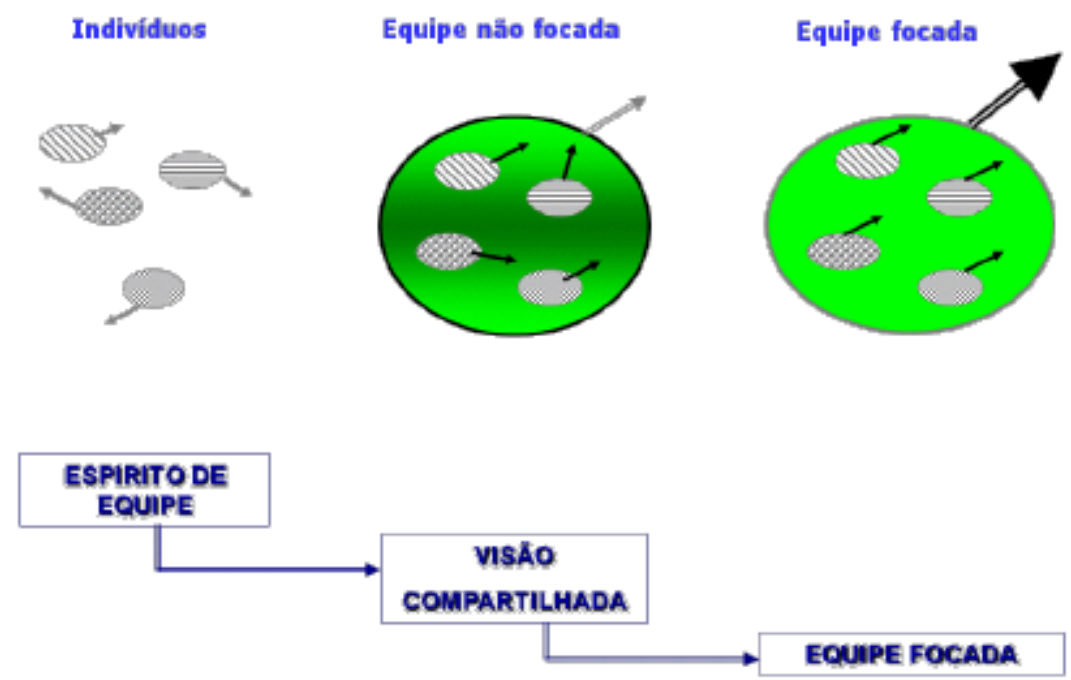

\section{QUE OS OBJETIVOS COMPARTILHADOS EM EQUIPE SÃO ASSIM IMPORTANTES?}

- ajudam a definir uma direção futura da organização

- auxiliam na construção de compromisso para a equipe"para uma direção futura

- fornecem uma base para a responsabilização na execução

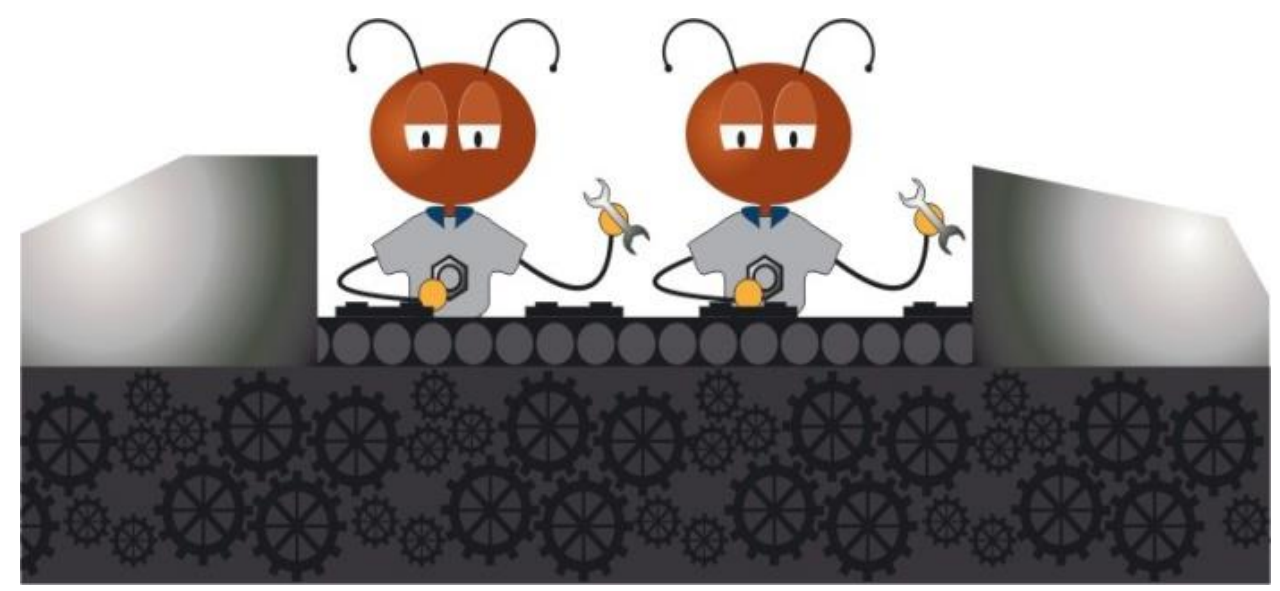




\section{Desafios da psicologia no Brasil}

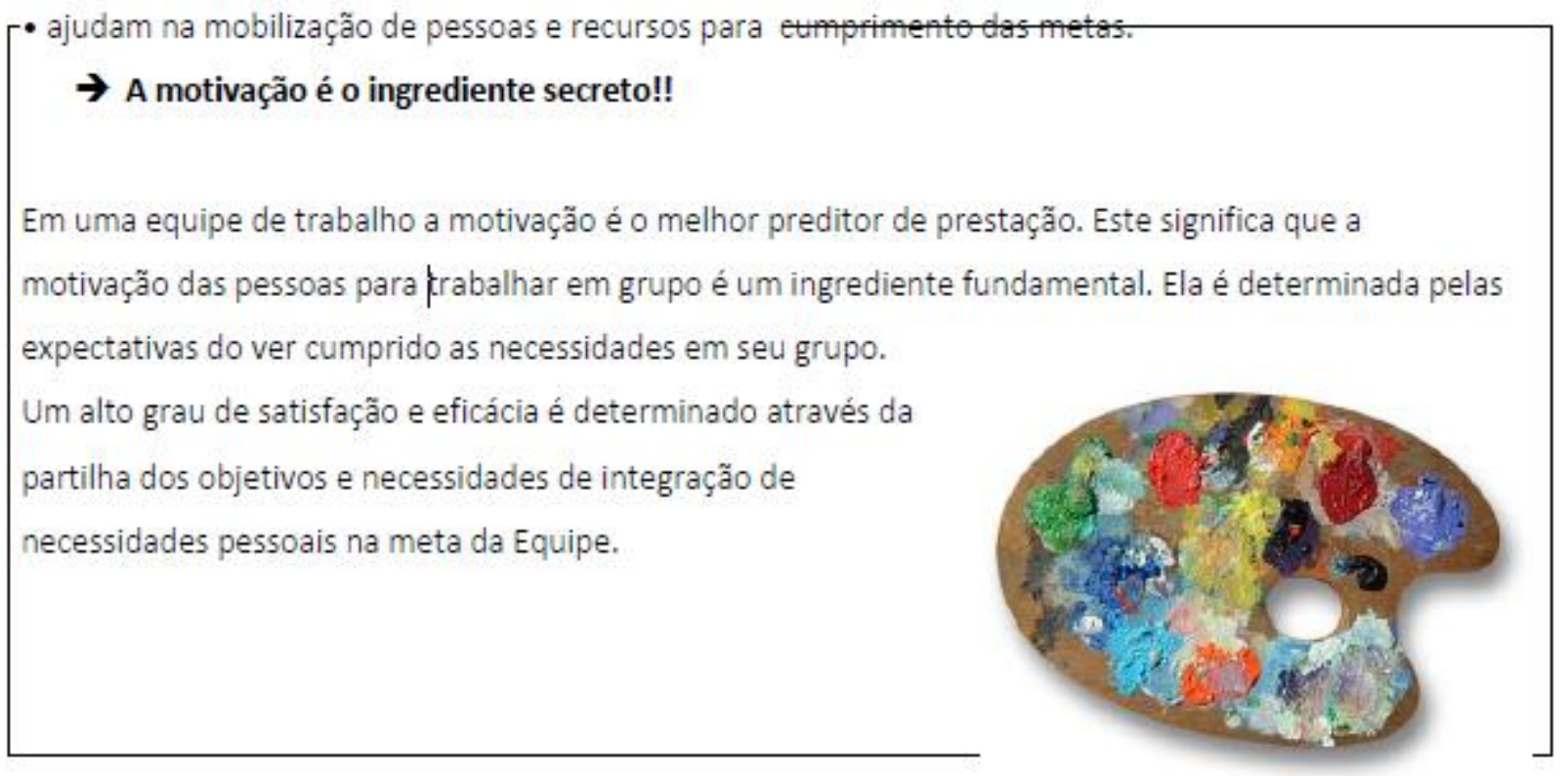

A motivação no trabalho em equipe é como a cor brilhante, que faz uma obra de arte mais luminosa

\section{MÉTODO DE TRABALHO EM EQUIPE}

O método é a estratégia com a qual enfrentar um percurso, uma tarefa, um objetivo.

Estabelecer um meio eficaz para clarificar e partilhar:

O método de discussão e de tomada de decisão e as ferramentas utilizadas.

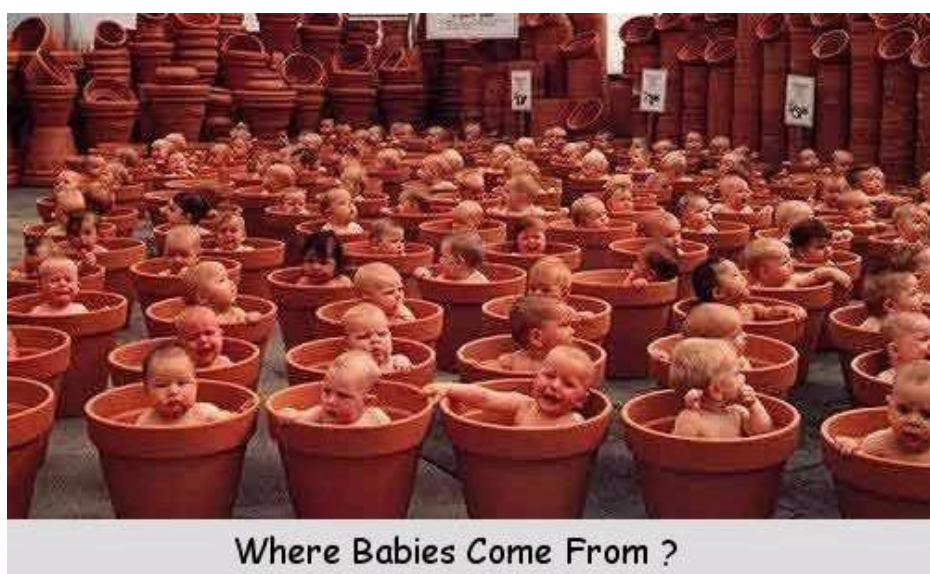

O método é a regra de trabalho. Como determinar qual o método de trabalho?

1. Fazendo uma análise dos recursos e restrições.

2. Discutindo em grupo: o diálogo e a troca de membros, mesa redonda, a inscrição para falar.

4. Planejamento e uso do tempo (aquecimento, a definição da tarefa, a tomada de decisão, o período 


\section{Desafios da psicologia no Brasil}

conclusões) para criar um pensamento de grupo.

5. Tomando decisões usando ferramentas de resolução de problema.

6. Estabelecer um caminho de trabalho.

7. Ajustando para alcançar a eficácia.

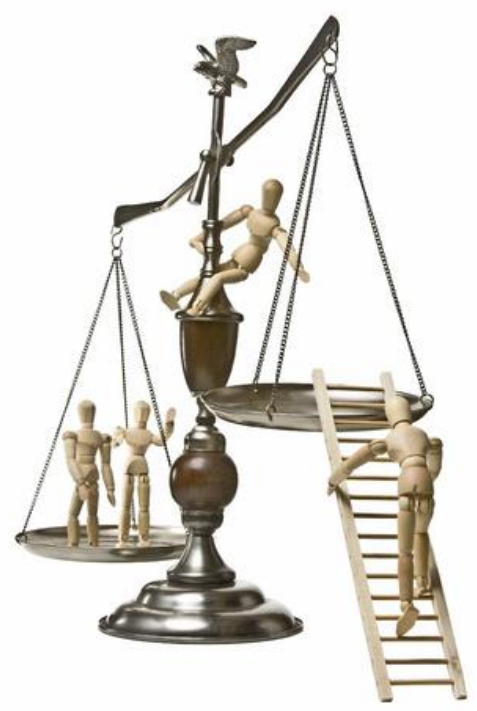

\section{CUIDADO!!}

O método orienta as atividades do grupo e pode levar ao conformismo e à igualdade entre os membros, destacando os problemas de dependência mútua, mas exige a aceitação do estilo de pensamento e ação dos outros.

Assim, podem ser afetados por desinteresse individual. Esta recusa pode ser sentida ao nível em que o sintoma conhecido como "marcha lenta (quando não é apreciado o mérito das questões), é sentido. Compartilhar um método significa renunciar dum método individual para aceitar as modalidades de trabalho de grupo numa forma comum.

Isto requer a confiança na própria capacidade e outros e a tolerância de insegurança para atravessar "ruas desconhecidas". 


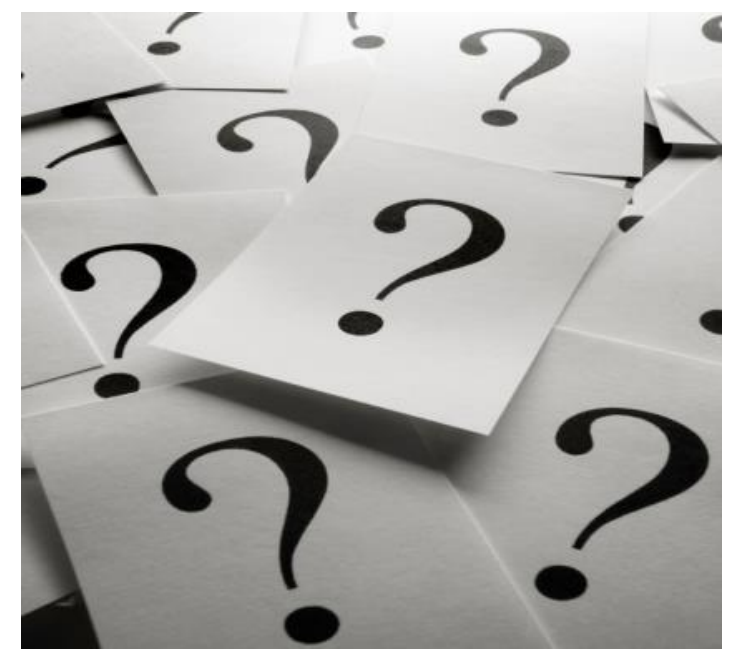

\section{Decidir em grupo: entre o acordo e o compromisso}

O indivíduo assume a responsabilidade direta de uma escolha, que implica a renúncia clara e completa para todas as outras opções possíveis. Cada membro do grupo confia especialmente nos seus pontos de vista, nas suas opiniões, nos valores que ele acredita. Então ele procura um compromisso satisfaz tanto ele quanto os outros: assim, a decisão pode perder o valor real.

\section{Decidir em grupo: entre a normalização e a polarização}

Um grupo pode chegar a um consenso através de compromisso (fenômeno de normalização), ou através de posições extremas (fenômeno de polarização).

Então a Equipe precisa de técnicas para a tomada de decisão, para ajudar o grupo a manter o conflito em termos de conteúdo e discussão dos dados (aspecto cognitivo), em vez de permitir que as discussões sejam sobre as pessoas e as relações entre elas (aspecto emocional).

\section{$\rightarrow$ Um Exemplo: o Brainstorming! \\ É uma atividade criativa do grupo, em que os membros são incentivados a propor idéias sobre como resolver um problema, ou como tomar uma decisão. A finalidade é}

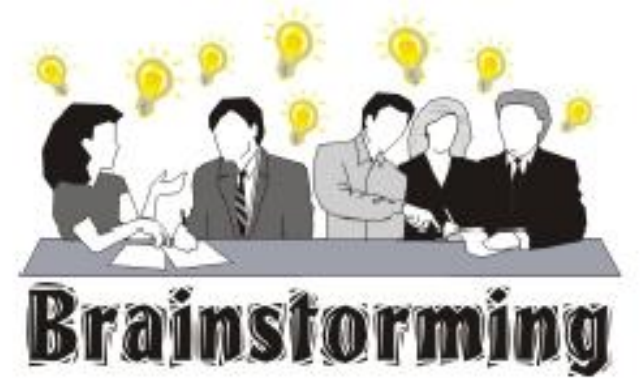

Gerar mais ideias possíveis, mesmo não formando sempre alternativas usáveis. Depois da fase de geração de ideia tem uma fase de seleção das melhores ideias. 


\section{Desafios da psicologia no Brasil}

\section{PAPEL / CARGO}

Conjunto de expectativas compartilhadas por todos os membros do grupo sobre como uma pessoa que possua certa posição deve se comportar. Estas expectativas afetam os sentimentos, comportamentos e valores de quem preenche um papel (espera-se que o chefe organize o trabalho do grupo).

Os papeis na equipe de trabalho são:

- interdependentes, se caracterizam pela relação de reciprocidade (ex.o professor e o aluno).

- o resultado da força do grupo e do poder individual.

"Equipe quer dizer comprometimento. Trata-se de um grupo de pessoas com um objetivo comum que batalham por sua conquista e respeitam as características e competências individuais de cada um. Um não se sobrepõe ao outro. Trabalham em conjunto, aproveitam o que cada um tem a oferecer, ao contrário do que acontece em um grupo sem foco, sem objetivo".

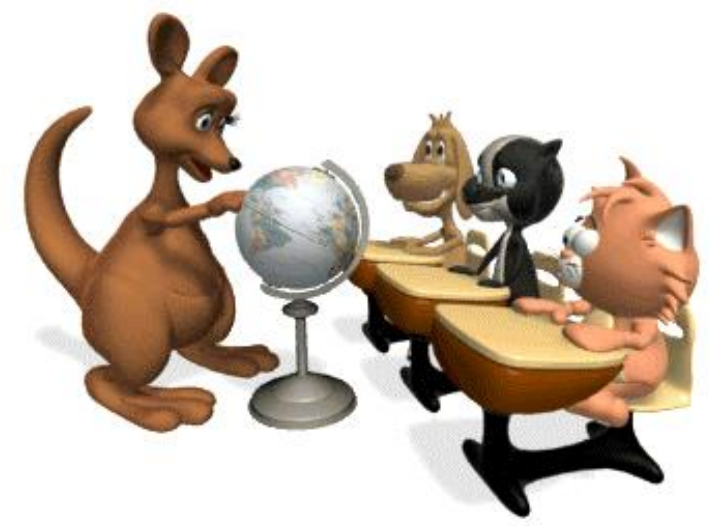

É fundamental que a equipe acredite que cada indivíduo tem algo a oferecer para transformar um grupo numa equipe de sucesso. $O$ segredo é aproveitar tais competências individuais para obter um bom resultado coletivo.

\section{Os papéis devem ser:}

- definidos e esclarecidos em fase de construção da equipe.

- Não redundantes ou sobrepostos.

- Atribuído em relação à capacidade e competências das pessoas.

- Coerente com as qualidades e características pessoais. 


\section{Desafios da psicologia no Brasil}

- Atribuídos em relação aos objetivos.

- Equilibrados.

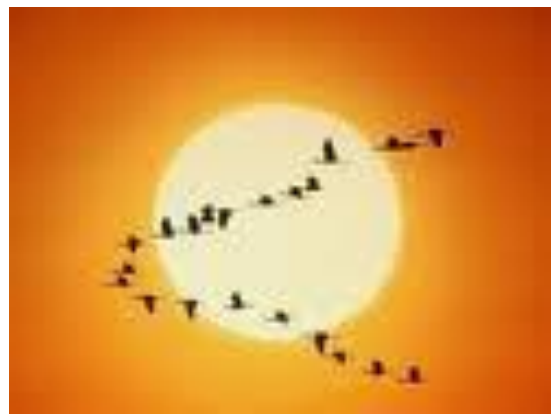

Uma Equipe precisa de diferentes papeis. Existem vários tipos de papeis:

1. Papéis de produção = papéis e atitudes centradas no estudo da pessoa, a eficácia do seu trabalho ou à tarefa a ser alcançada através do grupo.

2. Papéis de relação = comportamentos e papéis que se concentram nos membros da equipe em conjunto, sobre o funcionamento harmonioso do debate sobre o bom relacionamento entre os participantes.

3. Papéis individuais = comportamentos que tem o foco nas necessidades pessoais e as tendências da pessoa, na satisfação dos seus interesses.

Pode-se criar uma Equipe de papeis bem distintos, cada-um em uma área peculiar.

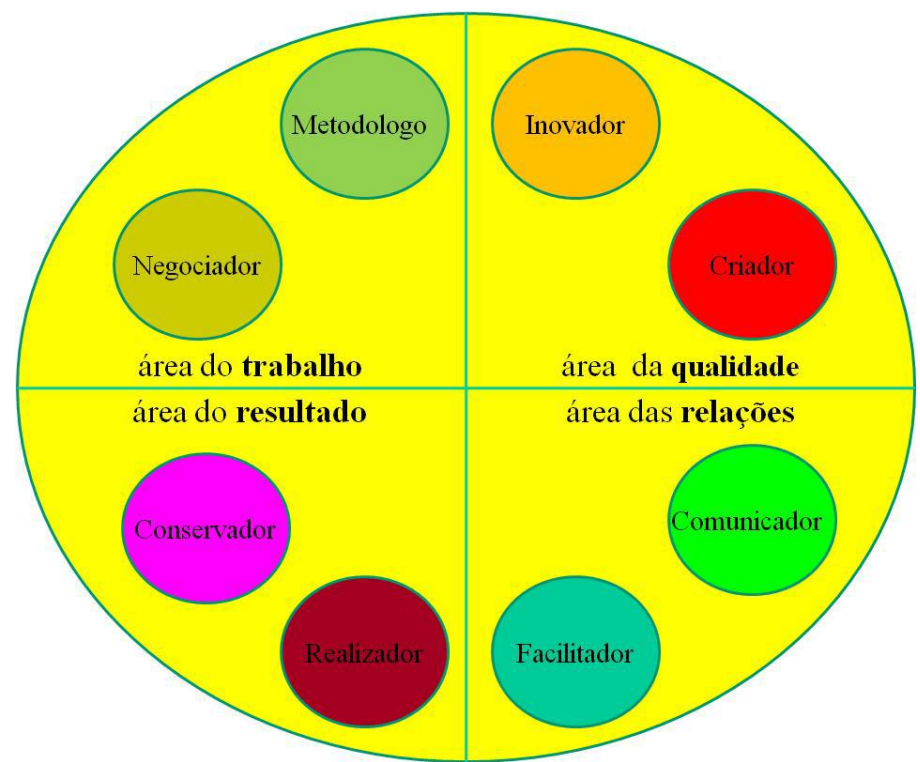




\section{Desafios da psicologia no Brasil}

DICA!

Essencial para um sistema eficaz de papéis é a qualidade da comunicação dentro do próprio grupo, porque o seu bom funcionamento permite que aconteça uma correspondência entre as expectativas e as demandas de cada um e também entre o desempenho e o comportamento na Equipe.

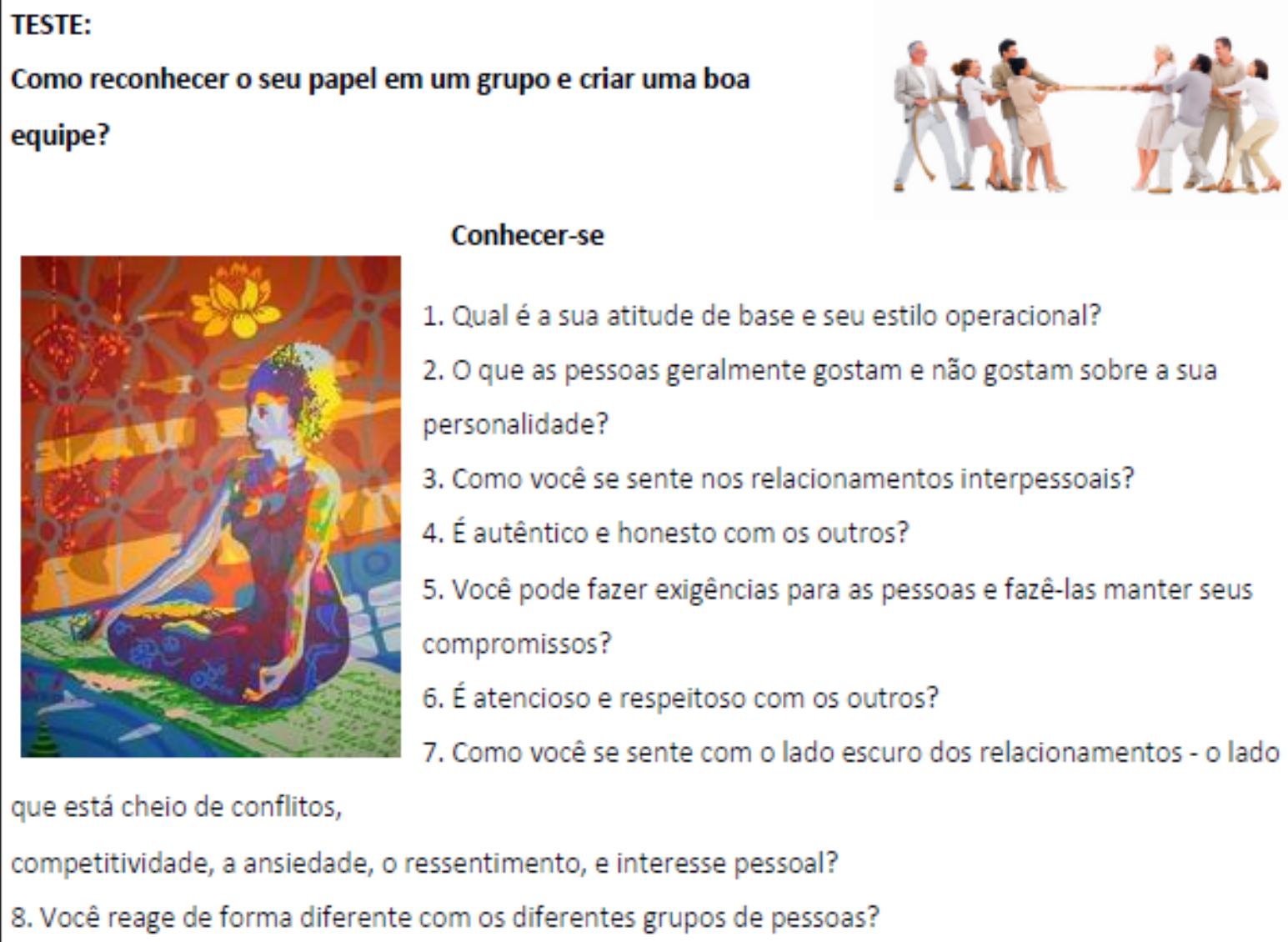

\section{BONS HÁBITOS}

1. Seja proativo.

2. Comece com o fim em mente.

3. Coloque primeiro as coisas essenciais.

4. Pense com jeito "ganha/ganha" ( por o termo inglês "win / win", que corresponde a um jeito de pensar em que as pessoas podem buscar o benefício mútuo em todas as interações humanas. 0 comportamento baseadas em princípios).

5. Procure primeiro compreender, depois ser compreendido. 


\section{Desafios da psicologia no Brasil}

6. Synergize: uma Sinergia geralmente ocorre quando duas pessoas com diferentes habilidades complementares cooperam.

Conheça sua equipe

Meu polegar verde só veio como resultado de erros que cometi enquanto aprendia a ver as coisas a partir do ponto de vista da planta. - H. Fred Ale

\section{LIDERANÇA}

Os líderes devem conceber e articular os objetivos em maneiras que vão tirar as pessoas da suas pequenas preocupações e juntá-las em direção a maiores objetivos.

- John Gardner

Características essenciais e valore do BOM LíDER

Características:

- Transparento

- Pragmático

- Flexínel

- Orientado para as relações e para as motas

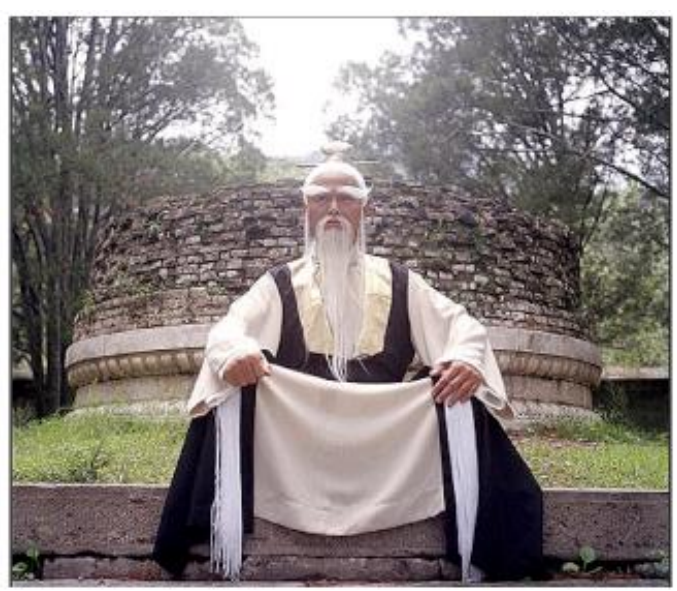

Um bom líder deve conhecer a si mesmo, e ser credível e fiável.

Isso deve ser empático, ou seja, capaz de compreender os outros.

Um caráter distintivo do bom líder é ser honesto, que se aplica aos outros e no seu próprio grupo.

Um bom líder usa a comunicação eficaz, é capaz de expressar claramente suas idéias e objetivos. É capaz de ser compreendido por todos, através da modulação do tipo de linguagem, dependendo do interlocutor.

É essencial que um bom líder seja capaz de ouvir e compreender os outros e as idéias dos outros (escuta ativa). 


\section{Desafios da psicologia no Brasil}

O verdadeiro líder tem sempre uma visão de liderança, enxerga longe, sabendo quais são os objetivos a serem alcançados e tendo a capacidade de transmitir sua visão para o seu grupo.

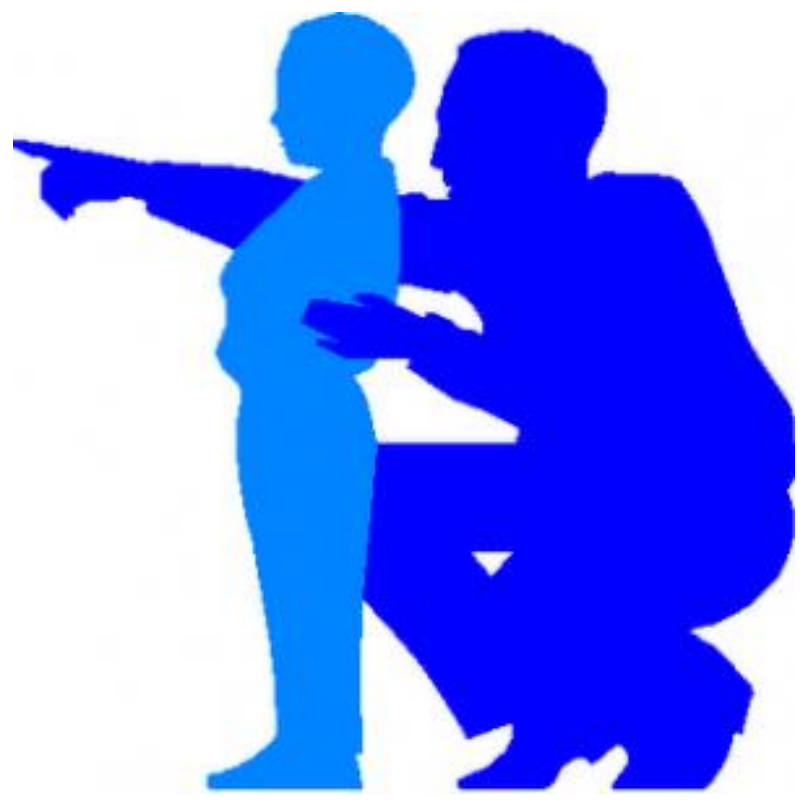

\section{Qual é a função do líder?}

Um bom líder desempenha inúmeras funções que servem para proporcionar o bem-estar do grupo e para gerir o trabalho da Equipe, ajudando principalmente a alcançar os objetivos.

Por exemplo, ele se compromete por:

- Contribuir para a integração entre o grupo.

- Lidar com os conflitos, Motivar as pessoas.

- Introduzir e esclarecer o método de trabalho.

- Envolver.

- Coletar informações para membros do grupo.

- Distribuir informações entre os membros do grupo.

- Reconhecer o valor de outros.

- Incentivar outras pessoas à experiência.

- Não ter medo de errar.

- Recompensar as pessoas que trabalham bem. 
- Criar boas relações.

- Ser sensível às novas necessidades e ao desenvolvimento.

- Verificar no grupo as relações positivas e não conflitos.

- Tomar decisões em acordo com seu grupo e por seu grupo.

- Melhorar o desempenho e as relações dos membros do grupo.

- Tornar as pessoas mais responsáveis, ouvir, comunicar-se eficazmente.

- Estimular o trabalho de indivíduos e consideram o trabalho de novos pontos de vista.

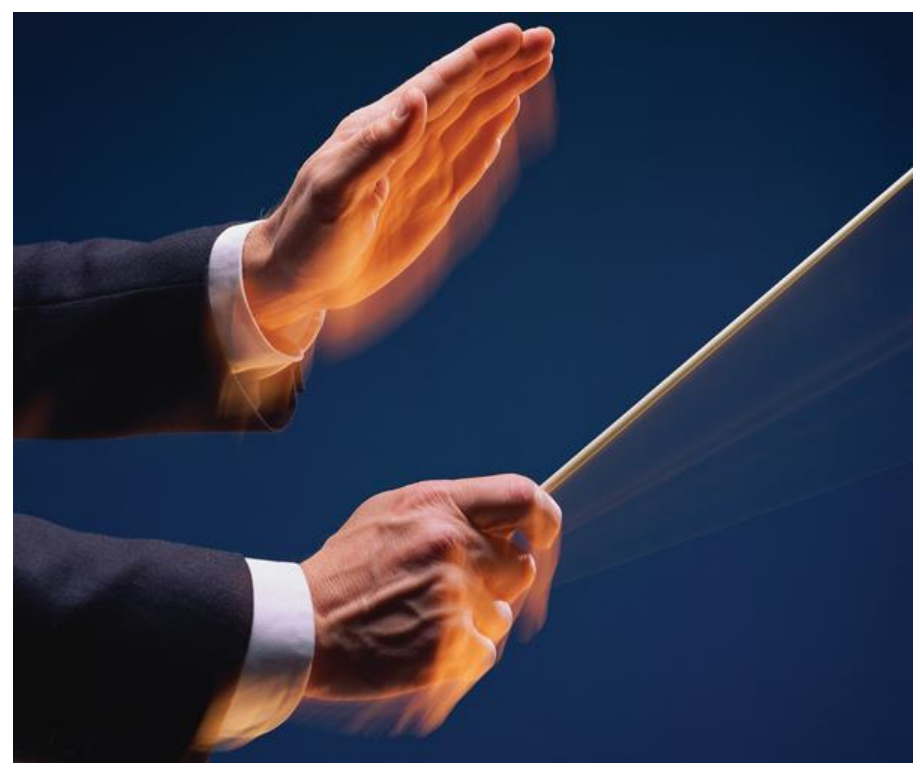

Você sabia que ..... Um bom líder usa a DELEGAÇÃo!

Mas ...... que significa DELEGAR?

A delegação representa a transferência de determinado nível de autoridade*, como um chefe em um grupo de trabalho, de um superior para um subordinado ou conjunto de subordinados.

Acontece com freqüência que ainda bons líderes não sabem delegar, não conseguem deixar os outros fazerem o que se está fazendo tão bem, principalmente para aqueles líderes que fazem da empresa uma projeção e extensão do seu ego. Mas, quando se deseja crescer, isto é tão necessário quanto os primeiros e hesitantes passos de uma criança.

Saber delegar com eficácia significa dar a tarefa certa à pessoa certa, concedendo-lhe o grau certo de liberdade, para que o trabalho se desenvolva de forma mais eficiente e produtiva. 


\section{Desafios da psicologia no Brasil}

Saber delegar permite ao chefe e a toda a sua equipe darem o seu melhor e aperfeiçoarem-se progressivamente, de modo a poder enfrentar novos desafios. Com uma fraca capacidade de delegação, a equipe fica constantemente ocupada a "apagar fogos" e perde tempo precioso.

Para que a delegação flua, gerentes e equipes precisam observar três pré-requisitos: (1) confiança recíproca; (2) competência técnica e interpessoal para assumir a responsabilidade delegada; (3) compromisso com metas comuns; e, (4) comunicação em tempo real sobre o andamento das atividades delegadas.

Os melhores empreendedores, no entanto, sabem que querer privilegiar o próprio ego coloca um teto nas possibilidades de crescimento do empreendimento. Para eles, trabalhar em equipe (uma verdadeira equipe) é buscar resultados, operando em conjunto, compartilhando experiências e conhecimentos, estimulando-se mútua e constantemente. $\left({ }^{*}\right.$ Autoridade $=0$ conceito de autoridade está relacionado com o conceito de hierarquia e corresponde ao poder de comandar os outros e leválos a agir da forma desejada e constitui a base para a responsabilidade. É, portanto uma relação de poder que se estabelece de superior para subordinado.

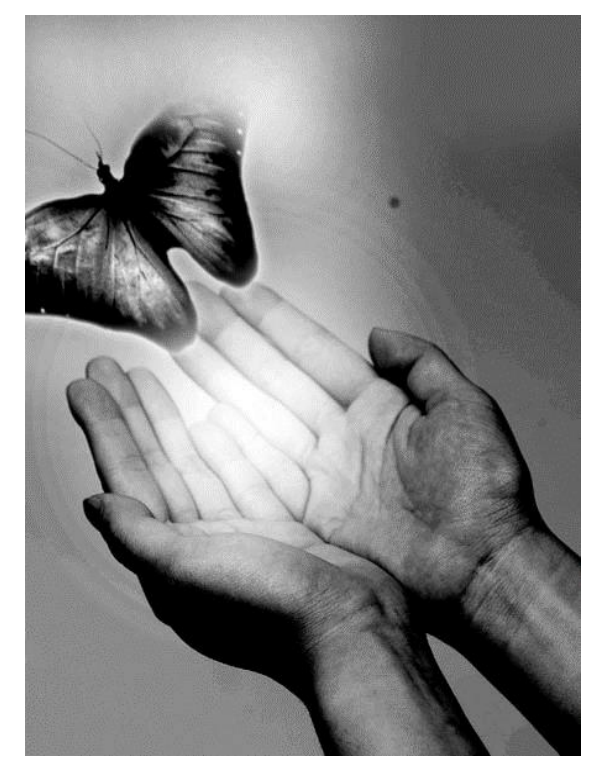

NO ANEXO 1 TEM UM TESTE QUE INVESTIGA A SUA CAPACIDADE DE DELEGAÇÃO !

\section{Estilos de liderança}




\section{Desafios da psicologia no Brasil}

\begin{tabular}{|l|l|l|l|}
\hline & AUTORITÁRIO & DEMOCRÁTICO & PERMISSIVO \\
\hline Estilo & $\begin{array}{l}\text { Exerce um poder } \\
\text { despótico, estabelece } \\
\text { as regras do grupo, } \\
\text { nenhuma mudança }\end{array}$ & $\begin{array}{l}\text { Estimulaa } \\
\text { participaçäo, aceita as } \\
\text { críticas, distribui a } \\
\text { responsabilidade }\end{array}$ & $\begin{array}{l}\text { Desinteressado } \\
\text { não estimula, năo } \\
\text { controla, não } \\
\text { coopera, respeito } \\
\text { passivo sobrea } \\
\text { atividade }\end{array}$ \\
\hline Efeitos & $\begin{array}{l}\text { Provoca } \\
\text { agressividadee } \\
\text { apatia }\end{array}$ & $\begin{array}{l}\text { Diminui a } \\
\text { agressividade, } \\
\text { estimula a motivação }\end{array}$ & $\begin{array}{l}\text { Grupo pouco } \\
\text { coeso, não } \\
\text { colaboração }\end{array}$ \\
\hline $\begin{array}{l}\text { Generali- } \\
\text { zações }\end{array}$ & $\begin{array}{l}\text { Funciona em } \\
\text { situações de } \\
\text { emergência. }\end{array}$ & $\begin{array}{l}\text { atençãoa a } \\
\text { individualidadeea } \\
\text { produtividade }\end{array}$ & $\begin{array}{l}\text { Se transforma } \\
\text { facilmente em um } \\
\text { autoritário ou } \\
\text { desaparece }\end{array}$ \\
\hline
\end{tabular}

\section{A Liderança expressa uma necessidade de equilíbrio entre as necessidades}

\section{DO LIDER}

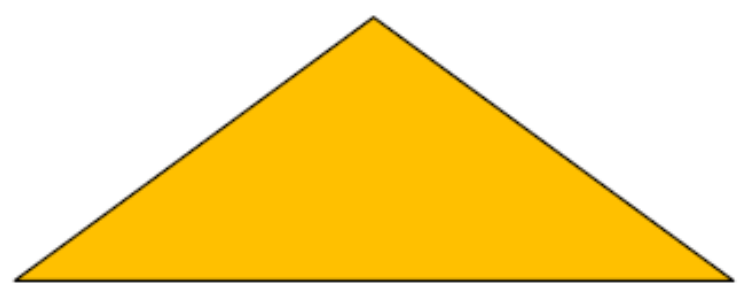

DO GRUPO

Uma liderança bem distribuída implica à uma divisão entre os membros do grupo de funções e papéis do líder!

\section{COMUNICAÇAO}

Sem comunicação não há nenhum grupo!

Qual é a função da Comunicação em um grupo? 


\section{Desafios da psicologia no Brasil}

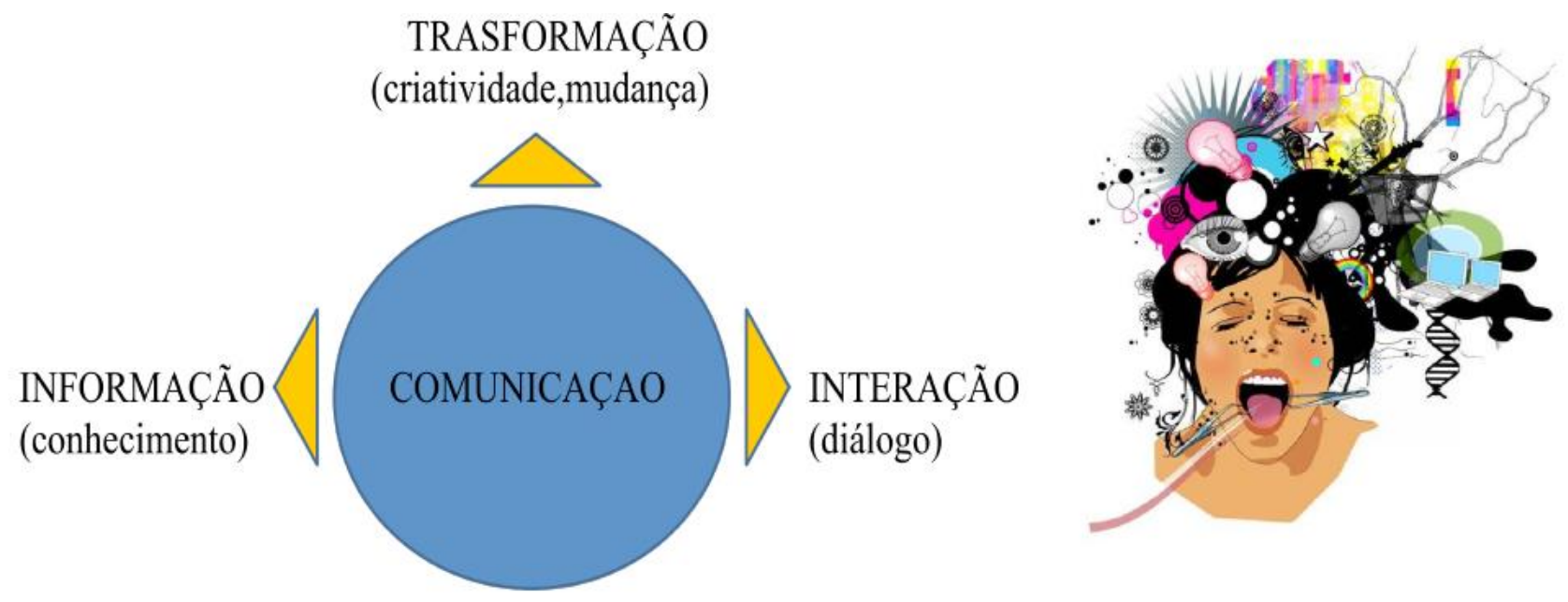

COMUNICAÇÃO E REDE DE RELAÇÕES

Em um grupo a comunicação pode ser:

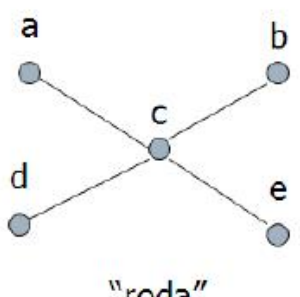

"roda"

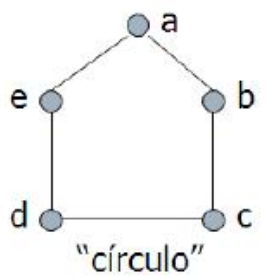

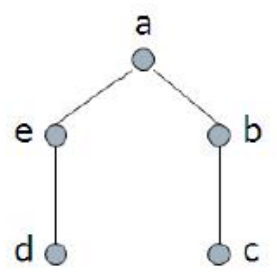

"cadeia"

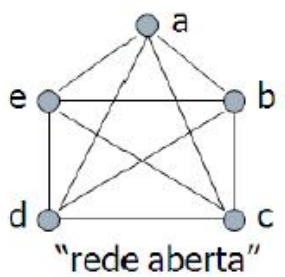

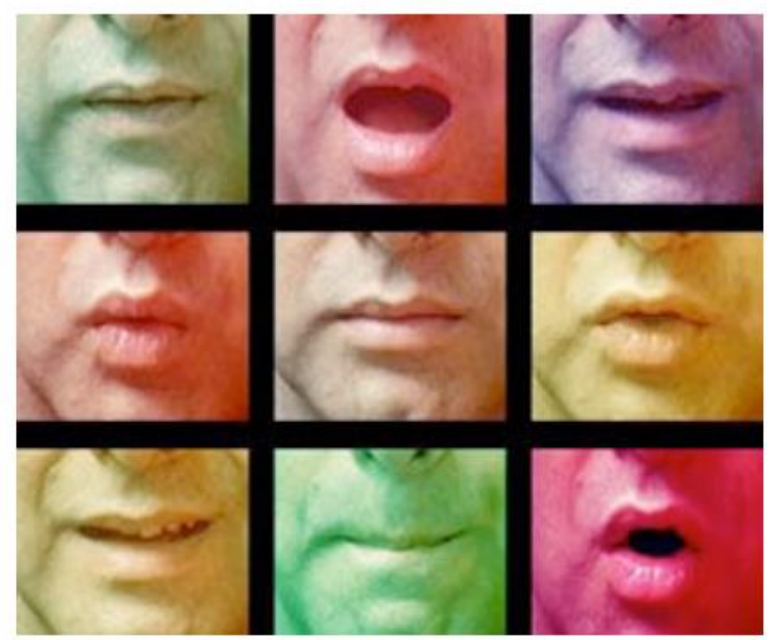

\section{Que significa Saber Comunicar?}

Em um trabalho em Equipe e quando for parte de um empreendimento, a capacidade de comunicar e expressar o próprio pensamento torna uma habilidade fundamental. 


\section{Desafios da psicologia no Brasil}

- ser claro e completo

- expor de forma lógica e ordenada -deixar falar

-demonstrar atenção e envolvimento

- verificar a sua compreensão

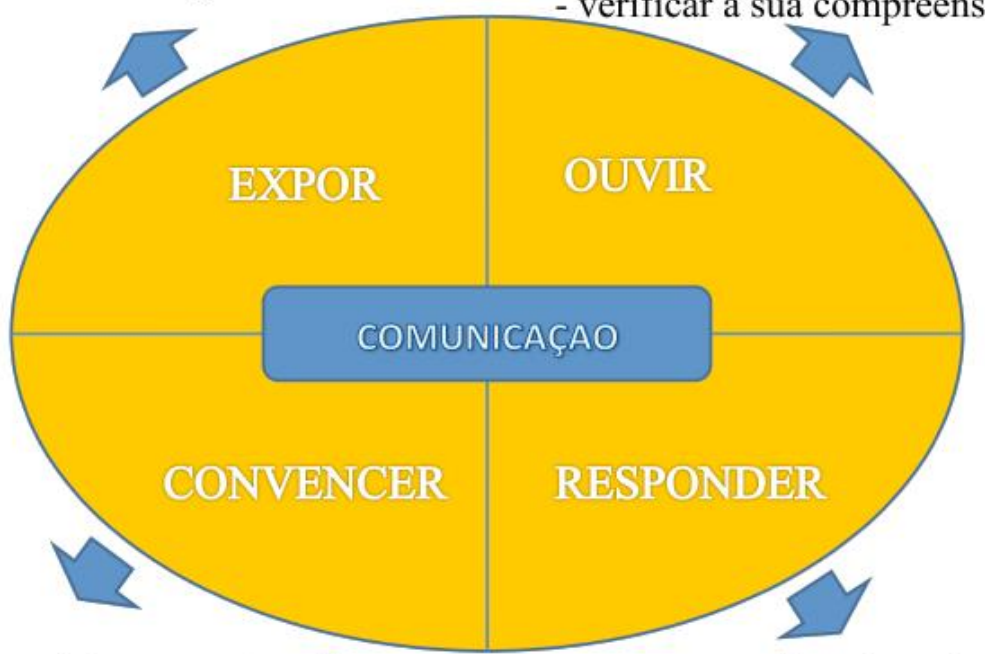

- permanecer aderente ao tema

- adaptar a linguagem para o interlocutor

- resolver dúvidas e incertezas

\section{CLIMA}

O clima na Equipe de trabalho é formado por um conjunto de opiniões, percepções e experiências dos seus membros. É um indicador da qualidade do grupo como sistema de trabalho.

A boa percepção do clima ocorre quando há um apoio e um carinho no grupo, os papéis das pessoas são reconhecidos e valorizados, a comunicação é aberta, clara e fornece opinião sobre o comportamento aceitável dos indivíduos e dos resultados alcançados pelo grupo. Uma liderança participativa e objetiva devidamente calibrada para a capacidade do grupo está entre os principais fatores que influenciam o clima.

Algumas pistas para detectar o clima em um grupo de trabalho são:

- Suporte e confiança mútua

- Reconhecimento dos papeis

- Abertura e feedback 


\section{Desafios da psicologia no Brasil}

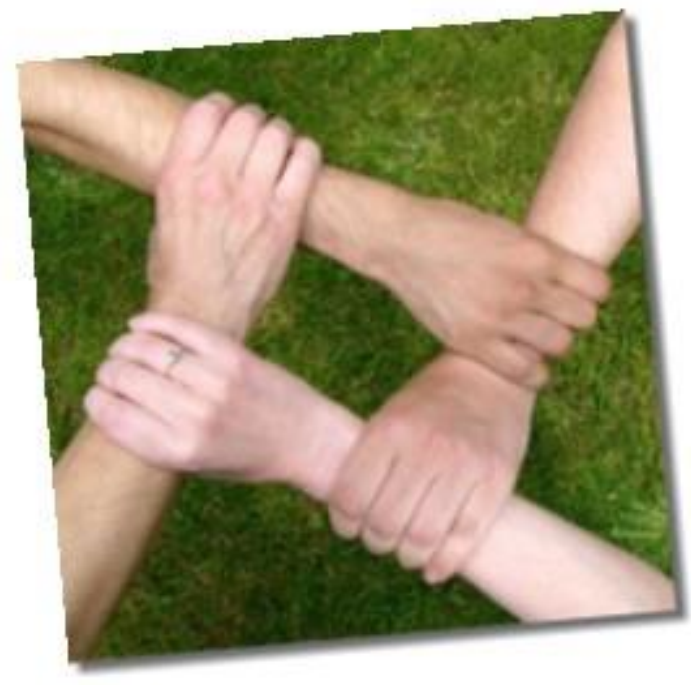

\section{O QUE PODE INFLUENCIAR O CLIMA?}

\section{Estratégia Organizacional:}

- Tempos de trabalho e descanso; - como o grupo está ligado à estratégia da empresa; - poder do grupo os recursos de grupo.

Infra-Estrutura Organizacional: - flexibilidade da organização; - a nomeação de líderes; - as regras formais que controlam o que deveria ser feito; - recursos do grupo; - recompensas para o indivíduo ou grupo. Cultura organizacional: são os valores do padrão cultural dominante

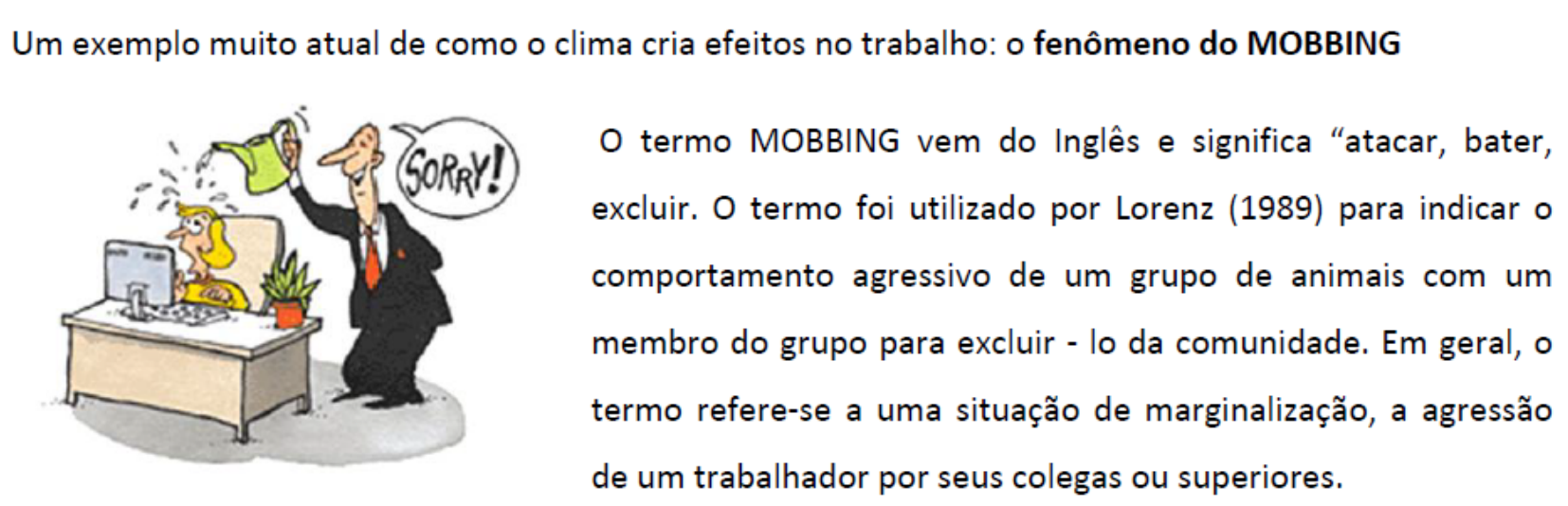

\section{DESENVOLVIMENTO}

Esta variável identifica a construção de um sistema de competências do grupo de trabalho e o crescimento paralelo do sistema de habilidades individuais. Os dois processos devem conduzir a um desenvolvimento do indivíduo dentro do grupo e a uma construção dos conhecimentos, difusão e capacidade dentro do grupo para trabalhar eficazmente. 


\section{Desafios da psicologia no Brasil}

\section{Como desenvolver uma equipe de sucesso?}

Fatores envolvidos:

- Capacidade dos membros, dimensão do grupo, nível de conflito, pressão interna em conformidade com as normas do grupo.

- Influências externas (os grupos não trabalham isoladamente, mas como parte de uma organização).

- Influências internas (capacidade, a inteligência, a motivação, os recursos do grupo, tipos de tarefas).

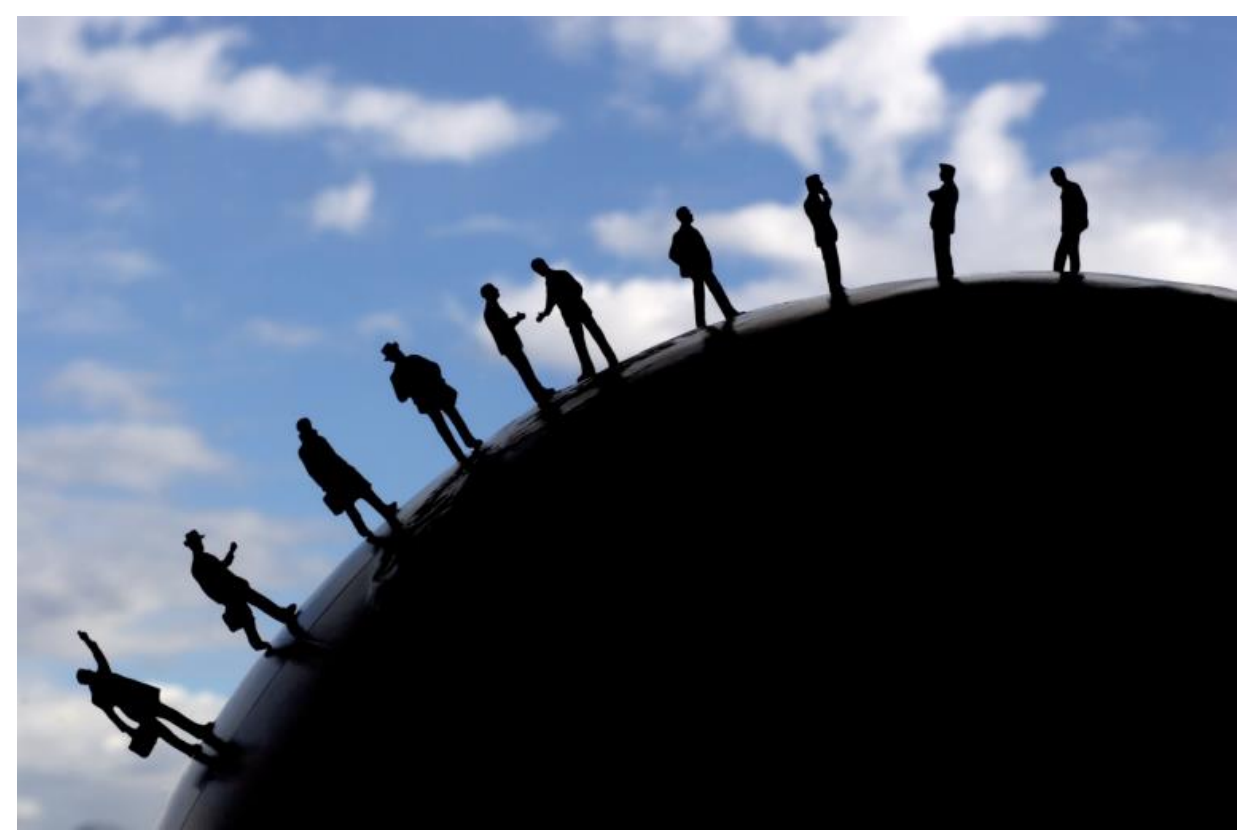

\section{DICAS PRATICAS PARA CRIAR UMA BOA EQUIPE DE TRABALHO}

Características de uma boa equipe:

- Alto grau de confiança mútua

- Apoio Mútuo caracterizado por uma verdadeira preocupação para o outro

- As comunicações são abertas e honestas

- A missão e os objetivos são claramente entendidos por todos os membros

- O Conflito é encarado, confrontado e resolvido

- O ambiente organizacional é caracterizado pela relação de apoio e respeito das diferenças individuais 


\section{Desafios da psicologia no Brasil}

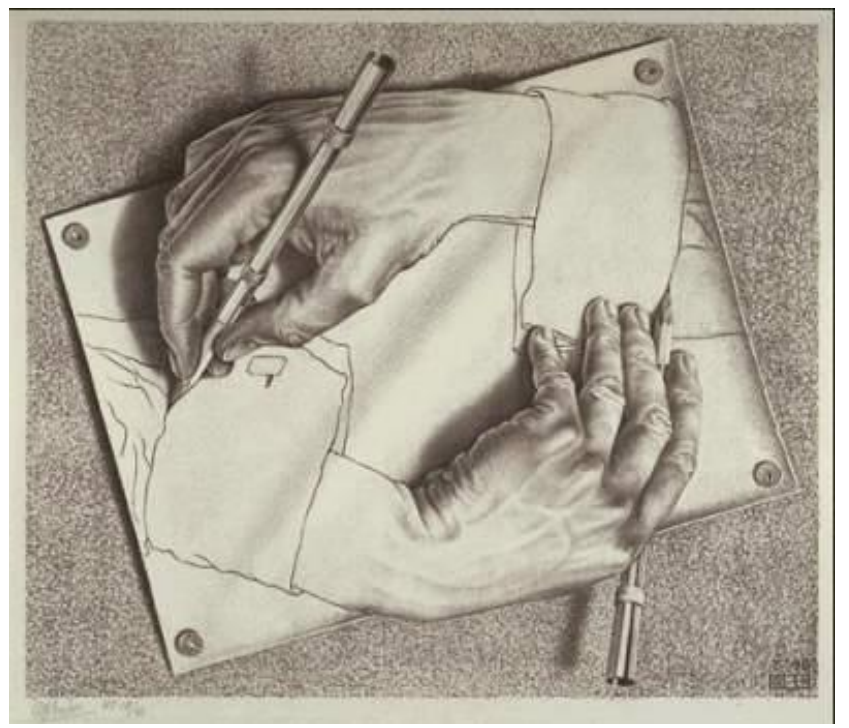

\section{Características das Equipes de Alto Desempenho}

- Objetivo claro e compartilhado para todos

- Papéis Claros

- Liderança aprovada

- Processos de Equipe eficazes

- Relações sólidas

- Excelente comunicação

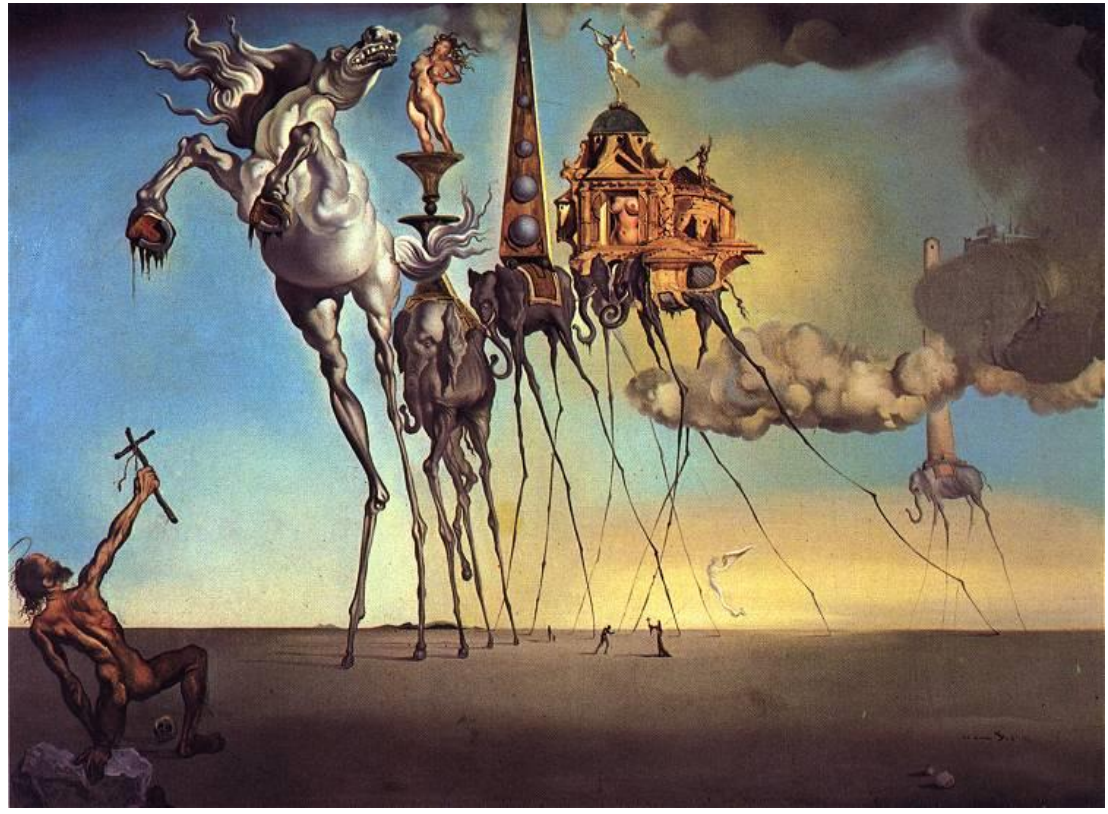




\section{Desafios da psicologia no Brasil}

A cola que puxa e mantém junto: FAÇA PERGUNTAS PARA A EQUIPE!

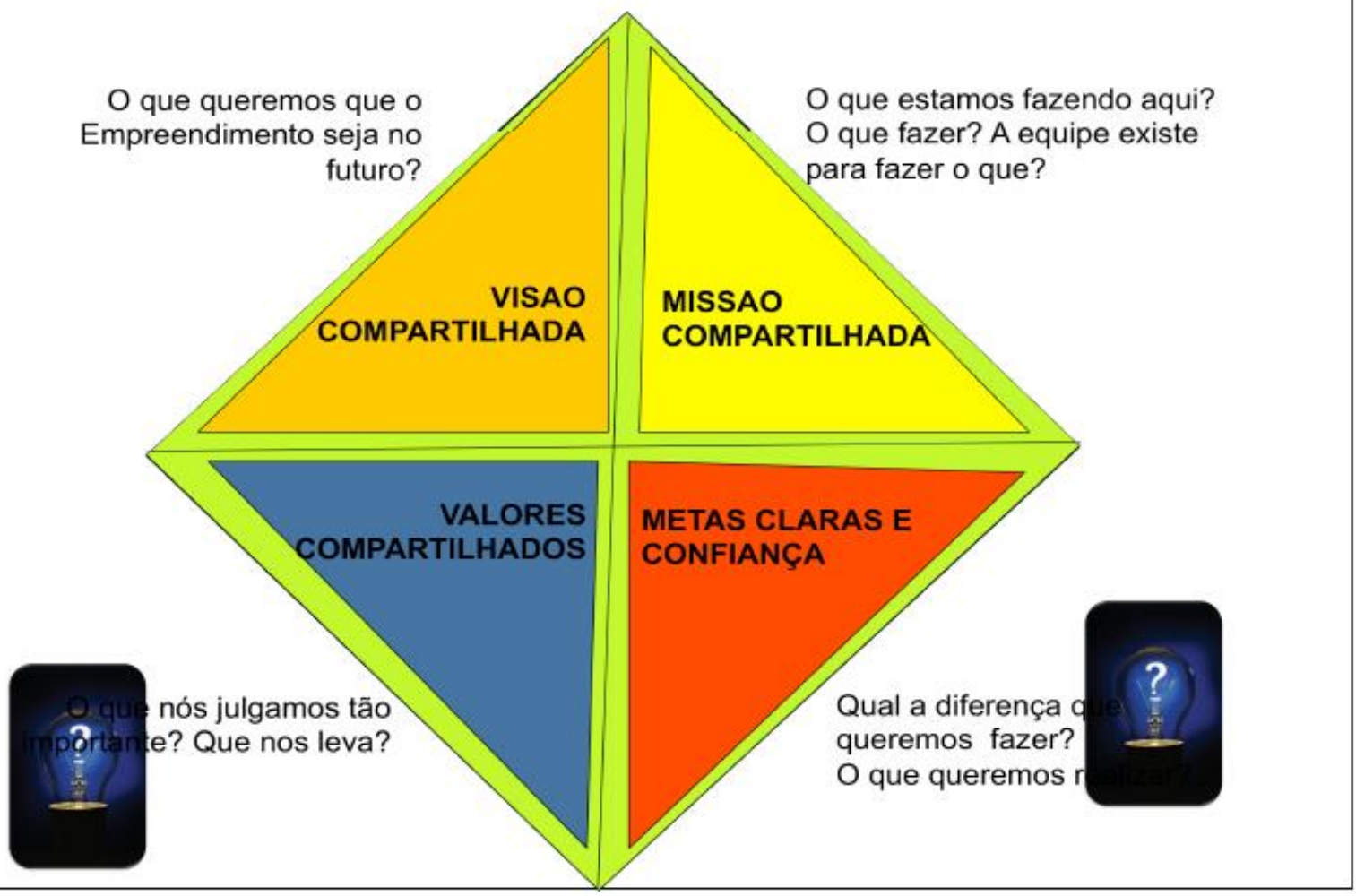




\section{IESTE: VOCE SABE DELEGAR?}

Deirando de lado as consideraçóes referentes a grans de autoridade uo processo de delegaçấ, segue um rápido teste para que o leitor possa situr-se em termos de sua posiçio atual de deleganie. Procure responder as questôes de acordo com saa realidade e unio pensando no que é ideal Se tiver dúvidas sobre a resposta adequada, solicite a opiniho de um subordinado.

Use as seguintes alternativas de resposta:

"SL" (S),

"NAO" $(\mathrm{N})$,

"MAIS OU MENOS" (M).

1. Você tem um substituto eventual formalmente desiguado?

(5)

(N)

(M)

2. Quando você tira férias ou se ausenta do trabalho, a produtividade cai siguificativamente?

(5)

(N)

(M)

3. Vocế possui tendência para "assumir" tarefas que mĩo lhe competem (especialmente aquelas que você erecutava como técuico antes de saa promoçio a gerente)?

(5)

(N)

(M)

4. Seu critério usual para delegaçăo é o de transferir para os sabordinados as tarefas que gosta de erecutar? 
(5)

())

(M)

5. Ao delegar é comnm vocể usar a frase: "isto agora é coum vocî̉, nầ quers mais ver este problema"?

(S)

())

(M)

6. Você tem sempre a comvirção de que executa as tarefas melhor e mais depressa que seas subordimados?

(S)

(N)

(a)

7. Seas subordinados, meswo depois de receberem qualquer delegação, teudem sempre a voltar a vorê para "dividir" a decisāo? (S)

())

QD

8. Você sempre ou quase sempre aceita dividir com seus subordinados a "ônus" das derisốes?

(S)

())

(A)

9. Vocề se considera un perfeccianista?

(S)

(ब)

(A)

10. Vơế considera mais agradivel executar diretamente as tarefas, em oposiçio a conseguir resultados através de terceiros? 
(5)

(N)

(M)

11. Quando delega, vocé tende a conceder mais repponsabilidades (atribuiçoes) do que antoridade (mais coisas para fazer do que o poder de decisho sobre elac)?

(S)

(N)

(M)

12. Logo depois que você delega uma tarefa, é comum se impacientar quando procurado para esclarecer eventuais dinidas?

(5)

(N)

(a)

13. Você costuma defimir a forma de controle da delegaçăo no momento em que ela é efetuada?

(5)

(N)

a)

14. Além de delegar "o que fazer" você costuma definir com sens subordinados exatamente qual deva ser o caminho a ser seguido por eles (o "como fazer")?

(S)

(N)

a)

15. Quaudo delega, você usualmente defime prazos e limites da delegaçio, procuraudo fazêtlo de comam acordo sen grau de comprometimento?

(S)

(N) 
(M)

16. No início do processo de delegação você sempre ou quase sempre procura deixar claro para seu subordinado sua disponibilidade para dirimir dúvidas eventuais (você tem consciência de que quem delega, a curto prazo, deve reservar tempo adicional para treinamento do subordinado)?

(S)

(N)

(M)

\section{INTERPRETAÇÃO DOS RESULTADOS:}

. Atribua 1 ponto se respondeu SIM nas questões 2, 3, 4, 5, 6, 7, 8, 9, 10, 11, 12 e 14;

. Atribua também 1 ponto se respondeu NÃO nas questões 1, 13, 15 e 16;

. Atribua meio ponto às respostas $\mathbf{M}$ (mais ou menos).

Eis a chave de interpretação para suas respostas, bem como algumas sugestões para melhorar sua competência para a delegação:

- Entre 16 e 12 pontos: Você tem problemas sérios com seu esquema de delegação. Reveja suas prioridades, discuta com seus subordinados sugestões para delegar mais. Registre um dia todo de trabalho e analise as oportunidades de delegação.

- Entre 11 e 18 pontos: O problema existe. Não é tão sério, mas a situação pode piorar.

- Entre sete e 4 pontos: Você utiliza bem o instrumento delegação, mas sempre é possível melhorar.

- Entre três e 0 pontos: Você é um Executivo perfeito no que tange à delegação. Nossos parabéns. É meio caminho andado para a Presidência da Companhia.

\section{LEMBRETES:}

Qualquer que seja sua posição no teste lembre-se de que a delegação sempre pressupõe:

- Conhecimento exato de como você gasta seu dia de trabalho para poder relacionar o que é ou não 


\section{Desafios da psicologia no Brasil}

delegável (a delegação exige uma comparação; tenha à sua mão o conjunto de atividades diárias, a comparação ficará mais fácil).

- Que você não perde poder delegando; pelo contrário, quanto maior o "poder de fogo" de seus subordinados, maior poder como Executivo você terá (você é "avaliado" pelos resultados de sua equipe e não apenas pelo que você faz).

- Que o erro é inerente ao processo de aprendizagem (e de delegação); admita erros dos subordinados, procure usar esses erros como instrumentos e oportunidades para treinamento.

- Que outras pessoas podem fazer seu trabalho tão bem, ou melhor, do que você. Experimente conceder a elas uma oportunidade.

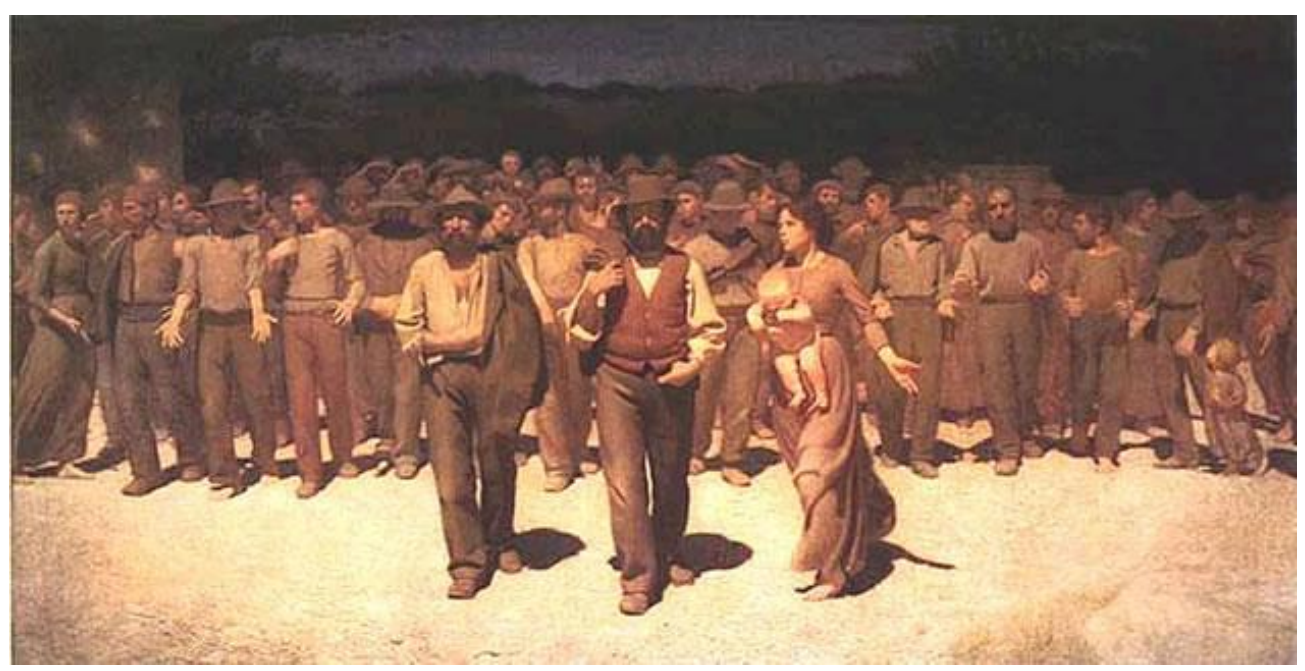




\section{Capitulo 8}

\section{DIAGNÓSTICO ESCOLAR: UM ESTUDO DE LEVANTAMENTO DE DEMANDAS EM PSICOLOGIA ESCOLAR NA REDE MUNICIPAL DE BARBACENA}

DOI: $10.37423 / 200200169$

Andreia Patricia de Sousa

andreiapsousa@yahoo.com.br

Kennya Rodriguess Nézio Azevedo

kennyapsique@gmail.com
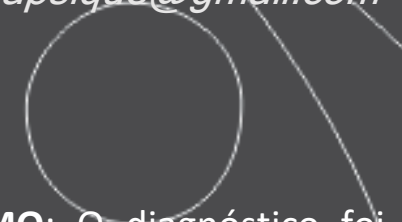

RESUMO: O-diagnóstico foj realizado nas escolas que compõem a Rede-Municipal de Barbacena, durante o segundo semestrę de 2015, cơm o objetivo de fornecer informaçōes e conhecimentos pàra subsidiar a atuação do Setor/de Psicologia da Secretaria Municipal de Educação a partir do-ano de 2016. Com esta fipalidade, realizou-se-a-elaboração de dois roteiros de entrevistas semi-estruturadass, correspondentes a dois seguimentos de profissionaís das escolas: Diretores/Vice-diretores e/Técnicos em Educação. Foram entrevistadas 48 profissionais. $\mathrm{Na}$ confecção dos instrumentos de pesquisa, realizou-se a articulação das questões em torno de três eexos: Eixo I- Escola, Eixo II- Aluno e Eixo IIIFamilia/comunidade. As informações e relatos pobtidos por meio das entrevistas foram subrnetidas a métodos de-análise quantitativa descritiva e qualitativa, pormejo de Análise do

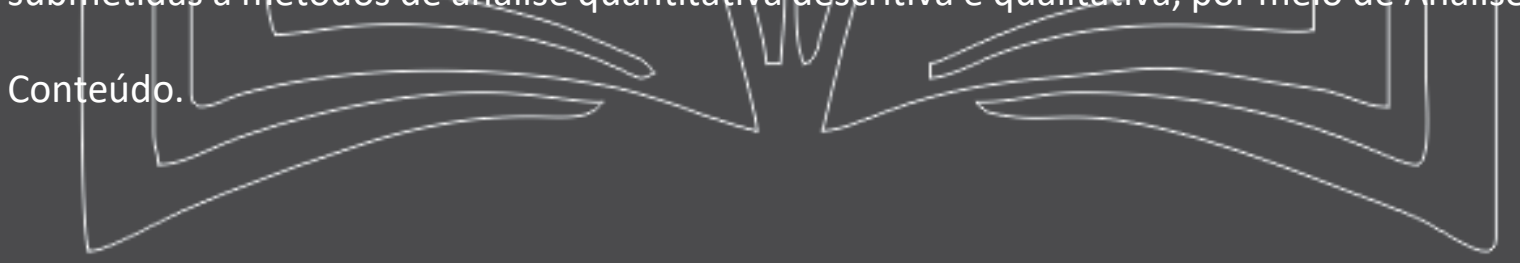




\section{Desafios da psicologia no Brasil}

O processo de diagnóstico envolveu 23 escolas da Rede Municipal de Ensino. Estas escolas atendem a aproximadamente 7.000 alunos e possuem um total de 333 funcionários e 503 professores. Foram realizadas 78 visitas às escolas durante o período de coleta de dados, que ocorreu entre setembro a dezembro de 2015. Os resultados do diagnóstico demonstraram que as escolas vivenciam diversas dificuldades, como: infraestrutura inadequada e pouco envolvimento da família nas atividades pedagógicas e na vida escolar dos filhos.

PALAVRAS-CHAVE: Psicologia Escolar; Diagnóstico; Escola. 


\section{Desafios da psicologia no Brasil}

\section{INTRODUÇÃO}

A Psicologia Escolar é uma área com inúmeras possibilidades de atuação. Seu campo de trabalho é marcado pela diversidade em termos de demandas, contextos e públicos com os quais se atua. Pensando em como lidar com toda esta complexidade, surgiu como proposta a implementação de um diagnóstico na Rede Pública Municipal de Barbacena. Este trabalho foi realizado pelo Setor de Psicologia, através de duas profissionais de psicologia com o objetivo de fomentar estratégias de intervenção contextualizadas. O diagnóstico escolar envolveu 23 escolas que compõem a Rede Municipal de Barbacena. Estas escolas atendem a aproximadamente 7.000 alunos e possuem um total de 333 funcionários e 503 professores. Foram realizadas 78 visitas às escolas durante o período de coleta de dados, entre setembro a dezembro de 2015.

Através da implementação do Diagnóstico Escolar pelo Setor de Psicologia, percebeu-se entre outras demandas a necessidade de maior apoio às escolas municipais. Com um pequeno número de equipamentos públicos e gratuitos em funcionamento nas comunidades em que atuam, consideramos que as escolas vivenciam um acúmulo de funções e recebem pouco apoio de equipe auxiliar, tais como Psicólogos e Assistentes Sociais. Como resposta, ocorreu a criação, em março de 2016, do Núcleo de Apoio Psicológico e Social às Escolas Municipais (NAPSEM), abrindo a possibilidade de atuação de profissionais de outras áreas, juntamente com os de psicologia, para oferecer apoio às Escolas Municipais de Barbacena. O NAPSEM é ligado à Secretaria Municipal de Educação. No entanto, até o momento, o núcleo é composto por apenas duas profissionais de Psicologia. Pretende-se, futuramente, conquistar a inclusão de mais profissionais de Psicologia e de outras áreas.

O Diagnóstico Escolar foi realizado com base nos pressupostos de Vigotsky, denominados teoria Sóciohistórica, que relacionam aprendizagem e desenvolvimento e enfatizam a importância dos processos de mediação para a aprendizagem escolar. Segundo este teórico, a aprendizagem possui papel central nos processos de desenvolvimento, ou seja, o desenvolvimento ocorre somente por meio dos processos de aprendizagem, pois "o homem nasce equipado com certas características próprias da espécie (por exemplo, a capacidade de enxergar por dois olhos, que permite a percepção tridimensional, ou a capacidade de receber e processar informação auditiva), mas as chamadas funções psicológicas superiores, aquelas que envolvem consciência, intenção, planejamento, ações voluntárias e deliberadas, dependem de processos de aprendizagem. O homem é membro de uma espécie para cujo desenvolvimento a aprendizagem tem um papel central, especialmente no que diz respeito a essas funções superiores, tipicamente humanas. " (Oliveira, 2005, p.56). Através do conceito 


\section{Desafios da psicologia no Brasil}

de Zona de Desenvolvimento Proximal, Vigotsky nos fala da importância da mediação para a aprendizagem. Este conceito demarca uma fase do processo de desenvolvimento em que a criança consegue realizar alguma atuação ou aprendizagem através da intervenção de alguém ou de algum equipamento de mediação, este processo implica em avanço no desenvolvimento. A escola é, de acordo com Vigotsky, um instrumento privilegiado dos processos de aprendizagem planejados. $\mathrm{O}$ professor adquire neste contexto extrema relevância, como representante dos processos de mediação. Tendo como base a fundamentação teórica proposta pela Psicologia sócio-histórica, as técnicas de referência da SEDEC propuseram uma análise crítica e reflexiva das práxis da Psicologia escolar no município. Todo o trabalho desenvolvido, inclusive o de diagnóstico escolar, teve como cerne o foco na construção do processo de aprendizagem mediado por suas relações históricas.

\section{METODOLOGIA}

Para realização deste estudo, foram elaborados dois roteiros de entrevistas semiestruturadas, correspondentes a dois seguimentos de profissionais das escolas: Diretores/Vice-diretores e Técnicos em Educação. Foram entrevistadas 48 profissionais, 24 profissionais de direção e 24 técnicos. $\mathrm{Na}$ confecção dos instrumentos de pesquisa, realizou-se a articulação das questões em torno de três eixos: Eixo I- Escola, Eixo II- Aluno e Eixo III- Família/comunidade.

Dada a importância da história e da realidade concreta em que se dão as relações sociais nas escolas, decidiu-se iniciar as entrevistas por uma abordagem à escola. Assim no EIXO - I, implementou-se uma investigação acerca de seis aspectos das instituições escolares da rede municipal de Barbacena: a história, o funcionamento, a estrutura física, Projeto Político Pedagógico, Atividades culturais e Atividades extracurriculares. O Eixo II, denominado aluno, enfatiza as relações estabelecidas no contexto escolar. Neste foram incluídas perguntas que abordam os relacionamentos entre alunos e professores; alunos e funcionários; e entre alunos, a quantidade de alunos incluídos em Atendimentos Educacionais Especializados, de alunos com dificuldades de aprendizagem, de alunos com diagnósticos relacionados às dificuldades de aprendizagem e medicamentos utilizados pelos alunos. Através do Eixo III, sobre Famílias e comunidades, foram construídas perguntas voltadas para a obtenção de informações e relatos acerca das comunidades atendidas por cada escola e da participação das famílias. Este Eixo favoreceu a compreensão destas duas instâncias, família e comunidade, em relação à Violência Doméstica e Sexual, aos diversos tipos de Preconceito e Discriminação, ao Trabalho Infantil e às Drogas. Procurou-se realizar uma abordagem das intervenções realizadas acerca destes temas, 


\section{Desafios da psicologia no Brasil}

considerados de relevância social. Além disso, a rede de serviços foi pesquisada através do levantamento de equipamentos e serviços públicos e gratuitos disponibilizados à comunidade escolar. Com o propósito de realizar uma contextualização das instituições pesquisadas e dos entrevistados, através da realização de uma análise quantitativa. Foram destacados: a localização das escolas, situadas em zona urbana ou rural; tempo de fundação; turnos de funcionamento; turmas; números de funcionários, efetivos e contratados. Com relação aos entrevistados foram enfatizados dados acerca de: Idade; Vínculo de trabalho, efetivo ou contratado; e tempo de trabalho na função e na escola. Tais dados passaram por análise descritiva.

$\mathrm{Na}$ análise qualitativa foram destacados alguns dos temas apresentados nos dados coletados. Neste trabalho serão apresentados dados referentes ao Eixo I e ao Eixo III. Priorizamos a análise no Eixo I dos aspectos relacionados à Estrutura Física das Escolas. Publicações posteriores pretendem enfatizar os outros temas identificados. Referente ao Eixo III será apresentada a análise acerca da participação da família nas atividades pedagógicas e na vida escolar dos filhos. Os dados analisados referem-se às entrevistas realizadas com profissionais de direção. Para o tratamento do material coletado, utilizouse a análise do conteúdo. Como método de análise interpretativa, a análise do conteúdo vem sendo usada desde às décadas de 1920 e 1930 do século passado. Este método é um conhecimento sistematizado, que foi sendo desenvolvido com o objetivo de fomentar novas formas de análise da realidade concreta, da história e da sociedade. Seu surgimento ocorre, portanto, como resposta à necessidade das ciências humanas de desenvolver métodos de pesquisas apropriados às especificidades de seus objetos de estudo (Oliveira et. al, 2003, p.2).

Segundo Oliveira et. al (2003, p. 5), “Na área de educação, a análise de conteúdo pode ser, sem dúvida, um instrumento de grande utilidade em estudos, em que os dados coletados sejam resultados de entrevistas (diretivas ou não), questionários abertos, discursos ou documentos oficiais, textos literários, artigos de jornais, emissões de rádio e de televisão. Ela ajuda o educador a retirar do texto escrito seu conteúdo manifesto ou latente. " Neste sentido, o método da Análise do Conteúdo foi utilizado neste estudo como forma de identificar e compreender às demandas manifestas e latentes direcionadas ao setor de psicologia. Assim como, os aspectos explícitos e implícitos acerca das instituições escolares pesquisadas. 


\section{Desafios da psicologia no Brasil}

\section{RESULTADOS E DISCUSSÃO}

De acordo com a análise descritiva dos dados coletados, do número total de entrevistados (48), 26 eram supervisoras-orientadoras; 23 Diretoras e 01 Vice-diretora. 0 grupo de participantes era composto integralmente por pessoas do sexo feminino. Quanto ao estado civil das entrevistadas, 39 participantes são casadas ou amasiadas; 08 são solteiras e 03 divorciadas. 0 tempo de trabalho médio na função atualmente desempenhada foi de 13 anos e 6 meses, sendo que o tempo mínimo de trabalho nesta foi de 01 mês e o máximo de 30 anos. Acerca do número de funcionários das escolas, no período da coleta de dados, as escolas possuíam um total de 185 profissionais contratados, 155 profissionais efetivos, 81 professores contratados e 438 professores efetivos. Quanto à localização, 09 de nossas escolas estão localizadas em Zona Rural, o que representa $39 \%$ do total de escolas pesquisadas. A média de tempo de fundação das escolas foi de 47 anos, tendo sido a instituição mais antiga fundada em 1920 e a mais recente em 2000. Referente aos turnos de funcionamento, 02 escolas funcionam de manhã, 18 escolas de manhã e à tarde e 03 escolas perfazem os três turnos. Para facilitar a análise e a leitura de dados ocorreu a atribuição de uma identificação numérica a cada escola, de acordo com o quadro abaixo:

\begin{tabular}{|c|c|}
\hline Identificação Numérica & Escolas \\
\hline 1 & E. M. Alberto Correia \\
\hline 2 & E. M. Cel. Camilo Gomes de Araújo \\
\hline 3 & E. M. Crispim Bias Fortes \\
\hline 4 & E. M., Crispim de Paula Nésio \\
\hline 5 & E. M. Embaixador Martim Francisco - CAIC \\
\hline 6 & E. M. Martim Paulucci \\
\hline 7 & E. M. Higino José Ferreira \\
\hline 8 & E. M. José Benedito Câmpara \\
\hline 10 &
\end{tabular}




\section{Desafios da psicologia no Brasil}

\begin{tabular}{|c|c|}
\hline 11 & E. M. José Felipe Sad \\
\hline 12 & E. M. José Moreira dos Santos \\
\hline 13 & E. M. Jovelino Jacinto Furtado \\
\hline 14 & E. M. Lia Salgado \\
\hline 15 & E. M. Monsenhor Lopes \\
\hline 16 & E. M. Oswaldo Fortini \\
\hline 17 & E. M. Padre Sinfrônio de Castro \\
\hline 18 & E. M. Professora Yayá Moreira \\
\hline 19 & E. M. Sebastião Francisco do Vale \\
\hline 20 & E. M. Tony Marcos de Andrade \\
\hline 21 & E. M. Visconde de Carandaí \\
\hline 22 & E. Motary \\
\hline & \\
\hline &
\end{tabular}

A estrutura física é um aspecto de fundamental importância na composição do ambiente escolar, de suas possibilidades de ensino e das relações que se estabelecem. Além disso, de acordo com a Teoria Sócio-histórica, a estrutura física faz parte dos equipamentos de mediação, pois são permeados pela cultura e sua forma de organização pode favorecer a aprendizagem escolar. A presença do outro social pode se manifestar por meio dos objetos, da organização do ambiente, dos significados que impregnam os elementos do mundo cultural que rodeia o indivíduo. Portanto, nem sempre é necessário um processo explícito de instrução ou de um instrutor dedicado deliberadamente a essa tarefa. (Oliveira, 2005)

O Ministério de Educação e Cultura (MEC), em uma publicação do ano de 2006, também considera a estrutura física de uma escola, como sendo representativa dos valores culturais e tecnológicos do seu ambiente. Ele reflete os objetivos educacionais definidos pela sociedade e dá forma a esse atendimento, estabelecido pelas políticas públicas, e é um dos meios pelos quais se realiza a ação pedagógica e educativa. 


\section{Desafios da psicologia no Brasil}

Percebe-se que, na Rede Municipal de Barbacena, poucos prédios atendem às demandas atuais das escolas. As demandas que deixam de ser atendidas apontam para o que é relegado para segundo plano: as atividades extracurriculares, a convivência entre pares, a recreação e a própria qualidade de ensino. Portanto, tomar como objeto de análise a Estrutura Física é uma forma de expressar os problemas e conflitos das instituições escolares.

$\mathrm{Na}$ análise deste tema, Estrutura Física, escolhemos trabalhar com três categorias de análise: 1) Prédios que não foram construídos originariamente para comportar escolas, por isso, não possuem projeto adequado e não atendem às demandas atuais. Pertencem a esta categoria os seguintes prédios escolares: 09 e 14; 2) Prédios que, embora tenham sido projetados para finalidades educativas, carecem de reformas ou adaptações para atender às demandas atuais. Este é o caso das seguintes unidades de ensino: $01,02,03,04,05,06,08,10,11,12,15,16,17,18,20,21$ e 23; e 3) Prédios considerados adequados às demandas da escola. Enquadram-se nesta categoria, os prédios a seguir: 07, 13 e 19.

Neste contexto, encontramos escolas que realizam atividades extracurriculares, através das quais os alunos são atendidos no contraturno, em outros espaços da comunidade, por falta de espaço físico adequado nos prédios escolares. O Programa "Mais Educação" vem sendo executado no espaço da "Pastoral ${ }^{2 "}$, por conta da falta de espaço físico no próprio prédio da Escola 01 . O convênio foi a alternativa encontrada pela direção da escola para garantir a execução das atividades.

Outros problemas vêm sendo enfrentados por algumas escolas com projeto originário destinado a fins escolares, mas com falta de adaptações de acordo com as necessidades atuais. A escola 02, por exemplo, não conta com espaço para Educação Física e atividades externas à sala de aula. A quadra esportiva está sem ser utilizada, devido às reformas. Com esta situação, percebemos redução nos espaços de recreação e, consequentemente, nas possibilidades de convivência entre alunos no âmbito escolar. Outro entrave é a falta de salas de aula, o que causa uma inadequação destes espaços por causa do excesso de alunos, comprometendo enormemente a qualidade de ensino.

Muitas outras escolas demandam um maior número de salas, como as Escolas 11, 14, 16, 20, 21 e 22. $\mathrm{Na}$ Escola 14, que atende alunos de Educação Infantil, de $1^{\circ}$ e $2^{\circ}$ períodos, existem salas com número de alunos maior que o indicado. As salas são pequenas. Nesta modalidade de ensino, Educação Infantil, as atividades devem estimular o desenvolvimento da chamada coordenação motora grossa, exigindo o desenvolvimento de atividades de psicomotricidade, que necessitam de espaços maiores. Esta situação, portanto, gera um grave prejuízo a qualidade de ensino. 


\section{Desafios da psicologia no Brasil}

Na Escola 14, também faltam sala de professores e brinquedoteca, dois espaços importantes de convivência e recreação. A sala de professores é um espaço onde ocorre a troca de experiências entre os profissionais, onde estes partilham as angústias e conflitos da profissão que compartilham. Por outro lado, a brinquedoteca é um local de interação entre alunos e de fundamental relevância em uma escola de Educação Infantil, devido à importância pedagógica atribuída às atividades lúdicas para o desenvolvimento nesta fase.

O espaço insuficiente é o problema mais frequente em relação a estrutura física das escolas da rede. Esta demanda foi apontada por diversas escolas: 04, 05, 15, 23, 10 e 18. A Escola 15 precisa ser ampliada, uma creche próxima à escola fechou e os alunos remanescentes vieram transferidas para esta escola. Tiveram que abrir mão das salas de Direção e de Professores. Sem espaço para Telecentro, a Escola 04 permanece com os computadores do programa sem uso. A falta de quadra de esportes ocorre em diversas escolas e foi apontada pela diretora da Escola 12. Novamente, importantes espaços de interação em âmbito escolar deixaram de existir, diante da falta de espaço físico. Além disso, perdeu-se um espaço de gestão e coordenação com a ausência da sala de Direção.

A Escola 08 possui um prédio bem antigo. Segundo a diretora, a estrutura física é inadequada para Educação Infantil e Fundamental I. O prédio passou por muitas reformas, mas estas não foram suficientes. A diretora acredita que o ideal é uma nova construção. Nesta escola também ocorre uma demanda grande de vagas, para pouco espaço físico, a profissional elencou em sua entrevista a ausência de diversos ambientes pedagógicos e de convivência. Faltam biblioteca, local para reuniões com os pais, telecentro e sala dos professores. O refeitório é pequeno.

Além da ausência de espaços escolares importantes e o número insuficiente de salas de aula, foram informadas outras necessidades de reforma e adequação das estruturas físicas das escolas. A necessidade de reformas na cantina foi a demanda apontada pela Escola 12. Na Escola 20 a profissional relatou a existência de uma sala de aula sem janela. O que compromete a ventilação. A nucleação, com anexo de duas escolas, fez com que a estrutura física da Escola 16 ficasse defasada, segundo sua diretora. Faltavam também banheiros para funcionários e para alunos menores. Existe a necessidade de adaptação também na Escola 03, cuja demanda é a construção de um banheiro infantil, o mesmo ocorre com a Escola 09. Esta necessita também de cobertura que ligue o prédio à quadra e manutenção em sua estrutura física.

Em grande parte das escolas da rede, podemos perceber que a estrutura física atual não atende às demandas. Apenas três dos 23 prédios pesquisados apresentam estrutura física adequada às suas 


\section{Desafios da psicologia no Brasil}

demandas de funcionamento. Destacamos que, dos prédios considerados adequados, um foi construído pelo estado(19), um pela União(07) e um por iniciativa da própria comunidade onde está localizado(13).

Família e escola são corresponsáveis na formação e no desenvolvimento dos alunos. A interação entre ambas é de extrema relevância. Ocorre que, às vezes, ocorre uma cisão entre as duas instituições. "Normalmente, quando o aluno aprende, tira boas notas e se comporta adequadamente, mães, pais e professores se sentem como agentes complementares, corresponsáveis pelo sucesso. Todos compartilham os louros daquela vitória. Mas, quando os alunos ficam indisciplinados ou têm baixo rendimento escolar, começam as disputas em torno da divisão de responsabilidades pelo insucesso. $O$ insucesso escolar deveria suscitar a análise de causas dos problemas que interferiram na aprendizagem, avaliando o peso das condições escolares, familiares e individuais do aluno. O que se constata é que, em vez disso, o comportamento mais comum diante do fracasso escolar é a atribuição de culpas, que geralmente provoca o afastamento mútuo." (MEC, 2009, p.31)

Procurando investigar acerca da participação da família no contexto escolar, perguntamos às diretoras se as famílias dos alunos são participativas. Algumas diretoras responderam considerar as famílias dos alunos de sua escola participativas, porém apresentaram ressalvas em suas respostas, demonstrando que as famílias participam, mas que sua participação é insuficiente, por não contemplar certas ações que consideram importantes. "Sim. Em reuniões bimestrais, quando são convocados. A diretora acredita que a participação poderia ser melhor em eventos e se inteirando da vida escolar dos filhos."(4) "Sim. Se chamar a família comparece. Porém ainda existe falta de interesse." (5)"Sim. Existem exceções. $80 \%$ mais ou menos são participativos em reuniões, festas, no caso de problemas de disciplina e aprendizagem. Às vezes, comparecem a escola, mas não atendem o que é necessário. Deu os exemplo dos encaminhamentos à especialista, quando os pais deixam de levar os filhos." (8)

Em outros casos, em que as diretoras consideram os pais participativos, foram excluídos da participação um grupo de pais. Destas respostas, compreende-se que nem todos os pais são participativos. "Ressalta que os pais que "mais precisam" participar não vem. Porém de modo geral, eles são participativos."(1)"Sim. Grande parte. Alguns pais específicos não participam."(15)"Sim. Poucos casos (geralmente os que mais precisam, não vem). Porém, as reuniões são lotadas."(18)"Sim. Participam de reuniões e festas. Os pais trabalham, mas participam na medida do possível. Faz a ressalva que não são todos." (23)“Sim. Razoável. São poucas as familias que não participam, porém, a 


\section{Desafios da psicologia no Brasil}

maioria trabalha."(12)“Sim. Muito disse que 90\% dos pais são participativos." (3)“Sim. 50\%. Até o 5o ano muito presentes. No 6ㅇ ano piora e no 70 ano a participação é muito pequena." (16)

Duas diretoras destacaram a diferença de participação entre familiares de alunos mais novos e familiares de alunos mais velhos. Ambas consideram que a família de alunos mais novos participam mais que as famílias de alunos mais velhos. "Não. O grande problema da escola. Falta cooperação na maioria. Os pais da Educação Infantil são mais participativos. No caso dos alunos maiores (3 ao 5o anos) é mais complicado." (11) "Sim. 50\%. Até o 50 ano muito presentes. No 60 ano piora e no 70 ano a participação é muito pequena." (16)

Respostas afirmativas acerca da participação da família foram reforçadas por explicações da forma como esta ocorre, por parte de algumas entrevistadas. "Sim. Considera que no ano de 2015 a participação aumentou com o fechamento de um turno. Pintaram a escola, capina, etc." (10)“Sim. Presença nas reuniões, atividades festivas e Hora Cívica. Na Virada da Educação também ocorreu muita participação." (13)“Sim. O número de participação tem crescido nos últimos meses. A supervisora chama os pais que não participam na reunião coletiva para conversa individual. Eles chamam isso de recuperação dos pais. Acredita que isso tem melhorado a participação." (14)“Sim. Sempre que são chamadas comparecem. Mães já colaboraram com mão de obra voluntária na escola. A escola sempre pode contar com a ajuda." (17) "Sim. Regra da escola: "Não trabalhar sem a família." A família atende a todos os chamados da escola. Reuniões de pais com presença boa. Questionadoras, interativas, participativas." (19) "Sim. "Até enxeridas". Opinam bastante quanto à merenda escolar." (20)

Em alguns casos, enfatizou-se que a família só comparece à escola em função de outras finalidades ou reforçadores, oriundos de interesses particulares. Nestes casos, as famílias não são consideradas participativas. "Não. Participam apenas em eventos com sorteios de brindes ou com lanches." (07) "Não. Poucas famílias acompanham. A maioria só vem se "obrigar". Tem que condicionar com presença/entrada do aluno." (21) “Não. As suspensões chegam à escola sem assinatura. Só comparece na escola se for para falar do Bolsa Família." (02)

Respostas negativas foram acompanhadas de explicações que fortaleceram a negativa em relação a participação dos pais. Isto ficou expresso em algumas entrevistas. "Não. Os pais alegam que trabalham e que não podem comparecer à escola." (02) “Não. Melhorou bastante, mas ainda não é." (09)

O mecanismos de participação da família identificados nas entrevistas demonstram serem insuficientes, pois as famílias atuam apenas como expectadoras ou como responsáveis pelos 


\section{Desafios da psicologia no Brasil}

problemas escolares dos alunos e dos comportamentos inadequados. Uma atitude bastante comum das técnicas e diretoras é a realização de encaminhamentos aos especialistas, demandando um diagnóstico e a consequente medicalização dos problemas escolares e dos comportamentos inadequados. Os problemas enfrentados no contexto escolar não são compartilhados com as famílias e as "soluções" passam longe de surgirem de um diálogo, representam imposições da visão da escola. O Conselho de Classe é um dos mecanismos capazes de articular uma participação democrática no contexto escolar. Em sua constituição participam os diversos agentes do contexto escolar: Diretor, Técnico, Professor, Pais e alunos. Este mecanismo parece ser inexistente na Rede, pois nenhuma das entrevistadas o citou.

\section{CONCLUSÕES}

As análises apresentadas representam uma forma de organizar e entender o grande volume de trabalho atribuído ao Setor de Psicologia, enquanto componente da Secretaria Municipal de Educação. As demandas, em sua maioria, são constituídas pelos "encaminhamentos individuais". Isso confirmou que o trabalho de atendimento clínico e individual perpassa o imaginário dos atores envolvidos com as demandas escolares, tais como supervisores, professores, diretores e familiares, demonstrando a falta de entendimento da práxis da Psicologia escolar, que privilegia a perspectiva individualizante dos problemas escolares. Através das vivências, enquanto profissionais da área escolar, percebemos que o lugar que se delega a psicologia na educação frequentemente é o clínico. O papel destinado à este profissional é o de, fazendo juz ao posto de "especialista", diagnosticar e indicar as condutas diante de cada caso individual. O Diagnóstico Escolar implementado representa, antes de tudo, uma tentativa de "desconstruir" este lugar, analisando os problemas escolares de forma contextualizada e crítica. Acredita-se que o processo de medicalização, do qual pretendem que façamos parte, não leva em conta a realidade de nossas escolas públicas e tão pouco as contradições e valores de nossa sociedade. Consideramos a medicalização um assunto de fundamental importância e, por isso, será retomado em um estudo a parte.

Consideramos que as escolas vivenciam um acúmulo de funções, devido à ausência de diversas políticas públicas de assistência social e de saúde. As escolas recebem diversas demandas, as quais não conseguem atender, fazendo muitas vezes com que o ensino-aprendizagem fique em segundo plano, já que estas demandas são relativas a outros direitos fundamentais. As escolas recebem pouco apoio de equipe auxiliar, tais como Psicólogos e Assistentes Sociais, vinculados a Secretaria, pois tais profissionais são alocados para esta em número reduzido. 


\section{Desafios da psicologia no Brasil}

O diagnóstico foi uma tentativa de aprofundar o entendimento do Setor de Psicologia acerca de cada instituição escolar, fazendo com que o nosso esforço seja sempre no sentido de realizar intervenções que contemplem a complexidade dos problemas escolares. Ele pode ser considerado um passo importante no processo de estruturação dos serviços e intervenções que podem ser oferecidos pelo Setor de Psicologia. Contudo, consideramos que são necessárias pesquisas complementares com o objetivo de atualizar e de amplificar a compreensão da Rede Municipal de Ensino de Barbacena. Neste sentido, faz-se necessária a inclusão de outros atores e de outras perspectivas de apreensão e análise de dados. Seria importante a realização de trabalhos que contemplassem as perspectivas de professores e alunos e, ainda, outras dimensões do contexto escolar, como, por exemplo, condições de trabalho e ensino.

\section{REFERÊNCIAS}

Brasil (1990). Lei Federal 8.069/90, de 13 de julho de 1990. Brasília, DF.

Brasil. Ministério da Educação. Secretaria de Educação Especial. Saberes e práticas da inclusão: recomendações para a construção de escolas inclusivas. Brasília: Ministério da Educação. 2006.

Brasil. Ministério da Educação. Interação escola-família: subsídios para práticas escolares. Brasília: Ministério da Educação, 2009.

Brasil. Ministério da Educação. Secretaria de Educação Básica. Pradime : Programa de Apoio aos Dirigentes Municipais de Educação. Secretaria de Educação Básica. Brasília : Ministério da Educação, 2006.

GASPARIN, João Luiz. Prática social inicial do conteúdo: o que os alunos e o professor já sabem. In: Uma didática para a pedagogia histórico-crítica. Campinas: Autores Associados, 2007.

JOLY, Maria Cristina Rodrigues Azevedo. VECTORE, Célia (orgs.). Questões de pesquisa e prática em psicologia escolar. São Paulo: Casa do Psicólogo, 2006.

LERNER, Emilia Ferreiro Delia. OLIVEIRA, Marta Kohl de. Piaget-Vigotsky: Novas contribuições para o debate. São Paulo: Editora Ática: 2005.

LISBOA, Carolina. KOLLER, Silvia Helena. Interações na escola e processos de aprendizagem: fatores de risco e proteção. In: BORUCHOVITCH, Evely. BZUNECK, José Aloyseo (orgs.). Aprendizagem: Processos psicológicos e o contexto social na escola. Petrópolis: Vozes, 2004.

MEIRA, Marisa Eugênia Mellilo. Construindo uma concepção crítica de Psicologia Escolar: Contribuições da Pedagogia Histórico Crítica e da Psicologia Socio Histórica. In: BOCK, Ana Mercês Bahia. CHECCIA, Ana Karina Amorim. SOUZA, Marilene Proença Rebello de. (orgs) Psicologia Escolar: Teorias Críticas. São Paulo: Casa do Psicólogo, 2003. 


\section{Desafios da psicologia no Brasil}

MESQUITA, G. R. (2014). Configurações subjetivas de alunos com histórico de fracasso escolar. Tese de Doutorado, Instituto de Psicologia, Universidade Federal da Bahia, Salvador.

Minas Gerais. Secretaria de Estado de Educação de Minas Gerais. Programa de Educação AfetivoSexual-PEAS. Belo Horizonte: Secretaria de Estado de Educação de Minas Gerais, 2005.

MONTEIRO, Helena Rego. Medicalização da vida escolar. In: GOUVÊA, Guaracira. BITTENCOURT, Cristiane. MARAFON, Giovanna. (orgs). Pesquisas em educação. Rio de Janeiro: Sete Letras, 2007.

OLIVEIRA, Marta Kohl de. Pensar a educação: Contribuições de Vygotsky. In: CASTORINA, José Antônio.

OLIVEIRA, Eliana de. ENS, Romilda Teodora. ANDRADE, Daniela B. S. Freire. MUSSIS, Carlo Ralph de. Análise de Conteúdo e pesquisa na área da educação. Revista Diálogo Educacional, Curitiba, v. 4, n.9, p.11-27, maio/ago. 2003. 


\section{Desafios da psicologia no Brasil}

\section{NOTAS}

Notas 1

Programa do Governo Federal, executado por escolas de Ensino Fundamental, que realiza atividades no contraturno.

Nota 2

Entidade da Fundação João XXIII. 


\section{Capítulo 9}

\section{CRIANÇA COMO SER DE DIREITOS: IMPLICAÇÕES PARA O LAÇO SOCIAL}

DOI: $10.37423 / 200200170$

Camila Miranda de Amorim Resende (Mestre e Doutura em Psicossociologia de Comunidades e Ecologia Social pelo Programa EICOS/IP/UFRJ, Professora do curso de Psicologia do UGB - Volta Redonda Psicóloga do IFRJ-Pinheiral). camila.mdamorim@gmail.com

Ana Marla Szapird (Doutora em Psicologia pela PUC-Rio. Pós-Doutora pela Universidade de Vincennes, Raris 8. Professora Adjunta do Instituto de Psicologia e do Programa de Pós-Graduação em Psicossociologia de Comunidades e Ecologia Social UFRJ, Brasil). anaszapiro@uol.com.br
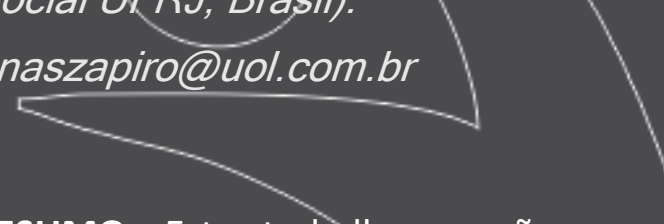

RESUMO: Este trabălho propõe uma discussão sobre um novo estatuto da criança compreendida como sujeito de direitos e suas implicações para o laço social. No contexto atual apontado por Supiot (2010) como marcado por um "mercado de direitos" todos, inclusive crianças, autorizam-se a reivindicar algum direito para o qual se reivindica igualmente a legislação que o corresponda. Delegar a criança a este lugar condữ a uma concepção de infância que se filia à ideia de um sujeito que se autoconstitui. Supostamente capaz de se autoconstituir, o sujeito contemporâneo sente-se cada vez mais liberado das determinações sociais, o que torna a relação com $\oint$ outro profundamente comprometida. Não por acaso, assistimos a situações de crianças e adoleseentes que, com dificuldades para impor coerções às suas vontades individuais, protagonizam diversos problemas no confronto com o limite.

PALAVRAS-CHAVE: criança; direitos; autoconstituição; laço social. 


\section{Desafios da psicologia no Brasil}

\section{INTRODUÇÃO}

O debate sobre os direitos da criança adquire nos dias atuais um lugar central nas sociedades que, no pós-guerra, dedicaram-se com ênfase ao trabalho de legislar acerca dos direitos do homem. Desde então, importantes tratados de proteção dos direitos humanos foram assinados e assim esta temática vem se desdobrando em uma série de debates sobre os direitos voltados a grupos específicos.

No Brasil, os direitos da criança tomaram corpo com a ampla divulgação do Estatuto da Criança e do Adolescente (ECA), promulgado no país em 1990. A implantação do ECA no Brasil e a consequente emergência de um conjunto de leis voltado à criança materializou um novo olhar do Estado sobre este público. Emergiu, a partir de então, um discurso sobre a criança concebida como "sujeito de direitos".

Este novo modo de conceber a criança implica em transformações não só no processo de constituição subjetiva, como também na sociedade de um modo geral, questão que vamos colocar aqui em discussão.

\section{A EMERGÊNCIA DE UM DISCURSO SOBRE A CRIANÇA COMO “SUJEITO DE DIREITOS"}

Até o fim da década de oitenta do último século, apenas as crianças órfãs, abandonadas, maltratadas ou então aquelas chamadas delinquentes eram alvo das ações de proteção do Estado. Estas eram, inicialmente, colocadas em asilos para órfãos, costume que foi prática corrente no Brasil no século XIX. Rizzini e Pilotti (2011) ressaltam que esta prática de recolher crianças em asilos deu origem, no Brasil, a uma cultura institucional denominada como "assistência ao menor" e considerada, na época, a melhor forma de assistência a esta população. Novas propostas, com o tempo, substituíram o asilo pelas "escolas de preservação", educandários, institutos, entre outros, mas mantinham a cultura institucional como a melhor forma de assistência a este público.

Esses autores chamam atenção para a década de vinte do século passado, quando ocorreu o I Congresso Brasileiro de Proteção à Infância. Este abriu a discussão que culminou em normas que visavam à proteção dos chamados "menores abandonados". Ainda na década de vinte, mais especificamente em 1927, foi criado o Código de Menores - por meio da lei 17.943-A - que se destinava a legislar sobre o menor que era então entendido, segundo Rizzini (1993, p. 96), como o que é

(...) proveniente de família desorganizada, onde imperam os maus costumes, a prostituição, a vadiagem, a frouxidão moral e mais uma infinidade de 


\section{Desafios da psicologia no Brasil}

características negativas, tem a sua conduta marcada pela amoralidade e pela falta de decoro, sua linguagem é de baixo calão, sua aparência é descuidada, tem muitas doenças e pouca instrução, trabalha nas ruas para sobreviver e anda em bandos com companhias suspeitas.

Este Código, permeado pelos ideais higienistas da época, considerava estes menores portadores de acentuados defeitos morais e defendia que só por meio da exclusão da sociedade, realizada através da internação dos mesmos em reformatórios, seria possível corrigi-los ou controlá-los (BRITO, 2000).

Este modelo de intervenção começou a se modificar em meados do século XX, no contexto do pósguerra, por influência da adoção pela Organização das Nações Unidas da Declaração Universal dos Direitos Humanos. Uma nova compreensão sobre a infância se expressou através de um Novo Código de Menores Brasileiro estabelecido por meio da lei 6.697 de 10 de outubro de 1979. Baseado então na doutrina de situação irregular, como assinala Brito (2000), o Novo Código compreendia todos os menores de idade considerados vítimas ou em situação irregular e atribuía aos mesmos um ajuda clínico-terapêutica e não mais a prática de exclusão social que antes imperava.

Apesar das mudanças deste Novo Código, o olhar do Estado brasileiro continuava se voltando unicamente para algumas crianças e adolescentes. Interessava legislar apenas sobre os chamados "menores abandonados", o que remetia a uma situação de irregularidade ligada a uma ausência da família. Nos demais casos, a interferência do Estado era praticamente nula.

Vamos encontrar no texto da Constituição Federal de 1988 o início de um discurso sobre a criança e o adolescente como "sujeitos de direitos". Passou a ser garantido a este público, a partir do artigo 227 da referida Constituição, o direito “à vida, à saúde, à alimentação, à educação, ao lazer, à profissionalização, à cultura, à dignidade, ao respeito, à liberdade e à convivência familiar e comunitária".

A então doutrina da situação irregular que embasava o trato do Estado com a infância e a adolescência até então foi substituída por outra doutrina, a da proteção integral de crianças e adolescentes. Estes passaram a ter seus direitos explicitamente regulamentados a partir da criação, em 1990, do Estatuto da Criança e do Adolescente (ECA), implantado pela Lei Federal n 8.069 de 1990 em consonância com o artigo 227 da Constituição Federal de 1988 e com a Convenção sobre os Direitos da Criança.

Um conjunto de direitos voltados à infância foi, pouco a pouco, sendo apropriado subjetivamente de modo que se constitui hoje em um universo discursivo que comporta uma diversidade de demandas, 


\section{Desafios da psicologia no Brasil}

muitas delas por parte das crianças, agora porta-vozes de reivindicações relativas aos seus direitos. Esta forma de apropriação do discurso sobre a criança como "sujeito de direitos" está, não por acaso, em consonância com uma tendência atual mais geral do campo jurídico e que pode ser examinada como parte das transformações societárias da contemporaneidade.

Supiot em "L'esprit de Philadelphie" (2010) analisa estas transformações do ponto de vista da demanda de inserção nas leis destes novos direitos denominando tal fenômeno de "law shopping", ou "mercado de direitos". O autor interpreta o fenômeno como uma tendência no campo jurídico ao abandono da Lei como lugar universal em favor de uma proliferação de "leis" de cada caso, segundo a ideia de que a liberdade individual deve se sobrepor ao caráter de universalidade da Lei, esta baseada na discussão sobre o bem comum. Deste modo, a cada momento, e pautando-se nas escolhas individuais, emergem demandas sempre renovadas por "novos direitos" que têm resultado em uma proliferação de leis e regulamentações onde a Justiça é chamada a responder legislando caso a caso, em nome da liberdade individual.

Essa cultura jurídica, destaca ainda Supiot (2005), uma vez dominada pela concepção de "common law", determina que a fonte primeira do Direito seja buscada em precedentes, em casos decididos anteriormente pelo juiz, e não segundo diretrizes traçadas pelo Estado. Assim, o Direito tende a diluir em um conjunto de direitos individuais. "Distribuem-se os direitos como se distribuíssem armas e depois, que ganhe o melhor! Assim debitado em direitos individuais, o Direito desaparece como bem comum." (Supiot, 2005, p.21). Estamos, deste modo, diante de um progressivo enfraquecimento da concepção do Direito como instância reguladora comum a todos. Neste sentido, como observa Dufour (2008), é a ideia de um "fazer justiça" que se sobrepõe ao ato de fazer valer a lei. O princípio destas duas ações, ele argumenta, é bastante divergente, uma vez que aplicar a lei “(...) implica na existência de um terceiro imparcial acima dos interesses particulares, ao passo que o fazer justiça implica apenas resolver conflitos de interesses entre duas pessoas" (Dufour, 2008, p. 223).

Neste novo contexto de "mercado de direitos", todos, adultos, jovens e crianças, passam a reivindicar o direito de que se considerem merecedores. Transformam-se, assim, sem distinção no que diz respeito à etapa da vida em que se encontram, em consumidores de direitos. Deste modo, encontramos nas varas de família crianças pleiteando fazer valer seus direitos, em especial nos casos de guarda nos quais este público ganha cada dia mais voz e poder de decisão. A possibilidade de escolha nestas situações pode, no entanto, ter importantes efeitos, nem sempre positivos, para as 


\section{Desafios da psicologia no Brasil}

próprias crianças, que na maior parte dos casos podem ainda não possuir os recursos psíquicos necessários à sustentação das escolhas que devem fazer. Diferentemente do adulto que, como tal, presume-se poder escolher com a compreensão do que envolve suas escolhas, a, criança, pela sua condição, ainda não possui os recursos psíquicos necessários à sustentação do lugar nem sempre confortável que implica a liberdade de escolha.

O fato de a criança poder decidir não tendo ainda maturidade psíquica para tal é sublinhado por Théry (2007) como um paradoxo nas legislações sobre os direitos da criança. Segundo esta autora, estas legislações apontam para dois sentidos, não somente diferentes, mas contraditórios. O primeiro diz respeito ao direito de seres humanos vulneráveis, não autônomos, que reconhecidamente necessitam e por isto têm como direito assegurado a proteção do Estado. Há, no entanto, outro sentido, cada vez mais afirmado hoje. Consiste em "libertar" as crianças de uma "dominação adulta", baseando-se na Estes dois sentidos dos direitos da criança ficam visíveis nas leis quando afirmam que as crianças têm direito à proteção e ao cuidado, mas que têm igualmente direito à liberdade de opinião, de expressão, de pensamento, entre outros. A Declaração dos Direitos da Criança, ideia de que elas muito têm a ensinar aos adultos.

adotada em 20 de novembro de 1959 pela Assembleia Geral das Nações Unidas destaca que "a criança, por motivo de sua falta de maturidade física e intelectual, tem necessidade de uma proteção e cuidados especiais (...)" (ONU, 1959, p. 1). A Convenção sobre os Direitos da Criança, por sua vez, ressalta em seu início esta última afirmação da Declaração dos Direitos da Criança e, no mesmo documento, em seu artigo treze, destaca:

A criança tem direito à liberdade de expressão. Este direito compreende a liberdade de procurar, receber e expandir informações e ideias de toda a espécie, sem considerações de fronteiras, sob forma oral, escrita, impressa ou artística ou por qualquer outro meio a escolha da criança. (UNICEF, 1989, p. 11)

Ao invés de uma liberdade como algo a ser conquistado, a liberdade é, neste contexto, concebida como uma espécie de direito inato de todos... O homem contemporâneo seria, assim, já inicialmente, livre. Transformado em seu próprio empreendedor deve apenas a si mesmo a sua própria liberdade. O ECA e os outros documentos voltados ao discurso sobre os direitos da criança, a nosso ver, exaltam tal pensamento. Ainda que enfatizem a criança como um ser em desenvolvimento, afirmam como centro de suas proposições uma concepção de um estado de liberdade inerente ao ser criança, o que se filia à ideia de um sujeito que se autoconstitui. 


\section{Desafios da psicologia no Brasil}

\section{TRANSFORMAÇÕES NA IDEIA DE INFÂNCIA E SUAS IMPLICAÇÕES PARA O VIVER JUNTO}

A concepção de um sujeito se constitui por si mesmo, sem que um outro da sociedade lhe transmita o que quer que diga respeito aos valores e códigos próprios à experiência do viver juntos, nos remete a importantes transformações em curso na atualidade. Arendt (2009)

As analisa e sublinha que destas mudanças resulta uma verdadeira "crise na educação" que está associada a transformações nas relações com a autoridade, com a parentalidade, no sentido de um questionamento quanto à diferença hierárquica de lugares, como entre pais e filhos. Nas palavras de Arendt (2009, p. 129):

\footnotetext{
A relação autoritária entre o que manda e o que obedece não a a se assenta nem na razão comum nem no poder do que manda; o que eles possuem em comum é a própria hierarquia, cujo direito e legitimidade ambos reconhecem e na qual ambos têm seu lugar estável predeterminado.
}

O estado adulto consistiria, assim, em um estado diferenciado da infância que, para ser atingido, demandaria a passagem por um processo de educação que, por sua vez, requereria a ajuda da geração que a precede. Concepção esta distinta da de "sujeito de direitos" que compreende crianças, jovens e adultos como igualmente "consumidores" dos direitos que lhes convier.

Indistinção de papéis entre "ser adulto" e "ser criança" característica desta concepção dificulta aos pais assumir a função de "apresentar" as regras da sociedade aos filhos. Tradicionalmente as gerações se distinguiam pelos diferentes lugares que ocupavam na transmissão, cabendo aos mais velhos transmitirem aos mais novos os elementos que os instituíam na cultura. Aos pais cabia introduzir os filhos na sociedade, assumindo "(...) a responsabilidade, ao mesmo tempo, pela vida e desenvolvimento da criança e pela continuidade do mundo" (ARENDT, 2009, p. 235). Aos pais, primeiros outros na vida dos filhos, cabia, deste modo, a tarefa de transmitir regras e valores da sociedade e desta forma os limites que a vida em sociedade impõe.

A criança seria assim cuidada e preparada pela família para o exercício do convívio social. Seu processo gradual de preparação para a vida em sociedade prosseguia com a adição da escola que tinha também um importante papel a cumprir. O educador seria, como ressalta Arendt (2009), um outro representante do mundo para a criança assumindo, ele também, a função de ajudar a criança a compreender as regras do mundo em que vivemos. 


\section{Desafios da psicologia no Brasil}

Neste cenário de valorização da transmissão das regras do viver em sociedade, a criança é concebida como um novo ser humano em formação que necessita ser protegido "para que nada de destrutivo Ihe aconteça de parte do mundo" (Arendt, 2009, p.235) que, por sua vez, necessita de proteção “(...) para não ser derrubado e destruído pelo assédio do novo que irrompe sobre ele a cada nova geração" (Arendt, 2009, p.235). A educação é, assim, nas palavras da autora:

(...) o ponto em que decidimos se amamos o mundo o bastante para assumirmos a responsabilidade por ele e, com tal gesto, salvá-lo da ruína que seria inevitável não fosse a renovação e a vinda dos novos e dos jovens. A educação é, também, onde decidimos se amamos nossas crianças o bastante para não expulsá-las de nosso mundo e abandoná-las a seus próprios recursos, e tampouco arrancar de suas mãos a oportunidade de empreender alguma coisa nova e imprevista para nós, preparando-as em vez disso com antecedência para a tarefa de renovar um mundo comum. (Arendt, 2009, p. p. 247)

Partindo desta compreensão sobre a educação, caberia, portanto, à geração precedente assumir uma dupla responsabilidade que concerne tanto à vida e ao desenvolvimento da criança, como à manutenção do mundo. Legendre (1996) a isto denomina transmissão genealógica, referindo-se a esta transmissão que diz respeito ao conjunto dos sistemas institucionais fabricados pela humanidade para sobreviver e continuar. Um sistema genealógico é, então, um jogo de referências que, como tal, funciona como um amparo para que o sujeito caminhe. A criança, nesta perspectiva, seria um elo da cadeia transgeracional, anterior e muito maior do que ela. A criança seria, desta forma, preparada para viver em sociedade por aqueles que tomaram para si o encargo da questão da sua origem, a geração precedente. A função parental implicaria, neste sentido, em uma dívida para com a geração precedente, dívida que se transmite de geração em geração, inerente ao processo de transmissão genealógica (Hurstel, 2006).

O discurso das crianças como "sujeito de direitos" reforça, no entanto, a possibilidade de se pensar em um sujeito pretensamente "pronto", "completo", como frisou Supiot (2005), uma vez que não lhe é demandado nenhum tipo de preparação para usufruir de seus direitos. Do mesmo modo, contribui para a indistinção entre o que é ser criança e o que é ser adulto, já que ambos tem igualmente garantida a reivindicação de seus direitos.

A criança sujeito de direitos tende, assim, a não ser mais compreendida como um "recém-chegado" a um mundo preexistente, o que demandaria aprender sobre as regras do mundo, dentre elas aquelas que dizem respeito à complexidade da vida coletiva. A afirmação de uma liberdade como um "direito 


\section{Desafios da psicologia no Brasil}

inato" e não como algo a ser conquistado parece se sobrepor a qualquer outro princípio, até mesmo ao da dependência inicial do pequeno ser quando chega ao mundo.

Supostamente capaz de se autoconstituir, a criança seria concebida, portanto, como desligada da cadeia geracional, o que implicaria em uma fragilização do processo de transmissão genealógica. Neste sentido, assistimos hoje a um desenraizamento do sujeito das instâncias coletivas cujo efeito é, nos parece, uma incapacidade psíquica de compreensão do que o viver junto nos impõe. Acreditando-se liberada de todo o compromisso com o laço social, renunciar, limitar a liberdade e a autonomia em prol de uma construção coletiva, passa a ser visto como algo desvalorizado.

Estaríamos, pois, experimentando uma espécie de viver junto "sem amarras". Liberado da dívida com o outro, uma nova compreensão de sujeito e do viver coletivo parece emergir. Assim, para este novo sujeito, é "difícil representar, em geral, a dimensão do público, o que interessa ou deveria interessar todo mundo (...)". (Gauchet, 2009, p. 252)

Deste modo, num mundo em processo de acelerada destradicionalização, onde o último lócus de relações hierárquicas - a família - vem passando igualmente nas últimas décadas por transformações enormes as figuras parentais parecem ter dificuldades de exercer sua função de autoridade.

Neste sentido, o que está em jogo é o processo de interdição do sujeito. De acordo com a tese freudiana (1930[1929]/1996), é através do interdito ao desejo incestuoso, à agressividade, e à raiva infantil, que a criança pode perceber o limite à sua onipotência, uma vez que a interdição a tornará capaz de sublimar, capaz de construir caminhos de expressão na cultura para a sua energia de modo a torná-la capaz de viver a vida coletiva.

É então através da interdição que o sujeito inicia um processo de deslocamento de si como ideal, onde reina a onipotência originária, para tomar como ideal algo que a transcende.

Existiria, portanto, nesse momento, um processo de "desfalicização" que conduziria o sujeito à experiência de alteridade. Isto implica no descentramento do sujeito do "eu ideal" e na perda da arrogância fálica, é o que tornará possível ao sujeito caminhar no sentido de dar lugar ao outro, reconhecendo-o como tal - fundamentalmente diferente - e não como simulacro de si mesmo. Desta forma, é através da experiência de interdição que o sujeito é inscrito num sistema de filiação e de reconhecimento do outro. Se os pais, no entanto, se encontram desprovidos de autoridade é o trabalho de socialização e de renunciar ao todo-poder infantil que está em risco. 


\section{Desafios da psicologia no Brasil}

\section{CONSIDERAÇÕES FINAIS}

As transformações em curso na sociedade ressoam, sem dúvida, na concepção de todos e igualmente da criança como "sujeito de direitos". Esta concepção supõe, como aqui salientamos, uma espécie de autonomia "inata' do sujeito. Observamos a consonância desta concepção de sujeito com a emergência de um "mercado de direitos" (Supiot, 2010). A diversidade de reivindicações de crianças ligadas aos seus desejos contribui para fazer surgir um modo de constituição subjetiva que nomeamos aqui, seguindo outros autores como Dufour (2005), de autoconstituição. Segundo esta concepção, os limites e restrições à liberdade é que impediriam o desenvolvimento do sujeito em todas as suas potencialidades.

Não por acaso, assistimos a situações de crianças e adolescentes que protagonizam diversos problemas no confronto com o limite. Sentimentos e atitudes de crianças e adolescentes muitas vezes incompreensíveis para os pais e que os levam à clínica psicológica e psiquiátrica estão relacionados à busca de sentido diante da falta de um trabalho de interdição, de educação, que possibilite ao sujeito a experiência fundamental da falta, do limite.

Nesta perspectiva, compreende-se porque em alguns casos, crianças e jovens que num momento qualquer em suas vidas encontram algo que lhes coloque diante da perda, por exemplo, um fracasso escolar ou amoroso, não encontram recursos psíquicos próprios para enfrentar essa situação. Assim, surgem comportamentos que parecem desproporcionais em relação à situação, passando rapidamente a episódios de violência contra si mesmo e/ou comtra o outro. Exemplos destas situações se multiplicam nos ambulatórios da clínica infanto-juvenil, indicando a urgência de uma reflexão sobre a concepção de que a criança seria um sujeito autônomo.

\section{REFERÊNCIAS}

Arendt, H. (2009). Entre o passado e o futuro (M.W. Barbosa, Trans.). São Paulo:Perspectiva.

Brito, L. (2000). Avaliação dos adolescentes pelas equipes que atuam no sistema socioeducativo. In L. Brito (Eds.), Jovens em conflito com a lei. Rio de Janeiro: Eduerj, 115-126.

Dufour, D.-R. (2005). A arte de reduzir as cabeças: sobre a nova servidão na sociedade ultraliberal (S.R. Felgueiras, Trans.). Rio de Janeiro: Companhia de Freud.

Dufour, D.-R. (2008). O divino mercado: a revolução cultural liberal (P. Abreu, Trans.). Rio de Janeiro: Companhia de Freud.

Gauchet, M. (2009). A democracia contra ela mesma. São Paulo: Radical Livros. 


\section{Desafios da psicologia no Brasil}

Freud, S. (1996). O mal-estar na civilização. In S. Freud (J. O. A. Abreu, Trans.) O futuro de uma ilusão. O mal-estar na civilização e outros trabalhos (Vol. 21). Rio de Janeiro: Imago. (Trabalho original publicado em 1930[1929]), 67-150.

Hurstel, F. (2006). Autoridade e transmissão da "dívida de vida": uma função fundamental dos pais. Epistemo-somática, III, 163-173.

Legendre, P. (1996). El inestimable objeto de la transmisión: estudio sobre el principio genealógico en Occidente (I. V. Núñez, Trans.). México: Siglo XXI Editores.

ONU. (1959). Declaração dos direitos da criança. Proclamada pela Resolução da Assembleia Geral 1386 (XIV), de 20 de Novembro de 1959. Retirado de http://www.gddc.pt/direitos-humanos/textosinternacionais-dh/tidhuniversais/dc- declaracao-dc.html

Rizzini, I. (1993). O elogio do cientifico: a construção do "menor" na pratica Jurídica. In:

Rizzini, I.. (org.) A criança no Brasil hoje: desafio para o terceiro milênio. Rio deJaneiro: Editora Universitária Santa Úrsula, 81-100.

Rizzini, I., \& Pilotti, F. (2011). A infância sem disfarces: uma leitura histórica. In I. Rizzini \& F. Pilotti, A arte de governar crianças: a história das políticas sociais, da legislação e da assistência à infância no Brasil. São Paulo: Cortez, 15-30.

Supiot, A. (2005). Homo juridicus: ensaio sobre a função antropológica do direito (J. Chaves, Trans.). Lisboa: Éditions du Seuil.

Supiot, A. (2010). L'esprit de Philadelphie: la justice sociale face au marché total. Paris: Seuil.

Théry, I. (2007). Novos direitos da criança - a poção mágica? In S. Altoé (Eds.), A lei e as leis: direito e psicanálise. Rio de Janeiro: Revinter, 135-161.

UNICEF. (1989). Convenção sobre os direitos da criança. Nova lorque: UNICEF. Retirado de http://www.unicef.pt/docs/pdf_publicacoes/convencao_direitos_crianca2004.pdf 


\section{Capítulo 10}

\section{A (AUTO) FORMAÇÃO E O DESAFIO DA DOCÊNCIA NUMA PERSPECTIVA (AUTO) BIOGRÁFICA ${ }^{1}$}

DOI: $10.37423 / 200200171$

MARTINES, Elizabeth Antônia Leonel de Moraes

bethmartines@gmail.com

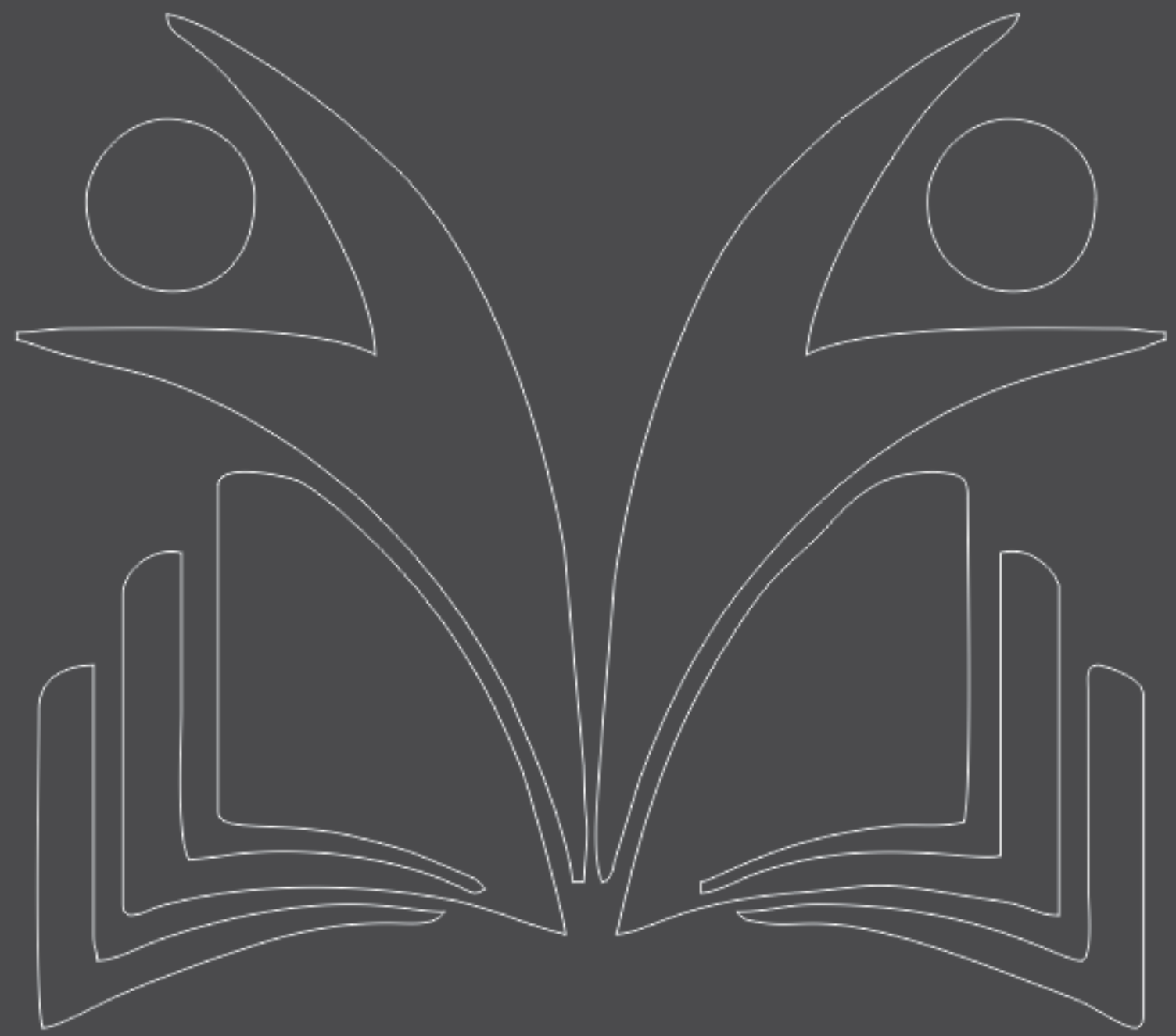




\section{Desafios da psicologia no Brasil}

\section{INTRODUÇÃO}

Este trabalho refere-se à experiência de uma professora com um aluno do curso de Licenciatura em Ciências Biológicas da Universidade Federal de Rondônia (UNIR) ao se defrontar pela primeira vez com a complexidade da atividade docente e do processo de formação que se desenvolveu em colaboração com sua orientadora ao longo do estágio supervisionado e de outras experiências de aprendizagem que ocorreram no mesmo período.

Do ingresso na universidade com o desejo de ser um pesquisador à certeza da escolha da profissão docente, as intensas experiências vivenciadas em sua formação acadêmica propiciaram momentos de aprendizado e descoberta que têm lugar de destaque na vida profissional e pessoal dos envolvidos. $O$ cenário dessa marcante experiência foi uma escola pública na periferia de Porto Velho / RO. A escola havia convidado a UNIR para ajudá-la a desenvolver atividades que ampliassem a utilização do laboratório de ciências, construído e equipado com recursos da escola, mas que não vinha sendo bem aproveitado como um espaço de aprendizagens e descobertas.

Em 2008, foram enviados àquela escola alunos do curso de Licenciatura em Ciências Biológicas em fase de estágio curricular e que previa uma pesquisa-ação colaborativa. As atividades desenvolvidas durante a primeira etapa do estágio da licenciatura nos anos finais do ensino fundamental (6 ao 9은 anos) ajudaram a realizar um diagnóstico inicial como, por exemplo: estrutura e funcionamento da escola; condições sócio-econômicas da clientela atendida; relações entre professores, alunos e coordenadores e da escola com a comunidade; nível cognitivo, clima afetivo e organização das aulas (Krasilchik, 2004).

De posse do diagnóstico (etapa de observação) os estagiários e supervisores / orientadores passam a planejar sequências didáticas, material e recursos pedagógicos e instrumentos de avaliação para a etapa de regência de aulas em turmas de séries finais do ensino fundamental e de projetos de participação, relativamente aos problemas identificados ou projetos em andamento na escola.

No caso desta escola, o projeto de participação seria com aulas práticas no laboratório, mas, ocorreram alguns problemas que inviabilizaram as mesmas. Entretanto, no âmbito da relação alunosprofessores, durante as aulas de Ciências de turmas de sexto ano, se percebeu uma intensa agitação dos alunos, o que era entendido por muitos professores como sendo indisciplina e desinteresse pelos conteúdos escolares. Os problemas testemunhados geravam situações de não aprendizado de turmas 


\section{Desafios da psicologia no Brasil}

inteiras e, além disso, infligiam aos professores um grande desgaste emocional para lidar com essas turmas, tidas como "problemáticas" e percebidas como "sem solução" pela maioria deles.

Em situações como estas, é comum encontrarmos explicações - tanto nos relatórios de estágio, nas falas dos professores e na literatura (Collares \& Moysés, 1996; Patto, 1996) em fatores relativos ao contexto sócio-econômico, problemas familiares ou mesmo incapacidades dos alunos, sem uma correspondente intervenção pedagógica em busca de alternativas. Entretanto, alguns estudos sugerem que o conteúdo que se pretende ensinar também é um fator que pode estar interferindo no interesse e aprendizado dos alunos.

O problema da falta de aproveitamento escolar causado pelos "atos de indisciplina" dos alunos nos incomodou profundamente. A escola já havia chegado à metade do ano letivo e tanto professores como coordenação pedagógica não tinham feito nenhum trabalho específico para tentar resolver aquele problema. O convite da escola, é verdade, fora feito para dar suporte no uso do laboratório, mas o que foi visto nos sextos anos pedia uma intervenção imediata. Buscando encontrar alternativas para esse problema negociou-se com a escola a implantação de um projeto de extensão para ser executado com essas "turmas problemáticas".

Com o aceite por parte das professoras e coordenadoras, foi realizado o planejamento de um pequeno projeto de intervenção participativa que chamamos "Conhecendo a si mesmo" e com o apoio do Programa Institucional de Bolsa de Iniciação à Docência (CAPES) foram executadas as ações previstas, com replanejamentos ao longo do mesmo para adequação às necessidades e condições encontradas ao longo do último bimestre do ano letivo de 2009.

Essas experiências e as que se seguiram com o desenvolvimento do estágio no ensino médio pelo estagiário, seu registro, a avaliação e reflexão realizadas com a colaboração da orientadora permitiram uma identificação de pontos que poderiam ser melhorados e evidenciam aprendizagens profissionais que foram descritas e analisadas em um texto monográfico, de forma autobiográfica, dentro de um contexto de investigação-formação profissional (Ferreira, 2012).

O texto está organizado da seguinte forma: uma seção em que se apresenta o referencial teórico-metodológico: (Auto)formação e (auto)biografia na formação docente, a segunda seção descreve a primeira experiência docente do estagiário, a seguir relata-se a experiência de um projeto 


\section{Desafios da psicologia no Brasil}

de extensão sobre educação sexual com alunos de 6‥ Ano e na última seção se apresenta a formação docente com o projeto do clube de ciências seguida das conclusões da autora.

\section{(AUTO) FORMAÇÃO E (AUTO)BIOGRAFIA NA FORMAÇÃO DOCENTE}

O modelo de formação de professores adotado pelo grupo de pesquisa coordenado pela pesquisadora/orientadora Laboratório de Ensino de Ciências (EDUCIENCIA) (Martines et al., 2010) assume que a realidade social, na qual se inserem as escolas e a prática docente, é historicamente construída, situada, complexa e em processo permanente de transformação. O conhecimento da disciplina a ser ensinada e o domínio de um kit de ferramentas técnicas é necessário, mas insuficiente para uma boa docência e a reflexão sobre os complexos processos em que se inserem as práticas docentes se faz necessária (Bruner, 2001; Pozo, 2002; Sacristán \& Gómez, 1998).

Assim, o grupo atua dentro de um paradigma no qual a docência vem deixando de ser considerada um sacerdócio ou apostolado (uma vocação) e o professor vai conquistando o status de profissional, que necessita cada vez mais de alta qualificação para exercer com responsabilidade e autonomia sua prática de formação de novas gerações, numa sociedade complexa, mutante e contraditória. (Nóvoa, 1992; Goodson, 2007; Bruner, 2001; Pozo, 2002).

Além disso, a grande produção de conhecimento nas diversas áreas e a expansão da tecnologia (acelerada pela popularização do computador e da Internet) produz a necessidade de formação continuada de professores e professoras para o desenvolvimento profissional, relacionando teoria com a prática, através da reflexão e/ou da pesquisa-ação (professor-pesquisador) em torno do currículo escolar (Schön, 1983, 1992; Stenhouse, 1991).

Paralelamente, desde a década de 1990, vários pesquisadores/formadores (Josso, Dominicé, Pineau, Delory-Momberger, Nóvoa entre outros) vêm sistematizando conhecimentos a respeito da formação docente que desenvolveu a noção de formação permanente, a qual inclui a compreensão de (auto)formação, isto é, que "[...] é o sujeito que se forma e forma-se a partir das experiências que viveu e das aprendizagens que construiu, ao longo da vida." (Souza, 2010, p. 163).

Esse processo de formação e o tipo de aprendizagem que predomina no adulto - aprendizagem narrativa - (Goodson, 2007; Bruner, 2001) cruzam história de vida pessoal com história de formação e acabaram consolidando um novo modelo de formação de professores em que há toda uma valorização da história de vida e da trajetória de formação, da necessidade de reflexão sobre: a prática, 


\section{Desafios da psicologia no Brasil}

os conteúdos e técnicas adotadas em sala de aula, os fins da educação e os objetivos educacionais propostos, as teorias que subsidiam o currículo prescrito, planejado e o currículo em ação, bem como sua avaliação.

A pesquisadora/orientadora e seu orientando passaram, então, a planejar atividades dentro deste referencial teórico-metodológico para a realização do estágio supervisionado da licenciatura e fizeram à escola a proposta de realização de uma intervenção pedagógica a ser desenvolvida na forma de uma pesquisa ação colaborativa, seguindo a proposta de Carr, Kemmis e Wilkinson, que apresenta três condições: 1) a colaboração entre diferentes atores (pesquisadores, professores, técnicos e estudantes em processo de formação); 2) a coprodução de conhecimentos e 3) ciclos sucessivos de reflexão crítica (Pereira \& Zeichner, 2002). Nesse processo, o conhecimento prático dos professores em formação deve se articular ao conhecimento teórico, bem como a reflexão sobre a prática e os saberes dos professores, devem levar os pesquisadores a rever a teoria, no processo de compreensão das vicissitudes da prática docente. (Ibiapina, 2008).

A seguir, reflete-se sobre a primeira experiência docente de um aluno da licenciatura e como esta impactou o projeto de estágio supervisionado desta dupla aluno de graduação-orientadora de estágio supervisionado e de Trabalho de Conclusão de Curso (TCC).

\section{A PRIMEIRA EXPERIÊNCIA DOCENTE}

A primeira experiência docente do referido aluno de graduação aconteceu durante a fase de estágio curricular obrigatório do curso de licenciatura em uma escola da periferia de Porto Velho, capital do estado de Rondônia, que aqui não será identificada para fins de preservação da instituição e das pessoas com quem interagimos nesse processo, mas se assemelha a tantas instituições escolares existentes neste país.

Ao analisar os registros da etapa de observação do estágio supervisionado (1ạ. Etapa) nos deparamos com o seguinte texto escrito pelo estagiário:

Naquele dia, eu acompanhei a professora de Ciências em suas três últimas aulas durante a manhã nos $6^{\circ}$ anos $\mathrm{A}, \mathrm{E}$ e F. $\mathrm{O} 6^{\circ} \mathrm{A}$, segundo a professora, era uma das turmas mais comportadas. A primeira aula de observação transcorreu normalmente. Os alunos do $6^{\circ}$ ano $A$, e mais outras duas turmas, não receberam livro didático de Ciências. A professora tinha, então, sempre que começar a aula distribuindo para os alunos livros pegos emprestados da biblioteca da escola. Isso, além de atrasar a aula, também prejudica o aprendizado dos alunos, já que eles não podem levar o livro para casa e é 


\section{Desafios da psicologia no Brasil}

apenas dentro de sala de aula que eles podem usar o livro para estudar. Dos 50 minutos de aula, grande parte era perdida com aplicação de resumo no quadro pela professora. Esse resumo é a única fonte de informações dado pela escola aos alunos para que eles pudessem estudar. A turma de modo geral é bem comportada e organizada. No dia da observação, foi feita uma correção de um exercício da aula anterior sobre "O ar e suas propriedades" e o resto do tempo os alunos usaram para realizar uma nova atividade usando o livro didático. Para as turmas que não ganharam livros, as atividades são sempre realizadas dentro de sala de aula. As turmas seguintes em que fiz observação, os $6^{\circ}$ anos $E$ e $F$, são referidas pela professora como a "filhos do cão" e "turma dos reprovados", respectivamente, dado a grande dificuldade que ela tem em dar aula nessas turmas. Os alunos eram muito bagunceiros, indisciplinados, atrapalhavam constantemente a aula da professora e a condição de limpeza da sala era insuficiente. A professora chamava constantemente a atenção de alunos, trocava-os de lugar para reduzir as conversas paralelas e, em casos extremos, chegava a expulsar alunos de dentro de sala, dizendo "Vá passear no pátio, vá bonitinho". Explicava-se dizendo que essa era a única maneira de conseguir dar aula, já que não adiantava chamar-lhes a atenção repetidas vezes e trocá-los de lugar. Diante das expulsões, a turma ficava mais silenciosa, mas não menos dispersa. Pelo seu mal comportamento durante as aulas, os $6^{\circ}$ anos $\mathrm{E}$ e $\mathrm{F}$ não eram levados para o laboratório de Ciências para realização de experiências. Era uma forma de punição aplicada pela professora para obter mais tranquilidade durante suas aulas. Se a turma se comportasse bem, eram levados para o laboratório, se não, permaneciam dentro de sala de aula realizando exercícios chatos e entediantes. Parece que esse método, por vezes, funcionava. Quando não bagunçavam muito a turma ganhava como prêmio uma aula no laboratório de Ciências. Mesmo assim, tal método é questionável. Sempre que nos dirigíamos para as turmas $\mathrm{E}$ ou $\mathrm{F}$, eu podia perceber a alteração de humor da professora. Seu estresse ficava elevado e sua animação da aula anterior decaia. (...) 0 desânimo e o descontentamento de entrar no $6^{\circ} \mathrm{F}$ aumentaram ainda mais depois do relato dela de um episódio de briga que acontecera entre alunos e no qual ela acabou sendo atingida por um golpe na testa e tendo o pé ferido quando tentava apartar os briguentos (Ferreira, 2009).

No momento de definir em que turmas seria feita a última etapa do estágio supervisionado nas séries finais do ensino fundamental - a regência-, a professora definiu que uma delas seria o 60 E. Para o estagiário, chegar à escola e ter em mãos uma turma como a mencionada foi desafiante, ao mesmo tempo em que era assustador. Para a primeira experiência docente, lecionar numa turma tão complexa do ponto de vista pedagógico foi desestimulante. Entretanto, a sensação de frustração que se criou diante das aulas pouco proveitosas no 6 으 foi desfeita com a regência em outras turmas mais avançadas e foi possível experimentar, do ponto de vista da experiência pessoal, inovações, como uma aula dialogada e participativa, buscando-se maior contextualização do conteúdo.

Esta experiência também permitiu a tomada de decisões durante a aula sobre atitudes negativas de alunos no relacionamento com colegas e que tem sido comum em nossas escolas, com freqüente 


\section{Desafios da psicologia no Brasil}

aparição tanto na mídia como em revistas da área educacional, com a denominação de bullying. Segue

o relato do estagiário sobre esta experiência.

A regência no $7^{\circ}$ ano $E$ foi bem mais tranquila. $O$ conteúdo trabalhado durante as quatro aulas foi sobre os Fungos. [...] Comecei perguntando o que eram fungos, que ideia que eles tinham desses organismos, se sabiam dar algum exemplo. Uma aluna que se senta na frente, muito timidamente respondeu que fungo "é aquela coisa preta que dá no pão e na fruta estragada". Anotei a informação no quadro, corrigindo para a turma o nome "coisa preta" dado pela aluna para bolor ou mofo, termo mais correto. Segui instigando ainda mais. "Fungos são apenas os bolores que se formam na fruta estragada?". Enquanto aguardava a resposta, observava os olhares dos alunos em cima de mim, esperando que eu lhes dissesse a resposta ao mesmo tempo em que queriam respondê-la. "Cutuquei" mais uma vez os alunos para que eles percebessem que sabiam a resposta, bastava apenas parar e pensar. A mesma aluna da frente respondeu que fungos também eram "bichinhos que causavam doenças". Pedi que a colega repetisse em voz alta para que todos da turma ouvissem a nova informação dada por ela (de novo). "Fungos também são bichinhos que podem causar doenças". "Gêênio", disse um aluno do fundão arrancando risinhos da turma e um olhar esnobe da aluna. Novamente corrigi a informação de "bichinhos que causavam doenças" para "organismos que também podem causar doenças", deixando claro que "bichinhos" não era uma definição adequada para os fungos. O quadro estava se pintando na minha frente conforme o planejado, e o resultado me agradava muito. Apesar da participação de uma única aluna, o resto da turma estava prestando atenção. Fiquei animado e queria mais. "Vamos lá pessoal, quero um exemplo mais próximo do cotidiano de vocês, um exemplo que faça parte do dia-a-dia de cada um de vocês". Silêncio. Os olhares me acompanhavam enquanto eu lentamente caminhava de um lado para o outro da sala aguardando uma resposta. A turma estava totalmente silenciosa. Mas não era um silêncio que se quer diante de muita bagunça. $O$ silêncio deles era o silêncio da espera pela resposta. Depois de um instante, a mesma aluna, agora insegura pela brincadeira feita com ela, acrescentou que fungo também podia ser o fermento. "Ah, olha só o que a colega disse", exclamei eu. "Fungo também pode ser fermento". "Gêênio", repetiu o brincalhão do fundo, referindo-se mais uma vez à colega, que dessa vez ignorou. Lançei um olhar [de reprovação] sobre ele e voltei à aula: "Pessoal, quem aqui gosta de pão?". Em coro, a turma respondeu: "Eu". "Quem gosta de queijo?". A turma: "Eu". "E de cerveja?", brinquei, interrompendo imediatamente a resposta deles dizendo que a cerveja era uma aula para outro dia. "Pessoal, o que será que pão, queijo e (também!) cerveja tem a ver com fungos?". Quando um aluno ia abrir a boca para responder, eu o interrompi: "E então gênio, o que você acha?", perguntei para o brincalhão do fundo. A turma soltou urros de exclamações diante do desafio. Mas, o aluno não soube responder à pergunta. Foi uma boa lição para ele. Pedi ao outro aluno que respondesse e ele disse que "são coisas feitas pelos fungos" (Ferreira, 2009).

Diante do relato do estagiário envolvendo bullying em sala de aula desafiamos o estagiário a refletirmos sobre o tema com base no que dizem os especialistas. Para estes, o bullying "[...] se caracteriza por agressões intencionais, verbais ou físicas, feitas de maneira repetitiva, por um ou mais 


\section{Desafios da psicologia no Brasil}

alunos contra um ou mais colegas. $\mathrm{O}$ termo bullying tem origem na palavra inglesa bully, que significa valentão, brigão." (Nova Escola, 2010).

Segundo eles, o papel do professor é fundamental, pois ele pode identificar os atores do bullying: autores, espectadores e alvos que formam um ciclo vicioso, consolidando o poder do autor diante dos espectadores e a humilhação e até doenças psicossomáticas na criança ou jovem que é vítima desse tipo de agressão.

A recomendação dada aos professores é de que a intervenção deve ser imediata, quando surgir uma situação deste tipo em sala: "Se algo ocorre e o professor se omite ou até mesmo dá uma risadinha por causa de uma piada ou de um comentário, vai pelo caminho errado. Ele deve ser o primeiro a mostrar respeito e dar o exemplo" (Nova Escola, 2010).

Concluímos assim que o estagiário agiu corretamente quando fez uma intervenção invertendo os papéis: de autor o aluno brincalhão passou a sentir na pele o resultado de suas brincadeiras, quando o estagiário o desafiou diante da turma (expectadores) que reagiram imediatamente.

A seguir, analisaremos um projeto de intervenção que foi desenvolvido pelo estagiário sob a orientação da supervisora do estágio com as turmas "problemáticas" dos 6‥ Anos daquela escola em que se realizava o estágio da licenciatura em Ciências e Biologia.

\section{O PROJETO DE EDUCAÇÃO SEXUAL COM O 6․ ANO}

Diante da complexidade que o professor tem que enfrentar em sala de aula, não dá para jogar toda a culpa das mazelas do nosso sistema educacional sobre o aluno ou sua família, nem somente sobre o professor e considerando a experiência desafiadora que a regência com a turma de 60 ano representou para o estagiário (o que para muitos seria traumatizante) e, incitados e munidos da vontade de realizar um trabalho específico com aquelas turmas "problemáticas", de tomar uma "atitude pedagógica", decidimos propor para a escola um pequeno projeto de extensão a ser realizado no último bimestre do ano.

Essa intervenção nos permitiu testar uma hipótese sobre a importância do conteúdo a ser trabalhado em relação com a fase de puberdade que estes alunos estavam vivenciando. Partimos do pressuposto de que o planejamento de aulas com conteúdos relacionados com o momento de vida que os alunos estão vivendo no sexto ano (a puberdade) despertaria maior participação dos alunos nas atividades 


\section{Desafios da psicologia no Brasil}

propostas, diminuiria a indisciplina e o desgaste físico-emocional-psicológico por parte de todos os envolvidos. Negociamos com a escola a proposta de desenvolvimento do projeto para identificar expectativas, sonhos em relação ao futuro e dúvidas dos alunos sobre o que está acontecendo com seus corpos nessa fase da vida. Após o aceite, iniciamos o projeto como uma atividade com apoio do Programa Institucional de Bolsa de Iniciação a Docência (PIBID) da Coordenação de Aperfeiçoamento do Pessoal do Ensino Superior (CAPES) no curso de Ciências Biológicas da UNIR.

O trabalho de identificar, dentro da disciplina de ciências, conteúdos mais relevantes para essa fase da vida dos alunos foi aprovado pela escola e pelos professores. Os Parâmetros Curriculares Nacionais (PCN) fazem recomendações para a seleção de temas de estudo e orientações didáticas para sua aplicação, visando mobilizar o interesse dos alunos e seu envolvimento ativo com o processo de aprendizagem. Relacionado com o Tema Transversal Orientação Sexual ${ }^{2}$, os PCN afirmam que a oferta, por parte da escola, “[...] de um espaço em que as crianças possam esclarecer suas dúvidas e continuar formulando novas questões, contribui para o alívio das ansiedades que muitas vezes interferem no aprendizado dos conteúdos escolares." (Brasil, 1998, p. 292).

Ao mesmo tempo em que os alunos descobriam as mudanças biológicas, comportamentais e sociais advindas com a puberdade, como professor-estagiário em processo de formação inicial, o orientando vivenciou a descoberta da docência, com todos seus desafios, complexidades e expectativas de formação.

Durante o planejamento, orientadora e o acadêmico da licenciatura se apoiaram nos PCN de Ciências e Temas Transversais (além de outras literaturas sobre o tema) para propor atividades para as duas turmas de 6으 ano consideradas as mais problemáticas (6ㅇano E e 6으 ano I).

Após cada aula, discutiam os acontecimentos e as reflexões foram registradas em cadernos de campo e registro ampliado no computador, gerando novas reflexões posteriores, como a que se segue.

Uma mescla de ansiedade e receio se confundiam em mim quando eu me imaginava dando aula no 6 OE novamente. Ansiedade pela expectativa de que tudo desse certo; medo porque eu não guardava lembranças muito agradáveis de minha passagem por lá (...). Criança tem, claro, sonhos do tipo "o que você vai ser quando você crescer?", mas não os nutrem, e despertá-los para os seus sonhos e o que fazer para realizá-los era meu objetivo para aquela aula, pois através dessa tomada de consciência, esse click para o "Quem sou eu e o que eu quero?", eu esperava levá-los a compreender o papel dos estudos nesse trajeto, uma vez que a indisciplina que eles apresentavam acabava por interferir em seu aprendizado. Passei à distribuição das fichas que os alunos deveriam 


\section{Desafios da psicologia no Brasil}

preencher com nome, profissão dos pais e as duas pergunta chaves: "O que você gostaria de ser quando crescer?" e "O que você acha que seria importante fazer para realizar seu sonho?". O envolvimento da turma na realização da atividade foi grande. Todos estavam tão empolgados que acabavam por emendar uma bagunça [não como aquela das aulas do estágio], que era prontamente suprimida pela professora da sala ${ }^{3}$. Houve, de fato, momentos em que o 60 E estava se comportando como 60 E: bagunceiros, dispersos e indiferentes à aula e aos meus apelos por silêncio. Duvidei do resultado que o projeto poderia alcançar (Ferreira, 2009).

Este relato mostra a insegurança do estagiário no início do projeto e seu desejo de acertar, bem como de realmente contribuir para um desenvolvimento saudável por parte destes alunos que vivenciavam um momento decisivo para sua constituição pessoal em meio à condições sociais adversas. Seu empenho com o projeto e sua dedicação no planejamento e desenvolvimento das atividades deve ser destacado.

[...] Na noite anterior à aula [seguinte], analisei as fichas preenchidas pelos alunos que estiveram presentes na última aula. Dei especial atenção às respostas para a pergunta "O que você acha que deveria fazer para realizar seu sonho?". [...] Não foi necessário ficar pedindo organização para que eu pudesse dar início à aula. Sentaram-se e esperaram. Silenciosa e comportadamente. [Falei] sobre as fichas que analisei na noite anterior e para manter a atenção dos alunos mais dispersos - as locomotivas do trenzinho da bagunça - usei de uma estratégia. Guardei na memória o sonho de profissão que esses alunos tinham para si no futuro e os usei como exemplo para falar um pouquinho de cada profissão. Deu certo. Eles ficaram atentos durante toda a aula e os próprios colegas de sala ficaram impressionados com o sonho de ser advogado, professora universitária e médico daqueles que regiam a orquestra da bagunça. Dei a oportunidade para que os outros falassem sobre seu sonho de profissão. Um a um, levantaram-se e compartilharam com todos o sonho de profissão que tinha para si mesmo no futuro. Falaram futuros médicos, engenheiros, veterinários, policiais, professores, biólogos. Tínhamos os mais variados sonhos de profissão numa mesma sala. Ver o brilho nos olhos deles e a empolgação com que cada um falava, me fez sentir parte daquela futura realização de sonho; parte futuro médico, parte futuro engenheiro, parte futuro veterinário... Ressaltei a resposta que a turma deu à pergunta "O que você acha que deveria fazer para realizar seu sonho?". Foi unanimidade na turma que estudar era o que eles precisavam fazer para realizar seu sonho. "Quantos anos a gente tem que estudar até terminar a faculdade?". [Escrevi] no quadro as palavras "estudar" e "sonho", separando-as com uma longa seta, o estudar levando ao sonho. Sobre a linha da seta a quantidade de tempo que eles levariam para terminar o ensino fundamental, o ensino médio e, também, a faculdade. "[Temos que] acrescentar alguns ingredientes fundamentais ao lado dessa nossa equação, como: dedicação, força de vontade, persistência, compromisso, desejo de realização. Somente combinando todos esses ingredientes é que teremos a REALIZAÇÃO DO SONHO", disse-Ihes [..]. 


\section{Desafios da psicologia no Brasil}

A estratégia deu certo, considerando a reação da turma, que não só se tornou participativa, mas demonstrava interesse e atenção como nunca vistos durante o estágio de observação e regência.

Pela primeira vez desde que entrei no $60 \mathrm{E}$, ainda durante o período de estágio, tive certeza de que eles estavam entendendo o que eu queria dizer. Todos me olhavam muito atenciosamente. A impressão que tive era de que aquela turma não era o 6 ㅇ E. Dado o desfecho desejado, passei ao próximo tema: puberdade. Comecei com um breve diálogo das mudanças físicas e psíquicas que alguns deles já estavam passando e pela qual os outros ainda iam passar. Disse-Ihes que essa fase de mudanças, na qual o menino se transforma em homem e a menina se transforma em mulher, chama-se... - "Puberdade!", respondeu um aluno. Dizer-lhes, através das minhas explicações, que eles estavam deixando de ser crianças para se tornarem adolescente e posteriormente adultos, e ter que abandonar os brinquedos e comportamentos infantis [se não completamente] para se comportarem como adultos, com todas as suas responsabilidades e deveres, fazia parte desse processo natural de crescimento foi encarado de forma frustrante por alguns e de forma empolgante por outros. Eles não queriam ganhar a maturidade e liberdade de um adulto sem ter que deixar as brincadeiras de criança. Deixei claro que o tornarse adulto era um processo lento e natural e conforme ganha-se a vida adulta, deixa-se a infância. Tiveram um comportamento exemplar, não somente pela ausência de indisciplina, mas também pela participação, pelo envolvimento e pela empolgação e interesse demonstrados na realização da atividade. Se existe um ideal de aula, tanto para o professor quanto para o aluno, é essa que eu consegui, surpreendentemente, realizar no 6ํE. Pelas características e comportamentos que definem aquela turma, sai com a impressão de que ela não era o 6으 E (Ferreira, 2009).

Para continuidade do projeto, planejamos a apresentação da Caixinha de dúvidas, recomendada por vários manuais de educação sexual dirigidos a educadores e produzidos por várias organizações que se dedicam a este trabalho. Esta estratégia didática permite que os alunos se manifestem sem receio de serem ridicularizados pelos colegas e permite aos educadores refletirem sobre as perguntas feitas pelos alunos, muitas delas embaraçosas para o adulto que dirige a atividade.

O passo seguinte foi apresentar-Ihes a Caixinha da Dúvida, um receptáculo de todas suas indagações, dúvidas e curiosidades acerca de puberdade e sexo. Todos depositaram seus questionamentos dentro da caixinha, demonstrando o interesse e curiosidade que o conteúdo Ihes despertava. [...] Engraçado como indagações e questões que fazemos quando somos crianças nos parecem tão bobas quando [nos vemos] adultos. Alguns desses questionamentos feitos quando crianças parecem tão fundamentais que é muito grande o anseio para obter uma resposta e a atividade da Caixinha da Dúvida se propõe justamente a essa tarefa: a de acalmar os anseios dos alunos. Enquanto eu analisava as perguntas deixadas por eles, não pude deixar de recordar alguns dos meus próprios questionamentos quando criança e, agora adulto, rir de mim mesmo, não porque eram perguntas tolas ou ridículas, mas sim porque eram tão ingênuas que chegava a ser engraçado mesmo. Analisei e organizei as perguntas dos alunos por gênero para facilitar e organizar numa linha lógica as respostas sobre puberdade e sexo. As perguntas de modo geral eram mais de ordem biológica, revelando que o interesse dos alunos é maior pelas explicações que envolvem os fatos naturais e os processos biológicos do corpo humano. Eles ainda estavam tentando entender o quando, como e o porquê 


\title{
Desafios da psicologia no Brasil
}

\begin{abstract}
das coisas. [Já na aula] comecei com a questão fundamental para a discussão levantada por um aluno: "o que é puberdade?" e fui seguindo numa sequência lógica: "como acontece o amadurecimento?"; "pode causar aborrecimento ou doença?" [perguntas feitas por eles]. Algumas das perguntas deles como, "Por que essas transformações acontecem já por volta dos 12 anos e não mais tarde?" e "Existe alguma possibilidade de que as transformações cheguem mais tarde?", demonstravam um não querer crescer para continuar a ser criança, demonstrando a angústia que as mudanças físicas e psíquicas advindas com a puberdade [trazem]. O sentimento de deslocamento, de "patinho feio" é comum nas crianças que estão entrando na adolescência, trazendo o medo da rejeição, às vezes até levando-os a rejeitar a si próprios e, consequentemente, a negar essas mudanças. Relembrando a segunda aula, quando já havia falado da transição da infância para a adolescência, disse-lhes que aquele sentimento era tão natural quanto o próprio processo de crescimento, que deveríamos viver o melhor de cada fase da vida: a inocência, as brincadeiras e a despreocupação da criança dariam lugar à maturidade, liberdade e responsabilidades de um adulto. [...] Na minha concepção, simples momentos como esse são gratificantes por si só na profissão professor (Ferreira, 2009).
\end{abstract}

No desenvolvimento das atividades dialógicas de educação sexual nas aulas de ciências, os alunos se mostraram participativos, interessados e respeitosos com os que as coordenavam ${ }^{4}$ e as professoras das salas ${ }^{5}$ se mostravam mais descontraídas e colaboradoras.

Como resultado, tivemos maior interesse, disciplina e envolvimento dos alunos nas atividades propostas e menos autoritarismo em sala, com professoras participando conjuntamente com o licenciando, o que indica a necessidade de mudar a forma como os problemas dentro da escola são encarados, com atitudes de profissionais e atividades de ordem pedagógica mudando situações até então tidas como perdidas. "Os conflitos podem dar origem a novas formas de relacionamento e de organização do trabalho pedagógico" (Vasconcellos, 2009, p. 221).

Lançamos um outro olhar ao que estava acontecendo por meio da "desalienação da relação pedagógica" (Vasconcellos, 2009) e instauramos o diálogo entre os alunos e destes com o professor, criando vínculos entre os envolvidos e despertando e / ou resgatando a consciência dos alunos para a importância da escola. Mas, quando as aulas ficaram mais expositivas, novamente a agitação da sala reaparecia e houve dificuldades de se conseguir a atenção dos alunos, com o coordenador /bolsista assumindo uma postura mais autoritária semelhante à da professora da sala, o que aponta para a importância não só dos conteúdos, mas também dos procedimentos didáticos no decorrer da aula.

Outras atividades foram desenvolvidas mostrando a complexidade do problema de educação sexual na escola nas séries iniciais e finais do ensino fundamental, pois muitas questões levantadas pelos 


\section{Desafios da psicologia no Brasil}

alunos indicam que muitos já tinham iniciado uma vida sexual ativa, alguns deles dando indícios de abuso sexual e pedofilia no âmbito da própria escola.

Ao final do projeto, realizamos uma avaliação com a equipe pedagógica e as professoras apoiaram a continuidade dele, desde que fosse realizado em horários fora das aulas de ciências (pois estavam preocupadas com o cumprimento do programa pré-estabelecido no início do ano, o qual não considerou o tema transversal de Orientação Sexual), o que inviabilizou temporariamente sua continuidade. $\mathrm{O}$ registro das atividades e a reflexão realizada com supervisores e professores envolvidos permitiram uma identificação de pontos que poderiam ser melhorados, mas não houve apoio por parte da direção da escola e condições para sua continuidade.

\section{CONCLUSÃO}

A mudança de paradigma de formação de professores se deu por entendimento da complexidade presente na sociedade contemporânea e na escola nela inserida, sendo que a formação que ocorre na licenciatura se mostra insuficiente, exigindo-se do professor uma formação permanente. Também se reconhece que o processo de formação profissional tem um forte componente de (auto)formação que envolve o registro da prática desenvolvida e a reflexão sobre essa prática com a participação de orientadores/supervisores mais experientes e à luz das teorias educacionais, psicológicas, sociológicas e filosóficas.

Essa formação não despreza o papel dos formadores como mediadores no processo e, no presente caso, a interação estagiário/bolsista PIBID com sua orientadora foi muito frutífera, trazendo aprendizagens para ambos, que certamente se refletirão em novas formações e na continuidade da formação permanente. Todo o processo e as aprendizagens profissionais que ocorreram por parte do licenciando foram descritas e analisadas em um texto monográfico, de forma autobiográfica, para produção do Trabalho de Conclusão de Curso (Ferreira, 2012).

O PIBID / Ciências Biológicas da UNIR permitiu o acompanhamento deste estagiário em um projeto que Ihe permitiu ir reconstruindo concepções, atitudes, valores e relacionamentos no processo de iniciação à docência na escola pública e isto mostra, a nosso ver, a importância deste programa apoiado pela CAPES junto a licenciaturas do país.

Assim, a iniciação à docência de alunos da licenciatura de Ciências Biológicas da UNIR vem intercalando atividades de estágio curricular nas disciplinas de ciências e biologia com atividades do PIBID. No 


\section{Desafios da psicologia no Brasil}

estágio curricular, o acadêmico tem o primeiro contato com a profissão docente, observando aulas, realizando projetos de participação e planejando aulas para posterior regência. No PIBID, o acadêmico tem a oportunidade de inserir-se mais no espaço escolar, conhecendo melhor sua dinâmica através da realização de projetos de interesse da escola e da comunidade.

Com o projeto "Conhecendo a si mesmo" o acadêmico da UNIR teve a oportunidade de aquisição de experiências que auxiliaram na sua formação profissional e pessoal e, ainda, contribuiu para que alunos da Educação Básica conhecessem melhor a si mesmos, aumentassem o respeito mútuo, expressassem oralmente e por escrito suas dúvidas e ansiedades próprias da idade de transição entre a infância e a vida adulta, valorizando mais o papel da escola em seu processo de formação. Durante as aulas desse projeto foram utilizados muitos recursos didáticos existentes no laboratório da escola e que são pouco utilizados nas aulas de ciências e biologia, regularmente, estimulando, assim, o senso crítico, a curiosidade e a experimentação.

O problema inicial de subutilização do laboratório de ciências apresentado pela escola e que aproximou a universidade desta instituição, teve ainda outras intervenções com os bolsistas do PIBID, mas, infelizmente, outros obstáculos intervieram não permitindo que os professores e colaboradores utilizassem mais e melhor o laboratório de ciências da escola.

\section{REFERÊNCIAS}

Brasil. MEC / Secretaria de Educação Básica. (1998). Parâmetros Curriculares Nacionais. 5ạ. a 8ạ. Séries. Temas Transversais. Brasília: MEC.

Brasil. MEC / Secretaria de Educação Básica. (1998). Parâmetros Curriculares Nacionais. 5ạ. a 8ạ. Séries. Ciências. Brasília: MEC.

Bruner, J. S. (2001). A Cultura da Educação. Porto Alegre: ArtMed Editora.

Collares, C. A. L. e Moysés, M. A. A. (1998). Preconceito no cotidiano escolar: ensino e medicalização. SP: Ed. Cortez.

Ferreira, A. R. de A. (2009). Relatório de Estágio. Porto Velho, julho.

Ferreira, A. R. de A. (2012). Narrativa autobiográfica de formação docente em Biologia: cenas formativas de um ator-autor de sua própria trajetória. Monografia (Trabalho de Conclusão de Curso). Universidade Federal de Rondônia (UNIR). Porto Velho.

Goodson, I. F. Currículo, narrativa e o futuro social. (2007). Revista Brasileira Educação. 12(35), Maio / Ago. Trad. de Eurize Caldas Pessanha e Marta Banducci Rahe. 


\section{Desafios da psicologia no Brasil}

Ibiapina, I. M. L. M. (2008). Pesquisa colaborativa: investigação, formação e produção de conhecimentos. Brasília: Liber Livro Editora.

Lima, V. M. R. (1999). Psicologia e Educação: o significado de aprender. Porto Alegre: EDIPURCS.

Martines, E. A. L. M.; Souza, L. S. de; Almeida, A. D. de; Oliveira, A. C. G. de; Silva, M. F. (2010). Laboratório de ensino de ciências - espaço de formação docente para o ensino de ciências com ênfase na (auto)biografia. Anais IV CIPA. São Paulo.

Nova Escola. (2010). 21 perguntas e respostas sobre bullying. São Paulo: Ed. Abril, nov. 2010. Disponível em <http://revistaescola.abril.com.br/crianca-e-adolescente /comportamento/bullyingescola-494973.shtml>. Acessado em 09/12/2010 às $11 \mathrm{~h}$.

Nóvoa, A. (1992). Formação de professores e profissão docente. Em Nóvoa, A. (org.). Os professores e a sua formação. Lisboa / Portugal: Publicações Dom Quixote.

Patto, M.H.S. (1996). A produção do fracasso escolar. São Paulo: Ed. T.A. Queiroz.

Pereira, J. E. D. e Zeichner, K. M. (Orgs.) (2002). A pesquisa na formação e no trabalho docente. Belo Horizonte: Autêntica.

POZO, J. I. Aprendizes e Mestres: a nova cultura da aprendizagem. P. Alegre: Artmed Ed, 2002.

Sacristán, J. e Gómez, A. I. (1998). Compreender e transformar o ensino. Porto Alegre: ArtMed.

Schön, D. (1983). The reflective practitioner. New York: Basic Books.

Schön, D. (1992). Formar professores como profissionais reflexivos. Em Nóvoa, A . (org.). Os professores e a sua formação. Lisboa / Portugal: Publicações Dom Quixote.

Stenhouse, J. (1991). Investigación y desarrolo del curriculum. 3ed. Madrid / Espanha: Morata.

Vasconcellos, C. dos S. (2009). Indisciplina e disciplina escolar: fundamentos para o trabalho docente. São Paulo: Cortez. 


\section{Desafios da psicologia no Brasil}

\section{NOTAS}

\section{Notas 1}

Este texto foi inicialmente publicado nos Anais do X CONPE em co-autoria com um aluno da graduação que passa a ser citado neste trabalho pela autora.

\section{Nota 2}

Os PCN se referem a Orientação sexual, mas aqui estamos usando a expressão Educação sexual, considerando que o termo "orientação sexual", nos últimos anos vem se referindo ao processo de desenvolvimento psicológico de inclinação de uma personalidade por um determinado gênero (masculino, feminino, transsexual) ao lado do desenvolvimento biológico. O termo veio substituir a expressão "opção sexual" e está ligado às atrações afetivas e sexuais que cada indivíduo manifesta sua sexualidade.

\section{Nota 3}

A professora regente de Ciências acompanhou todas as aulas ministradas pelo estagiário ao longo do desenvolvimento deste projeto.

Nota 4

A orientadora participou desta aula fazendo a supervisão do bolsista (PIBID) e colaborando com algumas considerações

Nota 5

A turma E tinha uma professora regente e a turma I tinha outra. 


\section{Capítulo 11}

\section{CONTRIBUIÇÕES DA PSICOLOGIA DE ORIENTAÇÃO ANALÍTICA NA ESCUTA DO SUJEITO AUTOR DE CRIMES ${ }^{1}$}

DOI: $10.37423 / 200200173$

Cláudio Júnio Patrício (Psicólogo. Mestre em Promoção da Saúde e Prevenção da Violência pela Faculdade de Medicina da UFMG. Especialista em Psicanálise e a Clínica contemporânea pelo Centro Universitário Una. Diretor de Atendimento de um centro socioeducativo de Minas Gerais. E-mail: claudejunio@gmail.com.

Resumo: A psicologia no sistema prisional está circunscrita por inúmeros impasses e contradições. Afinal, ela eștá a serviço do ordenamento jurídico ou éstá no campo das políticas públicas? De acordo com o referencial teórico produzido pelo próprio Conselho federal de Psicotogia não há consenso sogbre o fazẹr da profissão nas prisø̋es. Por isso, muitas das ações das/os profissionaais se restringem a seguir o que está descrito nos códigos e normativas legais, assim como, atender as demandas dos operadores jurídicos tais como: os promotores públicos e os juízes de execução penal. O presente artigo pretende pensar como psicólogas e psicólogos orientados pela teoria psicanalítica podem atuar de uma forma mais crítica e menos normatizadora no acompanhamento dos indivíduos privados de liberdade.

Palavras-chave: Sistema prisional, psicanálise, responsabilização subjetiva, crime

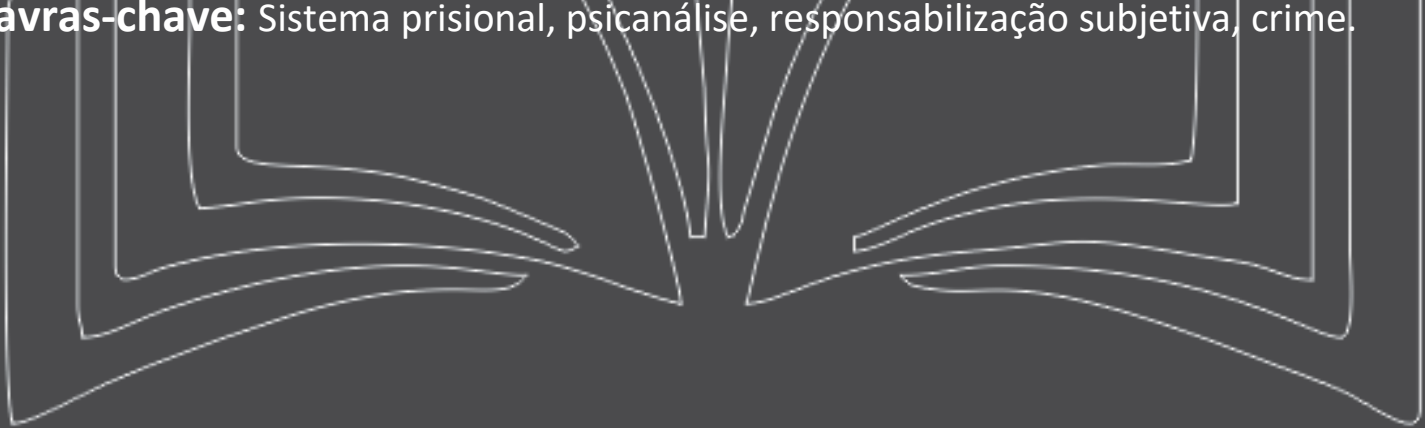




\section{Desafios da psicologia no Brasil}

\section{INTRODUÇÃO}

A psicologia, enquanto ciência e profissão, está cada vez mais inserida no contexto de atuação das políticas públicas, produzindo saberes e levantando reflexões importantes para o desenvolvimento da própria prática profissional. Uma das áreas que, apesar de existir desde 1930 (CONSELHO FEDERAL DE PSICOLOGIA, 2012) ainda é pouco conhecida e reconhecida é a psicologia aplicada no sistema prisional. Atualmente 1.265 psicólogas/os estão atuando nos presídios brasileiros atendendo uma massa carcerária de mais 700 mil pessoas (SANTOS, 2017). Essa atuação ainda é marcada por contradições e indefinições.

Regulada pela Lei de Execução Penal (LEP) (BRASIL, 1984), um dos impasses que a psicologia no sistema prisional tem que lidar é sobre sua real função. Afinal, ela está a serviço do ordenamento jurídico ou está no campo das políticas públicas? Apesar de responder ao Poder Executivo, portanto, tendo como função executar políticas públicas, a atuação da profissão é regulada pelo Poder Judiciário, provocando, assim, um conflito de competências. De acordo com o referencial teórico produzido pelo próprio Conselho Federal de Psicologia (2012) não há consenso sobre o fazer do profissional de psicologia nas prisões. Por isso, muitas das ações das/os psicólogas/os se restringem a seguir o que está descrito nos códigos e normativas legais, assim como, atender as demandas dos operadores jurídicos tais como: as/os promotoras(es) públicos e as/os juízas(es) de execução penal.

No que concerne ao atendimento daquele que cumpre pena, verifica-se que a maioria dos profissionais orienta a sua prática por modelos classificatórios e psicopatológicos em ações avaliativas e diagnósticas que, muitas vezes, visa apenas segregar o sujeito (CONSELHO FEDERAL DE PSICOLOGIA, 2012). Ainda segundo o relatório produzido pelo CRP (2012), a LEP ao determinar a presença de um/a psicólogo/a na equipe multiprofissional definiu que sua principal função é compor a Comissão Técnica de Classificação (CTC). Comissão esta que tem como objetivo classificar os presos e presas a partir dos seus antecedentes criminais e sociais, além de aspectos da personalidade, para orientar um programa individual de ressocialização. Entretanto, na prática, percebe-se que a Comissão, na grande maioria dos casos, tem sido utilizada de forma burocrática ou com o intuito apenas de atender aos interesses das unidades prisionais, não levando em consideração as reais necessidades biopsicossociais do indivíduo privado de liberdade.

A Lei de Execução Penal ao definir um "tratamento penitenciário" ao indivíduo privado de liberdade não o fez com o objetivo de uma recuperação do sujeito, como o termo tratamento é entendido no campo da saúde. A expectativa era/é única e exclusivamente de uma alteração da conduta desse 


\section{Desafios da psicologia no Brasil}

sujeito a partir da regulação da pena e da disciplina penitenciária (CONSELHO FEDERAL DE PSICOLOGIA, 2012). É desse lugar de normalizador dos corpos e de condutas que a psicologia tem que atuar? E a psicanálise, como deve se posicionar neste contexto? Como pensar a prática, e a escuta, psicanalítica em instituições totais, tais como as prisões?

O presente artigo pretende pensar como as/os profissionais de psicologia orientados pela teoria psicanalítica podem atuar de uma forma mais crítica e menos normatizadora no acompanhamento dos indivíduos privados de liberdade. Utilizando-se da transferência para ter acesso a singularidade de cada caso, será pensando em como as psicólogas e psicólogos podem contribuir para que esses indivíduos problematizem suas relações com o ato criminal e com o contexto social no qual está inserido. E, a partir disso, se responsabilize subjetivamente, ou não, pelo crime cometido.

\section{A ESCUTA ANALÍTICA DO SUJEITO AUTOR DE CRIMES}

Nosso sistema penal é marcado pela tentativa de apagamento do sujeito desde o momento em que ele é apreendido por ter cometido, ou não, um crime. Além da perda do direito de ser chamado pelo nome próprio, o processo de apagamento da subjetividade é intensificado com a obrigação da utilização de um uniforme padrão para todos/as. Como aponta Goffam (1996) uma das características das instituições totais é a de promover sistematicamente uma "mortificação do eu". Pune-se não apenas o corpo do indivíduo, mas também, e principalmente, a sua alma.

Para Foucault (1987), as prisões, ao violarem a maioria dos direitos humanos básico do sujeito encarcerado, gera revolta e produz delinquentes ainda mais perigosos. Para o autor, as prisões são fábricas de indivíduos que realizam crimes devido ao tratamento que é ofertado ao detento.

A tentativa de assujeitamento e as violências institucionais não são aceitas de forma natural, sem resistência. Para Barcinski e Cúnico (2014) há um movimento de não passividade das pessoas privadas de liberdade diante da tentativa de apagamento das suas subjetividades. Esses movimentos, que podem se dar de inúmeras formas, são o que permitem uma diferenciação, uma visibilização dessas pessoas dentro da prisão. São eles que, em última instância, permitem uma sobrevivência psíquica do sujeito. Tais atitudes reafirmam o imperativo da subjetividade mesmo diante de normas reguladoras. Regido pela lógica da segurança, os atendimentos técnicos (psicologia, serviço social, pedagogia...) realizados dentro das unidades prisionais são relegados a um caráter secundário. Como aponta Santos (2015) a atuação dos profissionais das áreas psicossocial e saúde está condicionada ao imperativo da segurança. O discurso da segurança que, no sistema prisional, pode ser entendido como o discurso do 


\section{Desafios da psicologia no Brasil}

mestre, é aquele que vai tentar definir todo o entendimento que se tem em relação àquele/a que está encarcerado/a. Desta forma, significantes como: 'bandido', 'ladrão' e outros de cunho pejorativos são os que norteiam o saber produzido nesses espaços. A lógica da segurança é de caráter totalmente punitivo, sendo qualquer coisa fora dessa lógica considerada privilégio ou supérfluo. Assim, caberia aos profissionais que se orientam pela teoria psicanalítica tentar fazer vacilar essa concepção de indivíduo, que desconsidera completamente a subjetividade e, até mesmo, a humanidade dos que estão encarcerados. É importante que se tente mostrar que o indivíduo não é apenas o ato criminoso que ele cometeu e que, por trás de todo ato há uma história que precisa ser escutada.

A psicanálise, conforme expressa a sua ética, tem como compromisso central o sujeito e a sua subjetividade. Enquanto a instituição "sistema prisional" utiliza-se de todos os recursos possíveis para anular a condição de sujeito dos indivíduos, os profissionais que utilizam a teoria psicanalítica como referencial trabalham no sentido oposto. Eles querem dar voz a esse sujeito, para que ele possa, a partir da apropriação da sua singularidade, falar de suas angústias e desejos.

De acordo com Lacan (1950/2003) os/as analistas, por saberem como revirar as resistências do eu, seriam capazes de libertar a verdade por trás de um ato criminoso. A psicanálise irrealiza o crime, mas não desumaniza o criminoso (LACAN, 1950/1998). A teoria lacaniana nos mostra que é preciso pensar o crime e aquele que o comete de forma articulada, pois, uma das possibilidades de compreensão de um ato criminal é que ele é uma resposta do sujeito a um determinado embaraço na sua realidade psíquica (1962-1963/2005). A proposta de Lacan não isenta o sujeito denominado criminoso, não o desresponsabiliza. Pelo contrário: ela o convoca a falar e a responder pelo seu ato, garantindo sua permanência na comunidade humana (SIQUEIRA, 2015).

Se para Lacan uma das formas de compreender os atos criminais é que eles são atuações que têm como endereçamento a sociedade (1962-1963/2005), para Freud as transgressões dos pactos sociais estariam relacionadas com um sentimento de culpa (FREUD, 1916/1996).

A partir do seu trabalho analítico Freud constatou que alguns dos seus pacientes cometiam ações tidas como proibidas pelo simples fato de tais atos romperem com o pacto social. Transgredir a lei ocasionava um alivio psíquico àquele que o fazia. Entretanto, essa mesma ação revelava um sentimento de culpa de origem, até então, desconhecida (FREUD, 1916/1996). Sentimento este já presente antes mesmo da execução da ação tida como proibida. $O$ ato seria, justamente, uma forma de apaziguamento de tal sensação. Tais sujeitos foram definidos por Freud como criminosos em consequência de um sentimento de culpa (FREUD, 1916/1996). 


\section{Desafios da psicologia no Brasil}

Freud em sua reflexão sobre as possíveis origens dos crimes não descarta a existência de criminosos que não tenham nenhum sentimento de culpa diante do seu ato ou que consideram suas ações justificada pelo seu conflito com a sociedade (FREUD, 1916/1996). Contudo, para ele, a maioria dos criminosos visam ser punidos pelos os seus crimes como uma forma de aliviar sua culpa inconsciente (FREUD, 1916/1996).

O sujeito que comete um crime, muito além de uma punição, precisa se responsabilizar subjetivamente por aquilo que ele fez. Para a teoria psicanalítica, a ação de se responsabilizar por algo compreende não apenas assumir o ato que está Ihe sendo imputado. Implica uma relação com a causa do seu ato, com aquilo que, de alguma forma, tocou a sua subjetividade e produziu o ato criminoso como resposta. É diante disso que se deve responder, pois pela posição de sujeito, sempre somos responsáveis (LACAN, 1966/1998).

Diferentemente da Justiça que visa obter uma confissão, a/o psicanalista ao estabelecer uma relação transferencial com esse sujeito quer lhe dar voz, voz essa que possa fazer emergir os pontos de angústia e que sinalize os laços sociais possíveis de serem (re)estabelecidos no contexto egresso. É preciso que a/o analista convoque o sujeito a tentar decifrar os enigmas que o levaram a estar naquela situação de encarceramento. O sujeito pode não assentir com o ato que está respondendo criminalmente, mas cabe ao profissional questioná-lo sobre os caminhos que culminaram com aquela situação. Para a teoria psicanalítica, o sujeito é, antes de qualquer coisa, uma posição (SALUM, 2009), posição esta que precisa ser sustentada em qualquer situação ou contexto social. Desta forma, acredita-se que todos precisam ser responsabilizados pelos os seus atos, pois a responsabilidade é uma posição subjetiva (SALUM, 2009, p. 113).

Uma visão bastante difundida é que o sujeito psicótico, ou louco, não teria condições de responder pelos seus atos por estar estruturalmente fora do discurso. De acordo com a teoria psicanalítica, todo sujeito é responsável por sua posição subjetiva, sendo ele neurótico, psicótico ou perverso (QUINET, 2009, p. 162). Ainda segundo Antônio Quinet (2009) o sujeito é responsável pelos seus sintomas e por todas as manifestações do seu gozo, sejam elas sociais ou sexuais, subjetivas ou objetivas, individuais ou coletivas. Por isso, estar fora do discurso não é um elemento para balizar a exclusão dos sujeitos psicóticos das instituições civis (QUINET, 2009). Tal compreensão mostra-se destoante, por exemplo, do conceito de inimputabilidade utilizado pelo Direito que afirma que, o indivíduo pode não ser responsabilizado pelos seus atos caso constatado algum tipo de sofrimento mental ${ }^{2}$. 


\section{Desafios da psicologia no Brasil}

Para Barros-Brisset (2013) a não possibilidade de responsabilização do louco-infrator é uma das formas encontradas socialmente de retirar a sua humanidade, de reduzi-lo única e exclusivamente a sua "doença". Confinado a um manicômio judiciário, ao louco-infrator não lhe é permitido responder pelos seus atos como qualquer ser humano, nem ter acesso aos documentos ou processos que lhe dizem respeito; sua voz , muitas vezes, não é escutada ou levada em consideração (BARROS-BRISSET, 2013). Nomeações tais como: "louco", "perigoso", "incapaz"," doente" estarão inscritas em seu corpo, de forma definitiva, em razão do seu ato. A partir disso seus gestos não serão mais reconhecidos como uma resposta de uma ser humano qualquer diante dos embaraços que a vida apresenta (BARROSBRISSET, 2013). Desta forma, tem restado aos loucos infratores "apenas o silêncio, o isolamento, o massacre subjetivo e o sequestro institucional dos direitos fundamentais válidos para qualquer pessoa humana" (CONSELHO FEDERAL DE PSICOLOGIA, 2012, p. 57).

Ao propiciar um espaço de escuta e de palavra, a psicanálise aposta no sujeito, aposta que ele consiga traduzir em palavras aquilo que estava tentando dizer com os seus atos criminais; que consiga localizar os pontos que lhe causem angústia e que encontrou na transgressão das normas sociais uma forma de apaziguá-los. Assim, sob a égide da transferência, a/o analista poderia ajudar no despertar do sujeito daquilo que o condena (SALUM, 2009).

Desta forma, a atuação do profissional orientado pela teoria psicanalítica visa apresentar ao sujeito, a partir das suas intervenções e elaborações, que há possibilidades de caminhos a serem trilhados que não estejam relacionados com uma morte prematura ou com atuações criminosas. É importante apontar que além de ser um sujeito de desejos e deveres, ele/ela também é um sujeito de direitos. É preciso escutar o que cada sujeito inventa para conseguir viver no mundo. Se considerarmos o crime como uma resposta singular diante de um embaraço, a saída da dinâmica criminal também se dará de forma diferente para cada um/a.

\section{CONCLUSÃO}

O sistema prisional atual, amparado pela Lei de Execução Penal, não tem por objetivo dar voz e escutar as demandas dos sujeitos autores de atos criminais. Regido por uma lógica punitivista e de vingança social, as unidades prisionais cumprem, muito bem, o seu papel de subjugar e anular as subjetividades daqueles tidos como criminosos. Acredita-se que a "recuperação" se dará apenas pelo castigo que as prisões proporcionam (FOUCAULT, 1987). Tal modelo tem se mostrado falido desde a sua concepção, 


\section{Desafios da psicologia no Brasil}

pois, como aponta Foucault (1987), as prisões não diminuem a taxa de criminalidade, pelo contrário, pode aumentá-la, multiplicá-la ou simplesmente transformá-la.

A orientação de todo o tratamento dispendido ao indivíduo privado de liberdade é baseada na Lei de Execução Penal. A LEP foi instituída tendo como um dos seus objetivos proporcionar condições para uma integração harmônica do condenado à sociedade (CONSELHO FEDERAL DE PSICOLOGIA, 2012). Entretanto, para se obter essa suposta "harmonia na integração social" se idealizou um tratamento penal no qual tornaria as pessoas "ressocializadas", "reeducadas" e "ajustadas" ao modelo hegemônico de sociedade (CONSELHO FEDERAL DE PSICOLOGIA, 2012, p. 44). É um modelo de tratamento marcado pela a imposição de saberes ao indivíduo e que impossibilita a emersão da sua subjetividade. Tenta-se controlar não apenas o corpo, mas também a alma daquele que ousou romper com o pacto social.

A psicanálise, enquanto teoria, deveria tentar romper com essa lógica normativa e patologizante presente no sistema prisional. Ao propiciar um espaço de escuta e palavra, está-se dando voz a sujeitos, até então, silenciados. Muitas vezes é preciso que esses sujeitos transgridam a lei para que "a lei" saiba que eles existam. A partir da transferência, é importante que a/o analista crie um espaço capaz de fazer o sujeito questionar seus atos criminais, que faça furos nas suas certezas subjetivas. Será esse espaço que poderá lhe proporcionar a possibilidade de ele criar um significado, dar um sentido ou contextualizar o ato na sua história. É importante que ele seja capaz de problematizar suas escolhas e o contexto social no qual está inserido.

O pensamento analítico no contexto criminológico não pode ficar alheio as tramas sociais nos quais os sujeitos estão submetidos, pois, ao negligenciar tais tramas, corre-se o risco de patologizar ou culpabilizar os sujeitos por todas as mazelas pelas quais eles estão submetidos. Tal exercício teórico é fundamental em uma sociedade desigual e marcada por uma seletividade penal como a brasileira, na qual aquele que é apreendido por romper com a lei tem cor e classe social definidos. É preciso considerar as subjetividades e as formas com que cada um (a) responde aos seus embaraços, sem, entretanto, perder o posicionamento crítico diante de tais análises.

Ao possibilitar que o indivíduo socialmente definido como criminoso ascenda ao status de sujeito, a psicanálise propicia um tratamento em que esse mesmo sujeito não fique alienado em si mesmo, que consiga questionar o contexto social e racial no qual está inserido e o quanto este meio pode influenciar sua tomada de decisões. O resultado deste tratamento seria uma integração, pelo sujeito, 


\section{Desafios da psicologia no Brasil}

de sua verdadeira responsabilidade em relação ao ato cometido. Afinal, era isso que ele tendia na busca por uma punição e seria desumano não possibilitar esse encontro (LACAN, 1950/2003).

\section{REFERÊNCIAS}

BARCINSKI, M.; CÚNICO, S. D. Os efeitos (in)visibilizadores do cárcere: as contradições do sistema prisional. Revista PSICOLOGIA, v. 28, n. 2, p. 63-70, 2014.

BARROS-BRISSET, F. O. D. Assassinato d'alma: impasses sobre a responsabilidade na leitura de "O crime louco". Responsabilidades, Belo Horizonte, v. 3, n. 1, p. 23-35, março-agosto 2013.

BRASIL. Lei de Execução Penal n. 7.210, de 11 de julho de 1984. Brasília. 1984.

CONSELHO FEDERAL DE PSICOLOGIA. Referências técnicas para atuação das (os) psicólogas (os) no sistema prisional. Conselho Federal de Psicologia. Brasília, p. 65. 2012.

FOUCAULT, M. Vigiar e Punir: nascimento da prisão. Tradução de Raquel Ramalhete. 20ạ. ed. Petrópolis: Vozes, 1987.

FREUD, S. Alguns tipos de Caráter encontrados no trabalho psicanalítico. In: FREUD, S. Edição Standard Brasileira das Obras Psicológicas Completas de Sigmund Freud. Rio de Janeiro: Imago, v. XIV, 1916/1996. p. 347-348.

GOFFMAN, E. Manicômios, prisões e conventos. Tradução de Dante Moreira Leite. São Paulo: Editora Perspectiva, 1996.

LACAN, J. Introdução teórica às funções da psicanálise em criminologia. In: LACAN, J. Escritos. Tradução de Vera Ribeiro. Rio de Janeiro: Jorge Zahar, 1950/1998. p. 127-152.

LACAN, J. Premissas a todo desenvolvimento possível da criminologia. In: LACAN, J. Outros Escritos. Rio de Janeiro: Jorge Zahar Editor, 1950/2003. p. 127-131.

LACAN, J. Passagem ao Ato e Acting out. In: LACAN, J. O Seminário: A angústia, 10. Tradução de Vera Ribeiro. Rio de Janeiro: Jorge Zahar, 1962-1963/2005. p. 128-145.

LACAN, J. A ciência e a verdade. In: Escritos. Rio de Janeiro: Jorge Zahar Editor, 1966/1998.

QUINET, A. Psicose e laço social: esquizofrenia,paranóia e melancolia. 2ª. ed. Rio de Janeiro: Zahar, 2009.

SALUM, M. J. G. A Psicanálise e o crime:causa e responsabilidade nos atos criminosos, agressões e violência na clínica psicanálitica contemporânea. Universidade Federal do Rio de Janeiro. Rio de Janeiro, p. 173. 2009.

SANTOS, M. C. O. A Escuta Analítica Numa Instituição Prisional. Instituto de Psicanálise e Saúde Mental de Minas Gerais - Almanaque On-line, Belo Horizonte, n. 09, 2015. ISSN ISSN 1982-5617.

SANTOS, T. Levantamento nacional de informações penitenciárias:INFOPEN Atualização- Junho de 2016. Ministério da Justiça e Segurança Pública. Brasília, p. 65. 2017. 


\section{Desafios da psicologia no Brasil}

SENADO FEDERAL. Código Penal. Coordenação de Edições Técnicas. Brasília, p. 138. 1940/2017.

SHIMIZU, B. Criminologia Psicanalítica: O mal estar e a sociedade punitiva. 1a. ed. Rio de Janeiro: Lumen Juris, 2016.

SIQUEIRA, F. G. Da culpa em Freud à responsabilidade em Lacan: paradigmas para uma articulação entre psicanálise e criminologia. Psicologia em Revista, Belo Horizonte, v. 21, n. 1, p. 141-157, abril 2015. 


\section{Desafios da psicologia no Brasil}

\section{NOTAS}

Nota 1

Este artigo é produto de uma apresentação no IX Seminário Nacional de Psicologia e Políticas PúblicasEtapa Sudeste intitulado "Diálogos em rede e desafios ético-politico da Psicologia nas políticas públicas: do desmonte à resistência" ocorrido de 07 a 08 de junho de 2018 em Belo Horizonte/MG.

Nota 2

Segundo o Código Penal brasileiro: "Art. 26: é isento de pena o agente que, por doença mental ou desenvolvimento mental incompleto ou retardado, era, ao tempo da ação ou da omissão, inteiramente incapaz de entender o caráter ilícito do fato ou de determinar-se de acordo com este entendimento." ( (SENADO FEDERAL, 1940/2017) 


\section{Capítulo 12}

\section{AVALIAÇÃO PSICOEDUCACIONAL EM CRIANÇAS ENCAMINHADAS COM DIFICULDADE DE APRENDER}

DOI: $10.37423 / 200200175$

Maria Eni de Mattos (Acadêmica do nono período do curso de Psicologia da Faculdade Guairacá- FAG - Guarapuava Paraná).

mariaenimattos@yahoo.com.br

Josemary Giraldi (Professora Supervisora do Estágio Profissional I da Faculdade Guairacá - FAG - Guarapuava - Paraná).

josegiraldi@hotmail.com

RESUMO: Este trabalho conșiste na discussão de um/caso de ávaliação psicoeducacional de uma criança com dificuldades de aprendizagem, como parte de um estágio curricular đó curso de Psicologia da Fàculdade Guairacá, en Guarapuava. Esta prática teve como objetivo a melhoria do desempentho educacional e a funcionalidade dos contextos de ensino/aprendizagem frente às dificuldades encontradas na escola. O processo de avaliação psicoeducacional deu-se através de entrevista com os pais, atendimento individual com a criança, utilização de teste projetivo e de inteligência,/jogos, visitas à escola em que a-criança atendida estuda e ao Núcleo Regional de Educação $/$ NRE, além de contato com profes\$ores e equipe pedagógica da escola para esclạrecimento de dúvidas e para fornecer orientações referentes ao trabalho com a-eriança em questão. Purante o processo de avaliação constatouse evolução do aluno no que se refere à sua forma de-se comportar em seus contextos e mudança- de postura de sua mãe após orientações de como lidar com seư filho.

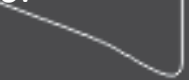




\section{Desafios da psicologia no Brasil}

A realização deste trabalho indica a eficácia do olhar atento e abrangente diante dos contextos e comportamentos da criança, possibilitando, assim, possíveis e claras intervenções relacionadas às dificuldades de aprendizagem.

Palavras-chave: avaliação psicoeducacional; dificuldade de aprendizagem; psicologia educacional. 


\section{Desafios da psicologia no Brasil}

\section{INTRODUÇÃO}

A avaliação psicoeducacional tem por objetivo intervir junto a crianças com problemas de aprendizagem da região de Guarapuava e a partir deste princípio, apresentaremos aqui um caso de avaliação psicoeducacional. Esta avaliação faz parte de um estágio curricular tendo como prioridade crianças com necessidades educativas especiais, transtornos de aprendizagem e/ou de desenvolvimento. Seu objetivo é melhorar o desempenho desta população com análise e reflexões dos determinantes do sucesso ou fracasso escolar.

Inicialmente, o presente material traz algumas reflexões epistemológicas nas quais demonstra o referencial teórico-metodológico que fundamenta a prática da avaliação psicoeducacional. Este engloba um breve apanhado histórico da teoria utilizada, os princípios epistemológicos e a teoria psicanalítica como uma proposta para o contexto escolar e a importância da inserção do psicólogo neste ambiente.

Em seguida apresenta o método utilizado, ou seja, a descrição do caso atendido e do ambiente no qual o atendimento acontece, a quantidade de sessões realizadas e o tempo de duração, além da descrição das técnicas e procedimentos utilizados no processo avaliativo.

Posteriormente é descrito o processo em si. A demanda trazida pela mãe da criança atendida e os objetivos para este caso. Também é apresentada a análise do processo, na qual é feita uma reflexão sobre as mudanças hipotéticas observadas na criança atendia, fazendo a devida correlação com a literatura utilizada.

Finalmente é apresentada a conclusão a partir do trabalho realizado onde se demonstra as habilidades e reflexões levantadas dentro do enfoque utilizado.

\section{REVISÃO DE LITERATURA}

A população escolar vive em constante mudança e a escola continua atuando como há muito tempo e muitas vezes não consegue atender a todos os alunos levando muitos deles a se sentirem desmotivados e insatisfeitos.

O homem, como um ser inacabado, está sempre em busca de satisfação e, para isso, precisa aprender as regras para que se adeque à sociedade. Para tal intento, necessita frequentar a escola na intenção de receber os conhecimentos que sozinho não conseguiria. Dessa forma, cabe ao psicólogo auxiliar no entendimento dos problemas da escola e, principalmente, aqueles relacionados às crianças que não 


\section{Desafios da psicologia no Brasil}

conseguem aprender. Assim, o psicólogo tem a possibilidade de intermediar entre o professor, o aprendizado e a criança com dificuldade de aprendizagem.

Conforme Queiróz, 2008:

O papel do educador e da Educação nesse momento dentro da perspectiva psicanalítica é o de aceitar e mostrar que existem outros saberes além dos já conhecidos, deve mostrar que nem ele e nem a criança tem as verdades absolutas, sempre haverá possibilidades de novos arranjos dos dados da realidade. $O$ ser humano é um ser angustiado, está sempre à procura de uma satisfação, mas nunca alcançará sua plenitude (p. 02).

Diante da necessidade de se lidar com as dificuldades, a psicologia foi introduzida na escola para lidar com crianças "problema", por não se adequarem às normas e princípios institucionais. Silva (2008) afirma que na década de 1970 o olhar do psicólogo era direcionado apenas para a criança, com o fim de ajustá-la ao ambiente escolar. Com o tempo, “o psicólogo voltou-se também para os docentes, mas restringindo o enfoque aos aspectos emocionais e visando ao aluno que não acompanhava os demais. O centro de sua atenção continuava sendo a criança" (SILVA, 2008, p. 140).

Coll et al (2004, p. 31) afirmam que "a Psicologia da Educação/Escolar contribui para a elaboração de uma teoria que permita compreender e explicar melhor os processos educacionais". Auxilia na preparação de estratégias e modelos de planejamento e intervenção que possam orientar no processo, bem como ajudar no estabelecimento de "práticas educacionais mais eficazes, mais satisfatórias e mais enriquecedoras para as pessoas que participam dela". (p. 31). Desse modo o contato direto da Psicologia da Educação/Escolar com problemas cotidianos da prática educacional contribui para a tomada de consciência da importância de sua contribuição para a melhoria dos processos de ensino/aprendizagem da instituição.

O psicólogo escolar busca enfatizar a importância da afetividade e das relações que são estabelecidas com o aluno, valorizando sua subjetividade que está se estruturando, além do componente puramente cognitivo.

Vale ressaltar aqui, segundo a Associação Brasileira de Psicologia Escolar/Educacional - ABRAPEE, que Psicólogo Escolar é aquele cuja atuação se caracteriza mais pela intervenção na prática, enquanto que a dos psicólogos educacionais, geralmente, se direciona para as áreas de ensino e pesquisa.

Cabe lembrar, ainda, que o Psicólogo Escolar, como conhecedor das necessidades de todas as crianças, independentemente de sua condição social, habilitadas ou que apresentem déficit cognitivo ou não, abandonadas ou acolhidas por suas famílias, busca defender os direitos dessas crianças ao 


\section{Desafios da psicologia no Brasil}

atendimento de suas necessidades e à promoção de seu desenvolvimento, sem discriminação ou intolerância de qualquer tipo.

Assim, também Piletti (2006) afirma que a Psicologia da Educação é indispensável para que o docente tenha condições de compreender seus alunos e desenvolver um trabalho mais eficiente, pois pode ajudá-lo a entender as características de cada fase pela qual o aluno está passando e, dessa forma, auxiliar o discente de maneira que ele aprenda mais facilmente. Ressalta também que o psicólogo que atua na área da educação precisa compreender não somente o aluno como ator dentro do processo educacional, mas também, o professor.

Nesse sentido, o psicólogo pode auxiliar os docentes, orientando-os em como trabalhar com essas crianças que apresentam algum tipo de dificuldade, seja de aprendizagem ou não, de forma que a escola cumpra o seu papel de formar um cidadão que possa lutar por aquilo que deseja e com condições de ocupar seu lugar na área de trabalho que elas escolherem.

Dessa maneira, o profissional também ajuda o professor a buscar um método para aplicar em sala de aula que abarque todos os seus alunos, motivando-os e fazendo com que eles queiram saber e ir em busca de mais conhecimentos. Para isso, a "Psicologia Escolar deve voltar-se para a metodologia do ensino. Para ela, teoria e prática são duas dimensões inseparáveis da produção científica enquanto ciência humano-social" (PATTO, 1997, p. 456).

E Hohendorff (1999) afirma que no ato educativo, além da transmissão de saberes metodologicamente estabelecidos e executados, ocorre a transmissão de sentimentos inconscientes, tanto por parte do professor quanto por parte dos alunos. Para a autora, este espaço de transmissão faz limite ao saber pedagógico na medida em que não pode ser mensurado, quantificado, nem metodologicamente reproduzido, pois é singular a cada pessoa. Este espaço da transmissão só é acessível por meio de seus efeitos que são sempre da ordem do singular, ou seja, quando se percebe a individualidade de cada aluno e, por conseguinte de cada professor.

Ao considerar que as vivências de aluno e professor interferem nesse processo de ensinoaprendizagem, o psicólogo escolar tem a possibilidade de auxiliar o docente para que compreenda o comportamento do aluno e ajude-o a entender aquilo que está sendo exposto, e dessa forma, a aprendizagem possa se efetivar.

\section{OBJETIVO E PROPÓSITO}




\section{Desafios da psicologia no Brasil}

O objetivo deste trabalho é entender de que forma a avaliação psicoeducacional pode contribuir para a melhora do desempenho de crianças encaminhadas ao serviço de Psicologia com queixa de problemas/dificuldades de aprendizagem. Teve como propósito investigar um menino encaminhado pela mãe porque apresentou baixo rendimento em algumas disciplinas no primeiro bimestre do ano letivo de 2010. Partindo-se da hipótese de Altas Habilidades levantada pelo resultado do Teste R-2 e atividades desenvolvidas com a criança, buscou-se uma forma de ajudá-la a melhorar seu desempenho na escola e em casa, fazendo com que ao final dos atendimentos o resultado fosse positivo.

\section{METODOLOGIA}

Esta prática teve como método de trabalho: entrevistas com pais, professores, equipe de ensino do Núcleo Regional de Educação do Estado, Testes projetivo e de inteligência e atividades com a criança.

\section{OBJETO ESTUDADO E PROCEDIMENTOS}

A avaliação psicoeducacional apresentada foi realizada com uma criança de dez anos, que veio encaminhada pela mãe devido à nota baixa no primeiro bimestre escolar. Segundo a mãe, a criança encontrava-se muito quieta, não falava sobre os acontecimentos da escola, evitava comentar sobre os colegas e professores e chorava por qualquer motivo.

O primeiro passo após a entrevista com a mãe foi dar inicio aos atendimentos com o menino, ao longo dos encontros com a criança, fizeram-se uso de jogos, desenhos, conversas e desafios, com a finalidade primeira de criação de vínculo e, sequencialmente, de identificar as causas de sua dificuldade de aprendizagem e notas baixas, bem como atividades para desenvolver sua autoestima e também Teste projetivo e de inteligência para avaliar a hipótese levantada. Durante os atendimentos pôde-se perceber a evolução da criança, que inicialmente estava tímida, mas no decorrer do trabalho ficou mais à vontade, comunicando-se bastante, falando sobre a família, a escola, professores, colegas e suas dúvidas em relação a algumas disciplinas.

Houve a necessidade de um encontro com os pais, visando orientações em relação à melhor forma de lidar com o filho dentro do ambiente familiar.

Também foram feitas duas visitas à escola para coletar mais informações e conversar com os docentes no sentido de como trabalhar com o garoto. Sugeriu-se aos professores o desenvolvimento de atividades que favorecessem a sua interação com o grupo escolar e sua autoestima. 


\section{Desafios da psicologia no Brasil}

Aconteceu, ainda, uma visita ao Núcleo Regional de Educação para conversa com a equipe de ensino e obtenção de maior conhecimento da política educacional paranaense em relação à sala de recursos. A acadêmica entrou em contato com a psicóloga responsável pela parte de educação especial do NRE, em Guarapuava, para conversar sobre a legislação educacional relacionada a crianças que apresentam AH/SD. A mesma garantiu que a professora que atuará na sala de recursos está se preparando há um ano com cursos na área de AH/SD oferecidos pelo governo do Estado. A pedagoga responsável pela sala de recursos juntamente com a psicóloga está fazendo a triagem dos alunos que chegam com indicativos de AH/SD. Elas alegam o fato de crianças com AH/SD ser pouco conhecido e, por conseguinte, pouco divulgado.

Houve também um contato com a professora de Educação Física, que solicitou este encontro através da mãe da criança atendida, devido ao fato do aluno se encontrar, segundo ela, muito apático em suas aulas. A acadêmica orientou-a a incentivá-lo elogiando-o, além de buscar promover sua interação com os demais jogadores durante a atividade.

Também foi solicitada uma avaliação pedagógica com a criança para a possibilidade de confirmar ou não a hipótese de altas Habilidades/Superdotação.

Durante todo o processo de atendimento que aconteceram no Centro de Psicologia Aplicada (CPA) da Faculdade Guairacá, foram lidos textos relacionados à queixa apresentada pela mãe e após as avaliações realizadas, foram pesquisados e lidos textos científicos sobre as hipóteses levantadas.

Este estágio tratou de avaliação, atendimento e acompanhamento de crianças entre seis e quatorze anos que tivessem problemas significativos de aprendizagem. Para tal foram executadas as seguintes atividades: identificação das dificuldades de aprendizagem e identificação das necessidades educativas especiais das crianças, entrevista clínica com os pais, observações diretas com a criança, delimitação do problema e análise do caso.

Além dos atendimentos foram realizadas supervisões em grupo regulares dos casos, nos quais cada um dos estagiários apresentou as intervenções realizadas bem como sua proposta de continuidade do caso. Este espaço foi usado para realizar a discussão e embasamento teórico sempre que necessário. Em cada supervisão o estagiário apresentou as evoluções e os obstáculos do caso atendido, com análises e discussões feitas regularmente em grupo, além de orientação para a confecção de materiais que se fizeram necessários. Bem como, a leitura e a apresentação periódica dos assuntos relacionados com a área de: Avaliação Psicoeducacional/ psicopedagógica, Intervenção Psicoeducacional/ psicopedagógica, Psicoterapia infantil, Desenvolvimento infantil e Necessidades Educativas Especiais. 


\section{Desafios da psicologia no Brasil}

Na devolutiva feita à mãe e à criança foi enfatizado que o menino pode continuar melhorando e se dedicando em seus estudos. Ele tem consciência de que vem melhorando e que recuperou a nota baixa que tirou no primeiro bimestre e esteve mais participativo nas aulas, mais socializado ao ambiente e com mais amigos. Em casa está mais comunicativo e segundo a mãe, os professores em geral o elogiam dizendo o quanto ele está mais dedicado aos estudos, que faz as tarefas e trabalhos e a mãe ressalta que ele parece mais confiante. Ela relatou também que outros familiares perceberam a mudança de comportamento do garoto. Para encerrar a acadêmica comentou na possibilidade de o menino frequentar a Sala de Recursos em 2011, mas, que antes passará pela triagem feita no ambiente escolar e pela equipe do NRE.

Na devolutiva feita à escola foi sugerido aos professores trabalharem atividades que promovessem sua autoestima e interação com os demais alunos.

\section{ANÁLISE DOS PROCEDIMENTOS E RESULTADOS}

Nas entrevistas iniciais a mãe expôs que a criança tirara nota vermelha na escola, não se relacionava com os colegas, não comentava o que acontecia na escola e chorava sempre que ela mandava que ele fizesse algo. A mãe tinha como expectativa que o filho se abrisse, falasse sobre o que o incomodava e como ele gostaria de ser tratado em casa.

De acordo com a entrevista feita com a mãe e o desempenho do menino no Teste R-2 levantou-se a hipótese de Altas Habilidades/Superdotação. Para confirmação solicitou-se a pedagoga da escola onde ele estuda que realizasse uma prova pedagógica para confirmação ou não da hipótese. Na sequência foi investigado o comportamento de isolamento, não socialização e notas baixas em algumas disciplinas. Optou-se, então, pelo Teste Projetivo H T P que revelou insegurança, baixa autoestima e inadequação ao meio.

No decorrer dos atendimentos percebeu-se que a criança estava mais comunicativa, falava mais sobre si, família e escola. Segundo a mãe, seu relacionamento melhorou na escola, agora ele já tem mais amigos com quem conversa e brinca no horário do recreio. Tem feito seus trabalhos e tarefas e suas notas melhoraram. Ela relatou que a orientadora da escola disse que o menino já não vai mais à sua sala para reclamar dos colegas. Em casa está mais comunicativo, não chora mais por qualquer motivo, conversa mais e sorri o que não acontecia há algum tempo. 


\section{Desafios da psicologia no Brasil}

De acordo com a professora de educação Física, o menino está mais participativo e falante em suas aulas. Segundo ela, ele discute os assuntos da aula e na parte escrita da matéria vai muito bem, apenas na prática é que ele não evoluiu muito.

Os atendimentos proporcionaram mudanças significativas, como a melhora da autoestima e seu relacionamento em casa e na escola. Possibilitou que ele falasse sobre seus sentimentos e auxiliou-o na compreensão de si e da necessidade de se relacionar, despertando-o para se sentir mais ambientado à escola, aos colegas e professores. Mudou seu comportamento em casa e na escola, passando a interagir mais com as pessoas com quem convive.

\section{DISCUSSÃO}

A partir do trabalho realizado com a criança em questão, pode-se identificar que processos familiares estão influenciando no seu desempenho escolar, pois, a mesma apresentava-se de forma retraída, quase não se comunicava em casa e na escola, apresentava nota baixa em algumas disciplinas e não queria ir para a escola. Assim, Barros e Valente (2005, p. 105) ressaltam que "a família e a dinâmica de relações estabelecidas por ela influenciam no desenvolvimento e na formação do sintoma da criança". Elas afirmam que problemas escolares podem mascarar ou expressar que algo não está bem com a criança, pois, conforme Bleger (1984, p.79) todo comportamento está sempre relacionado a um acontecimento na vivência da pessoa.

O modo como é feita a avaliação psicoeducacional, na qual, muitas vezes, deixa-se de compreender o contexto em que a queixa escolar foi produzida, analisa-se tão somente o que o aluno apresenta nos testes, desconsidera-se fatores histórico-sociais que têm produzido o fracasso escolar, sem conhecimento anterior da história do aluno, é uma das críticas que podem ser usadas também em relação aos testes unificados. Quando se leva em consideração somente o resultado dos testes, sem investigar a história devida do sujeito, corre-se o risco de cometer um erro, pois se desconsidera informações que poderiam ajudar a compor o diagnóstico do problema apresentado.

Com os atendimentos pôde-se aprender que é possível acontecer na escola o aparecimento dos conflitos dos estudantes, por meio de comportamentos de isolamento, falta de socialização e participação nas atividades e até mesmo sentimento de baixa autoestima que fazem com que o aluno apresente baixo desempenho escolar. De acordo com Mckay e Fanning (2010, p. 284) a "autoestima é a armadura que protege a criança dos dragões da vida: drogas, álcool, relacionamentos doentios e delinqüência". Assim, percebe-se a importância de considerar que nem todos os problemas em 


\section{Desafios da psicologia no Brasil}

relação à nota baixa têm relação com dificuldade de aprendizagem, havendo a necessidade de investigar o que de fato leva a criança a agir dessa forma para, então, fazer as intervenções necessárias.

Diante das avaliações feitas com a criança percebeu-se que o sofrimento interno pelo qual ela passava aparecia retratado nos desenhos ou em suas falas, enquanto desenvolvia suas atividades. É preciso também ter um olhar atento e diferenciado sobre o comportamento da criança para que se compreenda e possa auxiliá-la a superar aquilo que está Ihe incomodando.

Ao longo do trabalho foi possível perceber a evolução da criança em sua forma de se comportar, pois, a mãe diz que em casa ele já conversa mais, está mais alegre e já não chora quando ela chama a sua atenção. Ela conta que os professores comentam que o mesmo está mais participativo, a professora de educação Física percebeu que ele se dedica mais, porém é melhor falando e escrevendo do que praticando atividades físicas. E no decorrer de todo o processo notou-se uma nova postura da mãe em relação ao filho, no sentido de auxiliá-lo, incentivando sempre que conseguia atingir um objetivo, seja melhorando a nota, interagindo mais com colegas e professores, seja em casa, falando e expressando os sentimentos. Também está se buscando confirmação da hipótese de altas habilidades por meio de documentos que possam comprová-la como: testes, informações junto à equipe de docentes, comunidade escolar e família.

\section{CONCLUSÃO}

Este trabalho fez parte de um estágio curricular do curso de Psicologia com ênfase em Processos Educativos que tem como prioridade intervir junto às crianças que apresentam dificuldades de aprendizagem, para tal, apresentaremos aqui um caso de avaliação psicoeducacional. Seu objetivo era melhorar o desempenho destes alunos com análise e reflexões dos determinantes do sucesso ou fracasso escolar. Possibilitou a compreensão de que é necessário demonstrar o respeito pelo outro, aceitar o que ele traz, de que forma e como isto lhe causa sofrimento. Foi por meio da escuta atenta e empática que pôde juntamente com outro refletir ou fazer apontamentos que o levaram a reflexão e as possíveis mudanças de comportamento.

O psicólogo escolar não pode trabalhar de forma isolada, só com o sujeito que apresenta dificuldade, mas com todo o coletivo, de modo a intervir nos diversos contextos em que esse indivíduo frequenta, de forma que todos possam contribuir para uma possível mudança de comportamento. 


\section{Desafios da psicologia no Brasil}

A parte prática contribuiu para a percepção da importância de ouvir, de respeitar o silêncio e a dúvida do outro, de pensar junto sem dar a palavra final. Entender que cada pessoa tem o seu momento e que é importante que o outro sujeito se sinta acolhido e compreendido, sem receio de ser julgado pela sua maneira de ser e agir. Pôde-se aprender o quanto é necessário trabalhar com a comunidade escolar em relação a mudar seu olhar sobre o aluno no sentido de entendê-lo e não culpabilizá-lo pela sua dificuldade.

Esse trabalho, tanto prático quanto teórico, proporcionou a possibilidade de repensar valores sobre o comportamento dos profissionais da educação em relação a crianças que apresentam baixo desempenho escolar e o quanto a escola precisa se atualizar para acompanhar as mudanças que estão ocorrendo. Foi interessante e gratificante observar o quanto a escuta e a aceitação pode auxiliar a pessoa a expressar aquilo que a incomoda, seja falando ou desenhando e pensar sobre o que pode ser feito para a mudança de atitude quando ela se sente entendida, aceita e respeitada pelo outro. Ficou visível o quanto os pais podem, de forma inconsciente, interferir no desempenho escolar de suas crianças e, quando isso lhes é mostrado, o quanto eles podem auxiliar no sentido de reverter a situação, como na queixa trazida no início dos atendimentos e o resultado obtido ao final do mesmo. Notou-se também que é importante investigar a queixa levando em conta tudo o que pode influenciar a criança a ter determinado comportamento e procurar saber o que realmente a leva a agir dessa forma, buscando meios que possam auxiliar no diagnóstico e uma possível solução para o caso.

\section{REFERÊNCIAS}

ABRÃO, Jorge Luís Ferreira. As Influências da Psicanálise na Educação Brasileira no Início do Século XX Psic.: Teor. e Pesq., Brasília, Mai-Ago 2006, Vol. 22 n. 2, pp. 233-240. Disponível

em: http://www.scielo.br/pdf/ptp/v22n2/a13v22n2.pdf. Acesso em: 20 Nov. 2010.

BARROS, Maria Silvana da Rocha e VALENTE, Maria Luísa L. Castro. A criança como sintoma da família. IN: VALENTE, Maria Luísa L. Castro e WAIDEMAN, Marlene Castro (Org.). E a família, como vai? Assis FLC - Assis - UNESP - Publicações, 2005.

BLEGER, José. Psicologia da Conduta. Trad. Emília de Oliveira Diehl. Porto Alegre: Artes Médicas, 1984. BOSSA, Nádia Aparecida. Dificuldades de Aprendizagem O Que São? Como Tratá-Las? Disponível em: http://www.psicopedagogia.com.br/entrevistas/entrevista.asp?entrlD=32 Acesso em: 29 Nov. 2010.

COLL, César. MARCHESI, Álvaro e PALACIOS, Jesus. Desenvolvimento psicológico e educação: Psicologia da educação escolar. Vol. 2. Trad. Fátima Murad. 2a ed. Porto Alegre: Artmed, 2004. 


\section{Desafios da psicologia no Brasil}

FACCI, Marilda Gonçalves e Cols. Contribuições da Teoria Histórico - Cultural para o Processo de Avaliação Psicoeducacional. Psicologia USP, 2006, 17(1), 99-124. Disponível

em: www.revistasusp.sibi.usp.br/pdf/psicousp/v17n1/v17n1a08.pdf Acesso em: 20 Nov. 2010.

HOHENDORFF, Clara Maria Von. Cultura é aquilo que fica de tudo que se esquece. Revista da Associação Psicanalítica de Porto Alegre / Associação Psicanalítica de Porto Alegre. - $n^{\circ} 16,1999$. - Porto Alegre: APPOA, 1995. Disponível em:

http://www.revistasusp.sibi.usp.br/pdf/psicousp/v17n1/v17n1a08.pdf. Acesso em: 20 Nov. 2010

MCKAY, Mathew e FANNING, Patrick. Autoestima. Trad. Áurea Arata. 1a ed. São Paulo: Centro de Estudos Vida \& Consciência, 2010.

PATTO, Maria Helena Souza. Introdução à psicologia escolar. 3ạ ed. São Paulo: Casa do Psicólogo, 1997.

PILETTI, Nelson. Psicologia Educacional. 17ạ ed. São Paulo: Ática, 2006.

Queiroz, Raquel N. Vaz de. O Diálogo Entre A Psicanálise E A Educação. Publicado em: 04/05/2010. Disponível em:

http://psicopedagogiaclinicaeinstitucional.blogspot.com/2010/05/o-dialogo-entre-psicanalise-eeducacao.html Acesso em: 20 Nov. 2010

SABATELLA, Maria Lucia Prado. Talento e Superdotação: Problema ou Solução de 2a edição, da editora Ibpex, 2009

SÁNCHEZ-CANO M.; BONALS, J e Cols. Avaliação Psicopedagógica. Trad. Fátima Murad. Porto Alegre: Artmed, 2008. reimpressão 2010.

SILVA, Silvia Maria Cintra da e Cols. O Psicólogo Escolar e a Infância - uma experiência em escola pública. EDUCAÇÃO: Teoria e Prática - v. 18, n.31, jul. - dez. -2008 p.137-152. Disponível em: http://www.periodicos.rc.biblioteca.unesp.br. Acesso em: 20 Nov. 2010. 


\section{Capítulo 13}

\section{A FORMAÇÃO DE PROFESSORES EM EXERCÍCIO NOS ANOS INICIAIS DO ENSINO FUNDAMENTAL}

DOI: $10.37423 / 200200176$

Benedita de Almeida (UNIOESTE) - beneditaalmeida@yahoo.com.br

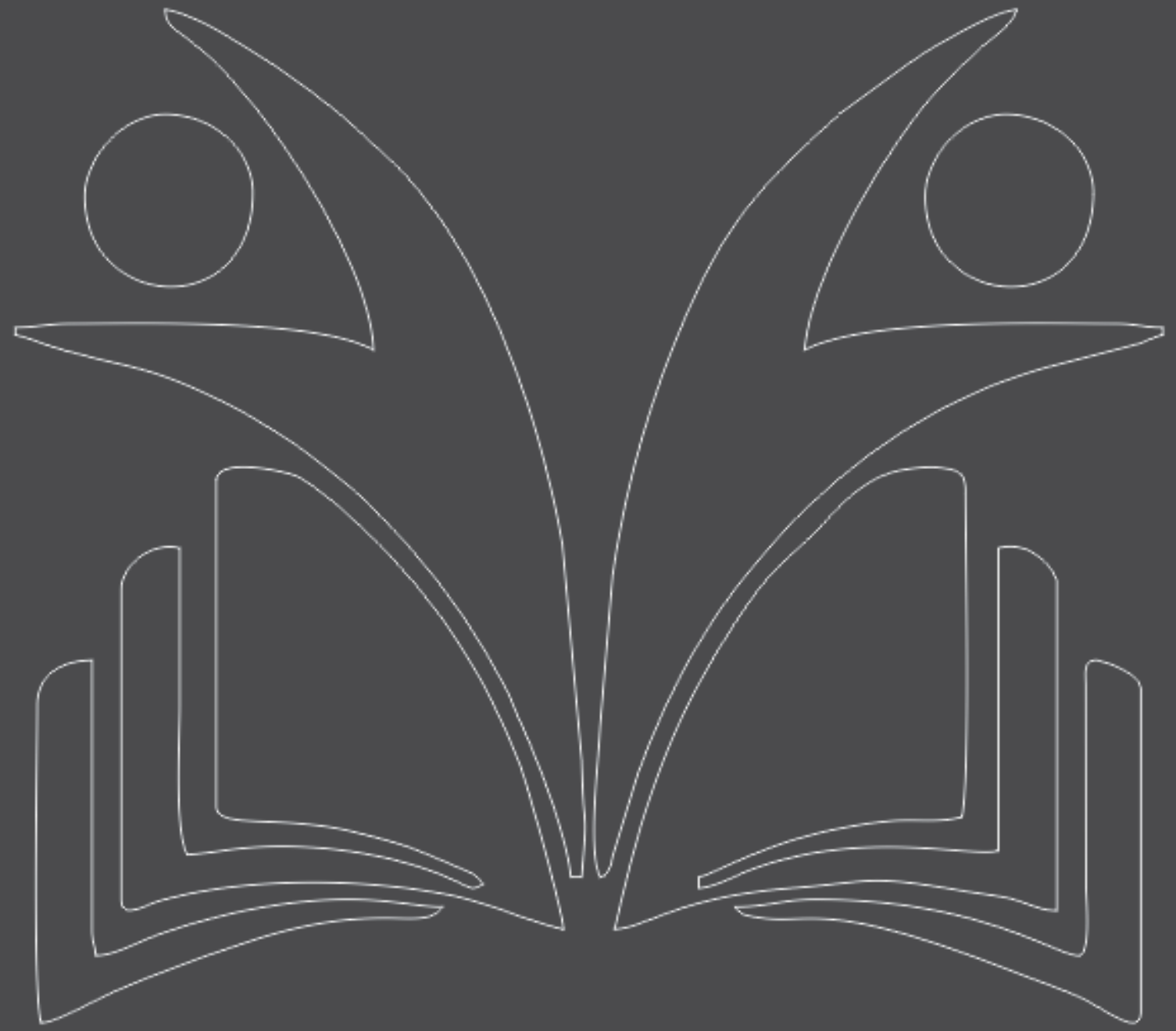




\section{Desafios da psicologia no Brasil}

\section{PONTOS DE PARTIDA}

Os problemas que acompanham a qualidade na educação básica brasileira situam-na como foco de muitas preocupações e pesquisas e se refletem em baixos índices de desempenho dos estudantes, amplamente divulgados por instrumentos oficiais ${ }^{1}$. Questões político-administrativas, destinação de recursos, grande desigualdade socioeconômica e na distribuição de bens culturais, condições inadequadas de trabalho nas escolas são alguns fatores que favorecem esse quadro. Contudo, o preparo dos professores que atuam nesse nível educacional é condição indispensável para a melhoria do ensino. E esse preparo ultrapassa a formação inicial, pois a profissão docente se constitui na continuidade das relações entre o preparo profissional dos cursos de formação inicial e o exercício da profissão, com a interação de conhecimentos e atuação profissional (Pimenta, 1996). É nessa interação que muitas questões da prática pedagógica afloram e desafiam os professores às decisões necessárias para superá-las, o que ressalta a importância de sua contínua formação.

O campo de investigação sobre a formação de professores vem recebendo, nos últimos anos, uma fértil contribuição de pesquisas que enfocam a formação continuada, a partir de experiências realizadas na escola, em parcerias entre pesquisadores da universidade e professores das escolas de educação básica. São importantes estudos que evidenciam o potencial formador dessa parceria colaborativa, pela possibilidade de trazer ao campo de discussão do trabalho educativo, pelos próprios professores, a realidade das escolas, suas práticas e problemas. Trata-se, portanto, de destacar as necessidades específicas de formação de grupos de professores em exercício da profissão docente, a partir do próprio contexto de trabalho, e buscar respostas que, construídas em coparticipação e mediadas pela teoria pedagógica, possam assegurar resultados mais qualificados e maior envolvimento e comprometimento dos participantes. Resultados que podem contribuir para a melhoria da educação básica, mas, também, da própria educação superior, pois os professores da universidade também levam para as aulas que ali ministram uma percepção mais próxima da escola real, o que thes permite o reconhecimento de necessidades e desafios que ela impõe à efetivação do trabalho docente. Sem dúvida, essa parceria pode provocar o aprofundamento da teoria educacional, pelo seu potencial formativo que se estende a todos os participantes (Garrido, 2000; Giovanni, 1994; Mizukami, 2002; Pimenta, 1996).

Pensar alterações na qualidade da educação brasileira, portanto, requer atuação na formação do profissional que atua na educação básica. Pela perspectiva histórico-cultural do desenvolvimento humano, a formação do professor para atuar nos anos iniciais representaria elemento fundamental 


\section{Desafios da psicologia no Brasil}

na dinâmica do sistema educativo, dadas as especificidades da fase em que se encontra a criança, no que se refere às possibilidades de desenvolvimento. Trata-se de uma etapa que inaugura um período diferenciado de aprendizagens na experiência infantil, pela ampliação do convívio com processos sistemáticos e intencionais de ensino-aprendizagem, responsáveis pela introdução de conhecimentos imprescindíveis à formação. Segundo Vigotski (1998a, p. 118), quando adequadamente organizado, o aprendizado "resulta em desenvolvimento mental e põe em movimento vários processos de desenvolvimento" que não ocorreriam de outra forma.

A reflexão proposta neste trabalho explora as relações constitutivas entre linguagem e pensamento, focalizando a formação continuada de professores dos anos iniciais do ensino fundamental, mediante apresentação de resultados de pesquisa sobre as relações entre escrita e desenvolvimento profissional docente. A pesquisa refere-se a um processo colaborativo de formação, realizado em parceria com uma escola do campo, de educação básica, no sudoeste do Paraná, cujo desenvolvimento é apresentado no próximo item. Em seguida, a experiência de formação é analisada, discutindo-se e papel da linguagem e as contribuições da escrita para a formação, na perspectiva histórico-cultural. No final, são apresentados os resultados, que sinalizam relevantes contribuições para a formação de alfabetizadores $^{2}$, por evidenciarem como a atividade de escrita sobre a prática potencializa o conhecimento de professores sobre o trabalho educativo e resultam em transformação de seus conhecimentos e práticas pedagógicas de ensino da escrita.

\section{PESQUISA E FORMAÇÃO - A MEDIAÇÃO DA ESCRITA}

De início, é importante considerar o contexto de realização da pesquisa, o meio rural, local de pequena circulação de materiais escritos, pelas características das atividades pessoais voltadas à sobrevivência das famílias e orientadas ao cuidado das propriedades agrícolas, e também pela precária oferta de livros e materiais de leitura diversificados nas escolas. Ou seja, trata-se de contexto em que as práticas de escrita e leitura dificilmente integram a dinâmica social e os bens culturais dos sujeitos. Elemento relevante, porque os contextos culturais de existência, de formação e de trabalho são determinantes do desenvolvimento dos sujeitos e das relações que mantêm com o conhecimento (Vigotski, 1998a).

Em contraste com essa realidade, a escrita ocupa papel privilegiado e preponderante nas sociedades modernas e nos espaços escolares, sendo importante fator de inclusão social. Tendo em vista tais desafios, a proposta de formação continuada desencadeou uma rede significativa de ações centradas num projeto pedagógico coletivo da escola. A experiência de formação continuada ancorou-se em dois 


\section{Desafios da psicologia no Brasil}

flancos principais: (i) a organização e implementação do projeto pedagógico coletivo, com foco no resgate da cultura das comunidades atendidas pela escola do campo e (ii) a escrita sobre a prática pedagógica pelos professores. Nos dois, a atividade de escrita foi instrumento de ensino, aprendizagem e formação.

Questões relativas à identidade cultural e social das comunidades dos escolares foram integradas à proposta pedagógica da escola. O resgate das memórias, características e especificidades da vida social dos sujeitos e seu contexto desdobraram-se em atividades pedagógicas, intencionalmente planejadas e desenvolvidas em sala de aula, para encaminhar o ensino e aprendizagem dos conhecimentos. Pesquisas no meio, problematizações e valorização das questões sócio-culturais e econômicas da realidade social dos escolares puseram em evidência a importante relação da identidade com a cultura e a diversidade cultural, para fortalecimento dos indivíduos. As práticas culturais da comunidade também se tornaram objeto de escrita pelos alunos, diversificando os textos do processo de ensino-aprendizagem, na perspectiva de evidenciar a escrita como prática sociocultural, e não apenas como exercício escolar.

Resgatar e escrever a história do grupo, além de enriquecer os programas de ensino, aproximou moradores, familiares, funcionários, professores e alunos, modificando atitudes em relação ao trabalho escolar. Destaque-se, todavia, que, para não cair no âmbito individual e abstrato, a complexa relação entre educação e sociedade, presente quando se trata da identidade cultural, fundamentouse numa perspectiva sociológica e antropológica (Falteri, 1998) da diversidade, considerando as dificuldades sobre a forma de acolher "a diferenciações, sem se cair em um relativismo que encerre a cada um no seu gueto de origem, sem cair em um populismo lúdico para os que, por sua origem, não poderão ascender à alta cultura com facilidade" (Sacristán, 1996, p. 50).

Ou seja, a valorização da cultura do aluno pela escola - os saberes locais - foi o ponto de partida para a aprendizagem, porque contém aspectos importantes ao desenvolvimento cultural dos grupos sociais. Mas envidaram-se esforços para superar essa restrita dimensão da cultura, para que o ensino escolar cumprisse seu papel no processo civilizatório representado pela apropriação do conhecimento historicamente elaborado e imprescindível à socialização dos indivíduos que a escola inclui ou exclui culturalmente. Afinal, segundo Sacristán (1996, p. 50), não se pode esquecer que "só tem a capacidade de desfrutar da diversidade cultural aquele que pode se distanciar relativizando as culturas diversas" - aspecto fundamental a ser considerado, quando se trata da escola do campo e de suas práticas de ensino da escrita. 


\section{Desafios da psicologia no Brasil}

Na proposta de formação continuada objeto deste estudo, foram realizados encontros semanais da pesquisadora com os professores, na escola, nos quais se promoveram discussões, problematizações, estudos e análises das práticas pedagógicas.

Considerado o objetivo de analisar as relações entre a escrita e o desenvolvimento profissional docente, os professores foram instigados a escrever sobre o processo que vivenciavam - sobre as atividades formadoras, as práticas que desenvolviam, as percepções e construções do processo, os desafios e os limites que encontravam. A escrita de relatos sobre os encontros de formação (atas), de diários, relatos de práticas, textos analíticos do processo, produções para apresentação na universidade e em encontros com outras escolas do campo integrou o objeto e o corpus de documentação da pesquisa. Situada como prática social, na formação, além de permitir as interações com o outro, essa escrita passou a contribuir para a objetivação e a compreensão da prática, constituindo-se em procedimento formador.

Apesar das significativas resistências e dificuldades iniciais, as produções escritas se ampliaram, no decorrer do processo, para apresentação da experiência em encontros acadêmicos e para outras escolas, com relevantes episódios de análise e reflexão sobre a prática.

\section{ENSINO DA ESCRITA, SUJEITOS DA LINGUAGEM E PRÁTICAS ESCOLARES: DA RUPTURA TRILHADA}

\section{ÀS POSSIBILIDADES POR PERCORRER}

Os processos de ensino e aprendizagem da língua escrita situam-se entre os grandes objetivos do trabalho do professor dos anos iniciais. Um trabalho que deve ser tratado com a intencionalidade de imersão da criança na compreensão do sistema simbólico da escrita e de aprendizagem do seu uso nas diferentes atividades que são mediadas pela escrita na sociedade, inclusive aquelas que se referem a estabelecer relações com o conhecimento.

Ou seja, nesse processo, a escrita deve ser compreendida na sua totalidade de prática social e cultural, cujo domínio se relaciona à constituição de sentidos, à compreensão e à possibilidade de o sujeito pôrse em interlocução com outros sujeitos e com o conhecimento. Um processo em que as interações ocorrem pela atividade de linguagem, considerada, a partir de Vigotski (1998b) e Bakhtin (2002), como um instrumento do pensamento, pelo qual os conceitos são apropriados e produzidos para o indivíduo, e que atua na mediação entre ele e a realidade. O ensino da escrita precisa considerar o papel fundamental da linguagem na constituição do universo sociocultural, para o sujeito agir no mundo, conhecer, formar-se e transformar-se. 


\section{Desafios da psicologia no Brasil}

Nas interlocuções de que participa, o indivíduo produz respostas aos enunciados, com as quais constitui sua compreensão sobre o mundo. É dessa forma que o discurso escolar sobre a língua escrita produz os significados dessa prática para os sujeitos, assim como os tipos de vínculos que eles constituirão com os aprendizados nele veiculados. A escrita é forma de linguagem privilegiada na escola e, como um sistema simbólico cultural, seu aprendizado desempenha papel fundamental no desenvolvimento sociocultural do sujeito, quer seja pela apropriação desse sistema simbólico, cuja compreensão, por si só, produz efeitos de desenvolvimento, por atuar na atividade mental mediada, quer seja pelas inúmeras possibilidades de acesso a bens culturais. Ensinar/aprender a praticar a escrita, portanto, é uma tarefa política que precisa ser reconhecida pela escola na sua complexidade de atividade cultural e intelectual, cujo "domínio é o culminar, na criança, de um longo processo de desenvolvimento de funções comportamentais complexas" (Vigotski, 1998a, p. 140).

Como objeto de ensino na escola, no entanto, a escrita nem sempre é vista neste vínculo intrínseco com os sujeitos. O ensino da língua e a seleção de conteúdos e materiais para realizá-lo, normalmente, são efetuados a partir de um conjunto de práticas que se consolidaram na escola. Com pequenas modificações, constituem-se do uso de cartilha ou livro-texto para alfabetizar, textos/trechos de um ou vários livros para interpretar e exercitar gramática, considerada apenas nas dimensões normativa e descritiva, e muita leitura de obras de literatura infanto-juvenil (algumas vezes mais pelos professores que pelos alunos).

Ou seja, essas práticas não se vinculam à experiência pessoal dos sujeitos, o que representa uma ruptura com os princípios constitutivos da linguagem. Por elas, a escola expõe para os alunos uma produção de linguagem considerada legítima, pela tradição escolar. É nesse espaço significativo de problemas no ensino e na cultura da escola que se produz a voz dos professores, e que a formação continuada precisava atuar para re-elaboração dos conhecimentos pedagógicos relativos ao ensino da escrita, uma vez que não foram superados, nem com a formação inicial, nem com a experiência profissional.

A mudança desse status quo, justamente por ser elemento da mencionada tradição, não se faz com facilidade. Exige uma compreensão profunda das concepções fundantes das práticas que se desejam alterar. Uma compreensão que precisa se produzir junto com a alteração da relação - conhecimentos, atitudes e ações - com essas práticas. No caso das práticas de escrita há conhecimentos indispensáveis ao professor, sinalizados pelos avanços da pesquisa na área. São conhecimentos introduzidos nas 


\section{Desafios da psicologia no Brasil}

escolas, mas nem sempre compreendidos pelos professores, para serem integrados às suas práticas de modo adequado ao favorecimento das aprendizagens.

A experiência de formação aqui tratada buscou atuar no conhecimento dos professores sobre a escrita. Para isso, procurou alterar as práticas escolares, vinculando-as à experiência social de alunos e professores: escritas vinculadas ao contexto cultural. As experiências da prática social passaram a ser tematizadas nas práticas de escrita e a se tornarem um elo para a compreensão e produção do conhecimento objeto da escolarização. Essas experiências trouxeram à tona o vínculo orgânico da linguagem com a esfera humana de atividade (Bakhtin, 2000), para caracterizar as produções de escrita dos alunos e promover o ensino da língua. No projeto pedagógico, o plano cultural, como objeto de conhecimento e de relações dos sujeitos, entre si e com o conhecimento, uniu dois polos mediadores do desenvolvimento humano: cultura e linguagem.

O discurso de formação trouxe à interlocução elementos que problematizaram o tratamento escolar da língua escrita e introduziram um movimento de renovação das práticas, no qual a escrita assumiu o caráter funcional de instrumento para promover sua compreensão. O objetivo era transformar as práticas pedagógicas com a língua escrita, na perspectiva de sua constituição como prática social, e a escrita das professoras teve uma primeira funcionalidade explícita: registro da memória da experiência formadora vivenciada. No decorrer do processo, todavia, foi percebida na sua instrumentalidade para a explicitação, análise e compreensão da prática e tomada como objeto de conhecimento.

A pesquisa e o processo formador foram orientados pelos pressupostos teórico-metodológicos da teoria enunciativa e sócio-histórica da linguagem, que a consideram como constituinte da consciência, portanto, do sujeito. Nessa abordagem, os processos de desenvolvimento humano são mediados pela linguagem, na interação social estabelecida pelos indivíduos, e são histórica e culturalmente contextualizados (Bakhtin, 2000, 2002; Vigotski, 1998a, 1998b). Ou seja, por esses pressupostos, desde que aprendem a linguagem, é por ela que os indivíduos vão conhecendo e dando sentido ao mundo. E isso ocorre pela mediação com o outro. Os significados constituídos ao mundo sempre se dão na relação interpessoal, antes de passarem para o âmbito intrapessoal (Vigotski, 1998a).

Tomar a escrita dos professores como objeto de investigação e por ela orientar a pesquisa e o processo de formação partiu do pressuposto de que o aprendizado e o domínio dessa prática social agregam grandes transformações no desenvolvimento cultural do indivíduo. Conforme Vigotski (1998a, 1998b), as operações com signos modificam a estrutura psicológica, gerando formas de comportamentos qualitativamente novas, autogeradas e que permitem controlar o próprio comportamento. 


\section{Desafios da psicologia no Brasil}

Para esse estudioso da linguagem, o pensamento é concebido em uma totalidade, ao contrário da fala que se constitui em unidades separadas. 0 "pensamento não tem um equivalente imediato em palavras, a transição do pensamento para a palavra passa pelo significado", e de forma diferente na fala e na escrita (Vigotski, 1998b, p. 186). A escrita é uma função linguística que "exige um alto nível de abstração" porque "é a fala em pensamento e imagem apenas", exige o desligamento dos aspectos sensoriais da fala e a substituição "de palavras por imagens de palavras". Gradualmente, "torna-se um simbolismo direto", cujo domínio agrega grandes transformações no desenvolvimento cultural, elemento que lhe confere uma qualidade abstrata e a situa como uma função mental que atua no processo de desenvolvimento intelectual. Nessa perspectiva, como atividade de linguagem, a escrita é objeto cultural e prática social de produção e criação. Uma prática que exige um elevado nível de implicação do sujeito, porque promove uma atitude de análise e reflexão deliberadas e não se realiza sem um esforço intencional. Esses elementos a situam como uma função mental atuante no processo de desenvolvimento intelectual (Vigotski, 1998a).

Ademais, a escrita é prática que sempre se efetiva a partir de um real ou imaginário diálogo com o outro - um outro diferente de mim. É uma forma de interlocução com um interlocutor ausente, mesmo quando realizada no ato solitário e silencioso de quem escreve (Bakhtin, 2000).

A esse respeito, segundo Bakhtin (2000), um texto tem "um autor (que fala, escreve)", e dois fatores o "determinam [...] e o tornam um enunciado: seu projeto (a intenção) e a execução desse projeto". Mas cada texto entra numa relação dinâmica com todos os outros textos de uma dada esfera, dialoga com eles, e sua significação, que é a execução do projeto, ou "o acontecimento da vida do texto, [...] sempre sucede na fronteira de duas consciências" (Bakhtin, 2000, pp. 330-333, grifo nosso).

Essa dimensão de alteridade na produção escrita é radicalizada por Bakhtin (2000), quando trata do enunciado literário, caracterizado por ele como uma dimensão da consciência do autor, que sempre sabe mais sobre o personagem do que ele próprio. $\mathrm{O}$ autor tem um excedente de visão e de conhecimento, condicionado pelo lugar que ocupa e pelo qual todos os outros se situam fora deleautor, dada a não coincidência de seus horizontes. Trata-se do princípio da exotopia, que marca a atividade criadora: uma consciência está fora de outra e pode vê-la como ela mesma não se consegue, como um todo acabado, da mesma forma que "o outro vê quando se trata de mim" (Bakhtin, 2000, p. 45).

Considerando esse princípio na atividade de escrita, a relação "autor/personagem" torna-se "autor/outro". Por ela, quem escreve precisa completar o horizonte do outro, mediante um processo 


\section{Desafios da psicologia no Brasil}

de objetivação e distanciamento. Ao objetivar-se (ao situar-se de fora), adquire a possibilidade de uma relação dialógica consigo mesmo (Bakhtin, 2000, p. 351). Nessa objetivação, instaura-se um estranhamento em relação à obra, à escrita, que passa a atuar sobre quem escreve - a escrita exerce um trabalho sobre o sujeito e se torna uma instância de criação. Essas características agregam-lhe uma função interna ao sujeito, além da externa, de interlocução.

Tomando a escrita como um instrumento de pensamento, a pesquisa partiu do pressuposto da existência de uma relação entre o ato de escrever a respeito da própria prática e a ampliação da compreensão sobre ela e para mudança das relações que os professores estabelecem com o conhecimento. Na perspectiva sociocultural, os processos de desenvolvimento se constituem e ganham sentidos dentro do grupo, pelas mediações que se realizam. Assim, a escrita utilizada para objetivar a prática, atua como instrumento mediador do desenvolvimento e, ao mesmo tempo, passa a ser considerada com um novo valor dentro do grupo social que a utiliza.

A tomada de Bakhtin e Vigotski como pressupostos teórico-metodológicos do processo exigiu a definição de alguns princípios para a formação. E um deles foi considerar a dimensão da alteridade, pela interação verbal no próprio discurso de formação, com a instauração do diálogo entre os participantes. Um diálogo no sentido de ouvir e reconhecer o conhecimento e os significados do outro, de se pôr em interlocução com esse conhecimento, para também engajar o outro na escuta e na formação. Assim, até por que a relação entre universidade e escola básica é sempre delicada, havia que se permitir, no início, a manifestação dos ruídos e dissonâncias dos diferentes pontos de vista. Havia que se permitir o confronto da heterogeneidade dos conhecimentos, para construir a polifonia na chegada, para que houvesse o encontro e a incorporação das diferentes vozes, tanto nas situações de análise das diversas questões, desafios e possibilidades da prática pedagógica, quanto para mobilizar as relações dos participantes com o conhecimento necessário ao exercício dessa prática.

\section{CONSIDERAÇÕES SOBRE O PROCESSO}

Entre os resultados do processo, destaca-se, de início, a relevância da pesquisa realizada na escola de educação básica para o acesso aos saberes dos professores e para o desenvolvimento de aprendizagens sobre a docência pelos professores e pesquisadores. A inclusão da escrita como instrumento de formação possibilitou maior compreensão sobre as dimensões que a constituem, ressignificando-a e alterando as práticas de seu ensino. A aproximação das práticas pedagógicas às práticas sociais dos alunos contribuiu para a compreensão dos vínculos da escrita com os sujeitos, 


\section{Desafios da psicologia no Brasil}

permitindo, por um lado, maior clareza aos propósitos e processos de ensino e, por outro, um distanciamento dos seus usos estritamente escolares.

Os alunos em alfabetização escreveram textos sobre suas histórias de vida e de suas comunidades, seus costumes, tradições e problemas. O respeito à diversidade cultural dos alunos e o estabelecimento de relação entre a aprendizagem escolar e a vida cultural da comunidade provocaram valorização da escrita e maior envolvimento dos sujeitos com as atividades, o que os tornou mais responsáveis e autônomos em suas aprendizagens. Aprendizagens pelas quais passaram a reconhecer a escrita como prática cultural, de produção e veiculação de "ideias", e para as quais já não bastava apenas aprender o "bê-a-bá".

Esse movimento é extremamente relevante, considerando-se a influência das formas de socialização com os objetos culturais na constituição de seus significados e valores para o grupo que os utiliza.

Na formação continuada, a problematização e análise da prática mobilizaram os participantes para a atitude analítica. O questionamento das práticas alfabetizadoras pôde desestabilizar algumas crenças que não se respaldavam em conhecimentos sociolinguísticos e não favoreciam as aprendizagens dos alunos. Ao buscarem suas respostas, que significariam a explicitação das concepções em que se fundamentavam, os professores se deparavam com suas compreensões, alguns "vazios", possíveis contradições, e o trabalho de escrita a que se propuseram atuou como elemento catalisador para a produção e sistematização de conhecimentos sobre a alfabetização e ensino da língua materna nos anos iniciais. Foram mobilizados à busca de conhecimentos.

Nesse movimento, a tessitura da escrita se efetua como um trabalho de gerir pessoalmente a dimensão do sentido daquilo que se constitui no texto e da forma de assegurar linguisticamente a integração das informações que o compõem, as já escritas e as por escrever. É um processo que requer de quem escreve o movimento constante de progressão ao novo material e retornos ao já escrito, para dar conta da tarefa. Movimento pelo qual os professores se conectam ao seu universo de referência, constituído em linguagem (material constitutivo da consciência), e se projetam na dimensão alteritária da escrita, de ocupar o lugar de um outro para dialogar consigo mesmo e criar a escrita. Um movimento criador, portanto, e com o qual se constitui a materialidade do texto que, pensado dessa forma, trabalha sobre o sujeito e sua escrita. A dimensão analítica da escrita remete os professores à dissecação dos significados constituídos para o ensino, para constituir a escrita e compor o texto. A subjetividade se recria nessa atividade, com a sistematização dos conhecimentos que são objeto da intervenção formadora (Bakhtin, 2002; 2000; Riolfi, 2003; Vigotski, 1998a). 


\section{Desafios da psicologia no Brasil}

A dimensão técnica da escrita é importante nessa tarefa, mas considerada na relação com as atividades de planejar cada movimento, selecionar, reescrever, aperfeiçoar o encadeamento das palavras que se interorientam na criação do texto. Cada palavra provoca uma relação dialógica com as outras que constituem o texto e também com o autor, para resultar a escrita. Assim, o ato de escrever contém uma incompletude, que necessita de um deslocamento para a posição e os valores do outro, para se fazer - a exotopia. Sem esse deslocamento, sem tornar-se um outro em relação a si mesmo, sem se olhar com o "excedente de visão", não há criação, segundo Bakhtin (2000).

$\mathrm{Na}$ escrita dos professores, deslocar-se à posição do outro foi considerar as representações construídas no discurso de formação: nas discussões, na reflexão compartilhada, nos estudos, na própria escrita e nas aprendizagens das crianças. Nessa perspectiva, suas práticas também passaram a considerar a natureza dialógica da linguagem no ensino da escrita, com a proposição de trabalhos cooperativos entre as crianças, discussões em classe, para desenvolver atividades que relacionassem as expressões orais e escritas das diferentes instituições (comunidades, famílias, escola), escritas em duplas, escritas realizadas junto com outras turmas de outras séries, entre outras.

A mudança exigiu, em primeiro lugar, assumir que havia outros pontos de vista, o que ressalta o valor do reconhecimento da alteridade, do caráter intersubjetivo da construção de significados para a formação de alunos e professores. Ao escrever, as professoras procuraram recriar uma interpretação própria e responsiva a partir das vozes sociais do outro. Por isso, sua escrita foi criação de um lugar próprio, que pulsou na luta e interação com a palavra alheia. Tomando a linguagem como constitutiva da consciência, esse movimento de participação em diferentes experiências sociais de linguagem, com diferentes sujeitos - pesquisadores, autores dos textos estudados, colegas professores, alunos, comunidades - promoveu alteração no seu universo de referências. Sua escrita e a produção de conhecimento sobre a prática foram dialógicas e polifônicas, porque ocorreram na relação com os sentidos das vozes presentes nessas experiências e dos valores nelas contidos (Bakhtin, 2000).

As práticas e as relações dos professores com o conhecimento ocorrem em contextos específicos e que sofrem interferências de inúmeros fatores, na dimensão global da prática sociocultural em que todos nos constituímos: da formação científica, dos processos de socialização durante a formação, das necessidades do trabalho docente cotidiano, das buscas de alternativas para superação de dificuldades, das configurações de relações e condições de trabalho, da vida pessoal etc. Há, contudo, uma condição básica para entendimento dessas questões e de seus desdobramentos na formação de 


\section{Desafios da psicologia no Brasil}

alunos e professores - o desenvolvimento de atitudes de autonomia (intelectual, pedagógica, profissional, pessoal).

No decorrer da pesquisa, a escrita se evidenciou como importante elemento de formação, com contribuições à produção de autonomia e compreensão dos aspectos contextuais e sócio-políticos da prática pedagógica, assim como para criar formas de superação das dificuldades no ensino da língua. Uma autonomia que resultou, entre os professores, no desenvolvimento de uma atitude inquieta para localizar as necessidades de seu trabalho e que se traduzia na busca de compreensão das dificuldades que a escrita apresentava às crianças. Esse aspecto é relevante no quadro da escola pública brasileira, eivado de problemas para constituir "proficiências" em leitura e escrita - uma condição básica para a educação escolar, como evidencia Cook-Gumperz (1991, p. 54), ao afirmar a "força preponderante" da escolarização nos sistemas sociais modernos, nos quais, "ter escolarização sem alfabetização é impossível".

A pesquisa ressalta a atividade de escrita como importante recurso para engajar o sujeito na própria formação, porque, ao escrever, ele precisa remeter-se ao objeto sobre que escreve; buscar significados e conhecimentos sobre o objeto; estabelecer relações entre objeto, conhecimentos e, ainda, com um presumido leitor de sua palavra, para constituir um novo sentido à situação.

Como evidenciado na pesquisa, isso ocorre pelas próprias características do ato de escrever, que implica quem escreve e o convoca a preencher com conhecimento a materialidade do suporte que utiliza e que atua sobre o sujeito. Como afirma Canário (2005), os indivíduos aprendem "a partir de processos de teorização (implícita ou explícita) da sua experiência", portanto a passagem pela "experiência de escrever" desenvolve uma compreensão e apropriação do papel dessa atividade pelo professor, conhecimento que passa a acompanhar sua prática docente, estendendo-se aos alunos.

Os resultados evidenciam que, ao longo do acompanhamento, com o recurso da escrita sobre a prática e da reflexão com a escrita, os professores foram produzindo conhecimentos sobre o trabalho educativo e os mobilizaram no ensino. Evidenciam também que a possibilidade de tornar a escrita um instrumento constituinte de aprendizagem e formação precisa ser entendida e criada simbolicamente pelo sujeito e seu grupo de pertencimento, pois o discurso escolar sobre a língua escrita produz os significados dessa prática para os sujeitos, assim como os tipos de vínculos que eles construirão com os aprendizados constituídos (Smolka, 2000). Considerando os problemas com ensino, aprendizagem e uso de leitura e escrita na escola, a experiência pode representar uma boa estratégia para outras 


\section{Desafios da psicologia no Brasil}

situações que tenham o objetivo de integrar a atuação dos profissionais da escola, no seu desafiador papel de contribuir à formação humana.

Ampliar a distribuição da escrita, portanto, parece tarefa indispensável. Principalmente entre grupos sociais que mantêm relações restritas com essa prática. À escola cabe o papel de seu ensino direto, intencional e explícito. Mas a escrita não pode ficar restrita à escola e às atividades escolares. Ler e escrever são práticas de produção cultural, precisam ser integradas aos diferentes contextos culturais, pois representam a possibilidade de desenvolver novas formas de agir, interpretar a realidade e nela se inserir. É importante que a escola do campo amplie as relações de seus sujeitos com a escrita, quer seja nas próprias atividades que desenvolve para ensiná-la, quer seja na criação da necessidade de sua prática nas experiências sociais desses sujeitos e no favorecimento da circulação de livros ou produções impressas das comunidades entre alunos e suas famílias, para deslocar da escola as fronteiras da escrita e inserir as comunidades "na corrente da comunicação verbal".

\section{REFERÊNCIAS}

BAKHTIN, M. (2000). Estética da criação verbal. (3a ed.) São Paulo: Martins Fontes.

BAKHTIN, M. (2002). Marxismo e filosofia da linguagem. (9a ed.). São Paulo: Hucitec, Annablume.

CANÁRIO, R. (2005). Prefácio. In: PRADO, G.do V. T.; SOLIGO, R. (Orgs.). Porque escrever é fazer história: revelações, subversões, superações. (pp.11-15). Campinas, SP: Graf. FE.

COOK-GUMPERZ, J. (1991). A construção social da alfabetização. Porto Alegre: Artes Médicas.

FALTERI, P. 1998. Interculturalismo e culturas no plural. In: R.M. FLEURI (Org.), Intercultura e movimentos sociais. Florianópolis, Mover/NUP, p. 33-43.

GARRIDO, E. (2000). Pesquisa universidade-escola e desenvolvimento profissional do professor. Tese de Livre-docência. Faculdade de Educação da Universidade de São Paulo.

GIOVANNI, L. M. (1994). A didática da pesquisa-ação: análise de uma experiência de parceria entre universidade e escolas públicas de 10 e 20 graus. Tese de Doutorado. Faculdade de Educação da Universidade de São Paulo.

MIZUKAMI, M.G. N. (2002). Escola e aprendizagem da docência: processos de investigação e formação. São Carlos: EdUFSCar.

PIMENTA, S. G. (1996). Formação de professores: saberes da docência e a identidade do professor. Revista da Faculdade de Educação, v. 22(no 2). pp. 72-89.

RIOLFI, C. R. (2003). Ensinar a escrever: considerações sobre a especificidade do trabalho da escrita. Leitura: teoria \& prática. Revista da Associação de Leitura do Brasil. UNICAMP, Campinas, SP. (jan.jul.). pp. 47-51. 


\section{Desafios da psicologia no Brasil}

SACRISTÁN, J.G. (1996). Escolarização e cultura: a dupla determinação. In: SILVA, L.E. Reestruturação curricular: novos mapas culturais, novas perspectivas educacionais. Porto Alegre, Sulina, pp. 34-57.

SMOLKA, A. L. B. (2000). A criança na fase inicial da escrita: a alfabetização como processo discursivo. (9a ed). São Paulo: Cortez; Campinas: Editora da UNICAMP.

VIGOTSKI, L. S. (1998a). A formação social da mente: o desenvolvimento dos processos psicológicos superiores (6a ed.). São Paulo: Martins Fontes.

VIGOTSKI, L. S. (1998b). Pensamento e linguagem. (2a ed.) São Paulo: Martins Fontes. 


\section{Desafios da psicologia no Brasil}

\section{NOTAS}

Nota 1

PISA, IDEB, por exemplo. Embora reconheçamos alguns importantes limites desses indicadores, como os fundamentos das informações que os balizam; condições em que são aferidos; padronização e controle pelo estado etc., não podemos simplesmente negá-los.

Nota 2

A expressão alfabetizadores refere-se aos professores que trabalham em todos os anos iniciais do ensino fundamental, e não somente aos do 1ㅇan ano, especificamente, uma vez que a alfabetização é um longo processo de compreensão e apropriação do sistema de escrita e seus significados, de aprendizagem das habilidades necessárias às práticas de leitura e escrita para interação social.

Nota 3

Embora consideremos a relevância para a prática pedagógica, não é nosso propósito neste texto discutir os equívocos com que a expressão "interpretar" é considerada nos exercícios escolares.

Nota 4

Usamos a palavra tradição como o conjunto de significados construídos para a educação escolar, sem nenhuma conotação valorativa. 


\section{Capítulo 14}

\section{INICIAÇÃO ESPORTIVA E ESPECIALIZAÇÃO PRECOCE: O DISCURSO E A PRÁXIS}

DOI: $10.37423 / 200200179$

Maria Luiza Bertoni (bacharel em educação física pela UNIFAE e graduando do curso de edicaçãa física licenciatura pelo Centro Universitário das Faculldades Associadas de Ensino - FAE - malu_bertoni@hotmail.com

Cassio José Silva Almeida (Rrofessor do curso de Educação Física Licenciatura da UNIFAE, orientador do trabalho).

Resumo: presente trabatho refere-se a parte de/um trabaltho de conclusão do curso de Licenciatura que es̀tá sendo desenvolvido como requisito de obtenção do grau de licenciado em Educação Física. Iniciąção esportiva entende-se como o período em que a criança aprende de forma específica e planejada a prática de uma ou mais modálidades esportivas, onde seu objetivo é dar continuidade ao seu desenvolvimento e não a competição regular (RAMOS, 2008). A iniciação esportiva é importante para 0 desenyolvimento integral da criança, desde que seja respeitada cada fase de aprendizado. Quando as fases são atropeladas e as competições sắo mais importantes que Q lazer e a vivencia da criança naquela determinada modalidade, acontece a especialização precoce que tende-reduzir as poss bilidades educacionais do-esporte na infância, influenciando ao abandono precoce da prática esportiva (GALATTI, 2012), trazendo consequências sérias para o desenvolvimento-social, intelectual e motor da criança. 


\section{Desafios da psicologia no Brasil}

A pedagogia do esporte vem investigar a prática educativa e está presente desde a iniciação esportiva ao treinamento de alto rendimento. Tendo como objetivo a reflexão, sistematização, avaliação, organização e a crítica do processo educativo por meio do esporte (LEONARDI, 2014). O objetivo do trabalho é questionar a forma como o esporte é conduzido pedagogicamente na escola, observando como o esporte é desenvolvido nas aulas de educação física do ensino fundamental I, no Município de São João da Boa Vista - SP, e observar o discurso e a práxis em relação a iniciação esportiva na escola. A coleta de informações será desenvolvida a partir da observação das aulas de educação Física que tem como referência as participações obrigatórias decorrentes das horas de estágio. A abordagem da pesquisa é qualitativa e participativa. Todo esse conteúdo oriundo das sessões de estágio será transcrito em texto e posteriormente analisado segundo a metodologia da análise de conteúdo de BARDIN (2013). As análises mostram que no primeiro e segundo ano do ensino fundamental houve iniciação esportiva precoce, porém não houve uma especialização precoce. Já no terceiro, quarto e quinto ano do ensino fundamental, identifica-se que a iniciação esportiva está na sua fase correta, não identificando especialização precoce.

Palavras Chave: Iniciação Esportiva, Especialização Precoce, Pedagogia do Esporte. 


\section{Desafios da psicologia no Brasil}

\section{INTRODUÇÃO}

Iniciação esportiva entende-se como o período em que a criança aprende de forma específica e planejada a prática de uma ou mais modalidades esportivas, onde seu objetivo é dar continuidade ao seu desenvolvimento e não a competição regular (RAMOS, 2008). A iniciação esportiva é importante para o desenvolvimento integral da criança, desde que seja respeitada cada fase de aprendizado. Quando as fases são atropeladas e as competições são mais importantes que o lazer e a vivência da criança naquela determinada modalidade, acontece a especialização precoce que tende reduzir as possibilidades educacionais do esporte na infância, influenciando ao abandono precoce da prática esportiva (GALATTI, 2012), trazendo consequências sérias para o desenvolvimento social, intelectual e motor da criança.

A pedagogia do esporte vem investigar a prática educativa e está presente desde a iniciação esportiva ao treinamento de alto rendimento. Tendo como objetivo a reflexão, sistematização, avaliação, organização e a crítica do processo educativo por meio do esporte (LEONARDI, 2014). A Pedagogia do Esporte está presente desde a iniciação esportiva ao treinamento de alto rendimento, passando pela formação de professores e treinadores. O esporte também está presente na educação física escolar para que os alunos possam vivenciar a cultura corporal de movimento.

Esse trabalho pode contribuir para um melhor entendimento da forma com que o esporte é trabalhado dentro do ambiente escolar, para que se possam propor novas formas de desenvolvê-lo onde discurso e a práxis caminhem próximas no ensino aprendizagem da iniciação esportiva dentro da escola e que as fases de aprendizagem sejam respeitadas.

Com isso o objetivo do trabalho é questionar a forma como o esporte é conduzido pedagogicamente na escola, através da observação de como o esporte é desenvolvido nas aulas de educação física do ensino fundamental $\mathrm{I}$, além de questionar o discurso e práxis em relação a iniciação esportiva na escola.

\section{ESPORTE NA ESCOLA OU ESPORTE DA ESCOLA}

Esporte é a modalidade definida como uma ação social institucionalizada, com regras, que se desenvolve com base lúdica, em forma de competição entre dois ou mais oponentes, onde o objetivo é determinar um vencedor ou mesmo o recorde através de comparação de desempenho, o resultado 


\section{Desafios da psicologia no Brasil}

é determinado pela habilidade e estratégia do participante, sendo para este gratificante intrinsecamente e extrinsecamente (BETTI, 1991).

O esporte no contexto escolar é entendido como uma manifestação da cultura corporal de movimento, caracterizando-se pela prática motora. Suas regras proporcionam aos adversários iguais condições de vencer, mantendo assim, a incerteza do resultado (GONZÁLEZ, 2006).

A função da educação física como componente curricular da educação básica é introduzir e integrar o aluno na cultura corporal de movimento, formando o cidadão para usufruir do jogo, do esporte, da dança e qualquer outra prática de aptidão física em beneficio da qualidade de vida (BETTI E ZULIANI, 2002).

O esporte escolar é uma importante ferramenta de inclusão social, oportuniza o aprendizado da cultura da comunidade, além de ser formativo (MACHADO, 2011).

O esporte da escola permite que as diferenças existam, onde na mesma aula participam meninos e meninas, gordo e magro, o portador de necessidades especiais. Para que isso aconteça é necessário adaptar o esporte para encaixá-lo na realidade daquela determinada sala de aula. Infelizmente existe na aula de educação física escolar a formação de atletas, caracterizando o esporte na escola, visando o auto nível e o rendimento (SOLER, 2003).

Baseando-se na ideia que a nova geração é educada para uma sociedade competitiva, o esporte funciona como um mecanismo de mobilidade social; oferece a oportunidade de aprendizagem de diferentes papéis sociais e por fim a competição reflete os valores importantes na sociedade (MATTOS, 2013).

A prática esportiva oferece vantagens a nível físico, melhorando a saúde e a forma física, além de prevenir doenças; e a nível psicossocial, desenvolve a capacidade de liderança e iniciativa, a autodisciplina, auto-confiança, auto-estima, respeito pela autoridade, da competitividade e cooperação (MACHADO, 2011).

A prática esportiva na escola deve ser diferente das instituições não escolares (escolinhas de futsal, ballet, etc.) que focam no rendimento e perfeição de movimentos e sistematização das práticas corporais. A disciplina da educação física na escola não deve desconsiderar as escolinhas para que os 


\section{Desafios da psicologia no Brasil}

alunos conheçam e compreendam as diversas formas de vivenciar o esporte, como lazer, participativo e de rendimento (LIÇÕES DO RIO GRANDE, 2010).

O esporte também é definido como prática social, com isso é necessário que o aluno compreenda que a prática esportiva não é só jogar com o objetivo de vencer, é necessário entender os valores sociais e morais, normas e regras a serem cumpridas, portanto é necessário que ele conheça suficientemente o esporte para criticá-lo e compreende-lo (KUNZ, 2006).

Infelizmente algumas políticas educacionais estabeleceram movimentos estudantis para adoção de estereótipos de atletas, levando à esportivização da Educação Física Escolar, causando a seletividade e competitividade onde os professores passaram a montar equipes para representar as escolas em competições, assim o professor se dedicava aos alunos escolhidos enquanto os outros ficavam sem aulas (MOREIRA, 2011).

O esporte está em um processo de transformação didática, sendo a escola fundamental nesse processo estimulando os alunos a ter o acesso ao esporte. Nesse sentido o diálogo entre o professor e aluno é importante para construir de forma clara e objetiva o processo de ensino aprendizagem. 0 papel do professor é motivar e envolver os alunos no conteúdo planejado e deixá-los seguros para realizar as atividades (QUADROS, 2014).

\section{INICIAÇÃO ESPORTIVA}

Iniciação esportiva entende-se como o período em que a criança aprende de forma específica e planejada a prática de uma ou mais modalidades esportivas, onde seu objetivo é dar continuidade ao seu desenvolvimento e não a competição regular (RAMOS, 2008).

A primeira experiência da criança com a modalidade esportiva escolhida é decisiva para manter ou perder o gosto pela prática da mesma, nesse primeiro contato ela deve sentir-se recompensada, útil e hábil pelo desafio que se expôs e risco que assumiu, pois uma experiência negativa pode causar traumas e afastar a criança da prática esportiva. O esporte infantil deve ser mais lúdico e menos rígido, representado por uma atividade alegre e prazerosa (MACHADO, 2011).

A iniciação esportiva começa aos oito anos de idade, nessa fase devem ser trabalhadas as habilidades motoras e destrezas específicas e globais através de movimentos básicos e jogos pré-desportivos. Aos dez anos de idade inicia-se o aperfeiçoamento desportivo, nessa fase são introduzidos elementos 


\section{Desafios da psicologia no Brasil}

técnicos, táticas e regras através de jogos educativos e atividades esportivas com regras. Aos doze anos a criança já é introduzida ao treinamento, aperfeiçoando as técnicas individuais, além de desenvolver as qualidades físicas necessárias para a prática desportiva escolhida (RAMOS, 2008).

A prática esportiva prazerosa traz benefícios à criança, tanto biológicos aumentando o gasto calórico e controlando o metabolismo basal, quanto socioafetivo principalmente nos jogos esportivos coletivos (JECs), pois articulam a prática esportiva com a convivência e o sentimento de pertencer a um grupo (GALATTI, 2012).

Outra prática esportiva prazerosa se faz com os Jogos Cooperativos, este está centrado na união, sua estrutura é cooperativa como processo de superação de desafios e de busca de objetivos comuns, e não como busca de vitória sobre os adversários. É desafiador propor um jogo cooperativo perante aqueles que entendem o jogo como sinônimo de competição, já que essa prática está enraizada em nossa cultura ocidental (MOREIRA, 2011).

A prática esportiva infantil oferece alguns aspectos positivos quando se evita o fanatismo de resultados imediatos, sendo elas: auxilio no desenvolvimento corporal, psíquico e social; transmissão de experiência e meios que auxiliam a autovalorização e o reconhecimento de capacidades individuais próprias, a influencia positiva sobre sua auto-imagem e concepção de vida; além de oferecer a criança liberdade e participação nas decisões, desenvolvendo sua autonomia e independência (KUNZ, 2006).

\section{ESPECIALIZAÇÃO PRECOCE}

Especialização precoce acontece quando a criança é especializada em determinado esporte antes da idade apropriada, sem fazer a prática das atividades motoras (RAMOS, 2008).

O treinamento especializado precoce no esporte ocorre quando as crianças (antes da fase da puberdade) iniciam um processo de treinamento planejado e organizado a longo prazo, no mínimo três sessões semanais, com o objetivo do aumento do rendimento e participação periódica em competições (KUNZ, 2006).

A especialização precoce tende reduzir as possibilidades educacionais do esporte na infância, influenciando ao abandono precoce da prática esportiva.

Consequentemente a criança escolhe outras opções de lazer de uma forma sedentária (televisão e videogame), podendo se estender até a fase adulta (GALATTI, 2012). 


\section{Desafios da psicologia no Brasil}

No esporte, a especialização precoce é a exigência prematura da realização dos gestos técnicos com perfeição e eficiência, antecipando as fases da aprendizagem esportiva, sendo mais importante a execução das tarefas do que a compreensão do esporte e o prazer em sua prática (SILVA et al., 2009).

Os erros cometidos na especialização precoce torna a iniciação esportiva pouco atrativa e traumática, fazendo com que perca seus inúmeros benefícios de ser prazerosa, diversificada, rica em aprendizagem motora, técnica e tática, além dos valores e modos de comportamento que são proporcionados às crianças (GALATTI, 2012).

O treinamento especializado precoce acarreta em problemas para a vida da criança e também em seu futuro, são elas: formação escolar deficiente; a unilateralização de um desenvolvimento que deveria ser plural; participação reduzida em atividades, brincadeiras e jogos infantis, que são indispensáveis para desenvolver a personalidade na infância. A saúde física e psíquica também são comprometidas com o treinamento especializado precoce, sendo os de ordem psíquica mais graves onde houve desilusões, fracassos ou até mesmo pela falta de talento para a modalidade ou o esporte de forma geral (KUNZ, 2006).

\section{PEDAGOGIA DO ESPORTE}

A pedagogia do esporte investiga a prática educativa, tendo como objetivo a reflexão, sistematização, avaliação, organização e a crítica do processo educativo por meio do esporte. O processo educacional pelo esporte desenvolve a criticidade, autonomia, liberdade de expressão e a reflexão, formando um indivíduo cidadão (LEONARDI, 2014).

Galatti, 2014 completa que a pedagogia do esporte estuda e intervém no processo de ensino, vivência, aprendizado e treinamento do esporte nas suas diversas manifestações e sentidos.

A iniciação esportiva nos primeiros anos de idade escolar é vista positivamente quando são considerados os benefícios que o esporte proporciona para seus praticantes na dimensão biopsicossocial. Portanto, é necessário evitar a especialização precoce que reduz esses benefícios pela cobrança de resultados, sobrecarregando fisicamente e psicologicamente as crianças e também adolescentes que se destacam no esporte, e a exclusão dos que não se destacam reduz os benefícios sociais que a prática esportiva proporciona (GALATTI, 2012). 


\section{Desafios da psicologia no Brasil}

O esporte infantil que se preocupa com a participação de todas as crianças, sendo cooperativo, lúdico, reflexivo assume a pedagogia que se contrapõe às ideias de seletividade de especialização esportiva precoce (MOREIRA, 2011).

A pedagogia da educação física e dos esportes tem como objeto de estudo as formas de manifestação humana, o movimentar-se do homem, tanto no campo dos esportes sistematizados, como no mundo que não abrange o esporte, ou seja, o contexto onde vive, família, trabalho (KUNZ, 2006).

A pedagogia do esporte na infância preocupa-se em ampliar as possibilidades das pessoas se realizarem, atribuindo ao esporte novos significados (PAES; BALBINO, 2005).

O esporte ensinado deveria contribuir para que a criança se descobrisse, aprendesse cooperação e autonomia, pois quem joga coopera, tem oportunidade de rever as suas atitudes, reconhecer o próprio esforço, assim como coletivo e alheio, também pode compartilhar ideias, concentrar-se, aproximar-se de outras pessoas, conviver com as diferenças, com a vitória e derrota, colocar-se disponível, expressar sentimentos, solidarizar-e e criar estratégias para interagir com os desafios da disputa (MOREIRA, 2011).

\section{METODOLOGIA}

A coleta de informações foi desenvolvida a partir da observação das aulas de educação Física que tem como referência as participações obrigatórias decorrentes das horas de estágio. A abordagem da pesquisa é qualitativa e participativa. Todo esse conteúdo oriundo das sessões de estágio será transcrito em texto e posteriormente analisado segundo a metodologia da análise de conteúdo de BARDIN (2013).

A pesquisa foi dividida nas seguintes fases: observação, participação, transcrição das observações em texto, seguido da análise do conteúdo.

\section{RESULTADOS E DISCUSSÕES}

\section{ANALISE DAS TABELAS DE CATEGORIZAÇÃO:}

A partir das observações das aulas do 10 ao $5^{\circ}$ ano do ensino fundamental, foram tabelados os indicadores de inter-relação: esporte da escola, esporte na escola, iniciação esportiva e especialização precoce. 


\section{Desafios da psicologia no Brasil}

\begin{tabular}{|c|c|c|c|c|}
\hline \multirow[b]{2}{*}{$\begin{array}{l}\text { Objeto de } \\
\text { comparação }\end{array}$} & \multicolumn{4}{|c|}{ Indicadores de Inter-relação } \\
\hline & Esporte da escola & Esporte na escola & Iniciação Esportiva & $\begin{array}{c}\text { Especialização } \\
\text { Precoce }\end{array}$ \\
\hline $\begin{array}{l}\text { Primeira semana } \\
\text { de observação da } \\
\text { aula do } 1^{\circ} \text { ano do } \\
\text { ensino } \\
\text { fundamental, } \\
\text { handebol. }\end{array}$ & $\begin{array}{l}\text { Jogo de queimada para } \\
\text { simular um jogo de } \\
\text { handebol, onde os } \\
\text { passes e arremessos } \\
\text { deveriam ser com uma } \\
\text { mão e nunca invadir a } \\
\text { área do cemitério } \\
\text { (equivalente a área do } \\
\text { goleiro). }\end{array}$ & $\begin{array}{l}\text { Iniciando } \\
\text { handebol, o } \\
\text { professor mostrou e } \\
\text { explicou sobre as } \\
\text { linhas. As crianças } \\
\text { andaram nas linhas } \\
\text { para reconhecer o } \\
\text { espaço. }\end{array}$ & $\begin{array}{l}\text { Exercício de condução } \\
\text { de bola em duplas e } \\
\text { troca de passe por cima } \\
\text { da cabeça e quicado em } \\
\text { trios (circulo). Logo em } \\
\text { seguida foi desenvolvida } \\
\text { a brincadeira do bobinho. }\end{array}$ & $\begin{array}{l}\text { A iniciação esportiva } \\
\text { inicia-se aos } 8 \text { anos de } \\
\text { idade, porém muitas } \\
\text { crianças nessa fase } \\
\text { escolar tem } 6 \text { anos de } \\
\text { idade. }\end{array}$ \\
\hline
\end{tabular}

Tabela 1

\begin{tabular}{|c|c|c|c|c|}
\hline \multirow[b]{2}{*}{$\begin{array}{l}\text { Objeto de } \\
\text { comparação }\end{array}$} & \multicolumn{4}{|c|}{ Indicadores de Inter-relação } \\
\hline & Esporte da escola & $\begin{array}{c}\text { Esporte } \\
\text { na escola }\end{array}$ & Iniciação Esportiva & Especialização Precoce \\
\hline $\begin{array}{l}\text { Segunda semana } \\
\text { de observação da } \\
\text { aula do } 1^{\circ} \text { ano do } \\
\text { ensino fundamental, } \\
\text { handebol. }\end{array}$ & $\begin{array}{l}\text { Jogo de queimada para } \\
\text { simular um jogo de } \\
\text { handebol, onde os passes e } \\
\text { arremessos deveriam ser } \\
\text { com uma mão e nunca } \\
\text { invadir a área do cemitério } \\
\text { (equivalente a área do } \\
\text { goleiro). }\end{array}$ & Não houve. & $\begin{array}{l}\text { Atividade de gol a gol, com } \\
\text { várias bolas ao mesmo } \\
\text { tempo, para desenvolver a } \\
\text { percepção do limite das } \\
\text { linhas e desenvolver a } \\
\text { coordenação para lançar a } \\
\text { bola com uma mão. }\end{array}$ & $\begin{array}{l}\text { A iniciação esportiva } \\
\text { inicia-se aos } 8 \text { anos de } \\
\text { idade, porém muitas } \\
\text { crianças nessa fase } \\
\text { escolar tem } 6 \text { anos de } \\
\text { idade. }\end{array}$ \\
\hline
\end{tabular}

Tabela 2

\begin{tabular}{|c|c|c|c|c|}
\hline \multirow[b]{2}{*}{$\begin{array}{l}\text { Objeto de } \\
\text { comparaçäo }\end{array}$} & \multicolumn{4}{|c|}{ Indicadores de Inter-relação } \\
\hline & Esporte da escola & Esporte na escola & Iniciação Esportiva & $\begin{array}{c}\text { Especialização } \\
\text { Precoce }\end{array}$ \\
\hline $\begin{array}{l}\text { Terceira semana de } \\
\text { observação da aula do } \\
1^{\circ} \text { ano do ensino } \\
\text { fundamental, } \\
\text { handebol. }\end{array}$ & $\begin{array}{l}\text { Jogo de queimada } \\
\text { para simular um jogo } \\
\text { de handebol, onde os } \\
\text { passes e arremessos } \\
\text { deveriam ser com } \\
\text { uma mão e nunca } \\
\text { invadir a área do } \\
\text { cemitério (equivalente } \\
\text { a área do goleiro). }\end{array}$ & $\begin{array}{l}\text { Nessa série o } \\
\text { professor não insere o } \\
\text { jogo propriamente } \\
\text { dito, ele continua nas } \\
\text { atividades para } \\
\text { desenvolvimento } \\
\text { motor. }\end{array}$ & 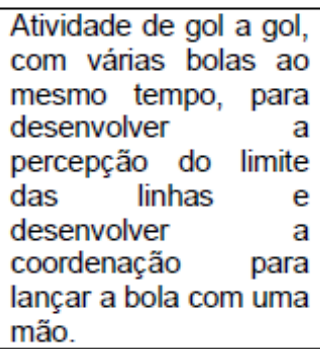 & $\begin{array}{l}\text { A iniciação esportiva } \\
\text { inicia-se aos } 8 \text { anos } \\
\text { de idade, porém } \\
\text { muitas crianças nessa } \\
\text { fase escolar tem } 6 \\
\text { anos de idade. }\end{array}$ \\
\hline
\end{tabular}

Tabela 3

As tabelas 1, 2 e 3 correspondem ao 10 ano do ensino fundamental, observa-se que é trabalhado o esporte handebol, porém com a característica de esporte da escola de forma lúdica, através do jogo de queimada, porém já ensina algumas regras do esporte e gestos motores, mesmo não sendo muito cobrado o esporte nessa série, observa-se que a iniciação esportiva é precoce nessa fase, pois as crianças têm em média seis anos de idade, e de acordo com Ramos, 2008, a iniciação esportiva inicia- 


\section{Desafios da psicologia no Brasil}

se aos oito anos de idade com habilidades motoras e destrezas específicas e globais através de movimentos básicos e jogos pré-desportivos. Percebe-se que as crianças têm muita dificuldade em jogar a bola com uma mão, elas tendem a jogar com as duas, não compreendem a delimitação do campo de jogo, não respeitam as linhas, ultrapassa o campo, invadindo a área do time adversário, a área do cemitério (que no caso corresponde a área do goleiro).

\begin{tabular}{|c|c|c|c|c|}
\hline \multirow[b]{2}{*}{$\begin{array}{c}\text { Objeto de } \\
\text { comparaçáo }\end{array}$} & \multicolumn{4}{|c|}{ Indicadores de Inter-relação } \\
\hline & Esporte da escola & Esporte na escola & Iniciação Esportiva & $\begin{array}{c}\text { Especialização } \\
\text { Precoce }\end{array}$ \\
\hline $\begin{array}{l}\text { Primeira semana de } \\
\text { observação da aula do } \\
2^{\circ} \text { ano do ensino } \\
\text { fundamental, } \\
\text { handebol }\end{array}$ & $\begin{array}{l}\text { Jogo de queimada } \\
\text { para simular um jogo } \\
\text { de handebol, onde os } \\
\text { passes e arremessos } \\
\text { deveriam ser com } \\
\text { uma mão e nunca } \\
\text { invadir a área do } \\
\text { cemitério (equivalente } \\
\text { a área do goleiro). }\end{array}$ & $\begin{array}{l}\text { Iniciando o handebol, } \\
\text { o professor mostrou e } \\
\text { explicou sobre as } \\
\text { linhas. As crianças } \\
\text { andaram nas linhas } \\
\text { para reconhecer o } \\
\text { espaço. }\end{array}$ & 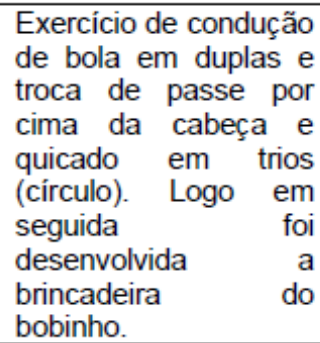 & $\begin{array}{l}\text { A iniciação esportiva } \\
\text { inicia-se aos } 8 \text { anos } \\
\text { de idade, porém } \\
\text { muitas crianças nessa } \\
\text { fase escolar tem } 7 \\
\text { anos. }\end{array}$ \\
\hline
\end{tabular}

Tabela 4

\begin{tabular}{|c|c|c|c|c|}
\hline \multirow[b]{2}{*}{$\begin{array}{l}\text { Objeto de } \\
\text { comparação }\end{array}$} & \multicolumn{4}{|c|}{ Indicadores de Inter-relação } \\
\hline & Esporte da escola & Esporte na escola & Iniciação Esportiva & $\begin{array}{c}\text { Especialização } \\
\text { Precoce }\end{array}$ \\
\hline $\begin{array}{l}\text { Segunda semana de } \\
\text { observação da aula do } \\
2^{\circ} \text { ano do ensino } \\
\text { fundamental, } \\
\text { handebol }\end{array}$ & $\begin{array}{l}\text { Jogo de queimada } \\
\text { para simular um jogo } \\
\text { de handebol, onde os } \\
\text { passes e arremessos } \\
\text { deveriam ser com } \\
\text { uma mão e nunca } \\
\text { invadir a área do } \\
\text { cemitério (equivalente } \\
\text { a área do goleiro). }\end{array}$ & Não houve. & $\begin{array}{l}\text { Atividade de gol a gol, } \\
\text { com várias bolas ao } \\
\text { mesmo tempo, para } \\
\text { desenvolver } \\
\text { percepção do limite } \\
\text { das linhas } \\
\text { desenvolver e } \\
\text { coordenação para } \\
\text { lançar a bola com uma } \\
\text { mâo. }\end{array}$ & $\begin{array}{l}\text { A iniciação esportiva } \\
\text { inicia-se aos } 8 \text { anos } \\
\text { de idade, porém } \\
\text { muitas crianças nessa } \\
\text { fase escolar tem } 7 \\
\text { anos. }\end{array}$ \\
\hline
\end{tabular}

Tabela 5

\begin{tabular}{|c|c|c|c|c|}
\hline \multirow[b]{2}{*}{$\begin{array}{l}\text { Objeto de } \\
\text { comparaçáo }\end{array}$} & \multicolumn{4}{|c|}{ Indicadores de Inter-relação } \\
\hline & Esporte da escola & Esporte na escola & Iniciação Esportiva & $\begin{array}{l}\text { Especialização } \\
\text { Precoce }\end{array}$ \\
\hline $\begin{array}{l}\text { Terceira semana de } \\
\text { observação da aula do } \\
2^{\circ} \text { ano do ensino } \\
\text { fundamental, } \\
\text { handebol }\end{array}$ & Não houve. & $\begin{array}{l}\text { Jogo de handebol } \\
\text { propriamente dito. }\end{array}$ & $\begin{array}{l}\text { O professor cobra a } \\
\text { posição correta dos } \\
\text { jogadores em quadra, } \\
\text { auxilia no momento de } \\
\text { atacar e defender, } \\
\text { porém o jogo é feito } \\
\text { em meia quadra. }\end{array}$ & $\begin{array}{l}\text { A iniciação esportiva } \\
\text { inicia-se aos } 8 \text { anos } \\
\text { de idade, porém } \\
\text { muitas crianças nessa } \\
\text { fase escolar tem } 7 \\
\text { anos. }\end{array}$ \\
\hline
\end{tabular}

Tabela 6 


\section{Desafios da psicologia no Brasil}

As tabelas 4, 5 e 6 apresentam o 20 ano do ensino fundamental, o esporte trabalhado também foi o handebol, nessa série é trabalhado da mesma forma, porém com um pouco mais de cobrança do professor e pela idade das crianças nessa fase escolar pode também caracterizar uma iniciação esportiva precoce. Isso acontece pelo fato da escola ser particular e participar de competições de diversas modalidades esportivas, tanto coletivas como individuais, por isso, os professores trabalham com os esportes desde o primeiro ano do ensino fundamental até o último ano do ensino médio.

\begin{tabular}{|c|c|c|c|c|}
\hline \multirow[b]{2}{*}{$\begin{array}{l}\text { Objeto de } \\
\text { comparação }\end{array}$} & \multicolumn{4}{|c|}{ Indicadores de Inter-relação } \\
\hline & Esporte da escola & Esporte na escola & Iniciação Esportiva & $\begin{array}{c}\text { Especialização } \\
\text { Precoce }\end{array}$ \\
\hline $\begin{array}{l}\text { Primeira semana de } \\
\text { observação da aula do } \\
3^{\circ} \text { ano do ensino } \\
\text { fundamental, } \\
\text { handebol. }\end{array}$ & $\begin{array}{l}\text { Jogo de queimada } \\
\text { para simular um jogo } \\
\text { de handebol, onde os } \\
\text { passes e arremessos } \\
\text { deveriam ser com } \\
\text { uma mão e nunca } \\
\text { invadir a área do } \\
\text { cemitério (equivalente } \\
\text { a área do goleiro). }\end{array}$ & $\begin{array}{l}\text { Iniciando o handebol, } \\
\text { o professor mostrou e } \\
\text { explicou sobre as } \\
\text { linhas. As crianças } \\
\text { andaram nas linhas } \\
\text { para reconhecer o } \\
\text { espaço. }\end{array}$ & 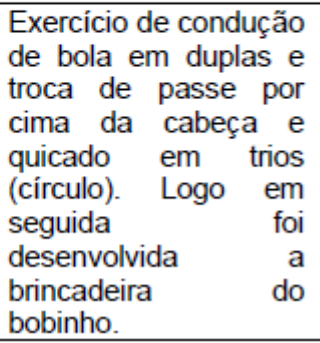 & $\begin{array}{l}\text { O professor cobra a } \\
\text { atenção das crianças } \\
\text { para não ter "atrasos" } \\
\text { quando forem para o } \\
\text { jogo propriamente dito, } \\
\text { porém nessa aula não } \\
\text { observei atitudes que } \\
\text { causam a } \\
\text { especialização } \\
\text { precoce. }\end{array}$ \\
\hline
\end{tabular}

Tabela 7

\begin{tabular}{|c|c|c|c|c|}
\hline \multirow[b]{2}{*}{$\begin{array}{l}\text { Objeto de } \\
\text { comparação }\end{array}$} & \multicolumn{4}{|c|}{ Indicadores de Inter-relação } \\
\hline & Esporte da escola & Esporte na escola & Iniciação Esportiva & $\begin{array}{c}\text { Especialização } \\
\text { Precoce }\end{array}$ \\
\hline $\begin{array}{l}\text { Segunda semana de } \\
\text { observaçäo da aula do } \\
3^{\circ} \text { ano do ensino } \\
\text { fundamental, } \\
\text { handebol. }\end{array}$ & $\begin{array}{l}\text { Jogo de queimada } \\
\text { para simular um jogo } \\
\text { de handebol, onde os } \\
\text { passes e arremessos } \\
\text { deveriam ser com } \\
\text { uma mão e nunca } \\
\text { invadir a área do } \\
\text { cemitério (equivalente } \\
\text { a área do goleiro). }\end{array}$ & Reforço de regras. & $\begin{array}{l}\text { Atividade para } \\
\text { aprender a tınalızaçäo, } \\
\text { colocando três } \\
\text { bambolês para marcar } \\
\text { os três passos, as } \\
\text { crianças deveriam } \\
\text { pisar dentro deles e } \\
\text { lançar a bola ao gol. }\end{array}$ & $\begin{array}{lr}\text { Como o professor a } \\
\text { cada aula ensina uma } \\
\text { parte do jogo de } \\
\text { handebol antes de } \\
\text { colocar o } & \text { jogo } \\
\text { propriamente } & \text { dito, } \\
\text { acredito não houve } & \\
\text { preconização } & \text { do } \\
\text { aprendizado. } & \end{array}$ \\
\hline
\end{tabular}

Tabela 8

\begin{tabular}{|c|c|c|c|c|}
\hline \multirow[b]{2}{*}{$\begin{array}{l}\text { Objeto de } \\
\text { comparaçäo }\end{array}$} & \multicolumn{4}{|c|}{ Indicadores de Inter-relação } \\
\hline & Esporte da escola & Esporte na escola & Iniciação Esportiva & $\begin{array}{l}\text { Especialização } \\
\text { Precoce }\end{array}$ \\
\hline $\begin{array}{l}\text { Terceira semana de } \\
\text { observação da aula do } \\
3^{\circ} \text { ano do ensino } \\
\text { fundamental, } \\
\text { handebol. }\end{array}$ & Não houve. & $\begin{array}{l}\text { Jogo de handebol } \\
\text { propriamente dito. }\end{array}$ & $\begin{array}{l}\text { O professor cobra a } \\
\text { posição correta dos } \\
\text { jogadores em quadra, } \\
\text { auxilia no momento de } \\
\text { atacar e defender. }\end{array}$ & $\begin{array}{lr}\text { Como o professor a } \\
\text { cada aula ensina uma } \\
\text { parte do jogo de } \\
\text { handebol antes de } \\
\text { colocar o jogo } \\
\text { propriamente } & \text { dito, } \\
\text { acredito não houve } \\
\text { preconização } \\
\text { aprendizado. }\end{array}$ \\
\hline
\end{tabular}




\section{Desafios da psicologia no Brasil}

Tabela 9

As tabelas 7, 8 e 9 correspondem ao 3ㅇ ano do ensino fundamental, a modalidade trabalhada é o handebol, estão presentes na aula o esporte da escola e o esporte na escola, inicia-se com o jogo prédesportivo (queimada) e depois passa para o jogo de handebol propriamente dito, primeiro utilizando meia quadra e depois passando para a quadra inteira. Agora com oito anos de idade e pelas características das aulas, o jogo pré-desportivo, o desenvolvimento das habilidades motoras e destrezas específicas e globais através de movimentos básicos, caracterizam a iniciação esportiva respeitando as fases de desenvolvimento.

\begin{tabular}{|c|c|c|c|c|}
\hline \multirow[b]{2}{*}{$\begin{array}{l}\text { Objeto de } \\
\text { comparação }\end{array}$} & \multicolumn{4}{|c|}{ Indicadores de Inter-relação } \\
\hline & Esporte da escola & Esporte na escola & Iniciação Esportiva & $\begin{array}{c}\text { Especialização } \\
\text { Precoce }\end{array}$ \\
\hline $\begin{array}{l}\text { Primeira semana de } \\
\text { observação da aula do } \\
4^{\circ} \text { e } 5^{\circ} \text { ano do ensino } \\
\text { fundamental, } \\
\text { handebol. }\end{array}$ & $\begin{array}{l}\text { Jogo de queimada } \\
\text { para simular um jogo } \\
\text { de handebol, onde os } \\
\text { passes e arremessos } \\
\text { deveriam ser com } \\
\text { uma mão e nunca } \\
\text { invadir a área do } \\
\text { cemitério (equivalente } \\
\text { a área do goleiro). }\end{array}$ & $\begin{array}{l}\text { Iniciando o handebol, } \\
\text { o professor mostrou e } \\
\text { explicou sobre as } \\
\text { linhas, regras básicas } \\
\text { sobre não andar com } \\
\text { a bola na mão, não } \\
\text { pisar ou passar da } \\
\text { linha da área do } \\
\text { goleiro. }\end{array}$ & $\begin{array}{l}\text { Em duplas são } \\
\text { realizados exercícios } \\
\text { de condução de bola, } \\
\text { passe. }\end{array}$ & $\begin{array}{l}\text { O professor cobra a } \\
\text { atenção das crianças } \\
\text { para não ter "atrasos" } \\
\text { quando forem para o } \\
\text { jogo propriamente } \\
\text { dito, porém nessa aula } \\
\text { não observei atitudes } \\
\text { que causam a } \\
\text { especialização } \\
\text { precoce. }\end{array}$ \\
\hline
\end{tabular}

Tabela 10

\begin{tabular}{|c|c|c|c|c|}
\hline \multirow[b]{2}{*}{$\begin{array}{l}\text { Objeto de } \\
\text { comparação }\end{array}$} & \multicolumn{4}{|c|}{ Indicadores de Inter-relação } \\
\hline & Esporte da escola & Esporte na escola & Iniciação Esportiva & $\begin{array}{c}\text { Especialização } \\
\text { Precoce }\end{array}$ \\
\hline $\begin{array}{l}\text { Segunda semana de } \\
\text { observação da aula do } \\
4^{\circ} \text { e } 5^{\circ} \text { ano do ensino } \\
\text { fundamental, } \\
\text { handebol. }\end{array}$ & $\begin{array}{l}\text { Jogo de queimada } \\
\text { para simular um jogo } \\
\text { de handebol, onde os } \\
\text { passes e arremessos } \\
\text { deveriam ser com } \\
\text { uma mão e nunca } \\
\text { invadir a área do } \\
\text { cemitério (equivalente } \\
\text { a área do goleiro). }\end{array}$ & $\begin{array}{l}\text { As regras são } \\
\text { reforçadas. }\end{array}$ & $\begin{array}{l}\text { Atividade para } \\
\text { aprender a finalização, } \\
\text { colocando três } \\
\text { bambolês para marcar } \\
\text { os três passos, as } \\
\text { crianças deveriam } \\
\text { pisar dentro deles e } \\
\text { lançar a bola ao gol. }\end{array}$ & $\begin{array}{lr}\text { Como o professor a } \\
\text { cada aula ensina uma } \\
\text { parte do jogo de } \\
\text { handebol antes de } \\
\text { colocar o } & \text { jogo } \\
\text { propriamente } & \text { dito, } \\
\text { acredito não houve } \\
\text { preconização } \\
\text { aprendizado. }\end{array}$ \\
\hline
\end{tabular}

Tabela 11 


\section{Desafios da psicologia no Brasil}

\begin{tabular}{|c|c|c|c|c|}
\hline \multirow[b]{2}{*}{$\begin{array}{l}\text { Objeto de } \\
\text { comparaçäo }\end{array}$} & \multicolumn{4}{|c|}{ Indicadores de Inter-relação } \\
\hline & Esporte da escola & Esporte na escola & Iniciação Esportiva & $\begin{array}{l}\text { Especialização } \\
\text { Precoce }\end{array}$ \\
\hline $\begin{array}{l}\text { Terceira semana de } \\
\text { observação da aula do } \\
4^{\circ} \text { e } 5^{\circ} \text { ano do ensino } \\
\text { fundamental, } \\
\text { handebol. }\end{array}$ & Não houve. & $\begin{array}{l}\text { Jogo de handebol } \\
\text { propriamente dito. }\end{array}$ & $\begin{array}{l}\text { O professor ficou de } \\
\text { técnico de um time e } \\
\text { eu do outro. Durante o } \\
\text { jogo auxiliamos o } \\
\text { momento de atacar e } \\
\text { defender. Houve } \\
\text { cobrança da posição } \\
\text { da defesa. }\end{array}$ & $\begin{array}{lr}\text { Como o professor a } \\
\text { cada aula ensina uma } \\
\text { parte do jogo de } \\
\text { handebol antes de } \\
\text { colocar o } & \text { jogo } \\
\text { propriamente } & \text { dito, } \\
\text { acredito não houve } \\
\text { preconização } \\
\text { aprendizado. }\end{array}$ \\
\hline
\end{tabular}

Tabela 12

As tabelas 10, 11 e 12 representam o 4ㅇ e o 5ㅇaㅇ ano do ensino fundamental, como citado anteriormente o esporte da escola está presente no jogo da queimada e o esporte na escola caracterizado pelo jogo de handebol, utilizando a quadra inteira, com as regras e uma exigência do professor maior. Nessas séries são cobradas as posições corretas para atacar e defender, o professor fica em quadra fazendo o papel de técnico, instruindo os jogadores. Para finalizar a modalidade é realizado um campeonato interno para desenvolver melhor as habilidades da modalidade.

\section{CONSIDERAÇÕES FINAIS}

Observou-se que no primeiro e segundo ano do ensino fundamental houve iniciação esportiva precoce, porém não houve uma especialização precoce. Justifica-se pelo fato de terem seis anos quando a iniciação é indicada a partir dos oitos anos de idade. A iniciação esportiva inicia-se aos oito anos de idade, nessa fase devem ser trabalhadas as habilidades motoras e destrezas específicas e globais através de movimentos básicos e jogos pré-desportivos (RAMOS, 2008).

Chegando ao terceiro ano do ensino fundamental, já com oito anos, identifica-se que a iniciação esportiva está na sua fase correta, não identificando especialização precoce. Os anos seguintes quarto e quinto também caracterizam a iniciação esportiva sem especialização precoce. Pois o treinamento especializado precoce ocorre quando o treinamento é realizado em longo prazo, no mínimo três sessões semanais objetivando aumento de rendimento e participação periódica em competições (KUNZ, 2006), não sendo identificadas essas características, pois a prática é realizada somente nas Este trabalho não tem pretensão esgotar o assunto, até mesmo pela falta de tempo, disponibilidade da escola, portanto sugere que outras pesquisas sejam desenvolvidas a fim de aprofundar na questão especialização precoce dentro do ambiente escolar -, principalmente durante as aulas de educação 


\section{Desafios da psicologia no Brasil}

física onde o principal objetivo é envolver a maior quantidade de alunos.aulas de educação física escolar.

\section{REFERÊNCIAS}

ALMEIDA, C. J. S. A contribuição dos jogos cooperativos em situação de vulnerabilidade social. Dissertação (mestrado), UNIFAE, São João da Boa Vista, 2012.

BARDIN, L. Análise do Conteúdo. Lisboa: Edições 70, 2007. 2013.

BETTI, M. Educação física e sociedade: a educação física na escola brasileira de 1 으 e 2 음 graus. São Paulo: Movimento, 1991.

BETTI, M.; ZULIANI, L. R.; Educação Física escolar: uma proposta de diretrizes pedagógicas. Revista Mackenzie de Educação Física e Esporte. São Paulo, V.1, N.1, p.73-82, 2002.

DARIDO, S. C. Educação fisica na escola: questões e reflexões. Araras, SP: Topázio, 1999.

GALATTI, L. R; PAES, R.; SEOANE, A. M. Pedagogia do esporte e obesidade: perspectivas para um estilo de vida saudável com base na adequada iniciação

esportiva na infância. Pensar a Prática, Goiânia, v. 15, n. 2, p. 272550, abr./jun. 2012.

GALATTI, L. R; REVERDITO, R. S; SCAGLIA, A. J; PAES, R. R; SEOANE, A. M. Pedagogia do esporte: tensão na ciência e o ensino dos jogos esportivos coletivos. Rev. Educ. Fís/UEM, v. 25, n. 1, p. 153-162, 1. trim. 2014.

GONZÁLEZ, F. J. Projeto curricular e educação física: o esporte como conteúdo escolar. Chapecó: Argos, 2006.

KUNZ, E. Transformação didático-pedagógica do esporte. 7 ed. ljuí: Ed. Unijuí, 2006. Pag 49-54, 64

LEONARDI, T. J; GALATTI, L. R; PAES, R. R.; SEOANE, A. M.; Pedagogia do esporte: indicativos para o desenvolvimento integral do indivíduo. Revista Mackenzie de Educação Física e Esporte, São Paulo, v. 13, n. 1, p. 41-58, ago. 2014.

LIÇÕES DO RIO GRANDE: Linguagens Códigos e Suas Tecnologias Arte e Educação Física - Caderno Do Professor - Ensino Fundamental e Ensino Médio. 2010

MACHADO, A. A; GOMES, R. Psicologia do Esporte da Escola à Competição. 1ạ Ed. 2011. P.20, 55, 56, 57,60

MATTOS, M. G; NEIRA, M. G. Educação Física na Adolescência: construindo o conhecimento na escola. 6ạ Ed. São Paulo: Phorte, 2013. P. 94.

MOREIRA, E. C.; PEREIRA, R. S. Educação física escolar: desafios e propostas 2. 2.ed.-Várzea Paulista, SP: Fontoura, 2011. 


\section{Desafios da psicologia no Brasil}

PAES, R. R.; BALBINO, H. F. Pedagogia do esporte: contextos e perspectivas. Rio de Janeiro: Guanabara Koogan, 2005.

QUADROS, R. B.; STEFANELLO, D.; SAWITZKI, R. L. A prática da cultura esportiva nas aulas de educação física. Motrivivência v. 26, n. 42, p. 238-249, junho/2014.

RAMOS, A. M.; NEVES, R. L. R. A iniciação esportiva e a especialização precoce à luz da teoria da complexidade - notas introdutórias.Rev. Pensar a prática 11/1: 1-8, jan./jul. 2008

SILVA, Y. P. G. et al. Pedagogia do esporte e métodos de ensino: entre a especialização e a iniciação precoce. In: CONGRESO INTERNACIONAL DE DEPORTES DE EQUIPO, 2. A Coruña: 2009.

SOLER, R. Educação Física Escolar. Rio de Janeiro: Sprint, 2003. P 90 


\section{Capítulo 15}

\section{EDUCAÇÃO E INFORMÁTICA NA ÁREA PROJETUAL}

DOI: $10.37423 / 200200183$

Danilo Émmerson Nascimento Silva (Universidade Federal de PernambucoK(EAAVCaruaru/FACEPE). danilo-emerson@hotmail.com

Robertø Alcarria do Nascimento (Universidade Estadual Paulista/UNESP/BAURU). alcarria@faac.unesp.br Aniceh Farah Neves (Universidade Estadual Paulista/UNESPIBAURU). aniceh@faac.umesp.br

Resumo: presente trabalho apresenta uma produção científica e textual a respeito da inserção das novas tecnologias na área projetual - Arquitetura, Engenharia e Desenho Industrial. Trata, portanto, de uma reflexão a partir de reyisão teórica envolvendo as áreas de educação, informática e projeto, a partir da implementação das novas tecnologias e suas conexões com a área projetual. Traça ùm paralelo comparativo do ensino projetual antes e após a introdução das novas tecnologias nos curs $\phi s$ de ensino superior, nos bacharelados de Arquitetura, Desenho-Industrial (Design) e Engenhharias trazendo à-tona questões didáticopedagógicas, suas contribuições etransformações metodológicas, aspectos favoráveis e desfavoráveis ao proeesso de ensino-aprendizagem na área projetuât-dentro da perspectiva da virtualidade.

Palavras-chave: Educação. Desenho Industrial. Novas Tecnologias. 


\section{Desafios da psicologia no Brasil}

\section{INTRODUÇÃO}

Houve um tempo em que a educação na área projetual (Engenharias, Arquitetura e Desenho Industrial) se consolidava, exclusivamente, com o emprego das habilidades manuais e intelectuais. As atividades relativas aos componentes curriculares da graduação eram processadas adotando-se desenhos à mão livre, com instrumentos de desenho técnico tradicionais, com o uso e a manipulação de inúmeros materiais, máquinas, equipamentos ou ferramentas manuais. As atividades exigiam uma grande preparação intelectual - base teórica - e uma enorme habilidade e domínio dos instrumentos manuais e mecânicos para fins práticos e projetuais. Isto cobrava dos envolvidos (alunos e docentes) grande envolvimento, conhecimento e desprendimento de tempo durante a realização das atividades. A junção entre as habilidades manuais com as intelectuais permitia um enorme controle e conhecimento dos processos e procedimentos a serem desenvolvidos.

Com a chegada das novas tecnologias, aquelas advindas, por exemplo, das inovações no campo da eletrônica, da cibernética e da computação, a educação, na área projetual, tem passado por mudanças

profundas e, ainda, transitórias uma vez que não estão totalmente consolidadas. Ainda, vive-se um processo de adaptação que exigirá tempo e maturação desencadeando processos de reflexão nos indivíduos quanto a sua intervenção no campo projetual. Correntes antagônicas surgiram com posturas favoráveis e contrárias ao uso das novas tecnologias. De um lado, são elogiadas e aclamadas, de outro, são crucificadas e abominadas. Há ainda aquelas correntes que permanecem no meio termo.

No país, a nova geração que está se bacharelando em Desenho Industrial (Design), já vem passando, aproximadamente, desde o final da década de 1980, por esse processo de transformação no ensino. Nesta década, as primeiras iniciativas nos cursos de ensino superior introduziram as "maravilhas da informática" em algumas universidades. Essa nova geração já não consegue perceber qual a diferença entre ter um processo formativo baseado em habilidades manuais e intelectuais em contraposição ao processo formativo da era da eletrônica fundamentada na digitalização e na virtualização, da sua relação com o ensino e com a aprendizagem.

Não consegue perceber pelo simples motivo de não ter vivenciado aquele processo. Por outro lado, a antiga geração - de profissionais egressos ou docentes da academia - a qual vivenciou este processo e, atualmente, tem se esforçado para se adequar a estas inovações possui maiores condições de perceber e discernir as vantagens, as desvantagens e as diferenças entre cada contexto. 


\section{Desafios da psicologia no Brasil}

Essa reflexão fez parte da produção textual da disciplina Estruturas geométricas, computação gráfica e educação, durante doutoramento no Programa de Pós-graduação em Design, da Universidade Estadual Paulista, durante o segundo semestre do ano de 2012.

\section{OBJETIVOS}

Por objetivos, pode-se destacar:

1) Estabelecer uma revisão teórica nas áreas de artes, desenho, educação, informática e desenho industrial para contextualização e compreensão do estado-da-arte;

2) Recuperar a transformação do ensino em desenho industrial antes e após o processo de informatização na educação superior;

3) Refletir e questionar sobre os aspectos favoráveis e desfavoráveis com a introdução da informatização e da virtualidade no ensino de desenho industrial.

\section{METODOLOGIA}

A pesquisa, do tipo qualitativa e descritiva, a partir da revisão e fundamentação teórica e da prática docente nas áreas de artes, desenho industrial, arquitetura, engenharia, computação e educação. Inúmeros são os trabalhos produzidos envolvendo questões como a arte, o desenho, a educação e a informática inserida ou relacionada com o desenho industrial. NEVES (1998), NASCIMENTO (1999), SILVA FILHO et al (2006), ALMEIDA et al (2008), RODRIGUES (1998), COELHO \& REGO (2007), GOMES et al (2011), SCHROEDER et al (2000), MACHADO (2011), GOMES \& MEDEIROS (2005) são alguns dos exemplos de pesquisadores reconhecidos no assunto, os quais serviram de base para a construção desta reflexão.

\section{DISCUSSÃO}

a) O ensino do desenho industrial antes da informatização

Ao iniciar um curso superior na área projetual em qualquer universidade brasileira, àquela época, significava saber que, essencialmente, deveria se dominar e gostar de desenhar ou representar graficamente o entorno, as ideias ou os conceitos. A começar por um teste de aptidão durante o processo seletivo vestibular habilitando, ou não, o candidato para ingressar no Curso de Desenho Industrial ou de Arquitetura, por exemplo. De acordo com CHING e JUROSZEK (2001, p.1) “[...] 


\section{Desafios da psicologia no Brasil}

Qualquer que seja a forma do desenho, representa o princípio com base no qual organizamos e expressamos pensamentos e percepções visuais". Uma vez aprovado no processo seletivo vestibular o recém-ingressante já deveria começar a planejar ou investir, efetivamente, em materiais e equipamentos na sua formação garantindo um processo de maior qualidade, CHING (2000, p.11).

Os primeiros investimentos, normalmente, se caracterizavam em adquirir uma mesa de desenho (prancheta), diversos tipos de lápis - grafite, lápis de colorir - madeira, giz cera, bastão a seco e a óleo, inúmeros tipos e formatos de papéis - ofício, cartolina, canson, vergê, sulfite, manteiga, vegetal etc.; diversas canetas nanquim com as tintas preta e coloridas, normógrafo, escalímetro, compasso, transferidor, par de esquadros, régua $T$, régua paralela, curvas francesas entre outros. De acordo com GUTIÉRREZ et al (1990, p.5), o desenho é a base para carreiras da licenciatura como física e matemática e uma linguagem técnica para disciplinas como a geometria, o projeto e o desenho industrial.

Os trabalhos e atividades pertinentes aos primeiros semestres de graduação exigiam a utilização desse aparato que uma vez bem conservado poderia ser utilizado durante toda a vida profissional. Afora essa listagem havia a necessidade de investir-se em matérias-primas e seus instrumentos auxiliares para transformação e experimentação das formas tais como massa de modelar, papelão, arame, argila, gesso, isopor, espuma de poliuretano, madeira, metal, plástico, resina entre outros. Outras aquisições também podiam ser feitas para especificidades como é o caso da fotografia, da tipografia, da aerografia, da ergonomia etc. As disciplinas e as suas dinâmicas anunciavam a necessidade do acadêmico experimentar as inúmeras possibilidades como parte integrante do seu processo de ensino e de aprendizagem, criativo e de projetação. Dificilmente, alguém conseguia dar seguimento na sua formação sem os esforços da instituição em equipar laboratórios e estrutura física e sem os esforços individuais e particulares de cada acadêmico. Usava-se bastante a lousa, o projetor de slides e, mais recentemente, o retroprojetor; o aparelho videocassete e o televisor de modo complementar. A calculadora, às vezes, se permitia em atividades de componentes envolvendo cálculos como na matemática e na física.

Portanto, naquela época o acadêmico de Desenho Industrial era instruído pelos docentes e estimulado a planejar, representar e idealizar explorando suas habilidades manuais e intelectuais na busca de domínio da técnica da representação gráfica, do controle do processo criativo e projetual além de constituir uma ferramenta poderosa de comunicação. CHING (2000, p.163) reforça alguns aspectos relativos a isso. 


\section{Desafios da psicologia no Brasil}

MONTENEGRO (1981, p. s/n) durante a apresentação e dedicatória do seu livro sobre A Perspectiva dos profissionais destacava a importância da representação gráfica em perspectiva para os geômetras, os artistas e planejadores da cultura material.

Os componentes curriculares de cunho metodológico e projetual preconizavam essas necessidades: planejar, idealizar, conceber, criar, desenhar, representar, visualizar, perceber, compreender, modelar, prototipar, produzir, simular etc., inicialmente, em "pranchas" e registradas em papéis de formatos diversificados $A 3, A 2, A 1$ e $A 0$, sempre unindo as duas capacidades. Se por um lado, o caminho era mais longo e demorado, por outro, era prazeroso e envolvente. Até mesmo os componentes mais "duros" advindos de outras áreas do conhecimento eram estimulados pelas coordenações de cursos para direcionamentos práticos na área. A física, a matemática, a geometria entre outras fazem parte desse rol. O controle excessivo sobre o espaço bi e tridimensional planificado ou não - se fazia por intermédio das mãos, do cérebro e do meio físico. Enfim, a carga horária total do curso de graduação era composta em grande parte de atividades que se resumiam em capacidades intelectuais e cognitivas juntamente com as habilidades manuais.

Durante essa jornada familiarizava-se com os métodos projetuais que são instrumentos sistematizados do processo criativo e de solução projetual de problemas adotados pelos desenhistas industriais. Sabe-se que existem vários desses métodos com nomenclaturas distintas, características particulares e diferenciadas. Mas, em todos se faz comum o uso e a exploração das habilidades manuais em consonância com as habilidades do intelecto. Para CHING e JUROSZEK (2001, p.2) "durante o processo de projetação, o desenho é utilizado para guiar o desenvolvimento de uma ideia, desde o conceito até a proposta concreta".

Por exemplo, GOMES (2011, p.186) ao comentar sobre a fase de Elaboração, forte estimuladora do processo criativo e projetual - também responsável pela modelagem 2D e 3D caracterizadas pelos delineamentos, debuxos e desenhos e pelas maquetes, mocapes e protótipos - dos métodos projetuais assegura que são esses instrumentos que o diferenciam dos amadores existentes no mercado.

b) O ensino do desenho industrial após a informatização

Com o surgimento inicial da computação gráfica, dos computadores e programas de desenho, das impressoras e escâneres 2D seguidos das versões de aplicativos, das impressoras e dos escâneres 3D, 


\section{Desafios da psicologia no Brasil}

essa revolução tecnológica se dá início nos cursos de graduação na área projetual, em especial, no caso do Desenho Industrial. Gradativamente, a relação estabelecida entre as habilidades manuais com as intelectuais tem sido modificada. Permanece-se o lado intelectual, por outro lado, muito do que se desenvolvia manualmente tem sido alterado para o computador e seus periféricos. Agora, parece não haver mais teste de aptidão em desenho durante o processo seletivo vestibular. Para se cursar Desenho Industrial, por exemplo, parece não haver mais a exigência e rigorosidade em saber desenhar, mas não é o que afirmam MEDEIROS \& GOMES (2010, p.20) quando foram questionados pelo fato de existirem profissionais no mercado do trabalho sem saberem desenhar e, no entanto, se autodenominam designers.

Na realidade, os componentes curriculares de desenho - a mão-livre ou com instrumentos de desenho técnico - estão cada vez mais tendo sua carga horária reduzida; a mesa de desenho e os instrumentos auxiliares estão cada vez mais entrando em processo de extinção; os componentes curriculares "ricos" em representação e composição visual - preto e branco e a cores - antes realizados de um modo, agora são executados no computador e impressos digitalmente; a filmadora e a fotografia analógica e suas aplicações foram substituídas pela tecnologia digital; o domínio das técnicas e experimentação com a plasticidade das matérias-primas tem-se reduzido drasticamente em substituição às impressoras 3D ou modelagem virtual; a execução dos projetos em componentes curriculares projetuais sofrem redução de carga horária e seu modus operandi substituído para a execução e desenvolvimento no computador e em programas informatizados 2D e 3D, conhecidos por tecnologia CAD - Computer Aided Design; chegaram os equipamentos multimídia como o datashow, a lousa digital, os cdroms e DVDs; as telas dos monitores e dos equipamentos televisores ampliaram trazendo outros recursos.

Os acadêmicos da nova geração já ingressam nos cursos superiores adquirindo computadores, programas de desenho 2D e 3D e demais periféricos e aparatos eletrônicos. Se já não possuem uma experiência informatizada anterior, muitas vezes herdada do ambiente familiar, assimilam que esse tipo de conhecimento o fará um exímio designer e começam a priorizar tais insumos em detrimento de outros manuais e mecânicos. Matriculam-se em inúmeros cursos de informática e de

programas associados aos desenhos 2D, 3D, animação gráfica, tratamento de imagens digitais, criação de páginas para a rede internet etc., acreditando cegamente que isso fará a diferença na sua profissão. 


\section{Desafios da psicologia no Brasil}

Aqueles que ainda primam e resistem por desenhar investem, por exemplo, em mesas digitalizadoras em substituição ou complemento às mesas de desenho clássicas como ilustra SILVA FILHO et al (2006) ao demonstrar que as mesas digitalizadoras ainda são mais interessantes que os aplicativos "rígidos" CAD.

Para Vincent e Nardelli (2007) citados por GONÇALVES (2009, p.159) isso fica bastante evidenciado quando afirmam que muitos estudantes dessas áreas ingressam nas universidades já dominando as novas tecnologias digitais e, portanto, não é salutar ao processo educacional, simplesmente, ignorar o fato.

Enfim, tudo está passando por um processo de virtualização. A versatilidade aliada à rapidez é a grande promessa das novas tecnologias. Muito tempo do que se usava para fazer procedimentos e operações manuais agora se faz em tempo menor e de modo mais fácil desde que se domine a nova tecnologia. Essa é outra característica presente nessa fase e, para tanto carece do conhecimento tecnológico dos indivíduos, algo que se configura na mudança de carga horária ou criação de componentes nas grades curriculares para essa finalidade.

Essa necessidade veemente e velada de acompanhar o processo formativo, enquanto estudante e, naturalmente, a exigência recai para os docentes em consonância com as inovações tecnológicas informatizadas tendo provocado uma mudança de foco na essência da formação, da base, da fundamentação, por conseguinte, das grades e matrizes curriculares da prática projetual talvez irreversíveis. Parece que essa nova lógica tenta colocar, em primeira instância, o controle das ferramentas informatizadas deixando em segundo plano o domínio dos processos da projetação. Acreditamos que essa mudança de prioridades, em função do processo natural da quebra de paradigmas, não deva ocorrer sob essa ótica. É inegável a necessidade e o surgimento de nova expertise, mas uma não exclui ou pode ser superior à outra e, sim, talvez complementar. Fazendo uma analogia à indústria automobilística: Os automóveis de última geração estão saindo das fábricas mais "inteligentes" graças a um computador de bordo. Antes, havia a necessidade de um conhecimento e de profissionais direcionados exclusivamente ao campo da engenharia mecânica. Na atualidade, quando há uma pane elétrica em algum veículo se faz necessário recorrer a alguém com competência e conhecimento específico no âmbito da engenharia eletro-eletrônica ou da computação. Aquele antigo profissional especializado apenas em mecânica não atenderá mais a nova realidade a não ser que também detenha de outros domínios de áreas. Algo que por vezes se torna difícil de compor e 


\section{Desafios da psicologia no Brasil}

construir devido a inúmeros fatores como perfil, estilo, gosto, preferência, motivação, interesse, curiosidade, prioridade, tempo, dentre outros aspectos.

Algumas mudanças foram mais rápidas e outras estão acontecendo ou irão precisar de mais algum tempo para ocorrer. Por exemplo, não está muito distante da realidade virtual aumentada se fazer presente no ensino projetual. Daqui a pouco - não sabemos com exatidão - mas a holografia pode ser outra ferramenta adotada futuramente.

Por fim, algo que SOARES (2005) nos lembra da real necessidade das inovações informatizadas serem disponibilizadas e ofertadas durante o processo formativo de estudantes para que não ocorra um processo de exclusão digital onde, muitos, não teriam acesso às oportunidades de conhecimento, consequentemente, de trabalho no mundo profissional.

\section{c) As implicações do processo transformador para a virtualização}

Deixemos claro que temos a consciência de que tudo muda e se transforma. Não há nada estanque, ainda mais no processo educacional de indivíduos. Deveremos ter a percepção e entendimento das características do ensino em Desenho Industrial (Design) antes e após a informatização para compreendermos as implicações da sua adoção ou não. Do mesmo modo, descobrirmos os momentos, fases ou etapas onde abdicar-se de algum procedimento manual ou se complementar com outros provenientes da computação.

O que se sabe, inclusive faz parte do senso comum, é que o nível de aprendizado está diretamente relacionado ao nível de envolvimento e desenvolvimento prático. Por exemplo, quando crianças, os indivíduos ao aprenderem as letras e os números podem assimilar visualmente, de modo sonoro, tátil ou escrevendo cada um deles. Certamente, o fato das crianças desenharem e escreverem as letras e os números parece conseguir "gravar" com maior profundidade em determinadas regiões do cérebro distintamente se lhes fosse mostrado apenas elementos visuais, por sons ou de modo tátil. $\mathrm{O}$ fato de "construir" as letras e os números, cada linha, cada parte até formá-las completamente lhes proporciona uma experiência interior ímpar diferente de outras maneiras. O mesmo raciocínio serve para a construção das formas bidimensionais e tridimensionais. Ou seja, os desenhos planificados e em perspectivas construídos manualmente asseguram a experiência de aprendizagem com maior garantia do que se fossem mostradas apenas visualmente ou extraídas prontas ou semiacabadas de programas informatizados, copiando (ctrl-c) e colando (ctrl-v). Do mesmo modo, a construção de 


\section{Desafios da psicologia no Brasil}

modelos físicos (baixa, média e alta fidelidade), maquetes, mocapes e protótipos quando produzidos com o emprego das habilidades manuais, ainda que se utilize de modo auxiliar de algumas ferramentas rústicas, se faz bastante diferente, em termos de aprendizagem e de estímulo ao processo criativo e projetual do que quando se adota a computação gráfica, os sistemas de prototipagem e de manufatura rápida CAD, CAE ou CAM. Para GOMES (2011, p.190), aliar as habilidades mentais às manuais tem sido o procedimento adotado mais recomendado.

Isso corrobora com o pensamento de EDWARDS (2000) sobre os estudos do desenho e sua relação envolvendo o hemisfério esquerdo e o direito do cérebro ao tomar emprestada a descoberta de Sperry (1968), na área da psicobiologia. Ou seja, para EDWARDS, o lado esquerdo é responsável pela oralidade, a lógica, a analítica e pela razão enquanto o lado direito pela emoção, visualidade e percepção. Os hemisférios do cérebro estão estreitamente conectados com os membros (inferiores e superiores) e demais partes do corpo humano. Por isso, ao se usar as mãos, os pés, até mesmo a boca (como é o caso de pessoas excepcionais) essas partes do corpo humano oferecem uma oportunidade natural de comunicação entre o interior (a mente) e o exterior (o entorno). Ao introduzirmos outras ferramentas tecnológicas, cada vez mais complexas, a comunicação para se desenhar parece sofrer ruídos podendo, até mesmo, se perder no meio do caminho. EDWARDS $(2000$, p.66) apresenta um quadro comparativo detalhado estabelecendo as características de cada hemisfério do cérebro humano.

Isso nos leva a acreditar que durante o processo de ensino e de aprendizagem, na área projetual, as habilidades manuais e mecânicas - o uso de instrumentos complementares - tem sua devida importância, seja no nível da aprendizagem e no tempo gasto para se apreender algo. Uma vez experimentados, dificilmente se esquece de como se fazer. Quanto mais se pratica e se experimenta, mais se "grava" e se memoriza nos lugares mais escondidos do cérebro. Parafraseando GOMES (2011, p.190), ao usar um provérbio chinês, temos: “ouço, esqueço; vejo, lembro; faço, aprendo". GOMES (1998, p.105) conclui categoricamente que "o nosso sistema educacional, bem como a ciência em geral, tende a desprezar a forma não-verbal de intelecto. A sociedade moderna discrimina o hemisfério direito".

Afora isso, o indivíduo adquire maior segurança e autonomia. Potencializa seu processo criativo e projetual para outras dimensões distintas daquelas meramente 


\section{Desafios da psicologia no Brasil}

repetitivas e sem grau de originalidade. As ideias e formas não-óbvias e divergentes encontram um terreno mais fértil para construir, desconstruir ou inovar uma vez que o limite transcende a sua imaginação. Metaforicamente, o conhecimento apreendido desse modo parece se impregnar na alma se misturando com a matéria física das células, do sangue, dos membros, dos órgãos.

No âmbito da passagem dos estudos das formas do meio físico para o virtual, se por um lado há um ganho em termos de rapidez e versatilidade, por outro, há perdas irreparáveis da supervalorização dos recursos informatizados em detrimento aos procedimentos manuais e mecânicos. O envolvimento manual e mecânico na produção das formas parece proporcionar um processo retroalimentativo mais profundo nos indivíduos. Imaginemos a construção das formas 3D com o uso da informatização maquetes, mocapes e protótipos digitais. Tudo se reduz à tela plana! Inúmeras percepções físicas e sensoriais estão comprometidas, pois a tela plana do computador não demonstra de modo real nem representa de modo verídico aspectos como os de escala, volume, área, peso, superfície, conforto, desconforto, texturas entre outros. Essas questões são melhor assimiladas com o meio físico, com as réplicas em miniaturas, ampliadas ou em tamanho real possibilitando as simulações de uso, toque, manipulação, operacionalidade, sustentação, manuseio, erguimento etc.

A modelagem bi e tridimensional serve ainda para que durante a fase finalizadora do projeto uma lista de requisitos iniciais seja retomada e verificada quanto às metas se foram atingidas ou não. Os desenhos são analisados e os modelos físicos são testados a partir dos requisitos estipulados no início do desenvolvimento do projeto. GOMES (2011) denomina essa etapa de Verificação. Alguns dos requisitos podem até ser analisados complementarmente em programas informatizados, mas outros não! Questões técnicas como resistências, esforços e cargas submetidas, entre outras questões, que antes eram calculadas usando-se fórmulas e calculadoras podem agora ser verificadas em simulação virtual em programas específicos tão bem adotados pelas Engenharias.

Portanto, acreditamos que a proposta de graduação em Desenho Industrial (Design) no ensino superior deverá ainda sofrer novas transformações para as próximas décadas. Alguns dados atuais já apontam para isso: i) "enxugamentos" de carga horária estipulada pelo Ministério da Educação e Cultura em detrimento do surgimento de novas áreas do conhecimento; ii) o dilema gerado pelas Diretrizes Curriculares Nacionais em Design do MEC entre formação generalista ou especialista ; iii) o domínio de habilidades manuais e mecânicas versus competências digitais; iv) o diálogo mantido entre conhecimentos informatizados versus projetuais; v) a preparação mentor-intelectual versus tecnicista- 


\section{Desafios da psicologia no Brasil}

operacional; vi) a complexidade da formação versus o tempo destinado. Enfim, são várias preocupações que necessitam se esclarecer melhor. Entretanto, o que aparenta ser inconcebível, pelo menos exigindo alta qualidade durante o processo e nos resultados é juntar tudo isto em uma única preparação de quatro anos diluída em diversos componentes curriculares para contemplar todas as particularidades emergentes além das tradicionais mais antigas.

\section{CONSIDERAÇÕES FINAIS}

O presente trabalho discorreu, portanto, da análise reflexiva dos autores, a respeito do processo de surgimento e introdução da informatização na área projetual, passando pelas suas mudanças observadas, o "conflito" de gerações com perfis diferentes, as competências atribuídas e exigidas dos docentes, os aspectos favoráveis e desfavoráveis da virtualização do ensino e as possíveis implicações em momentos futuros no ensino e na profissionalização da área do Desenho Industrial.

\section{REFERÊNCIAS}

ALMEIDA, I. A. C. et al. Construções Geométricas com Papel e Lápis ou Utilizando Software Gráfico: que mudanças ocorrem quando se opta por uma dessas mídias? In IV Colóquio de História e Tecnologia no Ensino de Matemática (HTEM). Rio de Janeiro: UFRJ, mai. 2008.

CHING, F. D. K. Representação gráfica em arquitetura. 3ạ Ed. Porto Alegre: Bookman, 2000.

CHING, F. D. K.; JUROSZEK, S. P. Representação gráfica para desenho e projeto. Barcelona: Gustavo Gili, 2001.

COELHO, E. da S.; REGO, R. de M. Percepção Visio-espacial: combinando representação gráfica e modelagem 3d. In XVIII Simpósio Nacional de Geometria Descritiva e Desenho Técnico Graphica 2007 - Curitiba: UFPR, nov. 2007.

EDWARDS, B. Desenhando com o lado direito do cérebro. Rio de Janeiro: Ediouro, 2000.

GUTIÉRREZ, A. A. et al. Antecedentes de dibujo. 3a Ed. México: Trillas: UNAM, Faculdad de Ingeniería, 1990.

GOMES, L. A. V. de N. Criatividade e design: um livro de desenho industrial para projeto de produto. Porto Alegre: sCHDs, 2011.

. Desenhando: um panorama dos sistemas gráficos. Santa Maria: UFSM, 1998.

et all. O desenho operacional no projeto de produto industrial. In XX Simpósio Nacional de Geometria Descritiva e Desenho Técnico Graphica 2011, Rio de Janeiro: UFRJ, out. 2011.

; MEDEIROS. Lígia. M. S. de. Ordem e arranjo em desenhos industriais: malhas e grelhas, revisão e retomada. In . In XVII Simpósio Nacional de Geometria Descritiva e Desenho Técnico Graphica 2005, Recife: UFPE, set. 2005. 


\section{Desafios da psicologia no Brasil}

GONÇALVES, M. de M. O uso do computador como meio para a representação do espaço: estudo de caso na área de ensino do digital \& virtual design. São Paulo, 2009. Tese de doutorado defendida na FAUUSP, Área de Concentração Design e Arquitetura.

MACHADO, S. R. B. A. A compatibilização do ensino tradicional de desenho com as novas tecnologias. In XX Simpósio Nacional de Geometria Descritiva e Desenho Técnico Graphica 2011, Rio de Janeiro: UFRJ, out. 2011.

MEDEIROS, L. S. de; GOMES, L. A. V. N. Ideias, ideais e ideações para Design/Desenho Industrial. Porto Alegre: UniRitter, 2010.

MONTENEgRO, G. A. A perspectiva dos profissionais. São Paulo: Edgard Blücher, 1981.

NASCIMENTO, R. A. A função do desenho na educação. Marília: UNESP, Tese de Doutorado defendida na Universidade Estadual Paulista/Faculdade de Filosofia e Ciências, 1999.

NEVES, A. F. Em busca de uma vivência geométrica mais significativa. Marília: UNESP, Tese de Doutorado defendida na Universidade Estadual Paulista/Faculdade de Filosofia e Ciências, 1998. RODRIGUES, M. H. W. Desenho, conhecimento e novas tecnologias. In XIII Simpósio Nacional de Geometria Descritiva e Desenho Técnico Graphica 1998, Feira de Santana: UEFS, set. 1998.

SCHROEDER, N. et all. Tecnologias gráficas: da racionalidade instrumental à razão crítica. In XIV Simpósio Nacional de Geometria Descritiva e Desenho Técnico Graphica 2000, Ouro Preto: ABEG, jun. 2000.

SILVA FILHO, A. R. da et al. O desenho e as novas tecnologias. In 50 EREG/NE - Encontro Regional de Expressão Gráfica - Educação Gráfica - perspectiva histórica e evolução. Salvador: UFBA, ago., 2006.

SOARES, C. C. P. Computação gráfica: uma mudança nos paradigmas das técnicas de representação? In XVII Simpósio Nacional de Geometria Descritiva e Desenho Técnico Graphica 2005, Recife: UFPE, set. 2005. 


\section{Capítulo 16}

\section{ATIVIDADES EXTRACURRICULARES NO BRASIL: REVISÃO SISTEMÁTICA DA LITERATURA}

DOI: $10.37423 / 200200192$

Neyfsom Carlos Fernandes Matias (Professor do Departamento de Psicologia da Universidade Federal de São João Del-Rei (UFSJ).

Resumo: o objetivo deste estudo foi o de identificar artigos que relatem efeitos das atividades extracurniculares estruturadas sobre o desempenho/escolar, desenvolvimento socioemocionale físico de seus participantes. A partir/de consulta às bases-de dados SciELO BrąziL_(Scientific Electronic Lịbrary Online), Portal de Periódices Etetrônico de Psicotogia (PePsic), portal da Coordenação de Aperfeiçoamento de Pessoal e Ensino Superior (CAPES) e portal Educ@ publicaçõès online de educação, foram levantados seis artigos que investigaram impactos das atividades extracurriculares. Os trabalhos selecínnados demonstram que são poucas as evidências de impactos positivos das atividades sobre seus participantes e a necessidade de pesquisas de campo sobre o tema no Brasil.

Palavras-chave: atividades extracurriculares; educação de tempo integral; projetos sociais.

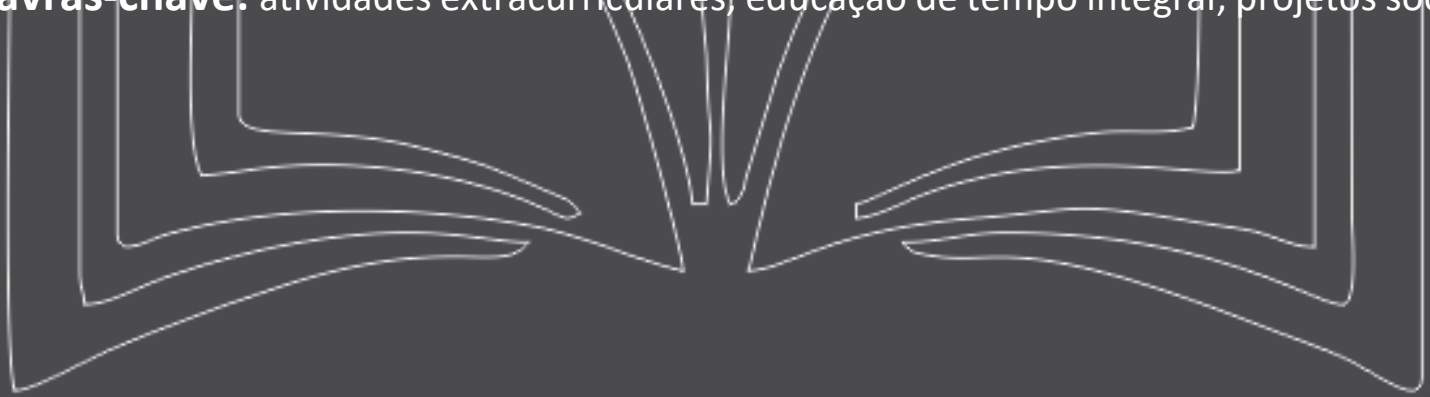




\section{Desafios da psicologia no Brasil}

\section{INTRODUÇÃO}

Crianças, adolescentes e jovens, ao longo de suas atividades diárias, se dividem em três contextos, a saber: o familiar, o escolar e o das atividades extracurriculares. O ambiente extracurricular pode ser caracterizado de duas formas: as atividades extracurriculares desestruturadas que compreendem as ações desenvolvidas no lar na companhia da mãe ou de outro adulto, como, brincar, assistir à televisão, jogar videogame e lazer; e as atividades extracurriculares estruturadas (AEE) que podem ser aulas em escolas particulares, por exemplo, de línguas, esportes, músicas e danças ou desenvolvidas por organizações não governamentais e projetos socioeducacionais que promovam atividades complementares à escolarização contemplando atividades artísticas, culturais, pedagógicas e esportivas (ALVES et al., 2007; CENTRO DE ESTUDOS E PESQUISAS EM EDUCAÇÃO, CULTURA E AÇÃO COMUNITÁRIA, 2002; 2003). O primeiro tipo de atividade extracurricular estruturada, de maneira geral, é voltado para as classes mais favorecidas economicamente, como, as atividades promovidas por cursos particulares de línguas estrangeiras. Já no segundo, as ações são voltadas para estudantes filhos de pais sem recursos financeiros para arcar com os custos de aulas especializadas e que precisam de um lugar para deixar seus filhos enquanto estão no trabalho (CAVALIERE, 2007; LEONE; BALTAR, 2008; MAHONEY; PARENTE; ZIGLER, 2010).

O foco deste artigo recai sobre esse último, pois, as AEE promovidas por organizações sociais e dentro de instituições de ensino, têm ganhado força nos últimos anos como ações vinculadas à educação. Elas são as principais estratégias de implantação da educação de tempo integral e de promoção do vínculo, da reinserção e manutenção dos estudantes na escola no Brasil (BATISTA; ANDRADE, 2010; CAVALIERE, 2007; 2009). Isso acontece, por exemplo, por meio de ações públicas como o Programa Mais Educação (BRASIL, 2007; FARIA, 2011) e o ProJovem (GONDIN; MORAES, 2014).

Devido à expansão dessas ações, urge a elaboração de pesquisas acerca dos impactos das AEE sobre seus participantes, seja através de trabalhos teóricos ou empíricos. Ademais, é possível detectar estudos contraditórios acerca dos efeitos das atividades extracurriculares nacionais. Há indícios de pouca ou nenhuma influência dessas ações sobre os estudantes (CASTRO; LOPES, 2011; FARIA, 2011) e de que elas proporcionam ganhos aos seus participantes como demonstrado nos estudos de Gondim e Moraes (2014) e do Fundo das Nações Unidas para a Infância (2008; 2010). Além disso, pesquisas mostram que o universo extracurricular brasileiro ainda é pouco explorado, mesmo no âmbito da educação de tempo integral (MATIAS, 2009), o que justifica a busca criteriosa de investigações que 


\section{Desafios da psicologia no Brasil}

apresentem contribuições sobre o tema (CASTRO; LOPES, 2011; SOUZA; CASTRO; VIALICH, 2012). Assim, este artigo, relata os resultados de uma revisão sistemática da literatura sobre o assunto. Especificamente, o estudo teve o objetivo de identificar artigos que demonstrem efeitos das AEE sobre o desempenho escolar, desenvolvimento socioemocional e físico de seus participantes.

\section{MÉTODO}

No intuito de se destacar informações de pesquisadores brasileiros para elaboração de pesquisas sobre o assunto foram estabelecidas estratégias que permitissem o alcance do maior número de trabalhos possíveis. Assim, os procedimentos metodológicos adotados, para levantamento do material que compõe a revisão pautam-se nos apontamentos de Sampaio e Mancini (2007). Já os critérios de seleção do material e extração dos dados foram estabelecidos em sintonia com a bibliografia que discute questões sobre as atividades extracurriculares (por ex. ALVES et al., 2007; ECCLES; TAEMPLETON, 2002) e educação de tempo integral (por ex. CASTRO; LOPES, 2011; CAVALIERE, 2007; 2009; FARIA, 2011).

Bases e estratégias de busca: A fim de alcançar o objetivo proposto, foram consultadas as seguintes bases de dados: SciELO Brazil (Scientific Electronic Library Online), Portal de Periódicos Eletrônico de Psicologia (PePsic), portal da Coordenação de Aperfeiçoamento de Pessoal e Ensino Superior (CAPES) e portal Educ@ publicações online de educação. A pesquisa aconteceu entre os meses de agosto setembro e outubro de 2015 sem restrições de ano.

Não houve limitação quanto ao idioma de publicação. O tipo de trabalho pesquisado foi exclusivamente artigo revisado por pares. Os descritores utilizados foram definidos com base em leituras prévias de trabalhos que relatam impactos das atividades extracurriculares internacionais (MAHONEY; PARENTE; ZIGLER, 2010; PIERCE; BOLT; VANDELL, 2010) e da descrição de projetos que atendem a crianças e adolescentes no Brasil (CENTRO DE ESTUDOS E PESQUISAS EM EDUCAÇÃO, CULTURA E AÇÃO COMUNITÁRIA, 2002; 2003). A princípio, a pesquisa foi desenvolvida a partir de buscas com nomenclaturas utilizadas para nomear as ações realizadas fora da escola. Ressalta-se que o termo organização não governamental foi acrescentado porque essas instituições são as principais executoras dos projetos voltados para o público infanto-juvenil e parceiras do poder público nessa empreitada. Em seguida, as denominações foram associadas pelo operador booleano and com os termos relacionados aos seus participantes, aos possíveis impactos e objetivos, a ações oferecidas e áreas de atuação. Foram realizadas ainda buscas com os nomes de programas vinculados à política 


\section{Desafios da psicologia no Brasil}

educacional brasileira. Como o foco do trabalho recai sobre o contexto brasileiro, a busca foi realizada com descritores na língua portuguesa. A pesquisa abrangeu todos os campos: palavras do título, resumo, palavras-chave, conteúdo. A amplitude de termos utilizados tinha como intuito alcançar trabalhos que, de fato, apresentassem o panorama da pesquisa sobre o tema no Brasil. Todos os descritores utilizados, e a forma como foram conjugados, estão descritos na Tabela 1.

\begin{tabular}{|c|c|}
\hline Tipo de Descritor & Conjugações \\
\hline $\begin{array}{l}\text { Nomenclatura } \\
\text { atividades } \\
\text { extracurriculares }\end{array}$ & $\begin{array}{l}\text { "Programa Segundo Tempo", "Associação } \\
\text { Comunitária", "Atividades } \\
\text { Extracurriculares", "Projeto(s) } \\
\text { "Organizações Não Governamentais", "Educação não formal". }\end{array}$ \\
\hline $\begin{array}{l}\text { Nomenclatura } \\
\text { atividades } \\
\text { extracurriculares } \\
\text { participantes }\end{array}$ & $\begin{array}{l}\text { "Projeto Social and Adolescentes", "Projeto Social and } \text { Crianças", "Projeto } \\
\text { Social and Jovens", "Organizações Não Governamentais and } \\
\text { criança(s)/adolescente(s)/jovem(s)", "ações } \\
\text { crianças/adolescentes". }\end{array}$ \\
\hline $\begin{array}{l}\text { Nomenclatura das } \\
\text { atividades } \\
\text { extracurriculares } \\
\text { impactos e objetivos. }\end{array}$ & $\begin{array}{l}\text { "Avaliação de Programas", "Avaliação de Programas Sociais", "Intervenção } \\
\text { and Desempenho Escolar", "Intervenção and Esporte", "Intervenção and } \\
\text { Habilidades Sociais", "Intervenção and Para Casa", "Intervenção and Prevenção } \\
\text { do uso de Drogas", "Intervenção and Reforço Escolar", "Intervenção and } \\
\text { Segundo Tempo", "Intervença and Uso de Drogas", "Programa and } \\
\text { Competência Social", "Programa and Crianças and Adolescentes", "Programa } \\
\text { and Formação Integral", "Programa and Habilidades Sociais", "Programa and } \\
\text { Reforço Escolar", "Programa and Desempenho Escolar", "Programa and Para } \\
\text { Casa", "Organizações Não Governamentais" and "Desempenho Escolar" and } \\
\text { "Habilidades Sociais". }\end{array}$ \\
\hline $\begin{array}{l}\text { Nomenclatura das } \\
\text { atividades } \\
\text { extracurriculares e áreas }\end{array}$ & $\begin{array}{l}\text { "Educação and Não-Formal", "Intervenção and Arte", "Intervenção and } \\
\text { Música", "Programa and Esporte", "Programa and Música", "Programa and } \\
\text { Vulnerabilidade Social", "Programa and Prevenção de Riscos", "Intervenção } \\
\text { and Vulnerabilidade Social", "Programa and Prevenção de Riscos", "Programa } \\
\text { and Proteção Social", "Programa and Vulnerabilidade Social", "Programa and } \\
\text { Esporte", "Projeto and Esporte", "Projeto Social and Cultura". }\end{array}$ \\
\hline $\begin{array}{l}\text { Nomenclatura } \\
\text { relacionada à política } \\
\text { educacional brasileira }\end{array}$ & $\begin{array}{l}\text { "Escola(s) de Tempo Integral", "Educação de Tempo Integral", "Tempo } \\
\text { Integral", "Programa Mais Educação". }\end{array}$ \\
\hline
\end{tabular}

Critérios de seleção: A revisão é composta de artigos completos que atenderam aos seguintes critérios: a) pesquisa realizada no Brasil; b) relato de AEE desenvolvidas por meio do esporte, da arte, da cultura e de apoio pedagógico, sem associação com o currículo formal; c) utilização de dados quantitativos; e d) apresentação de impactos das AEE sobre seus participantes relacionados ao desenvolvimento cognitivo, socioemocional e físico.

Os artigos que discutiam apenas aspectos teóricos, de revisão da literatura, relatos de experiências, com participantes que vivem em abrigos, inclusão no mercado de trabalho de adolescentes e jovens foram excluídos. Isso também aconteceu com os trabalhos publicados sob a forma de editoriais, notas, entrevistas e apresentação de projetos. A justificativa para seleção de trabalhos que utilizaram apenas 


\section{Desafios da psicologia no Brasil}

dados quantitativos pauta-se na possibilidade de comparar resultados de diferentes estudos por adotarem instrumentos padronizados e que medem o desempenho dos participantes em diversos aspectos, sobretudo, no desempenho escolar. Destaca-se que os trabalhos qualitativos são de suma importância, tanto que alguns trabalhos que utilizaram esse delineamento são citados na introdução deste artigo.

Extração dos dados: Foram elaborados dez critérios para análise, organização e registro dos artigos numa ficha construída para a realização da revisão contemplando: objetivos dos estudos; participantes; delineamento; instrumentos de coleta de dados; características das AEE; tratamento estatístico utilizado nas análises; resultados relacionados a impactos das AEE nos seus participantes; indicações de pesquisas futuras; explicação sobre quais variáveis e aspectos estão relacionados aos efeitos das atividades sobre seus participantes; e principais conclusões.

\section{RESULTADOS}

Ao aplicar as conjugações dos descritores foram destacados 3.007 trabalhos. Em cada pesquisa efetuada, os títulos e resumos eram analisados no intuito de identificar o critério de que se tratava de "relato de questões relacionadas a atividades extracurriculares no Brasil". Ou seja, destacou-se que, primordialmente, o trabalho deveria possuir essa característica. Além disso, não foram estabelecidas delimitações quanto à faixa etária dos participantes das pesquisas e a utilização do número elevado de descritores se fez necessária pela grande quantidade de termos utilizados para definir as AEE brasileiras. Após a leitura dos resumos excluíram-se 2.946 por não atenderem à condição de discutirem questões específicas das AEE. Nos 61 artigos restantes, foi realizada leitura completa por apresentarem indícios de informações acerca de impactos das AEE.

Com isso, a partir dos outros filtros predeterminados, foram eliminados: sete que abordam aspectos relacionados à gestão e ao financiamento das escolas de tempo integral e de projetos sociais desenvolvidos por organizações não governamentais; oito por se tratarem de discussões acerca da formação dos educadores de projetos sociais; 37 que são estudos que utilizaram exclusivamente delineamentos qualitativos; um que, apesar de tratar da temática escola de tempo integral, não apresenta informações sobre $A E E$, mas sim, de oficinas curriculares. E, por fim, dois, sendo que um discute estratégias de programa que tem como foco a prevenção de homicídios entre adolescentes e jovens utilizando, como parte das estratégias, oficinas com o público atendido, mas sem detalhes acerca de seus efeitos, e outro com o objetivo de avaliar os efeitos de intervenções para estudantes 


\section{Desafios da psicologia no Brasil}

com problemas comportamentais. Por meio dos critérios pré-estabelecidos chegou-se ao corpus desta revisão, como é apresentado na Figura 1, que se constituiu com seis trabalhos.

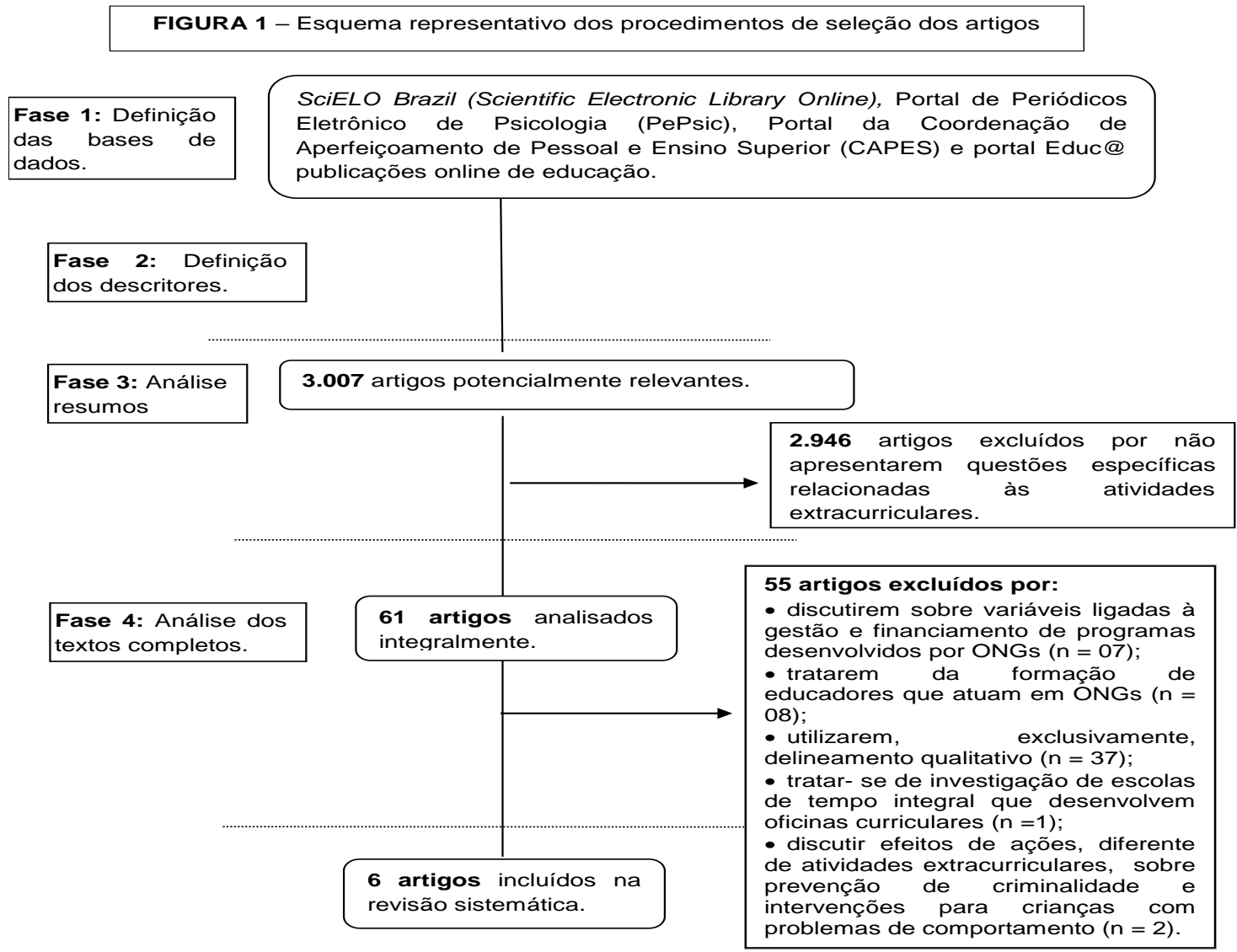

Os pesquisadores dos artigos revisados buscaram identificar impactos das AEE em crianças, adolescentes e jovens dos sexos masculino e feminino. Foram observadas hipóteses, tanto explícitas como implícitas, de que haveria relação entre a frequência a projetos fora da escola, e o uso de álcool e drogas - neste caso, aqueles que participam não seriam consumidores dessas substâncias (CARVALHO; CARLINI-COTRIM, 1992), desempenho escolar, qualidade de vida e estresse (CORTÊSNETO et al., 2010; MACHADO et al., 2007; IWANTSCHUK \& NAVARRO, 2011) e desenvolvimento da aptidão física (FONSECA et al., 2010; SANTOS, NETO, PIMENTA, 2013). Os detalhes de cada artigo, a partir dos critérios de análises definidos, são apresentados a seguir.

\section{CONTEÚDOS DOS ARTIGOS}

Carvalho e Carlini-Cotrim (1992) tiveram como objetivo identificar se havia relação entre atividades extracurriculares e o uso de drogas e álcool numa amostra de 16.117 alunos, do primeiro e segundo graus, matriculados em escolas públicas e privadas de 15 cidades, no Brasil. Os autores delinearam um 


\section{Desafios da psicologia no Brasil}

levantamento a partir de questionário fechado, preenchido pelos próprios participantes. Nesse estudo, consideraram-se como AEE as esportivas, comunitárias (instituições de caridade, partidos políticos, associações de bairro e sindicatos), religiosas e artísticas (dança, pintura, teatro e música). As análises das informações coletadas deram-se a partir de medidas de associação. Contrário ao que era esperado, não se identificou que o consumo de drogas e álcool e o envolvimento nas atividades investigadas estariam associados. Nos casos em que isso aconteceu, as correlações foram fracas ou, no máximo, moderadas, caso, por exemplo, da cidade de Salvador - BA - nas atividades em sindicatos. Identificou-se ainda a "correlação negativa fraca entre o uso de álcool e drogas e a prática de atividades religiosas" (p. 147). Sobressaíram as religiosidades católica e protestante, sendo que os estudantes vinculados à última demonstraram correlações negativas de maior intensidade. Os autores supõem que "tal resultado se explique, não pela ocupação de tempo que tais atividades demandam, mas pelo código moral subjacente a grupos religiosos" (p.147). Os pesquisadores ressaltam que estudos futuros devem ser realizados com vistas a complementar os dados encontrados por eles considerando, por exemplo, as atividades realizadas em instituições, caracterizadas como formais e aquelas informais.

Segundo Carvalho e Carlini-Cotrim (1992), o consumo de substâncias psicotrópicas estaria associado à falta do que fazer. As estratégias de prevenção e de solução do problema perpassam pela possibilidade de serem oferecidas alternativas para os jovens, por exemplo, através da prática de esportes. A ocupação do tempo livre, na linha de ditos populares como cabeça vazia é oficina do diabo, seria a explicação para os possíveis efeitos das AEE. O jovem, sobretudo, aquele que vive em regiões de baixo poder aquisitivo, estaria mais propenso à inserção no mundo das drogas, devido à falta do que fazer. Logo, participar de uma AEE evitaria comportamentos desviantes. Os impactos das atividades extracurriculares são esperados em questões para além de aspectos comportamentais, por exemplo, no desempenho acadêmico.

A pesquisa realizada por Cortês-Neto et al., (2010) buscou identificar diferenças no desempenho escolar de 51 participantes, crianças, adolescentes e jovens, com faixa etária entre 08 e 18 anos, que viviam na cidade de Natal - RN. O delineamento do estudo foi longitudinal e as avaliações conduzidas nos anos 2007 e 2008. Os pesquisadores realizaram entrevistas semiestruturadas a partir de um roteiro e utilizaram dados do Sistema Nacional de Avaliação da Educação Básica. A amostra foi dividida em dois grupos: grupo de aderentes ao Projeto Nova Descoberta e não aderentes. Essa ação oferecia atividades esportivas através de parcerias com universidades e o Instituto Ayrton Senna e era 


\section{Desafios da psicologia no Brasil}

caracterizada como complementar à escola. Submeteram-se os dados a testes de diferenças entre médias. O grupo de frequentadores do projeto apresentou resultados superiores aos não frequentadores na disciplina de português, no ano de 2008. Os autores destacaram esse dado como indicador de eficácia do projeto. Eles sugerem que, em pesquisas futuras, outros aspectos sejam considerados como indicadores de impactos de projetos sociais como a motivação para a participação nas atividades, comportamentos apresentados na escola e no contexto familiar.

Segundo Cortês-Neto et al. (2010), a partir das atividades desenvolvidas pelo projeto, criaram-se oportunidades que proporcionaram às crianças e aos adolescentes o desenvolvimento de "competências cognitivas, pessoais, sociais e produtivas" (p. 212) que se relacionam com comportamentos saudáveis. Nesse sentido, o envolvimento nas ações facilitou a aprendizagem de conteúdos escolares. A ideia subjacente, na explicação dos autores, é a de que as relações envolvidas nos diversos contextos pelos quais crianças e adolescentes passam impactam habilidades que, não necessariamente, relacionam-se com o ambiente imediato. Ou seja, o que é aprendido nas atividades fora da escola proporciona novas capacidades que permitirão às crianças e aos adolescentes habilidades importantes para a absorção de conteúdos escolares. Essa premissa, também, está presente nos outros artigos que compõem a revisão.

O estudo de Machado et al. (2007) teve como objetivo avaliar o impacto de projeto de educação pelo esporte no desempenho escolar, qualidade de vida, no estresse e em atitudes sociais e acadêmicas de 39 crianças alunas da 1a à 4a série do Ensino Fundamental. Os estudantes, que frequentavam a mesma escola, foram divididos entre participantes e não participantes do projeto, grupo de comparação, e pareadas por sexo, idade, nível socioeconômico e série. Os pesquisadores delinearam um estudo longitudinal que foi desenvolvido durante seis meses. As testagens aconteceram em dois momentos: no início das atividades do programa e no seu encerramento através de dois instrumentos. Utilizaramse um teste de desempenho escolar e uma escala de avaliação da qualidade de vida. As atividades oferecidas eram esporte, ações educativas com ênfase na saúde, arte e de apoio à escolarização. A análise dos resultados deu-se a partir da diferença entre as médias dos grupos. Contrário ao que era esperado, o grupo de indivíduos que participavam das atividades do projeto não apresentou diferenças significativas em relação ao outro nos quesitos avaliados. Além das discrepâncias entre participantes e não participantes do projeto, os autores compararam os resultados dos próprios grupos a partir dos resultados da primeira e segunda aplicação dos testes. Eles detectaram diferença significativa no grupo de participantes em relação à avaliação do estresse infantil, com diminuição nos 


\section{Desafios da psicologia no Brasil}

valores. Os pesquisadores consideraram tal dado como impacto positivo do projeto. Eles ressaltam ainda a importância de pesquisas relacionadas à avaliação de projetos sociais, desenvolvimento e validação de instrumentos para a área. Além disso, consideram importante que estudos futuros abarquem ainda os profissionais envolvidos, professores das escolas e familiares dos frequentadores.

Numa perspectiva bioecológica (BRONFENBRENNER, 2002), Machado et al. (2007) destacam que nas atividades desenvolvidas em projetos existem processos que contribuiriam para o desenvolvimento infantil. A partir disso, pode haver diminuição do estresse dos participantes, bem como aumento nos índices de qualidade de vida e desempenho escolar. Ou seja, as inter-relações recíprocas que ocorrem em diferentes contextos estão ligadas e no projeto esportivo são promovidas capacidades pessoais que vão se relacionar com o ambiente escolar e familiar influenciando, respectivamente, o desempenho acadêmico e a qualidade de vida. Os achados de Machado et al. (2007), no que se refere ao desempenho acadêmico, se repetiram em outros estudos.

Iwantschuk e Navarro (2011) tiveram como objetivo verificar se estudantes participantes de atividades extracurriculares têm algum benefício quando comparados a não participantes. A amostra desse estudo foi composta por 44 alunos de um colégio particular da cidade de São Paulo com idades entre 11 e 17 anos. As atividades frequentadas pelos estudantes eram "de caráter de capacitação, focado em lazer e aprimoramento cultural" (IWANTSCHUK; NAVARRO, 2011, p. 271). O delineamento utilizado pelos autores foi o transversal e para a coleta de dados utilizaram um questionário que foi aplicado aos alunos e as notas das disciplinas escolares. Após as respostas ao instrumento os discentes foram divididos em dois grupos participantes e não participantes de atividades extracurriculares. Os dados foram analisados por meio da estatística descritiva. Nesse estudo, não foram destacadas diferenças no desempenho escolar entre os grupos. Os pesquisadores tinham como expectativa de que o fator participação nas atividades extracurriculares iria contribuir para destacar o desempenho escolar dos alunos em comparação aos outros que não as frequentavam. Para os autores, novos estudos devem ser realizados sobre o tema considerando ainda a relação entre professor, escola, família e aluno.

Diferente dos estudos anteriores, Fonseca et al. (2010), identificaram aspectos dos componentes da aptidão física relacionados à saúde, em conformidade com idade e sexo, de 104 estudantes, que estavam na faixa etária entre 08 e 10 anos, frequentes a uma escola de tempo integral, entre a 2a e 4a séries, na cidade de Ponta Grossa, no Estado do Paraná. Os autores utilizaram o delineamento 


\section{Desafios da psicologia no Brasil}

transversal, e a coleta dos dados deu-se com a utilização de bateria de aptidão física, cálculo de massa corpórea, medida de altura, flexibilidade e teste de capacidade respiratória. Todos frequentavam as atividades do contraturno constituídas por "atividades psicossomáticas e psicomotoras somadas a atividades de cunho esportivo" (p. 158). Os dados foram submetidos a testes de diferença entre as médias pela idade e sexo das crianças. Os resultados não apresentaram níveis satisfatórios, segundo os índices da bateria utilizada, e a massa corporal dos grupos avaliados mostrou-se com excesso de peso. Essa informação indica a possibilidade de essas crianças apresentarem doenças crônicas ao longo da vida. Em relação a estudos futuros, os autores evidenciam a necessidade do levantamento de dados de outras regiões brasileiras e de verificar a existência de influências nas questões relacionadas à aptidão física e de saúde, considerando a frequência nas escolas de tempo integral, e único com vistas a observar se o número de horas nas atividades impacta, em alguma medida, nesses fatores.

Para Fonseca e colegas (2010), as crianças que frequentam atividades esportivas no contraturno escolar deveriam apresentar melhores índices de aptidão física em relação aos outros. A explicação para essa melhora estaria na relação causal de que participar de atividades esportivas aumenta a aptidão física. Já que os estudantes da escola de tempo integral têm mais acesso a essas ações, seus resultados em baterias que analisam o condicionamento físico destacar-se-iam como superiores. Os efeitos das AEE esportivas na aptidão física e em outros aspectos relacionados à saúde seriam, a princípio, eminentes.

Os resultados encontrados no estudo de Fonseca et al. (2010) não se repetiram no trabalho de Santos, Neto e Pimenta (2013). Esses autores tiveram como objetivo avaliar as habilidades motoras de estudantes que participavam de projetos sociais educacionais, esportivos e de não participantes de AEE na cidade de Florianópolis (SC). Os participantes desse estudo foram 136 crianças, com idades entre 8 e 9 anos, separados em três grupos: 1) grupo de não participantes de AEE, 2) grupo de participantes de atividades proporcionadas por projetos sociais com diversas ações (reforço escolar, música, artes, dentre outras), 3) participantes de projetos sociais esportivos (futebol/futsal, tênis, caratê, dentre outros). Os autores utilizaram uma escala de desenvolvimento motor para avaliar os participantes e os dados foram analisados por meio da Análise de Variância. Os resultados desse estudo indicaram desempenhos superiores do grupo de participantes de atividades de projetos esportivos em relação ao de não participantes na escala geral, motricidade fina e global, na 


\section{Desafios da psicologia no Brasil}

organização espacial e temporal. Não se destacou diferença significativa entre os participantes dos projetos com atividades variadas e os não participantes de AEE.

Para Santos, Neto e Pimenta (2013) os participantes dos projetos sociais deveriam se destacar nas tarefas que avaliaram a motricidade porque as atividades oferecidas nesses contextos têm potencial para impactar sobre esse aspecto. Nesse estudo, destaca-se que os projetos esportivos sobressaíramse em relação aos que possuem conjunto de atividades variadas. Os autores indicam que, em novas pesquisas, as avaliações sejam realizadas pré e pós intervenção. Além disso, consideram pertinente a análise de aspectos para além do desenvolvimento motor, mas também em questões sociais, emocionais e físicas.

\section{DISCUSSÃO}

Essa revisão teve como objetivo identificar estudos brasileiros que apresentem impactos das AEE sobre seus participantes no desenvolvimento físico, cognitivo e socioemocional em seis artigos selecionados a partir dos critérios preestabelecidos. Dentro dos resultados encontrados, observou-se a existência de pesquisas sobre os impactos destacados, respectivamente, o estudo de Fonseca et al. (2010) e Santos, Neto e Pimenta (2013); Cortês-Neto et al. (2010), Machado et al. (2007) e Iwantschuk e Navarro (2011); Carvalho e Carlini-Cotrim (1992).

O número de trabalhos levantados evidencia que a investigação sobre os efeitos das $A E E$ ainda não ganhou proeminência na agenda de pesquisa do Brasil, apesar da abrangência dos descritores utilizados. Dado que o desenvolvimento de projetos e programas, voltados para crianças, adolescentes e jovens, tem ganhado destaque nos últimos anos, principalmente, pela sua articulação com a educação de tempo integral, torna-se pertinente a realização de investigações que demonstrem quais os efeitos dessas ações a fim de contribuírem na elaboração de programas/projetos eficazes.

Os seis artigos possuem similaridades com relação à expectativa dos efeitos das AEE. Suas hipóteses destacam a perspectiva de que os efeitos das atividades seriam positivos e que haveria discrepâncias significativas entre seus participantes e não participantes, favoráveis aos primeiros. 0 estudo de Carvalho e Carlini-Cotrim (1992) demonstra informações nesse sentido em relação aos frequentadores de atividades religiosas que ingerem menos álcool e drogas quando comparados aos que não frequentam práticas vinculadas às religiões. Porém, os autores destacam que isso se deve mais aos aspectos morais, presente nas doutrinas, do que sua frequência per si às atividades. Observa-se que 


\section{Desafios da psicologia no Brasil}

as conclusões do estudo são contrárias às explicações acerca de como as AEE impactam na não utilização de substâncias lícitas ou ilícitas. Isso conduz à mudança no foco da discussão da questão fazer versus não fazer atividades fora da escola, mas sim "para a do como fazer, tendo como pressuposto que um jovem realizado em suas potencialidades (e não apenas ocupado, ou assimilando padrões e códigos)" (CARVALHO; CARLINI-COTRIM, 1992, p. 148) deveria ser o principal objetivo de projetos e programas que atendem a crianças, adolescentes e jovens. Cortês-Neto et al. (2010) encontraram diferença significativa no desempenho de português dos participantes de um programa social, o que remete a eficácia do mesmo. Machado et al. (2007) mostram dados que apontam impactos positivos quando relatam que os participantes do projeto investigado diminuíram os índices de estresse infantil. Santos, Neto e Pimenta (2013) destacaram a eficácia de projetos esportivos e que esses se sobressaem em relação aos que oferecem atividades variadas. Ou seja, há indícios de que, assim como em outros países, as AEE brasileiras possuem efeitos positivos.

O baixo número de pesquisas sobre estudantes em escolas de tempo integral, especificamente no que tange ao seu desenvolvimento acadêmico, destaca a importância de serem iniciadas investigações sobre o tema. Principalmente, pelo fato de que a ampliação da jornada escolar tem acontecido de forma recorrente no Brasil. Mas nem sempre com estratégias eficazes (COELHO, 2009). A indicação de que os estudantes de escolas de tempo integral não apresentaram bons resultados relacionados à aptidão física, que seria resultado da participação em AEE, como destacado por Fonseca et al. (2010), indica certa urgência em saber de fato quais, caso existam, os impactos da permanência de crianças e adolescentes em atividades no contraturno escolar.

O questionamento da eficácia dos projetos brasileiros não significa depreciação de seu valor protetivo para seus atendidos. A principal característica dessas ações pauta-se na necessidade de atender a pessoas desfavorecidas economicamente e moradores de áreas onde a vulnerabilidade social é marcante. Há concepções implícitas voltadas para atender e suprir necessidades a que o Estado, através de suas políticas públicas, é omisso. Ou seja, essas ações têm o valor de proteger o público atendido e proporcionar experiências que, muitas vezes, serão possíveis apenas por estar inscrito e frequente a projetos sociais ou em escolas de tempo integral. Fatos nesse sentido ocorrem quando são proporcionados, por exemplo, contatos com instituições culturais como cinema, teatro e exposições artísticas (PARO et al., 1988). Mensurar esse tipo de efeito é uma atividade complexa e requer elaboração de estratégias metodológicas que considerem essas questões. Machado et al. (2007) indicam a necessidade de se criar instrumentos que contemplem essa área de pesquisa. 0 


\section{Desafios da psicologia no Brasil}

desafio não é particularidade do contexto brasileiro, pois, pesquisadores de outros países têm destacado que a identificação dos impactos dessas atividades não é tarefa fácil e nem sempre há consenso nos resultados encontrados (ROTH; MALONE; BROOKS-GUNN, 2010).

Ao se observar os porquês que as atividades relatadas nos seis artigos analisados teriam impactos positivos sobre seus participantes, a justificativa que se sobressai é a de que aquilo que é desenvolvido nos projetos proporciona aprendizagens comportamentais e cognitivas que se relacionam com habilidades importantes para outros contextos, por exemplo, o escolar e o familiar. Com isso, a principal pergunta, dentre inúmeras, que deriva dessa consideração passa por aspectos teóricos e metodológicos: de que forma ocorrem e como identificar esses impactos? Pesquisadores do tema têm destacado que, para se entender os efeitos dessas ações, torna-se essencial a adoção de perspectivas ecológicas (MAHONEY, LORD; CARRYL, 2005; MAHONEY, et al., 2009).

Dos 61 artigos analisados integralmente, 37 utilizaram delineamentos exclusivamente qualitativos e discutem questões diversas, sendo que os fatores avaliação de programas/projetos e impactos sobre seus participantes não se destacam. Essa informação ressalta a possibilidade de haver certa resistência na avaliação de resultados dessas ações, através de métodos quantitativos que não se solidificaram e nem ganharam abrangência no país nos estudos em educação (TRÉZ, 2012). Área que se vincula fortemente com os programas/projetos realizados fora da escola, como já evidenciado. Essa vinculação, em certa medida, explica a preterição por essas estratégias investigativas. Gatti (2004, p. 13) destaca que "os métodos de análise de dados que se traduzem por números podem ser muito úteis na compreensão de diversos problemas educacionais". Ao mesmo tempo, utilizar esse tipo de dado com outros provenientes de métodos qualitativos pode ser benéfico e ainda enriquecê-los. Nos seis trabalhos analisados, é unânime a opinião de que novos estudos devem ser realizados. A interlocução entre diferentes metodologias contribuirá, significativamente, para o entendimento dos efeitos das atividades e programas realizados fora da escola.

Com exceção dos trabalhos de Fonseca et al. (2010) e Iwantschuk e Navarro (2011), todos os trabalhos analisados nesta revisão relatam atividades desenvolvidas por ONG ou em parceria com esse tipo de instituição. Costa, Silva e Bonan (2011) mostram que o aumento de trabalhos desenvolvidos por ONG é desacompanhado de estratégias avaliativas. O que apresenta preocupações pela ausência de dados com relação aos impactos das ações promovidas por elas, bem como pela aplicação dos recursos financeiros dessas entidades que provêm - na sua grande maioria - de órgãos governamentais ou da 


\section{Desafios da psicologia no Brasil}

isenção de impostos. Dessa forma, trata-se de financiamento público. Ao considerar que as AEE no Brasil, estão atreladas a essas instituições, encontram-se explicações para a ausência das informações investigadas nesta revisão que culminou com o levantamento de seis artigos em um universo de 3.007.

\section{CONSIDERAÇÕES FINAIS}

Pesquisas sobre impactos de AEE remetem a questionamentos sobre influências ambientais no desenvolvimento humano. Não há dúvidas de que essa interferência existe. No entanto, torna-se urgente pensar em estratégias para a pesquisa de campo que possam destacar esses efeitos no que se refere aos contextos extracurriculares. Novos estudos empíricos devem ser realizados a fim de se destacar, principalmente, ações que tenham efeitos benéficos sobre seus participantes. Esta revisão privilegiou estudos quantitativos não por desprestigiar estudos qualitativos, mas sim no sentido de levantar dados que pudessem ser comparados entre si e instrumentos que poderiam contribuir para outros estudos. Torna-se pertinente a análise dos trabalhos qualitativos levantados a ser realizado em estudos futuros.

A partir dos artigos debatidos na presente revisão, para que haja efeitos sobre seus participantes, é preciso considerar aspectos além da frequência nas atividades. É preciso considerar os processos envolvidos e de que forma eles se relacionam com habilidades de outros contextos, por exemplo, o da sala de aula. De maneira abrangente, os trabalhos analisados indicam esse caminho. Assim, não olhar para outros ambientes para identificar os efeitos das atividades extracurriculares como o escolar, é conceber tais ações como espaços de ocupação do tempo livre. É preciso levantar novos dados pelo fato de que essas ações têm implicações diretas em questões de políticas públicas. Além disso, para muitas crianças e adolescentes as organizações não governamentais e as AEE como um todo têm se consolidado como terceiro contexto de desenvolvimento.

\section{REFERÊNCIAS}

ALVES, P. B. et al. Instituições de atendimento socioeducativo à adolescentes em situação de risco do distrito federal: panorama e perspectivas. PSICO, Porto Alegre, v. 38, n. 2, p. 166-173, 2007.

BATISTA, C. B.; ANDRADE, V. S. F. de. Educação integrada e espaços de aprendizagens: diálogos entre escola e projeto social. Gerais: Revista Interinstitucional de Psicologia, Belo Horizonte, v. 3 n. 1, 2-11, 2010.

BRASIL. Portaria Normativa Interministerial № 17, de 24 de abril de 2007, que institui o Programa Mais Educação, que visa a fomentar a educação integral de crianças, adolescentes e jovens, por meio de atividades socioeducativas no contraturno 


\section{Desafios da psicologia no Brasil}

escolar. <http://portal.mec.gov.br/arquivos/pdf/mais_educacao.pdf>. Acesso em: 26 junho 2014.

BRONFENBRENNER, U. A ecologia do desenvolvimento humano: experimentos naturais e planejados. Tradução Maria Adriana Veríssimo Veronese. Porto Alegre: Artmed, 2002. Trabalho original publicado em 1979.

CARVALHO, V. A., \& CARLINI-COTRIM, B. Atividades extracurriculares e prevenção ao abuso de drogas: uma questão polêmica. Revista de Saúde Pública, São Paulo, v. 26, n.3, p. 145-149, 1992.

CASTRO, A. D; LOPES, R. E. A escola de tempo integral: desafios e possibilidades. Ensaio: Avaliação e Políticas Públicas em Educação, Rio de Janeiro, v. 19, n. 71, p. 259-282, 2011.

CAVALIERE, A. M. Tempo de escola e qualidade na educação pública. Educação \& Sociedade, Campinas, v. 28, n. 100, p. 1015-1035, 2007.

CAVALIERE, A. M. 2009. Escolas de tempo integral versus alunos em tempo integral. Em Aberto, Brasília, v. 22, n.80, p. 51-63, 2009.

CENTRO DE ESTUDOS E PESQUISAS EM EDUCAÇÃO, CULTURA E AÇÃO COMUNITÁRIA. Guia de Ações Complementares à Escola para crianças e adolescentes. São Paulo: Cenpec/UNICEF, 2002.

CENTRO DE ESTUDOS E PESQUISAS EM EDUCAÇÃO, CULTURA E AÇÃO COMUNITÁRIA. Muitos Lugares para Aprender, São Paulo: Cenpec/Fundação Itaú Social/Unicef, 2003.

COELHO, L. M. C. da C. História(s) da educação integral. Em Aberto, Brasília, v. 22, n. 80, p. 83-96, 2009.

CORTÊS-NETO, E. D. et al. Elaboração de indicadores de sucesso em programas de saúde pública com foco sócio-esportivo. Revista de Saúde Pública, São Paulo, v. 12, n. 2, p. 208-219, 2010.

COSTA, A. M. A. M.; SILVA, K. S. D.; BONAN, C. Organizações Não Governamentais na área da Saúde da Criança - revisão da literatura. Ciências e Saúde Coletiva, Rio de Janeiro, v. 16, n. 7, p. 3.181-3.196, 2011.

ECCLES, J. S.; TAEMPLETON, J. Extracurricular and other after-school activities for youth. Review of Educational Research, Washington, v. 26, p. 113-180, 2002.

FARIA, T. C. L. de. Reflexões sobre a implantação do Programa Mais Educação na rede municipal de ensino do Natal, RN. Revista Científica das Escolas de Comunicação e Artes e Educação, Natal, v. 1, n.1, p. 25-37, 2011.

FONSECA, H. A. R. da, et al. Aptidão física relacionada à saúde de escolares de escola pública de tempo integral. Acta Scientiarum. Health Sciences, Maringá, v. 32, n. 2, p. 155-161, 2010.

FUNDO DAS NAÇÕES UNIDAS PARA A INFÂNCIA. Caminhos do Direito de Aprender: boas práticas de 26 municípios que melhoraram a qualidade da educação. Brasília: UNICEF, 2010.

FUNDO DAS NAÇÕES UNIDAS PARA A INFÂNCIA. Redes de aprendizagem: boas práticas de municípios que garantem o direito de aprender. Brasília: INEP, 2008.

GATTI, B. A. Estudos quantitativos em educação. Educação \& Pesquisa, Campinas, v. 30, n. 1, p. 11-30, 2004. 


\section{Desafios da psicologia no Brasil}

GONDIN, E. P.; MORAES, L. C. S DE. Juventude e cidadania no contexto do Projovem Urbano: repercussões na vida dos egressos. Caderno de Pesquisa, São Luís, v. 21, n. 1, p. 1-12, 2014.

IWANTSCHUK, P. de A.; NAVARRO, A. C. O efeito da relação das atividades extracurriculares sobre o desempenho escolar de alunos de ensino fundamental II e ensino médio. Revista Brasileira de Futsal e Futebol, São Paulo, v. 3, n. 10, p. 267-274, 2011.

LEONE, E. T.; BALTAR, P. A mulher na recuperação recente do mercado de trabalho brasileiro. Revista Brasileira de Estudos de População, Rio de Janeiro, v. 25, n. 02, p. 233-249, 2008.

MACHADO, P. X., et al. O impacto de um projeto de educação pelo esporte no desenvolvimento infantil. Revista Semestral da Associação brasileira de Psicologia Escolar e Educacional, Campinas, v. 11, n.1, p. 51-62, 2007.

MAHONEY, J. L.; LORD, H.; CARRYL, E. An ecological analysis after-school program participation and the development of academic performance and motivational attributes for disadvantaged children. Child Development, New York, v. 76, n. 4, p. 811-825, 2005.

MAHONEY, J. L.; PARENTE, M. E.; ZIGLER, E. F. After-school program participation and children's development. In: J. MEECE; J. ECCLES (Org.), Handbook of research on schools, schooling, and human development. New York: Routledge, 2010, p. 379-397.

MAHONEY, J. L., et al. Adolescent out-of-school activities. In: LERNER, R. M.; STEINBERG, L. (Org.). Handbook of adolescent psychology: Contextual influences on adolescent development. Hoboken: Wiley, 2009, p. 228-267.

MATIAS, N. C. F. Escolas de tempo integral e atividades extracurriculares: Universos à espera da psicologia brasileira. Psicologia em Revista, Belo Horizonte, v. 15, n.3, 120-139, 2009.

PARO, V. H., et al. Escola de tempo integral: desafio para o ensino público. São Paulo: Cortez, 1988.

PIERCE, K. M.; BOLT, D. M.; VANDELL, D. L. Specific features of after-school program quality: associations with children's functioning in middle childhood. American Journal Community Psychology, Nort Palm Beach, v. 45, p. 381-393, 2010.

ROTH, J. L.; MALONE, L. M.; BROOKS-GUNN, J. Does the amount of participation in afterschool programs relate to developmental outcomes? A review of the literature. American Journal Psychology, Nort Palm Beach, v. 45, p. 310-324, 2010.

SAMPAIO, R. F.; MANCINI, M. C. Estudos de revisão sistemática: um guia para síntese criteriosa da evidência científica. Brazilian Journal of Physical Therapy, São Carlos, v. 11, n. 1, p. 83-89, 2007.

SANTOS, A. M.; NETO, F. R.; PIMENTA, R. A. Avaliação das habilidades motoras de crianças participantes de projetos sociais/esportivos. Motricidade, Ribeiro de Pena, v. 9, n. 2, p. 50-60, 2013.

SOUZA, D. L D.; CASTRO, S. B. E. D.; VIALICH, A. L. Barreiras e facilitadores para a participação de crianças e adolescentes em um projeto socioeducativo. Revista Brasileira de Ciência do Esporte, Porto Alegre, v. 34, n. 3, p. 761-774, 2012. 


\section{Desafios da psicologia no Brasil}

TRÉZ, T. de A. E. Caracterizando o método misto de pesquisa na educação: um continuum entre a abordagem qualitativa e quantitativa. Atos de Pesquisa em Educação, Blumenau, v. 7, n. 4, p. 1.1321.157, 2012. 


\section{Capítulo 17}

\section{REPRESENTAÇÕES SOCIAIS DE PSICÓLOGOS(AS) SOBRE DIFICULDADES E LIMITES EM RELAÇÃO AO CONTEXTO DA POLÍTICA DE ASSISTÊNCIA SOCIAL}

\section{DOI: $10.37423 / 200200193$}

Vinicius Tonollier Pereira - viniciustonollier@hotmail.com

Pedrinho Guareschi - pedrinho.guareschi@ufrgs.br

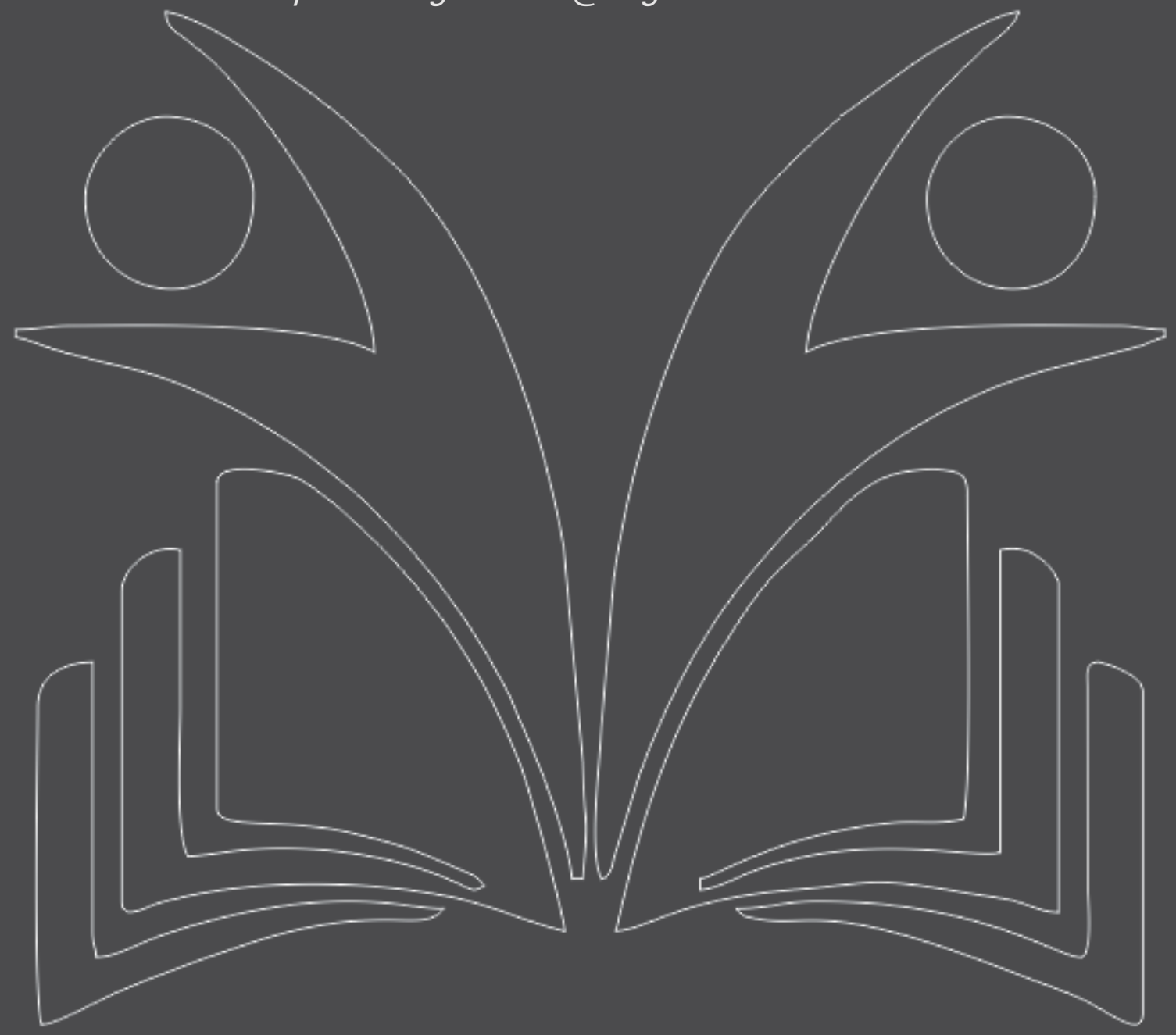




\section{Desafios da psicologia no Brasil}

\section{INTRODUÇÃO}

Este trabalho é parte do resultado de uma pesquisa de dissertação que se propôs a investigar as representações sociais de psicólogos(as) que atuam nos Centros de Referência de Assistência Social (CRAS) sobre os(as) usuários(as) deste serviço. A justificativa para tal estudo é compreender mais profundamente a concepção de profissionais da psicologia sobre os(as) usuários(as) da assistência social. Acreditamos que isso é fundamental e balizador para suas práticas profissionais. Muitas formações acadêmicas privilegiam ainda o conhecimento técnico e científico pautado em práticas avaliativas e adaptacionistas. Além disso, a criação do próprio Sistema Único de Assistência Social (SUAS) é relativamente recente, sendo ainda incipiente sua abordagem nos currículos de graduação. Isso faz com que o profissional que se insira na política da assistência social necessite de sensibilidade para questões muitas vezes pouco contempladas na academia. Dentro da pesquisa mais ampla (Pereira, 2013), para além propriamente das representações sociais construídas e compartilhadas sobre os usuários dos CRAS, produziu-se também uma gama de sentidos sobre o próprio contexto da política de assistência social, incluindo serviços, profissionais e a própria assistência social enquanto política pública. Os resultados deste campo temático específico, recorte da pesquisa maior, é que são apresentados neste trabalho.

É interessante notar que os achados aqui trazidos apontam para uma dificuldade dos(as) profissionais de psicologia participantes do estudo em falar especificamente sobre os(as) usuários(as) do CRAS, que era o objetivo central da pesquisa. Para tanto, é comum que recorram à forma como os(as) usuários(as) acessam o CRAS, aos limites dos serviços e dos profissionais, às práticas e ações no cotidiano de trabalho e à dificuldade ou facilidade de lidarem com os(as) usuários(as), para, por essas vias, tentar elaborar uma compreensão sobre tal contexto. Assim, mesmo que as representações sociais aqui não tenham sido foco central da pesquisa, optou-se por organizá-las, acreditando que possam contribuir para a reflexão e discussão em torno do tema, já que de alguma maneira são sentidos que contribuem para o conhecimento e desvelamento de aspectos importantes de tal contexto. Tratam-se das dificuldades e limites tanto do CRAS e de seu funcionamento, como dos próprios profissionais e da política de assistência social como um todo, constituindo-se, de todo forma, como um desafio ainda atual para a psicologia no cenário do SUAS. 


\section{Desafios da psicologia no Brasil}

\section{SOBRE A PSICOLOGIA E O CONTEXTO DA POLÍTICA DE ASSISTÊNCIA SOCIAL}

O advento do SUAS inseriu definitivamente a psicologia no campo da assistência social, já que a presença de profissionais psicólogos é prevista e inclusive obrigatória, em alguns casos, na composição das equipes dos dois principais serviços de proteção social que estruturam essa política: CRAS e CREAS (Centro de Referência Especializado de Assistência Social).

A Proteção Social Básica (PSB), foco deste estudo, materializada nos CRAS, unidades públicas estatais localizadas geralmente nas áreas de maior pobreza e vulnerabilidade social, tem como objetivo evitar situações de risco, desenvolvendo potencialidades e fortalecendo vínculos familiares e comunitários (MDS, 2004). Algumas atividades realizadas pelas equipes dos CRAS, incluindo a psicologia, são descritas pelos cadernos e normativas do SUAS, como o acompanhamento de famílias e as visitas domiciliares (MDS, 2009).

\section{Sobre as representações sociais}

As representações sociais são tanto uma teoria, que se interessa pela forma como os saberes são produzidos e transformados na interação social; como um fenômeno, compreendendo ideias, valores e práticas inseridos em um contexto comunicativo e que constroem a realidade social (Jovchelovitch, 2008), o que é de interesse neste estudo. Assim, as representações sociais se tornam um operador teórico imprescindível para esta análise. Deve se admitir que os fenômenos representacionais são mais complexos que o objeto de pesquisa construído a partir deles, ou seja, há uma simplificação quando passamos do fenômeno à pesquisa, e é justamente isso que permite sua inteligibilidade. Assim, utilizar as representações sociais é ter consciência que a pesquisa é uma aproximação da realidade estudada, nunca plena, mas aproximada, o que justifica sua utilização neste estudo.

\section{MÉTODO}

\section{PARTICIPANTES}

Os participantes do estudo foram reunidos por conveniência, em CRAS de mais fácil acesso ao pesquisador, que reside em Porto Alegre, no Rio Grande do Sul. Para a coleta de dados, foram feitas entrevistas abertas. No total, foram entrevistadas 21 psicólogas, todas mulheres, no ano de 2012. No decorrer do artigo, nas citações de suas falas, elas serão chamadas abreviadamente de P1 (participante 1), P2, P3 e assim sucessivamente, até a P21. As entrevistadas foram oriundas de 20 CRAS diferentes, de 9 cidades da região metropolitana de Porto Alegre e 5 da região central do Rio Grande 


\section{Desafios da psicologia no Brasil}

do Sul, totalizando 14 municípios. Destes, de acordo com a classificação do SUAS (BRASIL, 2004), dois são de pequeno porte I (até 20.000 habitantes), três de pequeno porte II (de 20.001 a 50.000), dois de médio porte (50.001 a 100.000), seis de grande porte (100.001 a 900.000) e uma metrópole (mais de 900.000). A média de idade ficou em 32,5 anos, tendo a participante mais velha 58 anos e a mais nova 24. O tempo médio de anos transcorridos após a conclusão de graduação é de 7 anos, sendo o maior tempo de 27 anos e o menor de 1 ano e 6 meses. Cerca de 70\% se formaram em universidades particulares, sendo as outras $30 \%$ oriundas de universidades federais. O tempo total de trabalho em CRAS é em média de 1,8 anos. O maior tempo de trabalho em CRAS foi de 6 anos e 6 meses e o menor de 4 meses. O tempo médio de carga horária semanal foi de 30 horas, sendo as maiores de 40 horas, e a menor de 16. Quanto ao vínculo empregatício, a maioria, 13 delas, eram servidoras estatutárias, enquanto 8 tinham contratos temporários. Sobre as participantes da pesquisa, a presença única de mulheres está em consonância com os dados de Macedo et al. (2011), que indicam que do total de 8.079 psicólogos(as) que atuavam em CRAS no Brasil em 2011, 89,6\% são mulheres, evidenciando a preponderância do público feminino. Isto tem a ver com a maior presença feminina do que masculina nos cursos de psicologia, e também nos de serviço social, que fazem com que os serviços da política de assistência social sejam executados predominantemente por mulheres.

\section{Procedimentos para a entrevista}

Antes das entrevistas, as participantes tomaram ciência do Termo de Consentimento Livre e Esclarecido, assinando-o ao concordar em participar da pesquisa, sendo informadas da possibilidade de desistência a qualquer tempo. Um tópico-guia auxiliou na entrevista, tentando, contudo, preservála o mais livre possível. O tópico-guia foi composto por cinco itens: 1) quem são os usuários do CRAS e como caracterizá-los?; 2) como são as famílias usuárias do CRAS e como caracterizálas; 3) como é a vida desses sujeitos (em termos de rotina e cotidiano, o que ia sendo explorado a partir de mais perguntas de acordo com o que era trazido pelas entrevistadas); 4) há aspectos dos usuários que podem ser vistos como obstáculos para a efetivação das propostas do CRAS/SUAS e, se sim, quais são eles; e 5) se há aspectos dos usuários que podem ser vistos como positivos e que contribuam para a efetivação da proposta do CRAS/ SUAS e, caso existam, quais são eles. A definição por 21 entrevistas obedeceu ao critério de saturação indicado por Bauer e Aarts (2008), no qual as entrevistas vão sendo realizadas, produzindo diferentes representações e um bom volume de dados, até que a inclusão de novos participantes não acrescente mais tantos dados inéditos ou significativamente relevantes, 


\section{Desafios da psicologia no Brasil}

produzindo, em sua maioria, discursos recorrentes. Ou seja, mais entrevistas não levariam necessariamente a um entendimento mais detalhado.

Procedimentos para análise das entrevistas

Posteriormente, todo o material levantado nas entrevistas foi submetido à análise de discurso, conforme proposta por Gill (2008). Para a autora, não há um roteiro delimitado para tanto, mas sim etapas que podem ser mais ou menos estruturadas. Segundo a autora, o primeiro passo é a transcrição das entrevistas, a partir dos registros literais das falas. A manutenção dos registros literais das fontes no decorrer do trabalho - ao invés da seleção de pequenos recortes que apenas legitimam o que diz o autor - foi uma proposta mantida nesta pesquisa, baseada na ideia de que o registro literal indica confiabilidade, como afirmam Gaskell e Bauer (2008), já que dão margem para diferentes interpretações, permitindo ao leitor que aceite ou refute os pontos de vistas explorados. Após a primeira parte, Gill (2008) relata que se inicia a análise propriamente dita, através de uma leitura que seja capaz de tornar o familiar estranho, a partir de um espírito cético, atento ao contraditório e ao detalhe. Feito isso, passa-se à codificação, em um movimento de mergulho no material, que desta vez torne o conteúdo familiar, para que seja possível a organização em campos temáticos, mais gerais no início. Em seguida, acontece uma análise mais profunda, em que se refinam as primeiras análises. Embora o material seja categorizado, não significa que ele não suporte contradições e fragmentos. Pelo contrário, já que as representações sociais são totalmente afeitas à ambivalência.

\section{RESULTADOS}

A partir do material produzido, os resultados foram organizados em cinco campos temáticos. 0 primeiro aborda a localização do CRAS. Conforme as entrevistadas, há uma dificuldade de acesso dos usuários aos CRAS que se localizam fora ou longe dos territórios de maior vulnerabilidade, gerando assim um recorte na procura do serviço, já que quem acaba procurando são as pessoas mais ou menos organizadas ao invés daquelas que vivenciam situações vulneráveis mais extremas. O segundo campo temático se refere às dificuldades do trabalho em/da rede, que expõem a dificuldade de encaminhamentos e relações entre os serviços. No terceiro campo temático se aborda o dilema enfrentado pelas profissionais entre realizar ou não psicoterapia, devido aos limites na/da rede. A psicoterapia não é uma atribuição do psicólogo dentro do CRAS, já que não são recomendadas intervenções com caráter terapêutico. Como muitos municípios contam com redes limitadas, sem opções de encaminhamento, os profissionais ficam em dúvida sobre o que fazer. O quarto campo 


\section{Desafios da psicologia no Brasil}

temático aborda a discussão, ainda existente, sobre qual seria o papel dos profissionais e principalmente da psicologia no CRAS. As psicólogas questionam as ações e capacitações profissionais. E, por fim, no quinto e último campo, são apresentadas as falas que remetem às próprias dificuldades da assistência social enquanto política, limitada em diversos aspectos.

\section{1) "Quem chega aqui ainda não está tão ruim": CRAS fora do território}

Um dos limites apontados pelas entrevistadas diz respeito às dificuldades geradas pela localização do CRAS, o que se acentua quando o serviço está fixado fora do território de maior vulnerabilidade pelo qual é responsável, produzindo, como consequência, o fato de que as pessoas que vivenciam situações de extrema vulnerabilidade não cheguem até ele, pela própria dificuldade de acesso. Isso se contrapõe a lógica de proximidade do cidadão em que se organiza o SUAS.

"Eu acho que a gente tem uma demanda muito menor que a gente teria se a gente estivesse aqui realmente na zona de maior vulnerabilidade. (...) Viriam mais, se apropriariam desse espaço. Muita gente não sabe o que é aqui. $E$ aí a gente fica assim 'ah é o lugar do Bolsa-Família'. (...) Então acho

que é isso, no momento que estivesse mais perto da comunidade as pessoas viriam mais, saberiam o que é o trabalho, o acompanhamento, viriam mais aos grupos, que acho que a distância física aí mesmo. (...) O CRAS nunca vai estar do lado da casa das pessoas, mas que fique onde as pessoas mais precisem. (...) Então as pessoas viriam mais né, e isso se disseminaria, seria um jeito de acessar também as pessoas mais difíceis. (...) Mesmo se for pra gente contrareferenciar, pra gente indicar pra outro serviço, bate mais se tu está mais próximo delas". P12

"O CRAS aqui atende $90 \%$ da população assim (da cidade), então ele não é territorializado. Isso complica bastante o trabalho. O outro CRAS (...) atende especificamente três ou quatro bairros. Então o público aqui ele é bem variado. (...) Eles vêm de todos os bairros assim, e são comunidades bem diferentes. Então a gente não teria assim pra caracterizar como uma comunidade né. São várias". P4

“O obstáculo que eu vejo aqui é a questão da localização do CRAS. Que é um lugar privilegiado pra quem realmente mora nesse bairro. Mas tem alguns bairros que a gente compõem aqui que são muito longes, que eles têm que pegar uma lotação às vezes para vir, mas daí não têm dinheiro. Ou eles vêm a pé de muito longe. Eu tenho famílias dentro do grupo que eles saíam uma hora antes de casa, agora a gente conseguiu passagem. Mas elas saíam antes uma hora antes de casa, com nenê pequeno, mais os outros filhos tudo pendurado juntos. E eu vejo que localizado aqui ele não está muito bem sabe. Teria que ser uma coisa, se bem que tem mais central também, mas os bairros que compõem aqui, aqui só tem uma lotação que passa e essa lotação passa lá no centro. Então as pessoas têm que ir até o centro pra vir aqui, então é duas passagens pra pessoas que às vezes não têm dinheiro nem pra comprar um leite né. Então eu vejo essa barreira assim". P5

"Eu acho que ainda quem chega aqui não está tão ruim né. O principal, a maior área de vulnerabilidade, não chega até a gente. Ainda são pessoas que têm 


\section{Desafios da psicologia no Brasil}

condições (...) Então, eu acho que dessas que vêm para o CRAS, eu tinha uma expectativa pior da que eu encontrei. Pior a partir dos nossos valores e vivências né. Eu achei que ia encontrar uma desestrutura muito maior assim. Então no momento que a demanda é 'bom, eu não estou passando fome', bom o básico de alguma forma já está suprido assim né. Por isso que eu digo, lá na vila, onde passam frio, não chega muito. Então quem chega aqui já está de alguma forma tendo sua renda, tendo sua moradia". P11

Essa questão é bem importante, e o que parece é que quanto mais deslocado o CRAS está do território de vulnerabilidade e, portanto, quanto mais difícil o acesso das pessoas até ele, menos parecem ser as pessoas em situação de extrema vulnerabilidade que o acessam. Claro que o devido cuidado deve ser tomado com essa afirmação, não generalizável, mas que indica algo importante e que de fato acontece em alguns locais, conforme as próprias entrevistadas.

Além disso, o CRAS deslocado do território fere um dos dois grandes eixos estruturantes do SUAS, juntamente com a matricialidade sócio-familiar: a territorialização. Este conceito se refere "à centralidade do território como fator determinante para a compreensão das situações de vulnerabilidade e riscos sociais, bem como para seu enfrentamento" (MDS, 2009, p. 13) E, complementa: "adoção da perspectiva da territorialização se materializa a partir da descentralização da política de assistência social e consequente oferta dos serviços socioassistenciais em locais próximos aos seus usuários" (MDS, 2009, p. 13), o que aumentaria sua eficácia e efetividade. Nessa definição, território tem a ver muito mais com o espaço coletivo do que geográfico, e com as formas de relações estabelecidas, incluindo os sentimentos de reconhecimento e identidade compartilhados pelas pessoas nos locais em que vivem. Pode-se também aproximar este conceito de territorialidade ao conceito de mundo da vida, ligada à ideia de comunidade, de pertença e compartilhamento de um comum. A capilaridade dos CRAS opera nesta mesma lógica, buscando-se aproximar da "vida vivida" da população, conhecendo-as de perto e também suas necessidades e potencialidades. Para Yazbek et. al (2010), a sintonia com a realidade dinâmica onde e os cidadãos vivem os conflitos sociais e também as relações de solidariedade, permite descobertas aos profissionais, a partir da identificação de relações e forças, não só quanto às necessidades, mas também as possibilidades, em uma perspectiva contraditória do próprio território e das questões sociais que eles refletem.

Contudo, quando o CRAS não consegue materializar a presença do Estado próximo às pessoas e dos locais onde vivem, acabam dificultando o acesso aos direitos socioassistenciais, falhando por não fortalecer a cidadania e, principalmente, por não conseguir desenvolver ações preventivas. Portanto, 


\section{Desafios da psicologia no Brasil}

este fato deve ser levado em conta pelos municípios na instalações do CRAS, sempre de acordo com suas especificidades socioterritoriais, a fim de ampliar a possibilidade de acesso aos serviços.

2) "A gente não trabalha em conjunto": dificuldades do trabalho em/da rede

Outro problema trazido pelas profissionais diz respeito aos limites do trabalho em rede e também da própria rede de serviços dos municípios - principalmente nos de pequeno porte - com consequente falta de articulação entre os profissionais e dificuldades de encaminhamento, principalmente quando os outros serviços remetem indistintamente ao CRAS. Este problema também se relaciona ao levantado na temática anterior, já que cabe ao CRAS o protagonismo da conjugação entre as políticas de proteção básica, principalmente pela sua localização no território, conforme Reis, Giugliani e Pasini (2012), o que pode ficar comprometido quando o CRAS se situa fora deles.

"Eu estou impressionada como eles têm vindo até se auto-diagnosticando assim com depressão. Mas muito também os médicos e as médicas dos hospitais, postos de saúde, dos PSFs e ESFs que a gente têm aqui em volta, também dizendo, dando medicação. E eu faço uma leitura disso, que às

vezes esses médicos não sabem lidar com a situação da pobreza. E aí é mais fácil medicar né, do que se tiver uma pessoa que está na tua frente, chorando porque não tem o que dar de comer pros filhos, então assim é mais fácil medicar porque acha que vai sanar essa dor dessa maneira, com medicamento". P6

"Essa questão do trabalho em rede que eu acho que ainda dificulta bastante. 0 SUAS ainda é segmentado eu acho, o próprio SUS muitas vezes, se ele faz um grupo no CAPS então ele não vai num grupo do CRAS. A gente não trabalha em conjunto né, as políticas mesmo, que eu acho que dificulta bastante. Às vezes tu faz todo um trabalho na assistência, daí chega lá na saúde e não tem interlocução com nada né. Às vezes ele participa de algum grupo na saúde e ter um acompanhamento aqui talvez ia ser muito mais eficaz pra família. Mas não né, a gente segmenta, a gente continua segmentando". P4

“O usuário foi até o 'Postão' aqui porque queria se internar. E a médica disse que ele não tinha cara de drogado. E aí onde é que ele vem? Ele vem no CRAS e era meu horário de acolhida. Por mais que eu seja psicóloga, eu não estou num serviço de saúde, e eu não tenho como encaminhá-lo para uma internação. (...) Não é fácil nosso serviço. A gente é porta de entrada pra muita coisa e às vezes tu se sente de braços amarrados porque não é com o nosso serviço". P6

"A gente faz uma reunião de rede, mas parece que sempre a gente tá inventando a roda. 'Eu vou mandar para uma avaliação, tem problema de Fono' diz a orientadora 'e tu avalia?' 'Não, não é pra mim, mas enfim, eu escuto a família. Não é pra mim, mas é um jeito de a gente conhecer a família, pode ter um conflito, uma situação $x$, daí a gente vê'. $O$ resto eu vou ver realmente se não é uma demanda da saúde, daí vou remeter ao posto, pra uma avaliação, etc., etc. As pessoas não sabem nem os profissionais, que a gente que está no SUAS está se apropriando, os assistentes sociais, os psicólogos, o que é esse fazer né". P12 


\section{Desafios da psicologia no Brasil}

A ausência de rede é um grave problema da assistência social, visto que esta é considerada muitas vezes como uma política de travessia (Hillesheim e Cruz, 2012), em que as pessoas buscam auxílios diversos, muitas vezes em casos que precisam ser encaminhadas para outros serviços e políticas. Quanto a isto, vale a ressalva de Sposati (2004) (citado por Agüinsky, Fernandes e Tejadas, 2009) para que se tome o devido cuidado com a noção extrema de travessia, evitando que a assistência social fique em um lugar de inespecificidade como política pública.

Para Kern (2006), a rede pode ser entendida como estratégia central de operacionalização do SUAS, que, não por acaso, organiza-se a partir de redes de proteção básica e redes de proteção especial. Conforme Silveira e Mendes (2009), é a partir da multiplicidade de perspectivas e de confronto de abordagens, em uma verdadeira interdisciplinaridade que integra conhecimentos de áreas distintas, é que se pode ter melhor compreensão sobre os fenômenos, o que é imperativo na execução da política de assistência social.

Senra (2009), em sua pesquisa, observou que a desarticulação entre os profissionais constitui um dos principais obstáculos na construção de estratégias de enfrentamento, resultando em uma individualização e isolamento dos psicólogos que atuavam em CRAS. Como agravante, está a incompreensão do papel de outros profissionais e serviços sobre o papel da psicologia no CRAS, atrelando-a ainda a prática liberal e privada, responsável por diagnósticos e psicoterapias, como atesta Andrade (2009). Outra consequência de uma rede de serviços limitadas é a consequente deformação do trabalho do CRAS. Por falta de opções de encaminhamento, por exemplo, mais comum em cidades de pequeno porte, os psicólogos acabam se sentindo obrigados a realizar psicoterapia, mesmo que isso não seja previsto na assistência social, como será visto no próximo campo temático.

3) "A gente fica muitas vezes naquele embate profissional" - entre fazer ou não fazer psicoterapia e limites na/da rede

A falta de uma rede complexa em articulação com o CRAS, sejas elas de quais políticas forem, faz com que os profissionais vivenciem dilemas éticos e profissionais. No caso da falta de um lugar adequado para encaminhamento à psicoterapia, por exemplo, o psicólogo(a) do CRAS costuma viver um dilema, originado pela ausência de serviços ou de psicólogos na rede pública que possam oferecer atendimento nessa modalidade. Assim, dois desfechos se apresentam: primeiro, o de realizar o procedimento, mesmo que intervenções de caráter terapêutico não sejam sua atribuição dentro do CRAS; e, segundo, a opção por deixar a pessoa sem atendimento, esperando que surjam novas 


\title{
Desafios da psicologia no Brasil
}

possibilidades de encaminhamento, já que essa não é o papel do CRAS. As experiências desse "drama" podem ser conferidas abaixo:

\begin{abstract}
“A gente tem o grande limite da rede né. A gente sabe o que preconiza o MDS para o trabalho do psicólogo dentro do SUAS né, mas daí a gente fica muitas vezes naquele embate profissional: de um lado da tua ética, tu está ali vendo o sofrimento daquela mãe, um caso de depressão grave, é vitima de violência doméstica, ou perdeu um filho, enfim, até a violência doméstica tem pra onde encaminhá-las, mas os outros casos, que não forem pacientes de CAPS, tu não tem pra onde mandar. Então tem muitos casos que chegam e eu acabo atendendo porque é o limite da rede né. (...) Então eu acabo ficando. Eu procuro nos atendimentos, já deixo claro desde o início, que por não ser um serviço de saúde vai ser algo mais focado assim no problema, algo mais específico. E quando eu percebo então que é um caso que a precisa de um acompanhamento mais sistemático então eu tento fazer esses encaminhamentos pra rede, mas aí os limites são muitos né. Mas é isso assim, a gente acaba tendo que dar conta do que não deveria porque bom né, tu vai fazer o que, mandar a pessoa embora?". P10

"A gente tenta trabalhar o que dá né. Não vai fazer coisa que também não é de CRAS, mas a gente tenta nesse primeiro momento dar esse atendimento, não deixar o usuário descoberto. Os ESFs também não dão conta, principalmente na parte da psicologia, eu sei porque trabalhei em ESF, então é uma fila enorme. Então às vezes quando são questões familiares, questões escolares, a gente acaba atendendo porque a gente sabe que a demanda é muito grande também nos ESFs, então vai ficar um serviço jogando pro outro e ninguém sendo atendido né". P18
\end{abstract}

Nos dois próximos trechos de relatos fica evidente que as psicólogas entrevistadas acabem optando pela primeira opção, isto é, realizar a psicoterapia, mesmo que isso não seja de competência do psicólogo no CRAS, muito provavelmente devido aos limites de rede.

"E um ponto positivo que eu tenho visto assim no que diz respeito à psicologia, como eu te disse, na maioria dos casos que chegam até mim são de crianças, e tem sido assim a participação dos pais sabe, acho que a preocupação deles de aderirem aos encaminhamentos das escolas, de estar aqui toda semana, de estar trazendo, conversando, então acho que com eles assim as combinações tem dado certo sabe, bastante coisa tem sido possível aí sabe, com esses pais, então acho que é um ponto positivo né". P10

"Quando tu acessa, falando do meu trabalho especificamente, eu procuro buscar o que faz com que elas ajam, as mães né, que é o que mais aparece, por que elas agem daquela forma com seus filhos. Às vezes elas batem né. Então pra que elas possam entender o que aquilo ali vai gerar nas crianças, por que elas está precisando fazer isso, às vezes é uma coisa de alívio sabe, literalmente botar pra fora as angústias delas sabe. Então eu acho que quando a gente consegue acessar assim com as famílias, tu consegue acessar o emocional delas, que elas se desarmam, eu acho que daí dá certo. Eu acredito muito nisso. Antes eu estava adotando uma coisa de atendimento mais individualizado assim, e eu comecei a perceber que não adiantava. Por exemplo, tem um problema na família, não adiantava só eu falar com um, fazer que ele repensasse as atitudes dele, se eu não chamasse o outro, entende, pra que eles pudessem fazer um 


\section{Desafios da psicologia no Brasil}

acordo. Então uma das coisas que eu acho que ajuda é quando eles vêm, a família vem, daí a gente consegue mexer nas coisas assim, acho que isso ajuda, pelo menos na psicologia. Eu acho que por eles serem também carentes afetivamente, eu acho que essa coisa de a gente cuidar deles ajuda eles também". P14

Conforme indica o documento "Referências técnicas para a atuação do psicólogo no CRAS/SUAS (CFP, 2008), em casos de identificação de demandas de natureza psicoterapêutica, "o profissional de Psicologia deve acessar outros pontos da rede de serviços públicos existentes" (CFP, 2008, p. 30). Como a psicoterapia tem sido utilizada como sinônimo de atuação psicológica, os psicólogos se ressentem dessa "proibição" e acabam criando artifícios, ou inclusive a realizando no CRAS, como forma de se sentirem psicólogos, como atestam Oliveira (2012) e Reis, Giugliani e Pasini (2012). Porém, nesses casos, o previsto é o encaminhamento para outros serviços, em especial da política de saúde. Para Oliveira (2012), os discursos produzidos sobre os sujeitos na psicologia têm vindo acompanhados da despolitização de práticas, operando uma dicotomização entre o

individual e o social. E, segue ela, dentro do pressuposto da política social como estratégia capitalista, isto é, gerada não para eliminar a pobreza mas para apaziguar as contradições do sistema, pensar em uma atuação transformadora, que combata a desigualdade resulta, em última análise, em uma atuação que não é nem defendida pela política nem aquela sobre a qual se erigiu a psicologia como ciência e profissão. Uma prática que ultrapasse os referenciais já existentes e que incorpore aspectos que a psicologia colocou fora de seu campo de saber. Portanto, torna-se necessária "uma práxis que, se não revolucionária, tenha a superação da desigualdade como meta; que não culpabilize os sujeitos por sua condição e não coloque sobre eles a responsabilidade pelo seu sucesso. Uma práxis cuja operacionalização se dê tendo em vista os limites da ciência psicológica e suas possibilidades de avanço em direção à justiça social e ao resgate dos direitos humanos e sociais". (Oliveira, 2012, p. 49).

Em meio a esse dilema profissional, talvez um ponto elucidativo para a discussão seja a possibilidade da escuta e da clínica ampliada (Susin e Poli, 2012; Scisleski e Fernandes, 2012) visando a produção de um cuidado ampliado (Reis, Giugliani e Pasini, 2012). Conforme Susin e Poli (2012), os dispositivos clínicos da assistência social são possíveis, porém em uma organização não tradicional. Nesses espaços, geralmente o sofrimento individual vem marcado pelas condições sociopolíticas - pobreza, exclusão, ausência de cidadania - que, contudo, não definem integralmente quem são essas pessoas. Assim, o compromisso ético da psicologia deve ser o de possibilitar lugar à palavra, a fim de incluir a dimensão subjetiva dos sujeitos, que escapa a qualquer enquadramento. Complementando essa ideia, Scisleski e Fernandes (2012) defendem a ideia da clínica ampliada na assistência social a partir de um 


\section{Desafios da psicologia no Brasil}

formato mais livre, em diferentes espaços, oscilando entre uma escuta ao mesmo tempo singular e contextualizada, não engessada tecnicamente, mas fundamentalmente sensível ao outro. Portanto, a realização da escuta pode, e deve, ser parte do repertório de atuação da psicologia no CRAS o que, todavia, não significa a realização de psicoterapia. Talvez uma discussão em torno desse eixo seja chave para o entendimento dos alcances e limites da escuta e da prática clínica ampliada, assim como o quanto não seria sua responsabilidade a psicologização do sofrimento psíquico, como levantam Reis, Giugliani e Pasini (2012).

4) Pouco conhecimento, pouco comprometimento: qual é mesmo o papel dos técnicos do CRAS e principalmente da psicologia?

Outro tema trazido, e muito delicado, diz respeito aos limites de atuação dos profissionais, do entendimento sobre seu papel nessas equipes e de suas funções perante os usuários. Em alguns momentos, como se observa nas falas, fica claro que há ainda uma certa dúvida sobre o papel da psicologia tanto no CRAS como na dinâmica dessas equipes:

"A parte pensante, que seria a equipe técnica, a parte pensante que tem o poder do conhecimento, do discernimento, que tem que ajudar essa parte que não tem, está acomodada, muito mal comprometida, nesse ponto eu acho que é um problema ainda. O concurso público escolhe muito mal os seus profissionais. (...) Então eu acho que a perspectiva da vida desses usuários depende muito da força de trabalho técnico. Se essa massa 'pensante' (aspas da própria entrevistada), que eu acho que não é tão pensante assim, seria mais comprometida, se comprometesse realmente em intervir com os usuários, ajudar a mudar a perspectiva deles, de como enxergar que tem que fazer as coisas, meu Deus, uma cidade pequena que nem essa, faria uma mudança enorme". P20

“O trabalho técnico que eu acredito que ainda engatinha né, por isso que não funciona, o próprio técnico não sabe muito bem qual o seu papel, são poucos os que sabem que é esse o nosso papel, poder fornecer a cidadania, e não só a comida". P20

"Eu vejo assim o CREAS funciona muito igual, tu conversa com vários CREAS e tem uma diretriz muito igual, bem seguida assim. E o CRAS não, o CRAS tu conversa e cada lugar funciona de um jeito, acho que não segue bem a diretriz, acho que o pessoal não lê assim LOAS, SUAS, Norma Operacional do SUAS, acho que falta isso também. (...) O problema está do lado de cá, desde gestão, enfim, que pra isso é necessário um conhecimento e um comprometimento né, e nem sempre quem coordena, quem é responsável por essa gestão, tem esse esclarecimento até conceitual mesmo, de como as coisas têm que ser". P20

"E a questão da interdisciplinaridade, que eu acho ainda bem complicada. Pelo menos aqui a gente discute bastante. A gente tem quatro assistentes sociais aqui no CRAS mais a coordenadora, que é assistente social também, e aí fica, quando eu cheguei aqui, a coordenadora antiga disse 'ah essa é tua mesa', eu não tinha menor ideia do que ia fazer aqui. Até conversar e construir né acho 


\section{Desafios da psicologia no Brasil}

que a gente tem um bom caminho pela frente, de qual o nosso papel aqui dentro". P4

"Ninguém sabe o que é o SUAS, o SUAS é meio invisível, é a política pra pobre. (...) Entra isso de forma perversa né. E assim se divulga pouco o que é o CRAS né. (...) Esse lugar é muito complexo. No CAPS o que tu vai fazer lá? Vai fazer um grupo de saúde mental, um atendimento individual, tu sabe, tu está apropriada. Aqui, é uma construção. E eu acho que não é só pra mim. Às vezes eu sinto meu Deus, que resposta eu vou dar? Parece que tu não tem também o que ofertar, em alguns momentos assim né. (...) Que não consegue dar um seguimento, um acompanhamento, enfim, faz o Bolsa, o cadastro sabe, e aí? E isso eu fico pensando sabe, não deve ser uma dificuldade só daqui da cidade". P12

"Elas ficaram aqui, como preconiza o SUAS, em um grupo de convivência de um ano. E depois? Qual é a real eficácia disso? O que modifica isso? Aonde a gente quer chegar? Porque é muito vago tu dizer ah vamos desenvolver autonomia, ta, mas autonomia pra quê? Qual é o objetivo? A gente faz o acompanhamento familiar, tudo bem, tem alguns objetivos que a gente traça junto com a família. Ta, mas e aí, em que rede ela vai estar inserida?". P4

Essas falas evidenciam que perguntas sobre o papel do psicólogo, o que ele pode fazer nesse serviço e nessas equipes, e o que mesmo o CRAS pode fazer, são questões ainda bem vivas, não totalmente superadas e que, portanto, ainda precisam ser trabalhadas. Para Oliveira (2012), os modelos de atuação no SUAS, independente da categoria profissional, ainda estão em construção. A fase atual desse processo, conforme a autora, parece ser a discussão do que deva ser o trabalho, de capacitação dos profissionais e também da busca por melhores condições de trabalho. Portanto, qualquer análise deve considerar que não há, ainda, modelos de trabalho predefinidos que norteiem as ações, nem consensos éticos-políticos sobre as práticas.

Para Oliveira (2012), os principais desafios na construção de parâmetros de atuação para o psicólogo na assistência social, de maneira geral, têm múltiplos aspectos. Alguns têm origem macroestrutural e dizem respeito às políticas sociais no marco capitalista; outros, referem-se ao desenvolvimento e consolidação da psicologia enquanto ciência e profissão. Quanto ao primeiro, a própria política de assistência social acaba guardando marcas de seu passado, vinculadas ao assistencialismo e caridade, o que dificulta uma compreensão crítica a seu respeito e a sua importância. Outro aspecto relacionado a este é que, enquanto o SUS começou a ser pensado e implementado em meio à efervescência democrática dos anos 80 e início dos anos 90, o SUAS começa a se desenvolver em tempos liberais, ao longo da década de 90, o que implicava em desresponsabilização do Estado pelas políticas sociais, panorama que só mudou com o governo Lula, embora presente ainda as ideologias geradas pela agenda neoliberal. Por fim, quanto ao contexto macroestrutural das políticas sociais, uma outra 


\section{Desafios da psicologia no Brasil}

dificuldade é que, diferentemente do SUS que é destinado a todos os brasileiros, o SUAS se dirige à parcela mais pobre da população, que, em virtude das condições de vida, tem pouca articulação política ou poder decisório, o que dificulta alguns avanços. Se tratando especificamente da psicologia, o primeiro ponto destacado por Oliveira (2012) é o pouco conhecimento dos psicólogos sobre a política de assistência social, presos ainda a conhecimentos mais tradicionais da psicologia, o que, contudo, parece estar gradativamente se modificando. Isto se interliga com outro aspecto, o da identidade profissional, que, principalmente na proteção social básica, não é tão claramente definido conforme cada categoria. Desse modo, as atividades geralmente são distribuídas de acordo com o que marca historicamente cada profissão, e não de forma radicalmente interdisciplinar, como preconiza o MDS.

Outro ponto é quanto a proibição de psicoterapia no CRAS, o que já foi acima discutido. Quanto à especificidade do psicólogo no CRAS, qual mesmo seria seu papel? Não seria dar conta mesmo das questões subjetivas? O psicólogo social está lá justamente para dar conta do individual, do social e da materialidade, todos intrínsecos, o que constitui a subjetividade. Fazer uma escuta e trabalhar com a lógica da clínica ampliada é diferente do que realizar psicoterapia, e talvez este seja um caminho a ser explorado na construção da práxis profissional da psicologia nesse contexto.

\section{5) Limitações da própria política de assistência social}

No último campo temático, são expostos sentidos que remetem aos limites da política de assistência social como um todo, e não só ao que se refere especificamente ao CRAS ou aos profissionais.

"Como profissional, eu acho bem sinceramente que a gente faz de conta um pouco sabe, eu procuro, acho que todos nós procuramos fazer o melhor que a gente pode, mas acho que a gente não chega lá, a impressão que eu tenho. Porque eu acho que esse modelo assim de trabalho acho que é uma coisa que está muito ligada ao assistencialismo, essa política, que acho que não adianta fugir disso sabe. Nós não tínhamos cesta básica desde o início do ano, esse é um exemplo que eu vou te dar. Vinha oito cesta básicas ano passado pra gente dar pra extrema necessidade, tipo assim uma injeção né. $E$ aí este ano não veio nenhuma. Aí a gente quis saber da verba, das licitações, daí nos deram uma desculpa sabe, que não nos convenceu, isso em off né, e agora aparecem três. E aí uma colega que já está aqui há 23 anos como assistente social disse 'duvido que em época de campanha política não vai aparecer essas cestas básicas'. Apareceram três agora este mês, daqui a pouco vão vir mais sabe. Nós continuamos com esse trabalho de dar a cesta básica para a extrema necessidade, mas acho que a política permeia muito esse trabalho social assim né. Então sempre tem uma coisa desse tipo, tu pode ter a intenção de fazer a coisa, mas tem por trás aí coisas políticas sempre né. Claro que nesses anos todos de trabalho eu sei que a gente tem que trabalhar muito com nossa frustração né, porque a gente não faz milagre. Mas a conclusão é que nesse 


\section{Desafios da psicologia no Brasil}

trabalho social eu acho que fica muita coisa a desejar. (...) Na área social ficam muito no papel os projetos, o projeto bolsa-família é isso né, pagar por um tempo, pra gente capacitar essa família, aí depois ela buscar andar sozinha, mas isso não acontece. Isso me frustra. (...) Isso me inquieta, inquieta mesmo". P8

"Claro que a gente tem uma população que a gente tem que atender, mas eu faço uma crítica, que nem no PSF, a gente nunca vai conseguir dar conta de tantas mil famílias. Não tem, é um trabalho muito complexo, muito formiguinha. (...) Nós somos uma porta de entrada, que tem o Bolsa-Família que o cadastramento também é feito aqui, mas a gente não pode ficar nisso. $\mathrm{E}$ muitas vezes eu sinto que a gente fica nisso". P12

"O município também não oferece uma rede organizada de serviços, em termos de políticas públicas, SUAS, SUS, e em termos culturais também é uma cidade empobrecida. Acho que é uma das cidades da região metropolitana que sofre mais com esse empobrecimento né. Não tem indústrias, enfim, não tem oferta de trabalho pras pessoas, é escassa a oferta de cultura também, de

outras possibilidades, de circulação, é muito pobre. As pessoas vivem as restrições e privações na carne o tempo todo né, é a impressão que eu tenho. (...) A gente não consegue trabalhar com prevenção, as coisas estão instaladas". P12

Consideramos que pelo menos dois pontos se destacam nessas falas. O primeiro diz respeito ao atravessamento político ou da politicagem - já que não se trata de político no sentido pleno do tempo - que acaba interferindo de maneira negativa na política de assistência social. Talvez de todas as políticas essa seja a mais vulnerável a esses atravessamentos, ligados ainda às práticas assistencialistas que vigoraram durante muito tempo no país e que ainda são usadas principalmente em épocas eleitorais. Para Yazbek (1993), as relações clientelistas, não baseadas na noção de direito, fazem com que impere a lógica do favor e da lealdade de quem recebe os serviços, que aparecem como inferiores e não autônomos, que "ganham" favores ou vantagens a partir do encobrimento da noção de direitos. Para Agüinsky, Fernandes e Tejadas (2009), novo e velho - assistência social e assistencialismo misturam-se ainda na prática cotidiana dos trabalhadores e gestores do SUAS e usuários. Ou seja, mesmo que já exista uma perspectiva de sujeito de direitos, insistentemente permanecem processos de subalternização e tutela nas tramas da política de assistência social, ainda não integralmente superadas.

O segundo ponto, bem mais complexo, diz respeito à própria limitação da assistência social enquanto entendida como política paliativa de amenização das contradições sociais. Ao mencionar que o problema está instalado, isto é, que não importa o que o CRAS faça, as mazelas são muito mais profundas e macro-estruturais, evidencia-se a limitação e o paradoxo próprio da assistência social, que, por um lado, garante direitos sociais aos sujeitos e pelo menos um padrão mínimo de vida digna, 


\section{Desafios da psicologia no Brasil}

enquanto que por outro ameniza ou atenua as contradições sociais, impossibilitando que "as coisas estourem" ou que cheguem a um ponto insustentável que leve à luta pela real cidadania.

\section{CONSIDERAÇÕES FINAIS}

A partir do que foi exposto neste trabalho, percebem-se que ainda são muitos os desafios para a psicologia em tal contexto, o que se estende também para a política de assistência social. Ao longo dos anos, desde que este estudo foi realizado, o cenário para as políticas públicas piorou consideravelmente, sendo que vivemos atualmente um período de

desmonte que coloca em risco o próprio SUAS, tornando as questões levantadas ainda atuais.

O recorte de pesquisa apresentado aqui mostrou as dificuldades de acesso ao CRAS quando situado fora dos territórios de maior vulnerabilidade; as dificuldades do trabalho em rede, tanto intra como intersetorial; aspectos sobre a práxis profissional, que envolvem as possibilidades e limites de atuação, como evidenciado nas questões em torno da psicoterapia e do papel da psicologia nos CRAS; e, por fim, questões sobre os próprios limites da política de assistência social.

Isto nos leva a concluir que as políticas públicas, incluindo a de assistência social, assim como a sociedade de maneira geral, encontram-se sempre em meio a forte tensionamentos, em um processo contínuo de movimentos, em que determinadas forças se impõem mais que outras. Quando aos aspectos macropolíticos, que se referem a continuidade e fortalecimento das próprias políticas públicas, vivenciamos um período de entraves e dificuldades, em que opera claramente uma lógica neoliberal de Estado Mínimo, em que são difíceis a implementação de novos equipamentos e o fortalecimento dos serviços e das redes assistenciais, o que compromete o avanço em torno dos aspectos aqui mencionados. Quanto aos aspectos micropolíticos, que apontam diretamente para o fazer cotidiano da profissão, vemos um processo contínuo de mobilização e de discussão da psicologia em torno de sua práxis nas políticas públicas, o que contribui, de modo geral, para uma permanente problematização e avanço nas práticas profissionais.

Portanto, seguimos, enquanto psicólogos(as), em meio a este processo em movimento, vivenciando encruzilhadas que nos levam a (im)possibilidades, com mostram os significados aqui produzidos, que apontam a caminhos múltiplos. Que possamos, enquanto psicólogos(as), encarar os desafios do presente para nos fortalecermos, juntos, na construção de políticas públicas inclusivas, que possam oferecer condições melhores de vida às pessoas frente ao nosso contexto de desigualdade social, fazendo da psicologia uma profissão potente, contributiva e crítica em tal processo de transformação. 


\section{Desafios da psicologia no Brasil}

\section{REFERÊNCIAS}

AGUINSKY, B. G.; FERNANDES, I.; TEJADAS, S. S. Entre a garantia de direitos e o reforço à subalternização: concepções e práticas ainda em disputa sobre o público-alvo da Política de Assistência Social. In MENDES, J. M. R.; PRATES, J. C.; AGUINSKY, B. G. (Orgs). O Sistema Único de Assistência Social: as contribuições à fundamentação e os desafios à implantação. Porto Alegre: EDIPUCRS, 2009.

ANDRADE, L. F. O psicólogo no Centro de Referência de Assistência (CRAS) de Fortuna de Minas - MG: na trilha cartográfica dos territórios subjetivos. Dissertação de Mestrado não-publicada, Pontifícia Universidade Católica de Minas Gerais, Belo Horizonte, 2009.

BAUER, M. W.; AARTS, B. A construção de um corpus: um princípio para a coleta de dados qualitativos. In BAUER, M. W.; GASKELL, G. (Orgs.). Pesquisa Qualitativa com texto, imagem e som: um manual prático. 7ạ ed. Petrópolis, RJ: Vozes, 2008.

CFP - Conselho Federal de Psicologia. Referências técnicas para atuação do(a) psicólogo(a) no CRASSUAS. Brasília - DF, 2008.

GASKELL, G.; BAUER, M. W. Para uma prestação de contas pública: além da amostra, da fidedignidade e da validade. In BAUER, M. W.; GASKELL, G. (Orgs.). Pesquisa Qualitativa com texto, imagem e som: um manual prático. 7a ed. Petrópolis, RJ: Vozes, 2008.

GILL, R. Análise de discurso. In . 7a ed. Petrópolis, RJ: Vozes, 2008.

HILLESHEIM, B.; CRUZ, L. R. Do território às políticas públicas: governamento, práticas psicológicas e busca ativa no CRAS. In CRUZ, L. R.; GUARESCHI, N. (Orgs.). O psicólogo e as políticas públicas de assistência social. Petrópolis, RJ: Vozes, 2012.

JOVCHELOVITCH, S. Os contextos do saber: representações, comunidade e cultura. Petrópolis, RJ: Vozes, 2008.

KERN, F. A. A rede como estratégia metodológica de operacionalização do SUAS. In MENDES, J. M. R.; PRATES, J. C.; AGUINSKY, B. (Orgs.). Capacitação sobre PNAS e SUAS: no caminho da Implantação. Porto Alegre: EDIPUCRS, 2006.

MACEDO, J. P.; SOUSA, A. P.; CARVALHO, D. M.; SOUSA, F. M. S.; DIMENSTEIN, M. O psicólogo brasileiro no SUAS: quantos somos e onde estamos? Psicologia em Estudo, Maringá, v. 16, n. 3, p. 479-489, 2011.

MDS - Ministério do Desenvolvimento Social e Combate à Fome. Política Nacional de Assistência Social. Brasília, 2004.

MDS - Ministério do Desenvolvimento Social e Combate à Fome. Orientações Técnicas CRAS. Brasília, 2009.

OLIVEIRA, I. F. Os desafios e limites para a atuação do psicólogo no Suas. In CRUZ, L. R.; GUARESCHI, N. (Orgs.). O psicólogo e as políticas públicas de assistência social. Petrópolis, RJ: Vozes, 2012. 


\section{Desafios da psicologia no Brasil}

PEREIRA, V. T. A Psicologia no mundo da vida: representações sociais sobre os(as) usuários(as) do CRAS. Dissertação de Mestrado, Programa de Pós-Graduação em Psicologia Social e Institucional, Universidade Federal do Rio Grande do Sul, Porto Alegre, 2013.

REIS, C.; GIUGLIANI, S.; PASINI, V. L. Conversando sobre a psicologia e o SUAS: potencialidades e desafios para a atuação profissional dos psicólogos na política de assistência social. In CRUZ, L. R.; GUARESCHI, N. (Orgs.). O psicólogo e as políticas públicas de assistência social. Petrópolis, RJ: Vozes, 2012.

SCISLESKI, A.; FERNANDES, V. Além das fronteiras da psicologia, o estrangeiro: A coordenação. In CRUZ, L. R.; GUARESCHI, N. (Orgs.). O psicólogo e as políticas públicas de assistência social. Petrópolis, RJ: Vozes, 2012.

SENRA, C. M. G. Psicólogos sociais em uma instituição pública de Assistência Social: analisando estratégias de enfrentamento. 251 p. Tese de Doutorado, PUC-Campinas, Campinas - SP, 2009.

SUSIN, L; POLI, M. C. O singular na assistência social: do usuário ao sujeito. In CRUZ, L. R.; GUARESCHI, N. (Orgs.). O psicólogo e as políticas públicas de assistência social. Petrópolis, RJ: Vozes, 2012.

SILVEIRA, E.; MENDES, J. M. R. Derrubando paredes: a construção da interdisciplinaridade. In MENDES, J. M. R.; PRATES, J. C.; AGUINSKY, B. G. (Orgs). O Sistema Único de Assistência Social: as contribuições à fundamentação e os desafios à implantação. Porto Alegre: EDIPUCRS, 2009.

YAZBEK, M. C. Classes subalternas e assistência social. São Paulo: Cortez, 1993.

YAZBEK, M. C.; MESTRINER, M. L.; CHIACHIO, N. B.; RAICHELIS, R.; Paz, R.; NERY, V. O Sistema Único de Assistência Social em São Paulo e Minas Gerais - desafios e perspectivas de uma realidade em movimento. In COUTO, B. R.; YAZBEK, M. C.; SILVA, M. O. S.; RAICHELIS, R. A. (Orgs.) O Sistema Único de Assistência Social no Brasil: uma realidade em movimento. São Paulo: Cortez, 2010. 


\section{Capítulo 18}

\section{A HETERONORMATIVIDADE NA CONSTRUÇÃO DE VÍNCULOS CONJUGAIS}

DOI: $\underline{10.37423 / 200200195}$

Willian Guimarães

willgaspar@gmail.com

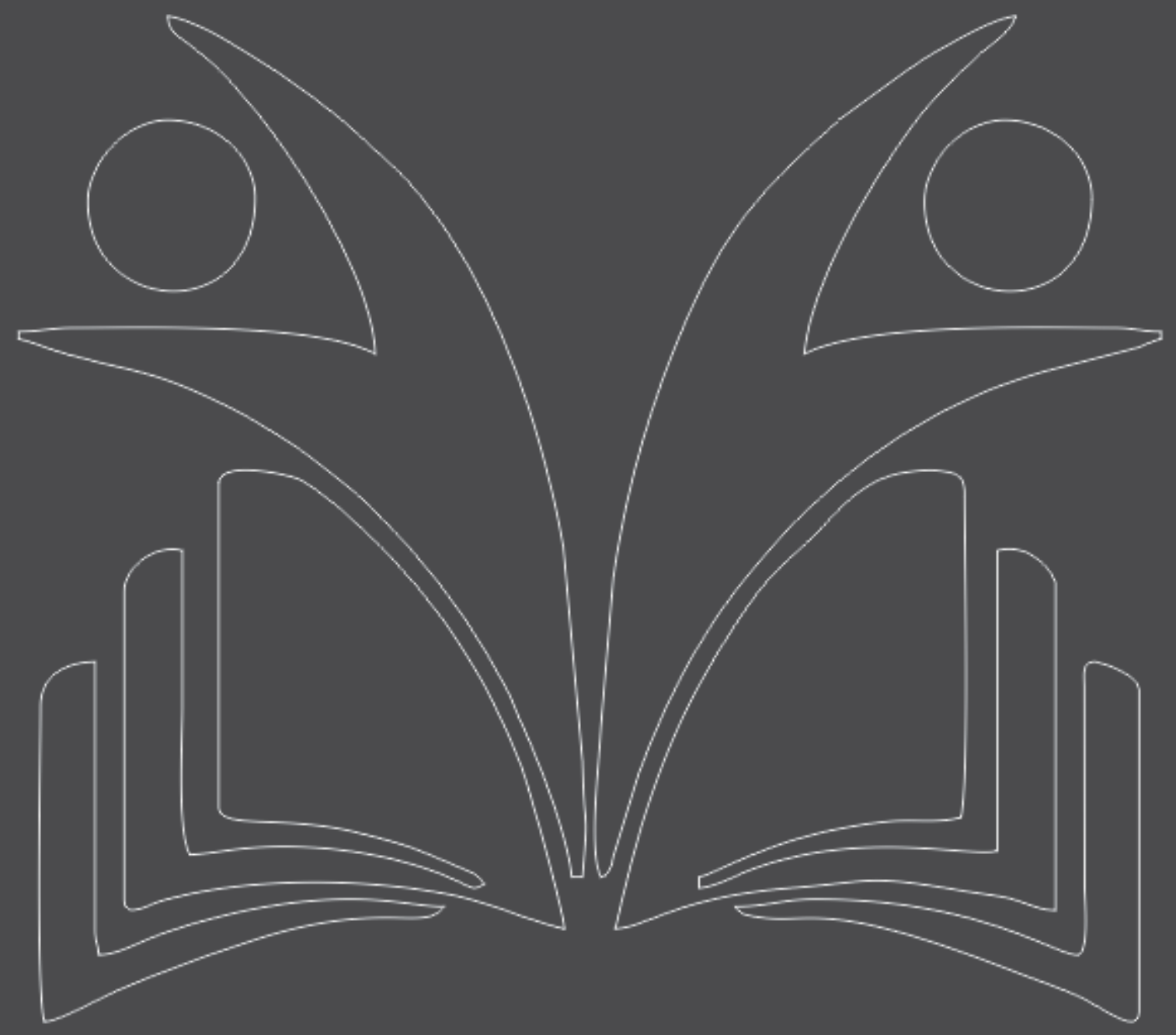




\section{Desafios da psicologia no Brasil}

Atualmente, a família se constitui pela diversidade, sendo a conjugalidade organizada pelo afeto, elaborando as suas próprias regras. Aparentemente, tudo inicia, quando duas pessoas movidas pelo afeto começam a se relacionar. Há o encontro de desejos, planos e sonhos, mas há também o encontro de famílias, valores e crenças sobre a realidade. Tudo isso ocorre mediado por uma realidade social que não pode ser ignorada. Hoje um dos grandes debates se organiza em torno das chamadas novas configurações familiares, ligações afetivas entre os sujeitos que não tem relação direta com a parentalidade. Dentre elas, encontram-se as relações afetivas entre pessoas do mesmo gênero, conhecidas atualmente por relações homossexuais.

Considerada por décadas como um desvio sexual, a homossexualidade é hoje vista como uma expressão natural da sexualidade apesar de todo o preconceito, tabu e estigmas que ainda rondam essa temática. Segundo França (2004), as características mais marcantes dessas relações é que elas são relações como quaisquer outras, justamente porque nenhum casal é igual ao outro. Logo, antes mesmo de se rotular esses casais como diferentes, eles são casais e por isso são tão iguais e diferentes quanto qualquer outro.

Sabe-se que as uniões por pessoas do mesmo gênero ocorrem por diferentes razões e intuitos, dos quais podem ter ou não relação com a sua sexualidade. O que não é diferente, portanto, de casais de pessoas de gêneros diferentes. Realizar estudos para compreender essa forma de união amorosa significa também encontrar maneiras para se combater o preconceito contra essa forma de relação, como também entender de que maneira a própria discriminação, nos mais diversos ambientes sociais, influencia na construção dessa conjugalidade.

\section{A VISÃO SOCIAL DA HOMOSSEXUALIDADE: A HETERONORMATIVIDADE E A HOMOFOBIA}

Compreender o fenômeno social do relacionamento conjugal entre pessoas do mesmo sexo em sua totalidade é extremamente complexo, e até, de certa forma, inviável. Contudo, não é possível observar a homossexualidade e suas raízes nas relações familiares sem entendê-la também como fenômeno sócio-histórico e observar alguns preceitos básicos que a influenciam e são influenciados por ela. Mesmo sendo essa uma questão da vida privada de cada um, ela influência de modo marcante a vida pública e é influenciada por ela também (PRADO; MACHADO, 2008).

Segundo Prado e Machado (2008), na sociedade em geral, a não-heterossexualidade foi gravemente condenada pelo discurso hegemônico impregnado nas relações entre as pessoas. Mesmo práticas 


\section{Desafios da psicologia no Brasil}

sexuais entre pessoas do mesmo gênero ser tolerada em determinadas épocas da sociedade, como, por exemplo, na Grécia Antiga dentro de dados contextos e finalidades, o impacto das religiões alterou sensivelmente os paradigmas sociais que orientavam a visão das pessoas sobre esse tipo de relacionamento. Com a entrada do discurso médico-científico, a homossexualidade passa do status de pecado para doença, elevando a perseguição a manifestações da homossexualidade a nível, supostamente, científico. Em 1990, diante de uma pressão social de diversos órgãos de entidade e de diversos movimentos sociais, a Organização Mundial de Saúde retira dos manuais de diagnósticos utilizados na área da saúde a homossexualidade, que, a partir desse momento, passa a não ser mais considerada uma doença (DIAS, 2011). Influenciada pelo discurso religioso e médico-científico, essa maneira de perceber a homossexualidade condenou e legitimou instituições e prática sociais baseadas em um conjunto de valores que se construíram no pressuposto da heterossexualidade como a orientação sexual normal, esperada e mais adaptada. Essa maneira particular de observar a sexualidade é caracterizada pelos autores como heteronormatividade (DIAS, 2011; RIOS, 2009). Ainda Prado e Machado (2008) colocam que esses valores levaram a discriminação negativa e a punição de diversos comportamentos sexuais, sob a acusação de crime, pecado ou doença.

O corpo e a sexualidade tornam-se objetos privilegiados das políticas de controle e de moralização da vida (PRADO; MACHADO, 2008). Num panorama social em que a homossexualidade sempre foi condenada, fica evidente certa dificuldade social de tornar esta uma forma de expressão da sexualidade aceita e bem vista por todos. Como consequência, toda sexualidade que não seja a heterossexual é considerada desviante e suas manifestações são coibidas das maneiras diversas. Um dos produtos desse processo discriminatório é a homofobia.

Segundo Rios (2009, p.181), “a homofobia é a modalidade de preconceito e de discriminação direcionada contra homossexuais." Segundo o mesmo autor, partindo de perspectivas psicológicas e sociológicas, permite-se compreender o fenômeno da homofobia tanto como uma questão de cunho individual como algo de cunho social e institucional. Seja através de situações, nas quais os sujeitos que utilizam dessa forma de violência como defesa ao contato de seus próprios conteúdos internos, seja em instituições que se valem da homofobia como forma de manter suas próprias doutrinas funcionando (RIOS, 2009). O autor faz um adendo à questão trazendo a discussão da heteronormatividade como uma das causas fundantes da homofobia, uma vez que é instituído socialmente a heterossexualidade, de modo implícito ou explicito, como ponto de partida da normalidade, colocando a homossexualidade como modo inferior de vivência da sexualidade (RIOS, 


\section{Desafios da psicologia no Brasil}

2009, p. 184-185). Esse binômio irá nortear as relações dos indivíduos e irá afetar diretamente a constituição dos casais de pessoas do mesmo gênero.

França (2004, p.152) aponta a homofobia como forma de opressão social que dificulta as uniões entre pessoas do mesmo gênero, uma vez que muitas pessoas não assumem sua sexualidade publicamente e impede, assim, a vivência plena do casal no âmbito social. Diferentemente do casal heterosexual, o casal composto por pessoas do mesmo gênero pode sofrer algum tipo de preconceito ou discriminação ao se expor de forma pública. A ausência de modelos públicos positivos de casais de pessoas homossexuais acaba por dificultar a identificação dos jovens que não encontram modelos positivos para se espelhar (FRANÇA, 2004, p. 152). Optando por não se expor, restringe-se a vida social do casal. França (2004, p.154) coloca que "vivendo numa cultura homofóbica e heterocêntrica, o próprio homossexual acaba por internalizar esses preceitos e aplicá-los de forma inconsciente em suas relações. " O mito da promiscuidade, a desvalorização da relação entre pessoas homossexuais de forma ampla pela sociedade atuando em conjunto com o que a autora chama de homofobia internalizada tem por consequência fazer com que os casais não invistam tanto no relacionamento quando este mergulha em dificuldades (FRANÇA, 2004, p. 153-157). Dias (2011, p.54) também conceitua a homofobia internalizada apresentando esta como uma forma de sofrimento e rejeição a si mesmo que pode levar ao suicídio. Um indivíduo que não é capaz de se aceitar integralmente de forma positiva dificilmente conseguirá estabelecer laços amorosos saudáveis com outros. As dificuldades da sociedade em conceber as uniões ntre pessoas do mesmo sexo como um ato de amor tem influência direta na dificuldade de manutenção destes vínculos, que, por pressão social e familiar, acabam cedendo aos obstáculos. Dessa maneira, pode-se perceber que a construção de um relacionamento está diretamente relacionada às percepções individuais, familiares e sociais sobre a homossexualidade.

\section{RECORTE DE PESQUISA}

A pesquisa foi organizada em torno de entrevistas realizadas com casais de pessoas do mesmo gênero. A pesquisa foi aprovada pelo Comitê de Ética em Pesquisa, vinculado a Universidade de Passo Fundo, sobre o protocolo $n$ o: 212/2012. O trabalho aqui apresentado trata-se de um recorte de uma pesquisa maior intitulada "Conjugalidade LGBT, Justiça e Direitos Humanos: atravessamentos possíveis", vinculada ao Projeto de Pesquisa "Temas de bioética: principialismo, ética ambiental, ética e animais 


\section{Desafios da psicologia no Brasil}

e o sentido da morte", com o Sub-projeto: Ética e racionalidade moderna" da Universidade de Passo Fundo/RS e parceira da Fundação de Amparo à Pesquisa do Rio Grande do Sul (FAPERGS).

Foram agendadas entrevistas com cada casal em seu ambiente familiar e ambos, os membros, responderam juntos questões livres sobre o funcionamento do relacionamento. Para a construção deste trabalho, na pesquisa inicial, foi realizado um recorte, que consistiu na utilização da seguinte pergunta: - Como o fato de vocês se tornarem um casal afetou sua relação com outros membros de família, amigos e comunidade gay e comunidade heterossexual? - para análise e comparação com as teorias apresentadas anteriormente, a partir do tema proposto. O recorte em questão foi autorizado por todos os pesquisadores vinculado a pesquisa maior. As entrevistas foram agendadas previamente com um dos membros dos casais e realizadas em suas respectivas residências com os dois membros presentes. Foi apresentado o Termo de Consentimento Livre e Esclarecido, TCLE, com os objetivos da pesquisa, respeitando os aspectos éticos necessários. Após isso, foram realizadas as questões norteadoras, permitindo ao pesquisador conhecer mais a respeito da dinâmica conjugal dos casais entrevistados. O tempo médio de entrevista foi cerca de uma hora.

\section{AMOSTRA DA PESQUISA}

A seleção dos casais para a realização da entrevista contou com os critérios de estes casais estarem em relacionamento afetivo há pelo menos um ano e residirem juntos há pelo menos seis meses. Respeitaram-se esses critérios com o objetivo de encontrar casais que estejam vivendo uma relação conjugal distante espacialmente da família de origem, a fim de compreender o ciclo de vida que estes casais estão vivendo nesse momento e suas implicações em seus vínculos sociais. Além dos critérios apontados, buscou-se encontrar um número igual de casais do mesmo gênero para que esse fator não cause uma influência profunda na análise dos dados.

Trata-se de uma amostra intencional, ou seja, os casais foram escolhidos e convidados intencionalmente para participar da pesquisa com base no preenchimento dos critérios estabelecidos apontados anteriormente. Buscaram-se casais, a partir de anúncios públicos sobre a pesquisa realizados em diversas reuniões de um movimento social que busca a defesa dos direitos de lésbicas, gays, bissexuais e transgêneros chamado de Plural - Coletivo LGBT. A partir do conhecimento da pesquisa, os casais entrevistados foram aqueles que se ofereceram voluntariamente para participar de tal. Diante disso, foram realizadas seis entrevistas com seis casais diferentes, sendo que destes três eram casais compostos por dois homens e três eram casais compostos por duas mulheres. As 


\section{Desafios da psicologia no Brasil}

entrevistas foram gravadas e transcritas. Os resultados apresentados abaixo possuem recortes das falas dos entrevistados.

Ao final de cada fala, a sigla utilizada vai mostrar se aquele recorte pertence a um casal masculino (CM) ou feminino (CF), seguido por uma letra que funciona como enumeração dos casais (A, B ou $C$ ) com uma referência, por fim, de qual sujeito está falando (S1 ou S2).

\section{RESULTADOS DAS ENTREVISTAS}

Definir exatamente onde o preconceito que afeta a homossexualidade está é um processo bastante complicado e difícil de ser realizado, já que este se manifesta nas relações e nas instituições das mais diversas formas. O que é evidente é que o preconceito é nocivo para o desenvolvimento de um sujeito homossexual e suas relações afetivas. Para entender o funcionamento do preconceito, é necessário entender como a sociedade percebe e aborda a temática da homossexualidade como também percebe a própria expressão da sexualidade como um todo. A maneira que a sociedade, aqui descrita através da visão de suas instituições e relações entre as pessoas, lida com a questão da homossexualidade vai ter influência na própria maneira que o sujeito lidará com a sua própria sexualidade.

Segundo as entrevistas realizadas, o primeiro passo para a construção de uma vida afetiva com outra pessoa é assumir sua própria sexualidade, o desejo por uma pessoa do mesmo gênero, o assumir para si mesmo. Diferente de uma pessoa que tem uma orientação afetiva direcionada a pessoas do gênero oposto, um sujeito homossexual precisa aceitar que tem um desejo sexual que está além do que a sociedade considera adequado e esperado. Realizar esse processo pode ser particularmente difícil para muitas pessoas. O próximo passo diz respeito a assumir para as demais pessoas: "Quando você resolve assumir a tua homossexualidade, você tem que pensar acima de qualquer pessoa, acima dos teus pais, acima da felicidade dos teus pais. Você tem que ser de certa forma um pouco egoísta no começo e pensar em você. Que tipo de vida você vai querer levar e que situações você vai ter coragem de enfrentar daqui pra frente" (CFA - S1). Na visão desse sujeito, o processo de assumir a sua própria sexualidade trata-se de um ato de coragem e um ato de amor por si mesmo. Aceitar, no seu fórum íntimo, ter o desejo sexual e afetivo por uma pessoa do mesmo gênero é, na visão desse sujeito, um passo necessário para a construção de um relacionamento afetivo. 


\section{Desafios da psicologia no Brasil}

Quando se observa o fenômeno do relacionamento entre pessoas do mesmo gênero fora de quatro paredes, outras impressões podem surgir. No caso dos casais entrevistados, o relacionamento os levou a expor, de certa forma, a sua vida nos espaços onde se encontram. No caso de um dos casais entrevistados, estes residem em uma comunidade afastada no interior e a construção de um relacionamento homossexual nesse espaço gerou algumas reações peculiares: "Como é um lugar pequeno, as pessoas falavam muito, comentavam muito, criticavam muito, mas a gente acabou não dando bola pra isso, não abrindo os ouvidos para esse tipo de comentário, mais uma vez repito que a gente pensou só na gente, na nossa vida. Hoje é assim também, não dou direito a ninguém para falar ou julgar, a gente trabalha, paga as nossas contas, ninguém tem nada a ver com a nossa relação $e$ acho que ninguém tem razão de julgar também" (CMA - S1). O surgimento de um relacionamento diferente dos demais gerou curiosidade e reações aversivas que fizeram o casal buscar se defender do espaço onde se encontravam. Começa assim certo isolamento social vivenciado pelos casais entre pessoas homossexuais. Em ordem de se proteger do preconceito e dos olhares críticos da sociedade, eles tendem a manter sua vida afetiva escondida de outras pessoas. Normalmente, há uma fronteira entre a vida afetiva e a vida social de um sujeito. Contudo, no caso dos casamentos entre pessoas do mesmo gênero como referido anteriormente, há uma barreira que os impede de realizar trocas significativas com o ambiente social que os cerca. Novamente, um casal com uma rede social mais ampla tende a ter uma série de benefícios psicossociais em relação a aqueles que estão mais isolados do contato social.

Uma consequência desse isolamento é um discurso da necessidade de manter uma postura que não denuncie sua orientação sexual, o que faz com que esses casais reproduzam também um discurso preconceituoso, como maneira de se proteger do preconceito: "É você saber se portar. Para ti, adquirir um certo respeito pelo casamento [...] Existem gays que são extravagantes, que são loucos [...] Não estou julgando a personalidade da pessoa, mas é a sociedade que não aceita esse tipo de coisa. Não tenho porque estar julgando se eu sou homossexual. [...] Precisa ser mais discreto, a sociedade exige isso, por exemplo, um travesti chegou lá na loja abraçado em outro homem, eu não tenho preconceito nenhum com isso, tenho amigos que são meus melhores amigos que são gays e são bem extravagantes, só que a sociedade tem preconceito com isso. Tinham outros clientes lá na loja, cuidando descaradamente com uma cara horrorizada e ficavam cochichando comigo, falando mal da pessoa. E o que eu vou falar? Não tem o que eu falar. É questão de saber se portar. É travesti? Beleza! Não precisa ter chegado abraçado. Quando ela viu que a mulher que eu estava atendendo estava 


\section{Desafios da psicologia no Brasil}

cuidando, estava comentando, começou a abraçar o cara e dar beijo no rosto. Para aparecer, para mostrar... não sei o que ela queria mostrar" (CMA - S2). No discurso desse sujeito, a necessidade de um comportamento que não denuncia às outras pessoas a orientação sexual é necessária se essas pessoas quiserem serem aceitas socialmente. É perceptível através desse discurso uma espécie de normatização do comportamento social, do qual, os sujeitos devem adotar determinadas regras se quiserem conviver socialmente de forma aberta. De certa forma, esses casais reproduzem aquilo que sofrem, numa lógica protetiva, mas que restringe a expressão de sua própria afetividade.

Essa necessidade de proteção que se traduz por uma restrição da expressão afetiva em público, pode criar um discurso que diferencia aquelas pessoas que buscam viver uma vida mais aberta socialmente daquelas que tendem a restringi-la a quatro paredes. A justificativa para o preconceito se torna, desse modo, responsabilidade daqueles que não se escondem e se expõem, ou seja, aqueles que demonstram sua afetividade, suas personalidades e gostos, denunciando, em alguns casos, a sua orientação sexual. Há aqui a inversão da lógica da violência, a vítima se torna o próprio agressor, ou seja, aqueles que sofrem discriminação acabam discriminando: "A única dificuldade disso são os paradigmas da sociedade. Isso tem muito peso da classe homossexual, sou um tanto chato $e$ posicionado que nós precisamos nos dar ao respeito e muitos gays não se dão ao respeito. O pejorativo está nisso. Eu nunca sofri nenhum tipo de preconceito. Eu já tive amigos heteros que tinham preconceito contra outros gays, mas contra mim não. Quando eles lembravam que eu era gay diziam 'Mas o L. é gay também', 'Não, ele gosta de guris, mas não é gay' Como se o ser gay já fosse pejorativo em si, aquela coisa suja, aquela coisa errada" (CMC - C1). Aqui é possível observar que há uma espécie de etiqueta de comportamento homossexual para evitar o preconceito. Criam-se duas categorias de pessoas que se relacionamento afetivamente com o mesmo gênero: o homossexual discreto, que não expõe sua afetividade e aquele que se expõe ou coloquialmente caracterizado, aquele que "dá pinta".

Essa subcategorização e afastamento do chamado homossexual não-discreto é uma forma peculiar de preconceito que o sujeito exerce sobre essas pessoas e sobre si mesmo, uma vez que, ao condenar ao outro, ele também se encerra dentro dos mesmos valores e tem a sua própria expressão afetiva limitada. Aqui há o homossexual desejável, não-feminino, que não expressa afeto por pessoas do mesmo gênero, que não "dá pinta" e há do outro lado o gay feminino, que se expressa afetivamente e não segue necessariamente as regras sociais ligadas ao gênero. No discurso relatado acima, o primeiro é bem visto e o segundo não, o primeiro é digno de respeito e consideração, enquanto o segundo não. A diferenciação ganha outros entornos: "Eu vejo uma diferença entre os termos 


\section{Desafios da psicologia no Brasil}

homossexualidade e homoafetividade. Homoafetividade me lembra mais o relacionamento sério, posicionado, aquele que se dá o respeito, se respeita e respeita as pessoas ao redor dele, sem promiscuidade. Os gays hoje são muito promíscuos, eu já fui assim e não me dava ao respeito e via que as pessoas ao meu redor não me respeitavam. Eu era uma pessoa errada, eu era um gay" (CMC - S2). No relato, o sujeito diferencia os sujeitos que buscam e estão em relacionamento, daqueles que não, como também diferencia novamente aqueles que não expressam afeto publicamente, daqueles que o fazem. Há um juízo de valor que valoriza os primeiros e condena os segundos. A sexualidade, nesse viés, é construída por preceitos de moralidade. Contudo, não se pode esquecer que há uma espécie de sofrimento invisível nesse discurso, pois ele é produto também do medo que essas pessoas têm de se expor publicamente.

O receio de se expor publicamente faz com o que sujeito busque, então, restringir a expressão do seu afeto em público. Casais heterossexuais não expõem toda a sua vida afetiva em público, mas também não sentem, de várias maneiras, a necessidade de mantê-la em quatro paredes, como acontece com casais homossexuais. Tudo começa com a diferenciação da vida particular e da vida social: "Aqui dentro de casa é uma relação tão igual aos outros, mas lá fora a relação é diferente, porque lá fora a gente tem que escolher bem que lugar a gente vai andar de mão dada, que lugar a gente vai poder se dar um beijo, se dar um selinho [...] Por que tem essa questão do medo, o medo da agressão, o medo da discriminação direta por parte de pessoas que você nem conhece, pessoas que podem em algum momento te identificar aquilo que você está fazendo como algo agressivo pra elas" (CMB - S2). No relato acima, o sujeito relata um receio de levar a sua expressão afetiva para fora de casa, por medo de sofrer alguma agressão de pessoas que nem este mesmo conhece. Há a constante de sofrer algum tipo de agressão, caso ficar evidente que este tem uma orientação sexual diferente daquela aceita socialmente. O receio os leva a uma vida social mais restrita, o que limita os contatos sociais dos casais entre pessoas homossexuais.

A família também pode acabar reproduzindo os valores que condenam a homossexualidade, como também, por razões peculiares do próprio sistema familiar, únicas para aquele sistema, coibir a expressão homossexual. A consequência é a mesma, o sujeito terá dificuldades de expressar seu afeto publicamente: "Eu tenho muita dificuldade de sair de mãos dadas com a F. na rua. Eu tive uma criação muito complicada, eu era sempre vigiada pela minha família. Eu me acostumei muito com isso e estou sempre me cuidando. Eu ainda não sei andar na rua. Em Santa Maria, eu saia tranquilo, mas aqui é complicado, porque não tinha ninguém que eu conhecia" (CFC - S1). No caso desse sujeito, percebe-se 


\section{Desafios da psicologia no Brasil}

que há uma forte influência do sistema familiar para esconder o relacionamento, de maneira que o sujeito apenas sente-se livre pra expressar sua afetividade em outra cidade, longe do olhar da família. Como consequência, o sujeito não consegue também ir a lugares que são vistos como espaços frequentados por pessoas homossexuais: "Eu acho muito aberto, é algo exposto e se as pessoas procuram saber o que é, veem que é uma comunidade que gays frequentam e se sabem que eu vou lá, vão saber que eu sou gay. Como eu não consigo nem sair de mãos dadas com a minha mulher, então, ir lá é complicado" (CFC - S1). Segundo o que o sujeito descreve, este não consegue frequentar espaços que denunciem sua sexualidade, com medo de uma retaliação que se iniciou na sua família e se tornou um valor a ser seguido em sua própria subjetividade. Como consequência, o sujeito restringe também sua vida social.

Há um efeito em longo prazo no preconceito que os casais acabam por sofrer em suas relações sociais que é o efeito da discriminação sobre seus planos de vida. No estabelecimento do sistema conjugal, o casal elabora e discute planos para o futuro. Esses planos orientam a vida conjugal. No caso dos casais homossexuais os planos também acontecem, mas o preconceito e a discriminação são uma questão também a ser considerada neste. Isso se manifesta, por exemplo, quando um dos casais pensa em ter filhos no futuro. Ao imaginar a vida escolar desse filho, esse casal considera o preconceito como um agravante desse desejo: "Primeiro, ele teria que conviver com as mães, ir na escola, e ter mães e não ter um pai, algo assim, a gente sabe, entende isso, mas tem muitas pessoas que não sabem e não entendem e tem muitas crianças que são cruéis" (CFC - S2). No relato, o casal deseja ter um filho, mas tem medo de como a sociedade vai lidar com a criança e com as suas duas mães. O medo e o desejo andam próximos um do outro, o que pode dificultar a realização de seus planos conjugais.

Nos últimos anos, os casais entre pessoas homossexuais foram salvaguardados com alguns direitos como ao casamento civil e a adoção conjugal. Esses são direitos que permitem a existência jurídica dessas famílias, marco importante para o combate do preconceito. Na visão dos casais, a garantia dos direitos básicos é importante: "Acho também que casamento, a gente tem o mesmo direito que qualquer casal, os homossexuais têm o mesmo direito que um casal heterossexual. Se diante da sociedade temos que cumprir as mesmas obrigações como cidadão, a gente também tem que ter os mesmos direitos como cidadão. Beleza, ter o casamento homossexual, vai do casal resolver se isso é necessário e importante para a relação. Eu hoje gostaria de casar no civil, eu gostaria, mas não faço questão nenhuma de um casamento religioso, por exemplo. É uma questão de casal, uma questão pessoal"(CMA - S1). Observando esse relato, é possível perceber que há um desejo constante por parte 


\section{Desafios da psicologia no Brasil}

desse casal de formalizar a sua relação em função de um planejamento anterior realizado dentro do casal. O receio de realizar esse processo pode estar de acordo também com uma visão preconceituosa que a sociedade ainda possui do casamento entre pessoas do mesmo gênero, fazendo esses casais terem certo receio de realizar sua união jurídica.

Em direção da mesma medida, hoje há uma ampla discussão com relação à criminalização da homofobia. Contudo, sabe-se que isso não é o suficiente para eliminar o preconceito e a discriminação. A exemplo do que aconteceu com o racismo e a violência doméstica que foram elaboradas leis para combater sua ocorrência, a violência racial e a violência familiar continuam ocorrendo de diferentes maneiras, o que se pode supor que o mesmo aconteceria com a homofobia. Sem negar a importância da justiça, modificar valores sociais impregnados nas relações demandam transformações maiores do que uma lei por si só pode propor. Uma das maneiras viáveis de realizar esse processo está nos próprios casais: a aceitação de si mesmo e a aceitação dos espaços onde esses sujeitos convivem.

Como foi abordado anteriormente, os casais homossexuais são influenciados socialmente a restringirem a sua vivência afetiva à vida doméstica e a ambientes dedicados a pessoas homossexuais, como também a reproduzirem um discurso que diferencia aqueles que vivem uma vida afetiva mais aberta socialmente, daqueles que não o fazem. No entanto, os casais também podem funcionar como uma maneira de se repensar o preconceito. A aceitação gradual dos casais nos espaços de convivência destes também se torna uma forma de refletir sobre o quão diferente estes são dos demais: "Com relação a respeito das pessoas, a gente acabou adquirindo isso também. No começo não foi fácil, as pessoas não aceitavam. Mas com o tempo as pessoas foram aceitando a ideia de ter um casal que não é convencional, mas que é um casal, que se respeita, que está junto, que tem uma vida juntos. Então, hoje a gente não pode reclamar de qualquer tipo de preconceito ou desrespeito a gente estar junto" " (CMA - S1). No caso desse casal, os sujeitos conseguiram a aceitação dos espaços onde se encontraram, a partir do momento em que abriram gradualmente a sua relação a convivência social. Há um estranhamento inicial, uma tensão frente o que parece estranho e desconhecido a esses espaços. Entretanto, na medida em que esses casais se tornam conhecidos e as diferenças sentidas serem apenas próprias a de qualquer casal, o estranhamento e a tensão tendem a diminuir. Esses espaços tendem a ser mais respeitosos com a diversidade e a convivência com casais entre pessoas do mesmo gênero oferecem às demais pessoas a possibilidade de refletir e repensar suas próprias concepções e valores. Também é uma oportunidade para esses casais repensarem seus valores quando a expressão afetiva, na medida em que vão se sentindo aceitos e bem vistos pelas pessoas a 


\section{Desafios da psicologia no Brasil}

sua volta. Não é um processo automático, fácil ou simples. Tudo se inicia quando, além de estereótipos, os casais homossexuais vivem sua vida afetiva da maneira que se sentem satisfeitos em fazer e recebendo do ambiente nada mais, nada menos, do que a visão e tratamento merecedor de um casal como qualquer outro. Mas como realizar tudo isso?

O preconceito é um processo que está enraizado nas relações e nas instituições e se traduz em diferentes formas. É um fenômeno difícil de se observar já que este se manifesta de muitas maneiras e causa diversos efeitos nas relações das pessoas. O que se sabe é que é um fenômeno que denuncia uma sociedade que tem dificuldades em lidar com a diversidade e que, sem perceber, também condena a si mesma a restringir suas possibilidades. Há o dito normal, esperado "natural" e há tudo aquilo que foge a norma. Os que se colocam na primeira ordem tendem a condenar os da segunda e esses também acabam reproduzindo o preconceito sofrido em algum momento. A resposta para solucionar esse problema é a aceitação e respeito às diferenças e a percepção da diversidade como parte da natureza humana. Processos dos quais os casais homoafetivos podem colaborar para sua existência, a partir do momento que escolhem gradualmente aceitar suas relações como parte dessa diversidade. Aqueles que fogem a norma tem em suas ações a possibilidade de reflexão, de repensar valores e alterar paradigmas ultrapassados que não se adequam a realidade moderna e a multiplicidade de relações afetivas existentes. Enfim, relacionar-se com outras pessoas significa, no geral, repensar a sua própria história, refletir sobre a realidade da qual está inserido e, dessa forma, como apontado por um dos sujeitos entrevistados, "[...] Transgredir as regras da realidade. Ter um relacionamento é transgredir as regras da realidade"(CMA - S1).

\section{CONCLUSÃO}

Compreender um fenômeno como o da conjugalidade entre pessoas do mesmo sexo vai muito além das questões individuais de cada um dos sujeitos. Necessita um olhar sobre a sociedade e suas influências sobre a homossexualidade. Por muito tempo, a ciência isolou os sujeitos de sua realidade social, analisando-os, avaliando-os, fatiando suas subjetividades e criando um padrão de ser que devia ser seguido por todos. A sexualidade sofreu esse controle e toda a expressão sexual que fugia a normal era considerada desviante e anormal. Apenas recentemente, o estudo científico voltou o olhar para fenômenos como o da homossexualidade com um olhar menos preconceituoso e excludente. A curiosidade científica permitiu um olhar que compreende a homossexualidade não distante de onde de fato esta acontece: a realidade, o contexto cultural e relacional, no qual esse fenômeno ocorre. 


\section{Desafios da psicologia no Brasil}

Tudo aparentemente inicia quando o sujeito tem o desejo de se relacionar com alguém do mesmo gênero. As razões que o levam a querer isso estão além do seu desejo. Naturalmente, na construção de uma possibilidade de sua vivência afetiva, o indivíduo sofre influência de seu próprio ciclo desenvolvimental, da sua relação com sua família, amigos e trabalho, como também de sua realidade social. Trata-se de um fenômeno que não pode ser analisado isoladamente, cada sistema relacional acaba por influenciar os demais.

O ponto nodal do preconceito sofrido pelos casais homossexuais corresponde a uma visão desses relacionamentos como desviantes e não-naturais que é difundida amplamente na sociedade por inúmeras maneiras e razões. Todo o relacionamento possui suas peculiaridades, mas apenas alguns destes ganham rótulos com base em suas características. Apesar da força do preconceito estar na constituição desses casais, os relacionamentos homossexuais apresentam em si uma força de transformação que podem também promover a reflexão sobre os paradigmas que afetam as normas que dizem como os casais devem ser. Sendo esses casais que vão além da norma, estes permitem também questioná-la. Mas antes de tudo, os casais precisam estar completamente resolvidos quanto a aspectos de sua sexualidade, tanto para si mesmos, quanto para os seus respectivos sistemas familiares. Entende-se estar bem resolvido, como a capacidade de dialogar a respeito de sua afetividade com pessoas do seu círculo social, de maneira aberta e flexível.

A psicologia se valeu basicamente da sexualidade, como porta de entrada para a explicação da subjetividade. A psicanalise e outras linhas teóricas que emergiriam dela, buscaram explicar a construção dos sujeitos através de fases chamadas de etapas psicossexuais que, com o passar do tempo, foram distorcidas e transformadas em pontos de partida para a norma da vivência da sexualidade. Ao invés de questionar e trazer o debate das manifestações da sexualidade na sociedade, a psicologia, na maioria das vezes, contribuiu para reforçar a hegemonia sobre a sexualidade, através de práticas que patologizam identidades, voltando-se para uma realidade intersubjetiva que ignora o contexto social do qual esses sujeitos estão inseridos. Com a despatologização da homossexualidade e a constante luta de movimentos sociais, a psicologia reviu sua postura e hoje, cada vez mais, busca permitir a reflexão do preconceito contra a homossexualidade, lutando por uma sociedade que não discrimine aqueles que estejam distantes do que a sociedade ainda considera a norma. A Psicologia tem o compromisso social de promover o diálogo e a reflexão sobre as manifestações da sexualidade, visando desmitificar as vivências que são consideradas desviantes. A psicologia deve servir de ferramenta de debate e da não reprodução de valores que condenam as expressões da sexualidade 


\section{Desafios da psicologia no Brasil}

que são distantes da norma sexual pregada pela sociedade. A psicologia não deve servir como ferramenta de controle e administração de corpos, encerrando todos aqueles que desejam por si viver uma sexualidade diferente da pregada como normal. Os psicólogos carregam em si o compromisso social de que quando diante de iniquidades possam promover a reflexão, que diante de situações de discriminação e preconceito possam promover o diálogo e a justiça social. A psicologia pode ser a ferramenta de transgressão da norma, na medida que esta assume seu compromisso social de propor transformações na sociedade.

\section{REFERÊNCIAS BIBLIOGRÁFICAS}

DIAS, Maria Berenice. União homoafetiva: o preconceito \& a Justiça. 5. ed. São Paulo: RT, 2011.

FRANÇA, Maria Regina Castanho. Terapia com casais do mesmo sexo. In: VITALE, Maria Amália Faller (org). Laços Amorosos: Terapia de casal e psicodrama. São Paulo: Agora, 2004.

PRADO, Marco Aurélio Máximo; MACHADO, Frederico Viana. Preconceito contra homossexualidades: a hierarquia da invisibilidade. São Paulo: Cortez, 2008.

RIOS, Roger Raupp. O conceito de homofobia na perspectiva dos direitos humanos e no contexto dos estudos sobre preconceito e discriminação. In: RELATÓRIO AZUL. Rio Grande do Sul. Assembleia Legislativa. Comissão de Cidadania e Direitos Humanos. Porto Alegre: Corag, 2009. 


\section{Capítulo 19}

\section{EXERCÍCIOS ESPIRITUAIS DE INÁCIO DE LOYOLA}

E A PSICANÁLISE: UM DIÁLOGO POSSÍVEL ${ }^{1}$

\section{DOI: $10.37423 / 200200196$}

Maria Teresa Moreira Rodrigues

mteresa.mrodrigues@gmail.com

Palavras-chave: exercícios espirituais: Inácio de Loyola; psicanálise.

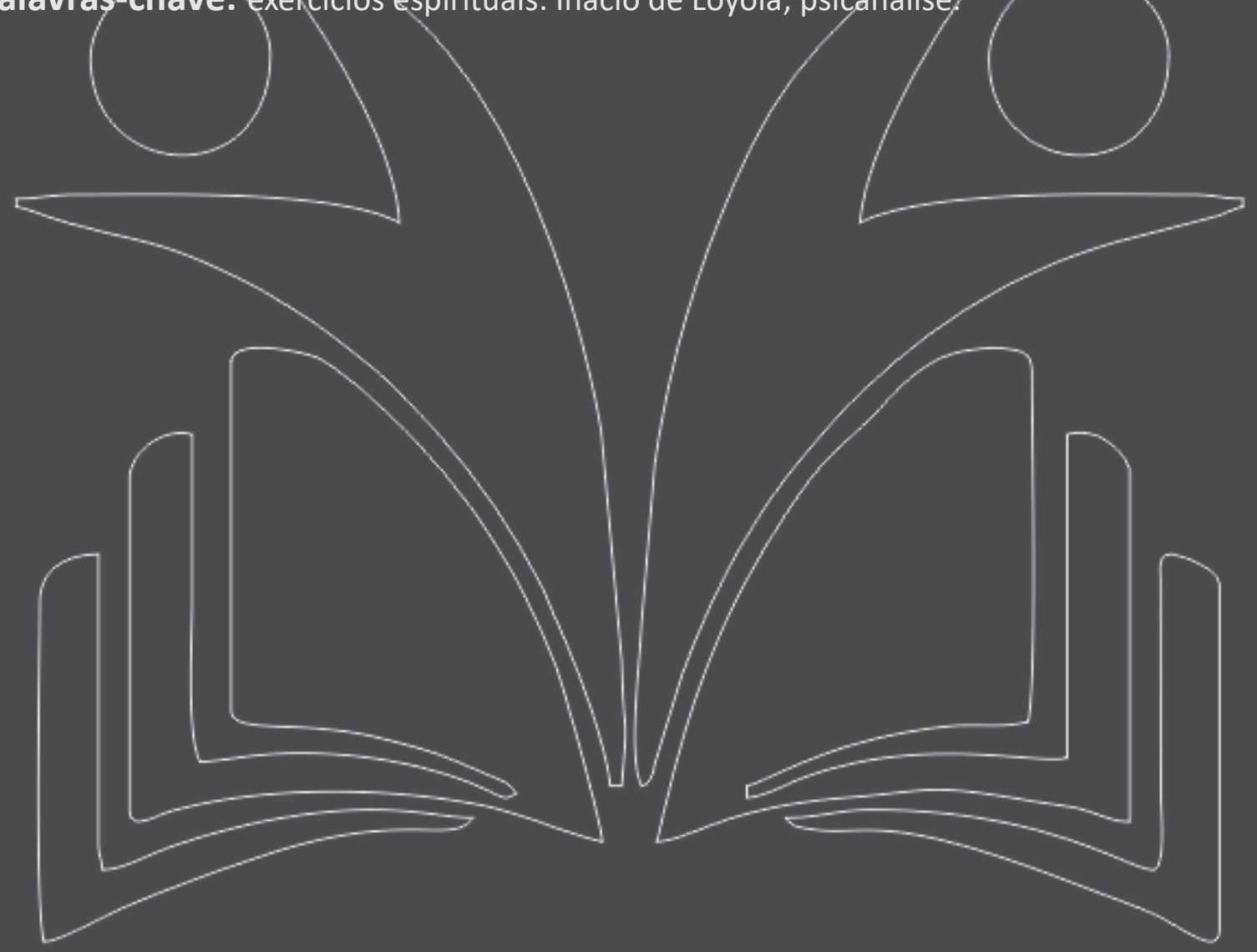




\section{Desafios da psicologia no Brasil}

\section{INTRODUÇÃO}

A Psicanálise é uma disciplina extremadamente íntima, e de sensibilidade e habilidade. A prática da psicanálise converte essa intimidade em uma relação especializada entre duas pessoas, as quais, através da mesma natureza de sua exclusividade, transformam-se mutuamente. A primeira coisa que quero dizer acerca do trabalho refletido nestes escritos, é que meus pacientes têm me ajudado a converter e personalizar meu pensamento, afetividade e esforço potenciais, em uma forma de vida que me é profundamente satisfatória. Se tivesse seguido outra carreira, talvez minha vida tivesse sido mais cheia de acontecimentos e variada, mas não teria sido mais completa. A relação com meus pacientes tem-me ensinado a humildade e a necessidade do outro para eu ser e converter-me em mim mesmo.

\section{M.Masud R.Khan ${ }^{2}$}

Assim como uma mesma partitura pode ser interpretada de formas diversas por diferentes maestros, os Evangelhos são sempre os mesmos, porém continuamente animados pela sensibilidade, pela história pessoal e pela ciência de cada um. Uma escritura-fala que renasce, linguagem própria a cada homem, cuja veia jamais se esgotará, linguagem criadora de sua vida e de sua dignidade. Não pretendo compreender a totalidade desses escritos, que permanecem uma revelação espiritual. E a psicanálise trata da psicologia; ela propõe uma leitura que responde aos "comos" e "porquês" de certas atitudes e comportamentos; não trata do que é espiritual, pois este imprime o movimento da reivindicação profunda do coração humano: a busca da verdade, o insondável sonho de justiça, o culto da beleza, o encontro com Deus. De qualquer forma, a psicanálise pode, no entanto, alertar leitores indiferentes a esses manuscritos e tirar da rotina aqueles que com eles estão familiarizados demais.

Françoise Dolto ${ }^{3}$

Não há nenhuma utilidade em tentar "enxergar o que está por trás" dos primeiros princípios. Se você "enxergar o que está por trás" de todas as coisas sem exceção, então tudo se tornará transparente para você. Mas um mundo completamente transparente é um mundo invisível. "Ver o que está por trás" de todas as coisas é o mesmo que não ver nada.

Carl S.Lewis ${ }^{4}$

\section{O SENTIDO E O PORQUÊ DESSE TRABALHO}




\title{
Desafios da psicologia no Brasil
}

\author{
Así voy devolviendole a Diós unos centavos del infinito caudal que me pone en \\ las manos. \\ Luna de enfrente. Jorge L. Borges 5
}

Este trabalho não pretende apresentar em sua complexidade já tão decantada, as relações possíveis entre Psicanálise e Religião, Psicanálise e Fé. Nunca foi fácil o diálogo entre elas pelas posições préestabelecidas, pelo medo e preconceitos, e mesmo pelos mecanismos de ordem inconsciente, que têm impedido o face-a-face com a disposição suficiente para escutar o que a outra parte diz. "Os psicanalistas têm sido particularmente cegos frente ao tema da religião", já afirmava Bion. E as pessoas que crêem, precaveram-se e resguardaram-se da Psicanálise, sentindo-a como uma fúria poderosamente iconoclasta. A despeito da cegueira e da desconfiança, ambas terão que manter um diálogo interminável, como nos diz Domínguez Morano: “A questão entre elas coloca-se de modo radicalmente novo cada vez que alguém fala, e enuncia seu Credo. A psicanálise nunca pretenderá contar de antemão com a interpretação deste dizer, e nunca tampouco aquele que crê poderá esquivar-se da pergunta que se oculta por baixo desse dizer. ${ }^{\prime \prime}$

Pretendo apenas apresentar os Exercícios Espirituais (doravante EE) de Inácio de Loyola, desde a experiência pessoal que tive com eles, e o que inferi e estudei, sempre tendo presente a psicanalista que existe em mim, assim como as inumeráveis lembranças que marcam essa longa jornada profissional. Compartilho com todos e com meus pares da área Psi, um pouco do que tenho vivido e estudado, por entender que assim devemos proceder quando temos consciência e clareza do que nos foi dado, e que portanto deve também ser doado. Agradeço a todos os que me ajudaram a fazer com que esse caminho fosse possível; e gratidão implica em reconhecer que nada somos sem a companhia daqueles que nos querem bem, e mesmo daqueles que não nos querem. Afinal, necessitamos de todos os que trabalham e lutam conosco no acontecendo de nossas vidas!

Estar aqui é parte de um caminho que começou há 10 anos, recém cumpridos aos 14 de agosto. Estes têm sido anos de viver, dar e estudar Inácio e os EE, num contato intenso e ininterrupto. Encontreime com Inácio sem tê-lo buscado. Buscava algo que me transcendesse, e que desse novo sentido ao que eu vivia; e também buscava algo que pudesse apaziguar o sentimento de desamparo que em mim permanecia, a despeito do que a Vida e a Psicanálise já me haviam dado. Para o que clamava em meu interno, eu intuía que ela já não tinha recursos a oferecer-me. Conforme caminhei e olhei para trás, fui compreendendo o que se passava em mim. Ajudaram-me as palavras de Françoise Dolto: 


\section{Desafios da psicologia no Brasil}

“(...) É sempre depois dos fatos que se analisa. Raras são as previsões. Sim, o sentido chega depois à nossa consciência como uma realização em movimento de um sentido inconsciente que guiou nossos passos, falsos ou verdadeiros, no dia a dia." 7

"Só poderemos reconhecer o sentido com algum recuo, quando desprendidos de nossa ação, estaremos menos tomados por nossa paixão de agir." (...) E é no silêncio que se segue, quando a última palavra já foi pronunciada, que a frase libera seu sentido. É portanto no silêncio, que o sentido se manifesta. Ele nasce dentre as palavras mortas. Depois ${ }^{87}$

Assim como um dia fui "tocada" pela Psicanálise e por Freud, depois o fui pelos EE e por Inácio. Assim como se faz "formação" em Psicanálise, fui fazendo minha formação nos EE. Como parte também desse caminho de vivência, estudo e formação, fiz o Mestrado em Ciências da Religião na PUCSP, tendo terminado em maio de 2011, com o trabalho: Os EE de Inácio de Loyola: uma revisão do texto e um diálogo com Roland Barthes. Deixando entrever sua simpatia "pelo santo de olhos marejados" , Barthes chama Inácio apenas de Loyola, em sua inspiradora leitura do texto dos EE, no livro Sade, Loyola e Fourier ${ }^{10}$.

Para a psicanalista foi possível apreender a tensão psíquica que está presente no processo dos EE, e que remete o exercitante não só à busca da vontade divina para sua vida, mas também a uma busca de si mesmo. Desde o início foi possível apreender a movimentação psíquica que Inácio viveu, e deixou entrevista em suas Regras de Discernimento, avisos que deixou para nos ajudar na compreensão de nós mesmos, desde nossos afetos ordenados e desordenados. Freud, desde sua compreensão do funcionamento psíquico, estruturou uma teoria que nos permite entrever o que se passa internamente, em nossos afetos ordenados e desordenados. Inácio, desde sua vivência, estruturou um método que nos permite ordenar esses diferentes afetos, com a força psíquica que a motivação de buscar a interlocução com a divindade é capaz de gerar. No entanto, naqueles inícios, o que tinha primazia sobre mim era a vivência trazida pelos $E E$, e que se sobrepunha a qualquer motivação para olhar os EE sob a ótica da Psicanálise. A aproximação entre os EE e a Psicanálise estava em mim, mas desde a experiência como pessoa e como profissional. Só depois de passados sete (7) anos é que pude "pensar" os EE com a Psicanálise. Compreendo que era necessário "viver" o objeto, antes de "estudálo". Tomo para mim as palavras de Eduardo Montagne ${ }^{11}$ :

“(...) este trabalho é de alguma maneira, um testemunho pessoal: nele quero deixar refletido algo do encontro que, no meu mundo interno, tiveram duas correntes poderosas de pensamento e de inspiração espiritual e intelectual. Desejo simbolizá-las em duas personagens, separadas por 383 anos, e aparentemente por perspectivas e lugares muito diferentes: Inácio de Loyola (1491-1556), fundador da Companhia de Jesus, e Sigmund Freud (1856-1939), 


\section{Desafios da psicologia no Brasil}

criador da psicanálise. Inácio tem inspirado minha atitude de fé e Freud minha atitude científica. Ambos me ensinaram, de modos diferentes, mas não necessariamente contrapostos, o valor e o significado do encontro com meu próprio mundo interno, como meio indispensável para conhecer a realidade exterior e localizar-me nela. E penso que ambos podem ter muitas coisas em comum, muito além das divergências históricas, culturais e religiosas que os separam no tempo e no espaço" ${ }^{\prime 2}$.

\section{BREVÍSSIMO OLHAR SOBRE INÁCIO E SEU TEMPO}

A espiritualidade de Inácio foi moldada não só por sua experiência religiosa, mas também pelo mundo em que vivia; sua história pessoal e seu contexto social deram forma e direção ao seu modo de entender e viver a vida cristã, além de ser também fonte para suas tentativas de resposta aos problemas e necessidades do mundo de seu tempo.

Inácio nasceu em 1491: tempo de horizontes geográficos em expansão. Na sua meninice, Cristóvão Colombo descobriu América, enquanto outros descobriram a rota marítima para as Índias. Enquanto ele ia se expandindo em sua vida pessoal, tanto em tempos de cavaleiro, jovem cortesão, soldado, como de peregrino solitário e estudante, a costa leste da América era explorada e também se expandia. Inácio não só acompanhava estes acontecimentos, como inclusive teve um irmão que seguiu as expedições espanholas e morreu na América.

Muitos anos depois, já na década de 1540, quando superior geral da Companhia de Jesus, enviou missionários à Índia e ao Japão. Importante ressaltar a diferença entre o tempo de Inácio e o de hoje; essas viagens de conquista não geravam o questionamento moral que hoje despertariam; pelo contrário, recebiam as bênçãos da Igreja e homens e missionários partiam em grande número.

Outro fator da época a moldar e influenciar a espiritualidade de Inácio: em 1492, os exércitos do rei e da rainha da Espanha puseram fim ao domínio muçulmano em solo espanhol. Embora hoje todo o legado islâmico seja valorizado e tenha se tornado relíquia, naquele tempo o povo árabe era malvisto e odiado, tidos como déspotas estrangeiros e infiéis. Daí talvez o entusiasmo em levar o Evangelho também a terras muçulmanas.

Vale lembrar que enquanto Inácio era cavaleiro e cortesão, quase sem conhecimento da Alemanha e com pouco interesse pela espiritualidade, surgiam Martinho LUTERO e seu protesto contra a Igreja Católica (Wittenberg,1517), assim como o reformista João CALVINO (1509-1564). É na década de 1520 que Inácio inicia sua caminhada de peregrino pela própria Espanha, e indo depois para Jerusalém. No entanto, entre 1526 e 1538, durante viagens e estudos, ele já se inteira dos problemas religiosos de seu tempo, vivendo estas controvérsias em Paris, na década de 1530. Numa breve visita à Inglaterra, 


\section{Desafios da psicologia no Brasil}

mendigando dinheiro para pagar as taxas universitárias, convive com o tumulto generalizado provocado pelo casamento do rei, que provoca a separação da Igreja, e quando também Tomás MORE é executado (1535). Depois, entre 1537 e 38, ele e seus companheiros de então, caminharam entre Paris e Roma, também convivendo com as controvérsias e desgastes da Igreja. Lembremos sua experiência com a Inquisição (em Alcalá, Salamanca e Toleco), suas viagens prolongadas, seus estudos, suas relações com dignatários religiosos; tudo foi dando a ele conhecimento direto dos problemas e das necessidades dos cristãos contemporâneos. Sua espiritualidade orientada para o serviço foi sua resposta a essas necessidades.

Quando em ROMA, de 1538 até 1556 (ano de sua morte), Inácio conviveu com a efervescência das artes, embora demonstrasse pouco interesse por elas. Na pintura: Ticiano, Palladio, Cellini e Tintoreto; em 1541, Michelangelo concluiu o teto da Capela Sistina. Na música, Palestrina tornou-se diretor de música na Basílica de s.Pedro. No entanto, seu interesse estava depositado em outra área, plena de criatividade: "a nova aprendizagem", e que parecia ameaçar a ordem antiga. Inácio deixou um legado de muitas escolas, instaladas na década de 1550, que era uma estratégia pastoral aberta ao novo; a partir da educação, satisfazia as necessidades intelectuais, espirituais, morais e sociais da época, assim como o continuou fazendo.

\section{A RETOMADA DOS ESTUDOS SOBRE A ESPIRITUALIDADE INACIANA, E SUA CONTEMPORANEIDADE COM O DESENVOLVIMENTO DA PSICANÁLISE}

Interessante pensar que enquanto Freud publicava alguns de seus primeiros textos, como A interpretação dos sonhos e Psicopatologia da vida cotidiana, a Companhia de Jesus (ordem religiosa fundada por Inácio de Loyola) lançava a MHSI (Monumenta Historica Societatis lesu ${ }^{13}$ ), em Roma (1894), buscando resgatar suas origens, e gerando grande animação investigativa. Assim, já desde o início do século XX, peritos jesuítas vinham traduzindo e estudando os Exercícios Espirituais em seu original, buscando ser mais fiéis às diretrizes de Inácio. Com a popularidade que os EE foram ganhando, e com as demandas das mudanças culturais, e com o "aggiornamento" estimulado pelo Concílio Vaticano II, o que antes estava apenas entre os entendidos expandiu-se para muitos. A partir da década de 1960, publicações que já vinham sendo feitas há vinte e cinco (25) anos, se espalharam por muitas línguas e países, como a publicação do livro dos Exercícios Espirituais, do Diário e das Cartas de s. Inácio. Conheceu-se mais sua obra, e ampliou-se a possibilidade de seguir suas diretrizes iniciais, a partir da experiência espiritual e emocional que os EE propõem. 


\title{
Desafios da psicologia no Brasil
}

Desde as últimas décadas, e com a constatação do quanto isso se fazia necessário, o laicato (grupo de leigos) vê-se intensamente comprometido com o "Ministério dos EE", sobretudo com o dos EEVC (EE na Vida Cotidiana); e acompanhando a leigos, mas também a clérigos e religiosos, e não só cristãos, mas também aos não cristãos, numa experiência profunda de contato consigo mesmo.

\begin{abstract}
"A prática [dos EE], influenciada muito pela orientação psicológica competente, foi oferecida na situação de comunicação pessoal e individual. Foi impulsionada também pela sensibilidade de que indivíduos precisavam trabalhar para realizar suas próprias pessoas, necessidade que uma cultura globalizante acentuou, visto que a mesma enfraqueceu os papéis estabelecidos, referentes à família, gênero e trabalho. Diariamente, pessoas viram o curso violento de irreconciliáveis guerras locais e imagens de tortura desumana. (...) Todo mundo precisava de um lugar para narrar sua história. E pareceu que uma metade do mundo estava se perguntando: Quem sou eu? ${ }^{14 \prime \prime}$
\end{abstract}

Joseph Tetlow, responsável por um dos manuais mais conhecidos e usados para dar os EEVC, continua:

"E tudo provém dum manual que tem a idade de quatrocentos e cinqüenta anos. (...) E visto que, cada vez mais, o livro é melhor compreendido, a experiência espiritual oferecida se torna mais acessível para todas as culturas. Talvez, isto seja porque o diretor dos EE tem de ser, em primeiro lugar, um ouvinte. Isto pode ser a mais importante atividade no milênio. ${ }^{15 ”}$

O que dá os EE tem que ser um ouvinte. O psicanalista é o que ouve, e desde sua atenção flutuante pode dar outra composição às associações livres de seu paciente. A Psicanálise é um método que demanda a arte da escuta. Os EE são um método que também demanda a arte da escuta. Tanto nos EE como na Psicanálise, é a escuta quem permite a fala, assim como a fala pode levar à escuta! Acontece apenas que enquanto psicanalista e paciente estão atentos à "fala" do inconsciente, quem dá e quem faz os EE estão atentos à "fala" de Deus dentro de si. Assim como o psicanalista não "pode por o que não está ou o que está" no inconsciente de seu paciente, aquele que dá os EE não pode intervir no que se passa entre "Criador e criatura", na experiência de comunicação e oração. Aquele que fala é o agente do seu próprio processo, embora não possa prescindir daquele que o escuta, condição para viver sua relação quer seja apenas com o inconsciente, ou com Deus, desde o mais profundo de si mesmo.

\section{OS EXERCÍCIOS ESPIRITUAIS E A PSICANÁLISE}

Dizer algo sobre a relação entre os EE (como identidade espiritual gerada pelo processo dos EE) e a Psicanálise, pode despertar reservas e desconfianças, tanto por parte de teólogos como de psicanalistas, cada grupo sentindo o outro como um invasor de seu campo. Apesar de todo o avanço 


\section{Desafios da psicologia no Brasil}

já alcançado no diálogo interdisciplinar, ainda existe bastante reserva entre as pessoas de fé e os psicanalistas. Talvez ambos os grupos tendam a desenvolver um sistema de pensamento à margem de toda crítica ou de toda interpelação provenientes do "outro campo", respectivamente tido como desqualificado em relação à sua própria lógica. Tentar então uma relação entre fé e psicanálise é situar-se no terreno do desafio a qualquer postura irredutível e rígida de ambos os lados, a qualquer preconceito que feche os horizontes amplos do pensamento humano, a toda tentativa de bloquear o afã de investigação e paixão pelo encontro, pelo diálogo e pela confrontação.

É verdade e de fácil constatação, que tanto Inácio como Freud fizeram de sua experiência pessoal e das particulares circunstâncias de suas vidas, assim como das vicissitudes de seu mundo interno, uma permanente fonte de inspiração não só para si mesmos, mas também para muitos outros, que a partir do que eles deixaram, continuaram pensando, investigando e criando. Inácio deixou o que genericamente se chama "espiritualidade inaciana", um conjunto de escritos como a Autobiografia, os Exercícios Espirituais, as Constituições e as Cartas, que tem inspirado a vida dos jesuítas, e toda uma corrente de espiritualidade no mundo dos que crêem. Freud criou a escola psicanalítica, e através de sua imensa produção científica, inspirou uma abordagem completamente nova do mundo psíquico, ao descrever esse gigantesco "continente" que é o inconsciente, no universo mental do ser humano.

Temos que dizer que ambos foram, e muitas vezes continuam sendo incompreendidos por mentalidades pouco dispostas a receber, sem preconceitos e rejeições viscerais, o novo que vai surgindo em cada época, mas que constitui de alguma maneira, o impulso para os grandes saltos que o pensamento humano dá, de quando em quando. E podemos dizer também, que quem pretende estar aberto a todas as manifestações do espírito humano, sem fechar-se a nenhuma delas antes de examiná-las, poderá encontrar com certeza, tanto em Inácio como em Freud, dois modelos de atitude de busca, de indagação paciente e incansável, de exame minucioso da realidade interna e externa, em prol de uma visão coerente e responsável do que é o ser humano, seu lugar e finalidade neste mundo.

Podemos pensar que Inácio e Freud, desde suas perspectivas e conviç̧ões pessoais, nos ensinam a abertura ao novo, à busca incansável de novas perspectivas, e à revisão e ao questionamento do já vivido e afirmado. Inácio formulará sua atitude como homem de fé, em termos de uma identidade espiritual marcada por uma contínua busca da Vontade de Deus, através do discernimento, e que o leva a discriminar aquilo que "é de Deus" do que "não é de Deus". O discernimento é central na espiritualidade inaciana, e exatamente porque Inácio experimentou as inúmeras ocasiões em que se pode enganar a si mesmo, acreditando que "é de Deus" aquilo que não é, e que não passa de um mero 


\section{Desafios da psicologia no Brasil}

fruto das próprias circunvoluções mentais. Inácio tinha apenas o conhecimento de seu próprio itinerário espiritual, e uma imensa intuição que ele colocou a serviço de indagar-se. Assim, podemos afirmar que Inácio apontou-nos para aquilo que trezentos anos depois, Freud estruturaria numa complexa teoria: as motivações inconscientes.

\subsection{O DISCERNIMENTO EM INÁCIO}

Numa época ainda pré-científica, Inácio teve uma enorme percepção psicológica, como fruto de sua própria experiência interna. O que se chama "discernimento inaciano" é precisamente o conjunto de "regras" e outros escritos que constituem a síntese de sua espiritualidade, mas também de sua psicologia, na medida em que assinalam com clareza as inúmeras variáveis que podem levar a confundir motivações inconscientes com "vontade de Deus"; ou seja, podem levar a confundir o caminho da própria neurose com o caminho de Deus. Por isso, Inácio sempre nos pede muito cuidado, até mesmo na decisão de "dar" os EE. Para "dá-los" completos [EE 18] ${ }^{16}$, há que considerar o momento pessoal e o grau de maturidade de cada um, levando em conta a possibilidade de fazer uma "eleição", um caminho de escolhas. Com a mesma clareza e cuidado, ele também advertia ao que dava os EE, para que não se inclinasse por um ou outro assunto do exercitante, mas que se mantivesse "no meio", como um peso e medida [EE 15] ${ }^{17}$. E isso para não o influenciar inadequadamente, e muito menos intervir com seu próprio pensar, na decisões que surgem durante o caminho do processo dos EE. É algo parecido com o que na técnica psicanalítica constitui a "neutralidade", condição indispensável a ser mantida em nosso trabalho com os pacientes, durante o seu caminho no processo de sua Análise Pessoal.

$\mathrm{Na}$ concepção inaciana, em nenhum caso a experiência religiosa pode acontecer à margem da experiência humana. Discernir é não confundir, mas nunca é isolar. Uma experiência religiosa pretensamente "pura", ou seja, à parte e isolada do conjunto de experiências humanas emotivas, existenciais e históricas daquele que crê, é simplesmente o mais próximo de um grande engano. Isto supõe que para Inácio, todas as dimensões da pessoa estão necessariamente envolvidas na experiência religiosa. O que chamamos "Graça de Deus" apresenta-se em nós atuando sobre todo o psiquismo; ou seja, toda a estrutura psíquica fica envolvida e entra em jogo em qualquer decisão, atitude ou formulação de tipo moral ou religioso.

Inácio chegou a estes arrazoados observando seu próprio mundo interior, em que os afetos tiveram importância decisiva. Conforme ele os observava, percebia uma espécie de desdobramento do seu Eu: 


\section{Desafios da psicologia no Brasil}

havia um Eu que sentia e um Eu que observava. As primeiras experiências sobre o que vivia em seu mundo interno aconteceram durante sua convalescença no Solar Loyola, casa familiar para onde voltou ferido e com uma perna destroçada ${ }^{18}$, após uma batalha inglória contra os franceses. Como não havia os livros que Ihe interessavam, que eram os de Cavalaria, lia os únicos que ali estavam: o da Vida de Santos e o da Vida de Cristo. Inácio percebeu-se oscilando entre duas séries diversas de pensamentos e fantasias: numa série ele se via nas façanhas que lia da vida dos santos, e na outra ele se via nos grandes feitos de batalhas e de amor, próprias dos militares e cavaleiros de sua época e vida. Mas logo se deu conta de que sua reação interna era diferente em cada uma das duas séries de fantasias. Quando ditou, em terceira pessoa, sua própria autobiografia, Inácio chegou a dizer: "se Ihe abriram um pouco os olhos e começou a maravilhar-se desta diversidade e refletir sobre ela. Colheu então, por experiência, que de uns pensamentos ficava triste e de outros, alegre. Assim, veio pouco a pouco a conhecer a diversidade dos espíritos que se agitavam [nele], um do demônio e outro de Deus." Estavam assim estabelecidas as bases do que Inácio viria a chamar de discernimento de espíritos.

Para ele, o demônio é o "inimigo da natureza humana" ([EE 7 $]^{19}$ e seguintes), e portanto representa tudo aquilo que se opõe ao mais autêntico e legitimamente humano; opõe-se ao dinamismo do desejo, que é o que pode levar o homem à sua própria realização pessoal. Ou seja, em definitiva, o "inimigo da natureza humana" é a representação da capacidade de engano, de fracasso e de morte que cada um traz dentro de si; em expressão bíblica, é o "mentiroso" que há em cada um de nós.

\footnotetext{
"A partir desta experiência fundamental, deste "insight" em expressão psicanalítica, Inácio trará para os homens de fé que se inspiram em sua espiritualidade, algo fundamental e que poderíamos formular desta maneira: aquilo que nós, os que creem, chamamos "Vontade de Deus" não é algo que venha de Fora e que seja, portanto, completamente extrínseco à pessoa, mas sim que necessariamente se insere no Dentro, no mundo interno e intrapsíquico, e que por conter as representações mentais da realidade, está em contato com esta. ${ }^{20 \prime \prime}$
}

Mas há perguntas que podemos fazer a partir daí: - Que é esse Dentro acima mencionado? - Como funciona o mundo intrapsíquico, e que relação tem com a realidade exterior? - Não haverá aqui um risco de subjetivismo, ou de isolamento dos grandes desafios que nos traz o mundo exterior, de Fora? Essas e muitas outras interrogações também se colocaram para Inácio há cinco séculos. E ele respondeu a elas à sua maneira, muito mais a partir de sua experiência que de uma formulação teórica, embora nos tenha deixado um método, no qual estão suas intuições sobre o comportamento humano. Freud ajudou-nos também com sua experiência pessoal, mas muito mais com a sistematização 


\section{Desafios da psicologia no Brasil}

científica que fez, ao submergir nesse continente oculto que é o mundo psíquico. Tanto para Inácio como para Freud, os grandes momentos e situações que definem as atuações humanas, e em muitos casos o próprio curso da história, estão incrustados neste imenso continente oculto, e a nós cabe desvendá-lo. Inácio o fez à sua maneira e inserido em seu tempo, deixando-nos o método que está presente no processo dos EE. Assim deu-se também com Freud, que à sua maneira e tempo, deixounos sua escola psicanalítica. E é ela que nos dá subsídios para o passo seguinte:

\subsection{ASPECTOS PSICOLÓGICOS LATENTES NA PROPOSTA DOS EE 22}

A intenção que está sempre presente quando estudamos e relemos o texto inaciano é a de sua aplicação para os homens e mulheres de hoje. No entanto, isso obriga-nos a tratar de uma questão prévia: a das possibilidades e dificuldades que atualmente existem frente à experiência religiosa em geral. Isso é necessário porque os EE buscam basicamente introduzir o sujeito em uma experiência religiosa de grande monta, que com certeza pode ser classificada de "mística". No entanto, em nossos dias, uma experiência desse tipo coloca-nos sem dúvida, frente a algumas interrogações.

Desde o lluminismo, a experiência religiosa tem experimentado profunda crise em nossas sociedades ocidentais. As transformações sócio-culturais têm sido profundas, mas é somente nelas que a experiência religiosa pode e deve acontecer. Vale lembrar que após o Concílio Vaticano II, a evolução e as mudanças do pensamento teológico foram muitas e aceleradas. E ainda temos que considerar que a proposta inaciana nasceu em uma sociedade notavelmente diferente da nossa, e desde abordagens antropológicas e teológicas muito diferentes das atuais.

No entanto, neste trabalho apenas nos interessa a problemática que guarda relação com a psicodinâmica da experiência religiosa. Cabe-nos pensar as bases psíquicas nas quais a experiência religiosa encontra seu terreno de enraizamento. De um lado, a experiência pode vir de processos saudáveis e maduros, mas de outro pode trazer em seu bojo um processo alienante, infantil, quando não claramente patológico. Em muitos casos, até mesmo as defesas e rejeições a essa experiência de fé podem responder também a dimensões regressivas, a preconceitos irracionais, ou mesmo a dificuldades de saúde psíquica.

A psicologia da religião fez-nos saber que é alto o poder psíquico da experiência do sagrado. É um fato que as representações religiosas, enquanto "objetos internos", possuem valor psíquico de primeira magnitude, e despertam afetos, emoções, sentimentos intensos e comportamentos radicais. Tudo dependerá do "material psíquico" com o qual essas representações psíquicas foram se configurando, 


\section{Desafios da psicologia no Brasil}

tanto nos indivíduos como nos povos, ao longo de seus processos biográficos ou históricos. Nada talvez desperte tanto amor e ódio como a religião.

O radicalismo que possui a formação cultural religiosa é compreendido quanto mais se analisam os fatores que intervêm em sua constituição e desenvolvimento. As ciências humanas, e particularmente a Psicologia profunda, desvelaram os processos primitivos e arcaicos que sempre estão presentes na configuração das representações do sagrado. São estes os mesmos processos que intervêm na constituição do ser humano enquanto tal, e enraizados nas estruturas afetivas mais primárias e profundas. As representações religiosas nascem no ser humano, costuradas com os primeiros objetos de amor e ódio; é nessa inter-relação que se configura o mais importante da personalidade. Posteriormente, estas representações poderão ser reelaboradas num nível cognitivo. Mas poderão inclusive ser negadas, como nas posições mais acirradas de agnosticismo ou ateísmo. Todavia, permanecerão sempre nos estratos afetivos mais profundos, mobilizando e determinando as posições adotadas frente ao fato religioso. As representações religiosas nunca são alheias a estes "objetos internos". A força e o potencial que o acontecimento religioso sempre teve na vida dos indivíduos e dos povos, devem tributo a esses "objetos internos 22 ".

A relação primeira com a mãe, e logo depois com o casal parental, vão ter papel fundamental na estruturação da dinâmica pessoal, e vão servir de suporte básico para a configuração das representações religiosas que virão. Muito antes que se possa observar e avaliar o surgimento de qualquer tipo de comportamento religioso, essas primeiras relações parentais já serviram de base para a palavra da "catequese" (se for dada, e qualquer que seja ela, cristã ou não) encontrar terreno para germinar ou não. A "qualidade" diversificada desta terra primeira de relações internas, e o tipo de mensagem que trouxer uma catequese, converter-se-ão, em sua particular interação, nos fatores decisivos da futura religiosidade, e de sua eventual potência para o desenvolvimento e plenitude da pessoa, ou para seu bloqueio, mutilação ou destrutividade.

Tudo isso é importante quando pensamos numa proposta religiosa como a dos EE. Eles supõem introduzir o sujeito em uma experiência de grande e particular intensidade, que afeta as estruturas psíquicas do ser humano; e que ainda coloca em prática uma ampla e extensa gama de recursos técnicos, também de grande porte. Portanto, será sempre valioso levar em conta a ambivalência e ambiguidade que este tipo de experiência pode comportar. Já sabemos o quanto alguns modos de se entender a prática dos EE contribuiu para que em muitos setores da população, a proposta inaciana fosse assimilada como uma técnica de controle, repressão e culpabilidade; e também fosse entendida 


\section{Desafios da psicologia no Brasil}

como um protótipo do que a experiência religiosa pode supor de mutilação do humano. Portanto, mais do que nunca será importante ter a consciência muito desperta a respeito da ambivalência que facilmente se pode esconder no coração da mesma experiência de fée ${ }^{23}$, e de suas manifestações particulares.

\section{O MÉTODO DOS EE}

\subsection{O QUE SÃO OS EXERCÍCIOS ESPIRITUAIS}

[EE 1] Anotação 1. A primeira é que por estes termos, exercícios espirituais, entende-se qualquer modo de examinar a consciência, de meditar, de contemplar, de orar vocal e mentalmente, e outras operações espirituais, conforme se dirá mais adiante. Pois, assim como passear, caminhar e correr são exercícios corporais, da mesma forma se dá o nome de exercícios espirituais a todo e qualquer modo de preparar e dispor a alma para tirar de si todas as afeições desordenadas e, afastando-as, procurar e encontrar a vontade divina na disposição de sua vida para a salvação da alma.

[EE 21] Exercícios espirituais: para vencer a si mesmo e ordenar sua vida, sem determinar-se por afeição alguma desordenada.

Nesta definição, Inácio permite-nos ver claro o objetivo primordial que se pretende. Em primeiro lugar, trata-se de um trabalho na ordem dos afetos. Neste sentido, desde um ponto de vista psicológico, tem como finalidade primordial entrar no mundo afetivo do sujeito, para provocar uma remodelação do mesmo, e que assim o acomode e o ordene conforme uma determinada concepção de ser humano, que está formulada no "Princípio e Fundamento" [EE 23].

[EE 23] O homem é criado para louvar, reverenciar e servir a Deus Nosso Senhor e mediante isto salvar sua alma. As outras coisas sobre a face da terra são criadas para o homem e para o ajudarem na consecução do fim para o qual é criado. Daí se segue que o homem há de usar delas tanto quanto o ajudam para seu fim, e há de desembaraçar-se delas tanto quanto o impedem para o mesmo fim. Por isso, é necessário fazer-nos indiferentes a todas as coisas criadas, em tudo o que é permitido à nossa livre vontade e não lhe é proibido, de tal maneira que não queiramos - de nossa parte - antes saúde que enfermidade, riqueza que pobreza, honra que desonra, vida longa que vida breve, e assim em tudo o mais, desejando e escolhendo somente o que mais nos conduz ao fim para que somos criados.

Trata-se do que poderíamos chamar, em termos socioeconômicos e psicanalíticos, de uma espécie de "reconversão libidinal". Isto é, trata-se de um trabalho que consiste em retirar a carga afetiva dos 


\section{Desafios da psicologia no Brasil}

objetos libidinalmente investidos; e depois de retirada essa carga, buscar e encontrar a vontade divina. Ou seja, trata-se de iniciar (procurar) o processo de um novo investimento libidinal, e assim encontrar (encontrar) um novo objeto (a vontade divina).

Como já dissemos, desde o início da vida psíquica, nosso mundo emocional realiza uma série de vinculações afetivas com aqueles objetos que se enlaçaram a qualquer tipo de gratificação. Entre estes primeiros objetos, encontram-se naturalmente as figuras parentais, as que garantem a sobrevivência, proporcionando os meios necessários para a satisfação das necessidades primárias, assim como oferecendo um clima de proteção e de amor, tão obrigatório para a sobrevivência, como o é o alimento. Desde esses primeiros estágios, nosso mundo afetivo irá ampliando suas vinculações de objeto, de um modo rico e complexo, tanto com as pessoas como com os objetos materiais, e inclusive com as próprias ideias e fantasias. Também a própria realidade pessoal, incluído aqui nosso corpo físico, formará parte importante desse mundo de "objetos de amor", que irão constituindo a dinâmica pessoal, singular e particular de cada um de nós.

"É nessa dinâmica afetiva pessoal [prenhe de vinculações emocionais], sempre mutante em suas atrações e rejeições profundas, que Inácio pretende que o exercitante entre a fundo para discerni-la e transformá-la, de maneira a tornar possível uma vinculação tão radical com Deus, que "ordene" todas as demais e possibilite um novo modo de orientar sua vida." ${ }^{24}$

Aqui vale trazer a distinção que Françoise Dolto fez entre necessidade e desejo ${ }^{25}$, em seu livro A fé a luz da Psicanálise:

(...) Necessidade nos coloca em relação com um objeto que promete prazer. Desejo é um encontro interpsíquico com o outro. Trata-se de uma dinâmica, de um elã, de uma fonte que impele a viver e a buscar os outros que também nos chamam - incessante caminhar. $O$ desejo é o elã do indescritível que sempre nos falta... Ele está para além da música, da página de um livro, de um rosto, de um gesto de compaixão. Ele nos faz viver no eterno inacabado e na contradição ${ }^{26}$.

É nessa dinâmica afetiva pessoal, singular e particular de cada um de nós que a necessidade irá se transformando em desejo. E na abordagem inaciana, no processo dos EE, a nova experiência de amor não poderá ficar reduzida ao campo do mero emocional. A experiência religiosa deverá ter uma repercussão decisiva na configuração da vida (na disposição de sua vida). Ou seja, a experiência do amor no processo dos EE é chamada a modificar profundamente o conjunto do universo de valores, de pensamentos, de condutas, etc.; e tudo será para a saúde da alma. Neste sentido, os EE são uma proposta de transformação profunda na identidade pessoal, assim como o foram para o próprio Inácio. 


\section{Desafios da psicologia no Brasil}

Ele sabia que é necessário que os EE recaiam sobre o processo pessoal, para assim incidir sobre a disposição de sua vida. Se não for assim, os EE poderão ficar reduzidos a uma experiência puramente imaginária; isto é, reduzidos à criação de um mundo afetivo que busca apenas fugir do enfrentamento com a realidade, ou dito de outra forma, reduzido a um mundo fantasmático afastado do real, do intersubjetivo. E portanto, um mundo afetivo não relativizado pelo enfrentamento com algum tipo de limite. São muitas as experiências religiosas que desafortunadamente acabam apenas nisso. E, até porque o campo da religiosidade é dos mais propícios para esse modo patológico e infantil de fuga mundi.

Uma experiência cristã vivida no nível do simbólico, somente é possível através dessa disposição de vida, modelada a partir do encontro com o desejo de Deus sobre a própria vida, assim como também através do longo caminho pessoal de discernimento e decisão. Quer dizer, uma experiência em que o afetivo entra em jogo de maneira importante, mas é modelado, informado, organizado e relativizado pelo intersubjetivo. Ou dizendo em termos mais freudianos, submetido às leis do Princípio da Realidade.

O processo da Eleição (fazer escolhas e mudanças em si mesmo) é o ponto central da dinâmica dos EE. Mas esta eleição não será possível se antes não se alcançou discernimento suficiente para detectar os condicionamentos afetivos que, de fato, limitam a liberdade do sujeito, e que podem fazê-lo errar nessa eleição. Inácio sabe que somos livres, mas sabe também que estamos e somos condicionados de maneira ininterrupta; e que esses condicionamentos não se devem apenas ao que podemos chamar de "condição humana", já que é dado que nossa liberdade é limitada em si mesma. O fato é que, tanto nossas circunstâncias históricas de vida, como nossa dinâmica interna afetiva acrescentamnos condicionantes que sempre colocam em risco a liberdade conquistada, e assim supõem um impedimento para nossa capacidade de eleição. É por isso que toda a dinâmica dos EE vai buscar detectar quais são esses condicionantes, essas fixações afetivas. E serão julgadas como desordenadas ou não, através de uma determinada hierarquia de valores. E para estabelecê-los, Inácio usa a vida de Jesus como modelo de seguimento. Esse trabalho de autoanálise na detecção das ataduras e impedimentos da liberdade será elemento central da proposta inaciana. Todavia, Inácio sabe que estas afeições desordenadas não são fáceis de detectar; até porque pela própria experiência, ele sabe da imensa capacidade de auto-engano que temos. Por isso, os EE constituem-se uma autêntica "hermenêutica da suspeita", que tem por objeto avaliar e buscar compreender as estratégias do engano, no terreno da vida espiritual. 


\section{Desafios da psicologia no Brasil}

Os caminhos pelos quais a liberdade humana pode se desviar uma e outra vez são de ordem tanto externa como interna; por isso é que Inácio centra sua atenção sobre estes dois modos de desvio da liberdade. No processo dos EE, os condicionamentos estruturais poderão ser desmascarados dentro da meditação das "Duas Bandeiras"27”. . Já as ataduras internas, pessoais e afetivas serão frontalmente analisadas nas meditações dos "Três Binários" e nas dos "Três modos de humildade". Como se tudo isso não bastasse, Inácio não esquece que, assim como se passou com ele, ninguém retira seus afetos de algum objeto (sentido psicanalítico de pessoa, coisa, ideia ou situação), se não aparecer no horizonte um objeto de amor que englobe a busca pessoal; e que não só relativize esse objeto, como também o leve a desprezar e aborrecer (EE 63) todas suas antigas cargas libidinais. É necessário ter um importante objeto de amor para abandonar os amores antigos, como sempre nos disse Freud.

É a partir desse lugar que se ilumina toda a metodologia dos EE: é necessário entrar de cheio nos aspectos afetivos profundos da pessoa, já que é ali que se coloca em jogo toda a possibilidade de liberdade; e portanto, de eleição no viver.

De modo igualmente importante, Inácio sabe que esses aspectos profundos e afetivos da pessoa não se mobilizam por meio de puras ideias e nem de pensamentos elevados. Se essas ideias não se impregnam de afeto, se não arrastam atrás de si as aspirações profundas do sujeito, pouco ou nada será modificado. Por isso, faz-se necessário trazer a ajuda dos sentidos e da imaginação, elementos que são do psiquismo, e guardam grande proximidade com o mundo afetivo que há que se saber mobilizar.

Desde essa profunda intuição, Inácio convidará o exercitante, já na "Primeira Semana", a colocar sob um olhar atento essas estruturas afetivas. Nesses primeiros momentos será fundamental sensibilizar a pessoa a fundo, para que sejam transformadas estruturas mais arcaicas, condição para acontecer uma possível mudança, em vistas a torná-la mais livre.

A partir da "Segunda Semana", tudo vai centrar-se na figura de Jesus, proposta que Inácio apresenta ao exercitante como alternativa amorosa. No entanto, para que essa alternativa se torne central, não é suficiente o mero conhecimento; há que ser conhecimento interno, único capaz de colocar toda nossa afetividade em jogo, inclusive para gerar a resposta dupla que é necessária: a do amor e a do seguimento (para que mais o ame e siga) a Cristo.

Em relação à Anotação 1 (o que são os EE), observemos a totalidade de funções psíquicas que Inácio deseja por em jogo com o método dos EE: qualquer modo de examinar a consciência, de meditar, de contemplar, de orar vocal e mentalmente, e outras operações espirituais. Entra em jogo todo o mundo 


\section{Desafios da psicologia no Brasil}

interno, desde a ativação das faculdades intelectuais (examinar, meditar: isto é, análise e compreensão) como a das faculdades afetivas (contemplar e orar: isto é, imaginativas e relacionais). E assim seguidamente, nas várias anotações e em outras regras, poderemos ver como Inácio concede peso e presença a cada uma delas. Na Anotação 2 por exemplo, a primazia é das zonas afetivas sobre as intelectivas, pois se trata de pensar a modificação na vida, em que "não é o muito saber que sacia e satisfaz a alma, mas o sentir e saborear as coisas internamente".

E aproveitando essa frase de Inácio, podemos fazer aqui um paralelo com o trabalho psíquico durante um processo de Análise Pessoal: não é o saber e o conhecimento que levam uma pessoa a sentir-se plena e satisfeita consigo mesma, mas sim o sentir e saborear sua vida e processos internos. Se retomamos o que foi dito sobre os EE neste tópico que acabamos de desenvolver, fica evidente e presente, e sempre subentendido, o paralelo com o trabalho psíquico. Vejamos alguns destes pontos:

- É entrar no mundo afetivo do paciente, para que ele se acomode e ordene desde sua compreensão de si mesmo e do que deseja para si, conhecendo melhor os potenciais que tem, e assim se expandindo internamente, constituindo-se em um "Princípio e Fundamento" do seu Viver.

- Durante o processo, sabe-se que se torna necessário rever as cargas afetivas dos objetos libidinalmente investidos, retirando-as e/ou colocando-as em novos objetos amados. Tudo isso porque desde o início da vida psíquica, as vinculações afetivas vão se fazendo, quer com pessoas, objetos materiais, ideias e fantasias, como até mesmo com nosso próprio corpo físico.

- E faz-se mister também conhecer quais são nossas necessidades e desejos, rever valores, pensamentos, condutas, para colocar tudo a serviço de uma maior saúde interna, geradora de melhor disposição frente à vida e às muitas relações. Ou seja, uma vida confrontada com o mundo interno e externo, e não reduzida a um mundo fantasmático e voltado para si mesmo.

- Se os EE são uma "hermenêutica da suspeita", dentro do terreno da vida espiritual, a Psicanálise é uma "hermenêutica da suspeita", dentro do terreno da vida emocional.

\subsection{ORGANIZAÇÃO DOS EE: SUA ESTRUTURA E SUA DIVISÃO INTERNA}

Vimos que a atenção e o cuidado estão sempre presentes nas propostas de Inácio. E isso para que observemos com cuidado tanto o que nos acontece e vem de fora, como o que nos acontece vindo de dentro, naquilo que concluímos por nós mesmos. Vale mencionar que Inácio é pensado como um mestre da suspeita ${ }^{28}$, pois sempre coloca "sob suspeita o próprio sujeito, a própria pessoa crente e a 


\section{Desafios da psicologia no Brasil}

sua experiência de fé29" . No decorrer do processo dos EE, ele incita-nos continuamente a suspeitar de nós mesmos, oferecendo-nos "avisos e regras", nos quais temos que fazer uso de nosso aparato de inteligência, memória e vontade. Tudo tem como meta conhecer e ordenar os afetos, condição para que a pessoa humana alcance a liberdade e o sentido verdadeiro de sua vida. Não é isso que também almejamos quando nos debruçamos psicanaliticamente sobre o mundo interno de nossos pacientes? Inácio empenha-se em fornecer-nos meios e instrumentos (Regras, Anotações, Adições) que levam ao discernimento da mente e nos dão a dimensão pedagógica dos EE. Estes meios, entremeados com o processo das Quatro Semanas, nas orações de meditação e contemplação que ali se dão, favorecem o ordenar a vida (mas lembremos: não para tê-la resolvida!) e a acolhida do dom, sempre com "ânimo e generosidade para com o Senhor", num permanente discernimento do coração.

Dentro da dimensão pedagógica dos $\mathrm{EE}^{30}$, destacaremos algumas partes mais diretamente relacionadas ao discernimento, e que aqui nos interessam:

Regras para ordenar-se daqui por diante na alimentação [EE 210-217 - Introdução]:

É a busca da temperança. Inácio coloca estas regras apenas na Terceira Semana. No entanto, pe. Chércoles já as coloca na Introdução, pois nos trazem uma questão chave nos EE, e com a qual desde o início há que se enfrentar, que é a questão dos desejos. O problema é onde e como eles estão presos, enganchados, pois não é qualquer forma de desejar que nos convém. Estas regras são avisos que nos ajudam a compreender e a ordenar nossos desejos, independentemente de quais sejam eles; e tudo para que tenhamos ânimo e força para dar o melhor que há em nós, sentindo-nos livres, e não presos em nós mesmos. $(p .64,73)$

Regras para de algum modo sentir e conhecer as diversas moções que se produzem na alma [EE 313327]: Regras de discernimento de Primeira Semana.

Tratam de como interpretar o que sentimos dentro de nós, para saber como proceder em diferentes estados de ânimo que naturalmente nos acometem: ilusões, temores, depressões, etc. Isso é essencial para seguirmos em direção àquilo que vale a pena, e para não desistirmos quando o que sentimos é desagradável, e para não acreditarmos que tudo está resolvido quando estamos animados. Cabe àquele que "dá" os EE, saber e mostrar ao exercitante (como está dito no EE 6) que estes estados de ânimo não vão ser referidos a ele, o que "dá os $E E$, mas a Deus, que é com quem o encontro se dá, e com quem a interlocução é a razão última dos próprios EE. (p.91-92). 


\section{Desafios da psicologia no Brasil}

Regras para a mesma finalidade com maior discernimento de espíritos [EE 328-336]: Regras de discernimento de Segunda Semana.

Estas regras vão mostrar-nos que não é suficiente ter boa vontade, ideias claras e mesmo boas intenções, e ainda considerar que nossas ações são corretas. Pois mesmo assim, podemos nos enganar, e ainda causar mal a outros. Estas regras nos tornam humildes, conscientes de que não somos perfeitos, e de que não podemos estar tão seguros de nós mesmos. (p.246).

Regras a observar no encargo de distribuir esmolas [EE 337-344 - Segunda Semana]:

Atualizando o título destas regras, não se trata apenas de distribuir esmolas, mas de compartilhar, ajudar e servir ao próximo. Estas regras ajudam-nos também a pensar não apenas na partilha de bens materiais, mas na de bens internos; trata-se de distribuir o que, como, quando, quanto, e onde devemos distribuir o que temos e somos. (p.327).

Notas que ajudam a sentir e compreender os escrúpulos [EE 345-351 - Segunda Semana]:

São notas para não se fixar no exagero ou nos detalhes. Notas para ajudar a distinguir o que é um verdadeiro escrúpulo, do que é apenas um equívoco, um engano. Tomar consciência de que uma coisa é duvidar, outra é suspeitar: quando duvido, me angustio e não sei o que fazer, quando suspeito, fico mais alerta, vou com mais cuidado e estou mais atento. (p.334)

Regras a observar para ter o sentir verdadeiro, que deve ser o nosso, na Igreja militante [EE 352-370 - após a Quarta Semana]:

Inácio educa-nos na relação com a Instituição, com os superiores, com os iguais e com todos. Tomar por certo que isso se aplica a qualquer instituição, como a de trabalho, e inclusive a família; e não apenas à relação com a Igreja.

Atentar como em todas as Regras acima, Inácio está propondo que se desenvolva um olhar para si mesmo; uma introspecção que se volte para o próprio Ego, mas para poder pensá-lo à luz de outras possibilidades, de outro jeito de ser e proceder no mundo, tendo a Cristo como modelo de seguimento. Estar na vida e socializar-se é encontrar um modelo de seguimento que satisfaça e que dê oportunidade para o uso dos melhores recursos que se tem, buscando equilibrá-los na relação com o próximo. Entre muitas outras coisas, um processo de Psicanálise também visa facilitar que este processo se dê, sempre tomando a própria pessoa e seus valores como referência para o crescimento e expansão de si. O processo dos EE visa o mesmo, um "acertar na vida", mas desde um "para" (que busca a imitação de Cristo) que norteia o viver e dá sentido ao existir. E toda essa experiência tem 


\section{Desafios da psicologia no Brasil}

como corolário a busca da interlocução com Deus (com a divindade, se assim preferirmos falar), sempre considerando que o que se deseja alcançar é a transcendência de si mesmo.

\section{CONSIDERAÇÕES FINAIS}

Em termos da vivência de fé, a semente que encontra boa terra e dá fruto ${ }^{31}$ é a que se traduz em uma identidade espiritual, que é fruto do encontro consigo mesmo e com uma autêntica esfera de valores espirituais, nunca concebidos como algo alheio à experiência humana. Estes valores espirituais são livres de toda ideologização, pois esta é sempre um refúgio, mesmo que seja uma ideologia religiosa.

A Companhia de Jesus, desde as intuições fundamentais de Inácio, sempre teve sensibilidade especial para o diálogo entre a teologia do Espírito e as ciências humanas. A Psicologia implícita nos EE desenvolveu-se a partir de sucessivas referências culturais e científicas, a serviço do homem e de sua experiência espiritual. Apesar de suas possibilidades e limites, a ferramenta psicológica permite construir uma antropologia espiritual que, coerente com a dinâmica dos $E E$, abre o homem à transcendência, sem negar sua verdade psiquicamente corporal.

Os EE são um instrumento de mudança, e quer passem por uma eleição de vida ou mesmo por um crescimento espiritual, neles está em jogo uma conversão, que é a versão teológica da mudança psíquica. Vividos "com grande ânimo e generosidade", levam sempre a experimentar uma humanidade que implica uma transformação do ego, numa trama psíquica e espiritual, em diferentes níveis. Aquele que busca os EE, quer o queira ou não, traz uma histórica psíquica que o condiciona, bloqueando ou libertando; fazer os EE é colocar essa sua história humana dentro desse itinerário que o transformará, integrando todas suas dimensões pessoais. Aquele que "dá os EE" acompanha aquele que "os faz" com enorme respeito à sua liberdade, oferecendo-Ihe seu senso comum, seu realismo, seus conhecimentos, sua experiência, e contemplando a viabilidade humana, consciente do mistério de Deus. A Psicologia aqui considerada não é um luxo, e nem leva a um individualismo intimista; ela está a serviço da comunidade humana, pois não se esquece de que o exercitante dos EE é uma pessoa solidária, fruto e agente de uma história que a chama a se libertar, mas vinculada a um povo, no seguimento de Jesus.

Meissner afirma ${ }^{32}$ que no processo do desenvolvimento de uma identidade psicológica, a pessoa adquire um sentido consciente de sua própria e única identidade individual, em continuidade com sua personalidade, e com a satisfatória integração dos subsistemas estruturais que formam seu corpo e sua mente, assim como um sentido de solidariedade a um conjunto de valores que tem relação com 


\section{Desafios da psicologia no Brasil}

um contexto social e cultural específicos. Por sua vez, a identidade espiritual é algo cujo crescimento e maturação supõe que a pessoa aceite e responda à ação da Graça; e esse crescimento é mais firme quando se constrói sobre a base sólida de uma identidade psicológica madura. Do ponto de vista psicológico, a pessoa é levada a conceber o efeito da Graça como uma influência que enche de energia o seu Ego, consciente ou inconscientemente, capacitando-o para mobilizar seus próprios recursos e funções.

Podemos encontrar o desenvolvimento dessas identidades no Inácio maduro, depois de sua longa peregrinação exterior e interior. Se a Graça atua sobre todo o psiquismo, em consecução de uma identidade espiritual madura, poderíamos dizer então que Inácio saiu de uma etapa muito distante da realidade exterior, em que estava submerso em suas grandes fantasias narcisistas ou em sua atormentada submissão a um Super-Ego sádico, para um tempo em que estabeleceu adequadas relações objetais, dirigindo sua Pulsão de Vida para fora de si. Assim, o interesse por estabelecer vínculos espirituais com outras pessoas - as "conversões espirituais" passam a ser sua ocupação principal - substituiu o seu anterior isolamento. Psicanaliticamente, podemos dizer que a libido narcisista converteu-se em libido objetal, e que as pulsões de vida neutralizaram as pulsões de morte. O Super-Ego flexibilizou-se e permitiu o fortalecimento do Ego. Desse modo, a estrutura egóica permitiu-lhe estabelecer vínculos objetais adequados e criativos, na busca de um projeto pessoal, e em consonância com a busca de um projeto em comum com outros companheiros. Ficou para trás a etapa do Inácio-eremita de Manresa, vestido de farrapos e com cabelo, barba e unhas crescidas $^{33}$, submerso em seus próprios pensamentos, e em suas grandes consolações e desolações. Nas etapas seguintes - Alcalá, Salamanca, Paris - apareceu o Inácio-universitário, em relação estreita com um grupo de companheiros que ele congrega em torno de um projeto comum, que inspira e alenta. $E$ neste projeto estão os $\mathrm{EE}$, experiência fundamental que traduz seu próprio itinerário, com toda a riqueza da experiência acumulada. Uma serena visão crítica permitiu-lhe tomar distância da idealização de figuras religiosas e de grandes penitências, e reconhecer que naquela época "não olhava a circunstância alguma interior" (isto é, não havia discriminação suficiente do exterior, que ele tomava falsamente como próprio, criando uma identidade artificial) "nem sabia o que era humildade" (isto é, vivia no inautêntico, submerso em um falso encontro consigo mesmo), "nem caridade, nem paciência, nem discrição para regular ou medir estas virtudes ${ }^{34 \prime \prime}$. A discrição ou discernimento passa a ser o centro de sua disposição espiritual; ela o torna capaz de descobrir que até a oração pode ser uma tentação, quando não for "discreta"; ou seja, quando impedir a realização do projeto total ${ }^{35}$. Desse modo, a discrição ou "bom juízo" passam a ser a chave de uma identidade espiritual madura e 


\section{Desafios da psicologia no Brasil}

formada, qualidade que sempre deverá ter o Geral da Companhia de Jesus (Const. 735), mesmo que Ihe faltem outras qualidades. Na verdade, isto é reflexo da chave de sua própria identidade espiritual, vale dizer, do efeito transformador da graça sobre seu psiquismo. Da impulsividade anterior restou pouco. O Super-Ego deixou de ser persecutório e rígido. O Ego cumpre suas funções, e é a porção da vida anímica que, mediante uma adequada auto-observação, pode normatizar a relação do interno com o externo.

E se o Inácio maduro de Roma aspira a que seus seguidores vivam também uma identidade espiritual sedimentada, pode-se dizer que "não parece lhes dar outra regra... senão aquela que a discreta caridad Ihes ditar" (Const. 582). Assim resume Eduardo Montagne:

Poderíamos dizer então que para Inácio maduro, o sacrifício, a renúncia e a abnegação, tão importantes para quem quer comprometer toda sua vida no projeto, deixam de ser uma expressão masoquista de submissão a um objeto sádico externo ou interno, e convertem-se em uma conseqüência do Princípio de Realidade que rege o Ego. Ao Ego ficará a decisão consciente de aceitar, postergar ou deixar de lado uma exigência pulsional. Desse modo, as exigências instintivas do Id ou as recriminações tanáticas do Super-Ego passam pelo filtro de uma estrutura egóica fortalecida, e que os tempera com sua mediação ${ }^{36}$.

Assim, vemos que a identidade espiritual madura de Inácio não tem a ver somente com sua realidade interior, mas sim que é precisamente a possibilidade de assumir a realidade exterior, em toda sua complexidade, situando-se frente a ela com uma resposta pessoal. Isto só acontece na medida em que o isolamento narcisista cede lugar a um adequado investimento libidinal no mundo externo, que encontra então uma verdadeira significação e ressonância interior, e que torna a pessoa capaz de nutrir e definir um projeto pessoal.

Para concluir, recapitulamos o que já vimos, colocando três pontos em destaque:

1. A dimensão psicológica da pessoa está sempre presente na consecução de uma identidade espiritual: quaisquer que sejam as influências externas que as regras de discernimento assinalem em termos de "bom espírito" e "mau espírito", estas influências serão experimentadas como fenômenos psicológicos que alteram, modificam ou transformam dinamicamente a estrutura psíquica.

2. A identidade espiritual é alcançada mais plenamente quando construída sobre uma identidade psicológica madura, discriminada tanto de núcleos narcisistas que isolam da realidade ou a 


\section{Desafios da psicologia no Brasil}

deformam, assim como discriminada de severos conflitos intrapsíquicos de tipo neurótico, como pode ser um Super-Ego persecutório e rígido.

3. Uma espiritualidade, nos dias de hoje, tem que possibilitar àquele que crê, a consecução de uma identidade espiritual que necessariamente leve em conta os desafios da realidade externa, e do dinamismo do mundo psíquico pessoal. Só assim o crente pode formular, em comunhão mútua com outras pessoas, aquilo que chamamos Vontade de Deus.

Pois é assim que tanto INÁCIO como FREUD nos dão o testemunho de uma busca infatigável da verdade, da autenticidade no encontro consigo mesmo e com os demais. Na perspectiva de ambos, o que possibilita uma relação autêntica é a possibilidade de discriminar o Eu e o Outro; ou seja, é a possibilidade de interpenetrar-se, sem perder-se de si. A identidade psicológica e espiritual situa-se nesse estreito espaço em que se dá o registro dessa diferença entre o Eu e o Outro.

\footnotetext{
Maria Teresa Moreira Rodrigues

Rua Padre Vieira 268 - Bosque

13026-026 - Campinas - SP

(19) 3236-8032/ 9.9112-8032

mteresa.mrodrigues@gmail.com
}

\section{EXERCÍCIOS ESPIRITUAIS DE INÁCIO DE LOYOLA E A PSICANÁLISE: UM DIÁLOGO POSSÍVEL}

Os EE (exercícios espirituais) são um instrumento de mudança, e quer passem por uma eleição de vida ou mesmo por um crescimento espiritual, neles está em jogo uma conversão, que é a versão teológica da mudança psíquica. Vividos "com grande ânimo e liberalidade", levam sempre a experimentar uma humanidade, que implica uma transformação do ego, numa trama psíquica e espiritual, em diferentes níveis. Aquele que busca os EE traz, quer queira quer não, uma histórica psíquica que o condiciona, bloqueando ou libertando; fazer os EE é colocar essa sua história humana dentro desse itinerário que o transformará, integrando todas suas dimensões pessoais. Aquele que "dá os EE" acompanha aquele que "os faz" com enorme respeito à sua liberdade, oferecendo-lhe seu senso comum, seu realismo, seus conhecimentos, sua experiência, e contempla a viabilidade humana, consciente do mistério de Deus. A Psicologia aqui considerada não é um luxo e nem leva a um individualismo intimista; ela está a serviço da comunidade humana, pois não se esquece de que o exercitante dos EE é uma pessoa solidária, fruto e agente de uma história, que a chama a se libertar, mas vinculada a um povo, no seguimento de Jesus. 


\section{Desafios da psicologia no Brasil}

\section{REFERÊNCIAS BIBLIOGRÁFICAS}

ALEMANY, Carlos e GARCÍA-MONGE, José A. (ed.) Psicología y ejercicios ignacianos. Colección Manresa, v. 5/6, Bilbao/Santander:Mensajero/Sal Terrae, s/d, 2v.

BARTHES, Roland. Sade, Fourier, Loyola. São Paulo: Martins Fontes, 2005.

CHÉRCOLES MEDINA, Adolfo. Apontamentos para dar Exercícios espirituais de s. Inácio de Loyola. Segunda versão. Impresso, 2009,

DICCIONARIO de Espiritualidad Ignaciana. Organizado pelo GEI, Grupo de Espiritualidad Ignaciana. Colección Manresa, n.38, Bilbao/Santander: Mensajero/Sal Terrae, 2007.

COLEÇÃO DOCUMENTA S.J. Pedagogia Inaciana - uma proposta prática. 6ạ ed., São Paulo: Ed. Loyola, 1993.

DOLTO, Françoise. O evangelho à luz da Psicanálise. [Entrevistada por Gérard Sévérin], Rio de Janeiro, Imago Ed.Ltda., 2 vol., 1979.

DOLTO, Françoise. Solidão. São Paulo: Martins Fontes, 1998.

DOLTO, Françoise. A fé à luz da psicanálise. [Entrevistada por Gérard Sévérin]. Campinas, SP: Ed. Verus, 2010.

DOMínGUEZ MORANO, Carlos. Crer depois de Freud. São Paulo: Ed. Loyola, 2003.

DOMíNGUEZ MORANO, Carlos. Orar depois de Freud. São Paulo: Ed. Loyola, 1998.

DOMíNGUEZ MORANO, Carlos. Psicoanálisis y religión: el diálogo interminable. Madrid: Editorial Trotta, 2000.

DOMÍNGUEZ MORANO, Carlos. Psicodinámica de los Ejercicios Ignacianos. Colección Manresa, n. 30, Bilbao/Santander: Ediciones Mensajero/Sal Terrae, s/d.

DOMÍNGUEZ MORANO, Carlos. “Inácio de Loyola à luz da psicanálise” (1ạ. parte). In: Revista Itaici. São Paulo, 2006, n.66, p. 25-45.

DOMÍNGUEZ MORANO, Carlos. “Inácio de Loyola à luz da psicanálise” (2ª. parte). In: Revista Itaici. São Paulo, 2007, n.67, p.63-78.

LOYOLA, Inácio de. Autobiografia de Santo Inácio (até Manresa) [Introdução e notas de Maurizio Costa, sj.] São Paulo: Loyola, s/d.

LOYOLA, Inacio de. Diário Espiritual de Santo Inácio de Loyola. São Paulo: Edições Loyola. 2007.

LOYOLA, Ignacio de. El relato del peregrino: autobiografia. Bilbao: Mensajero, s/d.

LOYOLA, Santo Inácio de. Exercícios Espirituais [Orientou a tradução e fez anotações: pe. Géza Köveczes.]. 1a. ed., Porto Alegre, 1996.

LOYOLA, San Ignacio de. Obras. 6 ed. Madrid: Biblioteca de autores cristianos, 1997 


\section{Desafios da psicologia no Brasil}

MAIA, Pedro Américo. “Uma experiência de Deus: Os 'Exercícios Espirituais' de Santo Inácio: texto e contexto (IV)”. In: Revista Itaici. São Paulo, 1995. n.25, p.51-58.

MARTINI, Carlo, in GARCÍA LOMAS, Juan M. (Ed.). "Ejercicios Espirituales y mundo de hoy"- Congreso Internacional de Ejercicios. Bilbao/Santander: Ediciones Mensajero/Sal Terrae, s/d.

PAIVA, R. O Caminho do peregrino. 3ạ. ed., São Paulo, Ed. Loyola, 2007.

RAMBLA BLANCH, Josep. In: Maestros de la sospecha, críticos de la fe. Centre d'Estudis Cristianisme i Justícia. Série Estudios. n.12. Barcelona.

TETLOW, Joseph A. Os exercícios espirituais no século XX, texto fotocopiado, sem referência. 


\section{Desafios da psicologia no Brasil}

\section{NOTAS}

\section{Nota 1}

Trabalho a ser apresentado no I Congresso Internacional Pessoa e Comunidade: fenomenologia, psicologia e teologia. Setembro 2014

Nota 2

Psicanalista pela SBPSP. Mestre em Ciências da Religião pela PUC-SP.

Nota 3

KHAN, M. Masud R., La intimidad del sí mismo. Madrid, Editorial Saltés, 1980, p. 9, Prefacio. A tradução é um exercício livre da autora, assim como o são os itálicos.

Nota 4

DOLTO, Françoise. A fé à luz da psicanálise. Campinas, SP: Verus, 2010, p. 7-8.

Nota 5

LEWIS, Carl S. A abolição do homem. São Paulo, SP: Martins Fontes, 2010, p. 77.

Nota 6

Verso anotado da placa em frente ao prédio em que Borges morou. Buenos Aires. Julho de 2011.

Nota 7

DOMíNGUEZ MORANO, Carlos. Psicoanálisis y religión: el diálogo interminable. Madrid: Editorial Trotta, 2000. Há uma tradução para o português, editada pelas Edições Loyola.

Nota 8

DOLTO, Françoise. A fé à luz da psicanálise, p. 25.

Nota 9

DOLTO, Françoise. A fé à luz da psicanálise, p. 27.

Nota 10

BARTHES, Roland. Sade, Fourier, Loyola, p.XXIII.

Nota 11

BARTHES, Roland. Sade, Fourier, Loyola. São Paulo: Martins Fontes, 2005.

Nota 12

Eduardo Montagne é membro associado da Sociedade Peruana de Psicanálise, tendo sido jesuíta por longos anos. Tem um valioso artigo e conversa com Moisés Lemlij, no livro Beyond belief: psychotherapy and religion, editado pela Karnak Books (nota da autora deste trabalho).

Nota 13

MONTAGNE, Eduardo. "Identidad espiritual y psicoanálisis. Una aproximación psicoanalítica a la autobiografía de San Ignacio de Loyola". In: ALEMANY, Carlos e GARCÍA-MONGE, José A. (ed.) 


\section{Desafios da psicologia no Brasil}

Psicología y ejercicios ignacianos. Colección Manresa, v. 5/6, Bilbao/Santander:Mensajero/Sal Terrae, s/d, 2v. p.253-270, p. 254. Os negritos são da autora deste trabalho.

Nota 14

MHSI: A Monumenta Historica Societatis lesu encontra-se hoje em Roma, ao lado da Cúria Geral dos Jesuítas, mais precisamente no Instituto Histórico da Companhia de Jesus. Esta grande coleção é fruto do desejo dos Padres, em 1892, reunidos na Congregação Geral XXIV, de ver estudados e publicados os documentos que tratam das origens da Companhia de Jesus, de sto. Inácio e seus companheiros e colaboradores, das Constituições, Pedagogia e missões na Ásia e América. Na ocasião, o então Padre Geral Luis Martin recebeu a incumbência de realizar esse desejo de toda a Companhia. Constituiu-se uma equipe internacional para iniciar a coleção, que teve a sua 1a publicação em Madri, no ano de 1894.

Nota 15

TETLOW, Joseph A. Os exercícios espirituais no século XX, texto fotocopiado, sem referência.

Nota 16

TETLOW, Joseph A. Os exercícios espirituais no século XX. Os itálicos e negritos são da autora do trabalho.

Nota 17

[EE 15] Anotação 15: "Aquele que dá os exercícios não deve induzir o exercitante mais à pobreza nem a qualquer promessa, do que aos seus contrários, nem a um estado ou modo de viver, mais do que a outro. (...)"

Nota 18

LOYOLA, Inácio de. Autobiografia de Santo Inácio (até Manresa) [Introdução e notas de Maurizio Costa, sj]. São Paulo: Loyola, s/d. p.31-32 (Aut. 1).

Nota 19

[EE 7] Anotação 7: "Se o que dá os exercícios vir que o que os recebe está desolado e tentado, não se mostre duro e áspero para com ele, mas brando e suave, infundindo-lhe ânimo e forças para ir adiante, descobrindo-Ihe as astúcias do inimigo da natureza humana (...)".

Nota 20

MONTAGNE, Eduardo. In: Psicología y ejercicios ignacianos. p. 259. Os negritos são meus.

Nota 21

DOMÍNGUEZ MORANO, Carlos. Psicodinámica de los Ejercicios Ignacianos. Colección Manresa, n. 30, Bilbao/Santander: Ediciones Mensajero/Sal Terrae, s/d. Este foi um texto fundamental para a elaboração deste capítulo.

Nota 22

"A esse respeito, não deixa de ser significativo o otimismo expresso por FREUD na obra O futuro de uma ilusão, em que augurava um quase imediato fim da religião, desbancada que seria pela razão científico-técnica (o deus Logos). No entanto, poucos anos depois, ele mesmo confessa que a religião gozaria de vida muito longa, dado o alto poder que tinha no nível mais profundo e primitivo da 


\section{Desafios da psicologia no Brasil}

afetividade. Os avanços da ciência e da razão pouco poderiam contra ela (em O problema da concepção do universo)." In: DOMínGUEZ MORANO, Carlos. Psicodinámica de los Ejercicios Ignacianos. p.15.

Nota 23

Aqui não se faz distinção entre experiência religiosa e experiência de fé. Do ponto de vista psicológico, ocupamo-nos do sujeito que acredita em um objeto transcendente, e que em virtude desta crença desenvolve uma série de comportamentos específicos.

Nota 24

DOMÍNGUEZ MORANO, Carlos. Psicodinámica de los Ejercicios Ignacianos, p.44.

Nota 25

Para entender o contexto em que Dolto coloca essa distinção, vale citar: “(...) não é o virtuoso aquele que segue a lei, seja até mesmo a lei divina, mas aquele que experimenta a do Espírito, que é a presença final do desejo em nós. 'Jesus prega o desejo, e não uma moral. [Ele] é o que nos leva a buscar o que nos falta'. (...) É graças a essa ausência, a essa falta, que o jogo pode funcionar." DOLTO, Françoise. A fé à luz da psicanálise, p.9.

Nota 26

DOLTO, Françoise. A fé à luz da psicanálise, p.10.

Nota 27

Estes EE, assim como os que são citados na sequência, compõem o trabalho psicológico e espiritual da Segunda Semana. Não estão explicados porque não é o propósito neste trabalho.

Nota 28

Claro que não por estar alinhado com os grandes críticos da religião, na modernidade, que são: Marx, Freud e Nietzsche, conforme RAMBLA BLANCH, Josep. In: Maestros de la sospecha, críticos de la fe. Centre d’Estudis Cristianisme i Justícia. Série Estudios. n.12. Barcelona.

Nota 29

RAMBLA BLANCH, Josep. In: Maestros de la sospecha, críticos de la fe. Rambla considera Inácio "mestre da suspeita", porque entende que: "A suspeita é o campo mais próprio da razão. A razão é um dos instrumentos mais valiosos que o ser humano tem para afrontar o mundo. Ela não é criadora, pode ser explicadora, mas é, sobretudo, crítica e 'inquisidora' (no bom sentido da palavra): por isso é também crítica de si mesma e de seus próprios condicionamentos e limitações".

Nota 30

A cada parte "pedagógica" que compõe os EE, apresentamos uma breve explicação da mesma, feita pela autora, a partir do material do padre jesuíta Adolfo CHÉRCOLES MEDINA, in: Apontamentos para dar Exercícios espirituais de s. Inácio de Loyola. Segunda versão. Impresso, 2009. O uso do pronome em primeira pessoa deve-se ao fato de que aquele que faz os EE é sempre o autor de sua história e assim se refere a ela. As páginas de referência estão entre parênteses, após cada explicação.

Nota 31

Parábola evangélica Mt 13,8. 


\section{Desafios da psicologia no Brasil}

Nota 32

W.W.Meissner, Psychological notes on the Spiritual Exercises, citado por MONTAGNE, Eduardo. In: Psicología y ejercicios ignacianos. p. 267.

Nota 33

LOYOLA, Inácio de. Autobiografia de Santo Inácio, p.50-57 (Aut. 18-19).

Nota 34

LOYOLA, Inácio de. Autobiografia de Santo Inácio, p.46-47 (Aut. 14).

Nota 35

LOYOLA, Ignacio de. El relato del peregrino: autobiografia. Bilbao: Mensajero, s/d, p.44-45 (Aut. 55). Nota 36

MONTAGNE, Eduardo. In: Psicología y ejercicios ignacianos. p. 269. 


\section{Capítulo 20}

\section{O RECONHECIMENTO HUMANO COMO PRÁTICA EDUCATIVA NA CONSTITUIÇÃO DA SUBJETIVIDADE}

DOI: $10.37423 / 200200197$

Aleir Ferraz Tenório

aleirtenorio@gmail.com

João Luiz Gașparin gasparin01@brturbo.com.br

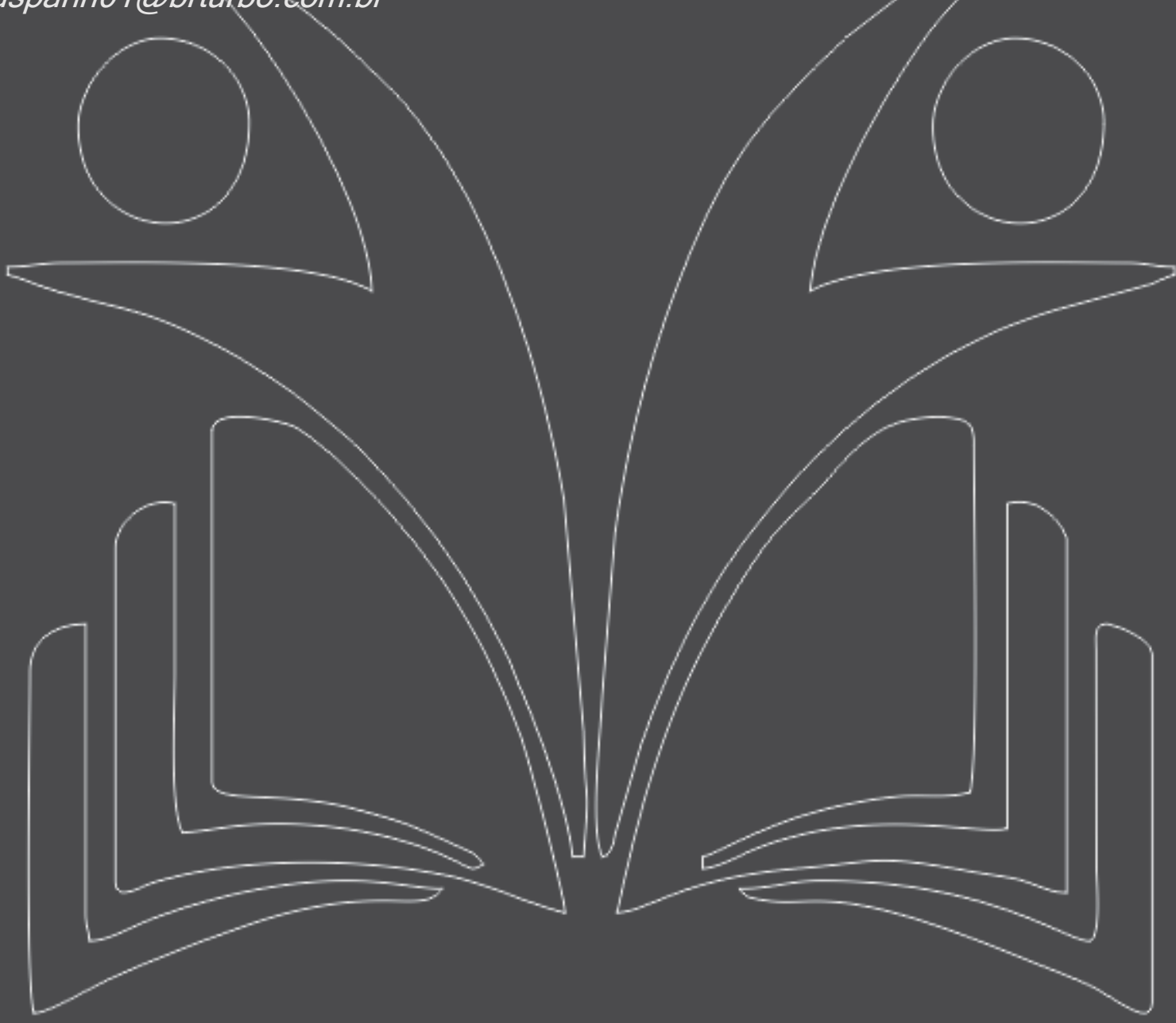




\section{Desafios da psicologia no Brasil}

\section{INTRODUÇÃO}

[...] com a dor dos deserdados, com o sonho escuro da criança que dorme com fome, aprendi que o mundo não é só meu. Mas sobretudo aprendi que na verdade o que importa, antes que a vida apodreça, é trabalhar na mudança do que é preciso mudar. Cada um na sua vez, cada qual no seu lugar (Thiago de Mello).

Um dos grandes desafios a ser enfrentado pela escola é a construção de políticas públicas focadas na valorização das várias experiências socioculturais, presentes nos diversos agrupamentos humanos. E hoje, mais do que a construção destas políticas, é premente realizar esforços pela defesa e manutenção daquelas que já foram criadas. O reconhecimento da sociedade como realidade plural, que agrega uma heterogeneidade de identidades culturais faz parte de uma discussão que não pode passar despercebida no campo da educação escolar. A lição: "o mundo não é só meu" aprendida e apreendida pelo poeta citado acima precisa ser ensinada com eficácia e entusiasmo em nossas instituições escolares.

Aqui se insere a importância de discutir a relação existente entre educação e diversidade ${ }^{1}$, entendendo que tal discussão possibilita a abertura de caminhos para a aprendizagem de valores que considere o reconhecimento humano como uma prática imprescindível a ser vivenciada na sociedade, visto a sua importância na constituição de nossa subjetividade. Subjetividade que, enquanto dimensão do sujeito, realiza-se no coletivo a partir das múltiplas relações travadas no âmbito social e define-se "por um terreno interno que se opõe ao mundo externo, mas que só pode surgir deste" (Crochik,1998).

Neste sentido, este estudo é resultado de um estudo bibliográfico, inserido numa pesquisa cujo objetivo fora investigar algumas políticas públicas educacionais voltadas à diversidade cultural a fim de compreender como as mesmas são incorporados aos currículos escolares. Mais especificamente, focamos o olhar sobre a Lei 10.639/2003 e a recomendação da presença nos currículos da escola básica do tema Diversidade Cultural Brasileira. Neste estudo bibliográfico nos deparamos com recortes teóricos importantes que nos levaram a refletir a importância do reconhecimento humano na constituição de nossa subjetividade. Neste artigo procuraremos discutir tal assunto e a importância que se faz de um currículo comprometido com o respeito às diferenças sócio-culturais.

Miguel Arroyo (1996) há muito nos advertia e continua a advertir que o movimento social e cultural, cada dia mais dinâmico e diverso, está a nos mostrar que a diversidade sociocultural de gênero, de raça e outras tantas se fazem presente em nossa sociedade e nas escolas e, nós - seres humanos nela estamos envolvidos. Portanto, constitui-se um desafio à nossa prática pedagógica e profissional, 


\section{Desafios da psicologia no Brasil}

não havendo como ignorá-la. Não a considerar, ou mesmo, em seu nome, praticar a exclusão social é um ato extremamente antidemocrático e antipedagógico. Representa um compromisso a mais com as estudantes e os estudantes em seu direito de aprender e de superar os condicionamentos sociais que as/os conformam. É nesse sentido que, em seu livro Imagens Quebradas, chama os educadores ao reconhecimento da diversidade como meio de reparação às inúmeras práticas de perversidades a que, parcela importante de brasileiros, foi, por muito tempo, submetida:

Reconhecer e estar atentos à diversidade de contextos de aprendizagens, estar atentos às trajetórias humanas, sociais de cada educando e de cada coletivo racial, social, porém não interpretaremos essa diversidade como alunoproblema, como lentos, burrinhos, ignorantes, menos capazes de aprendizagens e de formação. Que dêem conta do trato perverso dado por séculos a determinados coletivos sociais. [...] Agrupamentos afirmativos de igualdade. Democráticos, nunca segregadores [...] Por aí a escola se torna mais democrática. Mais pública. (Arroyo, 2005, p. 364).

O espaço escolar, como espaço público e democrático, que busca vivenciar relações de igualdade entre todos, indistintamente, não deve ser um lugar de exercício da segregação e nem mesmo da intransigência. Neste sentido, para que a diversidade seja respeitada,

É necessário aceitarmos que as pessoas que nela [na escola] interagem têm interesses, visões de mundo e culturas diferentes e nenhum de nós tem o monopólio da verdade, da inteligência e da beleza. Assim, para que todos façam concessões e tenham ao menos parte dos seus interesses e valores contemplados no espaço público da escola, são necessárias negociações permanentes (Praxedes, 2005, p. 123).

Ao tratar da questão curricular, Apple (2001a) enfatiza o fato de que o currículo não é apenas uma sobreposição neutra de conhecimentos que, de algum modo, aparecem nos manuais didáticos e nas escolas de um dado país. Ao contrário, ele sempre parte e envolve uma tradição seletiva, que nada mais representa senão a seleção feita por uma determinada pessoa, visão que determinado grupo tem daquilo que vem a ser o conhecimento legítimo. É o poder que certos grupos detêm na sociedade que decide e define qual será o conhecimento a ser considerado autêntico e oficial. Em resumo, sempre haverá "uma política de conhecimento oficial [...] enquanto o de outros grupos dificilmente chega a ver a luz do dia" (Apple, 2001a, p. 53).

A discriminação que, de modo aparentemente natural, classifica as pessoas em superiores e inferiores, manifestando-se na falta de reconhecimento humano é uma afronta à ética universal do homem e, diante de tal ultraje, precisaríamos sempre nos indignar. Freire (1998, p. 17), ao dela falar, assim se manifestou: "falo da ética universal do ser humano [...] A ética que se sabe afrontada na manifestação discriminatória de raça, de gênero, de classe". 


\section{Desafios da psicologia no Brasil}

São atitudes inaceitáveis eticamente e merecem, por parte de todos nós, no cotidiano de nossa ação pedagógica, posicionamentos contrários, firmes e coerentes. O silenciar sobre estes fatos só opera a reprodução das desigualdades e da propagação da ideologia da superioridade e inferioridade das raças, há muito tempo naturalizada, portanto, nessa sociedade, eticamente aceitável.

Felizmente, um número considerável de pessoas, educadores ou não, têm se levantado para propagar o grande absurdo que tem sido a separação existente na sociedade, marcando negativamente algumas mulheres e homens. Nesse aspecto, compartilhamos da idéia de que ainda que o preconceito e a discriminação não tenham sido gestados na escola, nela se fazem presentes e permeiam as relações ali vivenciadas. Entendê-los e lutar por superá-los pressupõe o compromisso de cada educadora e cada educador para com a criação de um "[...] espaço democrático de produção e divulgação de conhecimentos e de posturas que visem uma sociedade mais justa" (Gonçalves e Silva, 2004, p. 15).

McLaren (2000, p. 264) relata que o processo de escravidão foi o responsável pelo nascimento do racismo. Mostra-nos que as pessoas “[...] não discriminam grupos porque eles são diferentes. $\mathrm{O}$ ato da discriminação constrói categorias de diferença que localizam hierarquicamente as pessoas como superiores ou inferiores e, então, universalizam e naturalizam tais diferenças". Assim, os brancos utilizaram-se do que eles acreditavam - na inferiorização natural dos africanos - para fazê-los escravos.

De acordo com lanni (2007), o conceito de raça representa uma criação social que envolve jogo de forças sociais, em que ocorrem processos de dominação e apropriação. Classificar e hierarquizar constituem-se, desse modo, estruturas de poder sobre o outro, "[...] bloqueando relações, possibilidades de participação, inibindo aspirações, mutilando práxis humana, acentuando a alienação de uns e outros, indivíduos e coletividades" (Ianni, 2007, p. 3).

Desde o princípio da organização social brasileira, o negro habita um mundo social que não foi organizado para ele, ao contrário, organizou-se apenas para os segmentos privilegiados da raça branca dominante. Sua existência esteve sempre fadada ao não reconhecimento. A participação das negras e dos negros nesse mundo de pessoas brancas lhes custaram a negação da cor de sua pele e a viver um processo de identificação com o que Fernandes (2007) chama de branqueamento psicossocial e moral, capaz de simular a "condição humana por excelência", ou seja, a condição de ser branco.

Nesse sentido, Souza (1983) discute que foi com o objetivo de ser tratado como gente que as pessoas negras buscaram se assemelhar às brancas e a negarem-se como negras. Isto porque, na organização social vigente, o cidadão, ou seja, o indivíduo sujeito pleno de direitos e respeitabilidade social, era 


\section{Desafios da psicologia no Brasil}

branco e ser bem tratado representava ser tratado como branco. Tudo se resumia, portanto, ao desejo de ser humano. De ser gente. E foi com essa disposição que, segundo a autora, negros e negras se organizaram para a ascensão social, ainda que tudo isto implicasse na renúncia de si.

Ao teorizar sobre o estigma, Goffman (1975, p. 23) acrescenta que alguém que possua um estigma tem a sua existência marcada pelo constante medo de que os outros possam desrespeitá-lo por algo que ele exiba, ou seja, "o indivíduo estigmatizado pode descobrir que se sente inseguro em relação à maneira como os normais o identificarão e o receberão". O indivíduo estigmatizado vive "a sensação de não saber aquilo que os outros estão 'realmente' pensando dele". O reconhecimento antes de ser uma atitude cortês, dirigida a uma pessoa, representa uma necessidade humana vital. A falta deste mesmo reconhecimento não apenas revela o esquecimento do respeito devido a outrem, ela pode vir a "[...] infligir uma ferida cruel ao oprimir suas vítimas de um ódio de si paralisante" (Munanga, 2001, p. 6).

O racismo que, no entendimento de Guimarães (2005, p. 11), representa um modo particular de “[...] naturalizar a vida social, isto é, de explicar diferenças pessoais, sociais e culturais a partir de diferenças tomadas como naturais", passa a organizar nosso psiquismo. Racismos que, uma vez instalado em nossas mentes e modos de vida, faz parte de aspectos corriqueiros do nosso dia-a-dia e, como sabemos, manifesta-se em atitudes discriminatórias: nas piadas, nos ditados populares, nos apelidos, em algumas letras de música, entre outras coisas, as quais necessitam de estratégias inteligentes de combate.

Baibich (2001, p. 103), ao analisar a literatura de escritores judeus brasileiros contemporâneos, encontra revelações de sentimentos e comportamentos que denotam a identificação das personagens judias com os mitos do preconceito nutrido pelas maiorias psicológicas, caracterizando níveis de Autoódio. Lembra que "dentre as conseqüências mais danosas do preconceito alberga-se um fenômeno estranho e complexo que, em última instância, é o preconceito contra si mesmo, contra aquilo que seu grupo representa aos olhos dos Outros". Consequências que têm levado ao sentimento chamado de Auto-ódio, trabalhado pela autora. Sentimento, este, dirigido ao próprio grupo ao qual a pessoa pertence e decorre da identificação com o agressor.

O Auto-ódio pode ser visto como uma decorrência quase que direta do mecanismo de defesa chamado de "identificação com o agressor": indivíduos pertencentes ao grupo que é vítima do preconceito e da perseguição identificam-se com os indivíduos do grupo dominante, assimilando inclusive valores relativos à visão deturpada de seu próprio grupo, passando a 


\section{Desafios da psicologia no Brasil}

manifestar, em diferentes níveis, sentimentos e condutas deste mesmo preconceito (Baibich, 2001, p. 19).

$\mathrm{Na}$ análise conclusiva dos seus estudos, Baibich (2001) enfatiza que o indivíduo, vítima do preconceito, ao perceber que é da natureza de sua identidade que emana a perseguição do Outro contra si mesmo, toma a atitude quase reflexa de separar-se do seu grupo, destruindo sua condição de estado de pertença, no intuito de escapar do perigo iminente que o mesmo lhe representa. Segundo a autora, o ataque impetrado, pelo indivíduo vítima de preconceito, à sua identidade se revela de modo variado: desde o disfarce daquilo que se é (no caso do negro, atitude esta de difícil realização, uma vez que a sua aparência o denuncia), passando pelas formas que buscam esconder a identidade, até as formas de total aniquilamento identificatório.

Costa (1983), ao prefaciar o livro de Neusa Santos Souza, Tornar-se Negro, afirma que a violência racista imposta pelo branco ao negro exerce-se no sentido de destruir a identidade do negro como sujeito. Este, mesmo sabendo que ao desejar se tornar branco estará negando a si mesmo, não consegue se desvencilhar de tal aspiração. Nesse sentido explica:

O negro sabe que o branco criou a inquisição, o colonialismo, o imperialismo, o anti-seminitismo, o nazismo, o stanilismo e tantas outras formas de despotismo e opressão ao longo da história. O negro também sabe que o branco também criou a escravidão e a pilhagem, as guerras e as destruições, dizimando milhares de vidas. O negro sabe igualmente que, hoje como ontem, pela fome de lucro e poder, o branco condenou e condena milhões e milhões de seres humanos à mais abjeta e degradada miséria física e moral. O negro sabe de tudo isto e, talvez, muito mais. Porém, a brancura transcende o branco. [...] Eles são a cultura, a civilização, em uma palavra, a "humanidade". O racismo esconde assim o seu verdadeiro rosto. Pela repressão ou persuasão, leva o sujeito negro a desejar, invejar e projetar um futuro identificatório antagônico em relação à realidade de seu corpo e de sua história étnica e pessoal (Costa, 1983, p. 5).

A autora, neste excerto, sintetiza a intensidade do modo de atuação da ideologia do branqueamento sobre a constituição da subjetividade do negro. O fato de saber que foram as pessoas brancas que construíram sua própria imagem de superioridade e, conseqüente, a inferiorização da imagem dos outros elementos constituintes de nossa identidade; que elas são as responsáveis pela morte e destruição de milhares de pessoas negras; que, em busca do poder e do aumento de riquezas, fabricaram a escravidão, não são suficientes para operar uma mudança no sentido de desmistificar a imagem dessas pessoas brancas e de deixar de lado o desejo de "ser" uma delas. A expectativa de ser branca/o, que para as pessoas negras carrega a simbologia do respeito, da consideração, da estima, da valorização e da não-discriminação, entre tantas outras coisas, continua-lhes a atravessar a razão e, hoje ainda, opera na realidade psíquica dos/das afro-descendentes. 


\section{Desafios da psicologia no Brasil}

O Estado brasileiro sempre se omitiu em relação à questão racial e nunca buscou enfrentar as desigualdades históricas que afetaram e afetam, particularmente, as/os afrodescendentes e, muito menos, no que diz respeito políticas de reparação social no âmbito da educação escolar. Daí a necessidade que se faz premente, hoje, de trazer para a sala de aula tal discussão.

De acordo com Gonçalves e Silva (2004), o Estado precisa oportunizar às pessoas afrodescendentes políticas curriculares que garantas às crianças negras sucesso em suas vidas acadêmicas. Isto representa não apenas a garantia de acesso à escola. É preciso dar-lhes condições de, nesta escola, permanecerem e de, sendo Ihes oferecida uma educação de qualidade, concretizarem suas aprendizagens.

Para tanto, é necessário que se invista em políticas de reconhecimento, capazes de propiciar mudanças em nível dos discursos, raciocínios, lógicas, gestos, posturas e modos de tratamento reservado às/aos estudantes negras/os. São, portanto, mudanças de caráter ético, culturais pedagógicas e políticas, relacionadas às relações raciais que precisam ocorrer nas escolas de todo o país. Uma vez que essas questões não dizem respeito apenas à escola, deverá ser fruto de um trabalho conjunto que se dará no diálogo permanente entre as instituições escolares, o estado e suas instituições centrais e os movimentos sociais.

No parecer que aprovara a Lei 10.639/03 que a instituía nos currículos escolares o Ensino da História da África e da Cultura Afro-Brasileira e depois a cultura indígena (Lei) sancionada há quase duas décadas, estava a defesa de que uma forma de respeitar as matizes étnico-raciais e de contribuir para um real processo de democratização, que precisa ser vivenciado no Brasil. E para tanto era preciso avivar, na lembrança do povo brasileiro, as individualidades históricas e culturais das populações que deram ao Brasil a feição que lhe é própria.

Isto porque, a predominância de apenas uma visão de mundo, a carência de experiências positivas voltadas à uma educação anti-racista e o silenciamento ante a desigualdade social e cultural cooperam, na escola, para a formação de mentes etnocêntricas. A respeito do etnocentrismo, de modo bem prático, Praxedes (2005, p. 112) conceitua como sendo um "[...] conjunto de representações, idéias, opiniões, em uma palavra, preconceito sobre os outros, que pode levar à atitudes de discriminações e violência material ou simbólica contra aqueles considerados estranhos e diferentes e que são estigmatizados por isso". Considera ele, um paradoxo o fato de que uma grande conquista das ciências - como a constatação da igualdade universal da espécie humana - seja de tão difícil assimilação por parte dos seres humanos. 


\section{Desafios da psicologia no Brasil}

A escola precisa, pois, preocupar-se com o desenvolvimento da conscientização crítica relacionada aos processos de imposição das culturas e visões de mundo, bem como da convivência entre identidades culturais e sociais múltiplas. A escola deve se constituir em espaço educativo significativo. Precisa e pode contribuir na redução da intolerância e do desrespeito às diferentes maneiras de ser humano, posicionando-se contrariamente a todas e quaisquer manifestações discriminatórias e preconceituosas. Para tanto, sua organização escolar, sua prática pedagógica e propostas curriculares precisam ser, constantemente, alvos de sistemático processo de reflexão.

Em relação a construção destes espaços educativos é preciso considerar reflexões em torno de propostas curriculares que afirmem as vozes das pessoas oprimidas, excluídas e marginalizadas (MCLAREN, 1997). É preciso reconhecer que diferenças existem nas salas de aula e, assim, os currículos precisas levar em conta a importância do encorajamento da manifestação dos diferentes sujeitos e, também, do desenvolvimento de uma pedagogia fundada no diálogo. Assim, é preciso:

Reconhecer a importância de espaços de encorajamento para a multiplicidade de vozes em nossas salas de aula e de se criar uma pedagogia dialógica na qual as pessoas vejam a si e aos outros como sujeitos e não como objetos. Quando isso ocorre, os estudantes tendem a participar da história, em vez de tornaremse suas vítimas (Mclaren, 1997, p. 145).

A abertura e a disponibilidade para elaborar um plano formal e não formal de ensino, que dialogue com as diferenças, subtendem a compreensão de que, assim como na sociedade, também nas salas de aula, nem todas as vozes são igualmente válidas (Mclaren, 1993). Segundo Giroux (1993, p. 53), que "precisamos de teorias que expressem e articulem a diferença, mas precisamos também compreender como as relações nas quais as diferenças são constituídas operam como parte de um conjunto mais amplo de práticas sociais, políticas e culturais". Somente após isso, será possível articular uma política de resistência à opressão sofrida, que deve se dar a partir do diálogo a respeito de como as identidades são constituídas no interior das relações de opressão.

Uma vez que, por meio da análise da realidade escolar, percebe-se que o padrão de funcionamento da escola não favorece o acolhimento às diferenças, Gimeno Sacristán (2001) informa sobre a importância de se discutir, no processo de escolarização, a integração das diversas culturas. Para ele, a cultura escolar tem valorizado em maior grau determinados componentes curriculares em detrimento de outros. Tem sido, assim, manipulada por uma racionalidade imposta pelo progresso

científico e tecnológico. Progresso que direciona a formação de currículos cada vez mais próximos às atividades econômicas e profissionais, privilegiando conhecimentos pragmáticos com prejuízo para a dimensão social. 


\section{Desafios da psicologia no Brasil}

Por currículo que respeite as variadas culturas, nomeia aquele capaz de acolher a diversidade. Para ele, toda a cultura escolar deve voltar-se a este objetivo. Ao mesmo tempo, porém, há que se considerar que os padrões de funcionamento da escolarização não favorecem o acolhimento, antes, tendem à homogeneização. Neste sentido, chama a atenção para o fato de que é necessário, então, modificar os padrões gerais de funcionamento da educação. Como ação mais concreta, sugere a mudança de padrões na seleção e desenvolvimento dos conteúdos do currículo.

Contrapondo-se à visão de formar o cidadão conforme às novas necessidades tecnológicas ou industriais, defendemos, assim como os autores aqui citados, o desenvolvimento de um currículo fundamentado por teoria pedagógica capaz de refletir acerca do processo de exclusão e permita capacitar os agentes sociais para a participação e para a luta por justiça social. Em relação à escola, é essencial que a mesma proporcione momentos de reflexão em torno do processo de marginalização ao qual foram submetidas as pessoas negras e outros agrupamentos humanos e que se discutam modos variados de reconhecimento destas humanidades.

\section{REFERÊNCIAS}

APPLE, Michel W. (2001a). Política cultural e educação. São Paulo: Cortez.

ARROYO, Miguel. (2005). Imagens quebradas. Rio de Janeiro: Vozes.

. (1996) Assumir nossa diversidade cultural. Revista da Educação AEC. Brasília, no. 98, p. 42-50.

BAIBICH, Tânia Maria. (2001). Fronteiras de identidade: o auto-ódio tropical. Curitiba: Moinho do Vento.

BRASIL. Resolução no 1, de 17 de junho de 2004. (2004) Institui Diretrizes Curriculares Nacionais para a Educação das Relações Étnico-Raciais e para o Ensino de História e Cultura Afro-Brasileira e Africana.

. Lei no. 10.639 de 09 de janeiro de 2003. (2003). Inclui a obrigatoriedade da temática "História e Cultura Afro-Brasileira" no currículo oficial da rede de ensino. Diário Oficial da União, Brasília: MEC.

CEERT. (2003) - Centro de Estudos das Relações de Trabalho e Desigualdades. Prêmio Educar para a Igualdade Racial - Experiências de Promoção da Igualdade Racial/Étnica no Ambiente Escolar. São Paulo: CEERT.

COSTA, Jurandir Freire. (1983). Da cor ao corpo: a violência do racismo (prefácio). In SOUZA, Neuza Santos. Tornar-se negro. Rio de Janeiro: Graal.

CROCHIK, J.L. (1998). Os desafios atuais do Estudo da Subjetividade na Psicologia. Instituto de Psicologia - USP.

FANON, Franz. (2008) .Pele Negra Máscaras Brancas. Salvador: EDUFBA. 


\section{Desafios da psicologia no Brasil}

FERNANDES, Florestan. (2007). O negro no mundo dos brancos. São Paulo: Global.

FONSECA, Dagoberto José. (2009). De Palmares à Consciência Negra. Recuperado em 20 fevereiro, 2009, de http://www.revistamissoes.org.br/quadro2.php?url=edicoes.

FREIRE, Paulo.(1998). Pedagogia da autonomia: saberes necessários à prática educativa. Rio de Janeiro: Paz e Terra.

GIMENO SACRISTÁN, J. (2001). Currículo e diversidade cultural. In: SILVA, Tomaz Tadeu; MOREIRA, Antônio Flávio Barbosa (Orgs.). (2001). Territórios contestados: o currículo e os novos mapas políticos e culturais. Petrópolis/RJ: Vozes.

GIROUX, Henry A. (1993). O pós-modernismo e o discurso da crítica educacional. In: SILVA, Tomaz Tadeu (Org.) Teoria educacional crítica em tempos pós-modernos. Porto Alegre: Artes Médicas.

GOFFMAN, Erving. (1975). Estigma: notas sobre a manipulação da identidade deteriorada. Rio de Janeiro: Zahar.

GONÇALVES \& SILVA, Petronilha Beatriz. (2007) Pode a educação prevenir contra o racismo e a intolerância? Artigo apresentado no Seminário "Racismo, Xenofobia e Intolerância". Recuperado em 11 de novembro, 2000 de http://www.lpp-uerj.net/olped/documentos/ppcor/0083>.

- (2004). Parecer das Diretrizes Curriculares Nacionais para a Educação das Relações ÉtnicoRaciais e para o Ensino de História e Cultura Afro-Brasileira e Africana. Brasília: MEC/CNE.

GUIMARÃES, Antônio Sérgio Alfredo. (2005). Racismo e anti-racismo no Brasil. Fundação de Apoio à Universidade de São Paulo. São Paulo: Editora 34.

HALL, Stuart. (2006). Da diáspora: Identidades e mediações culturais. Belo Horizonte: Editora UFMG.

IANNI, Octávio. (2007). A dialética das relações raciais. Recuperado em 11 novembro, 2007, de <http://www.sociologia.com.br/arti/colab/a16-oianni>.

. A era do globalismo. (1999). Rio de Janeiro: Civilização Brasileira.

MCLAREN, Peter. (2000). Multiculturalismo revolucionário: Pedagogia do dissenso para o novo milênio. Porto Alegre: ARTMED.

Multiculturalismo crítico. (1997). São Paulo: Cortez.

MUNANGA, Kabengele. (2001). Políticas de ação afirmativa em benefício da população negra no Brasil: um ponto de vista em defesa de cotas. Revista Sociedade e Cultura, Goiânia.

PPP - Projeto político pedagógico. (2006). Maringá/PR. Escola - campo de pesquisa.

PROJETO NEGRITUDE E CIDADANIA. Escola - campo de pesquisa. Maringá/PR: 2008.

PRAXEDES, Walter Lúcio de Alencar. (2005). A questão da educação para a diversidade sócio-cultural e o etnocentrismo. In: ASSIS, Valéria Soares de (Org.). Introdução à antropologia. Formação de Professores, EAD, n. 7. Maringá: UEM. 


\section{Desafios da psicologia no Brasil}

SOUZA, Neuza Santos. (1983). Tornar-se negro. Rio de Janeiro: Graal 


\section{Desafios da psicologia no Brasil}

\section{NOTAS}

\section{Notas 1}

Atitudes de apreço à diversidade, de acordo com McLaren (2000) não podem vir qualificadas com hipócritas afirmações de assimilação e consenso, que, apenas, têm servido como apoio aos "modelos democráticos neoliberais de identidade". Para este autor, ao tratarmos a questão da diversidade, devemos fazê-lo com ênfase na reflexão a respeito do processo pelo qual foi construída e continua a ser afirmada a supremacia de alguns grupos humanos em detrimento de outros, no intuito de questionar o poder e os privilégios presentes nas relações sociais. (HALL, 2006; MCLAREN, 2000). 


\section{Capítulo 21}

\section{TRANSTORNO DO ESPECTRO AUTISTA E COMORBIDADES: UMA PROBLEMÁTICA POSSÍVEL}

\section{DOI: $10.37423 / 200200201$}

Claudia Moreira de Lima

cml_claudiamoreira@hotmail.com

Tamires Fortunato de Lima Rosa tamires_tfl@hotmail.com

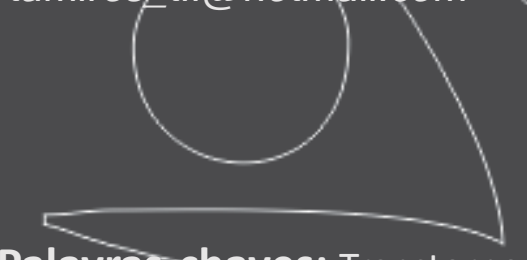

Palavras-chaves: Transtorno do Espectro Autista./Comorbidades.
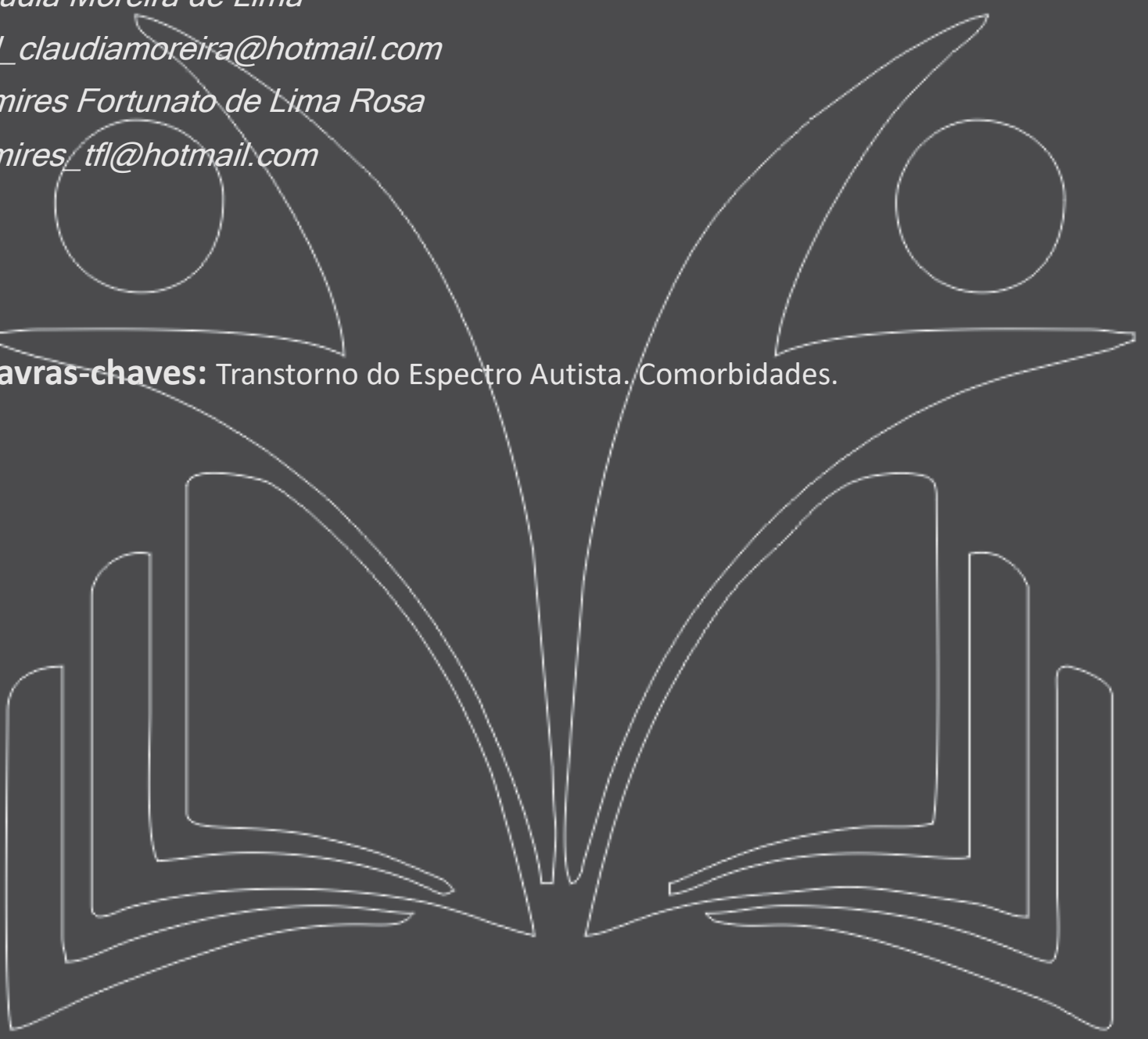


\section{Desafios da psicologia no Brasil}

O Transtorno do Espectro Autista (TEA) é uma síndrome com etiologias diversas, desencadeado por fatores genéticos e/ou ambientais ((BAILEY et. al., 1995) (MUHLE, TRENTACOSTE, \& RAPIN, 2004) (SANDIN et al., 2014) (GRABRUCKER, 2013; TORDJMAN et al., 2014) (GAUGLER et al., 2014)), caracterizado como um desenvolvimento anormal com grande heterogeneidade, e afeta o processo de desenvolvimento infantil podendo afetar as áreas de identificação, o uso inapropriado da linguagem e comportamentos estereotipados e repetitivos (MESQUITA; PEGORARO, 2013). A incidência deste transtorno tem crescido de forma significativa em todo o mundo, estima-se que 0 transtorno afete $1 \%$ da população e acomete quatro vezes mais sexo masculino que o feminino (CHRISTENSEN et al., 2016). Em estudo realizado em Massachusetts, apontou que até o ano de 2025 o índice de autismo correspondera a 50\% das crianças (GARCIA et al., 2016) (BIELEMANN et al., 2019). Esse aumento na prevalência do TEA é, em grande parte, um resultado da ampliação dos critérios diagnósticos e do desenvolvimento de instrumentos de rastreamento e diagnóstico com propriedades psicométricas adequadas (GRINKER, 2010). Neste sentido, deve-se atribuir um maior cuidado no diagnóstico pela possibilidade da existência de comorbidades que são detectadas estão presentes em 20\% dos indivíduos com Transtornos do Espectro do Autismo em amostras não selecionadas (GARCIA et. al., 2016), podendo ser de $70 \%$ a prevalência de um transtorno mental e de $40 \%$ de dois ou mais transtornos (AMERICAN PSYCHIATRIC ASSOCIATION, 2013). Mister a identificação de condições que coexistam com um quadro de TEA, como: Transtorno de Déficit de Atenção e Hiperatividade (TDAH); as encefalopatias crônicas e as paralisias cerebrais e síndrome de Tourette, síndrome de Down, bem como deficiências visuais e auditivas (CHARMAN \& BAIRD, 2002), problemas comportamentais, sensoriais e médicos. Sendo assim, todas elas (uma ou mais) podem coexistir em uma criança com TEA ((ZAZFEIRIOU; VARGIAMI; CHILDHOOD, 2007) (SILVA; MULICK, 2009)), assim contribuindo para uma melhor identificação de tratamento. Diante do exposto, o objetivo deste estudo é reconhecer a dificuldade do diagnóstico de TEA pela presença de comorbidades que coabitam com este transtorno. Tratou-se de um estudo quantitativo de cunho exploratório descritivo. A coleta de informações foi realizada entre os meses de janeiro a maio do ano de 2018. Os dados foram extraídos dos prontuários dos usuários de dois Centro de Atenção Psicossocial Infanto Juvenil (CAPSi) em Mato Grosso. A escolha da população envolveu o universo de prontuários que se encontravam ativos no momento da coleta, totalizando 45 prontuários. Dentre os documentos analisados, foram destacados e notabilizados aqueles que se encontravam com as informações necessárias completas, o que caracterizou 100\% dos prontuários identificados. Posteriormente, os dados coletados foram codificados e armazenados em planilha eletrônica do programa Microsoft Excel para análise. De acordo com os resultados, observou- 


\section{Desafios da psicologia no Brasil}

se que $15,9 \%$ dos prontuários trazem o diagnóstico de TEA associado à outra comorbidade. De acordo com as informações encontradas, levando em conta os anos em que foram diagnosticadas, as comorbidades mais frequentes foram: TDAH com 4,54\%; Hiperatividade com 4,54\%; Transtorno Opositor Desafiador (TOD), Síndrome de Asperger, Atraso Global do Desenvolvimento, Comprometimento cognitivo, Deficiência Intelectual, Síndrome de Down, Problemas de linguagem, Compulsão alimentar e Epilepsia aparecem com 2,27\% cada uma. Portanto, este resultado sugere que o TEA é frequentemente associado a comprometimentos intelectual e transtornos estruturais de linguagem. Portanto, é possível verificar que as comorbidades no TEA caracterizam-se como uma temática com muito pouco alcance no que tange os empreendimentos de pesquisas, tendo a necessidade de mais estudos que coloquem em pautas as relações comórbidas, com vista a construir intervenções práticas e precisas para reabilitação dos sujeitos acometidos (BIANCHINI; SOUZA, 2014). Quando o diagnóstico de TEA vem de forma tardia, por ausência ou iniciativas de detecção precoce da síndrome, o indivíduo perde a possibilidade de corrigir problemas já na primeira infância, este fato pode trazer consequências no desenvolvimento futuro, tendo que a identificação precoce possibilita uma intervenção também precoce o que gera melhoras no quadro clinico, além das idas e vindas dos pais a vários especialistas em busca de diagnóstico e tratamento ((VISANI e RABELLO, 2012; MACEDO, 2013)). Conclui-se, que as comorbidades estão presentes no diagnóstico de TEA, que leva a pensar sobre a necessidade do esgotamento das possibilidades de diagnósticos diferenciais, visando evitar distribuições de diagnósticos equivocados. Dessa forma, é necessário o diagnóstico diferencial diante do sujeito com sintomas característicos do TEA, assim como ter um olhar voltado para a subjetividade do sujeito, visto que, cada processo de desenvolvimento é próprio, existindo a possibilidade do desenvolvimento tardio de várias funções, que não necessariamente caracterizará um transtorno do desenvolvimento.

\section{REFERÊNCIAS}

AMERICAN PSYCHIATRIC ASSOCIATION. Diagnostic and Statistical Manual of Mental Disorders, Fifth Edition (DSM-V). Arlington, VA: American Psychiatric Association, 2013.

BAILEY A, Le COUTEUR A, GOTTESMAN I, BOLTON P, SIMONOFF E, YUZDA E, et al. Autism as a strongly genetic disorder: evidence from a British twin study. Psychol Med. 1995;25(1):63-77. 13.

BIELEMANN VLM, et al. A inserção da família nos centros de atenção psicossocial sob a ótica de seus atores sociais. Texto contexto - enferm. Florianópolis. 2009:18(1);131-139.

CHARMAN, T; BAIRD, G. (2002). Practitioner review: Diagnosis of autism spectrum disorder in 2- and 3-year-old children. Journal of Child Psychology and Psychiatry, 43(3), 289-305. 


\section{Desafios da psicologia no Brasil}

CHRISTENSEN DL, BAIO J, VAN NAARDEN BRAUN K, BILDER D, CHARLES J, CONSTANTINO JN, DANIELS J, DURKIN MS, FITZGERALD RT, KURZIUS-SPENCER M, LEE LC, PETTYGROVE S, ROBINSON C, SCHULZ E, WELLS C, WINGATE MS, ZAHORODNY W, YEARGIN ALLSOPP M; Centers for Disease Control and Prevention (CDC). Prevalence and characteristics of autism spectrum disorder among children aged 8 years--Autism and Developmental Disabilities Monitoring Network, 11 Sites, United States, 2012. MMWR Surveill Summ. 2016;65(3):1-23. Erratum in: MMWR Morb Mortal Wkly Rep. 65(15):404, 2016.

GARCIA AHC, VIVEIROS MM, SCHWARTMAN JS, BRUNONI D. Transtornos do espectro do autismo: avaliação e comorbidades em alunos de Barueri, São Paulo. Revista Psicologia: Teoria e Prática, 18(1), 166 177. São Paulo, SP. 2016.

GAUGLER T, KLEI L, SANDERS SJ, BODEA CA, GOLDBERG AP, LEE AB, BUXBAUM JD. Most genetic risk for autism resides with common variation. Nature Genetics, 46(8), 881-885, 2014.

GRABRUCKER AM. Environmental factors in autism. Frontiers in Psychiatry, 3(118), 1-13, 2013.

GRINKER RR. Autismo um mundo obscuro e conturbado. São Paulo: Larrousse do Brasil; 2010. 320 p.

MUHLE R, TRENTACOSTE SV, RAPIN I. The Genetics of Autism. Pediatrics, 113(5), 472-486, 2004.

SANDIN S, LICHTENSTEIN P, KUJA-HALKOLA R, LARSSON H, HULTMAN CM, REICHENBERG A. The familial risk of autism. JAMA; 311(17):1770-7, 2014.

SILVA M, MULICK JA. Diagnosticando o transtorno autista: aspectos fundamentais e considerações práticas. Psicol. cienc. prof., Brasília, v. 29, n. 1, p. 116-131, 2009.

TORDJMAN S, SOMOGYI E, COULON N, KERMARREC S, COHEN D, BRONSARD G, XAVIER J. Gene $\times$ Environment Interactions in Autism Spectrum Disorders: Role of Epigenetic Mechanisms. Frontiers in Psychiatry, 5(53), 1-17, 2014.

ZAFEIRIOU DI, VERVERI A, VARGIAMI E. Childhood autism and associated comorbidities. Brain Dev. 29(5):257-72, 2007. 


\section{Capítulo 22}

\section{PRINCÍPIOS DA INCLUSÃO ESCOLAR NA OBRA FREIREANA}

DOI: $10.37423 / 200200205$

Maria Lúcia Terra (UNESP/Faculdade de Ciências e Tecnologial Pós Graduação em Educação/Présidente Prudente/SP).

marialuciaterra@yahoo.com.br

Elisa Tomoe Moriya Schlünzèn (UNESP/Faculdade de Ciências e Tecnologia Pós Graduação em Educaçầ/Presidente Prudente/SP). elisa@fct.unesp.br

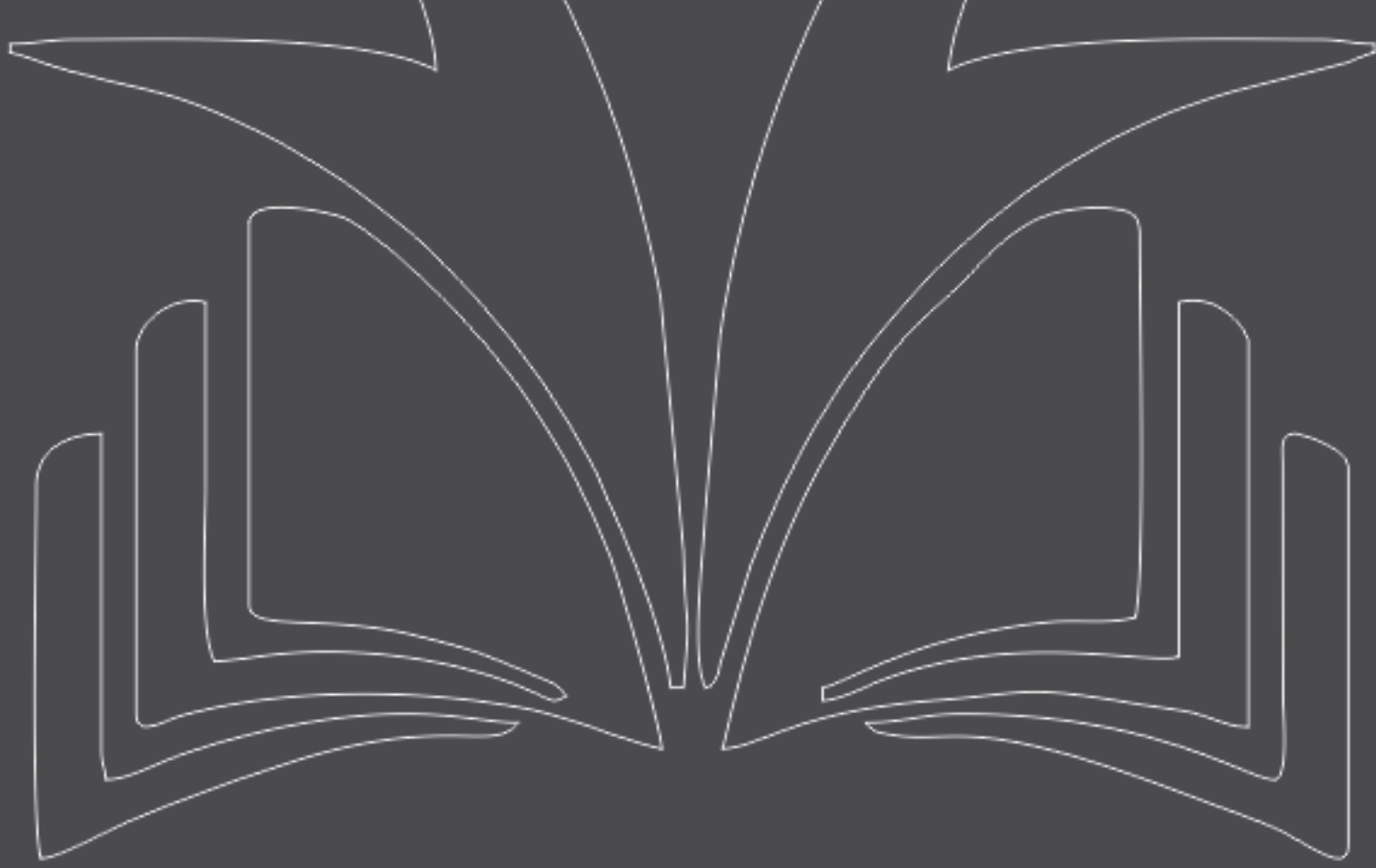




\section{Desafios da psicologia no Brasil}

\section{INTRODUÇÃO}

Este artigo teve origem em um trabalho de pesquisa bibliográfica sobre a obra freireana, com foco nos princípios da educação inclusiva. O interesse pela abordagem de tal temática nasceu de estudos sobre o pensamento do referido educador, desenvolvidos na disciplina "A Pedagogia de Paulo Freire", do Programa de Pós-Graduação da Faculdade de Ciências e Tecnologia da Universidade Estadual Paulista (FCT/UNESP), Presidente Prudente/SP, desenvolvida e concluída no ano de 2012.

A obra principal da análise realizada é Pedagogia da Autonomia (1996), acrescentada de outras ideias de Freire veiculadas em obras que discutem sua produção, como por exemplo, em Política e Educação Popular (BEISEGEL, 1982).

Na leitura das obras mencionadas não foi observado registro de nenhuma menção direta de Freire à temática da inclusão de estudantes público alvo da educação especial3(EPAEE) na escola regular. Contudo, ao analisar a fundo o seu pensamento foi possível identificar a presença de princípios basilares de inclusão, em seu sentido mais amplo, permeando de maneira intensa o texto e as ideias desse grande educador.

Nesse sentido, procuraremos identificar e comentar os momentos em que essa relação aparece, buscando relacionar a teoria freireana com os princípios norteadores da Política Nacional de Educação Especial na Perspectiva da Educação Inclusiva ${ }^{1}$.

Para nortear desenvolvimento dessa análise, elegemos o referencial teórico da escola especial na perspectiva da inclusão, na busca pela superação do segregacionismo e integracionismo, além dos pressupostos freireanos de educação popular.

Traçando um breve histórico da educação no Brasil, observamos uma situação de descaso que prevaleceu até meados de 1950. No que se refere à educação especial, até esse período, raras instituições como o Instituto dos Meninos Cegos (1854) e o Imperial Instituto dos surdos-mudos (1857) não eram suficientes para atender à parcela da população que apresentava tais deficiências.

De acordo com Januzzi (2004), a preocupação com a educação surgiu no contexto da urbanização e industrialização, trazendo como consequência a necessidade de expansão dos sistemas educacionais, de forma a garantir o acesso da população à escola, inclusive para os estudantes que não se encaixavam no padrão estabelecido pelo ensino regular. 


\section{Desafios da psicologia no Brasil}

A partir de 1990, no bojo dos movimentos internacionais pela inclusão, ganha força a concepção de uma escola inclusiva que chame para si a responsabilidade de se reestruturar para atender à diversidade dos estudantes, garantindo não apenas seu ingresso, mas sua permanência e seu sucesso.

A luta de Paulo Freire pela educação popular no Brasil está consolidada em princípios basilares que coincidem com os mesmos princípios que embasam hoje a luta pela educação inclusiva: princípios de respeito ao direito de todos à educação de qualidade, de respeito à diversidade humana e de valorização das diferenças, além da preocupação com a formação do professor.

Destarte, o objetivo central deste estudo é analisar a presença de pressupostos relacionados à Inclusão Escolar de EPAEE na obra de Paulo Freire, visando estabelecer os pontos e contrapontos existentes entre as duas abordagens.

\section{METODOLOGIA}

Para Ferreira (1994), a partir de 1970, o poder público, movido pela realidade do fracasso escolar, pela ampliação da oferta de vagas e consequente aumento das classes especiais em escolas regulares, passou a responder mais à questão da educação dos excluídos.

Marchesi (2004) aponta que o cenário educacional brasileiro daquele período, influenciado pelo movimento de integração escolar, apesar de receber estudantes com deficiência em salas especiais inseridas na escolar regular, ainda não tinha a concepção de mudança da escola, no sentido de criar condições para essas pessoas; ao contrário, prevalecia a ideia de que a responsabilidade de se adequar à escola cabia ao estudante.

Naquele contexto histórico e social, aos estudantes com deficiências era destinado um ensino de cunho emendativo, cujo objetivo era a reabilitação destas pessoas, que deveria anteceder sua integração na sociedade (JANUZZI, 1995).

Para elaboração do presente artigo partimos da revisão bibliográfica das obras de Paulo Freire, com vistas à seleção dos títulos que melhor se aplicavam ao objetivo em questão, traçando paralelos entre as ideias desse autor e os pressupostos da educação inclusiva.

As análises das obras foram realizadas dentro da disciplina "A Pedagogia de Paulo Freire", ministrada pelo Prof. Dr. Cristiano Di Giorgi, no Programa de Pós Graduação da Faculdade de Ciências e Tecnologia da Universidade Estadual Paulista (UNESP / FCT), Presidente Prudente/SP. 


\section{Desafios da psicologia no Brasil}

Foram estudados os seguintes títulos, de autoria Paulo Freire:

- . Educação como prática da liberdade. Rio de Janeiro: paz e terra,1967.

- Pegagógia do oprimido. Rio de Janeiro; Paz e Terra, 1970.

- A importância de ler três artigos que se completam. São Paulo: Cortez, 1982.

- A educação na cidade. São Paulo: Cortez, 1991.

- Pedagogia da esperança.São Paulo:Paz e Terra,1992.

- Pedagogia da autonomia.São paulo: Paz e Terra, 1997.

- Carta á Guiné - Bissau: Registros de uma experiência em processo.2ª ed.,Rio de Janeiro:Paz e Terra,1978.

- Educação e Mudança. 12a ed., Rio de Janeiro: Paz e Terra,1979.

- Ação cultural para a liberdade e outros escritos. 14ạ ed.,Rio de Janeiro:Paz e Terra,2011.

Além dos títulos acima, foi considerada também a obra "Política e Educação Popular", de Celso De Rui Beisegel (São Paulo, Editora Ática, 1982), por se tratar de análise importante da obra freireana.

A partir da leitura criteriosa dessas obras, selecionamos e categorizamos aquelas que apresentavam questões mais próximas à temática da inclusão: Pedagogia da Autonomia e Política e Educação Popular.

\section{DISCUSSÃO}

Ao analisar a obra Pedagogia da Autonomia, observamos que o próprio título remete diretamente à função da educação no desenvolvimento e na independência da pessoa, fatores essenciais à sua inclusão social e à conquista da cidadania, função esta que guarda estreita relação com os objetivos da educação especial, na perspectiva da educação inclusiva.

As reflexões foram desenvolvidas com base nas seguintes categorias:

\section{$>$ Determinismo}




\title{
Desafios da psicologia no Brasil
}

Em um dos pontos comuns localizados na referida obra encontramos a negação do determinismo na formação do ser humano, posta nos seguintes termos:

\begin{abstract}
Se sou puro produto da determinação genética ou cultural ou de classe, sou irresponsável pelo que faço no mover-me no mundo e se careço de responsabilidade não posso falar em ética. Isto não significa negar os condicionamentos genéticos, culturais, sociais a que estamos submetidos. Significa reconhecer que somos seres condicionados, mas não determinados. Reconhecer que a História é tempo de possibilidades e não de determinismo, que o futuro [...] é problemático e não inexorável. (FREIRE, 1996, p. 21)
\end{abstract}

O mesmo pressuposto de negação do determinismo pode ser observado em princípios da educação inclusiva, presentes inclusive em textos oficiais do Ministério da Educação do Brasil (Marcos Políticos e Legais da Educação Especial na perspectiva da Educação Inclusiva), como se pode constatar no trecho a seguir:

Os estudos mais recentes no campo da educação especial enfatizam que as definições e uso de classificações devem ser contextualizados, não se esgotando na mera especificação ou categorização atribuída a um quadro de deficiência, transtorno, distúrbio, síndrome ou aptidão. Considera-se que as pessoas se modificam continuamente, transformando o contexto no qual se inserem. Esse dinamismo exige uma atuação pedagógica voltada para alterar a situação de exclusão, reforçando a importância dos ambientes heterogêneos para a promoção da aprendizagem de todos os alunos. (BRASIL, 2010, p. 21).

Ao reconhecer, a despeito dos condicionamentos sofridos pelo ser humano e de sua própria carga genética, a possibilidade de superação e de transformação, Freire (1996, p. 21), embora o tenha feito em uma perspectiva social, lança possibilidade de que EPAEE são capazes de aprender, de se desenvolver e de atuar sobre o contexto, interferindo na configuração da realidade.

\section{Igualdade de Direitos}

inclusão escolar de EPAEE na escola e na sociedade está diretamente ligada às suas possibilidades de desenvolvimento, principalmente, pelo direito inegável de todos à participação na vida social.

A própria História da humanidade nos dá exemplos de pessoas que, a despeito das deficiências que apresentavam, destacaram-se nas mais diversas áreas de atuação humana: Ludwig Van Beethoven, na música, superando a deficiência auditiva; Christy Brown, nas artes plásticas e na literatura, a despeito da paralisia cerebral; John Nash, nas ciências, após diagnóstico de esquizofrenia; Hellen Keller, escritora e ativista política, superando as deficiências auditiva e visual. 


\title{
Desafios da psicologia no Brasil
}

Portanto, de modo não diferente, no nosso cotidiano também encontramos pessoas que venceram suas limitações, demonstrando ser possível o desenvolvimento de capacidades diversas.

\section{Discriminação}

A rejeição explícita a qualquer forma de discriminação aparece de maneira incisiva à página 39 da obra Pedagogia da Autonomia, circunscrita como um dos saberes necessários à prática docente progressista, quando Freire (1996, p. 39) preconiza que:

\begin{abstract}
Ensinar exige risco, aceitação do novo, e rejeição a qualquer forma de discriminação. Na continuidade de seu raciocínio, o autor relaciona essa competência à capacidade de pensar certo, numa referência à atitude de vigilância necessária ao educador. Para ele, Faz parte do pensar certo a rejeição mais decidida a qualquer forma de discriminação. A prática preconceituosa [...] ofende a substantividade do ser e nega a democracia. (FREIRE, 1996, p. 39 e 40).
\end{abstract}

Tal negação da discriminação está também presente em dispositivos legais e institucionais que regulam a inclusão de PD em escolas regulares, como se observa nos trechos selecionados a seguir:

Texto 1: retirado do documento pertinente à Política Nacional de Educação Especial na Perspectiva da Educação Inclusiva:

O movimento mundial pela educação inclusiva é uma ação política, cultural, social e pedagógica, desencadeada em defesa do direito de todos os alunos de estarem juntos, aprendendo e participando, sem nenhum tipo de discriminação. A educação inclusiva constitui um paradigma educacional fundamentado na concepção de direitos humanos, que conjuga igualdade e diferença como valores indissociáveis, e que avança em relação à ideia de equidade formal ao contextualizar as circunstâncias históricas da produção de exclusão dentro e fora da escola. (BRASIL, 2008).

Texto 2: retirado da coleção A Educação Especial na Perspectiva da Inclusão Escolar - vol. A Escola Comum Inclusiva, do Ministério da Educação:

\begin{abstract}
A inclusão rompe com os paradigmas que sustentam o conservadorismo das escolas, contestando os sistemas educacionais em seus fundamentos. Ela questiona a fixação de modelos ideais, a normalização de perfis específicos de alunos e a seleção de eleitos para frequentar as escolas, produzindo, com isso, identidades e diferenças, inserção e/ou exclusão. (BRASIL, 2010, P. 7)
\end{abstract}

A partir da confrontação desses textos com a obra freireana, é interessante observar que a luta a discriminação foi assumida de forma decisiva pelo autor.

\section{Atuação Docente}




\section{Desafios da psicologia no Brasil}

No tocante à atuação docente em um contexto educacional inclusivo, faz-se relevante formação para a aceitação e valorização das diferenças humanas. Paulo Freire já colocava essa questão, ao questionar: "Como ser educador, sobretudo em uma perspectiva progressista, sem aprender, com maior ou menor esforço, a conviver com os diferentes?" (FREIRE, 1996, p. 75).

Se situarmos este momento da obra freireana no contexto da trajetória de luta pela inclusão de EPAEE na escola regular, iremos identificar a década de noventa como um período de reformas educacionais e de acirramento do debate sobre a inclusão escolar.

De acordo com Michels (2002), apesar dos avanços postos pela legislação, essa modalidade educativa permaneceu no campo do assistencialismo. No início do século XXI, o movimento de luta pela efetivação da inclusão tem continuidade, ratificando o direito dos EPAEE de serem matriculados em escolas regulares. Neste contexto, a problemática da formação de professores se configura como uma necessidade urgente.

Ao admitirmos que, de forma complementar, a efetivação de sistemas educacionais inclusivos depende, na mesma medida, da formação humana e da competência profissional dos professores, podemos concluir que se faz necessário uma proposta de capacitação docente que considere aspectos humanos e competência técnica, de forma a contemplar o domínio de saberes específicos. Esse pensamento já era suscitado na teoria freireana sobre formação docente, ao discorrer sobre saberes necessários à prática docente progressista, igualmente necessários à prática pedagógica comprometida com a luta pela inclusão, conforme demonstramos a seguir:

\section{Trecho 1:}

“Ensinar exige segurança, competência profissional e generosidade. [...] A segurança com que a autoridade docente se move implica uma outra, a que se funda na sua competência profissional". (FREIRE, 1996, p. 56)

Trecho 2:

É preciso que saibamos que, sem certas qualidades ou virtudes como amorosidade, respeito aos outros, tolerância, humildade, gosto pela alegria, gosto pela vida, abertura ao novo, disponibilidade à mudança, persistência na luta, recusa aos fatalismos, identificação com a esperança, abertura à justiça, não é possível a prática pedagógica progressista, que não se faz apenas com ciência e técnica. (FREIRE, 1996, p. 136). 


\section{Desafios da psicologia no Brasil}

Defendemos a ideia de que tais virtudes são igualmente necessárias à atuação docente na perspectiva da inclusão, atuação que, segundo Paulo Freire, precisa estar aberta às diferenças e disponível à escuta, como se pode conferir no trecho a seguir:

Trecho 3:

Aceitar e respeitar a diferença é uma dessas virtudes sem o que a escuta não pode se dar. Se discrimino o menino ou a menina pobre, a menina ou o menino negro, o menino índio, a menina rica; se discrimino a mulher, a camponesa, a operária, não posso evidentemente escutá-las e se não as escuto, não posso falar com eles, mas a eles, de cima para baixo. Sobretudo me proíbo entendêlos.

Se me sinto superior ao diferente, não importa quem seja, recuso-me escutá-lo ou escutá-la. (FREIRE, 1996, p. 136)

\section{$>$ Respeito a Diversidade}

O princípio de respeito à diversidade presente na teoria freireana pode ser observado em documentos do Ministério da Educação (MEC), como na Resolução CNE/CP no 1/2002, que estabelece as Diretrizes Curriculares Nacionais para a Formação de Professores da Educação Básica, o qual define que as instituições de ensino superior devem prever formação docente que contemple atenção à diversidade e conhecimentos sobre as especificidades dos alunos com necessidades educacionais especiais.

Embora Freire não faça referência expressa à inclusão dos EPAEE, insistimos na ideia de que seus princípios são adequados a essa situação, tanto quanto o é a disponibilidade para a escuta e para a aproximação com o estudante, no sentido de abertura e respeito - questões presentes em suas veementes críticas à educação bancária.

Acreditar na riqueza da diversidade, no potencial dos EPAEE e ouvi-los, a fim de reconhecer sua capacidade de aprendizagem e desenvolvimento, desnudando-se de preconceitos e rótulos, permitindo que participem de seu processo de construção de conhecimentos, constitui-se em pressuposto essencial ao trabalho pedagógico com o EPAEE, coincidindo com as ideias de Freire sobre educação democrática e popular (BEISEGEL, 1982).

Tal pressuposto pode ser identificado em textos oficiais pertinentes à implementação dos processos educacionais inclusivos, como nos dois trechos retirados do documento do Ministério Público Federal intitulado “O Acesso de Alunos com Deficiência às Escolas e Classes Comuns da Rede Regular" (2004), como se lê a seguir: 


\section{Desafios da psicologia no Brasil}

Para ensinar a turma toda, parte-se da certeza de que as crianças sempre sabem alguma coisa, de que todo educando pode aprender, mas no tempo e do jeito que Ihe são próprios. É fundamental que o professor nutra uma elevada expectativa do aluno. $O$ sucesso da aprendizagem está em explorar talentos, atualizar possibilidades, desenvolver predisposições naturais de cada aluno. As dificuldades, deficiências e limitações precisam ser reconhecidas, mas não devem conduzir ou restringir o processo de ensino, como habitualmente acontece. (BRASIL, 2004, p. 42).

Um dos pontos cruciais de ensinar a turma toda é a consideração da identidade sóciocultural dos alunos e a valorização da capacidade de entendimento que cada um deles tem do mundo e de si mesmos.

Nesse sentido, ensinar a todos reafirma a necessidade de se promover situações de aprendizagem que formem uma trama multicor de conhecimentos, cujos fios expressam diferentes possibilidades de interpretação e de entendimento de um grupo de pessoas que atua cooperativamente. (BRASIL, 2004, p. 43).

\section{Escola Diferenciada}

A disposição para o exercício de uma educação inclusiva requer não apenas competência profissional, mas também uma escola diferenciada, comprometida com a transformação social, capaz de conceber os processos educacionais para além da aprendizagem estreitamente conceitual ou acadêmica, numa perspectiva de valorização da educação integral, que considere a pessoa em toda sua complexidade e historicidade e, sobretudo, que seja capaz de prepará-la para o exercício da cidadania.

Essa escola se constituiu em objeto do discurso e da militância de Paulo Freire. Uma escola que não se feche no isolamento, mas que entende a educação como processo sócio-político, em que as pessoas, mediadas pela realidade histórico-social e em relação dialógica umas com as outras aprendem, superam limitações e transformam a si e à realidade, em um movimento de luta contra todas as formas de discriminação e de opressão (BEISEGEL, 1982).

Nessa concepção de escola e de educação professadas por Freire, o sentido da utopia deve estar presente. Essa utopia - aqui concebida como a coragem de acreditar que as transformações são possíveis tanto quanto é possível a construção de uma sociedade mais justa e mais solidária - adéquase aos princípios da inclusão na medida em que engloba também a luta contra toda e qualquer forma de preconceito e discriminação (FREIRE, 1996, p. 130). 


\section{Desafios da psicologia no Brasil}

\section{CONSIDERAÇÕES}

A negação do determinismo, a possibilidade de transformação social, de esperança na construção de uma realidade mais justa e mais humana, o valor da utopia e do sonho de construção de uma sociedade igualitária são valores que permearam a militância de Paulo Freire e sua luta pelo desvelamento do caráter desesperançoso, fatalista e antiutópico da ideologia neoliberal (FREIRE, 1996, p. 159).

Tais valores são também imprescindíveis à luta pela inclusão social e escolar de EPAEE, uma construção que, partindo de um ideal em certa medida utópico, ganha hoje os primeiros contornos na realidade.

Desenvolvendo breve leitura da evolução histórica relativa à forma como a sociedade brasileira encarou e lidou com a questão dos EPAEE, constatam-se possibilidades reais de avanços em direção à sua inclusão na sociedade em geral e, de forma particular, na escola regular.

Se no século XVI, as práticas da sociedade para o EPAEE se baseavam em concepções místicas, levando à sua marginalização e segregação (MAZZOTA, 2005), na atualidade, os avanços no campo das ciências contribuem para o rompimento do paradigma do determinismo, em superação à visão biologizante da deficiência, ressaltando a importância das interações para o desenvolvimento humano, como postula a teoria histórico-cultural (VYGOTSKY, 2001).

Diferentes instrumentos de caráter legal ou pedagógico ratificam a relevância de a PD participar da vida em sociedade, a começar pela escola regular, atrelando o desenvolvimento dessas pessoas ao convívio social e ao acesso à cultura.

A Política Nacional da Educação Especial na Perspectiva da Inclusão (BRASIL, 2008) atribui à escola a responsabilidade de se adequar para receber a todos os estudantes, respeitando suas diferenças e garantindo condições para o seu desenvolvimento. Nessa perspectiva, a Educação Especial se insere em um movimento para transformar a sociedade, reconhecendo a diversidade como condição inerente ao ser humano, condição a ser reconhecida e valorizada. É certo que ainda há muito a se construir, no que se refere aos processos de inclusão social e escolar de EPAEE, no Brasil.

Entretanto, hoje já se podem observar experiências concretas de inclusão de EPAEE em escolas regulares em distintas regiões do país, demonstrando que propostas de superação da segregação dessas pessoas não são apenas utopia, mas podem ser concretizadas. 


\title{
Desafios da psicologia no Brasil
}

De acordo com as categorias analisadas, a luta pela inclusão escolar de EPAEE se insere em uma luta maior pela igualdade social e pela garantia de direitos, luta na qual Paulo Freire militou no campo teórico e pragmático, com coerência de princípios e ações.

Sabemos que, em diferentes campos e de forma particular no campo da educação especial, está ainda não é uma luta ganha; pelo contrário, como já foi mencionado, há muito que fazer, pois, mesmo que se reconheçam as conquistas que nasceram no campo da utopia e que se efetivaram na realidade, muitos são os desafios e as dificuldades a serem enfrentadas nos processos educacionais de EPAEE. De acordo com Gonçalves (2010),

\begin{abstract}
A realidade hoje da educação de crianças e jovens com necessidades educacionais especiais no país se caracteriza por um sistema dual onde de um lado existe um forte sistema caracterizado pelo assistencialismo filantrópico com patrocínio difuso de várias instâncias do poder público, e do outro um sistema educacional fragilizado que vem sendo incitado a abrir espaço para a educação escolar desta parcela da população. (GONÇALVES, 2010, p. 107)
\end{abstract}

No bojo dessa luta, vale lembrar o alerta de Freire, ao nos chamar a atenção para a importância de fazermos a leitura crítica das armadilhas da ideologia neoliberal, ideologia que, segundo ele, vem embasada em uma ética de mercado que coloca os interesses financeiros acima dos interesses humanos (FREIRE, 1996, p. 114).

Nesse sentido, Silva (2002, apud GONÇALVES, 2010, p. 107), corrobora para a análise crítica do contexto em que se insere a educação especial no Brasil, na atualidade, ao mencionar a força do pensamento neoliberal que estimula a privatização e o filantropismo, minimizando a responsabilidade do poder público sobre os serviços essenciais, incluindo-se aí o direito de todos à educação de qualidade - uma educação capaz de atender à diversidade humana, assegurando a valorização das diferenças.

Por fim, queremos aqui defender a ideia de que a vocação ontológica do ser mais, vocação postulada na obra de Freire e condição universal do ser humano, seja de fato um direito assegurado a todas as pessoas, por meio de uma educação pública de qualidade. Nesse sentido, a inclusão deve ser compreendida como um processo abrangente, que envolve não apenas os EPAEE, mas toda a diversidade humana, a partir de uma postura ética, dialógica, coerente e comprometida com a transformação social e com a defesa dos direitos humanos fundamentais. 


\section{Desafios da psicologia no Brasil}

\section{REFERÊNCIAS}

BEISEGEL, Celso de Rui. Política e Educação Popular: a teoria e a prática de Paulo Freire no Brasil. São Paulo: Ática, 1982. (Coleção Ensaios 85).

BRASIL. A educação especial na perspectiva da inclusão escolar. Brasília: Ministério da Educação, Secretaria de Educação Especial; Fortaleza: Universidade Federal do Ceará, 2010.

BRASIL. Marcos Político-Legais da Educação Especial na Perspectiva da Educação Inclusiva. Brasília: Ministério da Educação, Secretaria de Educação Especial, 2010.

BRASIL. O Acesso de Alunos com Deficiência às Escolas e Classes Comuns da Rede Regular. Brasília: Ministério Público Federal, Procuradoria Federal dos Direitos do Cidadão, 2.ed. 2004.

BRASIL. Política Nacional de Educação Especial na Perspectiva da Educação Inclusiva. Brasília: Ministério da Educação, 2008.

BRASIL. Resolução CNE/CP no 01/2002. Diretrizes curriculares nacionais para a formação de professores da Educação Básica. Brasília, DF, 2002.

FERREIRA, Julio Romero. A exclusão da diferença: a educação do portador de deficiência. São Paulo: Unimep, 1995.

FREIRE, Paulo. A Pedagogia da Autonomia. São Paulo: Paz e Terra, 1996.

GONÇALVES, Mendes Enicéia. Breve histórico da educação especial no Brasil.Revista Educación y Pedagogía. Medellín, Universidad de Antioquia, Facultad de Educación. V. 22, núm. 57, mayo-agosto, 2010, pp. 93-109.

JANUZZI, G. M. A educação do deficiente no Brasil: dos primórdios ao início do século XXI. Campinas: Autores Associados, 2004.

MARCHESI, Álvaro. A Prática das escolas inclusivas.In: COLL; MARCHESI;

PALACIOS. Desenvolvimento Psicológico e Educação: transtornos do desenvolvimento e necessidades educativas especiais.Porto Alegre: Artmed, 2004. P. 31-48.

MAZZOTA, M. J. S. Educação Especial no Brasil: história e políticas públicas. 5.ed. São Paulo: Cortez, 2005. v. 1.

MICHELS, M. H. Caminhos da exclusão: a política para a educação e a educação especial nos anos de 1990. Revista de educação e processos inclusivos, Florianópolis, v. núm. 3-4, p. 73-86, 2002.

SILVA, S. Exclusão do público, inclusão do privado: a terceirização dos serviços na educação especial.Educação on-line.

Disponível emhttp://www.educacaoonline.pro.br/index.php?option=com_content\&view=article

\&id=49:exclusao-do-publico-inclusao-do-privado-a-terceirizacao-dos-servicosnaeducacaoespecial\&catid=5:educacaoespecial\&Itemid=16. Acesso em: jun. 2012. 


\section{Desafios da psicologia no Brasil}

VYGOTSKY, L. S. A construção do pensamento e da linguagem. São Paulo: Martins Fontes, 2001. 


\section{Capítulo 23}

\section{A LINGUAGEM DO VIDEOGAME COMO FERRAMENTA AUXILIAR NO PROCESSO DE ENSINO E APRENDIZAGEM}

\section{DOI: $10.37423 / 200200165$}

Julia Yuri Landim Goya (Departamento de Design, Faculdade de Arquitetura, Artes e Comunicação, Universidade Paulista "Júlio Mesquita Filho", Campus de Bauru.).

jylgoya@hotmail.com

Dorival Campos Rossi (Departamento de Design, Faculdade de Arquitetura, Artes e Comunicação, Universidade Paulista "Júlio Mesquita Filho", Campus de Bauru) bauruhaus@yahoo.com.br

Wilson Yonezawa (Professor do Departamento de Computação). yonezawa@fc.unesp.br

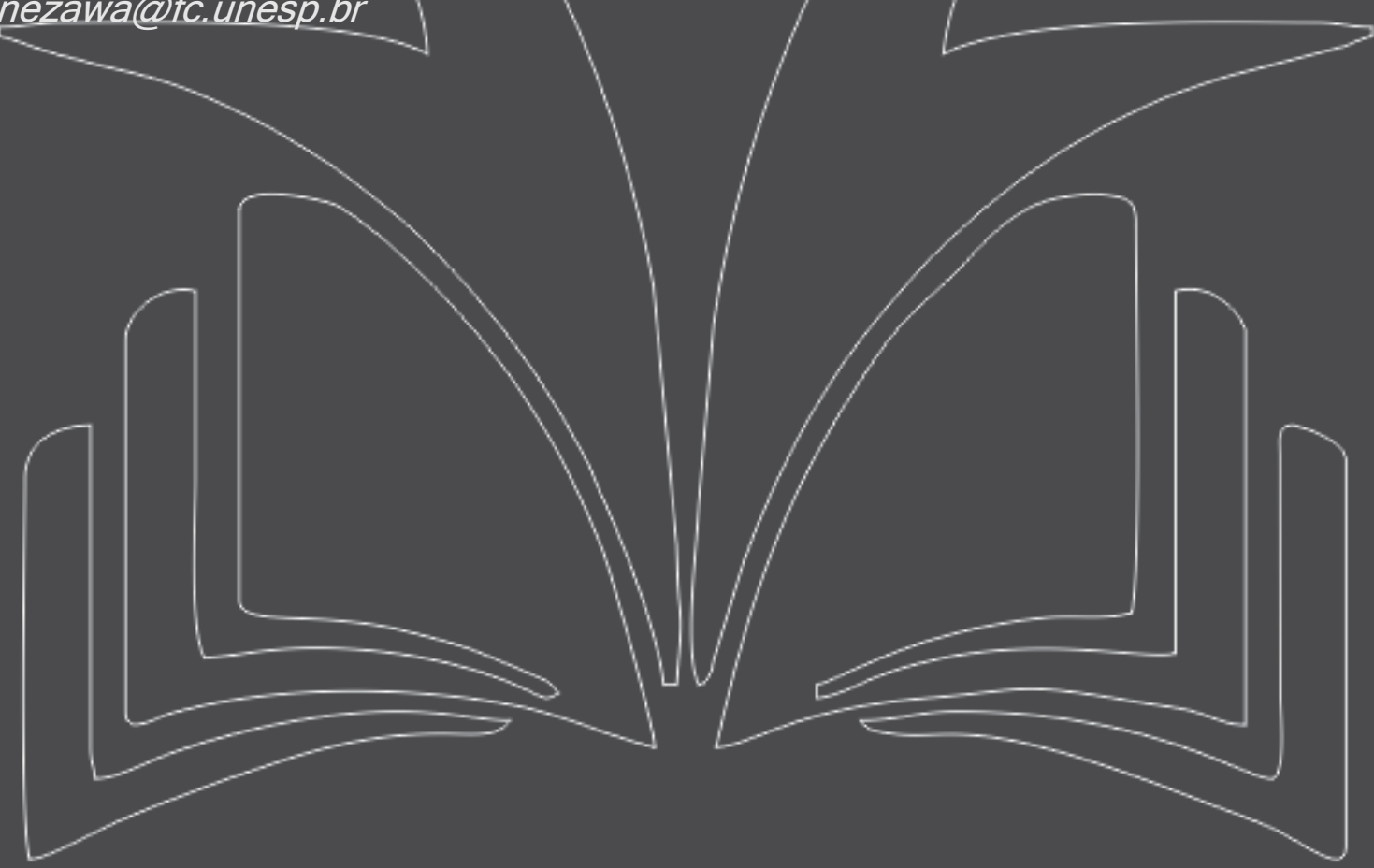




\section{Desafios da psicologia no Brasil}

\section{INTRODUÇÃO}

Os jogos eletrônicos - devido à dimensão lúdica - possibilitam o desenvolvimento, tanto emocional como cognitivo do ser humano e também auxiliam no processo de ensino-aprendizagem. Um exemplo de jogos eletrônicos são os videogames que já fazem parte da vida das pessoas, estão inseridos no cotidiano de pessoas de diferentes faixas etárias. Os videogames estão ganhando destaque quanto a sua aplicação, em especial, na educação como potencializador do processo de ensino e aprendizagem. Em se tratando de uma tecnologia relativamente recente seu potencial tecnológico, proporciona muitas possibilidades ainda não exploradas.

A indústria de videogames é em ascensão (Cf.: dados do relatório Theesa: http://www.theesa.com/facts/pdfs/esa_ef_2012.pdf), pois os videogames têm como pré-requisito perfeição das funções: visual, auditiva, cognitiva, motora, entre outras, além da necessidade da alfabetização de uma língua estrangeira, segundo Almeida e Poll (2010) os computadores e videogames tem sido, frequentemente, utilizados na faixa etária pediátrica além de serem presentes em muitas escolas brasileiras. Gazetta (1999) também ressalta este fato dizendo que até em escolas de rede pública estadual e municipal os estudantes tem disponibilidade de computadores. Nos Estados Unidos, Robert et al (1999) evidenciou que mais de dois terços tem computadores em seus domicílios e $70 \%$ delas possuem videogames. Na Europa Livingstone e Johnsson (1998) mostram que 41 a $85 \%$ das crianças entre 6 e 17 anos possuíam computador em suas casas e analisaram que seu uso varia de 44 a 89 minutos. Apesar de estes estudos serem do século passado, eles mostram um número alto de crianças e adolescentes em idade escolar tem acesso a computadores e videogames, quantidade que deve ter aumentado com a diversidade de tecnologias disponíveis no mercado ao longo dos anos.

\section{CAMPO DA PESQUISA}

Os jogos eletrônicos em suas múltiplas formas têm um papel importante na vida cultural e formação dos indivíduos e deve ser acessível a todos, mas a acessibilidade destes itens como computadores, vídeo games e seus consoles é impedida por causa da falta de visibilidade em sua fabricação, seja em seu conteúdo ou em seu modo de ser apresentado ou utilizado.

"Videogame é aqui entendido não apenas como um tipo genérico de jogo que se processa e opera por meio de um computador, independentemente do lugar em que seja jogado, mas também como uma linguagem que, como tal, possui suas particularidades" (SANTAELLA; FEITOZA, 2009). Ele é um dos fenômenos com maior interdisciplinaridade e complexidade e é muito pouco explorado devido aos 


\section{Desafios da psicologia no Brasil}

altos impostos dos itens importados, aqui no Brasil. "A importância do videogame enquanto fenômeno cultural também pode ser avaliada pela movimentação financeira de sua indústria, que é hoje a primeira na área de entretenimento - superior a do cinema, por exemplo - e uma das maiores de todas as indústrias" (NESTERIUK, 2009).

É um item que recebe um alto investimento e é extremamente lúdico, e ainda pode ser usado para auxiliar no crescimento do ser, pois através do videogame é possível estimular o desenvolvimento cognitivo e emocional do indivíduo e auxiliá-lo no processo de ensino (SINGER; SINGER, 2007), (MUNGUNBA, 2002), (MOITA, 2006), além de ajudar pessoas em suas atividades como resolver problemas do cotidiano usando simuladores (FALCO, 2007) e ensinar o jogador várias coisas sobre o mundo em que vive, como física aplicada, geografia, história, entre outras coisas (DEL CARLO, 2011), como em jogos feito "Age of Empires", "Civilization", "Colonization”, "Age of Mithology", "Alpha Centauri", "Rise of Nations", "Empire Earth", "Total War", entre outros exemplos menos explícitos. Os games não utilizam todo seu potencial e não atingem toda a população, apesar de, segundo Torres, Manzoni e Alves (2002), a acessibilidade estar associada ao desenvolvimento social e tecnológico.

Este valor cultural deve-se a ludicidade aplicada em suas ações. O conceito de ludicidade apresentada por Lopes (2004) diz que ela é uma condição do ser humano e gera constantemente consequências. Pode se manifestar de maneiras diversas como em experiências de lazer e humor como recrear, jogar, brincar e construir brinquedos e jogos sejam eles analógicos ou digitais.

Todas essas interações sociais apresentam e desenvolvem a ludicidade de forma diferenciada. Por exemplo, Lopes (2005) diz que

o recrear está sujeito à lógica do intervalo no tempo do trabalho, podendo, nele, coexistirem manifestações de jogar e de brincar. No lazer a interação é regulada pela lógica auto - intrínseca ao sujeito que nele faz o que lhe aprouver fazer, sendo distinto da actividade laboral. Ainda que no lazer o sujeito possa manifestarse brincando, jogando, ou trabalhando nos seus hobbies.

A ludicidade vista nos jogos pode ser uma ferramenta geradora de conhecimento, pois quão maior a possibilidade de reconhecimento, maior é a possibilidade de ser questionado, compreendido, aceito ou rejeitado, podendo, portanto, ser uma aproximação compreensiva que facilitaria a aprendizagem. Lopes (2005) também diz que a ludicidade "desenvolve se a partir de uma estrutura conceptual e metodológica, organizada em três processos estruturantes que intervêm com dimensões e níveis de especificidade distintos, de modo iterativo e se desdobram numa diversidade e multiplicidade de corelações, formando um sistema aberto.". Neste sistema o indivíduo é guiado primeiramente pelas 


\section{Desafios da psicologia no Brasil}

suas emoções, depois a razão domina e então a interação social ocorre equilibrando as instâncias que ordenam o sistema perceptivo.

Essa interação é um meio formador e transformador e pode ser usado no ensino via os videogames. Pois quando se joga o usuário não se dá conta das informações que estão sendo processadas, muitas vezes, devido à adrenalina presente no ato de jogar, mas este ato em si necessita de um alto nível de raciocínio e interação.

A ludicidade oferece este convívio para a criação de um vinculo de livre e espontânea vontade, muito necessitada na aprendizagem na necessidade de, por exemplo, memorização. Além disso, ela estabelece uma relação positiva, tornando-a uma ferramenta muito útil e divertida para a realização de comunicação e ensino.

De acordo com Del Carlo (2011), ao jogar games, e até mesmo após essa mesma ação, o indivíduo adentra uma região denominada T.A.Z. (Temporary Autonomous Zone ou Zona Autônoma Temporária - Bey, 1985) e entra em contato com novas ideias, aumentando o repertório do jogador, absorvendo parte ou todo o conteúdo do jogo e, dependendo da profundidade da TAZ, o jogo se transporta à mente, que pode se ausentar da vida real durante o tempo necessário por vários motivos.

O jogo, na cultura humana, está ligado à busca de diversão, do lazer e do desligamento das tarefas e responsabilidades do mundo cotidiano, é um objeto lúdico que leva o indivíduo à imersão [...]. Podemos considerar que a imersão é a propriedade que, a partir da interação que o ambiente virtual propõe, faz com que o sujeito (interator) se integre a esse ambiente. Ou seja, o interator passa a participar efetivamente deste ambiente. Esta participação difere de interator para interator, pois cada um fará sua própria exploração e interpretação do ambiente. Daí o fato de que peculiar o modo de como o interator imerge. Ao imergir, ele entra em um mundo virtual, as restrições são diferentes do cotidiano, pois se trata do mundo imaginário, imaginado. [...] A imersão está intimamente ligada à fantasia, à fuga da realidade para um mundo virtual (uma realidade virtual), podendo até parecer até mais real que a própria realidade do mundo cotidiano. (SATO, 2009).

O ser humano tem a predisposição a relacionar-se com seus semelhantes, reage rapidamente ao estímulo de competição e pode solucionar problemas reais utilizando simuladores. Quando se imagina em uma determinada situação e sente a emoção daquela experiência, ele adquire automaticamente o conhecimento daquela ação. Por essa visão, os videogames não são somente meios de entreter, mas também uma ótima ferramenta de aprendizagem que necessita claramente ser mais acessível à população. 


\section{Desafios da psicologia no Brasil}

Essa ludicidade que os jogos proporcionam podem auxiliar na educação, tornando-a mais fácil e possivelmente divertida. "Os games possuem a incrível facilidade de experimentação sem a necessidade de contato físico. [...] Através da simulação com os games, podemos experimentar de todos esses universos, apenas estimulando sentidos, mas não necessariamente tocando-os" (DEL CARLO, 2011). “A satisfação obtida a cada aprendizado e a superação de um desafio leva a diversão e ao prazer" (SATO, 2009), além de gerar emoções positivas aumentando a capacidade de absorver conhecimento, a curiosidade e o pensamento criativo (NORMAN, 2004). E segundo Solari (2011) as pessoas gostam de aprender sem saber que estão aprendendo.

Gastón Bachelard (1995) reforça a importância de metodologias que são intuitivas, pois elas dão forma a atividades especulativas e incentivam a imaginação e a criatividade. Tendo este grande potencial de auxílio ao aprendizado, os jogos eletrônicos e seus consoles devem ser acessíveis a todos. A Associação Internacional de Desenvolvedores de Games em 2004 definiu um jogo acessível quando qualquer um possa utilizar mesmo tendo uma limitação motora, deficiência ou necessita de cuidados especiais. Tendo sua eficiência com o menor esforço do indivíduo e tendo um retorno satisfatório (LYSLEY; COLVEN, 2005). Afinal, quando se joga os usuários buscam entretenimento e não frustação (ZAHAND, 2006).

A importância dos videogames está na vida dos indivíduos e como eles podem ajudar no processo de ensino e aprendizagem, inclusive na escola. Existem vários exemplos de como os jogos podem ser usados para instigar interesse em assuntos como filosofia e história ou geografia, considerado por muitos assuntos enfadonhos. Ao jogar o usuário não se dá conta das informações que são passadas para ele. Por exemplo na saga "Age of Empires" ou "Civilization" o jogador se foca em construir sua civilização e destruir o inimigo, mas durante todo o jogo são lançados dados históricos e geográficos que o jogador tem que saber para ter triunfo no jogo, assim como instiga o pensamento rápido e estratégico.

O jogador é transportado para uma realidade própria, quando ele está jogando ou até mesmo quando ele não está praticando a ação de jogar ou após essa atividade e como esta experiência interfere nele como pessoa, sendo uma reação negativa ou positiva. Este transporte é muito importante para qualquer pessoa, pois instiga vários aspectos da personalidade e do crescimento emocional e criativo, além de ensinar pessoas com deficiência ou sem a lidar com problemas cotidianos e viver experiências que na vida real elas não conseguiriam. 


\section{Desafios da psicologia no Brasil}

Este tópico descrevem nossas experiências de construção de videogames, como disciplina na formação de alunos de graduação em uma universidade pública. Esta experiência procurou:

- Desenvolver uma ação prática de carácter inter e multidisciplinar de ensino entre os alunos dos cursos de Design, Sistemas de Informação e Ciêncida da Computação, cursos oferecidos pela Faculdade de Ciências (FC) e Faculdade de Arquitetura, Artes e Comunicação (FAAC), fomentando a colaboração e prática interdisciplinar;

- Desafiar e habilitar processos criativos dos alunos na construção de propostas de videogames;

- Integrar as diferentes percepções e visões dos alunos em processo voltado para resolução de problemas;

- Colocar o desafio de uma linguagem nova, a dos games, como criação de projetos lúdicos em game design;

- Disponibilizar na rede (internet) os resultados para que haja uma difusão do conhecimento através do livre acesso e de forma aberta e colaborativa.

\section{METODOLOGIA}

Os games foram objetos na disciplina de Game Design oferecida aos alunos de graduação da computação e design. A disciplina foi oferecida em caráter regular. Ministradas presencialmente durante 15 semanas e assistidas por dois professores, um da área de computação e o outro da área de design. Durante o desenvolvimento da disciplina, foram propostas e realizadas diversas atividades, todas elas em grupo. Na formação dos grupos, foi incentivada a participação de alunos de áreas diferentes. Essas equipes híbridas receberam missões cujo objetivo era projetar games que explorassem a criatividade e ludicidade. Foram produzidos cinco jogos que podem ser conhecidos e conferidos no blog da disciplina www.gamedesignunesp.wordpress.com. Cada um dos jogos navegam por uma narrativa digital não linear, onde foram desenvolvidos roteiros, cenários e personagens.

O primeiro jogo a ser apresentado é o "Plumb". Lidando com fatores biológicos o personagem Plumb tem que contar com a ajuda dos elementos para se reproduzir e mantiver sua espécie viva em um mundo estranho. A proposta do jogo (Figura 1) é explorar as camadas do jogo de maneira não linear e interminável. O jogo também conta com um input externo que o jogador insere o dado climático e horário do seu local, mudando então o início do jogo toda vez, pois irá se basear com os dados preenchidos. O Jogo pode ser encontrado no link: 


\section{Desafios da psicologia no Brasil}

http://www.4shared.com/document/XLcOfOiQ/Plumb_mesmo.html?

Figura 1 - Proposta inicial do jogo Plumb

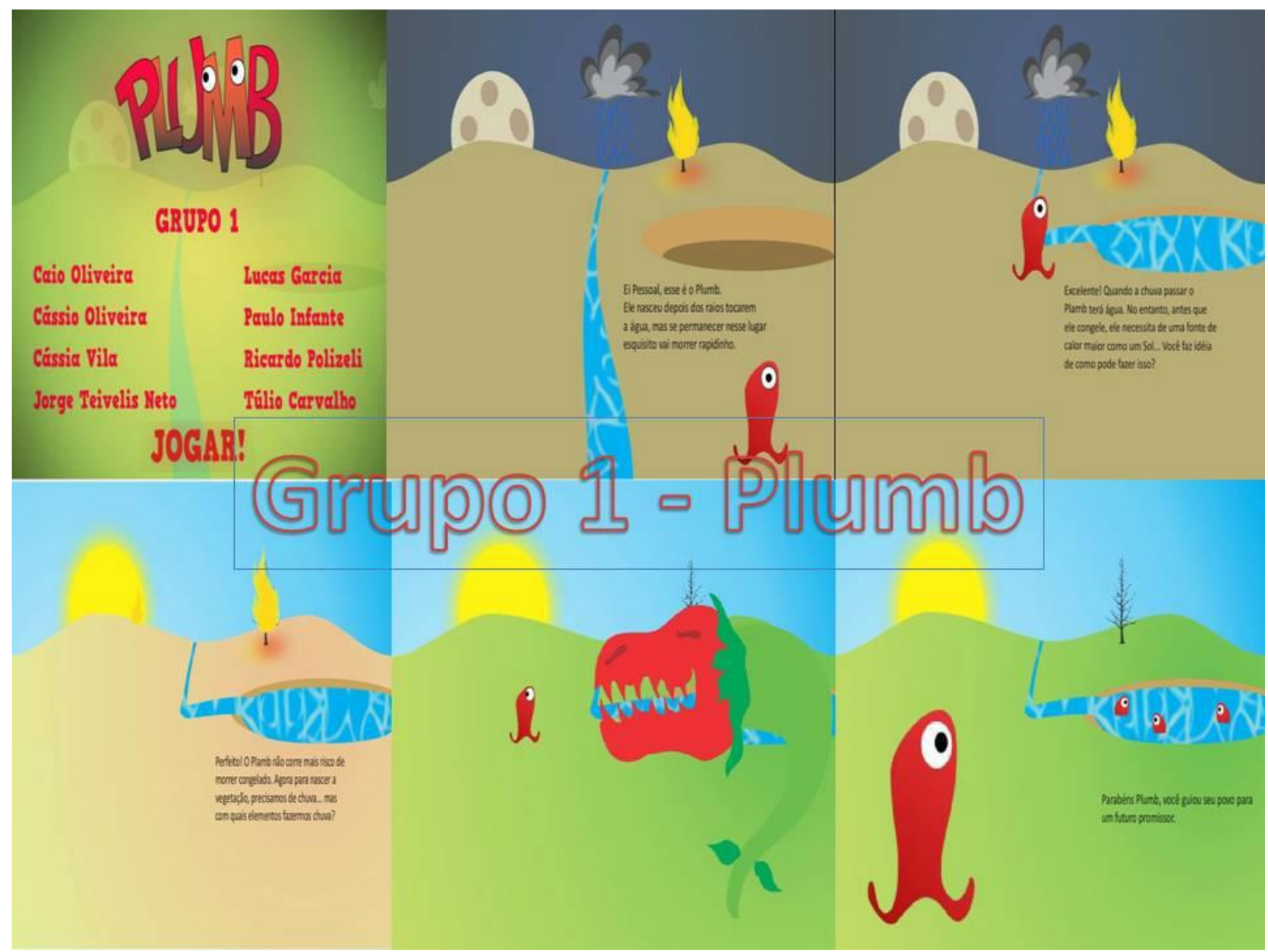

Noutro grupo (da mesma turma) foi criado o jogo "Squeezo Frenético" (Figura 2), ele começa quando um personagem esquizofrênico se vê privado de seu remédio e seguir um percurso pela cidade desviando dos perigos e lidando com sua própria loucura. O jogo proposto une uma missão comum do dia a dia com humor. O personagem principal tem esquizofrenia e no seu percurso foram agregados ao jogo elementos que as pessoas que vivem na cidade vêem em seu dia-a-dia. Tornando assim o jogo muito mais interessante. As fases podem ser terminadas de várias maneiras já que o personagem à medida que vai entrando em crise de esquizofrenia vai ganhando alguns poderes para serem usados em sua missão, mas por outro lado se sair demais do controle pode abortar sua própria missão. Ele pode ser visto no link:http://www.4shared.com/document/-490Wb5e/Squeezo.html?

Figura 2 - Squeezo Frenético 


\section{Desafios da psicologia no Brasil}

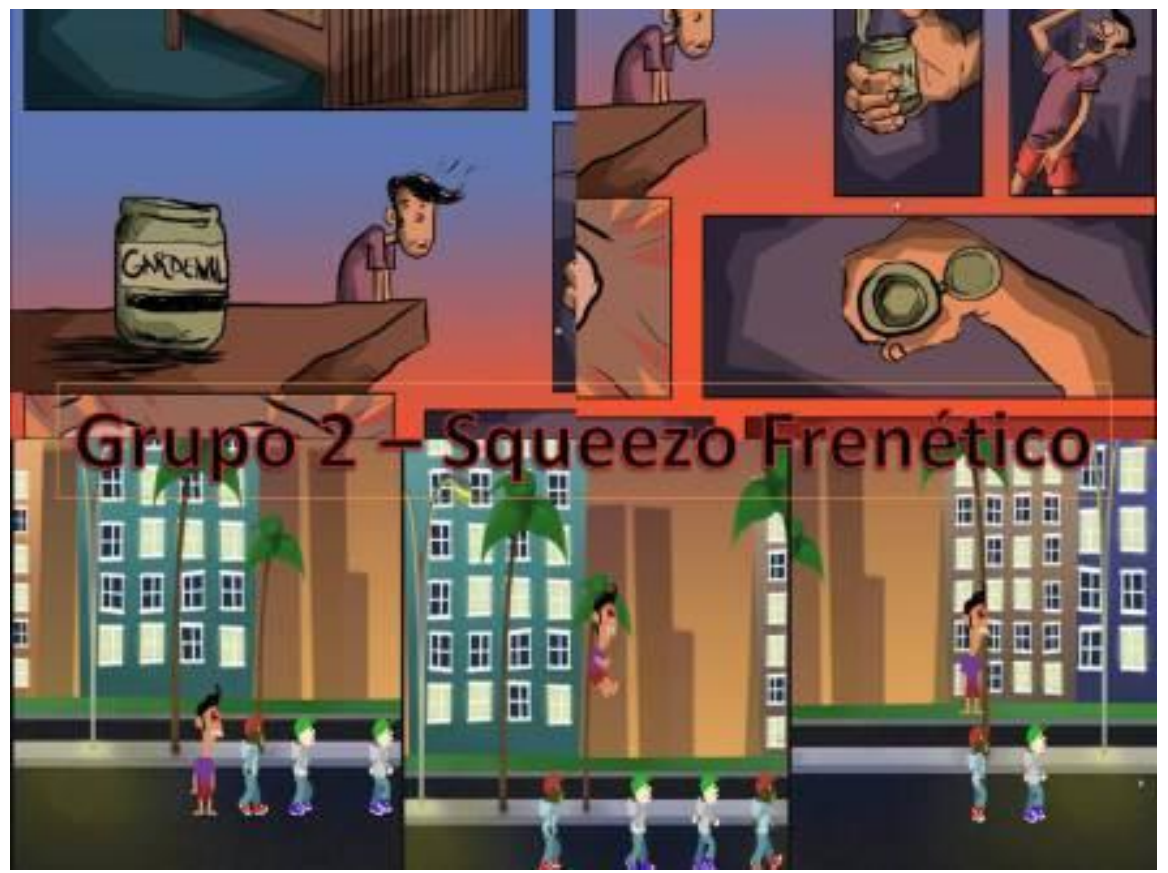

Já o jogo "Relembrando a Infância" remete as antigas brincadeiras de infância, onde uma criança tem que seguir padrões de calçada para ganhar o jogo. Com objetivo de ter uma abordagem fora do comum é composto por desafios individuais, cada um com uma temática diferente que dá asas a imaginação da mente de uma criança. Como exemplo inicial foram sugeridos os desafios, seguindo padrões de calçadas, pois quando mais jovens brincaram de só pode pisar no branco e imaginava que algo ruim iria acontecer. O personagem neste desafio tem que seguir o padrão pedido de calçada, pois se pisar errado poderá surgir monstros que irão te perseguir. Este jogo também pode ser baixado no link a seguir:http://www.4shared.com/rar/KEsOVGCO/Lembranas_da_Infncia.html?

Figura 3 - Lembrando a infância 


\section{Desafios da psicologia no Brasil}

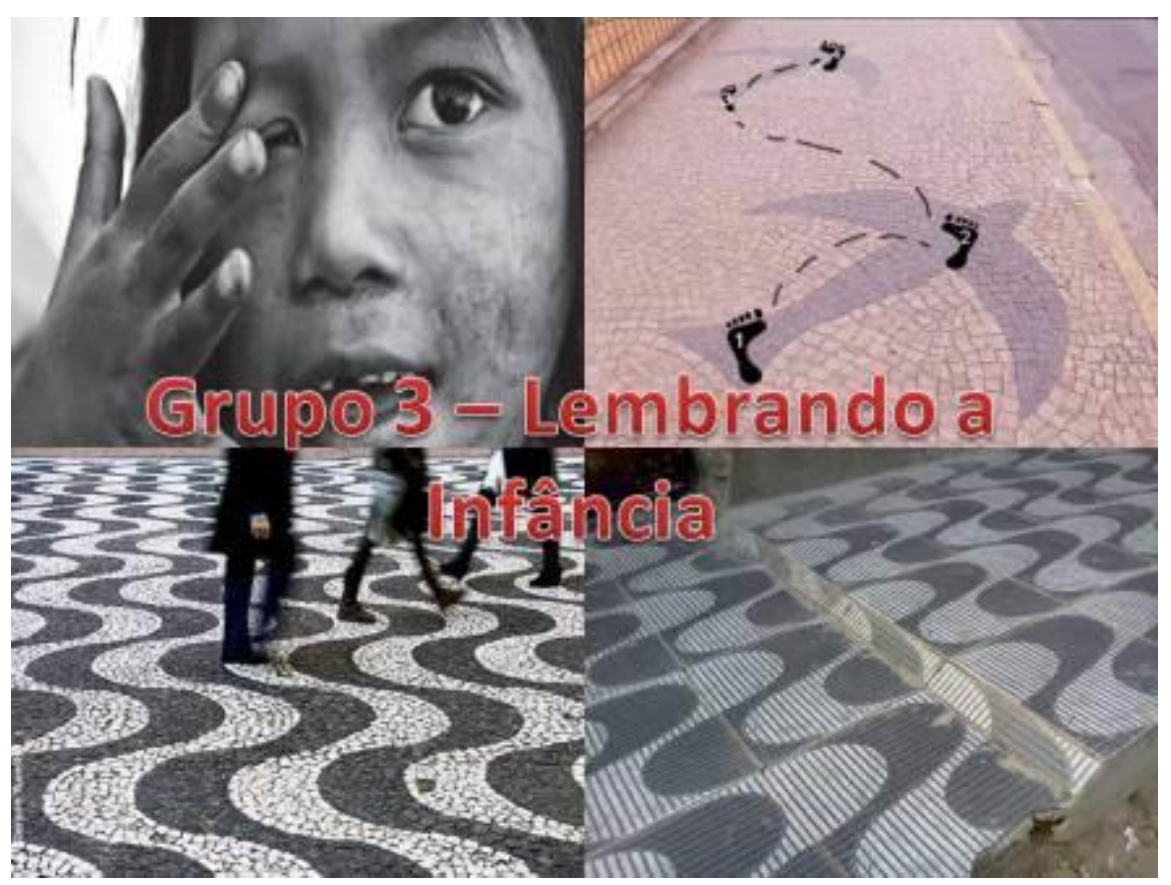

Outro jogo que mexe com um lado biológico é o "Bug", este jogo tem o foco no comportamento de animais, neste caso insetos, que vivem em comunidade. O jogador não tem um personagem fixo, atraindo então seu usuário a jogar mais vezes para explorar e se divertir de diferentes formas, pois cada personagem exerce uma função no jogo. Por exemplo, o usuário pode escolher no formigueiro uma formiga operária ou guerreira e desempenhar suas respectivas funções. O fato de ele tratar de uma temática de consciência ambiental reforça seu cunho educativo e mostra como é importante o papel de cada um em uma determinada comunidade para realizar o bem comum. Pode ser visto neste link:http://www.4shared.com/file/Brm7TpkK/Trabalho_Final_-_Grupo_4.html?

Figura 4 - Bug

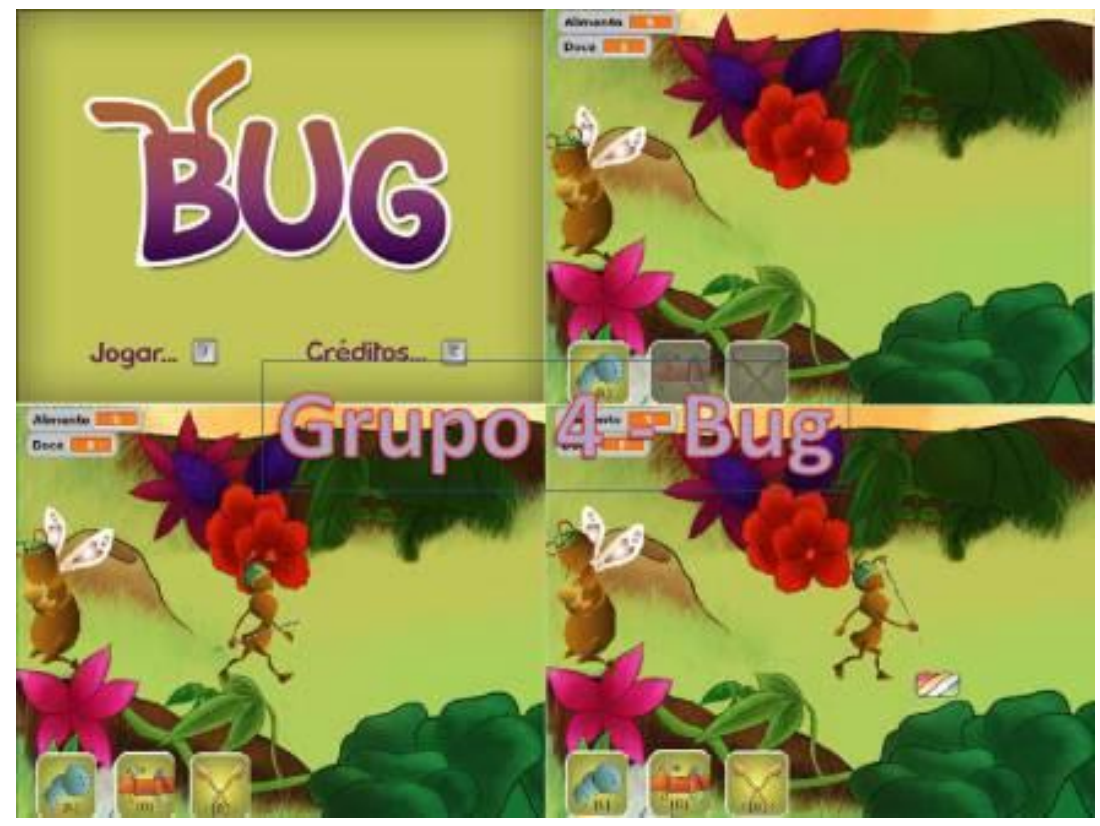




\section{Desafios da psicologia no Brasil}

O último grupo teve uma proposta de um game colaborativo. O "DIY galatic Puzzle (Figura 5)- faça você mesmo seu desafio galáctico" tem como idéia inicial criar um planeta seu em qualquer ponto da galáxia. Seu planeta deve possuir vários desafios (os Puzzles) para os seus visitantes. Os Puzzles devem ser criados pelo dono do planeta que podem ser do tipo: sudoku, quebra-cabeça, charada, jogo dos 7 erros entre outros. Quanto mais jogadores melhor será o jogo. Nessa proposta, a colaboração é o elemento chave. Conforme evolui no jogo, seu planeta evolui e o jogador começa a ter seu grupo de 'amigos', 'visitantes' e rivais'. O jogo pode ser baixado no link a seguir:

http://www.4shared.com/file/dE6hVBOK/DIY.html

Figura 5 - Puzzle

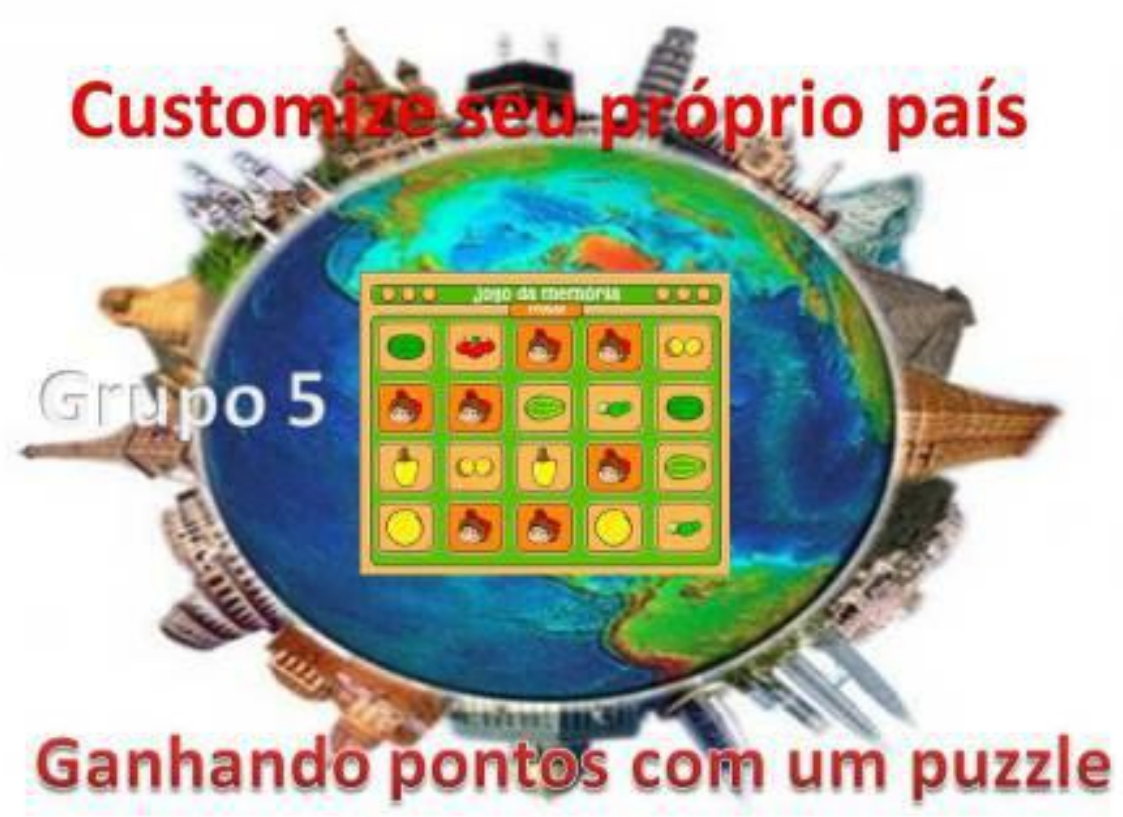

\section{DISCUSSÃO}

Apesar de sua importância crescente, poucos videogames são projetados para crianças em fase de alfabetização e ensino, assim como para deficientes. Menos ainda são aqueles que tem seus impostos abaixados para que todas as classes sociais o adquiram ou, se adquirem, tem dificuldade com a língua imposta pelo jogo, seja ela inglesa ou japonesa, como na maioria dos casos.

Com os dados de pesquisas, observações em livros e múltiplos trabalhos e com o que foi declarado neste artigo, pode-se constatar que o videogame, se já não mudou o modo de vida de uma boa parte da sociedade, tem muito potencial para tal. Seu poder imersivo e caráter lúdico fazem com que eles sejam rapidamente absorvidos e adorados pela maioria da população, possuindo, assim, um potencial 


\section{Desafios da psicologia no Brasil}

para conversar com outros campos, como o da filosofia, semiótica, psicologia, ciências da computação, antropologia, programação visual, ciências cognitivas, ergonomia, publicidade e marketing, animação, computação gráfica, critica literária e narratologia, telecomunicações, fisioterapia, artes, design, entre muitas outras, mas principalmente na área da educação. Apesar disso, essa integração com outros temas é, ainda, não suficientemente abrangente, pois não se investe na parte da acessibilidade. É então necessário abrir os olhos para as possibilidades do uso de games para o aprendizado e crescimento pessoal do ser humano.

\section{CONSIDERAÇÕES FINAIS}

Os videogames são ferramentas de uso na criação de repertório audiovisual que auxiliem o ensino e aprendizado. O processo de construção de videogames permite aos designers criarem mais narrativas possíveis que não queiram somente reproduzir o conhecimento acumulado como apresentar novas formas de conhecer e perceber o mundo. Podemos perceber o mundo através de várias maneiras e os games possibilitam este universo. O paradigma revisto e ampliado tendo na condição contemporânea o argumento da sua existência. O efêmero e aquilo que distrai também pode ser incorporado como formas de se aprender. Parafraseando Caetano Veloso, navegar é preciso. O leitor agora é um navegador, aprende e assimila o mundo como tal. O leitor do século vinte descobre uma nova condição, a de navegador e isso lhe confere um leque de eventos a serem descobertos neste no mapa da realidade digital.

Assim o paradigma é revisto e ampliado uma vez que brincar e ficar horas na frente do computador era visto como algo prejudicial. Se bem orientadas essas ferramentas podem nos ajudar a ensinar e aprender neste universo imersivo que é o contemporâneo.

\section{REFERÊNCIAS}

ALMEIDA, Marcelo; POLI, Carolina, 2010. Video game: análise ergonômica do jogadorde playstation. Disponível

em:http://www.google.com.br/url?sa=t\&rct=j\&q=\&esrc=s\&source=web\&cd=1\&ved=0CE4QFjAA\&url =http\%3A\%2F\%2Fsitios.anhembi.br\%2Fdamt6\%2Farquivos\%2F04.pdf\&ei=QNQaUMT3EMjj0QH9sIG QCg\&usg=AFQjCNHNtSobnyNBddOvp7oxgbgbOJGbEA\&sig2=aYM14cGEPqODB23jdavnvg.Acesso em: 21 fev.2013.

BACHELARD, G.Le nouvel Esprit scientifique. Paris:PUF, 1995.(1a ed., 1934)

BEY, Hakim.T.A.Z Zona Autônoma Temporária.Editora Conrad,1985. 


\section{Desafios da psicologia no Brasil}

DEL CARLO, Gabrielly. Game Processing. 2011. Disponível

em: http://tccdagaby.files.wordpress.com/2011/11/tccgabyprint.pdf. Acesso em: 21 Jan. 2013.

FALCO, Alessandro de. Jogos eletrônicos: do real ao virtual e vice-versa. Inovação, Uniemp. v. 3, n. 3, mês mai/jun, 2007. p 52-55.

FAVA, Fabrício.Jogando com o ar: o sopro como instrumento de acessibilidadenos jogos eletrônicos. 2008. Disponível

em: http://www.sbgames.org/papers/sbgames08/gameandculture/full/gc15_08.pdf. Acesso em: 21 fev. 2013.

GAZETTA, R. Computadores invadem sala de aula. In: SILVA, Clóvis Arthur Almeida da. Dores e lesões músculo-esqueléticas associadas a computadores e video games em crianças e adolescentes. São Paulo, 1999.

JOHNSSON-SMARAGDI, U.; D'HAENENS, L.; KROTZ, F.; HASEBRINK, U.Patterns ofold and new media use among young people in Flanders, Germany and Sweden. European Journal of Communication; v.13, 1998, p.479-501.

LIVINGSTONE, S, VAN DER VOORT, T.; BEENTJES, J. W. J.; BOVILL; M., GASKELL, G.; KOOLSTRA, C. M. et al.Young people's ownership and uses of new and old forms of media in Britain and The Netherlands.European Journal of Communication, 1998; 13:457-77.

LOPES, C. Design de ludicidade: do domínio da emoção no desejo, àracionalidade do desígnio, ao continuum equifinal do desenho e à confiança que a interacção social lúdica gera. Livro de Actas 4 SOPCOM, Aveiro, 2005.

LOPES, M.C.O. Ludicidade, contributo para a busca dos sentidos do Humano. EdU Aveiro. Aveiro, 2004.

LYSLEY, A.; COLVEN, D. Making software inclusive and digital publicationsaccessible: guidelines for software developers and publishers.2005. Acecenctre.

MOITA, F.Games: contexto cultural e curricular juvenil. Tese (Doutorado) - UFPB, João Pessoa, 2006.

MUNGUNBA, M.Videogame: estratégias de aprendizagem, visão do terapeutaocupacional para o século XXI: aporte para terapeutas ocupacionais e pais. Fortaleza: Unifor, 2002.

NESTERIUK, Sérgio. Reflexões acerca do videogame: algumas de suas aplicaçõese potencialidades. In: O mapa do jogo. São Paulo:Cengace Learning,2009

NORMAN, DONALD. Emotional design: why we love (or hate) everyday things.Basic books: New York, 2004.

ROBERTS, D. F.; FOEHR, U.G. R.; IDEOUT, V. J.; BRODIE, M.Kids \& media @ the new millennium. Kaiser Family Foundation. 1999. Disponível em: http://www.kff.org/entmedia/1535-index.cfm. Acesso em: 21 fev. 2013.

SANTAELLA, Lucia; FEITOZA, Mirna.O Mapa do jogo. São Paulo: Editora 2AB, 2009. 


\section{Desafios da psicologia no Brasil}

SATO, Adriana Kei Ohashi.Do mundo real ao mundo ficcional: a imersão no jogo.In: O mapa do jogo.São Paulo: Cengace Learning, 2009.

SINGER, D. ; SINGER, J. Imaginação e jogos na era eletrônica. Trad. Gisele Klein. Porto Alegre: ARTMED, 2007.

SOLARI, Guilherme. Além do Jogo: Videogames e educação sem chateação; isso existe? 2011.Disponível em: http://jogos.uol.com.br/ultnot/multi/2011/04/20/alem-do-jogo-videogamessem-chateacao-isso-existe.jhtm. Acesso em: 31 Jul. 2012.

TORRES, E.; MANZZONI, A.; ALVES, J. A acessibilidade à informação no espaçodigital.Ciência da Informação. v.31, n.3, mês set/dez, 2002, p. 83-91.

ZAHAND, Brannon. Making videogames accessible: business justifications anddesign considerations. 2006. Disponível em: http://gamasutra.com/features/20060920/zahand_01.shtml. Acesso em: 20 fev. 2013. 


\section{Capítulo 24}

PENSANDO A PESSOA COM DEFICIÊNCIA E AS CONDIÇÕES DE

ACESSIBILIDADE NA UEMG - UNIDADE DIVINÓPOLIS: UM RECORTE

CONFECCIONADO PELOS DISCENTES DOS CURSOS DE LICENCIATURA ${ }^{1}$

DOI: $10.37423 / 200200208$

Andressa Cardoso Mariano - andressa.c.mariano@gmail.com

Letícia Maia Amaral - leticiamaia796@gmail.com

Rosângela Gonçàlves Martins - rosangelagoncalvesm1@gmail.com

Rosimar Conceiçầ Rodrigues - roserodriguesrcr@gmail.com.

Ronaldo Santhiago Bonfim de Souza - santhiagosouza@yahoo.com.br

RESUMO:presente estudo teve por finalidade identificar o número de alùnos com deficiência matriculados nos cursos de Licenciatura da Universidade do Estado de Minas Gerais (UEMG) unidade Divinónpolis, os tipos de deficiênçia que apresentam e investigar como os discentes, desses cursos em geral, avaliam o trabalho da unidade em relação à pessoa com deficiência. Constituiu-se um estudo introdutório a partir dá realização de um levantamento de dados descritivo e quantitativo por meio da aplicação de um questionário estruturađócom quinze perguntas: sendo quatorze objetivas, e uma dissertativa, contendo algumas destinadas aos estudantes em geral e outras especificas para os com deficiência. As enquetes foram respondidas de forma voluntária e individual após os alunos terem assinado um Termo de Consentimento Livre e Esclarecido (TCLE), permifindo que as informaçâes nelas contidas pudessem ser utilizadas para os fins desta pesquisa. Ao to to, 509 alunos responderam ao questionário sendo 364 mutheres, 143 hiomens e 2 nấo identificaram o sexo.

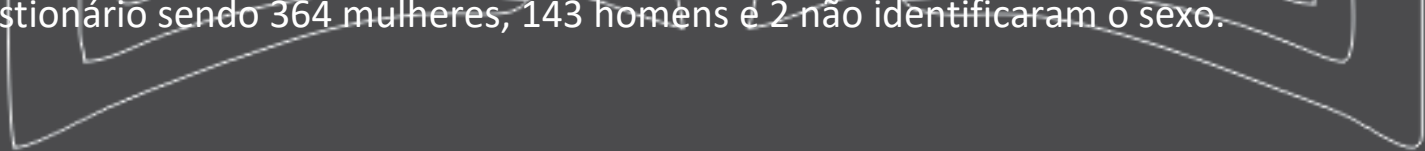




\section{Desafios da psicologia no Brasil}

Do total: 28 responderam apresentar algum tipo de deficiência e 13 não responderam. Ao que se refere à avaliação do trabalho da unidade em relação à pessoa com deficiência, 107 pessoas classificaram como ruim, 315 como bom, 41 como muito bom, 13 como ótimo e 33 não se posicionaram. Nesse sentido, possíveis demandas puderam ser detectadas acerca da acessibilidade oferecida dentro da unidade ao gerar parâmetros para que estudos e ações, futuramente, possam ser promovidos na busca de se avançar na garantia dos direitos assegurados pela Lei no 13.146/2015.

PALAVRAS-CHAVE: Acessibilidade; Deficiência; Ensino Superior; Inclusão. 


\section{Desafios da psicologia no Brasil}

\section{INTRODUÇÃO}

O trabalho aqui descrito faz parte de um projeto intitulado "Pensando a Pessoa com Deficiência" tendo iniciado no mês de maio do ano de 2017, foi executado durante todo o mês de junho, encerrando-se com a apresentação de seus resultados na segunda semana de julho do mesmo ano. Foi originado na intenção de seu coordenador, o professor Me. Santhiago Souza, desenvolver atividades extensionistas através da disciplina "Psicologia do excepcional", ministrada por ele no 70 período do Curso de Psicologia da UEMG-Unidade Divinópolis, a fim de oportunizar aos seus alunos mais possibilidades de atuação prática no decorrer da graduação, embasando-se na Lei Brasileira da Inclusão da Pessoa com Deficiência, mais conhecida como o Estatuto da Pessoa com Deficiência, Lei no 13.146/2015.

Nossa pesquisa caracteriza-se como descritiva por tratar-se de um levantamento de dados cujos resultados e análises correspondem à opinião dos discentes de licenciatura da Universidade investigada, representada pelo recorte amostral, sobre as características das ofertas de condições de acessibilidade das pessoas com deficiência em seu meio acadêmico (DALFOVO; LANA; SILVEIRA, 2008). Foi utilizado um questionário aplicado individualmente aos alunos, da categoria já mencionada, no intuito de delinear considerações a respeito do fenômeno estudado. Tendo em vista que esta também é uma pesquisa quantitativa, ao problematizar as questões específicas aqui citadas anteriormente, as informações foram coletadas e sistematizadas de forma numérica com auxílio de técnicas estatísticas (DALFOVO; LANA; SILVEIRA, 2008).

A Lei Brasileira da Inclusão da Pessoa com Deficiência (Estatuto da Pessoa com Deficiência), Lei no 13.146 homologada no ano de 2015, visa a asseguração do exercício dos direitos e liberdades fundamentais da pessoa com deficiência em condições de igualdade, sem que sofra qualquer tipo de discriminação, cabendo ao Estado, à família e a toda sociedade o dever de zelar com o cumprimento dessa proposta (BRASIL, 2015). O estatuto ainda prevê atribuição ao poder público para eliminar as barreiras causadoras de dificuldades e empecilhos ao acesso, a permanência e o processo de aprendizagem no sistema educacional, ao gerenciar seu aprimoramento visando a efetivar uma inclusão plena propiciada pelas condições de acessibilidade (BRASIL, 2015).

O termo "acessibilidade" quando referido, geralmente, apresenta-se em meios de empregar medidas a fim de favorecer o acesso de pessoas com mobilidade reduzida aos espaços físicos, bens, pessoas, atividades, obras, entre outros. A mobilidade é compreendida como aquilo que é móvel, quando esta, ao ser observada em condição reduzida, não deve conceitualmente levar-nos a pensar exclusivamente em casos de pessoas com deficiência, por não se restringir a elas, podendo ser destinado também a 


\section{Desafios da psicologia no Brasil}

idosos e crianças, por exemplo (ALVES, 2006). Arquitetar propostas as quais concretizem a acessibilidade em seu caráter de possibilidade e qualidade de acesso, implica em fomentar discussões e realizar ações pensadas para além de ser necessária no atendimento por meio do desenvolvimento de técnicas específicas às características de um determinado público exclusivo. Tendo em vista a possibilidade de resultar sobre si uma visão de uma medida para solucionar algo a posteriori, ao invés de ser eixo norteador e pensando do ponto de vista da perspectiva de um acesso viável, qualificado e universal (ALVES, 2006).

Percebe-se um grande avanço no processo de inclusão da pessoa com deficiência no Brasil. Isso se dá a partir da década de 1990, com base nos princípios da Declaração de Salamanca (UNESCO, 1994). Essa legislação parte da conjectura de que a educação inclusiva se caracteriza como uma expansão de acesso à educação dos grupos excluídos e marginalizados, em desvantagem de sua cor, gênero, classe social, idade e deficiência. A Declaração de Salamanca é vista como um relevante documento mundial apontado à inclusão social e a "Educação para Todos".

Porém, mesmo com avanços dos ideários e de projetos político-pedagógicos, muitas instituições de ensino ainda se encontram distante do ideal, e não implementaram ações favoráveis a formação de profissionais de diversas áreas para trabalharem com a integração. É importante a compreensão do contexto sócio-histórico da exclusão e da proposta de inclusão. Além disto, possuir o manejo de conhecimentos que os auxiliem a se aproximarem das pessoas com deficiência, no escopo de se integrarem com elas, obtendo assim subsídios para atuarem pedagogicamente (LIMA, 2002, p.122).

Nesse sentido este estudo teve por finalidade identificar o número de alunos com deficiência matriculados nos cursos de Licenciatura da UEMG-Unidade Divinópolis, os tipos de deficiência por eles apresentados e investigar como avaliam os discentes destes cursos em geral, o trabalho da Unidade em relação à pessoa com deficiência. No intuito de que possíveis demandas pudessem ser detectadas acerca da acessibilidade oferecida dentro da Unidade ao gerar parâmetros para que estudos e ações, futuramente, fossem possíveis de serem promovidos na busca de se avançar na garantia dos direitos assegurados pela Lei $\mathrm{n}$ ㅇ 13.146/2015.

\section{DESENVOLVIMENTO}

A realização do levantamento de dados constituiu-se por meio de uma pesquisa descritivaquantitativa, através da aplicação de um questionário estruturado com quinze perguntas, sendo quatorze objetivas e uma dissertativa, contendo algumas destinadas aos estudantes em geral e outras 


\section{Desafios da psicologia no Brasil}

específicas para os com deficiência. As perguntas destinadas aos discentes em geral referiam-se a: idade, sexo, profissão, curso, turno, se teria alguma dificuldade para se locomover na Unidade, o meio de transporte usado para ir à Universidade, a avaliação que fazia acerca do trabalho da Unidade em relação à pessoa com deficiência (ruim, bom, muito bom ou ótimo), contendo ao final a opção dissertativa, na qual poderia haver sugestões para este trabalho ser aprimorado. Estritamente aos alunos com deficiência, qual o tipo de deficiência, seu grau de acordo com a Classificação Internacional de Doenças - CID-10 (ORGANIZAÇÃO MUNDIAL DA SAÚDE, 1993), se total ou parcial, se possuía em sua decorrência algum tipo de benefício como passe livre e se fazia o uso de algum medicamento, caso sim, qual.

Tal instrumento foi respondido de forma voluntária e individual após os discentes terem assinado um Termo de Consentimento Livre e Esclarecido (TCLE), permitindo que as informações neles contidas pudessem ser utilizadas para os fins desta pesquisa. A participação desses foi de grande relevância pois, juntos ao corpo docente, será possível desenvolver estudos e trabalhos futuros voltados para atender, de forma inclusiva, os estudantes com alguma deficiência. Entendemos que o processo de inclusão vai muito além, portanto, precisa ser acompanhado e trabalhado. Assim, o estudante pode ter oportunidade e liberdade de acesso em igualdade aos outros que se dizem "normais". Nesse contexto, entende-se por inclusão a oferta do sistema educacional, na qual há participação ativa, dentro das suas potencialidades e singularidades.

A partir da colaboração acordada entre as alunas para a elaboração e cópias dos questionários do projeto "Pensando a Pessoa com Deficiência", não houve recursos financeiros extras, nem patrocinadores para a produção da pesquisa. Ficou definido o rateamento de todos os custos financeiros entre as integrantes do grupo em partes iguais. A questão dos horários em que cada uma iria aplicar ficou bem definida e aceita entre elas, havendo um bom desempenho do trabalho.

A coleta de dados se deu do dia 19 à 23 de junho, nos turnos matutino, vespertino e noturno. De acordo com a divisão estabelecida dentro do grupo responsável pelo projeto, aplicou-se nos cursos da área de educação (Ciências Biológicas, Educação Física - licenciatura, História, Letras, Matemática, Pedagogia e Química) em 509 alunos: sendo 364 mulheres, 143 homens e 2 não identificaram o sexo. Do total, 28 responderam apresentar algum tipo de deficiência. 


\section{Desafios da psicologia no Brasil}

\begin{tabular}{|c|c|c|c|c|}
\cline { 2 - 2 } & Sexo & $\begin{array}{c}\text { Pessoas com } \\
\text { deficiência }\end{array}$ & $\begin{array}{c}\text { Pessoas sem } \\
\text { deficiência }\end{array}$ & Total \\
\cline { 1 - 2 } Feminino & 364 & 28 & 468 & 509 \\
\hline Masculino & 143 & & & \\
\cline { 1 - 3 } Abstenções & 2 & \multicolumn{2}{|c|}{13} & \\
\hline
\end{tabular}

Tabela 1. Dados coletados na pesquisa

Diante de tal levantamento, foram observadas a relação de algumas profissões exercidas por pessoas com deficiência:

1 Educador físico - sexo masculino - 26 anos - deficiência motora;

1 Professora - sexo feminino - 29 anos - deficiência auditiva (parcial);

1 Professor - sexo masculino - 31 anos - deficiência auditiva (parcial);

1 Técnica de enfermagem - sexo feminino - 45 anos - deficiência motora (leve, parcial);

1 Operadora de telemarketing - sexo feminino - 27 anos - deficiência auditiva (total esquerdo);

1 Demonstradora de sistemas - sexo feminino - 27 anos - deficiência visual (total em um olho).

A partir disso, a deficiência (meio interno - órgão) pode ser classificada como lesão ou anormalidade de elemento ou função anatômica, fisiológica ou psíquica. Também é possível classificá-la por tempo determinado ou permanentemente. Ela pode corroborar para uma incapacidade (meio físico pessoal), apresentando restrição na desenvoltura de atividades classificadas como normais. A deficiência ou a incapacidade também podem engendrar uma desvantagem (meio social) que diz de um prejuízo para o indivíduo, o qual o limita e/ou o impede de desempenhar papéis. Há possibilidade de ocorrer deficiência acoplada à incapacidade e desvantagem ou somente à desvantagem. (ICIDH, 2004 apud AMIRALIAN, 2000). Percebe-se, por meio dos dados apresentados, que a incapacidade nem sempre está associada à deficiência, pois a lesão exposta por tais pessoas não as impediram de exercer suas profissões.

Em relação à acessibilidade, os estudantes apontaram como fatores dificultadores de locomoção dentro da universidade: falta de iluminação, inclinação da rampa da entrada (muito alta), dificuldade em estacionar, distância entre os blocos, "falta de passeios bons", e o não funcionamento do elevador. Também houve uma resposta sobre não ter dificuldade, mas possuir um irmão que é cadeirante e passa por muitos impedimentos para se locomover dentro da UEMG. Sobre o trabalho da universidade 


\section{Desafios da psicologia no Brasil}

em relação à pessoa com deficiência: 102 pessoas avaliaram como ruim, 295 como bom, 41 como muito bom e 11 como ótimo.

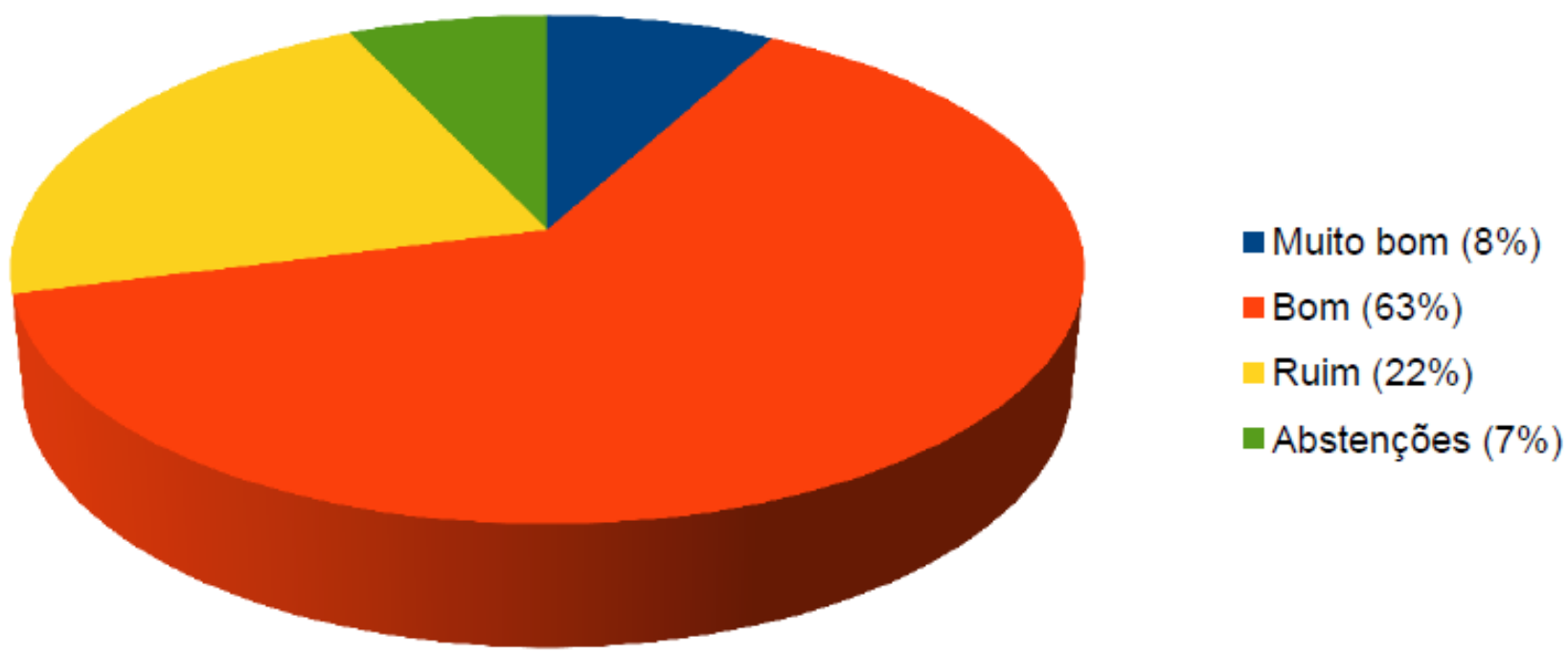

Gráfico 1. Avaliação sobre a acessibilidade na UEMG - Divinópolis

No campo de sugestões surgiu o relato sobre um caso específico: "Tem um aluno de engenharia de computação que é cadeirante, sempre o vejo com dificuldade para chegar na lanchonete do bloco administrativo. Seria legal facilitar o deslocamento dele na universidade e aumentar a largura da porta do bloco 1." (sic) Foram colocadas pontuações positivas quanto às mudanças já iniciadas dentro da UEMG: "creio que já é um avanço tudo isso que está sendo feito na instituição" (sic), entretanto foi também enfatizado sobre uma atenção maior quanto às necessidades peculiares e possibilidade das rampas serem menos íngremes.

Como crítica, foi apontado a possível análise ou coleta com o intuito de ouvir mais as pessoas com deficiência: "Bom, eles se adaptaram para atender a lei, porém nem todas as adaptações foram feitas de maneira que beneficiasse o próprio deficiente. Levando-nos a entender que as adaptações não foram feitas pensando $100 \%$ nos deficientes." (sic) Em contrapartida, outra pontuação nos chamou atenção: "É os alunos que devem se adequar. Conheço uma que ganhou até motocicleta adaptada, anda de cadeiras de rodas, mas na verdade, anda com amparo de bengala. Oportunismo dela." (sic) Nesse caso, o mesmo se refere à atitude de alguém que se diz com alguma deficiência e, ao mesmo tempo, demarca sua posição diante de tal fato, pois também aponta ter deficiência. Por fim, referenciar-se em universidades em que os índices de acessibilidade às pessoas com deficiência sejam elevados também foi um aspecto sugerido. 


\section{Desafios da psicologia no Brasil}

\section{CONSIDERAÇÕES FINAIS}

Diante dos resultados obtidos pela pesquisa "Pensando a Pessoa com Deficiência" esperamos que novos debates sobre as políticas de inclusão possam ser amplamente discutidas e aprofundadas dentro das universidades, para que se possa dar maior visibilidade às pessoas com deficiência e suas necessidades específicas e a partir disto aprimorar o atendimento educacional para este público. Visto que assegurar "O Direito à Educação" à pessoa com deficiência está para além de oferecer condições de seu acesso ao sistema educacional, devendo-se também para se atingir tal objetivo ofertar serviços e recursos de acessibilidade a fim de promoverem condições de sua permanência neste contexto evitando-se assim evasões ao propiciar uma inclusão plena (PEREIRA, 2008).

Espera-se que o sistema educacional como um todo, ao fazer cumprir o dever de ofertar recursos e condições de acessibilidade para as pessoas com deficiência, busquem em primeiro lugar oportunizar aos seus profissionais uma formação continuada. Para que o conhecimento destes possam sempre se atualizar e ampliar sobre as especificidades e instrumentos adequados, tendo como o objetivo favorecer a permanência e o melhor aprendizado dos alunos.

Percebe-se que a presença de pessoas com necessidades educacionais específicas no ensino superior é ainda um grande desafio. O processo de construção de um espaço inclusivo na educação se dá por meio do reconhecimento e interação das diferenças que deveria ser facilitado pelos seus próprios mecanismos, como as universidades, sendo assim ainda nos cabe questionar sobre os desafios e fatores dificultadores deste processo.

\section{REFERÊNCIAS}

ALVES, M. J. Mobilidade e acessibilidade: conceitos e novas práticas. Indústria e Ambiente, s./l., n. 55, p. 12-14. Disponível

em:http://ava.unicesumar.edu.br/moodledata/17580/extra/Atividade_Disciplinar/Texto_de_Apoio. pdf?md5=plRd-QmWe_N6mZuY4A8x-Zg\&expires=1560173695>. Acesso em: 06 jun. 2019.

AMIRALIAN, M. L. T. et al. Conceituando deficiência. Revista de Saúde Pública, São Paulo, v. 34, n. 1, p.97-103, fev. 2000. Disponível

em:<http://www.scielo.br/scielo.php?pid=S003489102000000100017\&script=sci_abstract\&tlng=pt. Acesso em: 06 jun. 2019.

BRASIL. Lei n. 13.146, de 6 de julho de 2015. Institui a Lei Brasileira de Inclusão da Pessoa com Deficiência (Estatuto da Pessoa com Deficiência). Brasília, 2015. Disponível em: <http://www.planalto.gov.br/ccivil_03/_ato2015-2018/2015/lei/l13146.htm>. Acesso em: 06 jun. 2019. 


\section{Desafios da psicologia no Brasil}

DALFOVO, M. S.; LANA, R. A.; SILVEIRA, A. Métodos quantitativos e qualitativos: um resgate teórico. Revista Interdisciplinar Científica Aplicada, Blumenau, v. 2, n. 4, p. 1-13, jul./dez. 2008. Disponível em: https://www3.ufpe.br/moinhojuridico/images/ppgd/9.1b\%20metodos_quantitativos_e_qualitativos _um_resgate_teorico.pdf>. Acesso em: 06 jun. 2019.

LIMA, P. A. Educação inclusiva e igualdade social. São Paulo: AVERCAMP, 2006.

ORGANIZAÇÃO MUNDIAL DA SAÚDE. Classificação estatística internacional de doenças e problemas relacionados com a saúde (CID-10). Porto Alegre: Artmed, 1993.

PEREIRA, M. M. Inclusão no ensino superior: trajetórias acadêmicas dos alunos com deficiência que entraram na Universidade Estadual do Rio Grande do Sul pelo sistema de cotas. Revista Educação Especial, Santa Maria, v. 21, n. 32, p. 163-174, jul/dez. 2008.

Disponível em:<https://periodicos.ufsm.br/educacaoespecial/article/view/94/pdf>. Acesso em: 06 jun. 2019.

UNESCO. Declaração de Salamanca: sobre princípios, políticas e práticas na área das necessidades educativas especiais. Brasília: Portal do MEC, [1994]. Disponível

em: <http://portal.mec.gov.br/seesp/arquivos/pdf/salamanca.pdf>. Acesso em: 06 jun. 2019. 


\section{Desafios da psicologia no Brasil}

\section{NOTAS}

Nota 1

O presente trabalho faz parte de um projeto maior que avaliou a perspectiva tanto dos discentes dos cursos de licenciatura quanto de bacharelado. Tendo o grupo se dividido em dois, cada um ficou responsável por uma modalidade, sendo este pela de licenciatura. Além do mais esta versão se configura em um formato resumido em razão de atender a proposta de publicação dos organizadores. A pesquisa foi avaliada e aprovada pelo comitê de ética da Universidade do Estado de Minas Gerais (UEMG) - Unidade Divinópolis sob o número do parecer: 1.756.715. 


\section{Capítulo 25}

\section{A ECONOMIA SOLIDÁRIA COMO FORMA DE EMPODERAMENTO PARA MULHERES: A EXPERIÊNCIA DE UMA INCUBADORA UNIVERSITÁRIA PARANAENSE.}

DOI: $10.37423 / 200200211$

Rosely Pisicchio

pisicchio@sercomtel.com.br

RESUMO: O Brasil tem muito ainda a desenvolver em relação às políticas públicas destinadas a população feminina de baixa renda, é nítida a necessidade de buscar formas de inclusão além da ordem assistenciàlista. Nesse cenário apontam-se estudø's e experiências que possuem como base o madelo de produção da Economia Solidária, que se constitui cómo uma alternativa eficiente, que proporciona, além da renda, bem estar, qualidade de vida e empoderamento. Este artigo traz uma análise da participação das mulheres na Economia Solidária a partir da experiência com um grupo de seis costureiras durante o- processo de incubação em uma Incubadora Universităria Parahaense. Como forma de coleta de dados utilizou-se entrevistas abertas. Como resultado, ressalta-se a melhoria da participação das mulheres no-entendimento do seu trabalho como costureirás, bem como a aumento da autonomia e participação, expressando opiniões sobre diferentes temas, tornando-se protagonistas não só no trabalho, mas de suas próprias vidas.

Palavras-chave: Economia Solidária; empoderamento feminino; incubadora universitária. 


\section{Desafios da psicologia no Brasil}

\section{INTRODUÇÃO}

A Economia Solidária é um modelo de produção que se opõe à lógica capitalista. Defende uma forma de organização que visa ultrapassar a divisão entre capital e trabalho, garantindo assim que trabalhadores acessem os meios de produção, conheçam todo o processo, gerenciem seu trabalho e também desfrutem dos resultados dele. A Economia Solidária abarca em sua forma de ser empreendimentos como cooperativas, associações e empresas autogestionárias.

Não é objetivo desse artigo aprofundar o conceito de Economia Solidária, mas fazer o relato de uma experiência com mulheres e o quanto isso trouxe ganhos e empoderamento para as participantes, além de um maior envolvimento nesse tipo de atividade; sendo o mais importante dizer que a Economia Solidária, conforme Calbino e Paula ( 2013 ) possui uma diversidade de concepções e entre os autores que estudam o tema, não há um consenso quanto ao seu significado no espectro de correntes e concepções.

Percebe-se por sua vez que a Economia Solidária, enquanto uma prática econômica, baseia-se na autonomia, democracia participativa, igualdade, equidade e solidariedade (Santos, 2002). Além disso, existem sete princípios considerados essenciais, que predominam desde o surgimento das primeiras cooperativas, na metade do século XIX. Esses princípios são: (1) as cooperativas ou associações devem estar sempre abertas para novos membros, (2) as decisões são tomadas em comum acordo entre todos os membros, o voto de nenhum trabalhador tem mais peso do que o de outro, (3) a distribuição da renda do empreendimento deve ser dividida de forma igual entre seus membros, (4) deve haver, por parte dos trabalhadores, um comprometimento com relação ao aprimoramento educacional, (5) o empreendimento deve ser independente do Estado e de instituições privadas, (6) deve-se priorizar a cooperação entre os empreendimentos locais, nacionais e mundiais e, por fim, (7) o empreendimento deve visar contribuir para o desenvolvimento da comunidade onde está inserido (Leite, 2009). Os princípios determinam uma forma de organização de trabalho, mas principalmente, valores importantes que marcam um modo de relação com o outro. Para aqueles que estão fora do mercado formal de trabalho, o ingresso em um empreendimento solidário pode contribuir para a integração e inclusão social do indivíduo.

Corroborando com tudo isso, França Filho (2001, 2002, 2003 ) afirma que a Economia Solidária se apresenta com a noção de uma nova forma de relacionamento entre a economia e as pessoas que dela participam pois tem uma perspectiva de regulação com a escolha de um projeto político de 


\section{Desafios da psicologia no Brasil}

sociedade e com uma outra forma de sustentação da maneira de viver dos indivíduos, uma sociedade não mais centrada nas esferas do Estado e do Mercado. Associam-se as ideias de iniciativa e solidariedade ao se inserirem em atividades coletivas.

Nesse estudo, ao longo do contato com o trabalho da Economia Solidária e suas participantes, da sua forma de desenvolver, de agir e de colocar seus princípios; contemplam-se diferentes atividades, o compromisso com as relações e uma forma híbrida de conviver com o tradicional e com o e contemporâneo. De acordo com Monje-Reyes (2011, p.707, minha tradução ) para quem expressa "desenvolvimento epistemológico que se interconectam e articulam entre si, como base de uma discussão crítica da atual concepção dominante da economia neoliberal". Apesar das concepções distintas de muitos autores a Economia Solidária, como afirma França Filho (2003) pode ser entendida como alternativa à crise de emprego em várias sociedades ou apenas como um paliativo à crise do sistema capitalista, indiferente a isso, é um fenômeno que ganha relevância no cenário atual.

No Brasil, as experiências de cooperativismo, até os anos 1980, concentraram-se principalmente no meio rural. No meio urbano, sua introdução se deu s pela crise econômica da década de 1980, quando houve aumento no índice de desemprego, diminuição do trabalho industrial, aumento da informalidade, elevado índice de terceirização e diminuição do valor real dos salários. Contudo, como consequência dessa crise e a democratização do país na década de 1980, ocorreu um fortalecimento dos movimentos sociais brasileiros e, consequentemente, da Economia Solidária (Leite, 2009).

Em relação aos movimentos sociais, um segundo momento surgiu em 1994 com a Associação Nacional de Trabalhadores em Empresas de Autogestão e Cogestão (Anteag), que, por meio da iniciativa de um setor sindical, tinha como objetivo auxiliar experiências já existentes, sobretudo no que se refere à assessoria técnica (Leite, 2009). A partir da segunda metade da década de 1990, algumas universidades começam a sistematizar o apoio às iniciativas de cooperativas populares. A primeira instituição de ensino foi a Universidade Federal do Rio de Janeiro, que, em 1995, através do centro de pós-graduação em engenharia, criou a COPPE/UFRJ, a primeira incubadora tecnológica de cooperativas populares do país (Singer, 2002). Por fim, a Central Única dos Trabalhadores (CUT), que compreende três entidades que concomitantemente impulsionam a Economia Solidária, a saber: a Agência de Desenvolvimento Solidário (ADS), a Central de Cooperativas e Empreendimentos Solidários (Unisol) e a Cooperativa Central de Crédito e Economia Solidária (Ecosol) (Leite, 2009). deste parágrafo (não vejo problemas ) 


\section{Desafios da psicologia no Brasil}

Conforme já foi dito, o capitalismo é um sistema econômico que exclui os sujeitos, promovendo desigualdades sociais. Tais desigualdades dominam e estruturam a nossa sociedade e se referem principalmente às desigualdades de classe, gênero e etnia. Segundo Santos (2010), para que isso seja revertido, seria necessário que a economia fosse solidária em vez de competitiva. Santos (2010) ainda destaca que tanto as desigualdades, quanto a competição, típica do capitalismo, não são naturais e que elas são resultado da maneira como a vida social e econômica está organizada, ou seja, são construções culturais.

Diante disso, não é difícil elencar as consequências para o trabalhador neste "mundo capital “; que é afetado emsua maioria, mas principalmente as mulheres de baixa renda e escolaridade, são elas que possuem maior dificuldade de adentrar ao mercado de trabalho. Observando as políticas direcionadas as mulheres, é possível constatar que estão, em geral, na categoria das políticas sociais, mas não nas políticas econômicas, dando a impressão de que essa população não tem relação com os processos macroeconômicos.

Segundo a ONU, a maior parte das mulheres ainda trabalha na informalidade e com escassa proteção de direitos; alcançar não só o empoderamento econômico das mulheres e isso requer alternativas de mudança para dividir prosperidade de forma equitativa. Esse é um compromisso na agenda 2030 para o desenvolvimento sustentável. As mulheres se deparam ainda com realidades diferenciadas; extremos como "baixos pisos salariais", pobreza, menores níveis de instrução, baixa produtividade e alta precariedade se chocam com mulheres com níveis médios e altos de formação laboral, mas que também se tornam vulneráveis às volatilidades do ambiente econômico ${ }^{1}$.

Frente ao contexto aqui elucidado, é necessário pensar em práticas que incluam as mulheres e forneçam a elas um exercício de participação ativa para a mudança desse cenário. A Economia Solidária se constitui uma alternativa que pode possibilitar essa mudança, pois promove a cooperação, a democracia e solidariedade. Uma vez que tem como base a valorização do ser humano nas relações sociais, leva em consideração a igualdade, seja de gênero ou de etnia (Santos, 2010). Ao contar essa experiência, sensibilizar novos espaços e identificar possibilidades que possam multiplicar os espaços de trocas; capaz de articular a vida familiar, profissional e relacional; tão importantes para a mulher, permitindo que elas se expressem e se desenvolvam integralmente. 


\section{Desafios da psicologia no Brasil}

\section{REFLETINDO SOBRE O TRABALHO DAS MULHERES E A ECONOMIA SOLIDÁRIA}

Desde a virada do século, as mulheres vêm buscando o reconhecimento de seus direitos sociais. Inicialmente, através do movimento sufragista, que lutava pelo direito das mulheres ao voto e que se espalhou por vários países do ocidente. Depois, a partir da década de 1960, um momento de efervescência social, onde várias minorias buscavam seus direitos, teve início uma luta para além das preocupações sociais e políticas, que se constituiu como um esforço para que fossem formuladas construções teóricas a cerca do lugar da mulher na sociedade. O objetivo das estudiosas do tema naquela época era tornar visíveis aquelas que estavam ocultas durante tanto tempo, ou seja, em razão da segregação social e política a que as mulheres foram historicamente submetidas, e teve como resultado a enorme invisibilidade dessas pessoas como sujeitos (Louro, 1997).

De acordo com Louro (1997), no que diz respeito ao mundo do trabalho, pode-se dizer que os discursos que caracterizam o ambiente doméstico como sendo o "verdadeiro" universo feminino já estavam sendo progressivamente rompidos, pois é sabido que, desde há muito tempo, as mulheres das classes popular e camponesa, com certa frequência, trabalhavam fora do lar. Todavia, tais atividades, quase sempre, foram consideradas como "secundárias" ou de apoio, geralmente relacionadas ao cuidado e à educação. Isso se reflete até os dias atuais.

Se pensarmos na convergência entre a Economia Solidária e o feminismo, nota-se que é necessário reconhecer a importância da centralidade do trabalho nessa relação. Sobretudo, para seguirmos nessa discussão, é necessário compreender a divisão social e a divisão sexual do trabalho como instrumentos significativos para analisar as relações entre os indivíduos. Uma das proposições da Economia Solidária é justamente romper com a divisão social do trabalho. Isso significa que, para esse modo de produção, não deve haver separação entre o proprietário dos meios de produção e o sujeito que vende a sua força de trabalho, ou seja, não existiria a relação patrão-empregado (Guérin, 2005). Já a divisão sexual do trabalho, de acordo com Carloto e Gomes (2011), compreende que o trabalho, enquanto prática social, não se constitui de forma homogênea para todas as pessoas e que possui significados diferentes no contexto das relações sociais entre os gêneros. Entretanto, a divisão sexual do trabalho não se constitui enquanto categoria distinta da divisão social do trabalho; tal categoria “(...) existe para organizar o trabalho de homens e mulheres na estrutura social" (Carloto \& Gomes, 2011, p. 132). Isso significa que existem socialmente atribuições e competências descritas como pertencentes ao gênero masculino e atribuições e competências do gênero feminino. 


\section{Desafios da psicologia no Brasil}

Ainda sobre a divisão sexual do trabalho, Hirata e Kergoat (2007) dizem que tal conceito compreende que há uma denominação prioritária dos homens na instância produtiva e das mulheres na reprodutiva e, consequentemente, a ocupação pelos homens das atividades com valor social mais elevado (atividades políticas, militares, científicas, etc.). Explicando mais detalhadamente, esse modo específico da divisão social do trabalho possui dois princípios: o de separação, que prevê que existem trabalho de homem e trabalho de mulher, e o hierárquico, o trabalho do homem é superior ao da mulher. Tais ideias estão legitimadas socialmente através de um processo de naturalização, que coloca tais questões como se elas não fossem sociais, mas como se fizessem parte do destino natural da espécie. Entretanto, isso não significa que a divisão sexual do trabalho seja imutável, pois, ao longo da história da humanidade, pode-se notar que essa divisão não permaneceu sempre da mesma forma. Pode-se notar também que, principalmente nas últimas décadas, as mulheres vêm conquistando espaço em ambientes que eram considerados masculinos. Desse modo, pode-se compreender que o movimento da Economia Solidária possui o potencial de romper com a dicotomia da valorização do trabalho do homem e a subordinação do trabalho da mulher, sendo um caminho viável para a superação da divisão sexual do trabalho (Guérin, 2005).

Por meio da Economia Solidária, as mulheres podem experimentar serem protagonistas através da participação nos empreendimentos. Tal protagonismo pode colaborar em médio e longo prazo para a superação das relações discriminatórias de gênero. Um dos principais obstáculos, no entanto, com relação a esse protagonismo feminino, é fazer com que as mulheres superem as dicotomias presentes na divisão sexual do trabalho, pois as mulheres também são influenciadas pelos discursos da supremacia masculina e subalternidade da mulher e pela lógica de que as mulheres possuem o "papel social" de colocar as necessidades dos outros como prioritárias a suas, ou seja, a mulher deve satisfazer as necessidades dos filhos, companheiro etc. A vivência em grupo que a Economia Solidária proporciona contribui para a superação desse obstáculo, pois auxilia o debate e, por sua vez, a concepção de estratégias de mudança. Dessa forma, as mulheres têm na Economia Solidária um espaço para tornarem-se pessoas empoderadas.

Segundo Simon, V. P.; Boeira, S. L. (2017) "o empoderamento pode ser entendido a partir de um a perspectiva em que os indivíduos, organizações e comunidades coletam recursos de forma a terem voz, visibilidade, influência e capacidade, tanto de ação, quanto de decisão, ou seja, poderem controlar os temas que afetam suas vidas“.'(p.538) 


\section{Desafios da psicologia no Brasil}

O empoderamento não pode ser fornecido ou realizado por pessoas ou grupos, realiza-se em processos que empodera a si mesmos (Horochowski e Meirelles, 2007). Entretanto é fundamental intervenções externas para que essas pessoas possam conseguir viabilizar recursos ( de qualquer ordem Inecessários para a viabilidade de mudanças. Portanto, o empoderamento é a antítese do paternalismo para a " a construção das capacidades, a partir das forças existente de maneira à potencializá-las“. ( Simon e Boeira, 2017, p. 539 )

Ao se empoderar, as mulheres passam a obter um alto poder de controle sobre as decisões que determinam sua vida. Mais especificamente no que diz respeito à capacidade de defesa das individualidades, como a luta pela igualdade com os homens na obtenção de direitos e nos espaços decisórios. Neste sentido empoderar as mulheres, entre outras coisas, significa ampliar o acesso delas à cidadania e reconhecer suas reivindicações e lutas com relação à discriminação, machismo e a dupla jornada de trabalho, por exemplo.

A Economia Solidária, como já citada anteriormente, visa a uma revalorização do humano, busca formas de sobrevivência e de relações sociais diferente do modelo capitalista e tecnicista. Esse modo diferente de produzir trabalho abre perspectivas e iniciativas que promovem mudanças e a criação de produções mais justas e sustentáveis.

Essas iniciativas tem sido buscadas por uma gama de atividades apoiadas por igrejas, sindicatos, ONGs, de diferentes instituições e também pelas universidades. Essa última tem papel importante e se manifesta através de usas atividades extensionistas. A extensão pode ser entendida como uma prática acadêmica que interliga a universidade, nas suas atividades de ensino e pesquisa, com as demandas da população e que possibilita a formação do profissional cidadão e se vincula cada vez mais à sociedade como espaço privilegiado de produção do conhecimento significativo para a superação das desigualdades sócias existentes. Segundo Paulo Freire (1977) a extensão visa o conhecimento, e "este se constitui nas relações homem-mundo, relações de transformação, e se aperfeiçoa na problematização crítica destas relações“. (p.36)

Assim, o conhecimento tão inserido na Universidade traz algo fundamental no empoderamento das pessoas envolvidas em seus projetos, atividades e ou oficinas: a educação. Esse é o recurso relevante no processo de emancipação, pois fornece saber, habilidades e autoconfiança, indispensáveis para a participação integral na sociedade. Os efeitos da educação são manifestados das mais diversas formas no empoderamento feminino, tais como: expansão nas possibilidades de geração de renda, liberdade 


\section{Desafios da psicologia no Brasil}

nas decisões pessoais, entendimento e controle sobre a própria fertilidade e uma ampliação no envolvimento com a vida pública.(Barreto e Paula,2014)

É através da universidade que a geração de trabalho e renda de trabalhadores organizados pode ser implementada com tecnologia simples e efetiva. O acompanhamento, e a aproximação da Universidade através de seus alunos, docentes e técnicos interessados em Economia Solidaria, faz surgir projetos, iniciativas educativas, oficinas e programas de geração de renda capazes de auxiliar na sobrevivência e no empoderamento dessas trabalhadoras e é sobre isso que descreveremos a seguir.

\section{O PROJETO INCUBADORA}

A Incubadora Tecnológica de Economia Solidária da Universidade Estadual de Londrina, INTES - UEL é um programa de extensão vinculada à Pró-Reitoria de Extensão. Ela é resultado da união de vários professores de diversas áreas da Universidade e está em atuação desde setembro de 2004; suas atividades foram desenvolvidas a partir de 2005, em consonância com o PRONINC - Programa Nacional de Cooperativas Populares, que constitui uma das principais ações inscritas na Política Nacional de Economia Solidária empreendida pela SENAES, por meio do Programa Economia Solidária em desenvolvimento no Ministério do Trabalho e Emprego. Este programa assume papel primordial no processo de fortalecimento dos que atuam com a Economia Solidária. As Incubadoras Tecnológicas de Cooperativas Populares (ITCPs) surgiram no Brasil na década de 1990, dentro da perspectiva de desenvolver ações que permitissem aos setores populares retomar suas condições econômicas de sobrevivência e o seu direito à cidadania.

Baseado nos princípios da Economia Solidária, a INTES/UEL visa a aproximação da Universidade com trabalhadores que estão à margem do mercado formal de trabalho ou situam-se em condições precárias, por meio de apoio técnico às cooperativas, associações, grupos de trabalho coletivo, entre outros.

A Incubadora em questão é constituída por um espaço de ação e reflexão de extensionistas e pesquisadores e tem como missão dar apoio profissional, auxiliando na esfera politica, social e econômica. Neste sentido, vincula-se ao processo de incubação ${ }^{2}$ e/ou acompanhamento dos empreendimentos econômicos solidários. Neste tipo de acompanhamento, os processos a que a incubadora está vinculada abrangem dimensões diversas e dificuldades que, ao longo da assessoria, 


\title{
Desafios da psicologia no Brasil
}

vão surgindo. Essas dificuldades são de natureza simbólica e material, de ordem política, econômica e psicossocial, em que a técnica é muito importante mas insuficiente, ou seja, o processo de acompanhamento aos grupos assessorados em uma incubadora universitária exige e confere um papel muito além da assessoria. Segundo Souza, Barbosa e Reis (2009, p. 263):

\begin{abstract}
O conhecimento científico não pode se constituir em objeto de poder, mas algo público, de acesso a todos, constituído a partir das demandas ou direitos sociais. Neste campo, a articulação entre o conhecimento popular com as interpretações técnico-científicas é imprescindível. Isso proporciona uma via de mão dupla, que garante a formação continuada tanto dos professores pesquisadores, técnicos e bolsistas como dos trabalhadores envolvidos.
\end{abstract}

Pode-se aferir assim que os atores sociais envolvidos nas incubadoras terão como desafio a inserção ativa na constituição de referenciais que consolidam a pluralidade política, a democratização da economia, a participação propositiva, a geração de conhecimentos comprometidos com a igualdade e a diversidade social, a conservação e o equilíbrio da ecologia, todos esses pontos ligados aos princípios da Economia Solidária e da qual a INTES participava diretamente, tentando compreender os limites e desafios dessas práticas e teorizações. Os principais objetivos da INTES/UEL são:

a) proporcionar aos estagiários acesso a uma nova realidade organizacional, auxiliando nas suas formações e no estabelecimento da relação teoria/prática;

b) identificar as formas de organização e as relações estabelecidas nos grupos incubados;

c) .promover a integração ensino-pesquisa-extensão;

d) facilitar a transferência de conhecimento acadêmico à sociedade;

e) realizar parcerias com o poder público e o setor privado, ampliando a possibilidade de construção de alternativas para a consolidação de relações sociais e de formas de desenvolvimento sustentáveis.

Para o processo de assessoria, a INTES possui três etapas fundamentais em seu trabalho: formação/diagnóstico inicial, conscientização/processo de organização do trabalho e avaliação contínua. Essas etapas são desenvolvidas por meio de encontros com os trabalhadores assessorados e são atividades dialogadas com o objetivo de fortalecer a autonomia e a construção da identidade e subjetividade dos trabalhadores da Economia Solidária. 


\section{Desafios da psicologia no Brasil}

Assim, o presente artigo integra parte das discussões realizadas junto ao grupo de estudos da INTES e do acompanhamento realizado de um grupo de costureiras em Ibiporã, cidade próxima de Londrina, que tinha como principal objetivo tornarem-se autônomas, gerando renda e produzindo roupas de academia e/ou fitness. Como objetivos específicos entender a visão de trabalho das mulheres e se ocorreram mudanças e um maior empoderamento delas em seu cotidiano.

A partir do acompanhamento das atividades apreendidas, como feiras, oficinas e trabalhos que visavam à socialização e consolidação do grupo de mulheres, buscou-se entender como elas se constituíam e como lidavam com estas experiências, visando principalmente a potência e o protagonismo das mulheres.

\section{MÉTODO}

A presente pesquisa relata a atuação da INTES - UEL no acompanhamento realizado junto a um grupo de costureiras . O delineamento da pesquisa se caracteriza como abordagem qualitativa de natureza descritiva, pois o que se pretendia era que os atores envolvidos expressassem suas opiniões sobre a vivência do trabalho solidário e também sua forma de ver a vida e/ou essa experiência. $\mathrm{O}$ grupo pesquisado era composto de 6 (seis) mulheres de baixa escolaridade e que possuíam alguma experiência em costura. A faixa etária estava entre 45 (quarenta e cinco) e 62 (sessenta e dois) anos. Todas residiam em Ibiporã, cidade próxima de Londrina-Pr.

Os instrumentos e técnicas utilizadas foram entrevistas e posteriormente a análise de conteúdo delas. A entrevista possibilita o diálogo e, segundo Trivinõs (1987, p.146) “(...) é aquela parte de certos questionamentos básicos, apoiados em teoria e hipóteses que interessam à pesquisa, e que, em seguida, oferecem amplo campo de interrogativas, fruto de novas hipóteses que vão surgindo à medida que se recebem as respostas do informante."

A análise de conteúdo é uma estratégia que, segundo Bardin (1977, p.21), conceitua-se em um:

Conjunto de técnica de análise de comunicação, visando procedimentos sistemáticos e objetivos de descrição de conteúdo da mensagem, obtém indicadores quantitativos ou não, que permitam a inferência de conhecimentos relativos à produção/recepção (variáveis inferidas) das mensagens.

Apesar de colocar a questão dos indicadores quantitativos, este é um método que privilegia a pesquisa qualitativa porque favorece uma análise criteriosa do processo de comunicação e visa à apreciação objetiva da mensagem. 


\section{Desafios da psicologia no Brasil}

Assim, como procedimento metodológico, a coleta de dados da pesquisa pode ser descrita na sequência:

1. Contato inicial com a INTES/UEL e com o grupo de mulheres assessoradas explicando a pesquisa e a garantia de sigilo, bem como o livre consentimento de participação.

2. Entrevista com roteiro semi-estruturada, sendo que, para o artigo em questão, o recorte de análise está nas perguntas relacionadas à visão de trabalho e conhecimento do processo de assessoria, dificuldades relatadas pelas mulheres durante o processo de acompanhamento e o papel efetivo das mudanças pós-acompanhamento.

3. Sistematização dos dados, que se deu por meio da análise de conteúdo, isto é, todo o material foi organizado até que se conseguisse identificar tendências e padrões relevantes. Serão apresentadas três categorias relevantes, que foram levantadas por meio dos relatos das trabalhadoras, seguindo a proximidade de conteúdo e que serão evidenciados no item abaixo.

A presente pesquisa teve o registro sob o n. 099/2014 e passou pelo comitê de ética com o CAAE: 04950912.3.0000.5231 faz parte de um recorte da Pesquisa maior sob o título: "O papel das Incubadoras das Instituições de Ensino Superior do Paraná.

\section{RESULTADOS E DISCUSSÃO}

Na tentativa de sistematização optou-se por algumas categorias de análise, que serão aqui descritas e discutidas. É importante colocar que encontrei um processo em construção, realidades diferenciadas na forma de ver e de entender a relação dessas mulheres com a Economia Solidária, mas todas ressaltaram o valor do coletivo e da importância dessa experiência em suas vidas.

\section{CATEGORIA 1- VISÃO DE TRABALHO}

De acordo com dados do "Atlas da Economia Solidária" (SENAES, 2007), a grande parte dos empreendimentos de maior porte - mais de vinte e uma pessoas - contam com a maioria de trabalhadores homens; já as mulheres, em geral, estão presentes nos empreendimentos de menor porte - vinte pessoas ou menos. De acordo com Pitaguari, Santos e Câmara (2012), isso de deve ao fato de que, para as mulheres, a Economia Solidária se constitui enquanto um complemento da renda 


\section{Desafios da psicologia no Brasil}

familiar e também pela dificuldade de conciliar o trabalho no empreendimento com as atividades domésticas.

Percebeu-se que o acesso da mulher ao trabalho e consequentemente a uma fonte de renda traz a possibilidade de uma maior autonomia e representa também uma autorrealização, coisas que estão para além de uma simples complementaridade da renda familiar. Sendo assim, muitas das mulheres que integraram o grupo de costureiras buscava por meio do trabalho na associação uma forma de valorização social e simbólica. Como no relato de uma das participantes: “(...) estar aqui é muito importante para mim, é trabalhar, mas é poder contar com a amizade de todas as colegas, uma ajuda a outra (...) dá força.". Neste relato esta a importância do trabalho, mas além disso as relações são ressaltadas. Aspectos como amizade, alegria e partilha estão presentes nas atividades e nas oficinas de Economia Solidária, as participantes do projeto ressaltaram um dos principais sentidos do trabalho relatando que ele não é só a fonte de renda; e que durante as assessorias e atividades pesa muito a amizade que se estabelece entre essas mulheres.

A noção de pertença e valorização de cada integrante complementa essa análise conforme outra participante relata: “(...) trabalhar aqui, com essas mulheres é tudo de bom, me sinto feliz e animada com esse trabalho.." o que mostra uma interferência na autoimagem e autoestima. A elevação da autoestima conduz a uma mudança no pensamento dos participantes do grupo sobre as suas aptidões, suas perspectivas da realidade, o envolvimento no processo decisório e a ampliação de suas competências de trabalho, que geram a agregação entre elas.

Esses grupos de trabalhadores, ao se integrarem, demonstram um sentimento de pertencimento e aceitação social importante e o expressam em seu trabalho. Cada um sabe um pouco das necessidades/dificuldades e anseios uns dos outros e isto deve ser considerado. Não há como negar que nas práticas sociais existem várias dimensões como: gênero, classe, crenças que devem ser discutidas; segundo Veronese (2010, p.25 ), "a dimensão social está ligada as emoções, a capacidade de interagir, de ser empático, de ser criativo e não deve correr o risco de ignorá-las, pois auxiliam na percepção das necessidades de seus atores".

Apesar de muitas mulheres atualmente buscarem sua autonomia e autorrealização através de um trabalho, sabe-se que, desde a época pré-industrial, homens e mulheres têm exercido papéis distintos no interior das famílias, sendo que as mulheres, em sua ampla maioria, ainda são responsáveis pelas atividades domésticas e de cuidado com os filhos (Kon, 2005). Com o avanço da luta das mulheres por 


\section{Desafios da psicologia no Brasil}

direitos iguais na sociedade, elas conquistaram e vem conquistando os espaços reservados ao mercado formal, porém, mesmo desenvolvendo jornada igual aos homens, recebem valores inferiores, além de ser minoria ocupando cargos de liderança e chefia. (CARVALHO, A; EVANGELISTA, A. e OLIVEIRA, P., 2018)

Assim algumas formas de pensar vão se perpetuando entre as mulheres; principalmente as mulheres de baixa renda, não sendo diferente com a experiência do grupo de costureiras aqui relatado, quando algumas delas verbalizam que seus companheiros fazem críticas ao fato de elas terem que se ausentar de casa por algumas horas semanais para participar da associação evidenciando a divisão sexual do trabalho e o tempo que as participantes gastam com o projeto ${ }^{3}$.

Complementando esse raciocínio há relatos significativos como:"Meu marido não acredita que isso possa realmente valer a pena.... tanto trabalho e ainda tem que conciliar tudo lá em casa". Ou até mesmo: "Lugar de mulher é em casa!" Portanto, é urgente analisar o lugar e o papel das mulheres no movimento que está em desenvolvimento. Segundo Simon e Boeira (2017) envolver a família, criar oportunidades de participação de homens e mulheres no entendimento da Economia Solidária e seus empreendimentos contribui para entender os riscos e empecilhos.

Os sentidos do trabalho, tão importante para o avanço da Economia Solidária e para a valorização das mulheres e participação no espaço público foi sempre discutido durante o atendimento ao grupo de costureiras em rodas de conversa e também de forma informal e notou-se que as trabalhadoras gostam muito do que fazem: "Ser costureira, trabalhar com os tecidos... é tudo que sempre quis". "Gosto muito do que faço." São relatos que marcam a identificação e o apreço positivo daquilo que fazem. A pesquisa mostrou que a atividade desenvolvida, o trabalho de "costurar", é algo de que esse grupo realmente gostava e se identificava fazendo com que essas continuassem no projeto independente de opiniões contrárias.

O trabalho possibilita o agir coletivo e torna-se uma alternativa para aqueles excluídos do mercado tradicional e assim permite a transformação do papel das mulheres na sociedade, e é sobre isso que a categoria abaixo irá explanar.

\section{CATEGORIA 2 - ECONOMIA SOLIDÁRIA E O EMPODERAMENTO DAS MULHERES}

Conforme já dito na introdução, quando falou-se à respeito da divisão sexual do trabalho (Carloto \& Gomes, 2011; Guérin, 2005; Carloto e Gomes, 2011), ainda na atualidade as mulheres são minoria nos 


\section{Desafios da psicologia no Brasil}

papéis de liderança na sociedade. O reflexo disso, visto na experiência com as costureiras, é que, de forma generalizada, as mulheres do grupo tinham dificuldade de colocar suas opiniões e de assumirem a responsabilidade pela associação, o que por vezes prejudicou o andamento das atividades do grupo. Ocorreram desistências de participantes, número significativo de faltas nos dias das reuniões e demora em tomar decisões. Percebia-se a dificuldade com os papéis de liderança, por não serem lugares comuns para essas mulheres, muitas delas com posturas bastante submissas, com histórico familiar patriarcal, somando-se à isso baixo grau de instrução e algumas pertencentes a terceira idade. Essas características muito apontadas em estudos e pesquisas que mostram dificuldades no empoderamento das mulheres.

Especificamente neste grupo, um fato que corrobora nos aspectos acima descritos é que, em determinadas ocasiões, quem acabou "liderando" as outras mulheres era uma das participantes mais jovens e que também tinha uma condição financeira um pouco melhor. Havia em algumas participantes com um discurso muito forte: "Eu não entendo muito disso, deixa que a fulana resolve"; "o processo está difícil, não sei se consigo".

Esse medo, culpabilização e a omissão de algumas participantes, era discutido durante o processo de assessoria. A equipe da INTES sempre acreditou que era possível converter as desigualdades, as visões distorcidas dessas mulheres por meio dos espaços coletivos, consolidando assim, o diálogo, a reflexão e a deliberação e o envolvimento nos processos de forma coletiva. No entanto isso teve uma variabilidade, com vários "altos e baixos do próprio grupo"; mostrando assim que o empoderamento não é algo fácil de acontecer.

Mas ressalta-se que, apesar de diferenças entre elas, houve o reconhecimento e o desenvolvimento da capacidade de ação, principalmente ao ter que decidir sobre a produção; relatos como: "Vamos lá gente...temos que entregar essas costuras" e ou "Vamos pensar juntas e nos organizarmos para dar conta do que precisamos fazer?"; mostrando assim certa autonomia e busca por um agir coletivo. Isso vem de encontro com as autores Simon, V. e Boeira (2017) que também em suas experiências demarcaram as intervenções externas, citadas na introdução, ou seja, apesar das dificuldades é preciso fornecer subsídios para que superem os limites da "consciência ingênua, para que os sujeitos se tornem cidadãos críticos e conscientes de sua posição enquanto indivíduos num processo histórico, situado“. (p.539) 


\section{Desafios da psicologia no Brasil}

Outro ponto encontrado no discurso das trabalhadoras é a forma como passaram a ver o trabalho solidário a partir do contato com a incubadora houve uma ampliação da visão de mundo: "Aqui é muito bom, pois passei a conhecer outras formas de trabalho... passamos a ter mais conhecimento das coisas, do mercado de trabalho e da nossa produção." (...)" nos organizamos e conversamos sobre tudo e até como vamos fazer.... do início ao fim“. Esta era uma característica marcante dentro do projeto, já que o trabalho da incubadora consistia em oferecer conhecimentos diversos através de sua equipe de docentes e estagiários de diferentes áreas, tais como design de moda, economia, direito, ciências contábeis, serviço social e psicologia, entre outros. O que se ressalta aqui é a transferência de conhecimentos diversificados, que contribui para o desenvolvimento dos grupos associativos. Todavia, segundo Dagnino (2010, p.19): “Todo o conhecimento deve ser adaptado para as características e especificidades dos empreendimentos cooperativos."

Esse conhecimento propiciará uma reconfiguração do significado do trabalho, uma conexão entre o trabalho manual e o trabalho intelectual, tão importante para o redimensionamento de uma nova concepção de mundo, ou seja, implicar o trabalhador na execução e em todo o processo produtivo. Tiriba (2001, p. 210) esclarece:

Como um espaço singular de produção de conhecimento, a produção associada ganha relevância à medida que os sujeitos, ao tentarem subverter a lógica do capital, em vez de controlar e dificultar o acesso do conjunto dos trabalhadores aos segredos do processo produtivo, promovem a articulação dos diferentes saberes dos trabalhadores.

Nessa concepção, o saber tanto popular como acadêmico apresenta-se como um processo em construção, não cristalizado, mas que auxilia na percepção da realidade. A conscientização dessa prática é entendida como um processo de recriação de conhecimentos, criando possibilidade para a emancipação dos sujeitos, fato que contribui enormemente para as mulheres em nossa sociedade, que ainda enfrentam a realidade da desigualdade com relação aos homens.

A pesquisa mostrou que essas mulheres, durante os encontros e com algumas responsabilidades específicas, como feiras, qualidade de produto e venda, passaram a acreditar em seu próprio trabalho: "temos dificuldades, mas estamos tentando desenvolver um bom produto"; "cada um usa o que sabe para ajudar o grupo". Essas falas demonstram o quanto elas se esforçam para entender e fazer com que o grupo tenha sucesso. Ressalta-se, ainda, que as mudanças e formas sutis de desenvolvimento são percebidas com a melhoria da linguagem e o fato delas se colocarem frente às situações e problemas em busca de resultados positivos, denotando assim a busca pelo empoderamento. 


\section{Desafios da psicologia no Brasil}

\section{CATEGORIA 3 - DIFICULDADES E O PROCESSO DE ASSESSORIA}

Um ponto que deve ser destacado é em relação às dificuldades relatadas sobre o processo de assessoria. Foi apontado pelas participantes a falta de recursos materiais e subsídios para compra dos insumos. A fala de uma das trabalhadoras é esclarecedora: “Eles vem... e falam para gente o que tem que fazer, mas nós já sabemos fazer... falta verba e isso é ruim, precisa de dinheiro, conseguir mais recursos." Fica evidente que as trabalhadoras estão sujeitas a condições bastante adversas e que os recursos são necessários para que possam manter o seu negócio. De acordo com Cordeiro e cols. (2010), tais dificuldades trazem reflexões acerca da importância que tem sido dada, pelo poder público e pela sociedade, à Economia Solidária enquanto alternativa para a geração de trabalho e renda, e também sobre as dificuldades enfrentadas pelo empreendimento solidário composto por camadas populares num contexto capitalista, antagônico ao trabalho cooperado.

Outra questão que necessita ser compreendida a cerca do processo de incubação de grupos em Economia Solidária é que ele variará de um grupo para o outro. Isso porque o processo é gradativo. Cada grupo, e cada indivíduo incluso nele, tem seu próprio ritmo de vida e de trabalho, o que faz desse processo algo singular em cada grupo. Sobre o processo de formação de grupos solidários, Santos e Rodriguez (2002, p. 64) afirmam que “(...) seu potencial emancipatório e as suas perspectivas de êxito dependem, em boa medida, da integração que consigam entre processos de transformação econômica e processos culturais, sociais, políticos".

A depender dos fatores econômicos, culturais, sociais e políticos dos quais o sujeito faz parte, 0 processo de incubação enfrentará maiores ou menores dificuldades em se consolidar. Conforme já falado, as trabalhadoras que constituíram o grupo de costureiras eram mulheres de baixa renda, acima de quarenta anos, que passaram a maior parte da vida trabalhando em seus próprios lares. Por estarem nesse contexto, é esperado que o processo de incubação fosse muito diferente de um grupo formado em sua maioria por trabalhadores homens, por exemplo, que possuem maior liberdade de tomarem suas próprias decisões e em geral não possuem compromisso com os cuidados da casa na sociedade na qual vivemos. Entretanto, essas questões subjetivas muitas vezes passam despercebidas pela equipe técnica de uma incubadora, ou mesmo que a equipe perceba tais questões, não consegue traçar soluções a fim de superá-las.

Durante o processo de incubação do empreendimento das costureiras, muitos dos técnicos se queixavam que as mulheres eram "desinteressadas", porque faltavam nas reuniões, por exemplo. Mas 


\section{Desafios da psicologia no Brasil}

conforme foi sendo apresentado ao longo desse artigo, o contexto social, econômico e cultural delas impunha barreiras para a realização do empreendimento.

\section{CONSIDERAÇÕES FINAIS}

Ao refletir sobre a temática da Economia Solidária enquanto uma perspectiva de trabalho para as mulheres, a partir da experiência de assessoria da INTES ao grupo de costureiras, pode-se perceber que as convergências entre o feminino e a Economia Solidária são extensas, principalmente no que diz respeito à conquista da autonomia e à autorrealização por parte delas, o que é essencial para o processo de empoderamento.

A participação das mulheres nos empreendimentos solidários revelou-se como uma possibilidade de atender necessidades subjetivas relacionadas à melhora da autoestima e do relacionamento interpessoal, obtidos por meio do engajamento em um trabalho em que elas podem ser ativas em todo o processo, do companheirismo entre as trabalhadoras e da cooperação diante das tarefas e das dificuldades. Sendo assim, pode-se concluir que o trabalho possui muitos aspectos subjetivos, fazendo com que essa atividade esteja para além da simples geração de renda para um indivíduo.

Entretanto, para que a Economia Solidária possa ser de fato uma alternativa para a igualdade social das mulheres com relação aos homens em nossa sociedade, é necessário que as políticas públicas, assim como o terceiro setor e a sociedade como um todo, apoiem as iniciativas solidárias. Pois, como foi visto na fala de uma das costureiras, muitas vezes faltam recursos, em forma de financiamentos, para que o trabalho cooperativo torne-se viável.

O acompanhamento do grupo de mulheres em questão e o relato da experiência INTES com essas trabalhadoras podem nortear trabalhos futuros e auxiliar na criação de metodologias eficazes, que intervenham nos processos de reprodução da desigualdade, com vistas a combatê-los.

\section{REFERÊNCIAS BIBLIOGRÁFICAS}

BARDIN, Laurence. (1977). Análise de conteúdo. São Paulo.

BOCAYUVA, Pedro Cunca (2009). Tecnologia social. Rio de Janeiro: FASE- UFRJ.

CARLOTO, Cassia Maria, \& GOMES, Anne Grace. (2011, jan-mar). Geração de renda: Enfoque nas mulheres pobres e divisão sexual do trabalho. Serviço Social \& Sociedade, 105, 131-146.

CORDEIRO, Sandra, PISICCHIO, Rosely., ALVES, Jeise, BATISTA, Luciana, BANSI, Ana Claudia, CLEMENTE, Vivian, DE OLIVEIRA, Mariana, \& SANCHES, Henrique. (2010). Incubadora Tecnológica de 


\section{Desafios da psicologia no Brasil}

Empreendimentos Solidários - INTES/UEL: História e desafios. In B. Borinelli, L. M. Santos, \& S. Pitaguar, (Eds.). Economia Solidária em Londrina: Aspectos conceituais e experiência institucional ( $p$. 107-118). Londrina: UEL.

CULTI, Maria Nezilda. (2008). Conhecimento e praxis: Processo de incubação como processo educativo. In: Sampaio, E.B. Almeida, M. C. Economia solidária e processos de incubação. São Cristovão : UFSE. p.28-36.

DAGNINO, Renato., \& FONSECA, Rodrigo. (2007, junho). Economia solidária, incubadoras universitárias, cooperativas e tecnologia: Uma definição de papéis. Revista Proposta, 31(12), 16-24.

DE OLIVEIRA, Adriana Lucinda. (2005). A trajetória de empoderamento de mulheres na economia solidária. Revista Gênero, v. 5, n. 2: 1-14, jan-jun.

GUERIN, Isabelle (2005). As Mulheres e a economia solidária. Edições Loyola.

HIRATA, Helena, \& KERGOAT, Danièle. (2007). Novas configurações da divisão sexual do trabalho. Cadernos de pesquisa, n.132, 37: p. 595-609.

HIRATA, Helena, \& ZARIFIAN, Philippe. (2003). Conceito de trabalho. SÃO PAULO Trabalho e cidadania ativa para as mulheres: desafios para as Políticas Públicas. São Paulo: Prefeitura Municipal Coordenadoria Especial da Mulher, p. 65-69, 2003.

KON, Anita. (2005). Considerações teóricas sobre a divisão sexual do trabalho na família: Repercussões sobre o mercado de trabalho. SEMINÁRIO AS FAMÍLIAS E AS POLÍTICAS PÚBLICAS NO BRASIL. Belo Horizonte, Abep.

LEITE, Marcia Paula (2009). A economia solidária e o trabalho associativo: Teorias e realidades. Revista Brasileira de Ciências Sociais, n 24, 69: 31-51.

LOURO, Guacira. (1997). Gênero, sexualidade e educação: Uma perspectiva pós-estruturalista. Petrópolis: Vozes.

PITAGUARI, Sinival. SANTOS, Luis Miguel, CÂMARA, Márcia Regina. (2012). Panorama da Economia Solidária no Brasil. In: PITAGUARI, Sinival. CORDEIRO, Sandra. LANZA, Líria (Eds.). A sustentabilidade da economia solidária: Contribuições multidisciplinares. Londrina: UEL. p. 33-62.

SANTOS, Boaventura de Sousa. (2002). Produzir para viver: Os caminhos da produção não capitalista. Rio de Janeiro: Civilização Brasileira.

SANTOS, Graciete. (2009). Economia solidária e feminista: Um encontro possível. Cadernos Feministas de Economia e Política, v. 5: 69-90.

SINGER, Paul. (2002). A recente ressurreição da economia solidária no Brasil. In: SANTOS, Boaventura de Sousa. Produzir para viver: Os caminhos da produção não capitalista. Rio de Janeiro: Civilização Brasileira. 2, p. 81-129.

SOUZA, Armando \& BARBOSA, Mourão Jose (2009). Incubadora universitária: Inovação social e desenvolvimento. In: Bocayuva, Pedro Claudio Cunca. Tecnologia social, economia solidária e políticas públicas. FASE: Rio de janeiro. p.87. 


\section{Desafios da psicologia no Brasil}

TIRIBA, Lia. (2001). Pedagogias da produção associada. Ijuí: Ed. Unijuí.

TRIVINÕS, Augusto. (1987). Introdução à pesquisa em ciências sociais. São Paulo: Atlas.

VERONESE, Marília. (2008). Psicologia social e economia solidária. Aparecida, SP: Idéias e Letras. 


\section{Desafios da psicologia no Brasil}

\section{NOTAS}

Nota 1

Homens ganham em média $19 \%$ mais que mulheres e $55 \%$ dos empregos das mulheres estão na economia informal ; segundo a OIT ( organização internacional do trabalho ) há necessidade de insistir na igualdade de gênero e criar melhores oportunidade às mulheres em idade de trabalhar (dados em www.nações unidas.org.br; consultada em 17/01/2020 )

\section{Notas 2}

Incubação entendida como uma construção social com base em diferentes saberes, condições instrumentais e institucionais transformadas continuamente a partir de uma nova forma de organização de trabalho (Bocayuva, P.C. Tecnologia Social. FASE, UFRJ, 2009, p. 288-289).

Nota 3

Segundo IPEA (2010) as mulheres dedicam 30,3 horas semanais à trabalhos domésticos, enquanto homens realizam apenas 10,1horas por semana. (Dados coletados em 10/01/2020 em www.ipea.org.br) 


\section{Capítulo 26}

\section{A INCLUSÃO DE ADOLESCENTES PRIVADOS DE LIBERDADE NA REDE PÚBLICA DE ENSINO ${ }^{1}$}

DOI: $10.37423 / 200200212$

Juliana Biazze Feitosa (Psicóloga da Semiliberdade de Cascavel. Diretora Adjunta do Departamento de Atendimento Socioeducativo DEASE- PR (2017 e 2018). Psicóloga dos Centros de Socioeducação de Cascavel 2 e de Pato Branco. Doutora e Mestre em Psicologia pela UEM, Especialista em Saúde Pública pela UNIOESTE e em Saúde Mental, Psicopatologia e Psicanálise pela PUCPR. Membro do Grupo de Estudos e Pesquisa sobre o higienismo e Eugenia (GEPHE)).

Juliana_biazze@yahhod.com.br

Luciana Funck (Psicóloga do Centro de Socioedúcação de Cascavel 2; Pedagoga petaPUC-RS; Especialista em Gestão Pública com ênfaselem-Bireitos Humanos pela Universidade Estadual de Ponta Grossa; Especialista em Psicologia Jurídica pelo Conselho Federak de Psicologia; Especialista em Saúde Mental e Atenção Psicossocial de Crianças e Adolescentes pela Escola Nacional de Saúde Pública Sergio Arouca / Fiocruz; Especialista em Saúde coletiva: perspectiva multidisciplinar pela Faculdade Assis Gurgacz.) lucifunck@gmail.com

Renata H. D. Oliveira (Terapeuta Ocupacional da Casa de Semiliberdade Masculina de Curitiba. Diretora da Casa de Semiliberdade Feminina de Curitiba|(2018-2019); Doutoranda em Terapia Ocupacional pela Universidade Federal de São Carlos UFSCar; Mestre em Educação pela Universidade Estadual do Oeste do Paraná UNIOESTE; Pós graduada em Terapia Ocupacional: Uma visão dinâmica aplicada a Neurologia pela Universidade Salesiana de Lins:/Pós-graduanda em Saúde Mental da Criança e do Adolescente pela FIOCRUZ. renatahdo@gmail.com

Terezinha Eerraz (Assistente Social do Centro de-Sectoeducaçẫo de Gascavel 2; Mestre em Servico Social, Políticas Sociais e Direitos Humanos pela Universidade Estadual do Oeste do Paraná - UNIOESTE, campus de Toledo/PR. Especialista em Projeto ético-político e as competências e habilidades; especialista em Docêneia no Ensino Superior; e Adolescente em conflito com a lei, pela UNIPAN/UNIBAN)

ter.m.ferraz@gmail.com 


\section{Desafios da psicologia no Brasil}

RESUMO: A inclusão escolar do adolescente privado de liberdade torna-se um desafio, considerando a frequente defasagem idade-série, o conflito estabelecido entre o adolescente e a escola e a evasão escolar. Neste sentido, na referida exposição pretendemos relatar duas experiências bem sucedidas de inclusão de dois adolescentes egressos do Centro de Socioeducação Cascavel 2/PR (entidade estadual que executa a internação socioeducativa), em duas escolas públicas do município, que inicialmente apresentavam resistência em acolhê-los. Compreendendo que a judicialização cria maior resistência para garantir o ingresso dos adolescentes no sistema escolar, a equipe do Centro de Socioeducação realizou intervenções com os profissionais da escola, com os adolescentes egressos e seus familiares. No tocante aos resultados, destacamos que eles foram satisfatórios, considerando que os colégios os incluíram de forma acolhedora, possibilitando a permanência deles no espaço escolar. Ademais, existiram avanços no relacionamento interpessoal, bem como na aprendizagem. Diante do exposto, concluímos que as experiências relatadas só reforçam a concepção de que a garantia de direitos de crianças e de adolescentes será mais facilmente assegurada por meio da consolidação de uma rede de proteção formada entre as esferas de governo, os diversos setores organizados da sociedade e as demais políticas intersetoriais.

Palavras-chave: inclusão escolar, adolescentes privados de liberdade, intersetorialidade. 


\section{Desafios da psicologia no Brasil}

\section{INTRODUÇÃO}

Crianças e adolescentes brasileiros, apesar de nossa legislação em vigor ${ }^{2}$ dispor a prioridade absoluta na garantia de seus direitos fundamentais são a parcela mais exposta às violações de direitos por parte da família, do Estado e da sociedade. Ainda compõe o cenário brasileiro as adoções irregulares, o extermínio, as prisões arbitrárias, o abuso e a exploração sexual, o trabalho infantil e os maus-tratos às crianças e adolescentes (VOLPI, 2006).

O Ministério da Saúde indica que o jovem do sexo masculino é a maior vítima de óbitos por causas externas, cerca de $80 \%$, sendo mais da metade devido a homicídios e acidentes de transporte (BRASIL, 2008).

Pesquisas realizadas com adolescentes privados de liberdade no estado de São Paulo revelam que é crescente o envolvimento dos mesmos com o crime organizado e que houve um aumento no percentual de infrações violentas cometidas por eles (PRIULI; MORAES, 2007, ASSIS; SOUZA, 1999 e ADORNO; BORDINI; LIMA, 1999). Conforme levantamento realizado pelo Conselho Nacional de Justiça - CNJ, em novembro de 2015 eram noventa e seis mil adolescentes em cumprimento de medidas socioeducativas no Brasil. No ano seguinte, este número equivalia a cento e noventa e dois mil, demonstrando que dobrou o número de adolescentes nesta condição (CNJ, 2016).

Ao examinar a existência ou inexistência de carreiras criminosas na adolescência, tomando como objeto de pesquisa os processos judiciais localizados na Vara da Infância, da Juventude e do Idoso de Ribeirão Preto-SP, D'Andrea (2008) constatou que: na data do primeiro boletim de ocorrência, ato que gerou abertura de processo judicial, os adolescentes possuíam entre 11 e 14 anos de idade e foram processados, pelo menos, duas vezes, sendo a média de processos em torno de 2 a 7 . Os atos infracionais mais praticados foram: furto, roubo, porte e tráfico de droga e lesão corporal. A pesquisa apontou o aumento de processos em adolescentes com maior idade, principalmente entre os de 16 a 17 anos, correspondendo a 70,8\% de um total de 514 fatos processados e ausência de variação entre a gravidade da primeira e da última infração registrada.

Tais dados conferem com as informações contidas no estudo sistematizado em 2012 pelo Conselho Nacional de Justiça - CNJ e nos Levantamentos Anuais do SINASE no que tange as principais infrações cometidas e as idades com que os adolescentes se iniciam na prática de delitos, bem como, as intensificam. A relevância deste estudo consiste, principalmente, na demonstração de que o mesmo 


\section{Desafios da psicologia no Brasil}

adolescente não tende a cometer delitos cada vez mais graves com o passar do tempo, colaborando desta forma para romper com o ideário preconizado atualmente pela mídia de que o adolescente se encontra numa escalada em termos de carreira criminosa, discurso que serve como pano de fundo, para justificar a proposta da redução da idade penal. Apesar de o estudo apontar a ausência de carreira criminosa, ele acena para outro fato: a reincidência, mostrando-nos que as alternativas que temos lançado mão para enfrentar a violência praticada por adolescentes estão sendo pouco resolutivas, conforme problematizaremos a seguir.

Quanto ao estado do Paraná, no ano de 2018, o Sistema Estadual de Atendimento Socioeducativo (responsável pela execução da internação e semiliberdade) atendeu aproximadamente 1000 adolescentes. A maior parte deles possuía 16 e 17 anos, certidão de antecedentes infracionais positiva e os atos infracionais mais praticados foram as ocorrências contra o patrimônio e o tráfico de drogas (PARANÁ, 2018).

Diante deste cenário, verificamos que a sociedade brasileira continua buscando alternativas para intervir frente à violência infantojuvenil, dentre elas, destacamos que na área do Direito temos observado a proposição de novas reformas nas Legislações que regulamentam a justiça infantojuvenil, tais como: a redução da maioridade penal para 16 anos $^{3}$ e o aumento do período máximo da internação socioeducativa para 5 anos $^{4}$.

Ainda na contemporaneidade acompanhamos propostas como a divulgada por pesquisadores da Pontifícia Universidade Católica do Rio Grande do Sul e da Universidade Federal do Rio Grande do Sul que pretendiam realizar estudos e mapeamentos de ressonância magnética do cérebro de cinquenta adolescentes autores de ato infracional internados na Fundação de Atendimento Socioeducativo $(\text { Fase })^{5}$, a fim de se comprovar a suspeita de que os homicidas têm partes do cérebro atrofiadas (Conselho Federal de Psicologia, 2008).

Já alguns teóricos da área social defendem a tese de que a violência entre os jovens latino-americanos possui íntima relação com as desigualdades e o não-acesso à riqueza e cidadania e entendem que seu enfrentamento acontecerá por meio de políticas públicas que busquem superar a condição vulnerável desses jovens e que operem em rede (ABRAMOVAY, 2002; CURYet al, 2005; NJAINE et al, 2007 e MINAYO; SOUZA, 1999). 


\section{Desafios da psicologia no Brasil}

Em síntese, percebemos que as ciências da contemporaneidade produzem diversificadas teorias sobre a violência e estabelecem parâmetros para protegermos a infância e adolescência, porém constatamos que estes conhecimentos não permitiram transpor os abismos existentes entre a legislação em vigor (que preconiza a proteção integral de crianças e adolescentes e que é muito valorizada inclusive internacionalmente) e a realidade social e nem sequer reduzir os índices de violência.

Portanto, reconhecemos a importância de avaliar as ações tomadas pelo Estado e a sociedade para o enfrentamento da criminalidade infantojuvenil e nos propomos neste artigo, sob a luz da história, a refletir sobre a inclusão escolar de adolescentes privados de liberdade, apoiando-se no relato de duas experiências bem sucedidas de retorno ao sistema escolar após o cumprimento da internação de socioeducativa.

\subsection{A CRIMINALIDADE INFANTOJUVENIL E SUA HISTÓRIA}

Estudos indicam que a criminalidade infantojuvenil no Brasil não é própria da modernidade e que há registros dela já no período imperial e principalmente nas primeiras décadas da instauração da República (SANTOS, 2002 e CUNHA, 2002).

O Código Criminal do Império de 1830, em seu artigo 10, parágrafo primeiro, estabelece que "não se julgarão criminosos os menores de quatorze anos" (BRASIL, 1830). Trinta e quatro anos após a sua publicação, o Tribunal de Relação da Corte retifica-o, acrescendo o seguinte adendo: "entre os 7 e os 14 anos, os menores que obrassem com discernimento poderiam ser considerados relativamente imputáveis" (KOERNER JUNIOR, 2008, p. 125).

Em 1898, a publicação do soneto de Amélia Rodrigues chamado "O Vagabundo" na revista chamada Álbum das Meninas tratava de uma preocupação recorrente na cidade de São Paulo: o grande número de menores nas ruas que ameaçavam a ordem pública e a tranquilidade das famílias paulistanas (SANTOS, 2002). Conforme o exposto, vê-se que desde o século XIX os menores aparecem nas estatísticas criminais do país, entretanto, é nas primeiras décadas do século XX que estas tomam uma maior proporção, em razão principalmente do processo de industrialização do país.

Ao resgatarmos a história, conforme Baer (1979), verificamos que até o século XIX o Brasil ainda era, predominantemente, uma sociedade agrícola cafeeira sustentada pelo trabalho escravo. Contudo, por 


\section{Desafios da psicologia no Brasil}

volta do fim do século XIX, o mercado do café entrou em franca expansão e o sistema comercial foi se tornando mais eficiente com a ampliação das rotas marítimas e a sofisticação das embarcações.

A abolição da escravatura e a Proclamação da República, impulsionaram a expansão industrial, provocando o êxodo de um grande número de fazendeiros para as cidades, que passaram a dedicarse à indústria e ao comércio. A grande quantidade de imigrantes (que substituíram a mão de obra nacional) vindos da Alemanha, Itália, Polônia, Portugal e Espanha também foi fortalecendo a incipiente industrialização que se iniciava no país, diversificando a economia, acarretando o crescimento das cidades e colaborando para o estabelecimento do modo de produção capitalista (BAER, 1979).

O crescimento populacional foi tamanho no Estado de São Paulo que se elevou "de 837.000 em 1872 para 2.283.000 em 1900 e quase 4000.000 ao irromper a Primeira Guerra Mundial (...). Nesse ínterim, a capital crescia ainda mais depressa. Aldeia de 23000 habitantes em 1872, sua população totalizava 580000 moradores em 1920" (DEAN, 1991, p. 10). Entretanto, as cidades brasileiras não apresentavam condições sociais e habitacionais para comportar este crescimento industrial e as crises sociais começavam a eclodir. Santos (2002) reforça que na cidade de São Paulo, neste período, estimase que a terça parte das habitações eram consideradas cortiços. Estes por sua vez, abrigavam uma grande quantidade de pessoas, sem ofertar condições mínimas de salubridade e saneamento; o que facilitou a propagação em larga escala de pestes e endemias.

Contrastando com o "progresso", centenas de brasileiros (principalmente os escravos abolidos) perambulavam pelas ruas sem trabalho, viviam em condições de extrema miséria, adoeciam em virtude das precárias e desumanas condições de saúde e habitação e praticavam delitos. Era evidente que a deterioração das condições sociais, as mudanças impostas pela forma de organização capitalista e os novos padrões de convívio que a urbanidade impunha potencializavam a prática de crimes cometidos por adultos e menores de idade.

Neste período, inúmeras prisões ocorriam, às vezes pelo simples fato de a pessoa não conseguir comprovar sua ocupação. Grande parte dessas prisões arbitrárias tinha como alvo os menores de idade, que eram acusados de vadiagem. Aliás, a sociedade paulistana da época abominava a vadiagem e requeria providências da polícia para inibi-la, pois os trabalhadores não absorvidos pelo mercado formal e as crianças nas ruas escancaravam a dicotomia: progresso versus exclusão social (SANTOS, 2002). 


\section{Desafios da psicologia no Brasil}

No Estado de São Paulo "entre 1900 e 1916 o coeficiente de prisões por 10 mil habitantes era distribuído da seguinte forma: 307,32 maiores e 275,14 menores", todavia, os crimes cometidos por menores se diferiam muito dos praticados por adultos, que eram responsáveis por $93.1 \%$ dos homicídios realizados entre 1904 e 1906. As prisões de crianças e adolescentes eram motivadas por vadiagem (20\%), embriaguez (17\%) e furto ou roubo (16\%) (SANTOS, 2002, p. 214).

Conforme o exposto, observamos que no rastro da industrialização brasileira, a pobreza e a criminalidade se alastraram no início do século $X X$, mostrando-nos que a violência é construída historicamente e que representa as contradições sociais da época.

\subsection{AS LEGISLAÇÕES EM VIGOR E O ADOLESCENTE AUTOR DE ATO INFRACIONAL}

Nacionalmente a Lei 8.069/1990 de 13 de julho de 1990, que dispõe sobre o Estatuto da Criança e do Adolescente e dá outras providências e a Lei 12.594 de 2012, que institui o SINASE, são reconhecidas como legislações que estabelecem os parâmetros para a construção de uma política pública voltada para a infância e a juventude e para o atendimento do adolescente em situação de conflito com a lei.

Vale lembrar que as Guerras Mundiais deflagraram a necessidade de se proteger a infância, entretanto, no Brasil, até a década de 1980, a assistência à população infantojuvenil ainda não possuía características de uma política pública. É com a Promulgação da Constituição Federal de $1988^{6}$ e mais especificamente com o Estatuto da Criança e do Adolescente que a proteção integral à infância e adolescência adquire mais visibilidade e importância.

A substituição de uma intervenção pautada na Doutrina da Situação Irregular ${ }^{7}$ por uma política de atenção à criança e ao adolescente foi resultado das condições materiais da época e do movimento social em defesa dos direitos da criança e do adolescente ${ }^{8}$ liderado pela população, estudantes, intelectuais e entidades na década de 1980 (PEREIRA e MESTRINER, 1999).

Em 13 de julho de 1990 aprova-se o Estatuto de Criança e do Adolescente, sustentado pela Doutrina da Proteção Integral que afirma o valor da criança e do adolescente como ser humano, o respeito a sua condição peculiar de desenvolvimento; o que os tornam merecedores de proteção integral por parte da família, da sociedade e do Estado (BRASIL, 1990).

Concomitantemente ao surgimento do Estatuto da Criança e do Adolescente, o Brasil ratifica a Convenção sobre os Direitos da Criança, promulgada pelas Nações Unidas. A Convenção estabelece 


\section{Desafios da psicologia no Brasil}

que a criança passa a ter prioridade absoluta no acesso às políticas públicas e define obrigações diferenciadas para a família, o Estado e a sociedade, com vistas a garantir a proteção das crianças (BRASIL, 2005). Além da Convenção sobre os Direitos da Criança, outras normativas internacionais serviram como referência para a elaboração do Estatuto da Criança e do Adolescente, dentre elas podemos citar: Regras Mínimas das Nações Unidas para a Administração da Justiça da Infância e da Juventude - Regras de Beijing (1985), Regras Mínimas das Nações Unidas para a Proteção dos Jovens Privados de Liberdade (1985) e Diretrizes das Nações Unidas para a Prevenção da Delinquência Juvenil - Diretrizes de Riad (1988).

No que se refere especificamente ao adolescente autor de ato infracional, o Estatuto da Criança e do Adolescente considera ato infracional "a conduta descrita como crime ou contravenção penal" e estabelece que são inimputáveis os menores de 18 anos (BRASIL, 1990, art. 103 e 104).

A este adolescente, em seu artigo 112, a referida legislação prevê o cumprimento de medidas socioeducativas, que são elas: "advertência, obrigação de reparar o dano, prestação de serviços à comunidade, liberdade assistida, semiliberdade e internação em estabelecimento educacional" (BRASIL, 1990). No parágrafo primeiro deste artigo consta que a medida aplicada levará em consideração a capacidade do adolescente em cumpri-la, as circunstâncias e a gravidade da infração.

O artigo 106 do Estatuto da Criança e do Adolescente prevê que nenhum adolescente será privado de sua liberdade senão em flagrante de ato infracional ou por ordem escrita e fundamentada da autoridade judiciária competente. A internação socioeducativa antes da sentença (nomeada de internação provisória), de acordo com a referida legislação, pode ser determinada pelo período máximo de 45 dias durante o período de apuração da prática de ato infracional, desde que haja indícios suficientes de autoria e materialidade e que seja demonstrada a necessidade imperiosa da medida. "A sentença de internação em nenhuma hipótese será aplicada havendo outra medida adequada e só se justifica, quando se tratar de ato infracional cometido mediante grave ameaça ou violência à pessoa, por reiteração no cometimento de outras infrações graves e por descumprimento reiterado e injustificável da medida anteriormente imposta" (BRASIL, 1990, art. 122).

Ademais, a lei estabelece que a internação está sujeita aos princípios de brevidade, excepcionalidade e respeito à condição peculiar de pessoa em desenvolvimento. Ela não comporta prazo determinado, devendo sua manutenção ser reavaliada, mediante decisão fundamentada, no máximo a cada seis meses (BRASIL, 1990). Considerando a condição peculiar da criança e do adolescente como pessoas 


\section{Desafios da psicologia no Brasil}

em desenvolvimento (diferentemente do que prevê o Código Penal aos adultos que cometem crimes ou contravenções penais), não se estabelece previamente a duração da internação na ocasião da sentença, haja vista a valorização da capacidade de resposta dos adolescentes na elaboração de um projeto de vida que os desvinculem da criminalidade, entretanto o art. 121, parágrafo 3o estabelece que, em hipótese alguma, ela excederá três anos.

Frasseto (2005) afirma que o Estatuto da Criança e do Adolescente é um inquestionável sistema penal destinado a adolescentes, sustentado pelo garantismo penal, que prevê essencialmente que os direitos fundamentais sejam eficazmente observados. "O Direito Penal juvenil pode ser singelamente compreendido como uma transposição dos ideais do garantismo penal para o sistema de responsabilização dos adolescentes autores de crime" (FRASSETO, 2005, p.30). É inegável que a referida legislação prescreve ao adolescente autor de ato infracional medidas severas, muito semelhantes àquelas destinadas a adultos, mas também estabelece um rol de garantias, como por exemplo, o direito a defesa ampla; o que a assemelha ao Sistema Penal de adultos.

No que tange ao Sistema Nacional de Atendimento Socioeducativo, pode ser compreendido como o "conjunto ordenado de princípios, regras e critérios, de caráter jurídico, político, pedagógico, financeiro e administrativo que envolve desde o processo de apuração do ato infracional até a execução da medida socioeducativa" (BRASIL, 2012). Sua elaboração se deu com o propósito de alinhar a execução das medidas socioeducativas, tendo como parâmetro os princípios dos direitos humanos.

O SINASE estabelece como objetivos das medidas socioeducativas: a responsabilização do adolescente quanto às consequências lesivas do ato infracional, sempre que possível incentivando a sua reparação, a integração social do adolescente e a garantia de seus direitos individuais e sociais, por meio do cumprimento de seu plano individual de atendimento e a desaprovação da conduta infracional, efetivando as disposições da sentença como parâmetro máximo de privação de liberdade ou restrição de direitos, observados os limites previstos na lei.

O Plano de Atendimento Individual (PIA) é o instrumento de previsão, registro e gestão das atividades a serem desenvolvidas com o adolescente. É por meio dele e com base nele que se formulam os relatórios de reavaliação de medida socioeducativa, sendo este o documento elementar para o acompanhamento do desenvolvimento do adolescente que cumpre medida socioeducativa. 


\section{Desafios da psicologia no Brasil}

Apesar das legislações em vigor preconizarem que o caminho para o enfrentamento da criminalidade envolve a garantia de direitos e a oferta de um atendimento humanizado, não discriminatório e individualizado, os estudos científicos como os de Budó (2013), Vicentin, Gramkow e Rosa (2010) e Tejadas (2008), sobre a execução das referidas medidas mostram que estas diretrizes não têm se efetivado na prática.

\subsection{O ADOLESCENTE AUTOR DE ATO INFRACIONAL E A ESCOLA}

Estudos realizados por Priuli; Moraes (2007), Assis; Souza (1999) e Adorno; Bordini; Lima (1999) mostram que os adolescentes em situação de conflito com a lei do Estado de São Paulo possuem uma baixa escolarização e no momento da apreensão encontravam-se evadidos do sistema escolar.

Na pesquisa desenvolvida com adolescentes em conflito com a lei das cidades do Rio de Janeiro e Recife, Assis e Souza (1999) observaram que cerca da metade dos entrevistados tinham, no máximo, concluído até o 5o ano do Ensino Fundamental e que nenhum dos entrevistados encontrava-se no Ensino Médio. Ao investigarem os motivos da baixa escolaridade, os jovens a justificaram devido: a necessidade de trabalhar, a dificuldade de conciliar o estudo com o trabalho, o desentendimento com os professores e colegas (envolvendo inclusive agressões físicas) e a falta de acompanhamento da família, no que se refere a frequência escolar. Ressaltamos que os dados descritos nesta pesquisa não podem desencadear processos de culpabilização da família da classe trabalhadora, uma vez que o não acompanhamento do processo de escolarização se dá, na maioria dos casos, devido ao não acesso às condições materiais concretas que possibilitem o exercício do cuidado protetor.

Assis e Constantino (2005) assinalam que as dificuldades no processo de escolarização contribuem para o envolvimento com a criminalidade, na medida em que o jovem vai se desestimulando diante das reprovações, da baixa qualidade de ensino e pouca supervisão familiar diante da vida escolar. Conforme as autoras, em 2002, 51\% dos que cumpriam internação socioeducativa no país estavam fora da escola no momento da apreensão e 6\% não eram alfabetizados. Neste mesmo levantamento estatístico deflagrou-se a defasagem entre a idade e o nível de escolarização, 89\% de 16 a 18 anos ainda não tinham conseguido concluir o Ensino fundamental.

Segundo Pereira e Mestriner (1999), a evasão escolar se dá também devido à ineficácia dos métodos educacionais em sua totalidade, por falhar em ensinar as habilidades acadêmicas necessárias, e também devido à exclusão social por parte dos colegas e professores da escola. Por serem tachados 


\section{Desafios da psicologia no Brasil}

de alunos problemáticos, colegas hostis e demais estigmas, tais adolescentes evadem-se das escolas e preferem assumir a identidade de bandidos. Como apresenta Jesus (2013), é comum estes adolescentes serem expulsos da escola não necessariamente de maneira formal, mas sutilmente, por não se enquadrarem como alunos ideais. Nestes casos, mesmo a determinação judicial ou a vinculação com programas de acompanhamento, como a liberdade assistida não se mostram eficazes, devido ao que Borba e Pereira (2016) chamam de lógicas inerentes ao próprio sistema escolar.

A escolarização, de acordo com Silva e Oliveira (2007) é concebida como fenômeno central nas trajetórias de vida e incide, sobretudo na reprodução dos modos de vida. A lógica da escola é delimitada pelo adulto, mas é no contato com o jovem que ela se desenvolve e confronta com os padrões adultos. Historicamente a escola foi criada para socializar os indivíduos, segundo os princípios do trabalho e por isso se tornaria a promessa de integração. Entretanto, ela entra em crise no momento em que o desemprego e o modo de produção em vigor não garantem o acesso ao trabalho, desestabilizando seus processos de disciplinarização.

Para Silveira (2003), desde sua criação, a escola tem sido considerada referência e detentora do saber e de uma verdade absoluta. Por muitos anos estivemos à mercê de uma educação ideologizante, que reproduz relações de dominação. Desta forma, a autora ressalta que a escola ainda se encontra pouco adaptada a um mundo em transformação e enfatiza que a família e a escola devem se abrir para a construção de uma nova relação, pautada na valorização de todos os saberes e na busca ativa entre os integrantes destas redes sociais. Para tanto, a escola deve conceber esta família contextualizada com a contemporaneidade, ou seja, composta por diferentes arranjos e formas de vínculo afetivo e reconhecer que ela é capaz de contribuir na educação de seus filhos.

É atribuição da escola, segundo Saviani (1997), formar sujeitos capazes de construir dialeticamente a história da humanidade. Ele preconiza que a educação também interfere sobre a sociedade, podendo contribuir para a sua própria transformação, fato que a torna histórica. Partindo deste entendimento cabe a escola aproximar o conhecimento formal do contexto social e do exercício democrático. Sua dimensão de educação ultrapassa a pedagogia logocêntrica, considera os determinantes sociais da educação e possibilita o planejamento de tomada de decisões, em acordo com a realidade social e acima de tudo mediado pelo conhecimento formal.

Fala-se da necessidade de uma educação libertadora e problematizadora, que compreenda que os homens devam ser impulsionados a desvelar sua constituição e a realidade social, que inclua a todos 


\section{Desafios da psicologia no Brasil}

e não reproduza preconceitos (Saviani, 1997). Entretanto, verificamos que a escola pública da atualidade tem encontrado muita dificuldade para ensinar o conteúdo formal e pouco tem colaborado para a formação de sujeitos críticos e para a promoção de mudanças no contexto social. A seguir, passemos aos relatos de experiência.

\section{RELATOS DE EXPERIÊNCIA}

A proposta de trabalho a ser realizada pelas equipes dos Censes prevê a inserção social do adolescente em uma nova condição, que lhe permita o exercício da cidadania. Dentre as atividades mais corriqueiras e necessárias a serem realizadas por esta equipe, está o apoio para o retorno a escola. Via de regra, os adolescentes internados, quando não evadidos das escolas, possuem histórico recente de problemas de conduta no interior destas instituições. Os relatos que seguem não são exceções, e fazem referência a duas experiências bem sucedidas de inclusão no sistema educativo no período pósinternação, devido ao trabalho integrado entre Cense e Escolas.

O Centro de Socioeducação Cascavel 2 é uma entidade estadual responsável pela execução da internação socioeducativa, vinculada a atual Secretaria de Estado da Justiça, Família e Trabalho do estado do Paraná.

A referida instituição é a primeira dos cinco novos Centros de Socioeducação do Paraná construídos em conformidade com o que prevê o SINASE. Foi inaugurado em 07 de fevereiro de 2007 e atualmente possui capacidade para atender 70 adolescentes do sexo masculino. Durante o período de internação o diretor do Centro de Socioeducação torna-se guardião e responsável legal pelos adolescentes.

O trabalho é desenvolvido por uma equipe multiprofissional composta em sua maioria por estatutários, sendo 53 (cinquenta e três) agentes de segurança socioeducativos, antes intitulados educadores sociais, sendo 47 (quarenta e sete) do sexo masculino e 06 (seis) do sexo feminino, 01 (um) diretor, 01 (um) diretor-assistente, 01 (um) administrador, 04 (quatro) técnicos administrativos, 02 (dois) assistentes sociais, 04 (quatro) psicólogos, sendo 03 (três) concursados e 01 (um) contratado por processo seletivo simplificado - PSS, 01 (um) dentista, 01 (um) pedagoga cedida pelo Secretaria de Estado da Educação, 01 (um) enfermeiro (PSS), 03 (três) auxiliares de enfermagem, sendo 02 (dois) contratados por processo seletivo simplificado - PSS, 01 (um) auxiliar de manutenção, além do acompanhamento de 10 (dez) funcionários terceirizados, sendo 04 (quatro) serventes, 03 (três) auxiliares de serviços gerais e 03 (três) copeiros, e 20 (vinte) membros da equipe do Programa de 


\section{Desafios da psicologia no Brasil}

Educação na Socioeducação - Proeduse, vinculados à Secretaria Estadual de Educação, sendo 17 (dezessete) professores, 01 (um) técnico administrativo e 02 (dois) coordenadores pedagógicos (PARANÁ, 2019, p. 9).

Para a garantia da escolarização dos adolescentes atendidos nas unidades socioeducativas, a Secretaria de Educação instituiu o Proeduse, em parceria com o antigo Instituto de Ação social do Paraná - $\mathrm{ASSP}^{9}$. O Programa estrutura-se na modalidade de Educação de Jovens e Adultos - EJA, considerando o perfil educacional do público atendido, tendo em vista a trajetória escolar fragmentada observada nos adolescentes, que na maioria das vezes vivenciaram situações como inserção prematura no mercado de trabalho, evasão ou repetência escolar (KRAVETZ; SILVA; CUNHA, 2018). Ainda, esta modalidade se mostrou a mais adequada considerando os diversos perfis dos adolescentes, no que diz respeito a faixa etária, nível de escolarização, situação social, econômica e cultural.

As escolas retratadas neste capítulo fazem parte da rede estadual de educação do município de origem de cada adolescente.

\section{1 CASO 1}

A primeira experiência a ser relatada refere-se a um adolescente do sexo masculino, 16 anos e 8 meses na ocasião da desinternação do Cense. Durante o período que antecedeu a internação socioeducativa, o adolescente estava matriculado na escola do bairro, próxima de sua residência. Ao ser trocado para o período noturno, passou a apresentar dificuldades em seguir as normas da instituição, gazear aulas, manter comportamento agressivo e de grande confronto com autoridades no interior da instituição, criando-se assim resistência da equipe pedagógica em acolhê-lo.

O educando é o segundo filho de uma prole de três, sendo a filha mais velha e o adolescente em questão do primeiro casamento, e a mais nova ( 8 anos) filha do $2 \circ$ casamento da mãe. Ao ser internado - jovem estava cursando o 90 ano do ensino fundamental, apresentando problemas de comportamento no interior da escola e frequência irregular. Após a elaboração do PIA, sua matrícula no ensino regular foi mantida, apesar da educação no interior do Cense ser na modalidade EJA.

No estudo de caso realizado pela equipe multiprofissional ficou evidente a ausência de intercorrências no desenvolvimento infantil, a boa adaptação inicial à escola, capacidade cognitiva, insegurança, baixa autoestima, uso continuado de maconha sem dependência química e a possibilidade de se trabalhar 


\section{Desafios da psicologia no Brasil}

a motivação para o estudo com frequência e aproveitamento, buscando um padrão de conduta mais adequado no interior da escola. A relação familiar mantém um vínculo de afeto, apesar da dificuldade

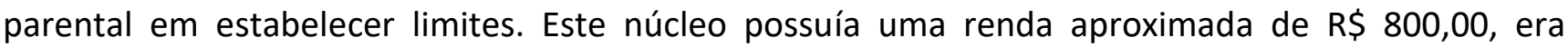
beneficiário do Programa Federal Bolsa Família e residiam em casa própria. O relacionamento social de amizades do adolescente era basicamente com outros usuários de maconha, ainda que mantivesse relacionamento amoroso com uma jovem sem envolvimento com drogas ou atos infracionais.

\subsection{CASO 2}

A segunda experiência diz respeito a um adolescente do sexo masculino, de 18 anos de idade, que desejava dar continuidade aos seus estudos no Ensino Regular e em razão disto deveria ser matriculado no 7o ano do Ensino Fundamental. Devido a recusa das escolas estaduais em matriculálo, o mesmo entrou em contato com a equipe do Cense 2 de Cascavel buscando apoio para efetivar seu retorno à escola.

Em decorrência de seu envolvimento anterior com a criminalidade e da defasagem idade e série, a direção e a equipe pedagógica da escola próxima de sua residência tinham receio de que ele exercesse uma liderança negativa perante os demais e infracionasse no interior da escola. Destacamos que sua inclusão ocorreu somente após as intervenções realizadas pela psicóloga e pedagoga do Cense 2 .

O adolescente em tela até o momento da apreensão residia com sua genitora, padrasto e três irmãos. A renda familiar girava em torno $\mathrm{R} \$ 400,00$, sendo que o valor de $\mathrm{R} \$ 95,00$ advinha do benefício Bolsa Família. Seus irmãos participavam de um Programa de Contraturno Social.

Quanto a sua trajetória escolar, ressaltamos que iniciou sua vida escolar no ano de 1998, aos sete anos de idade e concluiu a fase I do Ensino Fundamental em 2001, sem reprovações ou desistências. No ano seguinte, 2002, o educando efetuou matrícula em um Colégio Estadual para cursar a fase II do Ensino Fundamental, 6ำ ao 9ㅇan ano, alcançando aprovação no 6ㅇano, porém reprovando e desistindo da escolarização no $7^{\circ}$ ano. Ao ser internado no Cense foi matriculado no Centro Estadual de Educação de Jovens e Adultos - Ceebja, nas disciplinas de Língua Portuguesa, História, Educação Física e Educação Artística. No interior da unidade socioeducativa o mesmo retomou o vínculo com a escolarização e apresentou um excelente desempenho escolar, principalmente na disciplina de história. 


\section{Desafios da psicologia no Brasil}

\subsection{ANÁLISES DOS CASOS}

As intervenções realizadas em ambos os casos envolveram atendimentos individuais com os adolescentes, internos a nossa instituição, passando posteriormente para o estabelecimento de contatos externos com a rede de atendimento de cada jovem especificamente. Nos atendimentos individuais buscou-se avaliar as condições pessoais de motivação, desejo, resiliência, capacidade de autossuperação no que diz respeito as habilidades sociais e capacidade para firmar compromissos.

Posteriormente, a equipe do Cense passou a estabelecer contatos com a direção das escolas, avaliando a disponibilidade daquelas equipes em acolher os referidos adolescentes, sem necessitar de interferência jurídica para o alcance deste propósito. Foram então realizadas reuniões entre equipes do Cense e escolas, ainda sem a presença dos educandos, no intuito de criar uma parceria para solução de uma dificuldade que, a curto prazo, seria inevitável, pois os adolescentes estavam em processo de desinternação e compulsoriamente deveriam retomar sua educação formal em estabelecimento de ensino no território. Criada tal parceria, as equipes estabeleceram metas, prazos e objetivos a serem cumpridos, marcando reuniões com a presença dos adolescentes e de suas famílias, para o estabelecimento de contratos entre as partes: adolescentes, escolas e Cense. Este processo contou com a participação das famílias dos jovens, possibilitando o desenvolvimento de seu papel e atribuições.

Após a desinternação, os adolescentes foram regularmente matriculados nas referidas Escolas, sendo periodicamente acompanhados também pela equipe do Cense, mantendo-se os contratos estabelecidos entre as equipes nas reuniões prévias.

O principal resultado conquistado com o trabalho em rede foi a manutenção dos adolescentes no processo de escolarização formal, em um clima de acolhimento, sendo que também existiram avanços no relacionamento interpessoal e na aprendizagem. As escolas apresentaram-se disponíveis e abertas para solucionar os casos apresentados, evitando-se assim a judicialização. Atualmente esta é uma prática muito utilizada por assegurar a matrícula escolar, porém, o êxito da inserção depende da disponibilidade interna das instituições e das pessoas envolvidas neste processo. Em nossa experiência observamos que, nos casos de determinação judicial, é muito frequente o novo abandono e evasão escolar, deflagrando a falta de resolutividade da problemática inicial. 


\section{Desafios da psicologia no Brasil}

\section{CONSIDERAÇÕES FINAIS}

Enfrentar o problema da crescente violência requer a integração das políticas públicas e a efetivação de ações promovidas coletivamente pelas esferas do governo e pelos diversos setores organizados da sociedade.

Considerando os adolescentes que estiveram em conflito com a lei e foram submetidos a medidas socioeducativas de privação de liberdade, o trabalho realizado de busca por potencialidades e incentivo a prática de ações positivas pode ficar comprometido se a comunidade continuar a identifica-lo apenas por características negativas, assim como não considerando que características anteriormente existentes puderam ser modificadas após a intervenção socioeducativa.

Para que o trabalho em rede em prol da criança e do adolescente aconteça de fato, precisamos primeiramente reconhecer o homem em sua totalidade e não mais segmentá-lo em mente-corpo, objetivo-subjetivo, emoção-conhecimento. Somente o sujeito histórico na coletividade conseguirá atingir uma forma de organização que possibilite a universalização dos direitos.

Ademais também será necessário romper com o pensamento hegemônico que naturaliza a infância e adolescência e as desatrelam da historicidade. Por fim, o estudo indica que as crianças e os adolescentes brasileiros terão seus direitos efetivados na medida em que houver uma transformação no modo de produção e organização social. Enquanto não há passagem para essa nova forma de organização, compete às políticas públicas adotar uma perspectiva que valorize a formação da criança e a participação do adolescente na elaboração, aplicação e avaliação destas.

\section{REFERÊNCIAS}

ABRAMOVAY, M. Juventude, violência e vulnerabilidade social na Caso 2 América Latina: desafios para políticas públicas. Brasília: UNESCO, BID, 2002.

ADORNO, S; BORDINI, E.B.T; LIMA, R.S de. O adolescente e as mudanças na criminalidade urbana. São Paulo em perspectiva. São Paulo: vol.13, n. 4, 1999, p. 62-74.

ASSIS, S.G de; CONSTANTINO, P. Perspectivas de prevenção da infração juvenil masculina. Ciência e saúde coletiva. São Paulo: ano 10, n.1, 2005, p. 81-90.

ASSIS, S.C de; SOUZA, E.R de. Criando Caim e Abel: pensando a prevenção da infração juvenil. Ciência e saúde coletiva. São Paulo: ano 1, n. 4, 1999, p. 131-144.

BAER, W. A industrialização e o desenvolvimento econômico no Brasil. 4.ed. Rio de Janeiro: Fundação Getúlio Vargas. 1979. 


\section{Desafios da psicologia no Brasil}

BORBA, P. L. O., PEREIRA, B. P. Traçados de vida e as marcas do sistema socioeducativo. In LOPES, R. E., MALFITANO, A. P. S. (org) Terapia Ocupacional Social: desenhos teóricos e contornos práticos. São Carlos: EduFSCar, p. 331-338, 2016.

BRASIL. Conselho Nacional de Justiça. Tráfico de drogas é o crime mais cometido por menores infratores. Disponível em http://www.cnj.jus.br/noticias/cnj/84034-trafico-de-drogas-e-o-crimemais-cometido-pelos-menores-infratores, 2016, 25 de novembro.

BRASIL. Conselho Nacional de Justiça. Panorama nacional: a execução das medidas socioeducativas de internação. Brasília: CNJ, 2012. Disponível em de http://www.cnj.jus.br/images/programas/justica-ao jovem/panorama_nacional_justica_ao_jovem.pdf.

BRASIL. Constituição da República Federativa do Brasil. Brasília. 1988.

BRASIL. Decreto-lei no 8.069. Estatuto da Criança e do Adolescente - ECA, Brasília,DF, 13 jul. 1990.

BRASIL. Decreto n. 847, 16 de dezembro de 1830. Código Criminal do Império. Disponível em: <http://www2.camara.gov.br/legislacoes/publicacoes/republica>. Acesso em: 11 abr. 2011.

BRASIL. Lei no 12.594. SINASE - Sistema Nacional de Atendimento Socioeducativo. Brasília. 2012.

BRASIL. Ministério da Saúde. Temático prevenção de violência e cultura de paz. Vol III. Brasília-DF: Organização Pan-Americana da Saúde. 2008.

BRASIL. Ministério dos Direitos Humanos e Secretaria de Direitos Humanos Levantamento anual SINASE 2015. Brasília, DF: Secretaria Nacional dos Direitos da Criança e do Adolescente do Ministério dos Direitos Humanos, 2018.

BRASIL. Secretaria de Atenção à Saúde/ Área de Saúde do Adolescente e do Jovem. Marco legal: saúde, um direito de adolescentes. Brasília-DF: Ministério da Saúde. 2005.

BUDÓ, M. N. de. Vulnerabilidade, exclusão, seletividade: o menorismo vivo nas decisões do STJ sobre o ato infracional. In Anais do XXII Encontro Nacional do Conselho Nacional de Pesquisa e Pósgraduação em Direito (CONPEDI). Curitiba: Boiteux, 2013. Disponível em https://www.conpedi.org.br/publicacoes/02q8agmu/5qz06943

CASTRO, J. A. de; AQUINO, L. M. C. de; ANDRADE, C. C. de. Juventude e políticas sociais no Brasil. Instituto de Pesquisa Econômica Aplicada (Ipea), 2009.

CRP - CONSELHO FEDERAL DE PSICOLOGIA. Carta manifesto contra o projeto de mapeamento cerebral de adolescentes privados de liberdade. Ago, 2008. Disponível em http//www.pol.org.br. 2010

CUNHA, O. M. G da. Intenção e gesto: pessoa, cor e a produção cotidiana da (in)diferença no Rio de Janeiro, 1927-1942. Rio de Janeiro: Arquivo Nacional. 2002.

CURY, M et al. Estatuto da criança e do adolescente comentado: comentários jurídicos e sociais. 7.ed. São Paulo: Malheiros Editores. 2005.

D'ANDREA, G. Delinquência juvenil: a noção de trajetórias desenvolvimentais e a descrição de carreira. Dissertação de mestrado não-publicada, Universidade de São Paulo, São Paulo,2008. 


\section{Desafios da psicologia no Brasil}

DEAN, W. A industrialização de São Paulo. 4.ed. Rio de Janeiro: Bertrand. 1991.

FOLHA ONLINE. Psicólogos tentam impedir pesquisas com homicidas. Disponível em: <http://www1.folha.uol.com.br/folha/ciencia/ult306u365435.shtml>. Acesso em: 27 dez. 2008.

FRASSETO, F. A. Avaliação psicológica em adolescentes privados de liberdade: uma crítica a execução da medida de internação. Dissertação de mestrado não-publicada, Universidade de São Paulo, São Paulo. 2005.

JESUS, V. C. P. de, Condições escolares e laborais de adolescentes autores de atos infracionais: um desafio à socioeducação. Revista Eletrônica de Educação, v. 7, n. 3, p. 129-142, 2013

JUNIOR, R. K. A. Menoridade é carta de alforria? In: Fonacriad et al. Adolescentes privados de liberdade: a normativa nacional e internacional e reflexões acerca da responsabilidade penal. 4. ed. São Paulo: Cortez. 2008.

KRAVETZ, A. de L.; SILVA, C. dos S.; CUNHA, F. L. M. da. Política Educacional na Socioeducação. In: Cadernos de socioeducação: bases teórico-metodológicas da socioeducação.2 ed.Curitiba: Curitiba, 2018, p. 55-64.

MINAYO, M. C. de S. e SOUZA, E. R. de .É possível prevenir a violência: reflexões a partir do campo da saúde pública. Revista Ciência e Saúde Coletiva. São Paulo: ano 4, n. 1, 1999, p.7-32.

PARANÁ. Centro de Socioeducação de Cascavel 2. Projeto Político Pedagógico. Documento não publicado. Cascavel: Cense 2, 2019.

PARANÁ. Secretaria de Estado da Justiça, Trabalho e Direitos Humanos. Cadernos da Socioeducação: Fundamentos da Socioeducação. Curitiba: SEJU, 2018.

PEREIRA, I; MESTRINER, M.L Liberdade assistida e prestação de serviços a comunidade: medidas de inclusão social voltadas a adolescentes autores de ato infracional. São Paulo: Instituto de estudos especiais da PUC-SP. 1999.

PRIULI, R.M.A; MORAES, M.S. de . Adolescentes em conflito com a lei. Revista Ciência e saúde coletiva. São Paulo: ano 12, n. 5, 2007-, p.1185-1192.

SANTOS, M. A. C dos. Criança e criminalidade no início do século. In: PRIORE, D. M (org). História das crianças no Brasil. 3.ed. São Paulo: Contexto, 2002, p.210-230.

SAVIANI, D. Sobre a natureza e a especificidade da educação. In: SAVIANI, D. Pedagogia Históricocrítica: primeiras aproximações. 6ạ ed. Campinas, SP: Autores Associados. 1997

SILVA, I. L.F; OLIVEIRA, R. B de. Juventudes, educação e trabalho: estudos e políticas públicas em Londrina-PR. In: Jeolás, L. S et al. Juventudes, desigualdades e diversidades: estudos e pesquisas. Londrina: Eduel. 2007.

SILVEIRA, L.M de O.B. A família, a escola e a pós-modernidade. In: Guareschi, P.A et al. Psicologia em questão: reflexões sobre a contemporaneidade. Porto Alegre: EDIPUCRS. 2003. p.123-132 


\section{Desafios da psicologia no Brasil}

TEJADAS, S. Juventude e ato infracional: as múltiplas determinações da reincidência. Porto Alegre, RS: EdiPUCRS, 2008.

VICENTIN, M. C. G., GRAMKOW, G., ROSA, M. D. A patologização do jovem autor de ato infracional e a emergência de "novos" manicômios judiciários. Rev Bras Crescimento Desenvolv Hum, ano 20, n. 1, 2010, p. 61-69. Disponível em http://www.revistas.usp.br/jhgd/article/view/19944/22024

VOLPI, M. O adolescente e o ato infracional. 6.ed. São Paulo: Cortez. 2006.

SILVA, M. G. C da; Ziliotto, F. P. O de; BATISTA, A. A. Perfil do adolescente autor de ato infracional no estado do Paraná. In: PARANÁ. Secretaria de Estado da Justiça, Trabalho e Direitos Humanos. Cadernos da Socioeducação: Fundamentos da Socioeducação. Curitiba: SEJU, 2018. 


\section{NOTAS}

Nota 1

Esta produção foi inicialmente publicada no X Congresso Nacional de Psicologia Escolar e Educacional (CONPE, 2011), sendo revisada e atualizada para elaboração deste capítulo.

\section{Nota 2}

Lei no 8.069 de 13 de julho de 1990 - que dispõe sobre o Estatuto da Criança e do Adolescente e dá outras providências e Lei no 12.594 de 2012 - que institui o SINASE - Sistema Nacional de Atendimento Socioeducativo.

\section{Nota 3}

A maioridade penal refere-se à idade a partir da qual o indivíduo pode ser penalmente responsabilizado por seus atos, em determinado país ou jurisdição. O Estatuto da Criança e do Adolescente em seu artigo 104 dispõe que são penalmente inimputáveis os menores de 18 anos, sujeitos às medidas previstas nesta Lei (BRASIL, 1990). Compreende-se por inimputabilidade "causa de exclusão da responsabilidade penal, não significa absolutamente, irresponsabilidade pessoal ou social" (SARAIVA, 2008, p. 158). O conceito de imputabilidade penal, do ponto vista estritamente jurídico, denota a capacidade do agente de responder pelo delito que cometera; é a capacidade da pessoa compreender que o fato é ilícito e de agir em conformidade com esse entendimento (FILHO, 2008).

\section{Nota 4}

Quanto ao aumento do período máximo de internação, vale destacar que o elevado índice de violência praticado por jovens, a pressão popular para a punição destes e a popularidade da proposta de Emenda Constitucional que prevê a redução da maioridade penal para os 16 anos de idade, colaborou para que alguns juristas e estudiosos dos direitos humanos passassem a defender o aumento do período de internação para no máximo 5 anos.

\section{Nota 5}

Antes mesmo do projeto de pesquisa ser protocolado no Comitê de Ética da PUCRS, um grupo com mais de 100 pessoas já tentava impedir a realização desta pesquisa por considerá-la próxima a "práticas de extermínio" e de motivação "eugenista" (FOLHA ONLINE, 2008).

\section{Nota 6}

É o artigo 227 da Constituição Federal de 1988 que demarca o compromisso com a infância e adolescência. Art. 227. É dever da família, da sociedade e do Estado assegurar à criança e ao adolescente, com absoluta prioridade, o direito à vida, à saúde, à alimentação, à educação, ao lazer, à profissionalização, à cultura, à dignidade, ao respeito, à liberdade, e à convivência familiar e comunitária, além de colocá-los a salvo de toda forma de negligência, discriminação, exploração, violência, crueldade e opressão (BRASIL, 1988). 


\section{Desafios da psicologia no Brasil}

Esta doutrina é estabelecida no Código de Menores de 1979 e prevê a assistência aos menores abandonados e delinquentes não adaptados socialmente.

\section{Nota 8}

A Constituição Federal de 1988, o Estatuto da Criança e do Adolescente, assim como, as legislações internacionais sobre a infância e adolescência promulgadas nas décadas de 80 e 90 empregam com muita frequência o termo "direito". Vale lembrar que com o liberalismo econômico já se defendia essencialmente à garantia de direitos individuais e atribuía-se ao Estado o papel de proteger a propriedade privada. No referido estudo utilizaremos a terminologia "direitos" com a intenção de manter a fidedignidade das citações. Entretanto, é necessário esclarecer que temos o entendimento de que se trata de uma categoria neoliberal e que a ênfase na garantia de direitos individuais representa a tentativa de manter o modo de produção capitalista e esvaziar a luta de classes.

Nota 9

As atribuições deste Instituto, no que se refere a socioeducação, foram incorporadas às atuais funções do Departamento de Atendimento Socioeducativo - Dease - Sejuf. 


\section{Capítulo 27}

\section{MOTIVAÇÃO PARA A PRÁTICA DE ATIVIDADE FÍSICA EM ACADEMIAS: UMA REVISÃO SISTEMÁTICA}

DOI: $10.37423 / 200200215$

Maiara Vecchi de Carvalho Ferreira ( Psicóloga pela Universidade Luterana do Brasil (ULBRA)

Natalí Máximo dos Reis (Lic. e Bela em Ciências Sociais pela Universidade Federal de Rondônia (UNIR)

Mestra ena Psicologia pela Universidade Federal de Rondônia (UNIR).

RESUMO: É consensual o rẹconhecimento da prática đe atividådes físicas como uma ação voltada para a melhoria do bem-estar do indivíduo. Diante deste contexto, as academias de ginástica se-tornaram uma opção para a população urbana que almeja tais-benefícios. 0 objetivo desta revisầo foi identificar, na literatu/ra, os principais motivos para adesão e permanência de atividades físicas em açadempias. Para tanto, realizou-se uma revisão sistemática a partir das produçồes científicas indexadas nas bases de dados[SciELO, LILACS, Pepsic e Periódicos Capes, entre os anos de 2007 a 2017. Foi utilizado o descritor primário "motivação" em cruzamento com o descritor secundấrio "academia". Foram encontrados 14 artigos, cujos resumos foram submetidos a uma análise qualitativa. Atenderam aos critérios de inclusão sete destas publicações. Os resultados dos estudos destacam que saúde, estética e prazer são as dimensões-què mais motivam ă aderência-a atividade-física em academias, seguidas de-controle-do estresse,-socrabilidade, competitividade.

Palavras-chave: Motivação. Academias de ginástica. Exercício físico. 


\section{Desafios da psicologia no Brasil}

\section{INTRODUÇÃO}

O tema exercício físico tem sido discutido em diversos âmbitos. Debates diversos relacionam os aspectos benéficos da prática regular da atividade física (Vilarino et al, 2017). Destaca-se o sentimento de bem-estar mental; redução dos níveis de estresse; além dos benefícios físicos, associados à prevenção de doenças (Straub, 2015).

Sobre motivação, cabe ressaltar que é tema de diversas áreas do conhecimento humano, inclusive para a psicologia do esporte e do exercício físico, que se interessa pela análise das bases e efeitos psíquicos das ações esportivas e dos exercícios físicos nos indivíduos (Samulski, 2002). Ntoumanis (2001 apud Fernandes \& Raposo 2005), define motivação como a realização de atividades com o objetivo de conquistar certos benefícios pretendidos.

Apesar do incentivo de diversas fontes e conhecimento acerca dos benefícios do exercício físico, ainda é frequente a desistência à prática regular de atividades físicas. Pesquisas verificam a relação de fatores como falta de tempo (Straub, 2015) e baixa renda socioeconômica (Dishman, 1993 apud Capazzoli, 2010) à desistência acima citada. Compreendendo a importância da prática regular dos exercícios físicos e do crescente incentivo ao hábito, o presente trabalho interessa-se em reunir pesquisas feitas nos últimos dez anos, sobre motivação para atividade física, empenhando-se em compreender quais motivos têm levado os indivíduos a envolverem-se nesse hábito. Para tanto reuniu-se pesquisas de campo publicadas entre os anos de 2007 a 2017 sobre o tema motivação para a atividade física em academias de ginástica, com o objetivo de compreender os resultados obtidos nesses anos no Brasil.

\section{MÉTODO}

Este artigo expõe os resultados de um levantamento bibliográfico realizado nas bases de dados online SciELO, LILACS, Pepsic e Periódicos Capes, sintetizados em revisão sistemática. Foi utilizado o descritor primário "motivação" em cruzamento com o descritor secundário "academia". Foram encontrados 14 artigos, cujos resumos foram submetidos a uma análise qualitativa, que buscou verificar quais artigos abordavam a temática da motivação para adesão à atividade física em academias. Outro requisito era ter sido publicado dentro do recorte temporal determinado (2007 a 2017). Atenderam aos critérios de inclusão sete destas publicações, cujos resultados são apresentados neste estudo. 


\section{Desafios da psicologia no Brasil}

\section{RESULTADOS E DISCUSSÃO}

Na pesquisa de Liz \& Andrade (2014) foi analisado os motivos de aderência dos indivíduos de ambos sexos a academias da cidade de Florianópolis-SC. Os resultados desta investigação qualitativa destacaram que os principais motivos são a sensação de bem-estar, que se manifesta a partir de experimentações de prazer, contentamento, satisfação e felicidade (Machado \& Bandeira, 2012); busca pela melhoria da qualidade de vida, definida como a capacidade de viver sem doenças ou de superar as dificuldades dos estados ou condições da saúde (Silva et al, 2017); preocupação com a estética, que se relaciona com o maior índice de adesão e permanência na academia de musculação segundo a análise feita pelos discursos dos participantes; melhorias no condicionamento, na resistência e aptidão física; por indicações médicas; e fazer e encontrar amigos, pois acredita-se que academias podem ser consideradas também ambientes de convivência social, que reafirmam o status social e financeiro de seus praticantes (Cunha, 1999 apud Capozzoli, 2010). Foi identificado o prazer como motivo de aderência e permanência nas academias na modalidade de musculação, uma vez que há preferência à essa modalidade, além da satisfação relacionada aos resultados estéticos obtidos pela prática (Liz \& Andrade, 2014).

Corroborando com os resultados apresentados, o estudo de Capozzoli (2010) feito com 300 praticantes de academia de ginástica na cidade de Porto Alegre-RS identificou aspectos motivacionais por meio do Inventário de Motivação à Prática Regular de Atividade Física (IMPRAF-126). Os praticantes eram de ambos sexos e idades variadas (18 a 65 anos). Os fatores motivacionais foram divididos em seis dimensões: controle de estresse, saúde, ccompetivividade, sociabilidade, estética e prazer, que merecem ser pormenorizados.

Com relação ao controle de estresse, caracterizado como o processo de perceber e responder aos estímulos estressores (Straub, 2015), o exercício físico tem sido uma alternativa viável para combatêlo (Martins \& Jesus, 1999); Saúde, é definida pela capacidade do organismo em evitar o aparecimento de doenças motivadas pelo sedentarismo; Competitividade, relaciona-se com a forma de atingir certo grau de satisfação e metas, através dos resultados da prática esportiva (Deci et al, 1999 apud Capazzoli, 2010), autores afirmam que a competitividade colabora para a sociabilidade, pois apostam no efeito cooperativo da dimensão competição; Tratando-se de Sociabilidade, acredita-se que o indivíduo motiva-se para a prática regular com o objetivo de sentir-se incluído em um grupo, clube e relacionarse com outras pessoas; Estética, é a dimensão relacionada à prática de atividade física ao objetivo de 


\section{Desafios da psicologia no Brasil}

alcançar ou manter o corpo atraente e aprovado na sociedade na qual se insere (Medina, 1996 apud Capazzoli, 2010); Prazer, é indicado como forma de alcançar satisfação. Nesta pesquisa, os resultados apontaram a saúde como maior dimensão motivacional para a prática de ginástica, seguida pelas dimensões de prazer, estética, controle de estresse, sociabilidade e competitividade.

Fermino et al (2010) também reforça esta dimensão saúde, em seu estudo com 90 participantes, que teve o objetivo de identificar os motivos para a prática de atividade física e analisar sua relação com a imagem corporal em adultos frequentadores do centro de esportes da PUCPR. Para coleta de dados, foram feitas medições do índice de massa corporal (IMC) e aplicado um questionário composto pelo inventário de razões para o exercício físico desenvolvido por Silberstein et al (1988) e uma escala de avaliação da figura corporal. O inventário de razões para o exercício físico é dividido em 7 categorias: controle de peso, aptidão física, saúde, melhora da harmonia do corpo, da atratividade física, da disposição e diversão. Foi percebido que os motivos mais escolhidos foram saúde, aptidão física seguida de disposição, atratividade e harmonia. A partir da discussão dos resultados pode ser compreendido que a insatisfação com a imagem corporal demonstrou maior associação com aspectos relacionados ao bem estar do que com a condição física em si.

Neste sentido é oportuno destacar a relação da insatisfação com a própria imagem corporal com o sentimento de bem estar. Entende-se bem estar pela integração harmoniosa entre os componentes mental, físico e emocional (Nahas et al, 2012). Ainda na pesquisa de Fermino et al (2010) é evidenciado a influência da imagem corporal negativa, que paradoxalmente pode diminuir a motivação para a prática de atividades físicas ou aumentar o comprometimento, destacando a relação direta ou indireta do sentimento de bem estar com a motivação à prática.

Na mesma linha pode-se comentar o trabalho de Frazão \& Coelho Filho (2015) que teve como objetivo analisar a partir do discurso das participantes, o motivo de adesão em academia feminina, para tanto foi utilizado uma entrevista semi estruturada com 23 mulheres frequentadoras de três academias de ginástica exclusivas para mulheres na cidade de Juiz de Fora-MG. Esta pesquisa obteve como resposta que o principal motivo da escolha por academias de ginástica exclusiva para mulheres se dá pela relação que as mesmas mantém com os homens (cônjuges, parceiros ou familiares) no contexto social. Foi identificado ainda que as mesmas sentem maior liberdade nas academias femininas em comparação com as academias mistas. Esta liberdade foi contextualizada à expressão das próprias insatisfações corporais, sentimento de libertação dos padrões de beleza quanto a maquiagens e 


\section{Desafios da psicologia no Brasil}

vestimentas, além de ter sido pontuado que as mesmas sentem-se mais livres para focar no treino e exercitar sem intimidações pelos movimentos.

Rocha (2008) em seu estudo analisou os principais motivos de adesão à ginástica de academia, relacionando-os aos fatores idade e sexo. A pesquisa foi desenvolvida com 250 participantes, sendo 181 mulheres e 69 homens, praticantes de academia de ginástica com frequência mínima de três vezes por semana, adeptos a pelo menos três meses ininterruptos, em oito academias da cidade de Montes Claros-MG. Foi utilizado um questionário validado para este estudo o qual identificava informações relativas à sexo, idade e motivos de adesão. Os dados obtidos foram analisados seguindo o método descritivo. Os resultados desse estudo não demonstraram diferença relevante sobre os fatores de idade e sexo para os motivos de adesão. Foi percebido que independentemente de idade e sexo os motivos para adesão em academias de ginástica foi a melhora do componente estético seguido da melhora do condicionamento físico e qualidade de vida.

Salin et al (2014) realizaram um estudo para compreender a percepção dos idosos do Programa Academia da Melhor Idade (AMI), no município de Joinville - Santa Catarina (SC), quanto à motivação para o ingresso e permanência. O estudo trouxe dados consistentes sobre a dimensão da sociabilidade para a motivação para a prática de atividades físicas. A referida pesquisa apontou que a maior parte dos idosos encontra motivação em fatores intrínsecos, isto é a busca por saúde, sentir-se bem, gostar de se exercitar, prazer. Com relação aos fatores extrínsecos, incentivo de terceiros, indicação médica, socialização e ambiente diferente eram as razões para a inserção na atividade.

A pesquisa de Rodrigues \& Santos (2016) buscou investigar os aspectos motivacionais para a prática de musculação entre jovens de 18 a 25 em Fortaleza-CE. Neste estudo, houve predomínio da questão da melhora da estética corporal como fator principal para a iniciação da prática. Em segundo lugar, as motivações estavam relacionadas à saúde. Outras manifestações disseram respeito à melhora no condicionamento físico, lazer, evitação do sedentarismo, bem-estar, melhora na qualidade de vida e performance esportiva. Este estudo também apresentou os motivos que influenciam a continuidade da prática, quais sejam: melhora no padrão estético corporal, saúde, bem-estar, busca por melhores resultados, resultados positivos alcançados, melhora no condicionamento físico e por gostar de musculação.

Santos, Silva \& Viana (2017) interessaram-se em analisar o perfil socioeconômico e as dietas adotadas por praticantes de atividade física, suas motivações e fontes de informação, adotando como 


\section{Desafios da psicologia no Brasil}

participantes 60 frequentadores de uma academia de ginástica, localizada no município de Itapecerica da Serra - SP. Atendo-se ao escopo deste trabalho, os resultados referentes à motivação apontaram diferenças de acordo com o sexo. Para os homens as principais motivações são saúde e aumento da massa muscular. Para as mulheres interessa-lhes obter saúde, emagrecimento e definição do corpo, por meio das atividades físicas.

Os achados desta revisão sistemática podem ser também visualizados na tabela abaixo:

Tabela 1 - Estudos incluídos na revisão sistemática. Porto Velho, RO, Brasil, 2018

\begin{tabular}{|c|c|c|c|}
\hline $\begin{array}{l}\text { Título do artigo - } \\
\text { Autores }\end{array}$ & Objetivo & Tipo de estudo & $\begin{array}{l}\text { Fatores motivacionais para a } \\
\text { prática de exercício físico em } \\
\text { academias }\end{array}$ \\
\hline $\begin{array}{l}\text { Motivos de adesão à } \\
\text { prática de ginástica } \\
\text { de academia } \\
\text { (Rocha, 2008) }\end{array}$ & $\begin{array}{l}\text { Analisar os principais } \\
\text { motivos de adesão à } \\
\text { ginástica de academia, } \\
\text { assim como verificar a } \\
\text { existência de relação entre } \\
\text { idade, sexo e motivos de } \\
\text { aderência. }\end{array}$ & $\begin{array}{l}\text { Pesquisa } \\
\text { quantitativa }\end{array}$ & $\begin{array}{l}\text { Não foram constatadas diferenças } \\
\text { significativas da motivação com } \\
\text { relação à idade e sexo. O objetivo } \\
\text { predominante foi estético, seguido } \\
\text { pela melhoria do condicionamento } \\
\text { para melhor qualidade de vida. Em } \\
\text { terceiro, por indicação médica, } \\
\text { seguido por lazer. }\end{array}$ \\
\hline $\begin{array}{l}\text { Motivos para Prática } \\
\text { de Atividade Física } \\
\text { e Imagem Corporal } \\
\text { em Frequentadores } \\
\text { de Academia } \\
\text { (Fermino, Pezzini \& } \\
\text { Reis, 2010) }\end{array}$ & $\begin{array}{l}\text { Identificar os motivos para a } \\
\text { prática de atividade física e } \\
\text { analisar sua relação com a } \\
\text { imagem corporal em } \\
\text { adultos frequentadores de } \\
\text { academia. }\end{array}$ & $\begin{array}{l}\text { Pesquisa } \\
\text { quantitativa }\end{array}$ & $\begin{array}{l}\text { Saúde, aptidão física, disposição, } \\
\text { atratividade, harmonia, diversão, } \\
\text { controle de peso e insatisfação com } \\
\text { a imagem corporal. }\end{array}$ \\
\hline $\begin{array}{l}\text { Motivação à prática } \\
\text { regular de atividades } \\
\text { físicas: um estudo } \\
\text { com praticantes em } \\
\text { academias de } \\
\text { ginástica de Porto } \\
\text { Alegre } \\
\text { (Capozzoli, 2010) }\end{array}$ & $\begin{array}{l}\text { Avaliar diferentes } \\
\text { dimensões motivacionais } \\
\text { associadas à prática regular } \\
\text { de atividades físicas com } \\
\text { praticantes em academias de } \\
\text { ginástica do município de } \\
\text { Porto Alegre-RS. }\end{array}$ & $\begin{array}{l}\text { Pesquisa } \\
\text { quantitativa }\end{array}$ & $\begin{array}{l}\text { Saúde; } \\
\text { Prazer; } \\
\text { Estética; } \\
\text { Controle do estresse; } \\
\text { Sociabilidade; e } \\
\text { Competitividade. }\end{array}$ \\
\hline $\begin{array}{lr}\text { Golden Age } & \text { Gym: } \\
\text { reasons for entry, } \\
\text { permanence } & \text { and } \\
\text { satisfaction } & \text { among } \\
\text { participating } & \text { older } \\
\text { adults } & \\
\text { (Salin et al, 2014) }\end{array}$ & $\begin{array}{l}\text { Descrever a percepção dos } \\
\text { idosos do Programa } \\
\text { Academia da Melhor Idade } \\
\text { (AMI), no município de } \\
\text { Joinville - Santa Catarina } \\
\text { (SC), quanto à motivação } \\
\text { para o ingresso e } \\
\text { permanência, satisfação e } \\
\text { sugestões dos serviços } \\
\text { prestados. }\end{array}$ & $\begin{array}{l}\text { Pesquisa } \\
\text { quanti- } \\
\text { qualitativa. }\end{array}$ & $\begin{array}{l}\text { Fatores intrínsecos: busca por } \\
\text { saúde, sentir-se bem, gostar de se } \\
\text { exercitar, prazer. } \\
\text { Fatores extrínsecos: incentivo de } \\
\text { terceiros, indicação médica, } \\
\text { socialização e ambiente diferente. }\end{array}$ \\
\hline
\end{tabular}




\section{Desafios da psicologia no Brasil}

\begin{tabular}{|c|c|c|c|}
\hline $\begin{array}{lr}\text { Aspectos } & \\
\text { motivacionais para a } \\
\text { prática } & \text { de } \\
\text { musculação } & \\
\text { entre jovens de } & 18 \text { a } \\
25 \text { anos } & \text { do } \\
\text { município } & \text { de } \\
\text { Fortaleza-CE } & \\
\text { (Rodrigues } & \text { \& } \\
\text { Santos, 2016) } & \end{array}$ & $\begin{array}{l}\text { Analisar os } \\
\text { motivacionais que levam } \\
\text { jovens de } 18 \text { a } 25 \text { anos à } \\
\text { prática e adesão ao } \\
\text { treinamento de musculação. }\end{array}$ & $\begin{array}{l}\text { Pesquisa } \\
\text { quantitativa. }\end{array}$ & $\begin{array}{l}\text { Motivos da escolha inicial: melhora } \\
\text { na estética corporal, saúde, melhora } \\
\text { no condicionamento físico, lazer, } \\
\text { evitar o sedentarismo, bem-estar, } \\
\text { melhora na qualidade de vida e } \\
\text { melhora na performance esportiva. } \\
\text { Motivos para a continuidade: } \\
\text { melhora no padrão estético } \\
\text { corporal, saúde, bem-estar, busca } \\
\text { por melhores resultados, resultados } \\
\text { positivos alcançados, melhora no } \\
\text { condicionamento físico e gostar de } \\
\text { musculação. }\end{array}$ \\
\hline $\begin{array}{l}\text { Análise qualitativa } \\
\text { dos motivos de } \\
\text { adesão e desistência } \\
\text { da musculação em } \\
\text { academias } \\
\text { (Liz \& Andrade, } \\
2016)\end{array}$ & $\begin{array}{l}\text { Investigar os motivos de } \\
\text { adesão e desistência da } \\
\text { musculação em academias. }\end{array}$ & $\begin{array}{l}\text { Pesquisa } \\
\text { qualitativa. }\end{array}$ & $\begin{array}{l}\text { Mais frequentes: bem-estar, corpo } \\
\text { em forma, prazer, fortalecimento } \\
\text { do corpo e melhora do } \\
\text { condicionamento físico, } \\
\text { socialização, rapidez nos } \\
\text { resultados, melhora a saúde, produz } \\
\text { disposição. } \\
\text { Menos frequentes: auxilia na } \\
\text { prevenção de doenças, diminui a } \\
\text { fome, minimiza dores corporais, } \\
\text { ordens médicas, previne lesões e } \\
\text { melhora a postura corporal. }\end{array}$ \\
\hline $\begin{array}{l}\text { Perfil } \\
\text { socioeconômico, } \\
\text { dietas adotadas e } \\
\text { motivações } \\
\text { frequentadores de } \\
\text { uma academia em } \\
\text { Itapecerica da Serra- } \\
\text { SP } \\
\begin{array}{ll}\text { (Santos, Silva \& } \\
\text { Viana, 2017) }\end{array}\end{array}$ & $\begin{array}{l}\text { Analisar o perfil } \\
\text { socioeconômico e as dietas } \\
\text { adotadas por praticantes de } \\
\text { atividade física, suas } \\
\text { motivações e fontes de } \\
\text { informação. }\end{array}$ & $\begin{array}{l}\text { Pesquisa } \\
\text { quantitativa }\end{array}$ & $\begin{array}{l}\text { Para os homens as principais } \\
\text { motivações são saúde e aumento da } \\
\text { massa muscular, seguido de } \\
\text { emagrecimento. Para as mulheres, } \\
\text { saúde, emagrecimento e definição } \\
\text { do corpo. }\end{array}$ \\
\hline
\end{tabular}

Embora o presente trabalho tenha fornecido uma revisão de pesquisas feitas em público heterogêneo, a partir da discussão dos resultados foi percebido afinidade entre as dimensões motivacionais escolhidas. Deve-se levar em consideração que as motivações podem alterar devido a faixa etária e fase do desenvolvimento, cultura, sexo e nível socioeconômico dos indivíduos pesquisados.

\section{CONCLUSÃO}

O presente trabalho teve como questão central identificar na literatura, os principais motivos para adesão e permanência de atividades físicas em academias. Apesar da diversidade do público pesquisado, idade, sexo e classe socioeconômica, ainda assim a revisão dos resultados acerca do tema motivação demonstram que saúde, estética e prazer são as dimensões que mais motivam à aderência a atividade física, seguidas de controle do estresse, sociabilidade, competitividade. 


\section{Desafios da psicologia no Brasil}

A dimensão saúde aparece significativamente em todos os trabalhos abordados, destacando-se assim a importância das academias e profissionais envolvidos adequarem um ambiente salutar que proporcione ao indivíduo possibilidades de conquistar o objetivo esperado.

É compreendido que a dimensão saúde está direta ou indiretamente relacionado com melhoria de qualidade de vida, prevenção de doenças até mesmo com as dimensões menos votadas: estética, prazer, controle do estresse, sociabilidade e competitividade. Acredita-se que os indivíduos saudáveis ou que se sintam em bem estar, tendem a almejar outros motivos para aderir a atividade física, motivos esses, que só podem ser satisfeitos caso sua saúde esteja preservada.

Portanto, é importante que o tema continue a ser pesquisado, a fim de cada vez levar conhecimento e auxiliar os profissionais da área e academias a estimarem pelo objetivo do aluno, sendo esta ferramenta norteadora para montagem e acompanhamento do mesmo.

\section{REFERÊNCIAS}

Capozzoli, C. J. (2010). Motivação à prática regular de atividades físicas: um estudo com praticantes em academias de ginástica de Porto Alegre. 153 f. Dissertação (Mestrado) - Programa de Pósgraduação em Ciências do Movimento Humano/UFRGS Porto Alegre-RS. Recuperado de http://hdl.handle.net/10183/26880

Fermino, R. C., Pezzini, M. R. \& Reis, R. S. (2010). Motivos para Prática de Atividade Física e Imagem Corporal em Frequentadores de Academia. Rev Bras Med Esporte - Vol. 16, No 1 - Jan/Fev. Recuperado de http://www.scielo.br/pdf/rbme/v16n1/a03v16n1.pdf

Fernandes, H. M. \& Raposo, J. V. (2005). Continuum de Autodeterminação: Validade para sua Aplicação no Contexto Desportivo. Rev Estudos de Psicologia. Recuperado de http://www.scielo.br/pdf/epsic/v10n3/a07v10n3.pdf

Klain, I. P., Cid, L., Matos, D. G. de, Leitão, J. C., Hickner, R. C., \& Moutão, J. (2014). Motivational climate, goal orientation and exercise adherence in fitness centers and personal training contexts. Motriz: Revista de Educação Física, 20(3), 249-256. Recuperado

de http://www.scielo.br/scielo.php?script=sci_arttext\&pid=S1980-65742014000300249

Liz, C. M de \& Andrade, A. (2016). Análise qualitativa dos motivos de adesão e desistência da musculação em academias. Rev Bras Ciênc Esporte. 38(3):267-274. Recuperado de http://www.scielo.br/pdf/rbce/v38n3/0101-3289-rbce-38-03-0267.pdf

Machado, W.L., Bandeira, D.R. (2013). Bem Estar Psicológico: Definição, Avaliação e Principais Correlatos. Estudos de Psicologia (Campinas), 29(4), 587-595. Recuperado de http://www.scielo.br/scielo.php?pid=S0103-166X2012000400013\&script=sci_abstract\&tlng=pt 


\section{Desafios da psicologia no Brasil}

Martins, C. O. \& Jesus, J. F. (1999). Estresse, Exercício Físico, Ergonomia e Computador. Revista Brasileira de Ciências do Esporte, setembro, 21(1), p.807-813. Recuperado de http://artigosedfisica.br.tripod.com/stress\%20ergonomia\%20computador\%20exercicio\%20fisico.pdf

Nahas M, Barros M \& Francalacci V. (2000). O pentáculo do bem-estar - base conceitual para avaliação do estilo de vida de indivíduos ou grupos. Revista Brasileira de Atividade Física e Saúde, Pelotas, v. 5, n. 2, p. 48-59. Recuperado de http://rbafs.org.br/RBAFS/article/view/1002

Rocha, K. F. (2008). Motivos de adesão à prática de ginástica de academia. Motricidade, 4(3), 11-16. Recuperado em 05 de julho de 2018,

dehttp://www.scielo.mec.pt/scielo.php?script=sci_arttext\&pid=S1646107X2008000300003\&lng=pt \&tlng=pt.

Rodrigues, A. L. de P \& Santos, R. do V. (2016). Aspectos motivacionais para a prática de musculação entre jovens de 18 a 25 anos do município de Fortaleza-CE. Revista Brasileira de Prescrição e Fisiologia do Exercício, São Paulo. v.10. n.58. p.308-313. Mar./Abril. Recuperado

de https://dialnet.unirioja.es/descarga/articulo/5487125.pdf

Salin, M. da S; Virtuoso, J. F; Nepomuceno, A. S. N; Weiers, G. G; Mazo, G. Z. (2014). Golden Age Gym: reasons for entry, permanence and satisfaction among participating older adults. Rev Bras Cineantropom Desempenho Hum, 16 (2): 152-160. Recuperado

de http://www.scielo.br/scielo.php?script=sci_arttext\&pid=S1980-00372014000200152

Santos, K. M. dos., Silva, E. S. da, \& Viana, S. D. (2017). Perfil socioeconômico, dietas adotadas e motivações de frequentadores de uma academia em Itapecerica da Serra-SP. Revista Brasileira de Nutrição Esportiva, São Paulo. v. 11. n. 68. Suplementar 2. p.986-994. Jan./Dez. Recuperado de http://www.rbne.com.br/index.php/rbne/article/view/941

Silberstein L. R, Striegel-Moore R. H, Timko C, Rodin J. Behavioral and psychological implications of body dissatisfaction: Do men and women differ? Sex Roles 1988; 19:219-32.

Silva, R. S., Silva, I. da., Silva, R. A. da., Souza L., Tomasi, E.,(2017) Atividade e Qualidade de Vida. Revista ciencia e saude coletiva. Rio de Janeiro, v..15 n.1. recuperado

de http://www.scielo.br/scielo.php?script=sci_arttext\&pid=S1413-81232010000100017

Straub, R. O., Gann, A., Levine, M., Losick, R. (2015) Psicologia da Saúde: Uma Abordagem Psicossocial. Artmed, ed. 3.

Vilarino G. T., Dominsk, F. H., Andrade, R. D., Felden, E. P. G., Andrade, A. (2017); Análise dos Grupos de Pesquisa em Psicologia do Esporte no Brasil. Revista Brasileira de Ciências do Esporte, Florianópolis. Recuperado de http://www.scielo.br/pdf/rbce/v39n4/0101-3289-rbce-39-04-0371.pdf. 


\section{Capítulo 28}

\section{AVALIAÇÃO NEUROPSICOLÓGICA DO TDAH NO BRASIL: REVISÃO SISTEMÁTICA DOS ÚLTIMOS DEZ ANOS}

DOI: $10.37423 / 200200216$

\section{Edilânia De Oliveira Cavalcanti}

edilania_cavalcanti@hotmail.com

RESUMO: A presente pesquisa trata de uma análise do que caractepizam os processos de avaliação neuropsicológica do TPAH no Brasil. Buscou-se/identifjcar como tem sido esse processo, os instrumentos mais utilizados para avaliar of TDAH. Desse mbdo, a partir de uma revisão sistemática da literatùra, objetivou-se abordar/como tem sido o processo de avaliação neuropsicológica do TDAH no Brasil nos últimos dez anos. A análise retorna a-um breve histórico da Neuropsicologia do TDAH no Brasil, com a apresentação do campo e dados atuais da literatura. Procurour-se discutir pontos referentes a uma reflexão acerca da prática da avalição neuropsicológica do TDAH no Brasil. Sendo assim, foi realizada uma busca por estudos nas bases de dados LILACS, PEPSIC, SCIELO, PUBMED, CAPES e BVS-PSI. Inicialmente, a busca-contemplou os últimos cinco ąnos, mas, tendo/em vista a insuficiência de publicações, estendemos o período para os últimos dez anos, entre 2009 e 2019. A busca resultou na identificaçăo de 106 estudos, tendo sido incluídas, na análise, 30 pesquisas nacionais publicadas em português, que abordavan/çomo está sendo realizadla a avaliação neuropsicalógiea do TDAH no Brasit. O's result tados revela ram que há importâneia da avaliação neuropsieológica-como parte norteadora no processo quanto às possibilidades de diagnóstico e intervenção, nos quais há persistentes confusões que os permeiam e representam um desafio na prática clínica, visto que muitos indivíduos procuram atendimentos com diagnóstico do TDAH e este, às vezes, não é correto. 


\section{Desafios da psicologia no Brasil}

Evidenciou-se que no Brasil existe escassez de instrumentos normatizados para o TDAH. Contudo, percebeu-se que os padronizados mais aplicados são: WCST-Wisconsin, Teste Stroop, Torre de Londres, Figuras Complexas de Rey, WISC-IV, WAIS III, ETDAH-AD, entre outros. Certificou-se que, embora a avaliação neuropsicológica ainda não seja obrigatória, é importante na ajuda do diagnóstico e intervenção junto ao paciente, família e escola, com perspectivas de que haja um direcionamento de uma intervenção mais focada e planejada, intervenção multiprofissional e acompanhamento do progresso do tratamento. Foi possível identificar como tem sido registrada a avalição neuropsicológica no Brasil e perceber a necessidade de investimento na formação na área e articulação na prática clínica com os achados científicos.

Palavras-Chave: Neuropsicologia. TDAH. Testes Déficit de Atenção. Hiperatividade. Avaliação. 


\section{Desafios da psicologia no Brasil}

\section{INTRODUÇÃO}

A Neuropsicologia é uma área que utiliza conhecimentos de disciplinas acadêmicas que configuram as áreas das Neurociências, como a Neurofisiologia, Neurofarmacologia, Neuroanatomia e Neuroquímica, e de atuação profissional do psicólogo, Psicometria, Psicologia Experimental e Psicologia Cognitiva. A Neuropsicologia é o estudo das relações entre o comportamento e o cérebro, que investiga as alterações comportamentais e cognitivas associadas às lesões cerebrais (ARGIMON; LOPES, 2017).

O objeto de estudo da Avaliação Neuropsicológica (ANP) é a funcionalidade dos processos cognitivos. Sua prática busca analisar processos como a cognição, linguagem, memória, percepção, visoconstrução, funções executivas, entre outras. Contudo, a área não se detém a apenas identificar os potenciais e prejuízos, mas a analisar quais impactos os déficits têm na vida da pessoa (SCHWARTZMAN, 2011).

Atualmente, a ANP é útil na investigação clínica de uma ampla variedade de condições neuropsiquiátricas e possibilita obter informações específicas e gerais sobre os níveis de funcionamento cognitivo de um determinado indivíduo. Com o desenvolvimento de técnicas de neuroimagem, que permitem localizar lesões cerebrais de forma mais eficaz, a Neuropsicologia passa a se preocupar com as forças e fraquezas cognitivas do paciente, bem como com os mecanismos compensatórios disponíveis (RAMOS; HAMDAN, 2016)

Tisser (2017) pontua que, embora pesquisas tenham como foco a Neuropsicologia do TDAH, ainda há muito a compreender sobre a apresentação clínica neuropsicológica dos pacientes com o transtorno. As pesquisas atuais têm focado principalmente em funções cognitivas de duas redes neurais: 1 ) Córtico-talâmico-cerebelares, que envolvem funções executivas e processamento de informação temporal; e 2) circuitos ascendentes excitatórios, que envolvem estado de alerta, excitação, esforço e motivação.

De acordo com o DSM-5, o Transtorno de Déficit de Atenção/Hiperatividade (TDAH) está associado a desempenho escolar e sucesso acadêmico, rejeição social, e, nos adultos, a piores desempenhos, assiduidade no campo profissional, sucesso e a maior probabilidade de desemprego, além de altos conflitos interpessoais. Problemas escolares, déficits acadêmicos e negligência pelos colegas e, em 


\section{Desafios da psicologia no Brasil}

grau menor, lesões acidentais são proeminentes, com sintomas acentuados de impulsividade ou hiperatividade (WECHLER, 2014).

A prevalência do TDAH no Brasil é alta. Em crianças em idade escolar, a prevalência média varia de 5 a $18 \%$, podendo se alterar conforme a região do país e a forma como a avalição diagnosticada é realizada, além da faixa etária avaliada (GONÇALVES; PUREZA; PRANDO, 2011).

Com efeito, tem-se a Avaliação Neuropsicológica enquanto importante ferramenta para a compreensão deste funcionamento: diagnóstico, intervenção, tratamento do TDAH. Nesse sentido, é necessário entender como é realizada a avaliação neuropsicológica do TDAH no Brasil. O diagnóstico do TDAH é essencialmente clínico, baseado em critérios estabelecidos em sistemas classificatórios como o DSM-5 e a CID-10 (WAGMER; ROBDE; TRENTENI, 2016).

Bolfer (2009) destaca que as causas desse transtorno, apesar de ainda não completamente definidas, podem ser atribuídas a uma combinação de fatores genéticos, biológicos e ambientais. A autora cita, em seu estudo, pesquisas neuropsicológicas e de neuroimagem indicando comprometimento no córtex pré-frontal nos portadores de TDAH e ressalta a importância dessa região em relação aos sintomas apresentados. Complementa ainda, ao destacar pesquisas de imagem cerebral que demonstram áreas de tamanho reduzido de córtex pré-frontal, núcleos de base e cerebelo dos paciente com TDAH, discorrendo sobre as múltiplas projeções de neurônios ricos com dopamina e noradrenalina, serotoninas, glutaminas e acetilcolinas que tais regiões recebem, reforçando os aspectos multi-determinantes do TDAH.

A partir disto, tem-se a avaliação neuropsicológica, que consiste no método de investigar as funções cognitivas e o comportamento. Trata-se da aplicação de técnicas de entrevista, exames quantitativos e qualitativos acerca da investigação das funções que compõem a cognição, de modo a abranger processos de atenção, percepção, memória, linguagem e raciocínio. Tal avaliação fornece tanto dados da áreas deficitárias do indivíduo quanto sobre as habilidades preservadas e o potencial para reabilitação.

Ao longo da História, a hiperatividade, a impulsividade e a desatenção são três dos sintomas centrais que criaram entre si laços diversos no interior da história oficial que os vincula e os chama de TDAH. Considera-se ainda que cada um dos três sintomas se desdobra em quadros mais específicos, caso estejamos nos referindo à maneira do menino ou da menina, da criança, adolescente e do adulto com 


\section{Desafios da psicologia no Brasil}

TDAH. Os dois últimos vieram a fazer parte da década de 1980, pois o transtorno antes era considerado prioritariamente infantil. O TDAH é um transtorno que em menos de um século mudou de classificação mais de dez vezes (SOUZA et al., 2012).

O TDAH tem sido tradicionalmente conceituado como um transtorno de neurodesenvolvimento. Assim, não surpreende que a idade de início na primeira infância tenha emergido como elemento chave. Nas últimas quatro décadas, especialistas por trás dos manuais de diagnósticos têm lutado contra a falta de evidências para definir um limiar preciso para a idade, a partir da qual os sintomas não são considerados como parte da síndrome do TDAH. Apenas baseado na soberania.

clínica, o DSM III introduziu o critério B de TDAH, o qual insistia que os sintomas estivessem presentes antes dos sete anos. O DSM-IV-TR acrescentou que o comprometimento deveria também estar na mesma faixa etária. O comitê científico do DSM-5 decidiu por alterá-lo, exigindo a presença dos sintomas antes dos 12 anos (ROHDE et al., 2019).

Conforme os autores previamente mencionados, a questão final sobre o diagnóstico do TDAH no DSM5 é a caracterização da apresentação atual com base na distribuição de sintomas de desatenção e/ou hiperatividade/impulsividade. As possíveis apresentações são três: 1) predominantemente desatento; 2) predominantemente hiperativo/impulsivo e 3) combinados.

A partir da década de 1980, as publicações sobre a temática que envolvem o TDAH tiveram um profícuo crescimento, alcançando um nível de best-seller. Isto evidencia o forte interesse público pela temática, que foi oficialmente reconhecida após a publicação do DSM-IV em 1994, em especial nos Estados Unidos. Mediante a Resolução 370, em 2004, o TDAH ganha reconhecimento, com a publicação de 7 de setembro como o dia da "Consciência Nacional sobre o TDAH" (SOUZA et al., 2012).

Outra faceta do TDAH é a heterogeneidade, e também a heterogeneidade neuropsicológica. O TDAH tem se mostrado associado a várias deficiências neuropsicológicas. Estudos descobriram que o transtorno apresenta pior desempenho em várias funções, incluindo inibição, alcance de memória, memória de trabalho, velocidade de processamento, excitação, processamento de informação temporal, variabilidade de resposta, bem como prejuízo nos processos motivacionais (ROHDE et al., 2019).

Ainda na década de 1980, passa a ser aceita a interpretação neuropsicológica do TDAH, que era considerado uma disfunção neuropsiquiátrica que afetava o desenvolvimento das funções cerebrais, 


\section{Desafios da psicologia no Brasil}

de capacidade de autocontrole, de planejamento e de execução de ações orientadas para objetivos futuros (SOUZA et al., 2012).

O tratamento do TDAH abrange abordagens múltiplas, envolvendo intervenções psicossociais e psicofarmacológicas (COUTO; MELO-JUNIOR; GOMES, 2010).

O metilfenidato, conhecido como "ritalina", e a lisdexanfetamina, conhecida como "venvance", são dois tipos de psicoestimulantes disponíveis para tratar o TDAH no Brasil, ambos com eficácia e segurança comprovadas por inúmeros estudos. Tais substâncias podem ser usadas como tratamento único ou em combinação com outras intervenções, a depender das caracterizações do paciente e de sua família (TANNURI, 2016).

O TDAH é um transtorno altamente comórbido, tanto em amostras clínicas como comunitárias. Esse perfil se evidencia em especial na hora de os clínicos determinarem se o comportamento vem do TDAH ou de suas frequentes comorbidades (ROHDE et al., 2019).

Diante disso, o presente artigo objetivou, a partir de uma revisão sistemática da literatura, identificar a Avaliação Neuropsicológica do TDAH no Brasil nos últimos dez anos.

Tendo em vista o diagnóstico precipitado, a incompreensão dos pais, do próprio paciente e da escola, a pesquisa justifica-se pela necessidade de compreender quais os principais instrumentos utilizados na Avaliação Neuropsicológica do TDAH no Brasil (CAVALCANTI; MELO, 2015).

\section{MÉTODO}

\section{ESTRATÉGIA DE BUSCA}

O levantamento de dados para a construção do presente trabalho deu-se entre os meses de abril a junho de 2019. A pesquisa foi realizada nas principais bases de dados que indexam periódicos no país, a saber: LILACS, PEPSIC, SCIELO, PUBMED, CAPES e BVS-PSI. O intervalo estabelecido foi entre 2009 e 2019, totalizando a margem de dez anos de produção científica sobre a temática. O recorte temporal foi estabelecido para alcançar o maior número possível de estudos. Os seguintes descritores foram utilizados na busca: 1) Neuropsicologia; 2) TDAH; 3) Testes; 4) Déficit de Atenção; 5) Hiperatividade e 6) Avaliação. 


\section{Desafios da psicologia no Brasil}

Foram incluídos nesta revisão apenas textos que apresentavam referências à temática do trabalho que estivessem disponíveis em língua portuguesa, que analisassem a avaliação neuropsicológica do TDAH no Brasil, que tivessem como público-alvo crianças, adolescentes e adultos e que fossem estudos nacionais.

A busca empreendida resultou na identificação de 106 estudos, dentre os quais 16 não apresentavam referências à avaliação neuropsicológica do TDAH no Brasil, 25 estavam redigidos em língua estrangeira, 16 não apresentavam o público-alvo como participantes das pesquisas empreendidas e outros 19 artigos foram removidos duplos.

Dessa forma, devido à não adequação aos critérios de inclusão mencionados acima, foram excluídos no total 76 artigos, restando para análise apenas 30 artigos. A Figura 1 apresenta o número total de trabalhos encontrados na primeira busca nas referidas bases e a qualidade de artigos incluídos após serem verificados os critérios de inclusão e exclusão.

Figura 1 - Descrição dos procedimentos de coleta.

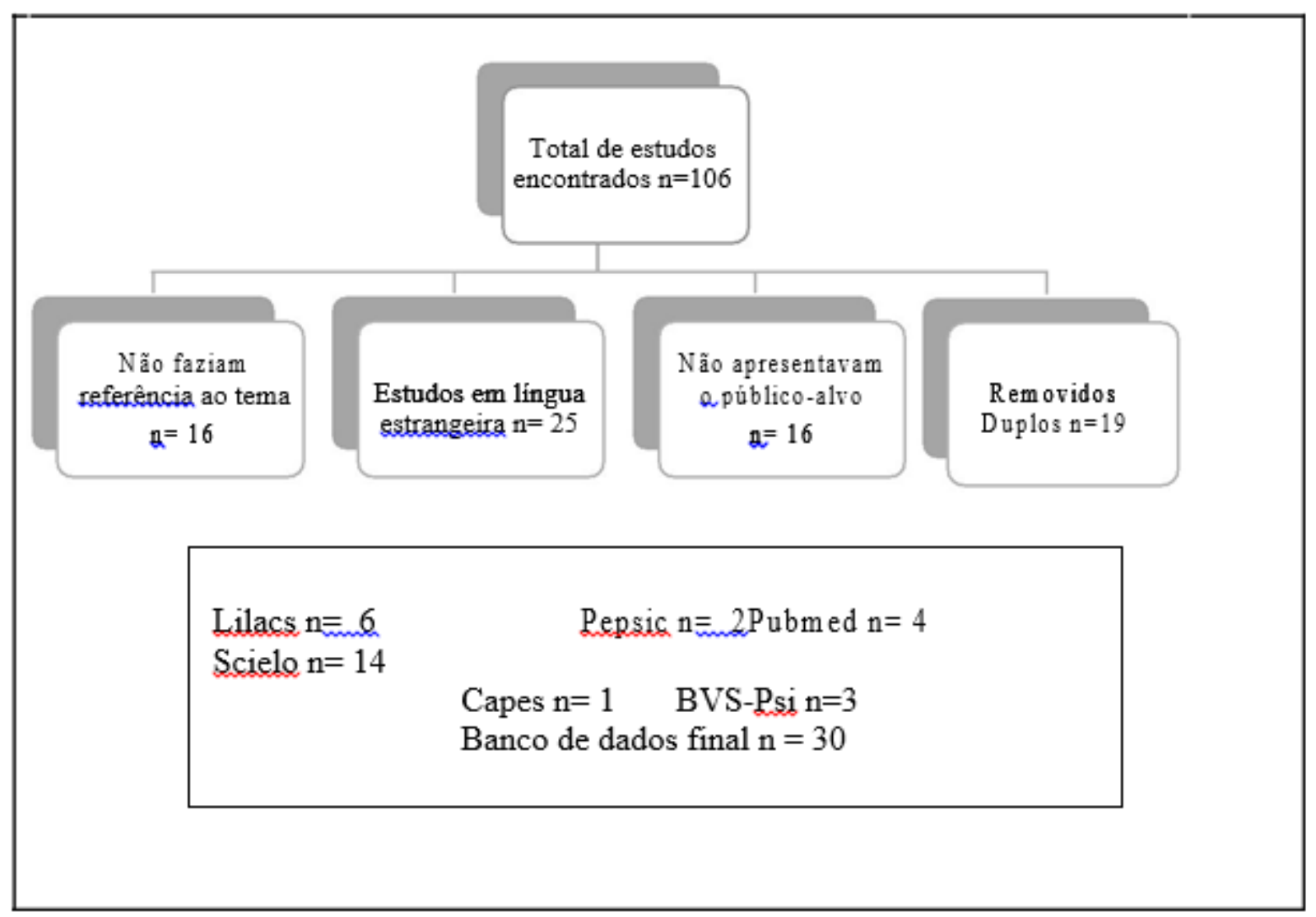

Fonte: Elaboração própria. 


\section{Desafios da psicologia no Brasil}

Para a realização do processo do presente artigo, foram seguidos os oito estágios propostos por Costa e Zoltowski (2014). Os autores criaram uma hierarquia de passos com o objetivo de sistematizar e dar cientificidade às versões da literatura, pois, segundo eles, são oito os estágios recomendados: 1) delimitação da questão a ser pesquisada; 2) escolha das fontes dos dados; 3) eleição das palavraschave para.

a busca; 4) busca e armazenamento dos resultados; 5) seleção de artigos pelo resumo, de acordo com o critério de inclusão e exclusão; 6) extração dos dados dos artigos selecionados; 7) avaliação dos artigos e 8) síntese e interpretação dos dados.

Para Costa e Zoltowski (2014), a Figura 2 demostra a construção do presente trabalho, com base nos estágios dos autores. Algumas das variáveis foram selecionadas a partir da resposta dos principais itens para realizar revisões sistemáticas. As demais foram criadas com vistas a alcançar os objetivos da presente revisão. Foram utilizados: 1) Tipo de Estudo Teórico e Empírico; 2) Funções Neuropsicológicas; 3) Tamanho da Amostra; 5) Idade; 6) Instrumento; 7) Resultados; 8) Idade e 9) Limitações.

Figura 2 - Construção do trabalho.

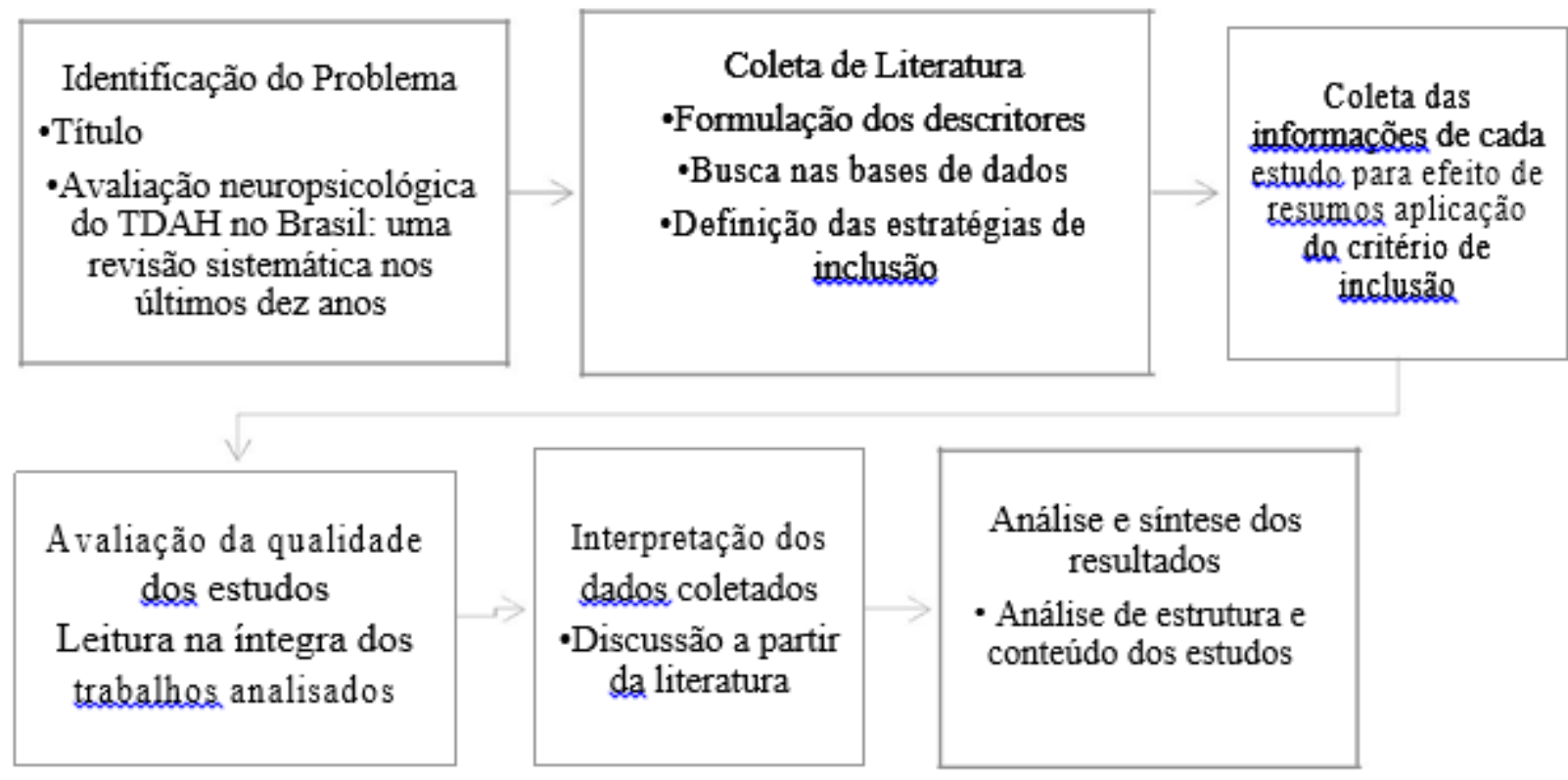

Fonte: Elaboração própria a partir de Costa e Zoltowski (2014). 


\section{Desafios da psicologia no Brasil}

Foram utilizados 30 artigos que atenderam aos critérios de elegibilidade para o estudo. $\mathrm{O}$ ano de publicação dos artigos se enquadrou nos últimos dez anos, 2009-2019. Pode-se considerar que ainda são poucas as pesquisas nacionais desenvolvidas sobre o tema acessíveis online. Quanto ao diagnóstico do TDAH, os dados deste estudo revelaram que, entre as pesquisas publicadas no período de 2009 a 2019, dos 30 artigos, três utilizaram apenas entrevistas, anamneses ou escala, aplicadas em professores e pais.

Ainda quanto aos instrumentos de avaliação, verificou-se que o teste WISC-IV-Escala Wechsler de Inteligência para crianças esteve presente em seis dos artigos e quatro vezes o Teste WAIS

O teste WAIS-III - Escala de Inteligência Wechsler, cuja aplicação se destina a adultos, é mencionado quatro vezes nos achados científicos deste estudo, enquanto o Colúmbia é pontuado duas vezes nos artigos inseridos para esta pesquisa (BURGEMEISTER; BLUM; LORGE, 2011). Os dados resumidos na Tabela 1 evidenciam um panorama dos instrumentos e dos principais achados neuropsicológicos citados em estudos empíricos nacionais. Evidências sintetizadas a partir de uma revisão sistemática podem ser consultadas na tabela a seguir.

Tabela 1 - Síntese de instrumentos nacionais sobre a avaliação neuropsicológica do TDAH no Brasil.

\begin{tabular}{|c|c|c|c|c|}
\hline INSTRUMENTOS & FUNÇÕES & $\begin{array}{c}\text { PÚBLICO- } \\
\text { ALVO }\end{array}$ & EFICÁCIA & REFERÊNCIA \\
\hline WISC IV & $\begin{array}{l}\text { Capacidade } \\
\text { intelectual e o } \\
\text { processo de } \\
\text { resolução de } \\
\text { problemas. } \\
\text { Obtém-se a } \\
\text { capacidade } \\
\text { intelectiva total, } \\
\text { com sub-testes } \\
\text { que são divididos } \\
\text { em quatro } \\
\text { índices: } \\
\text { Compreensão } \\
\text { Verbal, } \\
\text { Organização } \\
\text { Perceptual, } \\
\text { Memória } \\
\text { Operacional e } \\
\text { Velocidade de } \\
\text { Processamento. }\end{array}$ & $\begin{array}{l}\text { Faixa etária de } \\
6 \text { anos até } 16 \\
\text { anos e } 11 \\
\text { meses. }\end{array}$ & $\begin{array}{l}\text { O instrumento } \\
\text { avalia o que se } \\
\text { propõe em sua } \\
\text { base teórica. }\end{array}$ & Wechsler (2014) \\
\hline \multirow[t]{2}{*}{ WAIS - III } & $\begin{array}{l}\text { Capacidade } \\
\text { Intelectual. }\end{array}$ & $\begin{array}{l}\text { Faixa etária de } \\
16 \text { a } 89 \text { anos. }\end{array}$ & $\begin{array}{l}\text { O instrumento } \\
\text { avalia o que se } \\
\text { propõe em sua } \\
\text { base teórica. }\end{array}$ & $\begin{array}{l}\text { Wechsler } \\
\text { (2014) }\end{array}$ \\
\hline & $\begin{array}{l}\text { Fornece } \\
\text { estimativa da }\end{array}$ & Crianças com & O instrumento & \\
\hline
\end{tabular}




\section{Desafios da psicologia no Brasil}

\begin{tabular}{|l|l|l|l|l|} 
Colúmbia & $\begin{array}{l}\text { capacidade de } \\
\text { raciocínio geral, } \\
\text { indicando qual o } \\
\text { nível de } \\
\text { maturidade }\end{array}$ & $\begin{array}{l}\text { idade entre 3 } \\
\text { anos e 6 meses } \\
\text { a 9 anos e 11 } \\
\text { meses. }\end{array}$ & $\begin{array}{l}\text { avalia o que se } \\
\text { propõe em sua } \\
\text { base teórica. }\end{array}$ & $\begin{array}{l}\text { Alves e Duarte } \\
(1993)\end{array}$ \\
\hline
\end{tabular}

\begin{tabular}{|c|c|c|c|c|}
\hline & $\begin{array}{l}\text { mental } \\
\text { correspondente. }\end{array}$ & & & \\
\hline TAC & $\begin{array}{l}\text { Atenção seletiva, } \\
\text { atenção seletiva } \\
\text { com maior nível } \\
\text { de dificuldade, } \\
\text { atenção seletiva } \\
\text { com uma } \\
\text { demanda de } \\
\text { alternância (em } \\
\text { cada uma das } \\
\text { três partes do } \\
\text { TAC). }\end{array}$ & $\begin{array}{l}\text { Faixa etária de } \\
5 \text { a } 14 \text { anos. }\end{array}$ & $\begin{array}{l}\text { O instrumento } \\
\text { avalia o que se } \\
\text { propõe em sua } \\
\text { base teórica. }\end{array}$ & $\begin{array}{l}\text { Montiel e } \\
\text { Seabra (2012) }\end{array}$ \\
\hline TT & $\begin{array}{l}\text { Atenção, } \\
\text { sequenciamento, } \\
\text { rastreio visual e } \\
\text { flexibilidade } \\
\text { mental e função } \\
\text { motora. }\end{array}$ & $\begin{array}{l}\text { Faixa etária de } \\
6 \text { a } 14 \text { anos. }\end{array}$ & $\begin{array}{l}\text { O instrumento } \\
\text { avalia o que se } \\
\text { propõe em sua } \\
\text { base teórica. }\end{array}$ & $\begin{array}{l}\text { Spreen e } \\
\text { Strauss (1998) }\end{array}$ \\
\hline TDE & $\begin{array}{l}\text { Capacidades } \\
\text { essenciais para o } \\
\text { desempenho } \\
\text { escolar, mais } \\
\text { especificamente } \\
\text { escrita, aritmética } \\
\text { e leitura. }\end{array}$ & $\begin{array}{l}\text { Abrange } \\
\text { crianças da } \\
\text { primeira à sexta } \\
\text { série do ensino } \\
\text { fundamental. }\end{array}$ & $\begin{array}{l}\text { O instrumento } \\
\text { avalia o que se } \\
\text { propõe em sua } \\
\text { base teórica. }\end{array}$ & Stein (1994) \\
\hline$A C$ & $\begin{array}{l}\text { Atenção } \\
\text { concentrada. }\end{array}$ & $\begin{array}{l}\text { Escolaridade } \\
\text { do fundamental } \\
\text { ao superior. }\end{array}$ & $\begin{array}{l}\text { O instrumento } \\
\text { avalia o que se } \\
\text { propõe em sua } \\
\text { base teórica. }\end{array}$ & $\begin{array}{l}\text { Cambraia } \\
\text { (2009) }\end{array}$ \\
\hline Wisconsin (WCST) & $\begin{array}{l}\text { Comportamento } \\
\text { executivo. } \\
\text { Representa uma } \\
\text { medida clássica } \\
\text { de função } \\
\text { executiva, } \\
\text { especificamente } \\
\text { flexibilidade e } \\
\text { planejamento; } \\
\text { capacidade de } \\
\text { raciocínio } \\
\text { abstrato; } \\
\text { capacidade de } \\
\text { alterar } \\
\text { estratégias } \\
\text { cognitivas, como } \\
\text { reação a } \\
\text { mudanças do } \\
\text { meio externo e } \\
\text { de desenvolver e } \\
\text { manter uma }\end{array}$ & $\begin{array}{l} \\
\text { Indivíduos dos } \\
61 / 2 \text { aos } 89 \\
\text { anos de idade. }\end{array}$ & $\begin{array}{l}\text { O instrumento } \\
\text { avalia o que se } \\
\text { propõe em sua } \\
\text { base teórica. }\end{array}$ & $\begin{array}{l}\text { Heaton et al. } \\
\text { (2005). }\end{array}$ \\
\hline
\end{tabular}




\section{Desafios da psicologia no Brasil}

\begin{tabular}{|c|c|c|c|c|}
\hline & $\begin{array}{l}\text { estratégia } \\
\text { apropriada de } \\
\text { solução de } \\
\text { problemas. }\end{array}$ & & & \\
\hline \multirow[t]{2}{*}{ Stroop } & $\begin{array}{l}\text { Aspectos } \\
\text { executivos, de } \\
\text { flexibilidade } \\
\text { cognitiva, inibição }\end{array}$ & $\begin{array}{l}\text { População: } \\
\text { adultos }\end{array}$ & $\begin{array}{l}\text { O instrumento } \\
\text { avalia o que se } \\
\text { propõe em sua } \\
\text { base teórica. }\end{array}$ & Stroop (1935) \\
\hline & $\begin{array}{l}\text { de resposta } \\
\text { automática. }\end{array}$ & & & \\
\hline $\begin{array}{l}\text { Complexas Figuras de } \\
\text { Rey }\end{array}$ & $\begin{array}{l}\text { Habilidades de } \\
\text { organização } \\
\text { visuoespacial, } \\
\text { planejamento e } \\
\text { desenvolvimento, } \\
\text { de estratégia e } \\
\text { memória. }\end{array}$ & $\begin{array}{l}\text { Faixa etária dos } \\
4 \text { aos } 88 \text { anos. }\end{array}$ & $\begin{array}{l}\text { O instrumento } \\
\text { avalia o que se } \\
\text { propõe em sua } \\
\text { base teórica. }\end{array}$ & $\begin{array}{l}\text { Oliveira e Rigoni } \\
(2010)\end{array}$ \\
\hline $\begin{array}{l}\text { Escala de Transtorno } \\
\text { do Déficit de Atenção e } \\
\text { Hiperatividade/ETDAH- } \\
\text { AD }\end{array}$ & $\begin{array}{l}\text { Distinguir a } \\
\text { apresentação do } \\
\text { transtorno, a } \\
\text { intensidade e o } \\
\text { nível de prejuízo } \\
\text { existente entre } \\
\text { leve, moderado e } \\
\text { grave. }\end{array}$ & $\begin{array}{l}\text { Faixa etária de } \\
12 \text { a } 87 \text { anos. }\end{array}$ & $\begin{array}{l}\text { O instrumento } \\
\text { avalia o que se } \\
\text { propõe em sua } \\
\text { base teórica. }\end{array}$ & Benczik (2013) \\
\hline $\begin{array}{l}\text { Escala de Transtorno } \\
\text { de Déficit de } \\
\text { Atenção/Hiperatividade: } \\
\text { Versão para } \\
\text { professores. }\end{array}$ & $\begin{array}{l}\text { Desatenção, } \\
\text { hiperatividade, } \\
\text { problemas de } \\
\text { aprendizagem, e } \\
\text { comportamento } \\
\text { antissocial. }\end{array}$ & $\begin{array}{l}\text { Faixa etária dos } \\
6 \text { aos } 17 \text { anos. }\end{array}$ & $\begin{array}{l}\text { O instrumento } \\
\text { avalia o que se } \\
\text { propõe em sua } \\
\text { base teórica. }\end{array}$ & Benczik (2011) \\
\hline Torre de Hanói & $\begin{array}{l}\text { Resolução de } \\
\text { problemas. }\end{array}$ & $\begin{array}{l}\text { Faixa etária a } \\
\text { partir dos } 10 \\
\text { anos. }\end{array}$ & $\begin{array}{l}\text { O instrumento } \\
\text { avalia o que se } \\
\text { propõe em sua } \\
\text { base teórica. }\end{array}$ & Shallice (1982) \\
\hline Torre de Londres & Planejamento. & $\begin{array}{l}\text { Faixa etária de } \\
11 \text { a } 14 \text { anos. }\end{array}$ & $\begin{array}{l}\text { O instrumento } \\
\text { avalia o que se } \\
\text { propõe em sua } \\
\text { base teórica. }\end{array}$ & $\begin{array}{l}\text { Krikorian et al. } \\
\text { (1994) }\end{array}$ \\
\hline & & & & \\
\hline
\end{tabular}

Fonte: Elaboração própria

Em dois dos estudos, foram utilizados os instrumentos para medidas atencionais, sendo citados: Teste de Atenção por Cancelamento (TAC), de Trilha (TT) parte B.E. A investigação por desempenho foi realizada apenas em um dos estudos, através do teste TDE: Teste de Desempenho Escolar. Quatro dos artigos utilizaram o Teste de Atenção Concentrada (AC), sendo por 10 vezes nos artigos analisados os Testes Complexas Figuras de Rey. O teste de distribuição de cartas Wisconsin (WCST) foi achado oito vezes nesta pesquisa. O WCST é um Instrumento desenvolvido em 1948 para avaliar a capacidade de o indivíduo raciocinar abstratamente e modificar suas estratégias cognitivas como resposta a alterações nas contingências ambientais (SOUZA et al., 2012). 


\section{Desafios da psicologia no Brasil}

A Escala ETDAH-AD foi disposta uma única vez para esta revisão. Dos 30 artigos selecionados para este estudo, dois fizeram menção à Escala de Transtorno de Déficit de Atenção/Hiperatividade (Versão para professores). Instrumentos como Torre de Londres e de Hanói também foram citados uma vez nesta pesquisa.

O teste de Stroop é citado nove vezes neste trabalho de revisão. Este instrumento tem a versão mais comum desse paradigma, que consiste em cronometrar o tempo que o sujeito leva para nomear as cores com as quais estímulos neutros (como um círculo) estão impressos no papel.

Podem existir uma ou duas condições de interferência, como nomear rapidamente a cor com a qual palavras que identificam cores estão impressas (e.g. ver a palavra "azul" impressa em verde e dizer "verde"). Como ler costuma ser uma tarefa mais automática e rápida do que nomear cores, a condição de interferência geralmente demanda um tempo maior para ser realizada. O tempo de execução, portanto, é tomado como uma medida de eficiência de mecanismo de supressão e interferência (inibição) (COSTA; ZOLTOWSKI, 2014).

O DSM-5 e o CID-10 são citados em 90\% dos achados no referido estudo. Também aparecem nesta pesquisa o questionário ASRS-18 (Adult Self-Report Scale) e a Escala de Pontuação para pais e professores MTA-SNAP-IV. A Anamnese constitui parte importante desse processo ANP do TDAH no Brasil e coleta dados fornecidos pelo cuidador responsável, que relata os sinais descritos, o histórico de gestação, parto e desenvolvimento, como também o histórico de avalições e intervenções realizadas (CARREIRO et al., 2014).

\section{ANÁLISE DE DADOS}

Dos artigos analisados, percebe-se que o público participante foi maior com crianças, tendo a atenção sido o item mais avaliado. Ademais, $90 \%$ dos artigos mencionam as funções executivas (FE). Embora os critérios de diagnóstico atuais não se refiram de forma explícita a "funções executivas", muitos sintomas incluídos na lista atual de critérios de diagnóstico evocam tais funções (ROHDE et al., 2019).

Wagner, Rohde e Trenini (2016, p. 03) afirmam:

O termo "funções executivas" (FE) engloba um conjunto de capacidades cognitivas responsáveis por processos como planejamento, inibição, sequenciamento e monitoramento de comportamentos complexos. Disfunções executivas têm sido associadas com lesões no córtex com tálamo e núcleos de base. 


\section{Desafios da psicologia no Brasil}

Não existe uma bateria fixa de testes para avaliar o TDAH. Sendo assim, os instrumentos utilizados para avaliação variam de acordo com a demanda do paciente e a escolha do profissional. Há uma escassez de instrumentos validados no Brasil para a avaliação neuropsicológica do TDAH (SOUZA, et al., 2012).

Embora os instrumentos sejam exímios, no Brasil, todavia, diferentes testes foram desenvolvidos para este fim ANP do TDAH, abordando algumas das áreas avaliadas pela Neuropsicologia, especificamente atenção, processamento visoespacial, memória e funções executivas (CAPOVILLA, 2006).

Com relação às áreas de saúde que este estudo contempla, evidencia-se a participação expressiva de psicólogos em conjunto com profissional da área da Medicina, em especial médico neurologista e psiquiatra. Profissionais de Fonoaudiologia, Pedagogia, Psicopedagogia e Terapeuta Ocupacional aparecem nas pesquisas como um intercâmbio multiprofissional (ALVES; NEME; GUARDIA, 2014).

Componentes atencionais constituíram a função neuropsicológica mais examinada nos estudos nacionais consultados. O funcionamento executivo em pacientes com TDAH tem sido foco de inúmeros estudos.

No que se refere ao diagnóstico do TDAH, percebeu-se ser importante salientar que este é essencialmente clínico, baseado em dois sistemas classificatórios: a Classificação Internacional de Doenças (CID-10), proposta pela Organização Mundial da Saúde (WORD HEALTH ORGANIZACION, 1992) e o DSM-V, pela Associação Americana de Psiquiatria (2014). Este último é utilizado no diagnóstico operacional em grande parte das pesquisas científicas realizadas em TDAH (WAGNER; ROHDE; TRENTINI, 2016).

É de se esperar que a Neuropsicologia ainda tenha muito a desenvolver. Para que isso seja possível, clínicos e pesquisadores da área devem investir ainda mais no desenvolvimento de instrumentos ecológicos de avaliação neuropsicológica que mensurem funções cognitivas como atenção, memória de trabalho, memória episódica e componentes das funções executivas. Por exemplo, na avaliação da atenção, deve-se investigar e interpretar com rigor clínico como são processadas as atenções concentrada ou sustentada, focalizada ou seletiva, alternada, dividida, entre outras (FONSECA et al., 2011). 


\section{Desafios da psicologia no Brasil}

\section{CONSIDERAÇÕES FINAIS}

O presente artigo objetivou identificar a avaliação neuropsicológica do TDAH no Brasil nos últimos dez anos. Para tanto, a busca realizada se deu através de uma revisão sistemática da literatura, com o intuito de compreender quais instrumentos são utilizados na avaliação neuropsicológica do TDAH no Brasil.

Ao analisar os elementos estruturais e metodológicos dos respectivos trabalhos incluídos, observouse que, embora existissem pesquisas que abordassem a avaliação neuropsicológica do TDAH no Brasil, destaca-se o fato de haver uma escassez de instrumentos específicos para ANP do TDAH no Brasil. Uma limitação desta pesquisa se deu devido à escassa produção científica da temática produzida em língua portuguesa. Havia vários testes que poderiam ser utilizados para aplicação em uma avaliação neuropsicológica do TDAH no Brasil. Porém, não o foram por não estarem padronizados em português.

Outro ponto de destaque analisado é que, embora a avaliação neuropsicológica ainda não seja obrigatória no Brasil, ela é importante na ajuda do diagnóstico e intervenção junto ao paciente, à família e à escola, na perspectiva de direcionamento de uma intervenção mais focada e planejada, intervenção multidisciplinar e no acompanhamento do progresso do tratamento.

Por fim, apesar da limitação da presente revisão sistemática em virtude da carência de instrumentos traduzidos de outros idiomas para o português para aplicação na avaliação neuropsicológica do TDAH no Brasil, foi possível analisar como tem sido registrada a avaliação no país e perceber a necessidade de investimento na área de articulação da prática clínica com os achados científicos.

\section{REFERÊCIAS}

ALVES, I. C. B.; DUARTE, J. L. M. Escala de maturidade mental Colúmbia: padronização brasileira. São Paulo: Casa do Psicólogo, 1993.

ALVES, G. G. N.; NEME; C. M. B.; CARDIA, M. F. Avaliação neuropsicológica de crianças com Transtorno de Déficit de Atenção e Hiperatividade (TDAH): Revisão da Literatura. Revista Ibero-Americana de Estudos em Educação, v. 9, n. 4, 2014. Disponível

em: <https://periodicos.fclar.unesp.br/iberoamericana/article/view/7334>. Acesso em: 12 ago. 2019.

ARGIMON, I. I. L.; LOPES, R. M. F. Avaliação neuropsicológica infantil: aspectos históricos, teóricos e técnicos. In: TISSER, L. (Org.). Avaliação neuropsicológica infantil. Novo Hamburgo: Sinopsys, 2017. p. 21-48. 


\section{Desafios da psicologia no Brasil}

ASSOCIAÇÃO AMERICANA DE PSIQUIATRIA. Manual e estatística de transtorno mentais: DSM 5. Tradução de Maria Inês Corrêa Nascimento et al. Revisão técnica de Aristides Volpato Cordioli et al. Porto Alegre: Artmed/ American Psychiatric Association, 2014.

BURGEMEISTER, B. B.; BLUM, L. H.; LORGE, I. CMMS - Escala de Maturidade Mental Colúmbia: Manual para aplicação e interpretação. 3. ed. Tradução de Heloisa da Costa Marques Faria. São Paulo: Casa do Psicólogo, 2011.

BENCZIK, E. B. P. Escala do Transtorno de Déficit de Atenção/Hiperatividade:

Versão Adolescentes e Adultos. 1. ed. São Paulo: Vetor, 2013 (v. 1. Coleção ETDAH-AD).

. A importância da figura paterna para o desenvolvimento infantil. Rev. Psicopedagogia, v. 28, n. 85, p. 67-75, 2011. Disponível em: <http://pepsic.bvsalud.org/pdf/psicoped/v28n85/07.pdf>. Acesso em: 18 ago. 2019.

BOLFER, C. P. M. Avaliação neuropsicológica das funções executivas e da atenção em crianças com transtorno do déficit de atenção/hiperatividade (TDAH). 2009 .123f. Dissertação (Mestrado em Ciências) - Faculdade de Medicina da Universidade de São Paulo, São Paulo, 2009.

CAMBRAIA, S. V. Teste de atenção concentrada - AC - manual. São Paulo: Vetor, 2009.

CAPOVILLA, A. G. S. Contribuições da neuropsicologia cognitiva e da avaliação neuropsicológica à compreensão do funcionamento cognitivo humano.

Bragança Paulista: Universidade São Francisco, 2006.

CARREIRO, L. R. R. et al. Protocolo interdisciplinar de avaliação neuropsicológica, comportamental e clínica para crianças e adolescentes com queixas de desatenção e hiperatividade. Revista Psicologia: Teoria e Prática, São Paulo, v. 16, n. 3, p.

155-171, set./dez. 2014. Disponível em: <http: //dx.doi.org/1015348/1980-6906/psicologia.vl 6n3p155-171>. Aceso em: 01 jun. 2019.

CAVALCANTI, E. O.; MELO, M. R. A. Avaliação Neuropsicológica do TDAH no Brasil. In: CONGRESSO BRASILEIRO DA SBNp, 14, Coned, 2, 2015, Natal. Anais...

1. ed. Natal, RN: UFRN. Disponível em: <https://docplayer.com.br/76263189-Anais-do-xiv-congressobrasileiro-da-sbnp-1a-edicao.html>. Acesso em: 13 ago. 2019.

COSTA, A. B.; ZOLTOWSKI, A. P. C. Como escrever um artigo de revisão sistemática. In: KOLLER, S. H.; COUTO, M. C. P.; HOHENDORFF, J. V. (Orgs.). Manual de Produção Científica. Porto Alegre: Penso, 2014. p. 55-70.

COUTO, T. S.; MELO-JUNIOR, M. R.; GOMES, C. R. Aspectos neurobiológicos do transtorno do déficit de atenção e hiperatividade (TDAH): uma revisão. Revista Ciências \& Cognição, v. 15, n. 1, p. 241-251, 2010. 


\section{Desafios da psicologia no Brasil}

GONÇALVES, H. A.; PUREZA, J. R.; PRANDO, M. L. Transtorno de Déficit de Atenção e Hiperatividade: breve revisão teórica no contexto da neuropsicologia infantil. Revista Neuropsicologia Latinoamericana, v. 3, n. 3, p. 20-24, 2011.

Disponível em: <http://pepsic.bvsalud.org/pdf/rnl/v3n3/v3n3a03.pdf>. Acesso em: 12 ago. 2019.

HEATON, R. K. et al. Wisconsin Card Sorting Test: Computer Version 4 Research Edition. Odessa: Psychological Assessment Resources, 2005.

KRIKORIAN, R.; BARTOK, J.; GAY, N. Tower of London procedure: a standard method and developmental data. Journal of Clinical and Experimental Neuropsychology, v. 16, n. 6, p. 840-850, 1994.

MONTIEL, J. M.; SEABRA, A. G. Teste de trilhas - partes A e B. In: SEABRA, A. G.; DIAS, N. M. (Orgs.). Avaliação neuropsicológica cognitiva: atenção e funções executivas. São Paulo: Memnon, 2012, v. 1, p. 69-75.

OLIVEIRA, M.; RIGONI, M. S. Figuras Complexas de Rey: teste de cópia e de reprodução de memória de figuras geométricas complexas. São Paulo: Casa do Psicólogo, 2010.

ORGANIZAÇÃO MUNDIAL DA SAÚDE. Classificação de Transtornos Mentais e de Comportamento da CID-10: Descrições clínicas e diretrizes diagnósticas. Tradução de Dorgival Caetano. Porto Alegre: Artmed,1993.

RAMOS, A. A.; HAMDAN, A. C. O crescimento da avaliação neuropsicológica no Brasil: uma revisão sistemática. Psicologia: Ciência e Profissão, v. 36, n. 2, p. 471-485, abr./jun. 2016. Disponível em: <http://www.scielo.br/pdf/pcp/v36n2/1982-3703-pcp-36-2-0471.pdf>. Acesso em: 12 ago. 2019.

ROHDE, L. A. et al. (Orgs.). Guia para compreensão e manejo do TDAH da World Federation of ADAH. Porto Alegre: Artmed, 2019.

SCHWARTZMAN, J. S. Neurobiologia dos transtornos do espectro do autismo. In:

; ARAÚJO, C. A. (Orgs.). Transtornos do espectro do autismo. São Paulo: Memnon Edições Científicas, 2011. v. 6, p. 65-111.

SHALLICE, T. Specific Impairments of Planning: Philosophical Transactions of the Royal Society B. Biological Sciences, v. 298, p. 199-209, 1982. Disponível em: <http://dx.doi.org/10.1098/rstb.1982.0082>. Acesso em: 12 ago. 2019.

SOUZA, A.; CARVALHO, F.; DIAS, J.; COSTA; L.; BAZHUNI, N. F. M. Avaliação neuropsicológica do Transtorno do Déficit de Atenção/Hiperatividade. Psicologia.pt, set. 2012. Disponível em: <http://www.psicologia.pt/artigos/textos/A0736.pdf>. Acesso em: 13 ago. 2019.

SPREEN, O.; STRAUSS, E. Executive functions. In: Compendium of Neuropsychological Tests. New York: Oxford University Press, 1998. p. 171-231.

STEIN, L. M. Teste de desempenho escolar. São Paulo: Casa do Psicólogo, 2011. 


\section{Desafios da psicologia no Brasil}

. TDE - Teste de desempenho escolar: Manual para aplicação e interpretação. São Paulo: Casa do Psicólogo, 1994.

STROOP, J. R. The basis of Ligon's theory. American Journal of Experimental Psychology, v. 47, p. 499504, 1935.

TANNURI, J. G. C. G. O que dizem famílias homoparentais sobre as relações estabelecidas com a escola dos filhos: tensões entre aceitação e discriminação. 2016. 196f. Dissertação (Mestrado em Educação) - Universidade Estadual Paulista

"Júlio de Mesquita Filho", Instituto de Biociências, Rio Claro. Disponível em: $<$ https://repositorio.unesp.br/bitstream/handle/11449/152150/tannuri_jgcg_me_rcla.p df?sequence=3\&isAllowed=y>. Acesso em: 12 ago. 2019.

TISSER, L. (Org.). Avaliação neuropsicológica infantil. Novo Hamburgo: Sinopsys, 2017.

WAGNER, F.; ROHDE, L. A.; TRENTINI, C. M. Neuropsicologia do Transtorno de Déficit de Atenção/Hiperatividade: modelos neuropsicológicos e resultados de estudos empíricos. Psico-USF, Bragança Paulista, v. 21, n. 3, p. 573-582, set./dez. 2016. Disponível em: <http://www.scielo.br/pdf/pusf/v21n3/2175-3563-pusf-21-03-00573.pdf>. Acesso em: 12 ago. 2019.

WECHSLER, D. Wais - III: Escala de Inteligência Wechsler para Adultos. 3. ed. Tradução de Elizabeth do Nascimento. São Paulo: Casa do Psicólogo; Londres: Pearson, 2014.

WORLD HEALTH ORGANIZATION (Coord.). Descrições clínicas e diretrizes diagnósticas. Tradução de Dorgival Caetano. Porto Alegre: Artmed,1993. 


\title{
Capítulo 29
}

\section{REGULAÇÃO DE ESTADOS AFETIVOS: BENEFÍCIOS DO CONTATO COM A NATUREZA}

\author{
DOI: $10.37423 / 200200223$
}

\section{Thiago de Almeida}

thiagodealmeida@thiagodealmeida.com.br

RESUMO: Há um bom tempo se sabe dos efeitos benéficos da natureza para a saúde do ser humano. No entanto, gada vez mais, o ser humano está desconectado da natureza. Infelizmente nossa potina nós afasta cada vez mais da natureza e isso pode ser prejudicial para nosso corpo e mente. Quais às implicações que a falta/desse contato com a natureza acarreta para a sociedade como um todo? Esse manuscrito, que é uma revisão bibtíográfica, fundamentada na perspectiva Psicobiológica, abarca esse assunto e propões algumas soluções para essa questão.

Palavras-chave: regulação emocional; Psicobjologia; natureza.

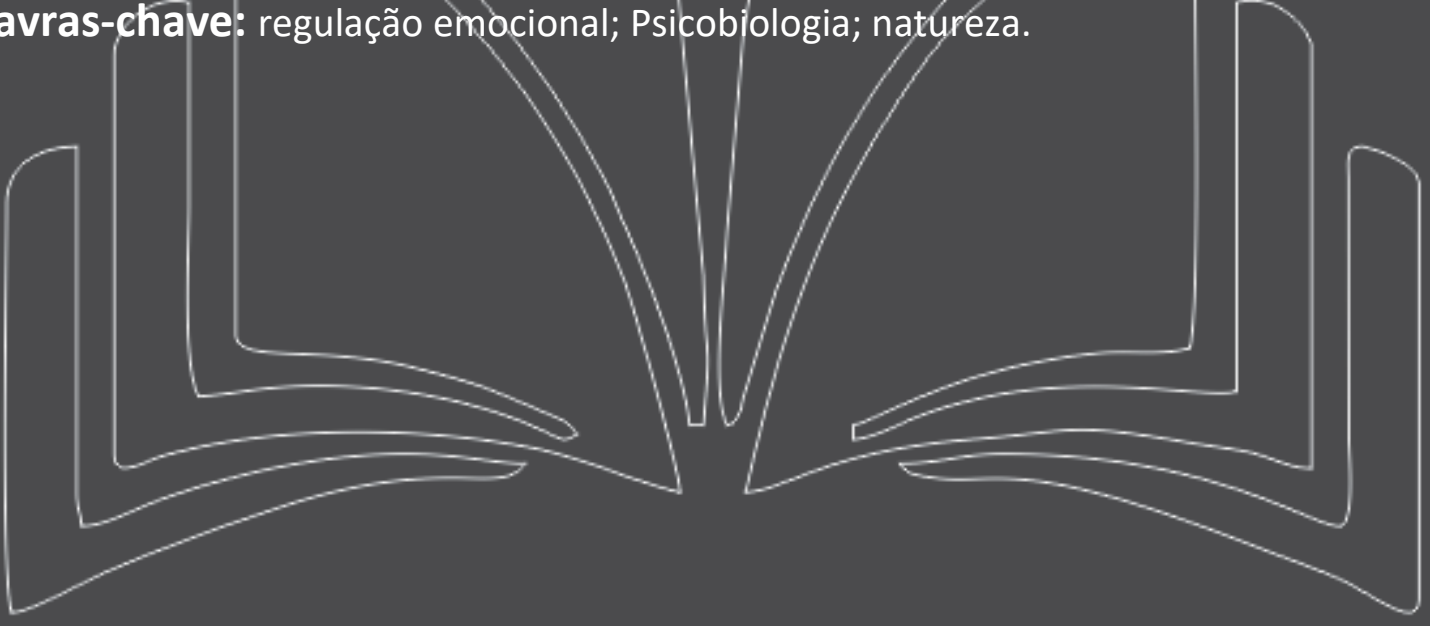




\section{Desafios da psicologia no Brasil}

\section{CONSIDERAÇÕES INICIAIS}

Cada vez mais, o ser humano está desconectado da natureza. Segundo estudos, tais como podem ser citados Clements (2004); Frost (2010); Pergams e Zaradic (2008), atividades como visitas a parques, caça, pesca, acampar na natureza e jogos ao ar livre diminuíram substancialmente nas últimas décadas. Um jornalista americano, de nome Richard Louv, em seu livro "Last Child in the Woods: Saving Our Children From Nature-Deficit Disorder" criou o termo "Transtorno de Déficit da Natureza" para descrever possíveis consequências negativas para a saúde individual e psicológica, sobretudo para as crianças se afastam cada vez mais do contato físico com o mundo natural e do contato com a natureza. Este autor que já publicou outras obras como: "The Nature Principle: Reconnecting with Life in a Virtual Age", "The Nature Principle: Human Restoration and the End of Nature-Deficit Disorder", "Vitamin N: The Essential Guide to a Nature-Rich Life: 500 Ways to Enrich Your Family's Health \& Happiness". Em suas obras, Louv cita pesquisas que apontam para distúrbios de atenção, obesidade, amortecimento da criatividade e depressão como problemas associados a uma infância com a deficiência do contato com a natureza. Neste contexto, nos últimos anos tem se observado um florescimento do interesse científico acerca dos benefícios do contato com a natureza para a saúde humana e o bem-estar. Várias revisões recentes (e.g. Frumkin et al., 2017) resumiram e avaliaram a crescente base de evidências que apoiam as contribuições do contato com a natureza para o bemestar geral, físico e psicológico do ser humano. E, quais as implicações que a falta desse contato com a natureza acarreta para a sociedade como um todo?

De acordo com muitos autores como Gustavsson et al. (2012), Olesen et al. (2012), os custos econômicos da ansiedade e distúrbios do humor, como a depressão, foram estimados em 187,4 bilhões de euros, por ano, apenas para a Europa, somente para citarmos um exemplo de transtornos psiquiátricos que afligem o ser humano. Problemas de saúde como esses, pelo menos em parte, têm sido atribuído à crescente desconexão entre as pessoas e o mundo natural resultante de estilos de vida mais urbanizados e sedentários (Miller, 2005; Soga \& Gaston 2015). Isso é apoiado por pesquisas que mostram que as interações com a natureza promovem a restauração psicológica (Kaplan, 1995), humor melhorado (Hartig, Evans, Jamner, Davis, \& Gärling, 2003; Barton, \& Pretty, 2010; Roe \& Aspinall, 2011), atenção aprimorada (Hartig, Evans, Jamner, Davis \& Gärling, 2003; \& Grahn, 2005) e redução do estresse e da ansiedade (Ulrich, Simons, Losito, Fiorito, Miles, \& Zelson, 1991; Grahn \& Stigsdotter, 2003; Hartig, Evans, Jamner, Davis, \& Gärling, 2003; Maas, Verhejj, Groenewegen, Vries, \& Spreeuwenberg, 2006). E, todos esses fatores estão relacionados a um constructo contemplado pela 


\section{Desafios da psicologia no Brasil}

psicologia denominado regulação emocional, ou como mais recentemente está sendo divulgado, autorregulação emocional.

De acordo com Franco e Santos (2015): a autorregulação (emocional) ou "A regulação das emoções refere-se à capacidade de modular a intensidade ou a duração dos estados emocionais" (p. 340), de tal forma que sejam adequadamente gerenciados os nossos impulsos e emoções. Complementarmente para outros autores (e.g. Batista \& Noronha, 2018), autorregulação emocional pode ser compreendida, para muitos autores como o processo dinâmico intrinsecamente ligado a esforços conscientes no controle dos comportamentos, dos sentimentos e das emoções para que algum objetivo seja alcançado. Em outros termos é o ato de administrar seus pensamentos e sentimentos para se envolver em ações direcionadas a objetivos, como organizar comportamento, controlar impulsos e resolver problemas de forma construtiva. Ser capaz de se autorregular ajuda-nos a ter sucesso em muitos aspectos da vida, incluindo criar relacionamentos satisfatórios, tolerar dificuldades, prosperar na escola e trabalhar, gerenciar as finanças e manter a saúde física e mental. Logo, a autorregulação emocional é uma habilidade crucial para a qualidade de vida. A autorregulação emocional depende não somente da biologia e ações individuais da criança ou do adulto, mas também nas contribuições de pais, professores, outros mentores, bem como as condições da vizinhança para ambientes globais. Embora o aprendizado da autorregulação emocional seja provavelmente mais fácil quando criança, os humanos têm a capacidade de alcançá-la em qualquer idade, seja por meio de relacionamentos saudáveis, psicoterapia ou neuro feedback. Uma grande parte do trabalho psicoterapêutico é ajudar os indivíduos de todas as idades a aprender a se autorregular emocionalmente.

Todas as sociedades têm as suas regras para a regulação das emoções, como por exemplo, o que é aceitável na forma como são expressos os sentimentos emocionais. Por exemplo, essa adequação se aplica à comportamentos agressivos, que precisam ser inibidos e canalizados para que não haja prejuízos à vida social, no entanto, isso também se aplica às emoções positivas, como a alegria e o orgulho. Em algumas culturas, manifestar a expressão de tais sentimentos também é desaprovado e desencorajado. As crianças devem, por isso, aprender a dissociar sentimentos internos de sua expressão aberta e, descobrir como fazê-lo, é parte importante do processo de socialização dessas (Schaffer, 2004). 


\section{Desafios da psicologia no Brasil}

Certamente não podemos generalizar o contato com a natureza como uma panaceia e maniqueizar a falta de contato com a natureza para justificar todas as questões que interferem na autorregulação emocional, até mesmo porque os fatores causais por trás de uma pobre saúde mental são complexos e diversos (Kinderman et al., 2015). O que quer demostrar, por este ensaio são as contribuições positivas do contato com a natureza, sobretudo, para a autorregulação emocional. Posto isso, seguese para a discussão por que estar em contato com a natureza é tão importante? E quais as repercussões positivas da conexão do homem contemporâneo com a natureza?

\section{O CONCEITO DE AUTORREGULAÇÃO}

O autor pioneiro que se ocupou em tematizar em suas pesquisas o processo de regulação emocional foi James J. Gross. Em um capítulo intitulado: "Individual differences in emotion regulation", no livro "Handbook of emotion regulation", os autores Oliver P. John e James Gross, conceitualizam a regulação emocional como o conjunto de processos pelos quais os indivíduos influenciam quais tipos de emoções as pessoas irão ter, quando as têm e como as experienciam e expressam (John \& Gross, 2007). O modelo processual da regulação emocional, desenvolvido por esses autores, distingue diferentes estratégias de regulação emocional, sendo as mais estudadas a reavaliação cognitiva e a supressão emocional.

A reavaliação cognitiva envolve modificar o significado da situação de uma forma que altera o seu impacto emocional. A evidência empírica (e.g. John \& Gross, 2007) revela que o uso dessa estratégia permite a vivência de mais emoções positivas e menos emoções negativas, um melhor funcionamento emocional e interpessoal, menor sintomatologia depressiva, maior satisfação com a vida, mais otimismo e maior autoestima.

Por sua vez, ainda segundo esses mesmos autores, a supressão emocional, tem a capacidade de inibir o comportamento emocional expressivo, mas não a vivência da emoção negativa (John \& Gross, 2007). Nesse sentido, suprimir a expressão das emoções parece conduzir à menor manifestação de emoções positivas e à maior experiência de emoções negativas, a um alienamento psicológico, a um afastamento social, a níveis mais elevados de sintomatologia depressiva e a níveis reduzidos de satisfação com a vida, autoestima e otimismo.

Complementarmente, Gratz e Roemer (2004) propõe uma conceitualização multidimensional da regulação emocional, que envolve: (a) a consciência e a compreensão das emoções; (b) a aceitação 


\section{Desafios da psicologia no Brasil}

das emoções; (c) a capacidade para, em momentos de emoção negativa, controlar comportamentos impulsivos e agir de acordo com os objetivos desejados e (d) a capacidade para usar a regulação emocional apropriadamente mediante a implementação de estratégias que modulem as respostas emocionais de um modo flexível de forma a alcançar objetivos individuais, ao mesmo tempo, que se atende às exigências da situação.

A autorregulação emocional, por exemplo, pode ser a capacidade para não fazermos aquilo que não queremos fazer. Quando interagimos uns com os outros, muitas das vezes, não dizemos diretamente ou literalmente aquilo que pensamos e, por um bom motivo: estamos sujeitos às regras da nossa cultura para interagir de uma maneira que se possa respeitar os sentimentos e espaço pessoal daqueles que estão interagindo conosco. As emoções podem, por vezes, iniciarem-se muito rapidamente. De fato, tão rapidamente que sequer tomamos consciência que a nossa mente e o nosso corpo desencadearam uma emoção específica num determinado momento particular. Essa velocidade pode salvar as nossas vidas em uma emergência, mas também pode arruinar as nossas vidas quando nós temos uma reação excessiva e perdemos o controle das nossas ações. Em outras palavras, embora não se tenha muito controle sobre as respostas emocionais, em determinadas situações de vida, ainda é possível, mesmo que não seja fácil fazer algumas mudanças no que provoca as nossas emoções e como nos comportamos quando estamos emocionalmente alterados. Desde o começo do novo Milênio, alguns estudos (e.g. Hoyle, 2010; Gallagher, Fleeson, \& Hoyle, 2010) caracterizam a autorregulação emocional, considerando-a como um traço de personalidade e uma habilidade. Os traços de personalidade são definidos em função de como o indivíduo interpreta rotineiramente situações e as autorregula (Hoyle, 2006).

Pessoas com capacidade de autorregulação elevada têm mais facilidade em controlar os seus impulsos do que pessoas com capacidade de autorregulação baixa. No entanto, a habilidade a autorregulação pode ser treinada: atos repetidos de autorregulação potenciam a autodisciplina e a capacidade de direcionarmos a nossa energia para aquilo que é mais importante para cada pessoa (Muraven \& Baumeister, 2000).

Estudos de gêmeos confirmam uma base genética no esforço de controle. Entretanto, as práticas parentais também estão associadas a diferenças individuais relacionadas ao esforço de controle. Em termos gerais, a autorregularão de crianças pequenas - incluindo comportamentos que refletem o esforço de controle - tem sido associada positivamente ao apoio materno e, negativamente, ao estilo 


\section{Desafios da psicologia no Brasil}

de cuidados diretivo e controlador. Do mesmo modo, um apego seguro, aos 13 meses de idade, e a sensibilidade materna, aos 22 meses de idade da criança, são fatores preditivos do esforço de controle em uma avaliação futura.

Pesquisas recentes (e.g. Sosnowskaa, Kuppens, Fruyt, \& Hofmansa, 2019) mostram consistentemente que a autorregulação é necessária para reforçarmos o nosso equilíbrio emocional. Na perspectiva comportamental, a autorregulação é a capacidade de agir no seu melhor interesse em longo prazo, de forma consistente com os seus valores mais arraigados. A violação dos seus valores mais profundos pode originar sentimento de culpa, vergonha e ansiedade, que minam o bem-estar pessoal. $\mathrm{Na}$ perspectiva emocional, a autorregulação é a capacidade de acalmar-se quando está chateado, irado, frustrado ou descontrolado e motivar-se, energizar-se e elevar-se por ocasião de quando as pessoas se sentem cabisbaixas por esses motivos. A autorregulação estabelece, assim, uma forte relação com a capacidade que cada pessoa tem para gerir as emoções.

\section{O CONTATO COM A NATUREZA SOB O OLHAR DA PSICOBIOLOGIA}

De forma geral, a Psicobiologia refere-se à mente como um conjunto de mecanismos para processamento de informações, que tem como substrato o tecido nervoso, portanto passível de sofrer pressões seletivas como qualquer outro órgão. Este conjunto de mecanismos é o responsável por nossas atividades mentais conscientes ou não, pela regulação do nosso corpo e pela expressão dos nossos comportamentos, funções que refletem sua origem filogenética e que foram instalados e desenvolvidos, em grande parte da nossa existência. Pioneiramente, o psicanalista Bowlby (1969/1984) denominou este ambiente ancestral, de aquisição de estratégias evolutivas, como Ambiente de Adaptação Evolutiva (AAE). O termo Ambiente de Adaptação Evolutiva, ou, é usado para denotar as qualidades do ambiente ancestral em que os seres humanos se tornaram adaptados para viver. Este termo que foi adotado pela Psicobiologia, pode ser definido como uma combinação estatística das propriedades adaptativas relevantes dos ambientes encontrados por membros das populações ancestrais (Crawford \& Krebs, 1997; Irons, 1998; Tooby \& Cosmides, 1990). Assim, a Psicobiologia não localiza o AAE no tempo e no espaço, por exemplo, no Pleistoceno da savana africana, embora não desconsidere que certas adaptações que possuímos hoje sejam herança dos ancestrais hominídeos dessa época e região. No entanto, estima-se que o Ambiente de Adaptação Evolutiva (AAE), seja de mais de dois milhões de anos (Izar, 2009). Há que se evidenciar que os modos de vida atuais, inteiramente dependentes de recursos como agricultura, pecuária, sociedades 


\section{Desafios da psicologia no Brasil}

organizadas e a escrita não estavam presentes naquele período, tendo surgido há apenas 10 mil anos (Rodrigues, 2009). A estrutura da mente humana, dessa maneira, foi delineada tendo como fulcro as condições de sobrevivência e os problemas ancestrais enfrentados previamente ao surgimento desses recursos, havendo um descompasso entre os módulos mentais fixados e os modos de vida atuais (Pinker, 2004). Os seres humanos, como qualquer outra espécie, foram moldados pelas forças da evolução. Obviamente, este ambiente compreendeu uma presença mais próxima da Natureza em comparação com o que a maioria das pessoas experimenta hoje. As plantas eram de importância crucial para a sobrevivência durante a maior parte de nossa história evolutiva; como um recurso alimentar, para abrigo e como indicador da água. Num terreno puramente teórico, seria de esperar que a presença de plantas, como parte integrante do Ambiente de Adaptação Evolutiva humano, tenha tido um impacto na evolução do cérebro. Estamos presumivelmente adaptados para viver em um ambiente verde. $\mathrm{E}$, como esses dados se relacionam com o tema central desse ensaio, qual seja, a regulação de estados afetivos: benefícios do contato com a natureza?

Praticamente $99,9 \%$ de todo o processo evolutivo foi concentrado e talhado em um ambiente natural, no qual homens e mulheres viviam em contato direto com a natureza. Atualmente e, sobretudo o homem urbano, relaciona-se incipientemente com a natureza em relação a esse período primevo. Em outras palavras, estamos adaptados para vivermos em constante contato com a natureza. A rotina do homem contemporâneo, sobretudo o citadino, não leva em consideração tal importância. Partindose dessas considerações, não tardaremos a inferir que o homem contemporâneo vive e convive em um ambiente no qual ele ainda não se adaptou plenamente, a despeito da sua grande plasticidade comportamental. E é o que várias pesquisas revelam como veremos a seguir.

Pesquisas diversas apoiam fortemente o valor do aumento do contato com a natureza (Berman et al., 2012; Berman et al., 2012; Cervinka, Roderer, \& Hefler, 2012; Hartig, Mang, \& Evans, 1991; Mayer, Frantz, Bruehlman-Senecal, \& Dolliver, 2009; Leather et al., 1998, Mayer, Frantz, Bruehlman-Senecal, \& Dolliver, 2009; Nisbet, Zelenski, \& Murphy, 2011; Ryan et al., 2010; Taylor, Kuo, \& Sullivan, 2001; Townsend, \& Weerasuriya, 2010, Ulrich 1984). Essas pesquisas originam-se de várias abordagens psicológicas diferentes (psicologia evolutiva, cognitivo-comportamental, psicodinâmica, fenomenológica e transpessoal). É utilizada uma ampla variedade de métodos de pesquisa (análise de conteúdo narrativo, levantamento, métodos quasi-experimentais, experimentais e qualitativos). Os desenhos experimentais que discorrem sobre o papel da natureza sobre a regulação emocional incluem uma ampla gama de encontros com a natureza: imagens e vídeos de cenas da natureza, 


\section{Desafios da psicologia no Brasil}

aromas naturais, plantas de interior, árvores e campos vistos a partir de uma janela, prática de jardinagem, interação com animais, proximidade com a natureza, visitas a parques da cidade ou espaços verdes em um desenvolvimento habitacional, caminhadas florestais e zonas selvagens. A maioria das descobertas dessas pesquisas são baseadas no tempo em contato com a natureza e nas imagens da natureza, principalmente porque essas configurações são mais fáceis para os pesquisadores trabalharem. Estes achados são corroborados com configurações experimentais altamente controladas e encontros da natureza mais realistas e intensivos.

Mais especificamente, o contato com a Natureza foi relatado como tendo benefícios psicológicos ao reduzir o estresse (Ulrich et al., 1991; Chang, \& Chen, 2005), melhorando a atenção (Kaplan, \& Kaplan, 1989), tendo um efeito positivo na restauração mental (Hartig, Evans, Jamner, Davis, \& Gärling, 2003; Korpela, \& Ylén, 2007; Van den Berg, Hartig, \& Staats, 2007) e lidando com déficits de atenção (Taylor, Kuo, \& Sullivan, 2001; Taylor, \& Kuo, 2009). Além das vantagens mentais, parece haver benefícios diretos para a saúde física (Pretty, Peacock, \& Hine, 2006), como o aumento da longevidade (Takano, Nakamura, \& Watanabe, 2002) e a saúde auto relatada (De Vries, Verheij, Groenewegen, \& Spreeuwenberg, 2003; Maas, Verheij, Groenewegen, De Vries, \& Spreeuwenberg, 2006). Como seria de esperar, a disponibilidade de Natureza se correlaciona positivamente com a saúde (Mitchell, \& Popham, 2002). Os benefícios foram associados a vários tipos de experiências da Natureza, incluindo a verdadeira região selvagem (Kaplan, \& Talbot, 1983; Hartig, Mang, \& Evans, 1991), parques do bairro (Grahn, \& Stigsdotter, 2003; Fuller, Irvine, Devine-Wright, Warren, \& Gaston, 2007; Kuo, 2010), jardins (Lewis, 1973; Dunnett, \& Qasim, 2000; Loram, Tratalos, Warren, \& Gaston, 2007) e características naturais em torno das residências (Talbot, \& Kaplan, 1991; Wells, \& Evans, 2003).

Há um bom tempo se sabe dos efeitos benéficos da natureza para a saúde do ser humano. Os primeiros hospitais da Europa eram enfermarias em comunidades monásticas onde um jardim era considerado uma parte essencial do meio que apoiava o processo de cura (Gerlach-Spriggs, Kaufmann, \& Warner, 1998). Uma tendência para adicionar elementos da Natureza parece ser uma característica humana universal. Dos jardins suspensos da Babilônia, até o cultivo de plantas em apartamentos ou a criação de animais de estimações domésticos é buscado ativamente um contato com a natureza. Estudos mostram que estar envolvido na natureza contribui para o relaxamento e o aumento do senso de bem-estar, restauração da clareza mental, saúde física e cura, diminuição do tempo de recuperação da cirurgia e diminuição dos sintomas dos Transtornos de déficit de atenção e hiperatividade em crianças. Há estudos que apontam ainda que que caminhar com os pés descalços ou sentar-se na terra 


\section{Desafios da psicologia no Brasil}

tem benefícios de transtornos muito comuns, incluindo distúrbios do sono, dor e inflamação, estresse crônico e doenças cardiovasculares (Chevalier, Mori, \& Oschman, 2006). Estudos como o de Chevalier, Mori, \& Oschman (2006) revelaram um fator ambiental surpreendentemente positivo e negligenciado na saúde: contato físico direto com o vasto suprimento de elétrons na superfície da Terra.

Ulrich, Simons, \& Miles (2003) também investigaram os benefícios da natureza virtual. Este estudo verificou que os níveis de estresse de pessoas que esperavam em uma sala para doar sangue eram mais baixos quando a televisão mostrava imagens de ambientes naturais do que quando figuras de cidades apareciam.

\section{BIOFILIA E AUTORREGULAÇÃO EMOCIONAL SOB A PERSPECTIVA PSICOBIOLÓGICA}

A hipótese de que os seres humanos têm uma inclinação inerente a afiliar-se à Natureza foi referida como biofilia (Wilson, 1984; Kellert \& Wilson, 1993). O conceito "biofilia" significa, literalmente, "amor pela vida" e foi popularizado quando o biólogo americano Edward Wilson publicou um livro com este título em 1984. Dez anos depois, Wilson editou, com Stephen Kellert, outro livro, intitulado "A hipótese da biofilia", que discute a possibilidade de haver base genética para nosso apreço pela natureza. Não há pesquisas amplamente aceitas que comprovem esta teoria, mas não faltam indícios da influência saudável do verde.

E o tamanho do efeito da natureza sobre a autorregulação emocional no ser humano pode ser explicado por que motivo? O principal motivo é que $99,99 \%$ de nossos cinco milhões de anos de evolução como primatas em meio à natureza. Seríamos essencialmente conectados a ela. O estilo de vida moderno separa os seres humanos de tais contatos. Logo, esta desconexão com a natureza pode ser um importante contribuinte para a disfunção psicobiológica.

Um dos primeiros a demostrar que a natureza faz bem foi Roger Ulrich, em 1984, ao comparar pacientes em quartos com janelas voltadas para árvores com aqueles cujos quartos ofereciam vista para uma parede de tijolos, em um hospital na Pensilvânia, nos Estados Unidos. Seus resultados demonstraram que pacientes com acesso ao verde saíram mais cedo do hospital, tomaram analgésicos mais fracos ou em menor quantidade, tinham menos comentários críticos sobre a enfermagem e menor número de pequenas complicações pós-cirúrgicas (Ulrich, 1984). Depois, outros estudos (e.g. Evensen, Raanaas, Hagerhall, Johansson, \& Patil, 2015) testaram objetos coloridos, porém inanimados, no lugar de plantas, e verificaram que as plantas ofereciam benefícios ligeiramente maiores. 


\section{Desafios da psicologia no Brasil}

A partir da pesquisa de Ulrich (1984), citada em numerosos trabalhos, muitos autores (e.g. Dover, 2016) passaram a defender a construção de mais áreas verdes em hospitais e até mesmo o contato com a natureza como uma forma de medicina preventiva. Com o tempo, surgiram análises também em escritórios, escolas e apartamentos, tanto sobre o uso da natureza no interior quanto ao ar livre. Em um estudo de 2000, a pesquisadora Tove Fjeld, da Universidade de Agricultura da Noruega, viu que reclamações sobre dores de garganta, por exemplo, diminuíram $23 \%$ depois que um escritório foi decorado com plantas (Fjeld, 2000). Já o estudo dos pesquisadores Virginia Lohr e C. H. Pearson-Mins, da Universidade do Estado de Washington, percebeu que a presença de plantas torna a dor mais suportável (Lohr, \& Pearson-Mims, 2000).

As explicações para o efeito da natureza sobre nossa saúde variam desde fatores evolucionários à melhor qualidade do ar, ou ainda um gosto estético por tudo que é verde ou vivo. Grinde e Patil (2009) listaram possíveis causas apontadas por Ulrich em seus trabalhos: estar na natureza normalmente é relacionado a atividades físicas; atividades na natureza muitas vezes estimulam a socialização; e a natureza oferece uma oportunidade de fuga temporárias da rotina e suas exigências.

Uma das estratégias que são sugeridas por vários autores (e.g. Oschman, Chevalier, \& Brown, 2015) na tentativa de se reconectar à natureza é o que os autores chamam de "Grounding", "Earthing" ou Aterramento. Aterramento, ou ancoramento, como alguns autores o chamam, envolve colocar seus pés diretamente no chão sem sapatos ou meias como barreira. A lógica por trás dessa prática relaciona-se com a intensa carga negativa carregada pela Terra. Essa carga é rica em elétrons, teoricamente servindo como um bom suprimento de antioxidantes, ajudam em processos metabólicos como a participação em processos enzimáticos e elétrons ainda podem atuar como destruidores de radicais livres. Ao colocar os pés na terra acontece uma relação direta entre a carga elétrica de nossos corpos e o solo. Isso porque o coração, cérebro, sistema nervoso, músculos e sistema imunológico são todos subsistemas elétricos. Quando uma pessoa tem excesso de carga negativa (excesso de elétrons), ela é absorvida pela Terra. O mesmo acontece quando há uma deficiência de elétrons que podem ser fornecidas pelo solo. Dessa forma é possível alcançar o equilíbrio.

James Oschman, doutor em biologia pela Universidade de Pittsburgh e especialista em medicina energética, observa relatos na literatura e práticas de diversas culturas de todo o mundo de que caminhar com os pés descalços na Terra aumenta a saúde, de forma geral, e proporciona sentimentos 


\section{Desafios da psicologia no Brasil}

de bem-estar. Por uma variedade de razões, muitas pessoas estão relutantes em andar com os pés descalços, a menos que estejam, em algumas situações, por exemplo: de férias na praia.

Colocar os pés no chão permite que sejam absorvidas grandes quantidades de elétrons negativos através das solas dos pés, o que, por sua vez, pode ajudar a manter o corpo com o mesmo potencial elétrico da carga negativa que a Terra. A reconexão com os elétrons da Terra é uma teoria encontrada para promover intrigantes mudanças fisiológicas e relatos subjetivos de bem-estar (Chevalier, Sinatra, Oschman \& Delany, 2013; Chevalier \& Sinatra, 2011; Ghaly \& Teplitz, 2004; Sokal \& Sokal, 2011; Chamberlin, Smith, Appasani, Chirgwin \& Rioux, 2014). A ligação à terra (ou aterramento) refere-se à descoberta de benefícios - incluindo melhor sono e dor reduzida - de andar descalço no exterior ou sentado, trabalhando ou dormindo em ambientes fechados conectados a sistemas condutores que transportam os elétrons da Terra do solo para dentro do corpo.

Um estudo (Chevalier, Sinatra, Oschman, Sokal \& Sokal, 2012) publicado no Jornal de Saúde Ambiental e Pública intitulado "Aterramento: Implicações de Saúde de Reconexão do Corpo Humano aos Eletrólitos de Terra" postula que a terra pode representar um tratamento em potencial/solução para uma variedade de doenças crônicas e degenerativas. Este estudo sugere que um simples contato com a Terra, por meio de estar descalço ou conectado a sistemas condutores aterrados, poderia servir como uma estratégia ambiental natural e "efetivamente efetiva" contra o estresse crônico, inflamação, dor, sono fraco, sangue hiper-coagulável e muitos transtornos de saúde comuns, incluindo doenças cardiovasculares. O estudo conclui ainda, que o aterramento do corpo humano pode ser um elemento essencial na equação da saúde, juntamente com a luz do sol, ar limpo e água, alimentos nutritivos e atividade física. Segundo o estudo, quando o corpo está em contato com a terra, seu potencial elétrico torna-se equalizado com o potencial elétrico da Terra através da transferência de elétrons da Terra para o corpo. Isto, por sua vez, evita que o modo $60 \mathrm{~Hz}$ (voltagem ambiente) produza um potencial elétrico CA (corrente alternada) na superfície do corpo e produza perturbações nas cargas elétricas das moléculas do organismo. As pessoas que recebem mais fluxo de elétrons direta têm mostrado ser menos estressadas, tem uma melhor tensão muscular, e variabilidade da frequência cardíaca (Chevalier, 2010; Chevalier \& Sinatra, 2006; Chevalier, Mori, \& Oschman, 2006). Outro estudo, realizado pelo Departamento de Neurocirurgia do Hospital Clínico Militar em Powstancow Warszawy, juntamente com outras afiliadas como a Universidade Médica da Polônia, descobriu que as concentrações de uréia no sangue. são menores em indivíduos conectados à terra (Sokal et al., 2013). No entanto, existem apenas alguns estudos epidemiológicos sobre a relação entre a natureza 


\section{Desafios da psicologia no Brasil}

e a saúde. Estudos epidemiológicos realizados na Holanda mostraram que moradores de bairros com abundante espaço verde tendem, em média, a desfrutar de uma melhor saúde geral (De Vries, Verheij, Groenewegen, \& Spreeuwenberg, 2003; Maas, Verheij, Groenewegen, De Vries, \& Spreeuwenberg, 2006). Essa correlação foi encontrada mais forte entre os idosos, donas de casa e pessoas de grupos socioeconômicos mais baixos (Health Council of the Netherlands, 2004; De Vries, Verheij, Groenewegen, \& Spreeuwenberg, 2003). No entanto, o estudo de Beyer et al. (2014) apontou que mesmo para pessoas pobres que viviam perto de vegetação era ainda mais provável que tivesse relato de maior nível de paz e felicidade do que uma pessoa mais rica que vive em uma área com menos vegetação. Um estudo longitudinal japonês mostrou que viver em um bairro com relativamente acessível verde espaço para passear correlacionado com menor risco de mortalidade (Takano, Nakamura, \& Watanabe, 2002).

É um fato estabelecido, embora não amplamente apreciado, de que a superfície da Terra possui um abastecimento ilimitado e continuamente renovado de elétrons livres ou móveis. A superfície do planeta é eletricamente condutora (exceto em áreas de ultradição limitadas, como desertos), e seu potencial negativo é mantido (isto é, seu suprimento de elétrons reabastecido) pelo circuito elétrico atmosférico global (Williams, \& Heckman, 1993; Anisimov, Mareev, \& Bakastov, 1999). Dessa forma, evidências científicas sugerem que o potencial negativo da Terra podem criar um ambiente bioelétrico interno estável para o funcionamento normal de todos os sistemas corporais. Além disso, as oscilações da intensidade do potencial da Terra podem ser importantes para ajustar os relógios biológicos que regulam os ritmos do corpo diurno, como a secreção de cortisol (Oschman, 2008).

Ainda melhor, você não precisa estar subindo uma montanha ou remar um caiaque. O contato benéfico com a natureza pode variar de uma excursão de região selvagem extensa, passar um tempo em um parque ou até mesmo seu quintal, jardinagem e até mesmo assistir a cenas da natureza na TV! Mesmo olhar imagens de cenas da natureza em um livro ou revista pode ter um efeito benéfico. Todas essas possibilidades e cenários podem contribuir positivamente para a questão da autorregulação emocional.

Outra forma de se desfrutar dos benefícios do contato com a natureza são praias e cachoeiras, por que? O ser humano precisa de um volume de ar de aproximadamente 10.000 litros por dia e este ar precisa ter uma boa qualidade. Além de níveis de oxigênio e nitrogênio, nosso corpo precisa que o ar tenha uma carga energética. A sensação de bem-estar junto à uma cachoeira ou mar pode ser 


\section{Desafios da psicologia no Brasil}

explicada pela liberação de íons negativos. Quando moléculas de água se chocam com rochas ou a areia da praia, seus elétrons escapam e unem-se a outras partículas próximas. 0 átomo ou molécula resultante desta fusão tem mais elétrons do que prótons, e é criado o íon negativo, que traz benefícios para a saúde humana. Além disso os íons negativos também podem ser encontrados em grande quantidade em florestas, montanhas e mares. Em ambientes urbanos estes íons são raros pois a poluição do ar, da água e as ondas eletromagnéticas dos aparelhos eletrônicos, gera muitos íons positivos, que podem ser prejudiciais à saúde. Essa carga energética traz bem-estar e bom humor para nossas vidas, além de agir de forma bactericida, pois as bactérias não conseguem aguentar a carga elétrica modificada devido ao seu tamanho microscópico. Elas são feitas primeiramente de íons, ou seja, partes de átomos que se desprendem deles mesmos. A sensação é medida pelo número de íons negativos por $\mathrm{cm}^{3}$ de ar. Na praia, onde temos uma carga energética alta, há aproximadamente 50.000 íons negativos por $\mathrm{cm}^{3}$. Já dentro das nossas casas a média cai para impressionantes 10 íons negativos por $\mathrm{cm}^{3}$. Para deixar a nossa casa com aquela sensação de aconchego, podemos aumentar o número de íons negativos dentro dela adquirindo aparelhos ionizadores de ar fundamentados nesse princípio. Os ionizadores trabalham com íons negativos. No ar ambiente, pequenas cargas negativas controladas levam a um alívio considerável, através de cargas eletrostáticas fazendo com que as partículas em suspensão sejam atraídas para ele.

Reiterando: a teoria psicobiológica afirma que os seres humanos desenvolveram respostas restauradoras para a natureza e autorregulação emocional. Logo, uma exposição à natureza, de acordo com essa teoria, reduzirá as emoções negativas e aumentará as emoções positivas (restauração afetiva). E várias pesquisas apoiam essa afirmação. Estar exposto a um ambiente natural depois de ver um filme assustador mostrou melhorar o humor mais do que ser exposto a um ambiente construído artificialmente (Van den Berg, Koole, \& Van der Wulp, 2003).

Só fazia parte nos últimos 100 anos que a maioria de nós nos países industrializados começou a passar a maior parte do tempo dentro de casa. No entanto, durante a maior parte da nossa história como seres humanos, estávamos fora: caçar, cultivar, caminhar ou simplesmente assistir a natureza (Ulrich, 1993). Embora vários estudos tenham sido capazes de demonstrar os efeitos positivos sobre o humor e a atenção de uma exposição à natureza (e.g., Berman, Jonides, \& Kaplan, 2008; Bowler, Buyung-Ali, Knight, \& Pullin, 2010; Hartig, Evans, Jamner, Davis, \& Gärling, 2003; van den Berg et al., 2003), tais pesquisas centraram-se menos nos usos cotidianos da natureza em relação à regulação emocional. No entanto, alguns estudos relevantes foram conduzidos. O uso de lugares favoritos para a 


\section{Desafios da psicologia no Brasil}

autorregulação é altamente similar ao uso da natureza para a regulação emocional e um estudo experimental mostrou efeitos positivos (em experiências restaurativas) de prescrever visitas a um lugar favorito uma vez por dia, embora apenas um terço das visitas neste estudo foram para ambientes naturais (Korpela \& Ylén, 2007).

No artigo mencionado "Os benefícios 'transpessoais' da natureza" do autor John Davis fica bem esclarecido isso. Exemplos de benefícios transpessoais do contato com a natureza incluem:

- A natureza é um gatilho para as melhores experiências. Jesus, Moisés, Buda e Mohammed tiveram experiências místicas em ambientes selvagens;

- A natureza pode desencadear o despertar espiritual;

- A natureza é um antídoto para um mundo que é excessivamente racionalizado;

- A natureza pode promover uma mudança do que é inventado (o ego, estruturas construídas) para o que é essencial (o que existia antes ou antes da ação humana).

Davis, em outro artigo de 2004 intitulado: "Psychological benefits of nature experiences: an outline of research and theory" (Benefícios psicológicos das experiências da natureza: um esquema de investigação e teoria) ainda vai além e diz que há pesquisas limitadas, mas sugestivas, que essas descobertas são transculturais e universais (Davis, 2004).

Uma análise dose-resposta para depressão e pressão arterial elevada sugere que as visitas a espaços verdes ao ar livre de 30 minutos ou mais ao longo de uma semana podem reduzir a prevalência populacional dessas doenças em até $7 \%$ e $9 \%$, respectivamente (Shanahan et al, 2016). Dado que os custos societários da depressão sozinhos na Austrália são estimados em US \$12,6 bilhões por ano, a poupança para os orçamentos de saúde pública em todos os resultados de saúde pode ser imensa.

Um outro estudo traz números interessantes sobre a influência de caminhar em ambientes naturais. Depois do segundo dia de andanças numa floresta local, um determinado tipo de glóbulos brancos, as células de defesa do organismo, teve um aumento de 56\% nos indivíduos acompanhados (Miyazaki, Ikei, \& Song, 2014). Ainda, segundo este estudo, uma quantidade $23 \%$ maior das células em relação ao estado original foi mantida durante um mês após a caminhada e o retorno à vida urbana. Para esses pesquisadores, este foi um sinal claro de como a natureza pode contribuir para a medicina preventiva. Por causa disso, desde 2005, no Japão, há diversos locais onde se pode praticar a "Terapia de floresta" 


\section{Desafios da psicologia no Brasil}

(chamados shinrin-yoku), uma caminhada por áreas verdes com potencial de curar o estresse. 0 governo japonês já investiu, desde 2004, US\$ 4 milhões em pesquisas sobre o tema, visando também estabelecer mais de 100 lugares onde se pode participar da terapia.

Para os citadinos com dificuldades de encontrar espaços verdes, portanto, haveria alternativa: basta povoar varandas, mesas e paredes com belas flores e arbustos para sentir a diferença. Em território brasileiro os cariocas levam grande vantagem em relação a usufruir dos benefícios de áreas verdes. Em 2012, a Secretaria Municipal do Meio Ambiente mostrou: o Rio ostenta uma média de 55,83 $\mathrm{m}^{2}$ de área remanescente da Mata Atlântica por habitante - número bem superior aos $12 \mathrm{~m}^{2}$ mínimos recomendados pela Organização Mundial da Saúde. Outros benefícios que podemos considerar acerca do contato com a natureza, segundo as pesquisas citadas:

A. Relaxamento, redução de estresse e atenção plena. Esses benefícios afetam os indivíduos diretamente e se concentram em níveis que diferem de pessoas para pessoas, tais como os que são discutidos abaixo. A maioria tem fortes evidências empíricas;

B. Relaxamento, restauração, paz, tranquilidade. Redução da carga de papéis, conflito e ambiguidade. Redução do burnout e do tédio. Recuperação mais rápida do estresse em resposta aos estímulos da natureza do que as configurações construídas. Mais de cem estudos de pesquisa mostram que a redução do estresse é um benefício percebido chave da recreação da região selvagem. Comentários mais detalhados sobre essa questão foram feitos por estudos tais como os conduzidos por Hartig, Mang e Evans, 1991; Kaplan, 1995, dentre outros). Essas descobertas incluem uma variedade de configurações da natureza próxima à região selvagem. Este foco está no relaxamento físico, cognitivo e afetivo. Um exemplo é uma pesquisa apresentou um vídeo estressante (como acidentes industriais) para pesquisar participantes e mostra que um vídeo de natureza subsequente leva a uma recuperação mais rápida do que um vídeo com outros conteúdos (Ulrich, 1984);

C. Recuperação mais rápida do estresse. "Uma descoberta consistente em mais de 100 estudos de pesquisa de experiências de recreação em áreas selvagens e de natureza urbana tem sido que a mitigação do estresse é um dos benefícios mais expressivos expressados verbalmente" (Ulrich et al., 1991). 


\section{Desafios da psicologia no Brasil}

\section{AGENDA DE PESQUISA}

Cada vez mais, estudos como aponta o estudo de Goenka e Andersen (2016), tematiza como o design e transporte urbano para promover vidas saudáveis, tanto do ponto de vista físico como psicológico. Nesse sentido, os conhecimentos da Psicobiologia, podem contribuir, em muito, para fundamentar e assessorar esses planejamentos urbanos. Logo, os espaços urbanos, sob essa perspectiva podem ser uma profícua área de pesquisa, pois, até então, pela recenticidade da Psicobiologia, atualmente sejam incipientes.

\section{CONSIDERAÇÕES FINAIS}

A autorregulação emocional pode determinar, em grande parte, a qualidade das nossas vidas. Ela acontece e manifesta-se em qualquer relacionamento que temos, no trabalho, nas amizades, com os familiares, e nas nossas relações íntimas. Elas podem salvar a nossa vida, mas igualmente causaremnos danos graves. Podem conduzir-nos a ações que julgamos realistas e apropriadas, mas déficits no que concerne a autorregulação emocional pode também conduzir-nos a agir de formas a que nos arrependemos mais tarde.

Como vimos, por este ensaio, a regulação dos estados afetivos pode ser beneficiada pelo contato com a natureza, com sua importância caracterizada pelos conhecimentos da teoria da Biofilia e da Psicobiologia, de tal forma, que de uma maneira ou de outra, este contato com o natural pode viabilizar a qualidade de vida para o ser humano. Pesquisas experimentais confirmam cada vez mais a hipótese de que o contato direto com a natureza leva ao aumento da saúde mental e ao desenvolvimento psicológico. Diversas pesquisas encontraram evidências fortes no que diz respeito à exposição a ambientes naturais e a recuperação do estresse fisiológico e da fadiga mental, dando suporte à Teoria da Recuperação do estresse e a Teoria da Restauração da Atenção. Na verdade, as exposições a ambientes naturais protegem as pessoas contra o impacto de estressores ambientais e oferecem restauração fisiológica, emocional e de atenção mais do que ambientes urbanos.

Locais naturais que permitem a renovação de recursos adaptativos pessoais para atender às demandas da vida cotidiana são chamados de ambientes restauradores. Ambientes naturais provocam maior respostas tranquilizadoras do que ambientes urbanos, e em relação à sua visão, há uma redução geral dos sintomas fisiológicos do estresse. A exposição a cenas naturais medeia os efeitos negativos do estresse reduzindo o estado de humor negativo e, acima de tudo, aumentando as emoções positivas. 


\section{Desafios da psicologia no Brasil}

Além disso, pode-se recuperar a diminuição do desempenho cognitivo associado ao estresse, especialmente refletido em tarefas de atenção, através do efeito salutar de observando a natureza.

O espaço verde sempre esteve presente nas áreas urbanas e suburbanas, mas nas últimas décadas foi levado mais a sério por causa do declínio da porcentagem global dele. Embora as pesquisas apontem massivamente a importância da natureza para o equilíbrio físico e psicológico das pessoas, o espaço verde está declinando devido a fatores como os parques não estão sendo devidamente atendidos e a substituição para espaços verdes para mais urbanização, como estacionamentos, shoppings, etc. Esta diminuição no espaço verde nos alerta para uma preocupação por uma diminuição em atividade física, e a saúde mental das pessoas (Pietilä et al., 2015).

Desde então, a conexão entre vegetação e medicina terapêutica ou preventiva foi gradualmente ultrapassada, em parte devido ao avanço da ciência médica e às abordagens técnicas concomitantes de cura. Nas últimas décadas, no entanto, pesquisas consideráveis foram realizadas com os efeitos de estar na Natureza e de adicionar plantas a ambientes de outra forma estéril. Na medida em que os resultados são positivos, a ideia de que o acesso à natureza pode ajudar a curar ou ajudar a prevenir doenças, eventualmente, pode ser incorporada na medicina baseada em evidências.

Em geral, pesquisas mostram que a porcentagem de espaço verde no ambiente de vida das pessoas tem uma associação positiva com a saúde geral percebida dos residentes. O espaço verde parece ser mais que apenas um luxo e, consequentemente, o desenvolvimento do espaço verde deve ser alocado numa posição mais central em política de ordenamento do território.

\section{REFERÊNCIAS}

Anisimov, S. V., Mareev, E. A., \& Bakastov, S. S. (1999). On the generation and evolution of aeroelectric structures in the surface layer. Journal of Geophysical Research Atmospheres, 104(12), 14359-14367.

Batista, H. H. V., \& Noronha, A. P. P. (2018). Instrumentos de autorregulação emocional: uma revisão de literatura. Avaliação Psicológica, 17(3), 389-398.

Barton, J., \& Pretty, J. (2010). What is the best dose of nature and green exercise for improving mental health? A Multi-Study Analysis. Environmental Science and Technology, 44, 3947-3955.

Berman, M. G., Jonides, J., \& Kaplan, S. (2008). The cognitive benefits of interacting with nature. Psychological Science, 19(12), 1207-1212.

Berman, M. G. et al., (2012). Interacting with nature improves cognition and affect for individuals with depression, Journal of Affective Disorders, 140(3), 300-305. doi:10.1016/j.jad.2012.03.012 


\section{Desafios da psicologia no Brasil}

Beyer, K., Kaltenbach, A., Szabo, A., Bogar, S. Nieto, F. \& Malecki, K. (2014). Exposure to neighborhood green space and mental health: evidence from the survey of the health of Wisconsin. International Journal of Environmental Research and Public Health, 11(3), 3453-3472 DOI: 10.3390/ijerph110303453

Bowlby, J. (1984). Apego (Vol. 1, Trilogia Apego e Perda). São Paulo: Martins Fontes. (Obra original publicado em 1969).

Bowler, D., Buyung-Ali, L., Knight, T. \& Pullin, A. (2010). A systematic review of evidence for the added benefits to health of exposure to natural environments. BMC public health, 10, 456-.

Cervinka, R., Roderer, K., \& Hefler, E. (2012). Are nature lovers happy? On various indicators of wellbeing and connectedness with nature. Journal of Health Psychology, 17, 379-388.

Chamberlin, K., Smith, W., Appasani, A., Chirgwin, C. W., \& Rioux, P. T. (2014). Analysis of the charge exchange between the human body and ground: evaluation of "Earthing" from an electrical perspective, Journal of Chiropractic Medicine, 13 (4), 239-246.

Chang, C-Y., \& Chen, P-K. (2005). Human responses to window views and indoor plants in the workplace. HortiScience, 40, 1354-1359.

Chevalier, G. (2010). Changes in pulse rate, respiratory rate, blood oxygenation, perfusion index, skin conductance, and their variability induced during and after grounding human subjects for 40 minutes. Journal of Alternative and Complementary Medicine, 16(1), 1-7.

Chevalier, G., Sinatra, S. T., Oschman, J. L., \& Delany, R. M., (2013, November). Earthing (grounding) the human body reduces blood viscosity-a major factor in cardiovascular disease. The Journal Of Alternative And Complementary Medicine, 19, (2), 102-110.

Chevalier, G., Sinatra, S. T. (2011, July). Emotional stress, heart rate variability, grounding, and improved autonomic tone: clinical applications. Integrative Medicine, 10(3), 16-21.

Chevalier, G., Mori, K., \& Oschman, J. (2006). The effect of Earthing (grounding) on human physiology. European Biology and Bioelectromagnetics, 17, 600-621.

Clements, R. (2004). An investigation of the status of outdoor play. Contemporary Issues in Early Childhood, 5, 68-80.

Crawford, C., \& Krebs, D. (1997). Handbook of evolutionary psychology: ideas, issues and applications. New York, NY : LEA.

Davis, J. (2004). Psychological benefits of nature experiences: an outline of research and theory with special reference to transpersonal psychology. Boulder, CO: Naropa University and School of Lost Borders.

Dover, J. W. (2016). Green infrastructure: incorporating plants and enhancing biodiversity in buildings and urban environments. Journal of Insect Conservation, DOI: 20.10.1007/s10841-016-9887-5 


\section{Desafios da psicologia no Brasil}

Evensen, K. H., Raanaas, R. K., Hagerhall, C. M., Johansson, M., \& Patil, G.G. (2015). Restorative Elements at the Computer workstation: a comparison of live plants and inanimate objects with and without window view. Environment and Behavior, 47(3) DOI: 10.1177/0013916513499584

Fjeld, T. (2000). The effect of interior planting on health and discomfort among workers and school children. HortTechnology, 10, 46-52.

Franco, M. G. S. d'E. C., \& Santos, N. N. (2015). Desenvolvimento da compreensão emocional. Psicologia: Teoria e Pesquisa, 31 (3), 339-348.

Fuller, R. A., Irvine, K. N., Devine-Wright, P., Warren, P. H., \& Gaston, K. J. (2007). Psychological benefits of greenspace increase with biodiversity. Biology Letters, 3, 390-394.

Frost, J.L. (2010). A history of children's play and play environments: Toward a contemporary childsaving movement. A History of Children's Play and Play Environments: Toward a Contemporary ChildSaving Movement. New York, NY: Routledge,

Frumkin, H., Bratman, G. N., Breslow, S. J., Cochran, B., Kahn, P. H. Jr., Lawler, J. J., Levin, P. S., Tandon, P. S., ... Wood, S.A. (2017). Nature contact and human health: a research agenda. Environmental Health Perspectives, 125(7), 075001-1 - 075001-18. doi: 10.1289/EHP1663.

Gallagher, P., Fleeson, W., \& Hoyle, R. H. (2010). A self-regulatory mechanism for personality trait stability: Contra-trait effort. Social Psychological and Personality Science, 2, 335-342.

Gerlach-Spriggs, N., Kaufmann, R. E., \& Warner, S. B. (1998). Restorative gardens the healing landscape. New Haven, CT: Yale University Press.

Ghaly, M., \& Teplitz, D. (2004). The biologic effects of grounding the human body during sleep as measured by cortisol levels and subjective reporting. The Journal of Alternative and Complementary Medicine, 10(5), 767-776.

Grahn, P., \& Stigsdotter, U. A. (2003). Landscape planning and stress. Urban Forestry \& Urban Greening, 2, 1-18.

Gratz, K. L., \& Roemer, L. (2004). Multidimensional assessment of emotion regulation and dysregulation: development, factor structure, and initial validation of the Difficulties in Emotion Regulation Scale. Journal of Psychopathology and Behavioral Assessment, 26, 41-54.

Grinde, B. \& Patil, G. G. (2009). Biophilia: does visual contact with nature impact on health and wellbeing? International Journal of Environmental Research and Public Health, 6(9), 2332-2343. doi: 10.3390/ijerph6092332

Goenka, S. \& Andersen, L. B. (2016). Urban design and transport to promote healthy lives. The Lancelet, 388(10062), 2851-2853.

Gustavsson A, et al. 2012. Cost of disorders of the brain in Europe 2010. European Neuropsychopharmacology, 21, 655-679

Hartig, T. M., Evans, G. W., Jamner, L. D., Davis, D. S., \& Gärling, T. (2003). Tracking restoration in natural and urban field settings. Journal of Environmental Psychology, 23,109-123. 


\section{Desafios da psicologia no Brasil}

Hartig, T., Mang, M., \& Evans, G. W. (1991). Restorative effects of natural environment experiences. Environment and Behavior, 23, 3-26.

Health Council of the Netherlands, Dutch Advisory Council for research on Spatial Planning, Nature and the Environment. Nature and health. (2004). The influence of nature on social, psychological and physical well-being. The Hague, NE: Health Council of the Netherlands and RMNO.

Hoyle, R. H. (2006). Personality and self-regulation: trait and information-processing perspectives. Journal of Personality, 74 (6), 1507-1525.

Hoyle, R. H. (2010). Handbook of Personality and Self-Regulations. Oxford: Wiley.

Irons, W. (1998). Adaptively relevant environments versus the enviornment of evolutionary adaptedness. Evololutionary Anthropolology, 6, 194-204.

Izar, P. (2009). Ambiente de adaptação evolutiva. In E. Otta, \& M. E. Yamamoto (Ed.). Psicologia Evolucionista (pp. 22-32). Rio de Janeiro: Guanabara Koogan.

John, O. P., \& Gross, J. J. (2007). Individual differences in emotion regulation. In J. J. Gross (Ed.), Handbook of emotion regulation (pp. 351-72). New York, NY: The Guilford Press.

Kaplan, S. (1995). The restorative benefits of nature: toward an integrative framework. Journal of EnvironmentalPsychology, 15, 169-182.

Kaplan, R., \& Kaplan, S. (1989). The experience of nature: a psychological perspective. Cambridge, UK: Cambridge University Press.

Kellert, S.R., \& Wilson, E. O. (1993). The biophilia hypothesis. Washington, DC: Island Press.

Kinderman, P., Tai, S., Pontin, E., Schwannauer, M., Jarman, I., \& Lisboa, P. (2015). Causal and mediating factors for anxiety, depression and well-being. British Journal of Psychiatry, 206, 456-460

Korpela, K., \& Ylén, M. (2007). Perceived health is associated with visiting natural favorite places in the vicinity. Health Place, 13, 138-151.

Kuo, F. (2010). Parks and other green environments: essential components of a healthy human habitat. National Recreation and Park Association. Recuperado

de:http://www.nrpa.org/uploadedFiles/nrpa.org/Publications_and_Research/Research/ Papers/MingKuo-Research-Paper.pdf

Lewis, C. A. (1973). People-plant interaction: a new horticultural perspective. American Horticulturist, $52,18-25$.

Lohr, V. I., \& Pearson-Mims, C. H. (2000). Physical discomfort may be reduced in the presence of interior plants. HortTechnology, 10(1), 53-58.

Loram, A., Tratalos, J., Warren, P. H., \& Gaston, K. J. (2007). Urban domestic gardens (X): the extent and structure of the resource in five major cities. Landscape Ecology, 22, 601-615. 


\section{Desafios da psicologia no Brasil}

Maas, J., Verhejj, R., Groenewegen, P., Vries, S., \& Spreeuwenberg, P. (2006). Green space, urbanity, and health: how strong is the relation? Journal of Epidemiology and Community Health, 60, 587-592.

Mayer, F. S., Frantz, C. M., Bruehlman-Senecal, E., \& Dolliver, K. (2009). Why is nature beneficial? The role of connectedness to nature. Environment and Behavior, 41(5), 607-643. DOI: $10.1177 / 0013916508319745$

Mitchell, R., \& Popham, F. (2008). Effect of exposure to natural environment on health inequalities: an observational population study. Lancet, 372, 1655-1660.

Muraven, M., \& Baumeister, R. (2000). Self-Regulation and Depletion of Limited Resources: Does SelfControl Resemble a Muscle?. Psychological bulletin, 126, 247-59.

Nisbet, E., Zelenski, J., \& Murphy, S. (2011). Happiness is in our nature: exploring nature relatedness as a contributor to subjective well-being. Journal of Happiness Studies, 12, 303-322.

Olesen, J., Gustavsson. A., Svensson, M., Wittchen, H. U., \& Jonsson, B. (2012). The economic cost of brain disorders in Europe. European Journal of Neurology, 19, 155-162.

Oschman, J. L. (2008). Perspective: assume a spherical cow: the role of free or mobile electrons in bodywork, energetic and movement therapies. Journal of Bodywork and Movement Therapies, 12 (1), 40-57.

Oschman, J. L., Chevalier, G., \& Brown, R. (2015). The effects of grounding (earthing) on inflammation, the immune response, wound healing, and prevention and treatment of chronic inflammatory and autoimmune diseases. Journal of Inflammation Research, 8, 83-96.

Pergams, O. R. W., \& Zaradic, P. A. 2008. Evidence for a fundamental and pervasive shift away from nature-based recreation. Proceedings of the National Academy of Sciences, 105, 2295- 2300.

Pietilä, M., Neuvonen, M., Borodulin, K., Korpela, K., Tuija, S., \& Tyrvainen, L. (2015). Relationships between exposure to urban green spaces, physical activity and self-rated health. Journal of Outdoor Recreation and Tourism, 10, 44-54.

Pretty, J., Peacock, J., \& Hine, R. (2006). Green exercise: the benefits of activities in green places. Biologist, 53, 143-148.

Pinker, S. (2004). Tábula rasa: A negação contemporânea da natureza humana. São Paulo: Companhia das Letras. (Obra originalmente publicada em 2002).

Roe, J., \& Aspinall, P. (2011). The restorative benefits of walking in urban and rural settings in adults with good and poor mental health. Health and Place, 17, 103-113.

Rodrigues, M. M. P. (2009). Evolução humana. In E. Otta, \& M. E. Yamamoto (Eds.), Psicologia Evolucionista (pp. 33-53). Rio de Janeiro: Guanabara Koogan.

Ryan, R. M., Weinstein, N., Bernstein, J., Brown, K. W., Mistretta, L., \& Gagné, M. (2010). Vitalizing effects of being outdoors and in nature. Journal of Environmental Psychology, 30, 159-168.

Schaffer, H. (2004). Introducing child psychology. Singapore: Blackwell Publishing. 


\section{Desafios da psicologia no Brasil}

Shanahan, D., Bush, R., Gaston, K.. Lin, B.. Dean, J.. Barber, E. \& Fuller, R. (2016). Health Benefits from Nature Experiences Depend on Dose. Scientific Reports, 6, 28551. DOI : 10.1038/srep28551

Sokal, P., E., Jastrzębski, Z., Jaskulska, E., Sokal, K., Jastrzębska, M., Radzimiński, L., R., ... Zieliński, P. (2013). Differences in blood urea and creatinine concentrations in earthed and unearthed subjects during cycling exercise and recovery. Evidence-Based Complementary and Alternative Medicine, 382643.

Sokal, K., \& Sokal, P. (2011). Earthing the human body Influences physiologic processes. The Journal Of Alternative And Complementary Medicine, 17(4), 301-308.

Talbot, J. F., \& Kaplan, R. (1991). The benefits of nearby nature for elderly apartment residents. The International Journal of Aging and Human Development, 33, 119-130.

Takano, T., Nakamura, K., \& Watanabe, M. (2002). Urban residential environments and senior citizens' longevity in megacity areas. The importance of walkable green spaces. Journal of Epidemiology \& Community Health, 56, 913-18.

Taylor, A. F., \& Kuo, F. E. (2009). Children with attention deficits concentrate better after walk in the park. Journal of Attention Disorders, 12, 402-409.

Taylor, A. F., Kuo, F. E., \& Sullivan, W. C. (2001). Coping with ADD: the surprising connection to green play settings. Environment \& Behavior, 33(1), 54-77.

Tooby, J., \& Cosmides, L. (1990). The past explains the present: emotional adaptations and the structure of ancestral environments. Ethology and Sociobiology, 11, 375-424. DOI: 10.1016/01623095(90)90017-Z.

Townsend, M., \& Weerasuriya, R. (2010). Beyond blue tog green: the benefits of contact with nature for mental health and well-being. Burwood, AU: Deakin University.

Ulrich, R. F. Biophilia, Biophobia and Natural Landscapes. In: KELLERT, Stephen R., WILSON, Edward O. (Eds). The biophilia hypothesis. Island, Washington, D. C., 1993, p. 73-137.

Ulrich, R. F. (1984). View from a window may influence recovery from surgery. Science, 224, 420-421.

Ulrich, R., Simons, R., Losito, B., Fiorito, E., Miles, M., \& Zelson, M. (1991). Stress recovery during exposure to natural and urban environments. Journal of Environmental Psychology, 11 (3), 201-230.

Ulrich, R. \& Simons, R. \& Miles, M. (2003). Effects of environmental simulations and television on blood donor stress. Journal of Architectural and Planning Research, 20, 38-47.

De Vries, S, Verheij, R. A., Groenewegen, P. P., \& Spreeuwenberg, P. (2003). Natural environmentshealthy environments? An exploratory analysis of the relationship between green space and health. Environment and Planning, 35, 1717-1731.

Wells, N. M., \& Evans, G. W. (2003). Nearby nature - a buffer of life stress among rural children. Environment and Behavior, 35, 311-330.

Wilson, E.O. (1984). Biophilia. Cambridge, MA: Harvard University Press. 


\section{Desafios da psicologia no Brasil}

Williams, E. \& Heckman, S. (1993). The local diurnal variation of cloud electrification and the global diurnal variation of negative charge on the Earth. Journal of Geophysical Research, 98(3), 5221-5234. 


\section{Capítulo 30}

\section{PRÁTICAS NO SERVIÇO DE ATENÇÃO ÀS PESSOAS EM SITUAÇÃO DE VIOLÊNCIA NA REDE MUNICIPAL DE SAÚDE DE VITÓRIA/ES}

DOI: $10.37423 / 200200224$

Autor: Danielly Abreu Xavier- Psicóloga pela PUCIMG, Especialista em Saúde Coletiva/UFES, Mestre em Psicologia Institucional/UFES.

Co autores:

Leandra Mendes da Silva Barreto. Psicóloga pela FAESA/ES Maria José Capaż-Assistente Social pela UFES Rodrig o Barroso Araújo-Médico Pediatra pela FESO/RJ Thatiana Ferreira/Aquino- Assistente Social pela UFES Rosinere Magalhães- Auxiljar de enfermagem pelo Hospital Adventista Silvestre/RJ Vanusa Galacho- Técnica de enfermagem pelo/Lusiadas ES Clícia Dora Rocha da Silva- Enfermeira pela UFES Pryscila Therezinha-Scardua Onofre- Enfermeira pela UFES

RESUMO: Trata-se de estudo descoritivo e analítico baseado na experiência de um serviço de atenção às pessoas em situação dẹ violência da secretaria de saúde de Vittória/ES, que é realizado por equipe multi e interdisciplinar onde a psicologia vem construindo um càmpo que, se baseia numa clínica ampliada tendo a Política de Humanização como base norteadora de produção de cuidado. Nos últimos anos, a temática da violência foi aos poucos sendo incorporados à área da saúde públicàe vem ampliande seus espaços de discussão.

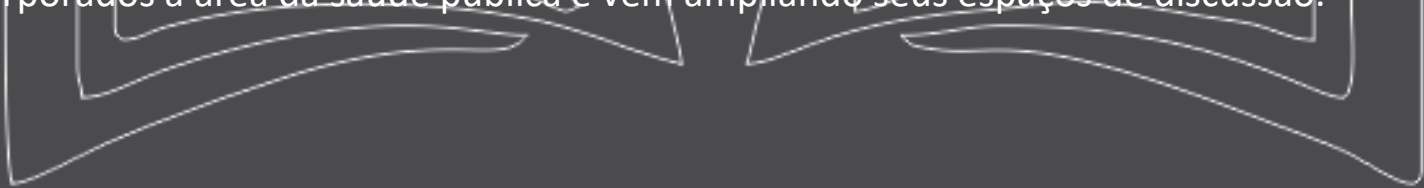




\section{Desafios da psicologia no Brasil}

Há que se destacar, porém que existem alguns desafios a serem superados pela incompreensão ou falta de informação sobre o tema através da formação profissional. Assim como, no que tange a atenção e cuidado às pessoas em situação de violência pressupondo o fortalecimento de redes de serviços que, toma como base o território como preconizado nas políticas públicas.

Palavras chaves: Violência; Políticas Públicas; Rede; Formação profissional; Humanização. 


\section{Desafios da psicologia no Brasil}

\section{INTRODUÇÃO}

A violência é um grave problema de saúde pública, que atinge indistintamente vários grupos sociais, instituições e faixas etárias da população. Diante dessa problemática, a Prefeitura Municipal de Vitória/ES implantou em maio de 2011 o Serviço de Atenção à Pessoas em Situação de Violência (SASVV), de média complexidade, a fim de oferecer cuidado em saúde às pessoas em situação de violência aos munícipes de Vitória/ES, por meio de ações de assistência, de prevenção, formação de profissionais e de pesquisa. O serviço foi instituído e baseia-se na Portaria no 485 de 01 de abril de 2014 do Ministério da Saúde - onde lê-se no art. 2o "O Serviço de Atenção às Pessoas em Situação de Violência Sexual no âmbito do SUS, que integra as redes intersetoriais de enfrentamento da violência contra mulheres, homens, crianças, adolescentes e pessoas idosas e tem como funções precípuas preservar a vida, ofertar atenção integral em saúde e fomentar o cuidado em rede, articulando e integrando as políticas públicas, a fim de propiciar o cuidado integral e garantia de direitos" (BRASIL, 2014).

No que se refere à atenção em saúde, a Política Nacional de Humanização (BRASIL, 2004) assegura a humanização como eixo norteador das práticas de atenção e gestão em todas as instâncias do SUS, sendo o referencial em que se baseia as práticas de cuidado do SASVV e suas interfaces com outras políticas específicas do Ministério da Saúde.

A política de enfrentamento às violências aos poucos vêm se constituindo tendo como marcos legais: a Política Nacional de Redução da Morbimortalidade por Acidentes e Violências (2001); Projeto de Redução da Morbimortalidade por Acidentes de Trânsito (2002); Rede Nacional de Núcleos de Prevenção de Violências e Promoção da Saúde (2004); Política Nacional de Promoção da Saúde (2006); Vigilância de Violências e Acidentes (VIVA) (2010); Projeto Vida no Trânsito (2010). E tem interfaces com outras políticas instituídas como: Política Nacional de Humanização (PNH) (2003); Política Nacional de Atenção Básica (2006); Linha de cuidado para a atenção integral à saúde de crianças, adolescentes e suas famílias em situação de violência (2010); Rede de Atenção Psicossocial (2011).

E de forma geral se articula a todas as outras Políticas Públicas para garantir a integralidade do cuidado (SUAS, Educação, Direitos Humanos, etc).

O município de Vitória/ES possui em sua rede municipal de saúde de atenção às pessoas em situação de violência: o Serviço de Atenção as Pessoas em Situação de Violência (SASVV); 29 Unidades de Saúde 


\section{Desafios da psicologia no Brasil}

( 12 Equipes sendo NASF) - que são gestora dos cuidados e deve monitorar os casos; 02 Pronto Atendimento; 02 Centro Municipal de Especialidades; serviços especializados de saúde mental ( 02 CAPS Adulto e 01 CAPS Infantil, 01 CAPS AD); serviço diagnóstico terapêutico (Laboratório; Imagem; Farmácia); Centro de Referência do Idoso/CRAI; 02 Equipes do Consultório na Rua. (VITÓRIA, 2018)

As notificação dos casos de violência são enviadas à vigilância epidemiológica do município pelos serviços da rede informados acima e por alguns dispositivos da secretaria de assistência social e dos direitos humanos, e hospitais privados localizados no município. A notificação se torna, então, uma importante ferramenta de prevenção e planejamento dessas políticas.

Assim, este é um estudo descritivo e analítico baseado na experiência de um serviço de atenção à pessoas em situação de violência do município de Vitória/ES.

O SASVV é composto por equipe multidisciplinar e interdisciplinar formada por psicólogas, médico, assistente social, enfermeira, técnica e auxiliar de enfermagem, e realiza desde atendimentos individuais e/ou familiar; capacita os profissionais da rede de saúde do município para o manejo clínico da Violência Sexual e intrafamiliar/ doméstica; colabora na organização da Rede de Atendimento as pessoas em situação de violência; realiza diagnóstico do contexto onde o episódio de violência se insere; articula e discute casos com demais profissionais dos serviços da Rede de Proteção intra e intersetorial, social e comunitária, de forma integrada; participa de espaços coletivos específicos da temática violência; desenvolve pesquisa junto às diferentes áreas de trabalho com objetivo de aprimorar a intervenção visando a produção de metodologias específicas para esta práxis. Realiza ainda, atendimento emergencial, para situações até 72 horas, com o estabelecimento de medidas de proteção (profilaxia das IST/HIV, contracepção de urgência) nos casos de violência sexual.

Uma das consequências da violência sexual é a gravidez indesejada ou forçada se configurando como uma segunda violência, intolerável para muitas mulheres. No que se refere aos direitos reprodutivos e sexuais, o SASVV atua com a realização de orientação, respeitando o direito da pessoa em ter controle e decisão sobre as questões relativas à sua sexualidade e reprodução, livre de coerção, discriminação e violência de acordo com as políticas públicas. Se necessário realiza o encaminhamento para a instituição responsável pela interrupção de gestação prevista em lei.

O público-alvo do serviço são crianças e adolescentes em situação de violação de direitos em decorrência de violência física, sexual, psicológica ou negligência crônica, e adultos exposto 


\section{Desafios da psicologia no Brasil}

a violência sexual, nos casos que extrapolam a capacidade de intervenção no território das equipes das Unidades Básicas de Saúde. De acordo com dados epidemiológicos, no ano de 2017, foram acolhidos 120 novos casos, sendo que destes, 86 (71,2 \%) eram do gênero feminino e 34 (28,8\%) do gênero masculino. Em 97\% são crianças e adolescentes sendo 57\% com idade entre 0 a 9 anos e 40\% adolescentes entre 10 e 19 anos. (VITÓRIA, 2017)

Nesse sentido, o papel do SASVV na formação e capacitação permanente de profissionais da rede é de extrema importância, buscando a sensibilização e engajamento dos diferentes atores sociais, visando desenvolver um atendimento de qualidade, que prima pelo acolhimento; atendimento humanizado, observados os princípios do respeito da dignidade da pessoa humana, da não discriminação, do sigilo e da privacidade; da escuta qualificada, propiciando ambiente de confiança e respeito; assim como informação prévia ao paciente, assegurada sua compreensão sobre o que será realizado em cada etapa do atendimento e a importância das condutas médicas, multiprofissionais e policiais, respeitada sua decisão sobre a realização de qualquer procedimento; conforme preconiza o artigo 5o da Portaria no 485, de 1ํ de abril de 2014 do Ministério da Saúde. (BRASIL, 2014)

\section{A ATUAÇÃO DA PSICOLOGIA NO SASVV}

As diretrizes e documentos das políticas específicas de atenção à violência no âmbito da saúde não são claras sobre as atribuições da psicologia. Considerando que o SASVV não atende apenas a violência Sexual. É partir da experiência do cotidiano, seguindo uma dimensão ético-política, as orientações do CFP, o estudo das políticas, documentos e normatizações, que temos, então, produzido nossa prática possível.

Ainda temos muitos desafios para não sermos capturados pelos processos normativos, modos de subjetivação e a judicialização que levam à revitimização.

A prática da psicologia não se restringe ao setting terapêutico. $O$ atendimento psicoterápico (individual e familiar) é realizado - escutar e acolher as dores, emoções e sofrimento psíquico vivenciados pelas pessoas que sofrem violência e/ou pais e responsáveis é importante para ressignificação e produção de vida, mas não é a única.

Atuação é na clínica ampliada, sendo essencial o trabalho interdisciplinar dentro do SASVV, além do diálogo com a rede, o Estado e sociedade.O acolhimento é interdisciplinar em duplas. Também há atendimentos compartilhados dentro SASVV e com equipes dos CAPS. 


\section{Desafios da psicologia no Brasil}

São realizadas atividade educativa- através de Roda de Conversa e Oficinas relacionados a temática e de produção de vida. São ações preventivas, educativas e de promoção à saúde.

Acompanhar psicologicamente as mulheres que optaram por não interromper a gestação proveniente da violência procurando integrar suas vivências emocionais, corporais e intrapessoais tem sido uma realidade.

Atuar junto à equipe no sentido de levá-las a identificar e compreender os fatores emocionais que intervém na saúde geral do indivíduo. Assim como, a importância de compreender o desenvolvimento psicossexual de crianças e adolescentes para diferenciar o comportamento típico das descobertas dos comportamentos atípicos que podem sinalizar suspeita de violência sexual e elaborar estratégias de enfrentamento.

Contribuir para o diagnóstico diferencial e, assim, a construção do plano de acompanhamento e, se necessário, o encaminhamento para os serviços de saúde mental.

A atuação da psicologia permite o enriquecimento dos diagnósticos (para além do enfoque orgânico, inclusive a percepção dos afetos produzidos nas relações clínicas) e a qualificação do diálogo (tanto entre os profissionais de saúde envolvidos no tratamento quanto destes com o usuário), de modo a possibilitar decisões compartilhadas e compromissadas com a autonomia e a saúde dos usuários do SUS.

Dentro desse contexto, a participação da psicologia é imprescindível na garantia do respeito a singularidade e processo de cada sujeito, na superação e ressignificação de suas vivências e, ruptura de ciclos e códigos de violências geracional na família buscando evitar revitimizações.

O trabalho nesse âmbito busca contribuir para a ampliação da discussão no campo da Saúde Coletiva e das Políticas Públicas com suas interfaces, sobretudo baseado em práticas de promoção, prevenção e a produção de cuidado, a partir de uma perspectiva interdisciplinar, de abrangência intersetorial e de acordo com os princípios da integralidade.

\section{CONSIDERAÇÕES FINAIS}

Como um fenômeno complexo e multifacetado, a violência exige uma compreensão e intervenção multi e interdisciplinares, e nos remete a atender suas famílias e/ou responsáveis, bem como efetivar 


\section{Desafios da psicologia no Brasil}

articulação com a educação, assistência social, órgãos de proteção e garantia de direitos, e também de responsabilização.

Ainda temos diversos desafios sendo alguns: Fortalecer o entendimento da Rede intra e intersetorial sobre o trabalho do SASVV e seu papel enquanto produção do cuidado em saúde diferentemente do papel policial e do judiciário.

Especificamente a psicologia recebe grande demanda de relatórios dos atendimentos por alguns órgãos policiais e do judiciário no que concerne se ocorreu a violência ou não.

Isso traz todo um investimento nos acolhimentos para descontruir esse pensamento e expectativa da família, e possibilitar um vínculo que já é muito complexo de ser construído.

Ter implantado um serviço especializado de atenção e cuidado às pessoas em situação de violência é um avanço para a efetivação da política no enfrentamento às violências e discriminações.

Nos últimos anos, a temática da violência foi aos poucos sendo incorporados à área da saúde pública e vem ampliando seus espaços de discussão. Há que se destacar, porém que existem alguns dos desafios a serem superados pela incompreensão ou falta de informação sobre o tema. A presença de estigmas e tabus, tanto nas famílias como nos profissionais, torna-se uma barreira para a prevenção e produção do cuidado, além de gerar subnotificação, dificultando o acesso, o manejo dos casos, e a construção e fortalecimento de políticas públicas (MINAYO, 2006)

Portanto, o SASVV visa defender as políticas públicas no que tange a atenção e cuidado às pessoas em situação de violência pressupondo o fortalecimento de redes de serviços que, tomando como base o território, articula saberes, práticas e políticas estabelecidas, pensa e viabiliza estratégias ampliadas de garantia de acesso, equidade e integralidade, como preconizado pelo referencial da humanização.

\section{REFERÊNCIAS BIBLIOGRÁFICA}

BRASIL. Linha de cuidado para a atenção integral à saúde de crianças, adolescentes e suas famílias em situação de violência: orientações para gestores e profissionais de saúde. Brasília: Ministério da Saúde. 2010.

. Ministério da Saúde. Portaria № 648 MS/GM, de 28 de março de 2006. Política Nacional de Atenção Básica. 4. ed. Brasília: Ministério da Saúde, 2007. 68p.

. Ministério da Saúde. Portaria № 687 MS/GM, de 30 de março de 2006. Política Nacional de Promoção da Saúde. Brasília: Ministério da Saúde, 2006. 60 p. 


\section{Desafios da psicologia no Brasil}

. Ministério da Saúde. Humaniza SUS: Política Nacional de Humanização: a humanização como eixo norteador das práticas de atenção e gestão em todas as instâncias do SUS. Brasília: Ministério da Saúde, 2004

- Ministério da Saúde. Portaria № 485 MS/GM, de 10 de abril de 2014. Redefine o funcionamento do Serviço de Atenção às Pessoas em Situação de Violência Sexual no âmbito do Sistema Único de Saúde (SUS). Brasília: Ministério da Saúde, 2014

BRASIL. Prefeitura Municipal De Vitoria. Fonte: RBE- Rede Bem Estar. 2017

CFP. Atribuições Profissionais do Psicólogo no Brasil- Brasília. 2008

https://site.cfp.org.br/wp-content/uploads/2008/08/atr_prof_psicologo.pdf

CFP. Código de Ètica Profissional- Brasília.2012

https://site.cfp.org.br/wp-content/uploads/2012/07/codigo_etica.pdf

MINAYO, M. C. de S. Violência e saúde. Rio de Janeiro: Editora Fiocruz, 2006. 


\section{Capítulo 31}

SAÚDE MENTAL NA UNIVERSIDADE: QUAIS OS ESTILOS DE

PENSAMENTOS DOS PROFESSORES?

DOI: $10.37423 / 200200225$

Andrisa Melo (Psicóloga, especialista em Saúde da Familia e Comunidade pela Universidade do Planalto Catarinense (UNIPLAC).

driadediesel@hotmail.com

Carolina Francielle Tonin (Psicóloga, Mestre em Saúde Mental e Atenção Psicossocial (UFSC), especialista em Saúde da Familia e Comunidade pela/Universidade do Planalto Catarinense (UNIPLAC).E-mail: carolf.tonin@gmail.com

Tatiane MunizBarbosa (Rsicóloga, Doutora em Saúde Colletiva (UFSC), docente do curso de Medicina UNIDA YII).

tatianemb.tmb@gmail.com

RESUMO: Com a reorientaçãa da atenção ẹm saúlde mental, os serviços sybstitutivos têm se dedicado à desinstitucionalização e às práticas mais humanizadas. Esta pesquisa investigou os estilos de pensamento dos professores de cursos de graduação em saúde de uma Universidade da região serrana de SC, sobre saúde mental em relação às políticas públicas do SUS. Tratou-se de um projeto de Iniciação à Pesquisá (Edital no 172/2011), financiado com recursos oriundos do Governo do Estado de Sd, através do Art. 170 da Constituição Estadual. O estudo, de caráter qualitativo, utilizou entreyista semi-estruturada, individual, gom nove docentes de Odontologia, Enfermagem, Psicol ogia, Servico Social e Medicina, profi\$sões contempladas nos-Programas de Residência oferecidos na Universidade.

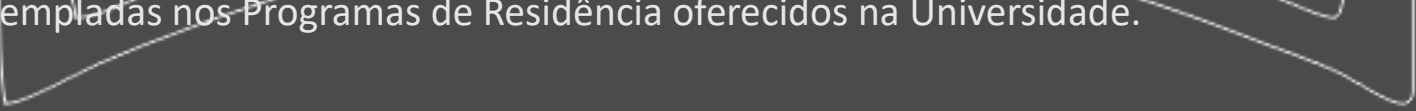




\section{Desafios da psicologia no Brasil}

Os dados, interpretados por análise de conteúdo temática, mostraram que os estilos de pensamento dos docentes apresentavam resquícios do modelo biomédico e hospitalocêntrico na assistência às pessoas com sofrimento psíquico, bem como a formação desses docentes também se apresentava nesta lógica. A temática de Saúde Mental não era abordada pelos pesquisados nos cursos em que lecionavam e pareciam se isentar da responsabilidade de construí-la com os acadêmicos. Assim, suscita-se a necessidade de reflexões e revisitações constantes aos estilos de pensamento dos docentes, pois estes apresentam influência evidente no pensar e no fazer dos futuros profissionais. Entende-se que é importante instigar os professores a falar sobre Saúde Mental para se construir práticas que "abracem" as necessidades de saúde da população. Assim, acredita-se que é possível alcançar meios para a efetivação de ações que superem a fragmentação no cuidado em saúde, com vistas a legitimar a Reforma Psiquiátrica no Brasil.

Palavras-chave: Saúde mental; formação profissional; estilos de pensamento; docentes. 


\section{Desafios da psicologia no Brasil}

\section{INTRODUÇÃO}

Por várias décadas, por todo o mundo, muitas pessoas em sofrimento psíquico tiveram suas vidas "arrancadas". Enquanto asiladas, não tinham voz e nem direitos, existiam distantes de suas famílias e rotinas, à medida que os hospitais psiquiátricos as controlavam e isolavam porque eram consideradas "ameaças" à sociedade.

No Brasil, a Saúde Mental enfrentou o tratamento da "loucura" a mesma maneira. Contudo, após a reorganização da assistência em Saúde Mental, por meio do movimento antimanicomial - Projeto de Lei Paulo Delgado que propôs a desinstitucionalização - e a instituição do Sistema Único de Saúde (SUS), em 1988, o tratamento do sofrimento psíquico passou a se pautar em princípios psicossociais, isto é, considerando o sujeito como um todo (ALVES; RIBAS; ALVES et.al 2009; CAMATTA; SCHNEIDER, 2009).

Apesar das transformações que vieram com a Reforma Psiquiátrica, principalmente, com a criação e execução dos serviços substitutivos; considera-se que é preciso uma continuidade nas transformações, não apenas legislativas. Mas nos estilos de pensamento sobre saúde mental dos usuários, familiares, profissionais e população em geral, para que se garanta o cuidado integral e resolutivo no modelo de atenção à Saúde Mental.

Apesar das mudanças, no compromisso social e no tratamento humanizado, parece haver ainda, mesmo que sob uma nova "roupagem", um exercício profissional de caráter assistencial e certa comodidade e dependência por parte dos usuários destes serviços substitutivos em saúde mental. Acredita-se que ainda exista hegemonia do modelo biomédico na formação e no desempenho dos profissionais em saúde.

Hirdes (2009), em pesquisa realizada em alguns serviços substitutivos, constatou que os profissionais de saúde apresentam ainda uma trajetória de formação profissional tradicional, desta forma, as ações permanecem norteadas por concepções coerentes com o modelo hegemônico, cujo objeto de trabalho é o indivíduo e sua doença. De certa forma, há resquícios de institucionalização nos novos serviços, sustentados por práticas que reproduzem a estigmatização e a medicalização da vida dos sujeitos.

Para que o cuidado em Saúde Mental seja consolidado, os profissionais em saúde requerem formações que acompanhem as políticas públicas e as necessidades em saúde das pessoas. Sobretudo porque o 


\section{Desafios da psicologia no Brasil}

movimento antimanicomial não pressupõe apenas a humanização do tratamento, mas a (re) construção de "outro lugar social" para a "loucura" (BIRMANN, 1992 apud AMORIM, 2003).

Dessa maneira, evidencia-se a relevância científica de uma investigação de como se tem concebido a saúde mental no contexto atual no SUS, tencionando a legitimação da Reforma Psiquiátrica. Até porque o aumento nos números dos serviços substitutivos é um dos principais indicadores de avanço da reforma, possibilitando a produção de novos modos de subjetivação e cuidados em saúde com os usuários.

Para que exista uma mudança eficaz e efetiva nessas políticas, os profissionais da área da saúde mental precisam revisitar suas concepções e reinventar suas práticas de saúde. Ou seja, acredita-se que o modo como os professores compreendem e constroem seus conhecimentos sobre a saúde mental, influencia na formação dos futuros profissionais de saúde. Pois, a partir do estilo de pensamento repassado ou construído pelos professores esta será reproduzida, futuramente, na prática profissional destes alunos.

Em vista disso, esse estudo investigou os estilos de pensamento de professores de cursos de graduação em saúde, de uma Universidade da região serrana de Santa Catarina, sobre a Saúde Mental em relação às políticas públicas do SUS.

\section{METODOLOGIA}

A pesquisa configurou-se como qualitativa, direcionando-se à compreensão do fenômeno atrelado às atitudes, crenças, motivações e significados da amostra estudada (Shmerling, Schattner e Piterman 1993 apud NOGUEIRA-MARTINS, 2001). O estudo foi financiado com recursos oriundos do Governo do Estado de SC, Iniciação à Pesquisa (Edital no 172/2011) através do Art. 170 da Constituição Estadual e realizado mediante o parecer de aprovação n0006 do Comitê de Ética em Pesquisa (CEP) da UNIPLAC.

A pesquisa foi realizada em uma Universidade da região serrana de Santa Catarina que contava, à época, com nove cursos de graduação na área da saúde. Selecionaram-se os cinco cursos, Odontologia, Enfermagem, Psicologia, Serviço Social e Medicina, em que as profissões eram contempladas nos Programas de Residência, modalidade de ensino em serviço financiado pelo Ministério da Saúde, da referida Universidade (Residência em Medicina de Família e Residência Multiprofissional em Saúde da Família). 


\section{Desafios da psicologia no Brasil}

Participaram da pesquisa nove docentes, os critérios de inclusão da amostra foram professores que atuavam há mais tempo na instituição e que atuavam há menos tempo, que obtinham formação profissional correspondente ao curso em que lecionavam e que estavam em atividades docentes durante o período da coleta de dados. Os participantes receberam, leram e assinaram o Termo de Consentimento Livre e Esclarecido, em duas vias, respeitando a Resolução 466/12 do Conselho Nacional de Saúde.

Para a coleta de dados foram realizadas entrevistas semiestruturadas (Laville e Dione, 1997), individuais e agendadas previamente na Universidade e em horários confortáveis aos participantes da pesquisa. O registro das entrevistas se deu através da gravação direta em áudio, pois, "a gravação permite contar com todo o material fornecido pelo informante, o que não ocorre com a utilização de anotações" (TRIVIÑOS, 1987 apud NOGUEIRA-MARTINS, 2001, p.53).

O tratamento dos dados se deu por meio da análise de conteúdo, com decomposição das respostas e construção de sete categorias de temáticas. De acordo com Minayo (2000), este método de análise consiste em descrever, analiticamente, os conteúdos que estão implícitos nas mensagens, interpretando e inferindo em conhecimentos relativos ao que está sendo investigado.

\section{RESULTADOS E DISCUSSÃO}

Os participantes entrevistados apresentavam idades entre 26 a 52 anos, sendo que sete deles eram do sexo feminino. Este dado indica que as mulheres ainda estão presentes nas profissões de cuidados à saúde. Como pontuam Barbosa, Wendhausen e Borda (2006), a profissão de professora é uma das profissões reconhecidas na história como sendo tipicamente feminina, além disso, as mulheres permanecem com papéis na sociedade associados à assistência às pessoas.

O tempo de serviço dos docentes apresentou diferença significativa, os docentes com mais tempo de atuação apresentavam de nove (9) a vinte sete (27) anos lecionando, enquanto os mais novos de dois (2) meses a sete (7) anos. Acredita-se que a diferença de idade e o tempo de atuação como docente têm relevância tanto no estilo de pensamento de cada professor, pensando que a formação apresenta uma média de vinte anos (20) de diferença, além da maneira como estes atuam como docentes ${ }^{1}$. 


\section{Desafios da psicologia no Brasil}

\section{ESTILOS DE PENSAMENTO: É POSSÍVEL FRAGMENTAR A SAÚDE?}

O estilo de pensamento, conceito desenvolvido por Ludwik Fleck (1896-1961), coloca-se como amplo e flexível, uma vez que está sujeito a mudanças temporais. Pode ser compreendido, simplificadamente, como aquilo que direciona o modo de ver e as ações das pessoas. Margulis (1997 apud DA ROS e DELIZOICOV, 2000) resume o conceito de estilo de pensamento "como sendo uma tribo profissional que fala uma linguagem comum, a tal ponto que, com certo número de palavras e pelas bandeiras que são defendidas, identifica-se um estilo de pensamento" (p.59).

Os estilos de pensamento dos docentes entrevistados acerca da saúde mental revelou que esses compreendem a saúde mental associada à saúde "geral", vinculada à qualidade de vida das pessoas e a um "equilíbrio" individual completo, envolvendo esferas biológicas, psicológicas, emocionais e sociais.

O conceito é um pouco parecido com o conceito de saúde em si, porque é o bem-estar. É o bem estar psíquico. Seria basicamente parecido mesmo, ter uma qualidade de vida. Estar em perfeito bem-estar (Violeta).

Acho que saúde mental é um equilíbrio, tanto fisiológico, quanto emocional e psicológico. Aonde você consegue ter uma homeostase de todos esses meios (Crisântemo).

As falas dos professores revelam que esses conceituam a saúde mental como bem-estar biopsicossocial, remetendo à qualidade de vida do sujeito. Contudo, acredita-se que a qualidade de vida vai além do bem-estar citado pelos mesmos, pois, refere-se a uma perspectiva individual. Ou seja, modifica de pessoa para pessoa, além de envolver várias dimensões, como habitação, inserção social, alimentação, amor, educação, lazer, cultura, liberdade, trabalho, entre outros.

O termo qualidade de vida também pode ser considerado polissêmico e humano, pois reflete a satisfação pessoal em todos os elementos considerados por uma sociedade "padrão" de conforto e de uma vida saudável, sem contar que é marcado por uma construção social. Pode-se considerar, então, que a qualidade de vida abrange necessidades humanas tanto fundamentais, materiais como espirituais (Minayo; Hartz; Buss, 2000).

Porém, as falas dos participantes ainda apresentam o conceito de saúde mental no qual o bem-estar está vinculado ao biológico e à ausência de doenças, desconsiderando as subjetividades. Mesmo que 


\section{Desafios da psicologia no Brasil}

se refiram aos aspectos psicológicos e sociais, o fazem num sentido reducionista. Assim, o estilo de pensamento dos professores parece estar pautado no conceito de saúde criado pela Organização Mundial de Saúde (OMS, 1948), oriundo no pós guerra e definido como "estado do mais completo bem-estar físico, mental e social e não apenas a ausência de enfermidade" (SCLIAR, 2007, p.36).

Essa conceituação tenta superar, como pontua Luz (2006 apud BATISTELLA, 2007), a visão negativa de saúde como mera ausência de doença, por outro lado recebe críticas por apresentar um caráter "inalcançável", uma vez que as pessoas não atingem ou permanecem em constante estado de bemestar. E ainda, como pontua Caponi (1997 apud BATISTELLA, 2007), gera práticas de controle e exclusão de tudo aquilo que for considerado indesejável ou perigoso, ou seja, a medicalização da vida.

Entretanto, quando os participantes mencionam qualidade de vida estão próximos do Conceito Ampliado de Saúde, acredita-se ser a mais próxima conceituação do que se vivencia, ou melhor, almeja-se em relação à saúde. O entendimento sobre saúde tem influências da época e suas transformações, do lugar, valores, da cultura, das condições socioeconômicas e política e de como cada pessoa a vive e representa. Ao que parece, os estilos de pensamentos desses professores acerca da saúde mental está transitando, uma vez que oscilam entre aspectos de conceito utópico da OMS e do conceito ampliado de saúde.

Afirma-se que o conhecimento está em constante movimento e dentro do coletivo de pensamento como afirma Fleck (1986 apud DA ROS, 2000) não pode existir um estilo de pensamento individual, há categorias vinculadas intimamente umas às outras - existem "matizes" de estilo de pensamento, pequenas diferenças que podem vir a ser novos estilos de pensamento e, consequentemente, novos coletivos de pensamentos. Pois, um dos motivos que conduz ao surgimento de outro estilo de pensamento é o tempo, assinala Fleck (1986 apud DA ROS, 2000) porque as teorias, normalmente, terão duas épocas, uma "clássica" onde há concordância geral e, uma segunda onde as "exceções", divergências e diferenças começam a fazer-se notar.

É este movimento que permite a ampliação do estilo de pensamento e possível transformação. Assim, o fato de os professores circularem entre os diferentes conceitos de saúde pode indicar uma possibilidade de revisitação do próprio estilo de pensamento, implicando num caminho para a legitimação da Reforma Psiquiátrica. 


\section{Desafios da psicologia no Brasil}

Ainda, pontuam Lancetti e Amarante (2012), ao se pensar sobre Saúde Mental vem à mente uma relação com campo de atuação onde os saberes se entrecruzam e, atrelado às variáveis de transformação ao longo dos anos, traz um caráter de complexidade, observado nas falas.

Eu entendo como uma política pública trabalha com as pessoas que têm transtorno mental. A saúde mental é um terreno desconhecido, a linha é muito tênue entre a pessoa tida como sã e a pessoa louca, a pessoa com transtorno mental, é um terreno desconhecido (Azaléia).

Ele tem um distúrbio psiquiátrico, mas, tem por que motivo? Pode ser que teve algum problema orgânico que acabou levando a um distúrbio da saúde mental. Se você tem um problema corporal, orgânico, somático que acabe te incomodando, isso cronicamente, você vai acabar tendo um distúrbio mental (Dente-De-Leão).

Ainda hoje na nossa sociedade é muito forte, falar em saúde mental a gente ta falando de quem tem doença mental, e isso tem que evoluir (Lírio).

Percebe-se que a complexidade do fenômeno saúde mental faz com que essa se restrinja a um campo de atuação que trata de pessoas com algum sofrimento psíquico, tornando-as classificações diagnósticas. Além disso, o entendimento de Saúde Mental como estudo da mente aponta carências desses estudos à medida que considera os meandros do organismo humano e do cérebro, o que pode indicar a tendência de valorização do discurso biomédico.

Como pontua Batistella (2007) devido à hegemonia do modelo biomédico, a saúde é entendida como não estar doente, desconsiderando que ausências de sinais e sintomas nem sempre indicam estar saudável. Em contrapartida, há pessoas que têm estes "sinais e sintomas" e consideram-se saudáveis. Apesar da Saúde Mental se apresentar dissociada da Saúde, acredita-se que essa dicotomia seja desnecessária, pois, como afirma Canguilhem (2006 apud BATISTELLA, 2007), a saúde é uma "margem de segurança" que cada pessoa possui e possibilita o enfrentamento de situações novas. Por isso, a própria doença faz parte da saúde, não o oposto e além disso, se trata de um conceito "vulgar", no sentido de comum e alcançável.

Sem contar que quando as pessoas recebem classificações diagnósticas, isto implica no modo como elas se constroem enquanto sujeitos. Afirma Caponi (2010) que essas "rotulações" modificam o modo de agir e de expressar emoções e sentimentos, além das pessoas deixarem suas "histórias em parênteses". Em tempos atuais tem acontecido uma epidemia de diagnósticos, destaca a autora, a 


\section{Desafios da psicologia no Brasil}

qual permite a todos iludirem-se com "frascos de felicidade" para livrar-se dos sofrimentos inerentes à condição humana.

Diante destas situações é que a transição para uma visão ampliada de saúde caminha morosamente, mas, acredita-se que isso tenha raízes na formação profissional pautada no modelo biomédico, que enfatiza o orgânico/anatômico, a causa-efeito, a fragmentação humana. Batistella (2007) expõe que o modelo biomédico é baseado na abordagem mecanicista onde fragmenta o corpo humano e estrutura um conhecimento especializado sobre cada função e disfunção orgânica e o parece conduzir a essa dissociação entre Saúde e Saúde Mental que direciona as falas dos professores para contradições.

Não, de jeito nenhum, porque são seres sociais completos, inteiros e complexos e, a saúde mental e a saúde estão intrinsecamente ligadas. Acredito que as manifestações fizeram com que tivesse esse recorte, mas, não que exista separação (Azaléia).

Acho que não tem como separar a saúde mental da saúde bucal, é um indivíduo, e se a pessoa ta com outro problema é tudo, tem que tá em conjunto, tanto que a gente tem que trabalhar o multi, a pessoa não vem aqui me deixa os dentes pra arrumar e depois vem buscar (Dália).

Os professores justificam a não fragmentação da saúde considerando que o ser humano é indissociável, deve ser visto de modo integral e as práticas em saúde devem partir do mesmo pressuposto. Ou seja, os profissionais de saúde e os professores têm que legitimar o que preconiza a política do SUS, principalmente, seus princípios de integralidade, equidade e universalidade. Assim, como pontua Serrano (et.al. 2004 apud BÜCHELE, et.al. 2006), a atenção integral (em saúde mental), deve propor um conjunto de dispositivos sanitários e socioculturais considerando todas as dimensões da vida do sujeito e os âmbitos de intervenção educativa, assistencial e de reabilitação.

O atendimento às pessoas deve ter características de humanização, pois, salientam Mielke e Kantorski (et. al. 2009), é considerada como estratégia no processo de produção de saúde, mas, para de fato ocorrer cuidado humanizado, faz-se preciso profissionais empáticos, afetivos, bem como condições de trabalho dignas. Amarante (2007 apud PATRIOTA et.al. 2010), afirma que a saúde mental, diz respeito, ao estado mental dos sujeitos, não apenas aquele "rotulado", envolve a coletividade, o modo de vida e faz-se preciso considerar o sujeito em sua totalidade, suas diferenças culturais, subjetivas. 


\section{Desafios da psicologia no Brasil}

\section{REFORMAR OU INOVAR? O SURGIMENTO DOS SERVIÇOS SUBSTITUTIVOS EM SAÚDE MENTAL}

Os docentes entrevistados consideram que a Reforma Psiquiátrica foi um avanço no tratamento e cuidado com portadores de sofrimento psíquico, onde as pessoas deixaram de ser enclausuradas e institucionalizadas, para serem inseridas no contexto social. Acreditam na importância dos serviços substitutivos, como serviços especializados em saúde mental, que promovem benefícios aos usuários e a sua inserção na sociedade, mesmo que estes precisem de melhorias e avanços.

Evitar ao máximo esse isolamento porque a internação institucionalizada ou hospital psiquiátrico, quanto mais forte ele se faz num processo de tratamento do paciente, doente mental, mais, ele isola esse indivíduo do contexto social e quanto mais isolado da realidade mais difícil de trazê-lo de volta a realidade. Acho que é uma evolução muito positiva... (Rosa)

Penso que no Brasil a gente vem crescendo enquanto serviço de atendimento à população. Antes se enclausuravam as pessoas que poderiam causar algum transtorno. Hoje as pessoas ganham a liberdade. (Bromélia)

Os professores acreditam na importância da evolução historicamente realizada pela Reforma Psiquiátrica, na diferenciação no modo como as pessoas com sofrimento psíquico eram vistas, em relação ao preconceito que existia, e maneiras de cuidado em que negavam o sujeito perante a sociedade. Assinalam que esse modo de ver as pessoas consideradas "loucas" perpassou anos, como também aponta Costa (2003) o louco foi massacrado durante anos, sendo o "hospício" o lugar com a função de segregar, punir e excluir da sociedade.

Os docentes acreditam que hoje os "doentes mentais" estão em liberdade, inseridos na sociedade, com uma melhor qualidade de vida, por meio da implantação dos serviços substitutivos. O objetivo da Reforma Psiquiátrica é a reinserção social, pois, visa potencializar a rede de relações do sujeito, criando um ambiente favorável para que aquele que sofre psiquicamente possa ter o suporte necessário para reinscrever-se no mundo como ator social (ALVES, ALVES e RIBAS et al. 2009).

A característica desses serviços substitutivos, além de reorganizar a rede de atenção em saúde mental, é desinstitucionalizar os sujeitos em sofrimento psíquico, oferecendo novas práticas sociais em saúde, através de programas multidisciplinares que visem o resgate dos elos familiares e, principalmente, a ressocialização, entendida como o direito à cidadania e às condições humanas de vida e tratamento (FERREIRA, 2007).Contudo, mesmo os docentes acreditando na importância e nos avanços dos 


\section{Desafios da psicologia no Brasil}

serviços em saúde mental, percebeu-se o desconhecimento de alguns acerca de quais são os serviços substitutivos, remetendo-se apenas aos Centros de Apoio Psicossocial (CAPS).

O serviço do CAPS, não conhecendo como ele funciona, a fundo, só de uma maneira mais de fora, mas, ele é um método de manter esse indivíduo inserido. Até porque, me corrija se eu estiver errada, no final do dia ele retorna pra sua casa. (Rosa)

O que eu conheço é o CAPS, eu não sei se trabalha ainda com isso, mas, até pouco tempo atrás eu tinha conhecimento do serviço. (Crisântemo)

O desconhecimento sobre os serviços substitutivos e sobre o trabalho dos profissionais nesses serviços faz refletir sobre as práticas dos docentes na formação dos profissionais de saúde. O desconhecimento das transformações e dos avanços que perpassam a saúde mental pode influenciar no modo como os estudantes dos cursos da saúde irão atuar, bem como nas práticas dos docentes em seus diversos ambientes de trabalho dentro do âmbito da saúde.

Assim, os serviços substitutivos, que formam a rede de atenção à saúde mental brasileira, parte integrante do SUS, são compostos, como afirmam Delgado et al. (2007), pelos Centros de Apoio Psicossocial (CAPS), em suas diferentes modalidades; Serviço de Residência Terapêutica (SRT); Centros de Convivência; Programa de Volta para Casa; Ambulatórios de Saúde Mental e Consultórios de Rua.

Estes dispositivos têm a característica de oferecer às pessoas espaços de sociabilidade e produção cultural com estratégias potencializadoras para emancipação e para efetivar o processo de reinserção social e desinstitucionalização. A maioria dos serviços substitutivos presta assistência às pessoas com diversos tipos de transtornos mentais por meio de atendimento individual ou grupal, orientação, atividades de sala de espera, educação em saúde, visitas domiciliares e atividades comunitárias. Tais serviços regulam a porta de entrada da rede de assistência em Saúde Mental (MINISTÉRIO DA SAÚDE, 2011; GARLA et.al 2010).

Esses serviços possuem equipes multidisciplinares, como enfermeiros, psicólogos, dentistas, médicos, técnicos, terapeutas ocupacionais e assistentes sociais, visando práticas de qualidade, que devem atuar de forma integral. Segundo as Diretrizes para um Modelo de Assistência Integral em Saúde Mental no Brasil (2006), deve-se fazer um trabalho em rede, contar com o princípio de integração num sistema integrado de referência e contra-referência no qual devem funcionar de forma harmônica, 


\section{Desafios da psicologia no Brasil}

complementando-se, sem se opor nem se sobrepor um ao outro, sem concorrência e nem competição entre si.

\section{A (FORM)AÇÃO EM SAÚDE MENTAL}

Percebe-se que a formação permanece com base no modelo hegemônico, caracterizado pela compartimentalização das disciplinas e focado em conteúdos e especialidades. Mesmo com as alterações que aconteceram nas Diretrizes Curriculares Nacionais dos cursos de graduação da área da saúde, acredita-se que qualquer processo de transformação é vagaroso e precisa de persistência e práticas que incitem mais mudanças.

Com a enfermagem eu trabalho uma área muito biológica, eu dou fisiologia e patologia. Então a gente fica muito aquém dessas questões de saúde mental (Rosa).

Pois é, enquanto professora essa não é a minha área de trabalho, eu não sou especialista na área da saúde. Eu não faço nenhuma fala superficial porque eu penso que a gente tem que ter muito respeito pela vida das pessoas (Bromélia).

Na parte da Odontologia, agora com a reestruturação curricular, eles têm mais a parte de Saúde Coletiva, saem mais da clínica, vem para a Unidade, têm mais esse contato. Eu acho que ainda falta, sabe? (Dália).

Nota-se que a educação superior apresenta-se de forma fragmentada, os entrevistados admitem que focam em suas especialidades e que não abordam a temática da Saúde Mental. Oscilam também entre a necessidade de uma mudança, nesta questão, ao mesmo tempo em que não vêem a necessidade de vincular seus assuntos a Saúde Mental indo de encontro ao que as Diretrizes Curriculares Nacionais preconizam, isto é, formar profissionais com perfis generalistas, atuantes nos vários níveis de atenção à saúde e capacitados para promover a saúde integral do sujeito (RONCA et.al 2008).

Porém, não se pode desconsiderar que esta maneira de se organizar em disciplinas, consequentemente em especialidades, tem relação com a época e as situações que aconteceram. A educação superior em saúde no Brasil apresentava-se como uma formação prática em laboratórios e serviços para saúde, junto a profissionais experientes, assim, adquiriram-se os conhecimentos específicos e necessários para atuação em determinada área. Além do fato, que durante vários anos, 


\section{Desafios da psicologia no Brasil}

os jovens brasileiros tinham o costume de ir ao exterior realizar suas formações superiores (Carvalho e Ceccim, 2008).

Com o "crescimento" da saúde pública brasileira surgiram discussões as quais apontaram relevâncias para alterar este método até então utilizado para formação de profissionais em saúde, sendo apenas em 1940 a regulamentação e cientificidade das formações superiores (Carvalho e Ceccim, 2008). Foi neste momento em que foi introduzido no Brasil, nas universidades, o Relatório Flexner que traz considerações acerca da educação médica estadunidense, elaborado por Abraham Flexner (1866 1959) e publicado em 1908, e que explicar o porquê das disciplinas fragmentadas, das especificidades e do entendimento da saúde como ausência de doença.

O Relatório teria base biológica, seria orientada pela especialização e pela pesquisa experimental e estaria centrada no hospital. Essa educação científica em saúde foi adquirindo um caráter instrumental e de habilitação para fazeres profissionais recortados em ocupações, fragmentados em especialidades e centrados nas evidências de adoecimento (...) (CARVALHO E CECCIM, 2008, p.5

Isto é, a partir desta reestruturação surgiu uma educação com conteúdos específicos e disciplinas fragmentadas em detrimento de uma matriz integrativa. É interessante observar que os entrevistados trazem um comparativo acerca da sua formação, sinalizando que existem diferenças significativas em relação ao período em que se formaram e o atual, destacando que hoje as práticas talvez não estejam condizentes com as "leis", mas, já sofreram mudanças significativas.

Acho que as pessoas que estão entrando nesses serviços (substitutivos) são pessoas novas que foram formadas a partir de outra lógica. Não a lógica que eu fui formada, de hospital psiquiátrico, onde as pessoas eram presas e amarradas. Vocês estão sendo formados na lógica do SUS, na lógica da rede, na lógica da referência e contra-referência, na lógica da assistência integral (Orquídea).

Estamos tendo um avanço muito grande depois da reforma sanitária e ainda temos muitos desafios pela frente. Hoje tem o CAPS, tem a questão da reforma trazendo o conceito de integralidade no cuidado e muitos profissionais tentando superar esse modelo. Até porque, fomos formados pelo modelo anterior, que é a medicalização e hospitalização (Lírio).

Essa diferença da parte social, psicossocial que os alunos têm em cima dos problemas que os pacientes têm, não atende esse paciente e relaciona a uma doença. Eu não tive nenhum contato assim. Mas, eles têm entendido bem, vi bastante nesses dois, três meses dando aula. (Dente-De-Leão). 


\section{Desafios da psicologia no Brasil}

Há docentes que vêm de uma formação anterior a Reforma Psiquiátrica, isto é, os pacientes que apresentavam algum sofrimento psíquico eram institucionalizados, as intervenções realizadas, torturas, altas dosagens de medicamentos, procedimentos técnicos (eletroconvulsoterapia, lobotomia, etc.) feriam os direitos humanos destas pessoas, mas, permaneciam como técnicas de tratamento mais "adequadas". Assinalam Carvalho e Ceccim (2008), na representação clássica da atuação profissional e da terapêutica utilizada, consideravam-se apenas as técnicas medicamentosas e eletrônicas interferindo no corpo biológico como se o processo saúde-doença fosse isolado da vida de cada sujeito quando deveria transcender a isso.

Os entrevistados pontuam que em suas experiências como docentes ocorre um processo inverso. Pois, salientam que os acadêmicos têm recebido uma formação condizente com a lógica do SUS e das Diretrizes Curriculares, ou seja, profissionais generalistas, trabalhando em equipe, com responsabilidade social, priorizando atenção à saúde com qualidade.

Diante desta situação, surge outro questionamento, o que é feito em relação aos professores que atuam nestas formações atuais, mas, formados em outra lógica? Como pontuam Ferronato e Garcia (2009), responder às DCNs e ao SUS exige muito mais do docente em relação a sua capacitação continuada. Desta forma, serão revistas tanto suas práticas enquanto docentes, bem como profissionais da saúde, pois, no momento em que sinalizam dúvidas e desconhecimentos acerca do sistema de saúde isso pode indicar que não têm conseguido atuar na lógica idealizada/pretendida.

\section{SER PROFESSOR: PROCESSO DE ENSINO-APRENDIZAGEM}

Os professores relatam como têm transmitido aos acadêmicos conhecimentos acerca da Saúde Mental, salientam que este conhecimento deve ser construído e não apenas repassado ou imposto, acreditam que o aluno é tão responsável quanto o docente neste processo de ensino-aprendizagem.

Colocar uma aula expositiva, falar o que eu penso e determinar aquilo, isso não é uma prática fidedigna que vai ensinar. Acredito que compilando todas as falas de todos os acadêmicos, as leituras, isso é imprescindível na nossa formação. Então, fazendo uma sistematização de tudo o que a gente viu ali em aula e do que já foi visto em prática, acredito que isso faça com que tenha um aprendizado de forma que qualifique a formação profissional. (Violeta)

Procuro desmistificar pra eles as questões das diferenças e ir contra a maré da sociedade que quer padronizar, que quer fazer com que as pessoas sejam sempre assim e assado, tem a ditadura da beleza, 


\section{Desafios da psicologia no Brasil}

tem a competitividade. Então, o sistema desfavorece a compreensão da diversidade e falar sobre Saúde Mental é falar sobre diversidade (Azaléia).

Constata-se que os docentes não acreditam em uma prática repetitiva de conteúdos, onde o saber é dominado pelo docente enquanto o acadêmico o memoriza, sem discutir e refletir acerca daquilo que está sendo "ensinado". Tornando-se, desta maneira, uma prática não legítima e que não traz resultados apropriados para aquilo que uma universidade se propõe. Pontua Anastasiou (2006, p.148), "como instituição social construída, coletivamente a partir de um projeto institucional coletivo e vinculada às questões regionais e universais", ou seja, não estaria formando sujeitos críticos e com responsabilidade social.

É interessante observar que os professores apresentaram não ter conhecimentos específicos sobre Saúde Mental, pois, não se tratava da área de atuação enquanto docente (disciplina) ou especialidade em sua área "geral". Contudo, quando relatam como são suas práticas docentes demonstram que poderiam (trans)formar seus conhecimentos sobre a temática em questão, unindo seus conhecimentos específicos ao assunto que eles mesmos consideram relevantes aos acadêmicos. Diante destas colocações, Schön e Alarcão (2000; 2001 apud ISAIA, 2006) propõem que o professor precisa ser reflexivo durante a "ação educativa" e sobre a mesma, assim, poderá reformular suas atividades docentes, pois, este exercício de reflexão faz parte do próprio processo de formação e desenvolvimento profissional.

Destaca-se que ensinar não deve ser reduzido ao ato de repassar conteúdos, mas, entendido como um processo de organização de saberes e fazeres daquilo que se conhece. É oferecer apoio aos alunos para que juntos possam construir as suas próprias estratégias de apropriação em direção a autonomia formativa. Afinal, a aula universitária é um espaço onde o aluno precisa compreender seu campo de atuação e tornar-se capaz de aplicá-lo, por isso, a mera recepção de conhecimentos fragmentados torna-se inviável (ISAIA, 2006).

Além do mais, para a construção das competências e habilidades enquanto futuros profissionais, os acadêmicos, de acordo com o que os professores trazem nas entrevistas, precisam dominar conhecimentos teóricos e práticos. As DCNs trazem que "fortalecer a articulação da teoria com a prática, valorizando a pesquisa individual e coletiva, assim como os estágios e a participação em atividades de extensão" (RONCA el.al. 2008, p.6). 


\section{Desafios da psicologia no Brasil}

Problematizaria com ele (aluno) a importância de estudar sobre esse assunto, se ele entender que é importante, ele tem que ir atrás. De qualquer forma a gente discute muito isso nas disciplinas de estágio, uma vez que nós não dominamos, nós procuramos quem sabe (Bromélia).

Acho que toda construção de conhecimento não pode ser só teórica, tem que olhar primeiro a realidade que você está inserido. Então, ter esse entendimento, correlacionar a Saúde mental, uma construção de conhecimento acerca dela, relacionada à docência na Enfermagem, inevitavelmente o aluno tem que conhecer a realidade onde ele vai se inserir (...) (Rosa).

Esse conhecimento é construído a partir das problematizações, ainda que sejam um recurso pedagógico, mas, quando a gente chega com um problema, com uma questão que a gente possa refletir, discutir, encaminhar para uma prática, que a gente possa colocar muitas perguntas e menos respostas (...) não é aquilo que o professor sabe, é aquilo que o professor sabe e se une ao saber è̀s experiências dos alunos. Tudo isso se confronta, se consolida em teoria, mas, quando vão para as práticas nos estágios é a possibilidade de vivenciarem os conceitos e teorias que tiveram em sala de aula (...) (Orquídea).

A Constituição Nacional (Art. 200) e a Lei Orgânica da Saúde (1990, art. 6ọ) que "ao sistema único de saúde compete, além de outras atribuições, nos termos da lei (...) ordenar a formação de recursos humanos na área de saúde (...)" (CECCIM, ARMANI E ROCHA, 2002, p.374). Explicam Ceccim e Feuerwerker (2004) que estes recursos humanos, "asseveram" que a política para os trabalhadores da área deve cumprir o objetivo de organizar um sistema de formação em todos os níveis de ensino. É neste momento que o sistema educacional, integrado ao da saúde, é incumbido de formar profissionais na área da saúde. Sendo função do SUS e das instituições formadoras, constatar, analisar e interpretar informações da realidade com intenção de construir práticas com orientação social e participação ativa de todos os professores, além de usuários dos serviços de saúde como os estudantes (CECCIM; FEUERWERKER, 2004). Ou seja, é durante a graduação que os (futuros) profissionais apropriam-se do entendimento de que se faz preciso desenvolver práticas que proporcionem um atendimento às necessidades de saúde da população.

Ceccim e Feuerwerker (2004) salientam que a formação trata de uma "tarefa" socialmente necessária, que apresenta compromissos ético-políticos com a sociedade. Desta forma, necessita reinventar-se à medida que a sociedade se transforma, proporcionando "autonomia e atender a interesses coletivos e à construção de novidade em saberes e em práticas" (p.49). Aqueles que formam para saúde não 


\section{Desafios da psicologia no Brasil}

devem preocupar-se apenas com preenchimento de vagas de trabalho, mas, formar profissionais que entendam que escuta e interação com o usuário são práticas indispensáveis para um atendimento de qualidade.

Percebe-se que os professores entrevistados valorizam o fato dos alunos aprenderem e aplicarem as teorias e práticas, além de construírem uma autonomia "intelectual" para irem à busca de conhecimentos dos assuntos que lhes interessam. Mas, nota-se que os docentes têm uma parcela de influência nesta busca quando "semeiam" alguns assuntos. Isaia (2006) coloca que o professor, além do saber e do saber-fazer, precisa ajudar o aluno a construir o conhecimento para aplicar na atuação profissional. Aproximando-se do que coloca Paulo Freire sobre este processo que o aluno precisa ser estimulado a buscar conhecimento. Entretanto, destaca que o aprendiz precisa querer aprender, precisa perceber a necessidade e a importância disso, por isso o docente universitário tem a importante função de propiciar a percepção da necessidade de aprender (SILVA, 2007 apud TESSMANN, GARCIA, 2007).

Para existir esta articulação entre os saberes dos professores e dos alunos e a busca por aprimorar estes conhecimentos é que as matrizes curriculares dos cursos de graduação oportunizam estágios e pesquisas. Não com a intenção de fazer apenas descobertas durante a graduação, mas, como salienta Anastasiou (2006), para desenvolver junto do aluno hábitos de estudo, de debruçar-se sobre um assunto com intuito de esgotá-lo dentro daquilo que se propôs num coletivo ou não. E para possibilitar ao aluno práticas de estudo "independente" para construção progressiva da "autonomia intelectual" e profissional, principalmente, porque as experiências adquiridas nesses espaços são relevantes para a área de formação.

Através destas ferramentas de ensino-aprendizagem é possível que os acadêmicos desenvolvam também suas responsabilidades, pois, articulam teoria e prática, mas, como salienta um dos professores, o acadêmico ao interessar-se precisa buscar meios que satisfaçam suas dúvidas em relação ao conhecimento. De acordo com Silva (2007 apud TESSMANN; GARCIA, 2007), o contexto no qual vivemos exige que o acadêmico seja sujeito-autor, crítico, autônomo e interventor, isto é, a partir da análise de suas vivências seja capaz de alterar sua realidade, retirando-se da condição acomodação para consciente do seu fazer.

Por vários anos os parâmetros curriculares estavam baseados no relatório de Flexner, mas com a implementação das DCNs exigem-se profissionais autônomos em sua formação para que assim, os 


\section{Desafios da psicologia no Brasil}

(futuros) profissionais percebam os "problemas" do mundo e, consequentemente, desenvolvam práticas condizentes com o SUS (MITRE, SIQUEIRA-BATISTA et.al. 2008).

Porém, como salienta Souza (1999 apud DA ROS, 2000) o modelo flexneriano permanece sendo reproduzido em muitos espaços de formação enquanto a proposta integradora ainda está restrita a um grupo pequeno de profissionais. Mudanças em nosso cotidiano e na formação em saúde dependem "da flexibilidade dos atores sociais envolvidos, na perspectiva de construção da saúde da população como norte unificador do trabalho, respeitando as especificidades profissionais e estilos de pensamento diferentes" (DA ROS, 2000, p.189).

\section{“EDUCAR" PROFISSIONAIS DE SAÚDE: INFLUÊNCIAS DA FORMAÇÃO NA PRÁTICA}

Visualiza-se que os docentes percebem que a formação em saúde tem refletido na prática profissional, mas, não são todos que acreditam ter uma parcela de responsabilidade na construção deste conhecimento. Percebem que a formação é "falha" e que os acadêmicos saem com desconhecimento de "temas" relevantes para a prática, com o é o caso da Saúde Mental, mas, parecem se isentar de alterar esta realidade.

Se esse futuro profissional não tiver esse entendimento da Saúde Mental como um todo, primeiro seu conceito e depois de tudo que abrange dessa temática, ele não vai conseguir executar suas ações adequadamente, esse processo de educação já tem que sair dos bancos escolares, tem que sair da graduação. A gente não pode cair lá pra trabalhar e daí descobrir na unidade de saúde como é que funciona, o que é que tem e o que não tem (Rosa)

Como a gente não discute muito isso, é muito vago responder algo que a gente não discute. A minha percepção é que eles não têm entendimento nenhum em relação à saúde mental (Crisântemo).

A gente não dá conta, nem do que é o SUS. A Medicina tem uma inserção do primeiro ao último ano na atenção primária, e eu pego os estudantes no quinto e sexto ano e mais os professores. $E$ se pergunta: ele ficou esse tempo todo na unidade de saúde e qual a concepção de SUS? Têm uns que não sabem nem o que é. Então, o que é que aconteceu nesses anos que ele não deu conta de construir? Não estimularam ainda essa construção do que é o SUS? (Lírio).

Os docentes percebem que seus alunos desconhecem a temática de Saúde Mental e o SUS, o que torna preocupante, uma vez que serão os futuros profissionais dos serviços de saúde. O porquê isso 


\section{Desafios da psicologia no Brasil}

ocorre, os professores não mencionaram, mas, observa-se que a universidade direciona e possibilita uma articulação da graduação com o SUS, há cursos da área da saúde em constante contato com essa prática integradora, humanizada, universal, exemplificado por uma das docentes, sobre o curso de Medicina. Assim, questiona-se: o que pode estar travando ou barrando o conhecimento e a prática?

Supõe-se que o que pode influenciar neste "desconhecimento" é que o SUS não é atrativo como profissão, o salário é "baixo", os recursos materiais são escassos, rotatividade profissional e publicidade de que é algo que não funciona. assim, o setor particular torna-se mais sedutor, mas, como pontuam Ceccim e Armani (et.al. 2008) é no setor público que se adquire uma gama de conhecimento e prestígio da população. É durante a graduação que critérios e valores são construídos como perfil ao exercício da profissão. Assim, como esse conhecimento de uma mudança no País provocada por um coletivo, lutando por direitos comuns, tem sido passado adiante? Uma ou duas disciplinas não dão conta de abranger toda a história de transformação do sistema de saúde brasileiro e nem a implementação do SUS.

Faz-se preciso se preocupar com gerações novas de profissionais capacitados para atingir a qualidade de vida das populações, o profissional de saúde não pode ter em vista sua "projeção técnica" apenas, sem intenção de assistir ao outro em suas necessidades e ter uma relação ética com a vida (Carvalho e Ceccim, 2008).

Dentre os entrevistados, apenas um demonstrou isentar-se da responsabilidade de revisitar seus estilos de pensamento. Explica Parreiras (2006) o "sistema de opiniões" batalha incessantemente para permanecer (fase clássica), veem-se somente fatos delimitados, aqueles que se encaixam no estilo de pensamento que predomina, assim, perde-se a capacidade de ver outra coisa que contradiga tal estilo, contudo, esta postura "inflexível" pode afetar significativamente os formandos.

Tem que estar trabalhando nisso todos os dias. Eu acho que tô em falta porque até mesmo eu não sei se eu estaria preparada para passar e acaba prejudicando porque os alunos irão sair sem saber, sem poder aprofundar mais (Dália).

Na enfermagem tem a disciplina específica de Psiquiatria na Comunidade e a disciplina que eu dou não tem nada relacionado, não me sinto responsável. Talvez se eu trabalhasse disciplinas que tivessem na prática, tipo Saúde Coletiva [...] não que eu me isente destas responsabilidades (Rosa). 


\section{Desafios da psicologia no Brasil}

Responsabilidade, a gente tem uma parcela de culpa em tudo. Em função de que a gente ajuda na construção de currículo, construir a formação. A gente transmite mais a experiência como docente, como pessoa, do indivíduo como um todo. Porque eu estou ajudando a formar um profissional da saúde (Crisântemo).

Outros professores sinalizaram se sentirem responsáveis diante do ensino acerca da Saúde Mental na graduação, o que é de grande relevância porque indica certa sensibilização para mudança. Veiga (2006) faz referências a como um docente universitário deve pautar sua prática de ensino além dos moldes formativos convencionais: ter vasto conhecimento sobre determinado assunto e saber como transmiti-lo. A docência universitária exige produção e socialização do conhecimento, atividades reflexivas e problematizadoras do futuro profissional, precisa de pluralidade metodológica para articular projetos de pesquisa e intervenção, bem como indissociabilidade entre ensino, pesquisa e extensão.

Como salientam Pimenta e Anastasiou (2002 apud PACHANE, 2006), a docência na universidade configura-se como um processo contínuo de construção da identidade e essa construção sucessiva acontece quando o professor se atualiza, com práticas novas, pois, isto afetará o acadêmico que será instigado a seguir o "ritmo" de construção de conhecimento.

Fleck (2010) afirma que os estilos de pensamento tendem à "persistência", diante de qualquer contradição "resistirão" à mudança. Mas, há possibilidade de mudanças nos estilos de pensamento, uma vez que, o docente, por exemplo, pertence a um coletivo específico de pensamento, mas, faz parte de um coletivo universal de pensamento e, ainda, de outros científicos e não científicos. Estes estilos de pensamento interagem entre si, constantemente, esse contato pode provocar mudanças, pois, "qualquer tráfego intercoletivo de pensamento traz consigo um deslocamento ou alterações dos valores de pensamento" (FLECK, 2010 p.28).

Supõe-se, que os docentes universitários por terem acompanhado mudanças em sua trajetória enquanto acadêmicos e enquanto professores, em relação ao SUS e a uma metodologia de ensino neste mesmo compasso, têm provocado "deslocamentos" nos seus estilos de pensamentos. Da mesma forma que foram "influenciados" e entenderam a mudança podem provocar isso nos acadêmicos dos cursos de saúde. 


\section{Desafios da psicologia no Brasil}

\section{SISTEMA ÚNICO DE SAÚDE - SUS (CESSO)}

Os docentes acreditam que as fragilidades do SUS influenciam no tratamento e cuidados dos pacientes portadores de sofrimento psíquico e na reintegração destes à sociedade. Afirmam que muitas pessoas ainda não têm o acesso aos serviços de saúde, bem como os serviços especializados em saúde mental, tendo como causas a falta de informação, o preconceito ou condições financeiras precárias.

Cresceu muito enquanto serviço de atendimento a população, mas as famílias não têm acesso, às vezes até conhecem, mas não tem acesso financeiro porque os programas e serviços públicos são limitados. Não se torna universal, não é todo mundo que tem acesso Está trabalhando com a coisa da emergência, com fila (Bromélia).

Há uma falha no sistema. Não vejo direcionamento para a parte da Psicologia, vejo mais na parte da Psiquiatria, não sei te apontar quais são as falhas, mas acho que é a própria parte psicossocial de reintegração do indivíduo na sociedade, não vi isso ainda. (Crisântemo)

O papel da sociedade seria fundamental para que fosse efetivado plenamente, mas, para que isso aconteça, esta tem que estar politizada para exigir e fiscalizar e se sintir sujeito de direito. Acredito que na saúde a gente tem um tratamento de benemerência, de favor, as pessoas temem em exigir coisas (Azaléia)

Os docentes acreditam que ainda há dificuldade no acesso aos serviços de saúde pelas famílias e pessoas com sofrimento psíquico, seja pela falta de vagas, o crescimento da demanda e a demora em se obter uma consulta, considerando o sistema de saúde um "caos". Percebe-se que, mesmo com os avanços, após a Constituição Federal, onde se estabelece a saúde como um direito e dever do Estado, o SUS ainda é visto como algo que não deu certo, com deficiências em seu modo de funcionamento.

Prevalece a concepção de que o SUS é somente para "pobres", a qual, por vezes, a mídia fortalece provocando nas pessoas representações negativas sobre o SUS, não a partir de suas vivências e sim, daquilo que se escutou falar e se viu (OLIVEIRA et al., 2011). Ainda, a participação da sociedade no processo de consolidação e melhorias dos serviços de saúde é essencial e fundamental, contudo, as pessoas demonstram medo de exigir seus direitos e melhorias no tratamento dos serviços de saúde. 


\section{Desafios da psicologia no Brasil}

Entretanto, existem algumas pessoas que divergem destas visões negativas quanto ao sistema de saúde brasileiro, contudo, a satisfação destes usuários não é conhecida e nem reproduzida pela mídia. Castro et al. (2008), aponta que diversas pesquisas mostraram a importância do conhecimento da perspectiva sobre a satisfação do usuário, comprovando-se que há relação direta entre usuários satisfeitos e maior adesão ao tratamento. Mesmo com as carências reconhecidas, é relevante que os usuários reconheçam e utilizem o SUS.

A sociedade brasileira é democrática e, como pontuam Martins e Cotta (et.al 2008), a cidadania consiste no direito das pessoas terem autonomia nas decisões, nos direitos e qualidade de vida. Porém, após algumas reformulações e movimentos populares, parece que o País (e o povo) paralisou. Supõe que o Brasil se submeteu a agentes econômicos internacionais, a globalização mundial, entre outros motivos.

Acredita-se que as pessoas não têm acesso à informações e estímulo para reconhecerem-se como atores sociais capazes de ressignificar e modificar a realidade do SUS e aquilo que se conhece do mesmo, no sentido, de desmistificar esse caráter de sistema falido. Para isso, faz-se relevante os profissionais da saúde promoverem ações que objetivem o empowerment (empoderamento) - termo compreendido como promoção aos sujeitos a adquirirem habilidades e capacidades para tornarem-se autônomos diante das transformações de suas vidas. A partir disso, salientam Martins e Cotta (2008), a população adquire maior controle sobre as decisões e ações que afetam sua saúde e sua própria existência.

Além de mencionarem as fragilidades dos serviços de saúde, os docentes acreditam que os princípios e diretrizes do SUS não são efetivados nos serviços de saúde mental, mesmo com os avanços do SUS e a implantação da Reforma Psiquiátrica.

Não conseguimos visualizar todos os preceitos do SUS na saúde mental, integralidade é um deles, a universalidade, acho que a gente tá muito longe ainda de ter isso na saúde mental. Há uma tentativa de organização das políticas, mas a gente sabe que além de ter uma diretriz definida legalmente, nós temos as concepções dos profissionais que atuam nos serviços de saúde. (Lírio)

Acho que está deixando muito a desejar, temos excelentes serviços substitutivos, é um avançar. Mas, ainda não conseguem garantir os princípios do SUS como um todo.(Orquídea) 


\section{Desafios da psicologia no Brasil}

Percebe-se que os docentes acreditam que o atendimento nos serviços de saúde mental não é suficiente, pois consideram difícil a aplicação dos princípios e diretrizes do SUS. Os princípios ficam somente na teoria e isso se dá pela grande demanda dos serviços, pelas diferentes formações e a falta dos profissionais de saúde, dificultando o acesso à saúde. Os docentes assinalam que se saísse do papel, chegar-se-ia a resolutividade no atendimento.

O SUS está embasado por diretrizes organizativas e princípios doutrinários que se articulam e se complementam no ajustamento do ideário e da lógica de organização e estão em sintonia com os preceitos de bem-estar. Universalidade, integralidade e eqüidade asseguram o direito à saúde a todos os cidadãos e acesso sem discriminação, sendo considerados os variados aspectos do processo saúdedoença com prestação continuada de ações e serviços, visando à promoção, a prevenção, a proteção, a cura e a reabilitação dos sujeitos e dos coletivos (VASCONCELOS e PASCHE, 2012).

Para colocar esses princípios em prática deve-se pensar ou repensar em aspectos importantes da organização do processo de trabalho, como gestão, planejamento e construção de novos saberes e práticas em saúde (Cecílio, 2006). Levando em consideração nas práticas e intervenções as reais necessidades das pessoas que buscam cuidados em saúde.

Dessa maneira, é papel dos docentes, estudantes e profissionais conhecerem os princípios e diretrizes do SUS, sendo estes princípios trabalhados em sala de aula, para possam ser aplicados na realidade de cada serviço de saúde pelas equipes multiprofissionais. Prevalecendo no encontro usuárioprofissionais o compromisso e a preocupação de se fazer escuta qualificada das necessidades de saúde, proporcionando o vínculo entre usuários e serviços de saúde e a autonomia destes frente a sua saúde.

Apesar dos participantes trazerem em suas falas os aspectos negativos, as fragilidades e a não efetivação dos princípios e diretrizes, acreditam que o SUS é o melhor sistema de saúde que o Brasil pode ter, sinalizando ele, inclusive, como modelo para outros países.

Olhando a saúde no âmbito geral, dentro das premissas que o SUS preconiza, acho que está muito próximo. Tem muito a caminhar esses serviços de saúde, mas, eu acho que ele faz um bom atendimento dentro do que se preconiza. (Rosa).

O SUS é o melhor convênio que tem, que libera tudo, você pode pedir qualquer tipo de exame e ele autoriza, às vezes demora. Mas, autoriza, pede medicação, se for medicação de alto-custo faz um 


\section{Desafios da psicologia no Brasil}

formulário específico, libera. O SUS é o melhor convênio que tem. Primeiro porque o paciente não paga nada, teoricamente. Tem tudo o que quer, medicação, tratamento com clínico, especialista, é lógico dentro do tempo necessário pra isso. (Dente-De-Leão)

O nosso sistema de saúde é fantástico, ele deve ser copiado e inclusive ele é por alguns países e elogiado porque é completo, ótimo, universal, integral, descentralizado, fantástico! Não é 100\% concretizado, mas, é muito bacana e muito bem feito, as nossas leis são boas. (Azaléia).

Os docentes entendem que o serviço de saúde oferecido está coerente com o que é preconizado, há valorização do SUS, no que se refere ao atendimento, aos exames disponibilizados para os usuários e aos medicamentos.

Falar de SUS é falar que este é formado pelo conjunto de todas as ações e serviços de saúde prestados por órgãos e instituições públicas federais, estaduais e municipais, com diretrizes e princípios a serem seguidos (BRASIL, 2011). O SUS pode ser considerado uma das maiores conquistas sociais, pois, como apontam Vasconcelos e Pasche (2012), é produto da Reforma Sanitária Brasileira, processo político que mobilizou os brasileiros a propor novas políticas e modelos de organização de serviços e práticas de saúde. O SUS se consolidou ao longo de duas décadas, sendo a maior política de Estado do País, fruto de uma permanente construção coletiva.

Com alguns resultados inquestionáveis, como o aumento das equipes na Estratégia de Saúde da Família, em 2010 com 30.300 equipes; eliminou o sarampo e a transmissão da cólera e da rubéola; consolidou-se como o principal fornecedor de medicamentos e no crescimento do número de genéricos no mercado. Ainda, o Sistema Nacional de Transplantes é respeitado pela sociedade brasileira, pelos pacientes e pela comunidade transplantadora, o Brasil encontra-se no segundo lugar em número absoluto de transplantes realizados ao ano em todo o mundo (Brasil, 2011).

Portanto, o SUS é reconhecido internacionalmente como uma referência, devido a essas e outras iniciativas do modelo de saúde brasileiro - reconhecimento que aparece legitimado nas falas dos sujeitos dessa pesquisa. Sendo ainda, um sistema com avanços e em desenvolvimento, assim, compete às pessoas tomar conhecimento de seus "ouros" e "louvores", não apenas reforçar as fragilidades, mas participar e acreditar que melhorias são necessárias, fazendo com que as ações do SUS cada vez sejam mais valorizadas. 


\section{Desafios da psicologia no Brasil}

\section{CUIDADOS EM SAÚDE ANTES E DEPOIS DA REFORMA PSIQUIÁTRICA}

Os professores apresentam um entendimento de que a Saúde Mental teve grandes avanços, principalmente, ao que se refere aos tratamentos com as pessoas em sofrimento psíquico. Parecem acreditar que somente o tratamento medicamentoso não dá conta de "solucionar" aquilo que o sujeito precisa, destacam a necessidade da atuação do profissional psicólogo. Enquanto outros docentes focam na necessidade de especialistas (psiquiatra) para atuar junto aos sujeitos.

Não sei como funciona o atendimento no CAPS, justamente por não ter o profissional psicólogo algumas coisas tendem a desejar. Acho que fica mais medicamentosa do que psicoterápica pros pacientes que precisam de uma abordagem em Saúde Mental. (Rosa)

Você precisa de vaga especializada pro psiquiatra pra tratar esse paciente e não consegue. Acompanhei o CAPS, ter um centro especializado, diferentemente de se tratar só no posto de saúde acompanhado pelo clínico geral dá uma diferença gritante no tratamento do paciente e É importantíssimo ter um centro de cuidados especializados, com preferência com psiquiatras todos os dias (Dente-De-Leão).

No momento em que o docente foca em uma única especialidade, além de desvalorizar, de certa forma, as outras profissões que poderiam atuar junto a pessoas em sofrimento psíquico tão bem quanto um psiquiatra. Contrariando as políticas de saúde brasileira, bem como o que preconizam os serviços de saúde, estes com o foco no trabalho e atendimento multiprofissional.

Sampaio (et al. 2011), pontua que não há garantia de que o trabalho em equipe seja mais eficaz que o individual, mas há pelo menos três vantagens no trabalho multidisciplinar. A primeira seria a ideológica: o trabalho em equipe impede a hegemonia de um saber sobre o processo saúde-doença; a segunda seria a teórica: pois o trabalho em equipe expõe as teorias à competição, obrigando-as ao aperfeiçoamento de seus instrumentos e técnicas e por último a organizacional: devido à complexidade crescente do conhecimento, pois não é possível um trabalhador dar conta da totalidade de um problema ou da demanda.

Visualiza-se que a maioria dos professores salienta a importância do trabalho multidisciplinar e a comunicação com a rede de serviços de saúde, ao mesmo tempo em que o retratam como "falho" e como um dos motivos para o SUS não funcionar efetivamente. 


\section{Desafios da psicologia no Brasil}

A rotatividade dos profissionais na Estratégia de Saúde de Família é muito grande, uma vez que é grande, o vínculo com a comunidade não se estabelece. Aquele paciente precisa confiar na equipe que tá trabalhando, mas, como confiar se um mês vai alguém na minha casa me visitar (consultar) e no outro vai alguém que eu já não conheço? Ainda as equipes não são completas. É um grande fator que conta contra a própria recuperação do paciente. (Rosa)

Há uma falha no próprio sistema que a gente não trabalha multiprofissionalmente, pelo menos, nas nossas áreas aqui a gente não tem nada. (Crisântemo)

Acho que o grande problema está na rede. A rede não se consolida, ainda há pouco diálogo entre os serviços e entre as unidades básicas. Existe a referência, mas, não existe a contra-referência. Acho que este é um ponto bastante falho na saúde mental. (Orquídea)

Acredita-se que através do trabalho multidisciplinar é que se consegue atender as pessoas de forma integral e humanizada. Pois, segundo Junges (et. al. 2012), a Política Nacional de Humanização (PNH) - estratégia lançada pelo Ministério da Saúde para operar em conjunto com o SUS - visa priorizar a integralidade e o acolhimento da atenção em saúde, buscando maior resolubilidade na resposta às necessidades dos usuários. Para isso, é necessário, segundo o manual do Ministério, qualificar os profissionais para saberem lidar com as dimensões subjetivas e sociais do processo de saúde-doença, superando a visão reducionista de responder às necessidades com procedimentos técnicos.

Todavia, como os professores pontuam, alguns profissionais dos serviços de saúde desconhecem como trabalhar em equipe, não sabem dialogar e compartilhar conhecimentos e informações. Percebe-se que é o que, às vezes, ocorre com os docentes nos cursos de graduação em saúde, as DCNs estabelecem que sejam necessários conteúdos e práticas integradoras, algo que também não ocorre.

Supõe-se que a dificuldade esteja em diferenciar que trabalho multidisciplinar não significa cada um trabalhar em sua especialidade e, sim, unir os saberes para que a atenção às pessoas na saúde integral ocorra. Além disso, isto implicaria na rotatividade dos profissionais, porque a possibilidade de insatisfação está na sobrecarga de trabalho, na falta de recursos materiais, na demanda alta, entre outros

Acredita-se que os profissionais e docentes precisam se apropriar de práticas interdisciplinares, pois, o trabalho em equipe, diante da demanda da população, exige atitudes para o enfrentamento da problemática tridimensional: entre os profissionais, oriundos de várias formações; entre a equipe e os 


\section{Desafios da psicologia no Brasil}

gestores, portadores de tecnologias de gestão produzidas em outros processos de trabalho; e, entre a equipe e os usuários, estes entendidos como cidadãos, para assim, aproximar-se do SUS (SAMPAIO et al. 2011).

Estas situações conduzem a uma prática diferente da esperada afetando significativamente o tratamento do usuário do serviço de saúde porque nem sempre aquele profissional que o usuário procura pode ser aquele que Ihe dará o auxílio apropriado. Às vezes, um diálogo com outro profissional pode ser mais resolutivo. Sousa (2000 apud ELSEN et al., 2001), pontua que ao se propor a humanização, busca-se a satisfação do usuário por meio do estreito relacionamento que este estabelece com a comunidade.

Os docentes entrevistados apontam a necessidade do trabalho multiprofissional e a comunicação entre os serviços de saúde para a resolutividade no atendimento com as pessoas portadoras de sofrimento psíquico. Acreditam que é por meio da Atenção Básica e pelas equipes da Estratégia de Saúde da Família que deve acontecer o primeiro contato das pessoas em sofrimento psíquico com o tratamento e as intervenções necessárias.

Na atenção básica isso acaba prevenindo algumas práticas, os agentes comunitários de saúde, tendo tempo de formação continuada, tendo essa clareza da saúde mental. Então esses serviços mesmo básicos como ESF, já previnem e eu acredito que isso fez com que evoluísse muito pra que não chegasse aos extremos. (Violeta)

A Estratégia de Saúde da Família eu acho já melhorou muito. O acesso às pessoas aos serviços de saúde, a consulta médica, ao atendimento no posto, ao medicamento, ele tá muito melhor, tem médico no posto de saúde todos os dias, a equipe de saúde vai até a casa do paciente pra fazer o atendimento. (Rosa)

A Estratégia de Saúde da Família é uma forma de trazer isso mais próximo, os profissionais revendo o conceito de saúde mental outros tentando ainda conhecer e o que deve ser feito dentro da atenção primária e nos cuidados na saúde mental. (Lírio).

Percebe-se que os docentes afirmam que é pela Atenção Básica que algumas práticas extremas em saúde mental são evitadas, como o cárcere privado. Ainda, assinalam que é pela Estratégia de Saúde da Família (ESF) que os profissionais devem conhecer e rever o conceito de saúde mental. Acreditam que a atenção básica e ESF melhoraram, uma vez que têm médicos todos os dias, acontecem visitas 


\section{Desafios da psicologia no Brasil}

domiciliares, há medicações, bem como os agentes comunitários de saúde são os que têm contato direto e vínculo com a comunidade que atendem.

Assim, como Brasil (2012) afirma, a Atenção Básica deve ser o contato preferencial dos usuários, realmente, a porta de entrada e centro de comunicação com toda a Rede de Atenção à Saúde. Por isso, é fundamental que ela se oriente pelos princípios da universalidade, da acessibilidade, do vínculo, da continuidade do cuidado, da integralidade da atenção, da responsabilização, da humanização, da equidade e da participação social.

A ESF surge como uma política nacional, para a consolidação dos princípios do SUS, mediante estratégias e ações preventivas, promocionais, de recuperação, reabilitação e cuidados das equipes de saúde da família. Comprometida com a integralidade da assistência à saúde, focalizando a unidade familiar e consistente com o contexto das comunidades (ANDRADE, BARRETO e BEZERRA, 2012).

A ESF apresenta-se como porta de entrada dos serviços de saúde, mas tem sua funcionalidade rompida devido à falta de comunicação da rede, da equipe e o fato dos profissionais destas Unidades desconhecerem como trabalhar com as pessoas com algum sofrimento psíquico, a não ser o encaminhamento para um serviço mais especializado. Observa-se que o trabalho com as pessoas em sofrimento psíquico não tem dado conta de fortalecer os processos de desinstitucinalização, ao mesmo tempo em que os profissionais não parecem preparados para esses cuidados em saúde.

Como pontua Dimenstein e Camuri (2010), os profissionais precisam estar capacitados para encontrar problemas de saúde mental nos contextos onde trabalham e propor estratégias interventivas adequadas. Além de consolidar o trabalho em rede de modo que aquilo que não for resolutivo de imediato seja encaminhado, deve permanecer em contato com esse serviço, efetivando a referência e a contra-referência exigida pela política de saúde.

Além disso, os profissionais de saúde precisam rever seus conceitos e práticas em Saúde Mental, pois, o que se percebe é que o usuário não é compreendido a partir das problemáticas sociais do território onde vive, mas como mero "portador" de algum diagnóstico. Essa mudança deve iniciar nos bancos universitários, contudo, parece distanciar-se ainda da formação em saúde. 


\section{Desafios da psicologia no Brasil}

\section{CONSIDERAÇÕES FINAIS}

Percebeu-se que os docentes entrevistados apresentam diferentes estilos de pensamento (EP) resultantes de diferentes "coletivos de pensamento". Este último permanece sob os "domínios" do coletivo de pensamento do modelo biomédico, principalmente, quando os professores descreviam seus EP acerca da saúde mental, já que os mesmos dissociaram-na da Saúde "geral", como se ambas não possuíssem relação. Além de considerarem que a Saúde Mental estaria voltada às pessoas que possuem algum sofrimento psíquico, distanciando-a das pessoas que não têm "diagnósticos" fechados. Entretanto, não existe garantia que aquele que não possui um diagnóstico não tenha seus sofrimentos e a necessidade de cuidado em saúde.

A maioria dos docentes, ao relatar suas práticas e compreensões acerca do funcionamento do SUS voltadas a atenção à Saúde Mental, "esbarrava" no coletivo de pensamento mais "integrador", pós Reforma Sanitária, onde se valoriza o sujeito como um todo, considerando sua história de vida, suas experiências, suas vontades, suas necessidades em saúde e etc. Ao que parece, os professores universitários têm revisitado seus EP, aproximando-se do que preconizam as DCNs para os cursos de graduação e as políticas de saúde, implicando-se com a formação de profissionais generalistas, humanistas e críticos.

Esta mudança torna-se necessária à medida que a reprodução dos EPs no modelo hegemônico implica em legitimar práticas de saúde que boicotam a autonomia dos usuários dos serviços de saúde mental. Porém, sobre o SUS os professores afirmam que existem propostas resolutivas e idearias, sua aplicação não é efetiva e o seu maior "entrave" é o não funcionamento da rede regionalizada em referência e contra-referência, tornando truncado o trabalho multidisciplinar. Ainda, são "problemas" do SUS a fragmentação em especialidades e a não funcionalidade dos princípios e diretrizes na Atenção Básica.

Essas afirmações conduzem a interpretação de que, enquanto entrevistados, os docentes se colocaram exclusivamente no papel de docentes, mas, surge o questionamento: será possível dissociar estas duas profissões? Entende-se que a formação como profissional de saúde implicará nas suas práticas como docentes. Observa-se que tanto nos serviços de saúde quanto na formação em saúde o foco está na especialidade.

Assim, a formação permanece centrada no professor, no repasse de informações, disciplinas compartimentalizadas, ausência de práticas interprofissionais e distanciamento dos acadêmicos da 


\section{Desafios da psicologia no Brasil}

prática. Por isso, têm-se estudantes se sentindo despreparados às vésperas da formação, (futuros) profissionais insatisfeitos e serviços de saúde com desaprovações da população por não garantirem atenção à saúde com qualidade (CARVALHO;CECCIM, 2006).

Considera-se relevante que os profissionais reavaliem criticamente suas práticas enquanto docentes e profissionais de saúde, com intenção de construir, como pontuam Carvalho e Ceccim (2006), "coletivos de produção da saúde" para que assim exista coerência entre a formação e as exigências da atuação profissional.

É difícil reinventar EPs e rever práticas de ensino quando as matrizes curriculares permanecem "enraizadas" no modelo hegemônico. Pois, observou-se, pelas falas dos participantes, que as práticas de ensino-aprendizagem ainda apresentam-se fragmentadas em conteúdos específicos que não interagem, mesmo com as mudanças das DCNs.

Nota-se que a graduação ainda apresenta dificuldades em formar profissionais com perfis correspondentes ao SUS. Contudo, como coloca Dimenstein (1998), é preciso "desinstitucionalizar" os saberes e práticas e questionar a formação acadêmica, é preciso desconstruir as formas tradicionais de atuação. Percebe-se que somente com uma revisitação em seus EPs e com práticas direcionadas ao bem-estar da população é que a se conseguirá legitimar a Reforma Psiquiátrica.

\section{REFERÊNCIAS}

ALVES, C.F.O.; RIBAS, V.R.; ALVES. E.V. et.al. Uma breve história da reforma psiquiátrica. Neurobiologia, 72 (1), jan/març., 2009.

AMORIM, S.M.F. Loucura, política e ética: a formação do psicólogo em questão. In. CONSELHO FEDERAL DE PSICOLOGIA. Loucura, ética e política: escritos militantes. São Paulo: Casa do Psicólogo, 2003.

ANASTASIOU, L.G.C. Docência na educação superior. In. RISTOFF, D., SEVEGNANI, P. Docência na educação superior: Brasília, 1ㅇ e 2 de dezembro de 2005. Brasília: Instituto Nacional de Estudos e Pesquisas Educacionais Anísio Teixeira, 2006.

ANDRADE, L. O. M.; BARRETO, I. C. H. C.; BEZERRA, R. C. Atenção Primária à Saúde e Estratégia Saúde da Família. In: CAMPOS, G. W. S. et al. Tratado de Saúde Coletiva. 2 ed. - São Paulo: Hucitec, 2012.

BARBOSA, T.M.; WENDHAUSEN, A.; BORBA, M.C. Empoderamento e Recursos para a Participação em Conselhos Gestores. Saúde e Sociedade (USP. Impresso), v. 15, p. 131-144, 2006.

BATISTELLA, C. Abordagens Contemporâneas do Conceito de Saúde. In. FONSECA, A. Ferreira (org.). O território e o processo saúde-doença. Rio de Janeiro: EPSJV/Fiocruz, 2007. 


\section{Desafios da psicologia no Brasil}

BRASIL. Ministério da Saúde. Saúde Mental em Dados - 9, ano VI, no 9. Informativo eletrônico. Brasília: Julho, 2011. Disponível

em: http://portal.saude.gov.br/portal/arquivos/pdf/mentalemdados2011.pdf. Acesso em 9 de fevereiro de 2012.

BRASIL. Ministério da Saúde. Secretaria de Atenção à Saúde. DAPES. Coordenação Geral de Saúde Mental, Álcool e Outras Drogas. Saúde Mental no SUS: as novas fronteiras da Reforma Psiquiátrica. Relatório de Gestão 2007־-2010. Brasília, jan. 2011.

BRASIL. Sistema Único de Saúde. Conselho Nacional de Secretários de Saúde. - Brasília: CONASS, 2011.

BÜCHELE, F.; LAURINDO, D.L.P.; BORGES, V.F. COELHO, E.B.S. A interface da saúde mental na atenção básica. Cogitare Enferm. 11(3): 226-33, set/dez, 2006.

CAMATTA, M.W.; SCHNEIDER, J.F. A visão da família sobre o trabalho de profissionais de saúde mental de um centro de atenção psicossocial. Rev. Enferm. 13 (3): 477 - 842, jul/set, 2009.

CAPONI, S. O diagnóstico de depressão, a "petite biologie" e os modos de subjetivação. In.: CAPONI, Sandra... [et al]. Medicalização da vida: ética, saúde publica e indústria farmacêutica. Palhoça: Ed. Unisul, 2010.

CARVALHO, Y.M.; CECCIM, R.B. Formação e educação em saúde: aprendizados com a saúde coletiva. In: CAMPOS, G.W.S.; MINAYO, M.C.S. (org.). Tratado de saúde coletiva. Rio de Janeiro, Hucitec;Fiocruz, 2006. p.149-182.

CASTRO, H. C. O. A Satisfação dos Usuários com o Sistema Único de Saúde (SUS). Sociedade em Debate, Pelotas, 14(2): 113-134, jul.-dez./2008.

CECCIM, R.B. ARMANI, T.B, OLIVEIRA, D.L.L.C., BILIBIO, L.F., MORAES, N.D.S. Imaginários da formação em saúde no Brasil e os horizontes da regulação em saúde suplementar.Ciênc.saúde coletiva.vol.13.n5. Rio de Janeiro, 2008.

. FEUERWERKER, L.C.M. Quadrilátero da Formação para a Área da Saúde: Ensino, Gestão, Atenção e Controle Social. PHYSIS: Rev. Saúde Coletiva, Rio de Janeiro, 14(1):41- 65, 2004.

ARMANI, T.B., ROCHA, C.F. O que dizem a legislação e o controle social em saúde sobre a formação de recursos humanos e o papel dos gestores públicos, no Brasil. Ciência \& Saúde Coletiva, $7(2): 373-383,2002$.

CECILIO, L. C. O. As necessidades de saúde como conceito estruturante na luta pela integralidade e equidade na atenção em saúde. In: PINHEIRO, R., MATTOS, R. A. Os sentidos da integralidade na atenção e no cuidado à saúde. Rio de Janeiro: UERJ, IMS: ABRASCO, 2006.

COSTA, M. N. Por uma sociedade sem manicômios: buscando a direção. In: CONSELHO FEDERAL DE PSICOLOGIA (Org.). Loucura, ética e política: escritos militantes. Casa do Psicólogo. - São Paulo, 2003.

DA ROS, M.A., DELIZOICOV, D. Estilos de pensamento em saúde pública: um estudo da produção da FSP-USP e ENSP-FIOCRUZ, entre 1948 e 1994, a partir da epistemologia de Ludwik Fleck. Santa Catarina: UFSC, 2000. 


\section{Desafios da psicologia no Brasil}

DELGADO, P. G. G. et al. Reforma psiquiátrica e política de saúde mental no Brasil. In: MELLO, M. F., MELLO, A. A. F., KOHN, R. Epidemiologia da saúde mental no Brasil. Ed. Artmed - Porto Alegre, 2007.

DIMENSTEIN, M.; CAMURI, D. Processo de Trabalho em Saúde: práticas de cuidado em saúde mental na estratégia saúde da família. Saúde Soc. São Paulo, v.19, n.4, 2010.

DIRETRIZES PARA UM MODELO DE ASSISTÊNCIA INTEGRAL EM SAÚDE MENTAL NO BRASIL. Associação Brasileira de Psiquiatria. 2006.

ELSEN, I. et al. Saúde da família: desafios teóricos. Fam. Saúde Desenv., Curitiba, v.3, n.2, p.89-97, jul./dez. 2001.

FERREIRA, M. C. G. A. A Política de Saúde Mental no Brasil - Ontem e Hoje: Alternativas e Possibilidades - Faculdade São Vicente De Pão De Açúcar - Fasvipa - Pão De Açúcar - Al, novembro de 2007.

FERRONATO, F.A., GARCIA, M.A.A. Significados do ensino no SUS para o docente de medicina. Anais do XIV Encontro de Iniciação Científica da PUC. Campinas - 29 e 30 de setembro de 2009.

FLECK, L. Gênero e desenvolvimento de um fato científico. Belo Horizonte: Fabrefactum, 2010.

GARLA, C. C., FUREGATO, A. R. F., SANTOS, J. L. F. Profissionais de ambulatórios de saúde mental: perfil, práticas e opiniões sobre as políticas. Cadernos Brasileiros de Saúde Mental, ISSN 1984-2147, Florianópolis, V. 2, n.4-5, p.74 - 93. 2010.

HIRDES, A. A reforma psiquiátrica no Brasil: uma (re) visão. Ciência \& Saúde Coletiva, 14(1): 297-305. 2009.

ISAIA, S.M.A. Desafios à docência superior: pressupostos a considerar. In. RISTOFF, D., SEVEGNANI, P. Docência na educação superior: Brasília, 10 e 2 de dezembro de 2005. Brasília : Instituto Nacional de Estudos e Pesquisas Educacionais Anísio Teixeira, 2006.

JUNGES, J. R. et al. O discurso dos profissionais sobre a demanda e a humanização. Saúde soc., São Paulo, v.21, n.3, set. 2012. Disponível

em:<http://www.scielo.br/scielo.php?script=sci_arttext\&pid=S010412902012000300014\&lng=pt\&nr m=iso> Acesso: 12 de novembro de 2012.

LANCETTI, A., AMARANTE, P. A. Saúde Mental e Saúde Coletiva. In: Tratado de saúde coletiva. Rio de Janeiro, Hucitec; Fiocruz, 2012.

LAVILLE, C., DIONNE, J. A construção do saber: manual de metodologia da pesquisa em ciências humanas. Porto Alegre: Artes Médicas, 1999.

MIELKE, F.B., KANTORSKI LP, J.V.M.R, et.al.. O cuidado em saúde mental no Caps no entendimento dos profissionais. Cien. Saude Colet. 2009.

MINAYO, M. C.S. O desafio do conhecimento: pesquisa qualitativa em saúde. São Paulo: Hucitec. Rio de Janeiro: Abrasco, 2000.

MITRE, S.M., SIQUEIRA-BATISTA, R. (et.al.). Metodologias ativas de ensino-aprendizagem na formação profissional em saúde: debates atuais. Ciência \& Saúde Coletiva, 13(Sup 2):2133-2144, 2008. 


\section{Desafios da psicologia no Brasil}

NOGUEIRA-MARTINS, M.C.F. Humanização das relações assistenciais: a formação do profissional de saúde. São Paulo: Casa do Psicólogo, 2001.

OLIVEIRA, D. C. et al. Memórias e representações sociais dos usuários do SUS acerca dos sistemas públicos de saúde. Rev. Eletr. Enf. [Internet].13(1):30-41. 2011. Disponível em: http://www.fen.ufg.br/revista/v13/n1/v13n1a04.htm. Acesso: 11 de novembro de 2012.

PACHANE, G.G.Teoria e prática na formação de professores universitários:elementos para discussão. In. RISTOFF, D., SEVEGNANI, P. Docência na educação superior: Brasília, 10 e 2 de dezembro de 2005. Brasília: Instituto Nacional de Estudos e Pesquisas Educacionais Anísio Teixeira, 2006.

PARREIRAS, M.M.M., CONDÉ, N.L.L.Ludwik Fleck e a historiografia da ciência: diagnóstico de um estilo de pensamento segundo as Ciências da vida. Belo Horizonte: Faculdade de Filosofia e ciencias Humanas (UFMG), 2006.

RONCA, A.C. ANCONA-LOPEZ, M., PEDERNEIRA, M.P. Relato de um processo do Ministério da Educação. Conselho Nacional de Educação: sobre a carga horária dos cursos de graduação na área de saúde. Disponível em <http://portal.mec.gov.br/cne/arquivos/pdf/2008/pces213_08.pdf> Acesso em 11 nov. 2012.

SAMPAIO, J. J. C. et al. O trabalho em serviços de saúde mental no contexto da reforma psiquiátrica: um desafio técnico, político e ético. Ciênc. saúde coletiva, Rio de Janeiro, v. 16, n. 12, dez. 2011. Disponível

em:<http://www.scielo.br/scielo.php?script=sci_arttext\&pid=S141381232011001300017\&lng=pt\&nr $\mathrm{m}=\mathrm{iso} \& \mathrm{t}$ Ing=pt> Acesso: 12 de novembro de 2012.

SCLIAR, M. A história do conceito de saúde. Rev. Saúde Coletiva, Rio de Janeiro, 17(1):29-41, 2007.

TESSMANN, F.B, GARCIA, R.A. Da execução à formação: refletindo o trabalho da monitoria no I Seminário Diálogos com Paulo Freire. Disponível

em<http://www.ufpel.tche.br/fae/dialogoscompaulofreire/da\%20execucao\%20a\%20formacao\%20r efletindo\%20o\%20trabalho\%20da\%20monitoria\%20no.pdf> Acesso em 11 nov. 2012.

VASCONCELOS, C. M.; PASCHE, D. F. O Sistema Único de Saúde. In: CAMPOS, G. W. S. et al. Tratado de Saúde Coletiva. São Paulo: Editora Hucitec, 2007.

VEIGA, I.P.A. Docência universitária na educação superior. In. RISTOFF, D., SEVEGNANI, P. Docência na educação superior: Brasília, 10 e 2 de dezembro de 2005. Brasília: Instituto Nacional de Estudos e Pesquisas Educacionais Anísio Teixeira, 2006. 


\section{Desafios da psicologia no Brasil}

\section{NOTAS}

Notas 1

Os professores entrevistados receberam nomes fictícios de flores para preservar o anonimato e o sigilo às informações. 


\section{Capítulo 32}

ATELIESCOLA ACAIA: EXPERIÊNCIA E TRANSMISSÃO EM PSICANÁLISE

DOI: $10.37423 / 200200227$

Ana Cristina de Araújo Cintra

ana.cintra@acaja.org.br

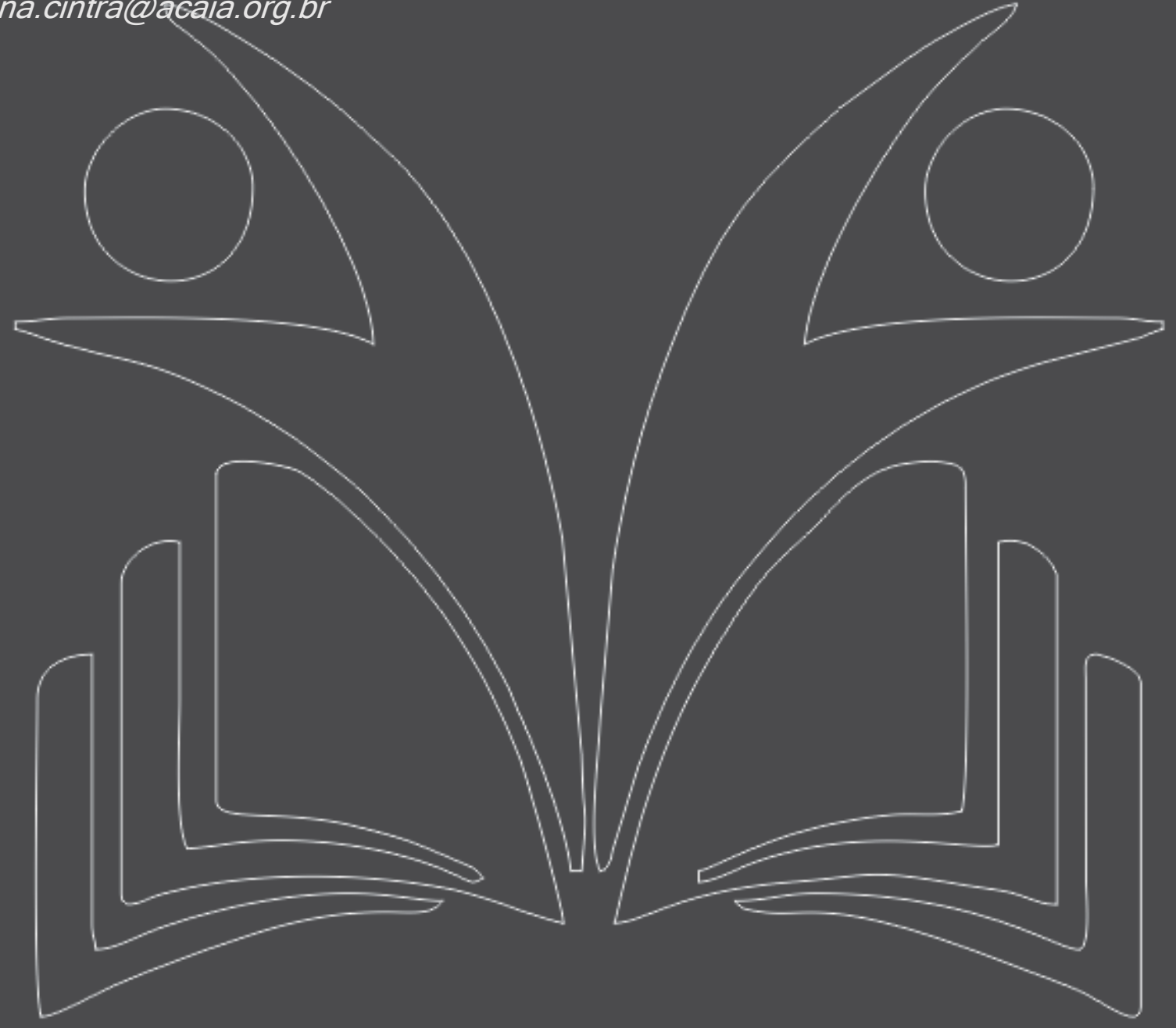




\section{Desafios da psicologia no Brasil}

Um pé na erudição, outro na magia, ou, mais exatamente e sem metáfora, nesta magia simpática que consiste em nos transportarmos em pensamento ao interior de alguém.

Marguerite Yourcenar

Caderno de notas das “Memórias de Adriano

Falar em transmissão nos remete ao conceito de mestre. Um mestre, antes de tudo, do meu ponto de vista, deve ser generoso pois conhecimento é para ser compartido, aberto, ter fruição.

Quero lembrar aqui com vocês de um trabalho que tive a oportunidade de participar junto a um grupo de psicanalistas da SBPSP - Sociedade Brasileira de Psicanálise de São Paulo, Fabio Herrmann, Marion Minerbo, Sonia Terepins e outros colegas nos anos 1999/2000 no ICHCFMUSP - Instituto Central do Hospital das Clínicas da Faculdade de Medicina da Universidade de São Paulo e que foi parte de minha dissertação de mestrado. Naquela ocasião Fabio foi chamado à partir de um pedido de ajuda do grupo de enfermeiros da hematologia em função do alto nível de stress a que a equipe era submetida.

Reunidos, psicanalistas e equipe para pensarem uma proposta de intervenção a primeira frase que escutaram foi: "aqui, tudo é sempre para ontem". Contaram de um paciente internado que se casaria no sábado e morrera na sexta. Obituou. O termo "obituar", como viemos a descobrir, era um neologismo que combinava magistralmente "hábito" e "óbito", um habituar-se à morte.

Entra a escuta psicanalítica. Percebe-se logo a existência de uma regra estranha, inconsciente para a equipe. "Tudo é para ontem", hoje é tarde demais. Vê-se aí o sentimento de impotência mostrando sua origem, pois a regra afirma ser tudo impossível, fora do tempo, pois o tempo no qual poderia ocorrer a cura já passou. Impossível casar no sábado e morrer na sexta. (Camargo, 2004, p.13)

Proposta de intervenção: encontros quinzenais com a ideia de entender e mostrar ao grupo seu funcionamento e a constelação de fatores que os levavam a um número expressivo de afastamentos por depressão e constantes brigas. Como novidade em relação aos atendimentos de grupo usuais, elaborávamos a cada 3 ou 4 encontros uma apostila que retomava os encontros anteriores destacando as falas mais significativas, mostrando à equipe seus próprios movimentos emocionais. 


\section{Desafios da psicologia no Brasil}

Optou-se então por oferecer um curso terapêutico cuja proposta era funcionar simultaneamente como grupo de investigação, tratamento e treinamento para a multiplicação da função terapêutica. Surgia o conceito de GIFT - Grupos de Investigação em Função Terapêutica.

Cabe aqui lembrarmos que a investigação é indissociável da função terapêutica uma vez que, o movimento investigativo é em si terapêutico e as regras que operam em determinado campo vão surgindo e os sentidos se revelando. Assim, o próprio caminho é curativo.

Investigativo para o grupo atendido - enfermeiras da hematologia, investigativo para os psicanalistas que coordenavam o grupo - Fabio e Marion, e também para o grupo de psicólogos ouvintes, equipe que estava sendo treinada e da qual eu fazia parte. (No ano seguinte, 2000, junto com Sonia Terepins, coordenamos o grupo que atendeu a equipe dos enfermeiros dos ambulatórios). Após o término dos encontros, nos reuníamos para refletir sobre o atendimento, as intervenções, sobre o manejo do grupo e destacávamos o que havia surgido de mais relevante.

Voltemos um pouco. Na graduação tive a oportunidade de ler "Ensaio sobre a dádiva" de Marcel Mauss - um estudo antropológico sobre tribos que, ao visitarem outras tribos levavam gift's/presentes e, deste modo, passavam à tribo que recebia o gift a incumbência de retribuí-lo. Uma dádiva que se transformava em dívida. Retomei este texto com Fabio em uma entrevista em dezembro de 2003 acerca do nome que escolhera para a proposta de intervenção no Hospital das Clínicas.

Ele me respondeu: "É claro que existem a dádiva e a dívida... Eu inventei este nome para dar conta do fato de que, além de uma função terapêutica, havia uma investigação. Investigação não só no sentido da investigação convencional na psicanálise, na qual não se pensa no que se está explorando, intelectualmente, mas na investigação mesmo, na micro-cultura do lugar" (naquela ocasião na hematologia). O Gift assinala esta mobilidade representacional e o trocadilho com dom, com presente... a palavra GIFT é uma palavra bonita, tem a ver com GIVE, é um presente, é um Dom...

O que me interessa tratar mais diretamente hoje com vocês é como penso a conexão do GIFT, da propagação da função terapêutica e do potencial da transmissão da psicanálise a partir da experiência de 20 anos de trabalho no ateliê acaia.

Dizia Fabio na mesma entrevista: Função terapêutica é o efeito do quantum de psicanálise existente numa análise, numa terapia, numa supervisão e serve para estabelecer linhas de mediação, de gradiente entre as várias formas de ação de um analista, até que não se trate mais de um analista, e 


\section{Desafios da psicologia no Brasil}

sim ação de uma pessoa qualquer ou só de um conjunto social - então, com os GIFT's, a idéia era criar uma expressão que desse conta do valor da ação grupal, ação que instala num grau maior que o habitual a função terapêutica, "cria um clima", um clima POR DENTRO, uma ambiência (Camargo, 2004, p.41).

Na pesquisa do Doutorado, com a orientação da Ana Loffredo, foi fundamental pensar a construção do Acaia e a relação entre psicanálise, universidade e transmissão. Loffredo diz: "essas pesquisas permitem que a universidade cumpra seu papel fundamental, que é garantir a produção de conhecimento alinhada às demandas concretas da comunidade, em suas vertentes de ensino, pesquisa e extensão" Ao referir-se ao volume disponível de produções acadêmicas psicanalíticas, igualmente aponta que: "este quadro também estimula a psicanálise a mais bem delinear seus contornos identitários como disciplina e a criar repertórios de comunicação que permitam o diálogo com outras áreas, num momento em que a demanda pelos trabalhos multidisciplinares se torna imperativa. (Loffredo, 2012, p.217)

O Instituto Acaia fica próximo à USP e recebe a população que vive nas favelas localizadas no entorno do CEAGESP. 


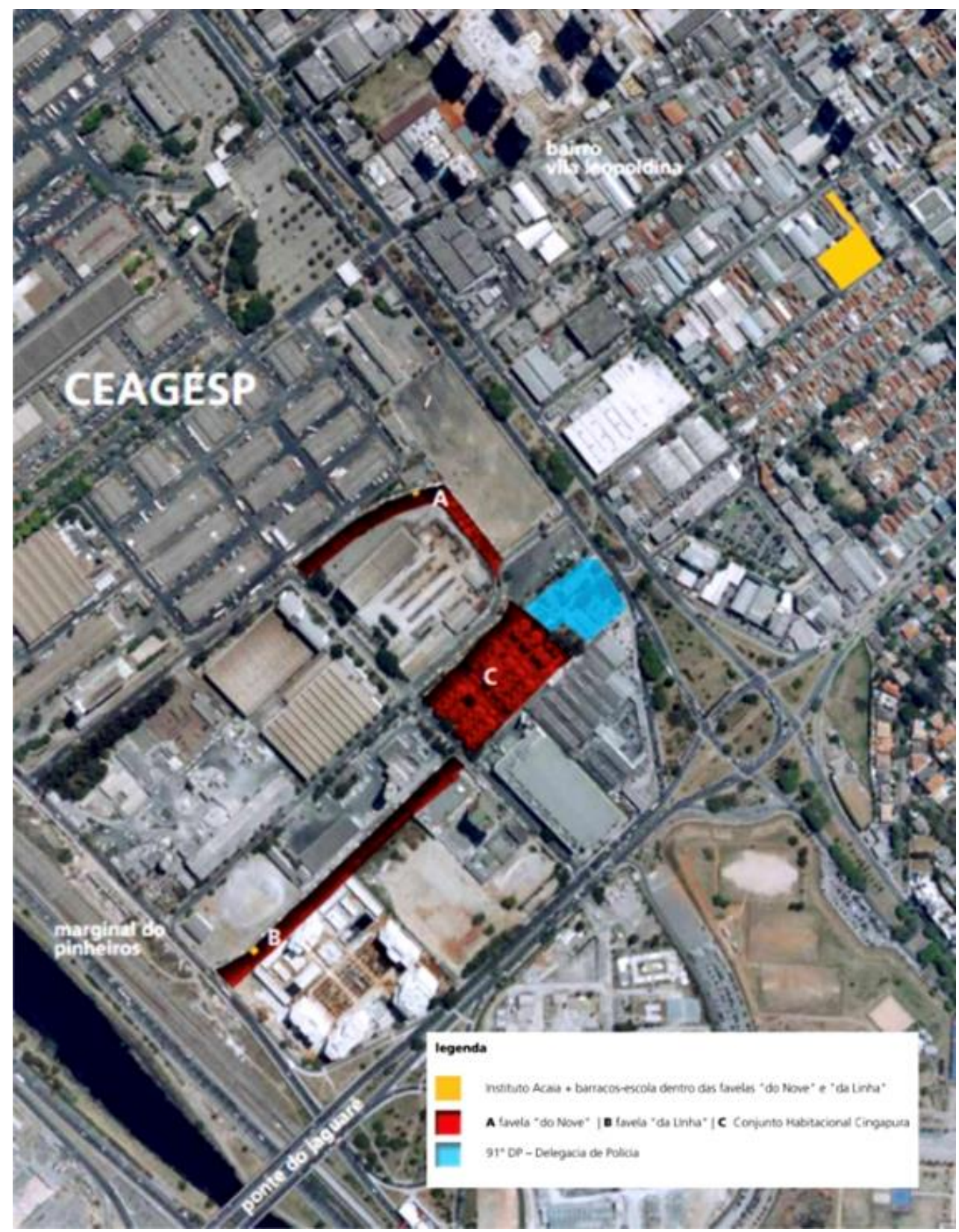

Teria muito a contar para vocês do trabalho lá realizado, atualmente uma escola de educação infantil e fundamental 1, (acabamos de aprovar a implantação do fund 2), cursos técnicos, atendimento noturno às famílias e à comunidade, jurídico e de saúde, além de dois postos dentro das favelas chamados de barracos-escola.

No ateliescola, temos 10 hs diárias de trabalho de segunda a sexta feira com as crianças em cuja rotina estão incluídas 5 refeições, banho, atendimentos de saúde, as aulas curriculares e as Oficinas e Ateliês Livres. A essência do trabalho e esta largueza de tempo nos permite ser um ponto pendular entre a educação e uma clínica de cuidados, a experimentação e a produtividade, desorganização e concentração, realidade e desejo, criando assim condições para que as pessoas experimentem fazeres, 


\section{Desafios da psicologia no Brasil}

potências, lugares de acolhimento e autonomia. Nesse sentido estamos inseridas num espaço e num grupo de trabalho que possibilita o fazer como um facilitador do encontro, de universalização da linguagem. A ideia é que os trabalhos e funções se complementem. As rotinas criadas e a organização da equipe funcionem como enquadre que favoreça a simbolização, estruturação emocional e também transmissão de conhecimento. Os fazeres e saberes não se separam.

Mas vamos partir do campo da saúde mental e de como entendo que se dá a propagação da função terapêutica na construção do trabalho junto às crianças e a equipe de educadores.

Oferecemos atendimentos individuais e em grupo - estes chamados de Oficina dos Sentimentos. Também disponibilizamos oficinas de: marcenaria, música, capoeira, biblioteca, artes, jogos que juntamente com a oficina dos sentimentos acontecem nos horários de Ateliê Livre. Aprender a escolher e optar no horário de Ateliê Livre pela Oficina dos Sentimentos já é, em si, um abrir-se para um espaço de cuidados.

\section{OFICINA DOS SENTIMENTOS}

Encontros que ocorrem semanalmente, com grupos abertos onde são oferecidos materiais de expressão plástica e simbólica. As crianças fazem usos distintos do espaço. Algumas vêm semanalmente, outras frequentam o grupo durante alguns encontros. Acontece um ir e vir natural e são acolhidas no grupo quem estiver ali e escolheu frequentar a oficina no dia do atendimento. Isso exigiu, ao longo do tempo, que fossem desenvolvidos recursos técnicos para lidar com a heterogeneidade das situações. Aquele encontro não se repete e é necessário nomear o que é observado enquanto movimento individual e/ou grupal. Aos poucos, foi sendo criado um conjunto de regras/um enquadre de funcionamento. 


\section{Desafios da psicologia no Brasil}

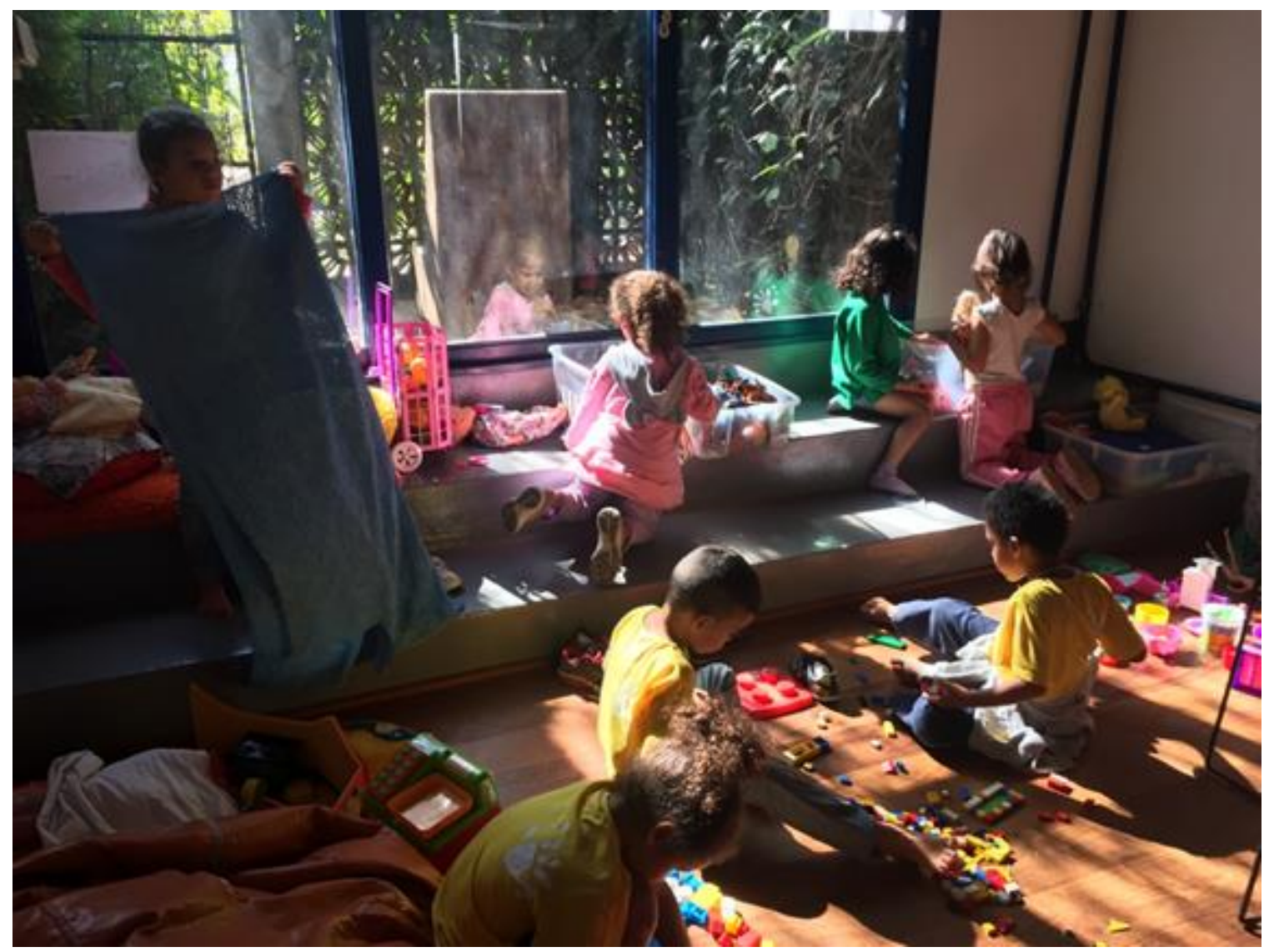

É importante relembrar que as crianças e os jovens que frequentam os grupos apresentam um repertório básico e comum, impregnado pela erotização e a violência a que estão expostos cotidianamente. Também há, em algumas situações, grande dificuldade de lidar com regras e limites. Ampliar esse repertório, criar condições para expressar experiências emocionais na maior parte das vezes manifestadas em estado bruto, em ato, sempre foi um desafio. Material de expressão e escuta aos poucos, se transformam em conversa e palavras.

Outro ponto fundamental é com relação à permanência do material, pois entendemos que a sobrevivência dos objetos é essencial para o estabelecimento de um vínculo transferencial. Há uma relação de confiança que sustenta a transferência, essencial para qualquer trabalho analítico. Onde a transferência é encontrada, abre-se espaço para a narrativa e a possibilidade do sujeito se reencontrar com a própria história.

Mais do que descrever uma Oficina dos Sentimentos, quero salientar com vocês, através de dois recortes, propagações do trabalho psicanalítico no Acaia. 


\section{Desafios da psicologia no Brasil}

1.T. é uma menina de 9 anos, perdeu a mãe ano passado, tem outros dois irmãos, um mais velho e um mais novo que frequentam o Acaia. Em sua sala de aula a professora e seus colegas criaram um altar com uma foto da mãe de T. Presencia situações violentas. Viu a madrasta ser espancada pelo pai e ser levada ao Pronto Socorro com a cabeça aberta. Na semana seguinte a este acontecimento, chega atrasada e chorando ao Acaia. A professora de sala percebe que ela não está em condição de acompanhar as aulas. Procura quem possa recebê-la para uma escuta mais individualizada. Naquele momento eu estava disponível (mas poderia ter sido a coordenadora da escola, a diretora do Acaia, alguém que pudesse ter um contato sensível com T....) Ela me conta do fim de semana: estava muito triste, houve batida policial na favela e o pai tinha sido espancado. "Ele só entrou no barraco para buscar um casaco para meu irmão" - diz T. procurando algum sentindo para a cena. Aos poucos se acalma e vai para a Oficina de biblioteca onde é recebida sem perguntas e consegue seguir com a turma. A professora de sala já havia avisado o professor da ausência de T. no início da atividade. No período da tarde tem Oficina de artes. Sem ter muitas notícias sobre o que havia se passado no período da manhã mas disponível para o pedido do fazer da criança, o educador constrói junto com ela um aparelho com colocação de pinos em sua perna simulando uma cirurgia complicada. Sua amiga, em sinal de solidariedade, também se enfaixa. Em conversa posterior com o educador contamos do dia de T. e ele disse ter percebido sua tristeza.

Há um espraiamento de uma clínica de cuidados pelo espaço físico e na capacidade de escuta dos educadores. A criação de uma ambiência, de um clima POR DENTRO como disse Fabio na entrevista. O educador de artes, com engenhosidade, ajudou a dar representação à dor de T. Cirurgia sob medida para sua "fratura exposta".

Os ambientes físicos e a disponibilidade psíquica dos educadores permitem movimentações e quebras de sintomas. Acredito que estes encontros humanizadores oferecem novas formas de estar no mundo. 


\section{Desafios da psicologia no Brasil}
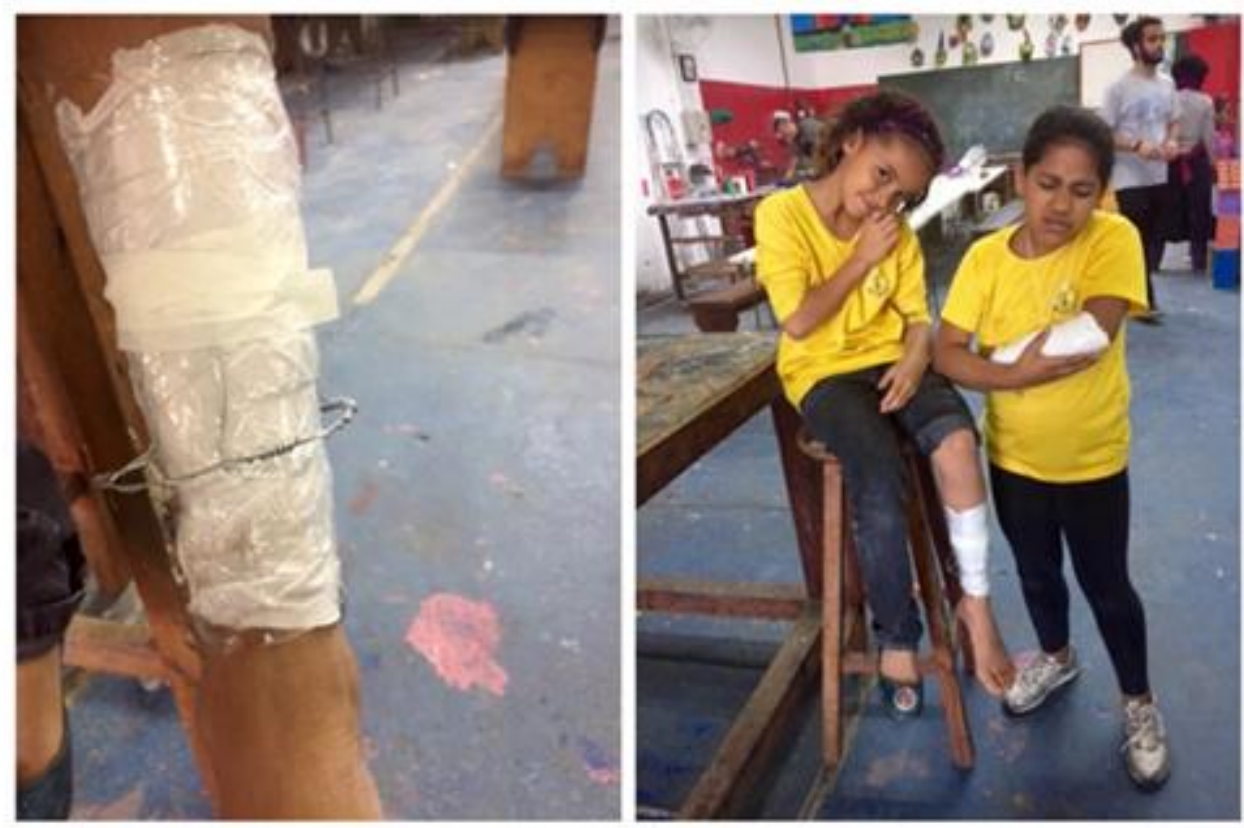

2. S. tem 6 anos e está no primeiro ano. Tem crises diárias, se desorganizando violentamente e levando a equipe à exaustão. É atendido individualmente pela psicanalista além de frequentar a Oficina dos Sentimentos mas volta e meia está na sala da coordenação porque não conseguiu seguir com uma atividade, grunhe como um bicho, chuta e morde os colegas, convulsiona o corpo e precisa de contenção física. Depois das crises, costuma dizer que não consegue se controlar e precisa de ajuda. Diante disso, todo o grupo do primeiro ano fica abalado pelo seu descontrole.

A psicanalista e a coordenadora pedagógica fazem reuniões com a equipe, conversam sobre as dificuldades de S. dão suporte à professora e à assistente de sala, pensam em estratégias para lidar com o garoto: a) a professora o espera na porta da sala, antecipando o que ele precisava fazer e isso o ajudava a se organizar; b) planeja atividades mais curtas que ele pudesse realizar do começo ao fim; c) reagrupou a sala, dividindo em grupos de quatro ou cinco crianças, e às vezes o tirava do grupo para realizar as atividades sozinho explicando para ele porque isso ia acontecer e qual era a meta.

Certa manhã, a professora de sala comenta: hoje fiz uma "roda dos sentimentos" com o grupo de alunos. "Eles chegaram muito esbaforidos, trazendo conflitos de outros espaços, percebi que precisaria mudar o planejamento. Muitos choraram e contaram de suas tristezas e medos. J., um aluno que está abrigado, falou das saudades da mãe. S. contou que teve um cachorro que ele gostava bastante mas que todo mundo batia nele... As dificuldades de S. puderam ser compartilhadas num contexto outro que não em presença do psicanalista. 


\section{Desafios da psicologia no Brasil}

Observamos aqui a migração da Oficina dos Sentimentos para a roda dos sentimentos. Retomo o princípio de lateralidade, considerado por Herrmann um dos princípios técnicos da interpretação, “...quando há uma espécie de repercussão lateral da ruptura de campo, incidindo sobre campos vizinhos, excitando-os e, não raro, propagando o efeito de ruptura de forma imprevista." (Herrmann, 1991, p.193)

Podemos ver nas fotos do atendimento psicológico e brincadeira de pátio onde S. procura contorno e contenção, e que de algum modo, o ambiente vai de encontro à sua necessidade.
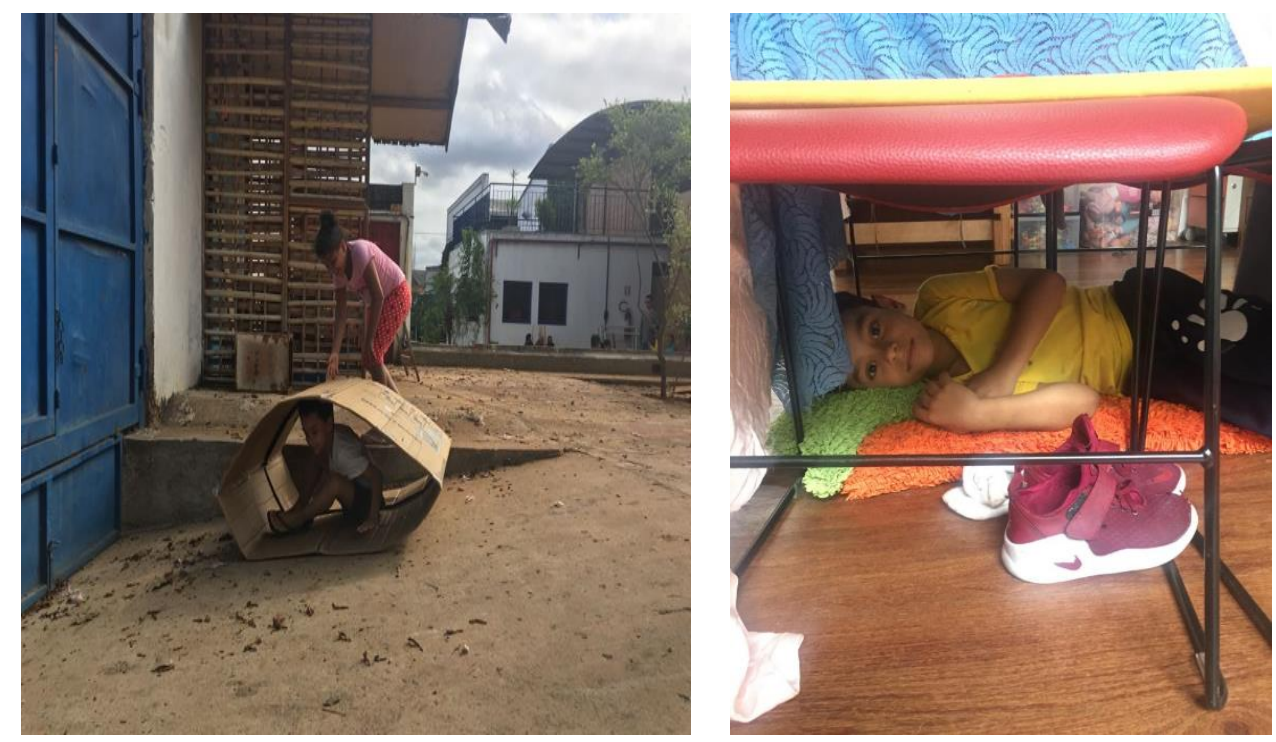

\section{PENSANDO A TRANSMISSÃO:}

Muitos atendimentos das crianças e especialmente dos pais são realizados em conjunto com a direção/coordenação e/ou com os professores, oficineiros e auxiliares. Antes e depois destes atendimentos, conversamos sobre aquela criança, o momento atual familiar, as estratégias de ação conjunta da instituição.

No setor de psicologia contamos com um grupo de estagiários da PUC-SP, e cada um deles acompanha uma turma do ateliescola com supervisões quinzenais com as psicanalistas. A supervisão é aberta à equipe.

Esta forma de proceder lembra a Clínica Transcultural de Marie Rose Moro, da Universidade Paris Descartes, onde, no Hospital Avicenne as famílias de refugiados são atendidas por um grupo de terapeutas de origens culturais diferentes e a escuta se dá na multiplicidade de crenças, origens e 


\section{Desafios da psicologia no Brasil}

formações. O grupo permite a materialização da alteridade e uma transformação desta alteridade em instrumento terapêutico.

Creio, com estes exemplos, não estar banalizando o lugar de escuta do psicanalista mas apontando como as valises teóricas da psicanálise podem inspirar e embasar trabalhos institucionais e políticas públicas.

Encerro retomando o artigo de Loffredo (2012), “...a questão de que se trata é de como viabilizar a extensão do saber psicanalítico para onde uma demanda de escuta se apresente, de modo a que seu método seja convocado, o que envolve pesquisa, necessariamente, no plano da elasticidade da técnica e da plasticidade do setting. (p.220).

\section{REFERÊNCIAS}

Bracco, S.M. Oficina dos Sentimentos: a construção de um espaço terapêutico. JORNAL de PSICANÁLISE 48 (88), 161-172.2015.

Camargo, A.C.C.(2004). Clínica Extensa, A Psicanálise onde ela se faz necessária. Dissertação de mestrado, Departamento de Psicanálise, Pontifícia Universidade Católica de São Paulo, São Paulo.

Camargo, A.C.C. Ateliê Acaia e Clínica Extensa: uma perspectiva psicanalítica na construção de um projeto institucional 2015 230f. Tese (doutorado) Instituto de Psicologia, Universidade de São Paulo, São Paulo.

Herrmann, F. (1991). Clínica psicanalítica: a arte da interpretação. São Paulo: Brasiliense.

Loffredo, A. M. (2012). Transmissão de psicanálise e universidade. Jornal de Psicanálise, (45), 82, 211222.

Moro, R. M. Psicoterapia Transcultural da migração. Psicologia USP 2015, vol 26 n.2 186-192. 


\section{Capítulo 33}

\section{OBESIDADE: UM DESAFIO MULTIFATORIAL}

\section{DOI: $10.37423 / 200200228$}

Natalia Luciane Amorin

nlamorin_1@yahoo.com.br

Ada Maria Riberti

adariberti@uol.com:br

Felipe David Mendonça Chaim

felipechaim@hotmail.com

RESUMO: A-obesidade é ùma doença de etiologia/multifatorial. Consideraeta epidemia mundial, sendo necessária abbrdagem terapêutica interdisciplihar, fö criado o GRUPO GESTO (Grupo Educacional em Saúde e Tratamento da Obesidade), oferecido gratuitamente pelo setor público, onde os pacientes são atendidos em único espaço físico,em sistema rotatório dos profissionais envolvidos. Os objetivos são a conscientização da população quanto às mudanças no estilo de vida e nos hábitos alimentares para o bem estar físico e mental, verificando os efeitos da terapia de lango prazo sobre mudanças no estilo de vida. Os pacientes são submetidos à anamnese clínica coleta de dádos psicológicos e ahtropométricos. Participam semanalmente de palestras médicas, rutricionais e psicológica\$, dinâmicas de grupos e consçientização corporal. Desde la implantação do grupo foram assistidos 4.870 indivíduos, sendo estudados 164 homens e 423 mulheres-com idade entre 16 a 70 anos e IMC médio de $37,3 \mathrm{~kg} / \mathrm{m} 2-\mathrm{e}-93,3 \%$ estavam dispoostas a mudar seu comportamento-em relação à comida.

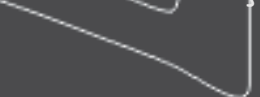




\section{Desafios da psicologia no Brasil}

A terapia interdisciplinar permite reduzir acentuadamente a obesidade, obtendo resultados satisfatórios nos quesitos antropométricos e psicológicos, principalmente nas questões de impulsividade e ansiedade, propiciando melhor adesão ao tratamento e possibilitando a melhoria da qualidade de vida.

Palavras-chave: obesidade; ansiedade; depressão 


\section{Desafios da psicologia no Brasil}

\section{INTRODUÇÃO}

Nas últimas décadas, o Brasil acompanhou uma transição nutricional, da grande prevalência de desnutridos de outrora para uma sociedade com sobrepeso e obesidade, estando atualmente mais da metade da população acima do peso ideal. A obesidade é definida como doença crônica e de difícil tratamento, apresentando-se como importante problema de saúde pública, com constante aumento de sua prevalência. Diretamente associado ao sobrepeso e obesidade estão diversas doenças, dentre elas hipertensão arterial, diabetes, dislipidemia, apnéia do sono, artropatias, colecistopatias, câncer e distúrbios psicológicos, com considerável morbimortalidade. Devido sua causa multifatorial, seu tratamento apresenta-se como um desafio, sendo a abordagem interdisciplinar a que tem se mostrado o método em longo prazo mais efetivo no controle do sobrepeso e obesidade, associado à cirurgia bariátrica quando necessário. Porém, para o sucesso cirúrgico, tão importante quanto à compensação das comorbidades clínicas é o adequado acompanhamento psicológico.

Nota-se que a alimentação inadequada e o sedentarismo têm sido uns dos principais fatores desta situação. Com o passar dos anos a alimentação saudável vem sendo substituída por alimentos de alto valor calórico e com pouco valor nutricional juntamente com mudanças nos hábitos de vida atual como excesso de trabalho, estresse, poucas atividades relacionadas ao lazer, que colaboram para a adoção de um estilo de vida ruim. O acúmulo excessivo de gordura no tecido adiposo ocorre normalmente por um desequilíbrio entre a ingestão de alimentos e o dispêndio energético.

Além dos prejuízos físicos e aumentos significativos dos custos com o tratamento, a obesidade também pode causar alterações comportamentais. Pessoas com excesso de peso são alvos de discriminação e preconceito, contribuindo para a manifestação de distúrbios psicossociais, citado como exemplo o transtorno de compulsão alimentar periódica, que consiste em ingerir grandes quantidades de alimentos em um curto período de tempo, acompanhado do sentimento de perda do controle e de culpa. O comer compulsivo pode estar ligado a outros transtornos psiquiátricos, sendo os mais frequentes, a ansiedade e a depressão.

Diferente de outras doenças, a obesidade tem incidência semelhante em diferentes idades, classes sociais e raças, sendo sua etiologia multifatorial, em que se pode destacar a genética, a ausência de atividades físicas, além de componentes psicológicos e sociais como fatores determinantes de sua ocorrência. 


\section{Desafios da psicologia no Brasil}

Os estudos relatam a necessidade de acompanhamento e tratamento desses pacientes, com visitas freqüentes, permitindo maior adesão ao tratamento e melhor resultado. Assim, faz-se necessária terapêutica interdisciplinar para exploração de assuntos quanto à importância da alimentação equilibrada, a prática de atividades físicas para adoção de um estilo de vida melhor, o acompanhamento e tratamento de transtornos psicológicos como a ansiedade, a depressão, e a inserção do indivíduo ao meio social, sendo estes realizados em único espaço físico com os profissionais envolvidos. Quando de indicação cirúrgica, este receberá as orientações quanto aos critérios pré-estabelecidos pelo nosso Serviço de Referência - UNICAMP, que após tratamento em sua própria cidade, será encaminhado para realização da mesma. É estabelecida uma meta de redução ponderal que varia de $5 \%$ a $10 \%$ do peso atual para este indivíduo, e esse compromisso é assumido por ambas as partes perante todo o grupo. São desenvolvidas atividades interativas, nas quais aborda a obesidade e seu tratamento, cirurgia bariátrica com suas indicações, contraindicações, modalidades, complicações imediatas e tardias e resultados reais. Além de tudo isso, que todos os participantes tornem-se multiplicadores desta informação para conhecidos e familiares.

Em 2009 foi criado o GRUPO GESTO (Grupo Educacional em Saúde e Tratamento da Obesidade), oferecido gratuitamente pelo setor público em duas cidades do interior de São Paulo e 01 cidade interior de Minas Gerais, com equipe constituída atualmente por 15 profissionais da saúde, sendo 1 médico cirurgião geral, 1 médico cardiologista, 1 psicólogo, 1 nutricionista, 1 fisioterapeuta, 1 educadora física, 2 enfermeiros e 7 técnicos de enfermagem e contando ainda, com a participação de profissionais convidados, que voluntariamente contribuem com o trabalho.

O objetivo principal do grupo educacional interdisciplinar é conscientizar a população quanto às mudanças no estilo de vida e nos hábitos alimentares para a promoção à saúde aos portadores de sobrepeso e obesidade com ou sem co-morbidades associadas. Não restringindo a participação de indivíduos sadios que queiram apenas aprender a se alimentar de forma balanceada e melhorar o convívio social. Sendo assim, verificar a adesão ao tratamento e os efeitos da terapia de longo prazo sobre a qualidade de vida para o bem-estar físico e mental.

\section{METODOLOGIA}

O Grupo GESTO é acessível a toda população das 02 cidades do interior de São Paulo, e 01 cidade do interior de Minas Gerais com idade entre 16 e 70 anos de ambos os sexos. O cadastro dos interessados é realizado mensalmente em dia pré-estabelecido, sendo a inclusão dos pacientes no grupo por 


\section{Desafios da psicologia no Brasil}

indicações médicas, agentes comunitários de saúde, ambulatórios de especialidades, postos de saúde da família e demanda espontânea, onde a triagem é realizada pela equipe multidisciplinar.

São submetidos à anamnese clínica (médica, nutricional e psicológica) e realizado coleta de dados psicológicos e principais características psicológicas, questionário de hábitos alimentares e dados antropométricos como peso, altura, circunferência de pescoço, braço, cintura, abdômen e quadril.

Após o cadastro, classificam-se os participantes em dois grupos, os que têm indicação para cirurgia bariátrica seguindo os critérios do Ministério da Saúde para seleção, onde atualmente o obeso precisa ter um Índice de Massa Corporal (IMC) igual ou superior a $35 \mathrm{~kg} / \mathrm{m} 2$ e apresentar doenças associadas como o diabetes ou a hipertensão arterial ou um IMC superior a $40 \mathrm{~kg} / \mathrm{m} 2$ (GRUPO A) e o grupo de reeducação alimentar (GRUPO B).

É aplicado posteriormente Escala Beck: inventário de depressão (BDI) e inventário de ansiedade (BAI) pela psicóloga e um questionário de frequência alimentar pela nutricionista. Após a coleta inicial dos dados pertinentes ao tratamento, o paciente participa de encontros semanais, com média de duração de 3 horas por encontro, onde são registrados perda de peso, IMC e pressão arterial. Os grupos com indicação cirúrgica e reeducação alimentar acontecem simultaneamente.

Os integrantes participam de forma ativa de palestras das áreas psicológicas, nutricionais e médicas, além de palestras extras com convidados voluntários, dinâmicas de grupos, oficinas de culinária, exercícios de alongamentos, exercícios de conscientização corporal, e recebem planos alimentares elaborados para cada fim.

\section{RESULTADOS E DISCUSSÃO}

O Grupo GESTO tem como banco de dados até Dezembro de 2014, 597 pacientes ativos. Desde a implantação do programa, foram assistidos 4.870, com a média de 840 pacientes anuais.

Foram realizadas ao longo de sete anos de trabalho, 37 cirurgias bariátricas, estas encaminhadas ao serviço de referência na cidade de Campinas. A redução de peso anual por pessoa é em média 10,23\% e a diminuição do IMC (Índice de Massa Corporal) por pessoa é de 5,05 pontos.

Cada indivíduo perde por mês a média de $1,250 \mathrm{~kg}$, num total de aproximadamente $15 \mathrm{~kg}$ ao ano. 


\section{Desafios da psicologia no Brasil}

Foram estudados 164 homens e 463 mulheres com idade entre 16 a 70 anos e IMC médio de $37,3 \mathrm{~kg} / \mathrm{m}^{2}$ (obesidade grau II). O nível de escolaridade predominante foi o ensino médio completo representando $62 \%$ da população estudada e, 86,7\% tinham emprego fixo.

Em relação ao uso de substâncias químicas, $72 \%$ já haviam usado algum tipo de droga antidepressiva, sendo entre estas com maior freqüência a fluoxetina, uso de sibutramina em 61,5\% e femproporex em $28,3 \%$. Foi observado uso de laxantes em $43,5 \%$ da população como alternativa para emagrecer, e outras fórmulas alternativas de nomes não identificados pelos participantes em 63,2\%.

Quanto ao desejo para mudança, 93,3\% estavam dispostas a mudar o seu comportamento em relação à comida, sendo este dado definido na entrevista inicial.

Nos resultados deste trabalho, foi verificada ao longo dos encontros, uma melhora significativa quanto às escolhas de alimentos mais saudáveis, aumento na procura de algum tipo de atividade física, estes refletindo diretamente nos níveis de motivação pessoal.

Verificou-se que com a diminuição do isolamento social os indivíduos apresentaram uma disposição para participação em atividades sociais como caminhadas e passeios.

Muitos integrantes do grupo passaram a preencher de forma espontânea seu diário alimentar e começaram a contribuir com depoimentos frente ao demais participantes, alguns se tornando voluntários da equipe.

Observou-se também um aumento na motivação, e melhora significativa quanto à expressão dos afetos.

O obeso geralmente enfrenta algum tipo de preconceito ao longo da sua vida afetiva e da sua carreira profissional. Estes acontecimentos podem contribuir de forma significativa para o isolamento social, a baixa auto-estima, a ansiedade os sintomas depressivos e conseqüentemente para o uso de alimentos, geralmente hipercalóricos, como forma compensatória.

Quanto às mudanças ocorridas nos sintomas de depressão e na compulsão alimentar, os resultados mostraram uma diferença significativa na reavaliação após a freqüência de seis meses no programa. A melhora na sintomatologia geral dos pacientes como o isolamento social, a ansiedade, os sintomas depressivos, a evolução no perfil nutricional e antropométrico, a redução do uso de medicamentos, a 


\section{Desafios da psicologia no Brasil}

resolução de algumas comorbidades como dislipidemia, hipertensão arterial, diabetes mellitus foram significativos após experiência e tratamento oferecido pela interdisciplinaridade.

A experiência realizada em grupo, esta intimamente relacionada à melhora e interação entre os membros, fazendo com que o sentimento de inclusão e a identificação com o problema sejam mais bem compreendidos e aceitos.

O atendimento grupal também aponta para outros pontos terapêuticos importantes como o aumento da motivação, o estabelecimento de metas e a socialização.

\section{CONSIDERAÇÕES FINAIS}

Ao longo destes sete anos de trabalho, é possível concluir que a proposta do trabalho interdisciplinar com relação ao problema da obesidade, realizado em um único espaço físico pela equipe sem sistema rotatório de palestras, apresentou resultados positivos nestas duas cidades atendidas pelo programa educacional Gesto.

O enfoque médico, nutricional e psicológico abordou a obesidade de diferentes ângulos, propiciando maior aceitação do trabalho junto aos demais indivíduos.

A perda de peso, a remissão dos sintomas da compulsão alimentar e a diminuição de comportamentos ansiosos e depressivos foram significativas entre os participantes que permaneceram no mínimo seis meses dentro do programa proposto. A exposição de temas relacionados não somente a obesidade, como também temas que levaram a maior reflexão sobre a questão do próprio posicionamento diante da vida, das escolhas, da possibilidade de obter outros caminhos, mostraram que os participantes conseguiram uma maior conscientização do seu problema e do seu significado emocional, quando se refere à alimentação.

O grupo Gesto espera contribuir de alguma forma para melhoria da qualidade de vida, a fim de compreender a obesidade na sua forma mais ampla, como um sofrimento que afeta milhões de pessoas, tendo como resultado imediato a redução de cinco toneladas desde o início do trabalho, e assim, possa dar continuidade em suas atividades, refletindo seu sucesso para a população.

\section{REFERÊNCIAS}

ALMEIDA, G. A. N.; SANTOS, J. E.; PASIAN, S. R.; (2005). Percepção de tamanho e forma corporal de mulheres: estudo exploratório. Psicologia em Estudo, 10(1), 27-35. 


\section{Desafios da psicologia no Brasil}

ANDRADE, L. H. S. G.; GORENSTEIN, C. (1998). Aspectos gerais das escalas de avaliação de ansiedade. Revista de Psiquiatria Clínica, 25(6). Recuperado

de http://www.hcnet.usp.br/ipq/revista/vol25/n6/ansi256a.htm.

ANDRADE, S. G. Teoria e prática de dinâmica de grupo: jogos e exercícios. 5ạ. ed. São Paulo: Casa do Psicólogo, 2010. 203 p.

ARASAKI, C. H. (2005). Cirurgia bariátrica para tratamento da obesidade. In A. M Claudino \& M. T. Zanella (Orgs.), Guia de transtornos alimentares e obesidade (pp. 287-296). São Paulo: Manole.

AVILA, L.A. O eu e o corpo. São Paulo: Escuta, 2004. 208 p.

CASH, T. F.; PRUZINSKY, T. (2002). Body Image: a handbook of theory, research, and clinical practive. Nova Iorque: Guilford Press.

CRUZ, M. R. R.; MORIMOTO, I. M. I. (2004). Intervenção nutricional no tratamento da obesidade mórbida: resultados de um protocolo diferenciado. Revista de Nutrição, 17(2), 263-272.

CUNHA, J. A. (2001). Manual da versão em português das Escalas de Beck. São Paulo: Casa do Psicólogo.

DIXON, J. B.; DIXON, M. E.; O’Brien, P. E. (2003). Depression in association with severe obesity: Changes with weight loss. ArchivesofInternal Medicine, 163(17), 2058-2065.

FRANQUES, A. R. M.; Ascencio, R. F. R. (2006). Depressão e obesidade. In A.

R. M. Franques\& M. S. A. Loli (Orgs.), Contribuições da psicologia na cirurgia da obesidade (pp. 125135). São Paulo: Vetor.

FRANQUES, A. R. M.; ARENALES-LOLI, M. S. Contribuições da psicologia na cirurgia da obesidade. São Paulo: Vetor, 2006. 279 p.

MELLO FILHO, J.; BURD, M.; COLABORADORES. Psicossomática hoje. 2ạ. ed. São Paulo: Artmed, 2010. $616 \mathrm{p}$.

OSÓRIO, L. C.; COLABORADORES. Grupoterapia hoje. 2a. ed. São Paulo: Artes Medicas, 1989. 358 p.

PICHON-RIVIERE, E. O processo grupal. 8ạ. ed. São Paulo: Wmf Martins Fontes, 2009. 296 p.

ROGERS, C. R. Grupos de encontro. 9ạ. ed. São Paulo: Wmf Martins Fontes, 2009. 216 p.

TAVARES, M. C. C. (2003). Imagem corporal: conceito e desenvolvimento. São Paulo: Manole.

XIMENES, E. Cirurgia da obesidade: um enfoque psicológico. São Paulo: Santos, 2009. 160 p.

ZANCANER, M. S. (2012). O papel do psicólogo no período perioperatório hospitalar de cirurgia bariátrica. In A. R. M., Franques\& M. S. A Arenales-Loli (Orgs.), Novos corpos, novas realidades: reflexões sobre o pós-operatório da cirurgia da obesidade (pp. 13-30). São Paulo: Vetor. 


\section{Capítulo 34}

\section{OLHARES SOBRE A MEDIAÇÃO ESCOLAR NO RIO DE JANEIRO}

DOI: $10.37423 / 200200233$

Imira Fonseca de Azevedo (UFRJ - imirafonseca@gmail.com)

Leila Sanches de Almeida (UFRJ - leilasanches@ufrj.br)

RESUMф: Atualmente, à inclusão escolar é tema de reflexão no m(eio acadêmico. Este processotem gerago discussõos sobre os sistemas educácionais brasileiros, especialmente no que diz respeito aos procedimentos de avaliação escolar. Falár sobre inclusão e avaliação escolar leva-a que se fale sobre mediaçăo escolar. Assim, este estudo, baseado na teoria de González Rey, teve como objetivo conhecer a atuação de mediadores em escolas do Rio de Janeiro. O estudo foi desenvolvido em três escolás particulares. A análise de conteúdo sobre as 16 entrevistas mostrou que a mediação é uma atividade jimportante para-a inclusão de crianças. o mediador é consideradoja pessoa que faz una ponte entre o aluno e o conteúdo escolar,é quem ajuda esse aluno a se desenvolver. Os mediadores relataram ter boa afinidade com as crianças, mas apontaram dificuldades com als famílias e as equipes pedagógicas na realização do seu trabalho.

Palavras-chave: inclusão, medłação escol an mediadores, subjetividade.

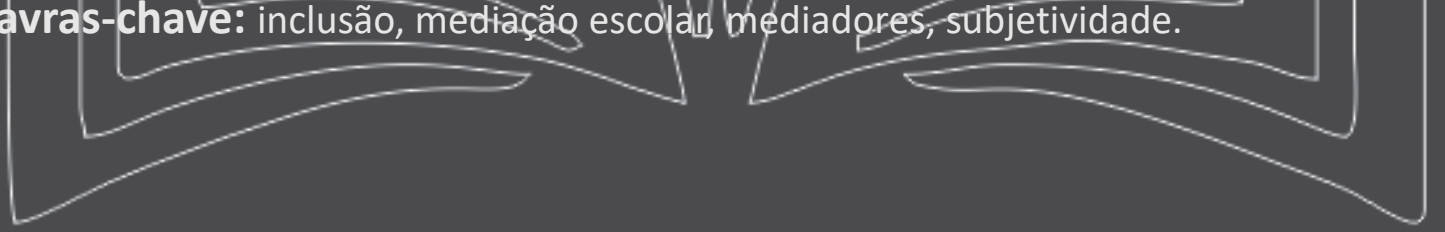




\section{Desafios da psicologia no Brasil}

\section{INTRODUÇÃO}

A década de 1990 foi marcada por reuniões internacionais que advogaram pelo acesso obrigatório de toda a população à educação. Nestas reuniões, foram formuladas duas declarações que influenciaram as práticas educacionais em diversos países, inclusive o Brasil: a Declaração Mundial sobre Educação para Todos, de Jomtien (UNESCO, 1990) e a Declaração de Salamanca (UNESCO, 1994), firmada na Conferência Mundial sobre Necessidades Educacionais Especiais. Segundo esta declaração, as escolas regulares devem acomodar todas as crianças, independentemente de suas condições físicas, intelectuais, sociais e emocionais (Roriz, Amorim, \& Rossetti-Ferreira, 2005).

Assim, as escolas do mundo inteiro iniciaram o processo de inclusão dos alunos que frequentavam as classes especiais para as classes regulares. Este processo gerou muitas reflexões sobre os sistemas educacionais brasileiros, em especial quanto aos modelos pedagógicos vigentes, aos procedimentos de avaliação e à adequação das escolas (Freitas, 2008). Dentre algumas alternativas implantadas pelas escolas e responsáveis dos alunos, surgiu a figura do mediador escolar. Segundo Mousinho e colaboradoras (2010), o mediador escolar começou a atuar de forma mais frequente no Brasil em 2000. Geralmente, essa função é exercida por profissionais diversos das áreas de Educação e Saúde.

Embora seja uma atividade que vem se tornando mais frequente ao longo desses 14 anos, há poucos estudos que apontam para o alcance das atividades pedagógicas desenvolvidas pelos mediadores escolares e para as novas relações que se estabelecem na presença dessa pessoa na sala de aula. Uma vez que grande parte das crianças acompanhadas por mediadores escolares são crianças com transtornos globais do desenvolvimento e com deficiências, investigações sobre o papel e as atividades do mediador escolar são de extrema importância, inclusive para que se possa conhecer indicadores das estratégias de aprendizagem dessas crianças.

Assim, este estudo teve como objetivo principal, a partir da Teoria da Subjetividade de Gonzalez Rey, conhecer a atuação de mediadores em escolas particulares do município do Rio de Janeiro. Especificamente, visou conhecer a figura do mediador escolar e suas atividades.

\section{A SUBJETIVIDADE POR GONZÁLEZ REY}

Fernando González Rey desenvolveu sua teoria da Subjetividade com o objetivo de compreender como se caracteriza a relação dialética estabelecida entre o indivíduo e a sociedade (Gomes, \& Souza, 2012). É uma teoria que está marcada por um movimento social que pretendia desenvolver uma 


\section{Desafios da psicologia no Brasil}

psicologia menos individualizada e mais comprometida com as práticas sociais nos países da América Latina na década de 1980 (González Rey, 2003).

Baseado na psicologia de Vigotsky, González Rey (2003) afirma que a compreensão do sujeito não pode estar baseada em argumentos deterministas, como as explicações que partem da biologia, ou que entende o sujeito como um ser formado apenas por seu aspecto cognitivo ou, ainda, como um ser resultante de pulsões. Sua teoria contempla a dialética entre o sujeito e o mundo, com interações entre a subjetividade individual e subjetividade social.

González Rey conceitua a subjetividade enquanto um "sistema de significações e sentidos subjetivos em que se organiza a vida psíquica do sujeito e da sociedade" (González Rey, 2002, p. viii). Ela não é tomada como uma realidade intrapsíquica, mas sim enquanto um sistema aberto que se constitui nos processos sociais.

A subjetividade individual e a social são interatuantes e integrantes de um processo complexo de produção de sentidos. A subjetividade individual é marcada pela organização que integra o funcionamento psicológico de um sujeito concreto (Tacca; González Rey, 2008) e se constitui em espaços sociais historicamente construídos (González Rey, 2003), enquanto que a subjetividade social resulta da produção de sentidos que caracteriza todos os cenários da vida social e que sustenta os espaços sociais (González Rey, 2003).

Uma das formas de expressão da subjetividade social é o discurso. Ele está organizado em diversos sentidos subjetivos que auxiliam na compreensão da realidade social (González Rey, 2003).

Portanto, ao se colocar em foco a questão da inclusão escolar é necessário ter em consideração que a subjetividade social da escola é composta por muito mais elementos do que as interações geradas dentro da escola (González Rey, 2003). Como espaço de subjetividade social, o discurso sobre a escola é influenciado e reconstruído pelas subjetividades individuais de alunos, professores, pais de alunos, mediadores, que por sua vez, constituem suas próprias subjetividades com aspectos de outros ambientes e espaços sociais. Além disso, esses indivíduos apresentam sentidos diferentes para as experiências de inclusão. 


\section{Desafios da psicologia no Brasil}

\section{BREVES CONSIDERAÇÕES SOBRE EDUCAÇÃO ESPECIAL}

Ao longo da história da humanidade, existiram diferentes formas de se lidar com pessoas que eram designadas como "diferentes" ou "anormais".

O percurso histórico da escolarização dos indivíduos considerados deficientes começou na época em que eles eram submetidos à internação em grandes instituições. A internação atendia ao desejo social de isolamento do anormal em defesa da proteção da sociedade normal (Mendes, 2006). Foi somente no século XVI que alguns profissionais, principalmente médicos e pedagogos, que atuavam nas instituições totais, passaram a acreditar na possibilidade de que tais pessoas pudessem aprender.

Com o passar dos anos, diante de mudanças geradas por lutas sociais a favor dos deficientes e por condições econômicas e políticas, a situação das pessoas com deficiência sofreu alterações. Foi conquistado o direito pelo não isolamento total em instituições. Com isso, elas passavam o dia nas instituições, porém voltavam para suas casas à noite (Omote, 2008).

No final do século XIX, em São Paulo e no Rio de Janeiro, foram implementadas classes especiais, vinculadas a escolas públicas, para que alunos com deficiência pudessem estudar (Mendes, 2006). Contudo, a formalização das classes especiais só ocorreu após a Constituição de 1946, que reconhecia a educação como um direito universal (Pletsch, 2009).

Na metade final da década de 1960 e durante toda a década de 1970, os questionamentos e a pressão social em favor dos direitos das pessoas com deficiência fizeram emergir o movimento denominado Integração Escolar (Machado, 2005). Seu lema era que a interação entre alunos com deficiência e sem deficiência é proveitosa para ambos os grupos. Nesse período, os achados de pesquisas educacionais também se constituíram como fatores que impulsionavam para uma mudança nas práticas.

Entretanto, enquanto na teoria se pensava em participação ampla na sociedade, as práticas integradoras ainda se constituíam, em sua maioria, como segregadoras. Apesar de se aceitar o direito de convivência dos deficientes, permanecia a idéia de que eles precisavam ser preparados para isso (Mendes, 2006). Essa preparação, na verdade, acabava por manter a segregação porque era baseada somente nos avanços conseguidos pelo aluno. Isto é, cabia aos alunos de classes e escolas especiais toda a responsabilidade pelo seu progresso, para ser considerado apto a participar da sociedade (Glat, Pletsch, \& Fontes, 2007). 


\section{Desafios da psicologia no Brasil}

Tendo em vista a manutenção das desigualdades que ainda contemplavam os deficientes, principalmente no campo da educação, no final dos anos 1980 e início dos anos 1990, o movimento da Inclusão ganhou força nos Estados Unidos e, pela grande influência política desse país, alcançou o mundo (Mendes, 2006). Como marcos desse movimento temos as declarações elaboradas nas convenções de Jomtien e Salamanca, anteriormente mencionadas.

A principal diferença entre o movimento de Integração e o de Inclusão é a ênfase dada ao processo de aprender: o foco não está mais na deficiência do aluno, ele não é mais o responsável pela sua inserção. Agora, olha-se para o ambiente, principalmente para a escola. Cabe investigar as características que falharam, ou não, na promoção da aprendizagem (Glat, Fernandes, \& 2005).

A educação inclusiva almeja que todos possam aprender, participar na sala de aula e não somente ocupar um lugar na classe (Sanches, \& Teodoro, 2006). A educação precisa ser apropriada, respeitando as capacidades e necessidades de cada aluno, assim como deve levar em consideração as características do ambiente onde as crianças se encontram (Brandão, \& Ferreira, 2013).

Nessa nova proposta de educação, as antigas classes e escolas especiais são transformadas em centros especializados e salas de recursos, que não podem substituir o ensino regular, mas aparecem como locais apropriados para o atendimento de apoio especializado (Alves, \& Barbosa, 2006).

\section{A MEDIAÇÃO ESCOLAR}

A mediação escolar é desenvolvida em diversos países, principalmente nos Estados Unidos, onde os profissionais atendem pelo nome de "teacher aide", "paraeducator", entre outros (Mousinho et al., 2010).

O mediador escolar existe no EUA há mais de 40 anos. O primeiro grande programa de recrutamento de mediadores aconteceu no final da década de 1960, para auxiliar os professores com as crianças que apresentavam dificuldades de aprendizagem (White, 2004).

Diferentemente da realidade estadunidense, não há no Brasil uma legislação que regulamente a função de mediador escolar. Há um projeto de lei relacionado à mediação que tem por objetivo "assegurar a presença de um cuidador na escola, quando necessário, ao educando com deficiência", mas não há a menção do nome "mediador" no documento. Também não há uma descrição clara das funções que devem ser realizadas pelo cuidador. 


\section{Desafios da psicologia no Brasil}

Assim, a começar pelo nome, este cargo parece estar mais vinculado ao cuidado físico da criança do que ao desenvolvimento cognitivo e pedagógico da mesma.

Diante da falta de uma clara definição de mediação escolar, adotamos o conceito do mediador escolar como "o intermediário nas questões sociais e de comportamento, na comunicação e na linguagem, nas atividades e/ou brincadeiras escolares, e nas atividades dirigidas e/ou pedagógicas na escola" (Mousinho et al., 2010, p. 95).

Assim, Mousinho e colaboradoras destacam a atuação do mediador escolar com crianças e adolescentes com dificuldades de diversas ordens, como motoras, de concentração e impulsividade, de leitura, comportamentais e de comunicação e interação. Como consequência, podemos perceber que o mediador escolar tem um campo de atuação muito maior que o das deficiências (deficiência visual, auditiva, intelectual, física e múltipla).

No município do Rio de Janeiro, encontramos o trabalho do mediador escolar tanto na esfera privada, quanto na pública. Nas escolas particulares, essa figura é chamada de mediador escolar (Mousinho et al., 2010) ou de facilitador (Carvalho, 2008). Geralmente, os mediadores que atuam nas escolas particulares são profissionais ou estudantes das áreas de saúde e educação (Mousinho et al., 2010), principalmente pedagogos, psicólogos e fonoaudiólogos. Já em escolas públicas, além do agente de apoio à educação já mencionado, essa função corresponde ao professor itinerante e/ou mediadorestagiário.

O ensino itinerante foi implementado na cidade do Rio de Janeiro em 1996. É um serviço de assessoria às escolas regulares que possuem alunos com necessidades educativas especiais nas turmas regulares. O professor itinerante acompanha os alunos e professores dentro da sala de aula. Além disso, pode prestar assessoria à direção e outras equipes da escola (Secretaria Municipal de Educação, 1999).

Outra figura encontrada nas salas de aula das escolas municipais é o mediador-estagiário (Cunha, Glat, Silva, \& Siqueira, 2012). Estes mediadores são alunos de cursos de graduação de faculdades públicas e privadas conveniadas com a Prefeitura do município do Rio de Janeiro. A capacitação para esses estagiários consiste, em média, em duas aulas teóricas por semestre, durante o período de atuação na escola. Cunha, Glat, Silva, \& Siqueira (2012) apontam que os estagiários desempenham função semelhante ao professor itinerante. Quando chegam às escolas, na maioria das vezes, não têm experiência, nem sabem qual é a necessidade educacional especial da criança que acompanharão. 


\section{Desafios da psicologia no Brasil}

Diferentemente do professor itinerante, que trabalha com várias crianças ao mesmo tempo em dias alternados, o mediador-estagiário cumpre toda a sua carga horária com a mesma criança.

\section{REPERCUSSÕES DO TRABALHO DO MEDIADOR ESCOLAR}

Ao longo do tempo de atuação dos mediadores escolares nos Estados Unidos, muitas pesquisas foram realizadas para investigar os efeitos desse trabalho e como os mediadores se sentem ao desenvolver suas atividades. Em contrapartida, no Brasil, poucos são os estudos que abordam esse tema.

No que se refere ao relacionamento entre mediadores e professores e a equipe de direção das escolas, muitos mediadores estadunidenses afirmaram se sentir desvalorizados. Eles alegam que, apesar de estarem interagindo com mais proximidade da criança, não são solicitados a emitir opiniões em reuniões e conselhos de classe sobre as crianças (Fisher, \& Pleasants, 2012; Riggs, \& Mueller, 2001).

Um estudo brasileiro conduzido por Carvalho (2008) obteve um dado semelhante. As mediadoras entrevistadas afirmaram que encontravam dificuldades no relacionamento com os professores regulares das classes. Este tipo de queixa era comum ainda quando uma mediadora também trabalhava, na mesma escola, em outro turno como professora. No turno que atuava como mediadora, eram visíveis diferenças no tratamento recebido dos colegas. Eles não atribuíam o devido valor ao papel de mediadora, de modo que, por exemplo, sua opinião sobre a criança que acompanhava não era requisitada.

Um outro achado a ser destacado das pesquisas estadunidenses é o excesso de responsabilidade que os mediadores atribuem a si mesmos. Mediadores entrevistados por Levine, Marks e Schrader (1999) afirmaram, entre outras coisas, ser responsáveis pelo processo de aceitação do aluno pelo professor regente. Daí que acreditavam que deviam manter a criança calma para não perturbar a sala de aula. Quando não conseguiam, sentiam-se frustrados e estressados. Eles consideravam que Ihes cabia controlar o comportamento do aluno porque julgavam que o professor regular não tinha influência nesse comportamento. Quando perguntados sobre a consulta ao professor para desenvolver as atividades com a criança, os mediadores afirmaram que só recorriam aos professores em última instância, quando realmente não sabiam o que fazer. Além disso, eles se posicionaram como um elo na escola. Por sua proximidade com a criança, eles deviam congregar as diferentes solicitações da família, de professores e de os outros profissionais envolvidos. Cabe destacar ainda neste estudo de Levine, Marks e Schrader (1999) uma queixa dos mediadores. Eles relataram que muitas escolas onde 


\section{Desafios da psicologia no Brasil}

atuavam não entendiam o propósito da inclusão e tratavam o aluno incluído com descrédito, afirmando que ele deveria estar em uma classe especial.

No Brasil, em um estudo que elaborou um programa para ensinar professores e mediadores a utilizar recursos de Comunicação Alternativa e Informática Acessível, desenvolvido em duas escolas municipais do Rio de Janeiro, Nunes et al. (2013) perceberam que as mediadoras que foram convidadas a participar da pesquisa se envolveram muito mais com as atividades do que as professoras das turmas. As professoras alegavam não ter tempo para participar das reuniões e não alteravam em nada suas práticas pedagógicas enquanto que as mediadoras, após a intervenção, passaram a buscar maior participação da turma na aprendizagem do aluno que acompanhavam, elaboraram estratégias próprias para melhorar suas ações pedagógicas e utilizaram os recursos apresentados pelas pesquisadoras para incentivar e ajudar na produção de textos orais e escritos dos alunos.

Alguns trabalhos (Giancreco, \& Broer, 2005; Cunha, Glat, Silva, \& Siqueira, 2012) apontam que o mediador escolar cumpre um papel paliativo no processo de inclusão escolar. Os mediadores surgiram nos Estados Unidos para suprir a carência de professores na educação especial e se mantém atuantes até os dias de hoje, sem que o problema da carência de professores fosse sanado, mesmo após quatro décadas. No Brasil, acentua-se a gravidade do problema, uma vez que sequer existe legislação a esse respeito. Não há nada que oriente a prática do mediador.

Com isso, tanto em nosso território quanto em outros países, pessoas com pouca capacitação e experiência estão se tornando os responsáveis, quase que exclusivos, pelo processo de aprendizagem de crianças que muito necessitam de auxílio e intervenção (Fisher; Pleasants, 2012; Giancrego, \& Broer, 2005). A falta de embasamento teórico e prático propicia que os mediadores acabem se tornando apenas "cuidadores" das crianças, ou seja, evitando que elas atrapalhem a aula. O foco no controle do comportamento impede que os mediadores se voltem para sua tarefa real: facilitar o processo de aprendizagem do aluno, assim como a sua socialização com a turma (Cunha, Glat, Silva, \& Siqueira, 2012).

Essa dificuldade com o manejo na sala de aula, especialmente com o professor, tem revelado outro aspecto negativo da presença do mediador na sala de aula: promove um distanciamento entre o professor regular e o aluno assistido pelo mediador (Carvalho, 2008; Giancrego, \& Broer, 2005; Fisher, \& Pleasants, 2012; Levine, Marks, \& Schrader, 1999; Daniels, \& Mcbride, 2001; Nunes et al., 2013). Mesmo quando os professores demonstram ter preocupação com o aluno com necessidades 


\section{Desafios da psicologia no Brasil}

educacionais especiais, a presença do mediador lhes suscita um pensamento de que aquela criança já está recebendo atenção suficiente, logo, ele pode se dedicar às outras crianças (Netto, 2012).

\section{METODOLOGIA}

O presente estudo adotou a metodologia qualitativa. Minayo e Sanches (1993) concebem a abordagem qualitativa como a mais apropriada para estudos desenvolvidos no âmbito da subjetividade e seus processos, na medida em que ela facilita a compreensão das relações humanas e dos significados produzidos nessas interações.

González Rey (2002) destaca, ainda, o que considera uma primazia da pesquisa qualitativa: seu processo de investigação não pressupõe a existência de uma única realidade. Pelo contrário, entende que a interação entre pesquisador e participante da pesquisa faz emergir diferentes pontos de vistas que compreendem múltiplas realidades. E é para essa complexidade da produção de sentidos que a pesquisa qualitativa se volta.

Contexto do estudo e participantes

Este estudo de campo foi desenvolvido em três escolas particulares, localizadas em diferentes zonas do município do Rio de Janeiro: zona norte, sul e oeste.

A escola representante da zona norte é uma escola católica, dirigida por freiras. Nesta escola, participaram da pesquisa a mediadora Fernanda, a diretora pedagógica Ruth, a professora Paula e a mãe Beatriz.

$\mathrm{Na}$ escola da zona sul, participaram duas mães de alunos com necessidades educacionais especiais (Ana e Cintia), duas mediadoras (Roberta e Gabriela) e uma supervisora de inclusão de uma escola (Valéria).

Na escola da zona oeste contamos com a participação do diretor do estabelecimento (Tadeu), da supervisora pedagógica (Barbara), da professora (Maria), da mediadora (Camila) e da mãe do aluno (Denise).

Por fim, também fizeram parte do estudo duas ex-mediadoras, Aline e Manuela.

\section{PROCEDIMENTOS E INSTRUMENTO}

O projeto deste estudo foi submetido e aprovado pelo Comitê de Ética do Centro de Filosofia e Ciências Humanas (CFCH) da Universidade Federal do Rio de Janeiro (UFRJ). 


\section{Desafios da psicologia no Brasil}

Para o processo de seleção dos participantes, utilizou-se a técnica da "bola de neve", que possibilita o acesso a possíveis participantes pela indicação de um ou dois informantes iniciais (Bernard, 2006).

Realizou-se, em um primeiro momento, um contato com a diretora da escola da zona norte. Em seguida, foi feito contato com os participantes por ela indicados, e assim sucessivamente. Uma vez que o sujeito demonstrasse interesse em participar do estudo, lhe era informado o objetivo da pesquisa e agendada uma entrevista.

As entrevistas realizadas foram integralmente transcritas e submetidas à análise de conteúdo (Bardin, 1977).

Todos os participantes do estudo assinaram um Termo de Consentimento Livre e Esclarecido.

Resultados e discussão

Mais do que conhecer exatamente as funções do mediador, coloca-se como ponto fundamental para a compreensão do processo de mediação, a necessidade de se saber o que a escola pratica como inclusão.

O conceito de inclusão se revelou muito complexo. Ele é composto por diversos fatores, que assumem diferentes níveis de importância para cada participante, além de, algumas vezes, ter se modificado em dados momentos da entrevista. Todo trabalho desenvolvido pelo mediador e pela escola mostrou-se relacionado ao sentido individualmente atribuído à inclusão.

Tal como apontado por Glat, Plestch e Fontes (2007), as atividades desenvolvidas com as crianças com N.E.E. (necessidades educacionais especiais) e o limite de atuação dos mediadores em algumas escolas revelam que ainda existem traços da política de integração escolar que se misturam, nas práticas desses profissionais, com as metas de inclusão. Glat, Plestch e Fontes (2007) consideram ser esta a realidade de muitas escolas brasileiras que, apesar de privilegiarem o discurso de aceitação da diversidade, na prática, não reorganizam o sistema escolar para atender a esses alunos, deixando-lhes, muitas vezes, deslocados em sala de aula ou sob a responsabilidade do mediador.

Alguns relatos de Roberta e Gabriela, mediadoras da escola da zona sul, ilustraram bem essa situação. Roberta afirmou que muitas escolas não estão preparadas para receber os alunos de inclusão. Ainda que preguem esse discurso, na prática, a criança vira apenas uma expectadora do que está sendo feito em sala de aula, principalmente quando não pode ter um mediador ao seu lado. 


\section{Desafios da psicologia no Brasil}

A situação vivida por Gabriela exemplifica a fala de Roberta. Ela considera seu trabalho limitado. Disse que não pode fazer nenhum tipo de adaptação para Milton, assim como não pode participar de nenhuma reunião sobre o menino. Vê-se, nesses casos, a impossibilidade de se considerar que haja inclusão. Ao contrário, a criança está apenas dentro de sala, mas não pode participar de nada. Outro exemplo que demonstra que as escolas não necessariamente transformam o discurso de inclusão em ação, foi dado pela ex-mediadora Aline. Ela contou que, muitas vezes, quando iniciava uma mediação, encontrava as crianças deitadas em um canto da sala e era advertida pelas professoras a não acordálas. Tais práticas remetem aos processos de inclusão excludente. Isto é, aparentemente, a inclusão é realizada porque a criança está na sala regular, mas ela não é respeitada em suas particularidades e, pior, é tomada como um perigo, uma grande ameaça.

Outros entrevistados, ao falarem sobre a atuação do mediador, também relataram que, frequentemente, ele se torna o único responsável pela criança que acompanha. Assume, assim, todo o dever pelo desenvolvimento daquele aluno.

abriela (mediadora) e Manuela (ex-mediadora) exemplificaram situações dessa ordem, em que a inclusão não ocorria. Por muitas vezes, elas perceberam que os professores se afastavam dos alunos, não os consideravam da turma porque essas crianças contavam com mediadores. Assim, não preparavam a tarefa para a criança, não tentavam fazê-la participar das atividades em grupo. Todas as atividades de aprendizado eram delegadas aos mediadores.

Essa também é a realidade de uma parcela de mediadores nos EUA, segundo Levine, Marks e Schrader (1999). Muitos dos entrevistados em sua pesquisa assumiam o dever que lhes era imposto: realizarem, sozinhos, a inclusão das crianças. Foi visto que eles acreditavam que comportamentos infantis desagradáveis, que poderiam atrapalhar a aula, deveriam ser por eles controlados.

No presente estudo, consideramos que quando Manuela e Aline, ex-mediadoras, disseram que a "mediação tem prazo de validade", estavam apontando para situações como as relatadas nessa pesquisa norte americana.

Outra questão que cabe ser destacada das entrevistas realizadas diz respeito ao excesso de responsabilidade do mediador. Viu-se que isto pode repercutir no comportamento do professor, levando-Ihe a se distanciar do aluno mediado. Fernanda, Gabriela, mediadoras, e Aline e Manuela, exmediadoras, contaram terem experienciado esta situação. Relataram que a maioria das professoras não faziam as tarefas para as crianças que acompanhavam, assim como não explicavam para os demais alunos o que estava acontecendo com aquela criança. Manuela falou ainda que, por muitas vezes, ao 


\section{Desafios da psicologia no Brasil}

usar algum objeto que não era permitido em sala de aula com seu mediando (computador ou celular), as demais crianças a interpelavam sobre o uso daquele recurso. Era ela quem precisava Ihes explicar o motivo de sua ação.

Nunes e colaboradoras (2013) perceberam posturas parecidas com as professoras participantes de seu estudo. Conforme previamente mencionado, no estudo que desenvolveram, somente as mediadoras compareceram aos encontros propostos para a coleta de dados, ocasião que aproveitavam para colocar em prática o que haviam aprendido. Quanto às professoras, embora concordassem que as atividades poderiam ajudar no seu trabalho, argumentavam que não tinham tempo para participar desses encontros. As autoras compreenderam esta postura das professoras como um modo de expressão de que elas se situavam principalmente como expectadoras do que estava sendo feito em sala de aula pelas mediadoras. Não se achavam responsáveis por aqueles alunos, em conseqüência, não faziam atividades para os mesmos.

Outro fator digno de destaque no processo mediação-inclusão, que surgiu nas escolas participantes do estudo, foi a avaliação escolar. Em todas as instituições, o processo de avaliação é acompanhado de perto pela direção e pela supervisão pedagógica.

Nas escolas de Ruth (zona norte) e Valéria (zona sul), a adaptação das provas a ser aplicada nos alunos que contam com mediadores é feita em conjunto pelas professoras e mediadores.

Na escola de Maria (zona oeste), a equipe para adaptação da prova também contou com a presença da psicopedagoga do menino. Na ocasião da entrevista, era a primeira vez que Maria estava adaptando a prova de Bernardo.

As escolas definem o procedimento a ser adotado. Nas escolas das zonas sul e norte, as profissionais relataram que os encontros com as mediadoras aconteciam nos corredores quase todos os dias, enquanto que as reuniões agendadas eram mais espaçadas. Já na escola da zona oeste, o procedimento era diferente. Desde a entrada da criança na escola, reuniões semanais eram realizadas com a mediadora, a professora, a supervisora pedagógica e a equipe de apoio técnico. Segundo a supervisora pedagógica da escola, Bárbara, tudo o que era decidido nessas reuniões era anotado em

uma ficha de acompanhamento da criança denominada de Anedotário. Ruth e Valéria, respectivamente diretoras das escolas da zona norte e sul, não mencionaram esse tipo de registro em seus estabelecimentos. 


\section{Desafios da psicologia no Brasil}

Em nenhuma escola existe um trabalho conjunto com todos os mediadores. Questionadas sobre o motivo, Ruth (diretora, zona norte), Valéria (supervisora de inclusão, zona sul) e Bárbara (supervisora pedagógica, zona oeste) consideraram que uma reunião com esse propósito não é conveniente. Os motivos alegados foram: tratam-se de crianças com problemas distintos; as crianças são acompanhadas por profissionais diferentes; e o fato de que muitas vezes, é necessário que se parta de princípios diversos para as orientações sobre a atuação dos mediadores. Já Tadeu (diretor da escola da zona oeste) se surpreendeu com a questão colocada e, um pouco perplexo, afirmou não saber porque não havia uma reunião desse tipo da escola, já que o colégio conta com infraestrutura para tal. Percebeu, ainda, que esta reunião poderia facilitar o trabalho dos mediadores no que compete ao conhecimento das regras e da política pedagógica da escola.

Outro dado relevante é o fato de, em todas as instituições, serem realizadas reuniões com os profissionais que atendem as crianças fora da escola: psicólogos, psicopedagogos, fonoaudiólogos, entre outros. Essas reuniões são marcadas conforme a solicitação dos profissionais ou quando a escola quer modificar alguma atividade. A importância dessas reuniões nos é dada, por exemplo, pela fala de Ruth, diretora da escola da zona norte. Ela contou que as orientações dos profissionais são sempre levadas em consideração ao se elaborar as avaliações dos alunos.

Contudo, a participação das mediadoras nessas reuniões não é unânime. Conforme conta Gabriela (mediadora, zona sul), nem ela, nem a mãe de Milton, podem participar das reuniões entre os profissionais do colégio e os demais profissionais que atendem o menino.

Em função do relatado, como pode ser previsto, o relacionamento das mediadoras com os profissionais que atendem as crianças fora da escola nem sempre é marcado por experiências positivas. Aline, ex-mediadora, lembra que, por diversas vezes, precisou brigar com esses profissionais porque discordava das avaliações que os mesmos faziam das crianças que ela acompanhava. Contou, inclusive, que uma vez, por decisão unilateral de uma médica, ela foi afastada da mediação de uma criança.

Roberta (mediadora, zona sul) nem sempre também concorda com a postura desses profissionais. Ela afirma que, algumas vezes, já presenciou inverdades de terapeutas e médicos sobre o comportamento da criança durante uma consulta. Ela entende que esses comportamentos se devam, em grande parte, da necessidade do terapeuta manter aquela criança como cliente. Segundo ela, entre os pais, a comparação de profissionais é muito grande e, quando um diz que determinado terapeuta faz algo melhor, os responsáveis logo trocam de profissional. 


\section{Desafios da psicologia no Brasil}

Além das dificuldades com a equipe pedagógica e os professores, Ruth (diretora), Paula (professora), Fernanda e Roberta (mediadoras) e ainda Aline (ex-mediadora) chamam atenção para os problemas no relacionamento com os responsáveis das crianças. Elas contaram que muitos responsáveis não conseguem reconhecer e aceitar as limitações de seus filhos, dificultando o trabalho da escola e das mediadoras. Ruth falou que, muitas vezes, os pais não acreditam quando ela cita comportamentos inapropriados da criança que poderiam estar relacionados com algum transtorno cognitivo ou de comportamento. Já Fernanda, Roberta e Aline chamaram a atenção para o fato dos responsáveis não conhecerem o trabalho do mediador cobrando-lhes, portanto, resultados inalcançáveis com as crianças, tal como notas máximas em todas as provas. Além do quê, muitos não colaboram com o processo de aprendizagem em casa, deixando de fazer a tarefa de casa com os filhos.

No que se refere ao trabalho do mediador propriamente dito, não houve um consenso nas falas das mediadoras. Roberta (zona sul) foi a única que considerou que as atividades que ocorrem fora do horário de aula (passeios ou festas) não devem ser realizadas pelo mediador. Para ela, os responsáveis devem acompanhar as crianças nestas atividades, já que isto favoreceria um maior entendimento pelo responsável das dificuldades do filho, além de não expor a criança aos demais responsáveis.

A questão da exposição da criança acompanhada por um mediador está presente em um dos estudos de Carvalho (2008). Ela questiona se a permanência constante de uma pessoa "de fora da sala" ao lado da criança não poderia ser mais um fator de exclusão. Para ela, as demais crianças podem acreditar que o aluno de inclusão é tão "prejudicado" que precisa de outra professora para auxiliá-lo, enquanto os demais, não necessitam.

No entanto, esta não foi a posição das mediadoras e ex-mediadoras que entrevistamos. Aline, inclusive, relatou uma situação em que, após a professora explicar para a classe a função da mediadora e as dificuldades da criança acompanhada, todas as crianças se dispuseram a cooperar.

Vimos que há profissionais de distintas áreas trabalhando como mediadores. Deste modo, não há um consenso quanto a formação esperada para um mediador. As mediadoras em atividade consideram que os cursos de graduação de Psicologia e Pedagogia são os mais apropriados. Esta ideia também é partilhada por Valéria (supervisora) e Denise (mãae). Elas afirmam, inclusive, que o mais apropriado seria uma pessoa formada em pedagogia com pós graduação em psicopedagogia. Seu principal argumento é a dificuldade que mediadores formados em outras áreas podem apresentar para adaptarem o material didático. É interessante que não houve menção à área de fonoaudiologia para a mediação, apesar das duas ex-mediadoras participantes terem sido as primeiras mediadoras de 


\section{Desafios da psicologia no Brasil}

muitas escolas do Rio de Janeiro. Além disso, Pelosi e Nunes (2009) mostram que no ano de 1998 grande parte dos professores itinerantes, que têm função similar aos mediadores, eram fonoaudiólogos.

Quanto ao tempo de atuação do mediador com uma mesma criança, nossos entrevistados mostraram opiniões variadas. Aline (ex-mediadora) e Fernanda (mediadora) concordam que não existe um prazo para a mediadora ficar com a mesma criança. Aline justifica sua opinião pela dificuldade em se estabelecer um vínculo satisfatório com a criança para a realização de um bom trabalho. As demais mediadoras divergiam quanto a três, quatro anos ou o período de um segmento escolar. Entretanto, acima de tudo, elas consideravam fundamental que o vínculo não deixasse de ser profissional, para não gerar muita dependência da criança pelo mediador ou para não dificultar a possibilidade de experimentarem outras formas de lidar com a criança, quando necessário.

Acreditamos que essas diferenças na implementação do trabalho e, principalmente, na qualificação profissional das mediadoras expliquem a demanda de boa parte dos participantes pela regulamentação da profissão, com a discriminação das atividades a serem desenvolvidas, o valor correspondente a tal atividade e a formação do profissional. Roberta (mediadora) diz que uma legislação específica ajudaria no oferecimento de um serviço de melhor qualidade. Na sua visão, muitos mediadores são pessoas pouco preparadas para lidar com crianças em processo de inclusão porque ainda estão na graduação ou se formaram em cursos que não necessariamente abrangem essa questão. French (2003) também tem um posicionamento similar no contexto norteamericano. Para ela autora, falta para muitos mediadores estadunidenses um preparo adequado para lidarem com as crianças de N.E.E. É necessário que tenham conhecimento teórico e prático, especialmente sobre estratégias de aprendizagem.

De fato, todas as mediadoras participantes de nosso estudo relataram que, em seus primeiros trabalhos como mediadoras, sentiram muita dificuldade em organizar e implementá-los. Não sabiam como agir com as crianças e demais pessoas envolvidas (pais, professores, diretores, entre outros), nem como realizar as adaptações necessárias dos materiais e atividades.

\section{CONSIDERAÇÕES FINAIS}

Os discursos de mediadoras e ex-mediadoras, de mães, de professoras e de diretores sobre a mediação escolar e o processo de inclusão de crianças com necessidades educacionais especiais mostrou que a mediação escolar ainda está longe de ser uma atividade plenamente estabelecida nas escolas do Rio 


\section{Desafios da psicologia no Brasil}

de Janeiro. É pouco conhecida em muitas instituições, mesmo após uma década de realização desse trabalho. Ao longo desse percurso, muitas dificuldades surgiram como a limitação da atividade do mediador, a desresponsabilização do professor sobre o aprendizado do aluno mediado e a falta de adequação da rotina escolar para receber mais uma pessoa em sala de aula.

Esses problemas são agravados pela falta de regulamentação do trabalho do mediador, conforme relatado pela maioria dos participantes deste estudo. A inexistência de uma legislação que descreva os direitos trabalhistas, as atividades e os deveres desse profissional implica em descompromissos. Por parte de alguns poucos mediadores, há o encerramento de seu acompanhamento com a criança antes do final do período letivo. Por parte de algumas escolas, vê-se a falta de um suporte adequado ao trabalho a ser desenvolvido, ou até mesmo a recusa pela presença do mediador na escola.

Contudo, mesmo com todas as dificuldades inerentes a essa atividade, é unânime a opinião de que a presença do mediador é muito importante para favorecer, ou até mesmo viabilizar, a inclusão. Todos avaliaram positivamente o trabalho do mediador, quando realizado com compromisso e responsabilidade, e destacaram o consequente desenvolvimento da criança assistida.

As mediadoras, especialmente, ao falarem de seu trabalho, também o reconheceram como fonte de crescimento individual. Disseram que o fato de lidarem com crianças que continuam felizes e lutando para melhorar, à despeito de suas muitas limitações e dificuldades, lhes fez refletir sobre aspectos de suas próprias vidas.

Aline e Manuela, ex-mediadoras, afirmaram inclusive que qualquer pessoa que pretende trabalhar com crianças com deficiência ou outras necessidades educacionais especiais, independentemente de sua formação acadêmica, deveria atuar como mediadora por um tempo, para conhecer mais sobre o dia-a-dia dessas crianças.

Mas o trabalho em mediação escolar, como qualquer outra atividade profissional, também tem seu ônus. Quase todas as mediadoras afirmaram que o processo de inclusão é muito desgastante e, por isso, não pensavam em desempenhar essa atividade para sempre. Muitas vezes, conforme relato de Aline, a mediação precede uma posterior atuação clínica em consultório particular por profissionais formados em psicologia, fonoaudiologia, entre outras áreas, que buscam melhor remuneração e uma posição mais valorizada na sociedade.

Por fim, cabe explicitar que os sentidos produzidos nos discursos sobre mediação escolar foram constituídos também em função de significados, normas e valores relacionados às instituições 


\section{Desafios da psicologia no Brasil}

escolares, às escolas particulares. Portanto, é fundamental que outras pesquisas sejam realizadas com o objetivo de se conhecer o processo de mediação escolar em instituições escolares públicas, que contam com outros dispositivos de inclusão, como os professores itinerantes e as salas especiais. Onde o profissional que desenvolve a atividade de mediação é custeado pelo governo e a organização da estrutura escolar é regulada por órgãos públicos, como as Secretarias de Educação.

\section{REFERÊNCIAS BIBLIOGRÁFICAS}

Alves, D. O. \& B arbosa , K. A. ( Expe riências Educacionais Inclusivas: refletindo sob re o cotidiano escolar. Em B. W. Roth (O rg Experiências educacionais inclusivas .

Brasília: Ministério da Educação, Secretaria de Educação Especial

Bardin, L. (1977). Análise de conteúdo. Lisboa: Edições 70.

Bernard , H. R . (2006 Research methods in anthropology: qualitative and quantitative aproach. 4th ed. Lanham: AltaMira Press

Carvalho, R. E. ( Cartografia do trabalho docente na e para a educação inclusiva.

Revista @mbienteeducação, 12 )), 2130.

Cunha , Glat, R., Silva, S., \& Siqueira, C. (2012). O perfil e a formação do estagiário mediador para suporte da educação inclusiva. Trabalho apresent ado no V Congresso Brasileiro de Educação Especial, R. J.,

Fisher, P leasants, S. L. ( Roles, responsibilities and concerns of paraeducators: findings $f$ rom a statewide s urvey. Remedial \& Special Education , 33 ( 5), 287297 F irst published on February 7, 2011

Freitas , N K. ( Inclusão socioeducativa na escola: avaliação do processo e dos alunos.

Ensaio: avaliação e políticas públicas em Educ ação 1660 ), 323336

French , N.K. (2003). Paraeducators in special education programs. Focus on exceptional children , 362

Giangreco, M. F. \& B roer, S. ( Questionable Utilization of Paraprofessionals in Inclusive Schools: Are We Addressing Symptoms or Causes? Focus on autism and other developmental disabilities, 201 ), 1026

Glat , F ernandes , E. ( Da e ducação segregada à educação inclusiva. Revista Inclusão , 11 )), 3539

Glat, P letsch , M. D., F ontes, R. S. ( Educação inclusiva \& educação especial: propostas que se complementam no contexto da escola aberta à diversidade. Revista Educação, 32 , (2). 


\section{Desafios da psicologia no Brasil}

Gomes , C. \& S ouza , V. L. T ( Psicologia e i nclusão escolar: reflexões sobre o processo de subjetivação de professores. Psicologia Ciência e Profissão, 323 ), 588603

González Rey, F. ( Pesquisa qualitativa em psicologia: Caminhos e desafios . São Paulo :González

Rey, F. (2003). Sujeito e subjetividade . São Paulo: Thomson.

Levine, M., Marks, S. U., \& Schrader, C. (1999). Paraeducator experiences in inclusive settings: helping, hovering, or holding their own? Exceptional Children, 65(3). Recuperado em 25 de março, 2013, de http://www.freepatentsonline.com/article/Exceptional-Children/54271787.html.

Machado , S.S.( A prática da inclusão de alunos com necessidades educativas especiais em classe regular: um estudo de caso com abordagem etnográfica. Dissertação de Mestrado, Programa de Pós Graduação em Educação Universidade do Estado do Rio de Janeiro, Rio de J aneiro, R.J.

Mendes, E. G. ( A radicalização do debate sobre inclusão escolar no Brasil. Revista Brasileira de Educação , 1133 )), 387406

Minayo, M. C. S. ( O Desafio do conhecimento pesquisa qualitativa em saúde. Rio de Janeiro: Abrasco.

Minayo, M. C. S. S anches, ( Quantitativo Qualitativo: Oposição ou Complementariedade? Cadernos de Saúde Pública , 93 ), 239262.

Mousinho, R., Schmid, E., Mesquita, F., Pereira, J., Mendes, L., Sholl, R., \& Nóbrega, V ( Mediação escolar e inclusão: revisão, dicas e reflexões. Rev ista P sicopedag ogia 2782 ), 92108

Netto , M. M. F. C. A . (2 012) Comunicação a Iternativa favorecendo a aprendizagem de crianças com autismo, Asperger e Angelman: formação continuada de profissi onais de educação e $s$ aúde. Dissertação de Mestrado , Programa de Pós Graduação em Educação Universidade do Estado do Rio de Janeiro, Rio de Janeiro, R.J.

Nunes, L. et al ( A prática pedagógica de mediadoras de alunos com deficiência física e dificuldade $s$ na comunicação em escolas do Rio de J aneiro Em R. G lat, M.D.

Pletsch (O rg s. Estratégias educacionais diferenciadas para alunos com necessidades especiais Rio de Janeiro: Edit ora da Universidade do Estado do Rio de Janeiro.

Pelosi , M. B. N unes, L. R. O. ( Caracterização dos professores itinerantes, suas ações na área de tecnologia assistiva e seu papel como agente de inclusão escolar. Rev ista Braileira de Educação Esp ecial , 151 ), 141154

Omote , ( Diversidade, educa ção e sociedade inclusiva. Em A. A. Oliveira , S. O mote

R. M. G iroto (O rgs ..). Inclusão escolar: as contribuições da Educação Especial . São Paulo: Cultura Acadêmica e Marilia: Fundepe

Riggs , C. G. M ueller , P. ( Employment and utilization of paraeducators in inclusive s ettings. The J ournal of Spec ial Educ ation , 3554 ), 5462.

Roriz, T. M. S., Amorim, K. S., \& Rossetti-Ferreira, M. C. (2005). Inclusão social/escolar de pessoas com necessidades especiais. Psicologia USP, 16(3), 167-194. 


\section{Desafios da psicologia no Brasil}

Secretaria Municipal de Educação ( Educação Especial . Rio de

Tacca , M. C. V. R. G onzález Rey , F. L.( Produção de sentido subjetivo: as singularidades dos alunos no processo de aprender. Psicologia Ciência e Profissão , 281 ),138 161

UNESCO. (1990).Declaração mundial sobre Educação para t odos: satisfação das necessidades básicas de aprendizagem . Jomtien. Recuperado em 30 de maio, 2013, de

http://unesdoc.unesco.org/images/0008/000862/086291por.pdf

UNESCO. (1994). Declaração de Salamanc a sobre $p$ rincípios, políticas e práticas na área das necessidades educativas e speciais . Recuperado em 30 de maio, 2013, de

http://unesdoc.unesco.org/images/0013/001393/139394por.pdf

White, ( The recruitment of paraeducators into the special ed ucat ion profession a review of progress, select evaluation outcomes, and new initiatives. Remedial and special e ducation , 25 (4), 214218 


\section{Capítulo 35}

\section{NEUROPSICOLOGIA E EDUCAÇÃO: UM DIÁLOGO A}

\section{FAVOR DO PROCESSO DE ENSINO-APRENDIZAGEM}

\section{DOI: $10.37423 / 200200234$}

Eliane Ribeiro Magalhães de Sousa Fortes de Melo (Graduada em Letras-Português pela UESPI e em Psicologia pela Universidade CEUMA. Especialista em Neuopsicologia Clínica (CEUMA); Avaliação Psicológica (IPOG); Terapia CognitivoComportamental (CAPACITAR); Psicopedagogia (FACAM); Metodologias do Ensino em Língua Rortuguesa e Estrangeira (UNINTER). Possui Curso de frormação em Psicologia Existencial/Humanista Fenomenológica e em Orientaça Profissional e de Carreira: A Facilitaçã̀ da Escolha (INSTITUTO DO SER) Mestra em Educação (UNINI).

RESUMO: Este artigo aborda a Neuropsicologia, como uná área interdisciplinar das neưrociências, enfatizando suta interfacẹ com a Eduçação. O objetivo deste estudo é discutir teórica e criticamente as contribuições da Neuropsicologia à aprendizagem escolar, assim como a tradução-desses conhecimentos em práticas pedagógicas mais consistentes e assertivas, pautadas em evidên cias científicals. A metodologia utiłizada refere-se a uma revisão de literatura com autores relacionados à temática desta pesquisa. Percebe-se que o estudo da Neuropsicologia, em correlação com a Educação, tem muito a contribuir com todos os envolvidos no contexto escolar, daí a jimportânciádde seu conhecimento, por parte dos educadores, para auxiliar no processo de ensino-aprendizagem.

Palavras-chave:-Neuropsicōtogia. Educaçầo. Formação do professor. Ensind-apren dizagem.

Prática interêisciplinar.

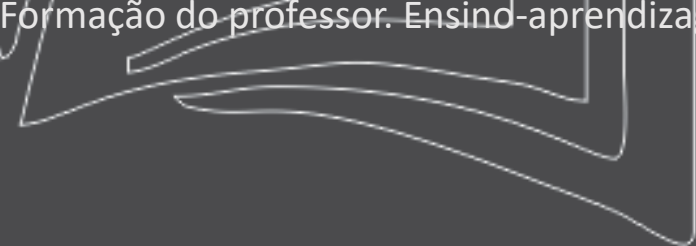




\section{Desafios da psicologia no Brasil}

\section{INTRODUÇÃO}

Este artigo centra-se no estudo da Neuropsicologia, área que vem sendo investigada devido à sua importância para a sociedade moderna, por se apresentar como uma ciência que procura desvendar as informações e possibilidades de mudanças do comportamento humano a partir dos processos de elaboração da aprendizagem no cérebro, contribuindo com os interessados em como melhor ensinar e aprender.

Camargo (2018) ressalta que essa ciência não só provê a interligação de praticamente todos os campos que lidam com o cérebro e o comportamento, como também reveste os já conhecidos e os novos achados de significado. Para tanto, possui bases sólidas para fornecer amplos e variados subsídios para uma diversidade de práticas, estudos e pesquisas, atuação clínica, estando aberta a todos que desejam investigar, analisar e colaborar com várias áreas do conhecimento.

Para a realização deste trabalho foram consultados artigos científicos, trabalhos de conclusão de cursos, dissertações, teses, revistas indexadas, além de livros sobre essa temática, caracterizando-se por um levantamento bibliográfico, principalmente do período de 2010 a 2018, mediante revisão da literatura especializada, com pesquisas nas seguintes bases de dados: Scielo, Google Acadêmico, Periódicos da CAPES e Portal Domínio Público.

A metodologia proposta é a partir da arguição conceitual, histórica e crítica sobre os temas principais focados neste estudo que são: neuropsicologia, educação, formação do professor, ensinoaprendizagem, trabalho interdisciplinar e avaliação neuropsicológica, com base em autores que se destacaram em suas pesquisas sobre o tema, enfatizando-se também os contemporâneos que possuem relevantes trabalhos sobre o assunto.

Ressalta-se que a investigação do perfil neuropsicológico é uma das formas de se compreender o funcionamento cognitivo, proporcionando um suporte para o planejamento de intervenções precoces (JARROS; TOAZZA; MANFRO, 2016).

Ao longo do corpo deste artigo, procura-se explicitar tópicos que deem visibilidade aos estudos científicos da Neuropsicologia com interface com a Educação e como essas duas áreas juntas podem auxiliar em uma prática pedagógica mais comprometida com os alunos que apresentam ou não dificuldades ou distúrbios de aprendizagem.

Objetiva-se fazer com este trabalho algumas considerações sobre as possíveis contribuições da Neuropsicologia para a Educação, uma vez que, através dela, podem-se compreender os processos 


\section{Desafios da psicologia no Brasil}

mnemônicos, perceptivos, de aprendizado e de solução de problemas, dentre outras atividades cognitivas.

Para se trabalhar, no ambiente educacional, com as dificuldades e os transtornos de aprendizagem, com conflitos e demais temas relacionados ao contexto escolar, nota-se que a Neuropsicologia tem muito a colaborar com o bom desempenho do trabalho do professor, assim também com os demais profissionais ligados à educação e à aprendizagem em geral, sendo uma aliada de grande relevância para melhorar o processo educacional.

\section{O QUE É NEUROPSICOLOGIA - CONSIDERAÇÕES RELEVANTES}

A Neuropsicologia é uma ciência que tem contribuído muito com diferentes profissionais de variadas áreas, acrescentando informações relevantes a respeito da funcionalidade do cérebro do ser humano. Fica claro, então, que a Neuropsicologia é um campo de trabalho e de pesquisa emergente, tanto para a Psicologia, quanto para as Neurociências, avançando e colaborando de forma única para compreender como se pensa e age no mundo (ALMEIDA, 2013). Pode-se defini-la como a ciência que tem por objeto o estudo das relações entre as funções do sistema nervoso e o comportamento humano.

Segundo Coutinho e Malloy-Diniz (2017), a neuropsicologia estuda a complexa organização cerebral e suas relações com o comportamento e a cognição, tanto em quadros de doença como no desenvolvimento normal. Malloy-Diniz et al (2013) ainda ressalta que a neuropsicologia é uma área do conhecimento em constante desenvolvimento. Sua interface com diferentes disciplinas a torna imprescindível para uma melhor compreensão dos processos cognitivos normais e de suas alterações em diferentes estados patológicos.

Abreu (2017) destaca que o neuropsicólogo pode trabalhar também na área escolar, na avaliação de dificuldades e no melhoramento cognitivo dos alunos na escola. Portanto, o neuropsicólogo procura identificar as funções que estão preservadas e as deficitárias, que possam estar inferindo sobre potenciais comprometimentos no sistema nervoso, tendo como objetivo principal correlacionar as alterações observadas no comportamento do paciente com as possíveis áreas cerebrais envolvidas, realizando um trabalho de investigação clínica, utilizando variadas atividades neuropsicológicas, além de testes apropriados aos casos em análise.

O indivíduo aprende por meio de modificações funcionais do Sistema Nervoso Central, principalmente, nas áreas das praxias, das gnosias, da atenção, da linguagem e da memória. Dessa forma, percebe-se 


\section{Desafios da psicologia no Brasil}

que para o processo de aprendizagem se estabelecer corretamente, é necessário que as interligações entre as diversas áreas corticais e delas com outros níveis do SNC sejam efetivas (ROTTA, 2016). A partir disso, enfatiza-se a importância de se estudar mais sobre Neuropsicologia.

A respeito da Neuropsicologia, trata-se de uma ciência com contribuições multidisciplinares. Vale ressaltar que, no Brasil, há a Sociedade Brasileira de Neuropsicologia, que é uma instituição multidisciplinar, fundada em 1988. Destaca-se também que, em 2004, o Conselho Federal de Psicologia reconheceu a especialidade de Neuropsicologia para os psicólogos e, em 2014, o Conselho Federal de Fonoaudiologia reconheceu essa especialidade para os fonoaudiólogos (MALLOY-DINIZ et al., 2018). Apresentando-se, portanto, como uma área em constante expansão.

Ohlweiler (2016) relata que toda operação é realizada no cérebro, que as funções cerebrais são executadas por um conjunto de neurônios, formando sistemas funcionais e que o cérebro tem a capacidade em armazenar, codificar e decodificar para serem utilizados posteriormente mediante a memória. Dessa forma, entende-se que a Neuropsicologia oferece mecanismos para se avançar nos estudos sobre a funcionalidade do cérebro, podendo assim ajudar diversas áreas e profissionais.

Nogaro (2012) comenta que atualmente são agregados conhecimentos que já servem como suportes de grande importância para o desenvolvimento do trabalho do professor. Sabe-se que tudo isso é bastante recente, gerando um pouco de insegurança e confiança na área, mas não se pode ignorar tais progressos uma vez que, no campo da neuropsicologia, várias pesquisas mostram significativos avanços científicos e tecnológicos dos quais a prática escolar não pode estar afastada.

Compartilham dessa concepção Gouveia e Parra (2016) quando relatam que a compreensão do complexo funcionamento do cérebro é fundamental para profissionais que atuam em clínica, tais como psicólogos, psicopedagogos, fonoaudiólogos, fisioterapeutas, dentre outros, e que, atualmente, vem despertando também o interesse dos profissionais da educação devido à intrínseca relação com a aprendizagem. E ainda destacam que o cérebro é a base para o entendimento do amplo processo de ensino-aprendizagem. "Hoje, sabemos que conhecer seu funcionamento tem significativa relevância para alcançar bons resultados em uma sala de aula, desde a pré-escola ao ensino superior". Giannesi e Moretti (2015), corroborando com esse mesmo pensamento, comentam que a investigação neuropsicológica possibilita o aprofundamento do conhecimento dos processos psíquicos, através da análise das correlações entre as condutas e determinadas zonas corticais. Ainda acrescentam que o domínio e a noção dessa concepção é uma condição indispensável para os profissionais que almejam 


\section{Desafios da psicologia no Brasil}

tanto investigar os problemas de aprendizagem de crianças e adolescentes quanto criar estratégias eficazes de reabilitação.

\section{CONTRIBUIÇÕES DA NEUROPSICOLOGIA PARA A FORMAÇÃO DO EDUCADOR}

A Neuropsicologia vem ganhando espaço entre os profissionais da educação. Educadores têm procurado aperfeiçoar-se, dando continuidades aos seus estudos, com o propósito de contribuírem para um ensino melhor, uma vez que se o professor tiver conhecimento da modalidade de aprendizagem do seu aluno, poderá transformar-se em um facilitador do processo ensinoaprendizagem.

Nos últimos anos, estudos no campo das neurociências e de suas subáreas (incluindo a Neuropsicologia) têm contribuído muito para melhor compreensão dessa diversidade cerebral. 0 professor precisa entender que "existe uma biologia, uma anatomia e uma fisiologia neste cérebro que aprende, tornando-se necessário, portanto, que o professor entenda o funcionamento do substrato neurobiológico para que possa ressignificar sua prática pedagógica" (SANTOS, 2011, p.3).

Compartilhando dessa visão, Gouveia e Parra (2016, p. 6) salientam que: “Compreender como ocorre a aprendizagem no cérebro humano tenderá a auxiliar os docentes a controlar variáveis que favoreçam e desfavoreçam a aprendizagem". Ainda acrescentam que entender as bases neurobiológicas da aprendizagem, torna-se fundamental na formação do professor no século XXI, porque esses estudos vêm contribuindo para as práxis em sala de aula, na compreensão das dimensões cognitivas, motoras, afetivas e sociais (GOUVEIA; PARRA, 2016). Entretanto, conteúdos relacionados à Neuropsicologia deveriam estar presentes na formação dos educadores para que tenham condições de fazer uma associação com a sua prática. Portanto, entendendo como o seu aluno aprende, o docente poderá buscar formas mais adequadas de estabelecer relações entre ensino e aprendizagem, a fim de favorecer uma melhor maneira de como ensinar.

Compreender como a aprendizagem acontece, do ponto de vista neuropsicológico, realmente tem despertado bastante o interesse de muitos estudiosos uma vez que a Neurociência está trazendo relevantes informações para mostrar e alertar aos mais variados profissionais, inclusive, os da educação sobre sua importância. Como destaca Sampaio (2014) por trás de cada aluno, há um cérebro e que se faz fundamental compreender seu funcionamento para que novas formas de ensino sejam criadas ou alteradas, proporcionando-Ihe melhor assimilação e acomodação das informações. 


\section{Desafios da psicologia no Brasil}

Sem dúvida que, contando com um domínio teórico e/ou prático maior em relação à funcionalidade do cérebro e como se aprende, o professor terá mais clareza sobre o modo mais adequado para ajudar seus estudantes. Isto lhe permite o desenvolvimento de um ensino bem sucedido, provocando alteração na taxa de conexão sináptica que afeta a função cerebral. Contudo, depende, também, do método de ensino, da capacidade do professor, do contexto da sala de aula e da participação da família (BARTOSZECK, 2011).

Cosenza e Guerra (2011) menciona que se pode intervir de forma mais assertiva, referente aos processos de ensinar e de aprender, uma vez que precisam ser criticamente avaliados antes de serem aplicados, para que sejam eficientes no cotidiano escolar. Os conhecimentos agregados pelas neurociências podem contribuir para um avanço na educação e, assim, haverá resultados mais efetivos para a qualidade do ensino e, consequentemente, para a sociedade como um todo.

A contribuição da Neuropsicologia é incontestável para a formação do professor, principalmente, no acompanhamento de alunos com dificuldades de aprendizagem, visto que os atuais métodos de investigação cerebral demonstram a importância dessa ciência na prevenção, no diagnóstico e tratamento de distúrbios da aprendizagem e do desenvolvimento educacional dos estudantes não só nas séries iniciais, mas também nas outras que prosseguem.

O principal objetivo da Neuropsicologia é a análise da relação entre o cérebro e o comportamento. Rodrigues e Ciasca (2010) enfatizam que é através dessa área de atuação que o indivíduo pode aprender como diferentes áreas cerebrais operam em conjunto para realizar comportamentos complexos, como é o caso de todo o percurso da aprendizagem.

Atualmente, tem-se discutido bastante entre os professores a contribuição da Neuropsicologia para a área da educação. O educador que possui conhecimentos relacionados a esse campo, que tem a capacidade de identificar comprometimentos relacionados ao desenvolvimento de seu aluno, nas atividades escolares, verificando neles dificuldades de aprendizagem, certamente, fará a diferença na análise de quais possam ser as causas e limitações que seu aluno apresenta. Só, assim, vai conseguir desenvolver seu trabalho na perspectiva de atender às individualidades e atingir o maior número possível de educandos (NOGARO, 2012).

Segundo Sampaio (2017), algumas alterações no comportamento e nos processos mentais já podem ser observados desde a fase pré-escolar, como dificuldades na motricidade, na atenção, na memória, na compreensão auditiva e outras só irão se manifestar após o processo de alfabetização, como é o caso da disgrafia, dislexia, disortografia e discalculia. Mesmo que alguns familiares possam suspeitar 


\section{Desafios da psicologia no Brasil}

que algo não vai bem com seu filho, certamente, é na escola que as alterações de comportamento ou de aprendizagem das crianças ficam mais evidentes, muitas das vezes, observadas nas suas limitações em acompanhar a turma.

Nogaro (2012) comenta bem sobre essas dificuldades dos discentes, relatando que na sala de aula, os docentes se deparam constantemente com situações de pouca assimilação, falta de atenção e de compreensão, ou seja, diversas dificuldades de aprendizagem e se angustiam, visto que não sabem como elaborar alternativas para demais problemas e terminam dividindo seus temores com colegas de profissão. E ainda destaca: “[...] responsabilizando a criança e o adolescente por ter 'pouca vontade', 'não esforçar-se o suficiente' [...] Somos desconhecedores de qual solução apontar, pois, nosso processo de formação não contemplou saberes maiores a este respeito (NOGARO, 2012, p. 2).

A formação de professores continua sendo uma temática de estudo e de reflexão, visto que, quando o professor é formado adequadamente, desenvolve a docência voltada para o aluno e com qualidade (NOGARO, 2012). Dessa forma, é importante que sejam fomentados debates relacionados a esse assunto.

Ressalta-se também a importância de se desenvolver, no contexto escolar, os estudos da Neuropsicologia no que se refere a elevar o potencial de aprendizagem com atividades e programas de enriquecimento cognitivo. Corrobora dessa concepção Santos (2011, p. 8): “[...] a escola, deve e pode, portanto, ensinar funções cognitivas que estão na base de aprendizagens, simbólicas ou não. Com ensino mediatizado, com prática e treino, as funções ou competências cognitivas de qualquer aluno, seja ele deficiente ou não [...]". Todas as pessoas possuem um potencial de aprendizagem e para ser desenvolvido de forma mais eficiente e assertiva, precisa ser estimulado.

Entende-se, portanto, que a Neuropsicologia tem muito a contribuir para a formação do profissional no atendimento aos alunos com as diversas dificuldades de aprendizagem. Ressalta-se também que não se refere a conhecimentos que sirvam apenas para estudar e compreender alunos com perfis irregulares, mas para todos.

\section{DIFICULDADES DE APRENDIZAGEM X TRANSTORNOS DE APRENDIZAGEM}

O professor para perceber especificidades no comportamento e nas funções cognitivas de seus discentes, é imprescindível constar, em sua formação acadêmica, conhecimentos sobre Neuropsicologia em relação aos diversos aspectos que envolvem o processo educativo. 


\section{Desafios da psicologia no Brasil}

Brito (2016) relata que os termos distúrbios, transtornos, dificuldades e problemas de aprendizagem têm sido utilizados de modo aleatório, tanto na literatura especializada como na prática clínica e escolar, para designar quadros diagnósticos diferentes. De acordo com o DSM-V, há os transtornos do neurodesenvolvimento e dentre eles há o transtorno específico da aprendizagem: "[...] déficits específicos na capacidade individual para perceber ou processar informações com eficiência e precisão, caracterizando-se por dificuldades persistentes e prejudiciais nas habilidades básicas acadêmicas de leitura, escrita e/ou matemática" (APA, 2014, p. 32).

Enfatiza-se que as dificuldades de aprendizagem aparecem, geralmente, nos casos de problemas emocionais; drogas e violência; desorganização no ambiente familiar; mudança de escolas; muitas atividades extracurriculares; os responsáveis muito ou pouco presentes; uso de medicamentos que diminuem a atenção do discente; problemas socioculturais (VILLAR, 2017). É imprescindível atentar que uma dificuldade de aprendizagem não se refere a um problema neurológico (ROTTA; RIESGO; OHLWEILER, 2016).

Giannesi e Moretti (2015, p. 11) ressaltam: "Transtorno de aprendizagem (TA) se vincula às dificuldades na aquisição e desenvolvimento de funções cerebrais envolvidas no ato de aprender, tais como dislexia, discalculia e transtorno de escrita". Portanto, enfatiza-se que precisa fazer parte da formação do professor conhecimentos de Neuropsicologia para que tenha condições de saber o que realmente acontece com seus alunos para, a partir daí, ter domínio dos devidos métodos e procedimentos a serem tomados.

É necessário, então, estabelecer uma diferenciação entre o que é uma dificuldade de aprendizagem e o que é um quadro de transtorno de aprendizagem, visto que, dentro da escola, o contexto de atender necessidades especiais torna-se mais complexo, por isso uma avaliação neuropsicológica seria fundamental já que, através dela, consegue-se descrever especificidades que sem uma avaliação bem detalhada, algo poderia passar despercebido.

\section{A NECESSIDADE DA NEUROPSICOLOGIA EM UMA EQUIPE MULTIDISCIPLINAR}

A Neuropsicologia é uma área interdisciplinar de pesquisa e aplicação, congregando profissionais das áreas de saúde e educação, com o propósito de investigar as bases cerebrais do comportamento 


\section{Desafios da psicologia no Brasil}

humano, contribuindo, assim, para o diagnóstico e intervenção em problemas cognitivos, comportamentais e emocionais (HAASE; PINHEIRO-CHAGAS; ANDRADE, 2012).

A Neuropsicologia pode ser definida em um sentido mais amplo, como o estudo das relações entre o cérebro e o comportamento. Na interface das neurociências - onde estão disciplinas como a neuroanatomia, a neurologia, a neuroquímica, a neurofisiologia e as ciências comportamentais -, os métodos em que ela se fundamenta são amplos e bem variados (TOMAZ et al., 2016). Por isso é de grande importância integrar dados que vêm dessas diversas fontes, buscando compreender o comportamento individual do sujeito.

Quando se trata da aprendizagem, há algumas regras e princípios comuns que podem ser utilizados para todos, por serem universais, contudo também existem situações que são mais específicas, individuais, pois são resultantes da experiência vivenciada de forma particular, a partir de cada ser. Portanto, o professor, juntamente com uma equipe multidisciplinar, incluindo o apoio do neuropsicólogo, pode trabalhar em conjunto e, para isso, é primordial investigar, conhecer, analisar para poder utilizar metodologias e intervenções diferenciadas. Conforme diz Mattos (2014), a Neuropsicologia é por definição multidisciplinar sendo, provavelmente, a área que possibilita maior interlocução entre diferentes profissionais nas neurociências.

Em relação à educação em nossos dias, ressalta-se que deve ser trabalhada com grupos multidisciplinares, por isso é necessário que se faça uma releitura das práticas curriculares, desenvolvendo atividades conforme cada faixa etária e sendo focados, principalmente, os aspectos afetocognitivos (LEITE, 2011).

O professor precisa sinalizar aos pais quando algo sobre o comportamento de seu filho não está funcional, alertando-os de que seria relevante realizar uma avaliação mais específica. É importante que essa sinalização seja feita, porque, quanto mais cedo a criança for acompanhada por especialistas, melhor sua evolução. Não se pode ignorar o problema, porque poderá agravá-lo, aumentando as chances de futuras e maiores dificuldades de aprendizagem.

O cérebro depende de estímulos do meio ambiente, da escola, da família, além de elementos essenciais que influenciam na aprendizagem, como a idade, nutrição, saúde física e psicológica e, principalmente, de motivação. Não se deve acreditar que as dificuldades de aprendizagem são responsabilidades exclusivas do aluno ou dos professores ou da família, esse pensamento seria inadequado e simplista diante da grandiosidade e complexidade do ato de aprender. 


\section{Desafios da psicologia no Brasil}

Conhecer e valorizar a contribuição da Neuropsicologia será útil tanto na fase de diagnóstico como na de intervenção psicopedagógica sendo que, na escola, deve-se ter caráter preventivo, visto que a escola não pode ser confundida com clínica.

O estudo da aprendizagem e seus distúrbios/dificuldades precisa, realmente, despertar a atenção de diversos profissionais. Giannesi e Moretti (2015) relatam que professores, psicólogos, psicopedagogos, médicos, entre outros, e, sobretudo a família, tendo em vista o número crescente de crianças em idade escolar que têm demonstrado dificuldades de aprendizagem, de modo geral, precisam integrar conhecimentos. Dessa forma, as equipes multidisciplinares só possuirão êxito quando agirem de forma integrada com a escola e a família para assim focar o melhor desempenho da aprendizagem, otimizando resultados.

Defende-se, portanto, que as atividades e intervenções realizadas por profissionais diversificados, em prol de uma educação de qualidade, são estratégias relevantes voltadas ao processo de ensino e aprendizagem. É preciso descobrir novas perspectivas, dividindo e somando esforços. Nesse sentido, observa-se o quanto cada profissional pode colaborar na realização de tarefas e instrumentos, com suas especificidades, tendo uma visão holística do aluno, uma vez que cada especialidade tem a sua importância, podendo contribuir muito com suas habilidades e experiências.

\section{CONSIDERAÇÕES FINAIS}

Ressalta-se que os objetivos deste trabalho foram alcançados uma vez que se pôde realizar um levantamento teórico e crítico relacionado às contribuições da Neuropsicologia voltadas à educação/aprendizagem escolar, destacando informações mais consistentes que auxiliarão, principalmente, os educadores quanto ao desempenho de práticas pedagógicas mais eficazes, proporcionando reduzir dificuldades encontradas em diversos contextos, em especial, no ambiente escolar, referentes ao ensinar e ao aprender. Observou-se também que existem poucos estudos que abordam a conexão entre Neuropsicologia e Educação, sendo, assim, imprescindíveis mais pesquisas sobre essas áreas e suas especificidades e implicações.

Verificou-se que há a necessidade de formar gerações de profissionais e pesquisadores em educação, agregando as novas descobertas em neurociências para o aprimoramento de novas práticas pedagógicas. Para tanto, é primordial unir saberes e esforços, voltados a um trabalho 


\section{Desafios da psicologia no Brasil}

multiprofissional. Salienta-se que é fundamental a colaboração do neuropsicólogo, com seu trabalho amplo e atuação mais específica, que tem muito a contribuir também com a área educacional.

No decorrer deste estudo, através de uma pesquisa minuciosa, comprovou-se que a relação da Neuropsicologia com a Educação, de modo bidireccional, pode muito contribuir com o processo de ensino-aprendizagem, com um olhar voltado para questões fundamentais para o âmbito educativo, oferecendo bases científicas e práticas para um melhor aprendizado.

Pais, educadores, neuropsicólogos e psicopedagogos devem possibilitar um diálogo sobre como promover o melhor desenvolvimento das funções executivas em cada criança. É preciso conhecer para se ter uma visão mais prática, aprofundada e multidisciplinar. Percebidas algumas dificuldades e que essas não foram sanadas com suas intervenções em sala de aula, o professor deverá chamar a família para que procure profissionais especialistas na dificuldade apresentada, porque sozinho não dará conta dessa demanda, visto que as intervenções devem ser realizadas de acordo com as necessidades específicas de cada discente. É necessário que o docente seja orientado pelos respectivos especialistas sobre a melhor maneira de lidar com cada criança após ser submetida a uma avaliação detalhada.

Enfatiza-se também a importância de um feedback bem detalhado do neuropsicólogo, no final do processo avaliativo, apresentando à escola e à família um relatório com as informações relevantes obtidas ao longo da avaliação, incluindo orientações, contemplando sugestões de estratégias de ensino que venham melhor atender às dificuldades do aluno, destacando seus pontos positivos observados para que possam ser explorados e potencializados durante as atividades que deverão ser realizadas com o apoio dos professores e familiares.

Buscou-se fomentar o desenvolvimento de iniciativas benéficas tanto para educadores como para neuropsicólogos, despertando-os para um estudo mais criterioso da funcionalidade do cérebro vinculado à educação, que possa auxiliar na formação dos professores quanto a conhecimentos da Neuropsicologia para ajudá-los a desenvolver um trabalho mais direcionado e efetivo em suas atuações em classe, como também para contribuir para que os neuropsicólogos tenham mais aproximação com as questões relacionadas às dificuldades vivenciadas pelos educandos e educadores em sala de sala.

Os resultados encontrados nesta pesquisa demonstraram que há um elevado número de alunos nas escolas que apresentam dificuldades/transtornos de aprendizagem e, na maioria das vezes, não contam com um apoio profissional que favoreça um melhor rendimento acadêmico (cognitivo e emocional). E, para a redução de tais dificuldades, a Neuropsicologia pode colaborar com intervenções 


\section{Desafios da psicologia no Brasil}

de prevenção, remediação e de reabilitação, podendo proporcionar benefícios de curto a longo prazos para a comunidade escolar.

Percebe-se que a Neuropsicologia é uma área considerada ainda nova, principalmente, em relação ao contexto educativo. Porém, há vários cursos voltados a seu estudo. No entanto, nota-se que ainda se mostram desconhecidos para muitos profissionais da educação.

Destaca-se, portanto, que a Neuropsicologia pode contribuir muito para a compreensão dos processos de aprendizagem e dificuldades dos alunos, auxiliando o professor em busca de intervenções e metodologias de trabalho mais assertivas, preocupando-se com aspectos preventivos, favorecendo o desenvolvimento biopsicossocial do ser humano.

\section{REFERÊNCIAS}

ABREU, N. Quais são as perspectivas de Trabalho do Neuropsicólogo no Brasil? - 2017. Disponível em: https://www.iluminaneurociencias.com.br/single-post/2017/01/10/Quais-s\%C3\%A3o-asperspectivas-de-Trabalho-do-Neuropsic\%C3\%B3logo-no-Brasil. Acesso em: 20 jan. 2020.

ALMEIDA, B. O que é Neuropsicologia? - 2013. Disponível

em:< http://www.psicologiamsn.com/2013/05/o-que-e-neuropsicologia.html>. Acesso em: 20 out. 2017.

APA - American Psychiatric Association. MANUAL DIAGNÓSTICO E ESTATÍSTICO DE TRANSTORNOS MENTAIS [recurso eletrônico]: DSM-5; tradução: Maria Inês Corrêa Nascimento ... et al.]; revisão técnica: Aristides Volpato Cordioli ... [et al.]. -5. ed. - Dados eletrônicos. - Porto Alegre: Artmed, 2014.

BARTOSZECK, Amauri. Neurociência na educação, 2011. Disponível em: www.sitedaescola.com. Acesso em: 24 jan. 2020.

BRITO, D. R. Distúrbios da aprendizagem. 2016. Disponível em: <http://www.drb-assessoria.com.br>. Acesso em: 24 jan. 2020.

CAMARGO, C.H. Introdução. In: Malloy-Diniz, L. et al. Avaliação Neuropsicológica [recurso eletrônico] - 2a. Ed. Porto Alegre: Artmed, 2018.

CONSELHO FEDERAL DE PSICOLOGIA. Resolução 02/2004. Disponível

em: < http://www.crp.org.br/legislacao/resolucoes/federais/2004/resolucao2004_2.pdf>. Acesso em: 20 jan. 2020.

COSENZA, R.; GUERRA, L. Neurociência e educação: como o cérebro aprende. Porto Alegre: Artmed, 2011.

COUTINHO, T.; MALLOY-DINIZ, L. F. Neuro Sem Neuras Descomplicando as Neurociências. Belo Horizonte, 2017. 


\section{Desafios da psicologia no Brasil}

GIANNESI, I. de L.; MORETTI, L.H. Contribuições da neuropsicologia nas dificuldades de aprendizagem escolar, 2015. Disponível em:<www.psicologia.pt/artigos/textos/A0866.pdf>. Acesso em: 24 jan. 2020.

GOUVEIA, T. C.M. P.; PARRA, C.R. Neurociência e didática, 2016. Disponível em:<http://www.psicologia.pt/artigos/textos/A0983.pdf>. Acesso em: 24 jan. 2020.

HAASE, V. G.; PINHEIRO-CHAGAS, P.; ANDRADE, P. M. O. Reabilitação cognitiva e comportamental. In: TEIXEIRA, A. L.; KUMMER, A. M.

(Org.) Neuropsiquiatria clínica. Rio de Janeiro: Rubio, 2012. p. 115-123.

JARROS, R.; TOAZZA, R.; MANFRO, G.G. Aspectos neuropsicológicos nos transtornos de ansiedade na infância e na adolescência. In: SALLES, J.; HAASE, V. G.; MALLOY-DINIZ, L. Neuropsicologia do desenvolvimento: infância e adolescência [recurso eletrônico] - Porto Alegre: Artmed, 2016.

LEITE, S. de F. B. Neurociência: um novo olhar educacional, 2011. Disponível em: <http://www.webartigos.com/artigos/neurociencia-um-novo-olhareducacional/63961/\#ixzz4voQaAD6H>. Acesso em: 20 jan. 2020.

MALLOY-DINIZ, L., et al. Neuropsicologia: aplicações clínicas [recurso eletrônico] - Porto Alegre: Artmed, 2016.

Avaliação Neuropsicológica [recurso eletrônico] - 2a. Ed. Porto Alegre: Artmed, 2018.

Artmed, 2013.

Neuropsicologia do Envelhecimento: Uma Abordagem Multidimensional. Porto Alegre:

MATTOS, P. Neuropsicologia: teoria e prática. In: FUENTES, D. et al. 2ed. Porto Alegre: Artmed, 2014.

NOGARO, A. Neuropsicopedagogia na sala de aula, 2012. Disponível em:< http://www.webartigos.com/artigos/neurociencia-formacao-de-professores-e-praticaspedagogicas/90118/>. Acesso em: 22 jan. 2020.

OHLWEILER, L. Introdução aos Transtornos da Aprendizagem. In: ROTTA, N.; OHLWEILER, L.; RIESGO, R. Transtornos da Aprendizagem: Abordagem Neurobiológica e Multidisciplinar - Recurso eletrônico. 2a. ed. Porto Alegre: Artmed, 2016.

RODRIGUES, S. D.; CIASCA, S. M. Aspectos da relação cérebro-comportamento: histórico e considerações neuropsicológicas. Rev. Psicopedagogia, v. 27, n. 82, 2010, 117-26.

ROTTA, N.. Introdução. In: ROTTA, N.; OHLWEILER, L.; RIESGO, R. Transtornos da Aprendizagem: Abordagem Neurobiológica e Multidisciplinar. Porto Alegre: Artmed Editora, 2016.

ROTTA, N.; OHLWEILER, L.; RIESGO, R.Transtornos da Aprendizagem: Abordagem Neurobiológica e Multidisciplinar - Recurso eletrônico. 2a․ ed. Porto Alegre: Artmed, 2016. 


\section{Desafios da psicologia no Brasil}

SAMPAIO, S. A importância da neuropsicologia no processo educativo. 2017. Disponível em: <http://www.construirnoticias.com.br/a-importancia-da-neuropsicologia-no-processo-educativo/>. Acesso em: 24 jan. 2020.

Prefácio. In: METRING, Roberte. Neuropsicologia e aprendizagem: fundamentos necessários para planejamento do ensino. 2ed. Rio de Janeiro: Wak, 2014.

SANTOS, D. Contribuições da neurociência à aprendizagem escolar na perspectiva da educação inclusiva. Revista Edu. Tec., v. 2, n. 1, 2011.

TOMAZ, C. et al. Métodos de estudo da relação entre cérebro, comportamento e cognição. In: MALLOY-DINIZ, Leandro et al. Neuropsicologia: aplicações clínicas [recurso eletrônico] - Porto Alegre: Artmed, 2016, p. 42-57.

VILLAR, J. M. Discalculia na sala de aula de matemática: um estudo de caso com dois estudantes. 2017. Disponível em: <http://www.ufjf.br/mestradoedumat/files/2011/05/Disserta\%C3\%A7\%C3\%A3oDiscalculia-conclu\%C3\%ADdo-1.pdf>. Acesso em: 03 jan. 2020. 


\section{Capítulo 36}

ESTRATÉGIA DE INTERVENÇÃO EM PSICANÁLISE: DIAGNÓSTICO PSICOLÓGICO ÉTICO POLÍTICO NA PRODUÇÃO DO LAÇO SOCIAL DOS ADOLESCENTES NO CREAS

DOI: $10.37423 / 200200236$

Soraya Souza

soraya.sza@bol.com.br

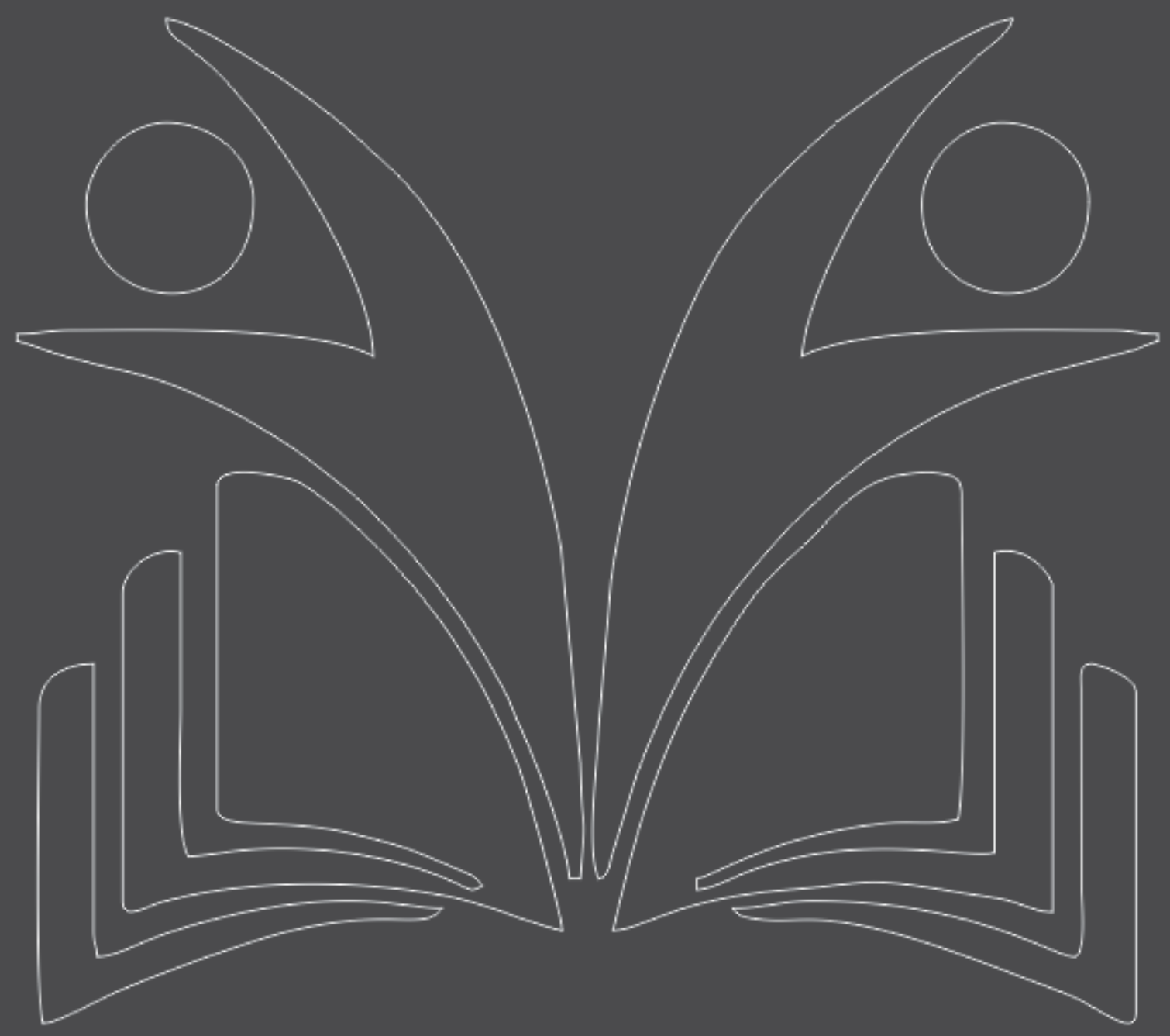




\section{Desafios da psicologia no Brasil}

\section{INTRODUÇÃO}

Este artigo é resultado de uma pesquisa de doutorado ${ }^{1}$ que se propôs a construir um modo de intervenção fundamentado na abordagem psicanalítica lacaniana, num campo psi jurídico, como uma das estratégias em que pode operar o diagnóstico na Instituição, incluindo o adolescente num modo ético-político e produzindo efeitos numa outra dimensão no e do acontecimento social.

A pesquisa justificou-se por questionar como o diagnóstico na Instituição afeta os profissionais e os adolescentes e produz laços nas relações sociais e, para contextualizar fez-se necessário reconhecer a especificidade em que a vulnerabilidade desses jovens foi produzida e entrelaçada pelas suas histórias nas dimensões física, social, psicológica e política no Centro de Proteção Social de Média Complexidade de São José dos Campos - CREAS/SJC, no Estado de São Paulo.

O objetivo foi construir uma estratégia para operar o diagnóstico psicanalítico como um dos modos de intervir do diagnóstico psicológico no acontecimento social que na sua dimensão ético-político, pela via da escuta e da transferência, objetiva instaurar uma Outra dimensão. Freud denominou essa via como um dos efeitos do amor na relação terapêutica. Para Rosa (2004), na via da transferência se produz o efeito da escuta:

[...] envolve tanto o sujeito como o psicanalista. A sua condição é construir um lugar situado como campo transferencial. A escuta psicanalítica implica que o analista suporte a transferência, ou seja, ocupe o lugar de suposto-saber sobre o sujeito - uma estratégia para que o sujeito, supondo que fala para quem sabe sobre ele, fale e possa escutar-se e apropriar-se de seu discurso. Esse campo permite uma relação que estrutura a produção do saber do sujeito, desde que o psicanalista renuncie ao domínio da situação e, pontuando e interpretando, possibilite a produção de efeitos de significação no sujeito: sujeito do desejo, engendrado pela cultura, mas que, em sua condição de dividido, pode transcender o lugar em que é colocado e apontar na direção de seu desejo. [...] A escuta psicanalítica é, desde Freud, transgressora em relação aos fundamentos da organização social; para se efetivar, implica um rompimento do laço que evita o confronto entre o conhecimento da situação social e o saber do outro como um sujeito desejante. Dessa escuta - principalmente quando o sujeito se revela como tal, como um dizer - não se sai isento: uma tomada de posição ética e política torna-se necessária (ROSA, 2004, p.335).

O diagnóstico psicológico ético- político é produzido por essa via, sob os efeitos do amor, e se caracteriza por ser um dos modos de estratégia da intervenção psicanalítica, o qual leva em consideração as condições sociopolíticas e subjetivas da produção discursiva. Essa estratégia acontece na dimensão do diagnóstico em direção ao tratamento, incluindo o sujeito do inconsciente como 


\section{Desafios da psicologia no Brasil}

possível de ser tratado, e não especificamente no tratamento, como o clínico-político. Segundo Alencar (2006, p. 8), a estratégia clínico-política:

É uma estratégia de intervenção que leva em consideração as pré-condições sócio-políticas e subjetivas necessárias à elaboração do luto, para fazer valer a dimensão do desejo, melhor defesa contra o gozo mortífero. Essas précondições podem ser realizadas na clínica estrito senso ou através de práticas coletivas que permitam a produção de ato que toca dimensões do real, simbólico e imaginário, contornando e significando aquilo que, por vezes, é negado socialmente. Restituir um campo mínimo de significantes que possam circular, referidos ao campo do Outro, permite ao sujeito localizar-se e poder dar valor e sentido à sua experiência de dor, articulando um apelo que o retire do silenciamento.

A estratégia clínico-política, como o diagnóstico psicológico ético-político, considera o contexto de produção do acontecimento para fazer valer a dimensão do desejo, permitindo ao sujeito localizar-se a partir de um campo mínimo de significantes e dar valor e sentido à sua experiência de dor, e podendo ser realizada na clínica estrito senso ou através de práticas coletivas.

Na realização tanto na clínica estrito senso como nas práticas coletivas, o diagnóstico psicológico éticopolítico caracteriza-se por três tempos conceituais trabalhados por Lacan (1945/1971) e reeditados por Rosa em Metáforas da Desordem: a) o instante de ver, tempo em que se é surpreendido por alguma coisa que não se esperava, b) tempo de compreender, no qual se constrói uma nova resposta, elaborando-se novas significações que permitam passar para c) o tempo de concluir, quando se pode dar conta de uma nova posição. Mesmo assim, a dimensão do Unheimlich não se perde, fica para sempre como marca do trabalho analítico, porém não significa seu destino (ROSA, 2004, p.3).

O diagnóstico psicológico ético-político, é um acontecimento que se situa, parafraseando Quinet $(2009,14)$, na clínica do discurso, e está articulado com a clínica do traumático e com a do nó borromeano, e a clínica estrutural, permite um acréscimo, investigando não só a relação estrutural do sujeito e suas estratégias para lidar com o desejo e o gozo do Outro, mas também como ele se insere nos discursos, sua relação com a mestria, com o saber, com o outro do laço social, com o mais-degozar, ou seja, os objetos pulsionais excluídos da civilização e sua posição em respeito ao gozo. Conforme as considerações de Leite (2000, p.29):

A clínica estrutural seria descontínua e categorial e estaria fundada sobre a modalidade da oposição orientando-se em função da oposição da existência e não existência da função paterna. Esta clínica é tripartida entre neurose, psicose e perversão. A clínica borromeana tem a característica de não se referir às categorias nosológicas da psiquiatria clássica e funda-se na relação dos 


\section{Desafios da psicologia no Brasil}

registros do imaginário, simbólico e real, segundo as propriedades de figura topológica do nó borromeano. Ela é uma clínica continuista e não categorial.

Apoiada na articulação da clínica topológica do nó borromeano e da clínica do traumático, penso em desenvolver o diagnóstico psicológico nessa condição ético-político, do acontecimento social como traumático, onde no sintoma social se implica o fantasma e se visa à posição do sujeito e o real do objeto causa de desejo, para formular uma ação que opera um Outro olhar, numa Outra cena ${ }^{2}$ e cria uma nova dimensão do sujeito no discurso.

O diagnóstico psicológico ético-político, compreendido como um dos modos de intervenção psicanalítico, permite-nos legitimar o diagnóstico psicológico com pessoas que experienciam situações sociopolíticas ou econômicas na dimensão do insustentável, que levam em conta contextos de exclusão e violência. (ROSA, 2009):

Na clínica do traumático há intervenções não convencionais que caracterizamos como prática psicanalítica clínico-política, para abordar a questão da angústia e do luto em sua face política, ou seja, considerando a produção sociopolítica da angústia e os processos de impedimento dos processos subjetivos de luto. Tal prática levanta questões metodológicas (individuais e/ou coletivas), armadilhas (intervir em nome do bem do outro) e impasses enquanto o desejo do analista. [...] A clínica do traumático não é específica das intervenções clínico-políticas (ROSA, 2004, p. 1-2)

No que concerne a tomar o diagnóstico psicológico como um acontecimento social, que produz um saber sobre outro acontecimento social - o crime -, isso significa colocar no jogo discursivo o seu contexto de produção, o que foi construído, para quem, como foi realizado e qual sua finalidade.

A formulação de um ato, ação ou acontecimento pode ser compreendida a partir das ideias de Foucault e Freud, em A arqueologia do saber (1972) e em Nietzsche, a genealogia e a história (1979). Foucault (1980) entende o acontecimento como "a irrupção de uma singularidade única e aguda, no lugar e no momento de sua produção." (p.46-51). No contexto específico em que o ato de diagnosticar é produzido ocorre a irrupção de uma singularidade única e aguda, que pode vir a ser traumática ou não, dependendo de como for vivenciada pelo sujeito, e produzindo efeito no laço social.

Para Freud, a noção de acontecimento traumático delineia-se quando um acontecimento, como um trauma externo, está destinado a provocar um distúrbio em grande escala no funcionamento da energia do organismo e a colocar em movimento todas as medidas defensivas possíveis.

Compreendemos o conceito de trauma a partir da ideia freudiana da concepção original, anterior à própria realização do mundo. Segundo Vieira (2001, p.61): 


\title{
Desafios da psicologia no Brasil
}

\begin{abstract}
Freud retoma as formulações de Otto Rank. Para Rank, o trauma é feito do encontro entre duas entidades distintas, o bebê e o mundo [...] o encontro com o mundo é sempre traumático. O trauma do nascimento seria o ponto zero, inevitável, de todos os encontros traumáticos entre o ser e o mundo. 0 aparelho psíquico constitui-se como uma camada de proteção contra o excesso de estímulos. Somente a partir desta operação inaugural, torna-se possível ler o caos e fazer dele um mundo. [...] o trauma é referido a um tempo mítico, universal, e é caracterizado como desamparo.
\end{abstract}

Após sua análise do Homem dos Lobos, Freud constrói uma articulação inovadora entre o ser, o mundo e o trauma, a partir da qual eles se tornam elementos constitutivos da realidade e organizam as experiências da vida. O trauma, como um elemento organizador do discurso, é um desamparo que demanda um amparo discursivo por parte do sujeito.

Esse amparo discursivo é compreendido aqui como um apoio que possibilita ao sujeito sustentar-se numa posição discursiva reconhecida socialmente, mas não pelos ideais sociais. Isso pode produzir um efeito de desamparo discursivo pela fixação do reconhecimento na idealização, ou seja, a correspondência biunívoca entre esses ideais que podem motivar e qualificar o ato, criando figuras do destino e impossibilitando a construção singular do sujeito.

\section{O DIAGNÓSTICO PSICOLÓGICO ÉTICO POLÍTICO COMO UM AMPARO DISCURSIVO NA ADOLESCÊNCIA}

No trabalho com os adolescentes, faz-se necessário pensar também a adolescência como um acontecimento discursivo, social, que sustenta os paradoxos entre identificação/fantasia e separação/alienação, e que se dá em diferentes momentos na vida dos sujeitos.

Entre os paradoxos da adolescência, no que diz respeito à identificação o que está em jogo é o saber sobre si, incluindo as referências parentais. Freud (1921) diz que a identificação não deve ser tomada como individual, mas trabalhada de forma integrada à formação do ideal do eu e ao funcionamento do sujeito nos grupos e instituições e na fantasia o poder da verdade. Já no que concerne à separação/alienação, na dimensão do psicológico deve operar a separação e a alienação opera no nível econômico-libidinal. Sendo assim, é necessário ao adolescente separar-se psiquicamente das figuras parentais, no entanto, este se encontra alienado nessa economia libidinal, o que pode causar um desamparo discursivo produzido pelas incongruências e forças não-ditas do campo social.

Segundo Rosa (2004), na adolescência, somada à condição de desigualdade social há um desamparo discursivo, "as incongruências e forças não-ditas do campo social expõem o sujeito ao risco de confrontação com o traumático, aquilo que está fora de sentido"(p.27). O risco de se confrontar com 


\section{Desafios da psicologia no Brasil}

o traumático, num momento da vida específico, onde o sujeito encontra-se perdido, produz o que vou denominar de vulnerabilidade psicopolítica, ou seja, uma condição que coloca em risco as categorias psicológicas e políticas no encontro do sujeito com o real.

A vulnerabilidade psicopolítica apresenta o que do sujeito está fora de sentido no acontecimento social, convocando-o a solucionar o conflito como for possível e colocando em jogo a causação da estrutura discursiva do acontecimento, e não da estrutura do sujeito.

O diagnóstico psicológico, neste caso específico, em que o ato dos adolescentes reincide, do e no acontecimento social nos permite questionar o que desse encontro faltoso está fora de sentido e insiste em retornar, identificando o sujeito como autor, isto é, criminoso, marginal, delinquente, representante das figuras do destino.

A identificação com as figuras do destino, na dimensão do real, produz uma identidade operacionalizada pela incorporação do objeto ao sujeito, pela fantasia. Já na dimensão simbólica e imaginária, esta é construída processualmente, num procedimento ético-político que opera pelo despertar de um sujeito que, em seu gesto singular de existir, inaugura um lugar que o referencia no mundo.

O despertar do sujeito em sua singularidade está imbricado na formulação de sujeito desenvolvida por Rosa (2006, p.8):

Mas o sujeito é um vazio sem autor e seu desejo é uma falta-a-ser. É preciso haver um ato de assentimento ao nada e a instauração de um lugar vazio, quando então a morte passa a sustentar a vida. Só a certeza do fim possibilita suportar essa história. O lugar vazio no Outro não enuncia a lei. Cabe, pois, ao sujeito, enunciá-la e tomá-la como esteio que determina o lugar do gozo. Desse modo, "cada um, cada uma, é responsável por seu inconsciente e pela Lei que nele se articula. É esse o móbil de nossa interrogação sobre a Lei: de fato, longe de ser uma simples negação privativa, ela deve ser uma borda que sirva de apoio" (JULIEN, 1996, p.94). Julien avança no tema, apontando que o próximo fica clivado entre o que pode ser rastreado até uma informação proveniente do corpo, que reconhecemos à nossa imagem, e a Coisa, o desconhecido, o irrepresentável. Toca-se aí o lugar do perigo, da maldade, da loucura, da perda do sentido (p.6).

Formulações de suposto sujeito definem-se pelo desejo como uma falta-a-ser e sem autor, num vazio, como uma potência de afetos que, orientada pelo inconsciente e por composição, cria e agencia, produz novas singularidades; é uma composição que se apresenta como um gesto que se "identifica em potência, isto é, como uma que propulsiona e atualiza-se em ato, expressa-se constantemente pelo esforço de perseverar na existência"(ESPINOZA, 2000) e, para Lacan, na ex-sistência. 


\section{Desafios da psicologia no Brasil}

No caso específico dos adolescentes do CREAS, o sujeito atravessado pelo discurso jurídico produzido pelo discurso capitalista é tomado na condição de um ator inferiorizado, ou seja, infrator, que nesse contexto prevalece como resultante da demanda do Outro como uma combinatória de significantes que, num campo do imaginário social, é identificado com as figuras do destino e é efeito da fantasia social.

Para Zizek apud Rosa, (2006, p.6), a fantasia social é a articulação da fantasia e da ideologia, tornando a fantasia uma categoria central do político, pois objetiva o fantasma, na fanthasia. A fantasia é compreendida pelo autor como uma cena imaginária protetora onde o sujeito realiza o desejo e dá direção ao gozo, e a ideologia como uma fantasia social que estrutura a determinação do valor e da significação da realidade socialmente compartilhada.

A fanthasia ${ }^{3}$ social opera num campo do imaginário social definindo lugares concretos, produzindo discursos e criando realidades para o sujeito. Castoriadis (1988) apud Rosa (2004, p.335), define o conceito de imaginário social:

[...] o conjunto de significações, normas e lógicas (dinheiro, sexo, homem, mulher, criança, etc) que determinam o lugar concreto que os indivíduos ocupam na sociedade. Esse conceito permite superar o de ideologia, na medida em que este último, ao definir crenças, também atribui um caráter falso às mesmas, enquanto o imaginário social envolve na própria definição sua índole de criação real e, ao mesmo tempo, de lugar de entrecruzamentos de ideais, cuja substância é tanto histórico-social como político-libidinal. Tais lugares permitem hipotetizar de que forma tais "realidades" interferem no sujeito ou fenômeno em questão(1988). Ressalta-se a ideia de que é a partir de uma certa concepção de lei, paternidade, sexualidade e domínio que alguns são considerados ou excluídos como sujeito humanos, e podem ter acesso à escuta, à palavra, ao gozo, à cidadania (ROSA, 2000).

O diagnóstico ético-político é construído levando em consideração a produção da fantasia no imaginário social, da substância histórico-social como político libidinal e o efeito de criar realidades que a partir de uma concepção específica afeta e produz sentido no sujeito. Segundo Freud, no capítulo VII, (1921), o sintoma compartilhado:

Apresenta o sintoma compartilhado, que pode ser considerado como precursor do sintoma social, que fornece a base das identificações histéricas na instituição de moças, fornecendo reforço narcísico de cada uma e do grupo, assim como referenciais para as identificações imaginárias mútuas. Freud assim se expressa: "algumas de suas amigas (...) pegarão a crise, assim por dizer, através de uma infecção mental, e sofrerão, por sua vez, um ataque igual". Ou seja, refere-se a construções de ideais, que articulam narcisismo e sociedade, e referências que articulam o sujeito no laço social, inserindo-o em todos os 


\section{Desafios da psicologia no Brasil}

âmbitos da cena social. (FREUD, 1921/1972a, p.135)

O sintoma compartilhado é precursor do sintoma social, referenciando-se pelas construções de ideais que indicam a qualidade de pertencimento e reconhecimento do sujeito no grupo e nas instituições. Faz-se necessário elucidar o sintoma como social, definido pelos autores nos escritos de Rosa (2004, p.35):

[...] como aquele que é sustentado por uma fantasia por meio da qual se denota o modo como os sujeitos controlam os ideais, buscando manter distante a castração. Apesar da fantasia ser a mesma, os sujeitos ocupam vários lugares na estruturação." (SOUZA,1991)

[...] considera que o sintoma social pode ser concebido como aquilo que está inscrito nas entrelinhas do discurso dominante de uma sociedade em dada época. (MELMAN,1992)

O sintoma como social articula o sujeito no laço e numa cena social, é sustentado pela fantasia que busca manter distante a castração e está inscrita no discurso dominante de uma sociedade. Já outros autores, como Volnovich, não adjetivam o sintoma e mostram como tende a tomar a forma da cultura à que pertence:

[...] não adjetiva o sintoma como social mas destaca seu estatuto de mensagem da conflitiva individual, familiar e sócio-política-institucional, mostrando como o sintoma tende a tomar a forma da cultura a que pertence; sintomas refletem uma organização subjetiva que contém uma mensagem e sinaliza processos sociais e particulares de sua forma de advir como sujeito (VOLNOVICH, 1993 apud ROSA, 2004, p.335).

Para Lacan, o sintoma social não é oposto ao sintoma particular, com uma psicologia individual e outra coletiva; não há relação com uma patologia social, mas descreve uma forma de laço social característico do discurso capitalista. No Seminário 17, Lacan refere o sintoma ao Discurso do Mestre, como objeção ao desejo do mestre, desejo de que as coisas funcionem; relaciona esse discurso com o Discurso do Inconsciente, esse saber que não pensa, não calcula ou julga, enfim, o trabalhador ideal, sendo a greve é o paradigma do sintoma, de sinal do que não vai bem no campo do real. Se o real não vai bem, isso impede que as coisas andem, trava a marcha, contraria o desejo do mestre e detém a produção do mais-de-gozar, causa do desejo do capitalista (ASKOFASRÉ apud ROSA, 2004, p.334). 


\section{Desafios da psicologia no Brasil}

Partindo desse contexto, o diagnóstico ético-político tem como função desdobrar uma Outra cena que poderá fazer emergir a inclusão do sujeito, através da narrativa, e sustentado em sua relação fantasmagórica, produzindo como efeito a construção do sintoma num campo social.

O sintoma construído num campo social pode ser uma alternativa para o sujeito se responsabilizar pelos seus atos e nos permite pensar e analisar a fanthasia nas articulações do sujeito pelo modo como ele controla e é controlado pelos ideais e pelos vários lugares ocupados na estruturação. Para Rosa (2004, p.336), na análise do sintoma social:

[...] deve-se escutar o não-dito do discurso sujeitos, cabe acrescentar a força de determinação dos não-ditos dos enunciados sociais . Nota-se que a crítica de que a Psicanálise está indo além de seu campo de origem refere-se muito mais a uma direção tomada pelo movimento psicanalítico do que a uma proposta imprópria ou externa a esse campo. Inúmeros são os modos como se pode desenvolver, dentro dos fundamentos éticos e teóricos da psicanálise, uma investigação dos fenômenos sociais, contribuindo para a elucidação de sua eficácia no processo de alienação do sujeito e apontando os laços que possibilitem a sua inclusão como sujeitos do desejo.

Visando essa inclusão do sujeito como desejante, faz-se necessário pensar uma formulação sobre o diagnóstico psicológico ético-político como um acontecimento social que só pode ser compreendido como produzido sob transferência e entre os discursos do pesquisador e dos sujeitos.

A formulação do diagnóstico psicológico ético-político fundamentou-se na utilização dos termos matemáticos: da teoria dos conjuntos, para pensar a estrutura do acontecimento, e a dos jogos e dos discursos lacanianos, a dinâmica discursiva.

Para se pensar o diagnóstico psicológico ético-político como um acontecimento social utiliza-se a teoria dos conjuntos para compreender a estrutura do acontecimento social, partindo do pressuposto de que a sociedade é constituída por $n$ conjuntos, sendo o acontecimento social uma composição dos conjuntos que, por jogos combinatórios, se entrelaçam e se afetam pelos sentidos constituíndo os discursos.

A teoria dos conjuntos permite-nos pensar a estrutura do acontecimento como um conjunto e/ou objetos que se entrelaçam nas relações de união, interseção e na diferença entre os conjuntos, e que se articulam por uma análise combinatória de permutação com elementos repetidos. Numa permutação simples, cada um dos agrupamentos que podemos formar com certo número de elementos, onde ao menos um deles ocorre mais de uma vez, tal que a diferença entre um agrupamento e outro se dê pela mudança de posição do sujeito entre os elementos, produz categorias 


\section{Desafios da psicologia no Brasil}

políticas que utilizam da lógica da inclusão, da exclusão e da segregação e resultam no efeito da direção do gozo e ou do desejo, especificando o modo de laço social do sujeito.

No diagnóstico psicológico ético-político como acontecimento social, a política de inclusão fundamenta-se na interseção dos conjuntos, e da exclusão é a interseção de dois conjuntos, subtraindo-se a inclusão e a segregação. Já a segregação é a união dos três conjuntos, subtraindo-se a inclusão e a exclusão. Na delimitação de uma Cena discursiva temos $n$ elementos que irão compor dois ou mais conjuntos, logo os elementos que estão no campo de interseção estão incluídos e os elementos que não fazem parte dessa cena estão excluídos. Já a segregação refere-se à aquilo que está fora da relação dos dois conjuntos, mas está dentro da sociedade.

A segunda formulação é a da teoria dos jogos, operando os discursos, no que concerne às proposições, isto é, à dinâmica dessas relações que podem ser compreendidas pela combinatória dos termos discursivos, a partir da posição que o sujeito ocupa no jogo, que constrói lugares, isto é, pro-posições, através das enunciações e dos enunciados, demonstrando sua posição em relação a verdade e ao gozo. No que diz respeito às enunciações e aos enunciados, sua produção e seu efeito, estes constituem um sinthoma no social, a partir do qual é possível formular uma demanda, construir um enigma e produzir sentidos numa existência ético-política. O sintoma social, tomado como um enodamento sinthomático que se situa no nó borromeano nas dimensões do real, simbólico e do imaginário, considera as categorias de inclusão, exclusão e segregação na sua dimensão política, como elementos que operam nos entrelaçamentos dos modos de enredamento discursivos.

A topologia dos nós é um novo recurso para se mostrar como opera a clínica psicanalítica e sua demonstração requer pensarmos o nó numa dimensão plana, onde os conjuntos são constituídos por entrelaçamentos discursivos, para depois pensarmos os casos clínicos. Primeiro o nó a três: Trata-se de um nó (ou cadeia) na qual: 1) se for solta uma rodela, as outras se desatam; 2) as rodelas estão superpostas e não entrecruzadas; 3 ) elas estão enodadas de tal forma que duas estejam livres; 4) elas fazem existir um buraco.

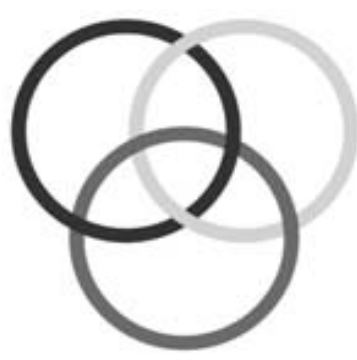




\section{Desafios da psicologia no Brasil}

Figura 1 - Nó borromeano de três aros.

Fonte:Ágora (Rio de Janeiro) v. XI n. 2 jul/dez 2008 p.287

O mais importante a destacar é que do fato de duas rodelas serem livres uma da outra que se suporta a ex-sistência da terceira, especialmente a do Real em relação à liberdade do Simbólico e do Imaginário. A partir do momento em que o Real é enodado borromeanamente aos dois outros registros, eles Ihe resistem. Isso quer dizer que o Real só tem ex-sistência na medida em que encontra no Simbólico e no Imaginário sua parada, seu limite. Daí Lacan afirmar e reafirmar continuamente que o Real não é apenas uma rodela do nó borromeu, mas o efeito da maneira como ele se amarra. O que importa é essa operação real que, como veremos, desloca o gozo, permitido por uma renomeação do sujeito.

O segundo ponto refere-se ao nó a quatro, pois na medida em que o Real é um efeito da forma como a amarração se dá - esse efeito de termos rodelas livres e, ao mesmo tempo, atadas, Lacan propõe um novo nó no qual, de fato, as três rodelas estão livres umas em relação às outras. Elas se encontram apenas sobrepostas. É o quarto elemento, inventado por cada sujeito, que trará a característica borromeana ao nó, concentrando esse efeito real em si mesmo.

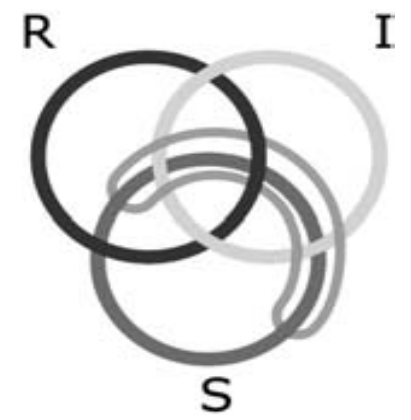

Figura 2 - Nó borromeano de quatro aros com reforço (sinthome) no Simbólico. Fonte:Ágora (Rio de Janeiro) v. XI n. 2 jul/dez 2008 p.287

Lacan chega a afirmar que abandona o nó de três, à proporção que não há mais nó, senão enquanto sustentado por esse quarto elemento, por ele denominado sinthome (LACAN, 1975-76/2005, p. 41) O importante a destacar nessa passagem do nó de três para o nó de quatro elos é a sustentação da amarração por este quarto elemento, podendo qualquer sujeito, a princípio, fabricá-lo. E, em sua repercussão clínica, verificarmos que o Simbólico avançando sobre o Sinthoma (no reforço que forma 


\section{Desafios da psicologia no Brasil}

com ele) pode se estender até certo limite quando, do uso do gozo do sinthoma que resta, o sujeito poderá extrair um savoir-y-faire com esse resto sinthomático. Podemos associar esse resto, que não desaparece, ao rochedo da castração, ao gozo opaco que resta inanalisável, e do qual o sujeito aprenderá a fazer novo uso.

Os entrelaçamentos discursivos são constituivos do nó e se apresentam nas enunciações e nos enunciados do sujeito e na sua relação com o Outro, como um dispositivo para análise. Nas palavras de Rosa (2004, p.334):

Um dispositivo útil para a análise da articulação da construção da subjetividade aos laços sociais possíveis em dados grupos sociais é destacar o que os enunciados e a enunciação presentes na cena social sobre referentes fundamentais da organização social e psíquica elucidam sobre o imaginário dos grupos sociais, que atribuem lugares específicos ao sujeito.

Os lugares específicos atribuídos aos sujeitos na cena social presentificam-se nas enunciações e nos enunciados, pelo modo como o sujeito construiu as proposições articulando a verdade e o gozo, e utilizando a lógica proposicional para compreender as combinações possíveis do e no acontecimento social.

$\mathrm{Na}$ teoria dos jogos, o discurso científico reduz a verdade a um tipo de valor: verdadeiro e falso, que só adquirem significado dentro da lógica proposicional. Então: se afirmo que o adolescente é reincidente (proposição A) e o motivo foi roubo (proposição B), tanto A quanto $B$ devem ser individualmente verdadeiras para que minha informação como um todo seja verdadeira, a de que reincidência aconteceu e o motivo foi o roubo. Se somente uma delas for verdadeira, minha informação como um todo é falsa. É apenas quando ambas são verdadeiras que minha informação como um todo é verdadeira.

Já na teoria psicanalítica, não utilizaremos a redução da verdade a um valor, pois um discurso pode ser verdadeiro e/ou falso dependendo do valor da atribuição do sujeito; no entanto, interessa-nos compreender as proposições discursivas do sujeito na constituição do sinthoma social.

O que nos importa destas duas formulações é pensar o diagnóstico psicológico ético- político a partir da posição do sujeito no acontecimento social, como as propositivas estão relacionadas no discurso e, consequentemente, a produção de verdade e/ou de gozo no efeito do laço social.

O diagnóstico psicológico ético-político como um acontecimento social, tem a responsabilidade ética de produzir efeitos sobre o sujeito que o redimensionem a uma Outra cena. Sendo assim, é ético compartilhar a ação para inscrever o sujeito numa Outra dimensão da cena social, operacionalizando 


\section{Desafios da psicologia no Brasil}

o real, incluindo aquilo que está fora de sentido, isto é, amparando discursivamente o sujeito.

\section{DIAGNÓSTICO PSICOLÓGICO ÉTICO POLÍTICO COMO UM ACONTECIMENTO SOCIAL}

Apresentaremos a construção do diagnóstico psicológico ético-político como uma estratégia de investigação que, sob transferência, delimita a construção da territorialidade, dos atores partícipes da cena social e dos procedimentos, como constituintes de um modo de operar entre os discursos Um acontecimento social.

$\mathrm{Na}$ construção do diagnóstico psicológico ético-político, o nascimento do conceito na trama da investigação nos possibilita obter formulações necessárias sobre o objeto. De acordo com Rosa (2004, p.337):

O conceito deve nascer da necessidade própria da trama a que pertence, sem descuidar, em sua formulação, de como este se firma no solo da teoria selecionado para a investigação; os elementos comuns vão sendo destacados desse material, a fim de constituir a questão a ser estudada.

E desse modo foi sendo construída a questão em estudo. Este trabalho científico se fundamentou no princípio epistemológico psicanalítico, buscando compreender o objeto pela pesquisa em psicanálise de orientação lacaniana aplicada ao social, buscando sustentar os impasses que a prática com a Instituição nos impõe, no que tange à política dos diagnósticos como um ato privado e público de inclusão, exclusão e segregação social. Nas palavras de Rosa (2004, p.2), caracterizando a psicanálise extramuros ou extensão:

A Psicanálise extramuros ou em extensão diz respeito a uma abordagem - por via da ética e das concepções da psicanálise - de problemáticas que envolvem uma prática psicanalítica que aborda o sujeito enredado nos fenômenos sociais e políticos, e não estritamente ligado à situação do tratamento psicanalítico. Consideramos que esse tipo de pesquisa da Psicanálise - iniciado por Freud e por ele nomeado psicanálise aplicada .

Uma abordagem psicanalítica leva em consideração que os fenômenos sociais e políticos que afetam o sujeito. No que concerne à psicanálise enquanto método, faz-se necessário compreender que esse é um dos modos e não o modo de operar, como está em Descartes. Sendo assim, podemos pensá-la não como método, mas a partir da formulação de estratégias, parafraseando Rosa (2005, p.3), "que vão se formando e transformando, engendrando táticas e propiciando "sacadas" em função das condições atuais em que são efetivadas. [...] deixam uma longa margem para o improviso, para os 


\section{Desafios da psicologia no Brasil}

processos primários, para as descobertas e para as invenções." Ainda segundo Rosa (2004, p.7), o método psicanalítico vai do fenômeno ao conceito:

[...] constrói uma metapsicologia não isolada, mas fruto da escuta psicanalítica, que não enfatiza ou prioriza a interpretação, a teoria por si só, mas integra teoria, prática e pesquisa. O psicanalista não aplica teorias, não é o especialista da interpretação, nem mesmo da fantasia, posto que não é só aí que o inconsciente se manifesta; o psicanalista deve estar a serviço da questão que se apresenta. A observação dos fenômenos está em interação com a teoria, produzindo o objeto da pesquisa, não dado a priori, mas produzido na e pela transferência. [...] O método é a escuta e interpretação do sujeito do desejo, em que o saber está no sujeito, um saber que ele não sabe que tem e que se produz na relação que será chamada de transferencial. Nessa medida, o psicanalista escuta o sofrimento e descobre que não deve eliminálo, mas criar uma nova posição diante do seu sentido. O sintoma é realização do desejo, o lugar da verdade do sujeito, uma mensagem, um enigma a ser decifrado; nele está o cerne da subjetividade.

O método psicanalítico é produzido a partir de uma metapsicologia compartilhada e sob o efeito da escuta e na e pela transferência é produzido o objeto da pesquisa. Na tentativa de sustentar os impasses teórico-prático psicanalíticos urge pensar-se um processo de investigação que se constitua a partir da mútua constituição e transformação do objeto, sujeito e meios, como diz Minerbo (2000, p.15):

Não seria a psicanálise ela mesma uma matriz de estratégias de investigação, mais do que um "método de pesquisa", considerando-se o quanto a noção de "método" está, desde Descartes, comprometida com a pretensão do homem da modernidade de exercer um pleno controle sobre seus próprios processos volitivos e cognitivos? Já as estratégias vão se formando e transformando, engendrando táticas e propiciando "sacadas", em função das condições atuais em que são efetivadas; estratégias deixam uma larga margem para o improviso e para os processos primários, para as descobertas e para as invenções.

O método aqui será tratado na sua pluralidade, como "estratégias de investigação", pois existem vários caminhos para compreender o homem, desconstruindo a pretensão científica de controlá-lo em seus processos volitivos e cognitivos. Segundo Miller (2009, p.19), "se seguimos a orientação lacaniana percebemos que ela está interessada no que não se encaixa às belas formas e escapa à luz da razão, ou seja, no que em cada um fracassa dando lugar ao 'não como todo mundo'”.

Diante do exposto, numa pesquisa-intervenção, essa estratégia de investigação lacaniana leva em consideração o diagnóstico psicológico ético-político como objeto da pesquisa, compreendido aqui 


\section{Desafios da psicologia no Brasil}

como uma "descrição que prioriza e recorta aspectos do objeto, procurando descrever e nomear, tendo como função ético-política, fundar uma ideia e a construção de um novo olhar sobre uma dimensão do humano e neste sentido limita o poder do psicólogo frente ao cliente". (ROSA, 1996, p.4).

O diagnóstico deve ser tomado como uma oferta para acolher os significantes que descartados pelo Discurso do Mestre pulsam, e diz sobre a articulação entre os corpos: imaginário, real e simbólico do sujeito.

O processo desta investigação está delimitado no Núcleo Psicanálise e Política (NUPSPO), que pesquisa sobre os modos de enredamento do sujeito - sua constituição e sua destituição - no campo social e político. As bases teórico-conceituais são advindas da Psicanálise, especialmente de S. Freud e J. Lacan, assim como de autores de outros campos teóricos, críticos das políticas e das estratégias de controle e de poder na contemporaneidade.

\section{TERRITORIALIDADE: LOCAL GEOGRAFICAMENTE CONSTRUÍDO NA PESQUISA}

A trajetória metodológica inicialmente construída caracterizou-se pela escolha da Fundação Casa de São José dos Campos, a qual não autorizou a realização do trabalho, alegando que o tema era pertinente apenas para a Perícia do Estado, tendo em vista a proposição da Fundação Casa: "não faz avaliação psicológica, logo, não realiza diagnósticos psicológicos, uma vez que essa Instituição está comprometida com as medidas socioeducativas."

Podemos nos questionar a partir dessa proposição: a equivalência de avaliação com diagnóstico psicológico, sendo que um classifica e o outro descreve? Por que o diagnóstico psicológico comprometeria a medida socioeducativa? Que medidas sociais e educativas são essas que são simplesmente executadas como castigo? E ainda, como as medidas socioeducativas são aplicadas aos adolescentes sem levar em consideração para que servem e quais os efeitos que produzem nesses jovens?

Num segundo momento, procurei a Secretaria de Desenvolvimento Social de São José dos Campos, a qual avaliou o projeto e o encaminhou para ser desenvolvido no Centro de Referência Especializado da Assistência Social (CREAS), de São José dos Campos, no Estado de São Paulo. Essa Instituição, vinculada à Secretaria de Desenvolvimento Social, tem a missão primordial de aplicar medidas socioeducativas de acordo com as diretrizes e normas previstas no Estatuto da Criança e do Adolescente (ECA) e no Sistema Nacional de Atendimento Socioeducativo (SINAES). 


\section{Desafios da psicologia no Brasil}

Os CREAS são unidades de serviços de proteção social especial (média complexidade), para atendimentos de famílias e indivíduos em situação de risco pessoal e social.

Sua missão é: fortalecer na família a função de proteção de seus membros; incluir as famílias na rede de proteção social e nos serviços públicos, romper com o ciclo de violência no interior da família, oferecer condições para reparar danos e interromper a violação de direitos, e prevenir a reincidência de violações de direitos.

As atividades socioeducativas para crianças e adolescentes acontecem nos Centros de Referência da Assistência Social (CRAS) de todos os núcleos regionais e em outras unidades executoras, como os projetos realizados em parceria com instituições governamentais, não-governamentais, entidades sociais e comunidade.

No que concerne aos objetivos e às atividades socioeducativas da Instituição CREAS, sendo sua proposição fortalecer na família a função de proteção de seus membros, cabe questionar se o CREAS realmente presta serviço de proteção social aos indivíduos e às famílias desprotegidas. Podemos pensar, diante da oferta de seus serviços, como é possível proteger famílias desprotegidas? Desprotegidas por quem e do quê? Quais são os limites dessa oferta? Por que atividades socioeducativas não são oferecidas à família?

Algumas características das atividades desenvolvidas são: conjugam educação e proteção social; não possuem currículo e programação pedagógica padrão; são planejadas conforme demandas, interesses particulares e potencialidades da comunidade; oportunizam o desenvolvimento de interesses, potencialidades e talentos; valorizam o aprendizado múltiplo, a troca de ideias e de experiências; estimulam o desenvolvimento de postura crítica; estimulam o desenvolvimento de relacionamentos interpessoais e o respeito às diferenças; $p$ Podem ser realizadas em unidades de execução diversificadas.

A metodologia adotada segue as orientações técnicas de âmbito nacional do Sistema Único de Assistência Social (SUAS), detalhadas no Protocolo de Gestão dos CRAS, documento elaborado pelos profissionais da Fundação da Ação Social (FAS). Este visa ao fortalecimento dos vínculos familiares e comunitários, à formação de valores, e ao incentivo ao protagonismo, entre outros princípios.O serviço de proteção social a adolescentes em cumprimento de medida socioeducativa Liberdade Assistida (LA) e de Prestação de Serviços à Comunidade (PSC) é executado nos CREAS. Sua finalidade é prover atenção socioassistencial e acompanhamento a adolescentes e jovens encaminhados pela Vara de Adolescentes em Conflito com a Lei. 


\section{Desafios da psicologia no Brasil}

Sendo que a metodologia do CREAS segue proposições do SUAS, detalhadas pelo CRAS e elaborada pelos profissionais da faz, será que a totalização do método é eficiente, levando em consideração que as Instituições são produzidas em contextos específicos? E ainda, o objetivo dos serviços é o de proteção social à família e o serviço realizado é de proteção aos adolescentes. Será que a proposição de focalizar o problema no adolescente é uma operação de individualizar o problema e incluí-lo como responsável por pertencer a uma família desprotegida?

O acompanhamento do adolescente realizado pelo CREAS contribui no trabalho de responsabilização quanto ao ato infracional praticado, cujos direitos e obrigações devem ser assegurados de acordo com as legislações e normativas específicas. O primeiro passo na realização dessa etapa consiste na elaboração do Plano Individual de Atendimento (PIA), com a participação do adolescente e da família, que inclui os objetivos e metas para o cumprimento da medida, perspectivas de vida futura e atendimento de necessidades e interesses do adolescente.

Os técnicos realizam encaminhamentos para a rede de proteção social, que incluem na escola, ações socioeducativas, atenção à saúde, atendimento e prevenção ao uso de drogas, inclusão em cursos profissionalizantes.

As ações devem favorecer o desenvolvimento pessoal e social dos adolescentes, criando condições para a construção ou reconstrução de valores sociais, ruptura da prática de atos infracionais e fortalecimento do vínculo familiar e comunitário.

O público atendido compõe-se de adolescentes de 12 a 18 anos incompletos, ou jovens de 18 a 21 anos, em cumprimento de medida socioeducativa de liberdade assistida (LA) e de prestação de serviços à comunidade (PSC), aplicadas pela Vara de Adolescentes em Conflito com a Lei.

Com relação ao acompanhamento dos adolescentes, o trabalho de responsabilização está submetido ao ato infracional, cujos direitos e obrigações devem ser assegurados de acordo com as legislações e normas específicas. Levando em consideração que o ato infracional direciona o fazer do trabalho de responsabilização, podemos nos questionar: O que é o trabalho de responsabilização nesse serviço de proteção social? Se o público atendido são os adolescentes, isso reafirma a hipótese de responsabilização do adolescente como responsável pela família desprotegida, enfraquecendo os vínculos familiares e comunitários, uma vez que ele somente fortaleceria este vínculo se lhe fosse atribuído um valor de reconhecimento social na experiência infracional. 


\section{Desafios da psicologia no Brasil}

Para concluir, podemos nos questionar por que o cumprimento da medida socioeducativa em condições de LA e PSC é realizado por uma Vara de adolescentes em conflito com a lei? Por que não é feito pela Vara da família se o objetivo da rede é de proteção social à família?

\section{ATORES PARTÍCIPES DA E NA CENA SOCIAL}

Propomos escutar os atores partícipes da e na cena social, como sujeitos da pesquisa, e para tal, foram escutados dois psicólogos, três assistentes sociais, além de cinco adolescentes em condição de reincidência que estão sob regime de LA no CREAS. Para realizarmos a análise do acontecimento social, a escolha não foi aleatória, pois foram escolhidos dois adolescentes que puderam comparecer às entrevistas.

O trabalho foi desenvolvido com adolescentes que, na condição de reincidência ao ato, eram partícipes dessa cena social. Os termos 'reincidente' e 'liberdade assistida' leva-nos a questionar: 0 que será que reincide, repete, insiste? O que será que será que não pode calar, mas não pode ser dito? Como funciona isso, regime de liberdade? O que significa liberdade assistida? Assistida por quem? $\mathrm{O}$ que os adolescentes insistem em nos dizer com a reincidência ao ato?A reincidência no ato seria uma passagem traumática da reedição da tragédia sob forma de um acontecimento social?

Como bem diz Lesourd (2004, p.151), "esses adolescentes que interpelam o social, no desvio, na errância, ou na delinquência, são jovens chamados de 'inclassificáveis' por causa da incapacidade das estruturas médico-sociais de encontrar com seus critérios um lugar para eles, os quais preferem chamar de desarrimados do social e de suas leis". Aichorn apud Lesourd (2004, p.150) refere-se a esses sujeitos como "jovens e/ou adolescentes em situações de sofrimento".

Concordamos com a crítica de Lesourd (2004), e com a afirmação de Aichorn. Consideramos a juventude e/ou adolescência um momento de transição, do mítico infantil à vida adulta, uma passagem conflituosa e traumática para todos os que a atravessam e para os que sucumbem nessa travessia. Sendo assim, os adolescentes interpelam o social pelas situações de dor.

No que diz respeito à legitimação social dessa clientela, esta é principalmente discriminada em sua esfera intelectual, econômica, social, cultural e psicológica, assim produzindo categorias descontextualizadas de deficiência, desvio e desigualdades, operando como efeito discursivo políticas de inclusão, exclusão e segregação dos sujeitos na sociedade.

Os sujeitos da presente pesquisa foram tratados com dignidade, respeito e autonomia. Houve garantia de consentimento livre e esclarecido por parte dos sujeitos e, ainda, a liberdade de se recusarem a 


\section{Desafios da psicologia no Brasil}

participar ou reiterar algo em qualquer fase da pesquisa, sem penalização alguma e sem prejuízo de sua parte.

\section{PROCEDIMENTOS DA ESTRATEGIA DE INVESTIGAÇÃO}

O procedimento metodológico foi construído a partir do conceito freudiano de transferência, compreendida como "uma repetição de protótipos infantis, onde haveria um deslocamento de afeto de uma representação para outra" (1912), articulado com a escuta psicanalítica na prática discursiva dos atores do contexto Institucional. Este processo emergiu da escuta e transferência psicanalítica, em seis momentos, descritos a seguir, e foi dividido em três tempos lógicos: o instante de ver, o tempo de compreender e o de concluir.

O primeiro momento, $o$ instante de ver, iniciou-se com a visita à Fundação Casa, da qual registrei a experiência que vivi em forma de Testemunho (Apêndice A), e foi desenvolvido na Instituição CREAS.

O segundo momento, encaminhamento para Avaliação da Comissão de Ética, e diante da aprovação foi marcado novos encontros na Instituição para solicitar a autorização do trabalho de campo.

O terceiro momento, caracterizou-se pela observação na Instituição CREAS. Fui recebida pelo Coordenador C., que demonstrou disponibilidade em participar da pesquisa, solicitou o projeto de pesquisa e agendou uma reunião com a equipe técnica para apresentação da proposta de trabalho. Nessa reunião com a equipe os atores demonstraram disponibilidade em participar, bem como interesse no tema, uma vez que a reincidência é um elemento de constante reflexão, devido à importância e complexidade desta na prática cotidiana. Acordamos, portanto, os termos de responsabilidade da pesquisa, tendo a equipe decidido levar em consideração a condição de reincidência ao ato e indicar um ou mais casos.

Ainda nessa fase, o Coordenador C. apresentou-me à psicóloga R., que nesse percurso Institucional me acompanharia no que fosse necessário para desenvolver o trabalho. Agendei com R. um outro momento para que pudéssemos compartilhar um planejamento. Na primeira entrevista R. narrou a história institucional e apresentou documentos institucionais relativos ao Projeto de Atendimento ao Adolescente em Conflito com a Lei e os prontuários. Posteriormente deu-se o agendamento dos adolescentes. R. recebeu dos profissionais o encaminhamento de cinco adolescentes e os agendou para o mesmo dia, alegando não apenas uma dificuldade no comparecimento destes, como também que, por tratar-se de uma pesquisa, eles poderiam escolher não participar do trabalho. 


\section{Desafios da psicologia no Brasil}

Concordei com R. e, nessa primeira marcação, apenas um adolescente compareceu e aceitou participar da pesquisa. Vários agendamentos foram realizados com essa dificuldade que afeta o serviço da psicóloga R. presente em todos eles: os adolescentes não compareciam e muitos não queriam participar. Podemos nos questionar: Neste contexto disciplinar o que significa a falta? O que significa para o adolescente faltar no CREAS?

Diante do exposto e atravessado pela escuta psicanalítica, intervi propondo um outro manejo para situação: um manejo institucional, isto é transferencial, influenciado pelos elementos institucionais. Propus aos profissionais que escolhessem o caso e agendassem comigo o horário em que o adolescente deveria estar na Instituição. Sendo assim, depois do atendimento com o técnico, estes poderiam encaminhar o adolescente, a quem caberia a decisão de participar ou não da pesquisa. Os adolescentes, portanto, não compareceriam ao CREAS por escolha, mas por determinação judicial, tendo eu decidido inserir esse processo determinado judicialmente, como parte da coleta de dados da pesquisa.

Os profissionais concordaram e assim foi possível realizar o trabalho. A psicóloga e as assistentes sociais diziam que se afetavam pela falta dos adolescentes, pois isso lhes causava o sentimento de vergonha. A imposição judicial e a oferta de serviços produzem categorias como a resistência do adolescente em participar da Instituição como infrator, delinquente, em conflito com a lei, e os efeitos no laço, que se marcam pela repetição da ausência do sujeito.

Oito adolescentes compareceram e apenas dois se comprometeram a participar da pesquisa. Estes demonstram dificuldades em comparecer ao CREAS para cumprir a exigência da medida socioeducativa, o que nos abre a possibilidade de questionar se a medida é do jovem e se é socioeducativa, pois quando o adolescente falta, ele se justifica muitas vezes valendo-se de mentiras que são aceitas pela lógica burocrática como verdade.

Considerando que a falta nesse contexto é operacionalizada pela política de denegação, por se negar o limite existente de se fazer todas as coisas ao mesmo tempo, faz-se necessário torná-la uma política da castração, um significante que se remete à perda de algo ou de alguém, perda essa que seja suportável para o sujeito e para Instituição. Mas, para tal, é necessário repensar a imposição judicial como medida socioeducativa e o CREAS como uma Instituição que oferta serviços, em vez de acolher os jovens naquilo que não conseguem parar de pensar. Como bem diz Mattos (2011, p.6): 


\section{Desafios da psicologia no Brasil}

Ao ser acolhido o que atenta as crianças e os jovens, ao ser escutado naquilo em que estão enredados e ao que realmente dão atenção - e não ao que lhes é exigido mas, ao que não conseguem parar de pensar -, eles acabam por encontrar um lugar para sua subjetividade e para seu modo de satisfação. Algo do pulsional pode ser regulado no dispositivo da conversação.

Para delimitar esse acontecimento social, utilizamos o termo construído por Rosa (2001, p.129) "encontros decididos", ou seja, encontros que foram decididos ao longo do processo com o jovem, na tentativa de fazer vacilar o significado da falta e escandir uma diferença no que concerne ao significante. A falta é real e deve estar incluída como um elemento imprescindível a ser analisado no processo da medida socioeducativa, pois indica a posição do suposto sujeito diante da castração naquele acontecimento social.

O primeiro caso estudado foi o do adolescente Alexsandre (nome fictício), que chegou encaminhado pela técnica R. que o acompanha desde 2010 no Projeto Juventude Cidadã. Percebi que o encaminhamento de R. havia sido determinante para o P. estar ali. Minhas palavras não faziam diferença enquanto explicava o termo de consentimento e o projeto de pesquisa, pois estava decido a participar do trabalho e sob relação transferencial com a assistente social $R$.

Durante o percurso foram marcadas oito entrevistas com ele, que compareceu a quatro e faltou em quatro. Para minha surpresa, ofertou sua palavra, tendo solicitado ser escutado, uma vez que o encontro não havia sido marcado. O jovem Alexsandre, que inicialmente demonstrava estar afetado pela desconfiança, foi aos poucos construindo uma relação transferencial com esta pesquisadora. Quando estava presente nos encontros decididos demonstrava estar afetado por esse acontecimento e mostrava o conflito psíquico na idealização da relação familiar e seu sofrimento diante da vida. A profissional R., na relação com o jovem, apostava na escola como uma saída real desse acontecimento traumático na dimensão do imaginário e do simbólico.

Já no segundo o caso estudado, o adolescente R. demonstrou que estava no momento de ver, ao querer saber qual era a proposta do trabalho e o que agregaria a ele. No final da explicação do Projeto concordou em participar, saiu da entrevista, sentou-se na sala de espera para aguardar seu pai, que estava falando com a técnica, e convenceu todos os adolescentes que haviam sido encaminhados pelos profissionais a participarem do trabalho. Naquele dia pude então entrevistar mais quatro adolescentes que acabaram desistido durante o processo. 


\section{Desafios da psicologia no Brasil}

Podemos nos questionar: $\mathrm{O}$ que fez a permanência de R. em nosso trabalho, se a oferta era apenas da escuta psicanalítica? O que a escuta psicanalítica poderia agregar à R.?

A permanência de R. no processo, foi difícil, pois das oito entrevistas marcadas, compareceu a apenas dois encontros decididos. Num terceiro encontro compareceu, mas justificou ter outro compromisso, tendo faltado aos outros cinco. O comparecimento de R. aconteceu graças ao manejo transferencial da técnica N., que sustentou sua permanência durante todo o processo da pesquisa.

R. demonstrou capacidade de liderança diante do grupo, marcada pela posição colaborativa e apresentou características como simpatia e meiguice, o que algumas vezes é interpretado pelos técnicos da Instituição como um modo de manipular a ação. "Um manipulador", tomado como significante do sujeito pela Instituição, como alguém que mani-pula-dor, como uma defesa egóica vivida de modo maníaco para não sentir a dor.

O adolescente apresentou desconfiança no estabelecimento de novos vínculos, produzindo o efeito de descomprometimento. A presença desse traço em sua relação com o outro resultava no isolamento e na descontinuidade como elementos que obstaculizam a realização do seu projeto de vida.

Na verificação dos documentos institucionais, a história institucional foi contada pela psicóloga R., por meio dos dados dos prontuários dos sujeitos da pesquisa, com a finalidade de mostrar como se constituem as tramas relacionais entre os atores e a produção do laço como efeito social e da apresentação do Projeto de Atendimento ao Adolescente em Conflito com a Lei.

No quarto momento, no tempo de compreender, incluiu o memorial dos profissionais do CREAS e foi solicitado à eles que narrasse como sua história de vida se articula, fazendo laço, com a dos adolescentes, levou-se em consideração o conceito freudiano de transferência como um operador ético-político na construção do diagnóstico.

Os profissionais não articulam as histórias, mas no cotidiano institucional, de maneira descontraída, um profissional fala para o outro: "eles estão lá e que todos tem um pezinho na infração". Essa fala traz para uns risos, comentários e para outros, olhares compenetrados e um silêncio mortífero. Podemos nos perguntar: Como as histórias desses sujeitos se (des)articulam? Será que são sujeitos que buscam amparo discursivo?

Ainda foram realizadas as entrevistas com as técnicas responsáveis pelo encaminhamento dos adolescentes escolhidos. Foi solicitado aos profissionais que contassem a história dos adolescentes. 


\section{Desafios da psicologia no Brasil}

Enquanto isso acontecia, elas se surpreendiam pela afetação de suas falas, por não haverem pensado naquilo, ou pelo afeto que predominava.

Em diversas situações os profissionais demonstram a impotência advinda da constatação do pouco que eles podem fazer para mudar essa realidade. A impotência como afeto produzido nessas relações pode ter o efeito de paralisação, se a intenção for situada na dimensão do impossível: de curar, educar, governar e/ou psicanalisar. No caso contrário podemos pensar que algo deve ser feito e isso pode fazer a diferença.

No quinto momento, foram realizadas as entrevistas com os adolescentes, objetivando escutar sua trajetória de vida a fim de conhecer o lugar e posição do sujeito nas tramas relacionais discursivas e seu efeito na produção dos laços sociais. Como diz Dutra (2009, p.9), para "deixar que na associação livre a palavra da fantasia ofereça seu material e suportar não dirigir a cena que se desenrola sobre temas que provocam angústia [...] suportar a sua dor, sem minimizar, apenas oferecendo a escuta."

Finalmente, o sexto, no tempo de concluir, na demonstração da construção do diagnóstico psicológico ético-político, apoiamo-nos na articulação destas discursividades e utilizamos da teoria dos conjuntos para pensar a estrutura e a teoria dos jogos para análise, mais especificamente da lógica proposicional, contida e entrelaçada nos discursos, em busca de compreender o sintoma no social como um lugar de afetação que produz a verdade e/ou gozo como efeito dos laços sociais do sujeito.

\section{ANÁLISE DO DIAGNÓSTICO PSICOLÓGICO ÉTICO POLÍTICO}

Analisamos os efeitos das articulações sociopolíticas da discursividade, através da narrativa, desconstruindo e construindo os entrelaçamentos discursivos que dizem da posição do sujeito e das Instituições, associados aos seus significantes primordiais no acontecimento social. Para tal foi utilizado o testemunho da visita à Fundação Casa, da Instituição CREAS: a história documental ${ }^{4}$ da instituição e a pessoal dos instituídos.

Nesse contexto, enunciados e factos ${ }^{5}$ associados pelo sujeito foram produzidos sob escuta e transferência, o diagnóstico psicológico ético-político em psicanálise lacaniana aplicada ao social.

Para Rosa (2004), a escuta e a transferência são compreendidas aqui como instrumentos e métodos não restritos apenas à situação de análise:

O sujeito do inconsciente está presente em todo enunciado, recortando qualquer discurso pela enunciação que o transcende. A escuta busca, na linguagem, a 


\section{Desafios da psicologia no Brasil}

articulação da libido e do simbólico. Freud já diz isso desde o início de sua obra, quando, para distanciar-se do estritamente patológico, vai do estudo do sintoma e do sonho, e escreve uma Psicopatologia da vida cotidiana, mostrando o inconsciente presente nos acontecimentos da vida diária, nos esquecimentos e chistes, presente, portanto, no diálogo comum (ROSA, 2004, p.337).

Partindo do diálogo comum, as discursividades são produzidas em contextos específicos pela escuta e pela transferência. São instrumentos utilizados pelo psicanalista para operar o modo pelo qual o inconsciente do sujeito transfere ao psicanalista um saber que é produzido nessa relação e que se desdobra num conhecimento sobre si mesmo. A produção do conhecimento neste trabalho foi realizada a partir de um olhar e um discurso psicanalítico, construindo e desconstruindo realidades. Nas palavras de Minerbo (2007):

[...] como aquele que desconstrói realidades, psíquicas ou sociais, recriando-as diversas e ampliando possibilidades, pela subversão dos usos rotineiros de um termo, de um conceito, de uma ideia até então consensual, naturalizada como ideologia (2007, p.152)

Esse modo de produzir conhecimento opera e amplia possibilidades, criando discursos alternativos e fundando o diagnóstico psicológico como ético-político na construção de uma Outra cena, compreendida aqui como um desdobramento da cena social em ficcional, trazendo à baila a posição do sujeito diante dos acontecimentos da vida.

Os dispositivos de análise da articulação sujeito e sociedade, para Rosa (2004), devem levar em consideração:

[...] a estrutura formal da linguagem com as estruturas concretas de parentesco, as formações ideológicas em que são vividas as funções específicas (paternidade, maternidade, infância), com sua condição de aparecimento histórico e quais as suas condições sociais de aplicação. Althusser (1964/1991). Birman (1994), retoma estes temas: como o poder, a crença, o valor, a ética, a violência, a cientificidade, a partir do lugar da função sujeito em psicanálise. (2004, p.334)

Já no campo dos processos políticos, Plon (1999) sugere a investigação dos modos de relação transferencial e organização pulsional utilizados para governar e os modos de evitação da castração a serviço da boa gestão empresarial. 


\section{Desafios da psicologia no Brasil}

Concordamos com esses autores e consideramos suas ideias como dispositivos da análise da articulação entre sujeito e sociedade. Também para Lacan apud Rosa (2004), a análise é realizada a partir da formulação dos discursos como laços discursivos:

[...] pela vertente dos discursos, que produzem uma certa forma de laço social, articulando-os à especificidade do fenômeno, suas determinações e seus efeitos subjetivos e intersubjetivos. Em Lacan, os laços sociais são laços discursivos; as relações de linguagem entre as pessoas definem as maneiras diferentes de distribuição de gozo. O discurso, um discurso sem palavras mas não sem linguagem, dá conta das relações intersubjetivas. Essas relações constituem-se a partir da circulação de certos elementos que, ao transitarem por diferentes lugares, produzem laços sociais específicos e promovem diferentes efeitos ou sintomas. (ROSA, 2004, p.334).

O processo de construção dos dados do diagnóstico psicológico ético-político foi possibilitado pela análise dos dados como discursos: dos documentos institucionais (história institucional e prontuários), do memorial e pela transcrição das entrevistas na íntegra, isto é, foi conservada a escrita, tanto no discurso dos profissionais como dos adolescentes, uma vez que a alteração da semântica na análise poderia mudar o sentido das palavras e alterar a posição do sujeito na discursividade.

A análise do acontecimento social foi construída a partir dos operadores teóricos da matemática e da psicanálise lacaniana aplicada ao social, através das discursividades das observações, das entrevistas e do memorial, recortados pela pesquisadora, levando em consideração a relação transferencial nas posições dos profissionais, dos adolescentes, das Instituições envolvidas e da própria pesquisadora, na produção do diagnóstico psicológico ético-político.

O processo de construção do diagnóstico psicológico ético-político fundamentou a estrutura do diagnóstico psicológico ético-político na teoria dos conjuntos. Os conjuntos e/ou os elementos foram recortados na cena social do seguinte modo: considerou-se como conjunto universal a sociedade e, dentro desse conjunto, os subconjuntos que o constituem. No acontecimento social em questão, estes são: Fundação Casa, CREAS, profissionais e os adolescentes. Nesta pesquisa, a família não foi escolhida como um conjunto, pois o serviço é desenvolvido com o adolescente, e, sendo assim, na construção da pesquisa não há dados que nos permitam pensar a família como um subconjunto.

A desconstrução/construção dessas discursividades foi articulada teoricamente nos tempos lógicos e fundada em três outros tempos: no instante de ver com a observação e contextualização das Instituições, no tempo de compreender com a relação transferencial dos profissionais e dos 


\section{Desafios da psicologia no Brasil}

adolescentes e no tempo de concluir com a articulação da história de vida do sujeito atravessado pelas relações transferenciais institucionais, da própria instituição e dos profissionais no diagnóstico psicológico ético-político como um acontecimento social.

Apoiamo-nos na teoria dos jogos, mais especificamente na lógica proposicional e dos discursos, considerando que as relações entre os subconjuntos se entrelaçam e produzem efeitos constitutivos/destitutivos no acontecimento social.

Levando em consideração o contexto de produção do diagnóstico psicológico ético-político, o subconjunto dos adolescentes A., e R. foi escolhido para fazer a composição do caso institucional éticopolítico, isto é, uma ficção institucional que só pode ser compreendida e produzida entre os discursos do pesquisador, das instituições e do sujeito no acontecimento social, e que demonstra na articulação do e no enodamento discursivo a constituição do sintoma como social.

\section{CASO INSTITUCIONAL ÉTICO-POLÍTICO: MEMÓRIAS DA ADOLESCÊNCIA - OUTRO LADO DA VIDA}

\section{BANDIDA}

Rememorar uma história é contar as lembranças do vivido, é recontar uma vida, é registrar um memorial, é criar outra narrativa, Outra cena que possibilite ao sujeito operar numa condição humana. Apresento-Ihes um caso institucional ético-político, o caso de um adolescente, com 19 anos, que cursa Direito numa universidade particular financiada pelo Fies e pelo Prouni, vive sozinho, no momento, não trabalha, mas conseguiu alugar um cômodo para morar num bairro considerado socioeconomicamente de "classe baixa", em São José dos Campos.

O adolescente relata que "sente dificuldade para pagar o aluguel e para comer, reclama que não tem dinheiro para nada e que nesse momento sente vontade de retornar para o tráfico porque pelo menos teria dinheiro para sobreviver.(Grifos do Adolecente, Entrevista concedida por A., Instituição de Proteção Social de Média Complexidade, 11/05/12)."

Segundo Endo e Cromberg:

Um homem necessita de todas as suas energias para combater eficazmente a fome. Na verdade é mais fácil encarar a aflição, a desonra e a perdição de nossa própria alma - do que uma fome prolongada. É triste, mas é verdade." É neste instante de violência iminente que o ego sai do reino psíquico e é obrigado a agir imediatamente na realidade. O corpo passa a representar o ego de forma literal, sem mediações. (2005, p.105). 


\section{Desafios da psicologia no Brasil}

(...) O ego perde seu caráter de "projeção de uma superfície" e passa a se confundir com o próprio corpo. Essas experiências tornam o ego cego, incapaz de autonomia e restrito a uma obediência inexorável. A violência muda a relação do ego com o corpo. A violência cola o ego ao corpo. Aqui surge uma contribuição princípio de sobrevivência. O homem, até então, habitando o conflito dualista princípio de prazer/princípio de realidade, na iminência da violência, passa a ser regido pelo princípio de sobrevivência/princípio de realidade. "É como se a única e principal providência a ser tomada fosse afastar o corpo imediatamente da chama que o queima. (CROMBERG, 2006, p.187)

Nesse instante de violência, o adolescente demonstra ser afetado pela aflição e pela desonra para suprir a fome, e predomina a dimensão da realidade corporificada sem mediações no ego, portanto perdendo seu caráter de projeção de uma superfície que se apresenta na dimensão do real. Essa corporificação operada pela violência produz uma colagem do ego ao corpo, uma obediência inexorável que sustenta o princípio da sobrevivência sob o efeito de "quase morto" do sujeito.

O adolescente, em seu relato regido pelo princípio da sobrevivência, demonstra a iminência da violência contida sobre a vida, e as dificuldades que o situam ora na chama, ora no tráfico, mas o destino indubitavelmente aponta para morte na sua corporalidade e incorporalidade, um sujeito marcado para morrer na "vida viva" . De acordo com Alencar (2011, p.6), a morte é:

(...) evidenciada em sua relação com o campo social e político contrariando a noção de morte como fenômeno natural. A morte é socialmente determinada e se inscreve nos laços sociais e políticos que se tecem e constituem a vida. Essa relação que faz da morte um acontecimento social, está implicada no luto.

Em sua dimensão social, a morte é determinada e inscreve-se nos laços sociais e políticos que se tecem na vida. O adolescente será renomeado por ele mesmo de Alexsandre, nome de um tio materno que guarda (in memoriam), por quem sente um grande afeto "e se tudo der certo na vida gostaria de ajudar a família desse tio". A. relata sobre a família materna: "A família da minha mãe, ela tem uma irmã e outro que faleceu envolvido com o tráfico de droga também. Tinha cinco filho ao todo. Eu acho que fiquei distante deles."(Grifos do Adolecente, Entrevista concedida por A., Instituição de Proteção Social de Média Complexidade, 11/05/12).

A. também traz à baila o seguinte enunciado: o tio foi baleado, morto num tiroteio, morreu em casa. Nessa enunciação "morreu em casa" estão contidos inúmeros afetos que traduzem para o jovem 


\section{Desafios da psicologia no Brasil}

um sofrimento de ter perdido um ente querido. Morrer em casa para alguns é um desejo, pois é estar entre os seus familiares na hora da partida. No entanto, o tio de Alexsandre morre em casa, mas baleado, e essa condição de baleado, politicamente desqualifica o sujeito e atribui um valor, um merecimento ao ato de morrer e não ao morto, "porque não estava fazendo a coisa certa." A partir desses enunciados surge a proposição: $O$ tio foi baleado, logo morreu em casa, porque não estava fazendo a coisa certa.

Como bem disse Alencar citando Abraham e Torok (1995 apud ALENCAR, 2011), "o inconfessável do luto pode constituir o luto vergonhoso". Nesse caso, a confissão do adolescente atribuída à morte é insuficiente para produzir o luto vergonhoso, mas suficiente para qualificar a causa-mortis: "morreu em casa”, "baleado, morto num tiroteio", associada à justificativa, "porque não estava fazendo a coisa certa". (Grifos do Adolescente, Entrevista concedida por A., Instituição de Proteção Social de Média Complexidade, 11/05/12). Essa operação de reconhecimento do fracasso, da errância, torna o luto digno. O luto digno de ser vivido é confessável, é justificável pelo ato da execução, ou seja, há um recálculo do valor da "vida viva" há um acerto da errância, em que se paga pelo erro com a própria vida; caso não houvesse a operação do recálculo na execução, seria o luto indigno.

A "vida viva" descartada e descartável, empurrada para fora dos limites do contrato social e da humanidade, produz laços que, corporificados na morte, constituem uma vida nua, na incorporalidade do acontecimento representada no afeto do adolescente pelo tio, e marcando um traço que faz laço social e inscreve uma referência de identificação.

Lacan, no Seminário Livro 9, Identificação, traz uma nova tradução da expressão alemã "Einziger Zug", a partir da lógica, e fala de traço unário. Segundo Rinaldi:

O traço unário surge no lugar do apagamento do objeto, sendo antes um traço distintivo, de pura diferença, que marca a divisão do sujeito pela própria linguagem, onde algo, que diz respeito ao objeto, se perde. Por isso, como um nome, marca um a um, na sua singularidade. O nome próprio seria um exemplo de traço unário, na medida em que se situa como marca distintiva e não se traduz. $(2008$, p.2).

O traço Uno, do fora da lei, apresenta-se no desfiladeiro dos significantes instituídos nos laços sociais e políticos que tecem e constituem a vida desse jovem e do tio, remarcando para o adolescente uma identidade familiar, num estilo trágico, caracterizada no modo de viver. 


\section{Desafios da psicologia no Brasil}

Da tessitura desses laços, o jovem A. fiou a reconstrução do seu nome que, nesse caso institucional clínico-político, o adolescente escolhe o do tio para substituir o seu nome próprio. O nome de um morto, mas um nome vivo na lembrança que guarda um registro afetivo e familiar. Identificado com esse tio que "traficava para ter as coisas" e marcado por esse traço de ascensão, de status que toma a cena social dessa família e reaparece nesse sujeito como possibilidade de obter um lugar reconhecido socialmente.

De acordo com Freud em O Estranho (1919, p.278), esse “é algo já conhecido que está enclausurado no inconsciente e, quando vem à tona, causa sensação de medo, terror e estranheza".

A reincidência, enquanto retorno do estranho familiar, produz um entorno que opera uma diferença no lugar do sujeito e na história familiar.

Na família de Alexsandre, os pais foram casados por 13 anos e tiveram cinco filhos, três do primeiro e dois do segundo casamento. Em relação ao trabalho, somente ele não trabalha e, em relação aos estudos, apenas os pais não estudaram. O pai é porteiro e a mãe é cabeleireira, o padrasto é motorista, uma irmã é pedagoga, e a outra telefonista e, em relação a W. e K., estes estudam e são menores de idade.

No memorial, dividiu sua trajetória em quatro momentos, mas, na entrevista, iniciou com a dúvida começava-se a contar do ato infracional ou da escola. Tomaremos como eixo o memorial, mas a construção do caso ético-político institucional dar-se-á pelo entrelaçamento das memórias com as entrevistas.

O primeiro momento dura dos cinco até aos 11 anos e marca os seguintes conflitos: separação dos pais, nascimento do irmão associado à "perda do trono", separação da irmã (saiu de casa, sua mente mudando e as brigas em casa com o padrasto). Quando refaz essa trajetória marca o conflito psíquico nas separações, ou seja, tropeça nas separações: na dos pais e na sua com os pais.

O conflito psíquico que desdobra no acontecimento traumático é enfatizado na sua separação com os pais, e aliena-se na fanthasia da idealização do apoio como equivalente a dar tudo o que ele "precisa", ou melhor, que gostaria de ter. Esse apoio todo é a tentativa de Alexsandre tamponar a sua falta, burlando a castração; é a lei do tráfico. Nessa lei está contida a conviç̧ão de obter o lugar para ser reconhecido socialmente; no entanto, para construir um lugar, faz-se necessário defini-lo a partir da posição do sujeito e não adquiri-lo como uma mercadoria. 


\section{Desafios da psicologia no Brasil}

Ainda nesse primeiro momento, elenca as memórias do romance familiar, marca sua posição de filho caçula, fala do destronamento com o nascimento dos filhos da mãe com o padrasto, depois, reposiciona-se a respeito da vinda do seu irmão, negando que tenha sentido ciúmes e afirmando que tem boas lembranças. Alexsandre vai reconstituindo a cena edípica e demonstrando o efeito desses entrelaçamentos em sua constituição subjetiva, essas perdas não elaboradas, isto é, o luto interrompido, comprometendo o lugar psíquico, o sujeito: "fica na correria, fica perdido".

Deixa claro nas entrevistas que se envolve nas brigas familiares e com o tráfico. O verbo envolver-se acompanha esses dois acontecimentos e significa tornar parte, intrometer-se, uma atitude que envolve certos compromissos.

No âmbito familiar, as brigas em que Alexsandre envolvia-se relacionavam-se com sua mãe e seu padrasto. Intrometia-se no lugar "do homem da casa" com o compromisso de impor uma ordem, objetivando que o padrasto saísse de casa, pois não aceitava que nenhum outro homem, fizesse parte desse contexto familiar.

Interferia nas brigas mesmo reconhecendo que são de casais. Esse é seu modo de dizer que não há lugar para aquele homem, entretanto a mãe não autoriza o adolescente a fazer isso, e ele sai de casa. Nessa cena o adolescente convoca a mãe a escolher entre o filho/marido e o marido/filho. A mãe dá o apoio que considera possível a Alexsandre, mas não é suficiente para ele, então, sai de casa mesmo não tendo condições de se sustentar.

Na separação dos pais, há um tropeço na reordenação dos lugares; a ausência paterna indica um desordenamento da lei, e o adolescente não sabe que lugar ocupar nessa Outra cena, ora desempenhando o papel do homem da casa, na figura do "Pai" e excluindo o padrasto dessa relação familiar, ora o do filho dessa mãe, mas não suporta as condições impostas por ela, pois ela opera uma mesma lógica em relação aos filhos e o padrasto.

A. demonstra na entrevista o que lhe causa mal-estar na separação dos pais: "A separação fez com que entrasse outro home na vida da minha mãe, praticamente. Foi rápido, tenho um irmão de 12 anos, tem 13 que eles estão separados. Eu tinha ciúme, mas da minha parte eu acho que era normal, ele tinha que compreende minha situação." Nesse período da vida percebe uma mudança em sua mente, começou a ir pra rua e a prestar atenção nas histórias que as pessoas contavam: "comecei a aprender a fazer as coisas erradas, sei lá o que aconteceu com a minha cabeça". 


\section{Desafios da psicologia no Brasil}

Um segundo momento transcorre dos 12 anos aos 13 anos, a primeira vez que foi para delegacia, porque estava pichando. Conta que sua mãe lhe bateu bastante com um fio, ele revoltou-se, saiu de casa e foi morar com a irmã S.. Também foi nesse momento que fez o primeiro uso da maconha.

Observo que, quando conta que foi preso, comete um ato falho e escreve a palavra com a letra $z, 0$ que a transforma em "prezo", que se refere ao verbo prezar, significando querer muito alguma coisa, apreciar, desejar ou respeitar-se, orgulhar-se, honrar-se e ufanar-se.

Como dizia Goethe, "no princípio era o verbo" e depois o substantivo. Alexsandre preza pelo verbo no tempo incondicional, ou seja, recusa-se a ser barrado, recusa a castração. Nesse caso, foi necessário ser preso no real para se prezar. O adolescente oscila entre as dimensões do imaginário e do real, demonstrando dificuldade de dimensionar simbolicamente os acontecimentos, pois fica preso imaginariamente na ideia de obter, lograr um lugar como um modo de existir na vida.

Como vimos, o adolescente foi preso, pela primeira vez, na Delegacia da Juventude por pichação. Esse ato de manutenção da ordem, do progresso e da segurança nacional do Estado, produziu um efeito no adolescente porque está associado a sua cadeia significante e, na cena familiar, inaugura, funda no real uma perda narcísica que, julgada, retorna ao estatuto de crime.

Diante desse desvelamento, dessa revelação do ato infracional na cena social, fica enfurecido com o acontecimento e decide aplicar a sua medida educativa: "minha mãe bateu bastante com o fio e eu me revoltei sai de casa, fui morar com minha irmã S., meu cunhado já fazia coisa errada e daí comecei a fumar maconha, a cannabis".(Grifos do Adolescente, Entrevista concedida por A., Instituição de Proteção Social de Média Complexidade, 11/05/12).

Num terceiro momento, aos 13, quase 14 anos, envolveu-se com o tráfico. O padrasto foi o primeiro a descobrir e contou para mãe, que conversou, e ele parou de vender drogas. No envolvimento com o tráfico, surge outra proposição: o compromisso que havia feito consigo mesmo de obter um lugar na vida a qualquer custo. Como bem diz Lacan, é preciso escolher: A vida ou a bolsa? Será que a vida de Alexsandre é uma bolsa?

Alexsandre vai demonstrando na sua trajetória que se aliena na idealização da família nuclear, pois a qualquer preço precisa representá-la. Na separação dos pais, a ausência paterna é presentificada pelas suas atitudes, e a permanência no tráfico é o seu modo de sustentação imaginária de um lugar social, que, mediante o poder do dinheiro, pode obter a vida. Um lugar ou a vida? "Vida viva"? Ou ainda, um lugar de vida? 


\section{Desafios da psicologia no Brasil}

A palavra "obter" é sinônimo de adquirir, ganhar, lograr, alcançar, granjear e conquistar. A confusão entre ganhar e conquistar a vida está marcada politicamente pela posição do sujeito. Na primeira posição, o sujeito é passivo a uma atitude e está submetido a uma condição que o outro coloca, ganhar a vida é sinônimo de comprar um lugar. Na segunda, o sujeito é ativo, pois conquistar significa lutar, construir um lugar possível na vida, um lugar de "vida viva".

Quando o padrasto descobriu o envolvimento com o tráfico, contou para sua mãe de Alexsander, que, dessa vez, tomou como medida educativa a conversa. Ele, momentaneamente, parou de vender drogas, mas alega que ela trabalhava, e ele acabou envolvendo-se de novo. Quando questionado se sua mãe não podia trabalhar, ele diz: "pode sim, é que faltava apoio, eu ficava sozinho e acabava indo pra rua." (Grifos do Adolescente, Entrevista concedida por A., Instituição de Proteção Social de Média Complexidade, 11/05/12). Para o adolescente, a palavra "apoiar" está associada ao sentido de ficar junto a ele, de não se separar dele, pois, se fica sozinho, não consegue parar, fica só na "correria". Essa correria demonstra o afeto que não engana, a angústia pela falta de um significante que o autorize a produzir o sentido de parar, mas no seu lugar.

Um quarto momento dá-se aos 16 anos, quando foi preso e encaminhado ao Centro de Atendimento Socioeducativo ao Adolescente. Nesse ato de prisão, fundou uma cena que, medida pelo julgamento, resulta num crime. O jovem com 16 anos que demonstrava a vontade de ter as coisas que os pais não Ihe podiam dar, ou seja, de ter aquilo que lhe faltava a qualquer custo, "rouba à mão armada uma drogaria e é preso no Centro de Atendimento Socioeducativo ao Adolescente". (Grifos do Adolescente, Entrevista concedida por A., Instituição de Proteção Social de Média Complexidade, 11/05/12). enunciado "foi preso na (...)" é revelador do caráter prisional que está presente no discurso do adolescente e associado à Instituição.

Numa das entrevistas, justifica o roubo dizendo:

(...) roubei porque queria terminar rápido, já tava construindo com o dinheiro do tráfico. Lá na minha casa tinha um porão que eu tava reformando pra mim, queria um lugar só meu, íntimo, coloquei até piso. Depois fui preso, e enquanto tava na Instituição, minha mãe soterro, porque precisava construir o salão dela. Fiquei contente, porque ela fazia faxina e agora era cabeleireira. (Grifos do Adolescente, Entrevista Concedida pelo Adolescente A., Instituição Pública de Proteção Social de Média Complexidade, 18/11/2011).

Cabe ressaltar que a fantasia social do Centro de Atendimento Socioeducativo ao Adolescente, 


\section{Desafios da psicologia no Brasil}

como uma casa, um lugar, não se sustenta pela ação pedagógica instituída de corrigir socialmente utilizando uma medida e um peso para todos. Nessa generalização, opera-se a dessubjetivação, a perda do sujeito. O adolescente afirma e sente que está preso nesse Centro, ato que contraria o Estatuto da Criança e do Adolescente (ECA). Diante do exposto, podemos questionar se as Instituições "Família" e "Centro de Atendimento Socioeducativo ao Adolescente", para se defender do que fazem, negam os seus atos e distorcem a história. Como podemos fazer para nos responsabilizarmos por nossos atos?

Alexsandre disse que o tempo que passou lá no Centro "foi bom porque conseguiram parar ele". (Grifos do Adolescente, Entrevista concedida por A., Instituição de Proteção Social de Média Complexidade, 11/05/12). Esse ato real de castração, para momentaneamente o adolescente, pois incide sobre o mesmo uma contenção da força pulsional a qualquer custo, como um modo de operar uma castração imaginária ou simbólica; entretanto não é duradoura porque não é utilizando a força física que controla a pulsão, ela convoca e reconvoca os significantes em busca de sentidos.

O diagnóstico de reincidência nos interpela e nos faz refletir sobre como a reincidência pode ser pensada ignorando-se os entrelaçamentos que constituem o reaparecimento, o assalto dos significantes e o roubo do lugar do sujeito. Como fazer justiça sem levar em consideração as subjetividades que a constituem?

Numa dimensão moral, tomar o roubo, o assalto, é comprometer-se imaginariamente com as artimanhas capitalistas, é uma armadilha, uma cilada, pois, se fazemos do adolescente um infrator, depois, devemos oferecer-Ihe o atendimento e cobrar-lhe a responsabilização pelo ato infrator e, dessa forma, construímos problemas sociais qualificados como intratáveis.

O julgamento moral condena a ação, institui como crime e castiga o sujeito com uma medida social para reparar o dano que cometeu contra a sociedade. Sendo assim, como reparar o dano de um assalto e/ou de um roubo, enquanto presos no Centro de Atendimento Socioeducativo ao Adolescente? Essa medida de reclusão dos adolescentes na Instituição e segregação da sociedade não é ortopédica? Aquela ortopedia pedagógica de consertar os adolescentes e/ou a adolescência?

No campo do judiciário, o juiz julga o ato infracional e aplica a pena no sujeito, muitas vezes não fazendo observância dos entrelaçamentos discursivos. Sendo assim, podemos pensar que a justiça é cega e surda? Será que Alexsandre foi julgado por se perder em sua própria história? Será que o ato infracional e sua consequência não podem estar associados ao assalto ou roubo do seu lugar familiar? 


\section{Desafios da psicologia no Brasil}

Será que a cena do crime é produzida pelo julgamento do infantil e/ou infantil que funda a cena do crime?

Quando Alexsandre conta do assalto/roubo, faz questão de dizer que não estava drogado. Apresenta um cuidado com os elementos envolvidos, narra como se fosse uma saga, uma aventura: conta do roubo do carro para fazer a viagem de São José dos Campos para Pindamonhangaba e, depois, a epopeia, quando começa a ser perseguido pela polícia, até ser preso. Destacamos o seguinte trecho da entrevista:

Em 2009 fiz o assalto que me levou prá Fundação. Nóis roubamo um carro aqui no Centro de São José e fomos lá prá Caçapava, depois lá resolvemo que ia roubá a drogaria em Pindamonhangaba. O meu amigo tava drogado, mais eu fiz questão, não tinha fumado, cheirado e nem bebido nada, tava assim mesmo, sei lá, a gente queria dinheiro. Fugimo das policia até Roseira, ali perto de Aparecida, a senhora conhece. Ali nóis abandono o carro e tivemo que entra mato a dentro fugindo das policia. Sai pulando de telhado em telhado das casa, quando eu avistei que um policial tava me acompanhando, resolvi entrar numa casa que tinha uma edícula no fundo, fiquei dentro do banheiro ouvindo as policia entrando de casa em casa se aproximando da edícula. Daí não tinha o que faze, só esperá, eu via o movimento pela janela do banheiro da edícula, eles chegaram, me pegaram e me levaram pro curral. S-Ficou em Caçapava no curral? R: É um lugar, uma sela, que não tem nem colchão, passei um dia lá, depois fui para DJU, lá já tinha tudo arrumado, tinha colchão a mãe podia visitar, levar roupa. (Entrevista Concedida pelo Adolescente A., Instituição Pública de Proteção Social de Média Complexidade, 18/11/2011)

A saga de ser pego termina com a queda do adolescente pego e levado pelos policiais para o curral, ou seja, finda com a prisão de Alexsandre, o que produz nele o efeito do aprisionamento do sujeito, um ato infrator, pois inferioriza e humilha, colocando-o numa dimensão animalesca e retirando o sujeito da dimensão humana. Na entrevista, Alexsandre narra como foi o tempo que passou no Centro de Atendimento Socioeducativo ao Adolescente, contando-nos um acontecimento que marcou sua passagem pela Instituição. Assim está escrito na entrevista:

[...] aconteceu uma coisa lá que tentaram me envolver, fazê maldade, mas eu consegui me livrar. Lá eu fiquei num quarto com um di menor e um di maior, nóis recebíamos as visitas e era assim: quem recebia visita subia, quem não recebia fica lá embaixo no pátio. Lá eu conheci a palavra, a palavra de Deus. Eu tava na oitava série, continuei estudando lá dentro, fiz o primeiro ano lá, em 2009 fiz o assalto que me levou pra Fundação.

S: Você pode me contar que coisa aconteceu lá? A: Posso, lá é assim quando tem visita, depois nós não podemos nos masturba, né. Nesse dia eu desci, os nossos pais tava lá visitando. Depois que termino a visita, então, eu avistei o 


\section{Desafios da psicologia no Brasil}

gordo lá do meu quarto se masturbando, eu tava machucado, tava mancando de tanto fazer exercícios, mais fui arrastando a perna e avistei o gordo se masturbando, daí já gritei no corredor: "o mano, para com isso, você não tem palavra, nois batemos muito nele. Senhora, nós não podemos fazer isso e ficar pensando nos parentes dos outros, isso não se faz. Nóis temos ética, não pode fazer isso não, o gordo sabia por isso apanhou." A. fez silêncio, como se assunto tivesse esgotado. A: Eu vivi muita coisa lá, é ruim fica preso, né eu tava lá. Esse tempo que eu vivi lá ensino eu não fica no tráfico, sei lá, lá dentro tem coisa errada também, a noite é mais difícil, eles ficam em pouco prá cuida da gente, então eles ficam mais bravo, pra mante a ordem. S: Parece que tem uma lei própria que organiza o lugar? A: É isso mesmo, é pro camarada aprender. (Grifos do Adolescente, Entrevista Concedida pelo Adolescente A., Instituição Pública de Proteção Social de Média Complexidade, 18/11/2011).

O adolescente conta como a regra é instituída, fundada no Centro de Atendimento Socioeducativo ao Adolescente e a palavra é cobrada entre eles, a palavra é de Deus. O descumprimento da regra implica uma correção rigorosa, mesmo que sua correção infrinja no descumprimento da regra que é respeitar, ou seja, desrespeitar-se será desrespeitado porque desrespeitou; só há um valor absoluto, mesmo que isso não resulte em aprender a respeitar.

A palavra recebe uma personificação de Deus: invoca-se um Pai-criador, todo poderoso, sem falhas, para absolutizar a palavra em um único significado. Se não for cumprido não tem palavra, então fica em dívida e para pagá-la precisa sacrificar o próprio corpo. Outro caso é a equivalência, ter ética corresponde a cumprir a palavra a qualquer custo, na dimensão do real, com valor absoluto e um único significado para o contexto e não ser ético.

Outro ainda é a corporificação do personagem Deus, na palavra e no próprio corpo. Alexsandre lidava com o seu excesso registrando-o na carne, machucando o seu próprio corpo de tanto fazer exercícios para suportar ficar lá, ficar "parado", só machucado ou machucando. O quanto ficar parado machuca Alexsandre? O que o adolescente suporta da castração?

Na relação do Alexsandre com sua mãe, ele relata que não ocorreram modificações. Entretanto, em uma das entrevistas, disse que sua mãe desistiu de impedir a sua relação com o tráfico. Surge, aqui, a seguinte proposição: se não ocorreram modificações na sua relação com a mãe, logo ele não reconhece que a mãe não impediu a sua relação com o tráfico. Destacamos o seguinte trecho da entrevista:

Quando sai de lá da Fundação, fui morá com a minha mãe, mais não deu muito certo porque eu eu meu padrasto, não nos entendemo, porque ele briga muito com ela e 


\section{Desafios da psicologia no Brasil}

eu não gosto disso, eu não gosto que ele briga com ela. Prá dá certo, só de longe (chorou). S: Você acha que estes acontecimentos modificaram sua relação com a sua mãe? A: Não, acho que não. Mãe é mãe. Quando eu sai eu não tinha aonde fica, fiquei lá na casa dela (choro). Não me do com meu padrasto ele não é sangue do sangue. S: Você pode me explicar como é a relação com o seu pai? A: Ah, minha relação com ele é que ele é separado da minha mãe, a gente se vê pouco. Agora a gente, às vezes sai junto, ele fica preocupado comigo, o trabaio que eu dei, mas depois eu trabaiava de segunda a segunda, eu não quero isso pro meu filho. (Grifos do Adolescente, Entrevista Concedida pelo Adolescente A., Instituição Pública de Proteção Social de Média Complexidade, 18/11/2011).

$\mathrm{O}$ adolescente demonstra segurança na figura materna. Aconteça o que acontecer, haverá um lugar que fará referência, mesmo que seja por consanguinidade: “Mãe é mãe, sangue do meu sangue."(Grifos do Adolescente, Entrevista Concedida pelo Adolescente A., Instituição Pública de Proteção Social de Média Complexidade,18/11/2011). Retoma a separação dos pais como sua perda de referência marcada pela ausência do pai.

Alexsander conta sua história como se tivesse "fabrincando signos" que pudessem dar conta de sustentar um lugar possível na "vida viva", para que ele pudesse existir, e aponta a escola como uma saída para ele.

Quando foi preso e encaminhado ao Centro de Atendimento Socioeducativo ao Adolescente, não estava estudando. Relatou que "parou de estudar porque, na hora do intervalo, ele fugia da escola e ficava na rua, foi assim o ano inteiro, e, no final do ano, passaram-no e reprovaram os amigos". (Grifos do Adolescente, Entrevista Concedida pelo Adolescente A., Instituição Pública de Proteção Social de Média Complexidade, 18/11/2011). Quando chegou para cursar o segundo ano, a escola informou que havia se enganado, que ele havia sido reprovado. Diante desse engano, ele resolve sair da escola.

Retorna à escola dentro do Centro de Atendimento Socioeducativo ao Adolescente, cursa o segundo e o terceiro ano. Em relação a essa Instituição, deixa claro que foi bom ser internado, "alguém precisava me parar". A Internação funda um ato, cessa, limita esse jovem que reordena sua vida pelos estudos. Nos oito meses em que ficou internado, terminou o ensino médio, fez cursos profissionalizantes, no entanto, não consegue um trabalho para the dar sustentação nesse novo caminho.

Os cursos são oferecidos pela Instituição, mas esta tropeça na operacionalização: não funciona como mediadora, não leva em consideração o interesse do jovem e nem o mercado de trabalho. 


\section{Desafios da psicologia no Brasil}

Aos 17 anos, já na Instituição Pública Estatal de Proteção Social de Média Complexidade na cidade de São José dos Campos, aos 19, no Programa Juventude Cidadã da Instituição cumprindo a medida socioeducativa de Liberdade Assistida. A família e os profissionais recontam sua experiência, que comporá os registros do seu prontuário de atendimento.

Nos dados do prontuário do adolescente, a mãe afirma que não há histórico familiar de comprometimento infracional, negando a história do irmão e a repetição do filho. Em termos psicológicos, a mãe comete um roubo duplamente qualificado. A negação da história familiar faz com que o adolescente tenha que sozinho pagar o preço, por estar fora da família, sem referência e logo sem lugar, tornando impagável o tropeço subjetivo. Ele torna-se a desonra da família, o estranho no ninho, "a ovelha negra da família".

No Relatório Técnico Psicossocial, ela explica que a separação ocorreu por incompatibilidade de gênero. Produz-se um ato falho, apoiado no modo popular de falar, "gênio". O que poderia ser uma incompatibilidade de gênio/gênero? A incompatibilidade de conviver? A incompatibilidade de conviver do masculino e do feminino? E, quanto à dinâmica familiar, está descrito na entrevista:

(...) sempre foi pautado no respeito e no diálogo, com a separação o genitor o visitava esporadicamente, (...) mas os laços de afetividade entre eles mantinham-se estreitados, assim a figura de autoridade era mantida pela genitora. (...) Quanto à família, essa é presente na visita ao adolescente, demonstrando interesse em auxiliálo no cumprimento da medida socioeducativa. Observamos que os laços afetivos encontram-se preservados e que ocorre diálogo entre os membros. (Grifos do Adolescente, Entrevista Concedida pelo Adolescente A., Instituição Pública de Proteção Social de Média Complexidade, 18/11/2011).

O que é isso da dinâmica familiar sempre pautado no respeito e no diálogo? O adolescente envolviase nas brigas do casal, apanhava de fio e enfatizava a falta do pai. Como os laços afetivos e o diálogo encontram-se preservados nessa dinâmica familiar? Esse encobrimento dos fatos, a-paga a história familiar e parece impedir a elaboração desses acontecimentos, a reconstrução da verdade histórica e a reinvenção de Alexsandre. Do Relatório Técnico Psicossocial, ainda no que concerne à construção do ato infracional, destacamos o seguinte trecho da entrevista:

No início de 2009 se envolveu com alguns jovens do bairro que possuía fama de má reputação. A família sempre avisava, porém ele não acreditava. Quanto ao ato infracional, (...) a família foi pega de surpresa e que não entende o que aconteceu, pois não ocorreu mudança de comportamento por parte do adolescente, e que $o$ 


\section{Desafios da psicologia no Brasil}

mesmo tinha sempre tudo que precisava dentro das condições financeiras da família. (Grifos do Adolescente, Entrevista Concedida pelo Adolescente A., Instituição Pública de Proteção Social de Média Complexidade, 18/11/2011).

A posição da mãe no discurso é de proteção do filho, de alguém que pertence a essa família e, ao mesmo tempo, defende-se, negando a história e a condição familiar, atribuindo ao adolescente a escolha, e aos outros a má reputação, responsabilizando-os pelo ato infracional.

A relação eu-outro parece confusa também para mãe, que também foi pega de surpresa pelos significantes, encontrando como uma saída defender-se pela negação dos fatos e se eximir de qualquer responsabilidade. Assim está descrito no final do Relatório Técnico Psicossocial, segundo a técnica registra: "Trata-se de um adolescente de dezessete anos e oito meses, privado de liberdade há dois meses, pelo ato infracional tipificado por roubo qualificado".(Grifos do Adolescente, Entrevista Concedida pela Assistente Social R., Instituição Pública de Proteção Social de Média Complexidade, 18/11/2011).

Diante do exposto, cabe indagar como tratar, como atender isso que é registrado nos prontuários? Trata-se um ato infrator? Quais instrumentos as ciências oferecem no tratamento do ato infrator tipificado por roubo qualificado? Os registros dos e nos prontuários fundam um personagem no imaginário social, "adolescente infrator", como o único responsável da cena social.

Todos que participam da e na cena social são responsáveis pela produção e pelos efeitos de subjetivação nesse processo de construção de uma "vida viva". É uma construção compartilhada. Como podemos compartilhar a responsabilidade pelas infrações dos atos institucionais, profissionais e do sujeito?

O adolescente denuncia a falta de responsabilidade do Estado dizendo: "se o tráfico pagasse imposto ele seria legalizado, ele é ilegal porque ele não paga imposto. Se pagasse imposto seria vendido na farmácia, não precisava mais de nóis".(Grifos do Adolescente, Entrevista Concedida pelo Adolescente A., Instituição Pública de Proteção Social de Média Complexidade, 18/11/2011). Diante dessa fala, podemos pensar, o que é isso? É considerado legal tudo pelo que se paga imposto, logo o que é ilegal é não pagar impostos. Esse axioma capitalista inverte os valores, tornando-os uma máquina subversiva de fazer valores, ou seja, vale a atitude que se traduz em lucro. Como desresponsabilizar a sociedade dessa partilha capitalista? 


\title{
Desafios da psicologia no Brasil
}

O jovem narra sua experiência individual com o trabalho na condição de transitório, porque, para conseguir realizar seu sonho de ser um soldador, precisa de experiência. Isso indica o sentimento de humilhação associado à figura de autoridade e demonstra a esperança de "dar certo" na faculdade. Destacamos os seguintes trechos:

\begin{abstract}
Depois que sai, trabalhei e estudei, um amigo arrumo pra eu trabaiá na padaria, mas era difícil, porque o patrão humilhava muito a gente, ele gritava muito e depois todo mundo lá do bairro via a gente com aquela roupa, varrendo a rua. Não tenho problema com o trabaio, mais sei lá, não precisa disso, de humilha.

Tô morando sozinho ainda, tô atrás de um serviço aí, com o curso de solda, de torneiro precisa de experiência. Tô quase conseguindo um serviço na construção civil, tá quase dando certo, tô esperando a resposta, ali perto da minha casa mesmo. (...) pra mimo trabalho na construção civil é provisório, porque pra mim na verdade o meu sonho maior é o de solda, mais precisa entrar dinheiro prá me ajudar manter, vou tirar habilitação também e a faculdade lá tá andando também. Eu fui lá fiz a inscrição do Prouni e tem que aguarda sai a resposta, se dé vai sair 50 por cento institucional, estou esperando ela entrar em contato comigo e vou fazer os outros 50 por cento pelo Fies, e também ir atrás de um estágio. Ela falou que assim que começar as aulas pode enviar currículo, pra prefeitura. Eles contratam, o serviço é de seis horas por dia e pra ganhar mais. A gente trabalha menos e ganha mais. (...) Eu preciso trabaiá, fica perdendo tempo e pensando besteira. Espero dar certo a faculdade $e$ o estágio. (Grifos do Adolescente, Entrevista Concedida pelo Adolescente A., Instituição Pública de Proteção Social de Média Complexidade, 18/11/2011).
\end{abstract}

A lógica capitalista de trabalhar menos e ganhar mais faz parte das ideias de Alexsandre, o que ele associa também ao tráfico, demonstrando um modo econômico de esforço que visa ao lucro, ou seja, apoia-se na proposição de ganhar mais esforçando-se o menos possível na vida.

Fui à Instituição para fazer uma entrevista com outro adolescente, que havia faltado. Enquanto o esperava, Alexsandre, que já estava desligado, retornara para pedir ajuda a R. para fazer seu currículo, pois iria entregar no Ciee. Perguntou se podia falar comigo. Demonstrava alegria e muita disposição, solicitou a entrevista e parecia confiante. A surpresa do encontro e da demanda de A. para ser escutado por mim funda outro laço, o da transferência, e naquele momento senti-me autorizada a escutá-lo.

Iniciou essa entrevista contando que havia passado no vestibular, contou-me que estava tudo bem, já havia começado a universidade, sua mãe e seu pai estavam muito orgulhosos dele e ligara também para R., para contar-Ihe que passara na universidade. 


\section{Desafios da psicologia no Brasil}

O sonho de Alexsandre de ser soldador parecia ser possível, por meio da experiência que fora possível construir na escola. O ingresso na universidade poderá ser seu Ato de Fundação, de soltura: estaria saldando a dívida com os pais e soldando a sua dor, rearticulando-se, reconstruindo-se. Assim está descrito na entrevista:

Estou bem, já encomendei os livros, quero estudar muito, porque eu preciso, não quero ser advogado, não posso ser juiz, porque na minha condição, não posso, não posso julgar ninguém. Não devemos julgar as pessoas eu não sei fazer isso, quero ser Defensor Público. $S$ - Porque escolheu ser Defensor Público? Ah, porque isso eu posso fazer, defender. Quando eu fui julgado, era - Defensor Público que estava lá do lado da minha mãe, ele que me ajudou, depois ele foi lá na Fundação Casa para saber como eu tava. (Grifos do Adolescente, Entrevista Concedida pelo Adolescente A., Instituição Pública de Proteção Social de Média Complexidade, 11/03/2012).

Nesse momento, ainda traz a equivalência de estar bem, feliz com o ter as coisas: está bem porque encomendou, comprou os livros; no entanto, nesse tempo ele não podia entrar na universidade porque havia comprado os livros didáticos, mas não tinha como pagá-los, mas sua irmã acabou assumiu a dívida e continua frequentando às aulas. Ele reincide inúmeras vezes nessa cilada de não ter como pagar, mas compra e depois fica angustiado, fica na "correria". Será que o ato de Alexsandre é uma repetição, um aprisionamento do e no discurso capitalista?

Alexsandre demonstra que o ingresso na universidade trouxe à baila novamente o sentimento de orgulho dos familiares por ele. Esse ingresso pode escandir uma marca, uma diferença, é o segundo filho que ingressou e cursa a universidade. Das cinco disciplinas cursadas no primeiro semestre, foi aprovado em quatro, apenas reprovou em Introdução ao Direito.

O jovem fala em uma das entrevistas que voltou a estudar e automaticamente saiu do tráfico. O que é esse automatismo? Será que isso é o efeito do sentido? E, ainda, espera, no futuro, formar-se no curso de Direito e ser defensor público, porque apoia a pessoa quando é preciso. Espera ter um futuro lindo e uma família feliz. Será esse um modo de construir laços, soldando os significantes, soldando a dor, saldando a dívida e construindo um lugar privado e social possível na "vida viva"?

Alexsandre procurou-me no consultório e disse que os nossos encontros haviam feito-lhe refletir sobre sua estória, o que viveu com seus pais, e concluiu que eles fizeram o possível para ajudá-lo. Associou esse acontecimento às aulas de Sociologia Geral e Jurídica em que o professor disse: "o homem age 


\section{Desafios da psicologia no Brasil}

conforme o meio em que ele vive", rapidamente, lembrou-se da música funk de Mc. Lano, O outro lado da vida bandida, para mandar o seu recado. Destacamos a letra da música:

Num vim aqui para ajudar mas para mandar o meu recado

Pra toda vida loca do nosso cotidiano

Contra fatos, não há argumentos, olho pra dentro de mim

Vejo o que fui no passado e no que hoje me tornei

Num barraco 3 por 3 pode morar 6

Menores que o tráfico foi pegando um por vez

Qual era o meu lazer? Neguinho vou te dizer:

Catar xepa na feira pra poder sobreviver

Videogame, cinema, shopping center? Que nada!

O menor pra zoar no bairro mal tinha uma bola.

Cresci em meio de armas, vários papos, só guerrilha

Mas se minha vida é assim eu não te culpo, se liga

Eu aprendi assim e faço pra sobreviver

Se eu tive outra escolha nem deu tempo pra eu ver

Falar é fácil tá ligado, mas porto pro meu sustento

A dor mais forte é saber que minha mãe tá sofrendo

Traído por inveja, recalque e simpatia

Eu fiz o crime valer mais que minha família

E agora? Chora a mãe com o filho no braço

Gritando: Deus, o meu filho tá baleado 


\section{Desafios da psicologia no Brasil}

Esse é o outro lado de uma vida bandida

Mamãe chorou pra te ver nascer

E não morrer dessa forma

Mc LANO. O Outro lado da vida bandida (Chora Mãe).

4m11s. https://www.youtube.com/watch?v=OSnAzIFK7aA . Acesso:15/12/2019.

Na música escolhida por A., ele deixa claro nas enunciações e nos enunciados que veio para mandar o recado, usa o substantivo "maloca", referindo-se à vida cotidiana, e indica uma transformação, quando diz: "o que fui e o que hoje me tornei. Afirma que aprendeu e faz o ato apoiado no princípio da sobrevivência e diz que se teve "outra escolha ficou na correria, nem deu tempo pra ver."

A música remete à dor da mãe, um sofrimento que faz ele sofrer. No jogo da separação, parafraseando Lacan, de jogar o bebê junto com água da banheira. E ainda, apresenta a cena da morte como social, e se marca pelo choro em dois momentos de constatação: pelo nascimento e pela morte do filho, baleado e falecido em casa, nos braços da mãe e na ausência do pai.

No tempo de concluir serão apresentado as propositivas construídas pelo instante de ver e pelo tempo de compreender que norteiam nosso caso do Alexsandre. O acontecimento social do caso do Alexsandre, um jovem de dezenove anos, que nos apresenta situações traumáticas em relação a sua posição nos acontecimentos sociais da e na vida, e nos mostra que os entrelaçamentos discursivos se apoiavam fundamentalmente nas proposições de ter e ser e de dar e receber.

No que diz respeito às Instituições, demonstra uma relação conflituosa com a família, pois recusa as condições financeiras de sua família, já que o cenário social afeta o adolescente no que diz respeito ao status quo imposto pela sociedade e aceito pelo jovem como um modo de se fazer reconhecer individualmente/socialmente, ou seja, parte-se da proposição primordial que, "queria ter aquilo que os pais não podiam dar, logo para ter aquilo que queria, ele precisava roubar".

Alexsandre produz uma operação utilizando da lógica de inversão entre a demanda e a necessidade: precisava roubar para ter o que queria e não o que precisava. O roubo como uma fantasia que se representa na modalidade de gozo de Alexsandre tem efeito de laço, isto é, ele se reconhece no ato 


\section{Desafios da psicologia no Brasil}

como alguém que faz algo, o ladrão que rouba - faz um serviço, que produz algo a mais, uma mercadoria - o dinheiro como mais valia, um mais-de-gozar.

Na cena social, o adolescente inclui a predominância da demanda do Outro, nesse caso o capital, e a do gozo sobre o desejo. Afetado pela demanda do Outro, Alexsandro queria ter o objeto a qualquer preço, porque não queria pagar por isso, queria apagar a condição da família, gozando disso. O desejo só pode emergir lá onde a castração opera a falta. Sendo assim, o desejo do jovem ficou encoberto pelo gozo da ascensão social, o que produziu o efeito de alienação no reconhecimento de si e na separação dos pais.

Alexsandre segrega dessa cena a propositiva de que "os pais não podiam dar, porque não tinham condições financeiras". Eis o jovem fixado no discurso capitalista, onde, como diz Lacan "todos são negociáveis". Portanto, todos os sujeitos são negociáveis, são objetos de troca e o valor do sujeito equivale ao valor de uso. O sujeito torna-se escravo de sua liberdade quando atende a demanda capitalista de "ter as coisas" e se recusa a aceitar a castração.

Na recusa da castração, o jovem perde o referencial da lei, tornando-se onipotente diante da impotência real dos pais, "de não poderem dar aquilo que ele queria ter". Essa operação na potência do adolescente, apoiada na lógica capitalista, aprisiona-o numa condição de mercadoria, cujo uso produz mais valia, ou seja, o roubo como excedente que é apropriado pelo capitalista, neste caso, idealizado e representado na figura do traficante, que produz no adolescente o efeito do fracasso pela idealização do complexo familiar.

Desse lugar construído por Alexsandre, ele se faz autor de seus atos. A cena primordial do "crime" é fundada na impotência do herói, ou melhor, um anti-herói, pelo discurso capitalista, e emerge outra proposição, "como seus pais não podem dar aquilo que o filho quer ter, logo esse filho não dá para os pais aquilo que eles desejam dele.". Alexsandre se orienta nessa trajetória de vida pela pulsão de morte, ou seja, na e pela errância se perde, se identifica com o morto e vive a morte a cada dia, o outro lado da vida, a vida morta, a vida bandida.

O conflito com a separação de A. da família fez irromper uma situação traumática demonstrada pelas propositivas relativas à repetição, ou seja, a reincidência do verbo em ato - "querer ter". Alexsandre aliena-se em "querer ter uma família ideal, logo os pais não podiam dar". Na cena da separação, a posição paterna acirra o conflito entre o adolescente e a figura materna, pois quando o adolescente, investido do poder concedido pelo pai real, tenta se colocar no lugar do pai e a mãe não autoriza, 


\section{Desafios da psicologia no Brasil}

iniciam-se as brigas entre o adolescente e o padrasto para a ocupação desse lugar que está "vazio", lugar do pai que é tamponado pelo lugar de homem traído.

Nessa relação homem-mulher, insuficiente por si só, a falta é deslocada para esse adolescente. Lembrando Garcia (2011, p.45), em “o pai como Medeia às avessas, a se ver confrontado com a perda da causa de seu desejo, "mata" seu filho para tocar sua mulher", podemos entender que, nesse modo de afetação, o pai de A. não toca, pois não é mais sua mulher, mas "mata" seu filho e afeta sua filha mais velha que, na ausência da mãe, responde nesse lugar para A.

O pai de A., na dimensão do real, denega sua ausência e, numa versão perversa, imaginariamente não autoriza a separação da mulher, sendo o pai na dimensão do imaginário o que se faz presente na fanthasia do jovem. O pai de Alexsandre goza da posição do filho, nessa cena da separação, como o representante do "homem da casa", portanto, impede a união dessa mulher com outro homem porque seria uma traição, "por inveja, recalque e simpatia", isto é, por amor.

O adolescente presentifica o pai mesmo na ausência, e goza desse apoio despendido ao pai de modo onipotente. Alexsandre estabelece uma relação de dependência com as figuras parentais e demonstra medo de ficar sem o amparo dos pais, o que produz na fanthasia o efeito de abandono. Segundo Leão e Pacheco (2011, p.32), "ser pai não é uma norma, mas um ato de consequências fastas ou nefastas. A filiação contemporânea remete, para além das normas, ao desejo particularizado de que a criança é produto, um desejo 'que não seja anônimo".

Esse romance familiar mostra o conflito na dimensão da relação edipiana, no que diz respeito à separação de Alexsandre dos pais, implica ressignificar as referências identificatórias, pois isto solicita incessantemente o olhar da figura materna e quando não pode tê-lo, substitui-o pelo olhar da irmã, dessa maneira, engendrando o gozo e constituindo, da falta de apoio, o abandono como verdade do sujeito.

O adolescente A. produz outra propositiva sobre o apoio: "se os pais não podiam dar o apoio, logo ele estava abandonado", pois podemos pensar diante disso que essa demanda faz Alexsandre recorrer à Cena do crime na tentativa de ser amparado por outras instituições, Fundação Casa, CREAS, Escola, na busca de encontrar com o objeto perdido e, por isso, causa de desejo, objeto $a$.

Na tentativa de encontrar com o objeto faltoso, Alexsandre constrói uma relação significante com a Escola, lugar onde foi reconhecido como um "bom" aluno. Nessa Instituição constrói uma trajetória singular, que produziu uma diferença, a alternância da errância, ou seja, ora se mostrava como o 


\section{Desafios da psicologia no Brasil}

"bom" aluno e ora como o filho "mau". A não sustentação de um lugar psíquico produz como efeito no laço social o desconhecimento. O jovem busca reparar o não lugar psíquico que outrora havia se fixado ocupando uma posição que pode ser vista por todos, do lugar de universitário, do Curso de Direito, e atualmente, como um microempresário da construção civil, mias especificamente, instalação de calhas.

O deslocamento dessa cena fantasmática faz um giro discursivo separando-se da dívida real do nascimento, ou seja, que os pais deveriam dar-lhe aquilo que ele queria ter. Essa propositiva indica a recusa da castração e causa outra: "ele pode ter aquilo que ele pode dar a si mesmo", que coloca o sujeito num lugar possível. Sendo assim, se ele sustentar o desejo pode ser reconhecido do lugar social de universitário, de microempresário, por ele e pelos familiares.

Em seu discurso, Alexsandre enuncia uma cadeia de significantes relacionados às suas condições de vida no princípio da sobrevivência: o tamanho do barraco, a quantidade de pessoas, a operação do tráfico que pega menores, e a justificação que dá relativa ao sobreviver e à escolha é que é necessário ter tempo para ver. Ter tempo significa parar para olhar a "vida viva", ter com-pai-xão7, sem compaixão parar a com-pulsão, isto é, deixar de responder ou fazer vacilar a pulsão escópica, no que diz respeito a atender a demanda do Outro.

No final de um escrito não culpa os pais, mas afirma que aprendeu e foi transmitido pelo meio, e justifica que faz por princípio, para sobreviver. Podemos pensar na predominância da necessidade sobre a demanda, presentificada no discurso capitalista e justificada por motivos e intenções que arbitrariamente desresponsabilizam o sujeito pelos seus atos, ao ver de Garcia (2011, p.12), "um discurso capitalista sem limite e sem ponto de impossível, leva ao retorno do real que foi recalcado, retorno sem palavras, entre reivindicação e violência". Cabe pensar, diante do exposto, que Alexsandre vem fazendo vacilar os sentidos, o que pode colocá-lo num outro lado, o da vida.

No que diz respeito à Instituição Fundação Casa, Alexsandre considera que foi bom o tempo que ficou internado, demonstrando que a Instituição cumpriu na sua vida o papel de sustentação, no que diz respeito "a tirá-lo da correria" e dar a ele condições básicas para sobreviver fora de casa. Já o CREAS ofertou apoio para o adolescente e para família.

A Instituição CREAS para o adolescente representa-se na figura da assistente social R. que produziu na relação transferencial com A., por um tempo transitório, um laço de confiança, que através do reconhecimento e da sustentação de uma Outra discursividade possibilitou apoiar Alexsandre para que ele desenvolvesse seu projeto ressituando na vida. 


\section{Desafios da psicologia no Brasil}

O sintoma de Alexsandre é construído e delimitado nesse entrelaçamento discursivo social, mostra a verdade e o gozo do sujeito nessa cena ficcional do diagnóstico psicológico ético-político, contribuindo na construção de um Outro discurso que aposta no adolescente apresentando suas possibilidades e seus limites, isto é, uma potência discursiva.

A escuta no e do diagnóstico psicológico ético-político, possibilitou ao Alexsandre fazer um giro discursivo resituando sua posição como sujeito no social, estabelece laços de gratidão com a família, reconsidera a culpabilização dos pais, reconhece os limites situacionais, pois os pais fizeram o possível para ajudar conforme suas condições de vida, e também percebeu, que tudo tem o seu tempo e nada acontece por acaso.

\section{REFERÊNCIAS BIBLIOGRÁFICAS}

ALENCAR, S. L. Uma experiência em Saúde Pública em São Mateus: algumas reflexões psicanalíticas sobre intervenções em situação de luto coletivo. In: CONGRESSO INTERNACIONAL DE PSICOPATOLOGIA FUNDAMENTAL, set. 2006, Belém, Anais [...]. Belém, set. 2006.

ALENCAR, S. L. A experiência do luto em situações de violência: entre duas mortes. São Paulo, 2011. 190p. Tese (Doutorado em Psicologia Social) - Programa de Pós-graduação em Psicologia Social, Pontifícia Universidade Católica de São Paulo, São Paulo, 2011.

BASTOS, A. O sinthoma: uma questão de escrita. Ágora, Rio de Janeiro, v. 11, n. 2, jul./dec. 2008.

CENTRO DE REFERÊNCIA ESPECIALIZADO DA ASSISTÊNCIA SOCIAL. Projeto de Atendimento ao Adolescente em Conflito com a Lei. São José dos Campos, mar. 2011.

DOSTOIÉVSKI, F. Notas do Subsolo. Porto Alegre: L\&PM Pocket, 2008.

ESPINOSA, B. Os pensadores. São Paulo: Nova Cultural, 2000.

FREUD, S. Um Caso de Histeria: Três Ensaios Sobre a Sexualidade. In: Fragmento da análise de um caso de histeria. (1901/1905), V.VII. Rio de Janeiro: Imago, Ed.

Standard Brasileira das Obras Completas, 1987.

FREUD, S. Sobre a Psicopatologia da Vida Cotidiana. 1901, V.VI. Rio de Janeiro: Imago, Ed.

Standard Brasileira das Obras Completas, 1987.

FREUD, S. Os Chistes e sua Relação com o Inconsciente. 1905, V.VIII. Rio de Janeiro: Imago, Ed.Standard Brasileira das Obras Completas, 1987.

FREUD, S. A Psicanálise e a Determinação dos Fatos nos Processos Jurídicos. 1906, V. IX.

Rio de Janeiro: Imago, Ed. Standard Brasileira das Obras Completas, 1987. 


\section{Desafios da psicologia no Brasil}

FREUD, S. Moral Sexual “Civilizada” e Doença Nervosa Moderna. 1908, V.IX. Rio

de Janeiro: Imago, Ed. Standard Brasileira das Obras Completas, 1987.

FREUD, S. Duas Histórias Clínicas ("O Pequeno Hans" e o "Homem dos Ratos") In: Análise de uma Fobia de um Menino de Cinco Anos. 1909, V.X. Rio de Janeiro: Imago, Ed.Standard Brasileira das Obras Completas, 1987.

FREUD, S. Notas Sobre um Caso de Neurose Obsessiva. 1909, V.X. Rio de Janeiro: Imago, Ed. Standard Brasileira das Obras Completas, 1987.

FREUD, S. As Perspectivas Futuras da Terapêutica Psicanalítica. 1910, V.XI. Rio de Janeiro: Imago, Ed. Standard Brasileira das Obras Completas, 1987.

FREUD, S. Recordar, repetir e elaborar. 1914, V.XII. Rio de Janeiro: Imago, Ed. Standard Brasileira das Obras Completas, 1987.

FREUD, S. Totem e Tabu. 1913-1914, V.XIII. Rio de Janeiro: Imago, Ed.Standard Brasileira das Obras Completas, 1987.

FREUD, S. O sentido dos Sintomas, 1916-1917, V.XVI. Rio de Janeiro: Imago, Ed. Standard Brasileira das Obras Completas, 1987.

FREUD, S. Criminosos em consequência de um sentimento de culpa. 1916, V.XIV. Rio de Janeiro: Imago, Ed. Standard Brasileira das Obras Completas, 1987.

FREUD, S. O Estranho. 1919, V.XVII. Rio de Janeiro: Imago, Ed. Standard Brasileira das

Obras Completas, 1987.

FREUD, S. Além do Princípio do Prazer. 1920, V.XVII. Rio de Janeiro: Imago, Ed.

Standard Brasileira das Obras Completas, 1987.

FREUD, S. As Relações Dependentes do Ego. 1923, apêndice A, V.XIX. Rio de Janeiro: Imago, Ed.Standard Brasileira das Obras Completas, 1987.

FREUD, S. A Dissolução do Complexo de Édipo. 1924, V.XIX. Rio de Janeiro: Imago, Ed.

Standard Brasileira das Obras Completas, 1987.

FREUD, S. A Perda da Realidade na Neurose e na Psicose. 1924, V.XIX. Rio de Janeiro:

Imago, Ed. Standard Brasileira das Obras Completas, 1987.

FREUD, S. Um Estudo Autobiográfico. In: Inibições, Sintomas e Ansiedades. 1925-1926, V.XX. Rio de Janeiro: Imago, Ed.Standard Brasileira das Obras Completas, 1987. 


\section{Desafios da psicologia no Brasil}

FREUD, S. O Mal-Estar da Civilização e Outros Trabalhos. 1927/1931, V.XXI. Rio de Janeiro: Imago, Ed. Standard Brasileira das Obras Completas, 1987.

FREUD, S. O Retorno do Reprimido. 1938, V.XXIII. Rio de Janeiro: Imago, Ed. Standard

Brasileira das Obras Completas, 1987.

GARCIA, C. Responsabilidade sem culpa. CIEN Digital, n. 6, jun. 2009.

KAËS, R. A Instituição e as Instituições: estudos psicanalíticos. São Paulo: Casa do Psicólogo, 1991.

LACAN, J. Escritos (1957-58). Tradução de Vera Ribeiro. In: A instância da letra no inconsciente ou a razão desde Freud. Rio de Janeiro: Jorge Zahar, 1998.

LACAN, J.O Seminário, Livro 2. O eu na teoria de Freud e na técnica da psicanálise (1954-55). Rio de Janeiro: Jorge Zahar, 1985.

LACAN, J. O Seminário, Livro 7. A Ética da psicanálise (1959-60). Rio de Janeiro: Jorge Zahar, 1997.

LACAN, J.O Seminário. Livro 9. A Identificação. Rio de Janeiro: Jorge Zahar, 2003.

LACAN, J.O Seminário, Livro 11. Os quatro conceitos fundamentais de Psicanálise (1964). Tradução de M. D. Magno. Rio de Janeiro: Jorge Zahar, 1990.

LACAN, J.O Seminário, Livro 15. O ato psicanalítico. 1967/68.

Inédito.https://pt.scribd.com/document/353682850/LACAN-Jacques-O-seminario-livro-15-O-atopsicanalitico-1967-68-pdf. Acesso em:15/12/2019.

LACAN, J.O Seminário. Livro 20: Mais, ainda. 1972-73. Rio de Janeiro: Jorge Zahar, 1985.

LACAN, J.O Seminário: Livro 23. O Sinthoma (1975-76). Rio de Janeiro: Jorge Zahar, 2007.

LACAN, J. O lugar da psicanálise na medicina (1966). Opção Lacaniana, 32:8-14. 2001.

LAURENT, E. Dois aspectos da torção entre sintoma e instituição. In: HARARI, A. (org.) Os usos da Psicanálise: primeiro encontro americano do Campo freudiano. Rio de Janeiro: Contra Capa, 2003.

LEBRUN, J. P. Um Mundo sem Limite: ensaio para uma clínica psicanalítica do social. Rio de Janeiro: Companhia de Freud, 2004.

LEGUIL, F. Mais além dos fenômenos. In: LACAN, J. et al. A querela dos diagnósticos. Rio de Janeiro: Jorge Zahar, 1989.

LEITE, S. C. O psicanalista, seu desejo e a instituição de saúde mental. In: FONTENELLE, L. (org.). Psicanálise teoria, clínica e conexões. Fortaleza: Edições Livro Técnico, 2006. p. 203-211.

LESOURD, S. A construção adolescente no laço social. Petrópolis: Vozes, 2004.

MAESSO, C. M. Fundamentos do diagnóstico e a posição do analista. 2011. Tese (Doutorado em Psicologia) - Instituto de Psicologia, Universidade de São Paulo, São Paulo, 2011. 


\section{Desafios da psicologia no Brasil}

MATTOS, C. P. Acolher, Conversar, Produzir Novas Estratégias, Leituras e Saídas a partir da Interdisciplinaridade do CIEN. CIEN Digital, n. 10, jun. 2011.

Mc LANO. O Outro lado da vida bandida (Chora Mãe).

4m11s. https://www.youtube.com/watch?v=OSnAzIFK7aA . Acesso:15/12/2019.

MEIRELLES, C. C. O Valor Diagnóstico do Acting out e da Passagem ao ato no Tratamento Psicanalítico. 2008. Tese (Doutorado em Psicologia) - Instituto de Psicologia, Universidade de São Paulo, São Paulo, 2008.

MENA, L. F. B. A Função do Pai em Psicanálise: para que serve a autoridade? Dissertação (Mestrado em Psicologia) - Instituto de Psicologia, Universidade de São Paulo, 2004.

MIGUELEZ, O. M. Linguagem e Esquizofrenia: de coisas e palavras. 2011. 240 f. Tese (Doutorado em Psicologia) - Pontifícia Universidade Católica de São Paulo, São Paulo, 2011.

MILLER, J. A.; MILNER, J. C. Silet : Os paradoxos da pulsão, de Freud a Lacan. Rio de Janeiro: Jorge Zahar, 2005.

MILLER, J. A.; MILNER, J. C. Você quer mesmo ser avaliado? Entrevistas sobre uma máquina de impostura. Barueri, SP: Manole, 2006.

MINERBO, M. Estratégias de Investigação: desconstrução e reconstrução do conhecimento. Belo Horizonte: Casa do Psicólogo, 2000.

MINERBO, M. A lógica da corrupção: um olhar psicanalítico. Novos Estudos - Cebrap, São Paulo, n. 79, nov. 2007. Disponível em: http://dx.doi.org/10.1590/S0101-33002007000300007. Acesso em: 3 ago. 2013.

MIRANDA JÚNIOR, H. C. O psicanalista no tribunal de família: possibilidades e limites de um trabalho na instituição. 2009. Tese (Doutorado em Psicologia) - Instituto de Psicologia, Universidade de São Paulo, São Paulo, 2009.

MOURA-COSTA, F. (org.). Psicanálise e laço social. Rio de Janeiro: 7 Letras, 2009.

OGILVIE, B. A formação do conceito de sujeito (1932-1949). Tradução de Dulce Duque Estrada. Rio de Janeiro: Jorge Zahar, 1988.

OLIVIERI, Filippo. A aletosfera, lugar de objetos agalmáticos. In: JORGE, Marco Antonio Coutinho; RINALDI, Doris (org.). Saber, verdade e gozo: leituras de 0 seminário, livro 17, de Jacques Lacan. Rio de Janeiro: Rios Ambiciosos, 2002. p. 71-76.

RINALDI, D. Psicanálise no Caps. [Palestra]. Associação Psicanalítica de Porto Alegre, Porto Alegre, 2008.

QUINET, A. Psicose e laço social: esquizofrenia, paranoia e melancolia. Rio de Janeiro: Jorge Zahar, 2006.

ROSA, M. D. Considerações sobre a polêmica do diagnóstico na Psicologia. Psicologia Revista, São Paulo, n. 1, 1995. 


\section{Desafios da psicologia no Brasil}

ROSA, M. D. O Não-Dito Familiar e a Transmissão da História. Psyché, São Paulo: Universidade de São Marcos, ano V, v. V, n. 8, p. 123-137, jul./dez. 2001.

ROSA, M. D. Uma escuta psicanalítica das vidas secas. Revista de Psicanálise Textura, n. 2, 2002.

ROSA, M. D. A Pesquisa Psicanalítica dos Fenômenos sociais e políticos: metodologia e fundamentação teórica. Revista Mal-Estar e Subjetividade, Fortaleza, v. IV. n. 2, p. 329-348, 2004.

ROSA, M. D. A Psicanálise e as Instituições: um enlace ético-político. An. 5 Col. LEPSI IP/FEUSP2004.http://www.proceedings.scielo.br/scielo.phppid=MSC0000000032004000100045\&script=s ci_arttext. Acesso em: 15/12/2019.

ROSA, M. D.; CARIGNATO, T. T.;BERTA, L. S.. Ética e política: a psicanálise diante da realidade, dos ideais e das violências. Àgora, v.9, n.1, Rio de Janeiro, Jan/Jun 2006.

ROSA, M. D et al.. A condição errante do desejo: os imigrantes, migrantes, refugiados e a prática psicanalítica clínico-política. Rev. Latinoamericana. Psicopatologia Fundamental. São Paulo, v. 12, n. 3, p. 497-511, set. 2009.

ROSA, M.D.; VICENTIN, M.C.; CATROLI, V.S.C. Viver em Tempos Sombrios. Psicologia em Revista, Belo Horizonte, v.15, n1, p.51-68, abr., 2009.

ROSA, M. D.; DOMINGUES, E. O método na pesquisa psicanalítica de fenômenos sociais e políticos: a utilização da entrevista e da observação. Psicologia \& Sociedade, v. 22, n. 1, p. 180-188, 2010.

ROSA, M. D. et al. A Elaboração Coletiva do Trauma: A clínica do Traumático. In: SERGIO, S. et al. (org.). Escrita e Psicanálise II. 1. ed. Curitiba: CRV, 2010. p. 15-25. v. 1.

ROSA, M. D.; VICENTIN, C.. Os intratáveis: o exílio do adolescente do laço social pelas noções de periculosidade e irrecuperalidade. Revista Psicologia Política, v. 10, p. 107-124, 2010.

ROSA, M. D.; VICENTIN, C.. A patologização do jovem autor de ato infracional e a emergência de "novos" manicômios judiciários. Rev. Bras. Crescimento desenvolvimento humano, São Paulo, v. 20, n. 1, abr. 2010.

ROSA, M. D.; VICENTIN, C. O jovem e o Adolescente na Cena Social: a relação de identificação, ato e inserção no grupo social. In: BIASOTO, J. G; PALMA SILVA, L. A. Políticas Públicas em Questão. São Paulo: Fundap, 2011.

SAFLATLE V. Transformação da crítica da razão em análise de patologias do social: o caso Theodor Adorno. Philósophos, Goiânia, v. 13, n. 2, p. 117-139, jul./dez. 2008.

SALUM, M. J. G. A psicanálise e o crime: causa e responsabilidade nos atos criminosos, agressões e violência na clínica contemporânea. 2009. Tese (Doutorado em Psicologia) - Instituto de Psicologia, Universidade Federal do Rio de Janeiro, Rio de Janeiro, 2009. Disponível em: http://www.psicologia.ufrj.br/teoriapsicanalitica/arquivos//documentos/55B47C1482EA7B2ED886E 80D22C0BF6B.pdf. Acesso em: 8 ago. 2013

SANTOS, T. C; SALUM, M. J. G. A psicanálise de orientação lacaniana e a criminologia. In: COSTA MOURA, F (org.). Psicanálise e Laço Social. Rio de Janeiro: 7 letras, 2009. 


\section{Desafios da psicologia no Brasil}

SCHAFFER, M. Cenas da clínica psicanalítica. Psicol. Soc., Porto Alegre, v. 18, n. 1, p. 92-94, abr. 2006. Disponível em: http://dx.doi.org/10.1590/S0102-71822006000100013. Acesso em: 4 set. 2019.

SOUZA, S. Diagnóstico Ético-Político da Juventude (Des)orientada? Uma condição humanizante no processo civilizatório. Curitiba: Appris, 2020.

VICENTIN, M. C. A vida em rebelião: história de jovens em conflito com a lei. São Paulo: Hucitec; Fapesp, 2005.

VICENTIN, M. C. Violência e Resistência: o que as rebeliões dos adolescentes em conflito com a lei nos ensinam. Impulso, Piracicaba, v. 15, n. 37, p. 35-48, 2004. 


\section{NOTAS}

\section{Notas1}

SOUZA, S. Diagnóstico Psicológico Ético-Político na produção dos laços sociais dos adolescentes no CREAS. São Paulo, 2013. 304p. Tese (Doutorado) Programa de Pós-graduação em Psicologia Social. Área de Concentração: Psicologia Social. Pontifícia Universidade Católica de São Paulo (no prelo) Intitulado: Diagnóstico Psicológico Ético-Político da Juventude (des)orientada? Uma condição humanizante no processo civilizatório. Curitiba: Appris, 2020.

\section{Nota 2}

Outra cena: uma composição discursiva em que, sob transferência, os atores compartilham a protagonização da história de um sujeito numa versão que inclui o desejo do Outro como operador de outra cena. Para Quinet, não há sujeito sem Outro, o que se passa com o sujeito depende do que se desenrola com o Outro (Outra cena), assim como o desejo do homem é o desejo do Outro e como o sujeito do discurso é vinculado ao outro do laço social. (2009, p. 49).

\section{Nota 3}

Fanthasia: criação do sujeito na objetivação do fantasma. (SOUZA,S.)

Notas 4

História documental são os registros que constituem a instituição e a instituem, através do laço social, num campo social: público e privado.

\section{Nota 5}

Factos: atos que constituem as produções subjetivas e representam as passagens na e da vida. Passagens na vida, que são transitórias, porque se movimentam articulando e rearticulando os significantes; e da vida: como destino, reincide, insiste na repetição do ato como uma colagem discursiva de um lugar social, de uma enunciação que traz implicitamente um enunciado que pode ser reconhecido na cena social.

\section{Nota 6}

Vida viva: (...) a vida viva, ou seja, aquela que não é mental nem inventada, (...) deve ser algo terrivelmente simples, aquilo que é mais comum e que se lança aos olhos de cada um, diariamente e a cada instante (...). (N.T.) (DOSTOIÉVSKI, 1864-2012, p.144)

\section{Nota 7}

Com-pai-xão: metáfora utilizada pela autora para designar o corte da palavra compaixão, originada do latim e da ideologia judaico- cristã que carrega consigo o atributo da piedade e não da lei - o amor ao pai. (SOUZA, S.) 


\section{Capítulo 37}

\section{A (DES) CONSTRUÇÃO PSICANALÍTICA DAS FORMULAÇÕES SOBRE O PATOLÓGICO E O NORMAL}

DOI: $10.37423 / 200200237$

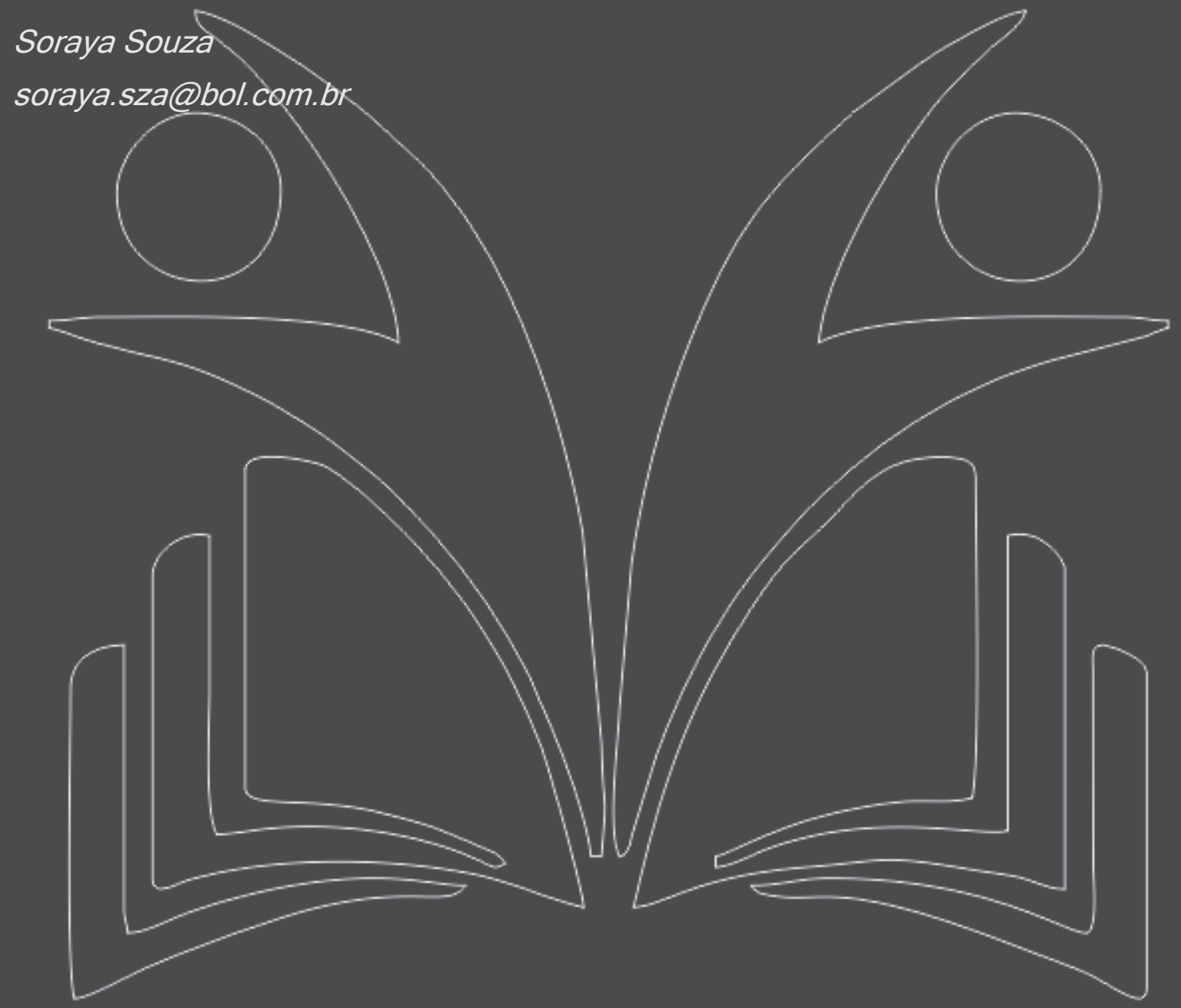




\section{Desafios da psicologia no Brasil}

Este artigo é resultado de uma pesquisa de doutorado ${ }^{1}$ que se propôs reconhecer, na obra freudiana, as formulações sobre anormalidade/normalidade que se constituem em momentos históricofilosóficos, operando efeitos políticos contextualizados e produzindo os paradigmas epistemológicos que fundam os conceitos e situam o homem na vida cotidiana como patológico ou normal.

Freud discorre sobre o axioma pensando a partir do patológico à normalidade, numa versão que opera os indicadores da estrutura do sujeito, levando em consideração o sentido que ele atribui ao acontecimento e o efeito produzido como sofrimento psíquico na experiência individual.

Cabe ressaltar que cada época traz à baila uma epistemologia, um dogma, uma teoria e formulações sobre referências que norteiam o pensamento científico, regulam e direcionam ou enquadram as ações entre os homens. Em seus escritos, Freud não desejava suscitar convicções, mas estimular o pensamento e derrubar os preconceitos. No que diz respeito à psicanálise, o autor pensava sob três aspectos. Em Freud apud ROSA (2004, p.332):

Destacamos esses momentos, entre outros da obra de Freud, para demonstrar que a articulação entre sujeito e sociedade faz parte da trama teórica e clínica da psicanálise, e consideramos com Plon que, apesar das oscilações de Freud quanto à pertinência dessas análises, ele visava, de um lado, desenvolver pontos obscuros em sua teoria e, de outro, testemunhar o seu conhecimento da irredutibilidade epistemológica da Psicanálise a outras ciências, mas também com a finalidade de evitar restringir o seu alcance, ou seja, caminhando na direção oposta das críticas. Recordemos que Freud pensava a psicanálise segundo três aspectos: um método de investigação do inconsciente, uma teoria e técnica de tratamento, mas também um corpo teórico que sistematiza os modos de funcionamento humano, tanto normal como patológico.

No que concerne a esse corpo teórico da psicanálise, não podemos nos eximir da nossa trama teórica, os textos foram escritos no contexto histórico do final do século XIX, quando o autor preocupava-se em desenvolver formulações para sistematizar os conceitos de normal/anormal, utilizando a comparação como método na tentativa de diferenciar as pessoas neuróticas das normais.

Pesquisamos, nos índices remissivos da obra freudiana, com a finalidade de levantar dados sobre o modo como o autor constrói e designa, na obra, levando em consideração o ano de produção dos seguintes termos: normais defesa (1886), neuróticos comparados às pessoas normais (1900-19061920), pessoas normais (1909), pessoas normais comparadas com neuróticos (1910), normais, pessoas comparadas a neuróticos (1916), neuróticos e pessoas normais (1923), dentro da classificação de neurose - pessoas normais (1925), neurótico comparado a pessoa normal (1939). 


\section{Desafios da psicologia no Brasil}

O autor inicia a designação dos termos tratando a normalidade como uma defesa, depois classifica os neuróticos e compara as pessoas normais. Cabe ressaltar a sutileza do autor, pois a palavra pessoa está associada à condição de normalidade e a palavra neurótico apresenta-se desacompanhada da palavra pessoa, o que nos indica uma delimitação do autor no que diz respeito ao sujeito e seus efeitos como manifestações sintomáticas.

Na obra freudiana não há referência ao assunto da anormalidade/ normalidade no índice remissivo dos seguintes livros: Estudos sobre a Histeria: Sobre o mecanismo psíquico dos fenômenos histéricos: comunicação preliminar (1893-1895); Primeiras Publicações Psicanalíticas: Sobre o mecanismo psíquico dos fenômenos histéricos: uma conferência(1893-1899); A Interpretação dos Sonhos: parte III. Sobre os Sonhos (1900-1901); Um Caso de Histeria e Três Ensaios Sobre a Sexualidade (1901-1905); Os Chistes e sua Relação com o Inconsciente (1905); Totem e Tabu (1913-1914); A História do Movimento Psicanalítico. In: Artigos sobre Metapsicologia (1915); O Caso Schreber e Artigos sobre a Técnica (1911-1913); Uma Neurose Infantil (1914-1919); O Futuro de uma Ilusão (1927); O Mal-Estar da Civilização (1927-1930) e Novas Conferências Introdutórias sobre Psicanálise (1932-1936).

Os livros que fazem referência ao assunto são: Publicações Pré-Psicanalíticas e Esboços Inéditos (18861899); Delírios e Sonhos na "Gradiva" de Jensen (1906-1908); Duas Histórias Clínicas: “O Pequeno Hans" e o "Homem dos Ratos" (1909); Cinco Lições de Psicanálise (1910); Conferências Introdutórias sobre a Psicanálise: Parte III (1916-1917); Além do Princípio de Prazer: Psicologia de Grupo e Análise do Ego (1920-1922); O Ego e o Id: Uma Neurose Demoníaca do Século XVII (1922-1923); Um Estudo Autobiográfico: Inibições Sintomas e Angústias (1925-1926) e A Questão da Análise Leiga e Outros Trabalhos $(1926)^{2}$.

Esses artigos são os nossos pontos de estofos, referenciam as formulações sobre a normalidade/anormalidade na obra freudiana. Na construção deste texto, tomaremos como marco conceitual a formulação da pulsão de morte que foi desenvolvido no artigo Além do Princípio de Prazer (1920-1922) como divisor temporal e, portanto, teórico dessa discussão.

Antes de 1920, o autor ainda não tinha construído o conceito da pulsão de morte, Freud defendia a ideia de homeostase psíquica, um estado de equilíbrio que diferenciava quantitativamente as concepções de normal e patológico e, posteriormente a 1920, com a construção desse conceito, prevaleceu a ideia de um desequilíbrio inerente ao sujeito. Nessa época, havia uma atmosfera positivista que influenciou os seguintes escritos freudianos: Esboço para a comunicação preliminar, e no Rascunho D: Sobre a etiologia e a teoria das principais neuroses (1980), De acordo com Prata, (1999, 


\section{Desafios da psicologia no Brasil}

p.40), existem dois modelos sobre o patológico:

Para rastrear a pluralidade de noções e conceitos que estão envolvidos na questão do patológico, teremos dois modelos como ponto de ancoragem: o primeiro apresenta a ideia de homeostase interna, e liga a concepção de patológico em Freud ao desequilíbrio energético do psíquico. Este modelo é balizado pelo princípio da constância quantitativa e posteriormente pelo princípio do prazer. Estava influenciado pelas ideias Breuer e Claude Bernard. O segundo modelo aponta para virada que o discurso freudiano teve a partir da postulação da pulsão de morte a partir da ideia de confronto, existiam forças desarmônicas, o desequilíbrio é inerente ao sujeito.

Ainda segundo Prata, antes de 1920, o axioma freudiano constituía-se de como o homem ordenava a normalidade da vida cotidiana a partir das psicopatologias, ou seja, da constituição da vida psíquica, da formação dos esquecimentos, das lembranças, lapsos, dos equívocos e dos atos falhos causais, sintomáticos e combinados, dos determinismos, da crença no acaso e nas superstições, das parapraxias e dos sonhos. Vemos, no prefácio de Sobre a Psicopatologia da Vida Cotidiana, que Freud tratava das primeiras descobertas em relação às neuroses como fenômenos experimentados na vida psíquica normal:

(...) o que lhe permitiu estender à vida psíquica normal as descobertas que fizera em relação às neuroses. Pela mesma razão ele os empregava regularmente como o melhor material preliminar para introduzir nas descobertas da psicanálise os estudiosos que não eram médicos. Esse material era simples e, pelo menos à primeira vista, imune a objeções, além de se referir a fenômenos experimentais por qualquer pessoa normal. (1901, p. 17).

O autor apresentava a hipótese de que os fenômenos psíquicos da vida normal estavam presentes nas pessoas neuróticas. Além disso, nesse texto, o autor aborda também a resistência como opositora das lembranças e das representações de pensamentos aflitivos e examina o esquecimento das experiências passadas e, além disso, afirma que as condições básicas do processo normal são desconhecidas. Nas pessoas saudáveis:

(...) encontramos sinais abundantes de que uma resistência se opõe à lembrança de impressões aflitivas, à representação de pensamentos aflitivos. Mas o sentido pleno desse fato só pode ser avaliado quando se investiga a psicologia das pessoas neuróticas (p.152). (...) para distingui-los desse esquecimento em sentido estrito, poderíamos dizer que o esquecimento de nomes próprios e de palavras estrangeiras, descrito nos Capítulo I e II, é um "lapso de memória", e que o esquecimento de 


\section{Desafios da psicologia no Brasil}

intenções é uma omissão. As condições básicas do processo normal de esquecimento são desconhecidas. (FREUD, 1901, p.268).

A produção do lapso de memória como efeito da resistência, atua como mecanismo de defesa e tem função protetora do ego, operando o esquecimento de pensamentos aflitivos e/ou ameaçadores da formação psíquica. Dando continuidade ao texto, Freud tem um interesse especial em considerar os atos falhos, causais e sintomáticos:

Se os compararmos aos produtos das psiconeuroses, os sintomas neuróticos, duas informações frequentemente repetidas - a saber, que a fronteira entre a norma e a normalidade nervosa é fluída e que todos somos um pouco neuróticos - adquirirão sentido e fundamento. Antes mesmo de qualquer experiência médica, podemos construir diversos tipos dessas doenças nervosas meramente insinuadas, de formas indistintas das neuroses: casos em que os sintomas são poucos, ou ocorrem raramente ou sem gravidade, em outras palavras, casos cuja moderação está no número, na intensidade e na duração de suas manifestações patológicas. Por conjetura, entretanto, talvez nunca se chegasse justamente ao tipo que mais frequentemente parece constituir a transição entre a saúde e a doença. De fato, o tipo que estamos considerando, cujas manifestações patológicas são os atos falhos e sintomáticos, caracteriza-se pelo fato de os sintomas se localizarem nas funções psíquicas menos importantes, ao passo que tudo aquilo que pode reivindicar maior valor psíquico permanece livre de perturbações. Uma distribuição dos sintomas contrária a essa - seu aparecimento nas funções individuais e sociais mais importantes, a ponto de serem capazes de perturbar a alimentação, as relações sexuais, o trabalho profissional e a vida social - é própria dos casos de neurose e os caracteriza melhor do que, por exemplo, a multiplicidade e o vigor de suas manifestações patológicas. (1901, p. 272).

Concordamos com o autor que, traçando uma fronteira entre a norma e a normalidade, a resultante configura-se como fluída, ou seja, não há uma linha fronteiriça, uma separação entre norma e normalidade, isto é, uma pessoa considerada normal também pode apresentar-se neurótica, dependendo do número, da intensidade e da duração das manifestações patológicas.

Em 1907 o autor traz no texto Escritos criativos e devaneios a ideia da patologia medida pela intensidade apresentada nos processos mentais pelo ego. Freud a rememora no seu texto com uma frase do ilustríssimo dramaturgo vienense Anzengruber "Nada me pode acontecer!", o ego na sua posição de majestade revela sua invulnerabilidade e demonstra que, na existência de acontecimentos insuportáveis para ele, nada pode acontecer. O ego utiliza o recalque e os mecanismos de defesa como processos auxiliares na construção da sintomática. Ainda nesse texto, abordando a fantasia, diz que há muito a dizer, mas limita-se ao aspecto de que o excesso de fantasia conduz à patologia: 


\section{Desafios da psicologia no Brasil}

Quando as fantasias se tornam exageradamente profusas e poderosas, estão ausentes as condições para o desencadeamento da neurose e da psicose. As fantasias também são precursoras mentais imediatas dos penosos sintomas que afligem nossos pacientes, abrindo-se aqui um amplo desvio que conduz à patologia. (FREUD, 1907, p..139)

A intensidade é a medida patológica do ego e, logo, o exagero é um desvio da norma, é uma patologia. No que concerne aos aspectos quantitativos e qualitativos, a intensidade representa-se pelo exagero das reações, por exemplo, das fantasias e, pelo poder, propiciam um desvio e desencadeiam a estrutura patológica da neurose e da psicose.

Em Moral Sexual Civilizada e Doença Nervosa Moderna (1908), Freud discute a diferença entre a moral sexual "natural" e a "civilizada": na primeira, o grupo humano é capaz de conservar sua saúde, e na "civilizada" há uma obediência moral sexual que estimula o homem a uma intensa e produtiva atividade cultural.

Nesse artigo, o autor apresenta a ideia de que todas as classes aumentaram as necessidades individuais, e a ânsia de prazeres materiais, a irreligiosidade, o descontentamento e a cobiça intensificam-se em amplas esferas sociais, consequentemente, produz um ideal de ego que só poderia ser correspondido com o efeito patológico:

Ocasionalmente, um desses pacientes nervosos chamará, ele próprio, a atenção do médico, para o papel que o antagonismo existente entre a sua constituição e as exigências da civilização desempenhou na gênese da sua enfermidade, dizendo, "Em nossa família todos tornamo-nos neuróticos porque queríamos ser melhores do que, com nossa origem, somos capazes de ser. Os médicos também encontram matéria para reflexão no fato de que os indivíduos vitimados por doença nervosa são, com frequência, justamente os filhos de casais procedentes de rudes e vigorosas famílias camponesas que viviam em condições simples e saudáveis, e que, fixando-se em cidades, num curto espaço de tempo elevaram seus filhos a um alto nível cultural. Os próprios neurologistas asseveram enfaticamente que existe uma relação entre a "alta incidência da doença nervosa e a moderna vida civilizada. (FREUD, 1908, p. 170).

O autor aborda esse antagonismo entre a constituição e as exigências da civilização como constituintes da neurose, sustentando a hipótese de que nos tornamos neuróticos como uma defesa do ego em relação à frustração que a realidade impõe-nos diante do limite da capacidade do nosso ser.

Nossa civilização repousa sobre a supressão dos instintos, ou seja, cada indivíduo renuncia a uma parte dos seus atributos, a uma parcela do seu sentimento de onipotência, o que resulta no acervo cultural 


\title{
Desafios da psicologia no Brasil
}

comum de bens materiais e ideais. No que diz respeito ao instinto articulado com a formulação de normalidade/anormalidade, podemos verificar que:

\begin{abstract}
Esse instinto coloca à disposição da atividade civilizada uma extraordinária quantidade de energia em virtude de uma singular e marcante característica: sua capacidade de deslocar seus objetivos sem restringir consideravelmente a sua intensidade. A essa capacidade de trocar seu objetivo sexual, mas psiquicamente relacionado com o primeiro, chama-se capacidade de sublimação. Contrastando com essa motilidade, na qual reside seu valor para civilização, o instinto sexual é passível também de fixar-se de uma forma particularmente obstinada, que o inutiliza e o leva algumas vezes a degenerar-se até as chamadas anormalidades. (FREUD, 1908, p. 174).
\end{abstract}

Assim, o autor sustenta a hipótese de que a atividade civilizada está ancorada na supressão dos instintos, ao passo que a anormalidade/normalidade resulta da capacidade de supressão da intensidade do instinto, pela via da sublimação, caracterizando-se pela flexibilidade de se deslocar dos seus objetivos sem alterar a intensidade e a custa de dispendiosas formações substitutivas, mas, se nessa trajetória o instinto fixar-se, degenera-se, inaugurando as anormalidades.

No artigo Sobre as Teorias Sexuais das Crianças (1908), Freud enfatiza a semelhança entre neuróticos e demais homens e afirma que não dá valor à objeção de que os neuróticos constituem uma classe especial:

(...) marcada por uma disposição inata "degenerada", e de cuja vida infantil não podemos tirar qualquer conclusão sobre a infância de outras pessoas. Os neuróticos são muito semelhante aos demais homens. Não se diferenciam acentuadamente das pessoas normais, e na infância não é fácil distingui-los dos que permanecerão sadios em sua vida posterior. Um dos resultados mais valiosos das investigações psicanalíticas é a descoberta de que as neuroses de tais indivíduos não possuem um conteúdo mental especial e peculiar, mas que, como Jung já analisou, eles adoecem devidos aos mesmos complexos com que nós, as pessoas sadias, lutamos. A única diferença é que as sadias sabem superar esses complexos sem sofrer danos graves e visíveis na vida prática, enquanto nos casos nervosos a supressão dos complexos só obtém êxito à custa de dispendiosas formações substitutivas, isto é, do ponto de vista prático tratase de um fracasso. Na infância, as pessoas neuróticas e as normais estão naturalmente muito mais próximas do que posteriormente, e assim não considero um erro de metodologia utilizar as comunicações dos neuróticos a respeito de sua infância para delas inferir, por analogia, conclusões sobre a vida infantil normal. (FREUD, 1908, p. 192).

O autor equipara a vida infantil normal à neurótica, e sugere que as pessoas neuróticas adoecem pelos mesmos complexos que as pessoas sadias lutam, sem sofrer danos graves na vida prática.

Em 1909, no texto Análise de uma Fobia de um Menino de Cinco Anos, Parte I, o autor trata da 


\section{Desafios da psicologia no Brasil}

observação do desenvolvimento e resolução de uma fobia e faz duas objeções:

A primeira objeção é quanto ao fato de que Hans não era uma criança normal, mas (como os eventos - a própria doença, de fato - mostraram) tinha uma predisposição para neurose, e era um jovem "degenerado"; seria legítimo, portanto, aplicar-se a outras crianças normais conclusões que talvez pudessem ser verdadeiras em relação a ele. Devo adiar a consideração dessa objeção, de vez que ela só limita o valor da observação, e não o anula completamente. De acordo com a segunda e menos comprometedora objeção, uma análise de uma criança conduzida por seu pai, que foi instilado ao trabalho com meus pontos de vista teóricos e infectado com meus preconceitos, deve ser inteiramente desprovida de qualquer valor objetivo (p.95). (...) A influência mais importante sobre o curso do desenvolvimento psicossexual de Hans foi o nascimento de uma irmãzinha, quando ele estava com três anos e meio. (...) Essa influência é também uma influência típica; em um número inesperadamente grande de históricos de vida, tanto normais quanto patológicos, vemo-nos obrigados a tomar como nosso ponto de partida uma explosão de prazer sexual e de curiosidade sexual ligada, como esta, ao nascimento da criança seguinte. (FREUD, 1909, p. 104).

O autor defende que as conclusões sobre as pessoas neuróticas contribuem para pensar a criança normal, mas adverte sobre o limite do valor da observação nessa análise da fobia, parte III, discutindo até que ponto a fobia do pequeno Hans oferece alguma contribuição geral sobre a vida e a educação das crianças, mas voltando à objeção à neurose de Hans:

(...) objeção que foi mantida por tanto tempo, de acordo com a qual Hans era neurótico, um 'degenerado', com uma má hereditariedade, e não uma criança normal, sendo possível aplicar o conhecimento sobre ele a outras crianças. Estive pensando por algum tempo, com pesar, na maneira como os que aderem à 'pessoa normal' vão cair em cima do pobre pequeno Hans logo que forem informados de que ele, de fato, pode ser mostrado como tendo tido uma tara hereditária (p. 126). (...) que não pode ser traçada qualquer linha nítida entre pessoas 'neuróticas' e 'normais' - quer crianças ou adultos -, que a nossa concepção de 'doença' é uma concepção puramente prática e uma questão de somação, que a disposição e as eventualidades da vida precisam combinar-se para que o limiar dessa somação seja ultrapassado e que, consequentemente, vários indivíduos estão passando constantemente da classe de pessoas saudáveis para a de pacientes neuróticos (1909, p.130).

Paciente: "O conflito nas raízes de sua doença era, em essência, uma luta entre a persistente influência dos desejos de seu pai e suas próprias inclinações amorosas" (p. 176). Nesse caso, a precipitação da doença constitui-se no complexo edipiano, no conflito que resulta numa luta entre o desejo do pai e o do sujeito.

Nas Cinco Lições de Psicanálise (1910), Freud aborda a natureza e a tendência da neurose, construindo uma formulação de doença e de doente, de um estado de anormalidade: 


\title{
Desafios da psicologia no Brasil
}

\begin{abstract}
Vemos que os indivíduos adoecem quando, por obstáculos exteriores ou ausência de adaptação interna lhes falta na realidade a satisfação das necessidades sexuais. Observamos que então se refugiam na moléstia para com o auxílio dela encontrar uma satisfação substituta (...) A fuga, da realidade insatisfatória para aquilo que pelos danos biológicos que produz chamamos doença, não deixa jamais de proporcionar ao doente um prazer imediato; ela se dá pelo caminho da regressão às primeiras fases da vida sexual à que na época própria não faltou satisfação. (...) Quanto mais profundamente penetrar-Ihes a patogênese das afecções nervosas, mais claramente verão os liames entre as neuroses e outras produções da vida mental do homem (p.60). (...) O que de mais importante pudemos conseguir pelo estudo psicanalítico dos nervosos, e vem a ser que as neuroses não têm um conteúdo psíquico que, como privilégio deles, não se possa encontrar nos sãos; segundo expressou C.G. Jung, aqueles adoecem pelos mesmos complexos com que lutamos nós, os que temos a saúde perfeita. Conforme as circunstâncias de quantidade e da proporção entre as forças em choque, será o resultado da luta a saúde, a neurose ou a sublimação compensadora. (p. 61).
\end{abstract}

A doença nervosa é constituída como uma fuga da realidade insatisfatória, proporciona um prazer imediato e regride nas primeiras fases da vida sexual em busca de satisfação. Em 1908, o autor apresentou uma hipótese de linha divisória entre a neurose e as pessoas normais, e em 1910, reafirmou a hipótese de indiferenciação entre as pessoas neuróticas e as normais, acrescentando que elas adoecem pelos mesmos complexos que as pessoas normais lutam.

No texto As Perspectivas Futuras da Terapêutica Psicanalítica (1910), Parte VI, Freud não nega que os leitores de seu tempo apreciam a investigação patográfica, mas que, no entanto, o exame dos conhecimentos adquiridos foi construído no campo da patologia. E aborda a diferenciação entre os normais e os neuróticos:

Não mais consideramos que a saúde e a doença, ou que os normais e os neuróticos se diferenciam tanto uns dos outros e que traços neuróticos devem necessariamente ser tomados como sendo prova de uma inferioridade geral. Hoje em dia, sabemos que os sintomas neuróticos são estruturas que funcionam como substitutos para algumas consequências de repressão, a qual devemos submeter-nos no curso de nosso desenvolvimento, desde a criança ao ser humano civilizado. Sabemos também, que todos nós produzimos essas estruturas substitutivas e que somente o seu número, intensidade e distribuição nos poderá justificar na utilização do conceito prático de doença e inferir a presença de uma inferioridade constitucional. (FREUD, 1910, p. 136).

Defendendo a indiferenciação entre os estados de saúde e doença e de normal e patológico, Freud afirma que os sintomas neuróticos são estruturas que funcionam como substitutos de algumas formas de repressão. E, ainda, que o conceito de doença equivale às estruturas substitutivas em que está presente uma inferioridade constitucional geral, justificada pelo seu número, intensidade e 


\section{Desafios da psicologia no Brasil}

distribuição.

Nas Conferências Introdutórias Sobre a Psicanálise (1916-1917), Parte III - Teoria Geral da Neurose, a Conferência XVII, O Sentido dos Sintomas (1917), traz o texto no qual Freud defende que os sintomas têm um sentido e se relacionam com as experiências do paciente, podendo se apresentar como um ritual normal, ou seja, como um rito de passagem que exige condições necessárias, ou um ritual patológico, inflexível e à custa de grandes sacrifícios. O autor exemplifica o rito, com um ritual de dormir:

Em certo sentido, pode-se dizer que toda pessoa normal tem seu ritual de dormir, ou que estabeleceu determinadas condições necessárias, cujo não preenchimento interfere com o adormecer; toda pessoa se impõe determinadas formalidades na transição do estado de vigília ao de sono, e repete-as da mesma maneira, todas as noites. Tudo aquilo que uma pessoa sadia exige como condição necessária para dormir, pode, contudo ser, compreendido racionalmente e, no caso de circunstâncias externas exigirem uma mudança, a pessoa cede com facilidade, sem perda de tempo. Um ritual patológico, porém, é inflexível, e insiste em ser levado a cabo, mesmo à custa de grandes sacrifícios; também se oculta atrás de uma fundamentação racional, e, a um exame superficial, parece divergir do normal apenas por uma exagerada meticulosidade. (1917, p. 313-314).

Toda pessoa normal tem seu ritual para dormir, isto é, formalizações da passagem de um estado de vigília ao de sono que se repetem todas as noites, e demonstram flexibilidade no caso de circunstâncias externas exigirem mudanças. Já a inflexibilidade e a meticulosidade são manifestações de características patológicas no sujeito.

Nas Conferências Introdutórias sobre Psicanálise, na conferência XIX, no texto Resistência e Repressão (1917), o autor propõe pensar o aparelho mental a partir das ideias de inconsciente, pré-consciente e consciente para explicar uma teoria geral do funcionamento normal e dos sintomas neuróticos:

Assim, será muito importante para mim admitirem que uma concepção do aparelho mental, conforme essa que aqui proponho para explicar os sintomas neuróticos, deve necessariamente exigir uma validade geral e dar-nos informações também a respeito do funcionamento normal. Naturalmente, nisto os senhores terão toda a razão. No momento, não podemos avançar com essa implicação, mas nosso interesse na psicologia da formação dos sintomas não pode senão aumentar em grau extraordinário, se existir uma perspectiva, através do estudo de situações patológicas, de se obter acesso aos eventos mentais normais que se ocultam tão bem. Os sonhos não são fenômenos patológicos; podem surgir em qualquer pessoa sadia, nas condições do estado de sono. Nossa hipótese referente à estrutura do aparelho mental, que nos permite compreender a formação análoga dos sonhos e dos sintomas neuróticos, tem o inquestionável direito de ser aceita como adequada à explicação da vida mental normal, também (1917, p. 349-350). 


\title{
Desafios da psicologia no Brasil
}

O autor sustenta a hipótese de que, no funcionamento normal das pessoas sadias, estão inclusos os sonhos, não sendo esses fenômenos patológicos. Na Conferência XXVIII, Terapia Analítica (1917), Freud trata do ponto de vista da teoria da libido, em que os sonhos de um neurótico, bem como suas parapraxias e suas associações livres, auxiliam-nos a descobrir o sentido dos seus sintomas e a revelar a maneira de distribuição da libido:

\begin{abstract}
Os sonhos dos neuróticos, contudo, não diferem, em nenhum aspecto importante, dos sonhos de pessoas normais; é possível de fato, que estes não possam absolutamente ser diferenciados daqueles. Seria absurdo fazer uma descrição dos sonhos de neuróticos que não pudessem também aplicar-se aos sonhos de pessoas normais. Logo, podemos dizer que a diferença entre neurose e saúde vigora apenas durante o dia; não se estende à vida onírica. Somos obrigados a extrapolar para pessoas sadias diversas hipóteses relativas aos neuróticos, em consequência do elo entre os sonhos destes e seus sintomas. Não podemos negar que também as pessoas sadias possuem em sua vida mental, aquilo que, por si só, possibilita a formação tanto dos sonhos como dos sintomas; e devemos concluir que também elas efetuaram repressões, que despendem determinada quantidade de energia a fim de mantê-las, que seu sistema inconsciente oculta impulsos reprimidos ainda catexizados com energia, e que uma parte de sua libido é retirada e deixa de estar à disposição do ego. Assim, também uma pessoa sadia é virtualmente um neurótico, mas os sonhos parecem ser os únicos sintomas que ela é capaz de formar. É verdade que, se alguém submete a um exame mais atento sua vida desperta, descobre algo que contradiz essa aparência, ou seja, que essa vida pretensamente sadia está marcada aqui e ali por grande número de sintomas banais e destituídos de importância prática. (FREUD, 1917, p. 532-533).
\end{abstract}

O autor formula as seguintes hipóteses sobre as pessoas sadias: a da indiferenciação entre os sonhos de pessoas normais e das neuróticas; a da diferença entre a neurose e a saúde vigora apenas na vida desperta, a de que as pessoas sadias possuem em sua vida mental, conteúdos que possibilitam tanto a formação de sonhos como a de sintomas, e a de que as pessoas sadias efetuaram repressões, ou seja, uma parte de sua libido foi retirada e deixa de estar à disposição do ego.

Esse texto ainda distingue saúde de neurose, devido às dimensões relativas à quantidade de energia que permanece livre e a que é ligada pela repressão, portanto, essa distinção:

Reduz se, por conseguinte, a uma questão prática e é decidida pelo resultado, isto é, a pessoa ter ou não ter um nível suficiente de capacidade para aproveitar a vida e ser eficiente. Não preciso dizer-Ihes que essa descoberta é a justificação teórica de nossa convicção de que as neuroses são, em princípio, curáveis, apesar de se basearem na disposição constitucional. A identidade dos sonhos de pessoas sadias e neuróticas capacita-nos a inferir, pois, muita coisa referente à definição das características de 


\section{Desafios da psicologia no Brasil}

saúde. Mas, com relação aos sonhos propriamente ditos, podemos fazer uma inferência adicional: não devemos desvinculá-los de sua relação com os sintomas neuróticos, não devemos supor que sua natureza essencial se esgota com a fórmula que os descreve como tradução de pensamentos em uma forma arcaica de expressão; porém, devemos supor que eles nos mostram distribuições da libido e catexias objetais que realmente estão presentes (1917, p. 533).

Por uma questão prática, é a capacidade de aproveitar a vida que distingue a saúde da neurose. 0 autor apresenta como justificação teórica que "as neuroses são, em princípio, curáveis, apesar de basearem na disposição constitucional". Com relação aos sonhos, há uma inferência adicional, não podemos desvincular de sua relação com os sintomas neuróticos, pois supomos que eles mostram distribuições da libido e catexias objetais presentes.

No texto, Além do Princípio do Prazer (1920), Parte II, Freud passa a examinar o método de funcionamento do aparelho mental em uma de suas primeiras atividades normais. Refere-se à brincadeira das crianças. As diferentes teorias sobre esse tópico foram ainda recentemente resumidas e discutidas do ponto de vista psicanalítico por Pfeifer, e essas teorias esforçam-se para descobrir os motivos que levam as crianças a brincar, mas deixam de trazer para o primeiro plano o motivo econômico, a consideração da produção de prazer envolvida:

Sem querer incluir todo o campo abrangido por esses fenômenos, pude através de uma oportunidade fortuita que se me apresentou lançar certa luz sobre a primeira brincadeira efetuada por um menininho de ano e meio de idade e inventada por ele próprio. Foi mais do que uma simples observação passageira, porque vivi sob o mesmo teto que a criança e seus pais durante algumas semanas, e foi algum tempo antes que descobri o significado da enigmática atividade que ele constantemente repetia (p.5). (...) Esse bom menino, contudo tinha o hábito ocasional e perturbador de apanhar quaisquer objetos que pudesse agarrar e atirá-los longe para um canto, sob a cama, de maneira que procurar seus brinquedos e apanhá-los, quase sempre dava bom trabalho. Enquanto procedia assim emitia um longo e arrastado 'o-o-o-ó', acompanhado por expressão de interesse e satisfação. Sua mãe e o autor do presente relato concordaram em achar que isso não constituía uma simples interjeição, mas representava a palavra alemã fort. (empregado como ir embora). Acabei por compreender que se tratava de um jogo e que o único uso que o menino fazia de seus brinquedos, era brincar de 'ir embora' com eles. Certo dia fiz uma observação que confirmou meu ponto de vista. O menino tinha um carretel de madeira com um pedaço de cordão amarrado em volta dele. Nunca Ihe ocorrera puxá-lo pelo chão atrás de si, por exemplo, e brincar com o carretel como se fosse um carro. O que ele fazia era segurar o carretel pelo cordão e com muita perícia arremessá-lo por sobre a borda de sua caminha encortinada, de maneira que aquele desaparecia por entre as cortinas, ao mesmo tempo que o menino proferia seu expressivo 'o-o-o-ó'. Puxava então o carretel para fora da cama novamente, por meio do cordão, e saudava o seu reaparecimento com um alegre 'da' (ali). Essa, então, era a brincadeira completa: desaparecimento e retorno (FREUD, 1920, p. 26). 


\title{
Desafios da psicologia no Brasil
}

$\mathrm{Na}$ atividade normal de uma criança aparece num hábito ocasional e perturbador de apanhar quaisquer objetos que pudesse agarrar e atirá-los longe para um canto, fato que o autor compreendeu como parte de um jogo de desaparecimento e aparecimento que as crianças fazem na tentativa de elaborar a separação das figuras parentais significativas.

No texto, Além do Princípio do Prazer (1920), Parte III, também aborda a diferença do interesse da psicanálise, da arte interpretativa de descobrir o conteúdo inconsciente, pela influência da transferência, para arte de descobrir as resistências do paciente rapidamente para abandonar suas resistências. Além disso, Freud aborda a extinção do florescimento precoce da vida sexual infantil e aponta o sentimento de inferioridade e a transferência como normal aos neuróticos:

\begin{abstract}
Esse florescimento chega ao fim nas mais aflitivas circunstâncias e com o acompanhamento dos mais penosos sentimentos. A perda do amor e o fracasso deixam atrás de si um dano permanente à autoconsideração, sob a forma de uma cicatriz narcisista, o que, em minha opinião, bem como na de Marcinowski (1918), contribui mais do que qualquer outra coisa para o sentimento de 'inferioridade', tão comum aos neuróticos. (...) O que a psicanálise revela nos fenômenos de transferência dos neuróticos, também pode ser observado nas vidas de certas pessoas normais. A impressão que dão é de serem perseguidas por um destino maligno ou possuídas por um poder 'demoníaco'; a psicanálise, porém, sempre foi da opinião de que seu destino é, na maior parte, arranjado por elas próprias e determinado por influências infantis primitivas. A compulsão que aqui se acha em evidência não difere em nada da compulsão à repetição que encontramos nos neuróticos, ainda que as pessoas que agora estamos considerando nunca tenham mostrado quaisquer sinais de lidarem com um conflito neurótico pela produção de sintomas (1920, p. 31-32).
\end{abstract}

O autor sugere que o sentimento de inferioridade constituído pela perda do amor e pelo fracasso deixa uma cicatriz narcísica e um dano permanente à autoconsideração que também pode ser observado na vida das pessoas normais.

Ainda nessa obra, Freud trata da normalidade/anormalidade sem se referir a essas palavras propriamente ditas, mas remetendo à repetição que ora causa espanto, ora não, bem como à compulsão e à repetição pelo domínio do processo de excitação na vida mental:

Essa 'perpétua recorrência da mesma coisa' não nos causa espanto quando se refere a um comportamento ativo por parte da pessoa interessada, e podemos discernir nela um traço de caráter essencial, que permanece sempre o mesmo, sendo compelido a expressar-se por uma repetição das mesmas experiências. Ficamos muito mais impressionados nos casos em que o sujeito parece ter uma experiência passiva sobre a qual não possui influência, mas nos quais se defronta com uma repetição da mesma 


\section{Desafios da psicologia no Brasil}

fatalidade. É o caso, por exemplo, da mulher que se casou sucessivamente com três maridos, cada um dos quais caiu doente logo depois e teve que ser cuidado por ela em seu leito de morte. (...) Grande parte do que poderia ser descrito como compulsão do destino parece inteligível numa base racional (...). O exemplo menos dúbio (de tal força motivadora) é talvez o do sonhos traumáticos. (...) Resta inexplicado o bastante para justificar a hipótese de uma compulsão à repetição, algo que parece mais primitivo, mais elementar e mais instintual do que o princípio do prazer que ela domina. Mas, se uma compulsão à repetição opera realmente na mente (...), sob que condições pode surgir e qual sua relação com o princípio do prazer, ao qual, afinal de contas, até agora atribuímos dominância sobre o curso dos processos de excitação na vida mental (1920, p. 33-34).

Portanto, a compulsão à repetição operaria nos processos de excitação da vida mental das pessoas normais quando se referem por parte da pessoa interessada a um comportamento ativo.

Já na parte IV dessa mesma obra, Freud menciona o escudo protetor dos organismos vivos contra os estímulos externos. As excitações que provêm de dentro, entretanto, em sua intensidade e amplitude, produzem dois resultados definidos, o segundo associado aos processos patológicos, sendo assim:

Primeiramente, os sentidos de prazer e desprazer predominam sobre todos os estímulos externos. Em segundo lugar, é adotada uma maneira específica de lidar com quaisquer excitações internas que produzam um aumento demasiado grande de desprazer; a uma tendência a tratá-las como se atuassem, não de dentro, mas de fora, de maneira que seja possível colocar o escudo contra estímulos em operação, como meio de defesa contra elas. É essa a origem da projeção destinada a desempenhar um papel tão grande na causação dos processos patológicos. (FREUD, 1920, p. 40).

No que concerne ao excesso de desprazer, a projeção é o mecanismo de defesa das excitações internas contra os estímulos externos, desempenhando um papel importante nos processos patológicos.

Depois de 1920, no momento profícuo da formulação teórica da pulsão de morte, o texto $A$ Psicogênese de um caso de Homossexualismo numa Mulher (1920), aborda a normalidade como algo esperado do complexo no e pelo social, no Édipo, e o inesperado, fixado como anormal, no homossexualidade:

Fizemos um levantamento das forças que conduziram a libido da jovem da atitude de Édipo normal à do homossexualismo, e dos caminhos psíquicos percorridos por nosso processo. O mais importante nesse respeito foi a impressão causada pelo nascimento do seu irmãozinho e a partir disso poderíamos inclinar-nos a classificar o caso como de inversão posteriormente adquirida (1920, p.179). 


\section{Desafios da psicologia no Brasil}

Nesse caso da jovem homossexual, o anormal constitui-se pela experiência do nascimento do irmãozinho, devido ao excesso das forças que conduzem a libido da jovem. No Em Alguns Mecanismos Neuróticos no Ciúme, na Paranoia e no Homossexualismo (1922), Parte (B), o autor trata do normal e do patológico referindo-se aos sonhos:

Os sonhos distinguem-se do pensamento de vigília pela possibilidade de incluir material (pertencente à região do reprimido) (...). Afora isso, os sonhos são meramente uma forma de pensar, uma transformação do material pré-consciente do pensamento pela elaboração onírica e suas condições. Nossa terminologia das neuroses não é aplicável ao material reprimido, que não pode ser chamado de histérico, obsessivo ou paranoico. Opondo-se a isso, a outra parte do material sujeita ao processo de formação onírica - os pensamentos pré-conscientes - pode ser normal ou apresentar o caráter de qualquer neurose; eles podem ser os produtos de qualquer dos processos patogênicos em que reside a essência de uma neurose. (1922, p. 244).

O autor reafirma que sonhos são meras formas de pensar que incluem o material reprimido, os pensamentos pré-conscientes, que podem ser normais ou apresentar o caráter de qualquer neurose. Em Dois Verbetes de Enciclopédia (1923), Parte A, Psicanálise, A Interpretação das Parapraxias e dos Atos Fortuitos, Freud trata dos atos mentais comuns de pessoas normais:

Constitui um triunfo para a arte interpretativa da psicanálise conseguir demonstrar que certos atos mentais comuns de pessoas normais, para os quais ninguém havia até então buscado apresentar explicação psicológica, deveriam ser considerados sob o mesmo ângulo que os sintomas dos neuróticos, isto é, que tinham um significado, desconhecido do sujeito, mas capaz de ser facilmente descoberto pelos meios analíticos. Os fenômenos em causa eram eventos como esquecimento temporário de palavras e nomes familiares e de efetuar tarefas prescritas, lapsos cotidianos de língua e de escrita, leituras erradas, perdas e colocações erradas de objetos, certos erros, exemplos de danos a si próprio aparentemente acidentais e, finalmente, movimentos habituais efetuados aparentemente sem intenção ou brincando, melodias murmuradas "sem pensar", etc. (...). A importância dessa contribuição para a psicologia foi de muitos tipos. $O$ âmbito de determinismo mental foi por ela ampliado de maneira imprevista; o suposto abismo existente entre os fatos mentais normais e patológicos se estreitou, em muitos casos logrou-se uma compreensão útil ao jogo das forças mentais que se deve suspeitar existir por trás dos fenômenos. (1923, p. 257).

A hipótese sustentada é de que os atos mentais comuns de pessoas normais, constituídos pelos fenômenos que causavam eventos como esquecimento, lapsos cotidianos e movimentos habituais efetuados, aparentemente, sem intenção ou brincando, deveriam ser considerados sob o mesmo ângulo dos sintomas neuróticos. Nesse mesmo texto, Freud retoma a afirmativa que a dinâmica da 


\title{
Desafios da psicologia no Brasil
}

formação dos sonhos é a mesma que a do sintoma e a partir disso explica a normalidade/anormalidade:

\begin{abstract}
Em ambos os casos encontramos uma luta entre duas tendências, das quais uma é inconsciente, normalmente reprimida, e se esforça por obter satisfação, isto é, a realização do desejo, enquanto que a outra, pertencente provavelmente ao ego consciente, é desaprovadora e repressiva. O resultado desse conflito é uma formação conciliatória (o sonho ou o sintoma) (...) Porquanto os sonhos não são fenômenos patológicos, o fato demonstra que os mecanismos mentais que produzem os sintomas de doença estão igualmente presentes na vida mental normal, que a mesma lei uniforme abrange tanto o normal como o anormal e que as descobertas da pesquisa em neuróticos e psicóticos não podem deixar de ter significação para a nossa compreensão da mente saudável (1923, p. 257).
\end{abstract}

No que diz respeito ao resultado do conflito como uma formação conciliatória, o autor sustenta a hipótese de que a lei geral abrange tanto o normal como o anormal e, portanto, os sonhos não são fenômenos patológicos.

Na obra O Ego e o Id (1923), Freud apresenta a normalidade/anormalidade no que concerne às identificações objetais como uma diferenciação dos conflitos do ego com o id, o superego e o mundo externo. A normalidade é operada pela tentativa de corresponder ao ideal do ego e a anormalidade é produzida pelo fracasso no funcionamento do ego em conciliar as exigências feitas a ele. Para Freud, se as identificações objetais do ego:

\begin{abstract}
Levam a melhor e se tornam numerosas demais, indevidamente poderosas e incompatíveis umas com as outras, um resultado patológico não estará distante. Pode ocorrer uma ruptura do ego, em consequência das diferentes identificações se tornarem separadas umas das outras através de resistências; talvez o segredo dos casos daquilo que é descrito como personalidade múltipla seja que as diferentes identificações apoderam-se sucessivamente da consciência. Mesmo quando as coisas não vão tão longe, permanece a questão dos conflitos entre as diversas identificações em que o ego se separa, conflitos que, afinal de contas, não podem ser descritos como inteiramente patológicos (1923, p. 43).
\end{abstract}

As identificações objetais do ego apresentam como indicador patológico o excesso, e as diferentes identificações do ego podem ocasionar uma ruptura do ego, pois se tornam separadas entre si pela resistência, permanecendo a questão do conflito. Nesse texto ainda, na parte V, As Relações Dependentes do Ego, o autor aborda a formação do ego a partir de identificações que tomam o lugar de catexias abandonadas pelo id, dizendo que o ego é a sede real da ansiedade que será substituída mais tarde pela efetivação de catexias protetoras, pois o que o ego teme do perigo externo e libidinal 


\section{Desafios da psicologia no Brasil}

não pode ser especificado, ou seja, o medo da morte: "Sabemos que o medo da morte faz seu aparecimento sob duas condições (as quais, além disso, são inteiramente análogas a situações que outros tipos de ansiedade se desenvolvem), a saber, como reação a um perigo externo e como um processo interno (como por exemplo, na melancolia)." (1923, p.70).

Parafraseando o autor, mais uma vez uma manifestação neurótica pode ajudar-nos a compreender uma normal. O medo da morte pode desenvolver um tipo de ansiedade, como reação a um perigo externo e como um processo interno.

No texto Uma Breve Descrição da Psicanálise (1923, p.227), Parte IV, Freud discutiu a capacitação do médico para lidar com o material analítico. O primeiro conceito analisado foi o da libido, e por meio disso, abordou processos da normalidade e da anormalidade da psique.

Um estudo mais completo demonstrou que era necessário colocar ao lado dessa "libido objetal" uma "libido narcísica" ou do "ego", dirigida para o próprio ego do indivíduo, e a interação dessas duas forças nos capacitou a explicar grande número de processos normais e anormais na vida mental. Uma distinção grosseira logo se fez entre o que é conhecido por neurose de transferência e os distúrbios narcísicos. As primeiras (histeria e neurose obsessiva) constituem os objetos propriamente ditos do tratamento psicanalítico, ao passo que as outras, as neuroses narcísicas, embora possam deveras ser examinadas com o auxílio da análise, oferecem dificuldades fundamentais à influência terapêutica. (...) Não se pode duvidar de que as neuroses e psicoses não estão separadas por uma linha rígida, mais do que o estão a saúde e a neurose. (1923, p.227-228).

A normalidade/anormalidade constituída como um processo que é efeito de um entrelaçamento discursivo coloca-nos numa dimensão de apreender os fenômenos em sua interação. Como resultado disso, há uma combinatória de reações da vida mental do indivíduo que produzem laços sociais. 0 autor sustenta a hipótese de que há uma linha flexível entre neurose/psicose e saúde/neurose.

É no texto A Dissolução do Complexo de Édipo (1924), em que é abordada a dissolução do fenômeno central do período sexual da primeira infância, que Freud declara uma linha fronteiriça entre o normal e o patológico: "chegamos aqui a uma linha fronteiriça, nunca bem nitidamente traçada, entre o normal e o patológico. Se o ego, na realidade, não conseguiu muito mais que uma repressão do complexo, este persiste em estado inconsciente no id e manifestará mais tarde seu efeito patogênico" (FREUD, 1924, p.197).

Essa linha fronteiriça estabelece-se pela repressão do complexo: se o ego não conseguiu muito mais que uma repressão, o conteúdo persiste em estado inconsciente no id e manifesta-se como anormal. 


\section{Desafios da psicologia no Brasil}

No texto freudiano A Perda da Realidade na Neurose e na Psicose (1924), o autor apresenta a diferenciação entre a neurose e a psicose e produz uma formulação sobre o comportamento normal ou sadio:

Por conseguinte, a diferença inicial assim se expressa no desfecho final: na neurose, um fragmento da realidade é evitado por uma espécie de fuga, ao passo que na psicose, a fuga inicial é sucedida por uma fase ativa de remodelamento; na neurose, a obediência inicial é sucedida por uma tentativa adiada de fuga. Ou expressa de outro modo: a neurose não repudia a realidade, apenas a ignora, a psicose a repudia e tenta substituí-la. Chamamos um comportamento de "normal" ou "sadio" se ele combina certas características de ambas as reações, se repudia a realidade tão pouco quanto uma neurose, mas se depois se esforça, como faz uma psicose, por efetuar uma alteração dessa realidade. Naturalmente, esse comportamento conveniente e normal conduz à realidade do trabalho no mundo externo; ele não se detém como na psicose, em efetuar mudanças internas. (1924, p. 207).

Freud sustenta a hipótese que o comportamento é considerado normal ou sadio quando combina características dessas reações na realidade, mas, depois, o indivíduo esforça-se, luta para efetuar, uma alteração nessa realidade.

No texto Algumas Consequências Psíquicas da Distinção Anatômica entre os Sexos (1925), o autor trata da necessidade - nas análises de neuróticos lidarem com o período mais remoto da infância para avaliar com exatidão as forças motivadoras que levaram à neurose e como se remodelam na vida adulta. Para Freud, o normal está associado ao ideal:

O complexo de Édipo, contudo, é uma coisa tão importante que o modo porque o indivíduo nele se introduz e o abandona não pode deixar de ter seus efeitos. (...) Em casos normais, ou melhor ideais, o complexo de Édipo não existe mais, nem mesmo no inconsciente; o superego se tornou seu herdeiro. Não posso fugir à noção (embora hesite em lhe dar expressão) de que, para as mulheres, o nível daquilo que é eticamente normal, é diferente do que é nos homens. Seu superego nunca é tão inexorável, tão impessoal, tão independente de suas origens emocionais como exigimos que o seja nos homens. (1925, p. 285-286).

O autor associa o normal ao ideal e apresenta o desaparecimento do complexo de Édipo e o aparecimento do superego, sugerindo uma diferença ética operada por uma diferença sexual do gênero, pois o superego da mulher depende mais das origens emocionais do que o dos homens. Em 1926, no texto, Um Estudo Autobiográfico: Inibições, Sintomas e angústias, parte IV, Freud trata dos sonhos como manifestação da vida mental normal: 


\section{Desafios da psicologia no Brasil}

Quando, no entanto, se tratava de sonhos, não estava mais lidando com sintoma patológico, mas com uma manifestação da vida mental normal que poderia ocorrer em qualquer pessoa sã. Se os sonhos viessem a ser interpretados como sintomas, se sua explanação exigisse as mesmas suposições - a repressão de impulsos, formação substitutiva, formação de conciliação, a divisão do consciente e do inconsciente em vários sistemas psíquicos, então a psicanálise não seria mais uma ciência auxiliar no campo da psicopatologia, mas antes o ponto de partida de uma ciência nova e mais profunda da mente, que seria igualmente indispensável para a compreensão do normal. Seus postulados e achados poderiam ser levados a outras regiões da ocorrência mental, estava aberto para ela um caminho que conduzia muito longe, até as esferas do interesse universal. $(1925$, p.51).

A psicanálise, como o ponto de partida de uma ciência nova, possibilitou-nos tratar dos sonhos como uma manifestação da vida mental normal. Nesse texto, na parte V, Freud trata da história da psicanálise, dividindo-a em duas fases: a primeira, quando ficou sozinho (1895-96 até 1906-07), e a segunda quando uma doença adverte-o do fim que se aproxima e, no entanto, depois disso, sua vida prosseguiu ativa por mais de 12 anos. Afirma em seus escritos que as neuroses não possuem conteúdos próprios:

Deve ser verdade, como Jung expressou tão bem nos primeiros dias em que ainda era analista, que as neuroses não possuem conteúdo peculiar algum que pertença exclusivamente a elas, mas que os neuróticos sucumbem às mesmas dificuldades que são superadas com êxito por pessoas normais. Essa descoberta estava muito longe de ser um desapontamento. Estava em completa harmonia com outra: que a psicologia profunda revelada pela psicanálise era de fato a psicologia da mente normal. Nosso caminho tinha sido como o da química: as grandes diferenças qualitativas entre substâncias eram remetidas às variações quantitativas nas proporções em que os mesmos elementos eram combinados. (1926, p. 59).

O autor sustenta a hipótese por intermédio da revelação psicanalítica de que a psicologia profunda era uma psicologia da mente normal e, nessa trajetória, as diferenças qualitativas eram remetidas proporcionalmente às variações quantitativas, levando em consideração a combinatória dos mesmos elementos.

Ainda na Parte IX, Freud considera a relação entre a formação de sintomas e a geração de ansiedades, apresentando duas opiniões: uma, que a ansiedade é um sintoma da neurose, e outra, que os sintomas só se formam a fim de evitar a ansiedade: reúnem a energia psíquica que, de outra forma, seria descarregada como ansiedade. No concernente à normalidade da ansiedade:

Num grande número de casos os antigos determinantes da ansiedade realmente declinam, após terem reações neuróticas. As fobias de crianças muito tenras, temores de ficarem sós ou no escuro ou com estranhos - fobias que podem quase ser 


\section{Desafios da psicologia no Brasil}

chamadas de normais - em geral desaparecem depois; a criança 'sai delas crescendo', como dizemos sobre algumas outras perturbações na infância. (1926-1980, p.145). Em vez do afeto da ansiedade tomemos por um momento, outro - o do pesar, por exemplo. Parece perfeitamente normal que aos quatro anos de idade uma menina chore penosamente se a sua boneca quebrar-se; ou aos seis, se a governanta reprovála; ou aos dezesseis, se for desprezada pelo namorado; ou aos vinte e cinco, talvez se um filho dela morrer. Cada um desses determinantes de dor tem a sua própria época e desaparece quando essa época terminar. Somente os determinantes finais e definitivos permanecem por toda a vida. (1926-1980, p.144-145). Outros determinantes de ansiedade, como o medo do superego, estão destinados a não desaparecer absolutamente, mas a acompanhar as pessoas por toda sua vida. Nesse caso, o neurótico diferirá da pessoa normal devido ao fato de que suas reações aos perigos em questão serão indevidamente acentuadas. (...) Por que só o afeto da ansiedade parece desfrutar da vantagem sobre todos os outros afetos de evocação de reações que se distinguem das restantes por serem anormais e que, através de sua falta de propriedade, vão de encontro ao movimento da vida? (...) De que provém a neurose - qual é a sua última, sua própria raison d'être peculiar? (1926, p. 146).

O autor questiona a origem da neurose e sustenta a hipótese de que existem reações fóbicas normais, como por exemplo, o afeto da ansiedade, mas cada um desses determinantes de dor tem sua época e, quando termina, desaparece.

No prosseguimento desse texto, Parte $X$, Freud afirma que a ansiedade é a reação ao perigo e o afeto de ansiedade ocupa uma posição sui generis na economia da mente. O autor busca uma explicação da razão de algumas pessoas sujeitarem-se ao afeto da ansiedade como elaborações normais da mente, e outras fracassarem na tarefa:

A primeira tentativa foi feita por Alfred Adler, sua asserção reduzida a sua essência, era a de que as pessoas que fracassavam na tarefa a elas atribuída pelo perigo eram aquelas muito impedidas por alguma inferioridade orgânica. Mas ao contrário, nossos estudos críticos dos últimos dez anos efetivamente demonstraram a total impropriedade de tal explicação - que põe de lado toda a riqueza do material descoberto pela psicanálise. A segunda tentativa foi feita por Otto Rank em 1923, afasta da questão do defeito orgânico do indivíduo e se concentra no grau variável de intensidade do perigo. $O$ processo de nascimento é a primeira situação de perigo, e a convulsão econômica que ele produz torna-se o protótipo da reação de ansiedade. Já traçamos a linha de desenvolvimento que liga essa primeira situação de perigo e determinante da ansiedade com todas as ulteriores, e vimos que todas conservam uma qualidade comum até onde significam, em certo sentido, uma separação da mãe - de início somente num sentido biológico, a seguir como uma perda direta do objeto e depois como uma perda do objeto incorrida indiretamente. (1926, p.147-148).

O material descoberto pela psicanálise afasta o defeito orgânico e concentra-se no grau variável de intensidade do perigo, a exemplo do nascimento, que é uma situação de perigo, vivida pela separação da mãe como uma perda direta e indireta do objeto. Na continuidade do texto, Um Estudo 


\section{Desafios da psicologia no Brasil}

Autobiográfico, Inibições, Sintomas e Ansiedade (1925-1926), Adendos, Parte B, Observações

Suplementares Sobre a Ansiedade, Freud afirma que a ansiedade tem inegável relação com a expectativa, ou seja, é ansiedade por algo que virá, e outra relação da ansiedade é com a neurose:

Ademais, além de sua relação com o perigo, a ansiedade tem uma relação com a neurose que há muito estamos tentando elucidar. Surge a questão: por que todas as reações não são neuróticas - por que aceitamos tantas delas como normais? $\mathrm{E}$ finalmente o problema da diferença entre a ansiedade realística e a ansiedade neurótica aguarda um exame completo. (...) O verdadeiro perigo é um perigo que é conhecido, sendo a ansiedade realística a ansiedade por um perigo desconhecido dessa espécie. A ansiedade neurótica é a ansiedade por um perigo desconhecido. 0 perigo neurótico é assim um perigo que tem ainda de ser descoberto. A análise tem revelado que se trata de um perigo instintual. Levando esse perigo que não é conhecido do ego até a consciência, o analista faz com que a ansiedade neurótica não seja diferente da ansiedade realística, de modo que com ela possa lidar da mesma maneira. Em alguns casos as características da ansiedade realística e da ansiedade neurótica se acham mescladas. O perigo é conhecido e real, mas a ansiedade referida a ele é super grande, maior do que nos parece apropriado. É esse excedente de ansiedade que trai a presença de um elemento neurótico. (...) a ansiedade no perigo, prosseguimos indagando qual é a essência e o significado numa situação de perigo. (...) consiste na estimativa do paciente quanto à sua própria força em comparação com a magnitude do perigo e no seu relacionamento de desamparo em face desse perigo. Denominamos uma situação de desamparo dessa espécie, que ele realmente tenha experimentado a situação traumática (1926, p. 160-161).

O autor reafirma o questionamento do porquê de todas as reações não serem neuróticas? E ainda, sustenta a hipótese de que a ansiedade neurótica é a ansiedade por um perigo desconhecido, instintual, entretanto, na análise, a ansiedade neurótica não se difere de ansiedade realística.

Em A Questão da Análise Leiga, in Conversações com uma Pessoa Imparcial (1926), Parte IV, o autor mostra-nos que a sexualidade tornou-se o motivo mais forte da hostilidade de outras pessoas em relação à análise, e aponta para o comportamento das pessoas neuróticas: "Isto simplesmente nos revela como é neurótica toda nossa vida civilizada, visto que pessoas manifestamente normais não se comportam de forma muito diferente das neuróticas." (1926, p. 201).

Freud reafirma que o comportamento das pessoas neuróticas não difere das pessoas normais. Nesse mesmo artigo, Parte $\mathrm{V}$, o autor demonstra qual espécie de conhecimento faz-se necessário a fim de praticar a análise, discutindo a relação entre ego e id e, dentro do próprio ego, o surgimento do superego como fundamental à saúde mental:

Esse superego ocupa uma posição especial entre o ego e o id. Ele pertence ao ego e partilha do seu alto grau de organização psicológica; mas tem uma vinculação particularmente íntima com o id. É de fato um precipitado das primeiras catexias do 


\section{Desafios da psicologia no Brasil}

objeto do id e é herdeiro do complexo de Édipo após seu falecimento. Esse superego pode confrontar-se com o ego e tratá-lo como um objeto; e ele muitas vezes o trata com grande aspereza. É tão importante para o ego continuar em boas relações com o superego como com o id. Desavenças entre o ego e o superego são de grande importância na vida mental. O senhor já terá adivinhado que o superego é o veículo do fenômeno que chamamos de consciência. A saúde mental muito depende de o superego ser normalmente desenvolvido - isto é, de haver-se tornado suficientemente impessoal. (1926, p. 215-216).

O autor reconhece a importância do superego, por sua posição mediadora entre o ego e o id, e ainda afirma que a saúde mental dependerá de o superego ser normalmente desenvolvido, isto é, suficientemente impessoal.

Na tentativa de explicar os fenômenos mentais patológicos, ainda no texto A Questão da Análise Leiga, in Psicanálise (1926), Freud trata da psicanálise como método terapêutico e sua aplicação nas neuroses mais brandas e nas malformações do caráter e inibições ou anormalidades sexuais:

A psicanálise está firmemente alicerçada na observação dos fatos da vida mental e por essa mesma razão sua superestrutura teórica ainda está incompleta e sujeita a constante alteração. Em segundo lugar, não existe motivo para surpresa que a psicanálise, que originalmente nada mais era que uma tentativa de explicar os fenômenos mentais patológicos, deve ter se desenvolvido numa psicologia da vida mental normal. A justificativa disso surgiu com a descoberta de que os sonhos e os erros ('parapraxias' como lapsos de linguagem, etc.) de homens normais têm o mesmo mecanismo que os sintomas neuróticos. (1926, p. 256).

O alicerce da psicanálise está nos fatos da vida mental, o que faz essa teoria estar em constante alteração, incompleta. E, visando a explicar os fenômenos mentais patológicos, desenvolveu-se numa psicologia da vida mental normal. No texto Pós-Escrito (1927), o autor afirma a contribuição dos seres humanos neuróticos para o estudo dos processos mentais normais:

Por motivos que podem facilmente ser compreendidos, os seres humanos neuróticos oferecem material muito mais instrutivo e acessível do que os normais, e sonegar este material a qualquer um que deseje estudar e aplicar a análise é privá-lo de boa metade das suas possibilidades de formação. (1927, p. 24).

Freud sustenta essa hipótese afirmando que as pessoas neuróticas oferecem, para a formação, um material mais instrutivo e acessível do que os normais. No texto Moisés, o seu Povo e a Religião Monoteísta (1938), Parte III (C), Freud trata da analogia que encontramos na história da religião judaica e aproxima-se da identidade e do trauma, e que é encontrada na psicopatologia, na gênese das neuroses humanas, num campo, equivale a dizer, pertencente à psicologia dos indivíduos, ao passo que os fenômenos religiosos são considerados como parte da psicologia grupal. No que concerne ao trauma: 


\section{Desafios da psicologia no Brasil}

Denominamos traumas aquelas impressões, cedo experimentadas e mais tarde esquecidas, a que concedemos tão grande importância na etiologia das neuroses. Podemos deixar de lado a questão de saber se a etiologia das neuroses em geral pode ser encarada como traumática. A objeção óbvia a isso é que não é possível, em todos os casos, descobrir um trauma manifesto na história primitiva do indivíduo neurótico. Com frequência, devemos resignar-nos a dizer que tudo que temos perante nós é uma reação anormal, fora do comum, as experiências e exigências que afetam a todos, mas são elaboradas e tratadas por outras pessoas de uma outra maneira, que pode ser chamada de normal. (1938, p. 87).

O autor afirma que não é possível descobrir um trauma manifesto na história primitiva do indivíduo neurótico; devemos apenas dizer de uma reação anormal, as experiências e exigências são tratadas por outras pessoas de maneira normal. Nesse texto citado acima, Parte III (F), o autor trata da linha fronteiriça entre os acontecimentos normais e patológicos:

Há uma quantidade de processos semelhantes entre os que a investigação analítica da vida mental nos ensinou a conhecer. Alguns deles são descritos como patológicos; outros se contam entre a diversidade dos acontecimentos normais. Mas isso pouco importa, já que as fronteiras entre os dois (os patológicos e os normais) não estão nitidamente traçadas, seus mecanismos são em grande parte os mesmos, sendo de muito maior importância saber se as alterações em apreço se realizam no próprio ego ou se confrontam com ele como estranhas a ele, caso que são conhecidos como sintomas. (1938, p.139).

Freud reafirma que a linha fronteiriça não é nítida, e os mecanismos entre o normal e o patológico são praticamente os mesmos. Atribui importância a verificar se as alterações realizam-se no ego ou se confrontam com ele, como no caso dos sintomas.

No texto Esboço de Psicanálise (1938), Capítulo III, "O Desenvolvimento da Função Sexual”, Freud aborda as inibições em seu desenvolvimento como um dos distúrbios da vida sexual:

Esse processo nem sempre é realizado de modo perfeito. (...) Quando é assim, encontramos fixações da libido a condições de fases anteriores, cujo impulso, que é independente do objetivo sexual normal, é descrito como perversão. Uma dessas inibições do desenvolvimento é, por exemplo, a homossexualidade, quando ela é manifesta. A análise mostra que em todos os casos um vínculo objetal de caráter homossexual esteve presente e, na maioria dos casos, persistiu em estado latente. A situação complica-se porque, via de regra, os processos necessários a um desfecho normal não se acham presentes ou ausentes, mas parcialmente anormais e presentes, de maneira que o resultado final fica dependente dessas relações quantitativas. (...) 


\section{Desafios da psicologia no Brasil}

Em primeiro lugar, as manifestações normais e anormais por nós observadas (isto é, fenomenologia do assunto) necessitam ser descritas do ponto de vista da sua dinâmica e economia (em nosso caso, do ponto de vista da distribuição quantitativa da libido). E em segundo, a etiologia dos distúrbios que estudamos deve ser procurada na história do desenvolvimento do indivíduo - ou seja, no começo de sua vida. (1938, p. 168).

Segundo o autor, a anormalidade presente na vida sexual do indivíduo encontra-se nas fixações da libido a condições anteriores, e deve ser descrita de modo dinâmico e econômico, como no caso da homossexualidade, porque os processos necessários para o desfecho normal não se encontram presentes, e o resultado depende das relações quantitativas.

No capítulo V, deste texto de 1938 , o autor aborda a contribuição dos estados de conflitos para a investigação dos estados normais e patológicos:

Uma investigação de estados estáveis, normais, em que as fronteiras do ego são resguardadas contra o id mediante resistências (anticatexias) e se aguentam firmes, e nos quais o superego não se distingue do ego, por trabalharem juntos harmoniosamente - uma investigação deste tipo pouco nos ensinaria. A única coisa que pode ajudar-nos são estados de conflitos e tumulto, quando os conteúdos do inconsciente têm perspectiva de forçar caminho para o ego, e a consciência e o ego mais uma vez se põem na defensiva contra essa invasão. É somente nestas condições que podemos fazer as observações que confirmarão ou corrigirão nossas afirmações sobre os dois parceiros. Ora nosso sono noturno é precisamente um estado desse tipo, e, por essa razão, a atividade psíquica durante o sono, que percebemos como sonhos, é o nosso objetivo de estudo mais favorável. Dessa maneira também, evitamos a acusação costumeira de basearmos nossas construções da vida mental normal em achados patológicos, pois os sonhos são ocorrências comuns na vida de uma pessoa normal, por mais que suas características possam diferir das produções de nossa vida desperta. (1938, p. 179).

Nesse texto, Freud indica que a investigação do sono noturno contribui para pensar os estados estáveis e ou normais porque os conteúdos inconscientes têm perspectiva de forçar o caminho para o ego.

Em Esboço de Psicanálise (1938), Capítulo VII, no artigo Um exemplo de Trabalho Psicanalítico, o autor apresenta que as neuroses e as psicoses são os estados em que se manifestam distúrbios no funcionamento do aparelho:

As neuroses (diferentemente das moléstias infecciosas, por exemplo) não possuem determinantes específicos. Seria ocioso buscar nelas excitantes patogênicos. Elas se 


\section{Desafios da psicologia no Brasil}

transformam gradualmente, através de fáceis transições, no que é descrito como normal, e, por outro lado, dificilmente existe qualquer estado reconhecido como normal em que indicações de traços neuróticos não possam ser apontadas. Os neuróticos possuem aproximadamente as mesmas disposições inatas que as outras pessoas, têm as mesmas experiências e as mesmas tarefas a desempenhar. Por que é, então, que vivem de modo tão pior e com tão grande dificuldade, e, no processo, padecem de mais sentimentos de desprazer, ansiedade e sofrimento? $\mathrm{O}$ que deve ser tido como responsável pela inadequação e sofrimentos dos neuróticos são desarmonias quantitativas. A causa determinante de todas as formas assumidas pela vida mental humana deve, na verdade, ser buscada na ação recíproca entre as disposições inatas e as experiências acidentais. Ora um determinado instinto pode ser inatamente forte ou fraco demais, ou uma determinada capacidade pode ser sustada ou desenvolvida de modo insuficiente na vida. Por outro lado, as impressões e experiências externas podem fazer exigências de intensidade diferente a pessoas diferentes e aquilo que é passível de ser manejado pela constituição de uma pessoa pode ser uma tarefa impossível para a de outra. Essas diferenças quantitativas determinarão a variedade dos resultados. (1938, p. 197).

O autor defende que as neuroses não possuem determinantes específicos, pois sua causa determinante deve ser buscada na ação recíproca entre as disposições inatas; todavia as experiências externas podem fazer exigências de intensidade diferente de uma pessoa para outra, que determinarão os resultados.

No prosseguimento desse mesmo artigo, Freud afirma que as neuroses possuem características específicas, sendo essas infelicidades de um tipo determinado:

Se acreditarmos que as neuroses não diferem, em qualquer aspecto essencial, do normal, o seu estado promete render valiosas contribuições para o conhecimento do normal. Pode ser que assim descubramos os "pontos fracos", de uma organização normal. A suposição que acabamos de fazer encontra confirmação. As experiências analíticas nos ensinam que existe, de fato, uma exigência instintiva para a qual as tentativas de com ela lidar muito facilmente fracassam ou conseguem um sucesso insatisfatório, e que há um período da vida que aparece exclusiva ou predominantemente em conexão com a geração de uma neurose. (1938, p. 198).

Não devemos, portanto esquecer de incluir a influência da civilização entre os determinantes da neurose. É fácil como podemos ver, a um bárbaro ser sadio; para um homem civilizado, a tarefa é árdua. $O$ desejo de um ego poderoso e desinibido pode parecer-nos inteligível, mas, tal como nos é ensinado pelos tempos em que vivemos, ele é, no sentido mais profundo, hostil à civilização. (1938, p.199). 


\section{Desafios da psicologia no Brasil}

O autor coloca-nos que há uma exigência instintiva, e as tentativas de lidar com ela fracassam ou conseguem um sucesso insatisfatório, período em que o indivíduo está em conexão com a neurose, como por exemplo, no caso do homem civilizado.

No texto da Análise Terminável ou Interminável (1938) Freud discute o término de uma análise e, na parte III, apresenta os três fatores decisivos para o sucesso ou não do tratamento analítico: a influência dos traumas, a força constitucional dos instintos e as alterações do ego. No que concerne ao segundo fator:

Partamos da presunção de que aquilo que a análise realiza para os neuróticos nada mais é do que aquilo que as pessoas normais ocasionam para si próprias sem o auxílio dela. A experiência cotidiana, contudo nos ensina que, numa pessoa normal, qualquer solução de um conflito instintual só é válida para uma força específica de instinto e a força do ego. Se a força deste diminui, quer pela doença, quer pela exaustão, ou por alguma causa semelhante, todos os instintos, que até então haviam sido amansados com êxito, podem renovar suas exigências e esforçar-se por obter satisfações substitutivas através de maneiras anormais. (1938, p. 241).

A solução de um conflito instintual de uma pessoa normal na experiência cotidiana só tem validade para uma força específica de instinto e de ego, e se a força diminui, todos os instintos podem renovar suas exigências e esforçar-se por obter satisfações substitutivas. Nesse mesmo escrito, Parte V, Freud discute o terceiro fator, as alterações do ego, e afirma que a normalidade, em geral, é uma ficção ideal:

Como é bem sabido, a situação analítica consiste em nos aliarmos com o ego da pessoa em tratamento, a fim de submeter partes de seu id que não estão controladas, o que equivale a dizer, incluí-las na síntese de seu ego. O fato de uma cooperação desse tipo habitualmente fracassar no caso dos psicóticos, nos fornece uma primeira base sólida para nosso julgamento. $\mathrm{O}$ ego, se com ele quisermos poder efetuar um pacto desse tipo, deve ser um ego normal. Mas um ego normal dessa espécie é, como a normalidade em geral, uma ficção ideal. O ego anormal, inútil para os nossos fins, infelizmente não é ficção. Na verdade, toda pessoa normal é apenas normal na média. Seu ego aproxima-se do ego do psicótico num lugar ou noutro e em maior ou menor extensão, e o grau de seu afastamento de determinada extremidade da série e de sua proximidade da outra nos fornecerá uma medida provisória daquilo que tão indefinidamente denominamos de "alteração de ego". (1938, p. 251).

Vemos anteriormente que o ego normal é, como a normalidade, uma ficção, pois toda pessoa normal é apenas normal na média. Ainda, nesse texto, Parte VII, preocupado com o término das análises, 


\section{Desafios da psicologia no Brasil}

Freud adverte que não se deve abreviá-las, mas aprofundá-las. O término da análise é uma questão prática, mas, no que se refere à normalidade:

Nosso objetivo não será dissipar todas as peculiaridades do caráter humano em benefício de uma 'normalidade' esquemática, nem tampouco exigir que a pessoa que foi 'completamente analisada' não sinta paixões nem desenvolva conflitos internos. A missão da análise é garantir as melhores condições psicológicas possíveis para as funções do ego; com isso, ela se desincumbiu de sua tarefa. (FREUD, 1938, p. 266267).

Diante do exposto, vemos que as hipóteses freudianas sobre as formulações do normal e do patológico constituíram-se das seguintes ideias: não há diferenciação da linha divisória entre saúde/doença, normal/patológico, pois as pessoas normais adoecem pelos mesmos processos que as pessoas sadias lutam; sonhos e atos falhos não são fenômenos patológicos; a quantificação determina a qualidade do fenômeno normal e/ou patológico; as pessoas se tornam neuróticas como uma defesa do ego em relação à frustração que a realidade impõe-lhes diante do limite da capacidade do seu ser; e as conclusões sobre as pessoas neuróticas contribuem para pensar a criança normal.

A diferença entre neurose e saúde vigora apenas na vida desperta; as pessoas sadias efetuam repressões, e grande parte dos sintomas são destituídos da sua vida prática; a linha fronteiriça entre o normal e o patológico estabelece-se pela repressão do complexo de Édipo; o comportamento normal e sadio constitui-se pela combinatória de reações que se apresentam na realidade, mas, depois, o indivíduo luta, esforça-se por efetuar uma alteração na realidade; a linha fronteiriça não é nítida e os mecanismos entre o normal e o patológico são os mesmos, não possuem determinantes específicos e o ego normal é como a normalidade em geral, uma ficção, pois toda pessoa normal é apenas normal na média.

A concepção de doença é uma concepção puramente prática, uma questão de somação; a disposição e as eventualidades da vida precisam combinar-se para que o limiar dessa somação seja ultrapassado e, consequentemente, pessoas saudáveis passam constantemente para pacientes neuróticos; o conceito de doença é equivalente às estruturas substitutivas e está presente uma inferioridade constitucional geral que é justificada por número, intensidade e distribuição.

O sentimento de inferioridade constituído pela perda de amor e pelo fracasso deixa uma cicatriz narcísica e um dano permanente, que também pode ser observado na vida das pessoas normais; a 


\section{Desafios da psicologia no Brasil}

compulsão à repetição opera nos processos de excitação da vida mental das pessoas normais quando se refere a um comportamento ativo por parte da pessoa interessada, e os sonhos são meras formas de pensar, incluindo o material reprimido e os pensamentos pré-conscientes, que podem ser normais, ou apresentar o caráter de qualquer neurose.

Os atos mentais comuns de pessoas normais constituídos por fenômenos que causavam eventos como esquecimentos, lapsos cotidianos, movimentos habituais efetuados aparentemente sem intenção ou brincando, deveriam ser considerado sob o mesmo ângulo dos sintomas neuróticos; os sonhos não são fenômenos patológicos; não há uma linha flexível entre neurose/psicose e saúde/neurose; o afeto da ansiedade é uma reação fóbica normal se cada determinante de dor tem sua época e desaparece quando terminar; a ansiedade neurótica é uma ansiedade por um perigo desconhecido.

Na construção freudiana, o autor escolhe como ponto de partida para análise o inconsciente na vida sexual dos seres humanos, considerando o desenvolvimento da libido, as organizações sexuais, o sentido dos sintomas e a fixação em traumas. Tal escolha coloca-nos diante de uma experiência universo/singular, ou seja, todos os seres humanos têm uma vida sexual, mas a vida sexual de todos eles é constituída pela inconsciência, que torna a vida incomparável, particular, singular.

Tomar as afecções patológicas e/ou normais pelo desenvolvimento lógico produzido numa história parece ser uma ideia útil, que leva à superação da contraposição anormalidade/normalidade. 0 homem julga sua experiência da posição de autor, daquele que consciente e inconscientemente é criador e criado dessa discursividade.

Partindo dessa ideia do autor, a dialética do universal e do particular em relação às formulações de anormalidade e normalidade constrói-se fundamentada no sentido que o sujeito atribui para o acontecimento na experiência singular; o que é patológico ou normal de um acontecimento está dado pelo homem em sua relação com o social, portanto, só se compreende bem que, nos meios próprios do homem, o mesmo homem seja, em momentos diferentes, normal ou anormal, dependendo da capacidade e do limite do nosso ser, é preciso saber viver...

\section{REFERÊNCIAS BIBLIOGRÁFICAS}

CANGUILHEM, G.. O Normal e o Patológico. 6. ed. Rio de Janeiro: Forense Universitária, 2010.

COLÓQUIO O LUGAR DA PSICANÁLISE NA MEDICINA, 2004, São Paulo, LEPSI IP/FEUSP.http://www.proceedings.scielo.br/scielo.php?script=sci_arttext\&pid=MSC00000000320040001 $00021 \& \operatorname{lng}=e n \&$ nrm=iso Acesso em: 15/12/2019. 


\section{Desafios da psicologia no Brasil}

FREUD, S. Rascunho D: Sobre a Etiologia e a Teoria das principais neuroses.(1882) V.I. Rio de Janeiro: Imago, Ed.Standard Brasileira das Obras Completas, 1987.

FREUD, S. Publicações Pré-Psicanalíticas e Esboços Inéditos. 1886/1899, V.I. Rio de Janeiro: Imago, Ed.Standard Brasileira das Obras Completas, 1987.

FREUD, S. Sobre o Mecanismo Psíquico dos Fenômenos Histéricos: uma conferência. V.III, 3 ed. Rio de Janeiro: Imago, Ed. Standard Brasileira das Obras Completas,1987.

FREUD, S. Esboços para Comunicação Preliminar de 1893. v.1. 3 ed. Rio de Janeiro: Imago, Ed.Standard Brasileira das Obras Completas, 1987.

FREUD, S. Primeiras Publicações Psicanalíticas. (1893/1899), V.III Rio de Janeiro: Imago, Ed. Standard Brasileira das Obras Completas, 1987.

FREUD, S. Um Caso de Histeria: Três Ensaios Sobre a Sexualidade. In: Fragmento da análise de um caso de histeria. (1901/1905), V.VII. Rio de Janeiro: Imago, Ed.Standard Brasileira das Obras Completas, 1987.

FREUD, S. Sobre a Psicopatologia da Vida Cotidiana. 1901, V.VI. Rio de Janeiro: Imago, Ed. Standard Brasileira das Obras Completas, 1987.

FREUD, S. A Interpretação dos Sonhos: Sobre os Sonhos. 1900/1901, V.IV. Rio de Janeiro: Imago, Ed.Standard Brasileira das Obras Completas, 1987.

FREUD, S. Os Chistes e sua Relação com o Inconsciente. 1905, V.VIII. Rio de Janeiro: Imago, Ed.Standard Brasileira das Obras Completas, 1987.

FREUD, S. A Psicanálise e a Determinação dos Fatos nos Processos Jurídicos. 1906, V. IX. Rio de Janeiro: Imago, Ed. Standard Brasileira das Obras Completas, 1987.

FREUD, S. Delírios e Sonhos na "Gradiva" de Jensen. 1906/1907, V.IX. Rio de Janeiro: Imago, Ed. Standard Brasileira das Obras Completas, 1987.

FREUD, S. Escritos Criativos e Devaneios. 1907, V.IX. Rio de Janeiro: Imago, Ed. Standard Brasileira das Obras Completas, 1987.

FREUD, S. Moral Sexual "Civilizada" e Doença Nervosa Moderna. 1908, V.IX. Rio de Janeiro: Imago, Ed. Standard Brasileira das Obras Completas, 1987.

FREUD, S. Sobre a Teoria Sexual das Crianças. 1908, V.IX. Rio de Janeiro: Imago, Ed. Standard Brasileira das Obras Completas, 1987.

FREUD, S. Duas Histórias Clínicas ("O Pequeno Hans" e o "Homem dos Ratos") In: Análise de uma Fobia de um Menino de Cinco Anos. 1909, V.X. Rio de Janeiro: Imago, Ed.Standard Brasileira das Obras Completas, 1987.

FREUD, S. Notas Sobre um Caso de Neurose Obsessiva. 1909, V.X. Rio de Janeiro: Imago, Ed. Standard Brasileira das Obras Completas, 1987. 


\section{Desafios da psicologia no Brasil}

FREUD, S. As Perspectivas Futuras da Terapêutica Psicanalítica. 1910, V.XI. Rio de Janeiro: Imago, Ed. Standard Brasileira das Obras Completas, 1987.

FREUD, S. Cinco lições de psicanálise de Leonardo da Vinci e Outros Trabalhos. 1910, V.XI. Rio de Janeiro: Imago, Ed. Standard Brasileira das Obras Completas, 1987.

FREUD, S. O Caso de Schrebere Artigos sobre Técnica. In: A dinâmica da transferência. 1912. V. XII. Rio de Janeiro: Imago, Ed.Standard Brasileira das Obras Completas, 1987.

FREUD, S. Recordar, repetir e elaborar. 1914, V.XII. Rio de Janeiro: Imago, Ed. Standard Brasileira das Obras Completas, 1987.

FREUD, S. Totem e Tabu. 1913-1914, V.XIII. Rio de Janeiro: Imago, Ed.Standard Brasileira das Obras Completas, 1987.

FREUD, S. A História do Movimento Psicanalítico. In: Artigos sobre Metapsicologia. 1915, V.XIV. Rio de Janeiro: Imago, Ed. Standard Brasileira das Obras Completas, 1987.

FREUD, S. O sentido dos Sintomas, 1916-1917, V.XVI. Rio de Janeiro: Imago, Ed. Standard Brasileira das Obras Completas, 1987.

FREUD, S. Conferências Introdutórias sobre psicanálise. 1916-1917, V.XVI. Rio de Janeiro: Imago, Ed. Standard Brasileira das Obras Completas, 1987.

FREUD, S. Criminosos em consequência de um sentimento de culpa. 1916, V.XIV. Rio de Janeiro: Imago, Ed. Standard Brasileira das Obras Completas, 1987.

FREUD, S. Resistência e Repressão. 1917, V.XVI. Rio de Janeiro: Imago, Ed. Standard Brasileira das Obras Completas, 1987.

FREUD, S. Terapia Analítica. 1917, V.XVI. Rio de Janeiro: Imago, Ed. Standard Brasileira das Obras Completas, 1987.

FREUD, S. O Estranho. 1919, V.XVII. Rio de Janeiro: Imago, Ed. Standard Brasileira das Obras Completas, 1987.

FREUD, S. Uma Neurose Infantil. 1914-1918, V.XVII. Rio de Janeiro: Imago, Ed. Standard Brasileira das Obras Completas, 1987.

FREUD, S. Além do Princípio do Prazer. 1920, V.XVII. Rio de Janeiro: Imago, Ed. Standard Brasileira das Obras Completas, 1987.

FREUD, S. A Psicogênese de um Caso de Homossexualismo numa mulher. 1920, V.XVIII. Rio de Janeiro: Imago, Ed. Standard Brasileira das Obras Completas, 1987.

FREUD, S Psicologia de Grupo e Análise do Ego. 1921, V.XVIII. Rio de Janeiro: Imago, Ed. Standard Brasileira das Obras Completas, 1987.

FREUD, S. Alguns Mecanismos Neuróticos no Ciúmes, na Paranoia $e$ no Homossexualismo. 1922, V.XVIII. Rio de Janeiro: Imago, Ed. Standard Brasileira das Obras Completas, 1987. 


\section{Desafios da psicologia no Brasil}

FREUD, S. Dois Verbetes de Enciclopédia. 1923, V.XVII. Rio de Janeiro: Imago, Ed. Standard Brasileira das Obras Completas, 1987.

FREUD, S. O Ego e o Id. 1923, V.XIX. Rio de Janeiro: Imago, Ed. Standard Brasileira das Obras Completas, 1987.

FREUD, S. Uma Breve Descrição da Psicanálise 1923, V.XIX. Rio de Janeiro: Imago, Ed. Standard Brasileira das Obras Completas, 1987.

FREUD, S. As Relações Dependentes do Ego. 1923, apêndice A, V.XIX. Rio de Janeiro: Imago, Ed.Standard Brasileira das Obras Completas, 1987.

FREUD, S. A Dissolução do Complexo de Édipo. 1924, V.XIX. Rio de Janeiro: Imago, Ed. Standard Brasileira das Obras Completas, 1987.

FREUD, S. A Perda da Realidade na Neurose e na Psicose. 1924, V.XIX. Rio de Janeiro: Imago, Ed. Standard Brasileira das Obras Completas, 1987.

FREUD, S. Algumas Consequências Psíquicas da Distinção Anatômica entre os Sexos. 1925, V. XIX. Rio de Janeiro: Imago, Ed. Standard Brasileira das Obras Completas, 1987.

FREUD, S. Um Estudo Autobiográfico. In: Inibições, Sintomas e Ansiedades. 1925-1926, V.XX. Rio de Janeiro: Imago, Ed.Standard Brasileira das Obras Completas, 1987.

FREUD, S. A Questão da Análise Leiga e Outros Trabalhos. 1926, V.XX. Rio de Janeiro: Imago, Ed. Standard Brasileira das Obras Completas, 1987.

FREUD, S. O Futuro de uma Ilusão. 1927, V.XXI. Rio de Janeiro: Imago, Ed. Standard Brasileira das Obras Completas, 1987.

FREUD, S. Pós-Escritos. 1927, V.XX. Rio de Janeiro: Imago, Ed. Standard Brasileira das Obras Completas, 1987.

FREUD, S. O Mal-Estar da Civilização e Outros Trabalhos. 1927/1931, V.XXI. Rio de Janeiro: Imago, Ed. Standard Brasileira das Obras Completas, 1987.

FREUD, S. Novas Conferências Introdutórias sobre Psicanálise e Outros Trabalhos. 1932/1936, V. XXII. Rio de Janeiro: Imago, Ed. Standard Brasileira das Obras Completas, 1987.

FREUD, S. O Retorno do Reprimido. 1938, V.XXIII. Rio de Janeiro: Imago, Ed. Standard Brasileira das Obras Completas, 1987.

FREUD, S. Esboço de Psicanálise. 1938, V.XXIII. Rio de Janeiro: Imago, Ed. Standard Brasileira das Obras Completas, 1987.

FREUD, S. Análise Terminável e Interminável. 1938, V.XXIII. Rio de Janeiro: Imago, Ed. Standard Brasileira das Obras Completas, 1987.

FREUD, S. Moisés, o seu Povo e a Religião Monoteísta. 1939, V.XXIII. Rio de Janeiro: Imago, Ed. Standard Brasileira das Obras Completas, 1987. 


\section{Desafios da psicologia no Brasil}

FREUD, S. Índices e Bibliografias.(1973) V.XXIV. Rio de Janeiro: Imago, Ed.Standard Brasileira das Obras Completas, 1987.

ROSA, M. D. A Pesquisa Psicanalítica dos Fenômenos sociais e políticos: metodologia e fundamentação teórica. Revista Mal-Estar e Subjetividade, Fortaleza, v. IV. n. 2, p. 329-348, 2004.

SOUZA, S. Diagnóstico Ético-Político da Juventude (Des)orientada? Uma condição humanizante no processo civilizatório. Curitiba:Appris, 2020. 


\section{Desafios da psicologia no Brasil}

\section{NOTAS}

Notas 1

SOUZA, S. Diagnóstico Psicológico Ético-Político na produção dos laços sociais dos adolescentes no CREAS. São Paulo, 2013. 304p. Tese (Doutorado) Programa de Pós-graduação em Psicologia Social. Área de Concentração: Psicologia Social. Pontifícia Universidade Católica de São Paulo (no prelo) Intitulado: Diagnóstico Psicológico Ético-Político da Juventude (des)orientada? Uma condição humanizante no processo civilizatório. Curitiba: Appris, 2020.

\section{Nota 2}

40 livro, Índices e Bibliografias, foi utilizado como orientador histórico do levantamento dos dados. Os livros: A Interpretação dos Sonhos (Parte I); Conferências Introdutórias sobre a Psicanálise (Parte I e II) não trazem índices remissivos sobre o assunto estudado. No livro Além do Princípio de Prazer, Psicologia de Grupo e Outros Trabalhos (1920-1922), o índice remissivo não coincide com a numeração das páginas. 


\section{Capítulo 38}

\section{COMPREENDENDO A AGRESSIVIDADE DA CRIANÇA: OBSERVAÇÕES E INTERVENÇÕES NA EDUCAÇÃO INFANTIL ${ }^{1}$}

DOI: $10.37423 / 200200238$

Conceição Aparecida Serralha (Universidade Federal do Triângulo Mineiro) Marilia de Souza Silva (Universidade Federal do Triângulo Mineiro) Roberta Espote (Universidade Federal do Triângulo Mineiro) Selene Aparecida Vilela Arruda (Universidade Federal do Triângulo Mineiro) Tarcila Barboza Silva (Universidade Federal do Triângulo Mineiro)

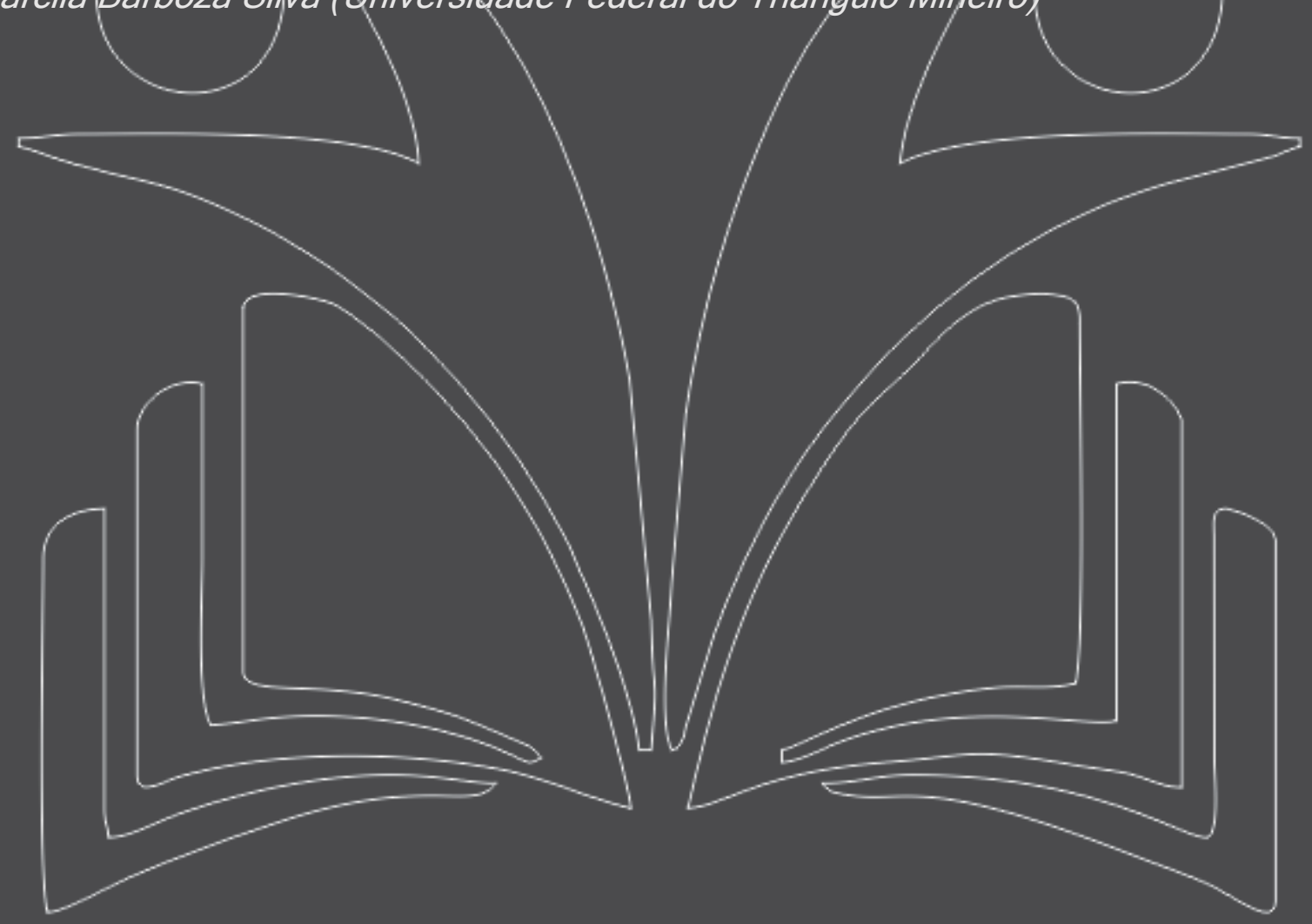




\section{Desafios da psicologia no Brasil}

\section{INTRODUÇÃO}

A agressividade no ser humano é um tema complexo, sendo contínua e persistentemente estudados. Desde o início da vida do bebê, ela está presente nos movimentos do feto dentro do útero e continuará vida afora em suas iniciativas, construções, desportos, luta pela vida, intervenções, e em suas reações a vários estímulos e experiências (Alves et al, 2017). Os estudos são dificultados pelo fato de a definição do termo agressividade carecer de um consenso entre os pesquisadores. De acordo com Dessen (2005), a maioria dos autores percebe a agressividade como uma disposição do ser humano, que pode gerar comportamentos causadores de danos físicos ou emocionais a alguém e/ou ao ambiente (agressões). Assim, expressões de agressividade poderão se apresentar em comportamentos tais como brigas, chutes, tapas, mordidas, empurrões, destruição de objetos, autoagressões, xingamentos, isolamento, silêncio, entre outros (Souza \& Castro, 2008).

Alguns estudos, de cunho essencialmente biológico, a exemplo dos trabalhos de Prado-Lima (2009) e Gauer (2001), consideram alterações neuroquímicas cerebrais na origem de comportamentos agressivos. A tendência tem sido relacionar a agressividade com um baixo nível de produção de serotonina no cérebro - substância responsável pela redução do medo e com função calmante -, como relatam Strüber, Lück e Roth (2005). Contudo, nenhum estudo sobre a disposição genética do indivíduo, ou sobre déficits orgânicos ou neuroquímicos, pode responsabilizar esses fatores isoladamente por comportamentos agressivos. Mesmo quando se observam graves lesões cerebrais na infância, não se podem descartar fatores psicossociais na origem do comportamento agressivo. Segundo os autores, a combinação entre fatores orgânicos e psicossociais como a qualidade do relacionamento inicial entre mãe e bebê, vivências de maus-tratos e abusos, negligência dos pais, rupturas e conflitos vividos constantemente na família, criminalidade no ambiente próximo e extrema pobreza, pode ser potencialmente importante para a manifestação de agressões e violência.

Dentro desse tema, destaca-se a agressividade na infância e, no tocante à sua causa, segundo França e Yaegashi (2005), existem três fatores que se relacionam e podem gerar comportamentos agressivos por parte da criança. São eles: instinto, comportamento e meio ambiente. As autoras entendem por instinto as características individuais da criança, levando em conta desde o sexo até a influência do temperamento. Por comportamento referem-se à influência familiar, que se manifesta por meio do vínculo, das interações que se estabelecem nesse ambiente e do modelo educacional doméstico. Somado a isso, percebem a influência de elementos ambientais como a televisão, videogames e a 


\section{Desafios da psicologia no Brasil}

escola. Ainda segundo essas autoras, as manifestações de agressividade vão variando conforme o desenvolvimento da criança.

À medida que o bebê se desenvolve, os movimentos dele precisam encontrar algo que se oponha a estes para ser percebido. A figura materna tem um papel essencial nesse processo. Ela passa a esperar ser descoberta pelos movimentos do bebê e, ao perceber o amadurecimento de recursos neste, faz oposição sem retaliação. Mostrando-se fora do controle onipotente do bebê, a figura materna o auxilia a encontrar a realidade externa, possibilitando que, aos poucos, o bebê se dê conta desse "lugar onde os objetos aparecem e no qual eles desaparecem" (Winnicott, 1990a, p. 126). Para Winnicott,

(...) o que logo será comportamento agressivo, não passa, portanto, no início, de um simples impulso que leva a um movimento e aos primeiros passos de uma exploração. A agressão está sempre ligada, desta maneira, ao estabelecimento de uma distinção entre o que é e o que não é o eu (1999, p. 104).

Em um primeiro momento, de acordo com Winnicott (1984/2005), sem intenção de provocar estragos em alguém ou coisa, a agressividade pode ser apenas uma expressão primitiva de amor. No entanto, com o crescimento da criança, bem como com a experiência e o entendimento das frustrações, a agressividade pode passar a ser expressa de forma intencional e a estar relacionada à organização do eu. A diferenciação, entre Eu e Não Eu, acarreta a percepção da criança de sua responsabilidade pelos próprios atos e, por fim, o pensamento sobre a necessidade de reparar atitudes agressivas para não destruir o que ama (Maciel, 2008).

Assim, conforme França e Yaegashi (2005), aos dois anos é comum que ela bata os pés e grite, por volta dos três anos, que ela direcione sua agressividade para outras crianças e, aos quatro anos, que ela já seja capaz de expressar a agressividade predominantemente de forma verbal. A questão principal tem sido delimitar até que ponto a agressividade que se manifesta é natural ao desenvolvimento e quando ela se torna uma situação que necessita de atenção.

O comportamento agressivo das crianças pequenas é algo muito difícil de lidar. Em muitos momentos, as pessoas que convivem com ela se sentem perdidas sobre que atitude tomar e a agressividade da criança pode despertar sentimentos nos adultos de culpa e impotência (França \& Yaegashi, 2005). As autoras retomam as ideias de Oaklander (1980), afirmando serem crianças agressivas aquelas que, nos vários contextos, têm comportamentos antissociais de gritar, agredir e destruir. Em outras palavras, elas têm comportamentos percebidos como inconvenientes pelos adultos. Sendo assim, a agressividade da criança deve ser compreendida na relação com o adulto. A criança vai se tornando agressiva, gradualmente, dando indícios de suas necessidades de diferentes formas, chegando a 


\section{Desafios da psicologia no Brasil}

comportamentos extremos nos casos em que não recebeu a atenção e os cuidados que precisava por parte dos adultos, já nos primeiros sinais. É preciso entender o que está na raiz dessa agressividade, uma vez que "a criança agressiva provavelmente possui sentimentos profundos de ira, sentimentos de rejeição, insegurança e ansiedade, sentimentos de mágoa, um senso de identidade difuso e uma opinião muito pobre a respeito do que conhece do seu eu" (França \& Yaegashi, 2005, p. 13). Segundo Luz (2008), pelo fato de a criança conhecer o mundo por intermédio de seus cuidadores, estes devem oferecer ambientes emocionais estáveis e confiáveis para que ela possa se sentir segura, compreendida e amada, nos momentos em que vivenciar outros sentimentos nem sempre bons, como a raiva, por exemplo (Luz, 2008).

Se houver segurança ambiental, ou seja, se existir apoio mútuo entre as figuras parentais - que pode ser exercido também pela família ou a sociedade -, a criança consegue integrar seus impulsos destrutivos com os amorosos, organizando-se construtivamente, protegendo pessoas e objetos que valoriza dos impulsos destrutivos (Serralha, 2016). Assim, a criança entenderá que mesmo quando não agir conforme o que é desejado pelos pais, ela ainda será acolhida, e isso poderá auxiliar no entendimento e tolerância para com sua própria agressividade (Luz, 2008).

Nota-se, contudo e comumente, um viés de culpabilização dos pais em relação ao comportamento "não adequado" dos filhos (França \& Yaegashi, 2005). Frases como, "é claro que a criança é assim, olha o pai que ela tem" ou "com uma família assim não podíamos esperar nada de diferente do menino", são muito frequentes. No entanto, discussões que caminham para a busca do "culpado" pelo problema, além de serem reducionistas, podem trazer mais sofrimento e inviabilizar a busca por alternativas mais adequadas para lidar com a situação. Por outro lado, não se pode afirmar que os cuidadores não tenham influência alguma. Torna-se, portanto, mais eficaz entender qual a participação destes na manifestação e no recrudescimento da agressividade da criança e buscar formas de auxiliá-los, conduzindo a um processo inverso de diminuição das reações agressivas.

A dificuldade maior por parte dos pais tem sido identificar o momento em que a agressividade da criança necessita de maiores cuidados. Hachet (2006) se atenta para o fato de que, sendo a agressividade da criança algo que incomoda as pessoas, é comum que ela não seja entendida em sua essência, chegando aos profissionais os pedidos para normatizar a criança dentro do que é socialmente aceito. A autora relata um caso em que uma criança havia se mostrado agressiva, agitada e com atitudes exageradas de cunho sexual e, apesar do conhecimento da mãe sobre o abuso sexual frequente pelo qual a criança havia passado por mais de dois anos, seu pedido ao terapeuta era de que ela se tornasse uma criança igual às outras, sem problemas. Influenciada pela professora, a mãe 


\section{Desafios da psicologia no Brasil}

pedia para que fosse tratada a tendência à dislexia apresentada pela filha. Esse é um exemplo da dificuldade que as pessoas têm de compreender o que leva ao comportamento agressivo de uma criança e de tratá-la, e acabam não levando em "consideração a apreensão de seu sofrimento" (Hachet, 2006, p. 33). Segundo Hachet (2006), os tratamentos visam à

(...) conformação dessa criança a um Ideal de Saúde mental e física: uma criança calma, sadia de corpo e de espírito, bonita, inteligente, que sabe falar, ler, escrever e contar perfeitamente, que se sai bem na escola e não apresenta nenhum problema àqueles que estão à sua volta. Em suma, uma criança-robô (p. 28).

De acordo com Santos (2006), "a busca de atendimento coincide com a entrada na escola e consequente aumento de exigências quanto à produção, comportamento e sociabilidade da criança" (p. 320). A autora afirma que, hoje, para considerarem uma criança adaptada na escola, além do sucesso na aprendizagem, é preciso que a criança não ameace a tranquilidade do ambiente.

\section{A AGRESSIVIDADE NO BEBÊ E NA CRIANÇA PEQUENA}

Ao iniciar o processo de separação, Eu - Não Eu, para que o bebê adquira uma "certa dose de crença" nas coisas e nas pessoas à sua volta, o ambiente deverá fornecer-lhe cuidados contínuos e seguros (Winnicott, 1993, p. 139). Com isso, surge "um sentimento de segurança, e o sentimento de segurança leva ao autocontrole" (p. 107). Contudo, a destruição inerente à motilidade e às tensões instintuais, que é não intencional no início, e que é aos poucos integrada na personalidade da criança devido aos cuidados suficientes do ambiente, pode irromper maciçamente de forma não controlada ou pouco controlada pelo bebê ou criança pequena, se esses cuidados não forem devidamente oferecidos. Nesses casos, a criança vive um estresse que

(...) resulta de um fracasso relativo ou total do suprimento ambiental. Essas deficiências podem ser descritas em termos de inconfiabilidade, destruição da confiança, interferência da imprevisibilidade, e um padrão definitivo ou repetitivo de quebra da continuidade da linha de vida da criança individual (Winnicott, 1993, p. 151).

Segundo Winnicott (1999), todo esse estresse pode alterar a personalidade da criança e estabelecer a base para um "distúrbio de caráter" (p. 151). De acordo com Wiese (2012), nos processos de filiação e parentalização, a criança pode vir a sofrer traumas e sua vulnerabilidade a estes resulta da interação de três categorias de fatores: "a vulnerabilidade intrínseca da criança (genética, cognitiva, funcional, emocional e psicológica), o ambiente social e familiar, e as circunstâncias relacionadas à situação" (p. 205). No caso de o relacionamento da criança com a figura materna ser perdido, em razão de um 


\section{Desafios da psicologia no Brasil}

afastamento dessa figura de uma forma imprevista por ela e fora de sua capacidade de dar conta desse afastamento, por exemplo, a criança pode perder a capacidade de encontrar objetos.

No tocante às relações iniciais, é importante salientar, porém, que o processo de integração do bebê em um eu não depende só das condições oferecidas pela figura materna. De acordo com Winnicott (1999), se a figura materna é apoiada pela figura paterna, isso a fortalece e traz segurança para toda a família, auxiliando a criança a integrar seus impulsos destrutivos com os amorosos, pois a criança sabe que a figura paterna estará ali caso ela se exceda. Se o ambiente falha no atendimento das necessidades da criança durante o seu processo de individuação, a criança começa a apresentar os primeiros sinais de uma tendência antissocial, que se caracteriza essencialmente pelo fato de ela ser capaz "de perceber que a causa do desastre reside numa falha ou omissão ambiental" (Winnicott, 1999, p. 145). Nesse caso, há um elemento na tendência antissocial, que força o ambiente a fornecer os cuidados dos quais a criança necessita. Esse elemento foi chamado, por Winnicott, de "valor de incômodo dos sintomas" - afeto produzido pelos comportamentos agressivos e destrutivos da criança -, que, em uma tendência antissocial aparece de forma mais exagerada e leva o ambiente a fazer algo pela criança (p. 142).

Vale ressaltar, que, na teoria winnicottiana, a presença de uma tendência antissocial leva a criança a ter esperança de encontrar o objeto anteriormente perdido, ao perceber que o ambiente tem aspectos de confiabilidade. Sem essa percepção, a criança pode entrar em depressão em vez de apresentar comportamentos antissociais (Winnicott, 1999).

\section{A AGRESSIVIDADE NO CONTEXTO ESCOLAR}

O papel da escola, principalmente o da educação infantil, cresce a cada dia em sua complexidade, em razão das especificidades do público sob os seus cuidados. Segundo Winnicott (1982), os educadores precisam se dar conta de que estão diante de "uma psicologia complexa de crescimento e adaptação infantis, a qual necessita de condições especiais de meio ambiente" (p. 215). O que torna a questão mais delicada é que o ambiente familiar da criança se encontra ele próprio muitas vezes bloqueado em seu desenvolvimento da capacidade de atender às necessidades de uma criança pequena. Para esse autor, contudo, o papel da educação infantil "não é ser um substituto para uma mãe ausente, mas suplementar e ampliar o papel que, nos primeiros anos da criança, só a mãe desempenha" ( $p$. 214). Desse modo, se nas relações primárias da criança em família, houve falhas ou omissões que levaram a criança a desenvolver uma tendência antissocial, a escola pode fornecer à criança uma “atmosfera emocional” não tão densamente carregada como a do lar (Winnicott, 1982, p. 217). Além 


\section{Desafios da psicologia no Brasil}

disso, pode ter a oportunidade de conhecer a situação e auxiliar indiretamente a criança, ao dar o apoio necessário às figuras parentais. Ainda, segundo Winnicott, na educação infantil "não há lugar para tudo quanto seja impessoal ou mecânico, visto que, para a criança, isso significa hostilidade ou (ainda pior) indiferença" (p. 220).

No Brasil, estudos como o da professora do Instituto de Psicologia da USP, Maria Abgail de Souza, “Intervenção psicoterapêutica em crianças agressivas no ambiente escolar" iniciado em 1998, e que desde 1991 já acompanhava crianças de comunidades de baixa renda de São Paulo, afirmou que, "rica ou pobre, a criança que não sente o afeto dos pais em geral tem mais propensão à agressividade" (conforme citado por Strüber, Lück \& Roth, 2006, p. 44). Em outro estudo, Souza e Castro (2008) destacam o "valor de incômodo da criança antissocial", teorizado por Winnicott (1999), que, segundo essas autoras, parece corresponder ao afeto produzido por um conjunto de elementos que elas puderam encontrar nas escolas durante sua pesquisa. Nesse conjunto, encontram-se "o desafio às normas, o baixo desempenho acadêmico, o comportamento agitado e a perturbação do ambiente" (Souza \& Castro, 2008, p. 839). Ter a compreensão de que esses elementos expressam uma esperança de reaver o que a criança sente ter sido retirado de si, em razão da confiabilidade que a escola possa estar lhe inspirando, pode fazer toda a diferença nas condutas adotadas por esta no trabalho com a criança.

Um sinal de saúde pode surgir com o brincar construtivo substituindo a destruição. Caso contrário, o recrudescimento da agressividade na criança, em reação a inadequações do ambiente no atendimento de suas necessidades, pode preceder o fracasso escolar. $O$ desencadeamento de uma série de reações negativas pode dificultar o desenvolvimento de aptidões cognitivas e sociais, facilitando a rejeição pelos pares e fazendo com que a criança, frequentemente, se ligue a grupos com condutas antissociais (Elias et al, 2014).

Durante a execução do projeto intitulado "Consultas Terapêuticas Familiares (CTF) com crianças pequenas em casos de agressividade elevada" (Serralha et al, 2016), realizado em 2010, notou-se que, em alguns casos, os comportamentos agressivos se manifestavam mais no ambiente escolar do que no familiar. Em razão disso, houve necessidade de observar a criança e intervir também no contexto escolar, sendo a proposta original ampliada no sentido de investigar mais sobre as manifestações agressivas da criança e favorecer a compreensão destas por parte dos professores.

Assim, este capítulo visa discutir, com auxílio de outros estudos realizados posteriormente, alguns dos casos encontrados nesse trabalho interventivo em famílias de crianças pré-escolares que apresentavam comportamentos mais agressivos, estendendo a análise ao ambiente escolar. 0 estudo 


\section{Desafios da psicologia no Brasil}

teve por base a teoria do amadurecimento emocional de Winnicott, cujo entendimento é de que dificuldades na interação dos cuidadores com a criança podem recrudescer a agressividade desta. Observações e intervenções no ambiente da educação infantil

O trabalho interventivo realizado nas escolas contou com a coordenação e supervisão de uma professora do Curso de Psicologia e seis graduandas deste curso. O projeto foi aprovado pelo Comitê de Ética em Pesquisa da UFTM (Protocolo 1368). As crianças participantes foram encaminhadas por profissionais das áreas de saúde e educação, que foram previamente informados sobre o projeto. $\mathrm{A}$ agressividade mais elevada foi constatada a partir dos relatos das figuras parentais e professores, em razão de seus efeitos na vida da criança, ou seja, pelo fato de a agressividade estar prejudicando seu desenvolvimento e socialização.

Após autorização dos cuidadores e da escola, a equipe realizou observações não sistemáticas de cada criança em dois momentos: na sala de aula e na quadra, no caso de aula de educação física e recreio. Foram feitas duas observações no ambiente escolar, em dias diferentes, para que fossem observadas situações diferentes. Os dados foram anotados com detalhes e depois analisados qualitativamente em reunião com a supervisora da equipe. Posteriormente, foram realizadas sessões devolutivas com os profissionais da escola, momento em que estes e a equipe trocavam informações, visando buscar um melhor entendimento da situação e possíveis maneiras de ajudar a criança. A equipe do projeto, inicialmente, esclareceu que não pretendia invadir o espaço pedagógico e ensinar o que eles deveriam fazer com o aluno, mas que conversariam sobre pontos importantes observados na escola, relacionados com o que vinham acompanhando nos atendimentos junto às famílias, de forma que as educadoras pudessem ter uma visão mais ampla sobre a criança, compreendendo melhor suas dificuldades e comportamentos agressivos. Ao final de um ano, das doze crianças encaminhadas ao projeto, foram observadas no contexto escolar quatro crianças, que, neste texto, são denominadas Criança 01, Criança 02, Criança 03 e Criança 04.

A Criança 01, de cinco anos de idade, foi encaminhada por uma agente de saúde. Ao chegar para atendimento, a família veio composta de mãe, avós maternos, tia materna, irmão de sete anos e da própria criança. Vieram em defesa desta, pois não tinham reclamações de agressividade a fazer. $\mathrm{Na}$ época, todos viviam o drama de ter o pai da criança sob pena privativa de liberdade, fato que parecia unir bastante a família. Ele tinha licença para sair uma vez por mês, o que era sempre bastante aguardado pela mãe e pelos filhos. Nas observações realizadas nos momentos em que os familiares se encontravam em interação, a equipe não percebeu comportamentos agressivos por parte da Criança 01. O seu irmão mostrou-se mais agressivo e, mesmo sendo provocada, a Criança 01 não reagiu 


\section{Desafios da psicologia no Brasil}

agressivamente. Como a escola havia chamado a mãe para falar do comportamento agressivo da criança, a equipe decidiu observá-la na escola.

Em uma das observações na sala de aula, havia 23 alunos na sala, incluindo a Criança 01, e a classe estava disposta em três grupos de alunos. Por um lado, a Criança 01 se mostrou empenhada e concentrada em suas atividades, e ainda, incomodada ao ter que mudar de tarefa antes de terminar a que estava executando. Por outro lado, mostrou-se mais isolada e até desmotivada em relação aos outros colegas: não falava muito, não ria muito, interagia pouco com os outros alunos e ao levantar a mão para pedir para falar, não retirava o cotovelo da mesa, falava baixo e, na sequência, encostava a mão na orelha, segurando a cabeça. Ao escrever e colorir, ela colocava muita força no lápis e fazia questão de cobrir fortemente todo o desenho. Durante o recreio, sentava-se afastada das outras crianças para comer o seu lanche, gastando quase todo o tempo do intervalo nessa atividade. Foi o último a sair do refeitório, enquanto as outras crianças corriam e brincavam pelo pátio.

Segundo relatos da professora, a mãe a levava no colo para a escola e quando chegava a esta, a criança tinha dificuldades de ficar. Além da agressividade, a principal queixa da professora era a falta de participação da família nas atividades escolares em casa e no cuidado com o material escolar. No entanto, a professora disse ter notado uma melhora no tocante à agitação e à agressividade nos últimos meses, mas o aluno se mantinha desmotivado em relação à escola. Nos dias em que o pai estava em casa, a criança ficava mais animada e feliz.

Após análise e discussão dessas observações, a equipe entendeu que a Criança 01, em meio ao ambiente de expectativa pela vinda do pai em definitivo para casa e o movimento aglutinado de todos os membros da família, tinha dificuldades por sentir a escola "intrusiva" e responsável pelo seu afastamento de casa. O seu isolamento parecia demonstrar o seu protesto em relação a esse sentimento. A sua tensão transparecia em suas atividades. Além disso, tanto nas horas interativas familiares (Serralha, Espote, Silva, Silva, \& Arruda, 2016) quanto na sala de aula, quando a criança se empenhava em uma atividade, ela sentia necessidade de prossegui-la até o fim. Nas horas interativas, o irmão o perturbava querendo mudar de atividade, muitas vezes provocando-o. Na escola, essa necessidade também não era muito respeitada, uma vez que a sequência de atividades propostas para o dia precisava acontecer independente do tempo que cada criança necessitasse para realizá-las. No caso desta criança, a sua demora não parecia estar relacionada a uma dificuldade de realizar a tarefa, mas à própria exigência de executá-la bem e do seu modo. Assim, encontrar uma forma de atender a essa necessidade da criança foi uma das questões discutidas pela equipe junto aos educadores. 


\section{Desafios da psicologia no Brasil}

A professora relatou também que a criança ficava empolgada com as visitas do pai e que gostava de contar as histórias que o pai Ihe contava. Esse pai, mesmo estando longe na maior parte do tempo, era visto como um herói. Ela disse que a criança chegou a dizer que desejava ser bandido quando crescesse. Essa fala fez a equipe se lembrar de que a mãe, em uma das horas de interação familiar, contou que, em certa ocasião, o filho perguntou por que seu pai estava em privação de liberdade. A mãe lhe respondeu que o pai havia feito bagunça.

A hipótese de que essa fala da mãe possa ter feito surgir a fantasia no filho de que, se fizesse bagunça, ele poderia ser levado a ficar junto do pai, pareceu à equipe bastante plausível, uma vez que a presença do pai o deixava nitidamente feliz e confiante. Assim, foi conversado com a mãe a importância de um diálogo claro com a criança, de modo a permitir que esta pudesse conhecer os fatos de maneira apropriada à sua idade, sem se assustar, mas também não dando margem a esse tipo de fantasia.

A Criança 02 - excepcionalmente dentro do projeto uma criança de sete anos - foi encaminhada por uma psicóloga que a acompanhou em uma consulta a um neurologista, cujo parecer foi de um distúrbio grave de comportamento. Compareceram às horas interativas familiares, os pais e dois irmãos, um adolescente e outro de cinco anos. No encaminhamento, foi relatado que era uma criança hiperativa, extremamente agressiva e com queixa de fraco desempenho escolar. Durante as horas interativas familiares a equipe observou seu comportamento agressivo, mas também a sua capacidade de ficar durante uma hora concentrado montando um brinquedo junto ao pai: a Criança 02 fazia montagens, em que o pai a direcionava no formato da estrutura e ela escolhia as cores, demonstrando uma habilidade discriminativa e classificatória, além de habilidade no encaixe das peças. Para uma criança de sete anos pode ser algo esperado como já adquirido há muito tempo, mas para uma criança encaminhada com pouca ou nenhuma expectativa quanto à aprendizagem de qualquer coisa, com nenhuma expectativa de se dedicar muito tempo a uma tarefa específica, isso foi muito importante de ser observado.

$\mathrm{Na}$ escola, as observadoras detectaram claramente suas dificuldades intelectuais intensificadas por dificuldades da interação escola-família, uma vez que os pais não cumpriam o compromisso de levála ao reforço escolar. Em uma sala com 32 alunos, a Criança 02 demonstrou dificuldade de compreensão da atividade proposta e necessidade de um tempo maior para realizá-la. Observou-se que ela ficava extremamente contrariada quando era interrompida pela mudança de atividade e, nesses casos, a sua ansiedade aumentava muito, contribuindo para a sua inquietude e comportamentos agressivos; percebeu-se uma coordenação motora ruim, apresentando muita força 


\section{Desafios da psicologia no Brasil}

para desenhar e escrever, o que atrapalhava principalmente os movimentos de curva que as letras exigiam e a velocidade da escrita; muitas vezes ela repetia coisas que ouvia e via os outros fazerem, mas parecia não ter noção da razão de estar fazendo aquilo; apresentava muita dificuldade de dimensionar as situações. Sua agressividade parecia ser uma brincadeira mal calculada, na qual ela nem sempre se dava conta das consequências ruins desta, mesmo vivenciando-as. Em outras palavras, ela parecia não conseguir relacionar as consequências à sua brincadeira. Foi possível perceber nas atividades de educação física, na quadra, que a criança muitas vezes não entendia a instrução do professor e acabava repetindo o que os outros alunos faziam, sem entender o sentido da brincadeira, e era isso o que se constatava em várias vivências dessa criança: ela não entendia algo e continuava uma brincadeira que podia levar a consequências negativas. Em alguns momentos, parecia se tratar de um brincar compulsivo, mas em outros, apenas uma falta de sintonia com todo o contexto.

A discussão sobre as observações contou com a presença da coordenadora pedagógica e da professora, na qual um dos pontos discutidos foi o de como o excesso de estímulos a uma criança, que tem dificuldade de entender as coisas, causa-Ihe excitação e ansiedade e, por falta de controle dos impulsos, culmina em comportamentos agressivos. Isso já havia sido percebido nas horas de interação familiar, e seu oposto também, quando o estímulo na dose certa o deixava tranquilo e produtivo. A coordenadora pedagógica pôde relatar sua experiência com a criança em certa ocasião, em que, estando apenas ela e a criança, esta conseguiu realizar uma atividade, não sem antes de a atividade ter-Ihe sido explicada novamente de outra maneira. Contudo, ela relatou também, que, ao final da atividade, a criança voltou a cometer os mesmos erros iniciais, denunciando sua dificuldade de memorização (memória de trabalho). Esse relato permitiu a todos entenderem porque ele "odiava" o jogo da memória. A criança que se frustra frequentemente em uma atividade, não sente prazer em realizá-la, muito ao contrário.

Sobre as tarefas de casa, a mãe estava sentindo falta destas, pois a criança, ao ver o irmão fazer as próprias tarefas, queria fazer tarefas também. A coordenadora pedagógica e a professora falaram sobre a desorganização da criança, que acabava estragando os cadernos que iam para casa, além da dificuldade de entender qual caderno servia a cada matéria. Esses motivos foram suficientes para que as educadoras se decidissem a não lhe enviar mais tarefas para serem realizadas em casa. Os pais, que revelavam sempre sua identificação com a condição da criança, quando de suas próprias infâncias, tinham dificuldade de ajudá-la. A equipe e as educadoras conversaram sobre o que poderia ser feito a respeito. As educadoras tiveram a ideia de deixar um caderno só para atividades de casa e de separar melhor os cadernos por matéria, com desenhos na capa que o ajudassem a reconhecer a matéria. 


\section{Desafios da psicologia no Brasil}

Ideias simples, mas que em meio ao tumulto emocional que a criança gerava no ambiente, muitas vezes ficavam inacessíveis.

Durante a conversa com as educadoras, ficou claro que elas esperavam um diagnóstico da criança, queriam um laudo que pudessem utilizar para justificar a não aprendizagem e a possível repetência de série escolar. Para abrir o diálogo sobre diagnóstico, foi lido pela equipe um poema de Manoel de Barros (1993, p. 25), chamado Enseada:

O rio que fazia uma volta atrás da nossa casa era a imagem de um vidro mole que fazia uma volta atrás de casa.

Passou um homem depois e disse: essa volta que o rio faz por trás de sua casa se chama enseada.

Não era mais a imagem de uma cobra de vidro que fazia uma volta atrás de casa.

Era uma enseada.

Acho que o nome empobreceu a imagem.

A partir desse poema, foi feita uma reflexão com as educadoras a respeito do que estávamos fazendo naquele momento, dando sentidos para as vivências da Criança 02 na escola, pensando em meios pelos quais ela poderia aprender melhor. Durante a conversa, a criança não foi identificada pelas queixas de agressividade ou pelo déficit de aprendizagem e não foi classificada dentro de nenhum quadro psicopatológico. O nosso objetivo foi o de conversar sobre a criança, buscar enxergar o seu potencial evidenciado nas observações e identificar os fatores que dificultavam o seu desenvolvimento escolar, como a falta de adequação das tarefas e das instruções para realizá-las em relação à compreensão e ao significado que a criança conseguia atingir; o excesso de informações e instruções ou a falta de confiança e de segurança em si, sentida sempre quando não havia um adulto acompanhando de perto a realização da tarefa.

Assim, atendendo ao que é disposto para se realizar a inclusão de pessoas com necessidades especiais no ensino regular, a conversa versou sobre como a Criança 02 poderia ir além do que ela vinha conseguindo, a partir da compreensão de suas necessidades e da disposição em atendê-las. Após a conversa com as educadoras, também foi conversado com os pais o que eles mesmos poderiam fazer em casa para ajudar a criança a se desenvolver, por exemplo, favorecendo e supervisionando a utilização de instrumentos de trabalho do pai para exercitar sua coordenação motora fina.

A Criança 03, de cinco anos de idade, vivia na casa de uma tia materna com o marido desta, um primo de sete anos e dois irmãos adolescentes. A mãe não o queria, pois vivia com um novo marido e um filho deste. A tia, muito carinhosa, tinha muita pena da criança e enfrentava uma situação difícil, pois o marido não queria a criança em sua casa. Ele aceitava bem os irmãos adolescentes, mas não ela. $\mathrm{A}$ 


\section{Desafios da psicologia no Brasil}

avó materna também não a queria. A criança estava prestes a não ter um lar que a acolhesse e foi nesse contexto que ela começou a apresentar comportamentos agressivos e a não se desenvolver na escola.

Na primeira entrevista, esteve presente apenas a tia e, na hora de interação familiar, esteve presente a tia, seu filho, a criança 03 e seus dois irmãos. Nesta sessão, verificou-se que a criança vivenciava um momento de grande incerteza, em razão de situações que intensificavam suas fantasias de abandono e insegurança na convivência familiar. Em dois momentos pôde ser notada sua demanda por atenção ao dizer "tchau, vou dormir" e quando colocou a casa de brinquedo nas costas e disse: "tchau, vou para a escola". Ela repetiu as duas frases algumas vezes e apenas o primo olhou brevemente para ela. Momentos como esses pareciam intensificar suas fantasias em relação ao quanto era pouco querido, ao quão pouco se importavam com a sua presença e se faria alguma diferença se o seu tio o mandasse embora de casa. Foram realizadas observações na escola, visto que a criança não foi agressiva nas sessões com a família, mesmo sendo provocada pelo primo, e porque havia queixa da escola em relação ao seu comportamento.

$\mathrm{Na}$ escola, foi observado que a criança fazia rapidamente e com boa vontade tudo o que lhe era pedido, denotando um desejo de agradar, ser bom e querido. Logo dizia para a professora que havia terminado, ajudava os colegas conversando ou fazendo mímicas, e era muito inquieto, mudando muito de posição na cadeira. Porém, em seu caderno, havia muitos erros e desproporções, como a escrita larga para além dos limites traçados, o traço forte, as letras com a grafia incorreta, as pinturas para fora do risco, fortes e da mesma cor. As atividades da pasta da criança estavam abaixo do esperado para sua idade. Ela respondia as perguntas verbalmente de forma correta, mas não conseguia realizar as atividades no papel. A força que colocava no lápis parecia dificultar sua grafia, e a ansiedade, por sua vez, parecia impedi-lo de terminar as atividades.

No recreio, os comportamentos da criança com um teor mais agressivo foram apenas brincadeiras que fez com seus colegas. As educadoras revelaram exigir um alto padrão de disciplina, devendo as crianças ficar quase imóveis para terem autorização para comer. Isso fez com que nossa equipe colocasse em questão os padrões da escola para descrever um comportamento agressivo. Durante a observação, o comentário de um colega mostrou que a Criança 03 estava rotulada como a "criança bagunceira", uma vez que esse colega ameaçou apelidar outra criança que estava fazendo bagunça com o nome da Criança 03.

criança foi observada no recreio e em uma sala com 20 crianças e, ao contrário da Criança 02, não foram percebidos comportamentos agressivos, mas desatenção, dificuldade de compreensão das 


\section{Desafios da psicologia no Brasil}

atividades propostas, desobediência às solicitações da professora e perturbação do ambiente. O seu comportamento parecia expressar toda a desorganização que a rejeição e a indecisão sobre o seu futuro acarretavam.

A equipe, ao apresentar as primeiras impressões do caso para um início de ajuda à escola, conversou com a pedagoga e com as professoras da criança. O momento de muita instabilidade no lar, que deixava a criança extremamente ansiosa, foi discutido como potencial para a dificuldade de administrar seus sentimentos, levando-a a ficar agitada e ou a se comportar de maneiras incomuns. Em relação às dificuldades escolares, a discussão se pautou no benefício de um trabalho individual com a criança, visto que esta necessitava de explicações detalhadas e diferenciadas para compreender o que devia fazer, bem como de uma atenção que diminuísse a tensão que dificultava sua coordenação motora. Essa dificuldade parecia estar menos associada a um problema neurológico, do que ao seu momento de vida.

As professoras se colocaram dispostas a pensar alternativas para ajudar a criança e ressaltaram que não possuíam recursos humanos para trabalhar individualmente com ela todo o tempo. No entanto, a tia da criança se dispôs a trabalhar junto com a escola, minimizando a falta desses recursos.

A Criança 04, também com cinco anos de idade, era filho único, e as observações das horas de interação familiar - em algumas, só a mãe e ele compareciam, e em outras, havia a presença de uma tia e uma prima da mesma idade - evidenciavam atitudes e comportamentos para com a criança, que pareciam gerar sentimentos de insegurança nesta. A mãe tinha dificuldades de atender aos chamados do filho, demonstrava cansaço, falta de paciência e humor deprimido. Poucas vezes ela brincou e interagiu com a criança e, na maioria das sessões, ficava sentada na cadeira vendo revistas. Em casa, segundo os seus próprios relatos, chegava a se esconder do filho por trás dos móveis desta, porque ele não lhe dava sossego e a chamava o tempo todo. Somado a isso, havia o fato de o pai não auxiliar nos cuidados ao filho, deixando a figura materna sobrecarregada, o que agravava a situação do menino diante da condição materna. Os comportamentos reativos da criança não eram percebidos como tais pelas figuras parentais, sendo que o pai compareceu apenas uma vez em uma entrevista com a equipe. Nas observações realizadas na escola, após a queixa feita por esta, puderam ser confirmados os vários relatos que a mãe já havia feito sobre o filho, de querer tudo do jeito dele, querer ser o primeiro da fila, querer ser o primeiro a falar, ser o primeiro a ir ao banheiro mesmo sem vontade quando alguém pedia para ir. Foi possível ver a transferência da relação com a mãe para a professora: o afeto e a insegurança em relação a esta. Chamava a professora constantemente para mostrar sua lição e mesmo que houvesse entendido o que era para fazer, a cada exercício chamava a professora, demonstrando 


\section{Desafios da psicologia no Brasil}

a necessidade que tinha de ser percebida e o receio de ser esquecida. A coordenadora pedagógica relatou que quando a Criança 04 estava com a professora, ela ficava muito calma; mas quando estava longe, ficava muito agitada. Até nos pequenos detalhes ela queria as coisas do jeito dela. Durante uma atividade de desenho, quando os outros alunos não colocavam o pote de lápis no centro da mesa, ela o arrumava centralmente. Assim, os comportamentos agressivos surgiam sempre, parecendo buscar ajuda externa para conseguir ou tentar recuperar o controle e, com isso, a estabilidade sempre prestes a ser perdida. A discussão de todos esses pontos junto à coordenadora e à professora visaram encontrar formas de trazer mais segurança para a criança nas relações com a professora, principalmente, propiciando seu desenvolvimento.

Ao finalizar as atividades desse projeto, a equipe considerou a grande contribuição que as observações no contexto escolar deram para o entendimento das queixas que foram apresentadas. Houve uma melhor compreensão do que estava por trás do comportamento agressivo da criança, ou mesmo da dificuldade de aprendizagem, e isso permitiu que a equipe de trabalho pudesse auxiliar pais e professores a compreender e a buscar alternativas para atender às necessidades das crianças, diminuindo seus comportamentos agressivos, que se revelaram em muitas ocasiões tratar-se de reações ao não atendimento dessas necessidades.

\section{ALGUMAS CONSIDERAÇÕES}

Após um ano de trabalho, a equipe pôde observar entre as causas intensificadoras da agressividade na escola, principalmente: o aumento da ansiedade da criança em razão de possíveis fantasias de ser a escola responsável pela sua separação das figuras parentais; a transferência da relação afetiva e do sentimento de insegurança da criança para com seu principal cuidador - a figura materna -, para a relação da criança com a professora, com uma exigência maior da criança de atenção e cuidados só para si; e a compreensão diminuída por parte dos educadores das necessidades e dificuldades da criança, muitas vezes pela impossibilidade de uma atenção individualizada, mediante um número muito grande de crianças sob seus cuidados e a falta de recursos.

Elias, Prodócimo, Serralha e Scorsolini-Comin (2014) observaram que o ciúme da relação da professora com outros colegas, a inveja da condição mais favorável de outra criança em relação à aprendizagem ou à capacidade de socialização, o olhar mais carinhoso ou de aprovação da professora para outro colega, geravam, frequentemente, comportamentos agressivos, a exemplo de chutes, beliscões, mordidas e destruição de materiais, naquela criança com uma história bastante singular. Essas reações se não forem bem compreendidas em suas reais motivações, podem passar a ser entendidas apenas 


\section{Desafios da psicologia no Brasil}

como modelações do ambiente familiar, ou como maldade pura e simples. Uma criança vítima de agressões por parte de um colega, pode nunca ter feito nada diretamente ao seu agressor, mas ela é e representa algo com o qual a criança agressora não está sabendo lidar. Cabe ao cuidador entender isso e encontrar meios de auxiliá-la.

A escola, como segundo ambiente da criança, sendo o primeiro, sua família, tem como responsabilidade também o atendimento de várias necessidades da criança. Contudo, se esse atendimento é dificultado pela capacidade diminuída de compreensão por parte dos educadores, a agressividade da criança pode recrudescer e permanecer assim, alimentada pelas fantasias da criança e pela transferência. Entende-se, porém, que essa compreensão insuficiente das necessidades da criança, na escola, não pode ser entendida tão somente como uma questão pessoal desses educadores, mas pelo apoio também insuficiente para o trabalho com as crianças, cujas necessidades individuais são bastantes e contínuas.

Ao oferecermos uma escuta aos professores, as reclamações mais comuns estiveram relacionadas à falta de estrutura dada pelo governo, à falta de pessoal para ajudar em sala de aula e ao processo de progressão continuada que, segundo eles, é cruel com a criança com atraso. Esta é obrigada a avançar de série sem condições de acompanhar a nova turma, uma vez que nesse processo não é permitida a reprovação do aluno. Por esta razão, muitas vezes, um só professor fica responsável por até três planos de ensino diferentes e sem o apoio de monitores. Constatamos, entretanto, que essas três reclamações não poderiam ser consideradas isoladamente; elas fazem parte de um complexo, cuja solução ainda parece distante de nossa realidade escolar.

Nesse contexto, também, é importante considerar a condição emocional desses professores para lidar com crianças tão ávidas por cuidados. Os professores, no contato com essas crianças, atualizam suas próprias necessidades muitas vezes nunca atendidas, ou parcialmente atendidas, o que acaba por bloqueá-los em sua capacidade de cuidar e ser criativo, e evidencia a necessidade de ações de apoio emocional e pessoal aos educadores.

Em uma extensão realizada em 2013, junto a professores e educadores de escolas de educação infantil (Elias et al, 2014), em um dos encontros, uma professora questionou a extensionista coordenadora sobre o fato de sua filha, de quatro anos, demorar muito para dormir à noite. A coordenadora tentou mostrar a essa mãe como era difícil para uma criança pequena entender e dar conta de se perceber separada dos pais. Explicou-lhe que a criança menor vive o sono como um "inimigo", que a separa da convivência com as figuras parentais, ainda mais quando estas, por não compreenderem a situação, 


\section{Desafios da psicologia no Brasil}

muitas vezes saem para trabalhar enquanto a criança está dormindo e poupam a si próprias de vê-la chorar com sua saída. Frequentemente fica faltando uma fala reasseguradora por parte dessas figuras, de que elas vão voltar e de que não vão esquecer a criança. Nesse momento da explicação, a filha de outra professora, de cerca de cinco anos de idade, que se encontrava em um canto da sala, desenhando, interrompeu a coordenadora e lhe disse, apontando para a mãe: "Mas ela esquece de mim... eu já falei pra ela que ela esquece de mim...". Afora os risos que se seguiram, esse momento foi naturalmente propiciador de um entendimento por parte de todos os presentes - educadores, professores e extensionistas - das angústias vividas pelas crianças pequenas e que, não raramente, estão na base de seus comportamentos de resistência e de agressão.

Durante as discussões com as educadoras, nas escolas, percebemos que se tratam de pessoas atenciosas e dispostas a ajudar as crianças, mas, em certa medida, também cansadas de tentar ações que não davam resultado, muitas vezes pelo fato de suas tentativas acontecerem solitariamente, ou talvez, a partir de um olhar parcial da problemática apresentada pela criança. Ao insistirem em recursos e estratégias pedagógicas já adotadas e teoricamente consolidadas, as educadoras perdiam a oportunidade de identificar a real necessidade da criança e buscar seu atendimento de forma criativa para o caso em particular.

O contato com nossa equipe possibilitou aos educadores que estes pudessem compreender, na medida do possível, as vivências de agressividade na escola de maneira nova e própria a cada caso, a partir de um olhar clínico sobre a problemática integral da criança, viabilizando o atendimento a esta e à sua família. Segundo Martins (2003), o olhar clínico é "aquele que toma em consideração um campo - de pesquisa ou de intervenção - estruturado por um jogo de relações e de interações dinâmicas e complexas", sendo essa complexidade construída a partir dos olhares colocados sobre esse campo (p. 43-44).

Os comportamentos agressivos das crianças pareceram se relacionar às suas ansiedades em relação à falta de segurança e de estabilidade, imprevisibilidade e incompreensão de suas necessidades. Proporcionar compreensão dessas ansiedades às educadoras foi essencial e, a partir desse conhecimento, elas puderam desenvolver ações que tivessem relação com as particularidades de cada criança, em razão da empatia que pôde ser desenvolvida. As educadoras contaram com subsídios para a elaboração de estratégias que diminuíssem a ansiedade das crianças na escola, intensificando os laços afetivos com estas e sua família. Segundo Dessen e Polônia (2007), isso é algo positivo, uma vez que esses laços, quando estruturados e consolidados na escola ou no lar, podem permitir às crianças 


\section{Desafios da psicologia no Brasil}

viverem conflitos, aproximações e situações nas relações que se estabelecem, resolvendo problemas e diminuindo os comportamentos agressivos.

Considerando o conjunto das intervenções realizadas nas escolas e nas famílias, foi percebida a melhora da participação dos cuidadores nas atividades escolares, não só pelas intervenções da equipe, mas por intervenções da própria escola a partir das discussões com a equipe. Além disso, percebemos a revisão dos educadores de seu modo de interação com a criança e de atendimento das necessidades desta. Em todos os casos, foi constatada uma diminuição da ansiedade e agressividade da criança tanto no ambiente escolar como familiar. A discussão dessas questões entre equipe, escola e família foi extremamente importante para o desenvolvimento e desempenho da criança na escola, principalmente pela forma como se estabeleceu essa interlocução, sem imposição de saberes. A equipe entende, porém, que essa discussão deve ser permanente, uma vez que ela possibilita não só melhor compreensão, mas também apoio mútuo a todos os componentes desse conjunto.

\section{CONSIDERAÇÕES FINAIS}

Na teoria winnicottiana, a facilitação dos processos de integração inatos ao indivíduo por meio de cuidados adequados a cada momento de sua linha do ser é que permite a contribuição do indivíduo para a sociedade, construindo relações amadurecidas e a capacidade de se cuidar e se preocupar com os outros e com as consequências de seus atos. Winnicott deixava bem claro que, "quando a família está ausente ou doente, alguma parcela da sociedade deve assumir a função da família" e, por certo, ajudar o indivíduo a integrar seus impulsos destrutivos e aprender a controlá-los, por meio de cuidados oriundos da identificação com suas necessidades. Isso é essencial, pois, impedir a expressão da agressividade não é o melhor caminho (1990b, p. 219).

O ambiente da escola de educação infantil, especialmente, pode exercer esse papel. Contudo, compreender as questões das relações primárias da criança que afetam o seu desenvolvimento e desempenho escolar, na maior parte dos casos por essas relações se reproduzirem dentro da escola, não retira a importância de se pensar as multideterminações dos problemas encontrados no cotidiano escolar, ou seja, as características do meio social e cultural na constituição desses problemas, para que mudanças sejam promovidas. Ainda assim, há necessidade de viabilizar cuidados de saúde mental às crianças que apresentam dificuldades interpessoais, muitas vezes por viverem em famílias que não estão conseguindo oferecer o suporte emocional de que necessitam (D’Ávila-Bacarji, Marturano, \& Elias, 2005). Em alguma medida, a escola pode participar e favorecer esses cuidados por meio dos 


\section{Desafios da psicologia no Brasil}

membros mais amadurecidos de sua equipe multiprofissional e de sua comunidade (Salvari \& Dias, 2006). Os psicólogos escolares podem se beneficiar da interlocução com psicólogos clínicos e viceversa, para o alcance do objetivo comum de ambos de promover o bom desenvolvimento da criança.

\section{REFERÊNCIAS}

Alves et al. (2017). O ambiente familiar no manejo da agressividade da criança. In: C. A. Chapadeiro, C. A. Serralha, \& M. F. D. Hueb (Orgs.). Questões de família. Curitiba: Editora CRV.

Barros, M. (1993). O livro das ignorãças. Rio de Janeiro: Record.

D’Ávila-Bacarji, K. M. G., Marturano, E. M., \& Elias, L. C. S. (2005). Suporte parental: Um estudo sobre crianças com queixas escolares. Psicologia em Estudo, 10(1), 107-115.

Dessen, M. A. \& Szelbracikowski, A. (2005). Compreendendo a agressão na perspectiva do desenvolvimento humano. In Dessen, M. A., Costa Junior, Á. L. \& Col. (2005). A ciência do desenvolvimento humano. Porto Alegre: Artmed.

Dessen, M. A., \& Polônia, A. C. (2007). A família e a escola como contextos de desenvolvimento humano. Paidéia (Ribeirão Preto), 17(36), 21-32.

Dias, E. O. (2012). A teoria do amadurecimento de D. W. Winnicott. (2a ed.). Rio de Janeiro: Imago.

Elias, L. B., Prodócimo, N. F., Serralha, C. A., \& Scorsolini-Comin, F. (2014). Barbarói, n. 41, pp. 174-188.

França, S. L., \& Yaegashi, S. F. R. (2005). A agressividade na infância: um estudo sobre suas causas e consequências. Iniciação Científica Cesumar, 7(1), 11-18.

Gauer, G. C. (2001). Personalidade e conduta violenta. Civitas - Revista de Ciências Sociais, 2, 45-66.

Hachet, A. (2006). Entre o previnir e normalizar, que lugar terá o sofrimento da criança?. Ágora (Rio de Janeiro), IX(1), 27-34.

Luz, I. R. (2008). A agressividade na concepção de Winnicott e suas implicações para a educação infantil. Aprender: Caderno de Filosofia e Psicologia da Educação, 11, 109 137. Recuperado em janeiro/2016, de

http://periodicos.uesb.br/index.php/aprender/article/viewFile/4249/pdf_220.

Martins, J. B. (2003). A atuação do psicólogo escolar: Multirreferencialidade, implicação e escuta clínica. Psicologia em Estudo, 8(2), 39-45.

Oaklander, V. (1980). Descobrindo crianças: A abordagem gestáltica com crianças e adolescentes. (11ª ed.). São Paulo: Summus.

Prado-Lima, P. A. S. (2009). Tratamento farmacológico da impulsividade e do comportamento agressivo. Revista Brasileira de Psiquiatria, 31(supl. II), 58-65. 


\section{Desafios da psicologia no Brasil}

Salvari, L. F. C., \& Dias, C. M. S. B. (2006). Os problemas de aprendizagem e o papel da família: Uma análise a partir da clínica. Estudos de Psicologia, 23(3), 251-259.

Santos, P. (2006). Problemas de saúde mental de crianças e adolescentes atendidos em um serviço público de psicologia infantil. Psicologia em Estudo, 11 (2), 315-321.

Serralha, C. A., Espote, R., Silva, M. S., Silva, T. B., \& Arruda, S. A. V. (2016). Consultas Terapêuticas Familiares no tratamento do comportamento agressivo em crianças. Interação Psicologia, v. 20, n. 2, p. 151-159.

Souza, M. A., \& Castro, R. E. F. (2008). Agressividade infantil no ambiente escolar: Concepções e atitudes do professor. Psicologia em Estudo, 13(4), 837-845.

Strüber, M., Lück, D., \& Roth, G. (2005). Psychobiologische Grundlagen agressives und gewalttägen Verhaltens. Oldenburg: BIS.

Strüber, D., Lück, M., \& Roth, G. (2006), Local do crime: O cérebro. Mente \& Cérebro, 166.

Wiese, E. B. (2012). Parentalidade, cultura e trauma: influências na saúde mental da criança. In: C. A. Piccinini \& P. Alvarenga (Orgs.). Maternidade e paternidade: a parentalidade em diversos contextos. (p. 197-226). São Paulo: Casa do Psicólogo.

Winnicott, D. W. (1982). A criança e o seu mundo. (A. Cabral, Trad.). Rio de Janeiro: Guanabara Koogan. Original publicado em 1957-1964.

Winnicott, D. W. (1984). Consultas terapêuticas em Psiquiatria Infantil. Rio de Janeiro: Imago. Original publicado em 1984.

Winnicott, D. W. (1990a). Natureza humana. (D. Bogomoletz, Trad.). Rio de Janeiro: Imago. Original publicado em 1988.

Winnicott, D. W. (1990b). O ambiente e os processos de maturação. (I. C. S. Ortiz, Trad.). Porto Alegre: Artes Médicas. Original publicado em 1979.

Winnicott, D. W. (1993). Conversando com os pais. (A. Cabral, Trad.). São Paulo: Martins Fontes.

Winnicott, D. W. (1999). Privação e delinquência. (A. Cabral, Trad.). São Paulo: Martins Fontes. Original publicado em 1987. 


\section{Desafios da psicologia no Brasil}

\section{NOTAS}

\section{Notas 1}

Este capítulo foi publicado anteriormente no livro Psicanálise e Universidade: um encontro na pesquisa, organizado por C. A. Serralha e F. Scorsolini-Comin, em 2013, pela Editora CRV, com o título "A agressividade na 1a e 2 a infância: observações e intervenções no ambiente escolar". Nesta segunda versão foram feitos acréscimos de outros estudos sobre o tema, visando ampliar e divulgar o conhecimento produzido. 


\section{Capítulo 39}

\section{DUAS SITUAÇÕES ENVOLVENDO DIVISÃO DE NÚMEROS DECIMAIS ABORDADAS JUNTO A UM GRUPO DE FABRICAÇÃO DE PRODUTOS DE LIMPEZA NO CONTEXTO DA EDUCAÇÃO NÃO FORMAL}

DOI: $10.37423 / 200200246$

Renata Cristina Geromel Meneghetti (Universidade de São Paulo - Instituto de Ciências Matemáticas e de Computação (ICMC-USP/São Carlos).rcgm@icmc.usp.br.

Solange Teresinha Poeta de Carvalho Ayusso (Universidade Estadual Paulista "Júlio de Mesquita Filho"- Instituto de Biociências, Letras e Ciências Exatas de Sấo José do Rio Preto (IBILCE), solangeayusso@hotmail.com.

Michelle Francisco de Azevedo Bonfim de Freitas (thiversidade Estadtral de Campinas - Faculdade de Educação (FE-UNICAMP/Campinas).

michelleazevedo2005@gmail.com.

Resumo: Este trabalho insere-se no contextb da educação não formal e focaliza uma intervenção em um grupo de fabricação de produtos de limpeza caracterizado como um Empreendimento em Economia Solidăria. O trabalho/fóca duas situações vivenciadas jünto a este grupo referentes à divisão com númẹros decimais, as quais foram trabalhadas de forma contextualizada a partir das situações do cotidjano do grupo. A pesquilsa seguiu uma abordagem qualitativa e a intervênção junto abs/membros-deste grupo aconteceu de maneira informal. A coleta-de dados se detratravés dos registros dos pesquisadores:-

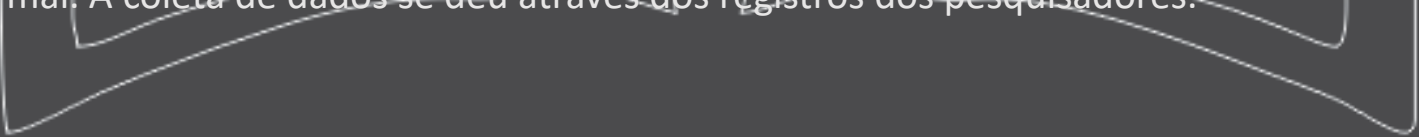




\section{Desafios da psicologia no Brasil}

Com isso visamos uma aprendizagem significativa que contribuísse com a autogestão do empreendimento. Os momentos vividos com o grupo não foram suficientes para que atingissem domínio e independência no conteúdo proposto. Entretanto, o trabalho efetuado despertou atenção para as questões referentes à divisão; a prática e a relação com suas atividades diárias fez com que as integrantes vivenciassem oportunidades de raciocinar e discutir suas dúvidas mesmo não tendo habilidade e domínio no momento de executar e/ou transcrever atividades.

Palavras-chave: Empreendimentos em Economia Solidária; Educação Não formal; Divisão de números decimais. 


\section{Desafios da psicologia no Brasil}

\section{INTRODUÇÃO}

Este trabalho insere-se numa pesquisa de caráter interdisciplinar, a qual busca colaborar com um projeto de âmbito maior, de políticas públicas em Economia Solidária, da Incubadora Regional de Cooperativas Populares da Universidade Federal de São Carlos (INCOOP/UFSCar, atual NuMIES Núcleo Multidisciplinar e Integrado de Estudos, Formação e Intervenção em Economia Solidária). Esta última propõe à criação de um sistema integrado de Empreendimentos em Economia Solidária (EES) como condição para o desenvolvimento socioeconômico de bairros carentes de uma cidade localizada no interior do estado de São Paulo. Nos EES há demandas próprias da Educação Matemática, no que se refere à apropriação dos conhecimentos matemáticos, por parte de seus integrantes, necessária para a implementação de tais empreendimentos.

Neste trabalho focalizamos um grupo de fabricação de produtos de limpeza caracterizado como um EES. Esse grupo surgiu em novembro de 2011, com a finalidade de potencializar a Economia Solidária do bairro em que está inserido, recebendo o suporte do NuMIES, sendo que este apoio ainda é essencial para o funcionamento do empreendimento. A autogestão é compreendida como uma administração democrática onde as ordens e instruções fluem de baixo para cima e as demandas e informações de forma inversa, exigindo um esforço adicional dos trabalhadores, pois, além de cumprirem suas tarefas, devem se preocupar com os problemas da gestão do empreendimento (SINGER, 2002). Para se aproximarem de práticas autogestionárias, os EES sempre deverão buscar capacitar seus membros a fim de que todos possam participar, efetivamente, no gerenciamento do empreendimento de forma a dependerem, cada vez menos, da ajuda de pessoas externas ao EES.

A respeito desta capacitação necessária, daremos uma abordagem ao ensino de matemática, no campo da educação não formal, como possibilidade para contribuir com o avanço dos EES, pois a matemática está intrínseca as mais diversas atividades humanas e é também essencial na administração dos EES, uma vez que seu domínio pode facilitar e agilizar os processos envolvidos na cadeia produtiva do EES.

Em nossas observações desse EES, pudemos constatar grandes dificuldades em relação aos afazeres que envolviam conteúdos matemáticos relacionados, principalmente, com conceitos envolvendo operações básicas com números racionais em sua forma decimal, principalmente por parte de uma das integrantes do EES; sendo que a divisão com números decimais apresentava-se como mais emergente. Detectou-se também a utilização da calculadora de forma automática, ou seja, sem compreensão, para confirmar os cálculos que eram feitos manualmente ou mentalmente; além disso, observou-se também que havia uma falta de confiança das integrantes do empreendimento nas 


\section{Desafios da psicologia no Brasil}

contas que faziam sem o uso da calculadora. Na direção de contribuir com o grupo visando sanar algumas de suas dificuldades no trato com a matemática necessária no cotidiano deste EES, neste trabalho focamos duas situações vivenciadas junto a este grupo referentes à divisão com números decimais. Tais situações foram trabalhadas de forma contextualizada a partir das situações do seu cotidiano. Assim, nosso objetivo foi abordar os conceitos antes mencionados visando uma aprendizagem significativa de forma a contribuir com sua autogestão.

A Economia Solidária que se diferencia da capitalista principalmente por seus objetivos, pois, enquanto nesta visa-se o acúmulo de capital, naquela privilegia-se o aprimoramento pessoal enquanto reinserção social; outro ponto que as distanciam é o modo de administração adotado pelos EES, observando-se na economia capitalista a heterogestão, isto é, empresas hierarquizadas enquanto que, na economia solidária, o foco é a autogestão dos EES (SINGER, 2002).

Podemos encontrar na educação não formal um mecanismo capaz de contribuir com os ideais da economia solidária no que tange a deficiência da educação formal, ou seja, um meio de inserir socialmente aqueles que foram de alguma forma, excluídos pela própria escola. Por educação formal:

[...] a educação não formal, embora obedeça também a uma estrutura e a última organização (distintas, porém, das escolas) e possa levar a uma certificação (mesmo que não seja essa a finalidade), diverge ainda da educação formal no que respeita à não fixação de tempos e locais e à flexibilidade na adaptação dos conteúdos de aprendizagem a cada grupo concreto (AFONSO, 1989, p.78 citado por GARCIA, 2001).

Desta forma, nosso objetivo foi abordar de modo contextualizado, por meio de uma intervenção educacional pautada na metodologia de resolução de problemas, alguns conceitos sobre números decimais utilizados pelas integrantes do grupo de fabricação de produtos de limpeza, focando especialmente a divisão de números decimais e visando uma aprendizagem significativa de forma a contribuir com a reinserção socioeconômica e com a autogestão do grupo. Tal aprendizagem é definida como sendo

[...] um processo por meio do qual uma nova informação relaciona-se com um aspecto especificamente relevante da estrutura de conhecimento do indivíduo, ou seja, esse processo envolve a interação da nova informação com uma estrutura de conhecimento específica, a qual Ausubel define como conceito subsunçor ou simplesmente subsunçor (MOREIRA, 1995, p.153).

Segundo Brasil (2002), para a educação de jovens e adultos, o trabalho com situações contextualizadas pode colaborar para uma aprendizagem mais significativa, já que tais situações favorecem a compreensão e contribuem para a construção de conhecimentos matemáticos que, por sua vez, são 


\section{Desafios da psicologia no Brasil}

ferramentas importantes para a compreensão da realidade. Além disso, o trabalho com situaçõesproblema em que as operações aparecem com diferentes significados, em contextos reais, permite que os alunos possam, de fato, compreendê-las.

Visando esse último tipo de aprendizagem e uma vez inseridos num contexto cultural próprio, nossa opção foi utilizar situações reais do cotidiano delas, coisas que elas mesmas tinham curiosidade de calcular, mesmo sem saber como, pois compreendemos.

Neste trabalho empregamos também a metodologia de Resolução de Problemas, na qual se compreende que um problema pode ser enunciado como sendo tudo aquilo que não se sabe resolver, mas há interesse em fazê-lo, isto é, qualquer situação que leve o aluno a pensar e que lhe seja desafiador e não trivial. (ONUCHIC,1999).

De acordo Onuchic (1999), no ensino de matemática através da resolução de problemas, o aluno passa a assumir um papel participante e ativo no processo de aprendizagem; o ponto central desta metodologia baseia-se na crença de que os alunos possam compreender os conceitos, os processos e as técnicas operatórias necessárias dentro do trabalho de cada unidade temática e consigam estabelecer relações entre os conceitos já aprendidos e outros que possam aprender através da exploração e generalização de problemas. Segundo a Proposta Curricular para a Educação de Jovens e Adultos (PCEJA), através do trabalho com a resolução de problemas, os jovens e adultos têm a oportunidade de ampliarem seus conhecimentos acerca de conceitos e procedimentos matemáticos e sua visão sobre o mundo, adquirindo autoconfiança (BRASIL, 2002).

\section{OBJETIVOS}

Nosso objetivo foi abordar de modo contextualizado, por meio de uma intervenção educacional pautada na metodologia de resolução de problemas, duas situações-problemas contextualizadas e envolvendo o conceito de divisão de números decimais, visando uma aprendizagem significativa de forma a contribuir com a reinserção socioeconômica e com a autogestão do grupo.

\section{METODOLOGIA}

Esta pesquisa é de cunho qualitativo: estudo de caso (LUDKE \& ANDRÉ, 1986; BOGDAN \& BIKLEN, 1994) e o caso focalizado é um grupo de fabricação de produtos de limpeza atualmente constituído por duas integrantes, as quais são mulheres de baixa renda com idade entre 35 e 40 anos. 0 empreendimento produz água sanitária, álcool perfumado, amaciante, brilha alumínio, cloro, detergente, sabão álcool, alvejante sem cloro, desinfetante, detergente, sabão líquido, sabão 


\section{Desafios da psicologia no Brasil}

querosene, multiuso e pinho gel. As integrantes do EES lutam pelo aumento de clientes fixos, pela fabricação de outros produtos além desses relacionados e pela formalização do EES. Para melhorar a leitura procuramos eliminar alguns erros de linguagem, por exemplo: "nois" foi substituído por "nós" e algumas concordâncias verbais foram modificadas também, tais como: a frase "Não confiança na realização da minha divisão." foi substituída por "Não tenho confiança na realização da minha divisão."

Num primeiro momento, por meio de observação participante foram realizadas algumas visitas e por meio de conversas informais procuramos obter um maior conhecimento sobre o cotidiano das integrantes do EES. Posteriormente alguns encontros ocorreram visando a objetivos específicos de aprendizagem. Os encontros totalizaram uma carga horária de 15 horas, sendo que estão inclusos os momentos de conversas informais e a troca de experiências com aplicação de problemas envolvendo operações básicas de números decimais. O conteúdo foi selecionado de acordo com o sugerido pelas integrantes. Numa fase anterior elas haviam participado de uma oficina pedagógica também sobre números racionais ${ }^{1}$, mas algumas dificuldades ainda persistiam, principalmente, quanto à divisão de números racionais.

Nesse sentido, retomou-se o assunto visando trabalhar principalmente divisão com números decimais, mas as situações vivenciadas, uma vez que se deram de forma contextualizada e inerentes a atividades do cotidiano do grupo envolviam também as operações de adição e multiplicação com números decimais. Respeitando os interesses das integrantes deste grupo, nas situações problemas vivenciadas junto ao grupo a abordagem foi feita utilizando-se a moeda corrente (real). As participantes foram designadas pelos nomes fictícios Eli e Rô. Durante os encontros foi observado que as integrantes do grupo aos poucos foram apresentando-se mais participativas.

\section{DESCRIÇÃO E DISCUSSÃO DAS SITUAÇÕES VIVENCIADAS}

Durante a intervenção realizada, de forma geral, observamos que a integrante Eli apresenta mais domínio dos conteúdos matemáticos, tem mais facilidade, antes de calcular o resultado já tem uma estimativa, sentindo-se confiante no que faz. Porém, não se sente segura em transmitir o conhecimento para a colega. Rô é mais quieta, levanta o olhar para escutar o comentário da colega e só movimenta a cabeça concordando ou levemente discordando. Observamos que a falta da aprendizagem dos pré-requisitos gerou insegurança em Rô ao realizar as operações necessárias. Além disso, no Empreendimento, recorrem à calculadora e em alguns momentos fazem o cálculo mental, principalmente Eli. 


\section{Desafios da psicologia no Brasil}

Os dois primeiros encontros foram individuais para que cada integrante do EES tivesse a liberdade de contar um pouco de sua história, colocando seus "medos", seus sonhos, assim foi possível criar vínculo com elas e desenvolver as atividades com uma linguagem de interesse mútuo. Foi sugerido que escolhessem o conteúdo a ser estudado e elas solicitaram a aprendizagem da divisão dada na Escola (comentaram os processos que os filhos utilizavam na divisão: "estimativa" e "método longo"), para que pudessem entender e acompanhá-los, percebeu-se que o interesse em aprender era mais motivador para a ajuda escolar do que para ser aplicado no empreendimento, parecia que a preocupação era mais com a família. A integrante Eli colocava na maioria das vezes estimava do resultado e a Rô timidamente arriscava um palpite, isso quando colocava sua opinião. Também percebemos que por um lado a integrante Eli necessitava verbalizar todo procedimento que realizava e, por outro lado, Rô muitas vezes aproveitava dessa verbalização ao fazer suas operações.

A cada encontro, inicialmente conversávamos assuntos gerais, perguntávamos primeiro sobre como estava a Família e o Empreendimento, somente depois disso é que se iniciava a atividade específica proposta a partir das situações que elas vivenciavam no empreendimento. Resolvíamos a atividade junto com elas, de maneira discreta, como se fizéssemos parte do empreendimento. Como a resolução da tarefa era efetuada com caneta, tudo ficava registrado, para posterior análise.

A primeira atividade foi trabalhar a partir do boleto do SAAE (Serviço Autônomo de Água e Esgoto), a conta mensal de água e esgoto; visando a compreensão do que é posto neste documento. Realizamos a leitura juntas, comparando o valor da água, sendo comentado que o esgoto é um valor proporcional à quantidade de água utilizada e outras informações que o boleto continha. Na sequência, coletamos o valor pago, realizamos a divisão por dois, uma vez que dividem as despesas do estabelecimento com outro empreendimento.

Rô: "-Nós recebemos o boleto e pagamos a metade. Quando faço a conta no papel, confiro na calculadora. Não tenho confiança na realização da minha divisão."

Pesquisadora: "-Vamos realizar juntas a divisão. O valor do boleto apresentado é de $R \$ 135,74$. Como a despesa é dividida entre os dois EES, dividimos por...?"

Rô e Eli: “-Dois.”

Eli: “-Bem... pego o $R \$$ 135,00 e divido por dois, dá $R \$$ 67,50. Daí os $R \$$ 0,74 também divido por dois, dando $R \$$ 0,37, logo, somo os dois resultando $R \$ 67,87$, é isso, não é? Mas para resolver no papel, não 


\section{Desafios da psicologia no Brasil}

consigo. Não entendo o que minha filha faz na Escola. Gostaria de saber para poder acompanhá-la e ajudá-la quando houver dúvidas.".

Rô: "-Sei fazer dessa maneira..."
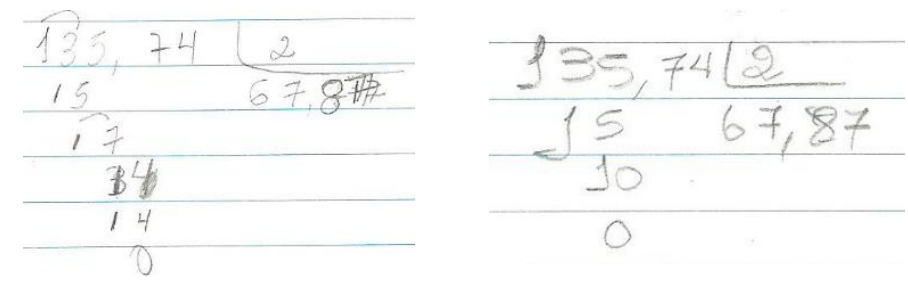

Figura 1: Divisão Rô (esquerda) e Eli (direita)

Nesta atividade observamos que Rô resolveu a divisão pelo processo curto até a multiplicação do quociente oito, depois realizou pelo processo longo. O número três foi colocado abaixo do número sete, logo após, riscado e colocado o número um. Como estávamos fazendo todas ao mesmo momento e os comentários orais eram falados para que todas escutassem, Eli verbalizou “... sete vezes dois é igual a quatorze" e Rô fez dezessete menos quatorze é igual a três. Depois Rô observou que já estávamos no ultimo número do quociente (R\$ 67,87$)$, então, ela corrigiu o número três, colocando o número um (Realizou mentalmente: oito vezes dois é igual a dezesseis. Dezessete menos dezesseis é igual a um) e abaixou o quatro, dando continuidade na operação pelo processo longo. A vírgula foi colocada no quociente, pois Eli tinha realizado o cálculo mentalmente e comentamos o que tinha dado para cada empreendimento pagar (sessenta e sete reais, oitenta e sete centavos).

Neste caso, observamos que Eli realizou a divisão do número inteiro pelo processo curto, restando um, acrescentou o zero e colocou a vírgula após o resultado do quociente inteiro. O restante do processo não sabia fazer e como mentalmente já sabia o resultado, colocou-o e também acrescentou o resto zero para indicar que a divisão foi exata.

Realizamos novamente a conta pelo processo longo para verificar e discutir passo a passo e também para que elas percebessem o registro de todo o processo do cálculo que estava sendo realizado. 


\section{Desafios da psicologia no Brasil}

Segue registro da divisão realizada por Rô e Eli:
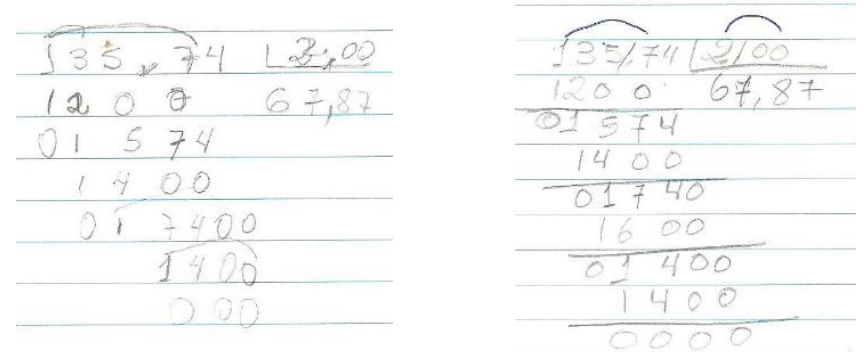

Figura 2: Divisão Rô (esquerda) e Eli (direita)

Nesta parte, observamos que Rô no início desenvolveu a divisão passo a passo. Quando dividiu um mil, setecentos e quarenta por duzentos, fez a multiplicação mental: oito vezes duzentos é igual um mil e seiscentos, então restou cento e quarenta. Acrescentou o zero: um mil e quatrocentos. Dividido por duzentos: quociente sete e resto zero. Divisão exata. Observamos que Eli realizou a divisão pelo processo longo, passo a passo, sempre abaixando todos os números do dividendo.

No desenvolvimento da divisão, que foi realizada em conjunto, de maneira paulatina e buscando fazer com que elas compreendessem cada passo do processo da divisão, elas lembraram momentos do minicurso do qual participaram anteriormente e, em alguns momentos, percebeu-se que elas conseguiram transferir para esta nova situação algumas coisas que aprenderam neste minicurso, por exemplo, Eli: "-Ah!...agora vamos igualar as casas, cortar as vírgulas,...você lembra lá no minicurso?" Isto mostra que elas conseguiram transferir alguns dos conhecimentos adquiridos no minicurso do qual participaram para esta nova situação. Entretanto, observou que algumas dificuldades ainda permaneciam, tais como: "O que fazer quando no dividendo não tinha mais números para abaixar?" Então, nós procuramos focar isso com mais atenção nas situações vivenciadas junto ao grupo neste novo momento. Assim, trabalhamos a divisão através do processo longo, com a finalidade de levá-las a compreender o significado de dividendo, divisor, quociente e resto e todo o processo de divisão.

A segunda atividade realizada com as integrantes deste empreendimento foi o cálculo do custo de um dos produtos fabricados, a água sanitária.

Eli: "Queremos saber qual foi a sobra... O que compensa fazer, o que não compensa fazer... é só fazendo conta para saber..."

Diante dos dados reais, coletados por meio de notas fiscais, foram resolvidas as operações com adição, multiplicação e divisão.

Pesquisadora: "... Qual o valor pago pelo cloro?...". 


\section{Desafios da psicologia no Brasil}

Eli: “-A gente paga $R \$ \$$ 68,40 na bomba... 60 litros... Para produção da água sanitária, coloca-se 40 litros de cloro com 160 litros de água resultando 200 litros de água sanitária..."

Rô: "-Para fazer água sanitária, nos precisamos de cloro, água, barrilha e sal".

Eli: "-O sal é $R \$ 0,85$ o quilo..."

Pesquisadora: "-Então sabemos que o valor do cloro é $R \$ 68,40$ com 60 litros, Para obter o valor de um litro, o que temos que fazer?... Qual operação realizar?".

Eli: “- $R \$ 68,40$ dividido por 60 para saber o litro do cloro"...

A divisão realizada por Eli e Rô foi efetuada conforme a figura abaixo:
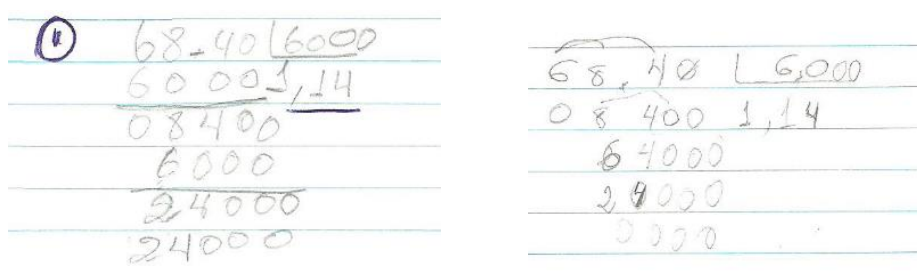

Figura 3: Divisão Eli (esquerda) e Rô (direita)

Nesta situação, observamos que Eli resolveu a divisão sem acompanhamento, observamos que não registrou o resultado da subtração de vinte e quatro mil menos vinte e quatro mil. Para ela o resultado do quociente estando certo é o que basta. Entretanto, Rô realizou a divisão, ainda de forma insegura, pelo processo curto e longo. Observamos que na terceira linha há rasuras (ela ia escrever seis mil, porém acabou mudando de ideia e colocou o número dois em cima do número seis escrevendo dois mil e quatrocentos) em seguida, ao multiplicar por quatro, utilizou o processo longo, uma vez que na quarta linha repetiu o valor dois mil e quatrocentos. A partir do resultado dessa operação, a pesquisadora questionou: “Logo, para saber o valor gasto de cloro, o que temos que fazer?”; Rô: “... $R \$ 1,14$ vezes 40, o valor gasto para fazer a água sanitária". Então, foi realizada a multiplicação. Observa-se que, antes da multiplicação, Eli fez outra operação. Porém, após os comentários, ela não teve dúvidas na colocação da vírgula e nem com o zero (40), mas Rô não resolveu corretamente, apresentou insegurança, primeiramente em qual operação fazer e, após observar a conta da colega, riscou a divisão que iria resolver e armou a conta de multiplicação. Percebe-se que esta última não tem conhecimento sobre a multiplicação por zero e um, uma vez que em alguns momentos ela colocou 


\section{Desafios da psicologia no Brasil}

o resultado da multiplicação por zero como se estivesse multiplicando por um e numa das multiplicações por um (quatro vezes um) ela colocou o valor um, conforme figura 4.
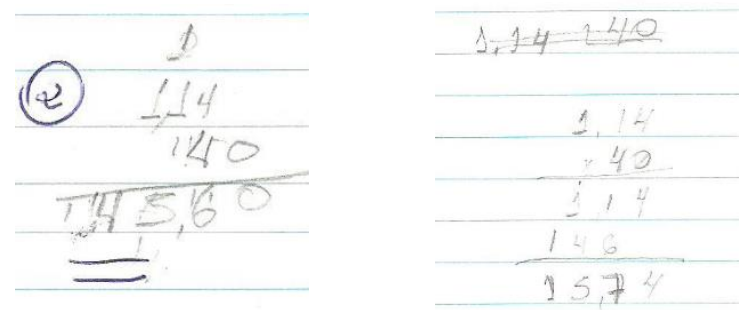

Figura 4: Multiplicação Eli (esquerda) e Rô (direita)

Nesta segunda atividade, como o nosso objetivo era calcular o valor do custo da Água Sanitária, elas efetuaram a adição do valor do cloro, da barrilha e do sal.
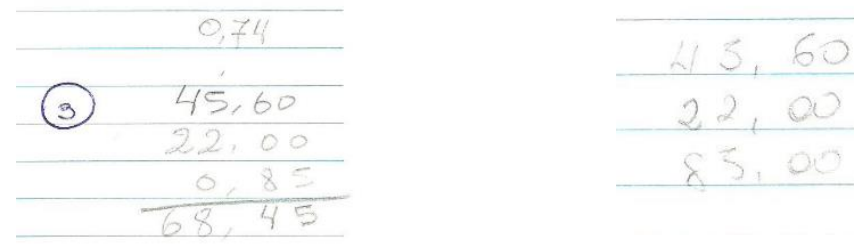

Figura 5: Adição Eli (esquerda) e Rô (direita)

Eli realizou a soma corretamente e com autonomia. Já Rô, observamos que colocou $R \$ 85,00$ e não $R \$$ 0,85 .

Pesquisadora: "-Como registramos as moedas?"

Eli: "-Colocamos após a vírgula."

Rô: “-Ah!...É mesmo..."

Após ser esclarecido, Rô verificou que o seu registro estava incorreto, porém como viu o que Eli já havia realizado, não deu sequencia na sua atividade.

Pesquisadora: "- Recordando... temos o valor do cloro $R \$ 45,60$, mais barrilha a $R \$ 22,00$, mais o sal $R \$$ 0,85 totalizando $R \$ 68,45$ de gastos para 200 litros de água sanitária, então, para saber quanto será o litro..."

Eli: “-...Dividiremos $R \$ 68,45$ por 200 dando mais ou menos $R \$ \$$ 0,35 o litro da água sanitária." 


\section{Desafios da psicologia no Brasil}

Pesquisadora: "-...Vamos realizar a divisão."
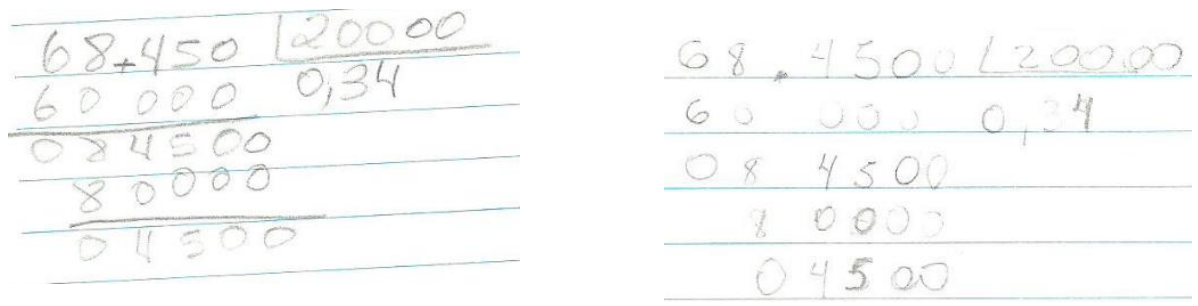

Figura 62: Divisão Eli (esquerda) e Rô (direita)

Neste caso, quando discutimos como realizar a divisão, decidimos que não haveria necessidade de realizar a divisão com o quociente com mais de duas casas decimais. Eli desenvolveu a divisão corretamente, Rose armou a operação, preferiu participar dos comentários da resolução de Eli, depois resolveu sozinha. No registro observamos que ambas não colocam o sinal de menos e quanto ao traço para o resultado da subtração Rô não o colocou. Observamos que ambas chegaram ao resultado do custo da Água Sanitária. Esse foi o momento que percebemos mais motivação das participantes, estavam felizes por chegarem ao resultado final. Saber que conseguiram calcular o custo do produto. Então Eli com entusiasmo continuou:

Eli: “-Como vendemos dois litros de água sanitária por $R \$ 2,50$, vamos dividir por dois, logo, cada litro sai por $R \$ 1,25 . "$
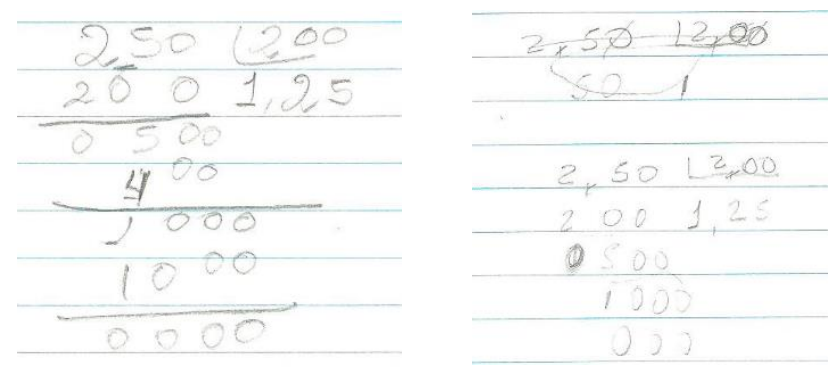

Figura 7: Divisão Eli (esquerda) e Rô (direita)

Aqui, observamos que Eli Resolveu a situação com autonomia. Rose iniciou com o processo curto, por si, armou a conta novamente e iniciou a divisão pelo processo longo, mas no segundo número do quociente ela deu continuidade pelo processo curto.

Eli: "-Logo, há um lucro de $R \$ 1,25-R \$ 0,35=R \$ 0,80$." 


\section{Desafios da psicologia no Brasil}

"- Como vendemos por $R \$ 1,25$ o litro, 0,35 mais 0,35 dá 0,70 e 0,70+0,35=1,05 e 1,05+0,35=1,40. Quase quatro vezes o valor do custo do produto."

Assim, pudemos perceber que nesta segunda fase, houve melhor participação. Ambas apresentaram crescimento, Eli com mais entusiasmo por conseguir desenvolver e registrar seu raciocínio, obtendo o valor do custo da água sanitária e Rô observou de maneira surpresa, o quanto lucra na fabricação do produto. A proposta foi desenvolver o processo longo para que vivenciassem toda etapa e se sentissem mais seguras. Com os registros, observamos que Eli assimilou e que Rô também entendeu, porém, automaticamente registraram o processo curto; este fato pode indicar que uma vez havendo assimilação o processo foi por elas simplificado; já que o processo curto é, de fato, uma simplificação do longo. Dessa forma, observamos que ambas cresceram no seu conhecimento, entretanto, entendemos que ainda há necessidade da continuidade do trabalho efetuado, é preciso exercitar situações semelhantes com os demais produtos para se verificar se há habilidade e independência do grupo rumo à autogestão e também se elas conseguirão transferir os conhecimentos adquiridos para outras situações.

\section{CONSIDERAÇÕES FINAIS}

Os resultados apresentados nesta pesquisa apontam para a importância de se trabalhar com a metodologia de resolução de problemas dentro de um contexto sociocultural próprio, de forma contextualizada e inerente aos princípios da educação não formal e da economia solidária. Nas situações vivenciadas junto a este grupo, percebemos que gradativamente as integrantes foram adquirindo uma postura mais crítica, interagindo com o processo; apresentando também melhor organização em transcrever o raciocínio, mais autonomia no desenvolvimento das atividades, além da motivação que esteve presente com mais intensidade na conclusão da atividade. Entretanto, acreditamos na expectativa de capacitação pessoal continuada a fim de obter a administração do empreendimento com maior segurança e autonomia para atingir o sucesso almejado; ou seja, a pesquisa apontou alguns progressos, porém alerta para a importância da continuidade de trabalhos nessa direção.

\section{REFERÊNCIAS}

AFONSO, A. J. Os lugares da educação. In: SIMSON, O. R. M.; PARK, M. B. e FERNANDES, R. S. Educação não-formal: cenários da criação. Campinas: Editora da UNICAMP, pp. 29-78, 2001. 


\section{Desafios da psicologia no Brasil}

BOGDAN, R.; BIKLEN, S. Investigação Qualitativa em Educação: uma introdução à teoria e aos métodos. Tradução de Maria J. Alvarez, Sara B. Santos e Telmo M. Baptista. Porto/PT: Porto, 1994.

BRASIL (país). Proposta curricular para a educação de jovens e adultos - Segundo segmento do ensino fundamental. v.3. Ministério da educação. Secretaria da Educação Fundamental, Brasília, 2002.

GARCIA, V. A. A educação não-formal no âmbito do poder público: avanços e limites. In: SIMSON, 0. R. M.; PARK, M. B.; FERNANDES, R. S. Educação não-formal: cenários da criação. Campinas: Editora da UNICAMP, pp. 147-165, 2001.

LUDKE, M.; ANDRÉ, M. E. D. A. Pesquisa em Educação: abordagens qualitativas. São Paulo: Editora Pedagógica e Universitária Ltda. (EPU), 1986.

MOREIRA, M. A. Monografia no10 da Série Enfoques Teóricos. Porto Alegre: Instituto de Física da UFRGS, 1995.

ONUCHIC, L. R. Ensino-Aprendizagem de Matemática através da Resolução de

Problemas. Bicudo, M. A. V. (Ed.). Pesquisa em Educação Matemática. São Paulo: Editora UNESP. cap.12, pp.199-218, 1999.

SINGER, P. Introdução à Economia Solidária. São Paulo: Editora Fundação Perseu Abramo, 2002. 


\section{Desafios da psicologia no Brasil}

\section{NOTAS}

Notas 1

A aplicação desta oficina foi coordenada pela primeira autora deste trabalho e teve também a participação da terceira e se deu através de um minicurso carga horária total de 18 horas, que se deu fora do ambiente do EES, diferentemente da atuação focada neste trabalho que ocorreu no próprio EES. 


\section{Capítulo 40}

\section{ECOVILAS E CIDADES EM TRANSIÇÃO: CRIANDO SUSTENTABILIDADE NO MEIO URBANO}

DOI: $10.37423 / 200200249$

Taisa Mattos

taisapmattos@gmail.com

Cecilia de Mello e Souza

cdemelløesouza@gmail.com

Resumo: Vivemos um momento de crise global, onde o atual modelo de desenvolvimento se mestra insustentável_A transição para outro estilo de vida e modo de desenvolvimento é emergencial. Para isso, precisamos não apenas de conscientização, mas de engajamento comunitário e de uma àção coletiva para garantir a possibilidade da vida no planeta.

Ecovilas são comunidades intencionais com foco no desenvglvimento local sustentável. São experiências ru rais e urbanas, que buscam a sustentabilidade em seus diversos aspectos. Com princípios semelhantes, o Movimęhto Cidades em/Transição mostra como é possível transformar nossas cidades através da mobilização e/do engajamento social, da reduçầo do consumo e do impacto ambiental, e do fortaledimento de economias locais.

Buscaremos evidenciar os princípios e as connexóes/entre ambos-os movimentos socialis e como estão contribuindo de forma efetiva para o redesenho do modo de vida nas-cidades, criando sustentabilidade e-methorando a qualidade de vida.

Palavras-Chave: Ecovilas, Cidades em Transição, Sustentabilidade, Resiliência, Ação Coletiva. 


\section{Desafios da psicologia no Brasil}

\section{INTRODUÇÃO}

\section{GLOBAL E NECESSIDADE DE TRANSIÇÃO}

Não duvide que um pequeno grupo comprometido de pessoas pode mudar o mundo. De fato, é o que sempre acontece! (Margaret Mead)

A escassez dos recursos naturais, aliada a perda da biodiversidade, a extinção de diversas espécies, as mudanças climáticas, a crescente desigualdade social e consequente violência, entre outros, nos mostram que o atual modelo de desenvolvimento não pode ser levado adiante. É urgente a transição para uma nova forma de desenvolvimento, capaz de contribuir para a manutenção da vida no planeta. Uma sociedade, para ser sustentável, precisa ser menor, mais simples e integrada, contando com a participação de seus membros, além criar uma economia local forte e utilizar tecnologias ecológicas para minimizar o uso dos recursos naturais e seu impacto ambiental (TRAINER, 2000).

Na maior parte dos discursos, o conceito de desenvolvimento está profundamente relacionado à noção de crescimento econômico, que depende do consumo crescente de energia e recursos naturais. Essa busca por um crescimento econômico contínuo, gerou um aumento sem precedentes da escala das atividades econômicas na modernidade, e efeitos adversos sobre o ecossistema global, desdobrando-se em toda uma crise referente aos limites do crescimento (MEADOWS, 1973), no contexto ambiental. $\mathrm{O}$ desenvolvimento merece ainda ser analisado a partir de outras perspectivas, como a socioeconômica, por exemplo. O paradigma desenvolvimentista, impulsionado por princípios materialistas e competitivos, culminou em enormes desigualdades sociais, guerras e conflitos. O que vemos é um esfacelamento do tecido social, quando o que importa é acumular bens materiais e não reforçar laços sociais e garantir uma vida de qualidade para todos. Com a premissa de desenvolvimento global, surgem ainda outros desafios, referentes aos aspectos culturais, pois as estratégias de globalização fragilizam os laços sociais e as tradições locais, ao utilizarem-se de modelos universais (HALL, 2003), além de tecnologias para mediarem nossas interações. Existem ainda outros desafios mais sutis, relacionados a questão da verdadeira liberdade de escolha (SEN, 2000), uma vez que os referenciais foram deslocados e as "preferências" individuais e coletivas passam a ser direcionadas pelos meios de comunicação de massa (EVANS, 2001).

A necessidade de transição é urgente e um dos grandes entraves é social (GILMAN, 2013), visto que, para fazer frente à situação atual, precisamos de organização comunitária e responsabilidade 


\section{Desafios da psicologia no Brasil}

compartilhada (TRAINER, 1997), além de desenvolver novas habilidades e espírito coletivo (TRAINER, 2000). É preciso reintroduzir valores comunitários, senso de comunidade e apoio mútuo (KOZENY, 1995). Muitos questionam os valores da cultura atual, mas depois de tantos anos de dominação sutil, (FOUCAULT, 1979) já não sabemos como proceder. Precisamos despertar para a transição da cultura consumista, do TER, para a uma cultura do SER. É urgente voltar a valorar a vida, em todas as suas formas. O que implica em uma boa qualidade de vida é ter o suficiente (TRAINER, 2000) e não degradar o planeta e ignorar o próximo. O consumo exacerbado e a falta de consciência nos torna coresponsáveis por essa crise generalizada. É preciso o engajamento e a mobilização social para que possamos assumir o nosso poder de ação frente a tantos desafios.

Segundo Hannah Arendt, "o poder resulta da capacidade humana, não somente de agir ou de fazer algo, como unir-se a outros e atuar em concordância com eles." (ARENDT, 1970 apud HABERMAS, 1980, p. 101). Implica na capacidade das pessoas chegarem a um acordo em relação a uma ação coletiva, a partir do diálogo. Esse poder relacionado à interação social, à comunicação e à capacidade de mobilização para uma ação conjunta em beneficio de todos, está cada vez mais escasso em nossa sociedade, gerando consequências diversas, como a apatia, o isolamento e o conformismo, que contribuem para o agravamento da crise na qual estamos imersos. Em meio a tamanho caos, alguns grupos e movimentos sociais emergem buscando fazer frente a tais desafios. Estão no exercício de criar e testar possíveis soluções ao implementarem novas formas de relacionamento entre as pessoas e com o ambiente, resgatando valores e princípios comunitários, e propondo outras estruturas sociais e econômicas, como é o caso do Movimento de Ecovilas (BANG, 2013; MATTOS, 2018) e das Cidades em Transição. São movimentos distintos entre si, mas com princípios e práticas semelhantes. Seu diferencial em relação a outros movimentos sociais está no engajamento coletivo e na ação por um propósito comum.

Essas experiências de grupos de pessoas, tornam-se espaços importantes para se desenvolver e aprimorar novos modos de vida possíveis (TRAINER, 1997). A partir da conscientização, do engajamento e do fortalecimento do tecido social e, utilizando-se de ferramentas e tecnologias socioambientais e econômicas voltadas para o desenvolvimento local sustentável, as Ecovilas e as Iniciativas de Transição propõe uma nova forma de vida e interação, partindo de outros valores e princípios éticos, contribuindo para construção da cultura da sustentabilidade (WAGNER, 2013). Ao contrário de outros movimentos sociais, são 'agentes de mudança'. Ao invés de lutar contra, ou de simplesmente cruzar os braços e esperar que o poder público resolva, colocam a mão na massa. Estão 


\section{Desafios da psicologia no Brasil}

não apenas se empoderando a partir de sua prática cotidiana, mas criando exemplos locais que podem ser adaptados e replicados globalmente. Nesse sentido, apontam possíveis caminhos a serem seguidos, ao proporem uma nova forma de vida e interação comunitária, pautada em uma nova visão de mundo, para a criação de modos de vida não apenas sustentáveis, mas harmônicos e resilientes ${ }^{1}$, que podem ser perpetuados.

Muito se fala hoje em sustentabilidade, mas não há uma definição consensual teórica em relação ao termo. Geralmente fala-se em criar sistemas que possam ser continuados em um futuro indefinido (SIRNA, 2000). Uma das definições mais usadas de sustentabilidade é "satisfazer as necessidades atuais sem comprometer a habilidade das futuras gerações de satisfazerem as suas" (UNITED NATIONS, 1987, tradução nossa). Atualmente, precisamos não apenas buscar a sustentabilidade, mas sim, tornar nossas comunidades e cidades resilientes, capazes de se regenerar após inúmeros distúrbios.

Esse artigo pretende evidenciar os princípios e práticas de ambos os Movimentos: das Ecovilas e Cidades em Transição, revelando a importância desses movimentos sociais que trazem soluções comunitárias (botton up) de novas formas de se viver e interagir nas cidades. São movimentos que, a partir de suas práticas, apresentam soluções, contribuindo, de forma efetiva, para a transição para um outro modo de vida, fortalecendo as comunidades locais e criando sustentabilidade no meio urbano.

\section{O MOVIMENTO DE ECOVILAS: DEFINIÇÃO, PRIORIDADES, ORIGEM E CONTRIBUIÇÕES}

Ecovilas representam uma visão completamente nova de desenvolvimento, com diferentes fundamentos econômicos, usos de energia, estruturas sociais e valores daqueles da sociedade industrial. Elas fornecem modelos para se viver próximos da terra e em comunidade uns com os outros. (NORBERG-HODGE, 2002 - tradução nossa).

O movimento das Ecovilas emerge globalmente como uma resposta consciente ao problema extremamente complexo de como mover a sociedade em direção a um modo de vida sustentável (KIRBY, 2004). Ele funciona como catalisador de uma mudança ética, ambiental, econômica, política e social, e aos poucos se torna a convergência de outros movimentos contemporâneos que também questionam o sistema atual e os valores da nossa sociedade (KOZENY, 1995). As Ecovilas nascem no contexto da globalização e da crise dos limites do crescimento (MEADOWS, 1973), e estão fortemente vinculadas a este momento histórico. O discurso da sustentabilidade e o interesse pelo desenvolvimento de tecnologias socioambientais, as reflexões em torno de identidades e práticas locais, além da noção de rede e os instrumentos de interconexão global, o empoderamento social e 


\section{Desafios da psicologia no Brasil}

uma maior integração com as demais organizações e instituições civis e governamentais estão presentes nos princípios e práticas das Ecovilas (MATTOS, 2018).

O movimento Ecovilas tem suas raízes e busca inspiração em diferentes linhagens. Entre elas: as comunidades intencionais religiosas e espirituais; o movimento pacifista antinuclear; o movimento dos direitos civis: raciais e feministas; o movimento ambientalista; o movimento Hippie; os Kibbutz (Israel) e Co-housings (Dinamarca); o movimento da Transdisciplinaridade, os princípios Gandhianos, entre outros (DAWSON, 2006). Todos esses movimentos questionavam os valores dominantes da sociedade pós-industrial: produção desenfreada, consumismo, desigualdade social, guerras, etc.

Ecovilas podem ser definidas como comunidades intencionais, multifuncionais, cujos princípios e práticas se voltam para a sustentabilidade, em suas diversas dimensões (GILMAN, 1991). São experiências de grupos que se unem, partindo de um propósito comum e de valores partilhados, para viver uma vida coletiva (KOZENY, 1995), a partir do trabalho cooperativo, do fortalecimento dos laços sociais e, principalmente, da busca pela sustentabilidade. Procuram criar relações harmônicas, respeitando os ecossistemas e os contextos socioculturais nos quais estão inseridas.

As Ecovilas possuem um forte senso de comunidade, talvez como resposta à alienação e à solidão da modernidade (DAWSON, 2006). Consomem menos e são um exemplo do viver simples (TRAINER, 2000; DAWSON, 2006; SEVIER, 2008). Buscam reduzir o uso de combustíveis fósseis, gerando a maior parte da energia possível. Produzem seus alimentos orgânicos, reciclam seus resíduos (fazem compostagem, etc), constroem com materiais locais, de baixo impacto, criam sistemas de tratamento de água, além de trabalharem ativamente na restauração ambiental (CHRISTIAN, 2003; DAWSON, 2006; KASPER, 2008). Também revitalizam os sistemas de governança participativos, em escala comunitária, buscando a inclusão social (DAWSON, 2006). São reconhecidas como centros de experimentação e treinamento (DAWSON, 2006; GILMAN, 2013), como verdadeiros laboratórios de sustentabilidade (OVED, 2013), uma vez que propõem inovações e desenvolvem tecnologias socais e ambientais, além de práticas econômicas locais, que podem ser replicadas em outros contextos.

As Ecovilas propõe um novo modelo de desenvolvimento, que leva em conta as questões ambientais e sociais. Buscam implementar uma nova economia, com princípios e ferramentas distintas. O que está no centro é o cuidado com a vida. Importam as relações, a saúde pessoal e comunitária, a educação, a preservação e recuperação do meio ambiente, a mobilização e engajamento para uma construção coletiva. Vale ressaltar que a típica Ecovila não existe. Cada uma tem o seu visual e caráter próprios, de acordo com sua localização, o clima, a cultura local, o tamanho do espaço, entre outros 


\section{Desafios da psicologia no Brasil}

(SEVIER, 2008). Trata-se de um movimento repleto de diversidade, com experiências rurais, urbanas, em subúrbios, vizinhanças, presentes em todas as partes do mundo, incluindo culturas e climas variados. De tribos tradicionais à retrofits urbanos, projetos recém criados ou já estabelecidos (JOSEPH, BETES, 2003; DAWSON, 2006). Ecovila é um processo, assim como uma visão (SIRNA, 2000). São experimentos em escala humana, onde é possível as pessoas conhecerem-se umas as outras (GILMAN, 1991; SIRNA, 2000) e influenciarem as decisões comunitárias (CHRISTIAN, 2003). Uma Ecovila se propõe a prover casa, oportunidades de trabalho e de crescimento pessoal e espiritual, criando uma comunidade o mais auto-suficiente possível (GILMAN 1991; CHRISTIAN, 2003).

O Conceito de Ecovila oferece um único modelo, embora com múltiplas manifestações locais. No núcleo do conceito está a celebração da diversidade cultural, espiritual, ecológica e o impulso de se recriar comunidades humanas onde as pessoas possam redescobrir relações saudáveis e sustentáveis consigo mesmas, com a sociedade e o planeta. O modelo das Ecovilas combina um contexto de apoio sociocultural com um estilo de vida de baixo impacto, ecologicamente sustentável, fomentando a educação e a saúde integral, através da implementação de sistemas participativos e justos.

Ecovilas são ricas em capital humano e cultural. Priorizam as necessidades à acumulação. Os objetivos do movimento estão relacionados com as ações do dia-a-dia. Ser um exemplo e disseminar essas novas práticas e valores. O princípio Gandhiano 'Ser a mudança que queremos ver' está profundamente enraizado nas ações dos 'ecovileiros' que acreditam que a mudança social será conquistada pela construção e demonstração de outro modo de vida (KIRBY, 2004). As Ecovilas funcionam como verdadeiros agentes de mudança nas áreas onde se instalam, disseminando seus princípios e práticas (KESSLER, 2008). Há um desejo de resgatar valores das culturas tradicionais (SEVIER, 2008) e somar isso a tecnologias de ponta, buscando demonstrar um novo modelo de desenvolvimento.

O maior objetivo das Ecovilas está relacionado à sustentabilidade. É vital para a identidade coletiva ser um modelo de sustentabilidade (ERGAS, 2010) As Ecovilas tem sido consideradas os melhores locais para se aprender sobre sustentabilidade, uma vez que vivenciam a sustentabilidade na prática da vida cotidiana, em seus diversos aspectos (KESSLER, 2008), e a educação tem sido um dos fatores de maior sucesso em criar pontes com o mainstream, tornando-se a base da economia de diversas Ecovilas (DAWSON, 2006). É através dos programas e treinamentos que as Ecovilas vêm ganhando reconhecimento e legitimidade (KESSLER, 2008).

Outros fatores de destaque nas Ecovilas são a importância da relação com a natureza e a noção de interdependência (KIRBY, 2004; KASPER, 2008; ERGAS, 2010). As Ecovilas apresentam um forte senso 


\section{Desafios da psicologia no Brasil}

de reconexão com a natureza e de responsabilidade para com o mundo natural (SEVIER, 2008). Promovem estilos de vida que regeneram ao invés de diminuir a integridade do meio ambiente (KASPER, 2008). Uma Ecovila é desenvolvida de tal maneira que os negócios, as estruturas físicas e tecnológicas não interfiram na habilidade inerente à natureza de manter a vida.

Ao contrário das comunidades tradicionais, Ecovilas não são produtos dos seus meios (ERGAS, 2010). São grupos formados por pessoas vindas, em sua maioria, de contextos urbanos, com perfil de "classe média" (FOTOPOULOS 2000; KIRBY, 2004), que conscientemente têm optado por buscar uma nova forma de viver, baseada nas relações sociais, na simplicidade e no cuidado com os impactos de suas ações (SEVIER, 2008). Muitas das Ecovilas já são Best Practice da ONU (reconhecidas como melhores práticas), ditando caminhos possíveis (SEVIER, 2008). Apesar de não existir uma 'Ecovila ideal' (JACKSON, 2004), pois são experiências em construção (JOSEPH, BETES, 2003; CHRISTIAN, 2003; JACKSON, 2004; SEVIER, 2008), as Ecovilas estão estabelecendo as fundações de uma nova cultura (SEVIER, 2008), exibindo uma ética distinta (KASPER, 2008;SEVIER, 2008), sendo este um dos grandes legados do Movimento: relembrar que somos seres interdependentes, e criar modelos cooperativos que possam ser perpetuados, fazendo frente a atual cultura dominante.

\section{A REDE GLOBAL DE ECOVILAS (GEN) E AS EXPERIÊNCIAS NO BRASIL E NO MUNDO}

A Rede Global de Ecovilas (GEN, em suas iniciais inglesas) foi fundada em 1995, com o objetivo de encorajar o desenvolvimento de assentamentos sustentáveis ao redor do mundo. A GEN possui um papel crucial na difusão dos princípios e práticas do Movimento, além de conectar as diversas iniciativas e projetos relacionados (SEVIER, 2008). Realiza serviços internos e externos de comunicação, facilitando o fluxo e a troca de informações entre Ecovilas e outros projetos afins (a partir da criação de diretórios e informativos, e também da realização de encontros e conferências internacionais); faz articulações em rede e coordenação de projetos em áreas relacionadas a assentamentos sustentáveis; além de se dedicar a cooperação global e parcerias, especialmente com as Nações Unidas (DAWSON, 2006). É interessante atentar para o fato de que o Movimento de Ecovilas já emerge enquanto rede, e dessa forma se articula e se expande (GEN, s.d).

Apesar de diversas iniciativas estarem formalmente registradas no site da GEN, parece não haver ainda um mapeamento detalhado das Ecovilas em cada país, indicando quantas pessoas vivem em cada uma, o tamanho dos locais, seu modo de organização, entre outros (BÔLLA, 2012). Ninguém sabe precisar, ao certo, o número de experiências, mas estima-se que haja cerca de 10 mil Ecovilas pelo mundo (GEN, 


\section{Desafios da psicologia no Brasil}

s.d). De uma vila medieval na Itália, a uma antiga sede do Serviço Secreto Soviético na Alemanha, incluindo vilas tradicionais no Senegal e comunidades espirituais no Sri Lanka, experiências muito simples ou altamente tecnológicas, cada uma com seu propósito e desafios próprios. Existem experiências com aproximadamente 20 pessoas, como é o caso de Terra Una (Brasil) ou Torri Superiori (Itália), assim como pequenas cidades, como Auroville (Índia) com mais de 2.500 integrantes.

Apesar da maior parte das iniciativas serem em contextos rurais, destaca-se a efetividade das Ecovilas urbanas na integração desses princípios e práticas em cidades e subúrbios, onde está hoje localizada a maior parte da população mundial. Podemos citar como exemplo, LA Ecovillage, em Los Angeles (EUA) e Ecovillage at Ithaca, localizada no subúrbio de Ithaca, NY. No Brasil não há registros de experiências consolidadas de Ecovilas urbanas.

A pesquisa sobre as Ecovilas ainda é um fenômeno recente, o que não é de se admirar, uma vez que o termo surge na década de 90 . É um tema de crescente interesse para estudos e publicações acadêmicas, principalmente do ano 2000 para cá, (WAGNER, 2012), ganhando também visibilidade a partir da divulgação das experiências na mídia, e dos relatos e impressões daqueles que estiveram em uma Ecovila, seja para visitar ou fazer algum treinamento. A partir dos estudos, que são, em sua maioria, dissertações de mestrado, incluindo também teses de doutorado, projetos de graduação e artigos publicados (WAGNER, 2012), podemos observar a abrangência do movimento, com iniciativas presentes em todos os continentes e em diversos países, embora a grande maioria esteja situada em países industrializados, de cultura ocidental, principalmente na Europa e nos EUA (FOTOPOULOS, 2000; WAGNER, 2012).

No Brasil, existem algumas iniciativas, a maior parte ainda em fase de estruturação. O Movimento chegou oficialmente ao Brasil em 2002, quando foi realizado o primeiro Treinamento de Ecovilas, no então Centro de Vivências Nazaré (atual Nazaré UNILUZ), no interior de São Paulo. Após o primeiro Treinamento, foram realizados mais dois, nos anos que se seguiram (2003 em Belo Horizonte e 2004 itinerante pelo Brasil), capacitando diversos interessados e fazendo emergir a rede nacional, ENA Brasil. Nessa época, algumas Ecovilas foram criadas e antigas comunidades e institutos de Permacultura foram adaptados para que pudessem ser considerados como tal.

Em 2006, foi lançado em São Paulo, e também mundialmente, o Gaia Education - um programa dedicado a investigar a sustentabilidade em diversos aspectos, a partir do conteúdo dos antigos Treinamentos de Ecovilas, mas muito mais abrangente, que passou a ser realizado anualmente, e aos poucos, se espalhou por diversos Estados brasileiros, capacitando os interessados em um modo de 


\section{Desafios da psicologia no Brasil}

vida sustentável. O currículo divide-se em quatro áreas: social, ecológica, econômica e cultural (denominada visão de mundo), dando um panorama geral das dimensões que devemos explorar na busca pela sustentabilidade. Apesar de inspirado nas experiências das Ecovilas, o programa é extremamente adaptável, podendo ser aplicado em outras organizações e contextos. É interessante observar que, ao contrário de outros países, onde o programa é geralmente realizado em regime de imersão, longe dos centros urbanos, a maior parte dos programas no Brasil ocorreu em cidades como São Paulo, Rio de Janeiro, Brasília, Curitiba, Salvador, Porto Alegre e Belo Horizonte, e apesar de potente na difusão dos princípios do movimento, não resultaram efetivamente na criação de novos experimentos comunitários, mas sim na aplicação dos princípios e ferramentas em outras iniciativas e organizações, além de mobilizarem pessoas para integrarem Ecolivas já existentes.

\section{DESAFIOS DO MOVIMENTO DE ECOVILAS}

Ao longo dos anos, diversos desafios se evidenciaram no caminho dos ecovileiros, de desafios ecológicos, de preservar o meio ambiente, evitar impactos ambientais, buscar fontes de energia renováveis, reciclar e compostar o lixo, tratar as águas e produzir alimentos saudáveis, até os desafios econômicos, de criar uma economia local vibrante, capaz de gerar os recursos necessários para a implementação e manutenção do projeto, sem explorar as pessoas ou o meio ambiente. Existem ainda, os desafios de governança, de se estabelecer efetivamente processos participativos e, antes disso, de se criar uma visão comum para o grupo. Sem contar as inúmeras mudanças necessárias para se adaptar a esta nova forma de se viver, que demanda tempo, recursos e planejamento (GILMAN, 1991).

Nas comunidades urbanas, os principais desafios são o custo das propriedades e as questões legais. Existem muitas leis e regulamentações que fazem as inovações serem ilegais ou demandem muita burocracia (KOZENY, 1995) Transformar espaços urbanos é geralmente mais difícil. (JOSEPH, BATES, 2003). As Ecovilas urbanas são normalmente adaptadas às construções já existentes, e não construídas (SEVIER, 2008) As vantagens é que possibilitam aos membros continuarem integrados a suas vidas e trabalhos nas cidades, favorecem as trocas entre a comunidade e a cidade e recebem um maior número de visitantes, tornando-se mais vibrantes socialmente (KASPER, 2008). Já nas regiões rurais, as propriedades são mais baratas e as regras menos rígidas (KASPER, 2008). Geralmente as iniciativas adquirem um visual mais próximo ao sonho coletivo, uma vez que podem testar as diversas tecnologias ecológicas. Ao mesmo tempo, os desafios econômicos são maiores, devido ao isolamento/distância, e também por possuírem um número menor de membros. Mesmo assim, são 


\section{Desafios da psicologia no Brasil}

as mais comuns, embora as cidades e subúrbios precisem mais ter experimentos inspiradores como esses por perto. (TRAINER, 2000)

Muita atenção tem sido dada aos aspectos ecológicos das Ecovilas, embora as Ecovilas dediquem, pelo menos, a mesma atenção às questões sociais, relacionadas principalmente a promoção de uma cultura de confiança, a busca por criar processos efetivos e participativos de tomada de decisão, e a gestão de conflitos (DAWSON, 2006). É fundamental destacar que, se os relacionamentos na comunidade não se sustentam, mais cedo ou mais tarde, ela morrerá (KESSLER, 2008). Apesar de algumas Ecovilas já serem referências no cuidado de alguns desses aspectos, tendo criado inclusive ferramentas próprias, essa ainda é uma área de vital importância para se aprofundar as experiências (DAWSON, 2006).

Muitas habilidades são necessárias para garantir a vitalidade comunitária, mas uma comunicação saudável, processos grupais claros e saber lidar com conflitos são o coração de uma comunidade saudável (CHRISTIAN, 2003). O diálogo constante é uma peça chave no processo de organização da ação coletiva e no estabelecimento dos objetivos do grupo (MARQUES NETO, 2005). É preciso não só garantir tempo e espaço para as conversas

e as relações interpessoais. O fato de não estarmos habituados a convivência comunitária e de termos fracas habilidades de comunicação, somados aos condicionamentos sociais da cultura vigente acaba por gerar questões emocionais que muitas vezes levam a conflitos graves. Não dedicar tempo suficiente para os processos grupais é um dos motivos que leva inúmeras comunidades ao fracasso (CHRISTIAN, 2003). É fundamental dedicar-se ao aprendizado e aprofundamento de ferramentas e processos para cuidar das questões sociais e da gestão comunitária, solidificando as bases dessa nova cultura.

Apesar das Ecovilas terem bastante diversidade cultural, com membros oriundos de diversos países e regiões, uma questão a ser trabalhada é conquistar uma diversidade étnica e socioeconômica. Pesquisas indicam que não há diversidade étnica na maioria das comunidades (KASPER, 2008) e que os 'ecovileiros' são, em sua maioria, advindos da "classe média" (FOTOPOULOS 2000; KIRBY, 2004). Como atrair pessoas com outros backgrounds continua a ser uma questão a ser equacionada pelas Ecovilas.

Outra questão a ser destacada refere-se à definição de Ecovila, que é bastante ampla e traz direcionamentos, mas não critérios claros. A partir de algumas características primordiais, como o foco na vida comunitária, a busca pela sustentabilidade e o fato de geralmente serem espaços voltados para a educação (DAWSON, 2006), podemos identificar algumas iniciativas, mesmo assim, vale 


\section{Desafios da psicologia no Brasil}

ressaltar que são experiências, muitas vezes, bastante distintas entre si, uma vez que cada uma tem o seu propósito específico. Além de nos depararmos com experiências completamente diversas que se denominam Ecovilas, existem ainda as que, à princípio, poderiam ser consideradas Ecovilas, mas que não se identificam com o conceito ou seguem integradas a outros movimentos, e também, as que se dizem Ecovila, mesmo sem atender a alguns aspectos fundamentais, como o foco na vida comunitária, por exemplo. É o caso de alguns condomínios residenciais, no Brasil, que por utilizarem tecnologias ecológicas adequadas, se denominam Ecovila, embora sejam apenas um agrupamento de residências particulares, ou ainda, projetos de uma única família ou casal, que possuem a vontade da vida comunitária, mas nunca conseguiram se efetivar enquanto comunidades.

\section{O MOVIMENTO CIDADES EM TRANSIÇÃO: BREVE HISTÓRICO, RECONHECIMENTOS, PRINCÍPIOS E} INGREDIENTES DA TRANSIÇÃO

O movimento Cidades em Transição ou Transition Towns, surgiu no Reino Unido, em 2005/2006, a partir da iniciativa do professor e permacultor inglês Rob Hopkins. Enquanto lecionava permacultura na Faculdade Kinsale Further Education em Kinsale, na Irlanda, Rob e seus alunos desenvolveram um “Plano de Ação para o Declínio da Energia” em Kinsale (Energy Descent Action Plan ou EDAP), dando as diretrizes de como a cidade irlandesa de West Cork poderia reduzir seu consumo energético de combustíveis fósseis, como resposta ao pico do petróleo. O EDAP apresenta uma proposta de ação e um cronograma de execução, abrangendo os mais diversos aspectos da vida na cidade, como alimentação, energia, turismo, educação e saúde. O relatório foi uma das primeiras iniciativas desse tipo em todo o mundo, sendo elaborado de maneira a permitir que outras comunidades e cidades pudessem se inspirar no modelo e iniciar um processo semelhante. Recebeu o prêmio 'Roll of Honour' do Fórum Ambiental de Cork, sendo adotado formalmente após votação unânime do Conselho da Cidade de Kinsale, no final de 2005. A iniciativa, que surge no âmbito acadêmico, foi abraçada pela municipalidade e implentada, pavimentando os caminhos da transição em relação à redução do consumo de energia e à necessidade de substituição da matriz energética dos combustíveis fósseis para outras matrizes renováveis (BRANGWYN; HOPKINS, 2008).

De volta a Totnes, em Devon, sul da Inglaterra, sua cidade natal, Rob dá início ao projeto da Cidade em Transição de Totnes (ou TTT, em suas iniciais inglesas: Transition Town Totnes), a primeira Cidade em Transição no mundo. O projeto começou no final de 2005 com um programa intensivo de conscientização da comunidade local em relação ao Pico do Petróleo e as Mudanças Climáticas, e um convite ao engajamento comunitário na busca de soluções. Inspirando-se no EDAP, parte do princípio 


\section{Desafios da psicologia no Brasil}

que uma cidade que consome menos energia e recursos, se adequadamente planejada e estruturada, pode se tornar mais forte, eficiente e abundante do que antes, contando com a capacidade coletiva da comunidade local de criar resiliência através de um processo de "relocalização" da maior parte dos recursos que precisa, quebrando a dependência dos sistemas globalizados de alimentação, energia, transporte, saúde e habitação. O Lançamento Oficial da Cidade em Transição de Totnes ocorreu em setembro de 2006. A partir daí, diversas comunidades britânicas adotaram oficialmente o Modelo de Transição, aumentando sua resiliência local e reduzindo sua pegada ecológica, abrindo caminhos para o redesenho de nossas cidades e consolidando o Movimento de Transição, que rapidamente se espalhou pelo mundo (BRANGWYN; HOPKINS, 2008).

Na perspectiva do Movimento, a necessidade de transição evidencia-se a partir de 4 reconhecimentos. São eles:

- A inevitável redução do consumo de energias fósseis - A vida com menos energia é inevitável e é melhor nos planejarmos em relação a isso do que sermos pegos de surpresa.

- A necessidade de re-localização dos recursos que precisamos para viver, criando resiliência local - Perdemos a capacidade de lidar com os choques externos quando tudo o que precisamos para viver vem de fora. É fundamental trazer para perto os recursos que realmente precisamos.

- A urgência em relação a uma ação coletiva em resposta aos desafios atuais. Precisamos agir por nós mesmos e precisamos agir agora. Ao invés de ficar se lamentando ou se queixando, devemos nos unir e agir. Sair do discurso para a prática.

- A crença na existência de uma "genialidade coletiva", na força e no potencial criativo dos grupos. Ao liberarmos o gênio coletivo da comunidade podemos desenhar formas de viver mais enriquecedoras e resilientes.

As Iniciativas de Transição são um exemplo do princípio de se pensar globalmente e agir localmente. Através do fortalecimento da comunidade local e do redesenho de espaços, ações e relações, estas iniciativas criam um processo que engaja pessoas e instituições para, juntos, pensarem e implementarem as ações necessárias - de curto, médio e longo prazo - para fazer frente aos desafios atuais como as mudanças climáticas, o pico do petróleo, a crise econômica, entre outros. O objetivo do Movimento de Transição é a conscientização e o engajamento comunitário para a implementação 


\section{Desafios da psicologia no Brasil}

de ações visando tornar as cidades resilientes, menos dependentes, mais harmônicas e integradas à natureza e mais resistentes a crises externas, tanto econômicas como ecológicas.

O Modelo de Transição inclui princípios e práticas, inspirados na Permacultura, que foram criadas ao longo do tempo através da experiência e observação de comunidades a medida em que avançavam no caminho do desenvolvimento sustentável, criando resiliência local e reduzindo o impacto ambiental. O Movimento parte de 7 Princípios. São eles:

1. Manter uma visão positiva do futuro, mesmo diante do caos.

2. Sensibilizar as pessoas, trazendo consciência em relação aos desafios atuais.

3. Inclusão. Precisamos de cada um. Todos são necessários para fazermos a transição.

4. Resiliência. Construir comunidades fortes e o mais auto-suficientes possível. Criar resiliência local.

5. A solução é do mesmo tamanho que o problema. Se o problema é enorme, a solução também será. Essa perspectiva ajuda a manter a tranquilidade frente aos desafios.

6. A transição que precisamos é interna e externa. Precisamos mudar a forma de fazer e também a forma de pensar. É importante rever hábitos e valores, não apenas nossas ações.

7. Criar um modelo viral, algo que possa se espalhar rapidamente, como um vírus, sendo facilmente replicado em outros locais e contextos, dada a urgência da situação.

As lições aprendidas em Kinsale deram origem ao que inicialmente chamou-se de 12 passos da Transição. Ao longo do processo tornou-se evidente que cada grupo tem seu desdobramento próprio, fazendo com que o "passo-a-passo" da transição fosse revisto. Cada passo passou, então, a ser considerado como um ingrediente, que pode ser utilizado, ou não, a partir das necessidades dos grupos. (BRANGWYN; HOPKINS, 2008)

Os ingredientes da transição passam pela formação de um grupo iniciador, estabelecendo seus fundamentos e acordos de funcionamento. Esse grupo deve servir como uma mola propulsora da transição naquela localidade, realizando ações para sensibilizar e mobilizar a comunidade, buscando engajá-la no Movimento. São grupos abertos, que ao crescer, tem por finalidade se diluir, subdividindo-se em outros pequenos grupos de trabalho, criados a partir das potencialidades e talentos dos envolvidos, e das demandas identificadas pelos próprios grupos. A proposta é de utilizarem metodologias colaborativas ao longo do processo, como a tecnologia do Espaço Aberto (Open Space) ou o Café Mundial (World Café), além de outras ferramentas participativas para facilitar 


\section{Desafios da psicologia no Brasil}

o diálogo e estimular a contribuição de todos. Os grupos definem juntos suas metas, desenvolvendo projetos e eventos, mapeando as iniciativas já existentes na localidade, e fazendo parcerias com movimentos afins, ONG's, empreendimentos e também com o poder público, para se fortalecer e legitimar a sua caminhada (BRANGWYN; HOPKINS, 2008).

Vale ressaltar que o modelo da transição é aberto, como descrito no último dos ingredientes: "Deixe ir aonde quiser ir", ou seja, trata-se apenas um modelo que traz direcionamentos, sendo a sua prática diferenciada em cada localidade, a partir das demandas e vontades de cada grupo (BRANGWYN; HOPKINS, 2008).

Durante o processo, não apenas a conscientização é importante, mas também o aprendizado de novas habilidades, como, por exemplo, aprender a plantar, a fazer compostagens domésticas, a separar o lixo e reaproveitar a água, a praticar as metodologias colaborativas, a facilitação de grupos e a mediação de conflitos, a criar redes de troca e moedas sociais, além de muitas outras práticas que não são comuns no cotidiano mainstream urbano.

Ao longo do processo torna-se evidente que o fortalecimento da comunidade local passa pelo empoderamento individual e pelo engajamento comunitário, pelo desenvolvimento de novas ferramentas econômicas, pela utilização de tecnologias ecológicas apropriadas para o uso eficiente dos recursos, e também, pela criação de novas subjetividades. Percebe-se a necessidade de honrar as tradições culturais locais, os saberes populares e os anciões, que, de alguma forma, zelaram por esse patrimônio antes de nós. Evidencia-se a necessidade do cuidado com a natureza, de buscar recuperar o controle sobre o que realmente é essencial para nossas vidas.

\section{O MOVIMENTO DE TRANSIÇÃO NO BRASIL E NO MUNDO}

O Movimento traz uma visão positiva do futuro, acreditando na ação transformadora dos indivíduos. Está hoje presente em 43 países ao redor do mundo, e em diversos Estados brasileiros. No Brasil, devido à grande extensão territorial e à densidade populacional das cidades, o movimento foi implementado por bairros, e não por cidades (TRANSITION BRASIL, s.d).

Os primeiros Treinamentos para a Transição foram realizados no Brasil no segundo semestre de 2009, em diversas localidades como: Serra (ES), Brasília (DF), Porto Alegre (RS), São Paulo (SP) e Rio de Janeiro (RJ), dando origem aos primeiros grupos de Transição no Brasil. A primeira Cidade em Transição no Brasil foi Serra, no Espirito Santo, oficializada em setembro 2009, a partir de uma parceria com as Secretarias Municipais do Meio Ambiente e de Desenvolvimento. 


\section{Desafios da psicologia no Brasil}

De lá para cá, muitos outros Treinamentos foram realizados, de norte a sul do país, expandindo o Movimento e garantindo a diversidade das iniciativas. De grupos da classe-média alta, como o núcleo da Granja Viana, em Carapicuiba (SP) para grupos de baixíssima renda, como o núcleo da Vila Brasilândia, uma favela na zona leste de São Paulo, cada um com seus objetivos e prioridades. As ações incluem a revitalização de espaços públicos, como a revitalização de uma praça com a construção de uma sala de aula ecológica e pequenas hortas, no terreno de uma escola municipal na Vila Brasilândia, o projeto "Luz nas Vielas" que embeleza becos antes obscuros da comunidade, e o plantio de mudas no Parque das Onças, zona leste de São Paulo. O grupo da Granja realiza feiras de trocas mensais, atentando para a questão do consumo, além de feiras orgânicas quinzenais, entre muitas outras atividades.

É bastante relevante o papel de cada indivíduo no processo de transição. Ressalto aqui a iniciativa de May East, a primeira treinadora brasileira do Cidades em Transição, responsável por impulsionar o Movimento no Brasil. Hoje são 5 treinadores oficiais no Brasil, contribuindo com a capacitação dos grupos de transição pelo país. Como explicita um dos princípios do movimento, a participação de cada um é fundamental, e a transição não seria possível sem a contribuição de muitas pessoas, que investem diariamente tempo e energia para fazer esta roda girar.

A Rede de Transição (Transition Network) surge para inspirar, informar, apoiar, e treinar comunidades que desejam estabelecer iniciativas de Transição. O papel da Rede de Transição é difundir o Movimento, dando suporte e capacitando os grupos na implementação da sua versão do modelo. (BRANGWYN; HOPKINS, 2008) No Brasil, a rede é impulsionada pela plataforma NING, onde estão disponíveis os materiais em português, notícias da transição, como eventos e treinamentos, além do cadastro dos grupos nacionais.

O processo de construir resiliência serve como um catalisador para repensarmos o local. Comunidades estão implementando sistemas de plantio, companhias de energias renováveis, moedas sociais (HOPKINS, 2012), como é o caso das cidades britânicas Totnes e Lewes, que criaram suas próprias moedas complementares: o Totnes pound e o Lewes pound, para fomentar suas economias. São adaptações locais para um futuro viável, que não dependem de políticas, mas da ação coletiva na direção da mudança (CONNORS, Mc DONALD, 2011). Os princípios do modelo de transição estão relacionados com os princípios do desenvolvimento comunitário: sensibilizar, ser inclusivo, trazer respostas positivas, não se posicionar contra instituições ou projetos, mas apresentar soluções viáveis. Trata-se de um movimento poderoso, que passam pelo desenvolvimento comunitário, envolve o 


\section{Desafios da psicologia no Brasil}

engajamento e participação social, além de outros princípios e formas de governança. A chave é fortalecer o local, já que é no nível local que a maior parte dos indivíduos se sente empoderado para agir (CONNORS, Mc DONALD, 2011).

É importante atentar para o poder dos grupos, das comunidades, e da grande potencialidade das pessoas unidas, com um propósito comum. A relevância da energia criativa presente nas soluções comunitárias (HOPKINS, 2012). Outro elemento decisivo é a colaboração, colaboração entre indivíduos, comunidades, governos e empreendimentos. Precisamos trabalhar juntos, partindo do local para o global, criando modelos e difundindo princípios, já que uma resposta global é necessária para realmente fazer frente aos desafios da nossa época (CONNORS, Mc DONALD, 2011).

\section{DESAFIOS, CRÍTICAS E CONTRIBUIÇÕES DO MOVIMENTO DE TRANSIÇÃO}

A quem diga que o Movimento Cidades em Transição se apropriou de redes pré-existentes e por isso se expandiu rapidamente (CONNORS, Mc DONALD, 2011). Pessoalmente, considero a articulação de redes, iniciativas e movimentos afins uma necessidade nesse momento de urgência, não vendo isso como apropriação, mas como a união dessas diversos agentes, para o fortalecimento mútuo com o propósito de atingirmos um objetivo comum.

Existem os que criticam o movimento por ser elitista, classe-média (CONNORS, Mc DONALD, 2011), embora esteja presente mesmo em comunidades carentes, como é o caso da Vila Brasilândia, no Brasil. Há ainda os que questionam as lideranças iniciais, embora não se disponham a partilhar a responsabilidade e levar os projetos adiante. Alguns criticam a existência de critérios para a oficialização das experiências, ou ainda uma suposta subordinação das experiências em relação aos pioneiros do Reino Unido. (CONNORS, Mc DONALD, 2011). O Brasil tem hoje cerca de 40 grupos de transição, sendo que, apenas 2 deles se tornaram oficiais (TRANSITION BRASIL, s.d). Os demais, não consideram a oficialização relevante, o que não os enfraquece ou os desconecta do Movimento.

Existem muitos desafios para os grupos de transição. Aqui no Brasil um dos grandes dilemas é a captação de recursos para manter os projetos funcionando. Enquanto no Reino Unido muitas iniciativas são abraçadas pelo poder público, que acaba por fomentá-las, contratando uma ou duas pessoas para levarem o projeto à diante. No Brasil, até o momento, o trabalho tem sido voluntário, o que certa forma limita a atuação dos grupos. Alguns conseguem parcerias com outras iniciativas para viabilizar suas ações, outros contam com os recursos dos próprios participantes. 


\section{Desafios da psicologia no Brasil}

Há estudos que mostram a relevância do Movimento de transição não apenas em termos de desenvolvimento comunitário, mas também trazendo benefícios para a saúde e o bem-estar das pessoas, a partir da mudança no estilo de vida. Os envolvidos com a Transição acabam por adotar hábitos mais saudáveis, como o consumo de alimentos orgânicos locais, além de se exercitarem mais, ao adotar outras formas de transporte, como a bicicleta e trabalharem no cultivo de seus próprios alimentos, por exemplo. Existem ainda os benefícios sociais e de bem estar advindos do engajamento social, relacionados ao senso de pertencimento, de segurança e apoio comunitário, além de desenvolverem novas habilidades, confiança e espírito de grupo. (RICHARDSON, 2012).

Nas iniciativas de transição, os indivíduos assumem um papel de cidadãos e não de consumidores. Desenvolvem a capacidade de trabalharem juntos e de transformar a sua realidade local (HEISKANEN, 2010). A transição promove uma mudança de comportamento, além de uma mudança de valores e visão de mundo (TAYLOR, 2012).

Em seu desdobramento o Movimento Cidades em Transição passa a ser chamado simplesmente de Movimento de Transição, dada a diversidade adquirida pelas iniciativas, presentes nas mais diversas localidades e contextos. De ruas em Transição no Reino Unido à prédios em Transição no Brasil. Toda e qualquer iniciativa é estimulada e bem-vinda.

\section{CONSIDERAÇÕES FINAIS}

Ecovilas e Cidades em Transição: intervenções sociais em territórios urbanos. Novas subjetividades, engajamento e ação coletiva para a transição.

Torna-se evidente o papel de destaque atribuído a movimentos sociais como o Movimento de Ecovilas e de Transição na criação de modelos viáveis de desenvolvimento, que, a parir de suas práticas, criam sustentabilidade social, econômica e ecológica, contribuindo para a emergência de comunidades resilientes. Não apresentam uma solução única, pois precisamos de respostas combinadas, mas são movimentos necessários para fazer frente aos desafios do séc XXI, mostrando como sensibilizar e mobilizar as pessoas para que contribuam efetivamente com a transição necessária para os nossos tempos, aprendendo novas habilidades e utilizando-se de ferramentas e tecnologias apropriadas para o redesenho econômico e ecológico de nossas cidades e comunidades.

Muitos consideram esses movimentos como sendo apolíticos (TRAINER, 2000; FOTOPOULOS, 2000; SANTOS JR, 2010; CONNORS, Mc DONALD, 2011). Parto de outra perspectiva. Vejo a contribuição para a transição para uma sociedade sustentável como uma ação política, consciente, efetiva e necessária. 


\section{Desafios da psicologia no Brasil}

De acordo com Buckminster Fuller, “A única forma de mudar algo é torná-lo obsoleto” e, para isso, é preciso criar novas formas de se fazer (GILMAN, 2013). Isso é pioneirismo e inovação. É o exercício do Movimento de Ecovilas e de Transição, contruir o novo aqui e agora e ir atraindo pessoas, gerando massa-crítica para essa mudança tão necessária (TRAINER, 2000). Dessa forma, não precisamos de confronto, mas sim, desenvolver, aprimorar e replicar modelos viáveis para realmente contribuição com a transição para uma sociedade sustentável (TRAINER, 2000). Pelas estratégias utilizadas, os movimentos não são visto como perigoso pelo status quo (KIRBY, 2004), o que é uma vantagem na a difusão de seus princípios e práticas.

Conforme artigo escrito por Madeleine Bunting no The Guardian:

"Se quiser ter um lampejo dos tipos de lugares fora do mainstream onde nas ovas políticas estão sendo incubadas, olhe para o Movimento de Transição. (...) Não é tão difícil de ver porque os políticos estão tão interessados. O Movimento de Transição está engajando as pessoas de forma que as políticas convencionais tem fracassado em fazer. Gera emoções que não tem sido vistas na vida política há um bom tempo: entusiasmo, idealismo e comprometimento apaixonado" (BUNTING, 2009 apud HOPKINS, 2012, p. 75 - tradução nossa).

É importante ressaltar que a possibilidade de sociedade sustentável depende não apenas de nossa ações, mas de como pensamos, daí a importância de se criar novas subjetividades para manter e reforçar uma visão de mundo sustentável e resiliente (KASPER, 2008).

\section{REFERÊNCIAS BIBLIOGRAFICAS}

ARROW, K. et al. Economic growth, carrying capacity, and the environment. Science, 268, p. 520-521, 1995.

BANG, Jan Martin. A Change of Direction? In: MELTZER, Graham (Ed). Conference Proceedings. Proceedings of the 11th International Communal Studies Association Conference, ICSA 2013 Communal Pathways to Sustainable Living. P. 9. The Findhorn Foundation, Forres, UK, 2013.

BÔLLA, Kelly. Perspectivas da Visão Transdisciplinar Holística e suas contribuições para a construção de uma sociedade ecológica: o caso da Ecovila Terra Una, Liberdade - MG. Dissertação (Mestrado) Programa de Pós-Graduação em Ciências Ambientais da Universidade do Extremo Sul Catarinense (UNESC), Criciúma, SC, 2012.

BRANGWYN, Ben ; HOPKINS, Rob. Manual das Iniciativas de Transição - como se tornar uma Cidade em Transição, um Município, Distrito, Vila, Comunidade ou mesmo uma Ilha. Versão: 26. Tradução para o Português de Christina Pinheiro. Dezembro 2008. Disponível 


\section{Desafios da psicologia no Brasil}

em: http://transitiontowns.org/TransitionNetwork/TransitionNetwork\#primer. Acesso em outubro de 2014.

CHRISTIAN, Diana Leafe. Creating a Life Together: Practical Tools to Grow Ecovillages and Intentional Communities. New Society Publishers, 2003.

CONNORS, Phil; Mc DONALD, Peter. Transitioning communities: community, participation and the Transition Town movement. Community Development Journal Vol. 46, No 4, pp. 558-572. Oxford University Press, 2011.

DAWSON, Jonathan. Ecovillages: New Frontiers for Sustainability. Green Books, 2006

ERGAS, Christina. A Model of Sustainable Living: Collective Identity in an Urban Ecovillage. Organization \& Environment, Vol.23(1), pp.32-54, 2010.

EVANS, P. Collective capabilities, culture and Amartya Sen's Development as Freedom, Studies in Comparative International Development 37 (2), Symposium on Development as Freedom by Amartya Sen. 2002.

FOTOPOULOS, Takis. The Limitations of Life-style Strategies: the Ecovillage 'Movement' is NOT the Way Towards a New Democratic Society. Democracy \& Nature 6.2 287-308, 2000.

FOUCAULT, M. Soberania e Disciplina. Curso do Collège de France, 14 de janeiro de 1976. In: Microfísica do Poder. Rio de Janeiro: Graal, 1979.

GAIA EDUCATION. Disponível em: <www.gaiaeducation.net> Acesso em: janeiro 2014.

GEN. Global Ecovillage Network. <http://gen.ecovillage.org > Acesso em: dezembro de 2013.

GUILMAN, R. et al. Ecovillages and Sustainable Communities. A Report for Gaia Trust by Context Institute; Bainbridge Island, WA, 1991.

. Keynote Address: The Dynamic Planetary Context for Intentional Communities. In: MELTZER, Graham (Ed). Conference Proceedings. Proceedings of the 11th International Communal Studies Association Conference, ICSA 2013 - Communal Pathways to Sustainable Living. P. 13-35. The Findhorn Foundation, Forres, UK, 2013.

HABERMAS, J. O conceito de poder de Hannah Arendt. In: FREITAG, B.; ROUANET, S.P. (orgs.) Habermas. São Paulo: Ática, 1980.

HALL, Stuart. A Identidade Cultural na Pós-Modernidade. Rio de Janeiro: DP\&A Editora, 2003.

HEISKANEN, E. et al. Low-carbon communities as acontext for individual behavioural change. Energy Policy No. 38, pp. 7586-7595. Elsevier Ltd, 2010.

HOPKINS, Rob. The Transition Handbook. From Oil Dependency to Local Resilience, Green Books, 2008.

Pick Oil and Transition Towns. Architectural Design, July 2012, Vol.82 (4), pp.72-77.

JACKSON, J. T. Ross. The Ecovillage Movement. Permaculture Magazine 40, 25-30, 2004. 


\section{Desafios da psicologia no Brasil}

JOSEPH, Linda; BETES, Albert. What Is an "Ecovillage"? Communities Magazine No 117 - Ecovillages What Have We Learned? 2003. Disponível em:

<http://gen.ecovillage.org/iservices/publications/articles/CM117WhatlsanEcovillage_E.pdf > Acesso em novembro de 2013.

KASPER, D. Redefining community in the ecovillage. Human Ecology Review, Vol.15(1), pp.12-24, 2008.

KESSLER, Sarah. Eco-Villages. Studying in sustainable communities throughout the world. A Broad View Magazine. P. 62-63. Spring 2008. Retrieved from

< http://gen.ecovillage.org/iservices/publications/articles/av_08_spring_ecovillages.pdf

Acesso em: dezembro de 2014.

KIRBY, Andy. Domestic Protest: The Ecovillage Movement as a Space of Resistance. Bad subjects, no 65, January 2004. Retrieved June 14, 2012, from <http://bad.eserver.org/issues/2004/65/kirby.html> Acesso em: dezembro de 2014.

KOZENY, G. Intentional Communities: Lifestyles Based on Ideals. Fellowship for Intentional Community, 1995 Disponível em: < www.ic.org/pnp/cdir/1995/01kozeny.php > Acesso em: janeiro de 2014.

MARQUES NETO, Murillo. A Construção da Solidariedade: Um Estudo de Caso da Comunidade Campina. Dissertação de Mestrado em Psicossociologia e Ecologia Social. Programa EICOS, Universidade Federal do Rio de Janeiro, Rio de Janeiro, 2005.

MATTOS, Taisa. Ecovilas: a construção de uma cultura regenerativa. Uma etnografia de Findhorn, Escócia. Novas Edições Acadêmicas, 2018.

MEADOWS, Donella H et al. Limites do crescimento, SP: Editora Perspectiva, 1973.

NORBERG-HODGE, Helena. Why Ecovillages? The Ecologist Vol. 32. No 1, February, 2002.

OVED, Yaacov. The Globalisation of Communes. Proceedings of the 11th conference of the International Communal Studies Association - ICSA 2013. Social Sciences Directory Vol. 2, No. 3, 9396, September 2013.

RICHARDSON, J; NICHOLS, A.; HENRY, T. Do transition towns have the potential to promote health and well-being? A health impact assessment of a transition town initiative. Public Health, v. 126 p.p $982-$ 989, 2012.

SANTOS JR, Severiano José dos. Zelosamente Habitando a Terra: Ecovilas, Ethos e Sustentabilidade no Viver Contemporâneo. Uma Contribuição sobre a Realidade Brasileira. Tese (Doutorado) Universidade de Brasília - UNB - Centro de Desenvolvimento Sustentável. Brasília - DF, junho/ 2010

SEN, A. Desenvolvimento como Liberdade. São Paulo: Companhia das Letras, 2000.

SEVIER, Laura. Ecovillages: a model life? The Ecologist, Vol.38(4), p.36-37, May, 2008. 


\section{Desafios da psicologia no Brasil}

SIRNA, Tony. What Is Ecovillage? Intentional Communities. IN: FELLOWSHIP FOR INTENTIONAL COMMUNITY. 2000. Disponível em: <www.ic.org/pnp/cdir/2000/08ecovillage.php> Acesso em dezembro de 2013.

TAYLOR, Peter J. Transition towns and world cities: towards green networks of cities. Local Environment Vol. 17, No. 4, April 2012, pp. 495-508. Routledge: Taylor \& Francis Group, 2012.

TRAINER, F.E. The global sustainability crisis. The implications for community. International Journal of Social Economics, Vol. 24 No. 11 pp. 1219-1240,

MCB University Press. Sydney, Australia, 1997.

TRAINER, Ted. The Global Ecovillage Movement: The Simpler Way for a Sustainable Society. Social Alternatives 19.3, 19-24. 2000.

. Where are we, where do we want to be, how do we get there? Democracy \& Nature, Vol. 6, No. 2 (July 2000).

TRANSITION BRASIL. Disponível em: http://transitionbrasil.ning.com Acesso em outubro de 2014.

TRANSITION CULTURE. Disponível em: transitionculture.org Acesso em julho de 2014.

TRANSITION NETWORK. Disponível em: http://www.transitionnetwork.org. Acesso em julho de 2014.

TRANSITION TOWNS. Disponível em: http://www.transitiontowns.org. Acesso em julho de 2014.

UNITED NATIONS. (1987). Report of the World Commission on Environment and Development (General Assembly Resolution 42/187). Retrieved May 24, 2008, from < http://www.un.org/documents/ga/res/42/ares42-187.htm > Acesso em março de 2014.

WAGNER, Felix. Ecovillage Research Review. In: ANDREAS, Marcus; WAGNER, Felix (Editors) Realizing Utopia. Ecovillage Endeavors and Academic Approaches. RCC Perspectives. Munich, Germany. 2012

. Ecovillages: Cradles for a culture of sustainability? In: MELTZER, Graham (Ed). Conference Proceedings. Proceedings of the 11th International Communal Studies Association Conference, ICSA 2013 - Communal Pathways to Sustainable Living. P. 215. The Findhorn Foundation, Forres, UK, 2013. 


\section{Desafios da psicologia no Brasil}

\section{NOTAS}

\section{Notas 1}

Resiliência pode ser entendida como a habilidade de um ecossistema retornar ao seu estado natural após um choque ou perturbação, sendo que, quanto menor o período de recuperação, maior é a resiliência de determinado ecossistema. Pode também ser definida como a medida da magnitude dos distúrbios que podem ser absorvidos por um ecossistema, sem que o mesmo perca seu potencial de equilíbrio estável. As atividades econômicas apenas são sustentáveis quando os ecossistemas que as alicerçam são resilientes (Arrow et al., 1995). 


\section{Capítulo 41}

\section{A DOCÊNCIA EM AVALIAÇÃO PSICOLÓGICA}

DOI: $10.37423 / 200200251$

Leonardo Augusto Couto Finelli (Doutor em Ciências da Educação, Mestre em Avaliação Psicológica, Professor adjunto das Faculdades Unidas do Norte de Minas FUNORTE, e, Universidade Estadual de Montes Claros - UNIMONTES). finellipsi@gmail_com

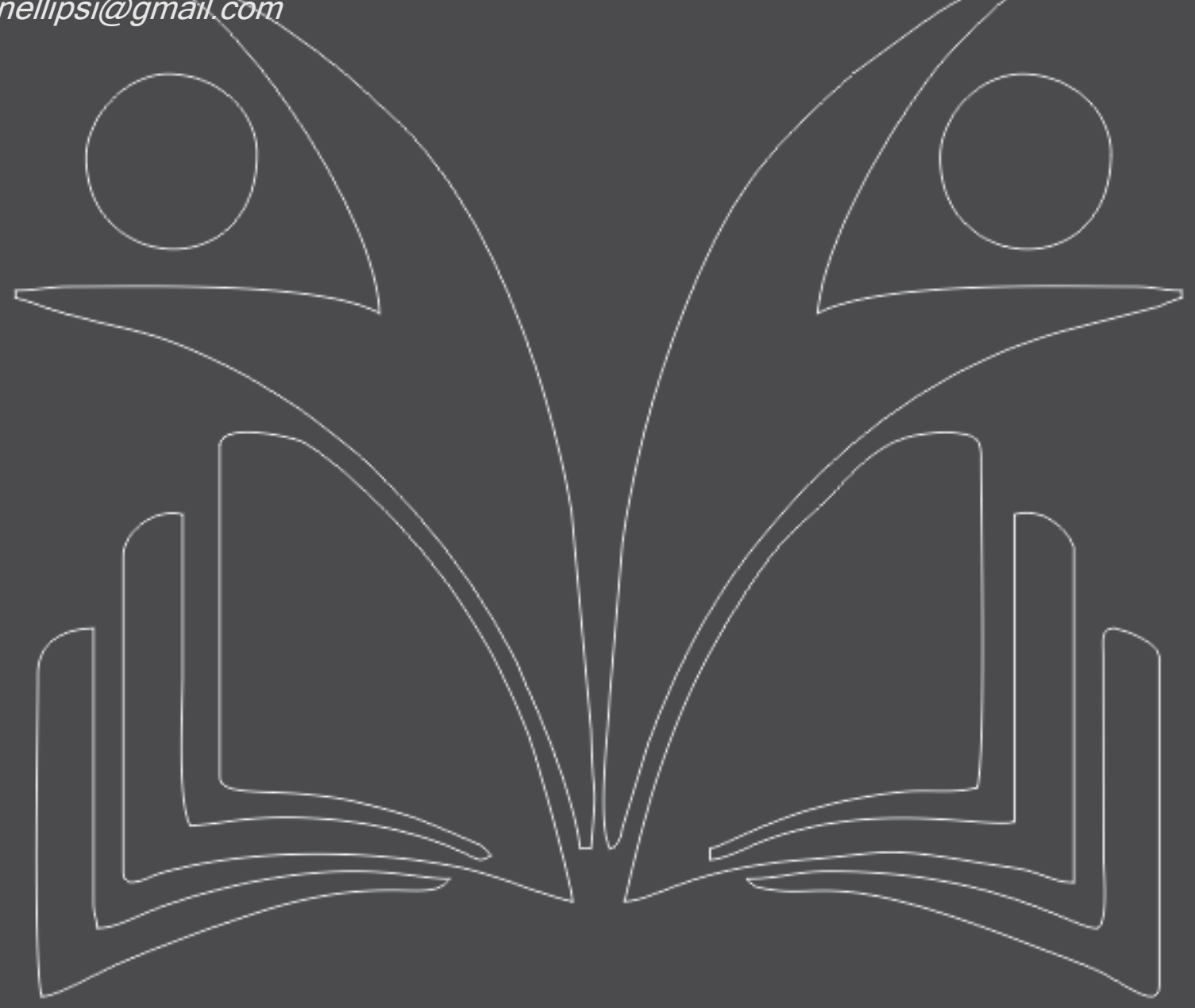




\section{Desafios da psicologia no Brasil}

\section{INTRODUÇÃO}

A experiência na atuação profissional oferece a prática, e essa, a oportunidade de lidar com as vicissitudes de cada campo de trabalho. A atuação docente demanda à busca constante de atualização, assim como se combina às vivências que muitas vezes, o neófito em qualquer campo de formação, carece. Nesse sentido, a proposta do presente texto é compartilhar com você, leitor, um pouco da experiência de mais de vinte anos de docência e engajamento profissional. O texto que se segue, então, contempla elementos técnicos, que são atualizados ao longo dos anos, acrescidos do aprendizado da experiência prática que nem sempre se encontrada na literatura.

Inicio com uma contextualização. A Avaliação Psicológica - AP é uma tarefa privativa do psicólogo, desde que a profissão foi reconhecida, no Brasil, em 1962. Seu foco recai sobre a busca de informações sobre o indivíduo, grupo, instituição, ou situação, a respeito dos fenômenos psicológicos, para que, a partir dessas, sejam tomadas decisões quanto à modificação de condicionantes da demanda inicial. Usualmente, a AP é reconhecida a partir de sua associação com o uso de testes psicológicos. Não obstante, é importante considerar que a AP é mais do que a mera aplicação e correção dos instrumentos, testes, e/ou técnicas de investigação do funcionamento psíquico, ou dimensionamento dos traços latentes.

\section{AVALIAÇÃO}

Avaliar, como processo natural ao ser humano, é uma atividade cotidiana realizada constantemente. Frente a qualquer situação que demande a escolha de duas, ou mais possibilidades, o ser humano precisa avaliar e decidir entre as ofertas. Nesse sentido, avaliar visa adaptar o organismo a sobrevivência em seu ambiente. Por exemplo, ao escolher o que comer no café da manhã, ou a roupa para ir ao trabalho ou para a universidade, não é comum o indivíduo dispender muita preocupação ou engajamento entre as opções que estão presentes. Isso porque tal avaliação lida com demandas cuja repercussão é de menor impacto na vida do mesmo. A escolha de se alimentar com pão, biscoitos, bolo, ou frutas, assim como a seleção da camisa A ou B não modifica muito a vida do indivíduo ao longo do dia.

Por outro lado, essas mesmas situações exemplo, simplórias, se acrescidas de complementos podem se tornar mais significativas para o indivíduo. Por exemplo, se o mesmo sofre de diabetes, ou apresenta sensibilidade ou intolerância a glúten, daí não será qualquer alimento que satisfará o sujeito, assim como poderá ser consumido sem grandes preocupações. O mesmo vale no exemplo da 


\section{Desafios da psicologia no Brasil}

vestimenta, se ao invés de ir para sua atividade cotidiana (escola ou trabalho) o mesmo participará de uma entrevista de emprego. Nessa situação a vestimenta pode ser elemento importante para compor a boa apresentação para o processo seletivo.

Em ambos os casos verifica-se que o indivíduo teve de avaliar a situação para deliberar sobre como se comportar. Inicialmente, as situações postas demandavam pouca preocupação, assim como os comportamentos apresentados são adaptativos e uma escolha afetiva atende ao seguimento da vida. Já nos exemplos seguintes, consideradas a(s) condição(ões) clínica(s) ou situação social de processo seletivo, a avaliação demandou maior atenção quanto ao que se selecionar, pois os resultados dos comportamentos apresentavam maior significado (ou resultados mais duradouros) na vida do organismo.

\section{AVALIAÇÃO PSICOLÓGICA}

Quando se fala em AP a mesma lógica se aplica. A avaliação será psicológica quando os elementos a serem considerados na observação, para a tomada de decisão, consideram construtos psicológicos. Tais podem ser traços latentes, dimensões psíquicas, padrões de comportamento, entre outras definições. E demandam maior atenção quando os resultados da escolha impactam de modo mais significativo, ou duradouro, na vida do sujeito.

Na formação em psicologia, a AP é uma área nevrálgica, pois contempla o único aspecto da atuação profissional que é exclusiva a atuação do psicólogo(a). Além disso, é uma atividade transversal para a atuação em qualquer área da psicologia, independente da teoria ou abordagem considerada pelo profissional.

Cabe aqui, brevemente, diferenciar, teoria (ou modelo teórico) de abordagem. Um modelo teórico é uma hipótese não comprovada, ou especulação, referente à realidade que ainda não está devidamente confirmada. Suas derivações podem ser verdadeiras ou falsas, sua premissa, que é um conjunto de convenções criadas por um autor/pesquisador, não. Logo, a teoria não é dada, mas construída (para representar os eventos em estudo), para confirmar as evidências propostas por seu autor. Sua proposição se dá como forma de orientar os comportamentos e inferências quanto a atuação dos indivíduos no mundo. (HALL; LINDSEY; CAMPBELL, 2000).

Como a teoria é formulada a partir de uma escolha convencional, não pode ser definida, a priori, como verdadeira ou falsa, mas útil ou inútil (confirmáveis ou não). Sua função é evitar que o observador seja ofuscado pela complexidade total dos eventos naturais ou concretos. Em psicologia, para se reconhecer uma teoria, a proposição deve apresentar pelo menos cinco características, a saber: I - 


\section{Desafios da psicologia no Brasil}

Concepção de ser humano (epistemologia); II - Modelo de desenvolvimento (explicação sobre como se dá a maturação do indivíduo); III - Modelo de personalidade (compreendida como padrão, mais ou menos estável, de comportamentos reproduzidos ao longo de tempo para adaptar o organismo ao ambiente); IV - Modelo de psicopatologia (que estabelece padrões de comportamento considerados saudáveis ou normais, e aqueles - ou os limites do - que são patológicos ou disfuncionais); e por fim, V - Modelo de intervenção (que compreende o conjunto de técnicas para atuação do profissional no sentido de acolher e propor mudanças nos/para os clientes/pacientes).

Por sua vez, a abordagem psicológica está relacionada ao campo de atuação profissional. A abordagem diz respeito à escolha, convencionada, de instrumentos, técnicas, modelo teórico, entre outros recursos psicológicos, para se atender a um conjunto de demandas. A abordagem considera então o aprofundamento profissional para o acolhimento/atendimento de determinada área de atuação. A abordagem determina a forma como o profissional trabalha. Essa guia sua maneira de atuar com as demandas apresentadas, assim como sua percepção epistemológica (forma de crer e reconhecer no ser humano).

Reconhecidas as diferenças expostas tem-se como teorias ou modelos teóricos, a Psicanálise, Gestalt, Existencialismo, Humanismo, Teoria Cognitivo Comportamental (ou cognitivismo), Behaviorismo (teoria comportamental) entre outras. E essas podem ser arroladas/classificadas de diversas maneiras, como, por exemplo, em um contínuo entre um reconhecimento de uma influencia mais biológica/genética ou ambiental/situacional, como determinantes do comportamento; ou proporem intervenções mais interpretativas (subjetivas, acolhedoras, ou não diretivas) às mais diretivas para modificar o funcionamento psíquico.

Já em termos de abordagem psicológica reconhece-se a Sistêmica, Clínica, Jurídica, do Trânsito, do Esporte, Escolar (ou Educacional), entre diversas outras. Cada abordagem costuma ter, por tradição, associação com determinados modelos teóricos, cuja base, melhor se adequa para explicar os fenômenos a serem trabalhados na prática profissional. Alguns autores, inclusive, desenvolvem a teoria de modo a propor instrumentos e técnicas de intervenção para atender as demandas da abordagem que acolhem. Não obstante, essa associação da teoria à abordagem é uma tradição meramente didática.

Por exemplo, no Brasil, a tradição clínica, em especial em saúde pública e/ou coletiva, tem forte influência da teoria psicanalítica. Sem aprofundar nos meandres históricos que promoveram essa aproximação, bastam fazer a leitura de qualquer edital de concurso para Psicólogo na Área da Saúde, que serão encontrados diversos autores e referências bibliográficas daquele modelo teórico ${ }^{2}$. De 


\section{Desafios da psicologia no Brasil}

modo similar, é frequente encontrar profissionais que acolhem o modelo Humanista e/ou Existencial que trabalham com a abordagem Sistêmica. Ou ainda, psicólogos que acolhem o Behaviorismo ou a Teoria Cognitivo Comportamental trabalhando na abordagem da Psicologia do Esporte, ou na Psicologia do Trânsito. Não obstante, insisto, que esses exemplos, dizem respeito a uma tradição tipicamente observada no mercado de trabalho. Não há uma regra formal (legislação ou normativa) que determine que um profissional que acolha o modelo Comportamental não possa trabalhar em órgãos de Saúde Publica ${ }^{3}$, ou que um psicanalista atue com Psicologia Escolar, pelo contrário, pessoalmente, conheço e indico diversos profissionais que fazem trabalhos excelentes mesmo consideradas as discrepâncias da tradição da relação entre modelo teórico e abordagem, mas essa discussão é para outro momento.

Retornando a AP, não é incomum (apesar de se reconhecer a redução da frequência com o passar dos anos) se escutar (em especial em eventos científicos de psicologia) de colegas de profissão que os mesmos não realizam avaliação psicológica. Uma escuta flutuante, em ambiente público, sempre revela tal gafe. Considero tal colocação, no mínimo, como ingênua, ou incongruente (para evitar o uso de adjetivos menos educados).

Explico-me, todos os psicólogos, em atuação profissional, independente da área de atuação ou abordagem, ou teoria que acolha para seu trabalho, necessariamente, realiza Avaliação Psicológica. Isso porque a AP é um processo amplo, que visa coletar informações. Nesse sentido tomem-se as mais diversas definições de avaliação psicológica:

[...] um processo de avaliação psicológica se caracteriza por uma ação sistemática e delimitada no tempo, com a finalidade de diagnóstico ou não, que utiliza de fontes de informações fundamentais e complementares com o propósito de uma investigação realizada a partir de uma coleta de dados, estudo e interpretação de fenômenos e processos psicológicos. (CFP, 2019).

Avaliação Psicológica é definida como um processo estruturado de investigação de fenômenos psicológicos, composto de métodos, técnicas e instrumentos, com o objetivo de prover informações à tomada de decisão, no âmbito individual, grupal ou institucional, com base em demandas, condições e finalidades específicas. (CFP, 2018, grifo no original).

A avaliação visa, através dos mais variados métodos e técnicas, descrever e classificar o comportamento dos outros com o objetivo de enquadrá-lo dentro de alguma tipologia, que permite ao sujeito tirar conclusões sobre os outros e, assim, saber como ele mesmo deve se comportar e agir em relação a esses outros e, assim, saber como ele mesmo deve se comportar e agir em relação a esses outros. A avaliação psicológica quer acrescentar a esta atividade universal 


\section{Desafios da psicologia no Brasil}

do ser humano algo de cunho científico, por estar baseada no método científico da observação em que são mantidas certas características de cientificidade: observações confiáveis e válidas, bem como inferências obtidas a partir delas, seguindo processo legítimos de teste de hipóteses e de inferência. (BARCLAY, 1991).

Avaliação psicológica é um processo no qual se verificam a medida e o grau como critérios presentes no comportamento a considerar, assim como suas metas e objetivos que se propõe atingir (CASULO, 1999).

Avaliação psicológica é um processo de coleta e interpretação de dados, realizado por meio de instrumentos psicológicos, tendo por finalidade o maior conhecimento do indivíduo, a fim de que sejam tomadas determinadas decisões (WECHSLER, 1999).

Ao sintetizar, e integrar, essas definições pode-se reconhecer algumas ideias chave na definição de AP. Entre elas, que a AP é um processo técnico-cientifico, sistemático, delimitado no tempo, que se vale de diferentes métodos, instrumentos, e/ou técnicas, de coleta de dados ou informações, que são traduzidas em termos tipológicos ou numéricos, sobre sujeitos ou situações, que tem impacto no funcionamento psíquico de indivíduos. A AP entende que tais dados determinam como aqueles se comportam perante as diversas situações que lhes são apresentadas. Tais dados devem, então, ser estudados a luz de referencial teórico de escolha do profissional da psicologia, para que se produza uma categorização dos processos e se infira intervenções que irão, ou não, propor mudanças para os comportamentos futuros.

Ao se traduzir e simplificar as definições tem-se que a AP visa conhecer indivíduos. Tal conhecimento pode se dar por diversos métodos, instrumentos, e/ou técnicas. Nesse sentido, como já exposto, é muito comum a associação da AP com o uso dos testes psicológicos, ao se reconhecer esses, como instrumentos, por excelência, para a realização da AP. Porém, em seguimento à análise, não é somente do uso de testes que a AP se vale.

Para realizar um procedimento de AP o profissional da psicologia pode recorrer ao diverso cabedal da psicologia, como os testes psicológicos, assim como uma série de outros recursos. Reconhece-se que alguns são mais, outros menos, sistematizados, mas todos se oferecem, em seu potencial e proposta, como instrumental para realizar a AP. Entre esses se tem, por exemplo: Entrevistas (que podem ser dos mais variados tipos, estruturada, semiestruturada, de livre estruturação, com questões abertas, mistas, ou fechadas) (CUNHA, 2000); Observação (que como a entrevista pode ser dos mais variados tipos e estruturas, como registro de evento, registro de duração, registro de intervalos, registro por amostragem de tempo, técnica mista, com ou sem roteiro de observação) (FAGUNDES, 1985);

Dinâmicas de grupo (coletivas ou individuais com técnicas de Role playing, situações fictícias, ou 


\section{Desafios da psicologia no Brasil}

dramatizações) (AFONSO, 2006; CUNHA, 2000; PINHEIRO, 2014); Protocolos ou Relatórios de equipes multiprofissionais (que configuram documentos técnicos, em geral prontuários de acompanhamento ou relatórios para demandas - diagnóstico - especificas produzida por equipe multiprofissional - em geral com acompanhamento de um psicólogo conjuntamente com profissionais de outras áreas, preservando-se a autonomia e a ética profissional dos envolvidos -) (CFP, 2019); História de Vida Anamnese (que se configuram como tipos de entrevista clínica, mas apresentados em separado em função de suas especificidades e usos) (BARROS, 2004; KLOETZEL, 1977); Questionários e/ou Inventários (que se assemelham aos testes psicológicos, ou a estruturação de entrevistas, porém, carecem dos procedimentos científicos de análise dos parâmetros psicométricos, a saber, validade, fidedignidade, padronização e normas) (ANASTASI, 1977; ANASTASI; URBINA; 2000; URBINA, 2007), entre outros.

Nesse sentido, como se verifica, os Testes Psicológicos são apenas um conjunto de recursos para se realizar a AP. Assim, o profissional que "não faz AP", muitas vezes, de forma ingênua, quer dizer, "não faço uso de testes psicológicos". Até aí, tudo bem, é uma escolha do profissional a seleção dos instrumentos, recursos e técnicas que melhor lhe aprouverem para sua prática. Tal percepção é inclusive respaldada pelo Código de Ética Profissional do Psicólogo (CRP, 2005), quando em seu artigo 1ํ, que versa sobre os deveres fundamentais, considera as alíneas:

b) Assumir responsabilidades profissionais somente por atividades para as quais esteja capacitado pessoal, teórica e tecnicamente;

c) Prestar serviços psicológicos de qualidade, em condições de trabalho dignas e apropriadas à natureza desses serviços, utilizando princípios, conhecimentos e técnicas reconhecidamente fundamentados na ciência psicológica, na ética e na legislação profissional;

Essa é reforçada em demais documentos que asseguram ao profissional a liberdade de escolha dos instrumentos e técnicas, em especial a Resolução CFP n09/2018 (CFP, 2018) que resolve das diretrizes básicas para a realização de avaliação psicológica no exercício profissional da psicologia e considera o parágrafo 2 do artigo 1 :

§2 - A psicóloga e o psicólogo têm a prerrogativa de decidir quais são os métodos, técnicas e instrumentos empregados na Avaliação Psicológica, desde que devidamente fundamentados na literatura científica psicológica e nas normativas vigentes do Conselho Federal de Psicologia (CFP). (grifo meu). 


\section{Desafios da psicologia no Brasil}

Pessoalmente, aprecio o uso de Testes Psicológicos, mas consigo compreender que nem todo colega de trabalho detenha a mesma estima pelo grupo de instrumentos. Novamente, justifico-me. Como instrumentos por excelência da AP, os Testes Psicológicos, passam por reconhecimento científico para uso na prática profissional da psicologia. Aqui subjazem os parâmetros psicométricos (validade, fidedignidade ou precisão ${ }^{3}$, padronização, e, normas; ou apenas, validade, fidedignidade ou precisão, e, normatização ${ }^{4}$ ), que devem ser pesquisados, analisados, e publicados nos manuais dos instrumentos (e/ou em seus complementos), no sentido de assegurar sua adequação a uso.

\section{TESTES PSICOLÓGICOS}

Cabe aqui o recorte para a apresentação de algumas definições formais do que são Testes Psicológicos.

Os Testes Psicológicos vêm a ser uma medida objetiva e padronizada de uma dada amostra de comportamento. Para o seu uso há necessidade de: a) Que todos os sujeitos realizem igual tarefa; deve haver uniformidade no processo de aplicação, ou seja, instruções e material de avaliação. Assim as respostas devem ser julgadas pelos mesmos critérios e o resultado é interpretado de acordo com determinadas normas; o desempenho em cada teste é avaliado com base em dados empíricos. Geralmente, o escore do teste de um indivíduo é interpretado através da comparação com os escores obtidos por outros no mesmo instrumento; b) Uma certa amostra de comportamento implica em economia no tempo de avaliação. Em geral, constitui-se em uma medida da capacidade, função ou traço que se pretende avaliar. (ANASTASI; URBINA, 2000).

Um teste é um procedimento sistemático para observar o comportamento e descrevê-lo com a ajuda de escalas numéricas ou categorias fixas. (CRONBACH, 1996).

Testes psicológicos são situações padronizadas, de realização de tarefas definidas, que possibilitam que se traduza os comportamentos em termos numéricos. (PASQUALI, 2001).

Teste Psicológico é um conjunto de tarefas predefinidas, que o sujeito precisa executar numa situação geralmente artificializada ou sistematizada, em que o seu comportamento na situação vai ser observado, descrito e julgado, e essa descrição é geralmente feita utilizando-se números. (PASQUALI, 2001).

Teste é uma palavra de origem inglesa que significa "prova"; deriva do latim testis e é usada internacionalmente para denominar uma modalidade de medição bastante conhecida hoje em dia em diversos campos científicos e técnicos. "Uma medição só é chamada de teste se for usada, primordialmente, para se descobrir algo sobre o indivíduo, em vez de responder a uma questão geral." (TYLER, 1973).

Um teste psicológico é um instrumento ${ }^{5}$ de uso do psicólogo tem por objetivo identificar, descrever, qualificar e mensurar características psicológicas, por 


\section{Desafios da psicologia no Brasil}

meio de procedimentos sistemáticos de observação e descrição do comportamento humano, nas suas diversas formas de expressão, acordados pela comunidade científica. (CFP, 2018).

Novamente proponho uma síntese. Testes Psicológicos são instrumentos dos mais variados tipos (questionários, inventários, escalas, provas, tarefas de execução motora, tarefas de produção gráfica, tarefas mediadas pelo computador, entre outras) de uso do psicólogo, que tem por objetivo promover a coleta de dados (observação, ou, análise do comportamento, traços latentes, ou atributos/construtos psíquicos) através da aferição dos comportamentos manifestos perante situações artificializadas, que devem ser padronizadas e sistematizadas, cujos dados auferidos são descritos pormenorizadamente, e, geralmente, traduzidos em uma linguagem numérica (ou categórica), para que sejam analisados, e se para possibilite a sua classificação em tipologias e, dessas, acrescidas dos condicionantes sociais e históricos da realidade do avaliado (sujeito, grupo, instituição ou situação) levar a interpretação, a luz de um dado referencial teórico, de modo a propiciar o desenvolvimento de propostas de intervenção para a manutenção, incremento, redução, extinção, e/ou, controle dos comportamentos aferidos.

Para ser reconhecido como Teste Psicológico o instrumento deve possuir consistência técnicocientífica e atender os requisitos mínimos obrigatórios, conforme descritos na Resolução CFP no 09/2018. Tal legislação considera:

I - apresentação de fundamentação teórica, com especial ênfase na definição do(s) construto(s), descrevendo seus aspectos constitutivo e operacional;

II - definição dos objetivos do teste e contexto de aplicação, detalhando a população-alvo;

III - pertinência teórica e qualidade técnica dos estímulos utilizados nos testes;

IV - apresentação de evidências empíricas sobre as características técnicas dos itens do teste, exceto para os métodos projetivos/expressivos;

V - apresentação de evidências empíricas de validade e estimativas de precisão das interpretações para os resultados do teste, caracterizando os procedimentos e os critérios adotados na investigação;

VI - apresentação do sistema de correção e interpretação dos escores, explicitando a lógica que fundamenta o procedimento, em função do sistema de interpretação adotado, que pode ser: 


\section{Desafios da psicologia no Brasil}

a) Referenciada à norma, devendo, nesse caso, relatar as características da amostra de normatização de maneira explícita e exaustiva, preferencialmente comparando com estimativas nacionais, possibilitando o julgamento do nível de representatividade do grupo de referência usado para a transformação dos escores.

b) Diferente da interpretação referenciada à norma, devendo, nesse caso, explicar o embasamento teórico e justificar a lógica do procedimento de interpretação utilizado.

VII - apresentação explícita da aplicação e correção para que haja a garantia da uniformidade dos procedimentos.

VIII - Atenção aos requisitos explicitados nos artigos 30, 31, 32 e $33^{6}$.

A referida resolução considera ainda, em seu anexo, que apresenta o "Formulário de Avaliação da Qualidade de Testes Psicológicos", os critérios para a avaliação dos instrumentos submetidos ao Conselho Federal de Psicologia, por meio da Comissão Consultiva em Avaliação Psicológica (CCAP) do Sistema de Avaliação de Testes Psicológicos (SATEPSI). Nesse anexo, discorre ainda sobre as diferenças quanto aos parâmetros de aferição para os testes psicométricos ou objetivos e dos métodos projetivos/expressivos.

Tais são os principais elementos da Resolução CFP no 09/2018, apesar de a mesma ainda versar sobre a adaptação de testes psicológicos estrangeiros adaptados para o Brasil; da avaliação de versões equivalentes de testes informatizados e não informatizados; atualização de normas e de estudos de validade; tempo de validade desses estudos; tempo e etapas para o processo de análise; justiça e proteção dos direitos humanos na avaliação psicológica; entre outros pormenores. Ou seja, como a avaliação psicológica, a referida resolução é elemento essencial para a atuação do profissional psicólogo.

É lícito ainda ressaltar que o manual do instrumento deve explicitar que o mesmo passou regularmente pelo processo de avaliação do SATEPSI e foi reconhecido como Teste Psicológico. Além disso, o mesmo deve incluir a ficha síntese do teste (com objetivo, público-alvo, material, aplicação e correção) e exemplo(s) de utilização, contemplando a administração, aferição, análise e interpretação dos resultados (CFP, 2018).

Tal cientificidade amplia a consistência das interpretações e análises realizadas no processo de AP. Essa oferece também respaldo às críticas e contestações, seja em processos judiciais, seja na mera descrença dos resultados da AP em uma entrevista devolutiva. Isso porque os testes apresentam 


\section{Desafios da psicologia no Brasil}

resultados concretos do comportamento produzido pelo sujeito naquela situação sistematizada específica. O uso do teste possibilita ainda determinar delimitação temporal sobre o diagnóstico/conclusão realizado na avaliação, assim como o prazo de validade do conteúdo do documento produzido associado àquela investigação de AP (CFP, 2019).

A produção de documentos respaldados por literatura científica é privilégio no campo da AP, visto que, com o uso de Testes Psicológicos, pode-se recorrer aos manuais para a apresentação precisa de definições de conceitos e construtos. Além disso, esses mesmos manuais apresentam indicadores de confiabilidade sobre a produção do sujeito, assim, considerados os elementos de variabilidade situacional ou intervenientes quanto à produção no teste (por exemplo, fome, cansaço, uso de medicações, variabilidades significativas na ansiedade de produção, ruídos, desconforto climático, entre outros) tem-se, nos manuais, os atenuantes a partir do Erro Padrão de Medida. Esse é o cálculo do erro provável da medida que o teste incorre se se considerar infinitas aplicações do mesmo para o mesmo candidato, o que mitiga a variabilidade na produção criada pelas variáveis intervenientes.

Nesse sentido, o uso do Erro Padrão de Medida, para realizar a correção e interpretação dos testes, é útil na interpretação dos escores individuais, pois define os limites do Intervalo de Confiança da medida $^{7}$. Tal Intervalo de Confiança é dado como um intervalo real no qual se situa o escore verdadeiro do sujeito (considerada a variabilidade na produção, para mais - por exemplo, ao marcar fortuitamente do modo correto um item cuja resposta é desconhecida -, ou para menos - quando, na dúvida de uma possível resposta, o respondente marca aquela que é indicativa de erro, ou anota de forma equivocada sua resposta -).

\section{SOBRE A DOCÊNCIA EM AVALIAÇÃO PSICOLÓGICA}

Posta tal introdução, retomo a docência em AP. Já há muito o tema pesquisado, assim como produziu diversos resultados. Dentre esses, verifica-se que no estado de Minas Gerais há uma variação significativa na carga horária ofertada pelos cursos de graduação de psicologia. Essa variou de 3.860 horas à 4.880 horas (FINELLI, 2013). É relevante retomar a legislação (CFP, 1999; FEITOSA et al., 1999) que determina a carga horária mínima de 3.000 horas para a formação como Bacharel (ou Licenciado) em Psicologia, e pelo menos 4.050 horas para a formação de Psicólogo. A partir de tal dado, verificouse que 14 (46,67\%) dos cursos não oferece a carga horária mínima para a formação de Psicólogo. 


\section{Desafios da psicologia no Brasil}

Quanto à formação em AP, a análise das matrizes curriculares dos cursos de graduação em psicologia do estado de Minas Gerais (a saber, 30 matrizes analisadas no estudo de FINELLI, 2013) apresentou variação na oferta de duas a quatro disciplinas que atendessem ao critério da investigação; isto é, ser nomeada como Testes Psicológicos; Testagem Psicológica, Técnicas de Exame Psicológico (TEP), Técnicas de Avaliação Psicológica (TEAP) e/ou seus correlatos. Tais disciplinas contemplam de 120 à 240 horas previstas dos cursos, ocupando cerca de 3,00\% à 5,10\% do número de horas aula de formação. Tal resultado parece pequeno frente à demanda de utilização dos recursos ofertados pelas disciplinas, o que leva a reflexão sobre a qualidade da formação.

Há também dados mais amplos de uma pesquisa nacional realizada em 2015 (FINELLI; FREITAS; CAVALCANTI, 2015). Essa indicou que o Brasil dispõe de 767 cursos de psicologia distribuídos entre os 26 estados e o distrito federal. De modo similar, o estudo analisou as matrizes curriculares desses cursos em busca de disciplinas referentes à avaliação psicológica: Testes Psicológicos Testagem Psicológica, Técnicas de Exame Psicológico (TEP), Técnicas de Avaliação Psicológica (TEAP), Métodos e Medidas em Avaliação Psicológica, Optativas em Avaliação Psicológica, Psicometria e/ou seus correlatos. O estudo analisou, efetivamente, 256 matrizes desses cursos (aquelas que foram disponibilizadas para a análise dos pesquisadores). Como resultados, o estudo apresenta que os cursos dispõem de uma variação de carga horária de 974 horas a 9700 horas, com uma média 4257,27 horas por curso em todo território nacional. É licito retomar os dados da legislação quanto a formação em psicologia, a saber carga horária mínima de 3.000 horas para a formação como Bacharel (ou Licenciado) em Psicologia, e pelo menos 4.050 horas para a formação de Psicólogo(CFP, 1999; FEITOSA et al., 1999). Tal dado demonstra resultados muito mais graves quanto ao tempo destinado à formação em psicologia, em análise da carga horária total verificou-se que 0,93\% tem até 3000 horas, com a menor carga horária contando com 974 horas; 5,79\% dos cursos tem entre 3001 à 3955 horas; 38,88\% dos cursos tem entre 4000 e 4048 horas, valor que margeia o estipulado pelo CFP, de 4050 horas, para a titulação de psicólogo; 23,55\% dos cursos tem entre 4050 horas e 4222 horas; 26,54\% vão de 4260 horas até 5000 , ultrapassando significativamente o valor padrão de 4050 horas; e 4,30\% tem mais de 5000 horas, chegando até o valor limite de 9700 horas, até dez vezes maior do que a menor carga horária encontrada naquela pesquisa. Dentre todas as cargas horárias pesquisadas, 54,39\% da amostra estão de acordo com o determinado e apresentam carga horária maior ou igual à definida pelo CFP para a titulação de Psicólogo. 


\section{Desafios da psicologia no Brasil}

De modo similar, com enfoque nas disciplinas de AP, o estudo demonstrou que as cargas horárias para as disciplinas de AP analisadas, apresentam uma variação significativa. Os dados demonstraram a variação que parte do mínimo de 36 horas ou 0,90\% da carga horária daquela matriz curricular, a 640 horas ou 16,00\% na carga horária disponível para a formação específica em avaliação psicológica da matriz curricular analisada para o curso. Considerado o contexto geral do Brasil há uma média de 257,11 horas ou 6,06\% de carga horária em avaliação psicológica para os 256 cursos que apresentam a carga horária para a análise. $O$ estudo indica ainda as diferenças por região considerando tanto os dados de números de horas gerais para a formação em psicologia, quanto às diferenças da carga horária disponibilizada à AP, remeto então ao estudo (FINELLI; FREITAS; CAVALCANTI, 2015) para interessados nos dados pormenorizados.

Avançando para uma análise qualitativa da prática da formação em AP apresento parte das discussões de Finelli e Silveira (2019) que discorrem sobre o ensino em AP. Os autores indicam que há pouco investimento das Instituições de Ensino Superior - IES para a formação em AP. Consideram que há poucos recursos econômicos alocados para a organização e manutenção dos Laboratórios de Avaliação Psicológica, o que prejudica a pratica docente. Além disso, apontam a limitação quanto a organização das turmas de graduação de psicologia, que costumeiramente apresentam números de 20 a 30 acadêmicos, às vezes mais, matriculados e em curso e que o ensino da prática em avaliação psicológica para tal contingente de alunos é inviável. Os autores indicam a divisão desse número em grupos de até 20 alunos (com até dois alunos trabalhando com cada kit de material - manual, caderno de aplicação, folha de aplicação, e, crivo de correção ${ }^{8}$ ) .

O capítulo de Finelli e Silveira (2019) versa também sobre a desvalorização a que é remetida a AP. apontam para o sucateamento do processo de ensino, o que limita a formação em AP e, consequente, promove profissionais que evitam fazer uso de Testes Psicológicos em AP, em função da defasagem em sua formação. Remeto esse dado ao Dilema Tostintes $^{9}$, onde a formação limitada acaba por criar profissionais que se esquivam da AP ou pelo menos do uso de parte de seus recursos, ou vice versa, mas que implica em distanciamento dos profissionais da AP, o que por sua vez, leva as percepções (ingênuas, incongruentes, ou equivocadas) que citei no início do texto. Nesse sentido a formação complementar deve se dar de modo autônomo a partir do interesse dos profissionais. Esses precisam fazer grandes investimentos econômicos em material e cursos privados (ou pelo menos organizaremse em grupos de pares para trocas de experiências, o que também é uma forma de investimento) de modo a conseguir acesso aos melhores e mais indicados instrumentos para sua prática. 


\section{Desafios da psicologia no Brasil}

Tudo isso considerando a formação em AP, e em especial a partir das disciplinas que versam sobre Testes Psicológicos. Avançando sobre essa percepção, a formação em Estatística e em Psicometria, apesar de carecer de dados objetivos, é ainda mais precária. A experiência demonstra que o interesse geral, cada vez mais, volta-se para que se foque nas disciplinas de Técnicas de Exame Psicológico, e seus correlatos, com ementas mais voltadas para a prática do uso (aplicação e correção) de Testes Psicológicos. Perde-se então a formação que contempla: a oferta da compreensão sobre o que são os testes; para que servem; como devem ser utilizados (em que contextos); como selecionar um instrumento/teste (a partir da leitura e compreensão do manual, considerando o construto, a situação e contexto de criação do instrumento, o publico para o qual o mesmo foi produzido ou adaptado); quais os parâmetros psicométricos estão indicados no manual (e o quanto esses são adequados para a avaliação que se pretende realizar, por exemplo, ao se considerar um teste como mais ou menos preciso); ética quanto ao uso dos instrumentos; entre outras características.

Qualquer trabalho psicológico, terapêutico ou não, individual ou coletivo, nos mais diversos modelos teóricos e abordagens, demanda levantamento inicial de informações. Um diagnóstico, psicodiagnóstico, tratamento de ensaio, entrevista preliminar, anamnese, escuta inicial, levantamento de demanda, ou qualquer outra nomenclatura que a literatura indique, considera sempre a ideia inicial da AP.

"O que te trouxe até aqui?", “Como posso te auxiliar?", “Qual a sua demanda?”, "O que você deseja?" e suas correlatas, são todas perguntas iniciais que contemplam, mesmo que minimamente, a investigação, por parte do profissional da psicologia, sobre qual é a queixa/demanda apresentada pelo cliente/interlocutor. O raciocínio clínico que subjaz a essas perguntas, que podem parecer, ingênuas ou inocentes, é um elemento da formação em AP que deve ser considerado durante a graduação, mas que vem se perdendo com a precarização do ensino. Não obstante, é o elemento fulcral que discuto nesse texto.

A AP é o processo mais básico, mais elementar da profissão e da ética. Só se pode auxiliar (se é que se presta algum auxílio, mas isso é outra discussão, no campo da deontologia) àquele que o solicita. $E$, nos mais diversos campos de atuação, cabe ao psicólogo, ouvir essa demanda e filtrá-la em termos operacionais (ou da linguagem do modelo teórico que o profissional abrace) previamente ao estabelecimento do contrato de trabalho. Até porque, conforme a alínea " $b$ " do artigo 10 do Código de Ética Profissional do Psicólogo, previsto na Resolução no 10/05 do Conselho Federal de Psicologia 


\section{Desafios da psicologia no Brasil}

- CFP, é dever fundamental do psicólogo "Assumir responsabilidades profissionais somente por atividades para as quais esteja capacitado pessoal, teórica e tecnicamente" (CFP, 2005). Assim, no início de qualquer acordo de trabalho profissional do psicólogo, há, necessariamente, AP.

Observe que a discussão sobre a AP contempla-a como um processo amplo e básico do trabalho profissional. Não obstante, não se pode deixar de reconhecer as mais diversas especificidades do campo da AP, já discutidos. Há diversos instrumentos, técnicas, testes, metodologias e formas de instaurar uma AP. Modificam-se os materiais e recursos, mas todas tem a mesma finalidade precípua, a saber: como conhecer o que há de influência na organização e funcionamento psíquico que determinam os comportamentos do organismo que busca o auxílio de um psicólogo.

Ao partir dessa premissa é fácil concluir que a formação em AP é o que há de mais importante no desenvolvimento do profissional. Observa-se que esse não se desconsidera o estudo das teorias e abordagens, assim como todos os elementos epistemológicos da psicologia, sua história, os processos básicos, assim como as discussões interdisciplinares (como a filosofia, sociologia, estatística, bases biológicas e demais conteúdos). Porém, é com a AP que o profissional irá integrar todo o conhecimento adquirido na formação.

Um grande domínio de técnicas de intervenção auxilia o profissional no atendimento, assim como o domínio da literatura do modelo teórico escolhido. Mas, de nada adianta toda a potência para atuação se não for direcionada ao caminho correto. A AP é o campo que provisiona esse caminho. Ao reconhecer corretamente a demanda, ao lapidar a fala do cliente, ao considerar os condicionantes sociais e históricos do indivíduo a AP estabelece os rumos para o tratamento/intervenção adequado.

Além disso, ainda há de se considerar os elementos da situação de investigação. Avaliar um indivíduo com demanda clínica, em consultório, é completamente diferente de avaliar um grupo de candidatos em um processo seletivo. Entram em jogo os fatores situacionais, como desejabilidade social, ansiedade de produção ${ }^{10}$, saúde, fome, sono, cansaço, uso de medicações/substâncias, familiaridade com o instrumento, rapport, idade e/ou sexo do avaliador, diferenças hierárquicas, entre outros (ANASTASI; URBINA, 2000; BUNCHAFT; CAVAS, 2002; HUTZ; BANDEIRA; TRENTINI, 2015; PASQUALI, 2001, 2016).

Inicialmente dividimos a situação quanto ao beneficiário da avaliação. Via de regra, esse deve ser o sujeito avaliado. Assim, em uma situação clínica, por exemplo, o avaliado costuma apresentar seu 


\section{Desafios da psicologia no Brasil}

melhor desempenho e respostas que acredita serem as mais próximas de seu real comportamento, pois será o beneficiário direto do resultado adequado da AP em termos de orientação para (possível) tratamento clínico. Nessa situação é comum estabelecer-se um bom rapport, até porque o sujeito é o demandante. Esse costuma se apresentar com um mínimo de desejabilidade social, assim como com ansiedade de produção adequada, além de comparecer para avaliação, normalmente, devidamente preparado para a situação (alimentado, descansado, com tempo suficiente, sem uso de medicações/substâncias atípicos), e costuma colaborar (inclusive ao indicar instrumentos aos quais, eventualmente, já tenha sido submetido anteriormente, de modo que o avaliador pode buscar similares e evitar o efeito de aprendizagem sobre a produção) o que minimiza as diferenças entre sua real produção e os possíveis erros de medida.

Lembro que os Testes Psicológicos são apenas instrumentos, e como tais devem ser reconhecidos e tratados. Não adianta analisar um Teste Psicológico atribuindo-Ihe juízo de valor como bom ou mal em si mesmo, ou como se aprecio ou não o uso daquele teste. Como instrumento, o Teste Psicológico é criado em uma dada situação e contexto, considerando um dado modelo teórico para definir seu construto, e como tal deve ser reconhecido.

Treinar o uso de Testes Psicológicos é importante para o melhor desenvolvimento das habilidades de realizar uma boa AP. Mas, mais do que isso, ensinar conceitos de parâmetros psicométricos e ensinar o acadêmico a ler manual (identificar os parâmetros e reconhecer se o instrumento é adequado para o que deseja avaliar) é mais importante do que meramente ensiná-lo o manejo com alguns instrumentos. Conhecer, ou saber buscar no material que compõe o teste, informações, por exemplo, quanto a definição do construto; situação de construção do instrumento; finalidade do teste; assim como analisar o tamanho e diversidade do grupo amostral cujos dados de resposta ao referido teste foram utilizados para as pesquisas de reconhecimento do instrumento (que estabeleceram seus parâmetros Psicométricos, a saber, validade, fidedignidade, padronização e normas); os tipos de pesquisas/análises realizadas; reconhecer os índices encontrados para cada parâmetro psicométrico; saber compará-lo aos de outras pesquisas, ou analisa-los a partir dos referenciais mínimos de adequação para o reconhecimento das pesquisas; entre outras análises, devem ser os conhecimentos que todos os Psicólogo deveriam utilizar para avaliar a adequação do instrumento ao seu interesse. Na prática, raramente encontro pares que entendem e/ou fazem tais análises. 


\section{Desafios da psicologia no Brasil}

Mas enfim, mesmo reconhecendo que "nem tudo são flores" continuo a perseverar na batalha cotidiana para promover a formação dos melhores profissionais em psicologia. A luta é árdua, mas os resultados, com cada profissional bem formado, é recompensadora.

\section{REFERÊNCIAS}

AFONSO, M. L. M. (org.). Oficinas em Dinâmica de Grupo: um método de intervenção psicossocial. São Paulo: Casa do Psicólogo, 2006.

ANASTASI, A. Testes psicológicos. 2. ed. São Paulo: EPU, 1977.

ANASTASI, A.; URBINA, S. Testagem psicológica. 7. ed. Porto Alegre: Artes Médicas, 2000.

BARCLAY, J. R. Psychological assessment: A theory and systems approach. Malabar: Krieger Publishing Company, 1991.

BARROS, I. C. Examinando pacientes - A anamnese. Mímeo, 2004, p.1-19. Disponível em: http://www.saudedireta.com.br/docsupload/1332097453Anamnese.pdf. Acesso em: 11 jun. 2015.

BUNCHAFT, G.; CAVAS, C. S. T. Sob medida - um guia sobre elaboração de medidas do comportamento e suas aplicações. São Paulo: Vetor, 2002.

CASULO, M. M. Evaluácion Psicológica. In: WECHSLER, S. M.; GUZZO, R. S. L. (orgs.). Avaliação Psicológica: perspectiva internacional. São Paulo: Casa do Psicólogo, 1999. p. 25-46.

CONSELHO FEDERAL DE PSICOLOGIA - CFP. Protocolo de Formação de Psicólogos é Assinado na América do Sul. Jornal do Federal. Informativo do Conselho Federal de Psicologia, v. 14, n. 57, 1999.

CONSELHO FEDERAL DE PSICOLOGIA - CFP. Resolução CFP no 10/2005. Aprova o Código de Ética Profissional do Psicólogo. Brasília: CFP, 2018.

CONSELHO FEDERAL DE PSICOLOGIA - CFP. Resolução CFP no 09/2018. Estabelece diretrizes para a realização de Avaliação Psicológica no exercício profissional da psicóloga e do psicólogo, regulamenta o Sistema de Avaliação de Testes Psicológicos - SATEPSI e revoga as Resoluções $n^{\circ}$ 002/2003, no 006/2004 e n005/2012 e Notas Técnicas n 01/2017 e 02/2017. Brasília: CFP, 2018.

CONSELHO FEDERAL DE PSICOLOGIA - CFP. Resolução CFP no 06/2019. Institui regras para a elaboração de documentos escritos produzidos pela(o) psicóloga(o) no exercício profissional e revoga a Resolução CFP no 15/1996, a Resolução CFP no 07/2003 e a Resolução CFP no 04/2019. Brasília: CFP, 2019.

CRONBACH, L. J. Fundamentos da testagem psicológica. 5. ed. Porto Alegre: Artes Médicas, 1996.

CUNHA, J. A. Psicodiagnóstico - V. 5. ed. Porto Alegre: Artmed, 2000.

FAGUNDES, A. J. F. M. Descrição, definição e registro de comportamento. São Paulo: Edicon, 1985.

FEITOSA, M. A. G.; COSTA, A. E. B.; BASTOS, A. V. B.; BORI, C. M.; LOPEZ, M. A.; GOMES, W. B. Minuta de Diretrizes Curriculares para os Cursos de Graduação em Psicologia. Brasília: DEPES/ SESu/ MEC, 1999. 


\section{Desafios da psicologia no Brasil}

FINELLI, L. A. C. Docência em Avaliação Psicológica: a formação em Minas Gerais - Brasil. Revista Galego-Portuguesa de Psicoloxía e Educación, v. 21, n. 2, p. 49-59, 2013.

FINELLI, L. A. C.; FREITAS, S. R.; CAVALCANTI, R. L. Docência em Avaliação Psicológica: a formação no Brasil. Revista de Estudios e Investigación en Psicología y Educación, v. Extr., n. 12, p. 12-30, 2015

FINELLI, L. A. C.; SILVEIRA, L. A. O ensino da avaliação psicológica. In: PEREIRA, D. F. G.; LOBOSQUE, E. M. (orgs.). Desafios da Avaliação Psicológica na Contemporaneidade. Belo Horizonte: Conselho Regional de Psicologia - Minas Gerais, 2019. p. 129-156.

HALL, C. S.; LINDSEY, G.; CAMPBELL, J. B. Teorias da personalidade. 4. ed., Porto Alegre: Artes Médicas, 2000.

HOGAN, T. P. Introdução à prática de testes psicológicos. Rio de Janeiro: LTC, 2006.

HUTZ, C. S.; BANDEIRA, D. R.; TRENTINI, C. M. Psicometria. Porto Alegre: Artmed, 2015.

KLOETZEL, K. Raciocínio Clínico. São Paulo: EDART, 1977.

PASQUALI, L. Instrumentos Psicológicos: Manual Prático de Elaboração. Brasília: LabPAM/IBAPP, 1999.

PASQUALI, L. (org.). Técnicas de exame psicológico - TEP. Manual. Vol. I: fundamentos das técnicas psicológicas. São Paulo: Casa do Psicólogo / CFP, 2001.

PASQUALI, L. Psicometria: Teoria dos Testes na Psicologia e Educação. Petrópolis, RJ: Vozes, 2009.

PASQUALI, L. Instrumentação Psicológica: Fundamentos e Práticas. Porto Alegre, RS: Artmed, 2010.

PASQUALI, L. TEP - Técnicas de Exame Psicológico: Os Fundamentos. São Paulo, SP: Vetor, 2016.

PINHEIRO, A. F. S. Técnicas e dinâmicas de trabalho em grupo. Montes Claros: Instituto Federal do Norte de Minas Gerais, 2014.

SISTO, F. F.; SBARDELINI, E. T. B.; PRIMI, R. (orgs.). Contextos e questões da avaliação psicológica. São Paulo: Casa do Psicólogo, 2001.

TYLER, L. E. Testes e Medidas. 3. ed. Rio de Janeiro: Zahar, 1973.

URBINA, S. Fundamentos da testagem psicológica. Porto Alegre: Artmed, 2007.

VAN KOLCK, O. L. Técnicas de exame psicológico e suas aplicações no Brasil. Petrópolis: Vozes, 1974. 2 vols.

WECHSLER, S. M.; GUZZO, R. S. L. (orgs.). Avaliação Psicológica: perspectiva internacional. São Paulo: Casa do Psicólogo, 1999. 


\section{Desafios da psicologia no Brasil}

\section{NOTAS}

\section{Notas 1}

Doutor em Ciências da Educação, Mestre em Avaliação Psicológica, Professor adjunto das Faculdades Unidas do Norte de Minas - FUNORTE, e, Universidade Estadual de Montes Claros - UNIMONTES.

\section{Nota 2}

Pode-se reconhecer aí o, vulgarmente, nomeado "Dilema Tostines" ou "Paradoxo Tostines" que remete a uma antiga campanha publicitária de venda de biscoitos dos anos 1980, cujo slogan era "Tostines vende mais por qué e fresquinho, ou é fresquinho por que vende mais?". O dilema se dá pela dificuldade de se estabelecer, claramente, a relação de causa e efeito. No exemplo supracitado, - Dilema Tostines se aplica, pois é difícil definir se a Área da Saúde acolhe mais psicanalistas porque esses apresentam maior domínio quanto a literatura do processo seletivo, ou porque como os psicanalistas, que por tradição, ocupam os cargos de gestão em saúde, determinam a forte influência dessa literatura para o processo seletivo.

\section{Nota 3}

Leia-se aqui os diversos dispositivos do Sistema Único de Saúde - SUS, operacionalizada, por exemplo através da Rede de Atenção Psicossocial (RAPS) composta por serviços e equipamentos variados, tais como: os Centros de Atenção Psicossocial (CAPS); os Serviços Residenciais Terapêuticos (SRT); os Centros de Convivência e Cultura, as Unidade de Acolhimento (UAs), e os leitos de atenção integral (em Hospitais Gerais, nos CAPS III); entre tantos outros serviços e equipamentos.

\section{Nota 4}

Fidedignidade ou precisão são reconhecidos como procedimentos sinônimos, na literatura em psicometria, utilizados para se estabelecer o parâmetro psicométrico que promove o reconhecimento do instrumento de aferição psicológica como um Teste Psicológico.

\section{Nota 5}

A literatura apresenta também a categorização dos parâmetros psicométricos agrupados em três, a saber, validade, fidedignidade ou precisão, e normas ou normatização. Nessa organização o conceito de padronização, que considera a oferta das mesmas condições de aplicação e correção, ou seja, adequação do material, das instruções, do mobiliário, das condições ambientais, etc... é agrupado ao conceito de normas, que consideram os critérios de interpretação dos resultados dos testes, sejam eles referenciados à norma (nomotéticos, produzidos em comparação do desempenho do respondente ao teste com o desempenho de diversos outros sujeitos, com características similares as suas, que já responderam ao instrumento anteriormente e cuja produção foi utilizada para a produção das tabelas normativas de referência do teste); ou interpretativos ou projetivos (idiográficos, que consideram a interpretação realizada pelo profissional da psicologia, referenciada a normas de interpretação, que não necessariamente são tabelas ou quantitativas, ao reconhecer os fatos individualmente, analisando as características idiossincráticas de cada respondente, associada aos condicionantes sociais e históricos da situação da avaliação, ou em comparação de duas, ou mais, produções de um mesmo sujeito em diferentes momentos no tempo, por exemplo, uma avaliação inicial - diagnóstica, e uma segunda avaliação pós intervenção). 


\section{Desafios da psicologia no Brasil}

Independente da escolha, por parte do profissional sobre a utilização de três ou quatro parâmetros psicométricos, é importante o reconhecimento da distinção ora posta. No texto, mantenho, por questões didáticas, a organização psicométrica em quatro parâmetros, por reconhecer as especificidades da realização de pesquisas para cada um desses quesitos, que podem ocorrer de forma independente, ou agrupada, para um mesmo instrumento. Por exemplo, na construção de um novo teste, é comum a pesquisa ser agrupada, com uma grande coleta de dados, cujas análises levam a produção dos diversos índices que vão para o manual. Por outro lado, em pesquisas de ampliação de normas ou atualização dos testes, é comum que o parâmetro que chamo de padronização, ou seja, as instruções de aplicação e correção, caso não apresentem limitações semânticas que possam gerar confusões (regionais, de gênero, etárias, etc...) e tenham, no passado, se mostrado como adequadas, sejam mantidas tais quais originalmente propostas no manual do instrumento, e se verifique, com um novo conjunto de dados de um, ou mais, grupo(s) amostral(ais), novos índices de validade, fidedignidade ou precisão, assim como novas tabelas de normas para interpretação de resultados, sem necessariamente se mandar alteração nas instruções de aplicação e regras para correção do instrumento.

Para avançar nessa discussão, recomendo as fontes Anastasi (1977); Anastasi e Urbina (2000); Cronbach (1996); Hogan (2006); Hutz, Bandeira, e Trentini (2015); Pasquali (1999; 2001; 2009; 2010; 2016); Sisto, Sbardelini, e Primi (2001); Urbina (2007); Van Kolck (1974); Wechsler e Guzzo (1999), que vão desde autores clássicos a literaturas mais contemporâneas, entre inúmeros outros que podem ser consultados.

\section{Nota 6}

Por instrumentos entendem-se: métodos, técnicas, escalas, inventários, questionários, sejam eles objetivos/psicométricos, ou projetivos/expressivos; de aplicação individual, coletiva, ou mista, com ou sem controle/registro de tempo, que demanda a produção (comportamento) do sujeito em processo de AP de forma verbal, escrita, mediada por computador, expressiva gráfica, ou outra. (BUNCHAFT; CAVAS, 2002; CFP, 2018; PASQUALI, 2001).

\section{Nota 7}

A saber, esses são os artigos que compõem a seção sobre "Justiça e proteção dos direitos humanos na avaliação psicológica" e versam sobre as relações da psicologia com convicções políticas, filosóficas, morais, ideológicas, religiosas, raciais, de orientação sexual e identidade de gênero; assim como, atividades que caracterizem negligência, preconceito, exploração, violência, crueldade ou opressão; sobre o atendimento aos princípios e artigos previstos no Código de Ética Profissional do Psicólogo (CFP, 2005); e ainda, sobre restrições a tarefas de produção, validação, tradução, adaptação, normatização, comercialização, aplicação, realização de estudos, pesquisas e atividades voltadas para a produção de conhecimento e desenvolvimento de tecnologias que envolvam testes psicológicos.

\section{Nota 8}

Com a consideração do Erro Padrão de Medida (EPM) para a análise da produção do respondente, para além de interpretar sua pontuação final no teste, chamada de Escore Bruto (EB) (seja esse dado por qualquer tipo de arranjo para pontuar as respostas), tem-se também a análise dos escores limites do Intervalo de Confiança (IC) que serão dados por IC Menor, dado pelo valor do EB subtraído do EPM; e IC Maior, dado pelo valor do EB acrescido do EPM. Assim verifica-se o Escore Padronizado (normalmente, no Brasil, dado por percentil) e Classificação para três escores (EB, IC Menor, e, IC 


\section{Desafios da psicologia no Brasil}

Maior), e não apenas pelo EB. Tal análise amplia o campo da interpretação sobre a produção do respondente.

\section{Nota 9}

Pessoalmente, acredito que esse número deva ser menor. Algo em torno de 10 acadêmicos por grupo de aula prática demonstrou, por minha experiência pessoal, ser o ideal para promover a melhor relação aprendizado x número de alunos em sala, o que ainda promove uma economia para a IES, e oferece excelente recurso para propaganda, com enfoque na qualidade da formação. Esses alunos devem preferencialmente trabalhar a prática com um Kit de teste (conjunto de manual, caderno de aplicação, folha de aplicação e crivo de correção) por aluno, mas até uma redução de dois alunos trabalhando com um Kit de material, demonstrou-se como pratica adequada e suficiente.

Nota 10

Conceito citado na nota de rodapé número 2.

Nota 11

Entendida aqui como alteração no padrão de respostas em função da avaliação, que pode ser consciente, quando o sujeito mente sobre seu potencial ou crenças (ao apresentar respostas que o mesmo sabe não serem reais, mas que acredita serem as apropriadas ao que o examinador espera ouvir), ou inconsciente, quando o sujeito responde a partir de um sistema de crenças de potencial e/ou auto percepção equivocados.

\section{Nota 12}

Compreendida como o nível de ansiedade existente frente à realização de uma tarefa nova. Esse deve ser ideal, de modo que o respondente ao teste compreenda a importância de se empenhar para responder, com seu melhor desempenho à tarefa. Não sendo elevado demais a ponto de comprometer o funcionamento do indivíduo (por exemplo, paralisando-o frente à tarefa, ou impossibilitando-o de realizar seus afazeres normais previamente a execução do exame), ou muito rebaixado, de modo que o respondente não leve a situação de avaliação à sério e responda de modo displicente e desinteressado à tarefa que precisa ser cumprida. 


\section{Capítulo 42}

\section{O MECANISMO DE PRODUÇÃO, MANUTENÇÃO E LIBERTAÇÃO DA DOR CRÔNICA: REFLEXÕES PARA A PRÁTICA CLÍNICA.}

DOI: $10.37423 / 200200252$

Ariádine Benetom de Campos (Psicóloga especialista em Psicologia Clínica Psicodinâmica e em Saúde Pública na área de concentração de Saúde Mental, com aperfeiçoamento em Orientação a Queixa Escolar. É delegada da XV Conferência Nacional de Saúde, co-idealizadora e membro do Fórum sobre Medicalização da Educação e Seciedade. Trabalhadora da Unidade Básica de Saúde do Butantã do Sistema Único de Saúde (SUS). Membro APOAIR no Instituto de Psicologia Universidade de São Pąulo).

ariadinebc@hotmail.com

Sueli dos Santos Vitorind (Psicóloga, doutoranda PSC-USP). suelidosantos@hotmail.com
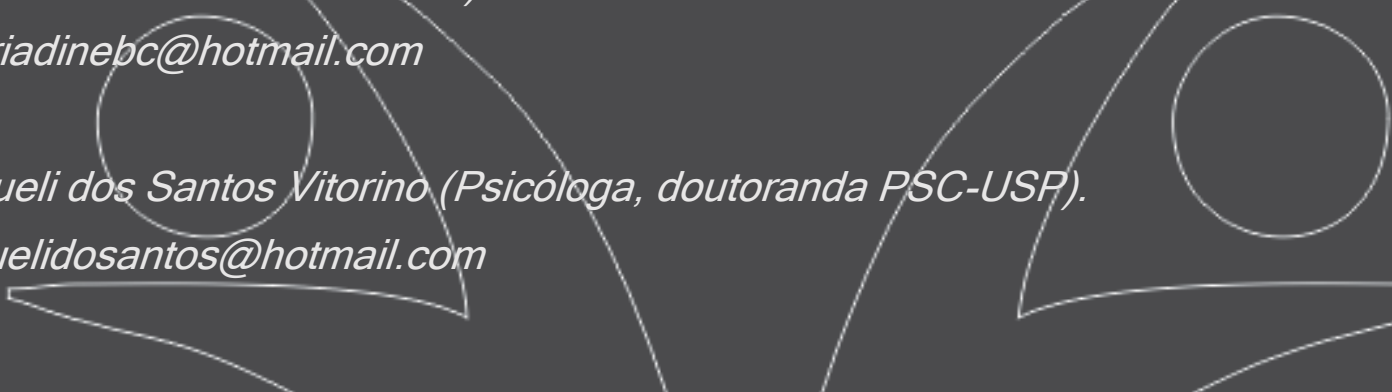

Leila Salomão de La Plata Cury Tardivo (Psióóloga, mestre, doutora, e livre docente pelo Instituto de Psicologia da USP. Coord. do Laboratorio de Saúde Mental e Psicologia Clínica Social do IRUSP).

tardivo@usp.br

RESUMO: Este trabalho propõe-se a reflettir as possiveis relações do desenvolvimento da dor crônica, com o rompimento de vínculos afetiv@s e p retorno ao estágio narcísico secundário, com o estabelecimento de um-qưadro melancólico. Quebraf-o elo narcísico e trodá-lo pelo vínculo objetal foi a meta almejadà no decobrrer do atendimento, através da análise intrapsíquica - a expansão da relação com o mundo externo.

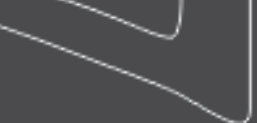




\section{Desafios da psicologia no Brasil}

Num processo de resistência a medicalização da vida, busca demonstrar a relação entre a diminuição da manifestação da queixa da dor crônica com a resignificação das representações objetais e ampliação dos vínculos afetivos nas diferentes dimensões do existir. Algumas memórias de histórias clínicas, de fragmentos de sessão de um paciente serão apresentadas, como forma de melhor compreendermos essa ligação com o quadro melancólico subjacente.

Palavras-Chave: psicodinâmica, comunicação, relação - mundo externo, medicalização, exploração integral, mudanças, movimento. 


\section{Desafios da psicologia no Brasil}

\section{INTRODUÇÃO - REFERENCIAL TEÓRICO}

As bases teóricas deste estudo estão alicerçadas na concepção de que o sujeito se expressa pelo corpo e pela mente. E pela concepção de que o ser humano é considerado um ser bio-psico-social. Segundo Tonelli ${ }^{1}, 2015$, todas as estruturas cerebrais mandam e recebem aferências de todos os locais do encéfalo, por essa razão cada indivíduo interpreta e reage a dor de forma diiferente; o que é influenciado, também, por experiências anteriores, aspectos culturais, étnicos, sociais, religiosos, etc. Destacaremos aspectos teóricos na obra de Freud que contribuiram para a construção deste trabalho, e de autores que nos abriram janelas com suas contribuições como Melanie Klein, Winnicott.

\section{INTRODUÇÃO}

Este trabalho faz parte dos estudos desenvolvidos no laboratório de Saúde Mental e Psicologia Clínica Social do grupo Apoiar da Dor Crônica, do Instituto de Psicologia da USP. O atendimento do caso em questão foi realizado em psicoterapia individual, iniciado em outubro de 2014, e se encontra em atendimento nos dias atuais. A abordagem do atendimento foi procurar levantar potencialidades do sujeito das quais não tinha consciência, através da tese de que ativando essas potencialidades na relação com o seu mundo externo as dores entrariam em declínio. Isto posto sabíamos que enfrentaríamos um grande desafio, pois iríamos em direção contrária à cultura hegemônica de justificar as dores como sendo produzida pelo indivíduo e controlada pelo medicamento. Mas a psicologia em seu caráter emancipatório mais uma vez se comprometeu em honrar suas premissas científicas e demonstrar que a compreensão e elaboração dos sentimentos reprimidos associado a expansão e integração psíquica, social, cultural e de exercício político do sujeito em seu cotidiano transforma a dor em saúde e realização pessoal.

Este estudo se justifica porque Atualmente o aumento de diagnósticos em dor crônica vem chamando a atenção para este quadro mórbido, que se apresenta com poucos estudos a respeito, e o quanto os procedimentos tem sido tomados no caminho da medicalização da saúde, numa época de acirramento das indústrias farmacêuticas e um retorno a visão biologizante do indivíduo. Estudos mais aprofundados sobre as causas do adoecer, na dor crônica, são necessários, e neste trabalho pretendo trazer contribuições significativas a este respeito. Acrescentando os diferentes recursos físicos com técnicas de respiração, pois a reserva de oxigênio aumenta a capacidade de ouvir, compreender e assimilar, e recursos psíquicos possíveis na busca de equilíbrio emocional e somático do ser humano. 


\section{Desafios da psicologia no Brasil}

Desse modo o objetivo é apresentar o percurso terapêutico de um paciente com dor crônica que obteve melhora a partir das intervenções psicoterapêuticas de abordagem psicanalítica. A hipótese norteadora das intervenções, cujos fragmentos estão sendo apresentados neste trabalho, é de demonstrar como a ampliação do universo do existir do paciente, através do estabelecimento de vínculos relacionais com suas diferentes dimensões, leva-o a sair do aprisionamento da dor crônica.

A abordagem é psicodinâmica, tal qual descrita por Freud, é (um) método de investigação; uma técnica interventiva, e um corpo de conhecimento. Desse modo, trata-se de uma forma de intervenção psicoterapêutica que considera as relações interpessoais e os aspectos intrapsíquicos do paciente. Dando especial ênfase no tipo de vínculo estabelecido entre a pessoa e o seu meio externo. Utiliza-se de recursos metodológicos da Psicanálise, da Compreensão Sistêmica e da Psiquiatria Dinâmica, para uma compreensão e uma ação integradora do paciente. Os recortes apresentados e discutidos neste artigo são oriundos de sessões passadas em que a exploração ocorreu concomitantemente à escuta da associação livre, assim como, intervenções técnicas psicanalíticas e os demais recursos potenciais do sujeito do lugar do sujeito social, incluindo a dimensão física com a importância de se usar adequadamente a respiração, sendo parte do soma, e utilizá-la como um dos recursos de restabelecimento psíquico, a dimensão política, espiritual, de lazer , cultural, profissional, afetivo familiar.

Assim começou o trabalho, como escreveu Freud:

Nosso trabalho científico em psicologia consistirá em traduzir processos inconscientes em conscientes, e assim preencher as lacunas da percepção consciente. (Freud 1923).

\section{APRESENTAÇÃO DO CASO:}

Em sua infância o paciente teve suporte familiar, morava com os pais e irmãs e a avó. O pai trabalhava e mãe era dona de casa. Tinha uma referência religiosa em que o pai levava a família para passear em outra cidade para fazer sua peregrinação. No entanto refere que este era muito rígido e que educava através de surras. Coloca que apanhava quando ele não ia para a escola, ou quando ele trazia objetos da igreja que frequentava para casa sem permissão. Mas coloca que sua avó acabavaempre de alguma forma reforçando suas atitudes. Quando o pai deixava-o de castigo, preso, a avó lhe passava cigarro, por exemplo. Sua última surra foi aos 16 anos, quando brigou com o pai por este não dar atenção a sua mãe que há um bom tempo, anos, se encontrava acamada devido a um acidente vascular cerebral, 


\section{Desafios da psicologia no Brasil}

fase que ele já sabia que seu pai já tinha outras mulheres. Nesta briga resolveu sair de casa. Já trabalhava, pôde se manter sozinho. Refere que tinha muitos agrados de senhores que trabalhavam ao seu redor e que isto lhe prejudicou na parte sexual, mas que sempre se saiu muito bem no comércio. Trabalhava num meio de muita competição e concorrência e que um dos donos da casa de comércio, vizinho ao seu trabalho, induziu-o a passar as informações sobre o comércio de seu patrão para ele, nesta época tinha por volta de 12 a 13 anos. Diz que foi aí que foi aprendendo a malandragem. Mais tarde abriu comércio com atividades não aceitas legalmente, onde junto com outros comerciantes tinham a prática de propina. Refere que conseguiu ganhar muito dinheiro nestas atividades, até que um dia ficou preso, então resolveu mudar de ramo. Mais tarde conseguiu se firmar em um emprego onde passou a ser gerente, mesmo com poucos anos de escolaridade. Refere que ele cuidou, com os seus recursos financeiros, da sua mãe. Continuou a frequentar a casa dos pais. Mas gostava de aproveitar a vida, saia com várias mulheres, bebia, começou a não cumprir com os compromissos até que perdeu o emprego. Já estava casado e teve uma filha. Mas largou o casamento e a filha para morar com outra mulher em outro estado. Abriu novamente os jogos de azar, que não deu certo e acabou se separando, voltando para São Paulo sozinho. As sessões foram continuando e revelam que tem conversado com várias mulheres pela internet. Mas que não sai com elas. Que está bem isolado.

\section{RETROSPECTIVA SOBRE O SURGIMENTO DOS SINTOMAS:}

Iniciaram-se as dores na coluna, mais ou menos aos 40 anos, quando estava residindo em outro estado. Teve uma fratura na coluna ao carregar peso (máquinas), começou a doer muito. Nos exames que fez descobriu que estava com osteosporose na coluna (equipo osteometabólica) e artrose. Há 15 anos entrou no Hospital das Clínicas na ortopedia. Há mais ou menos 12 anos na endocrinologia no Hospital SP, emagrecendo muito. Descobriu o aneurisma na aorta abdominal. Foi para o vascular. Tem herpes e diabete tipo dói controlada. A dor de ATM e DTM iniciou há 6 anos e está na odontologia do Hospital Universitário há mais ou menos 3 anos, de onde veio encaminhado para o Grupo Apoiar da dor crônica e pelo indícios de depressão, se queixando dos parentes não se preocuparem com ele.Começou a fumar com 12 anos. Sempre bebeu, mas começou a beber muito quando residia no outro estado. A companheira bebia junto e usava maconha. Refere que também usava, mas mais para a hora do sexo. Veio embora pra SP ficando de favor na casa da irmã. E depois ficou na casa de uma namorada. "Batalhou" (sic) para conseguir a aposentadoria por invalidez. Foi aí que começou a alugar uma casa para si. Quando voltou para SP tentou colocar a casa de jogos novamente, mas não deu 


\section{Desafios da psicologia no Brasil}

certo, refere não ter mais o contato social que tinha antes de ter saído de SP. Tinha, nessa época, um amigo muito rico, tinha muitos imóveis, viajava com ele para o litoral, mas que reparou que não dava para acompanhá-lo em suas aventuras só com o dinheiro da aposentadoria, não dava para continuar gastando. O amigo usava maconha. Aí resolveu parar com tudo isto e começou a frequentar um lugar religioso, ficando de 5 a 6 anos, onde era voluntário. Deu a ideia a eles de venderem água de garrafinha. Deu muito certo. Vendem até hoje. Vendem água na cirurgia espiritual. "Mas fui me isolando, entrei em depressão legal. Fiquei sozinho sem ninguém" (sic).

\section{RESULTADOS DURANTE O PERCURSO PSICOTERAPÊUTICO}

As queixas de dores raramente se apresentavam, ultimamente sem menção a elas. Apresenta-se mais integrado. Apresentado mais iniciativas nos contatos com seus familiares, com relações mais harmoniosas com os mesmos. Voltou a frequentar um espaço religioso. E aos tratamentos médicos. Aumentou confiança em si próprio, reconhecendo e fortalecendo seus aspectos bons que permitiu se aproximar de sua filha, marcando almoços para se encontrarem. Começou a marcar encontros com mulheres, mas passando para uma fase de comportamento de risco, em que passaram várias semanas para tomar consciência deste comportamento instintivo de pulsão de morte, autodestrutivo. Depois, passou a frequentar ambientes sociais, salão de dança. Foi fazendo mudanças sucessivas e crescentes em sua casa e hoje refere que deu uma geral, mudou tudo, mudou móvel do lugar, doou roupas também, deu uma "boa organizada" sic. Fez manutenção em seu carro, pois, andava sem breque de mão. Foram havendo mudanças no decorrer da terapia. Chegou a procurar uma nova residência para morar, optando em recomeçar uma vida nova, longe dos donos da casa que alugava que traziam lembranças e que continuavam com práticas que decidiu não voltar a introduzi-las em sua vida. Introduziu as caminhadas e fala que continua caminhando no parque, que quando sai para a caminhada conversa com os coroas. No entanto pelo estágio avançado da isquemia abdominal deverá passar pela cirurgia. Antes da operação da isquemia abdominal quer pintar a casa, já falou com o pintor. Está comprando o que faltava. Cesto de lixo. Já tem entrado em contato com duas de suas sobrinhas que levarão ao dia da cirurgia e contato com uma das irmãs onde irá passar o pósoperatório. "As dores hoje vem e voltam. Quando elas vêm tento contorná-las, não deixo elas me derrubarem. Continuo firme. Saio para as caminhadas e volto melhor. Mesmo mal, fui caminhar". "Consegui!" (sic). Fala que nem sabe de onde vem tanta força. Que esta força vem do além. Refere que se lembra das minhas orientações, no alto da montanha, no parque em que vai, faz respiração e pensa em "palavras boas" (sic). 


\section{Desafios da psicologia no Brasil}

Comenta que a sua irmã que devia uns dólares para ele, convidou-o a morar perto de sua casa quando estivesse mais velho para ela cuidar dele, quando voltou do outro estado. Apontei ao paciente que agora ele está conseguindo reconhecer aspectos bons em sua irmã, indicando o momento em que se encontra, de saber reconhecer o objeto bom presente em seu interior e em suas relações. A irmã apresentou-se também acolhedora, em seu lado bom. Desconstruindo a ideia de que a irmã só quer Ihe fazer mal, a qual não quis pagar o dinheiro que lhe devia, interpretando de forma subjetiva um aspecto destrutivo da irmã. Pude retomar essa dinâmica de elementos bons e maus. Ou de alguma forma ela já oferecia esse cuidado futuro como forma de pagamento da dívida, uma vez que não podia pagar em dinheiro. Foi possível sentir que de alguma forma sentiu um alivio ao levantar-se da cadeira para me cumprimentar. Refere que sentiu-se um pouco melhor pelo fato de não se sentir mais uma vez inferiorizado, em ter que ficar de favor na casa da irmã. O que eu pude apontar é que agora ele está podendo reconhecer aspectos bons no mundo externo, e tolerar o objeto bom também fora dele, e por consequência internalizá-los também. Anteriormente, no início do atendimento, não conseguia ver aspectos bons da vida e nem de si próprio. Hoje ele reconhece que a irmã não era tão má assim. Que isto, dela oferecer cuidar dele quando este envelhecer, ele nunca tinha trazido na sessão. Ele consegue dar lugar, visibilidade ao objeto bom internalizado. Esta lembrança ajuda-o a fazer com que o amor supere e domine o ódio.

O estado físico e emocional do paciente, nos primeiros atendimentos, apresentava- se com dores visíveis, se sentava com dificuldade na cadeira, se queixava de dores na coluna ao mesmo tempo em que se recriminava por ter errado no passado. Referia que tinha abandonado todos os tratamentos de dor crônica, só estava fazendo acompanhamento mesmo com o dentista. As sessões se passavam e o conteúdo permanecia o mesmo, sempre repetindo a mesma frase, "eu não me perdoo de ter errado no passado"..., o que me remeteu num primeiro momento aos escritos de Freud sobre Pulsão de Morte, para eu levantar algumas hipóteses sobre o que ocorria com o paciente. Atenta ao meu estado emocional, diante de seu sofrimento, à contratransferência, bem desenvolvido por Paula Heimann, fui percebendo que sua presença me absorvia, e me imobilizava. Ou seja, prestava atenção no movimento do paciente e em meu movimento. Era preciso que eu me libertasse desta suposta simbiose, que me levou a refletir que o mesmo estava bastante regredido, necessitando de um colo de mãe, mas eu precisava oferecer o colo de uma "mãe suficientemente boa", para eu sair deste estado de amalgama em que me colocou, num processo inconsciente, para que eu pudesse entender o que estava acontecendo e poder ajuda-lo. 


\section{Desafios da psicologia no Brasil}

“Psicoterapia não é fazer interpretações argutas e apropriadas; em geral, tratase de devolver ao paciente, a longo prazo, aquilo que o paciente traz. É um derivado complexo do rosto que reflete o que há para ser visto. Essa é a forma pela qual me apraz pensar em meu trabalho, tendo em mente que, se o fizer suficientemente bem, o paciente descobrirá seu próprio eu (self) e será capaz de existir e sentir-se real. Sentir-se real é mais do que existir; é descobrir um modo de existir como si mesmo, relacionar-se aos objetos como si mesmo e ter um eu (self) para o qual retirar-se, para relaxamento".(Winnicott 1975)

Gemidos e incômodos físicos entrecortavam frequentemente nosso diálogo, no início do tratamento. Com autoacusações intermináveis de ter errado muito no passado e de ter sido esquecido pelas pessoas e parentes. Meses se passaram em análise fazendo associações a possíveis culpas relacionadas às suas práticas ilícitas do comércio. Se apresentava como uma pessoa solitária, vítima de um mundo mal agradecido. Neste estado de estado narcísico, precário, veio sobrevivendo durante esses anos anteriores. No entanto, no decorrer da psicoterapia passou a se expressar mais e aspectos de ambiguidade começaram a aparecer, principalmente em relação aos afetos dirigido a sua filha e a ex- esposa, e foi se estabelecendo um fator específico associado à sua condição dolorosa e à análise das consequências que o acompanha. O que pode evidenciar um progresso no seu quadro clínico.

Um homem adoece porque oculta de si mesmo uma história cujo significado lhe é insuportável. Além do mais, sua doença é uma resposta simbólica que busca, inconscientemente, alterar o significado da história ou, o que é o mesmo, seu desenlace . (Chiosa, 1987)

Havia um rancor que estava embutido, por sua filha não demonstrar gratidão em relação ao apartamento que passou em seu nome e usufruto de sua mãe, antes de se afastar dela para o outro estado, e de não se perdoar diante deste ato do passado, causando-Ihe tantos transtornos somáticos e provocando este estado de prostração melancólica. E que se agudizam todo o ano próximo ao vencimento do aluguel. Pudemos reconhecer esta associação. Momento em que seu estado depressivo acirra e as ameaças de fúria se transbordam. O paciente não se conforma em ter que pagar aluguel, com sua pouca condição financeira lembrando que tem, ou melhor, teria este apartamento tão caro para si numa região privilegiada de SP.. Neste momento reconhece a causa peculiar de seu adoecimento. O chamado melancólico, em que se destaca a autocrítica, confronta a perda do objeto de amor através da identificação; o objeto perdido instala-se no ego. (Grotstein 1981) 


\section{Desafios da psicologia no Brasil}

Houve uma transformação visível relacionada a construção de identidade real, quando pode rever situações vividas no passado e poder entender o processo de formação de sua personalidade e a partir daí transformá-la. Verificando quais núcleos emocionais reprimidos que delineavam seus aspectos da personalidade. Percebo que a mais profunda de sua depressão estava relacionada a imagem da perda de seu apartamento, simbolicamente relacionado ao sentido de família, agora gerando um conflito interno, uma vez que não pode elaborar o luto da perda deste apartamento, identificado com ele, introjetando a raiva despertada pelo significado deste objeto e de não ter conseguido separá-lo dele, porque carregou consequências irreversíveis materialmente, mobilizadora de uma das suas principais queixas, econômica, e em seus aspectos reais de rompimentos afetivos relacionais familiares, difíceis de aceitar e de elaborar, que ainda ficam pendentes, gerando ansiedade, no entanto buscando formas para dar continuidade na vida apesar deste fato. Decidiu continuar com suas caminhadas no parque na companhia da família de capivaras que lá se encontram e planejar uma viagem de cunho religioso.

A partir desta compreensão se libertou das transferências e deslocamentos que fazia para outros relacionamentos originados deste status estabelecido. Pode retomar a dinâmica de elementos bons e maus. Passou a entender e aceitar os outros sujeitos de seus relacionamentos de forma mais real. Quanto a sua irmã percebeu que esta já Ihe dispensava uma atenção, pois de alguma forma ofereceu um cuidado futuro, na velhice, como forma de pagamento da dívida, uma vez que não podia pagar em dinheiro. Este sentiu um alivio com esta interpretação e levantou-se da cadeira para me cumprimentar. Refere que sentiu um pouco melhor pelo fato de não se sentir mais uma vez inferiorizado, em ter que ficar de favor na casa da irmã. O que eu pude apontar é que agora ele está podendo reconhecer aspectos bons no mundo externo, e tolerar o objeto bom também fora dele, e por consequência internalizá-los também. Anteriormente, no início do atendimento, não conseguia ver aspectos bons da vida e nem de si próprio. Hoje ele reconhece que a irmã não era tão má assim. Que isto, dela oferecer cuidar dele quando este envelhecer, ele nunca tinha trazido na sessão, um dado significativo. Ele consegue dar lugar, visibilidade ao objeto bom internalizado, se mostrando mais integrado. Esta lembrança, bem como outras em que a sobrinha recorda que ele dava o melhor presente de natal para os sobrinhos, e que a outra irmã já se prontificou em ficar no hospital na cirurgia, ajuda-o a fazer com que o amor supere e domine o ódio:

Por outras palavras, podemos supor que as repetidas experiências de um amor que supera e domina o ódio- em última instância, do instinto de vida que sobreleva o instinto de morte- constituem uma condição essencial para a capacidade de integração do próprio ego e de sintese dos aspectos 


\section{Desafios da psicologia no Brasil}

contrastantes do objeto. Nesses estados ou momentos, a relação com o mau aspecto do objeto, incluindo a ansiedade persecutória, retrocede e declina.

(Klein, 1948).

\section{CONSIDERAÇÕES FINAIS}

Com o maior conhecimento de sua dinâmica psíquica este paciente passou a demonstrar maior domínio nas expressões de seus afetos, com segurança para administrar sua vida sem prejuízos para sua consciência e na vivência relacional. Através de sua expansão real de vínculos no mundo externo, nas diferentes dimensões do existir, na prática esportiva, no acesso ao lazer, em exercícios de cidadania no protagonismo de reivindicação de seus direitos quando se manifesta para atendimentos de saúde mais precisos, nas práticas religiosas, no cultivo às relações afetivas familiares e de parentes próximos, e às próximas possibilidades de viagens. Encarando a cirurgia da isquemia abdominal próxima, como um momento necessário para retornar à vida com mais vigor e realizações. Sugere-se continuar pesquisando este caso, uma vez que o paciente adentrando à uma nova posição, terá novos desafios que exigirão atenção e apoio para que as ansiedades despertadas não impeçam o curso de seu amadurecimento pessoal.

\section{REFERÊNCIAS}

Brasil. Ministério da Saúde. (2003). O desenvolvimento do Sistema Único de Saúde.

Textos básicos de saúde, integralidade. Série B. Brasília.

Chiozza, L. Por que adoecemos? A história que se oculta no corpo. São Paulo, Papirus, (1987);

Figueira, S.A., Heimann. P. (1994) In Marcelleti de Oliveira, B.S Contra Transferência de Freud aos Contemporâneos. Casa do Psicólogo; (1994);

Freud, S., Edição Standart Brasileira das Obras Psicológicas Completas (Imago) vol XXIII (1990);

Klein, M, (1945) Os Progressos da Psicanálise. Rio de Janeiro, Zahar (1978); Winnicott D. W. (1975). O brincar e a realidade. São Paulo: Imago. 


\section{Capítulo 43}

\section{A IMPORTÂNCIA DO LÚDICO NO DESENVOLVIMENTO DA AUTOESTIMA DE CRIANÇAS COM PARALISIA CEREBRAL}

Danielle Brena Dantas Targino

dani.1603@hotmail.com

Eliane Ribeire-Magalhães

elianeek2@hotmali.som

Cândida Helena Lopes Alves candida.alves@hotmail.com
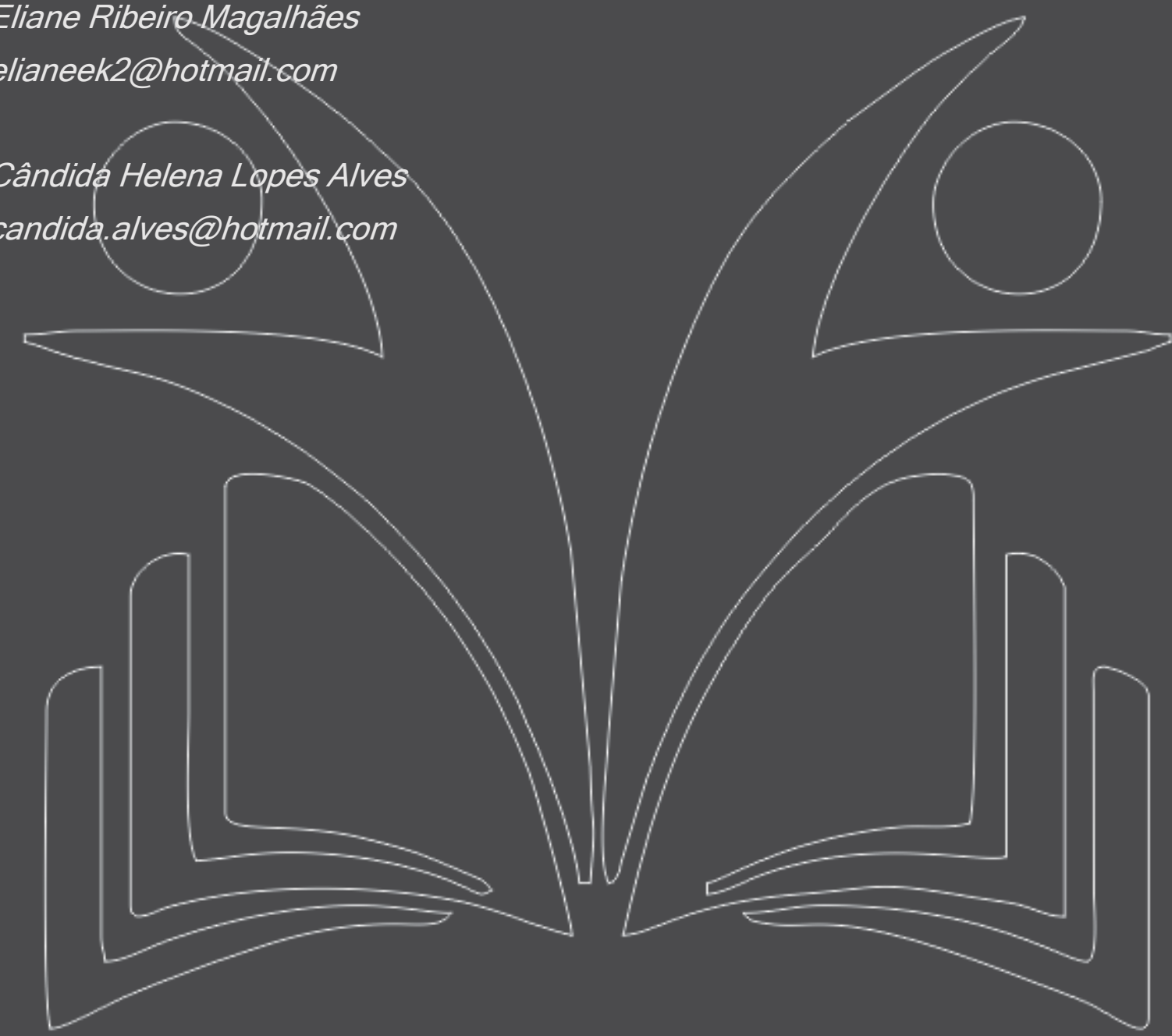


\section{Desafios da psicologia no Brasil}

\section{INTRODUÇÃO}

O propósito desta pesquisa é descrever de que forma o lúdico pode auxiliar no desenvolvimento da autoestima de crianças com Paralisia Cerebral (PC) que se trata de uma lesão que pode envolver e danificar algumas partes do cérebro. Este conjunto de distúrbios pode comprometer funções cerebrais e do sistema nervoso central (SNC), provocando limitações na cognição, comunicação, sensação, percepção, comportamento e por problemas musculoesqueléticos secundários, os quais dificultam o desempenho nas atividades diárias.

Para Rosan, Braccialli e Araújo (2016), a PC é um distúrbio não progressivo que ocorre no desenvolvimento encefálico fetal ou na infância, sendo representado por um grupo de desordem permanente do desenvolvimento relacionado à postura e ao movimento. Como consequência dessa lesão, ocorre limitação na participação de atividades e outras ações do dia a dia.

A Paralisia Cerebral é oriunda de uma má formação cerebral ou lesão não progressiva do cérebro que também é denominada de encefalopatia crônica não evolutiva que envolve afecções do SNC relacionadas a limitações na vida cotidiana e disfunções motoras (MELLO et al., 2019). Geralmente, acontece na gestação, durante o parto ou logo após o nascimento, momento em que o cérebro ainda está em processo de amadurecimento.

O lúdico auxilia a desenvolver competências, aumentando assim o aprendizado, os sentidos, além de permitir que a criança supere seus limites, suas dificuldades, e interaja mais socialmente, contribuindo positivamente em sua autoestima (MALUF, 2008). Nessa mesma direção, Fernandes, Amarante e Falad (2019) enfatizam a importância do lúdico no tratamento de pessoas com sequelas neurológicas.

Neste sentido, faz-se necessário uma pesquisa relacionando o mundo das brincadeiras e a PC, de modo que possa auxiliar pais, professores e diversos outros profissionais da saúde a entender melhor as chances de desenvolvimento da autoestima destas crianças.

É indispensável enfatizar que as atividades de vida diária comuns e o acesso a áreas de lazer são fundamentais para o desenvolvimento dos sujeitos com deficiência, o que não faz parte da realidade da maioria infelizmente. Desse modo, sem esses serviços de saúde e educação, esses indivíduos tornam-se dependentes e passam a ser parte de uma parte excluída de um convívio social de qualidade (SOUZA; ROCHA, 2017).

O principal objetivo será descrever de que forma o lúdico pode auxiliar no desenvolvimento da autoestima de crianças com Paralisia Cerebral. Para chegar a este ponto, será feito um levantamento sobre as concepções dos pais acerca da relevância do brincar e das suas noções sobre a autoestima de 


\section{Desafios da psicologia no Brasil}

seus filhos, a identificação da importância do lúdico e de suas influencias, e por fim, descrever a interação do lúdico e da autoestima.

\section{O LÚDICO}

O brincar é a essência infantil, atividade natural, espontânea e de fundamental importância para a criança. Deste modo, a metodologia lúdica na prática pedagógica do ensino infantil é de extrema importância, já que ao brincar a criança se depara com desafios novos, os quais proporcionam o desenvolvimento pleno da criança (SOARES NETO, 2018). Referente ao histórico do brincar, Martins (2009) afirma que desde a época da Grécia antiga é possível perceber traços de estudos de pensadores que viviam aquele momento e que já davam importância ao lúdico, como Aristóteles, que dentre as classificações que montou na época, apontou que existia o "Homo Ludens", aquele que valoriza o brincar.

O lúdico é natural e subjetivo, portanto, faz parte do ser humano, e assim, através destas atividades é perceptível o desenvolvimento das capacidades intelectuais, a partir das ideias, da imaginação e do raciocínio. É com o auxílio das brincadeiras que a criança vai desenvolvendo seus primeiros traços de caráter e personalidade. É necessário valorizar o lúdico dentro do cotidiano infantil (BONFIM, 2010). Desenvolver o lúdico no ambiente escolar exige que o professor tenha uma fundamentação teórica bem estruturada, entendendo que as atividades devem estar adequadas às situações. Os educadores não podem utilizar um jogo somente para distrair ou para que os alunos fiquem quietos, é preciso ter um objetivo para assim o lúdico ser proveitoso, voltado para uma aprendizagem mais efetiva e bem direcionada (ROCHA, 2017).

O lúdico se apresenta como estratégia pedagógica insubstituível a ser utilizada como estímulo na construção do conhecimento matemático. Servindo como ferramenta de extrema valia para o desenvolvimento pessoal da criança, bem como para o alcance de objetivos institucionais da educação (SOARES NETO, 2018).

Trabalhar a ludicidade é algo primordial para o desenvolvimento de competências de concentração, memória, reflexão, raciocínio, sensação e todos os aspectos básicos relacionados à aprendizagem. Da mesma maneira que influencia na melhora das habilidades sociais e da própria autonomia da criança. A Importância do lúdico é um assunto que vem sendo muito trabalhado, principalmente, na área da educação infantil, onde a brincadeira é algo muito presente no cotidiano das crianças, e é por meio do lúdico que a criança começa a entender e aprender que existem regras e como o mundo funciona (ROCHA, 2107). 


\section{Desafios da psicologia no Brasil}

Vale destacar que as infraestruturas das escolas para desenvolvimento de brincadeiras e demais atividades culturais, não são tão apropriadas, principalmente, para crianças com deficiências, apresentando inadequações, com ausências de adaptações para aplicações de ações metodológicas que venham a ajudar no desenvolvimento integral das crianças.

A metodologia lúdica na prática pedagógica é de extrema importância, uma vez que por meio da brincadeira e de jogos, a criança se depara com desafios novos, os quais proporcionam o seu desenvolvimento pleno, favorecendo ganhos cognitivos e sociais, além da sua motricidade de forma natural, especialmente para aquelas que possuem dificuldades motoras, onde certos jogos fazem com que eles precisem se esforçar mais fisicamente, trazendo benefícios a curto e longo prazo.

O lúdico é mais do que apenas brincar e se divertir, especialmente porque é capaz de estimular o aprendizado, contribuindo para o intelecto da criança. Este valor educativo dos jogos gera um conhecimento que se diferencia dos padrões mais rígidos, portanto, ele se torna prazeroso. O lúdico na educação infantil é uma das estratégias mais bem-sucedidas no que diz respeito à estimulação do desenvolvimento cognitivo e de aprendizagem da criança. (ROCHA, 2017). Salienta-se, então, a importância do uso do processo lúdico como um amplo elemento de motivação, onde a criança se desenvolve com autoconfiança e de forma ativa (SOARES NETO, 2018).

O ambiente educativo deve ser um espaço agradável, alegre e propício ao desenvolvimento psicossocial e emocional, à formação da identidade e desenvolvimento da autonomia do educando, favorecendo a autoestima e o autoconhecimento (LUCENA, 2016). Além de contribuir para a interação social, auxiliando o desenvolvimento dos pontos fracos/limitações, propiciando o processo de inclusão.

O brincar é primordial durante toda a infância, independente das condições físicas e econômicas da criança. É um modo de expressão e deve ser usado até mesmo dentro da psicoterapia, através da ludoterapia (CARVALHO, 2009). Portanto, o lúdico é a representação em ato e em pensamento, possuindo função simbólica, permitindo um contorno ao imediatismo e egocentrismo da ação. (SOARES NETO, 2018). As brincadeiras e os jogos são, portanto, mais que divertimento, tornando-se elemento imprescindível no processo de ensino aprendizagem da criança.

\section{AUTOESTIMA}

A autoestima refere-se a uma autoavaliação de valores que uma pessoa faz de si em diversas situações cotidianas, corresponde a um sentimento intrínseco e inerente ao ser humano (VIEIRA; FREITAS, 2017). É a soma de opiniões que o sujeito tem sobre si, sobre seu valor e suas competências, ou seja, 


\section{Desafios da psicologia no Brasil}

é um reconhecimento de suas capacidades e de sua importância na sociedade e na vida daqueles que o cercam. Ela pode ser positiva, quando traz satisfação para a pessoa e causa bem estar consigo mesmo, ou negativa, gerando sensação de fracasso e inutilidade (SBICIGO, BANDEIRA e DELL' AGLIO, 2010).

De acordo com os estudos de Branden (2009) a autoestima simboliza a concepção que possuímos sobre o que nós somos. O sujeito que possui uma autoestima estável é menos inseguro em relação aos julgamentos que possa vir a receber, compreende suas capacidades e as valoriza, sente-se bem sobre si mesmo, conhece e aceita seus próprios limites, em suma, são independentes de elogios alheios.

As pesquisas apresentadas até o momento evidenciam que a autoestima, apesar de ser inerente ao ser humano, é desenvolvida principalmente na etapa infantil e justamente neste momento da vida do ser humano que se determinará se será elevada ou baixa (VIEIRA; FREITAS, 2017).

A autoestima é acometida pelas interações e relações interpessoais, visto que é no contexto social que a pessoa vai formando opiniões a seu próprio respeito. É essencial que o indivíduo possa reconhecer suas características como positivas, para que seja evitado desprezo, insatisfação e rejeição por si mesmo, que acarreta em uma pessoa que se sente desmerecedora e inferior aos demais (PEREIRA, 2007). Esse tema vem se tornando cada vez mais importante devido à sua forte influência no comportamento das crianças (VIEIRA; FREITAS, 2017).

A psicologia enfatiza a grande importância que a autoestima tem na vida do indivíduo, justificando a presença de alguns aspectos do comportamento e afetividade, inclusive, a vontade de estar satisfeito consigo mesmo o que refletirá em suas ações em diversos contextos.

Indivíduos que nascem com algum tipo de deficiência possuem mais facilidade de desenvolver uma autoestima negativa, em especial aqueles que têm dificuldades em realizar tarefas e que se sentem classificados como incapazes pelo resto da sociedade, com isto, acabam por desconhecer outras habilidades e competências e seguem se sentindo inferiores aos demais (SADE e CHACON, 2008).

O período pré-natal refere-se a um momento de preparação tanto para o nascimento da criança quanto para a maternidade, proporcionando aos profissionais de saúde a possibilidade de desenvolver a dimensão do cuidado, assumindo o perfil de educadores que compartilham saberes, preparando e instigando a autoestima e autoconfiança da mulher para viver o período gestacional, o parto e o puerpério (RIBEIRO et al., 2016).

Durante o desenvolvimento infantil, tanto os professores quanto os pais precisam compreender a importância de um elogio, para que a criança possa ver que suas qualidades são contempladas e que 


\section{Desafios da psicologia no Brasil}

suas limitações podem ser desenvolvidas. Neste contexto de interação social, as entidades socializadoras, principalmente a família e a escola, atuam com papéis centrais na análise da origem e desenvolvimento da autoestima.

A família que transmite segurança e permite que a criança desenvolva uma autoimagem positiva revelará que seu potencial é importante para a sociedade, contribuindo para que sua autoestima seja sempre elevada e sua autoconfiança aliada aos desafios cotidianos (VIEIRA; FREITAS, 2017). Diante disto, torna-se imprescindível o papel do professor e dos responsáveis na evolução infantil, proporcionando experiências enriquecedoras que, por consequência, são capazes de fortalecer a autoestima infantil e promover a capacidade do aluno (SOARES NETO, 2018).

Um elogio honesto tem o peso de fazer uma criança passar pela infância e entrar na adolescência entendendo o seu valor e tendo autoconfiança. Dentro da sala de aula isto pode trazer mudanças, no sentido de incentivar o estudo, reforçar os comportamentos adequados e assim causar extinção no que precisa ser alterado.

É fundamental que os profissionais de saúde ultrapassem os limites do modelo clínico, sejam mais atuantes e humanizados, visando atender as necessidades dos pacientes na sua integralidade, estimulando sua relação saudável nas diversas fases da vida (RIBEIRO et al., 2016).

Enfatiza-se que a relação da criança com os adultos significativos compõe a construção da autoestima, com uma forte influencia no seu desenvolvimento, podendo, assim, tornar-se baixa ou elevada. A família tem papel fundamental, principalmente, por meio de comportamentos que são expressados em seus relacionamentos e, quando reforçam valores da criança, tendo o cuidado em corrigi-la nos momentos adequados, despertando sentimentos de valorização, algo necessário não somente durante o crescimento infantil, mas ao longo de toda a vida. No entanto, se essa relação for negativa, com rejeição, punição, agressões verbais e não-verbais, a criança apresentará comportamentos inadequados, insegurança e ansiedades, autoavaliando-se como incompetente, o que acarretará em uma autoestima negativa (VIEIRA; FREITAS, 2017).

\section{PARALISIA CEREBRAL}

A Paralisia Cerebral é definida como encefalopatia crônica não progressiva da infância e apresenta como características distúrbios motores e de postura. É classificada em relação às formas, o local da lesão, a etiologia e a distribuição topográfica (MELLO et al., 2018). A PC atinge o sistema nervoso central, provocando lesões no desenvolvimento motor, que pode resultar em transtornos no 


\section{Desafios da psicologia no Brasil}

movimento e no tônus postural de forma permanente e o diagnóstico comumente ocorre no início da infância, momento em que os sintomas ficam mais aparentes (DANTAS et al., 2010).

Destaca-se que o quadro clínico não é claro e invariável. Dessa forma, as síndromes de PC são caracterizadas por distúrbios motores e posturais que fazem do movimento voluntário algo complexo, tornando-se estereotipado, descoordenado e limitado. As lesões no SNC podem levar a alterações do equilíbrio, tônus, coordenação motora, postura e de movimentos voluntários (OLIVEIRA et al., 2019). As causas da PC variam de acordo com o período gestacional ou fase de desenvolvimento da criança. Assim, nos períodos pré-natais e perinatais as principais causas da PC são complicações da placenta, hipoxemia, infecções, más-formações no SNC e o nascimento precoce. Em relação ao pós-natal, a PC está ligada, geralmente, a procedimentos vasculares, traumas no crânio, convulsões metabólicas, infecções e encefalites (CAIANA et al., 2016).

Os tratamentos podem ser diversificados para as disfunções apresentadas pelo portador da PC, não ficando restrito à administração de medicamentos e técnicas cirúrgicas. Dentre as formas terapêuticas não invasivas empregadas na reabilitação neurológica, destacam-se a hidroterapia e a equoterapia visto que apresentam resultados bastante satisfatórios em relação à estimulação das atividades motoras, adequação de tônus e melhora do equilíbrio (BOARDMAN; HAWDON, 2015; MELLO et al., 2019).

O tratamento fisioterapêutico deve ser iniciado precocemente para estimular o desenvolvimento neuropsicomotor da criança com PC (SCHMITZA; STIGGER, 2014). Assim, a hidroterapia é uma abordagem terapêutica muito utilizada na busca da melhora e recuperação desses pacientes. A equoterapia busca ganhos motores para quem a pratica, mas também o desenvolvimento biopsicossocial, propiciando que o paciente experimente uma evolução das capacidades relacionais em conjunto com uma maior interação e comunicação afetiva dos praticantes com o meio social em que vivem (SOUZA et al., 2016). Causa estimulação sensório-motora com facilitação neuromuscular e proprioceptiva. Quando a sessão ocorre, a integração sensorial acontece entre os sistemas visual, vestibular e proprioceptivo. Os receptores específicos são ativados para capturar e codificar os estímulos necessários para executar a tarefa (MORAES et al., 2016).

Quanto ao diagnóstico de PC, salientam-se persistências de reflexos primitivos, atrasos no desenvolvimento motor, apresentando reflexos anormais e fraqueza referente ao desenvolvimento dos reflexos protetores (CAIANA et al., 2016).

Os indivíduos com PC devem ser tratados o mais cedo possível, devendo-se procurar estratégias diversificadas para estimular o desenvolvimento motor dessas crianças. Caiana et al. (2016) relata que 


\section{Desafios da psicologia no Brasil}

a realidade virtual vem se destacando, abrindo espaço referente aos métodos de tratamento, demonstrando nessa população muitos benefícios do uso desse recurso uma vez que o avanço da tecnologia vem fornecendo grande contribuição quanto ao desenvolvimento de jogos virtuais.

Os pacientes demonstram que perdurariam, por mais tempo, no tratamento, gerando um efeito "hipnótico", desviando a sua atenção da dor que sentem para as atividades geradas pelo ambiente virtual, fornecendo, assim, uma sessão de reabilitação para o paciente de forma mais prazerosa (LOPES et al., 2017). E, nessa visão, observa-se que novas técnicas têm surgido com o intuito de se obter cada vez mais resultados significativos no processo de reabilitação. É inegável a participação no processo tecnológico, portanto, a saúde deve usufruir dessa tecnologia a favor também dos pacientes com paralisia cerebral.

Segundo Teixeira-Arroyo e Oliveira (2007) a Paralisia Cerebral se caracteriza como um distúrbio não progressivo consequente de uma lesão cerebral, que pode causar alterações motoras e psíquicas.

Em relação à incidência dessa desordem neurológica, a literatura estudada informa um aumento nos últimos anos, apesar do quadro clínico da patologia causar um grande impacto à sobrevida. Em países desenvolvidos, está em 1,5 e 2,5 a cada 1000 crianças nascidas vivas nos países. Contudo há relatos que, incluindo incidências gerais, 07 a cada 1000 podem apresentar paralisia cerebral. Referente ao Brasil, não existem estudos conclusivos, no entanto estimam-se 30.000 a 40.000 novos casos por ano, assim, percebe-se uma incidência maior por conta da falta de atenção ao pré-natal da gestante (ANTUNES et al., 2017).

Os cuidados com as crianças que sofrem com a Paralisia Cerebral necessitam a união de equipes multiprofissionais, que contenham psicólogos, neurologistas, psiquiatras, ortopedistas, enfermeiros, fisioterapeutas, terapeutas ocupacionais, dentre outros. Estes atendimentos em diversas áreas da saúde contribuem para diminuir o impacto da patologia no desenvolvimento. É necessário compreender cada indivíduo como único e expô-lo a um tratamento que satisfaça todas as suas necessidades, que podem ser totalmente distintas de outras pessoas com a mesma condição (RIBEIRO; BARBOSA; PORTO, 2011).

Uma pesquisa realizada pelas autoras Zanini, Cemin e Peralles (2009) concluiu que a cada mil crianças, aproximadamente duas nascem com PC nos países com maiores índices de desenvolvimento. Porém, nos países mais pobres e que ainda não são tão desenvolvidos, o número sobe para sete a cada mil. Os motivos mais habituais estão conectados à problemas genéticos, inflamatórios, traumáticos, congênitos e infecciosos. Estas eventuais alterações são mais cabíveis de ocorrer ao longo do pré- 


\section{Desafios da psicologia no Brasil}

natal, perinatal e pós-natal. Os sintomas mais comuns são: movimentos involuntários, rigidez muscular, dificuldades na coordenação motora, atraso intelectual, distúrbio motor, entre outros. Maciel e Raposo (2010) qualificam a Paralisia Cerebral de acordo com os seus tipos mais comuns. A forma espática está conectada com o córtex cerebral, onde há uma lesão que diminui a força do músculo, causando dificuldades em se movimentar. A atáxica atinge diretamente a coordenação motora do paciente, podendo tornar o movimento irregular e trêmulo. A atetoide é causada por estímulos instáveis do cérebro para o corpo, proporcionando movimentos involuntários. Já a mista ocorre nos casos em que o sujeito desenvolve dois tipos ou mais de lesão no movimento. Estes mesmos autores definem que em relação à localização da lesão, há a monoplegia (apenas um membro danificado), paraplegia (quando atinge dois membros), a triplegia (compromete três membros), quadriplegia (danifica o movimento dos quatro membros), hemiplegia (abala membros de um lado do corpo) e hemiplegia dupla (ataca um dos membros superiores e outros dois membros do mesmo lado do corpo).

Deve-se levar em conta as dificuldades cognitivas que podem surgir em pacientes com PC, visto que existe uma contenção biológica que interfere no desenvolvimento global da pessoa (BOTTCHER, FLACHS e ULDALL, 2010).

Apesar dos problemas físicos e cognitivos percebidos nos indivíduos que sofrem de Paralisia Cerebral, é importante salientar as dificuldades que eles possam ter ao enfrentar os ambientes sociais/escolares. Com isto, torna-se fundamental os pais e professores os ajudarem a participar do meio em que vivem, estimulando suas capacidades, mesmo que seja necessário introduzir uma educação inclusiva. Esta convivência com as outras pessoas estimula a inteligência, aumenta o aprendizado e a autoestima, além de gerar prazer e satisfação para a criança (MACIEL e RAPOSO, 2010).

As pesquisas de Freitas (2009) afirmam que é provável perceber diferença nos comportamentos entre crianças com PC e crianças que não possuem patologias, devido a mudanças nos âmbitos cognitivo, biológico e fisiológico.

Santos (2012) esclarece através de suas pesquisas a notável importância da psicoterapia no cotidiano deste indivíduo que sofre com Paralisia Cerebral, dado que o efeito causado remete a melhora da criança de forma completa, desde a sua funcionalidade e autoestima, até o desenvolvimento global. Através da terapia, é possível aumentar a qualidade de vida deste paciente e até mesmo de seus cuidadores, além de trazer estratégias e intervenções que incentivam a um aumento das capacidades 


\section{Desafios da psicologia no Brasil}

cognitivas. Por fim, resulta em um auxílio para os pais que muitas vezes não compreendem a importância de deixar a criança viver sua infância, mesmo que haja restrições.

\section{METODOLOGIA}

O trabalho em questão trata-se de uma pesquisa descritiva, com abordagem qualitativa e natureza aplicada, resultante do levantamento e análise de artigos nos idiomas português, inglês e espanhol presentes nas bases eletrônicas de dados Medline, LILACS, SciELO, Google Scholar e Portal de Periódicos da Capes publicados no período de 2007 a 2019. A estratégia de busca de estudos foi composta por etapas. Iniciou-se com a procura de artigos nessas bases eletrônicas de dados, utilizando os descritores relacionados ao tema: paralisia cerebral, lúdico, autoestima, intervenções psicomotoras, dentre outros. Os artigos selecionados passaram por análise das referências, aquelas que se mostraram relevantes foram incluídas em uma nova busca direcionada.

Os títulos e resumos dos artigos pré-selecionados foram analisados a fim de determinar a real relevância dos trabalhos para o estudo. Na presença de dúvida sobre a relevância do artigo, realizouse leitura integral do conteúdo, com a inclusão ou exclusão, de acordo com os critérios destacados. Os artigos que corresponderam aos critérios de inclusão foram assim analisados e descritos nos resultados.

\section{INSTRUMENTOS DE COLETAS DE DADOS}

Além da leitura seletiva de artigos científicos datados a partir de 2007, foram elaboradas duas entrevistas: uma que foi aplicada com dois pais de crianças que sofrem com PC e outra com três psicólogos que trabalham com este tipo de patologia, a fim de compreender melhor a relação dessas crianças com o lúdico. Todos os entrevistados possuem idade entre 30 a 50 anos, ensino superior completo e classe social média. Os pais que concederam entrevista só possuem um filho.

\section{ANÁLISE E INTERPRETAÇÃO DE DADOS}

Foram realizadas leituras e fichamentos com o foco de ordenar as informações contidas nas fontes e também análise e interpretação dos resultados da entrevista, objetivando possibilitar a obtenção de respostas ao problema da pesquisa. Esta pesquisa se justifica pelo fato de incluir uma série de informações e atividades terapêuticas como alternativa de tratamento em pessoas com paralisia cerebral, visando à melhora global do desenvolvimento, proporcionando uma terapia de forma mais completa e lúdica para esse público. 


\section{Desafios da psicologia no Brasil}

\section{ASPECTOS ÉTICOS}

Houve o consentimento em referenciar os autores utilizados no estudo, respeitando a ABNT (Norma Brasileira Regulamentadora 10520:1992). Assim como, a identidade dos participantes desta pesquisa foi preservada. Foram seguidas as recomendações contidas na Resolução $n^{\circ}$ 466/12 do Conselho Nacional de Saúde, que tem como exigência, que os procedimentos de pesquisas, envolvendo seres humanos não ofereçam risco à dignidade dos participantes.

\section{RESULTADOS E DISCUSSÕES}

Foram realizadas duas entrevistas diferentes, uma específica para os pais que têm filhos com Paralisia Cerebral e outra direcionada aos psicólogos que trabalham diretamente com estas crianças, a fim de compreender o conhecimento que eles possuem acerca do tema pesquisado neste trabalho. Ao todo, participaram do estudo: um pai, uma mãe, e três psicólogos.

A primeira a ser entrevistada foi a mãe (nome fictício Julia), que relatou nunca ter parado para pensar sobre a importância do brincar e que sua filha, de 5 anos, faz diversos acompanhamentos com profissionais em prol de sua saúde, portanto, não lhe sobra tanto tempo para atividades lúdicas. No dia seguinte, o próximo a ser entrevistado foi o pai (nome fictício Carlos), que tem um filho de 6 anos. Este afirmou que compreende o brincar como significativo no desenvolvimento, porém, também relatou não prestar muita atenção sobre como o filho interage com seus brinquedos.

Foi perguntado a ambos se os filhos possuem algum brinquedo ou personagem preferido e o que faz com que ele (a) se identifique com este artefato, a Julia respondeu: "Ela tem uma boneca Barbie e acredito que ela se identifica porque tenta imitá-la bastante. Acho que a beleza da boneca chama a atenção dela". Carlos replicou: "Ele é muito fã de heróis e outros personagens que praticam o bem. Sempre o ensinei a ser bom com todos". Sobre se há algum espaço em casa destinado para estas atividades lúdicas, a mãe esclareceu: "Apenas o próprio quarto dela, mas nada específico, é um espaço que ela usa para dormir e brincar" e o pai disse: "Existe muito espaço ao ar livre, visto que moro em uma casa grande em condomínio fechado, porém, há limitações para que não haja perigos de cair e se machucar, além do mais, meu filho tem limitações na locomoção".

Também foi investigado se os pais acreditam que estes artefatos possam causar alguma influência em suas crianças e a resposta de Julia foi: "Acredito que sim, pois a boneca se produz muito e isto acaba motivando-a. A minha filha é muito preocupada com a aparência, mas até agora conseguimos lhe mostrar que a aparência vai além do corpo, e envolve o que somos por dentro. Ela costuma enfeitar a cadeira de rodas com laços rosa e fica muito legal". Carlos relatou: "Acredito que sim, apesar de não 


\section{Desafios da psicologia no Brasil}

achar que estes personagens sejam a única influência na autoestima dele, mas creio que de modo geral artefatos assim passam a sensação de superação e de perseguir os sonhos, incentivando-o e contribuindo para que ele sempre tente evoluir. A infância é um momento em que se começa a se inspirar nos outros e tentar descobrir quem somos, portanto, passamos por diversas fases de gostos e opiniões. A autoestima é relacionada a tudo que vivemos e tenho a precaução de ajudar o meu filho a mantê-la positiva". Quando foram questionados se os filhos fazem desenhos sobre si, a Julia disparou: "Sim, e ela se retrata com muita perfeição, desenha muito bem e sempre se enfeita demais, colocando acessórios e maquiagem" e o Carlos disse: "Ele costuma fazer desenhos, porém, sempre com características bem diferentes, até mesmo em função de que sua coordenação motora é um pouco prejudicada, sendo assim, não é sempre possível compreender os traços".

Outra questão indagada foi acerca da opinião deles sobre a autoestima dos filhos e o Carlos relatou: “A autoestima é instável e a própria Paralisia Cerebral contribui para que haja muitos problemas na saúde e na convivência social. A escola acaba ficando em segundo plano e a interação social em terceiro, visto que acaba se tornando prioridade cuidar dos sintomas da condição dele. São muitas consultas e muitos remédios, fico em falta ao não prestar atenção nesse cuidado com a socialização dele" e a Julia afirmou: "Hoje em dia acredito que a autoestima está ótima, porém, varia de períodos. Um tempo atrás ela sofria muito bullying na escola que estudava, então a mudei para outra e até agora não tivemos este tipo de problema. Ela faz acompanhamento psicoterapêutico e com uma terapeuta ocupacional. Sempre estamos abordando com ela a questão da aparência e lhe ensinando a se aceitar e gostar de quem é. Ela me dá muito orgulho".

A próxima entrevista foi realizada em momentos diferentes com três profissionais da Psicologia, que trabalham atualmente em um Centro de Reabilitação. Eles foram abordados sobre como se desenvolve a autoestima de uma criança com Paralisia Cerebral e o primeiro psicólogo a ser entrevistado (nome fictício P1) partindo de seus conhecimentos respondeu: "A autoestima, de modo geral é desenvolvida a partir de reforçamento positivo social, neste sentido, o desenvolvimento se dá de acordo com a interação a estímulos de diversos aspectos da criança", o segundo profissional (nome fictício P2) concluiu que: "A autoestima se desenvolve igualmente para todos, porém, deve-se levar em conta que uma criança com PC vai passar por restrições que podem ser físicas ou mentais, e também vai lidar com os padrões estéticos da sociedade, portanto, para uma autoestima saudável, é importante que ela entenda que somos todos diferentes e que a beleza verdadeira é a interna.", o terceiro psicólogo (nome fictício P3) afirmou que: "Se desenvolve através de seu contato com o ambiente externo, com sua família, com seus colegas de escola. A autoestima é uma autoavaliação e como as crianças com PC 


\section{Desafios da psicologia no Brasil}

costumam ter mais dificuldades comparado a uma criança sem patologias, é viável ensiná-la a se respeitar e ajudá-la a desenvolver suas habilidades".

Outro ponto abordado foi sobre a possibilidade de um personagem ou brinquedo influenciar na autoestima destas crianças que sofrem com PC e o P1 relatou: "É possível sim, tendo em vista que toda forma de interação da criança possui influência no desenvolvimento de sua autoestima", o P2 declarou: "Sim, com certeza, já que todo estimulo é influenciável, tanto positivamente quanto negativamente" e o P3 falou: "Sim, um brinquedo ou personagem muitas vezes se torna um referencial para a criança. Pode ser um referencial de beleza, de poder e até de personalidade".

Posteriormente, foi questionado sobre como as brincadeiras podem auxiliar crianças a desenvolverem habilidades e o P1 relatou: "As habilidades são desenvolvidas no decorrer da vida do indivíduo a partir da exposição a estímulos, desta maneira durante as brincadeiras as crianças aprendem a interagir, ter disciplina, dentre outras coisas, além de adquirir habilidades no âmbito social, influenciando seu padrão de relacionamento com o outro e consigo", o P2 afirmou: "Com certeza elas contribuem no desenvolvimento, especialmente se a brincadeira tiver um foco. Por exemplo, certas atividades ajudam no equilíbrio, outras a lidar com frustração e aprender a perder, outras a desenvolver a memória" e o P3 disse: "Há brincadeiras que contribuem para uma maior concentração, alguns jogos ajudam a elaborar estratégias e assim por diante".

Na sequencia, foi investigado se os profissionais acreditam que os pais, em geral, permitem que os filhos tenham um momento para o brincar e de acordo com a sua concepção, o P1 respondeu: "Algumas influências da demanda social atual muitas vezes atrapalham a relação da criança com o momento de brincadeiras, uma vez que os pais atribuem às crianças responsabilidades de maneira precoce, quando os sobrecarregam com atividades a fim de ocupar todo seu tempo. A criança com PC, muitas vezes, acaba não tendo permissão de ter momentos de brincadeiras, já que alguns pais adotam posturas extremamente rigorosas, dificultando a oportunidade para este tipo de estímulo", o P2 discursou: "Acredito que a maioria dos pais consideram a brincadeira apenas como uma atividade infantil simples, onde não é necessário ter preocupação, visto que é apenas uma opção da criança. 0 dia a dia pode ser tão corrido que os pais nem reparam como os filhos brincam e muito menos qual a função deste brincar dentro da infância. Eles parecem não se importar com o tempo da brincadeira, o objetivo, a função, dentre outros" e o P3 opinou: "Acredito que hoje em dia os pais levam menos em conta o brincar e menos ainda a qualidade deste brincar. Ultimamente tudo caminha mais rápido, até mesmo na questão escolar da criança, há mais trabalhos, mais aulas e mais atividades extras". 


\section{Desafios da psicologia no Brasil}

Também foi indagado se dentro do local de trabalho destes psicólogos as crianças que sofrem com Paralisia Cerebral tem a oportunidade de brincar e se isto traz bons resultados. O P1 relatou: "Sim, pois notamos que ela fica mais à vontade no ambiente terapêutico", o P2 afirmou: "Sim, os resultados são positivos visto que dentro do brincar podemos ajudar a criança a desenvolver habilidades, mas é necessário que os pais usem o lúdico dentro de casa para que o desenvolvimento seja mais completo. Não podemos acompanhar a criança 24 horas por dia" e o P3 comunicou: "Sim, nas clínicas o brincar tem uma função psicoterapêutica, então além de oferecer divertimento, ele é estratégico para se trabalhar algo com a criança, relacionado a desenvolver alguma habilidade e competência".

Por fim, foi perguntada a opinião dos profissionais sobre como aumentar a autoestima de crianças com PC e com isto o P1 declarou: "Há várias ações que envolvem a família, escola e comunidade em geral que poderiam agregar valor a este aspecto da criança. Inicialmente é importante ressaltar a necessidade de orientação e informação acerca da PC e as inúmeras formas de lidar com a mesma. Dessa maneira, os pais adquiririam maior segurança e confiança, podendo permitir que a criança tenha um pouco mais de autonomia, no sentido de evitar o excesso de proteção e aumentar a exposição a diversos estímulos", o P2 respondeu: "Primeiro deve-se entender o que é Paralisia Cerebral e qual é o tipo que a criança tem e ajudá-la a evoluir suas competências para que ela possa conhecer seus pontos fortes e os valorizá-los, com o apoio dos pais, que possuem papel fundamental neste processo", concluindo, o P3 opinou: “Acredito que além do acompanhamento médico, psicoterapêutico e outros que sejam necessários, os pais têm uma contribuição importantíssima, pois de nada serve a terapia se eles não a colocam em prática dentro de casa. Trabalhamos com as crianças estas questões de padrão de beleza e lhe ensinamos a compreender suas dificuldades e vangloriar suas competências, utilizando como recurso o brincar".

\section{CONSIDERAÇÕES FINAIS}

A pesquisa realizada buscou descrever como o lúdico pode auxiliar no desenvolvimento da autoestima de crianças com Paralisia Cerebral. Como anteriormente citado, a PC é uma lesão que pode ser combinada com diversos outros fatores que são capazes de causar prejuízos ao indivíduo, tanto mentalmente quanto fisicamente. Estes danos podem atingir a visão, a audição, a motricidade, o equilíbrio, o raciocínio, dentre outros.

A criança que sofre com esta patologia é muitas vezes privada de ter uma maior interação social, visto que passa muito tempo em acompanhamentos médicos e de outras áreas em prol de sua saúde. Ela 


\section{Desafios da psicologia no Brasil}

também terá que conviver com as dificuldades resultadas desta lesão, portanto, os pais e profissionais devem buscar formas de ela aprender a lidar com suas falhas e aptidões.

O lúdico faz parte da infância e é um auxiliador no processo de garantir uma autoestima equilibrada, já que pode facilitar a aprendizagem, interação social, imaginação, autonomia, dentre outros aspectos. É necessário apenas direcionar as brincadeiras para que tenham um foco no desenvolvimento da criança.

As entrevistas feitas nesta pesquisa mostraram que os pais não se preocupam tanto com a qualidade do brincar, porém, ambos concordaram que isto gera prazer e alegria aos filhos. Eles demonstraram preocupação com a parte física e biológica da criança, ou seja, com a parte que trata os danos da Paralisia Cerebral, e menos apreensão quando se trata dos momentos de brincadeiras. Para eles, os filhos se espelham nos personagens infantis e concordaram que estes podem influenciar diretamente em sua autoestima, mas eles não têm uma visão maior de como usar estes artefatos a favor do desenvolvimento dos filhos.

Os psicólogos entrevistados ressaltaram a relevância do lúdico dentro da infância das crianças que sofrem com PC e explicaram como que isto pode auxiliar na construção de uma autoestima positiva. Os profissionais responderam às questões abordadas a partir de suas visões e vivências práticas e enfatizaram que um dos principais contribuidores para que os pais não prestem tanta atenção no brincar é a rotina estressante e muitas responsabilidades atribuídas a eles. Os psicólogos também explicaram que os pais podem contribuir no desenvolvimento dos filhos compreendendo sobre o tipo de PC que a criança tem, e conhecendo seus pontos fortes e fracos, assim, o brincar teria um direcionamento e foco, ajudando-a a expandir suas habilidades e consequentemente, a sua autoestima.

Portanto, ficou claro que o lúdico contribui em diversos âmbitos do desenvolvimento infantil e consegue melhorar a autoestima visto que auxilia a criança a se socializar, a aceitar suas falhas, a progredir suas capacidades e também faz com que eles trabalhem sua individualidade, seu raciocínio e a formação de suas opiniões. Porém, em alguns casos ainda é necessário esclarecer sobre a importância das brincadeiras para que os pais as utilizem como recurso no crescimento e evolução das competências dos filhos.

Os avanços tecnológicos e científicos vêm cada vez mais promovendo eficácias significativas no meio da saúde, como estratégias de tratamento e recuperação de pessoas com PC que devem receber estímulos para estimular o desenvolvimento de sua área motora precocemente. Desse modo, podem- 


\section{Desafios da psicologia no Brasil}

se utilizar jogos como estratégica de reabilitação, onde os indivíduos apresentam maior interesse, em participar do tratamento, buscando cada vez mais uma interação com esse público.

Há a necessidade de oferecer às famílias informações, suporte, orientações e encaminhamentos para intervenções especializadas e intensivas após o nascimento do filho com paralisia cerebral. São imprescindíveis, ainda, intervenções específicas para ajudar a família a lidar com diversos desafios, além de implementação de políticas públicas que garantam igualdade de direitos sociais, contribuindo para que os pais não precisem abandonar os estudos, o trabalho e demais atividades que geram saúde e renda para cuidar de seus filhos.

Em suma, a criança que sofre com Paralisia Cerebral pode ter uma autoestima elevada, ao mesmo tempo em que tem uma boa qualidade de vida, tendo como apoio os pais, que são contribuintes diretos no processo de utilização do lúdico em prol de um desenvolvimento físico, social e mental, e assim, ela também acaba por usufruir dos benefícios advindos da própria infância.

\section{REFERÊNCIAS}

ANTUNES, M. D. et al. Treino de equilíbrio em crianças com paralisia cerebral diparética com Nintendo Wii: série de casos. Conexão Ciência,12(1), 2017,104-109.

BOARDMAN, J.; HAWDON, J. Hypoglycaemia and hypoxic-ischaemic encephalopathy. Developmental Medicine \& Child Neurology, v.57, p.29-33, 2015.

BONFIM, C. O jogo como fonte de humanização. UNESP, Londrina, 2010. Disponível em: <http://www.portalanpedsul.com.br/admin/uploads/2010/Educacao_e_Infancia/Trabalho/08_56_1 9_O_JOGO_COMO_FONTE_DE_HUMANIZACAO.PDF>. Acesso em: 12 fev. 2019.

BOTTCHER, L.; FLACHS, M.; ULDALL, P. Attentional and executive impairments in children with spastic cerebral palsy. Developmental Medicine \& Child Neurology. 2010, p. 43-47. Disponível em: <http://onlinelibrary.wiley.com/doi/10.1111/j.1469-8749.2009.03533.x/epdf>. Acesso em: 16 fev. 2015.

BRANDEN, N. Como aumentar sua autoestima. Rio de janeiro: Sextante, 2009, 160 p.

CAIANA T. L. et al. Os benefícios da realidade virtual aplicada a reabilitação em fisioterapia: Uma revisão. Anais do Congresso Brasileiro de Saúde. Campina Grande, PB, Brasil, 13(9), 2016.

CARVALHO, L. A atividade lúdica no processo terapêutico. In: MARCELLINO, N. Lúdico, Lazer e Educação Física. 3a. Ed. Editora Unijuí: RS, 2009.

DANTAS, M. et al. Impacto do diagnóstico de paralisia cerebral para a família. Florianópolis, v. 19, n. 2, p. 229-237, 2010. Disponível em: <http://www.scielo.br/pdf/tce/v19n2/03.pdf>. Acesso em 25 jan. 2019. 


\section{Desafios da psicologia no Brasil}

FERNANDES, D.; AMARANTE, D.; FALAD, T. Efeitos positivos da equoterapia em crianças com síndrome de down: uma revisão bibliográfica. Revista interciência - IMES Catanduva - v. 1, nº 2, junho, 2019.

LOPES, G. L. B. et al. Influência do tratamento por realidade virtual no equilíbrio de um paciente com paralisia cerebral. Revista Terapia Ocupacional da Universidade. São Paulo, 24(2), 121-6, 2017.

LUCENA, M. D. de. Importância do lúdico na educação infantil. Caicó, RN, 2016.

MACIEL, D.; RAPOSO, M. Metodologia e construção do conhecimento: Contribuições para o ensino da inclusão. In: (org.) MACIEL, D.; BARBATO, S. Desenvolvimento humano, educação e inclusão escolar. 2010, Brasília, Ed. UNB, p. 73-101.

MALUF, A. Atividades recreativas para divertir e ensinar. 4 Ed. Petrópolis, RJ: Vozes, 2008, 54 p.

MARTINS,M.O Homem lúdico. 2009. Disponível

em: <http://www.albertobernardo.com.br/o-homem-ludico/>. Acesso em: 13 fev. 2015.

MELLO, E. M. et al. Efeitos do uso de um simulador de equitação terapêutica no equilíbrio e força muscular respiratória de crianças com paralisia cerebral. Tese (Doutorado em distúrbios do desenvolvimento) Universidade Presbiteriana Mackenzie, São Paulo, p. 75, 2019.

MELLO, E. M. C. de L. et al. A influência da equoterapia no desenvolvimento global na paralisia cerebral: revisão da literatura. Cad. Pós-Grad. Distúrb. Desenvolv. [online]. 2018, vol.18, n.2, pp. 1227.

MORAES, A. G. et al. The effects of hippotherapy on postural balance and functional ability in children with cerebral palsy. J. Phys. Ther. Sci., v. 28, n. 8, p. 2220-2226, Aug. 2016.

OLIVEIRA, F. B. et al. Paralisia cerebral e resiliência por meio de programas de atividade física: revisão integrativa da literatura. Lecturas: Educación Física y Deportes, Vol. 24, Núm. 253, Jun., 2019.

PEREIRA, M. L. N. Autoestima: un factor relevante en la vida de la persona y tema esencial del proceso educativo. Revista Electrónica “Actualidades Investigativas en Educación, v. 7, n. 3, 2007, p. 01-27. Disponível em: <http://revistas.ucr.ac.cr/index.php/aie/article/view/9296/17752>. Acesso em: 18 jan. 2019.

RIBEIRO, M.; BARBOSA, M.; PORTO, C. Paralisia cerebral e síndrome de Down: nível de conhecimento e informação dos pais. Ciência e saúde coletiva, Rio de Janeiro , 2011, v. 16, n. 4, p. 2099-2106. Disponível

em:<http://www.scielo.br/scielo.php?script=sci_arttext\&pid=S141381232011000400009\&lng=en\&n rm=iso>. Acesso em: 11 fev. 2019.

RIBEIRO, J. F. et al. Contribuição do pré-natal para o parto normal na concepção do enfermeiro da estratégia saúde da família. Rev. Interd. 2016; 9(1):161-70.

ROCHA, P.S.V. A importância do lúdico na educação infantil: uma análise a partir da concepção de professores / Pâmella Suzetty Vieira de Sousa Rocha. - João Pessoa: UFPB, 2017. 


\section{Desafios da psicologia no Brasil}

ROSAN, L.; BRACCIALLI, L. M. P.; ARAÚJO, R. C. T. Contribuição da equoterapia para a participação e qualidade de vida do praticante com paralisia cerebral em diferentes contextos. Revista Diálogos e Perspectivas em Educação Especial, v. 3, n. 1, p. 48-61, jan./jun. 2016.

SADE, R.; CHACON, M. Os meandros familiares, escolares e sociais da construção da identidade do deficiente. In: (Org.) OLIVEIRA, A.; OMOTE, S.; GIROTO, C. Inclusão escolar: as contribuições da educação especial. 2008. São Paulo: Cultura Acadêmica Editora, Marília: FUNDEPE Editora, p. 93-107.

SANTOS, M. Implante Coclear em crianças com paralisia cerebral. 2012. Dissertação (Mestrado em Fonoaudiologia) - Faculdade de Odontologia de Bauru, Universidade de São Paulo, Bauru, 2012. Disponível em: <http://www.teses.usp.br/teses/disponiveis/25/25143/tde-04062013153835/>. Acesso em: 20 jan. 2019.

SBICIGO, B.; BANDEIRA, R.; DELL'AGLIO, D. Escala de Autoestima de Rosenberg (EAR): validade fatorial e consistência interna. 2010. Psico-USF. v. 15,n. 3, p. 395-403. Disponível em:

<http://www.scielo.br/pdf/pusf/v15n3/v15n3a12.pdf>. Acesso em 12 fev. 2019.

SCHMITZA, F. da S.; STIGGER, F. Atividades aquáticas em pacientes com paralisia cerebral: um olhar na perspectiva da fisioterapia. Revista de Atenção à Saúde, v. 12, no 42, out./dez. 2014, p.78-89.

SOARES NETO, P. B. O. A importância dos jogos matemáticos no processo de aprendizagem na educação infantil. Comunicação: reflexões, experiências, ensino - |Curitiba | v. 14| n.2|p. 121-130| $2^{\circ}$ Semestre 2018.

SOUZA, A. S. V.; ROCHA, L. C. As contribuições das práticas corporais no desenvolvimento da criança com Paralisia Cerebral. 2017. Anais eletrônicos Bahia UNEB. Disponível em: < http://www.desdc2.uneb.br>. Acesso em: 20 jan. 2019.

SOUZA, C. C. F. de et al. Os benefícios da equoterapia a curto prazo em uma criança com paralisia cerebral: estudo de caso. Revista Faculdade Montes Belos (FMB), v. 9, n. 2, p. 64-141, 2016.

TEIXEIRA-ARROYO, C.; OLIVEIRA, G. Atividade aquática e a psicomotricidade de crianças com paralisia cerebral. 2007. Motriz, Rio Claro, v.13, n. 2, p. 97-105

Disponível: <http://www.aquabrasil.info/Pdfs/psicomotricidade.pdf>. Acesso em: 26 jan. 2019.

VIEIRA, P. L. R.; FREITAS, M. C. M. A criança e o desenvolvimento da autoestima, 2017. Disponível em: <http://anais.unievangelica.edu.br/index.php/pedagogia/article/view/4464/2712>. Acesso em: 01 fev. de 2019.

ZANINI, G.; CEMIN, F.; PERALLES, N. Paralisia Cerebral: causas e prevalências. Curitiba: Fisioterapia em movimento, v. 22, n. 3, 2009, p. 375-381. 


\section{Desafios da psicologia no Brasil}

\section{APÊNDICE I}

\section{ROTEIRO DAS ENTREVISTAS SEMIESTRUTURADAS COM OS PAIS}

1) Qual a idade do seu filho?

2) Há um espaço em sua casa reservado para que seu filho possa brincar?

3) Ele possui um brinquedo ou um personagem de desenho animado preferido? Quais as características deste artefato que faz com que seu filho se identifique?

4) Seu filho já fez desenhos sobre si mesmo?

5) Há algum brinquedo ou personagem infantil que o seu filho imita ou gosta de se fantasiar?

6) Você acredita que este artefato possa influenciar na autoestima e autoimagem do seu filho?

7) Como você acha que é a autoestima do seu filho? 


\section{Desafios da psicologia no Brasil}

\section{APÊNDICE II}

\section{ROTEIRO DAS ENTREVISTAS SEMIESTRUTURADAS COM PSICÓLOGOS}

1) Como se desenvolve a autoestima de uma criança com PC?

2) A relação de uma criança com um determinado personagem infantil ou um brinquedo, pode influenciar em sua autoestima? Como?

3) As brincadeiras podem auxiliar crianças a desenvolverem suas habilidades? Como?

4) Na sua opinião, os pais permitem que os filhos tenham um momento para brincar?

5) Em seu local de trabalho, há crianças com PC? Elas têm oportunidade de brincar? Se sim, há bons resultados?

6) Na sua opinião, o que poderia ser feito para aumentar a autoestima de crianças com Paralisia Cerebral? 


\title{
Capítulo 44
}

\section{COMUNICAÇÃO E INTERATIVIDADE EM TEMPOS DE VIRTUALIDADE}

\author{
DOI: $10.37423 / 200200259$
}

Giuliana Cavalcanti Vasconcelos (Doutorado em Educação, atua como ProfessoraAssociada I no Departamento de Habilitações Pedagógicas/ Centro de Educação/ Universidade Federal da Paraíbal Paraíbal Nordeste/ Brasil).

giulianacy@yakoo.com.bk

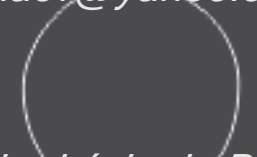

Alvanira Lúcia de Barros Y Doutorado em Letras, atua comb Professora-Adjunta II no Departamento de Língua Portuguesa e Linguístical Centro de Ciências Humanas, Letras e Artes/ Universidade Federal da Paraíbal Paraiba/ Nordeste/ Brasif). alvanirabar@gmail.com.br

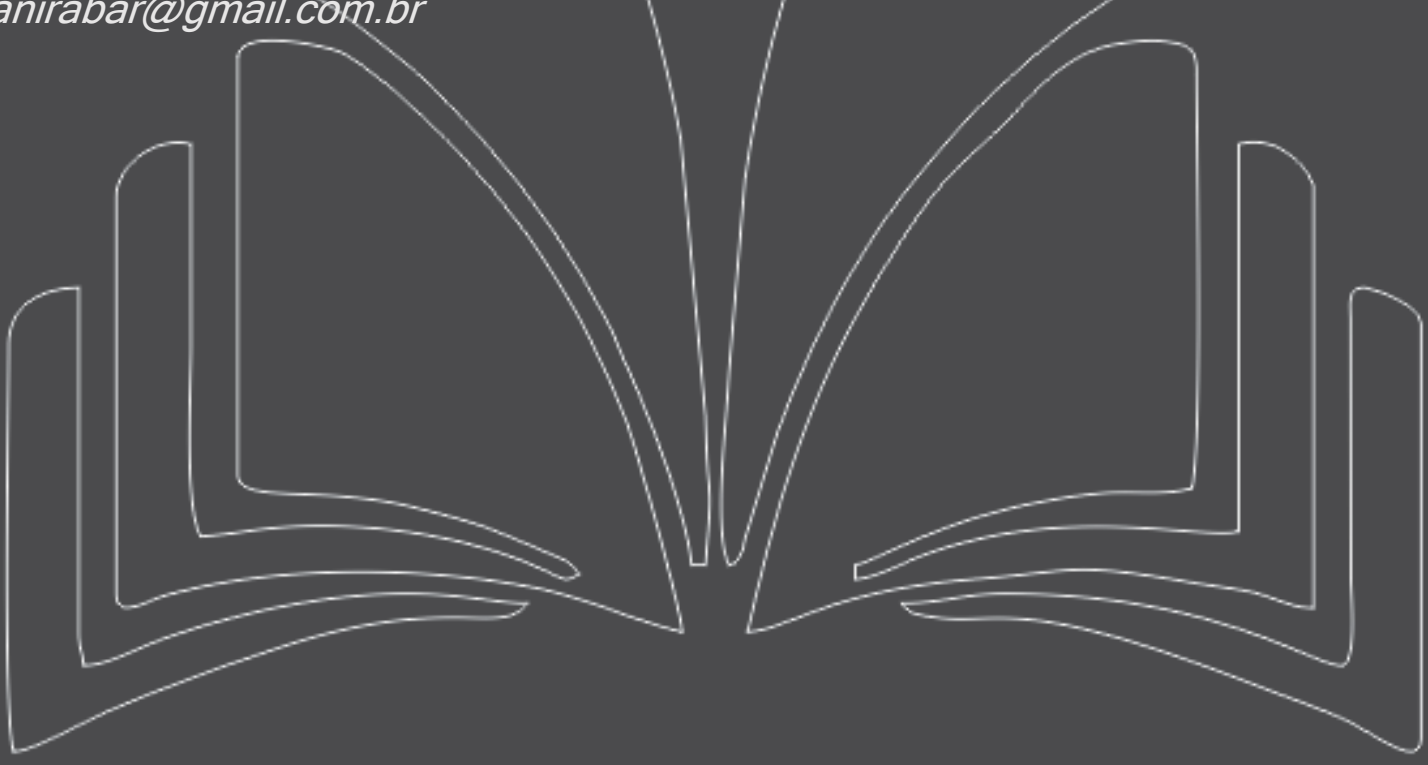




\section{Desafios da psicologia no Brasil}

\section{INTRODUÇÃO}

A busca pela compreensão da cognição tem aberto a oportunidade de refletir sobre a excepcionalidade de variedades distintas da aprendizagem, e sobre os novos gêneros comunicacionais que atendem a demandas educativas. Vê-se que no século XXI, um mundo globalizado, outrora inimaginável, organiza-se em redes de conhecimento que vêm tomando formas desde fins da década de 1960 e encontram-se marcadas por novos processos, novas formas de aprendizagem, novas formas de manifestação da cognição, e por avanços em todos os domínios do conhecimento.

Esse mundo distribui-se em diferentes culturas, desenhando um espaço cognitivo cuja exigência repercute na formação de competências múltiplas, na revelação de excepcionalidades e no uso permanente da inteligência para lidar com situações diferentes do cotidiano e com problemas inusitados, decorrentes de novas arquiteturas econômicas e tecnológicas de organização social em rede.

Mesmo num quadro de problemas sociais, de retrocessos de desenvolvimento político e econômico de uma dada democracia, há sujeitos-atores que se destacam pela excepcionalidade de seus comportamentos, de suas figuras ou personagens, colaborando para mudanças de mentalidades ou rompimento de tradições cognitivas que incentivam e motivam novas realizações.

Em cada época, uma percentagem de sujeitos destaca-se pela virtude de suas realizações. Cada teórico, físico, matemático etc., ao seu modo, de fato, destacou-se em termos de insights de sua própria mente. Mas, não obstante às suas qualidades cognitivas, a sociedade, silenciosamente, guarda inúmeras formas de exclusão social.

Por isso, grandes pensadores contemporâneos que se dispuseram a extrair lições que se levam do último século coincidem em um ponto fundamental. Verificamos progresso na ciência e na tecnologia, mas que segue acompanhado de destruição e crueldade. Nunca se verificou tanto aumento da prosperidade, acompanhado de modo igualmente funesto, do aumento estatístico das disparidades econômico-sociais e da pobreza elevada.

Morin (2009) diz que a humanidade vive sem saber lidar com a desordem, o inesperado e a incerteza, e que já está em tempos de dar-se conta disso. Para ele, há uma grande confusão que permeia um movimento diferente, o da reintrodução da consciência na ciência que não enriquece apenas o espírito dos cientistas, mas introduz a necessidade de um pensamento complexo, não mutilado. Ele destaca o século XXI como um período de mudança política e existencial quanto ao futuro da humanidade.

Dificilmente, poderia haver ocasião mais propícia para refletir sobre o futuro, tendo os testemunhos das lições deixadas pelas consecutivas décadas de desenvolvimento das nações. É importante que não 


\section{Desafios da psicologia no Brasil}

nos tomemos como estranhos ao cosmos, mas que compreendamos que somos originários da natureza e que devido à nossa cultura, tornamo-nos estranhos ao cosmos.

Convencidos dessas preocupações, levantamos uma questão que, originária do campo das ciências da educação em seu arcabouço interdisciplinar, permitiu-nos supor a existência de dificuldades da comunicação como preocupação para o desenvolvimento da consciência e da autonomia, como conditio sine qua nom. Porém, apesar de questionarmos sobre formas de ponderarmos os gêneros comunicacionais como meio de promoção da consciência e autonomia humana, testemunhamos a virtualidade comunicativa como um novo espaço de interatividade educacional. Este é o ponto de reflexão do qual e para o qual partimos nesta pesquisa.

Decerto, tamanha preocupação não há de encerrar-se num simples texto. Certamente, trata-se de uma questão, cujo teor de abordagem tem como vício os interesses teóricos daqueles que a tomam como fonte de inspiração do estudo. Eis, que neste artigo, objetivamos apenas apresentar impressões e leituras que nos permitem propor algo àqueles que conosco desejam assim compreender a questão. Este trabalho é resultado de debates que se definiram no âmbito de nossos encontros de estudo em diferentes grupos de pesquisa em nossas instituições. Seguindo nossa rotina de estudo, elegemos a relação dos estudos culturais com a comunicação e a educação como fonte de indagação, o que resultou no interesse de entender o gênero virtual.

Além disso, o objetivo principal desta pesquisa foi conhecer as possibilidades virtuais de realização de práticas comunicacionais/educacionais a distância, com base na produção compartilhada de conhecimentos.

\section{METODOLOGIA}

A metodologia utilizada abrangeu uma teorização da temática em questão, com ênfase nos debates científicos que vêm sendo tomados na última década. Foram destacadas duas categorias de análise argumentativa: o espaço desterritorializado da internet e a virtualidade como gênero comunicacional. Para disciplinar a escolha de tais categorias, optamos por conceituá-las com base no que Laville e Dionne (1999, p. 22) chamam de modelo de análise misto:

O pesquisador agrupa inicialmente o melhor possível das diversas unidades de conteúdos nas categorias previamente fixadas, com o risco de deixar algumas à parte. Depois, se sucedem as revisões críticas tomando muitas vezes como ponto de partida os elementos não classificados na primeira vez, que podem acarretar a criação de novas categorias [...]. 


\section{Desafios da psicologia no Brasil}

Dessa maneira, procedemos na construção das discussões hora apresentadas, pontuando as noções iniciais das categorias em análise, aprofundando-as e sequenciando nosso foco argumentativo sob o objetivo para o qual a realização deste estudo propôs-se. Percebemos que a ampliação das noções iniciais ocorreu com a constatação de subcategorias múltiplas de análise, como informação e arquitetura midiática, as quais mesmo não estando previamente definidas, constituíram o desvelamento do conceito de comunicação educativa.

Os referenciais teóricos em análise permitiram-nos conduzir esta pesquisa num contínuo impulso de retorno às nossas inquietações, num vaivém de ida e busca exploradora. Os significados extraídos desse movimento interpretativo levaram-nos ao que Laville e Dionne chama de "Construção Interativa de uma Explicação": cada passo dado e cada caminho teórico percorrido ocorreram num amplo e aberto diálogo convidativo.

\section{DISCUSSÃO}

\section{1 SÉCULO XXI, UM NOVO TEMPO DE DESAFIOS COGNITIVOS}

O conhecimento vem descrevendo-se através do paradigma do devir através da sua relação com o tempo e a relação de ambos com a inteligência humana. As áreas de conhecimento, em função de novas configurações sociais, estão manifestando novos sentidos e dando origem, em meio a encontros interdisciplinares, a sólidas áreas de conhecimento, como a genética e a computação. Os novos sentidos que emergem da Psicologia e da Filosofia põem no cenário científico teorias originadas no seio dos conflitos do século XX.

O indivíduo, no cenário de relações multimidiáticas, passou a espelhar diálogos polissêmicos transcrevendo-os em ações. Suas preocupações transpõem a cognição através de reivindicações de pensamentos sobre a existência social. No espaço dos saberes, ideias que espelham novas metodologias de compreensão do ser humano e da sociedade passaram a transitar, implicando em revisões teóricas sobre categorias como: subjetividade, conhecimento, verdade, inteligência, cultura, de forma explícita ou oculta, em novas ordens de discursos da sociedade de destino planetário. Pobreza, educação, política, economia, trabalho etc. são conceitos que estão sendo revisitados em virtude das práticas cometidas. Os múltiplos sentidos que passam por essas categorias pertencem à existência humana, mas têm força no imprevisível da natureza. Afinal, o que podemos entender sobre o aquecimento global? O que um milhão de pessoas vai fazer com a falta de água? Qual a nova extensão da miséria? Os pobres é quem os são vulneráveis. 


\section{Desafios da psicologia no Brasil}

A humanidade é, sobretudo, uma noção ética: "é o que deve ser realizado por todos e em cada um" (MORIN, 2001, p.114). O humano deixou de ser apenas biológico, abstrato e ideal para reconhecer-se como parte da biosfera, como realidade vital e tornar-se uma comunidade de destino planetário. Necessariamente, esse momento de início de século requer que todo conhecimento contextualize seu objeto para que seja pertinente. É fundamental que saibamos quem somos? Onde estamos? De onde viemos? Para onde vamos? Como vemos, a barbárie humana permanece no planeta agravando-se, é um problema antropo-histórico que, a priori, não tem soluções, apenas possíveis melhoras que poderiam civilizar a Terra e as diversas sociedades.

A atualidade humana repousa no propósito de que a sua experiência reivindica um aprofundamento no fenômeno da compreensão das coisas em seu espectro social. Vivemos uma inquieta excitação pela compreensão das incertezas. Vivenciamos, uns aos outros, tentando encontrar a razão da existência humana. Embora interditados pelos erros cometidos através de aplicações da inteligência humana, não nos confortam as obscuridades do novo século e nos esforçamos para compreender os fenômenos no mundo da vida. Segundo Morin (2000, p.40), “estamos numa época de mudança de paradigma: os paradigmas são os princípios dos princípios, algumas noções mestras que controlam os espíritos, que comandam as teorias, sem que estejamos conscientes de nós mesmos".

O momento exige que nenhum pesquisador seja estranho à sociedade, mas preocupado acerca do poder científico, do uso das pesquisas para fins destruidores, repressivos, de manipulação de indivíduos e efeitos irreversíveis no meio natural. Uma operacionalização de conceitos, teorias e hipóteses vem sendo relacionada aos princípios que pressuponham um confrontamento complexo. A "lucidez" individual e a lucidez coletiva são condutoras do século XXI. "[...] Homens e mulheres não podem ser brinquedos inconscientes não só de suas ideias, mas de suas mentiras" (MORIN, 2001, p.33).

Uma nova estrutura informacional e comunicacional vem tomando formas inusitadas no novo milênio. Diferentes aspectos vêm desencadeando interfaces múltiplas que repercutem nas práticas sociais. Vivemos uma época de mudanças paradigmáticas, levando-nos a revisões dos princípios racionalistas que dimensionam as culturas. O uso da informação, conforme Manuel Castells (2008), é uma atividade importante para o desenvolvimento de qualquer sistema social. Na virada do século, ela passou a ser um significante essencial para a tomada de decisões estratégicas.

Mas compreendemos que a informação não é apenas uma medida do sistema. Ela é o sistema em si. A informação é uma representação subjetivada da própria humanidade. Quando filtrada na criação humana, simultaneamente ela filtra a humanidade. Também é instrumento de desenvolvimento, uma 


\section{Desafios da psicologia no Brasil}

vez que a partir da informação que se tem sobre algo é que se pode pensar sobre algo mais, e se pode desenvolver-se cognitivamente e descobrir o que há de extraordinário em cada sujeito.

Entendemos que a informação é a base material da sociedade. A sua essência paradigmática é uma parte integral da humanidade. Ela (in)flitra a sociedade num mesmo dinamismo em que é filtrada pela mesma. No novo século a informação é riqueza e produção do conhecimento é capital.

Nesta pesquisa, optamos em compreender a informação como uma criação relevante, uma tecnologia. Acreditamos que a informação tem sua força na condição humana, só fazendo sentido para a sociedade a partir da singularidade extraordinária do sujeito e na especificidade situacional que lhe é dada.

A informação é considerada a matéria-prima do desenvolvimento tecnológico. É matéria-prima para agir sobre a tecnologia, como também, a própria tecnologia é um mecanismo para agir sobre a informação. Tecnologia e informação são abstrações sociais que se desenvolvem reciprocamente. Seus efeitos espelham uma simetria transcendental que penetra nos sistemas sociais.

Para Castells (2008), graças ao desenvolvimento informacional tecnológico, uma configuração topológica transfigura uma criativa cartografia relacional: um sistema de redes informacionais flexíveis, com amplas possibilidades de interação planetária. São possibilidades presentes na integração global da produção, na fragmentação das identidades, nos interiores dos movimentos sociais, nas conexões estratégicas de indivíduos, grupos, regiões e países.

Os caminhos que surgem desse desenvolvimento informacional dão aporte a uma sociedade que se transcende numa teia de relações informacionais tecnológicas, em pontos de mutações e intersubjetivações comunicacionais. Compreendemos que o âmago dos novos desafios cognitvos do século XXI não é, como diz Castells (2000, p.50) “[...] a centralidade de conhecimentos e informação, mas sua aplicação para a geração de conhecimentos e de dispositivos de processamento/comunicação da informação, em um ciclo de realimentação cumulativo entre a inovação e seu uso".

\section{2 DESTERRITÓRIO INFORMACIONAL}

Para Octávio lanni (2004), a comunicação parece ser a constelação da modernização, apresentandose sob uma teia de astros multimidiáticos e articulados entre si, alcançando todo o planeta. Nessa teia, expressam-se ideias, padrões e valores socioculturais que disseminam o modo pelo qual a multiplicidade de identidades sitia, repousam e repovoam evolutivamente, como uma espiral, os espaços complexos do universo. 


\section{Desafios da psicologia no Brasil}

Segundo lanni (2004, p.21), essa interconexão planetária expressa o movimento de uma aldeia global alicerçada pela mídia eletrônica que passa a desempenhar "[...] o singular papel de intelectual orgânico dos centros mundiais de poder, dos grupos dirigentes das classes dominantes". A mídia, embora seja matizada em âmbito local, regional ou nacional, adquire o caráter de um singular e insólito intelectualorgânico articulado às instituições predominantes nas relações que tecem o mundo, desvelando novas geopolíticas e geoeconomias regionais e mundiais.

lanni (2004) esclarece que a mídia, em consonância com os centros de poder de extensão mundial, apresenta as relações sociais como um caleidoscópio, transfigurando os fatos sob uma subjetivação desterritorializada e multívia. Nesse jogo, ela expressa multifaces em fragmentações, diversidades, desigualdades, conflitos, acontecimentos e acomodações presentes em seu alcance mundial.

O indivíduo apresenta-se como um elo de articulações local, regional, nacional e mundial através de deslocamentos de pontos de referência dispersos e desterritorializados. Vida social, empresas, música, igrejas, escolas, guerra etc. organizam-se eletronicamente, adquirindo reconfigurações em redes de interconexão. A nova estrutura social, no espectro das redes informacionais, empreende processos de dominação política e de apropriação econômica ilimitadamente, desterritorializando realidades e identidades.

Ao mesmo tempo em que a mundialização se estende, acontece um evento simultâneo, cria-se e generaliza-se uma cultura da mundialização como produto e condição própria para que se dissemine a sua germinação. Para lanni (ibid., p.125), os elementos que constituem o novo processo são “[...] díspares, convergentes e contraditórios, antigos e renovados, novos e desconhecidos". O principal entrecho deste processo é a mercantilização universal que constitui um hipertexto complexo, composto de interfaces inteligíveis, através de arranjos ciberespaciais.

O indivíduo, embrionado no sistema mundializado, apresenta-se num perfil multifacetado. Uma nova conduta reconfigura um intelectual-orgânico que expressa formas mutantes e excepcionais, adquiridas no âmbito das relações antifronteiriças que, relativamente, subvertem as condições de vida política dos povos, e as formas de produção e manutenção das hegemonias políticas. A extraordinariedade é latente.

São intelectuais diversos, com façanhas empreendedoras e proliferantes que atuam em diferentes lugares, com diversas especialidades, articulados em nós de redes digitais, telemáticas e de comunicação internacional, que influenciam a formação e o conformismo da opinião pública. Nesse contexto, acontece, sob uma força vital, uma metamorfose da mídia, simultaneamente à 


\section{Desafios da psicologia no Brasil}

complexidade do desenvolvimento do indivíduo intelectual orgânico. Aquele que representa e manipula as diversas linguagens e técnicas, pode estender a sua representação aos extremos. lanni (2004) entende que os meios de comunicação estão na parte mais íntima da cultura, na representação e na imaginação. A mídia pode ser um emblema de uma representação coletiva em amplas proporções, que pode determinar a si mesma e expandir sua influência no imaginário de muitos, transfigurando o real em virtual reciprocamente.

Para Castells (2008), as sociedades estão passando por uma nova morfologia social. O novo paradigma da tecnologia da informação expande uma condição material de existência de uma rede penetrante, em diversos cantos da estrutura social. Isso quer dizer que, através dos fluxos informacionais que são recebidos e emitidos na arquitetura midiática da nova sociedade, os nós da rede podem ser fontes cruciais de dominação e transformação da própria sociedade. Para ele, a dinâmica informacional é uma estrutura social que permite a informalidade e a capacidade autorreguladora de comunicação, sob um desvelamento de multipersonalizações descentralizadas e autogerenciadas que, certamente, num futuro próximo, se estenderá através do sistema educacional abrangendo maiores proporções da população mundial, não sendo restrito às elites.

A nova estrutura da sociedade em rede, para Castells (2008, p.484), emerge e se desenvolve exercendo elementares filtrações na cultura: “[...] o que deve ser considerado é o isomorfismo simbólico dos processos de trabalho, serviços feitos em casa e entretenimento na nova estrutura de comunicação". O sexo via computador já é incidente e está em rápida expansão. O temor de doenças contagiosas e de agressões pessoais são motivos, para os que buscam expressar a sexualidade através do contato virtual. A disponibilização de informações na rede causa mudanças sensoriais e cognitivas do indivíduo, relativas à facilidade de manuseio de diversas interfaces num mesmo momento.

A Milícia Norte-americana nos Estados Unidos e os Zapatistas no México são organizações políticas que utilizam o espaço da informatização e comunicação, a internet, para promover interações e difundir os seus interesses. Vemos que comunidades virtuais, de interatividade comunicacional e autogerenciáveis, desenvolvem-se em torno de um interesse compartilhado (CASTELLS, 2008).

São diversas as manifestações coletivas que, através de redes de comunidades virtuais identidárias, articulam-se dentre si, reconhecendo-se mutuamente, dando continuidade a seu movimento, num cenário mundializado. Podemos encontrar manifestações de movimentos populares, tanto libertários quanto reacionários. Destacamos o Hare Krishna On line, o Amaluz, o Dharmanet e a Chama Dourada que se organizam em torno da religiosidade, como também, o Movimento Sem Terra e o Movimento Negro no Brasil que vislumbram ações emancipatórias. 


\section{Desafios da psicologia no Brasil}

Consta, no século XXI, a criação de comunidades virtuais, uma ampliação de movimentos ou redes sociais em tempo real e, independentemente, da localização geográfica dos atores. Ela se desvela num ambiente simbólico de interfaces, múltiplas imagens e sons que fazem da virtualidade a realidade. A estrutura multimidiática da nova sociedade pode contribuir para o encerramento da separação entre educação popular e erudita, mídia audiovisual e impressa, entretenimento e informação, educação e persuasão etc.

Essa é uma superestrutura que mescla uma espiral de significados, camuflando a complexidade de interesses e valores opostos, entrelaçando conflitos e estratégias de uma dinâmica social herdada da contradição social e que se redefinem num conceito de tempo e espaço. Está claro que a desterritorialidade informacional é uma virtualidade-real:

[...] um sistema que a própria realidade [...] é inteiramente captada, totalmente imersa em uma composição de imagens virtuais no mundo do faz de conta, no qual as aparências não apenas se encontram na tela comunicadora da experiência, mas se transformam na experiência (CASTELLS, 2008, p.395).

A capacidade de abrangência de múltiplas expressões culturais leva-nos a comportar uma infinidade de caminhos que se entrelaçam, desencadeado importantes efeitos nos processos sociais, podendo enfraquecer os aparelhos tradicionais de conservação dos hábitos morais como os da igreja em matéria. Para Castells (2008), as sociedades perdem o encanto de práticas sociais tradicionais, para penetrar num mundo de imagens autoconstruídas, despojadas de suas localidades territoriais. A multiplicidade de nós que compõe a rede informacional torna-se a referência para a formação e orientação do espaço cibernético, ultrapassando os poderes das práticas sociais, para incorporar o poder dos fluxos informacionais que incorporam a sua estrutura.

Castells (2008) constata que a humanidade travou sua primeira relação com o mundo quando, na préhistória, tentou sobreviver às diversidades da natureza. A segunda, quando conquistou sua libertação da natureza, mas submeteu-se à opressão e exploração da própria humanidade. A terceira, na qual a humanidade encontra-se hoje, com o desafio de aplicar o conhecimento, de forma que se desenvolva um mundo predominantemente social, reconstruindo a natureza como uma cultura ideal.

$\mathrm{Na}$ nova estrutura social de interconexão desterritorializada e mundializada, o ciberespaço, a informação representa o principal elemento para a organização social da humanidade. As mudanças dessa cosmogonia incidem sobre o trabalho, a coletividade, a linguagem etc. de maneira que surpreende os grupos sociais. 


\section{Desafios da psicologia no Brasil}

A difusão tecnológica reconfigura os usos da informação midiática, ocasionando mudanças nas formas de aprendizagem, alterando a autonomia da mente humana e os sistemas culturais. A mídia, embora favoreça um padrão cognitivo comum, potencializa as competências singulares, a comunicabilidade e a compreensão das expressões culturais. Todo estranhamento discorre para um panorama obscuro de multiplicidade, indeterminação e ambiguidade, favorecendo o declínio das verdades e objetividades. Nasceu uma ecologia cognitiva, onde o sujeito encontra-se em permanente metamorfose.

Para Pierre Lévy (2000), as interfaces que emergem da singularidade, no espectro do ciberespaço, podem constituir-se numa reciprocidade de subjetivações filtrando coletividades. Assim, estamos vivenciando um crescimento, o da sociedade interconectada e este é o momento crucial para que possamos refletir coletivamente, renovar as relações e tentar resolver os problemas que afetam a humanidade.

A intersubjetivação pode ser vivenciada sem fronteiras na rede informacional. Internet, televisão, música etc. compõem uma multimídia que pode ser usada para manifestações intercomunicacionais necessárias para o desenvolvimento de pensamentos coletivos. As implicações da interconexão planetária incidem num reconhecimento das alterações das singularidades cognitivas. Raciocínio, memória, representação mental e percepção, estão sendo alterados como consequência do contato com bancos de dados, simulacros digitais etc. reforçando diferenças pelo acesso desigual de indivíduos às multimídias.

É evidente a desigualdade de desenvolvimento cognitivo entre os grupos sociais conectados e não conectados. Alguns desenvolvem uma acelerada sinergia cognitiva, os marginalizados adaptam-se lentamente. Porém, precisamos ser utópicos, desejar e manifestar, dentre ações comunicativas de grupos sociais marginalizados, o desenvolvimento de práticas sociais diversificadas que colaborem para a vida planetária.

\section{3 VIRTUALIDADE, UMA QUESTÃO DE GÊNERO COMUNICACIONAL}

Para Mikhail Bakthin e Valentin Volochinov (2010a), o gênero constitui-se e distribui-se entre tipos relativamente estáveis de enunciados, elaborados nas diferentes esferas sociais. Gênero é uma classe de eventos comunicativos, os quais são delimitados por objetivos comunicativos, através de tematizações, estilos estéticos e estruturas esquemáticas. É um modo de organização da informação que gera outras formas de comunicação, das quais novos fenômenos históricos, vinculados à vida cultural e social, tendem a ordenar e estabilizar as atividades comunicativas do cotidiano. 


\section{Desafios da psicologia no Brasil}

Os gêneros revelam de ações criativas, podendo apresentar-se como eventos dinâmicos, plásticos e maleáveis a partir de necessidades socioculturais, bem como na relação da comunicação-educativa com as inovações tecnológicas. Se gênero é uma força aglutinadora, dentro de uma determinada linguagem que organiza formas comunicativas, buscando assegurar a eficácia dessa comunicabilidade, gênero é um dos instrumentos de interferência dos processos de consciência individual.

Conforme Bakhtin (2010b), qualquer manifestação ou revelação do indivíduo em linguagem corresponde a determinado tipo de troca, ou intercâmbio, da comunicação social, apresentando formas sistemáticas ou tipos estáveis, distinguidos entre dois tipos de gênero, o primário e o secundário. Os primários seriam aqueles mais triviais, naturais de uma conversação espontânea da vida cotidiana imediata, enquanto que os secundários, mais elaborados e principalmente apresentados sob a forma escrita, seriam aqueles apresentados em circunstâncias de comunicações culturais mais complexas, e relativamente mais evoluídas: textos científicos, jornalísticos etc.

Seguindo a linha bakthiniana, concordamos que com a internet, um novo espaço virtual e mais complexo de enunciação do sujeito, o ciber ou hiperespaço, define-se como um terceiro gênero comunicacional, em que leitor e escritor se encontram em novos processos de elaboração e compreensão do cotidiano. Essa virtualidade traz consigo novos eventos de construção de linguagens que passam a abranger novas formas de pensamento abstrato e, ao mesmo tempo, teórico sobre o real. Evento este que de maneira evidente, interfere no cotidiano através da composição de estruturas comunicativas de descrição, narração e dissertação da realidade.

Gêneros virtuais são as novas maneiras de conceber o cotidiano a partir do uso da internet, dentro do hipertexto, um texto linkado, ramificado por links, não linear, com vias de mão dupla, multivias maleáveis em que o indivíduo se encontra livre para modificar o caminho de sua leitura ou navegação, permitindo a comunicação e a interatividade entre duas ou mais pessoas, mediadas pelo computador. A internet inaugurou uma forma significativa de comunicação e de uso da linguagem.

Os principais gêneros virtuais são: os e-mails, os chats, as listas de discussão, os webblogs etc. Acrescenta-se ainda que a internet possibilite a criação de um novo espaço de escrita, o que amplia a concepção de texto que, no espaço virtual, carrega marcas da oralidade e representa um hibridismo entre o oral e a escrita. Assim, o texto passa a ser dinâmico e interativo, sendo escrito por vários sujeitos, autor-atores.

O gênero comunicacional toma uma abordagem cujo aporte é móvel e múltiplo, a internet. A capacidade cognitiva toma novos rigores imaginários e representativos, a partir dos quais o sujeito abre-se a novas apresentações que faz de si mesmo. O destaque da extraordinariedade que há em 


\section{Desafios da psicologia no Brasil}

cada um tende a revelar-se de modo desinibido e é capaz de materializar-se nas relações mais simples do cotidiano. Como vemos, o computador pessoal é um dispositivo de informação e comunicação amplificado e teleconferente.

\section{4 OS MODELOS INFORMACIONAIS DE COMUNICAÇÃO EDUCATIVA}

A acelerada evolução da tecnologia de comunicação propicia o surgimento de novos gêneros e a renovação de outros. Novas estratégias de seleção e distribuição do conteúdo são empregadas e novos recursos linguísticos aceleram a transmissão de informações, no ambiente virtual.

Eugênio Trivinho (2003) destaca que o indivíduo está diante de um excelente mecanismo de desenvolvimento da autonomia, a internet. O sujeito pode usá-la para transcender os limites da comunicação entre corpos fisicamente próximos, para um âmbito maior da cultura, num espectro global. O computador pessoal, pcs, notebooks, handhelds, celulares etc. são tecnologias de acesso tautológico a unidiversidade cultural. Construímos um novo suporte eletrônico, novas formas de linguagem, um novo código, uma nova comunicação hipertextual, uma nova forma de conversar usando o teclado.

O computador é apenas um instrumento, com um papel artificial de emissor e de receptor, através do feedback entre os sujeitos das mensagens. Estas passam a apresentar imagens hologramáticas personificadas. É como se elas tivessem vida própria. Ideias e valores tomam configurações entre princípios universalistas.

A figura tanto do emissor quanto do receptor sai da fotografia e ressurge plasticamente, como sujeito nômade. $\mathrm{O}$ indivíduo passa a ser tele-intra-atuante a partir da experiência que possa viver durante a interatividade personalizada junto ao seu objeto de desejo. As interações traçadas, em meio ao virtual, levam-no a realizar intervenções, especulações e pesquisas na totalidade do ciberespaço. Seu objeto de desejo reveste-se da sua interferência e intraferência.

Trivinho (2003) revê, com base na originalidade da implosão do ciberespaço, os modelos metateóricos da informação e da comunicação, rumo à constituição de um novo modelo reflexivo para a educação. O ciberespaço, na sua totalidade, repercute numa multiplicidade de fontes e canais de informação e comunicação, candidatando o sujeito à posição múltipla de emissor - receptor - autor - coautor, indistintamente.

A partir da emergência do ciberespaço, percebemos que o modelo comunicativo da teoria da informação de Shannon e Weaver (1949) o modelo, teoria da informação baseado na física apresentado por Coadic (1996), e o modelo comunicativo semiótico-informacional de Eco - Fabri et al 


\section{Desafios da psicologia no Brasil}

(1965), podem incidir num reducionismo positivista sobre o processo de comunicação. Teríamos, a partir desses modelos, os aspectos qualitativos das relações humanas marginalizados do espectro comunicacional. Entendemos que esses modelos representam o estabelecimento de uma ordem do processo instrumental de comunicação, já corrompida no advento do ciberespaço.

Figura 1: modelo comunicativo da teoria da informação de Shannon e Weaver (1949,

apud WOLF, 2001).

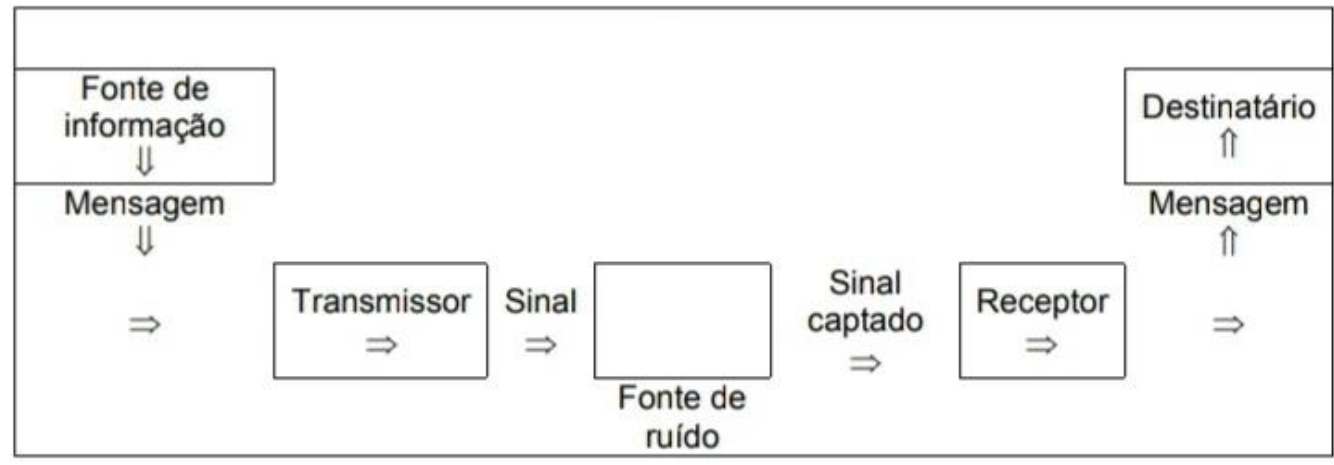

Figura 2: modelo teoria da informação baseado na física apresentado por Coadic

(1996)

\begin{tabular}{|c|c|c|c|c|}
\hline Emissor & & ensagem & & Receptor \\
\hline $\mathbf{E} \Rightarrow$ & $\Rightarrow$ & $\mathbf{M} \Rightarrow$ & $\Rightarrow$ & $\begin{array}{l}\mathbf{R} \\
\Downarrow\end{array}$ \\
\hline$\Uparrow$ & $\Leftarrow$ & $\Leftarrow$ & $\Leftarrow$ & $\Downarrow$ \\
\hline
\end{tabular}

Figura 3: modelo comunicativo semiótico-informacional de Eco - Fabri et al (1965,

apud WOLF, 2001).

\begin{tabular}{|c|c|c|c|c|c|}
\hline $\begin{array}{c}\text { (fonte) } \\
\text { emissor) } \rightarrow\end{array}$ & $\begin{array}{l}\text { mensagem } \\
\text { emitida } \\
\text { como } \\
\text { significante } \\
\text { que veicula } \\
\text { um certo } \\
\text { significado }\end{array}$ & $\begin{array}{l}\text { Canal } \\
\rightarrow\end{array}$ & $\begin{array}{l}\text { Mensagem } \\
\text { recebida } \\
\text { como } \\
\text { significante } \\
\quad \rightarrow\end{array}$ & $\begin{array}{c}\text { Destinatário } \\
\quad \rightarrow \\
\downarrow\end{array}$ & $\begin{array}{c}\text { Mensage } \\
\text { m } \\
\text { recebida } \\
\text { como } \\
\text { significado } \\
\uparrow\end{array}$ \\
\hline & $\vec{\uparrow}$ & & & $\downarrow$ & $\uparrow$ \\
\hline$\downarrow$ Código & $\uparrow$ & & & Código $\downarrow$ & $\rightarrow \uparrow$ \\
\hline $\begin{array}{c}\text { Subcódigos } \\
\rightarrow\end{array}$ & $\rightarrow \uparrow$ & & & Subcódigos $\rightarrow$ & \\
\hline
\end{tabular}

Cabe-nos realizar uma prova do que elegemos como real, pois o novo tempo nos apresenta múltiplas dimensões para experimentação de práticas sociais, nunca antes vivenciadas pela humanidade. A totalidade da internet manifesta a universidade 1971 humana, como aporte para a diversidade 


\section{Desafios da psicologia no Brasil}

cultural que pode fecundar, em meio ao virtual, o desenvolvimento cultural multi e inter, entre as sociedades humanas. A produção de saberes, em circulação livre, propiciada pela existência da internet, evidencia uma multiplicação de visões de realidade. Isto nos leva a rever os princípios universalistas que envolvem a humanidade, e a entender que as estratégias de formação educacional devem ser retomadas nas discussões teóricas e políticas. Os antigos modelos informacionais já não dão conta da virtualidade enquanto gênero comunicacional. Devemos propor modelos que situem o sujeito num círculo de relação com a linguagem. Vejamos a proposta de Steels (2003, apud BRENNAND, 2007):

Figura 4: Modelo do ciclo do ciclo semiótico de Steels.

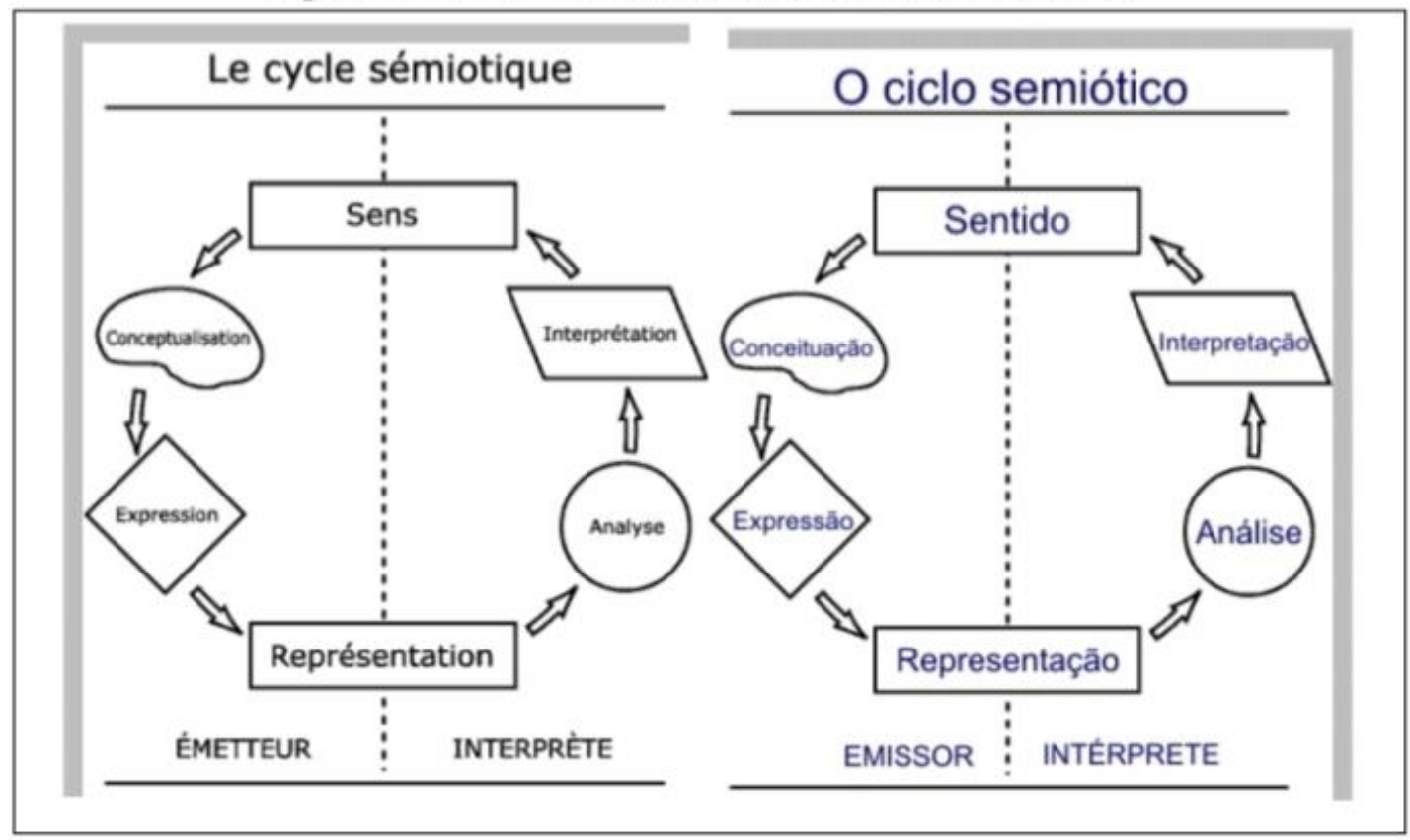

\section{CONSIDERAÇÕES FINAIS}

Constatamos que a realidade mostra uma interação planetária, transfigurada pela virtualidade, que está sendo reconhecida na reconstrução das práticas comunicacionais. Constatamos que o que é virtual amplia/amplifica as possibilidades de multipersonalizações, autogerenciamento e descentralização dos conhecimentos. Essas possibilidades são caminhos infinitos e desconhecidos, são habitações de novos conceitos de tempo, espaço e gênero comunicacional que redefinem as relações sociais. A nova estrutura convida-nos a reconhecer que os saberes estão em metamorfose, e que há desafios que se estendem à educação, numa ampla dimensão intercultural. 


\section{Desafios da psicologia no Brasil}

\section{REFERÊNCIAS}

CASTELLS, Manuel. A sociedade em rede. São Paulo: Paz e Terra, 2008.

BLACKBURN, Simon. Oxford de filosofia. Rio de Janeiro: Jorge Zahar, 1997.

BAKHTIN; VOLOCHINO. Marxismo e filosofia da linguagem. São Paulo: Hucitec, 2010. . Estética da criação verbal. São Paulo: Martins Fontes, 2010.

BRENNAND; LEMOS. TV digital interativa. São Paulo: Mackenzie; 2007.

IANNI, Octavio. Teorias da globalização. Rio de Janeiro: Civilização Brasileira, 2004.

LAVILLE, Christian; DIONNE, Jean. A construção do saber. Porto Alegre: Artmed, 1999.

LE COADIC. A ciência da informação. São Paulo: Briquet de Lemos, 1996.

LEGAY, Luc. Trois principes technologiques pour inventer les réseaux d'intelligence collective. Disponível em: <http://ru3.com/luc/. Acesso em: jan. 2007.

LÉVY, Pierre. Cibercultura. Rio de Janeiro: 34, 2000.

MORIN; MOIGNE. Inteligência da complexidade. Portugal: Instituto Piaget, 2009.

. Os sete saberes necessários à educação do futuro. São Paulo: Cortez, 2001. STEELS, Luc. Le cycle sémiotique. Disponível

em:<http://head.hesge.ch/ccc/CDROMCOLLECTOR/ARTICLES/2008/RU3RelierLesConnaissances.html >. Acesso em: mar 2013.

TRIVINHO. Epistemologia em ruínas. IN: MARTINS; SILVA (Orgs.). Para navegar no século XXI. Porto Alegre: Sulina, 2003.

WOLF, Mauro. Teorias da comunicação. Lisboa: Presença, 2001. 


\section{Capítulo 45}

\section{BARBÁRIE NA PSICANÁLISE, CIÊNCIA E CULTURA. UMA INTERSECÇÃO CONCEITUAL}

DOI: $10.37423 / 200200265$

Maria Aparecida da Silveira Brígido (Psicóloga. Psicanalista Mestre em Psicologia Clínica pelo Instituto Superior Miguel Torga, Coimbra, Portugal. Membro Pleno da Sigmund Freud Associação Psicanalítica Porto Alegre). masilveira@sinos.net

Resumo: As ideologias da barbárie e a relação com as ciências e a contemporaneidade são discutidas à luz da fenomenologia da vida de Henry, considerando as constatações sobre a dramática destruição da cultura e do sạber humano. A aniquilaçáo é um ato resultante de um procesšo-desenvolvido quando a energia da vida permanece sem utilização no ser-humano. A pulsão destrutiva se opõe ao processo civilizatório. A luta entre pulsão de vida e pulsão de morte desencadeia a evolução da cultura considerando a teoria freudiana $A$ agressividade existente no ser humano proporciona a necessidade de estabelecímento de limites, leis ou de direcionamento para a produção na cultura. A barbárie em relação à cultura remete ao sujeito desta cultura sendo este transformado por aquela e a transformando.

Palavras-chaye: barbárie; cultura; fenámenologia; psicanálise; pulsão.

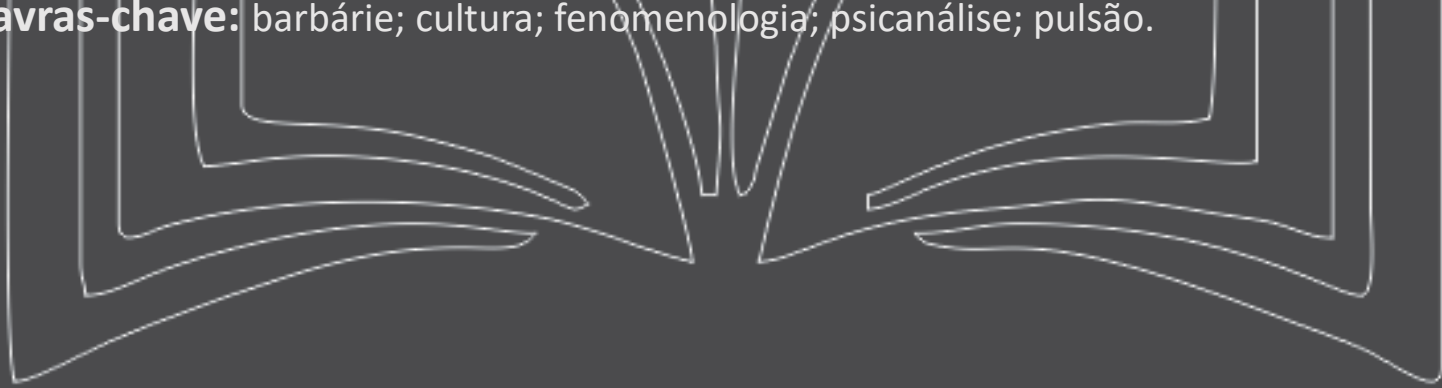




\section{Desafios da psicologia no Brasil}

\section{INTRODUÇÃO}

A convocação para discutir o tema pessoa, comunidade, Fenomenologia e Psicologia, despertou o interesse em abrir espaço para escrever sobre a barbárie fazendo uma interlocução entre os saberes psicanalíticos e filosóficos. A barbárie na cultura e nas ciências é um tema tratado pelo filósofo Michel Henry e as questões da destrutividade e a relação com pulsão de vida e de morte são investigadas em textos de Sigmund Freud de 1920 e 1930. A barbárie, enquanto uma ação que é premedita da mente destrutiva, ocorreu em muitos momentos da história da humanidade e ainda continua vicejando na contemporaneidade. É importante que possa ser aberto diálogo e construir-se possibilidades de reflexão sobre o assunto.

Em sua conferência no simpósio de Fenomenologia da Vida no II Congresso Internacional da Faculdades EST, Carla Canullo (2014) faz uma assinalamento sobre a concepção henryana da barbárie. De acordo com a autora, a palavra barbárie nasce de "barbaros"desde a Grécia que assinalava aqueles que não falavam grego; eram os estrangeiros que balbuciavam. Tanto em Atenas quanto em Roma, os estrangeiros balbuciavam, pois não conheciam ou não dominavam a lingua (grego e latim) que deveriam falar para que pudessem ser compreendidos. A palavra não tinha, portanto, o sentido a ela atribuída.

A autora fazendo a ligação com os escritos do filósofo Michel Henry assinala que que o filósofo nunca escondeu sua crítica frente à ideia de verdade e manifestação, principalmente frente à concepção galileana de mundo. Ela acrescenta ainda o destaque ou a estigmatização da barbárie na cultura moderna feita por Michel Henry, e este viés também o torna um bárbaro aos olhos da filosofia do pensamento grego.

Lima (2005) escreve sobre o tema barbárie e assinala que a primeira e segunda guerras mundiais são um exemplo surpreendente pior em desumanidade assassina do que as práticas guerreiras dos conquistadores, bárbaros, do fim do Império Romano. As tecnologias modernas, os tanques, o gás, a aviação militar, colocadas ao serviço de uma política imperialista de massacre e de agressão em uma escala imensa no século XX, teve, como palco, as Guerras Mundiais.

A utilização de meios técnicos modernos gera a industrialização do homicídio e a exterminação em massa graças às tecnologias científicas de ponta. Estas práticas associadas à impessoalidade do massacre em que populações inteiras, homens e mulheres, crianças e idosos são eliminados, com o 


\section{Desafios da psicologia no Brasil}

menor contato pessoal possível entre quem toma a decisão e as vítimas. Gestão burocrática eficaz é a ideologia legitimadora do tipo moderno sendo, portanto, biológica, higiênica, científica.

O autor assinala ainda que Auschwitz representa a modernidade não somente pela sua estrutura de fábrica de morte, cientificamente organizada e que utiliza as técnicas mais eficazes, mas pelos possíveis resultados do processo civilizador como racionalização e centralização da violência e como produção social da indiferença moral. Como toda outra ação conduzida de maneira moderna, o Holocausto, por exemplo, deixou para trás todos seus pretensos equivalentes pré-modernos, revelando-os em comparação como primitivos, esbanjadores e ineficazes.

Henry (2012) abrindo espaço para a compreensão das ideologias da barbárie, inicia diferenciando a natureza da humanidade. Ele em sua crítica a uma filosofia galileana entende que os humanos estão separados da natureza, pois apesar de toda a possível observação e visão, por exemplo, dos rios, das pedras, das cores, da luz que brilha, dos verdes e azuis, ela está separada do humano. Esta separação, de acordo com o filósofo, ocorre porque a subjetividade humana não é levada em conta, assim a possibilidade de ser afetado pela natureza não ocorre. Os efeitos da natureza são reduzidos a idealizações físico - matemáticas.

Decorre que os métodos precisos das ciências são na verdade restritivos, pois muitas vezes as pesquisas são incapazes de responder ao modo como se dá o objeto. O próprio objeto é definido à priori para que dele possa ser retido o dado a ser pesquisado (Henry, 2012).

\section{PSICANÁLISE E A PULSÃO DESTRUTIVA}

Nos seres humanos, em decorrência de sua construção psíquica, encontra-se o pulsional que é um processo dinâmico, uma carga energética oriunda das excitações internas e externas da pessoa (Laplanche \& Pontalis, 2001). A destrutividade direcionada ao mundo externo e a outros, possível constatar em atos de barbárie na contemporaneidade contra as pessoas, remete ao que em 1920 no artigo Além do Princípio de Prazer, Freud (1920/1976) desenvolve sobre a pulsão de morte e de vida. Há uma desfusão do componente das pulsões de vida e de morte e neste processo psíquico todas as energias que compõem as pulsões tornam-se autônomas ou independentes e criam caminhos de descarga. O surgimento da vida é a causa da continuação da vida e o esforço na direção da morte. Existem conflito e conciliação frente às duas tendências. Ao afastar- 633 se da própria pessoa, a pulsão de morte que é psíquica, dirige-se para o mundo exterior transformando-se em atos. 


\section{Desafios da psicologia no Brasil}

Na concepção psicanalítica de pulsão, esta é uma tensão psíquica que visa a descarga para o alívio do excedente pulsional. As descargas dirigem-se a um alvo interno ou externo, ou seja, a própria pessoa ou alguém no exterior assim como para objetos/coisas do mundo. O conceito em Freud da pulsão destrutiva é examinado por Laplanche e Pontalis (2001). Os autores afirmam que ela é utilizada para designar as pulsões de morte quando direcionada para o mundo exterior. É o "silêncio" que caracteriza a pulsão de morte, por causa disto que ela é reconhecida nas manifestações e expressões afastadas da própria pessoa.

Quando em 1930 no trabalho sobre o mal-estar dos homens relacionado à cultura, Freud ([1929]1930/1974) refletiu que os atos punitivos em si mesmos é que demonstram a culpa enquanto um sentimento inconsciente. A constatação, nas investigações freudianas, é que o sentimento de culpa é uma variedade topográfica da angústia. Desta forma pode-se entender que a angústia sempre está presente em algum espaço psíquico e por trás dos sintomas manifestados. Entende-se que sentimentos, afetos são energias circulantes provindas da separação de ideia pelo processo de recalcamento. A angústia, que é um afeto, circula pelos diferentes espaços psíquicos. Existe, portanto uma desproporcionalidade entre o sentimento de culpa e sua razão, sejam eles atos ou pensamentos. É que os sentimentos originalmente hostis que são percebidos geram a culpa e não necessariamente 0 ato em si.

A violência e a relação com a civilização levou Endo (2005) a opinar que no texto freudiano de 1930 estão indícios apontando caminhos de forma inédita para o entendimento de fenômenos sociais a partir da psicanálise. Afirma o autor que "Somente distendidos na cultura é que certos processos subjetivos podem ser observados..." (p.201) 634 e acrescenta que na cultura é onde a pulsão de morte assume formas devastadoras e onde também é regulada.

O desejo desloca-se constantemente, a fim de fugir do confronto e se esforça por encontrar substitutos - sejam eles objetos ou atos, segundo Freud ([1912-13]1913/1980). Observa-se que muitas das culpas nos sujeitos se apresentam de forma secundária, deslocadas ou distorcidas, dificultando sua correlação. Como resposta, a proibição também se desloca de forma a boicotar os disfarces da libido, num jogo contínuo e eterno. Desta forma surgem reações como o remorso, o adoecimento, a autopunição como tentativas de expiação. Se a reparação da transgressão ou violação pode ser corrigida com a expiação ou renúncia à liberdade, isso prova que se desejava algo proibido, evidenciando a ambivalência. 


\section{Desafios da psicologia no Brasil}

Assim Freud destacou "Aqui, talvez, nos possamos alegrar por termos assinalado que, no fundo, o sentimento de culpa nada mais é que a variedade topográfica da ansiedade". E acrescenta na seqüência: “...em fases posteriores, coincide completamente com o medo do superego" (Freud, [1929]1930/1974, p.159). A angústia, o temor e atos punitivos quando voltados ao exterior podem ser da ordem da destrutividade quando a ação é programada e executada nos atos de barbárie que se tem constatado. Encontramos em Brígido e Peres (2014) ao tratarem dos aspectos da culpa na construção do psiquismo, afirmam que o estabelecimento de normas é que garantem o interesse e o bem estar da população, pois esta é uma forma de conter os impulsos destrutivos naturais do ser humano. Não haveria necessidade de leis caso houvesse rejeição natural ao incesto, ao parricídio e aos crimes na população.

Conte (2014) amplia os aportes freudianos sobre as questões da consciência moral e a relação com o superego, pois sendo este um poder externo, uma autoridade parental que entra no circuito psíquico da perda de amor, castigo e renúncia. Para entrar no mundo 635 da cultura e no convívio com os demais é necessário aceitar que nem tudo é possível e que há interdição aos desejos.

A barbárie ou os atos bárbaros podem estar nesta complexidade relativa à dinâmica do sentimento de culpa quando não ocorre as interdições, quando o superego é sádico e a culpa e a dívida, ao invés de conter os indivíduos, proporcionam o rompimento de estruturas psíquicas gerando violência.

\section{FENOMENOLOGIA DA VIDA E BARBÁRIE}

A existência do grupo humano é possível pelos modos diferentes de cultura que ao longo dos milênios preservam o que existe e esperam ocasião para no saber adquirido a descoberta da construção de novos mundos. Para o filósofo a cultura é ao mesmo tempo constituinte do sujeito da cultura e seu objeto (Henry, 2012)

A vida segundo a qual Henry apoia sua tese, não se confunde com um saber científico, mas com o que denomina de subjetividade. O saber científico é objetivo, racional, universal e por todos conhecido. A subjetividade não é ter consciência do mundo, mas ter consciência da consciência do mundo. A cultura é quando não intervém o saber da consciência nem o da ciência, ela é a vida. Para o filósofo é a essência humana e não a relação com o objeto. A experiência de si é a subjetividade que se mostra do que emana, é um saber de si mesmo. Desta forma, a ideologia da ciência não leva em conta o ser humano como tal, o humano não é valorizado enquanto um ser que tem vida. A vida é a capacidade 


\section{Desafios da psicologia no Brasil}

de se sentir, ser afetado em si próprio e ser percebido nesta afetação. Esta afetação é o pathos, é interior e exterior, é a capacidade de sentir, ao perceber algo em si e fora de si (Henry, 2012).

Quando a ciência anula o saber e o conhecimento que não é científico, o saber e o conhecimento que remetem ao que o sujeito conhece em si e de si, estamos diante da 636 barbárie. 0 autor escreve sobre o progresso selvagem da ciência quando não há vínculos que possam remeter ao que ele chama de vida, pois esta não é a realidade objetiva e cognoscível. Uma descoberta genial que provocaria efeitos de progresso técnico se apresenta hoje com finalidades abstratas, como um estranho destino no qual é produzida prosperidade e também miséria para suprir um desenvolvimento. Um desenvolvimento econômico resultante da aplicação da ciência que pode ser traduzida por barbárie (Henry, 2012).

Antúnez (2014) entende que toda a Fenomenologia da Vida de Henry é um complexo trabalho sobre a afetividade e tem suas próprias leis. Estas, entretanto, não são redutíveis às leis racionalistas das ciências naturais da cultura ocidental cujo pensamento é dominado pela concepção racional e objetiva.

\section{CONSIDERAÇÕES FINAIS}

No trabalho sobre o mal-estar dos homens relacionado à cultura, elaborado em 1930, Freud ([1929]1930/1974) refletiu que a observação dos atos punitivos em si mesmos é que demonstra a culpa enquanto um sentimento inconsciente. É interessante constatar nestas investigações freudianas quando ele afirma que o sentimento de culpa é uma variedade topográfica da angústia. Desta forma pode-se entender que a angústia sempre está presente em algum espaço psíquico e por trás dos sintomas manifestados.

Vimos em Brígido (2014), que para a Fenomenologia da Vida na dor está a revelação da vida e a forma de expressão desta vida. Sentir que tem sentimento, ter consciência da consciência de si é uma possibilidade que os aportes filosóficos de Henry apontam como forma de não aderir aos atos de barbárie. Antúnez (2014), ao referir-se à clínica, assinala que é necessária uma adesão a si mesmo, ou seja, as necessidades 637 humanas passarem pela via afetiva. Sendo somente desta forma que os seres humanos constroem uma vida relacional.

A barbárie afeta o ser humano, pois destrói sua dimensão ética e estética. Mas a barbárie consegue maior visibilidade quando o crime de morte aparece em grandes proporções, numa forma antes impensável e surpreendente, obtendo imediato destaque de espetáculo na mídia. Assim, os 


\section{Desafios da psicologia no Brasil}

assassinatos dos moradores de rua de São Paulo são considerados atos de barbárie, a matança de crianças são igualmente atos de barbárie, ou, até mesmo, podem ser tipificados como genocídio. A barbárie é contrária ao viver e preservar.

As mais toscas formas de atividade e organização social são modos de cultura e tem em sua essência uma organização com leis que tornam possíveis a existência e sobrevivência do grupo. As atividades humanas desde a vida mais remota na terra, como manter-se sobre o solo, exercitar os sentidos, desenvolver sua subjetividade, seu comportamento erótico e etc. como realizações e construções de vida e de cultura, o homem construiu a partir de si. A constatação é que na atualidade o homem tem sido regulado pela ciência e não pelo saber próprio de ser humano

Ao referir sobre a relação da ciência no mundo moderno como sendo uma barbárie, Henry (2012) entende que a ciência se move inteira e exclusivamente no interior da relação com o mundo e, portanto, com seus objetos. O mundo é apenas exterioridade e coisas com um surgimento a cada momento de novas faces sem perceber ou se importar com aquilo que o ser humano é. Enquanto filósofo da Fenomenologia da Vida acredita que a cultura repousa sobre o saber da própria vida que consiste no autoconhecimento das potencialidades subjetivas. A cultura é o desenvolvimento dos saberes da própria vida. É interessante assinalar que para o autor, a arte, a ética e a religião são relativas à essência da vida humana e fazem parte de sua raiz. A crítica mais contundente que Henry (2012) 638 faz em relação às ciências é que o ser humano não é reconhecido em seu saber essencial, o saber não é mais próprio do homem, este perdeu a essência de seu saber-fazer.

A ciência surgiu pela necessidade do ser humano. O que se constata é que a ciência utilizada para fins destrutivos denota o uso perverso daqueles que não suportam o diferente. A barbárie é idealização, programação e sistematização de atos destrutivos de ideias, movimentos ou qualquer coisa que possa ser diferente. Atos de barbárie objetivam aniquilar aquele que pensa e age diferente ou que se diferencia culturalmente. Desta forma, entende-se que sendo a pulsão de morte, da ordem da destrutividade, resulta em ações humanas praticadas e exercidas com fins destrutivos de si e/ou de outro semelhante.

A barbárie pode ser entendida como pulsão de morte em sua mais pura manifestação de destrutividade. Resta a nós psicólogos e psicanalistas resgatar as manifestações da pulsão de vida como as que justificam e dão significado ao viver humano e a cultura. Conte (2014) deixa em seu texto sobre as questões de violência de estado que através da escuta dos psicanalistas abrem-se espaços 


\section{Desafios da psicologia no Brasil}

que possibilitam a transformação da dor em vias de recomposição simbólica. Desta forma, reconstroem-se as manifestações a partir da pulsão de vida.

\section{REFERÊNCIAS}

Antúnez A. E. A. (2014) A dialética dos afetos no acompanhamento terapêutico. In: A. E. A Antúnez; F. Martins \& M. V.; Ferreira (Orgs). Fenomenologia da Vida de Michel Henry. Interlocuções entre Filosofia e Psicologia. São Paulo: Escuta.

Brígido, M. A. S. \& Peres, M. (2014) Culpa e estruturação psíquica: analisando a história de Pinóquio. In: K. Wondracek, T. Heinmann; \& L. C. Hoch (Org.) Um olhar nos espelhos da culpa. São Leopoldo: Sinodal/EST.

Brígido, M. A. S. (2014) A passibilidade do corpo decorrente do sofrimento psíquico. . In: A. E. A Antúnez; F. Martins \& M. V.; Ferreira (Orgs). Fenomenologia da Vida de Michel Henry. Interlocuções entre Filosofia e Psicologia. São Paulo: Escuta.

Canullo, C. (2014). A barbárie na cultura e na clínica. II Congresso internacional religião, mídia e cultura. Simpósio temático: A visível e invisível barbárie na religião, na mídia e na cultura: reflexões a partir de Michel Henry.

Conte, B. A violência de Estado no espelho das culpas coletivas. In: K. Wondracek; T. Heinmann; \& L. C. Hoch (Org.) Um olhar nos espelhos da culpa. São Leopoldo: Sinodal/EST.

Endo, P. C. A violência no coração da cidade. Um estudo psicanalítico. São Paulo: Escuta/Fapesp, 2005. Freud, S. ([1912-13]1913) Totem e tabu. In: J. Strachey (Ed. \& Trad.) Edição Standard das Obras Psicológicas Completas de Sigmund Freud (vol. 13, pp.17-193). Rio de Janeiro: Imago, 1980.

Freud, S. (1920) Além do Princípio do Prazer. In: J. Strachey (Ed. \& Trad.), Edição standard brasileira das obras psicológicas completas de Sigmund Freud (vol. 18, pp.17-90) Rio de Janeiro: Imago, 1976.

Freud, S. ([1929]1930) O Mal- estar da civilização. In: J. Strachey (Ed. \& Trad.) Edição standard brasileira das obras psicológicas completas de Sigmund Freud (vol. 21, pp.81-178). Rio de Janeiro: Imago, 1974.

Henry, M. (2012) A Barbárie. São Paulo: É Realizações Editora.

Laplanche, Jean; Pontalis, J. (2001). Vocabulário da Psicanálise. São Paulo: Martin Fontes.

Lima, R. (2005) É 'barbárie', 'genocídio', 'holocausto', ou “massacre”? (60 depois de Auschwitz é preciso fazer mais do que distinguir conceitos). Espaço Acadêmico, 45, acessado em set. de 2014, www.espacoacademico.com.br/045/45lima.htm 


\section{Capítulo 46}

\section{ESSE BECO TEM SAÍDA: DIÁLOGOS INTERSETORIAIS NA INCLUSÃO DO PROJETO TERAPÊUTICO SINGULAR.}

DOI: $10.37423 / 200200271$

Dordania de Souza Resende (Bacharel de Psicologia pela Faculdade de Ciências Médicas de Minas Gerais, Belo Horizonte, MGBrasil). dordania@gmail.com.

Terezinha Marią Arąújo (Docente na Faculdade Ciências Médicas de Alinas Gerais, Belo Horizonte, MG-Brasil). te.araujo@yahoo.gom.br.

Resumo: Esse trabalho propõo refletik sobre o relato de experiência do acompanhamento terapêutico como dispositivo de intervenção clínica em Serviço Residenciál Terapêutico (SRT). A análise deste caso bem como a intervenção jưnto ao sujeito teye-como marco teórico a psicanálise. Partiu-se do construto Lacaniaho de "secretariar o alienado" e do manejo da transferência como operadores para possibilitar a criação de laços, o convívio e trocas subjetivas mesmo que atravessadas péla realidade psicótica do sujeito.

Pôde-se verificar um avanço no projeto tèrapêutico / do morador, no tocante as percepções de autocuidado. As intervenções intersetoriajis articularam soluções em conjunto, ao introduzir a abertura para oldiálege entre à escola e o centro/de saúde, o EERSAM e a equipe do SRT, numa corresponsabitizacão- vínculo mútưo. Rossjbilitando-asstm, a integração do território e dos direitos sociais -deste sujeito, que entendemos como possíveis saídas para acolhimento de seu sofrimento mental. 


\section{Desafios da psicologia no Brasil}

O acompanhamento terapêutico pode ser pensado como um eficaz dispositivo de intervenção clínica a partir dos avanços e do alcance de oportunidades ofertadas para o morador em seu território. Foi possível observar o interesse do morador em frequentar os espaços usuais tais como feira escolar, sala de laboratório de informática, espaço multimídia, grupos de convivência, etc., e puderam ser verificados como sendo aspectos terapêuticos no seu convívio.

A autonomia do sujeito e o sentimento de pertencimento em seu território foram percebidas como sendo essenciais para a diminuição do sofrimento e das desigualdades; ao aumentar a oferta de acesso, diminui-se a distância do sujeito com o seu sofrimento.

Palavras chaves: Acompanhante terapêutico. Acolhimento. Dispositivo clínico. Psicanálise. Intersetorialidade. 


\section{Desafios da psicologia no Brasil}

\section{INTRODUÇÂO}

De acordo com Ribeiro (2009) na perspectiva da reabilitação psicossocial, enfatiza-se o favorecimento da autonomia a partir da alternância dos lugares e possibilidades de estabelecer relações. A clínica do Acompanhamento Terapêutico (AT) existe desde a década de 1980 como um modo de intervenção para os profissionais de saúde mental (Barretto, 1998; Equipe de Acompanhantes Terapêuticos do Instituto A Casa, 1991; 1997 apud Ribeiro 2009).

Desta forma, no tratamento das psicoses o espaço das ruas e o contato com a cultura pôde ser pensado. Nessa clínica do encontro, o AT busca tentativas de superar possíveis limitações, desenvolver potencialidades e autonomia dos sujeitos psicóticos "apostando que uma maior autonomia e circulação no mundo podem influenciar uma movimentação psíquica" (Ribeiro, 2009).

A ruptura com o modelo manicomial significa muito mais do que o fim do hospital psiquiátrico, visto que ela toma como ponto de partida a crítica profunda aos olhares e concepções acerca deste fenômeno, "a cidade assume um lugar da inserção; a da possibilidade de ocupação, de produção e compartilhamento do território a partir de uma cidadania ativa e efetiva" (Luchmann e Rodrigues, 2007).

A trajetória do movimento antimanicomial de acordo com Amarante (1998), está relacionada com as primeiras manifestações no setor de saúde, em especial, através da constituição de 1976, do Centro Brasileiro de Estudos de Saúde (CEBES) e do movimento de Renovação Médica (REME). É no interior destes seguimentos, que surge o Movimento dos Trabalhadores de Saúde Mental (MTSM).

Estas rupturas, ainda segundo Amarante, foram também importantes para a criação do Manifesto de Bauru, do Movimento Antimanicomial, inaugurando o marco e a afirmação do laço social entre os profissionais e a sociedade no enfrentamento da loucura e de suas formas de tratamento. Estas conquistas foram responsáveis pelo fortalecimento de novos espaços de reflexões para que a sociedade se apropriasse desta luta. O lema 'Por uma sociedade sem manicômios' ganhou visibilidade e marco político ao se tornar o "Dia Nacional da Luta Antimanicomial” em 18 de maio.

Nesses avanços, conforme novas políticas de saúde, que teve como consequência o fechamento de hospitais e clínicas em regime asilar manicomial, surgiu o Serviço de Residência Terapêutica (SRT). Trata-se de casas instituídas para acolher moradores oriundos de instituições totais. A fundamentação psicanalítica foi escolhida como referencial de análise e intervenção por sua considerável contribuição com o campo da saúde mental, acompanhado do planejamento das ações propostas e das condutas terapêuticas, visando a uma experiência que favorece a escuta do sujeito e a sua inserção social. 


\section{Desafios da psicologia no Brasil}

A articulação e as ações intersetoriais serviram como critérios para as intervenções e abordaram os aspectos apontados como possíveis saídas para as demandas levantadas pelo sujeito, considerando a análise de suas narrativas, percebendo que quando se escuta o sujeito psicótico, escuta-se o testemunho da sua linguagem psíquica expressa em sua realidade. Para Maciel (2008), a psicose se endereça ao analista como sujeito para que este testemunhe sobre sua experiência na linguagem e sobre a maneira como consegue se posicionar nesse lugar.

Descomplicando o SRT - Serviços Residenciais Terapêuticos A criação das residências terapêuticas (SRT) segue determinação da Lei Federal 10.216, das portarias 106/01 e 3088/12 do Ministério da Saúde, e ainda as diretrizes da Reforma Psiquiátrica e da Luta Antimanicomial:

São um dispositivo de grande importância, por abarcar a reinserção social de sujeitos cronificados, por longos anos de internação em hospitais psiquiátricos, com ruptura de vínculos sócio familiares, ou, seriamente prejudicados.

O poder público e os programas de Saúde Mental dos municípios, são responsáveis por assegurar moradias a estes sujeitos. É relevante ressaltar que não se trata de serviços, e sim de locais que aspiram a ser moradias. Essas moradias possibilitam aos sujeitos, receberem apoio de profissionais para acompanhamento de sua saúde, incluindo os aspectos sociais, econômicos, políticos e culturais. Esses locais representam espaços de proteção para os moradores assegurando direitos como saúde, lazer e educação (Linha-Guia em Saúde Mental, 2006). ${ }^{1}$

A configuração da casa é sustentada por uma rede de assistência humanizada que busca assegurar aos seus moradores, a inclusão em projetos que visam garantir o cuidado integral por meio de estratégias substitutivas, na perspectiva da garantia de direitos com a promoção de autonomia e o exercício de cidadania; buscando sua progressiva inclusão social.

O estagiário no papel do acompanhante terapêutico De acordo com Lins (2001), entre as tecnologias de cuidado ${ }^{2}$ e suporte ao paciente psiquiátrico, destaca-se o acompanhante terapêutico (AT), com o qual busca-se cumprir o ideal de modificar minimamente a vida cotidiana, produzindo um máximo de impacto nas rotinas existenciais e pragmáticas, privilegiando o território, a historicidade e condição do sujeito. O papel do AT é reconhecido como uma modalidade de atendimento, tem funcionalidade técnica, qualificada e terapêutica.

O trabalho e o da equipe de assistência é consensado com morador e subsidiado pelo Projeto Terapêutico Singular (PTS). O PTS nos indica a direção que se pretende dar ao tratamento, levando-se em conta o que é possível e o que é desejável. 


\section{Desafios da psicologia no Brasil}

O at deve acompanhar a especificidade e traçar o PTS levando em conta os aspectos da vida cotidiana do morador e da sua estrutura psíquica, contemplando também, os atravessamentos e as limitações próprias de sua condição psíquica e da vida cotidiana.

Conquistando o território - Um relato de experiência O trabalho como AT desafia as dificuldades emergentes da prática. Elas surgem a medida em que o trabalho vai avançando.

Essa rede que nos conecta constitui parcerias para que possamos avançar tanto do ponto de vista teórico, como também, em relação à aplicação prática dos conhecimentos por ela produzidos. Os vínculos são pensados para responsabilização do cuidado e na tentativa de reatar o laço social. $A$ exemplo, cito a escola. Ambos atuam numa rede de assistência que valoriza o cuidado em liberdade, que busca a conquista da cidadania e a reinserção social. A perspectiva é a construção de ações coletivas e intersetoriais.

Saliento a importância do diálogo e da participação dos demais setores, que compartilham tecnologias de cuidados, e lutam por garantias de direitos na inclusão do projeto terapêutico de sujeitos que habitam os SRTs, pois, conforme o pressuposto de Foucault (apud Palombini, 2006), nessa experiência o encontro se dá no cotidiano social, ao que tange o exercício do AT, ressalta:

Podemos pensá-lo como sendo essa rede que articula os elementos em conjunto e os põe funcionar, nesse sentido, percebe-se a importância dessa figura dentro da SRT. Assim, a terapêutica que norteia a dimensão subjetiva desta experiência, é perpetrada através do encontro com o outro e parte do pressuposto do exercício do secretariar na relação da alteridade.

Assim, a partir do diálogo com a intersetorialidade ${ }^{3}$ no contexto escolar, com as parcerias que foram pactuadas ao longo dessa trajetória através da rede de referência e os demais atores envolvidos, destaco as cuidadoras (es), as (os) profissionais de saúde e as professoras (es), por priorizarem a valorização de aspectos positivos na qualidade de vida do morador.

A experiência do AT como sendo um dispositivo de intervenção clínica ${ }^{4}$ em SRT constitui uma modalidade de atendimento em articulação de rede, e busca na intersetorialidade do contexto escolar um diálogo inclusivo, visando os direitos de cidadania assegurados em Constituição, tidos como sendo essenciais para as contribuições do PTS do morador.

A escola entrou na vida deste morador a partir de seu desejo de ir embora da residência. Em relatos chegou a se descrever como sentindo-se triste, pois gostaria de ir para casa. As palavras proferidas por ele, elucidavam o sofrimento qual demonstrava estar vivenciando "eu quero matar eu"; dizia sentirse "sem paradeiro". Ao descrever-se, relatava que o pensamento era a morada de sentimento ruim, 


\section{Desafios da psicologia no Brasil}

que as intenções eram de todo tipo, prosseguia por dizer que se considerava "ser um homem transversal", encerrou dizendo que gostaria de ir embora.

Foi no manejo e na possibilidade de articular com ele que avançamos na relação transferencial, para o morador era preciso "merecer" a sua "confiança". Essa vivência no cotidiano nos leva a entender que a utilidade ou a inutilidade desse trabalho, dependerá de novas reflexões acerca do papel do AT, do seu compromisso no âmbito ético, político e clínico.

Para Lacan (apud Costa e Freire, 2010), frente a possibilidade de escuta da psicose, não se recua; na clínica das psicoses o psicanalista ocupará o lugar de objeto. O sujeito do suposto saber cai, e é justamente da posição de não saber, posição de esvaziamento, que ele deve se localizar, o lugar de secretariar.

A aproximação foi avançando aos poucos, o sentimento de tristeza e de incapacidade foram sendo verbalizados, à medida que na sutileza, a relação de "confiança" se estabelecia.

Frente ao questionamento sobre o que poderia ser feito para auxiliá-lo, diante da representação do sentimento de tristeza, o morador foi enfático" Sou formado em letras e ensino fundamental, eu quero estudar, fazer o ensino médio, eu sei ler e escrever". O contexto escolar para esse sujeito, reverberava um desejo "o fazer por merecer". No sentido de acolher o que estava sendo dito, pontuei dizendo, que iríamos juntos verificar essa possibilidade. Assim, nessa direção de escuta, busquei caminhar de acordo com os passos do sujeito, um começo de possibilidades que ocasionou a sua entrada na escola. A direção do tratamento, conforme proposto por Lacan em "A direção do tratamento e os princípios de seu poder" (1998), considera as particularidades estruturais e as singularidades de cada caso; implica-nos a responder somente a partir da transferência, é ela, que indica o fazer clínico.

O processo para articulação da escola, criou situações para que o sujeito se mobilizasse para visitar as escolas junto comigo e, nesse sentido, busquei fazer contato prévio e agendar visitas a escolas próximas ao território do morador. Para ele, a escola tinha uma grande importância pela inclusão, a participação e a promoção de igualdade de direitos; para a equipe, essa demanda pareceu favorecer o seu desenvolvendo, assegurando os seus direitos de cidadão e dando sentido para o seu sofrimento. Frequentar uma escola foi um recurso para o enlaçamento social e simbólico.

A disposição a dar ouvidos, a sensibilidade da escuta, tem que ser colocada desde o começo. O papel do at na posição de secretariar ${ }^{5}$ promove ao sujeito o sentido de ser ouvido.

Ao dizer "ser alguém", coloca-se como "ser sujeito", "ser, para ser melhor". Secretariar é ajudálo a transformar-se a partir de si mesmo, explorar as possibilidades que possui. 


\section{Desafios da psicologia no Brasil}

As articulações em rede se firmaram através das parcerias pactuadas entre a equipe da SRT, a equipe de referência do Centro de Saúde (CS), incluindo a médica psiquiatra e a escola como parceira nesse projeto, ações que buscaram garantir a efetivação de sua matrícula. Todas as ações e intervenções foram direcionadas a reabilitação psicossocial como modelo de redes múltiplas que põe no centro das questões a participação de ações conjuntas e intersetoriais.

Ao partilhar essa posição, evidencia-se a importância de deslocar o sujeito da perspectiva do real para o simbólico, dando-Ihe lugar de sujeito; esse que também fala a partir do seu território.

\section{UM BECO QUE TEM SAÍDA}

É possível pensarmos que o embaraço na psicose é à primeira vista, um beco sem saída, com o qual o sujeito se depara e com os obstáculos e as dificuldades expressas no real que o confronta. A articulação com a escola na efetivação da matrícula bem como, o intercâmbio com a intersetorialidade dos dispositivos da rede, possibilitaram a inclusão de estratégias que puderam ser implementadas no PTS do morador. Esse vínculo transferencial que se estabeleceu através da escuta ativa e atenta se faz necessários nos contextos embaraçados da psicose e nos diálogos intersetoriais entre diferentes setores de assistência. Nesse sentido, é possível proporcionar saídas para os conflitos intricados nesse gargalo da psicose.

Esse beco tem saída, exatamente, pelo fato de o tratamento caminhar de acordo com os passos do sujeito. É fundamental para o sujeito, a compreensão de que será acolhido em sua necessidade, enfrentando as dificuldades pessoais, sociais e quaisquer outras, que o impeça de as exercer plenamente.

Para o morador essa escuta facilitou o vínculo com o seu território, sendo notado através da sua participação nos espaços coletivos, tais como feira escolar, sala de informática, espaço multimídia, grupos de convivência, entre outros. Assim, reafirmando a sua conquista de pertencimento e o empoderamento em sua autonomia de sujeito. Ganhos no que tange aos aspectos terapêuticos na convivência, puderam ser visualizados a partir do seu interesse ao se inserir em contextos usuais do dia a dia, antes temidos pelo sofrimento de abandono e das desigualdades, por vezes presentes em suas narrativas.

Dessa forma, encontramos na escola um eixo, um campo de empenho na construção de novas redes e novas relações entre sujeitos sociais, no seu interesse pelo sujeito propriamente dito e não apenas pelo seu histórico de rompimento com a realidade. 


\section{Desafios da psicologia no Brasil}

A participação do morador nestes contextos sociais tanto no âmbito territorial quanto aos projetos pessoais que surgiram a priori, reafirmam a importância de uma atuação intersetorial. Desse modo, ambos, atuam como facilitadores de objetivos em comum, para que se articulem pontos de apoios e de conquistas. A cidadania se exerce quando se partilha a palavra. A tomada de decisão tem que ir ao encontrando das questões que afetam a cada um e o seu registro na cultura. O exercício da cidadania é indissociável da participação política e social.

\section{CONSIDERAÇÕES FINAIS}

É preciso promover a política pública como uma linha de ação coletiva que concretiza direitos declarados e garantidos em lei. A importância da intersetorialidade com a rede escolar e das Políticas Públicas de cidadania nos permitiram percorrer becos e vielas, diminuindo a distância nos caminhos tortuosos enraizados no contexto da loucura. Deste modo, foi possível para o morador experimentar o seu desejo e sonhar outros, não temendo o abandono e a exclusão. A partir dos avanços do morador e do alcance de oportunidades ofertadas em seu território, foi possível constatar, que o papel do AT participa da intervenção da inserção do sujeito no contexto social. Estas aproximações possibilitaram avançarmos com o PTS deste morador, e acima de tudo, criou-se com ele - e com a rede - , um vínculo consensual favorecendo o diálogo entre as equipes da rede. A relação de transferência nesse trabalho como AT me ensinou que morador, na sua singularidade, trouxe a sua história, a sua tristeza, a sua certeza, a sua vivência, o seu desejo expresso nos fragmentos da sua fala, detalhes importantes, que me guiaram nesse fazer.

Foi necessário ponderar a posição em que este sujeito se encontrava. A saída foi por ele mesmo que apontada. É por considerar que na psicose, o sujeito seja ora mais disponíveis, ora mais arredio, é convocado a enfrentar as rupturas da realidade, e esse amor e ódio tão manifestos como particularidades de suas vivências transformam-se a partir de si mesmo, pois é como sujeito que ele vai falar de sua posição de objeto. Secretariar o alienado é saber seguir as estratégias desenvolvidas pelo próprio sujeito como política para a sua reabilitação. Daí a advertência de Viganò apud Guerra (2004) para não cairmos numa nova cronicidade, institucionalizar o que busca ser desinstitucionalizado.

\section{REFERÊNCIAS BIBLIOGRÁFICAS:}

AMARANTE, P. Loucos pela vida: a trajetória da reforma psiquiátrica no Brasil. Fio cruz 1998.

COSTA, C. A. R., FREIRE, A. B. Lacan, secretário do alienado. Disponível em: 


\section{Desafios da psicologia no Brasil}

<http://pepsic.bvsalud.org/pdf/mental/v8n14/v8n14a05.pdf>. Acesso em: 02 abr. 2018.

GUERRA, A. M. C. Reabilitação psicossocial no campo da reforma psiquiátrica: uma reflexão sobre o controverso conceito e seus possíveis paradigmas. Disponível em: :

<http://www.scielo.br/pdf/rlpf/v7n2/1415-4714-rlpf-7-2-0083.pdf>. Acesso em: 12 maio. 2018.

LACAN, J. (1949). A direção do tratamento e os princípios de seu poder 1. In: Lacan, Jacques.

Escritos. Rio de Janeiro: Jorge Zahar, 1998, p.591-646.

LUCHMANN, L. H. H \& RODRIGUES, J. O movimento antimanicomial no Brasil. Disponível em:

<http://www.scielo.br/scielo.php?script=sci_arttext\&pid=S141381232007000200016\&lng=en\&nrm= iso> Acesso em: 02 Jun. 2018.

MACIEL. V. S. A transferência no tratamento da psicose. Disponível em:

<http://pepsic.bvsalud.org/pdf/mental/v6n10/v6n10a03.pdf>. Acesso em: 17 maio. 2018

RIBEIRO, A. M. A idéia de referência: o acompanhamento terapêutico como paradigma de trabalho em um serviço de saúde mental. Estudos de Psicologia, 14(1), Janeiro-Abril/2009, 77-83. 


\section{Capítulo 47}

\section{ORIENTAÇÃO À QUEIXA ESCOLAR: REFLEXÕES SOBRE AS PRÁTICAS DO PSICÓLOGO EDUCACIONAL.}

DOI: $10.37423 / 200200272$

Raquel Cabral de Mesquita - Doutora em Educação pela FAE/UFMG; Psicóloga com experiência em Clínica Psicanalítica e em Psicologia Educacional/Escolar; Professora no curso de Psicologia da Faculdade Pitágoras/Divinópolis).

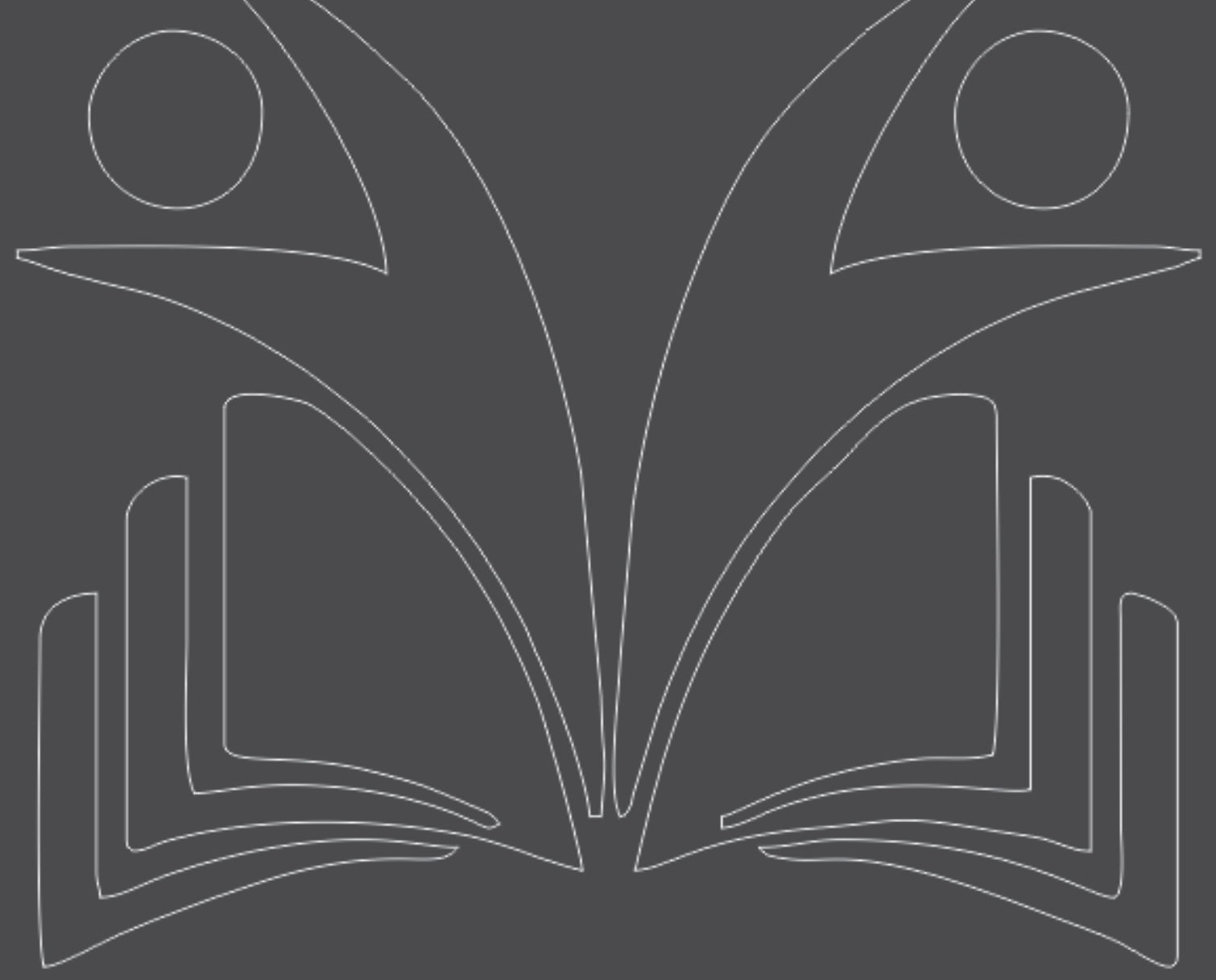




\section{Desafios da psicologia no Brasil}

\section{INTRODUÇÃO}

Como temos orientado à queixa escolar? Estamos superando práticas alienantes e adaptativas - que constituíram no passado uma história de críticas ao fazer da psicologia escolar - por práticas inovadoras e que posicionam em favor da emancipação do sujeito na educação? A precipitação diagnóstica ou patológica dos impasses escolares, numa visão unilateral, situada no aluno-problema, já nos trouxe muitos problemas apresentados pela história da psicologia. O psicólogo foi acusado de compactuar com uma lógica sutil de exclusão social, justificada pela proposta de nivelamento educacional de todos os alunos e pela pretensão de neutralidade científica da psicologia principiante. Assim, é preciso refletirmos e questionarmos se nossas práticas na escola e nossa atuação como psicólogos educacionais propiciam alienação ou emancipação dos sujeitos envolvidos no processo educacional.

É preciso que o psicólogo se encontre preparado para perceber o que há de implícito nas queixas que são direcionadas ao serviço de psicologia. A psicanálise nos ensina a não desconsiderar a queixa, uma vez que essa pode indicar o sintoma, entretanto, ela não é o sintoma. A queixa quando bem conduzida ou bem orientada numa escuta dos sujeitos perpassados por ela, pode nos levar ao sintoma.

Segundo Vieira (2008, p.187), as demandas direcionadas ao psicólogo nos contextos educativos, muitas vezes "assentam-se em expectativas irreais e desinformadas sobre a ação desse profissional". O que aponta para a importância do psicólogo escutar e acolher às demandas, entretanto, indo além delas, e evidenciando sua função nos espaços educativos.

Desde modo, cabe aos psicólogos educacionais, recorrer as atribuições profissionais nas quais são responsáveis. Tais atribuições do Psicólogo Educacional (CONSELHO FEDERAL DE PSICOLOGIA, 1992) nos direciona a pensar que a prática desse profissional não está situada nos atendimentos individuais em sua concepção abstrata e, supostamente, neutra, desconsiderando os contextos sociais dos sujeitos atendidos, contrariamente, convida-nos a direcionarmos às relações e aos laços que remetem a uma atuação que abrange o aluno, a família/social e a escola.

Assim, Souza (2006, p.313) considerando a orientação à queixa escolar uma modalidade de atendimento clínico breve e focal, aponta para uma abordagem que pela investigação e intervenção supere práticas baseadas numa concepção abstrata de indivíduo e interfira nas relações escolares:

Nosso objetivo é conquistar uma movimentação da rede de relações na qual emerge a queixa escolar no sentido de sua superação. Essa rede tem como personagens principais, via de regra, a criança/adolescente, sua escola e sua família. Assim, nosso 


\section{Desafios da psicologia no Brasil}

objeto de investigação/intervenção é essa rede e como as relações entre seus participantes se desenvolveram e se desenvolvem (Souza, 2006, p.313)

As pesquisas no campo da Psicologia e Educação, evidenciaram que as queixas escolares constituíam cerca de $75 \%$ da demanda infanto-juvenil para atendimento psicológico na rede pública de saúde, o que aponta para a prioridade que a queixa escolar deveria ter na formação do psicólogo e nas ações da saúde (Souza, 2006, p.313).

Ao considerarmos a orientação à queixa escolar como uma modalidade clínica (Souza, 2006), uma vez que pode ser situada na interface da psicologia clínica e escolar, somos convidados a superar as práticas historicamente centradas na clínica médica, normativa e patologizante. Desde modo, enfatiza-se a importância da investigação/intervenção voltar-se para as três dimensões de atuação da psicologia escolar: aluno, sua escola e sua família. Através dessa atuação, busca-se não responder com práticas adaptacionistas e normativas, no qual, a superação da queixa escolar consiste apenas na mudança do aluno, algumas vezes, se estendendo à família, entretanto, mantendo a escola intocada. Então, é preciso escutar os familiares e suas vivências sociais; é preciso escutar o aluno na sua singularidade subjetiva e em seu contexto social; é preciso escutar a escola na sua impossibilidade.

A impossibilidade na educação é uma das afirmações de Freud (1976[1925]; 1975[1937]) mais citadas por aqueles que trabalham na interface da psicanálise e da educação. Esse impossível repetidamente vem se inscrevendo como mal-estar na prática educativa e em suas inovações e pode ser lido a partir das manifestações sintomáticas de cada tempo.

Segundo Santiago (2005, p. 19-20), o adjetivo impossível na psicanálise refere-se "às modalidades de ato cujo efeito não se pode antecipar". Sendo o ato educativo uma transmissão, no qual o resultado não é previsível e nem passível de cálculo coletivo, a dimensão desse ato acarretaria um impossível. A autora esclarece ainda que, quando se admite a existência do inconsciente perpassando as relações humanas e de aprendizagem, "não é possível fixar uma relação de causalidade entre meios e os efeitos obtidos".

Santiago (2012) ainda propõe que se possa restituir o lugar de impossível na prática da educação, que consiste em suportar certa angústia diante de situações marcadas pela incerteza, que não tem uma resposta pronta ou imediata, mas que, pelo contrário, preserva um lugar de vazio que permite interrogar o sujeito sobre o que não vai bem (SANTIAGO, 2012).

Referenciando à clínica psicanalítica como teoria e prática que subsidia o tratamento dado à queixa escolar, refletimos que não devemos rejeitar de antemão qualquer vertente clínica em nossa prática 


\section{Desafios da psicologia no Brasil}

na educação, a clínica tem muito a colaborar com o espaço escolar. A abordagem clínica, proposta neste trabalho, se mostra bem diversa da tão criticada "clínica na escola", que levou psicólogos escolares a serem acusados de respaldar, através de sua ciência, a exclusão, ao centrarem sua atuação no aluno-problema, atribuindo o fracasso ou a inadequação escolar a características inerentes a esse aluno (PATTO, 2010). Esse processo culminou em psicopatologização dos problemas escolares e propiciou um deslocamento de questões e resoluções pedagógicas para causas e soluções pretensamente psicológicas ou médicas, consequentemente inacessíveis à educação (MOYSÉS; COLLARES, 1992a; 1992b).

É pertinente o exercício de uma clínica que reconhece o lugar do Outro Social ou das relações escolares nas manifestações sintomáticas e não desconsidera os saberes e práticas pedagógicas já existentes ou desenvolvidas pelos professores na escola. Essa proposta de intervenção é iniciada com uma questão que remete ao sintoma, ao escutar a queixa dos educadores, o que consiste numa leitura a partir da questão do que não vai bem no contexto escolar.

Essa abordagem de orientação à queixa escolar deve inserir a escola na investigação e na intervenção. Considera-se como princípio, que a pesquisa, ou seja, a investigação em educação ou em espaços escolares, inclua a intervenção, seja uma pesquisa/intervenção e, também, que a prática em educação, seja uma constante investigação, que não percamos nossa perspectiva de pesquisadores e questionadores enquanto profissionais atuante neste campo de trabalho.

Portanto, para concluir, apresenta-se uma proposta de pesquisa/intervenção no espaço educacional, no qual, começa-se pela escuta da escola, através das questões: o que não vai bem? O que aponta para o sintoma através da queixa?

Atentando-se a discussão interdisciplinar entre psicologia, psicanálise e educação, tem-se nesta pesquisa/intervenção, o uso de dispositivos metodológicos como a Entrevista Clínica de Orientação Psicanalítica (ECOP) e o Diagnóstico Clínico Pedagógico com os alunos e a Conversação junto aos educadores. O objetivo da utilização dessa metodologia consiste em investigar e intervir, respectivamente, sobre os impasses dos alunos que podem ser diagnosticados como questões conceituais e pedagógicas ou referentes à subjetividade, remetendo ao sintoma da criança; e/ou sobre os sintomas da escola, que aparecem como mal-estar impossibilitando a transmissão e, muitas vezes, inviabilizando a escolarização. Essa proposta de intervenção é iniciada com uma questão que remete ao sintoma, ao escutar a queixa dos educadores, que consiste numa leitura do que "não vai bem" no 


\section{Desafios da psicologia no Brasil}

contexto escolar, sendo que a partir dessa leitura, casos de alunos podem se especificar e demandar uma intervenção mais particularizada que considere a subjetividade de cada aluno (MESQUITA, 2017).

\section{SOBRE TAL METODOLOGIA, PODEMOS ESPECIFICAR:}

\section{ENTREVISTA CLÍNICA DE ORIENTAÇÃO PSICANALÍTICA (ECOP):}

Esse nome foi sugerido por Eric Laurent para uma atividade inspirada na prática de "Apresentação de Pacientes", porém, realizada em contextos que não são instituições especializadas em tratamento de saúde mental. Um atributo essencial na prática de "Apresentação de Pacientes" refere-se à subversão que Lacan estabeleceu a essa prática, ao propor que "o entrevistador deve despojar-se do próprio saber, pois, no que concerne à estrutura da entrevista, é o paciente que ensina seu savoir-faire", o que permite restituir ao entrevistado - louco, criança ou adolescente - seu estatuto de sujeito (SANTIAGO, 2009, p. 136).

Trata-se de uma intervenção pontual e de curta duração, que se apresenta como conversas com alunos, partindo das queixas dos professores sobre os variados problemas desses alunos. Quando oportuno, pais ou familiares também são convocados para entrevista. Nesta investigação junto ao aluno, quando se verifica "que o problema é da ordem de um sintoma, que está se manifestando sob a forma de inibições ou de angústia, objetiva-se localizar uma 'identificação mortífera'"(SANTIAGO, 2015, p.16). Através da oferta de espaço para falar, busca-se que a criança ou o jovem possa se livrar do peso das identificações que lhe são impostas pelo Outro (nomeações proferidas pelos professores). Muitas vezes, essas entrevistas se tornam o momento mais propício da passagem do sintoma do Outro para o sintoma do sujeito.

\section{CONVERSAÇÃO COM EDUCADORES:}

Conversação é o nome da metodologia, sugerida por Jacques-Alain Miller, para os encontros clínicos do Campo Freudiano, nos quais, se propõe a promoção de um debate entre os participantes em torno de temas cruciais, para lidar com questões que não têm saída prévia e que somente poderão ser construídas a partir daquela conversa. (SANTIAGO, 2008; MANDIL, 1998).

Trata-se de um dispositivo psicanalítico de investigação, tomado, num primeiro momento, como recurso de pesquisa e, seguidamente, de intervenção pelo Laboratório CIEN (Centro interdisciplinar de estudos sobre a criança) na França. A Conversação caracteriza-se pela aposta de que é possível pela 


\section{Desafios da psicologia no Brasil}

via da palavra a construção do novo ou inédito, de uma invenção, que leva em conta a experiência particular de cada um dentro de um grupo (LACADEÉ, 2000).

Portanto, a metodologia de Conversação se transfere de espaços puramente clínicos para espaços sociais, configurando-se como uma prática de intervenção sobre um coletivo, que, mesmo tendo a singularidade de seus componentes assegurada, visa efeitos, também, no social, ao intervir na desinserção de alguns sujeitos em desconexão com o Outro social.

Diante de situações e problemas que se repetem e se configuram em queixas na escola, mesmo depois de utilizados todos os recursos educacionais possíveis, a Conversação tem possibilitado um lugar em que o falar livremente pode mobilizar questões e inventar respostas, lidando com o que se evidencia como impossível. “O ponto de partida dessa prática é o sintoma, 'o que não vai bem'. A aposta da Conversação resume-se a passar da queixa, que paralisa a ação dos professores e produz identificações indesejáveis para os alunos, a outro uso da palavra em que dificuldades tomam a forma de questão e esta se configura em respostas, ou melhor, em invenções inéditas" (SANTIAGO, 2015, p. 16).

\section{DIAGNÓSTICO CLÍNICO PEDAGÓGICO (DCP):}

Um procedimento de investigação-intervenção que parte da dificuldade do aluno com a aprendizagem escolar e visa elucidar a trajetória intelectual deste, através da resolução de tarefas até o ponto em que permita identificar se seus impasses na aprendizagem situariam na esfera conceitual-pedagógica ou seriam de ordem subjetiva (SANTIAGO, 2011). É a partir dessa constatação que se propõe uma discussão interdisciplinar, na qual os limites e as diferenças das intervenções pedagógicas e psicanalíticas são reconhecidos. Dessa forma, nem todas as dificuldades de aprendizagem são sintomas, mas somente aquelas que se constituem em respostas particulares a impasses subjetivos e que, por essa razão, continuam se repetindo em fracasso, mesmo depois da execução de todos os recursos pedagógicos e educacionais disponíveis à escola.

O método de investigação dos conhecimentos da criança é inspirado na clínica psicanalítica, sendo a criança interrogada sobre seus impasses escolares, "como se interroga alguém sobre seu sintoma [...] e considera-se que a própria criança é quem tem o que dizer sobre sua dificuldade" (SANTIAGO, 2011, p. 97).

Ainda é fundamental enfatizar que a capacidade de escutar a criança, dando-lhe estatuto de sujeito, possibilitará não somente a possível constatação de elementos da subjetividade ou de sentido inconsciente, como também indicará um método de intervenção particularizado (SANTIAGO, 2005), 


\section{Desafios da psicologia no Brasil}

sinalizando um caminho na superação das suas dificuldades escolares. Portanto, o Diagnóstico Clínico Pedagógico constitui um modo de restituir ao aluno seu estatuto de sujeito de sua aprendizagem.

A metodologia de pesquisa aqui apresentada se evidencia como efetiva proposta de intervenção às queixas escolares, ao propor práticas fundamentadas no reconhecimento do impossível da educação. É óbvio que a busca por uma sociedade mais justa e uma educação de qualidade para todos deve avançar em suas lutas e seus ideais; porém, quando focamos no cotidiano atual das nossas escolas, marcado por uma intensa diversidade com suas mais variadas problemáticas (familiares, sociais, jurídicas, subjetivas, entre outras), somos convocados a intervenções não pautadas em ideais, mas, sim, direcionadas ao sintoma, ou seja, ao que se ressalta como aquilo que "não vai bem".

Um grande desafio da psicanálise e, também, da psicologia em sua aplicação ao campo da educação consiste em criar no âmbito institucional um espaço em que a singularidade possa se inscrever, de modo que as impossibilidades da educação, não sejam tratadas de forma generalista ou universal, mas numa adequação do universal da política e da legislação ao particular de cada escola e ao singular de cada sujeito. Entretanto, em tempos de psicanalistas engajados com o social, essa consideração à singularidade não finda seu efeito sobre o particular do sujeito e seu sintoma, mas é capaz de transcender e localizar essa singularidade nos sintomas sociais, permitindo efeitos sobre um coletivo através do laço social. Assim, a psicanálise pode atuar sobre o sintoma de desinserção social, no qual, a intervenção pode extrapolar o efeito da clínica do caso a caso, já constatado nos tempos de Freud, e repercutir sobre as instituições e suas políticas. Deste modo, ao considerar a singularidade, atributo específico das intervenções psicanalíticas, não se perde de vista a repercussão dessa consideração sobre um coletivo como possibilidade de atuação sobre os sintomas nas instituições (MESQUITA, 2017).

Portanto, é a partir desse desafio, que amplia a modalidade clínica da orientação à queixa escolar, que propomos uma prática psicológica no espaço educacional que seja, cotidianamente, refletida e questionada, uma vez que, em meio as melhores intenções e as mais consistentes teorias existem as impossibilidades da educação que sempre demandam um repensar dos efeitos de nossas atuações como profissionais e um reinventar constante de nosso fazer.

\section{REFERÊNCIAS:}

CONSELHO FEDERAL DE PSICOLOGIA. Atribuições Profissionais do Psicólogo no Brasil. Contribuição do Conselho Federal de Psicologia ao Ministério do Trabalho para integrar o catálogo brasileiro de 


\section{Desafios da psicologia no Brasil}

ocupações - enviada em 17 de outubro de 1992. Disponível em: < https://site.cfp.org.br/wpcontent/uploads/2008/08/atr_prof_psicologo.pdf >. Acesso em: 18/05/2019.

FREUD, Sigmund. Análise terminável e interminável (1937). ESB, vol. XXIII. Rio de Janeiro: Imago, 1975.

FREUD, Sigmund. Prefácio a juventude desorientada, de Aichhorn (1925). ESB, vol. XIX. Rio de Janeiro: Imago, 1976

LACADEÈ, Philippe. O dom da palavra. In: LACADEÉ, Philippe; MONNIER, Françoise (orgs). Le Pari de la Conversation. Institut du Champs Freudien: CIEN - Centre Interdisciplinaire sur L'enfant. Paris, 1999/2000. Brochure

MANDIL, Ram Avraham. Espírito da Conversação Clínica. Almanaque - Instituto de Psicanálise e Saúde Mental de Minas Gerais: Belo Horizonte, p. 6, 1998.

MESQUITA, Raquel Cabral de. Inclusão na impossibilidade da educação: uma proposta de intervenção psicanalítica. 2017. 163 f. Tese (Doutorado em Educação) - Universidade Federal de Minas Gerais, Belo Horizonte, 2017.

MOYSÉS, Maria Aparecida Affonso; COLLARES, Cecília Azevedo Lima. Diagnóstico da medicalização do processo ensino-aprendizagem na 1a série do 1o grau do município de Campinas. Revista em Aberto, Brasília:[s.n], ano 11, n. 53, jan./mar. 1992a.

MOYSÉS, Maria Aparecida Affonso; COLLARES, Cecília Azevedo Lima. O renascimento da saúde escolar legitimando a ampliação do mercado de trabalho na escola. Cadernos CEDES: O sucesso escolar um desejo pedagógico, Campinas: Papirus, n. 28. p. 23-29. 1992b.

PATTO, Maria Helena Souza. A produção do fracasso escolar: histórias de submissão e rebeldia. São Paulo: Casa do Psicólogo, 2010.

SANTIAGO, Ana Lydia. Apresentação. In. SANTIAGO, Ana Lydia; ASSIS, Raquel Martins de. O que esse menino tem? sobre alunos que não aprendem e a intervenção da psicanálise na escola. Belo Horizonte: Editora Sintoma, p. 9-16, 2015.

SANTIAGO, Ana Lydia. O saber da ciência na educação, o sujeito da psicanálise e a pesquisa intervenção sobre casos de fracasso escolar. In: SANTOS, Tânia Coelho dos; SANTIAGO, Jésus; MARTELLO, Andrea. De que real se trata na clínica psicanalítica? Psicanálise, ciência e discursos da ciência. Rio de Janeiro: Cia de Freud: PROAP/CAPES, 2012.

SANTIAGO, Ana Lydia. Entre saúde mental e educação: abordagem clínica e pedagógica de sintomas na escola nomeados por dificuldades de aprendizagem e distúrbios de comportamento. In: SANTIAGO, Ana Lydia; CAMPOS, Regina Helena F.(Orgs). Educação de crianças e jovens na contemporaneidade: pesquisas sobre sintomas na escola e subjetividade. Belo Horizonte: Editora PUC Minas, p. 93-99, 2011.

SANTIAGO, Ana Lydia. Efeitos da Apresentação de pacientes frente às exigências do mestre contemporâneo. Curinga - EBP- MG: Belo Horizonte, n. 29, p. 135-148, jul-dez. 2009. 


\section{Desafios da psicologia no Brasil}

SANTIAGO, Ana Lydia. O mal-estar na educação e a conversação como metodologia de pesquisaintervenção em psicanálise e educação. In: CASTRO, Lucia Rabello de; BESSET, Vera Lopes (Org.). Pesquisa-intervenção na infância e juventude. Rio de Janeiro: Trarepa/Faperj, p. 113-131, 2008

SANTIAGO, Ana Lydia. A inibição intelectual na psicanálise. Rio de Janeiro: Jorge Zahar, 2005.

SOUZA, Beatriz de Paula. Orientação à queixa escolar: considerando a dimensão social. Revista Psicologia Ciência e Profissão, Brasília: ano 26, n. 2, p. 312-319, 2006.

VIEIRA, Rita de Cássia. O psicólogo e o seu fazer na educação: uma crítica que já não é mais bem-vinda. Psicologia da Educação, São Paulo, 27, 2o sem. de 2008, p. 179-192. 


\section{Capítulo 48}

\section{ENTRE A MILITÂNCIA E A CIÊNCIA: A IMPLICAÇÃO DO PESQUISADOR NO PROCESSO DE PESQUISA EM PSICOLOGIA}

DOI: $10.37423 / 200200274$

Alciane Barbosa Macedo Pereira (Instituto Federal de Educação, Ciência e Tecnologia Goiás).

alcianebarbosa@gmail.com

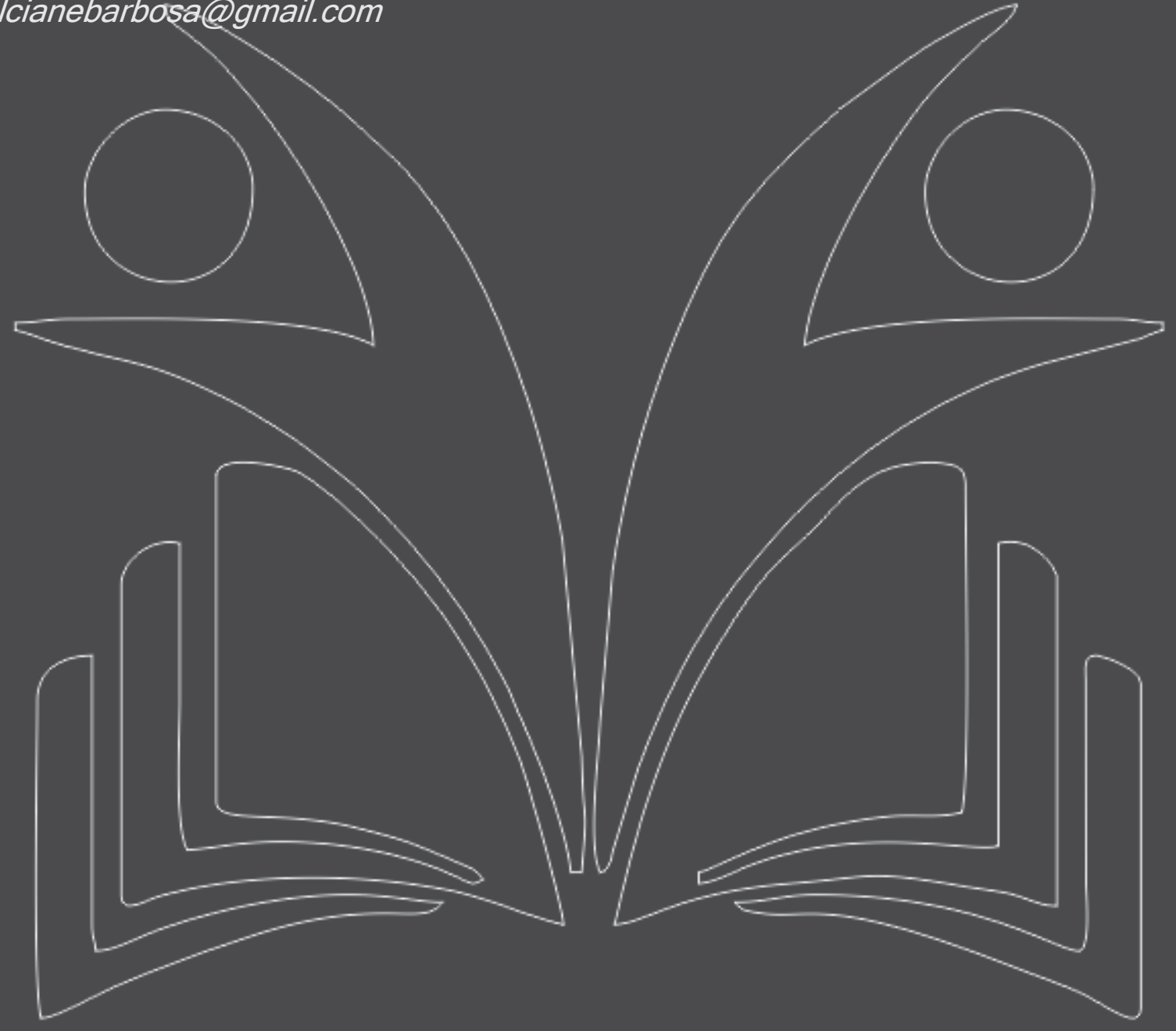




\section{Desafios da psicologia no Brasil}

Ao realizar estudos sobre Epistemologia, diante da minha proposta de pesquisa de doutorado relacionada à formação de professores/as e violência intrafamiliar contra crianças, surgiram questionamentos sobre a relação entre a militância e a ciência. A minha formação em Psicologia Social, a experiência de pesquisa nessa área e na formação de conselheiros tutelares e de direito contribuíram para que chegasse à proposta de pesquisa descrita com o olhar militante em busca da efetivação dos direitos das crianças, somado ao interesse em produzir conhecimento científico a respeito. Também havia o incômodo, a partir da minha atuação como docente de Psicologia da Educação, no que diz respeito ao excesso de responsabilidades e a falta de respaldo para a atuação dos educadores. Diante desse conflito, apresento algumas considerações sobre a possibilidade de fazer pesquisa entre a militância e a ciência. Nesse sentido, realizarei uma discussão sobre a implicação do pesquisador no processo de produção de conhecimento científico. Apresentarei também algumas discussões sobre a possibilidade de se tratar sobre a implicação ao considerar o impossível o exercício da neutralidade, particularmente no campo das ciências humanas e sociais, na qual se inclui a Psicologia de onde me origino e na qual me fundamento, sem excluir a possibilidade da inclusão e a discussão com outros saberes.

A noção de implicação, em oposição a de neutralidade sugere que o envolvimento subjetivo do pesquisador com seu objeto acontece nos diferentes contextos de pesquisa (Nasciutti, 2010). Assim, escolhemos nosso objeto de pesquisa porque nosso olhar é orientado por aquilo que toca-nos, ao mesmo tempo em que realizamos pesquisa diante do nosso desconhecimento parcial diante dele. Por isso, o pesquisar não se restringe a absorver técnicas e pô-las em prática, uma vez que é o cultivar da capacidade imaginadora e a engenhosidade que diferenciam o técnico do pesquisador (Oliveira, 1998).

A discussão sobre a impossibilidade da neutralidade na prática da pesquisa em Ciências Humanas viabilizou o surgimento de outras formas de fazer pesquisa distintas daquela com base nos princípios positivistas e na referência das ciências naturais e exatas. Considerar a ausência da neutralidade científica, por sua vez, é levar em conta a identidade entre sujeito e objeto nas pesquisas em ciências humanas e sociais.

Em Psicologia, como discute Neubern (2001), da mesma forma como em uma parte grande das ciências humanas e sociais, nasceu dentro de um conflito que objetivava buscar transpor as distâncias do abismo criado pelo paradigma científico dominante. O próprio Wundt, possivelmente ciente desse conflito e ainda que parcialmente fiel ao positivismo, constituiu a Psicologia, dita científica, dos laboratórios, ao mesmo tempo em que elaborou a pouco conhecida "Psicologia dos Povos". 


\section{Desafios da psicologia no Brasil}

No entanto, na atualidade, talvez mais do que antes, é possível ser contrário à dogmatização da ciência conforme proposto por Bachelard (1978) e assim, considerar que toda afirmação científica deve ser contextual, relativa, circunscrita a partir da compreensão de uma realidade específica e por meio da tensão entre os aportes teóricos e a ontologia da própria realidade. Assim, podemos afirmar, apoiados em Gergen (1996), que sempre há uma inteligibilidade alternativa. Assim, não se pode falar em conhecimento absoluto, final e separado de quem o produz, bem como da possibilidade de diálogo e de negociação entre os envolvidos. Dessa forma, como apresentam Calil e Arruda (2004), para as ciências humanas, a ciência é somente uma das formas de enxergar a realidade complexa, uma vez que ela não se esgota e o "esforço científico sempre possui o lado da descoberta daquilo que se pode conhecer mais e melhor" (Calil \& Arruda, 2004, p.175).

A tradição positivista, no entanto, nos acostumou ao dogmatismo, e à compreensão superficial da realidade junto ao distanciamento do pesquisador, nas diferentes áreas do conhecimento (Dionne, 2007). Mas é necessário considerar três níveis de abordagem do conceito de implicação em pesquisa, particularmente relacionados à pesquisa-ação: o nível psicoafetivo; o nível histórico-existencial; e o nível estrutural-profissional. O nível psicoafetivo está presente na pesquisa-ação, uma vez que o objeto de investigação sempre questiona os fundamentos da personalidade profunda (Barbier, 1985). Além disso, a implicação está presente em toda profissão em que se tem como base o desenvolvimento de relações humanas peculiares. O nível histórico-existencial, por sua vez, está articulado ao primeiro nível, pois a pesquisa acontece também ligada à própria vida do pesquisador, à sua história, na qual a sua existência também está em jogo e em que ele trabalha o mais profundo dos seus problemas no momento. O autor complementa ainda: “(...) é na medida que enfrento com seriedade os meus problemas que me torno mais disponível para os participantes" (Barbier, 2007, p. 111). Já o nível estrutural-profissional corresponde à procura de elementos que têm sentido com referência ao trabalho social do pesquisador e o contexto socioeconômico. Sobre esse último nível, o autor afirma que toda profissão apresenta um não-dito institucional. Este não-dito é a sua posição no campo das relações de produção e do sistema de valores que lhe dá coerência à própria profissão. Por fim, para Barbier (2007), os diferentes níveis de implicação se interpenetram e agem um sobre o outro:

A implicação, no campo das ciências humanas, pode ser então definida como o engajamento pessoal e coletivo do pesquisador em e por sua práxis científica, em função de sua história familiar e libidinal, de suas posições passada e atual nas relações de produção e de classe, e de seu projeto sócio-político em ato, de tal modo que o investimento que resulte inevitavelmente de tudo isso seja parte integrante e dinâmica de toda atividade de conhecimento (Barbier, 1995, p. 120). 


\section{Desafios da psicologia no Brasil}

A partir da ideia de implicação nas ciências humanas e sociais, considera-se que há na pesquisa militante a sugestão do engajamento consciente do pesquisador nos conflitos ideológicos e políticos da sociedade (Grubits \& Darrault-Harris, 2004). Nesse caso, a pesquisa tem por objetivo formação e ação para que exista a tomada de consciência pelos próprios pesquisados acerca dos seus problemas e das condições que o determinam e assim poderem organizar meios para se defender e buscar os seus interesses sociais.

No entanto, a proximidade que viabiliza a realização da pesquisa também abre espaço para a discussão de diferentes questões. Às vezes, a vinculação às pessoas estudadas em situações limite, particularmente relacionadas à violência, traz situações difíceis de serem remanejadas pelos pesquisadores (Costa, Penso \& Almeida, 2006). Nesse sentido, determinadas questões trabalhadas levam o pesquisador para o centro de um turbilhão e caos psíquico-emocional, apresentando-lhe impasses no planejamento metodológico, mobilizações subjetivas e conflitos éticos-morais. Ao mesmo tempo, para surgir desempenhando da melhor maneira seu papel de pesquisador e profissional, esse turbilhão leva-o a criar saídas nas diversas frentes de obstáculos para tentar contorná-los.

Como possibilidade de reflexão sobre a problemática da implicação, Barbier (2007) discute que o pesquisador deve desempenhar seu papel profissional numa dialética que articula constantemente a implicação e o distanciamento, a afetividade e a racionalidade, o simbólico e o imaginário, a mediação e o desafio, a autoformação e a heteroformação, a ciência e a arte.

Desse modo, é necessário conscientizar-se da sua implicação enquanto pesquisador para assim com rigor teórico e metodológico, além da consciência epistemológica, não permitir que apenas sua subjetividade oriente o trabalho, por meio do viés de seus desejos, defesas, crenças, certezas, partidarismos, militarismos ou preconceitos. Ao mesmo tempo em que essa consciência é fundamental para na direção oposta utilizar-se da sua implicação para enriquecer a pesquisa com suas experiências (Nasciutti, 2010).

Nesse sentido, o compromisso social da prática científica deve partir da ideia de que é necessário desvelar os interesses sociais e pessoais presentes na prática investigativa. Bem como, é preciso reconhecer a existência de conflitos, contradições e limitações do conhecimento, que longe de negar o rigor, enxerga a ontologia da realidade. Além disso, não é demais relembrar que as pesquisas de cunho acadêmico deveriam ter também como função servir como um dos fundamentos possíveis para as políticas públicas relacionadas às questões sociais, de saúde, educacionais, entre outras. 


\section{Desafios da psicologia no Brasil}

\section{REFERÊNCIAS}

Bachelar. G. (1978) O novo espírito científico. São Paulo: Abril cultura.

Barbier, R. (1985) A Pesquisa-ação na instituição educativa. Tradução Estela dos Santos Abreu e colaboradores de Maria Wanda Maul de Andrade. Rio de Janeiro: Jorge Zahar Ed.

Barbier, R. (2007) A pesquisa-ação. Tradução de Lucie Dibio. Brasília: Liber Libro.

Costa, L. F., Ribeiro, M. A., Penso, M. A. \& Almeida, T. M. C. de (2008). O desafio da supervisão e pesquisa-ação em casos de abuso sexual: os professores e suas questões. Paidéia, 18(40), 355-370.

Cail, R. C. C. \& Arruda, S. L. S. (2004) Discussão da Pesquisa Qualitativa com ênfase no método clínico. Em S. Grubits \& J. A. V. Noriega (orgs.). Método Qualitativo: epistemologia, complementariedades e campos de aplicação. São Paulo: Vetor (pp. 173-213).

Dionne, H. (2007) A Pesquisa-ação para o Desenvolvimento Local. Tradução: Michel Thiollent. Brasília: Liber Livro.

Grubits, S. \& Darrault- Harris, I. (2004). Método Qualitativo: Um importante caminho no aprofundamento das investigações. Em S. Grubits \& J. A. V. Noriega (orgs.). Método Qualitativo: epistemologia, complementariedades e campos de aplicação. São Paulo: Vetor. (pp. 105-132).

Gergen, K. (1996). Realidad y relaciones. Barcelona : Paidós.

Nasciutti, J. C. R. (2010). Reflexões sobre Pesquisa e Compromissos Sociais: Uma experiência de mobilização social e participação comunitária em projeto socioambiental. Em F. Lacerda Jr. \& R. S. L. Guzzo (orgs). Psicologia \& Sociedade: interfaces no debate sobre a questão social. Campinas, SP: Editora Alínea.

Neubern, M. S. Três Obstáculos Epistemológicos para o Reconhecimento da Subjetividade na Psicologia Clínica. Psicologia: Reflexão e Crítica, 2011, 14(1), pp. 241-252.

Oliveira, P. de S. (1998) Caminhos de construção da pesquisa em Ciências Humanas. Em P. de S. Oliveira (org). Metodologia das Ciências Humanas. São Paulo: Hucitex: UNESP.

Thiollent, M. (1996) Metodologia da Pesquisa-ação. São Paulo: Cortez.

Tripp, D. (2005) Pesquisa-ação: uma introdução metodológica, v. 31, n 3. São Paulo: Educação e Pesquisa, set/dez, p. 443-466. 


\section{Capítulo 49}

\section{A EXPERIÊNCIA NA UNIVERSIDADE ABERTA À TERCEIRA IDADE E A FORMAÇÃO DE ESTUDANTES DE PSICOLOGIA}

DOI: $10.37423 / 200200284$

Ana Alice da Silva Pereira

ana_alicep@hotmail.com

Cecilia Fernandes Carmona ce.zen@hotmail.com

Deise Coelho de Souza deisecsouza@hotmail.com

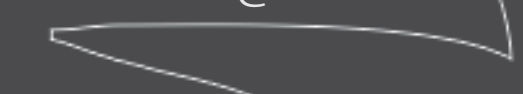

Vilma Valéria Dias Couto vilmacouto24@gmail.com

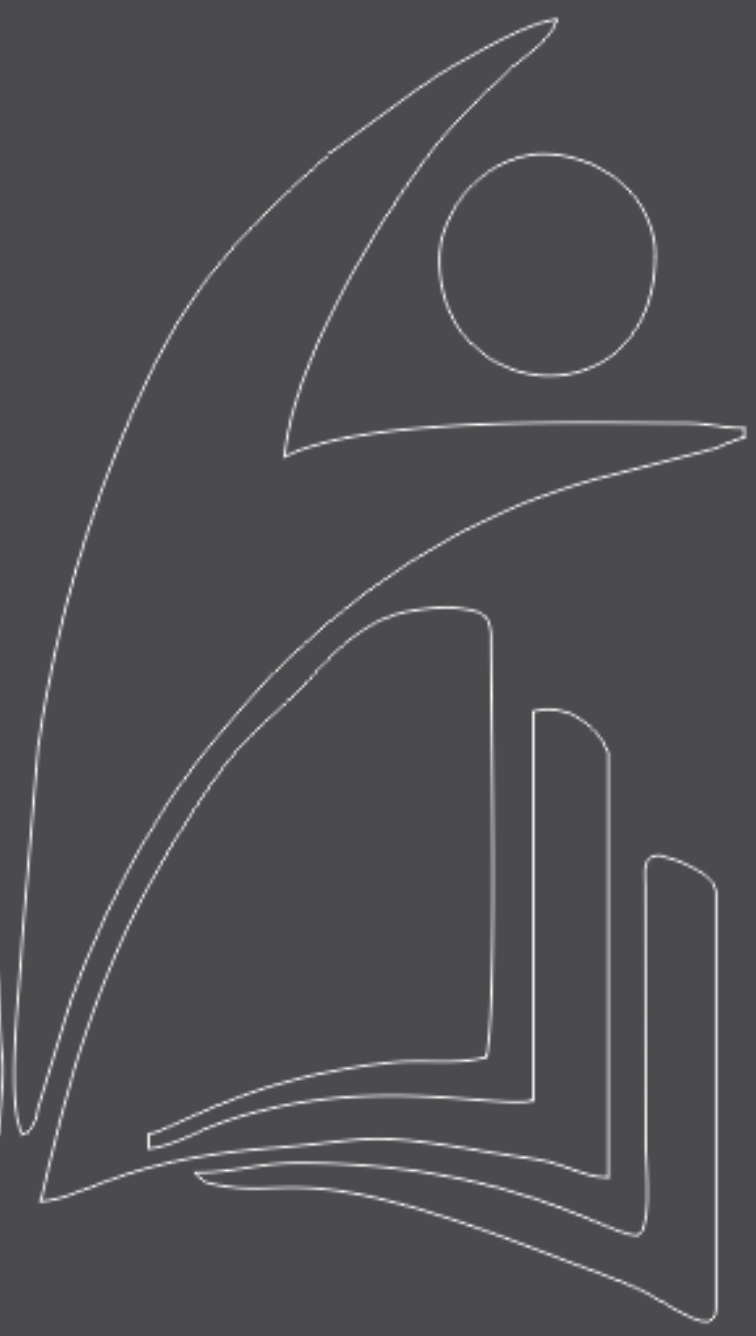




\section{Desafios da psicologia no Brasil}

\section{INTRODUÇÃO}

O envelhecimento da população brasileira é um fenômeno incontestável e o aumento de pessoas idosas gerou maior visibilidade desse público que passou a ser alvo de interesse e investimento da sociedade, das políticas públicas e de diferentes áreas de conhecimento que estudam o envelhecimento humano (Pereira, Couto \&Scorsolini-Comin, 2015). Embora esse interesse não seja recente, observa-se atualmente um maior esforço, da sociedade e do meio acadêmico, por projetos voltados para a manutenção da funcionalidade dos idosos e superação de atitudes negativas acerca da velhice (Ribeiro, 2015).

Atualmente a velhice tem sido destacada como uma fase não só de declínio eperdas, mas de aquisições, transformações e com possibilidades de aperfeiçoamento de habilidades e de busca de maior satisfação de vida (Pereira, Couto \&Scorsolini-Comin, 2015; Alves-Silva, Scorsolini-Comin, \& Santos, 2013; Ferreira \&Barham, 2011).

A busca por um envelhecimento saudável aumenta a necessidade da promoção de saúde nos programas de intervenção voltados para pessoas idosas, pressionando os serviços de saúde a irem além em suas ações, de modo a incluir práticas que privilegiem os componentes socioeconômicos e culturais da saúde. Este modelo de envelhecimento depende de políticas públicas e de participação social no processo desta conquista (Buss, 2003; Assis, Hartz \&Valla,2004). Deste modo, intervenções voltadas para promoção do envelhecimento saudável podem ser efetivas se as políticas públicas estiverem articuladas com a noção moderna de promoção de saúde, que entende a condição de saúde como resultante da combinação de determinantes tanto estruturais como individuais de saúde (Bus, 2003).

Em conformidade com a noção ampliada de saúde e seus determinantes na velhice, a Organização Mundial de Saúde (OMS, 2005) adotou o termo "envelhecimento ativo" queexpressa uma visão mais positiva e abrangente do envelhecimento, e reconhece outros fatoresque afetam o modo como os indivíduos envelhecem,além de considerar a participação ativa dos idosos na sociedade. Entende-se que o "envelhecimento ativo" engloba a visão da velhice como um processo natural do ciclo de vida que deve ser vivenciado com autonomia, independência, reconhecimento de direitos, segurança, dignidade, bemestar e saúde (Leandro-França \& Murta, 2014).

Considerando o desejo e a necessidade econômica de permanecerem ativos e engajados em atividades que permitam satisfação ou renda, mesmo após aposentadoria, os idosos procuram participar de programas em busca de novos conhecimentos e desenvolvimento de competências profissionais, visando complementação de renda, aprendizagem ou mesmo satisfação pessoal (França, 


\section{Desafios da psicologia no Brasil}

Murta, Negreiros, Pedralho\&Carvalhedo, 2013; Ferreira \&Barham, 2011). Na perspectiva de envelhecimento ativo, programas educacionais, sociais e de saúde direcionados aos idosos devem promover um envelhecimento equilibrado, em que os declínios, causados pela própria idade, possam se contrapor aos benefícios obtidos pela participação nas propostas ofertadas (Scoralick-Lempke\& Barbosa 2012; Pereira, Couto \&Scorsolini-Comin, 2015)

No que se refere a ações de promoção da saúde de idosos, Leandro-França e Murta (2014) destacaram as intervenções de Teixeira (2002) que visam o empoderamento das pessoas idosas, conduzidas por meio de encontros em grupos com o intuito promover a valorização do envelhecer e a discussão de questões referentes à longevidade. Considera-se que a abordagem de empoderamento pode fomentar a participação do idoso nas decisões de saúde e promover resultados positivos para a sua vida. Os autores (Leandro-França \& Murta, 2014) consideram também o impacto positivo de práticas desenvolvidas em Universidades de Terceira Idade. Este tipo de programa pode promover autoestima, resgatar a cidadania, incentivar a autonomia, o empoderamento e a busca de uma velhice bemsucedida (Veras \& Caldas, 2004).

A proposta de trazer a terceira idade para o contexto universitário teve origem na França, na década de 60, com a criação das Universidades do Tempo Livre, que tinham os propósitos de oferecerespaço para favorecer a relação entre os aposentados e forma de ocupar tempo livre, voltado à sociabilidade e atividades culturais (Cachioni\& Neri, 2004). Estas iniciativas foram precursoras das Universidades da Terceira Idade, que apareceram em 1973, por iniciativa de Pierre Vellas (1997, citado por Cachioni\&Neri, 2004), após ele ter verificado carência de programas voltados para os idosos. O modelo criado por Vellas se expandiu pelo mundo. No Brasil, a partir de 1990, foi criado inicialmente o programa Universidade da Terceira Idade da PUC-Campinas e depois outros programas foram implantados em vários estados brasileiros, tendo elescaracterísticas e abordagens que variam em conteúdo, maneira de apresentação e formato.

Além de promover a educação continuada e permitir que a aprendizagem se dê de modo contínuo, ou seja, ao longo de toda a vida do indivíduo, a UATI é também uma forma de respeitar a cidadania do idoso, uma vez que a educação também é um direito seu garantido no Estatuto do Idoso. A proposta de uma universidade que inclui os idosos baseia-se no conceito de educação permanente, que trata da educação e aprendizagem não como conjunto pontual de eventos institucionais, mas como um processo contínuo e cumulativo. Como objetivos da proposta de educação para a terceira idade, citase: aumento na qualidade de vida do idoso, promoção de saúde, participação e autonomia, além do 


\section{Desafios da psicologia no Brasil}

contato com oportunidades educacionais que possibilitem a promoção do desenvolvimento e uma maior inclusão social do idoso (Cachioni\& Neri, 2004).

Na Universidade Federal Triângulo Mineiro (UFTM), instituição pública situada na cidade de Uberaba/MG, o programa destinado ao idoso é denominado Universidade Aberta à Terceira Idade (UATI) e teve seu início no ano de 2009.Trata-se de uma atividade de extensão universitária que tem o objetivo geral de proporcionar o livre acesso do idoso à Universidade para a atualização do conhecimento, numa perspectiva de educação continuada, além de possibilitar inclusão, resgate da cidadania, promoção da saúde e desenvolvimento de convivência saudável.AUATI funciona anualmente, no período de março a dezembro e conta com a participação de discentes e docentes de vários cursos de graduação da UFTM. A programação das atividades da UATI é distribuída, organizada e executa pela comunidade acadêmica que integra o projeto. A participação da Psicologia teve início em 2010, sendo conduzida por três acadêmicas do curso de Psicologia, um psicólogo do Programa de Residência Multiprofissional em Saúde da UFTM e um discente da Psicologia. De um modo geral, a proposta desenvolvida visava a troca de informações e reflexões sobre o processo de envelhecer.

O foco do presente artigo é descrever a experiência dos acadêmicos da Psicologia no projeto UATI, buscando apontar os aspectos que favoreceram o processo de educação dos idosos e os benefícios desta experiência não apenaspara os idosos participantes, mas também para os executores da proposta. Cabe acrescentar que a UATI também tem por objetivo colocar os estudantes em contato com vivências a que eles não teriam acesso em outras circunstâncias, permitindo uma aprendizagem implícita a partir da experiência de vida de outras pessoas.

\section{A EDUCAÇÃO E O IDOSO}

De acordo com o Estatuto do idoso (Brasil, 2004), a pessoa idosa tem direito à educação respeitando as peculiaridades da sua condição de idade. O documento estabelece que o Poder Público deve criar oportunidades de acesso deste indivíduo à educação, considerando a necessidade de adequação de currículos, metodologias e material didático dos programas educacionais destinados ao idoso. Cabe também ao Poder Público apoiar a criação de universidade aberta para as pessoas idosas. $\mathrm{O}$ Estatuto demonstra que a educação é uma via importante de valorização do idoso como cidadão atuante e participativo, capaz de desenvolvimento de potencialidades.

A educação é apontada (Santos \& Sá, 2000; Neri, 2004) como um dos meios dos idosos vencerem os desafios impostos pela idade e pela sociedade, proporcionando-lhes o aprendizado de novos conhecimentos e oportunidades que favorecem seu bem estar. Para as autoras, a educação favorece 


\section{Desafios da psicologia no Brasil}

o fortalecimento da autoestima e da integração dos idosos na sociedade, procurando transpor as limitações e os preconceitos ligados a velhice. A educação do idoso sustenta-se na perspectiva de uma educação permanente que compreende que a educação do homem se faz ao longo da vida e que tem a finalidade de melhorar as competências e capacidades do indivíduo. A educação permanente para idosos vem sendo oferecida principalmente nas Universidades da Terceira Idade.

Para Oliveira (2008) os programas educacionais destinados aos idosos não devem assumir uma conotação meramente assistencialista ou de atividade de lazer, o que pode favorecer a concepção de velhice com uma etapa da vida marcada só de perdas, por não considerar e reconhecer a capacidade de aprendizagem do idoso. Por outro lado, quando a aprendizagem é o propósito destes programas, ressalta-se a perspectiva de aquisições do idoso e consequentemente seu desenvolvimento, além de aumentar a autoestima, favorecer uma imagem social mais positiva, aprimorar a capacidade crítica, a liberdade de expressão e participação social da pessoa idosa.

Confirmando a capacidade de ampliar as aquisições dos idosos, Vigueira (2005) observa que os idosos apresentam motivação para a reinserção em projetos educacionais. A autora enfatiza que os idosos estão mais disponíveis, devido a aposentadoria, por exemplo, e por isto tendem a se mostrar mais dispostos a aprender e motivados para desenvolver novas relações, tanto com outras pessoas como também com os conteúdos abordados. A autora acredita ainda que os idosos são capazes de retomar hábitos que se perderam com ritmo da vida adulta, tais como de leitura, escrita, reflexão e comunicação com pares.

De acordo com Valente (2001), muitas universidades oferecem programas educacionais para idosos que são organizados com aulas e conteúdos curriculares diversos e metodologias diferentes das propostas dos cursos tradicionais. Nos programas de educação voltados para os idosos, a ênfase não é a transmissão de informação e sim a discussão em grupo. Neste espaço grupal valoriza-se a diversidade de experiências e ideias, ao contrário da uniformização da formação; testes e provas são eliminados e não existe preocupação com certificação. Ainda sobre a relevância do dispositivo grupal no trabalho com idosos, Vigueira (2005) considera que esta estratégia é satisfatória ao processo de educação para o envelhecimento, pois o grupo possibilita ao idoso:

- O exercício introspectivo por meio do trabalho de reflexão que pode advir dos questionamentos do próprio grupo,

- O estabelecimento de projeto diários ou semanais, que podem ser compartilhados e realizados com outras pessoas do grupo,

- Espaço de escuta afetiva e solidária e 


\section{Desafios da psicologia no Brasil}

- O fortalecimento da identidade e aumento da autoestima do idoso

Portanto, o desafio é promover, pela via da educação o exercício da autonomia e uma melhor preparação para o processo de envelhecer que certamente passa pela valorização e resgate da imagem social do idoso.

\section{PERCURSO METODOLÓGICO: A PROPOSTA DESENVOLVIDA NA UATI}

De um modo geral, a proposta de trabalho da Psicologia consistia em abordar temas que o grupo de idosos considerasse relevante, a partir dos conhecimentos e contribuições do campo da Psicologia. Para isso, a proposta envolvia a realização de um encontro inicial com as turmas de idosos com a finalidade de apresentar os acadêmicos e o professor da Psicologia responsável pelo projeto e de levantar temáticas de interesse dos idosos a serem abordadas nos encontros. Com base nisto, os acadêmicos, sob supervisão do professor, realizavam uma breve revisão de alguns estudos na área da Psicogerontologia, segundo os temas foco e depois elaboravam os planos de aula que, em sua metodologia, deveriam envolver e valorizar a participação ativa dos idosos nas discussões, buscando incentivar a expressão de ideias e experiências de cada um.

A UATI da UFTM teve como público alvo idosos que se inscreveram espontaneamente no projeto. Em 2010, o projeto contou com a participação de 26 pessoas, sendo a maioria do sexo feminino e apenas dois idosos do sexo masculino. A idade dos participantes variou entre 60 e 76 anos, mas uma pessoa com 53 anos foi incluída. A inserção desta pessoa foi permitida porque ela acompanhava outra participante.O estado civil variou entre casados (13), viúvas (7), divorciados (2) e solteiros (4). Quanto a escolaridade, dezessete tem ensino médio, um idoso com ensino superior e oito com ensino fundamental incompleto.

Os participantes foram divididos em dois grupos e as atividades programadas adotaram metodologias semelhantes, conforme pode ser visualizado na Figura 1.

\begin{tabular}{|c|c|c|}
\hline & Grupo 1 & Grupo 2 \\
\hline Temas & Apresentação da & Apresentação da \\
& $\begin{array}{l}\text { Psicologia e escuta dos } \\
\text { temas sugeridos }\end{array}$ & $\begin{array}{l}\text { Psicologia e escuta dos } \\
\text { temas sugeridos }\end{array}$ \\
& Sono e insônia & Depressão \\
& & Ansiedade \\
\hline
\end{tabular}




\section{Desafios da psicologia no Brasil}

\begin{tabular}{|c|c|c|}
\hline & $\begin{array}{l}\text { Personalidade } \mathrm{e} \\
\text { autoestima } \\
\text { Ansiedade } \\
\text { angústia }\end{array}$ & $\begin{array}{c}\text { Tempo } \\
\text { envelhecimento }\end{array}$ \\
\hline $\begin{array}{l}\text { Estratégias } \\
\text { e recursos } \\
\text { utilizados }\end{array}$ & $\begin{array}{l}\text { Aulas expositivas } \\
\text { dialogadas, dinâmicas de } \\
\text { grupo, dramatizações, } \\
\text { construção de diário de } \\
\text { sono; data show e recursos } \\
\text { da literatura }\end{array}$ & $\begin{array}{l}\text { Aulas expositivas } \\
\text { dialogadas, dinâmicas de } \\
\text { grupo, dramatizações, } \\
\text { construção do relógio do } \\
\text { tempo de vida; data show e } \\
\text { livros de literatura }\end{array}$ \\
\hline
\end{tabular}

Figura 1. Distribuição dos temas e estratégias utilizadas na UATI

Com a primeira turma de idosos foram realizados 04 encontros. No primeiro, inicialmente, foi realizada uma dinâmica de apresentação com a finalidade de proporcionar maior integração dos participantes com os acadêmicos. Depois, promoveu-se um debate acerca do entendimento dos idosos sobre a Psicologia como área de conhecimento e de atuação profissional e o levantamento dos temas que eles gostariam de discutir nos próximos encontros. Os temas escolhidos: foram ansiedade e angústia, insônia e o sono, autoestima e personalidade.

No segundo encontro, a temática da insônia e qualidade de sono na velhice foi alvo de debate. Por meio de aula expositiva dialogada, discutiu-se que apesar da insônia ser uma das queixas mais frequentes entre os idosos é preciso considerar que existem alterações normais do sono em função da idade e que, por meio de condutas simples, a própria pessoa pode melhorar a qualidade do seu sono, evitando o uso de medicamento que induzem o sono. Ao final deste encontro, os idosos receberam um diário de sono e foram orientados a construir durante uma semana o registro diário da qualidade do sono deles. A finalidade era proporcionar que o próprio idoso fizesse uma avaliação mais cautelosa do seu sono e posteriormente pudesse refletir sobre o que ele poderia fazer para melhorar a qualidade do seu sono.

No terceiro encontro, os temas abordados foram personalidade e autoestima. Para refletir sobre a possibilidade de mudanças na personalidade relacionada à idade, as acadêmicas iniciaram o encontro com a apresentação de recortes de cenas de uma antiga novela assistida pela maioria dos integrantes da UATI chamada de "Mulheres de Areia". As cenas mostravam o embate de duas irmãs gêmeas que tinham personalidades muito distintas. Discutiu-se que não existe tipo de personalidade específico da 


\section{Desafios da psicologia no Brasil}

velhice e que, apesar da personalidade ser um traço consistente, ela pode variar durante a vida, em função da interação com o meio, das experiências vividas pelo indivíduo ou simplesmente, à medida que a pessoa vai amadurecendo.

No que diz respeito à autoestima do idoso, discutiu-se que a imagem pejorativa que a sociedade atual tem do idoso acaba interferindo na autoimagem e consequentemente na autoestima do idoso, aspecto ressaltado na fala de uma idosa que disse: nós não estamos preparados paralidar com a terceira idade, a nossa cultura não valoriza o idoso. Contudo, os idosos reconhecem também que a maior maturidade e experiência de vida favorecem a autoestima do idoso.

No quarto e último encontro com este grupo, que teve como temas ansiedade e angústia, foi realizada uma dramatização com a finalidade de refletir sobre a dimensão saudável da presença da ansiedade diante de situações que demandam atitude e até que ponto ela passa a ser patológica. Discutiu-se que a ansiedade e angústia são estados emocionais que as pessoas podem compreender a partir da própria experiência e que "não é a idade que traz a ansiedade, mas as modificações na vida" (fala de uma idosa). Sobre a angústia, trabalhou-se com poema Desencanto de Manuel Bandeira que possibilitou a reflexão sobre os destinos criativos a angústia.

Com o segundo grupo de participantes da UATI, foram realizados 05 encontros que aconteceram nos meses de outubro e novembro, e tiveram duração de 02 horas cada. As estratégias utilizadas no primeiro encontro, com o primeiro grupo, foram adotadas também para o segundo grupo. Entretanto os temas escolhidos foram depressão, ansiedade e a relação entre tempo e envelhecimento.

No segundo e terceiro encontros deste grupo foram abordadas as temáticas da depressão e ansiedade, respectivamente, por meio de aula expositiva dialogada. Buscou-se favorecer a expressão de ideias e sustentar o diálogo sobre a relação que os idosos estabelecem entre sofrimento psíquico e envelhecimento. Buscou-se refletir de modo a criticar a tendência de se associar a depressão ao idoso. Nesta discussão, os próprios idosos relataram que a velhice é marcada por situações de perda que implica num processo de elaboração e reconhecimento de uma tristeza, normal, que não deve ser precipitadamente chamada depressão patológica. Para favorecer a reflexão dos idosos sobre as situações de perdas e a possibilidade de sustentar novos e antigos projeto de vida foi apresentado recortes do filme "Up - altas aventuras", cujo enredo conta as aventuras de um idoso que perdeu sua esposa. Após a discussão do filme, os idosos descreverem seus planos e sonhos. A finalidade da tarefa era promover reflexão sobre a vida de cada um e depois compartilhar com o grupo. No terceiro encontro o tema da ansiedade foi trabalhado por meio de dramatização tal como descrito no encontro do primeiro grupo da UATI visando os mesmos objetivos já destacados anteriormente. 


\section{Desafios da psicologia no Brasil}

No quarto encontro, por meio da dinâmica que envolveu a construção de cada idoso de um relógio que retratasse o passado, o presente e o futuro, discutiu-se a perspectiva temporal do envelhecer, cujo processo se inscreve no tempo de vida. Depois de registro no relógio, os idosos compartilhavam com o grupo os momentos vividos e aqueles que ainda estão por vir. Diante de profundidade da experiência e da necessidade de mais tempo para acompanhar os relatos foi preciso marcar um quinto encontro para que todos pudessem compartilhar o seu relógio com o grupo.

Em fechamento às atividades da Psicologia na UATI, os idosos dos dois grupos avaliaram positivamente o trabalho realizado e consideraram que os encontros foram muito valiosos e possibilitaram enriquecimento e fortalecimento dos laços entre os idosos.

\section{BENEFÍCIOS DA EXPERIÊNCIA DA UATI PARA OS IDOSOS E PARA A FORMAÇÃO ACADÊMICA}

A realização deste projeto proporcionou benefícios tanto para os acadêmicos da Psicologia quanto para os idosos participantes. Quanto aos benefícios na formação acadêmica, é possível apontar que as discentes tiveram a oportunidade de um contato com área da Psicologia do Envelhecimento que não seria proporcionado pelas disciplinas ofertadas na graduação. De acordo com levantamento realizado por Souza, Espote, Silva e Couto (2010), no estado de Minas Gerais, são poucos os cursos de Psicologia que ofertam disciplinas específicas sobre envelhecimento e o idoso, ainda mais considerando que esta é uma temática emergente em Psicologia (Neri, 2004; Souza et al, 2010). Além disso, essa experiência proporcionou as discentes, aquisição de conhecimento mais completo da questão do envelhecimento, articulando teoria e prática. Durante as aulas, elas tiveram contato com os idosos e suas vivências, o que as levou muitas vezes a confrontar o que tinham visto em teoria, construindo um saber crítico acerca do envelhecimento. Sem essa prática, o conhecimento adquirido não estaria completo, pois como aponta por Goldfarb (2009), para compreender o envelhecimento é preciso voltar à teoria, mas para ser capaz de compreender a singularidade do processo de envelhecer, é preciso ouvir o outro.

Na experiênciacom os idosos, visões negativas da velhice e do idoso foram revisadas pelas acadêmicas. Comumente, os mais jovens costumam pensar queo idosotem poucas habilidade e capacidades, que ele está mais preocupado com questões de doença e morte, e que não está dispostoa realizar mais nada. O que foi visto na UATI é muito diferente disso, desde o momento da escolha dos temas. Antes do primeiro encontro, havia preocupação das discentes em saber como proceder se os temas escolhidos pelos idosos fossem todos voltados a condições patológicas. No entanto, para surpresa das acadêmicas, isso não ocorreu. Dos temas sugeridos, alguns, realmente,tem caráter patológico, como 


\section{Desafios da psicologia no Brasil}

depressão e ansiedade, mas outras escolhas remeteram para uma discussãomais voltada para preocupação com bem estar e qualidade de vida e aquisição de novos conhecimentos, como os temas autoestima e personalidade. Confrontada com a realidade observada, a informação veiculada pelo senso comum não se mostrou representativa, e o grupo pôde confirmar que envelhecer trata-se de uma vivência complexa e uma etapa do desenvolvimento que, como todas as outras, é marcada por perdas, mas também ganhos.

Frente às novas características da população, observáveis no Brasil e no mundo, há a necessidade de formar profissionais aptos a lidar com as demandas dessa nova população. Além disso, a questão da longevidade traz, muitas vezes, a questão da baixa qualidade de vida e da maior incidência de doenças crônicas, o que justifica a necessidade de trabalhar promoção de saúde para garantir uma maior qualidade de vida nos anos de sobrevida e também para evitar doenças crônicas que possam estar relacionadas a maus hábitos. A experiência na UATI permitiu a todo o grupo maior visibilidade a essas questões, fazendo com que tomassem para si a responsabilidade de pesquisar e difundir, tendo assim um papel ativo na disseminação dessas ideias que são indispensáveis na hora de se compreender o envelhecimento e as mudanças necessárias para se adequar às demandas da nova realidade populacional. O projeto também permitiu pensar a criação de um grupo de pesquisa sobre o envelhecimento, que tem se consolidado a partir da necessidade de entender melhor questões com que o grupo teve contato na UATI. Isso vai de encontro aos objetivos propostos por Pierre Vellas (citado por Neri, 2004) na constituição das primeiras Universidades de Terceira Idade, ao apontar que essas experiências viessem a tornar-se centros gerontológicos.

Para os idosos este projeto foi positivo, pois possibilitou aos mesmos a escolha dos temas que eles julgavam interessantes e que possibilitariam um maior conhecimento a eles em diversas áreas como a saúde mental, o bem estar, o processo de envelhecimento e suas características, entre outros. 0 projeto também possibilitou um maior convívio entre os idosos e o grupo da Psicologia, uma vasta troca de experiências entre todos os participantes, reflexões sobre a vida e um crescimento conjunto do grupo como um todo. Foi percebido também que o contexto educacional e de aprendizagem, possibilitou aos idosos superar alguns desafios e obstáculos impostos pela idade, através de novos conhecimentos e pela busca dos mesmos pelo próprio bem estar como visto por Santos e Sá (2000).

\section{CONSIDERAÇÕES FINAIS}

Considerando o que foi exposto, fica claro a importância e a necessidade do desenvolvimento na academia de projetos voltados para a população idosa para beneficiar a formação dos acadêmicos. 


\section{Desafios da psicologia no Brasil}

Questões relativas ao envelhecimento devem ser alvo de mais investimento,estudos e pesquisas de profissionais de diferentes áreas, já queo envelhecimento da população brasileira é fato incontestável e demanda esforços para promoção de envelhecimento ativo. Para que mudanças na compreensão da velhice e na abordagem ao idoso sejam efetivadas é necessário trabalhar a questão do envelhecimento ainda nos anos de graduação, colocando o aluno em contato com essa realidade e assim ajudando a formar profissionais mais aptos a lidar com o que será exigido dele futuramente.

Para as discentes que conduziram o projeto UATI, como disciplinas que contemplem especificamente o envelhecimento não foram ofertadas durante os anos de sua formação no curso de Psicologia da UFTM, foi a partir desta atividade de extensão que essa preparaçãofoi possível. Além disso, o projeto UATI, a um só momento, possibilitou o contato e a articulação da teoria e a prática, o que o permitiu não só aprender sobre o envelhecimento, mas compreender os diferentes discursos sobre o envelhecer construídos pelos idosos, o que demonstra que esse processo, longe de ser uma experiência homogênea, é vivido de forma única por cada indivíduo.

\section{REFERÊNCIAS}

Alves-Silva, J. D., Scorsolini-Comin, F., \& Santos, M. A. (2013). Idosos em instituições de longa permanência: Desenvolvimento, condições de vida e saúde. Psicologia: Reflexão e Crítica, 26(4), 820830.

Assis, M.; Hartz Z. M. A. \&Valla, V. V. (2004) Programa de promoção da saúde do idoso: uma revisão da literatura científica no período de 1990 a 2002. Ciência \& Saúde Coletiva, vol. 9, n. 3, 557-581.

Brasil. Estatuto do idoso (2004). Lei n.ㅇ 10.741, de 1ㅇ de outubro de 2003.

Bus, P. M. (2003). Uma introdução ao conceito de promoção da saúde. Em D. Czeresnia\& C. M. Freitas (Org.), Promoção da saúde: conceitos, reflexões, tendências (pp. 15-38). Rio de Janeiro: Fiocruz.

Cachioni, M. \& Neri, A. L. (2004). Educação e velhice bem sucedida no contexto das universidades da terceira idade. Em: Neri, A. L. \&Yassuda, M. S. (Orgs.). Velhice bem sucedida: aspectos afetivos e cognitivos. (pp. 29-49). Campinas, SP: Papirus.

Ferreira, H. G., \&Barham, E. J. (2011). O envolvimento de idosos em atividades prazerosas: Revisão da literatura sobre instrumentos de aferição. Revista Brasileira de Geriatria e Gerontologia, 14(3), 579590. doi: http://dx.doi.org/10.1590/S1809-98232011000300017

França, C. L., Murta, S. G., Negreiros, J. L., Pedralho, M., \&Carvalhedo, R. (2013). Intervenção breve na preparação para aposentadoria. Revista Brasileira de Orientação Profisional, 14(1), 99-110

Goldfarb, D. C. (2009). Envelhecimento e temporalidade: contribuições para uma clínica do envelhecimento. Em: Côrte, B., Goldfarb, D. C., \& Lopes, R. G. C. (Orgs). Psicogerontologia: fundamentos e práticas. (pp. 89-94). Curitiba: Juruá. 


\section{Desafios da psicologia no Brasil}

Leandro-França, C. \& Murta, S. G. (2014). Prevenção e promoção da saúde mental no envelhecimento: conceitos e intervenções. Psicologia:Ciência e Profissão, 34(2),318-329 https://doi.org/10.1590/19823703001152013

Neri, A. L. (2004). O que a psicologia tem a oferecer ao estudo e à intervenção no campo do envelhecimento no Brasil, hoje. Em: Neri,A. L. \&Yassuda, M. S. (Orgs.). Velhice bem sucedida: aspectos afetivos e cognitivos. (pp. 13-27). Campinas, SP: Papirus.

Oliveira, R. C. (2008). O tempo precioso da terceira idade: políticas públicas, cidadania e educação. Revista de Ciência da Educação- UNISAL - Americana/SP - Ano X - no 19, 17-52.

Organização Mundial da Saúde (OMS, 2005). Envelhecimento ativo: uma política de saúde. Brasília (DF): Organização Pan-Americana da Saúde

Pereira, A. A. S., Couto, V. V. D., \&Scorsolini-Comin, F. (2015). Motivações de idosos para participação no programa Universidade Aberta à Terceira Idade. Revista Brasileira de Orientação Profissional, 16, 2, 207-217

Ribeiro, C. C. C (2015). A Psicologia frente aos desafios do envelhecimento populacional. Gerais: Revista Interinstitucional de Psicologia, 8 (2), Edição Especial, dezembro, 269 - 283

Santos, A. T.; Sá, M. A. A. S. (2000). De volta as aulas: ensino e aprendizagem na terceira idade. Em: Neri, A. L. e Freire, S. A. (orgs.) Em: E por falar em boa velhice. Campinas, SP: Papirus.

Souza, D. C., Espote, R., Silva, M. S., \& Couto, V.V.D. (2010). A formação em psicologia no âmbito da saúde do idoso. Em: Anais da 3 a Semana Acadêmica da UFTM e 6a Jornada de Extensão Universitária, (pp. 34). Uberaba, MG: Universidade Federal do Triângulo Mineiro.

Teixeira, M. (2002). Empoderamento de idosos em grupos direcionados à promoção da saúde. Dissertação de mestrado. Curso de Pós-Graduação em Psicologia Clínica, Fiocruz, ENESP, Rio de Janeiro, RJ.

Valente, J. A. (2001). A aprendizagem continuada ao longo da vida. Em: Kachar, V. (org.). Longevidade: um novo desafio para a educação. São Paulo: Cortez Editora, 27- 44.

Veras, R. \& Caldas, C. P. (2001). Promovendo a saúde e a cidadania do idoso: o movimento das universidades da terceira idade. Ciência e Saúde Coletiva, vol. 9, n. 2, 423-432.

Veras, R. \& Caldas, C. (2004). Promovendo a saúde e a cidadania do idoso: o movimento das universidades da terceira idade. Ciência \& Saúde Coletiva, 9(2), 423-432. doi: http://dx.doi.org/10.1590/S1413-81232004000200018 


\section{Capítulo 50}

\section{PSICOLOGIA JURÍDICA E VIOLÊNCIA DOMÉSTICA: UMA EXPERIÊNCIA FORMATIVA}

DOI: $10.37423 / 200200286$

Jóice Macedo Vinhal (Graduada em Psicologia pela UFG - RC. Mestranda em Educação e cursando Especialização em Teoria e Técnica Psicanalítica pela UFG RC).joicemacedo_@hotmail.com.

Jerline da Siva Rocha (Graduada em Psicologia pela Universidade Federal de Goiás - Regional Catalão. rochajerline@gmail.com.

Italo Caique Grigorio Santos (Graduado em Psicologia pela UFG $-R C$ ) italogrigorio@gmajl.com

Carlos André Nunes topes (Formado em Psicologia pela UEG-RC. Mestrando em Educação e cursando Especialização em Teoria e Técnica Psicanalítica pela UFG RC).nuninslopes@hotmail.com.

Angela Maria Pereira (Graduado em Psicologia pela UFG RC).angelamariapsiufg@gmail.com.

Lucas de Moura Lima (Formado em Psicologia pela UFG - RC. Mestrapdo em Gestão Organizacional e cursando Especializaçáo em Neuropsicologia pelo Instituto).|lucasdemouralima@gmail.com.

Fernando César Paulino-Pereira (Professor adjunto da UFG-RC. Formado em Psicologia pela Universidade- Metodista delPiracicaba, mestre em Ciências da Religião pela Universidade Metodista de São Patto, doutor em-Psicologia-pela Pontificia bniversidade Católica de São Paulo).epifania.cps@gmail.com 


\section{Desafios da psicologia no Brasil}

\section{INTRODUÇÃO}

O presente estudo é produto da experiência do projeto de extensão intitulado "Situação de Violência Doméstica, a Psicologia na Justiça e estratégias de enfrentamento" vinculado ao departamento do curso de psicologia e à Liga Acadêmica de Psicologia Jurídica (Lapjur). O mesmo foi realizado durante o ano de 2017, na Delegacia de Atendimento Especializado à Mulher (DEAM), em um município do sudeste Goiano.

A Liga Acadêmica de Psicologia Jurídica foi um projeto criado buscando uma formação mais sólida no campo da Psicologia Jurídica, a partir de discussões iniciadas pelos próprios alunos do curso de Psicologia, de uma universidade federal do sudeste goiano.

Baseando no modelo utilizado frequentemente nos cursos das áreas médicas, a liga surgiu como forma de ampliar o contato dos discentes do curso com o campo jurídico, que nem contavam com uma disciplina na área de Psicologia Jurídica, na grade do curso. A proposta foi no sentido de refletir e potencializar a formação nas temáticas que perpassam esse campo psico-jurídico, de forma crítica e comprometida com a realidade social.

O projeto teve como objetivo a inserção dos serviços de Psicologia no âmbito da Delegacia de Atendimento Especializado à Mulher (DEAM), bem como realizar acolhimentos individuais focando no suporte psicológico no sistema de plantão psicológico. Todo o processo de execução do projeto se delineou pela perspectiva de Pesquisa-Ação, em constante processo de avaliação e reconstrução das ações, adequando à realidade dinâmica da instituição e da comunidade que ocorrem em três dias da semana.

A violência doméstica é um fenômeno complexo que atinge milhares de mulheres todos os anos, é um produto das relações de desigualdade de gênero, que estão imbricadas na estrutura do patriarcado, balizadas em pressupostos biologizantes. Envolvendo aspectos sociais, políticos, econômicos e históricos, bem como atinge a individualidade e a dinâmica das famílias (FARINHA; SOUZA, 2016).

Essa violência se apresenta historicamente enquanto um problema social com alta incidência de casos, que igualmente é banalizada socialmente. Desse modo, mesmo após o estabelecimento da Lei Maria da Penha de no 11.340, de 07 de agosto de 2006 (BRASIL, 2006) que visa coibir e prevenir a violência contra a mulher, seja ela de ordem física, moral, patrimonial ou psíquica, a violência permanece no cotidiano de milhares de indivíduos. 


\section{Desafios da psicologia no Brasil}

Com o estabelecimento desta lei, houve a criação e implantação de serviços como a Delegacia Especializada no Atendimento à Mulher (DEAMs), Serviço de Abrigamento Especializado (CasasAbrigo), de Centro Especializado de Atendimento à Mulher (CEAM) que servem de apoio e vias de enfrentamento ao que afirma o disposto no Art. 5 da Lei 11.340 de 2006 (p. 01), a violência doméstica é caracterizada como "qualquer ação ou omissão baseada no gênero que the cause morte, lesão, sofrimento físico, sexual ou psicológico e dano moral ou patrimonial".

Esse tipo de violência ocorre de forma sistêmica, atinge principalmente mulheres, é perpetrada predominantemente por homens e tem como loco de emergência as relações conjugais e familiares, e se constitui em violação dos direitos humanos e da dignidade dos sujeitos. Vale destacar ainda que, a violência doméstica, se estabelece como um desafio aos aparelhos de enfrentamento, principalmente devido aos fatores emocionais envolvidos, que se tornam grandes entraves para soluções puramente judiciais.

Dentro do projeto desenvolvido foram realizados acolhimentos individuais com as mulheres que procuraram a unidade da delegacia, essas eram convidadas a serem ouvidas pelos discentes integrantes do projeto (antes ou depois da coleta de depoimento). Enquanto proposta inicial, estabelecemos um número de atendimentos para cada mulher no âmbito da delegacia, e posteriormente buscava-se realizar o encaminhamento para atendimento nos serviços de saúde ou atendimento psicossocial disponíveis no município.

\section{METODOLOGIA}

A metodologia utilizada para a composição deste artigo consiste na sistematização da experiência e dos resultados do projeto desenvolvidos pelos integrantes da LAPJUR, alunos do curso de graduação em Psicologia, efetivado em uma Delegacia Especializada de Atendimento à Mulher (DEAM).

Têm-se na proposta deste projeto, um serviço de atendimento psicológico na Delegacia de Atendimento Especializado à Mulher (DEAM) de todos os tipos de violências. Desse modo, teve-se por início uma série de reflexões junto a instituição e aos profissionais que atuavam na mesma. A partir destes encontros laborais e elaborativos, construiu-se de modo coletivo um plano de trabalho pautado no atendimento tanto para os servidores e servidoras, quanto para as mulheres em situação de vítima, foco desse trabalho. 


\section{Desafios da psicologia no Brasil}

Neste último caso, foram realizados acolhimentos individuais no sistema de plantão psicológico, em que a mulher que procurava a unidade da delegacia era convidada para ser escutada pelos discentes integrantes do projeto (antes ou depois da coleta de depoimentos).

Os objetivos dos acolhimentos consistiram em prestar assistência psicológica, identificar fatores de risco e de proteção e agravos psicológicos, e auxiliá-las a elaborar recursos para o enfrentamento da situação de violência.

Todo o processo de execução do projeto se deu pela perspectiva de Pesquisa-Ação, em constante processo de avaliação e reconstrução das ações, adequando à realidade dinâmica da instituição e da comunidade. Semanalmente foram realizadas supervisões, estudos teóricos, elaboração de diários de campo e uma vez ao mês reunião com os gestores da instituição (TRIPP, 2005).

\section{ASPECTOS QUE TANGENCIAM A VIOLÊNCIA E O SERVIÇO DESENVOLVIDO}

Segundo os pressupostos apresentados por Sacramento e Rezende (2006) a violência se apresenta como um fenômeno multideterminado, complexo e que está presente em todos os setores da sociedade, assim o termo violência pode ser empregado tanto para falarmos de um homicídio, quanto para falar sobre maus tratos emocionais, psicológicos e verbais.

Muitos casos de violência estão ligados a relacionamentos amorosos, pessoas intimas e que vivem na mesma casa, e esses são os casos de violência doméstica, que estando tão arraigada na vida social de várias famílias ao longo dos anos, acabou passando de forma naturalizada até pouco tempo (SACRAMENTO; REZENDE, 2006).

Confirme aponta Morgado (2011), a violência doméstica contra as mulheres, apesar de se desenrolar em um campo relacional específico, não fica a ele limitado, indo além, relacionando-se com o contexto social, envolvendo a dinâmica sociocultural sobre ser homem e ser mulher.

Outro aspecto que dever observado é o ciclo de violência, como funcionam as relações, e como isto vai interferir diretamente na tomada de decisão da vítima. Morgado (2011, p. 260) aponta que "as relações de violência comportam, ao mesmo tempo, momentos de violência, sedução, afeto, presentes, arrependimentos, dentre outros". Neste sentido, a violência nem sempre está em primeiro plano na relação, pelo contrário, ela se entrelaça com circunstâncias de reconciliação, e isto pode ser considerado um dos fatores com que leva as vítimas estarem ligadas ao agressor, mesmo após verificarem que o que acontecem com elas são situações de violência e abuso. 


\section{Desafios da psicologia no Brasil}

Rosa et al (2008) analisando dados do World Health Organization (OMS) (2002) destacam que a violência doméstica apresenta um padrão de abuso continuo, o que a torna uma das principais ameaças para a saúde das mulheres, com graves consequências e diferentes dimensões, tais como: fraturas, luxações, depressão, ansiedade, dependência química e em casos mais extremos, desequilíbrios que podem levam ao suicídio. No entanto os autores defendem que embora haja um maior número de pesquisas sobre violência contra a mulher, ainda é difícil definir a real magnitude desse tipo de violência, já que a relação conjugal e o ambiente doméstico ainda são tidos como aspectos privados, o que acaba por banalizar um sério fenômeno social.

Para o Conselho Federal de Psicologia (2012) essa visão de que a violência contra a mulher é um fenômeno que deve se restringir ao campo do privado e que não pode ser divulgado publicamente, traz elementos dos primórdios da organização social humana, na qual a mulher estava restrita ao espaço do lar ocupando apenas o papel de mãe e esposa.

Assim, as mulheres não dispondo de meios para minimamente identificarem a agressão como tal, se tornaram vítimas de processos históricos de exclusão social, discriminação e violência dentro de suas casas, de forma que para muitas, a violência é um componente da história de vida, sendo essas, violentadas desde a infância por figuras masculinas, que mais tarde serão reeditadas pelo companheiro (CPF, 2012).

A Lei Maria da Penha estabelece uma tipificação do fenômeno de violência, dentre ela está: violência física, psicológica ou emocional, moral, patrimonial e sexual (BRASIL, 2006). E o que os dados cotidianos vem apontando é que estas violências não ocorrem de modo individualizado, configurando e se apresentando de forma combinada (HOEPERS; TOMANIK, 2019).

Ainda segundo o CFP (2012), a luta pela ampliação de direitos e a participação social das mulheres ganha força a partir de 1930, quando muitas delas passam a trabalhar fora do lar, buscando outros espaços de inserção social. No entanto essa maior exposição ampliou a violência contra a mulher do campo privado para o campo público, ou seja, se antes a mulher era agredida apenas pelo companheiro dentro de casa, agora ela passa a ser agredida por outros sujeitos, em outros espaços. Essa maior exposição aumenta também os conflitos no campo privado, já que os papeis ocupados por homens e mulheres, tão bem definidos anteriormente, agora são colocados em questão, sendo por muitos, encarado de forma violenta.

Dada a multicausalidade que envolve a violência contra a mulher, faz-se necessário então, um amplo conjunto de serviços que vão desde as intervenções no campo do terceiro setor, passando pela 


\section{Desafios da psicologia no Brasil}

assistência social e intervenções psicológicas, indo até as de competências da segurança pública. A criação das Delegacias Especializadas de Atendimentos à Mulher (DEAM) em 1985 na cidade de São Paulo se destaca como ação deste último campo como política pública de combate a violência.

O movimento de criação das DEAMs de acordo com a Norma Técnica de Padronização da Delegacias Especializadas de Atendimento às Mulheres (2010) foi motivado pela necessidade de resposta aos movimentos feministas que cobravam por uma ação mais efetiva por parte do estado em relação à violência contra as mulheres. Com a atribuição de investigar os crimes cometidos contra as mulheres pelo fato apenas de serem mulheres, a DEAM ganhou espaço, aumentando em número e importância na política para enfrentar esse tipo de violência.

O Conselho Federal de Psicologia (2012) pontua que outros fatores primordiais no enfrentamento a violência contra a mulher foi a visibilidade dada para o assunto ao caracterizar como agressão situações que antes eram tidas como naturais na vida íntima, assim como o aumento da escolaridade das mulheres, campanhas publicitárias dentre outras. Ou seja, estando as mulheres mais instruídas, passam a ter mais condições para denunciar os autores de violência, buscando ajuda nos serviços especializados públicos e privados.

De acordo com a Norma Técnica de Padronização da Delegacias Especializadas de Atendimento às Mulheres (2010) é na DEAM que se busca o primeiro acolhimento para queixas e denúncias, sendo essa caracterizada como:

Equipamentos vinculados às secretarias estaduais de Segurança Pública, às quais integram a Política Nacional de Prevenção, Enfrentamento e Erradicação da Violência contra a Mulher e representam uma resposta do Estado brasileiro à violência contra as mulheres e, nesse contexto, o compromisso dos Estados na implementação da presente norma técnica é essencial para que esta política possa efetiva e eficazmente ser executada, gerando-se mecanismos de monitoramento sistemático de ações por meio da produção de dados comparáveis ou equivalentes que possam ser analisados dentro de cenários locais, regionais e nacionais (p. 27).

As DEAMs foram reestruturadas, reorganizadas e expandidas no território nacional posteriormente pela Lei 11.340/2006 (lei Maria da Penha), que também é considerada como um marco na proteção dos direitos humanos das mulheres ao reconhecer a violência contra a mulher como uma violação dos direitos humanos, estabelecendo medidas para sua proteção, assistência, punição e possibilidade de reeducação para os agressores. 


\section{Desafios da psicologia no Brasil}

Contudo, estudos posteriores a esse período apontaram para um cenário em que suas ações foram caracterizadas como deficientes e de baixa resolubilidade. Em vários aspectos esse cenário é sustentado pelo sucateamento dessas instituições, tanto de recursos materiais quanto humanos (DATASENADO, 2016).

Uma pesquisa realizada pelo Datasenado (2016), apresentam dados que evidenciam a necessidade de se pensar o apoio e capacitação da equipe de servidores. Principalmente no que diz respeito ao treinamento dos agentes para atendimento específico de mulheres vítimas de violência, com destaque para o Centro-Oeste, que obteve o maior percentual de todo país de agentes que mencionaram não ter recebido esse tipo de treinamento (54\%), de acordo com 54\% dos entrevistadas nessa região, a unidade que trabalham não é suficiente para atender a demanda local e 70\% apontam que a falta de pessoal é o que mais dificulta o atendimento às mulheres em situação de violência. Isso contribui para o desgaste dos servidores que repercute diretamente no atendimento a comunidade, em especial, na atenção e proteção fornecida a mulher vítima de violência.

Mas porque desenvolver o Plantão Psicológico (PP)? O plantão psicológico se caracteriza como o um momento que os indivíduos que ofertam o serviço estejam disponíveis para atender as demandas de acordo com que ela surja na instituição (FARINHA; SOUZA, 2016). Como aponta Mahfoud (2012), seria então necessária uma disponibilidade para lidar com o não planejado. Ou seja, requer realizar um atendimento no momento exato de sua necessidade (TASSINARI, 2009).

Conforme Farinha e Souza (2016), o profissional necessita a partir de uma escuta qualificada, ser acessível do ponto de vista afetivos e temporal, dando foca à necessidade apresentada pelo sujeito, buscando propor intervenções.

De acordo com Braga et al (2012), é de suma importância a escuta profissional pois por meio dela é possível observar a postura de respeito e receptividade frente às questões apresentadas pelos sujeitos. Assim, a escuta neste contexto, não se refere a uma escuta passiva por parte do psicólogo, pois é por meio de novos diálogos (questionamentos e apontamentos) que está a possibilidade de construção de novos sentidos para as situações vivenciadas, contribuindo para minimizar o sofrimento apresentado pelo sujeito.

Mas como Souza e Souza (2011) ressaltam, o PP não pode ser compreendido como um recurso autônomo que independe da demanda da população ou dos serviços que estão disponíveis para utilização. Assim, tem-se a ideia de que com o plantão é possível criar uma aproximação entre a Psicologia e demais serviços de saúde, a saber a educação, assistência social e jurídica. 


\section{Desafios da psicologia no Brasil}

\section{CONSIDERAÇÕES FINAIS}

A partir do contato com a instituição, e com a realização dos atendimentos foi possível perceber, de modo geral, que as mulheres vítimas de violência doméstica apresentam condições de sofrimento psíquico atrelados aos eventos de violência, e comumente sentiam medo em realizar o procedimento de registrar o boletim de ocorrência. Sendo a tentativa de retirada do processo uma questão que tinha muita reincidência na instituição.

Os motivos que sustentam esse temor estão relacionados à: coerção do autor da violência; exposição; necessidade da apresentação de provas para abrir inquérito; desejos ambíguos em relação às medias a serem tomadas em sua proteção e contra o autor da violência; conviç̧ão de ineficácia das ações legais e falta de rede de apoio (ex: inexistência de Casa Abrigo, Centro de Referência de Atendimento à Mulher e articulação com a Rede de Atenção Psicossocial (RAPS), que são asseguradas por lei, no município); notou-se também que há uma naturalização da violência por parte dos profissionais, por vezes associadas a uma concepção de inutilidade de seus serviços uma vez que, grande parte das mulheres, abrem os procedimentos e depois desistem. Porém, não devemos deixar de ressaltar que o suporte, a escuta e as orientações às vítimas que procuram o serviço deveria ser um espaço que proporcione acolhimento, e esclareça dúvidas, buscando entender a situação ocorrida, sem tentar cupabilizá-las.

Observou-se que os acolhimentos psicológicos na DEAM contribuem com a oferta de um espaço para a (re)organização psíquica, além de contribuir para mitigarem os prejuízos da ausência de uma rede de suporte para mulheres em situação de violência, contudo não são suficientes para dar todo o apoio psicossocial e jurídico que precisam.

Nota-se nesse aspecto um distanciamento quanto às Políticas Públicas, em especial aquelas de normatização das DEAM's, que preveem a criação das redes de apoio associados as delegacias.

Com este projeto, buscou-se oferecer um espaço de promoção dos direitos da população em contexto de violência, bem como um lócus de formação profissional para os estudantes.

Por fim, indica-se que o acolhimento das mulheres vítimas de violência doméstica é de suma importância para a atenção e suporte, no sentido de fortalecê-la para sair da situação de violência. Além disso, a mulher ainda está sujeita a morosidade do sistema legal, fato este que não acompanha os desejos e necessidades desta mulher em relação a sua segurança física, moral e emocional. 


\section{Desafios da psicologia no Brasil}

\section{REFERÊNCIAS}

BRAGA, T. B. M.; MOSQUEIRA, S. M.; MORATO, H. T. P. Cartografia clínica em plantão psicológico: investigação interventiva num projeto de atenção psicológica em distrito policial. Temas em Psicologia, v. 20, n. 2, p. 555-570, 2012.

BRASIL. Lei N. ${ }^{\circ} 11.340$, de 7 de Agosto de 2006. Cria mecanismos para coibir a violência doméstica e familiar contra a mulher, nos termos do $\S 8$ 으 do art. 226 da Constituição Federal, da Convenção sobre a Eliminação de Todas as Formas de Discriminação contra as Mulheres e da Convenção Interamericana para Prevenir, Punir e Erradicar a Violência contra a Mulher; dispõe sobre a criação dos Juizados de Violência Doméstica e Familiar contra a Mulher; altera o Código de Processo Penal, o Código Penal e a Lei de Execução Penal; e dá outras providências. Presidência da República. Brasília, 2006, p. 1-12. Disponível em: < http://www.planalto.gov.br/ccivil_03/_ato2004-2006/2006/lei//11340.htm>. Acesso em: Mar. 2018.

BRASIL. Norma Técnica de Padronização das Delegacias Especializadas de Atendimento Às Mulheres (Deams). Edição Atualizada, 2010. Secretaria de Políticas para as Mulheres/Presidência da República Secretaria Nacional de Segurança Pública/Ministério da Justiça UNODC - Escritório das Nações Unidas sobre Drogas e Crime. Brasília, 2010.

CONSELHO FEDERAL DE PSICOLOGIA. Referências técnicas para atuação de psicólogas (os) em Programas de Atenção à Mulher em situação de Violência. Conselho Federal de Psicologia. Brasília: CFP, 2012. 82 p. ISBN: 978-85-89208-58-1.

DATASENADO. SENADO NOTICIA. Pesquisa do DataSenado revela falta de pessoal como problema em delegacias da mulher; 2016. Disponivel

em: < https://www12.senado.leg.br/noticias/materias/2016/12/26/pesquisa-do-datasenado-revelafalta-de-pessoal-como-problema-em-delegacias-da-mulher > Acesso em: 17/08/2017.

FARINHA, M. G.; SOUZA, T. M. C. Plantão Psicológico Na Delegacia Da Mulher: Experiência De Atendimento Sócio-Clínico. Revista da SPAGESP, v. 17, n. 1, p. 65-79. 2016.

HOEPERS, A. D.; TOMANIK, E. A. (Co)Construindo Sentidos: O Grupo Como Dispositivo de Enfrentamento À Violência Doméstica Contra as Mulheres. Psicol. Soc., Belo Horizonte, v. 31, Set. 2019.

MAHFOUD, M. (Org.). Plantão psicológico: novos horizontes. São Paulo: Companhia llimitada. 2012.

MORGADO, R. Mulheres em situação de violência doméstica: limites e possibilidades de enfrentamento. In: GONÇALVES, H. S.; BRANDÃO, E. P. (Orgs.) Psicologia Jurídica no Brasil, Rio de Janeiro: Editora Nau, 3a ed., p. 253-282. 2011.

ROSA, A. G.; BOING, A. F.; BÜCHELE, F.; OLIVEIRA, W. F. de; COELHO, E. B. S. A Violência Conjugal Contra a Mulher a Partir da Ótica do Homem Autor da Violência. Saúde Soc. São Paulo, Vol.17, n.3, p.152-160, 2008.

SACRAMENTO, L. de T.; REZENDE, M. M. Violências: lembrando alguns conceitos. Aletheia, n.24, p.95104, jul./dez. 2006. 


\section{Desafios da psicologia no Brasil}

SOUZA, B. N.; SOUZA, A. M. Plantão psicológico no HUBFS: uma experiência de assistência à comunidade. Revista NUFEN, v. 3, n. 1, p. 200-209, 2011.

TASSINARI, M. A. Plantão Psicológico como promoção de saúde. In A. Bacelar (Org.). A psicologia humanista na prática: reflexões sobre a Abordagem Centrada na Pessoa. Palhoça: EdUNISUL, pp. 185201, 2009.

TRIPP. D. Pesquisa-ação: uma introdução metodológica. Educação e Pesquisa, São Paulo, Vol. 31, n. 3, p. 443-466, set./dez. 2005. 


\section{Capítulo 51}

\section{CAPITAL HUMANO E INOVAÇÃO: IMPACTOS DA SAÚDE MENTAL NO DESEMPENHO DAS ORGANIZAÇÕES}

DOI: $10.37423 / 200200296$

SIL VEIRA, Marco Antonio (CTI Renato Archer)

CAMPOS, Priscilla Perla Tartarotti von Zuben (CTI Renato Archer, e USF)

KIKUCHI , Leticia Sayuri (CTI Renato Archer)

LIMA, Adiléia Souza, (CTI Renato Archer)

LUZ, Lais Oliveira, (CTL Renato Archer)

ResumQ: O capital humàno constitui-se em elemento/estratégico e fundamental para os vários fatores̀ que determinam o nível de competitividade das empresas, em èspecial, daquelas intensivas em tecnologia. A cognição humana é dotada de particularidades, as organizações visam utilizá-las na busca de uma melhoriad contínua do trabalhador e, consequentemente, dos seus resultados na empresa. Considerando-se que os processos de-geração de ideias, socialização e incorporação de conhecimento dependem do elemento humano, pode-se entender que este é a chave do súcesso para a geração de novas conceitos de u ma òrganização, afetando, positiva ou negativamente a capacidade de inovação organizacional e consequentemente na geração de riqựeza continula. Apesar disso, subjuga-se, até por desconhecimento, os impactos negativos dos fatores psicossociais na força de trabalho provocados por modelos organizacionais equivocaldos, os quais vêm cobrando um alto preço das indústrias-brasileiras na forma de-perda de produtividade, da qualidade e da-capacidade de inovação! 


\section{Desafios da psicologia no Brasil}

Atualmente há novas e diferentes formas de organização, formas que intensificam as relações interpessoais nas atividades laborais pela busca de uma evolução que signifique uma maior inovação tecnológica e/ou sócio-organizacional, além do aumento de competitividade perante um cenário globalizado. A fim de compreender melhor os impactos da saúde mental no desempenho das organizações, o presente artigo, por meio de uma pesquisa exploratória e seus resultados preliminares visa estudar as relações entre organização do trabalho, inovação e capital humano. Esta pesquisa faz parte de um estudo mais amplo sobre como os fatores organizacionais e humanos interagem entre si. Neste estudo, foram realizadas entrevistas semiestruturadas com profissionais da área de saúde mental. Os resultados preliminares apontam para algumas divergências entre os profissionais entrevistados pertencentes a diferentes linhas teóricas da psicologia e da psiquiatria, existindo convergência em relação à influência da organização nas condições de saúde mental, tendo em vista a importância do trabalho para o indivíduo enquanto um fator de equilíbrio, desenvolvimento e como um importante espaço de socialização.

Palavras-chave: capital humano. Inovação organizacional. Saúde mental 


\section{Desafios da psicologia no Brasil}

\section{INTRODUÇÃO}

Capital humano e inovação são dois temas amplamente discutidos tanto no meio acadêmico quanto no meio organizacional, visto que o investimento no capital humano tende a resultar em novas tecnologias, sistemas e serviços. Segundo Drucker (1997), o principal recurso de capital, o investimento fundamental e o centro de custos de uma economia desenvolvida é o trabalhado intelectual.

Contudo, pouco se tem discutido sobre os impactos dos elementos psicossociais nos indivíduos que compõem as organizações de trabalho, acreditando-se, portanto, ser fundamental que mais estudos busquem compreender e analisar tais disfunções organizacionais. Neste sentido, o presente artigo retrata um estudo realizado por meio de entrevistas com profissionais da área da saúde mental, para compreender aspectos importantes das relações entre organização do trabalho, inovação e capital humano, bem como os impactos causados no desempenho organizacional e nos trabalhadores.

A discussão aqui proposta se justifica especialmente neste momento histórico em que os mercados atuais impõem novos e maiores desafios às organizações, em especial as empresariais, cuja superação deve considerar não só os impactos das suas atividades no meio ambiente físico, como na qualidade de vida e na saúde física e mental dos seus trabalhadores. Esse desejado alinhamento das empresas ao fundamento da sustentabilidade organizacional, qual seja, harmonizar interesses econômicos, sociais e ambientais, é um imperativo atual devido aos graves prejuízos sociais e ambientais decorrentes das externalidades negativas associadas às atividades empresariais tanto na degradação dos recursos naturais e do meio ambiente físico, como na saúde física e mental dos trabalhadores.

As organizações na atualidade, por força da globalização e pela ênfase no uso da tecnologia da informática, imprimem nova fisionomia ao mundo do trabalho, buscando soluções mais imediatas e inéditas. Neste ínterim, o tipo de trabalho e o ritmo imposto por ele não deixam muito tempo para o individuo dar-se a atenção merecida. Embora os indivíduos reajam diferentemente a situações difíceis, Bergamini e Tassinari (2008) alertam quanto a consequências futuras, tanto de ordem física como psicológica, não saudáveis e quando isto ocorre, muitas dessas organizações acabam por desaparecer.

Torna-se necessário, assim, estar atento às razões que determinam este estado perigoso à sobrevivência organizacional e buscar medidas adequadas a fim de reverter tal situação. Tais exigências embatem de modo positivo e/ou negativo na saúde não apenas física, como mental dos 


\section{Desafios da psicologia no Brasil}

indivíduos, acreditando-se portanto, ser primordial compreender este fenômeno a fim de buscar-se estratégias adequadas para que ocorra a promoção de ações preventivas e não paliativas, e assim, corroborar para que a sustentabilidade organizacional ocorra de fato.

Deste modo, este artigo tem o objetivo de apresentar os resultados de um estudo conduzido com profissionais que atuam na área de saúde mental, de modo a identificar suas visões a respeito dos impactos da organização do trabalho nos trabalhadores, tendo em vista a importância da sua saúde mental na geração de capital humano. A seguir, serão apresentados serão apontadas analises de questões investigadas concomitantemente ao embasamento teórico a ela relacionada.

\section{OBJETIVO}

\subsection{DESEMPENHO COMPETITIVO: INOVAÇÃO E CAPITAL INTELECTUAL NAS EMPRESAS}

O processo de retomada do crescimento econômico no Brasil, após quase duas décadas consideradas perdidas, tem sido pautado pela busca de fortalecimento do parque industrial nacional e sua inserção competitiva nos mercados internacionais.

Sendo as organizações sistemas complexos e em contínua interação com o seu ambiente externo, mudam rápida e incessantemente, é neste contexto, faz-se fundamental que modificações internas apropriadas sejam constantemente implantadas. (Tidd; Bessant; Pavitt, 1997). Torna-se desejável que as contínuas inovações estejam integradas ao longo de toda a estrutura organizacional, sob pena de não serem internalizadas com a agilidade e a organicidade requeridas.

Na relação empresa-trabalhador, entende-se o capital intelectual como um ativo econômico e, assim, o capital humano passa a ser reconhecido como um recurso estratégico fundamental para o sucesso das organizações nos ambientes atuais. E na medida que o conhecimento é aceito como um recurso econômico questiona-se como mensurá-lo, já que esse ativo proporcionará ao seu possuidor a geração de benefícios futuros, que alterarão o patrimônio das organizações.

Santos et al (2008), argumentam que a capacidade de adaptação das empresas às mudanças esta mais diretamente relacionada com a administração dos recursos intelectuais do que com a coordenação do esforço físico dos funcionários envolvidos com a produção, manuseando os ativos tangíveis, considerando que a própria automação, produto do conhecimento humano, dispensa essa tarefa, e 


\section{Desafios da psicologia no Brasil}

deste modo, o que agrega mais ou menos valor ao produto é o intelecto decorrente do quadro de funcionários, resultando daí os ganhos ou perdas das organizações.

Contudo, embora se indague como mensurar tal valor, de acordo com Mayo (2003), as pessoas não podem ser avaliadas segundo os princípios financeiros tradicionais, por se tratarem de ativos intangíveis. Sendo que este aspecto vem mudando progressivamente desde 1990, quando se passou a atribuir um valor muito mais alto aos "ativos intangíveis" tais como conhecimento, competência, marcas e sistemas. Almeida (2008) salienta a importância do capital intelectual para a inovação, visto que, para inovar é preciso que as ideias que otimizam, agregam valor e integram indivíduos e empresas sejam implantadas.

Emerge a necessidade das empresas reconhecem o ativo intangível na sua produção de forma efetiva. A inovação torna-se condição fundamental para o sucesso das organizações no mercado atual, o qual muda continuamente e exige níveis de desempenho sucessivamente melhores. $E$, a gestão competente do capital humano é o fator que alavanca a inovação de produtos, de processos, de serviços e de outros aspectos de interesse para uma organização empresarial.

\subsection{APRENDIZAGEM ORGANIZACIONAL E ENRIQUECIMENTO COGNITIVO DO TRABALHO}

A inovação não acontece por acaso: é preciso ter um sistema que crie uma cultura organizacional adequada, busque a melhoria contínua, reconheça os bons colaboradores, aproveite oportunidades integradas com outras organizações (como nos mecanismos de "open innovation") e cuide da inovação disruptiva.

Portanto, existe uma relação causal entre inovação e aprendizagem, sendo esta influenciada tanto por fatores organizacionais e tecnológicos, pertencentes à dimensão objetiva da organização, como por fatores sociológicos e psicológicos inerentes à subjetividade humana. Disso decorre a importância de o desenho organizacional considerar as organizações como entidades sociais, tal como expressa Daft (2002) e, portanto, sujeitas à influência dos fatores psicossociais que afetam o trabalho em suas dimensões social e subjetiva (LANCMAN e DEJOURS, 2011).

Essas considerações reforçam a visão do capital humano como um recurso estratégico da maior importância em, virtualmente, todos os aspectos da organização, sendo ainda mais crítico naqueles processos cuja dependência do conhecimento é maior, como naqueles relacionados diretamente com os fenômenos da aprendizagem e da inovação. 


\section{Desafios da psicologia no Brasil}

O corolário dessas reflexões é que "saber aprender" é uma competência estratégica fundamental para as organizações atuais. Vários autores frisam isso, sendo Senge (1996), um dos mais conhecidos por cunhar a expressão learning organizations. A capacidade de aprender concede à organização alcançar e manter um desempenho superior e, portanto, de acordo com Boyett e Boyett (1999), permite desenvolver vantagens competitivas sustentáveis ao longo do tempo, proporcionando maiores condições para melhorar qualidade, gerar inovação, gerenciar mudanças, criar uma força de trabalho comprometida e energizada, superar os limites aparentes, melhorar o ambiente, aumentar o prazer no trabalho, aprimorar a qualidade de vida, entre outras razões.

\subsection{RELAÇÕES COOPERATIVAS NA PROMOÇÃO DO BEM ESTAR SOCIAL E DA INOVAÇÃO}

Numa perspectiva de recursos organizacionais, o trabalhador pode ser pensado como uma fonte de capital humano. Essa capacidade dependerá das suas capacidades intrínsecas e, também, do seu nível de integração (ou alinhamento) com os valores e interesses predominantes na organização. Caso o trabalhador não compartilhe dos propósitos organizacionais, seus interesses irão divergir dos interesses dos demais indivíduos e, neste caso, na melhor das hipóteses, ele se manterá alheio às necessidades da organização, podendo chegar ao extremo de trabalhar contra os objetivos comuns da organização, inclusive, de forma inconsciente. Por essa razão, Gardim e Corrales (2013), destacam que o desenvolvimento das relações cooperativas, assim como dos processos cognitivos dos indivíduos (capaz de aumentar seu potencial de aprendizado) no ambiente de trabalho, se mostra fundamental para uma efetiva sustentabilidade no âmbito das organizações.

Durante décadas, as premissas que norteavam o campo da ciência e tecnologia tinham como base a ideia de que inovação era um processo linear, no qual as fases de desenvolvimento/pesquisa, produção e comercialização de novas tecnologias constituíam uma sequência de processos bem definidos ao longo do tempo. No entanto, diversos autores como David; Foray (1995), Nonaka; Takeuchi (2006), revelaram que interações e feedbacks contínuos são características intrínsecas aos processos inovadores. A organização não pode criar conhecimento por si só, sem a participação ativa dos indivíduos e dos processos interativos que ocorrem dentro dos grupos. Tais processos de interação, no entanto, transpassam por uma infinidade de processos psicológicos, que em sua grande maioria vão além da fronteira do consciente de cada um.

Entendida como ação coletiva essencial para a integração da sociedade, a cooperação ainda é um conceito analisado sob diversos ângulos. Considerando as premissas que divergem dentro das 


\section{Desafios da psicologia no Brasil}

diferentes visões e autores, relações e processos cooperativos - principalmente no ambiente laboral frequentemente admitem a existência de "conflitos de interesses", mesmo com estudos/teorias preconizados em épocas distintas. Há um entendimento no campo dos estudos organizacionais que tanto características estruturais e culturais quanto psicológicas são fatores que influenciam o comportamento cooperativo.

Um contexto organizacional que favorece a criação do conhecimento, como um espaço compartilhado em movimento, favorece "as situações relacionais que energizam as pessoas, tornando-as criativas, dentro de uma interação positiva e dinâmica" e colabora com o comprometimento e cooperação do indivíduo no grupo (NONAKA E TAKEUCHI, 2006).

\subsection{ORGANIZAÇÃO SAUDÁVEL, DESENVOLVIMENTO SUSTENTÁVEL}

Pensar as organizações como instrumento de desenvolvimento socioeconômico requer olhar para a pluralidade de efeitos provocados por sua atuação, que não se restringem às questões ambientais. As perturbações no meio ambiente físico e a deterioração dos recursos naturais são os efeitos mais visíveis e contundentes de modelos industriais, econômicos e políticos contrários ao bem comum, que vêm sendo adotados em larga escala há séculos.

A relevância de estudos sobre os fatores presentes numa organização com maior potencial para promover simultaneamente a competitividade da organização e a qualidade de vida no trabalho, se deve ao fato de que o investimento em fatores que melhoram tanto os indicadores econômicofinanceiros como os indicadores humanos-sociais tendem a gerar o desejável desenvolvimento socioeconômico da organização.

Os resultados obtidos em vários estudos sinalizam fortemente no sentido da viabilidade de organizar os fatores organizacionais de modo tal que possam contribuir significativamente para o desenvolvimento sustentável da organização, melhorando de forma integrada o seu desempenho. Nessa perspectiva, os resultados disponíveis na literatura são bastante significativos, destacando-se que ações bem planejadas, como o desenvolvimento de um ambiente organizacional adequado, podem favorecer simultaneamente o desempenho competitivo da empresa e os seus trabalhadores.

Outro aspecto importante é o impacto positivo da promoção de mecanismos cooperativos, os quais possuem bom potencial para incrementar o desempenho da empresa em seus múltiplos aspectos. A grande maioria dos mecanismos para promoção da cooperação interna possui uma relação 


\section{Desafios da psicologia no Brasil}

custo/benefício bastante favorável para a empresa, uma vez que os custos para sua implantação são relativamente baixos quando comparados com os retornos potenciais para várias dimensões organizacionais. São exemplos desses mecanismos o estímulo ao trabalho envolvendo vários departamentos, a promoção de projetos multidisciplinares, o desenvolvimento de ambiente que contribua para o acolhimento e respeito aos trabalhadores e o reconhecimento ao desempenho em equipe (e não só ao desempenho individual).

Destaque-se também a importância de uma maior atenção das empresas para o desenvolvimento de tarefas que tenham um nível adequado de estímulo cognitivo aos trabalhadores, o que pode ser obtido também com soluções de custo muito baixo para a empresa.

Empresas que promovem a qualidade de vida no trabalho contribuem para integrar uma série de importantes benefícios para todas as partes interessadas, como ilustrado na Figura 1.

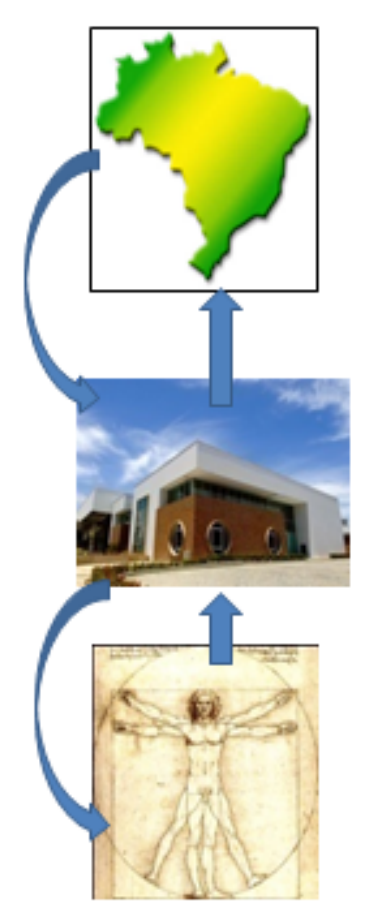

NIVEL NACIONAL (SOCIEDADE)

- SISTEMAS PÚBLICOS DE SAÚDE: redução de gastos públicos

- PREVIDÊNCIA SOCIAL: diminuição de afastamentos

- PLANO BRASIL MAIOR: Potencializar a capacidade de inovação / "Inovar para competir"

\section{NÍVEL ORGANIZACIONAL}

- EMPRESA: - ganhos significativos de desempenho - redução de passivos trabalhistas

\section{NIVEL INDIVIDUAL (FAMILIAR)}

- TRABALHADORES: qualidade de vida no trabalho, com saúde física e mental

FIGURA 1- Benefícios potenciais decorrentes da maior qualidade de vida e saúde no trabalho.

Empresas com uma maior valorização do funcionário, com investimentos na geração de conhecimento e a contínua busca de inovação tecnológica e organizacional possuem seu lugar à frente dos concorrentes na corrida da vantagem competitiva e na promoção de benefícios sociais. São essas as organizações promotoras do efetivo desenvolvimento socioeconômica, e que devem ser cada vez mais valorizadas pelas várias instâncias públicas e privadas de nossa sociedade. 


\section{Desafios da psicologia no Brasil}

\subsection{DIMENSÃO PSICOSSOCIAL DAS ORGANIZAÇÕES}

A dimensão psicossocial denota ser um tanto quanto desconhecida e, portanto, ignorada e negligenciada. Tal equivoco cobra um preço alto das organizações (na forma de desempenhos subótimos), dos seus trabalhadores (incluindo os gestores que também são submetidos a sofrimentos psíquicos e emocionais) e da sociedade como um todo, que arca com todos os ônus das mazelas socioeconômicas decorrentes dessa negligência.

É nessa dimensão que se enquadram os conhecimentos e as competências individuais, que são base do capital humano e do capital intelectual, importantes ativos econômicos no contexto da nova economia que se baseia muito na gestão competente da inovação.

A organização é um sistema social, onde todo trabalho é coletivo: o sentido que damos para as relações humanas irá afetar diretamente os resultados dos processos em termos de produtividade, qualidade, prazos, custos e outros indicadores. Assim, trabalhar por ambientes com bom clima organizacional, onde vicejam relações cooperativas é uma maneira bastante efetiva de conseguir também melhores resultados financeiros.

Segundo a OMS (Organização Mundial de Saúde ${ }^{1}$ ), "uma a cada quatro pessoas que procuram atendimento médico, sofrem de problemas ligados à saúde mental, que ocorrem porque o equilíbrio psíquico é danificado pelo meio em que vive ou trabalha e não pela própria estrutura emocional". Aliado a isto, cita-se Berlinguer (1983), apontando que a saúde é um problema de todo país e que cada um tem um dever a cumprir, para colocar um fim à demolição psicofísica daqueles que criam as riquezas do país e que estão sujeitos à pior exploração.

Entende-se assim, que a prevenção dos distúrbios psicológicos potencializa a saúde e a qualidade de vida dos funcionários, uma vez que o bem estar psicológico propicia maior estabilidade emocional, motivação, eficácia no trabalho, criatividade e inovação, bem como o aumento da auto-estima e sensibilidade aos objetivos da empresa, gerando maior produtividade, resultados e, consequentemente, o diferencial competitivo. Em contrapartida, o mal estar psicológico pode causar menor concentração e poder de decisão, diminuição da agilidade, queda de produtividade, acidentes, entre outros.

Situações tais como pressões constantes por aumento de produtividade e do nível de responsabilidade, acúmulo de funções, problemas de relacionamento com a chefia ou com grupo de 


\section{Desafios da psicologia no Brasil}

trabalho, más condições de trabalho, dentre outras, geram o sofrimento psíquico no trabalho, provocando doenças ocupacionais, como a gastrite, síndrome do pânico, alcoolismo, depressão, estresse, paranoia e drogadição.

\section{MÉTODO}

Em 2013 realizou-se uma pesquisa exploratória baseada em entrevistas semiestruturadas com profissionais da área de saúde mental. (SILVEIRA et ali, 2013). O intuito consistiu em ampliar o entendimento sobre as interações entre fatores psicossociais ligados à organização do trabalho e os trabalhadores, em especial, nas influências exercidas sobre a saúde mental, a capacidade de desempenho e a qualidade de vida no trabalho.

Foram realizadas entrevistas com doze profissionais da área de saúde mental por meio de um questionário semiestruturado, com perguntas abertas e fechadas. Seguindo a recomendação de vários autores, dentre eles Marconi e Lakatos (1999), realizou-se um pré-teste para evidenciar possíveis falhas nesse instrumento da pesquisa. Com este procedimento várias questões foram suprimidas, incluídas ou alteradas.

Quanto à população da pesquisa, de acordo com Minayo (1994) o critério não se refere ao número de pessoas envolvidas e entrevistas, mas sim quanto à possibilidade de reflexão da totalidade nas suas múltiplas dimensões. Os participantes foram escolhidos a partir de suas experiências e atitudes, pois estas irão refletir no escopo completo da questão estudada, tal como orientam Cooper e Shindler (2011).

Ademais, sendo a entrevista a técnica básica de coleta de dados em metodologia qualitativa, reconhece-se a importância de um entrevistador treinado e habilidoso. Neste sentido, foram utilizados alguns procedimentos padrões na realização das entrevistas. Antes de iniciar a aplicação do questionário explica-se aos entrevistados, a inquietação dos pesquisadores deste projeto no que se refere à compreensão quanto ao universo humano, afim de estimular e desenvolver-se modelos organizacionais que favoreçam a saúde mental, mantendo o bom desempenho da organização (sustentabilidade). Em seguida, que interessa investigar o trabalho no mundo organizacional.

As perguntas contidas no questionário abordavam os seguintes aspectos: a saúde mental do trabalhador, a organização do trabalho, a subjetividade do trabalhador e o seu desempenho 


\section{Desafios da psicologia no Brasil}

profissional. Além disso, continham questões sobre as características de personalidade do trabalhador como importância subjetiva da carreira profissional e sensibilidade às relações humanas.

Os respondentes foram questionados sobre a sua orientação teórica e abordagem científica através de questões como: o grau de influência de fatores genéticos, dos primeiros anos de vida, da história de vida e do ambiente social, na saúde mental (e nos transtornos mentais). Também foi importante saber o tipo de experiência profissional, se em clinica ou instituições de saúde, e o nível de formação acadêmica. Ao se realizar as análises, foi considerada a singularidade em cada resposta, bem com uma possível visão maculada da realidade, concomitante a uma observação ponderada a despeito de suas percepções e experiências, tanto de vida quanto de trabalho.

Dentre as questões envolvidas, este artigo prioriza perguntas que abarcam aspectos que relacionem a saúde do trabalhador e seus impactos em quesitos tais como, a exigência cognitiva, os impactos dos mecanismos de aprendizagem, o senso de pertencimento em equipe e o papel da liderança, os quais serão mais bem descritos a seguir.

\section{RESULTADOS E DISCUSSÃO}

Ao defrontar o indivíduo como produto e produtor da sociedade na qual se insere, pode ser possível detectar relações contraditórias entre os múltiplos sistemas existentes. Segundo Friedmann (1983 apud Kanaane, 2009), há de se considerar o papel que o trabalho desempenha para o indivíduo, atestando que a concepção de trabalho corresponde ao engajamento e às predisposições pessoais, diferentes das encontradas nas realizações de atividades coagidas, que são exercidas com o objetivo de atingir um fim prático.

O trabalho para Friedmann significa um fator de equilíbrio e de desenvolvimento para o indivíduo, que Ihe assegura a inserção no real, em termos dos diferentes grupos existentes na sociedade, pois de certa forma, ao sentir-se participante de um processo de trabalho, o indivíduo tende a responsabilizarse pelo mesmo. Tal participação proporciona-Ihe consciência mais ampla de si mesmo e dos meios de produção e possibilita-lhe desenvolver sua liberdade de opção diante do contexto de trabalho e, por extensão, da sociedade de maneira geral.

Durante as investigações realizadas nesta pesquisa, o posicionamento acima descrito, foi identificado através das respostas obtidas pelos entrevistados. Para melhor compreensão do assunto tratado, serão analisadas e apresentadas a seguir, quatro das quatorze questões levantadas no instrumento. 


\section{Desafios da psicologia no Brasil}

Dentre os apontamentos levantados, um deles refere-se ao sofrimento psíquico no trabalho e neste âmbito, busca-se maior compreensão sobre como o prazer com o trabalho atua sobre a saúde mental, independente de fatores externos, o que inclui a predisposição para as tarefas a serem executadas e outros fatores associados. Autores como Dejours (2003), atribuem uma grande importância ao prazer no trabalho, ou ao menos ao "não sofrimento", como fator de saúde e de externalização do potencial criativo do trabalhador, o que afeta positivamente a capacidade de inovação da empresa. Os entrevistados apontam a importância do equilíbrio para o exercício das atividades laborais, de modo que, a exigência cognitiva imposta por metas e tarefas precisa acontecer de modo harmonioso, levando em consideração as características individuais a fim de que a saúde ocupacional seja promovida, e não o oposto.

Os participantes da pesquisa também sinalizam a existência de situações que geram prazer e sofrimento, sendo necessário que este último passe por intervenções para que seja minimizado, com vistas a potencializar as vivências de prazer. Neste âmbito, estimular a visão sistêmica pode trazer benefícios ao processo, de modo a incitar o indivíduo a pensar sobre assuntos pertinentes às suas tarefas e compreender como estas se integram aos demais processos, em oposição a um trabalho mecânico ou repetitivo. Cabe acrescentar Senge (1999 apud Zanelli, 2011), ao considerar que muitas atividades estejam atingindo um nível de especialização ímpar na história da humanidade, a percepção integrada do conjunto, por meio do desenvolvimento do pensamento sistêmico, e a capacidade de interagir, tornando produtivo o trabalho em equipe, muitas vezes implica na própria manutenção e na sobrevivência da organização.

Outro aspecto relevante na pesquisa se refere à aprendizagem organizacional como fonte de conhecimento para a obtenção de vantagem competitiva, em que algumas organizações promovem a cultura de aprendizagem contínua, visto que na Sociedade do Conhecimento, as mudanças e as inovações tecnológicas ocorrem em um ritmo tão acelerado que, além dos fatores tradicionais de produção, é fundamental identificar e gerir o conhecimento das pessoas nas organizações. Para responder esta questão, investigou-se entre os participantes da pesquisa quais são os impactos dos mecanismos de aprendizagem na saúde mental. Dentre as respostas obtidas, pôde-se interpretar que, embora a aprendizagem seja benéfica, (pois quando a informação é usada de maneira positiva, o indivíduo se forma, se educa, transforma a realidade e gera inovação, emancipando-se pelo conhecimento), quando usada como símbolo de escravidão, leva ao conflito e consequentemente ao sofrimento mental e desgaste, em especial quando relacionada à empregabilidade do individuo. 


\section{Desafios da psicologia no Brasil}

Percebe-se o desafio ao qual se expõe tal aspecto, sendo este complexo e de longa duração. Mediante a aceitação do conhecimento como recurso econômico, faz-se necessário identificar formar para valorizar o ser humano, enquanto responsável pela disseminação do conhecimento, bem como buscar meios para retê-lo na organização, afinal, esse valor será parte integrante da geração de benefícios futuros.

Objetivando alcançar maior compreensão quanto ao sentimento de pertença nas organizações e sua influência na saúde mental, de modo a identificar quais são os transtornos acarretados quando acontece de modo desfavorável, tal questionamento foi abordado entre os entrevistados. O resultado obtido revelou um consenso no que tange ao fato de que o sentimento de pertencer à organização impacta de forma positiva a saúde do trabalhador, isto é, quando sente que faz parte, o indivíduo transforma de modo positivo o trabalho, no entanto, do contrario, este pode até chegar a adoecer. De acordo com os profissionais entrevistados, pertencer a um grupo exige responsabilidade, comprometimento, bom relacionamento, flexibilidade, sendo necessário conhecer cada um do grupo e saber lidar com os conflitos, com as diferenças e metas estabelecidas. O sentimento de pertença a uma equipe tende a diminuir os impactos negativos da carga imposta, criar apoios coletivos, bem como diminuir patologias da solidão.

Entende-se que, no contexto organizacional ocorrem constantemente interações do indivíduo com diferentes grupos, sendo necessário que exista uma fronteira simbólica entre o eu, o grupo, o trabalho e a organização. Neste âmbito, indivíduos que não se vinculam à organização, embora sigam regras e executem um trabalho, tendem a não assumir compromisso, diferentemente daqueles que se vinculam. Tais vínculos ocorrem através do sentimento de pertencer a um grupo, de modo a influenciar a saúde mental do indivíduo, uma vez que a organização pode desencadear processos emocionais positivos e, de outro modo, pode resultar em interferência negativa.

Para que uma pessoa sinta-se pertencente à organização, faz-se necessário um ambiente propício afim de que o indivíduo possa ser estimulado a criar e inovar, tendo responsabilidades e relações entre as pessoas baseadas na confiança e no respeito. Nota-se assim, que o indivíduo pode conseguir uma maior realização pessoal no ambiente profissional se existir um sentimento de pertença, o que contribui para resultados melhores. Do contrário, podem-se gerar problemas psicossociais tais como estresse, depressão, fobia social, síndrome de burnout, alcoolismo, agressividade, mudança de humor, sentimento de persecutoriedade, impactando assim, efeitos negativos não apenas para o indivíduo, 


\section{Desafios da psicologia no Brasil}

mas também para a organização e até mesmo a sociedade. De fato, o local de trabalho não deve ser considerado apenas como um lugar onde os indivíduos têm a oportunidade de contribuir construtivamente, mas também como um ambiente onde têm a oportunidade de estabelecer ligações interpessoais satisfatórias e trabalhar em coletividade para atingir um objetivo comum.

Um aspecto que interfere nitidamente nesta relação se refere à liderança, sendo que, dentre os muitos aspectos organizacionais que afetam o bem-estar e a saúde física e mental das pessoas, o estilo de liderança destaca-se como elemento determinante do bem-estar, da saúde, da qualidade de vida e da satisfação do trabalho. Buscando-se verificar os impactos da liderança sobre a saúde mental, investigou-se a habilidade em ouvir e respeitar por parte do líder em relação aos seus liderados, bem como seus efeitos. Considerando-se que o efeito da liderança é resultado de uma relação construída com os liderados, os relatos apontam para a importância em se colocar a escuta em ação para que a equipe seja saudável, o que tende a ampliar o senso de pertencimento, de modo tal que, uma chefia participativa não apenas previne transtornos, mas também gera resultados, qualidade e, além disso, cria oportunidades para resolver problemas. Outro apontamento se refere à influência do líder na saúde do trabalhador, uma vez que este exerce grande impacto na vida da sua equipe, sendo fundamental que haja respeito às diferenças e ao acolhimento das propostas, viabilizando-se transformar as fraquezas em forças.

\section{CONSIDERAÇÕES FINAIS}

Esta investigação aponta para uma visão discrepante em alguns aspectos entre os profissionais pertencentes às várias linhas teóricas das áreas da psicologia e da psiquiatria: existem visões bastante distintas tanto em relação aos impactos do trabalho na saúde mental, como também sobre a importância de outras variáveis associadas ao trabalhador, como suas características genéticas, os primeiros anos de sua vida e sua história pessoal como um todo.

Contudo, nota-se a convergência das respostas em relação à forte influência da organização do trabalho nas condições de saúde mental. Entende-se assim, que a prevenção dos distúrbios psicológicos potencializa a saúde e qualidade de vida dos funcionários, uma vez que o bem-estar psicológico propicia maior estabilidade emocional, motivação, eficácia no trabalho, criatividade e inovação, bem como o aumento da auto-estima e sensibilidade aos objetivos da empresa, gerando maior produtividade, resultados e, consequentemente, o diferencial competitivo. Em contrapartida, o 


\section{Desafios da psicologia no Brasil}

mal-estar psicológico pode causar menor concentração e poder de decisão, diminuição da agilidade, queda de produtividade, acidentes, entre outros.

Zanelli (2011) discorre sobre os efeitos da evolução e intensificação tecnológica, a diversidade da força de trabalho e a diminuição das relações humanas presenciais como algumas das dimensões que têm tornado o mundo do trabalho tão complexo como jamais foi visto. Nesse cenário, quanto ao nível estratégico e tático, o desafio é estabelecer políticas e práticas que motivem e comprometam pessoas com os propósitos da organização. Pois uma organização orientada para a construção psicossocial saudável tornar-se-á mais segura e o ambiente, mais motivador e comprometido. Os resultados, sejam os produtos ou serviços, serão de mais qualidade, para um entorno com o qual são firmadas boas relações.

Dada à importância do comprometimento e a influencia do líder, cabe acrescentar que quando a equipe percebe que é liderada por alguém que inspira confiança, possui visão e mantém o otimismo, cria-se uma atmosfera tranquila no desenvolvimento do trabalho e isto persiste numa relação mais saudável, ocasionado em melhoria da produtividade, da qualidade de vida, além da prevenção de problemas psicossociais, de modo a ser menor a demanda de carga psíquica, corroborando-se ao maior fomento à criatividade e inovação, bem como à sustentabilidade organizacional.

Neste contexto, acredita-se ser importante considerar a subjetividade do trabalhador na sua relação com o trabalho a fim de se alcançar tal diferencial competitivo. Para tanto, deve-se examinar os impactos da saúde mental no desempenho das organizações, pois, tal como indica Volkoff (1993 apud Ferreira e Mendonça, 2008), as novas formas de organização do trabalho são associadas a cargas invisíveis de trabalho com demandas nas esferas cognitivas e psicoemocional, tendo sérias implicações no processo saúde-doença dos trabalhadores envolvidos.

Por certo, compreender a sociedade contemporânea exige que as velhas abordagens conceituais e reducionistas de sua complexidade sejam repensadas. O mesmo se emprega na compreensão das organizações. Novas concepções são exigidas para que se compreenda o trabalhador e os espaços organizacionais, o que exige repensar os anseios e as necessidades das pessoas, principiando por um processo pessoal de redescoberta (profissional e pessoal).

Por fim, sugere-se a continuidade do presente estudo quanto à investigação a despeito do capital humano e, com isto, contribuir para que este seja um elemento gerencial cada vez mais eficiente, 


\section{Desafios da psicologia no Brasil}

eficaz e inovador. Isto, na lógica proposta por Salanova Soria (2008 apud Zanelli, 2011), organizações saudáveis mantêm empregados saudáveis - portanto, um capital psicológico positivo - que, por sua vez, obtêm resultados saudáveis, percebendo-se assim, a saúde como investimento, e não como custo.

\section{REFERÊNCIAS}

ALMEIDA, P. Inovação sem inteligência é apenas criatividade sem objetivo, 2008. Disponível em: http://www.agenciasebrae.com.br/. Acesso em 01/07/2014.

BERGAMINI, C. W.; TASSINARI, R. Psicopatologia do comportamento organizacional. São Paulo: Cengage Learning, 2008.

BERLINGUER, G. A saúde nas fábricas. São Paulo: Cebes/Hucitec, 1983.

BOYETT, J.; BOYETT, J. O guia dos gurus. Rio de Janeiro: Campus, 1999.

DAFT, R.L. Organizações: Teoria e projetos. São Paulo, São Paulo: Thomson Pioneira, 2002.

DAVID, P.A.; Foray D. Accessing and expanding the science and technology knowledge base: STI Review, 1995.

DEJOURS, C. A loucura do trabalho. São Paulo: Cortez, 2003.

DRUCKER, P. F. Fator Humano e Desempenho: o melhor de Peter F. Drucker sobre a administração. São Paulo: Pioneira, 1997.

FERREIRA, M.C.; MENDENÇA, H. Saúde e bem-estar no trabalho: dimensões individuais e culturais. Sao Paulo: Casa do Psicólogo, 2008.

GARDIM, N.; CORRALES, B.R. Fundamentos e práticas das relações cooperativas no trabalho: inovação, geração do conhecimento e fatores psicossociais. In: M. A. Silveira (org). Inovação para o desenvolvimento de organizações sustentáveis: trabalho, fatores psicossociais e ambiente saudável. (pp. 45-62). Campinas, São Paulo. Brasil: Cedet, 2013.

KANAANE, R. Comportamento humano nas organizações: o homem rumo ao século XXI. 2. ed. - 11. reimpr. São Paulo : Atlas, 2009.

LANCMAN, S.; SZNELWAR, C.I. Christophe Dejours: da psicopatologia à psicodinâmica do trabalho. Rio de Janeiro: Fiocruz, 2011.

MARCONI, M.D.A; LAKATOS, E.M. Técnicas de pesquisa: planejamento e execução de pesquisa, amostragens e técnicas de pesquisa, elaboração, análise e interpretação de dados. São Paulo: Atlas, 1999.

MAYO, A. O valor humano da empresa. São Paulo: Prentice Hall, 2003.

MINAYO, Maria Cecília de Souza. Ciência, Técnica e Arte: o desafio da pesquisa social. In: (org.)

Pesquisa Social: teoria, método e criatividade. 18a ed. Petrópolis: Vozes, 1994. 


\section{Desafios da psicologia no Brasil}

NONAKA, I.; TAKEUCHI, H. A empresa criadora do conhecimento. In: Aprendizagem organizacional: os melhores artigos da Harvard Business Review. Rio de Janeiro, Brasil: Elsevier, 2006.

SENGE, P.M. A quinta disciplina. São Paulo: Best Seller, 1990.

SILVEIRA, M. A.; PONTES, S.K; SILVEIRA, L.D; KIKUCHI, L. S.; POLICENO, C.A. Impactos da organização do trabalho no capital humano para inovação: estudo exploratório com profissionais da área de saúde mental. In: Anais do XV Congresso Latino-Iberoamericano de Gestão de Tecnologia ALTEC. Porto: Universidade Técnica de Lisboa, 2013.

TIDD, J.; BESSANT, J.; PAVITT, K. Managing innovation: Integrating technological, market and organizational change. Chichester: John Wiley \& Sons, 1997.

ZANELLI J. C, SILVA, N. TOLFO, S.R. Qualidade de vida no trabalho e organizações saudáveis como expressões da cultura. In ZANELLI J. C, SILVA, N. TOLFO, S.R. Processos psicossociais nas organizações e no trabalho. São Paulo: Casa do Psicólogo, 2011. 


\section{Desafios da psicologia no Brasil}

\section{NOTAS}

Nota 1

Disponível em: http://www.who.int/en/ 


\section{Capítulo 52}

\section{DEFICIÊNCIA MÚLTIPLA NO CONTEXTO DA ESCOLA COMUM: OS DESAFIOS E AS POSSIBILIDADES DA INCLUSÃO ${ }^{1}$}

DOI: $10.37423 / 200200301$

Patrícia tanganelli lara

patriciatanganelli@gmail.com

Resumo: A partir dos debates sobre a inclusão educacional das pessoas com deficiência múltipla/diante dos vârios documentos internacionais, leis e diretrizes nacionais sobre a educaçấp inclusiva no Brasil, o trabąlho prioriza o estudo/sobre os/limites da escola de ensino regular e a âtuação no cotidiàno escolar com a deficiência múltipla. O objetivo for o de analisar a importância da necessidade de profissionais qualificados para facilitar e atender a criança com deficiência múltipla de forma adequada, com qualidade e respondendo às suas necessidades educacionais especiais para o seu/acesso e a sua permanência na escola. A investigação se realizou por meio de um estudo/de caso e de entrevistas com os envolvidos no processo de inclusão desse alùno numa escola pública regular de educação infantil do município de São Paulo. O descontiecimento e o consequente medo das pessoas é um obstáculo nas situações em que os aluñós com deficiếncia múltipla passam ao convívio com os demais alunos. Os resultados indicaram que a escola não está preparada para enfrentar os desafios propostos nas políticas nacionais de acessso e permanência-de-todos na escola, com um ensino de qualidade.

Palavras-chave: deficiência múltipla, educação infantil, inclusão escolar.

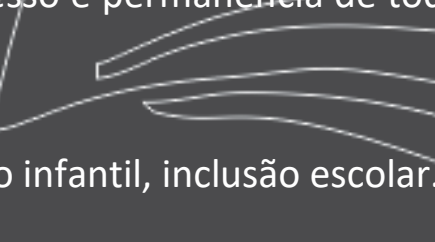




\section{Desafios da psicologia no Brasil}

\section{INTRODUÇÃO}

A defesa de que todas as crianças estudem juntas, em uma proposta de inclusão escolar, foi intensificada a partir de meados da década de 1990. A Declaração Mundial sobre Educação para Todos (Unesco, 1990), aprovada pela Conferência Mundial sobre Educação para Todos, realizada em Jomtien - Tailândia, no ano de 1990, e a Declaração de Salamanca (Unesco, 1994), firmada na Espanha em 1994, marcaram grandes momentos históricos para a inclusão escolar e social de todas as pessoas.

Em 1990, o Brasil promulga a Lei no 8.069, o Estatuto da Criança e do Adolescente - ECA (BRASIL, 1990), assegurando os direitos fundamentais a toadas as crianças (até 12 anos) e adolescentes (de 12 a 18 anos), o acesso à escola pública e gratuita e o atendimento especializado da criança ou adolescente com deficiência na área de saúde, e principalmente, o atendimento educacional do aluno com deficiência, preferencialmente na rede regular de ensino.

Outra importante Lei que surgiu na década de 90 foi a Lei de Diretrizes e Bases da Educação Nacional - LDBEN (BRASIL - 1996), que ratifica os princípios gerais expostos na Declaração de Salamanca (UNESCO, 1994) e dedica um capítulo somente para a Educação Especial (Capítulo V), indicando em seu art. 58 a oferta de educação escolar, preferencialmente na rede regular de ensino, e serviços de apoio especializado também na escola regular. 0 art. 59 da LDBEN estabelece que o sistema de ensino deve se adequar com currículos, métodos, técnicos, recursos educativos e organização específicos, para atender às necessidades especiais de cada aluno, sendo assim, não é o deficiente que deve se adequar à escola, mas a escola deve proporcionar um ambiente adequado para que ele aprenda.

A LDBEN /96 traz um outro fator essencial para a educação, à formação de profissionais para o atendimento aos diferentes níveis e modalidades de ensino. A Constituição Federal do Brasil de 1988 (Brasil, 1988), reafirma um movimento visando um conceito mais amplo de inclusão escolar e a determinação de "atendimento educacional especializado aos portadores de deficiência preferencialmente na rede regular de ensino" (Artigo 208, Inc III).

A partir de 1993, através do Decreto no 33.891 de 16 de dezembro de 1993, a Secretaria de Educação do Município de São Paulo, estabelece o atendimento educacional aos portadores de necessidades educacionais especiais, por meio das Salas de Atendimento aos Portadores de Necessidades Especiais (SAPNEs), como atendimento paralelo, aos alunos regularmente matriculados em classe do ensino comum, para receber apoio educacional complementar ou suplementar em horário diverso, ou 


\section{Desafios da psicologia no Brasil}

atendimento exclusivo. O Decreto no 45.415 , de 18 de outubro de 2004 revogou o Decreto no 33.891/1993, pois segundo o novo decreto, as SAPNEs passam a ser denominadas Salas de Apoio e Acompanhamento à Inclusão (SAAI). Muda-se o modelo organizacional, com o princípio da integração, onde os alunos deveriam adaptar-se às necessidades da escola e passa-se a adotar o princípio da inclusão escolar, onde a escola é que deve se adaptar às necessidades dos alunos.

Ocorreram muitos avanços no reconhecimento do acesso e permanência de pessoas com deficiência nas escolas regulares, contudo a construção de espaços educacionais inclusivos é uma ideia ainda muito nova para todas as pessoas e a adequação a essas novas medidas necessitam de múltiplos estudos e grande investimento em todas as dimensões: política, administrativa, financeira, organizacional, infraestrutura, formação de professores, entre muitas outras.

O aluno que apresenta uma deficiência múltipla é percebido pela escola, ainda, como um grande problema, maior do que ela acredita que possa atender. Esses alunos são remetidos para centros de atendimento, ou escolas especiais, com uma fila inesgotável, e muitas vezes, longe de suas residências, ficando assim segregados a uma vida de poucas perspectivas de avanço ou de inclusão em âmbito maior.

A deficiência múltipla é vista como a soma de duas ou mais deficiências, esse conceito não está errado, mas equivocado. Conforme Pires et all (2007), a deficiência múltipla se caracteriza pela existência, concomitante, de dois ou mais tipos de deficiência primária em uma pessoa, contudo, ela não é a soma das deficiências e sim uma organização qualitativamente diferente de desenvolvimento que irá requerer recursos muito próprios às necessidades apresentadas por essas pessoas para aprender e conviver no mundo de modo geral. Sendo assim, a múltipla deficiência deve ser encarada como uma deficiência, não como a simples soma de duas ou mais deficiências.

O estudo em tela refere-se a um estudo de caso, realizado junto a um aluno com deficiência múltipla, matriculado em uma EMEI na região Sul de São Paulo. Em seu diagnóstico preliminar foi possível verificar que o aluno nasceu com síndrome de Moebius $^{2}$, com apenas 1/3 do cérebro (malformação Chiari $\mathrm{II}^{3}$ ), originando uma hidrocefalia ${ }^{4}$, que o levou nos primeiros dias de vida passar por diferentes cirurgias.

psicológico, intelectual e social, complementando a ação da família e da comunidade, devendo cumprir as funções indispensáveis e indissociáveis como cuidar e educar. 


\section{Desafios da psicologia no Brasil}

Conforme o Referencial Curricular de Educação Infantil, a expansão da educação infantil no Brasil e no mundo tem ocorrido de forma crescente nas últimas décadas. A sociedade está mais consciente da importância das experiências na primeira infância, o que motiva demandas por uma educação institucional para crianças de zero a seis anos, apresentando como objetivos gerais da educação infantil o desenvolvimento de uma imagem positiva de si, o estabelecimento e ampliação das relações sociais, respeitando a diversidade e desenvolvendo atitudes de ajuda e colaboração (BRASIL, 1998), sendo assim, é essencial que as crianças com necessidades educacionais especiais participem da educação infantil em espaços inclusivos, para que tenham o direito de alcançar os objetivos propostos para seu desenvolvimento.

Os objetivos que o currículo da educação infantil deve alcançar na criança, como a "construção da identidade e da autonomia; a interação e socialização da criança no meio social, familiar e escolar, e a ampliação progressiva dos conhecimentos de mundo." (BRASIL, 2004, p.43). Nessa faixa etária, o processo de construção do conhecimento se dá por meio das conquistas realizadas na busca de novos desafios, que servem de base para novos saberes, utilizando-se das mais diferentes linguagens, exercendo a capacidade que possuem de terem ideias e hipótese originais sobre tudo e sobre todos. Se a educação infantil é importante para qualquer criança, para a criança deficiente múltipla é essencial.

Conforme Glat e Blanco (2007), a Educação Inclusiva não se resume à matrícula do aluno com deficiência na turma comum ou à sua presença na escola, ela precisa ser, mais do que um espaço para a convivência, um ambiente onde ele aprenda os conteúdos socialmente valorizados para todos os

alunos da mesma faixa etária. A autora aponta como objetivo da proposta de educação inclusiva "a possibilidade de ingresso e permanência do aluno na escola com sucesso acadêmico", e isso só poderá se dar a partir da atenção às suas peculiaridades de aprendizagem e desenvolvimento $(p .17,18)$.

As escolas necessitam se organizar para atender alunos com necessidades educacionais especiais, assegurando as condições necessárias para uma educação de qualidade, adequando seu sistema para atender, sem discriminar ou estigmatizar o seu aluno.

Conforme Carvalho (2004) as escolas enfrentam inúmeros limites que só poderão ser superados com mudanças sistemáticas nas políticas nacionais, é necessária uma reestruturação das escolas para atenderem as necessidades de todas as crianças, sejam elas com deficiência ou não. $\mathrm{O}$ acesso à escola 


\section{Desafios da psicologia no Brasil}

deve ser respeitado e objetivado numa lógica de combate ao preconceito e o desafio de lutar por uma escola melhor para todos.

Nessa perspectiva os objetivos dessa pesquisa foi o de estudar a importância da necessidade de profissionais qualificados para facilitar e atender a criança com deficiência múltipla de forma adequada e, ainda o estudo procurou verificar os limites e as possibilidades de um aluno com deficiência múltipla no ensino regular.

\section{MÉTODO}

\section{PARTICIPANTES}

Foi selecionado um sujeito do gênero masculino, com 5 anos de idade na época da coleta de dados. 0 aluno apresenta deficiência múltipla, com diagnóstico de Hidrocefalia, Síndrome de Moebius, mal formação tipo Chiari II, cujo maior comprometimento encontrava-se na sua compreensão dos fatos ocorridos à sua volta, devido à suas perdas após as convulsões, que já o levaram a diversas internações. Apesar de andar e correr, o aluno já havia passado por diferentes cirurgias nas pernas, fazendo com que ele caísse muitas vezes durante o dia. Sua inclusão na escola regular, diante do quadro grave de sua deficiência foi realizada através de diversas reuniões para analisar o quanto a escola poderia oferecer para sua aprendizagem e determinando que a mãe do aluno o acompanhasse diariamente.

Participaram também deste estudo os profissionais da escola envolvidos em sua inclusão: a diretora da escola, a assistente de direção, a coordenadora pedagógica, a professora de Sala de Apoio e Acompanhamento à Inclusão e a professora do aluno.

Os participantes desta pesquisa receberam todas as informações pertinentes ao projeto como: objetivos, procedimentos de coleta de dados, temporalidade. Resguardo de privacidade do participante e utilização dos dados para fins científicos, tendo sido, assim, convidados a assinar o termo de consentimento livre e esclarecido, confirmando anuência.

\section{LOCAL}

As atividades vinculadas à coleta de dados foram realizadas, na própria escola do aluno, uma escola regular de educação infantil situada no município de São Paulo - SP. 


\section{Desafios da psicologia no Brasil}

\section{RESULTADOS: HISTÓRICO DA CRIANÇA}

Mateus $^{5}$ nasceu em São Paulo - SP, no ano de 2002, após uma gravidez de risco, tendo sido diagnosticado nos exames pré-natais, onde a mãe teve conhecimento de que seu filho apresentava uma deficiência grave que poderia levá-lo à morte logo após o nascimento. Desenganado dos médicos, após o nascimento, o pai teve que procurar meios legais para a realização da primeira cirurgia do filho para a colocação de uma válvula no cérebro para drenar a água, devido a sua hidrocefalia. Mateus nasceu com um diagnóstico de Síndrome de Moebius, malformação de Chiari II e hidrocefalia. Apesar de todo esse comprometimento global, a criança com apenas 7 meses foi matriculada em uma creche particular, que mantinha convênio com a Secretaria da Educação municipal, próximo à sua residência. Após contato com a creche, ela informou que ele faltava muito devido às suas constantes internações e convulsões, porém que ali permaneceu até os 4 anos de idade. Aos 3 anos ele aprendeu a andar, após se submeter a diversas cirurgias para a correção dos pés. Até três anos enquanto não andava era mais fácil lidar com ele, recebia cuidados e atenção quase individuais. Os últimos anos de creche foram difíceis, pois ele mordia e batia muito nos colegas e algumas vezes na professora. Necessitava de uma professora auxiliar por tempo integral, usava fralda e tomava vários banhos durante o dia. Na creche também havia uma enfermeira para dar os primeiros socorros, quando aconteciam as crises constantes de convulsões, e chamavam a mãe para levá-lo, de imediato, a um hospital mais próximo. Geralmente as crises aconteciam enquanto ele dormia, a professora percebia, pois ele tremia e babava. Chegou a ter três crises no mesmo dia e a professora relatou que durante a semana costumava acontecer pelo menos duas convulsões, relataram também que aconteciam crises silenciosas. Como tem um andar sem equilíbrio caía muito pela creche. O espaço físico era menor, totalmente adaptado para suas crianças, com grades e portões que impediam e ou dificultavam a passagem para locais impróprios e perigosos. Pensando em um atendimento especializado para o aluno que pudesse melhorar o seu desenvolvimento a creche conseguiu uma vaga em uma Instituição de Educação Especial, mas os pais não aceitaram.

\section{A INCLUSÃO DO ALUNO NA EMEI}

Inicialmente, o aluno foi matriculado no 10 estágio, tentando integrá-lo a um grupo de crianças de faixa etária menor, pensando em seu desenvolvimento cognitivo, já que havia constatado o seu atraso. Conforme relatado no seu prontuário: 


\section{Desafios da psicologia no Brasil}

No primeiro dia de aula ele bateu em oito crianças das dez presentes, sempre muito agitado, não tinha noção de perigo e do que estava fazendo. Poderia machucar a si próprio, assim como as outras crianças, necessitando constantemente da presença de um adulto ao seu lado. Conforme esses fatos houve uma reflexão da equipe escolar que achou necessário a realização de uma reunião com os pais do aluno.

Tendo em vista a severidade da deficiência intelectual de Mateus foi realizada uma reunião logo no início do semestre ficando determinado que, considerando a falta de recursos humanos especializados, as dependências estruturais e a acessibilidade - escada que dá acesso à sala de aula e ao banheiro - a escola decidiu que: a criança nesse período de adaptação ficaria necessariamente com um adulto responsável (pai ou mãe); Nesta fase a escola procuraria sociabilizar e dar mais autonomia à criança; A escola solicitou relatórios que subsidiassem o atendimento do aluno pela equipe escolar, pois segundo informação da mãe a criança faz tratamento no Posto com pediatra, fonoaudiólogo, neurologista, e a fisioterapia e tratamento psicológico na Clínica. Foi acordado que a mãe entregaria os relatórios da equipe médica; Mudança de classe para o $3^{\circ}$ estágio, com crianças da sua idade, no período das 9:30h. às 11:00h., que corresponde ao horário do parque, tendo como objetivo uma maior sociabilidade do aluno.

Apesar de existir na escola uma professora especialista com uma Sala de Recursos Multifuncionais SRM, como era da especialidade de deficiência física e essa professora acreditar que a escola não tinha condições de atendê-lo em todas as suas necessidades, ele não obteve nenhum atendimento. A professora especialista acreditava que o Mateus deveria ser encaminhado para uma escola ou Instituição de educação especial.

A mãe encaminhou todos os relatórios médicos que ela tinha em casa, com a declaração da psicóloga, no qual havia o relato de que Mateus apresentava uma hiperatividade, e estava aprendendo regras e limites.

Todos os relatórios médicos, associado à gravidade da sua deficiência, com histórico de convulsões crônicas e prolongadas, trouxeram um temor por parte dos profissionais da escola.

A sala de aula, na época, contava com 35 alunos, com a entrada do Mateus houve uma diminuição para 30 alunos na sala de aula. Durante o mês de adaptação com a nova professora foi realizado um trabalho de inclusão com o grupo, através de sensibilização com a classe e como todos poderiam ajudar e incluí-lo nas atividades cotidianas. Conforme relatado no documento:

Com o passar do tempo às atenções e preocupações eram exclusivas para o Mateus. As tensões emocionais e físicas presentes provocavam um stress 


\title{
Desafios da psicologia no Brasil
}

relacionado ao real risco de morte que a criança apresenta. Nas atividades lúdicas o aluno permanecia pouco tempo em cada uma, do balanço para o escorregador, do tanque de areia para o jogo de bola, da música para a corrida. Tudo muito rápido, sem parar, sem controle. Na hora da história, onde os alunos ficam sentados em roda e quietos para ouvir e prestar atenção, o Mateus não para, cai sobre os colegas, levanta, dança, canta e quebra o ritmo da atividade. Na sala de aula, o aluno pegava uma penteadeira com rodas e ficava empurrando pela classe o tempo todo de maneira desgovernada, batendo nas mesas e nos colegas, fazia uso de brinquedos fora de hora, quebrando a rotina e os combinados com a classe. Era difícil para os colegas que também são crianças perceberem que o Mateus pode e eles não. Quando contrariado em suas vontades, joga-se no chão, bate, chora, teima até conseguir e com medo de suas crises convulsivas os adultos presentes cedem. Também apresentou em algumas ocasiões um comportamento inverso, muito parado, centrado em um só brinquedo, expressão ausente, cambaleando para andar. A mãe informou à Professora que seu comportamento estava relacionado à medicação.

Apesar da gravidade da deficiência a escola se mobilizava para incluí-lo nas atividades, e foram realizadas outras reuniões para encontrar caminhos para a sua inclusão. A equipe do Centro de Formação e Acompanhamento à Inclusão - $\mathrm{CEFAI}^{6}$, da Secretaria Municipal de São Paulo, esteve na escola e observou o Mateus, deixando o seguinte relatório:

\begin{abstract}
O aluno estava agitado, agrediu alguns colegas, ouviu música, tentou brincar com o baldinho, foi ao escorregador do parque e quase pulou de cima, mesmo acompanhado pela mãe. Também verificou que não interagia com seus colegas, não tinha nenhuma noção de perigo, presenciando suas dificuldades para subir e descer as escadas, sempre amparado pela mãe ou Professora.
\end{abstract}

Após essa primeira observação da equipe do CEFAl foi realizada uma nova reunião e apresentadas as seguintes sugestões: a permanência da mãe na escola, junto ao aluno no horário das 9:00h. ás 11:00h.; o Mateus deverá se integrar na rotina da classe; o CEFAI vai tentar encontrar um atendimento na SRM que contemple suas necessidades; possibilidade da presença de um estagiário na Escola para atender a criança; foi entregue aos pais um encaminhamento para uma escola especializada que tem uma equipe multidisciplinar, com suporte terapêutico completo para que possa atender o Mateus no período da tarde; solicitado novamente os relatórios médicos para subsidiar nosso trabalho.

As dificuldades em incluí-lo nas atividades escolares, era a grande preocupação de todas as pessoas da equipe escolar da EMEI. A coordenadora pedagógica juntamente com a Diretora da escola procurou uma orientação com uma médica especialista na Síndrome de Moebius, da Universidade Federal de 


\title{
Desafios da psicologia no Brasil
}

São Paulo (UNIFESP), levando o Mateus, juntamente com sua mãe em uma consulta, e após o atendimento a medicou relatou:

\begin{abstract}
A Síndrome de Moebius, em relação a este problema o Mateus está bem, pois ele anda, fala, come e tem relativo controle das funções esfíncteres. O real problema está na deficiência mental (mal formação Chiari II). E disse que ele aprende através de um exaustivo treinamento. As constantes convulsões precisam ser controladas rigorosamente, pois perde as sinapses estabelecidas anteriormente quando entra em crise. Mateus pode sofrer uma queda da própria altura e isso seria perigoso, pois ele tem uma válvula implantada na cabeça.
\end{abstract}

A escola agendou um encontro com a psicóloga da Clínica que a mãe relatou que o Mateus fazia tratamento. Após a conversa com a professora, a Coordenadora da EMEl e a psicóloga, foram realizadas o seguinte relatório:

Após visita à Clínica onde o aluno Mateus está em tratamento, foi relatado pela psicóloga responsável que ele estava em tratamento, por 40 minutos individuais uma vez por semana, mas faltava muito por causas das crises de convulsão que eram constantes e das várias internações. Através de testes a Dra S. ${ }^{7}$ constatou que o Mateus tinha idade mental de dois anos e 10 meses. Durante as sessões individuais, o Mateus agredia, agia por impulso e resistia diante das tentativas de colocar limites na criança e quando não queria fazer algo ele chorava muito e se jogava no chão, comentou que aos poucos está melhorando. Tem trabalhado seus distúrbios de comportamento, tentando melhorar sua hiperatividade, e dar limites. Ele tem mostrado bastante resistência, e na orientação com a família neste trabalho percebe que não gostam de contrariá-lo, pois fica nervoso e pode desencadear uma convulsão.

gravidade da deficiência do aluno e os problemas que a escola estava enfrentando, devido principalmente à sala ser no piso superior e as orientações da professora de SRM da escola, deixavam em dúvida se a escola tinha condições de incluí-lo, elaborando o seguinte relatório:

O aluno apresentou vários momentos de ausência, dentre esses, dois foram muito significativos, onde permaneceu imóvel, sem expressão, mesmo chamando pelo nome várias vezes, ficou sem reação. A mãe estava presente e com os remédios de convulsão (injetáveis), em sua mochila, para qualquer problema mais grave, que se fosse necessário ela utilizaria até chegar a um hospital mais próximo. No convívio com os colegas a Professora não observa envolvimento coletivo, ele não brinca com ninguém, são as crianças que tentam brincar com ele. Seus centros de interesse são a música, os jogos de montar e a bola de futebol. Em duas situações ele se colocou em risco eminente. A classe passou a ser trancada, pois ele quer sair da sala quando não percebe a presença da Professora. O Mateus faltou bastante durante um período devido a uma queda que desencadeou uma forte convulsão, e ficou internado muitos dias para passar por exames. A Professora percebeu alguns avanços, ele está mais 


\title{
Desafios da psicologia no Brasil
}

\begin{abstract}
interessado em desenhar. No parque está mais calmo, brinca bastante no balanço, já está conseguindo segurar sozinho, algo que não fazia no começo do ano. Está brincando no tanque de areia, e não pulou de cima do escorregador, já está sentando mais. Durante o mês a mãe esteve o tempo inteiro perto do Mateus, ajudando muito no seu desenvolvimento e no trabalho que está sendo realizado com ele na escola. Ele tem chamado as crianças pelo nome para brincar e aos poucos tem ocorrido alguma interação. Às vezes chama o colega pelo nome corretamente. É um aluno que necessita o tempo inteiro de um adulto ao seu lado, pois costuma ter algumas atitudes repentinas, inesperadas. Quando ele chega à escola, apesar da mãe estar perto, as atenções da Professora se voltam totalmente para ele, na tentativa de integrá-lo com o grupo e no cuidado com sua integridade física. Ele não tem nenhuma autonomia. As conquistas tem sido pequenas e acreditamos que necessita de um suporte especializado, apesar da disposição dos profissionais da escola em aprender como lidar com essa criança e repensar nossa prática. Incluir significa fazer parte do problema, contudo a severidade da deficiência do aluno nos impõe limites.
\end{abstract}

Nos meses subsequentes, a escola continuava tentando realizar a melhor inclusão possível para o Mateus, criando um ambiente adequado para sua aprendizagem.

No segundo semestre ele chegava à escola às $08 \mathrm{~h} 30 \mathrm{minh}$ e sua rotina diária era brincar com monta tudo na sala de aula, giz na lousa, canetão para escrever em papel A3, almoço junto com as crianças, higiene dos dentes, onde a professora procurava ajudá-lo, e o parque.

No final do ano a discussão na escola era se ele seria encaminhado para o Ensino Fundamental, ou permaneceria na EMEI. Após reunião com a Supervisora Escolar, ficou decidido que ele permaneceria na EMEI por mais um ano, e que ele estaria sendo atendido em uma SRM com especialidade de deficiência intelectual em outra Unidade Escolar.

Os dados do prontuário mostram que ao final do primeiro ano de inclusão na EMEI, não apresentou avanços em seu desenvolvimento cognitivo e às aprendizagens de conteúdos escolares, devido às dificuldades encontradas pela professora em encontrar caminhos para atender às necessidades da criança. Foram observados grandes avanços na sua socialização, pois deixou de bater nos colegas e na professora, respondendo a alguns combinados na rotina diária da EMEI.

\section{CONSIDERAÇÕES FINAIS}

O estudo possibilitou analisar os limites enquanto escola de educação infantil para atender alunos com deficiência múltipla. A escola não está preparada para enfrentar os desafios propostos nas políticas nacionais de acesso e permanência de todos na escola, com um ensino de qualidade. 


\section{Desafios da psicologia no Brasil}

Observou-se na análise dos dados obtidos e das entrevistas realizadas que o choque com o diferente é muito grande e existe um medo de enfrentar novos desafios, tornando-se o grande obstáculo para novas situações de aprendizagem.

É necessário investir mais nos professores e na equipe em geral da escola, oferecendo cursos de qualidade, valorizando momentos de formação continuada, para modificar práticas excludentes.

Por fim, a pesquisa apresentada não tem a pretensão de generalizar os resultados encontrados, pois foi realizada apenas em uma escola, através de um estudo de caso, portanto não cabem conclusões, somente algumas considerações, reforçando aspectos essenciais para a compreensão da falta de professores especialistas para o trabalho com deficiente múltiplo e do descaso do poder público na inexistência de um real investimento nas ações necessárias para o acesso e permanência de todos os alunos na escola.

\section{REFERÊNCIA}

BRASIL, Constituição (1988). Constituição da República Federativa do Brasil. Brasília, DF. Senado. 1988.

BRASIL, 1990. Estatuto da Criança e do Adolescente. Lei 8.069/90, de 13 de Julho de 1990. Brasília: Senado Federal.

BRASIL. Lei 9.394, de 20 de dezembro de 1996, estabelece as diretrizes e bases da educação nacional. Lei de Diretrizes e Bases da Educação. Diário Oficial da União, de 23 de dezembro de 1996. Seção1, p.27833-27841.

CARVALHO, Rosita Edler. Educação Inclusiva com os pingos nos is. Porto Alegre: Editora Mediação, 2004.

PIRES, Cláudia, BLANCO, Leila de Macedo Varela e OLIVEIRA, Mércia Cabral. Alunos com deficiência física e deficiência múltipla: um novo contexto de sala de aula. In: GLAT, Rosana (org). Educação Inclusiva: Cultura e Cotidiano Escolar. Rio de Janeiro 7 Letras, 2007, p. 137 -152.

GLAT, Rosana, BLANCO, Leila de Macedo Varela. Educação Especial no contexto de uma Educação Inclusiva. In: GLAT, Rosana (org). Educação Inclusiva: Cultura e Cotidiano Escolar. Rio de Janeiro 7 Letras, 2007, p. 15 - 35.

SÃO PAULO (Município). Prefeitura do Município de São Paulo. Secretaria Municipal de Educação. Decreto no 33.891, de 16 de dez. de 1993. Institui a Política de Atendimento aos Portadores de Necessidades Especiais na Rede Municipal de Ensino São Paulo: Diário Oficial do Município, 16 dez. 1993.

SÃO PAULO (Município). Prefeitura do Município de São Paulo. Secretaria Municipal de Educação. Decreto n. 45.415 de 18 de outubro de 2004. Estabelece diretrizes para a Política de Atendimento a Crianças, Adolescentes, Jovens e Adultos com Necessidades Educacionais Especiais no Sistema Municipal de Ensino. Diário Oficial do Município, 19 out. 2004. 


\section{Desafios da psicologia no Brasil}

\section{NOTAS}

Nota 1

Trabalho apresentado no Congreso Internacional PEDAGOGIA 2015 - Habana/ Cuba.

Nota 2

A Síndrome de Moebius é uma doença caracterizada por uma paralisia facial, ou seja, há perda de movimentos do rosto. São afetados os movimentos dos olhos e os movimentos da face que expressam emoções.

\section{Nota 3}

Malformações de Chiari (ou de Arnold-Chiari) são constituídas por hérnias do cerebelo e tronco cerebral de grau variável, através do buraco occipital. Podem aparecer tanto no adulto como na criança. Distinguem-se 3 tipos: No tipo II há um alongamento e deslocação inferior do tronco cerebral com emergência do vermis e bulbo através do foramen magnum que está alargado. O IV ventrículo é alongado e achatado, e atinge a charneira, razão pela qual na maioria dos casos de tipo II, a malformação de Chiari está associada a mielomeningocelo e hidrocefalia.

\section{Nota 4}

Hidrocefalia é o acúmulo anormal e excessivo de líquor dentro dos ventrículos ou do espaço subaracnóide.

\section{Nota 5}

O nome do aluno e das pessoas envolvidas na pesquisa são fictícios, para garantir o sigilo das fontes de informações.

\section{Nota 6}

Conforme o Art. 5ㅇ, do DECRETO № 45.415, DE 18 DE OUTUBRO DE 2004, o Centro de Formação e Acompanhamento à Inclusão - CEFAl, composto por membros da Diretoria de Orientação TécnicoPedagógica composto por membros da Diretoria de Orientação Técnico-Pedagógica das Coordenadorias de Educação das Subprefeituras, por Professores de Apoio e Acompanhamento à Inclusão - PAAI e por Supervisores Escolares, é parte integrante das referidas Coordenadorias e será por elas suprido de recursos humanos e materiais que viabilizem e dêem sustentação ao desenvolvimento de seu trabalho no âmbito das Unidades Educacionais, na área de Educação Especial.

Nota 7

Este relatório foi fornecido pela psicóloga que atendia o aluno pesquisado. 


\section{Capítulo 53}

\section{ACOMPANHAMENTO E INTERVENÇÃO PRECOCE COM BEBÊS PREMATUROS TARDIOS: UMA INTERVENÇÃO INTERDISCIPLINAR BASEADA NA PSICANÁLISE}

DOI: $10.37423 / 200200304$

Ana Paula Magosso Cavaggioni

anapaulamagosso@gmail.com

Manuel Morgado Rezende

manuel.rezende@ùol.com.br

Miria Beningasa

miria.belnincasa@gmail.com

Resumo: Tenđo em vista o àumento ąlarmante na incídência das psicopatologras da infância e adôtescência ao longo dầ última década, faz-se fundamental o desenvolvimento de programas de prevenção e promoção de saúde mẹtal voltados aos cuidađos do bebê e suas famílias. Este artigo-apresenta a experiência de trabalho de um grupo-terapêutico composto por bebês nascidos prematuros tardios e seus pais a partir daproposta do programa Grão de Areia, inspirada no modelo da Maison Verte, adaptado à situação clínica. Trata-se de uma intervenção terapêutica interdisciplinar em um espaço/dé convivência oferecido à grupos de bebêts de 0 a 36 meses e suas famílias, embasada pela psicanálise, com foco na promoção e prevenção de saúde mental. A discussão écentrada/na vivência de um grupo terapêutico. Com base na análise de duas situações clínicas, são discutidos aspectos referentes à importância do grupo no trabatho terapêutico de bebês e/seus pais, ctjo-exercício-clínico segue a perspectiva-teórica psicanalítica através da Metodología REI. 


\section{Desafios da psicologia no Brasil}

\section{INTRODUÇÃO}

O Programa Grão de Areia é um dispositivo de grupo terapêutico desenvolvido na CLIA Psicologia, Saúde \& Educação, na cidade de Santo André, em São Paulo, a partir da preocupação com o crescimento exponencial das psicopatologias da infância ao longo das últimas décadas, inspirado no modelo clínico da Maison Verte e na Metodologia IRDI.

Não muito diferente da realidade observada por Dolto na década de 1970, atualmente acompanhamos um aumento alarmante da incidência dos diagnósticos psicopatológicos da infância baseados nos critérios do Manual Diagnostico e Estatístico dos Transtornos Mentais (DSM), que se encontra agora em sua 5a edição, e da Classificação Internacional das Doenças (CID 10) que partem de uma visão organicista e determinista dos distúrbios, sem levar em conta a subjetividade, tanto do sujeito submetido à patologia como daquele que o submete ao diagnostico. (Lacet, 2014; Meira, 2012; Kupfer, 2011; Kamers, 2013). São imprecisos os números em torno da incidência e da prevalência epidemiológicas dos distúrbios do desenvolvimento e dos transtornos mentais na infância na maioria dos países em desenvolvimento (Fleitlich e Goodman, 2009). Os relatórios da OMS de 2001 apontavam para uma incidência de 10 a 20\% destes transtornos na infância, afirmando ainda que os transtornos mentais durante a infância e adolescência são comuns, mas é insuficiente a atenção dada a esta população tanto em relação ao diagnóstico quanto ao tratamento (OMS, 2001). Williams et al (2004) apontam que em torno de $15 \%$ das crianças atendidas em consultas pediátricas apresentam distúrbios de comportamento, mais comumente déficit de atenção e hiperatividade, ansiedade e depressão. Se levarmos em conta ainda a evolução nos números de diagnósticos do Transtorno do Espectro Autista, as estatísticas levantadas pelos Centros Americanos de Controle de Doenças (CDCs, 2010), mostram um aumento alarmante na prevalência do autismo. Os CDCs apontam que, em 2007, havia 1 criança com autismo para cada 150 crianças, aumentando para 1 em cada 110 crianças em 2009 e para 1 em cada 88 crianças em 2012, o que significa um aumento de quase $70 \%$ em 5 anos.

É diante deste quadro e da necessidade de melhorar e ampliar o atendimento desta população através de ações voltadas à prevenção e promoção de saúde mental, que a equipe da CLIA Psicologia, Saúde \& Educação iniciou, em 2014, o programa Grão de Areia com objetivo de acompanhar através de grupos terapêuticos o desenvolvimento global de bebes de zero à 36 meses de idade, nascidos ou não em situação de risco, contemplando o bem estar físico, social e psíquico desses indivíduos. Além disso, oferece suporte às suas famílias através de programas terapêuticos e psicoeducativos, de maneira a 


\section{Desafios da psicologia no Brasil}

favorecer, facilitar e estimular os laços entre pais e filhos, com o apoio de uma equipe interdisciplinar embasada na psicanálise.

Partindo do modelo no qual foi pensada a Maison Verte, adaptado a realidade clínica, o Grão de Areia consiste no oferecimento de um espaço lúdico, dentro da instituição, voltado a bebês acompanhados de seus pais, ou cuidadores principais, livre de qualquer diretriz educativa ou pedagógica, onde se pode falar com a criança sobre o que a interessa, tanto através da fala dos pais como de suas ações e comportamentos, buscando auxiliá-la na dissolução de entraves e dificuldades em sua constituição psíquica, responsável, em última instância, pela organização de seu desenvolvimento global (Jeruzalinsky, 2002). Trata-se de um espaço no qual a criança é acolhida e compreendida como um sujeito desejante, que tem algo a dizer a respeito de si para alguém que possa escutá-la.

Algumas adaptações foram realizadas para adequar o modelo da Maison Verte à nossa realidade institucional e ao objetivo de, não apenas impactar na prevenção e promoção de saúde mental, mas também de identificação precoce de riscos ao desenvolvimento infantil, através dos IRDIS, fundamental para o encaminhamento a tempo do bebê que apresente sinais de risco de desenvolvimento, o que garante um melhor prognóstico (Kupfer et al, 2009, Kupfer e Pesaro, 2012, Kupfer et al, 2014).

Faz-se importante contextualizar o modelo clínico da Maison Verte e a Metodologia IRDI para melhor compreensão do trabalho em questão.

\section{MAISON VERTE}

A Maison Verte é uma ONG francesa inaugurada em 1979 pela psicanalista Françoise Dolto, também atenta ao crescente número de crianças em início de idade escolar encaminhadas ao psicanalista com problemas psíquicos já estruturados. Sua proposta, dedicada ao atendimento de crianças e seus familiares, era voltada à prevenção do surgimento tanto de psicopatologias infantis quanto da violência advinda de uma entrada conturbada da criança no meio social. Trata-se de um espaço de convivência, de conversa, de lazer no qual bebês de 0 a 36 meses e seus pais - principais responsáveis pela segurança de sua identidade - podem ser auxiliados no processo de integração social, de saída do ambiente familiar, maternal, através da inserção de palavras onde existem rupturas e entraves. Desta forma, o bebê tem a oportunidade de ser inserido no meio social tendo garantido seu direito de ser reconhecido como sujeito psíquico, manifestando seus afetos, suas fantasias, tendo facilitado, através da palavra, a elaboração de angústias existentes na relação entre ele e seus pais. Da mesma forma, os 


\section{Desafios da psicologia no Brasil}

adultos que acompanham a criança têm a oportunidade de interagirem com seus pares e partilhar vivências e situações que permitem seu reposicionamento na relação com o bebê, enriquecendo suas experiências, promovendo novos contornos à relação (Dolto, 1988, 2005; La Maison Verte, 1986).

Na Maison Verte, o acesso das famílias é livre, sem necessidade de marcar horário ou estabelecer uma rotina determinada. Seu horário de funcionamento é na parte da tarde, todos os dias com exceção do domingo. Independente do número de participantes, os presentes são sempre acolhidos por 3 pessoas, sendo um necessariamente psicanalista, que só podem estar presentes uma vez na semana, garantindo a transferência para o espaço institucional e a ocorrência de múltiplos encontros (La Maison Verte, 2000).

Também são estipuladas algumas regras fundamentais, que facilitam o campo da introjeção das leis que dirigem a vida em grupo: o bebê só é recebido se acompanhado por um responsável relevante para a construção de sua identidade; há um espaço delimitado por uma linha vermelha que limita o uso de triciclos e velocípedes, protegendo os bebês menores; deve-se utilizar um avental para as brincadeiras com água, para proteger a roupa do frio e umidade (La Maison Verte, 1986).

\section{METODOLOGIA IRDI}

Os Indicadores de Risco de Desenvolvimento Infantil (IRDIs) foram desenvolvidos a partir da "Pesquisa Multicêntrica de Indicadores Clínicos de Risco para o Desenvolvimento Infantil (IRDI)", realizada pelo Grupo Nacional de Pesquisa (GNP) composto por 10 especialistas brasileiros em psicanálise, que validou, a partir de Sigmund Freud e das vertentes psicanalíticas de D. Winnicott, M. Klein e de J. Lacan, um instrumento composto por 31 indicadores clínicos. Os indicadores partem do pressuposto de que as bases da saúde mental se constituem ao longo dos primeiros anos de vida e estão diretamente relacionados às trocas afetivas, corporais e simbólicas entre o bebê e a pessoa que se dedica aos seus cuidados, geralmente a mãe (Kupfer et al, 2009). O IRDI permite investigar e acompanhar o desenvolvimento do bebê de maneira articulada à sua constituição psíquica, bem como a detecção precoce de risco psíquico ou de problemas para o desenvolvimento infantil, e possibilita, desta forma, o acompanhamento do desenvolvimento do bebê, a detecção precoce de sinais de risco do desenvolvimento infantil e a intervenção a tempo de reverter o quadro psicopatológico, ou minimizar seus desdobramentos, permitindo uma atuação na prevenção primaria e secundaria destas psicopatologias (Kupfer et al, 2009; Kupfer e Pesaro, 2012; Kupfer et al, 2014). 


\section{Desafios da psicologia no Brasil}

A Metodologia IRDI, desenvolvida para ser aplicada em ambientes de creches, nada mais é do que o acompanhamento sistemático do desenvolvimento infantil, dos encontros e desencontros do bebê e sua educadora, no caso das creches, orientado pelos indicadores. Este acompanhamento é realizado pelo psicanalista que realiza suas intervenções com intuito de facilitar o desenvolvimento psíquico do bebê a partir de sua relação com a educadora (Kupfer e Pesaro, 2012; Kupfer et al, 2014).

A psicanálise com bebês é um campo de trabalho clínico recente que vem se desenvolvendo ao longo das últimas décadas, clareando a necessidade de uma compreensão e intervenção o mais cedo possível no tratamento de problemas das psicopatologias da infância, sobretudo os mais graves. (Laznik, 2011).

\section{O PROGRAMA GRÃO DE AREIA}

O funcionamento do Grão de Areia, adaptando o modelo francês, não é diário, mas semanal, possuindo duração e horário delimitados previamente. Além disso, as famílias devem se inscrever no programa, e cada grupo é composto por 8 famílias, fixas, o que permite aos profissionais que acolhem estas famílias realizarem uma leitura mais atenta dos IRDIs de cada bebê, bem como o acompanhamento dos mesmos.

Como na Maison Verte, no Grão de Areia estão presentes sempre 3 profissionais no acolhimento aos participantes, envolvendo, além do psicanalista, profissionais das áreas da psicologia, fonoaudiologia, fisioterapia, terapia ocupacional e nutrição, todos atravessados pela psicanálise, atuando como uma equipe interdisciplinar. O psicanalista é o membro referência da equipe, presente em todos os encontros, juntamente com mais dois outros profissionais que se revezam ao longo das semanas e garantem uma flexibilização na relação de transferência, bem como a emergência da transferência para a instituição e para o próprio grupo. A transferência passa a ter endereçamentos múltiplos e passa a ocorrer, como ressalta Barbosa e Silva (2008), em relação ao modo de trabalho comum à equipe, não apenas a uma única pessoa. Além disso, permite um espaço de maior fluidez e de manutenção da palavra em seu caráter corriqueiro, como o modelo da Maison Verte.

A interdisciplinaridade do Programa Grão de Areia parte da premissa de que não podemos ser ingênuos a ponto de acreditar na existência de uma alternativa única na prevenção primária e secundária dos transtornos encontrados na primeira infância, quando corpo e psique encontram-se indiferenciados. Para apreensão do bebê em sua totalidade é imprescindível o olhar de uma esquipe interdisciplinar, uma vez que a interdisciplinaridade possibilita a criação de um espaço de diálogo entre 


\section{Desafios da psicologia no Brasil}

as especialidades, com a psicanálise atuando como "uma linha que costura" (Moreira e Arruda, 2011), os variados saberes, entrelaçando-os (Jerusalinsky, 2002).

Uma equipe interdisciplinar, "costurada", ou "atravessada" pela psicanálise, evita perder-se nas especificidades de cada especialidade, buscando atuar, tal qual uma orquestra, como facilitadora do desenvolvimento global do indivíduo, considerando seus aspectos físicos, psíquicos, emocionais, relacionais e familiares. Trata-se de uma intervenção primordial na relação mãe-bebe auxiliando a família e o bebê a elaborarem e cuidarem do conteúdo latente às perturbações que impedem o desenvolvimento saudável espontâneo (Jeruzalinsky, 2008).

Os princípios da ética psicanalítica são comuns a todos os profissionais do Grão de Areia no trabalho interdisciplinar. Um de seus pilares fundamentais considera que a criança deve ser tomada como sujeito desde o inicio de sua vida. Todas as práticas tomam como principio que no bebê existe um sujeito psíquico, o que é um desafio aos profissionais uma vez que as crianças, muitas vezes em condição de infans, convocam o outro para que fale por elas, especialmente aquelas com dificuldade de linguagem. Faz-se fundamental falar com as crianças enquanto sujeitos, estimular e valorizar a palavra de todos de forma a facilitar a expressão de seus sentimentos e a relação entre as pessoas. Isso produz efeito do lado de qualquer clinico, pois implica em operar sempre no caso a caso, deparando-se com a particularidade de cada participante. (Jerusalinsky, 2008; Lacerda, 2008, Pinho, 2003, Vorcaro, 1999).

Outro pilar fundamental baseia-se no princípio de que nenhum saber é total, de que nenhum conhecimento isolado é capaz de dar conta da complexidade do ser humano, da etiologia das patologias, dos sintomas e do tratamento, pois não há uma verdade única. Levanta-se uma questão epistemológica, cabendo aos profissionais envolvidos reconhecerem a legitimidade de outros campos do conhecimento não coincidentes com seu próprio, os pontos de cruzamento e os vetores que caminham numa mesma direção. Desta forma, o trabalho interdisciplinar exige formação e reflexão continua de toda a equipe. A pratica interdisciplinar requer uma constante interlocução entre os diferentes profissionais visando criar critérios clínicos comuns, e para isso é necessário que o compartilhamento de concepções acerca de como se produz um sintoma e o que ele representa, de como ocorre a constituição psíquica e de como se dão as diferentes aquisições no campo da linguagem, aprendizagem, psicomotricidade e hábitos de vida diária. Estes pontos são fundamentais para que os participantes do grupo Grão de Areia reconheçam a equipe como uma unidade, facilitando a transferência. 


\section{Desafios da psicologia no Brasil}

A transferência, de acordo com Freud $(1980,1912)$, permite a repetição da dinâmica libidinal do sujeito com o analista. No Grão de Areia, seu modo de funcionamento permite o acolhimento deste conteúdo ao longo dos encontros sem que seja personificado por apenas um analista, como no modelo de Dolto. Deste modo, facilita-se o aparecimento do sujeito no campo transferencial, sendo cada participante, criança ou adulto, chamado a se colocar de forma sempre diferente frente à escuta de cada profissional. O sofrimento psíquico é compreendido de forma singular pelos profissionais envolvidos, de forma que este possa segundo Ceccarelli (2005) "via transferência, refazer seus caminhos pulsionais e suas escolhas objetais".

No Grão de Areia também há, como na Maison Verte, a presença de regras e leis a serem seguidas. Há tanto a obrigatoriedade da presença dos pais/cuidadores significativos para a criança durante o encontro, bem como uma delimitação de área, através de piso colorido de borracha, que garante a segurança dos bebês menores e a liberdade daqueles que já se deslocam com facilidade. Como vivemos num país quente, o uso do avental é desnecessário.

A Metodologia IRDI, adaptada ao ambiente clínico e aplicada na observação das relações observadas no grupo terapêutico entre o bebê e seus pais (ao invés do bebê com as educadoras) e também com o grupo, oferece o suporte ao olhar e às intervenções dos profissionais neste espaço grupal lúdico, que impactam na promoção e prevenção da saúde mental dos participantes do grupo.

Os encontros no "Grão de Areia" são divididos em dois momentos. O primeiro, um momento de vivências grupais com a presença de bebês e seus pais/cuidadores principais em um mesmo ambiente, com objetivo de promover possibilidades de interações entre estes e entre os outros membros do grupo, buscando facilitar a dissolução de entraves e mal-entendidos nestes encontros, durante a qual são realizadas as intervenções baseadas na Metodologia IRDI, ou seja, na relação pais-bebês-grupo, a partir da leitura da presença e ausência desses indicadores nas relações. No segundo momento, os bebês permanecem com dois dos profissionais presentes, com objetivo de ações promotoras de desenvolvimento a partir da interação lúdica com os mesmos, com base no observado através da leitura dos IRDIs no momento conjunto com os pais. Estes, por sua vez, dirigem-se para um trabalho de grupo terapêutico e psicoeducativo com objetivo de impactar no empoderamento de sua parentalidade.

No Grão de Areia, a dinâmica do encontro é sempre determinada pelo grupo, que decide do que brincar, do que falar, o que fazer, o que garante a aplicação da regra fundamental da psicanálise: a associação livre. Como dito anteriormente, as famílias se inscrevem para participarem do programa, 


\section{Desafios da psicologia no Brasil}

e desta forma constituem-se grupos fixos, sendo necessário o manejo de questões grupais ao longo do trabalho.

\section{O GRUPO}

A prática da psicoterapia de grupo, compreendida aqui como a aplicação de técnicas psicoterapêuticas a um grupo de pacientes como instrumento de mudança e cura, vem demonstrando ao longo dos anos sua eficácia no auxilio do tratamento dos problemas emocionais (Vicentin e Terzis, 2011). Segundo, Lancetti (1995) a experiência grupal não apenas permite múltiplas expressões dos sujeitos envolvidos, como oferece um espaço para a emergência da solidariedade e de produção de singularidade que ganha força no encontro com o outro.

Mas bebês em grupo? Sim. Dentre vários autores, Buhler $(1943,1946)$ demonstra que desde uma idade muito precoce, os bebês são capazes de interagir, seja através do olhar, do toque, do sorriso, do balbucio ou de seus gestos, o que confirma a observações de importantes autores da psicanálise, como Donald Winnicott e Jacques Lacan, por exemplo, de que a capacidade de interagir está presente no bebê desde o seu primeiro ano de vida, e que desde pelo menos os seis meses de idade o outro já existe para o bebê e será percebido e distinguido progressivamente.

Segundo Lacan (1938), esta relação com o outro depende do tipo de laço que o bebê estabelece com o outro primordial, geralmente a mãe, e garantirá uma identidade ao sujeito. Para Winnicott (1951), a relação com o outro é compreendida em termos de espaço potencial, espaço que delimita o modo de interação do bebê e contribui de forma decisiva para a construção de uma noção bem mais abrangente de objeto, o qual ele pode amar, odiar, agredir, sentir culpa e reparar, ou seja, caminhar rumo à integração. Anteriormente à integração do bebê, os elementos não integrados mantêm-se reunidos através de um ambiente indiferenciado formado pela mãe e o bebê. Winnicott (1965) denomina este estágio, anterior à participação da criança em seu primeiro grupo, de formação primária pré-grupal. Para o autor, o grupo é uma conquista do self, cujo desenvolvimento encontra-se na dependência de um ambiente suficientemente bom, composto pela mãe e o grupo que os rodeia e também fornece o holding a esta mãe.

Vasconcelos et al (2003) adotam uma definição da interação realizada pelos bebês como um espaço de potencial regulação entre os membros do grupo, de modo que se configure um campo interacional, não necessariamente intencional, mas que provoca modificação mutua no comportamento. A fala e a 


\section{Desafios da psicologia no Brasil}

atitude dos adultos do grupo, especialmente dos pais, daí a importância de sua presença, fornecem tessitura cultural à situação do encontro (Rosseti-Ferreira et al, 2012)

O papel dos pais no desenvolvimento é destacado por vários autores, e é a partir desses vínculos afetivos desenvolvidos na relação que se dá o processo de subjetivação e constituição psíquica (Winnicott, 1965). Na presença de entraves nesta relação, a intervenção a tempo realizada no grupo pais-bebê possibilita que a abertura de novas possibilidades de significação da relação e de desenvolvimento do bebê a partir da continência das angústias dos pais e do recolhimento da comunicação do bebê.

"O Grupo tem como objetivo oferecer holding ao bebê e seus pais no sentido de propiciar a possibilidade de um novo ambiente reparador, onde as funções parentais podem ser revistas, possibilitando o atendimento das necessidades básicas do bebê. O sintoma trazido pelos pais é visto como um nó que pode ser desfeito ou afrouxado no trabalho conjunto, propiciando melhores condições de comunicação e desenvolvimento."(Setton e Callia, 2012)

Kupfer (1999) ressalta que o restabelecimento de um campo de linguagem em torno da criança, na medida em podemos supor nesta a existência de um sujeito, a retira de uma posição de repetição patológica que lhe imprima sofrimento psíquico, com o terapeuta e o grupo sustentando um lugar de subjetivação da fala.

Segundo Winnicott (1941), bebês muito pequenos já são capazes de repetir, na transferência, experiências vividas e fantasias inconscientes. A transferência para a experiência do grupo de ansiedades relacionadas aos vínculos iniciais e atuais permite, portanto, a ressignificação e a continência dessas ansiedades, tanto dos pais como dos bebês. Desta forma, os pais podem desenvolver sua capacidade de tolerar tanto seus próprios estados emocionais, como do bebê, aprendendo com a experiência emocional e estando em melhores condições de suprir as necessidades básicas da criança, tornando o grupo terapêutico um ambiente propício ao trabalho de prevenção e promoção de sáude mental na clinica com crianças de 0 a 3 anos (Bechelli e Mendes de Almeida, 2012; Mendes de Almeida e Bechelli, 2009).

Além disso, oferecer escuta regular aos pais, em grupo, propicia a construção de sabres simbólicos em relação aos seus filhos, descontruindo a replicação, a colagem ao discurso cientifico dos profissionais da infância, o que é fundamental para a subjetivação da criança (Kupfer, 1999).

Freud (1921) ressalta o fato de vivermos em grupo, sempre em comunicação uns com os outros. Segundo ele, para a constituição de um grupo é necessário que as pessoas interesse comuns e aptidão 


\section{Desafios da psicologia no Brasil}

para se influenciar mutuamente, tendo os afetos um papel fundamental. São principalmente as ligações amorosas e as identificações que permitem ao grupo manter-se coeso.

O trabalho com grupos de pais-bebês permite o encontro e a comunicação com o outro presente, em posse de sua individualidade, de sua subjetividade, e não apenas como um produto de projeções das fantasias de cada um (Puget, 1998). Insere-se na linha de prevenção e promoção de saúde mental, apoiado na comprovada importância, tanto pela psicanálise como pelas neurociências, das relações iniciais na constituição do psiquismo e da personalidade do sujeito (Verny e Weintraub, 2014; Freud 1969; Dolto, 1984; Winnicott, 1978).

\section{MÉTODO}

A fim de descrever o trabalho com grupo terapêutico de bebês e seus pais/cuidadores realizado no Grão de Areia, serão apresentados dois fragmentos clínicos, um referente ao primeiro momento de grupo, com os bebês e seus pais, e outro ao segundo momento vivido pelo grupo de pais. A partir desses relatos, será possível analisar a contribuição do trabalho em grupo no desenvolvimento psíquico dos bebês e no empoderamento da parentalidade, através das interações entre os participantes e o manejo dos profissionais.

O grupo do qual foi extraído estas vinhetas era composto por quatro com idade cronológica entre 13 e 20 meses (sendo 2 meninas e 2 meninos); e seus pais, com idades que variavam entre 22 e 41 anos. Estes se encontravam semanalmente no Grão Areia pelo período de duas horas, sendo 60 minutos dedicados a cada momento do trabalho. Atuei como psicanalista responsável por este grupo, juntamente aos outros profissionais da equipe cuja presença era alternada e variava de uma a duas vezes por mês.

Apesar da proposta de trabalho do Grão de Areia ser direcionada a qualquer família que tivesse desejo de frequentar um espaço terapêutico lúdico com seus bebês, as famílias que participavam deste grupo apresentavam uma peculiaridade: todos eram bebês nascidos prematuros tardios, entre 35 e 37 semanas gestacionais. Durante o Grão de Areia, através da Metodologia IRDI, pode-se constatar que 2 destes bebês apresentavam sinais de risco de desenvolvimento, sendo encaminhados para intervenções a tempo. Todos continuaram a participar do grupo paralelamente à intervenção. 


\section{Desafios da psicologia no Brasil}

\section{RELATO E DISCUSSÃO DE CASO:}

Ao chegarem para o grupo, os pais como de costumam dirigiram-se para o espaço com piso emborrachado juntamente seus bebês, onde se encontravam os brinquedos, e começaram a mostrar os mesmos para seus filhos, buscando interação. Aos poucos as crianças começam a se movimentar pelo espaço e explorar os objetos. Uma mãe começa a colocar sua angústia em relação ao filho M., de 18 meses, relatando que o pediatra acredita que ele tem sintomas autisticos, e começa a chorar enquanto a criança caminha pela sala com um bloquinho nas mãos. Outro pai também se coloca dizendo: a minha filha ainda não nos atende quando a chamamos pelo nome. E chama a filha, K., que de fato não atende.

Winnicott (1957) ressalta que para os bebês e as crianças pequenas, a vida é uma sequência de experiências intensas e o mundo compartilhado com eles faz parte também de seu mundo imaginativo. Desta forma, é importante não impor a realidade à criança, mas permitir que elas vão aos poucos integrando o mundo real ao seu mundo imaginativo, explorando e adaptando-se ao ambiente em seu próprio ritmo.

Outra mãe se diz muito angustiada ainda com o futuro de sua bebê, L., apesar das melhoras que percebe na filha, pois ainda vê diferenças em relação a outras crianças de sua idade. Olha para a mãe de M., que ainda chora, e lhe diz que realmente é muito difícil saber que há algo errado com o bebê, que ela muitas vezes não sabe o que fazer e se decepciona com as orientações dadas pelo médico. Refere ainda sentir muito medo do futuro, sente-se incapaz de cuidar de sua filha, além de muito culpada pelas suas dificuldades.

Neste momento, torna-se evidente a dificuldade dos pais em parentalizar seus bebês e as angústias decorrentes deste papel junto ao filho real. A mãe de L. e de M., e o pai de K., mostram-se fragilizados e submetidos ao saber do especialista, no caso, do médico. Kupfer (1999) refere que oferecer continência às angústias dos pais na relação com seus bebês auxilia na elaboração dessas angústias depositadas nos filhos.

Uma das terapeutas reflete ao grupo o que observa, declarando que neste momento, todos parecem bastante angustiados com o que dizem os profissionais em relação à saúde dos bebês e de seu desenvolvimento, parecendo desconsiderar o que eles mesmos percebem em relação aos seus filhos.

A mãe do outro bebê, de 13 meses, H., que ainda não permanece sentado sem apoio e emite apenas vocalizações guturais, diz preocupar-se muito com o que será de seu filho no futuro, pois o vê muito 


\section{Desafios da psicologia no Brasil}

atrasado e acha que realmente está no espectro autista. Diz que esse fato a deixa angustiada, mas o que mais a desespera são os olhares das pessoas quando perguntam a idade de H. e, quando ela responde, eles a olham com espanto e um olhar acusatório, como se não soubesse cuidar de seu bebê e esta fosse a razão de seu atraso. Enquanto isso, M. continuava a andar pela sala, sendo observado com muita tristeza por sua mãe, que comenta não suporta os domingos, pois almoçam com os familiares e estes não se cansam de criticar e dar palpites em tudo o que se refere ao filho. Acrescenta ainda que tem usado como estratégia ir embora cedo usando como desculpa recomendações médicas. Segue-se um momento de silencio prolongado.

Winnicott (1965) explicita que na formação grupal pode haver uma expectativa persecutória, relacionada à exposição implicada na formação do self, que pode funcionar tanto como um estímulo para a formação do grupo, como para torna-lo frágil, artificial e instável. O conteúdo persecutório, materializado no olhar acusatório da família e amigos pelas mães de $\mathrm{H}$. e $\mathrm{M}$. parece refletir o sentimento do grupo como um todo, que se encontra sob certa tensão. $O$ autor afirma que o grupo tem condição de contribuir para a integração do sujeito, servindo como uma cobertura materna que ampara.

A mesma terapeuta coloca que percebe que o grupo como um todo parece se identificar com os sentimentos de ameaça e acusações referidos pelas mães de H. e M. O pai de M. concorda e diz que é muito difícil de aceitar e faz com que ele e a esposa fiquem muito angustiados.

Durante esta conversa, M. continuava caminhando pela sala, L. brincava com um carrinho que fazia barulho junto com outra terapeuta, K. encaixava formas geométricas em e H. estava no colo da mãe. De repente, L. começa a chorar pois M. esbarra nela, que cai. Antes que a mãe de L. pudesse ir até eles, M. para, senta-se no chão, olha para L. e passa as mãos em seus cabelos. A terapeuta, dirigindose a M. diz: olha mamãe, como eu estou preocupado com minha amiga que está chorando, faço carinho nela para me desculpar, como sou um bom menino! M. sorri para a terapeuta quando esta se dirige a ele. Sua mãe mostra-se surpresa ao comentar que parecia realmente que o filho estava se desculpando com a amiga, que bonitinho.

No trabalho com pais e bebês lida-se simultaneamente com várias transferências e contratransferências, com cada um dos terapeutas, pais e bebês, além da transferência com a própria parentalidade, com algo que se constrói, segundo Winnicott (1951), a partir da relação, no campo transicional, fundamental para que o bebê possa vir a fazer parte de um mundo compartilhado. Em sua intervenção, a terapeuta utiliza desse campo transicional para facilitar a construção de um modo 


\section{Desafios da psicologia no Brasil}

diferente de M. e seus pais se relacionarem. Eliacheff (1993) afirma ser possível construir com o bebê um sentido para sua experiência, devolvendo-o ao lugar de sujeito de desejo, capaz de falar de si. A disponibilidade física e emocional do terapeuta possibilita conter a angustia e transformá-la, de forma análoga com o bebês e seus pais, oferecendo suporte para que eles possam desempenhar este papel junto ao filho, retirando-os do lugar do não-saber e permitindo que M. não permanecesse fixado à posição imposta pelo saber médico.

O pai de H., calado até o momento, diz que às vezes, em casa, não consegue perceber o que seu filho é capaz de fazer, como durante os encontros com o grupo. Diz que tem começado a notar que o filho não se cabe de alegria quando ele chega do trabalho, que fica todo agitado até que seja pego por ele no colo. Diz ainda sobre como ele adora a hora do banho, brincando com o cabelo da mãe enquanto esta o lava. E que essas coisas que percebe não combinam com o que os médicos e familiares veem de errado no bebê.

Uma terapeuta ressalta o que diz o pai de H., comentando que ele parece estar se referindo a uma preocupação embutida nos pais por terceiros, mas que ele percebe que as crianças têm suas singularidades que talvez outras pessoas não sejam aptas a perceber, por não serem os pais. Os outros membros do grupo parecem concordar.

O grupo demonstra, de acordo com Winnicott (1965), um movimento de integração do grupo neste momento, no qual cada um parece valer-se da cobertura proporcionada pelo grupo para elaboração da persecutoriedade projetada na fala de médicos, amigos e familiares externos ao grupo. Desta forma, abre-se espaço para que os indivíduos, integrados, responsabilizem-se pelo funcionamento grupal.

Outra terapeuta, brincando de bolinhas de sabão com K., com bolinha de sabão diz: mostra pra mamãe como você consegue pegar as bolinhas que estão voando. Ao que a criança sorri e corre abraçar a mãe. A terapeuta oferece a bolinha para a mãe, dizendo que K. prefere brincar com ela. Logo, M. também aproximou-se também para brincar, seguido por L. O pai de $\mathrm{H}$. também pegou um recipiente e começou a fazer bolinhas de sabão para as crianças, convidando a esposa a se aproximar com o filho. Logo, pais, bebês e terapeutas estavam as voltas com as bolinhas de sabão e as sensações que elas provocavam.

Neste trecho de sessão é possível observar o efeito o grupo em promover a experimentação e o encontro com possibilidades diferentes, construindo novas alternativas, novos modos de subjetivação e de existência. O grupo proporciona à criança e aos pais, tanto um espaço de continência como uma 


\section{Desafios da psicologia no Brasil}

armação simbólica dos sistemas de relação com o outro, sendo função do terapeuta a de facilitador (Bleichmar, 1995).

\section{CONSIDERAÇÕES FINAIS}

Ao contrário do modelo médico, classificatório e determinista, a intervenção em grupo de pais-bebês através de uma equipe interdisciplinar atravessada pela psicanálise propicia um espaço de escuta e acolhimento das angustias e ansiedades existentes nas relações pais-bebê que impactam no desenvolvimento psíquico da criança, através do holding promovido pelo grupo e pelos terapeutas. Tornar-se pais exige destes profundas transformações identificatórias e reedição de conflitos psíquicos na relação com a criança. E é a partir desta relação, desses vínculos afetivos primordiais que se inciará o processo de subjetivação e de construção da vida psíquica do bebê.

Entraves nesta relação, tanto em função da dificuldade dos pais no exercício da parentalidade, como dos filhos, pela imaturidade e consequente ineficiência de seus processos comunicativos iniciais, comprometem a formação dos vínculos iniciais e consequentemente, o desenvolvimento do bebê. Vale ressaltar que esta imaturidade é acentuada nos casos dos bebês nascidos prematuros, o que justifica uma atenção especial a esta população.

O holding oferecido pelo grupo tanto aos bebês quanto aos pais na relação com os bebês os auxilia a elaborar suas angustias, até então depositadas em seus filhos. A função de mãe suficientemente boa representada pelo grupo promove o acolhimento de identificações projetivas as quais, quando nomeadas e simbolizadas, permite que haja a emergência de novas significações através de um ambiente reparador.

Neste contexto, os pais podem não apenas rever suas funções parentais, como perceber e compreender seus filhos de maneiras diferentes, tornando-se mais sensíveis ao atendimento de suas necessidades e de sua singularidade, enquanto sujeito. Eles podem se apropriar de seu saber simbólico sobre seus filhos, facilitando sua subjetivação. Desta forma, aquilo que aparece como um sintoma pode ser visto como um obstáculo possível de ser transposto, permitindo que a criança não permaneça fixada, mas que possa se deslocar de discursos sociais e familiares patologizante.

\section{REFERÊNCIAS BIBLIOGRÁFICAS}

LACET, C. (2014). A escuta psicanalítica da criança e seu corpo frente ao diagnóstico de Transtorno de Déficit de Atenção e Hiperatividade (TDAH). 2014. Tese (Doutorado em Psicologia Clinica). 


\section{Desafios da psicologia no Brasil}

MEIRA, M. E. M. (2012). Para uma crítica da medicalização na educação. Psicol. Esc. Educ., v. 16, n. 1, p.136-142.

KUPFER, M. C. M. (2011). Educação terapêutica para crianças com Transtornos Globais do Desenvolvimento: uma alternativa à medicalização da educação. In: Jerusalinsky, A. \& Fendrik, S. O Livro negro da psicopatologia contemporânea. SP: Via Lettera.

KAMERS, M. (2013). A fabricação da loucura na infância: psiquiatrização do discurso e medicalização da criança. Estilos clin. SP, v. 18, n. 1 jan/abr, 153- 165.

ORGANIZAÇÃO MUNDIAL DA SAÚDE. (1993). CID-10: Classificação Estatística Internacional de Doenças e Problemas Relacionados à Saúde. 10ạ edição. São Paulo: EDUSP.

CDCS (CENTERS FOR DISEASE CONTROL AND PREVENTION) (2010). Identified Prevalence Of Autism Spectrum Disorder. Disponível em: http://www.cdc.gov/ncbddd/autism/data.html. Acesso em: 24/7/2015.

JERUSALINSKY, J. (2002). Enquanto o Futuro não Vem: A Psicanálise na Clínica Interdisciplinar com Bebês. Salvador: Ágalma.

KUPFER M. C. M, JERUSALINSKY A. N., BERNARDINO L. M. F, WANDERLEY D, ROCHA P. S. F., MOLINA S. E., et al. (2009). Valor preditivo de indicadores clínicos de risco para o desenvolvimento infantil: um estudo a partir da teoria psicanalítica. Lat. Am.Journal of Fund. Psychopath.;6(1):48-68.

KUPFER, M. C. M.; PESARO, M. E. (2012). Metodologia IRDI - uma intervenção com educadores de creche a partir da psicanálise. Anais Colóquio de Psicanálise Com Crianças, 2,São Paulo.

KUPFER, M. C. M.; BERNARDINO, L. M. F.; MARIOTTO, R. M. M. (2014). Metodologia IRDI: uma intervenção com educadores de creche. In: M.C. M.

MOREIRA, K. M. A e ARRUDA, A. A. A. (2011). Programa de Intervenção Precoce em Saude Mental sob a Perspectiva Psicanalítica e Abordagem Interdisciplinar. Paraiba:Biofar - Revista de Biologia e Farmacia, ISSN 1983-4209, vol 5, n.1

LAZNIK, M. C. (2011). Prefácio. In: M.-C. Laznik, Rumo à fala. Três crianças autistas em psicanálise. Rio de Janeiro, Companhia de Freud, pp. 11-18.

JERUSALINSKY, J. (2002). Enquanto o Futuro não Vem: A Psicanálise na Clínica Interdisciplinar com Bebês. Salvador: Ágalma.

JERUSALINSKY, J. (2008). Clínica interdisciplinar com bebês: qual a importância de considerar a especificidade desse campo clínico? In M. Wajntal (Org.), Clínica com bebês: enlaces e desenlaces (pp.31-50). São Paulo: Casa do Psicólogo.

LACERDA, E. T. (2008). A angústia inicial de transitar entre duas clínicas ou o exercício da castração que a interdisciplinaridade requer. In L. M. Atem (Org.), Cuidados no início da vida: clínica, instituição, pesquisa e metapsicologia (pp. 199-209). São Paulo: Casa do Psicólogo.

PINHO, G. S. (2003). A psicanálise e a clínica interdisciplinar com criança. Correio da APPOA, 11(120), 5-9. 


\section{Desafios da psicologia no Brasil}

VORCARO, A. (1999). Sobre a clínica interdisciplinar. In A. Vorcaro, Crianças na psicanálise: clínica, instituição, laço social (pp. 105-116). Rio de Janeiro: Companhia de Freud.

CeCCARELLI, P. R. (2005). O sofrimento Psiquico na Perspectiva da Psicopatologia Fundamental. Psicologia em Estudo, Maringa, v. 10, n.3, p. 471-477, set./dez.

DOLTO, Françoise. Dificuldade de viver. Porto Alegre: Artes Médicas, 1988.

A causa das crianças, 1908-1988. Aparecida, SP: Idéias e Letras, 2005

VERTE, La Maison. Esquisses Psychanalytiques, n. 5. Paris: Printemps, 1986(1986).

Le jeu des relations. In: DOLTO,Françoise. Aujourd’hui presente. Paris: Éditions

Gallimard, 2000.

As etapas decisivas da infância. São Paulo: Martins Fontes, 1999, p. 159.

(LANCETTI, A. 1995)(Para uma reformulação da experiência Grupal, In G. Baremblit (org), Grupos: Teoria e Tecnica, Rio de Janeiro, Col. Ibrapsi Graal, 83-88

Vicentin, Andrea; Terzis, Antonios. Psicoterapia de grupos: construções teóricas. Anais do XVI Encontro de Iniciação Cientifica e I Encontro de Iniciação em Desenvolvimento Tecnologico e Inovação da PUC Campinas. 2011

Kupfer, MCM. Psicose e autismo na infância: problemas diagnósticos. Estilos da Clinica 4(7), 96-107.. 1999

Buhler, C. Infancia y Juventud: la genesis de la consciência. Buenos Aires. Esparsa-calpe Arg. 1946

Lacan, J. (1938). Os complexos familiares na formação do individuo. In: Outros Escritos. Trad. Vera Ribeira. Rio de Janeiro. Jorge Zahar. 2003

Vasconcelos, CRF et al. A incompletude como virtude: interação de bebês na creche. Psicologia: reflexão e crítica. 16(2), p 293-301. 2003

Rossetti-Ferreira, M. C., \& Costa, N. R. A. (2012). Construcción de vinculos afectivos en contextos adversos de desarrollo: importancia y polêmicas. Scripta Nova - Revista Electronica de Geografia y Ciências Sociales, 16(395).

Setton, Audrey; Callia, Magaly Mirando Marconato. A intervenção precoce em situações de dificuldades alimentares criando condições de comunicação. Anais do II Coloquio de Psicanalise com crianças. Departamento de Psicanalise da criança. Sedes Sapientiae. São Paulo

Kupfer, M. C. (1999). Psicose e autismo na infância: Problemas diagnósticos. Estilos da Clínica: Revista sobre a Infância com Problemas, V (7), pp. 96-107.

VERNY, T. R., WEINTRAUB. O Bebê do amanhã. São Paulo: Barany, 2014. 384p. 


\section{Desafios da psicologia no Brasil}

WINNICOTT, D. W. (1978). Desenvolvimento emocional primitivo. In D. W. Winnicott (Org.), Textos

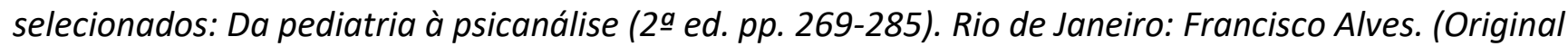
publicado em 1945)

FREUD, S. (1969). Psicopatologia da vida cotidiana. Rio de Janeiro: Zahar Editores.

DOLTO, F. L'image inconsciente du corps. Paris: Seuil, 1984.

Puget, J. (1988). Psicanálise do casal. Porto Alegre: Artmed.

Winnicott (1941) A observação de bebes numa situação padronizada. In: Da pediatria a Psicanalise. Obras Escolhidas. Trad. Davy Bogomoletz. Rio de Janeiro. Imago. 2000.

Winnicott (1965). A família e o desenvolvimento individual. Trad. Marcelo Brandoa Cipolla. 3a ed. São Paulo. Martins Fontes, 2005.

Winnicott (1951). Objetos transicionais e fenômenos transicionais. In: Winnicott, DW (1971). O brincar e a realidade. Trad. José Octavio de Aguiar Abreu e Vanede Nobre. Imago, Rio de Janeiro. 1975.

Winnicott (1957). A criança e seu mundo. Trad. Álvaro Cabral. 4a ed. Rio de Janeiro: Zahar Editores. 1977.

Freud(1921). Psicologia das massas e analise do ego. In: Freud, S. Edição standart brasileira das obras psicológicas completas de Sigmund Freud. V. 18. Rio de Janeiro: Imago. P. 89-179.

ELIACHEFF, Caroline. Corpos que gritam: A psicanálise com bebês. São Paulo: Ed. Ática, 1993

BLEICHMAR, Emilce Dio. Psicoterapia de grupo de crianças. In: Grupos, infância e

subjetividade. Huguet, Cláudio R.; Volnovich, Jorge. Rio de Janeiro: Relume-Dumará, 1995.

Bion, W. R. (1997). O aprender com a experiência. Rio de Janeiro: Imago. (Obra original publicada em 1962).

FLEITLICH, B. W.; GOODMAN, R. Epidemiologia. Rev. Bras. Psiquiatria. São Paulo, v. 22, p. 2-6, dez. 2000. Disponível em: . Acesso em: 3 março de 2009

WILLIAMS, J. et al. Diagnosis and treatment of behavioral health disorders in pediatric practice. Pediatrics. [S.I.], v. 114, n. 3, p. 601-606, 2004.

FREUD, Sigmund. A dinâmica da transferência. In: Standard edition da obra psicológica completa de Sigmund Freud. Rio de Janeiro: Imago, 1980/1912a, v. 12, p.133-143.

BARBOSA, C.A; SILVA, M.N. A. Um lugar para brincar e conversar. In: MILMAN, L.; BEZERRA JR., B. (orgs.). A Casa da Árvore: Uma experiência inovadora na atenção à infância. Rio de Janeiro: Garamond, 2008, p. 15- 29.

Freud, S. (1972). Psicologia das Massas e Análise do Ego. In Obras Completas de Sigmund Freud - Edição Standard Brasileira. Rio de Janeiro: Imago. (Obra original publicada em 1921). 


\section{Desafios da psicologia no Brasil}

MENDES DE ALMEIDA, M.; BECHELLI, I. A. B.; Grupo de Atendimento Pais-Bebês: Alternativas em Prevenção no Contexto Institucional e Alcance Terapêutico, X Congresso Nacional da Sociedade Portuguesa de Grupanálise e Encontro Luso Brasileiro de Grupanálise e Psicoterapia Analítica de Grupo, “Identidade Grupanalítica em Tempos de Mudança," em Lisboa - Portugal, 2009,

BECHELLI, I. A. B.; MENDES DE ALMEIDA, M.; Grupo de Atendimento a Pais e Bebês: Um Ninho Para o Desenvolvimento da Parentalidade ,Il Jornada de Psicanálise de Criança e Adolescente: novas perspectivas, Sociedade Brasileira de Psicanálise, São Paulo, 2012. 


\section{Capítulo 54}

\section{DOCÊNCIA EM PAUTA: ESTRESSE E BURNOUT SOB O PONTO DE VISTA PSICOLÓGICO}

DOI: $10.37423 / 200200306$

Daniela Arroyo Fávero Moreira danielaarroyo07@hotmail.com

Márcia Cristina Argenti Perez marcia.argenti@unesp.br
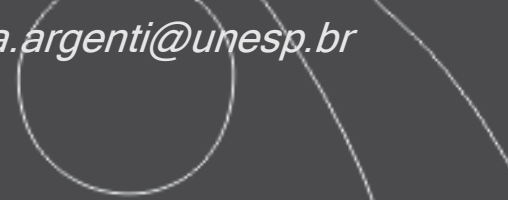

Resumo: Esta é uma pesquisa literária onde se aponta à importância da qualidade de vida das pessoas, principalmente nas esferas biológica, psicológica e social, para que haja um bom esclarecimento do ser humano consigo mesmo.

Pretende-se apresentar, pormeio de revisão literária, a Síndrome de Burnout expondo os seus principais ๔onceitos levando em conta o contexto organizacional e promoyendo reflexões quanto ao ambiente escolar. Espera-se identificar também se existe alguma relação entre a Síndrome e a ausência na qualidade de yida no trabalho.

Como objetivo, procura-se refletir sobre 0 conceito de saúde e em contraponto, o esgotamento emocional, de modo que seja possivel correlacionar-conceitos que possibilitem a verificação ou_a-possibilidade-de-identificar as possíveis causas e consequências da pessoa que sofre deste esgotamento mental e se existe alguma possibilidade dèpreveni-la-para evitar que este desconforto se instale.

Palavras-chave: Psicologia. Qualidade de vida. Estresse. Síndrome de Burnout. 


\section{Desafios da psicologia no Brasil}

\section{INTRODUÇÃO}

Nota-se atualmente que as pessoas estão mais suscetíveis ao estresse do que no passado. Provavelmente um dos motivos seja o fato de que as cobranças (externa e pessoal) juntamente ao acúmulo de funções, estarem cada vez mais acentuadas e em constante processo de transformação. Tal cenário encontra-se também no ambiente escolar por tratar-se de um ambiente onde se lida com vários conflitos (hierarquia, pressão, convivência social, autoestima) onde espera-se que os mesmos possam ser solucionados ou pelo menos, compreendidos para que haja uma boa convivência grupal. É neste contexto que se procura ressaltar para a importância do bem-estar do indivíduo principalmente nas esferas biológica, psicológica e social, para que haja um bom esclarecimento do ser humano consigo mesmo em contexto global e para que o mesmo exerça, em seu trabalho, um bom desempenho de suas funções.

Com a revisão de literatura será possível, de forma simples, identificar a importância de um bom compreendimento de si mesmo e possíveis consequências caso o indivíduo não valorize os três aspectos mencionados relativos à personalidade humana.

Com o objetivo de tentar refletir sobre o conceito de saúde, pretende-se correlacionar algumas leituras enfocando o tema em questão. A autora MARY SANDRA CARLOTTO (2010) afirma que o trabalho provoca desgaste e adoecimento. Em seu livro intitulado como Síndrome de Burnout: o estresse ocupacional do professor, na página 14, aponta:

Observou-se, assim, que os professores têm mais risco de sofrimento psíquico de diferentes matizes, e a prevalência de transtornos psíquicos menores é maior entre eles em comparação a outros grupos. Estudo epidemiológicos têm evidenciado a sobrecarga emocional proveniente das exigências de investimentos pessoais dos professores em suas relações com alunos, pais dos alunos e comunidade (BATISTA, 2010; CARLOTTO; PALAZZO, 2006; DELCOR et al., 2004; GASPARINI; BARRETO; ASSUNÇÃO, 2006).

Frente ao exposto, é preocupante o bem-estar do professor. Por isso e pretende-se colaborar, orientando sobre os sintomas correlacionados com esta Síndrome, levando em consideração o possível diagnóstico precoce preventivo e a busca de um tratamento adequado quando observados sintomas evidentes ou crônicos, visto que a Síndrome de Bournout é considerada uma manifestação de fundo emocional.

Sendo assim, de acordo com MARY SANDRA CARLOTTO (2010, p. 35): 


\section{Desafios da psicologia no Brasil}

Burnout é a expressão inglesa para designar aquilo que deixou de funcionar por exaustão de energia"(FRANÇA, 1987, p. 197). O termo burnout foi inicialmente utilizado em 1953, quando da publicação do estudo de caso de Schwartz e Will conhecido como 'Miss Jones'. Neste, é descrita a problemática de uma enfermeira psiquiátrica desiludida com o seu trabalho. Após uma breve ausência de seu trabalho, miss Jones sentia-se trabalhando abaixo de sua capacidade, percebia insatisfação por parte de seus colegas e observava que estes interagiam menos com seus pacientes. Ela tinha a impressão de que os pacientes se afastavam, estavam mais negativistas e resistentes, apresentavam um aumento de comportamentos agressivos e hostis, e realizavam mais cobranças sobre seu trabalho.

Nesta síndrome, acredita-se que docentes são expostos com freqüência a riscos psicossociais por lidarem com a sobrecarga do trabalho e os esforços nele envolvidos a fim de conquistarem seus objetivos atuais e/ou futuros. Através da revisão da literatura, pesquisas constatam um alto índice de desmotivação no Brasil não só em professores, mas também em profissionais de várias áreas, principalmente da área de saúde, que envolve vínculos afetivos, necessitando que tais profissionais possuam um equilíbrio psicológico. Um desequilíbrio psicológico pode gerar os primeiros sintomas da Síndrome de Burnout ou até mesmo transparecer sintomas não antes percebidos que necessitem de um acompanhamento.

Mais recentemente, as organizações têm revelado maior atenção quanto 'a significação e 'a repercussão do trabalho sobre o trabalhador, assim como os efeitos desta relação na instituição. Estudos demonstram que o desequilíbrio na saúde do profissional traz conseqüências na qualidade dos serviços prestados e no nível de produção. Os lucros também são afetados na medida em que os custos se incrementam em absenteísmo, auxílio-doença, reposição de funcionário, transferências, novas contratações e treinamento. Devido a estas e outras conseqüências, tem crescido a perspectiva de se investigar e investir na qualidade de vida do trabalhador.

( PEREIRA, A. M. T. B., Burnout: por quê? Uma introdução-. In: Ana Maria T. Benevides Pereira (Org.) p. 14)

Para uma melhor compreensão sobre o que é a Síndrome de Burnout revisaremos a leitura sobre o tema. Sabe-se que a mesma é o resultado do esgotamento físico e mental, possíveis de serem observados, e fatores sociais resultantes desse esgotamento, principalmente o trabalho. 


\section{Desafios da psicologia no Brasil}

Ana Maria T. Benevides Pereira (2002), autora do livro Burnout: Quando o trabalho ameaça o bemestar do trabalhador, aponta no Capítulo 2, da página 20:

A maioria dos autores indicam Herbet J. Freudenberger como o primeiro a utilizar esta denominação em seu artigo staff Burn-out, datado de 1974, para alertar a comunidade científica dos problemas a que os profissionais de saúde estão expostos em função de seu trabalho.

Através da citação observa-se que desde a década de 70, já existia a preocupação com a saúde do trabalhador e os demais fatores envolvidos neste processo, voltados principalmente para o ambiente de trabalho, de modo que se acreditava que os mesmos pudessem ser diagnosticados, de forma precoce, evitando que o fator prejudicial se instalasse interferindo na esfera pessoal e social do trabalhador.

A partir de então iniciaram-se estudos voltados para a saúde relacionada ao trabalho, confrontando com os fatores emocionais e sociais.

Complementando:

As leis brasileiras de auxílio ao trabalhador já contemplam esta síndrome. No Decreto n. 0 3048/99, de 6 de maio de 1996, que dispõe sobre a Regulamentação da Previdência Social, em seu Anexo II, que trata dos Agentes Patogênicos causadores de Doenças Profissionais, conforme previsto no Art. 20 da Lei n.o 8.213/91, ao se referir aos transtornos mentais e o comportamento relacionados com o trabalho (Grupo $\mathrm{V}$ da CID-10), no inciso XII aponta a Sensação de Estar Acabado ("Síndrome de BurnOut", "Síndrome do Esgotamento Profissional") (273.0). No entanto, o desconhecimento sobre a síndrome ainda é grande e não há instrumentos validados e sendo comercializados para este fim, que possa subsidiar e fundamentar o diagnostico (PEREIRA, A. M. T. B., Burnout: O processo de Adoecer pelo Trabalho. In: Ana Maria T. Benevides Pereira (Org.) p. 24).

Atualmente, o instrumento de pesquisa encontra-se em fase de teste, adaptando-se a população, para se validar seus resultados. Nesta síndrome um dos aspectos mais marcantes que pode-se correlacionar à mesma é a presença de sintomas depressivos, seu surgimento pode estar diretamente relacionado a tentativas sem sucesso de lidar com o estresse, resultando em frustrações, que geram a sensação de desânimo. Assim por não alcançar o resultado esperado, essa pessoa desenvolverá uma tendência depressiva sendo muitas vezes necessário o acompanhamento especializado (médico psiquiatra e/ou psicólogo) na persistência dos sintomas. 


\section{Desafios da psicologia no Brasil}

$\mathrm{Na}$ depressão, sob o ponto de vista psicológico, entende-se que os sintomas se manifestam e interferem em todas as situações da vida da pessoa e quando estes sintomas começam, mas quando isto passa a tornar-se a fazer parte do dia-a-dia aí o fato torna-se preocupante.

Em contraponto, já no Burnout compreende-se que o indivíduo possa apresentar dificuldade em lidar com situações diárias em apenas uma esfera, mas não necessariamente precisa estar desestabilizado em outra.

É preocupante o fato de que algumas pessoas não percebem o quanto é importante trabalhar enfocando a qualidade de vida a fim de que se possa garantir o bem-estar global do ser humano em seus fatores biológico, psicológico e social. Acredita-se que estando bem nestes três fatores o equilíbrio para o desenvolvimento de atividades será mais eficaz tendendo a um melhor desempenho e qualidade na produção.

Diferenciando estresse de Burnout PEREIRA (2002, p. 26) afirma que:

Desta forma, o estresse é um processo temporário de adaptação que compreende modificações físicas e mentais.

A palavra estresse obteve tamanha difusão, que acabou por se transformar quase que em um sinônimo de qualquer tipo de alteração, em geral negativa, sentida pelo indivíduo. É comum se ouvir um "não me estresse" nos casos em que uma pessoa se sinta pressionada, entristecida, ou venha a ter alguma expectativa (boa ou ruim) por algo que possa vir a suceder. $O$ menor sentimento de ansiedade ou tensão se atribui ao estresse, e no emprego cotidiano (e por vezes até mesmo no meio científico) observa-se uma confusão, pois o estresse é encarado tanto como o elemento desencadeante como o resultado da evolução.

O estresse sempre estará presente na vida cotidiana seja de forma positiva ou negativa. Espera-se que as pessoas encontrem formas de lidar com situações desgastantes. De forma geral são vários os agentes estressores e vale-se ressaltar alguns exemplos retirados do livro de PEREIRA (2002):

- Estressores físicos: ruídos, frio, calor intenso, dor, fome, etc;

- Estressores cognitivos: situação vivenciada que ficou marcada por aspecto negativo;

- Estressores emocionais: sentimentos de perda, medo, raiva, angústia etc.

Ainda PEREIRA (2002) aponta no livro Burnout: Quando o trabalho ameaça o bem-estar do trabalhador, no Capítulo 2, páginas 28 e 29, que existem três fases no processo de estresse. 


\section{Desafios da psicologia no Brasil}

Distinguem-se três fases no processo de estresse: reação de alarme, etapa de resistência e etapa de esgotamento.

a) Reação de alarme: é a fase em que o organismo é exposto ao agente estressor, quando se ativa o estado de alerta. Segundo Sandín (1995), esta etapa tem dois ciclos: o primeiro seria a fase de choque, constituído pelo momento da aparição do agente sentido como nocivo ou ativador e, o segundo, o que ele denominou de fase de contrachoque, quando o organismo põe em funcionamento suas defesas.

Quando possível, prevenir desconfortos é sempre importante. Entende-se que o estresse somente destaca-se quando a pessoa já alcançou o seu patamar de afazeres no sentido de estar no seu limite de paciência e/ou tolerância para ou por algo. Limite este seja para a leitura de um texto, diálogo em momento de reunião de trabalho, ou demais contextos que se exija paciência, dentre outras situações. Sendo assim, existem duas saídas para que haja uma tomada de atitude: agir de modo a enfrentar a situação ou esquivar-se e correr o risco de sofrer sérias conseqüências. Esta decisão é crucial para que o estresse se perpetue ou não e a energia, fruto do estresse bem acentuado, se canalize de maneira saudável com a realização de qualquer atividade que traga a satisfação pessoal.

Ainda sobre o estresse:

Persistindo o perigo ou desafio, passa-se ao estágio seguinte.

b)Etapa de Resistência: a ativação do organismo permanece, entretanto, manter a fase de alarme no mesmo patamar levaria o organismo rapidamente a exaustão e, em conseqüência, 'a morte. Nesta fase, o organismo tende a uma adaptação ao agente estressor. (PEREIRA, A. M. T. B., Burnout: O processo de Adoecer pelo Trabalho. In: Ana Maria T. Benevides Pereira (Org.) p. 29)

Estar em sintonia consigo mesmo, é a melhor maneira de lidar com o estresse. Para isto, espera-se que trabalhos sejam desenvolvidos para este bem-estar. Afinal, quando não há este trabalhado, por parte do indivíduo, pode-se causar grandes impactos no seu bem-estar psicológico, comportamental e social acarretando, muitas vezes, em sérias consequências na saúde-doença.

De qualquer forma, os resultados da informação sobre o impacto do stress na saúde-doença/ bem-estar tem revelado uma associação consistente entre o stress, designadamente profissional, e um maior risco de doença. (FERNANDES, 2008, p. 33) 


\section{Desafios da psicologia no Brasil}

Autores apontam que existem estratégias, ou coping, que podem ser utilizadas para lidarem com o estresse. Este processo pode ser encarado como esforços cognitivos a fim de que se criem estratégias objetivando amenizar o sofrimento, propriamente dito, e meios a fim de lidar com o estresse.

Do ponto de vista avaliativo, o coping de evitamento parece ser benéfico a curto prazo, quando a situação é percebida como incontrolável ou como recorrente, enquanto o coping activo ou de aproximação se revela mais adequado nas situações em que é possível controlar o problema (Semmer, 1996).

O coping de evitamento possibilita a sensação de alívio imediato da situação estressante, mas existem também os casos onde há a possibilidade de a situação ser corriqueira e difícil de ser controlada.

Já o coping ativo pode ser mais maleável onde, nesses casos, a pessoa lida com aproximações sucessivas frente ao estímulo estressor persistente e com isso busca-se maneiras as quais podem ser pontuadas como alternativas a fim de lidar com o estresse.

Comparando o que foi pontuado anteriormente com o que é observado em pacientes nos atendimentos clínicos, nota-se que os pacientes procuram exporem-se a fatos já vivenciados e que causaram desconfortos, mas desta vez em circunstâncias mais favoráveis. Como exemplo, pode-se dizer que situações mal resolvidas ocorridas no passado são relevantes para tal ilustração. Diante disto, a pessoa procura revivê-la, de maneira em que se acredita ser mais saudável, como tentativa de reelaborar a situação que resultou em frustração. Alguns autores nomeiam tal situação como experiência emocional corretiva (EEC). (SEMMER, 1996)

Estima-se que seja possível uma maior integração egóica a partir da (re) vivência de situações conflitivas dentro de um novo padrão de pensamento e comportamento. O que se pretende afirmar é que se a pessoa conseguir alcançar a totalização do seu EGO, que representa os impulsos e desejos conscientes e inconscientes, esta pessoa muito possivelmente tenderá a crescer no âmbito emocional e social e como conseqüência, sob o ponto de vista psicológico, possivelmente terá maior autocontrole de suas emoções sentindo-se mais motivado para a realização de suas atividades rotineiras.

No decorrer do livro intitulado como Burnout e engagement em contexto organizacional: estudos com amostras Portuguesas, as organizadoras citam: 


\section{Desafios da psicologia no Brasil}

Latack (1986) propõe uma conceptualização integrativa em que inclui três grandes categorias de coping: controlo, relativo a acções e reavaliações cognitivas pró-activas; escape, referente a acções e reavaliações cognitivas de tipo evitador, e gestão de sintomas de stress. Esta autora considera que as estratégias de acção e de reavaliação cognitiva correspondem respectivamente às categorias de coping centrado na resolução do problema e de coping centrado na regulação das emoções, propostas por Lazarus e Folkman (1984), mas procura especificar os tipos de acção e de reavaliação cognitiva que ocorrem, subdividindo-se em estratégias de controle e de escape.

A autora pontua que acredita ser importante incluir uma nova categoria de coping sendo esta relacionada a estratégias de gestão de sintomas emocionais e físicos associados às vivências de estresse.

No livro são correlacionados vários pontos de vista sobre esta mesma questão e cada autor utiliza-se da abordagem em que acredita para lidar com o estresse. De acordo com os mesmos, o acúmulo de estresse com os aborrecimentos diários é chamado de hassless e afirmam que este pode exercer influência negativa na saúde das pessoas.

“...Hassless são as exigências irritantes, frustrantes e penosas que em algum grau caracterizam as transacções quotidianas com o ambiente. Incluem problemas práticos aborrecedores como perder objetos ou os engarrafamentos de trânsito, e ocorrências fortuitas como o mau tempo, bem como discussões, desapontamentos, e preocupações financeiras e familiares..." (FERNANDES, 2008, página40)

Esses momentos são representações importantes a serem levadas em consideração já que interferem diretamente na tomada de atitude quando a pessoa se encontra desestabilizada, acarretando a perda do controle da situação geradora do estresse.

Pode-se dizer que, muitas vezes, são considerados geradores de desequilíbrio emocional quando o indivíduo não está preparado para lidar com determinadas situações que envolvem maior capacidade de estabilidade emocional.

O stress profissional crónico e em particular os aborrecimentos diários da vida profissional têm também sido invocados como causa fundamental do burnout. (...) Também Maslach (1982) considera que o burnout, mais do que uma reacção a crises agudas ocasionais, é uma resposta ao stress crônico. (FERNANDES, 2008, página 41) 


\section{Desafios da psicologia no Brasil}

O desgaste físico e mental, na Síndrome de Bournout, é muito intenso e pode gerar sérios conflitos internos (mental) e externos (comportamental) e por meio deste agravamento, gerar sérias consequências como, por exemplo, o desenvolvimento de uma depressão ou quadro psiquiátrico de ansiedade.

São várias as diretrizes que norteiam o estudo em questão sendo várias as convergências e divergências quanto a alguns pontos de vista. Por exemplo:

A Concepção Clínica: Nesta perspectiva, a síndrome de Burnout é caracterizada como um conjunto de sintomas (fadiga física e mental, falta de entusiasmo pelo trabalho e pela vida, sentimento de impotência e inutilidade, baixa auto-estima), podendo levar o profissional à depressão e até mesmo ao suicídio (PEREIRA,2002).

Este conjunto de sintomas e fatores interligados faz com que em longo prazo a pessoa sinta-se exausta e de certa forma tudo o que a cerca passe a deixar de ser interessante e estimulante para o bom desempenho das atividades rotineiras pelo fato do esgotamento mental perpetuar.

Desta forma, acarreta-se uma tendência a sintomas depressivos e se os mesmos não forem identificados a tempo de ser trabalhada pelo próprio indivíduo, ou através de terapia e outra especialidade, é possível que se transforme em uma grave depressão ou ansiedade.

A crise é relacionada à perda da construção imaginária do tempo, desejos do sujeito ou até mesmo ansiedades sofridas em momentos de estresse, tensão e que desestabilizou o equilíbrio interno (mental) da pessoa. Ou seja, esta crise é provocada por um fato novo e o mesmo provocará mudanças no pensamento da pessoa que já era constituído de certas crenças sobre si mesmo e o mundo exterior. Freudenberger é um psicanalista representativo desta concepção teórica e enfoca a questão relacionada ao contexto social como fator agravante do estresse. Pontua-se:

A Concepção Sócio-Psicológica: Em trabalho quase que paralelo ao de Freudenberger, as psicólogas sociais Christina Maslach e Susan Jackson (1977) evidenciaram as variáveis sócio-ambientais como coadjuvantes do processo de desenvolvimento do Burnout. (PEREIRA, 2002, página 35)

Esta concepção enfoca o aspecto social como elemento facilitador ao desenvolvimento do Burnout e pode-se correlacionar ao fato de que quando existe privação por parte do aspecto físico relacionado 


\section{Desafios da psicologia no Brasil}

à condição do trabalho e/ou aspectos emocionais tendendo ao esgotamento emocional são possíveis de que o cansaço, tendencial à desmotivação e baixa autoestima do indivíduo. Christina Maslach e Susan Jackson avaliam três dimensões as quais consideram ser fundamentais para identificar a presença ou a ausência da Síndrome de Burnout. São eles: a exaustão profissional, a despersonalização e a reduzida realização profissional. (PEREIRA, 2002, página 35)

Acredita-se que toda esta relação entre estímulo (aprendizado) e resposta (conhecimento) é mediada por algo (estresse). Portanto, sente-se que sob esta perspectiva, é que o aprendizado promoverá o desenvolvimento porque é através deste processo onde se entra em contato com a realidade, onde o indivíduo adquirirá informações, habilidades, atitudes, valores e demais fatores cuja importância para o desenvolvimento humano e internalização da cultura são fundamentais.

Quanto à concepção organizacional:

A Concepção Organizacional: Baseados na Teoria das Organizações, para Golembiewski, Hiller \& Dale (1987), o Burnout é a conseqüência de um desajuste entre as necessidades apresentadas pelo trabalhador e os interesses da instituição(PEREIRA,2002).

A cultura organizacional está relacionada à dinâmica da instituição, onde se espera que as pessoas precisam estar em constante comunicação e preferencialmente, é desejável que haja completa harmonia de modo que se estimule visando um ambiente acolhedor para que este proporcione objetivos em comum a serem conquistados. Pode-se afirmar que a mesma envolve normas, comportamentos e valores sociais que regem e norteiam as diretrizes do vínculo institucional. Notase, que em alguns casos, pode haver choque de culturas, pessoal com a do trabalho, e este fator pode acarretar em desânimo ou repressão pelo fato de que a pessoa precisa do emprego e precise aceitar as normas, mesmo sem crer nelas, ou estar aberto a compreendê-las, sendo passível de mudanças em sua forma de pensar e agir.

Pensa-se que o envolvimento de uma equipe de trabalho depende de um ambiente harmonioso, acolhedor e no sentimento de preocupar-se com o outro e demais atividades diárias. Essas questões correlacionam-se no sentido de a pessoa acatar e aceitar responsabilidades que lhe são muitas vezes impostas. Sob o ponto de vista psicológico acredita-se que esta sensibilidade pode ser herdada ou desenvolvida. Quando esta é trabalhada desde a infância tende a ser compensada na idade adulta de modo que se possibilite o fácil convívio social e melhor desenvolvimento na tomada de decisões em situações conflitantes. 


\title{
Desafios da psicologia no Brasil
}

Outro modelo importante no que diz respeito à Síndrome de Burnout é:

\begin{abstract}
A Concepção Sócio-Histórica: Esta vertente prioriza o papel da sociedade, cada vez mais individualista e competitiva, mais do que os fatores pessoais ou institucionais. Desta forma, ocupações voltadas para a ajuda e o desenvolvimento do próximo, que se aproximam de uma perspectiva comunitária, são incompatíveis com os valores predominantes na sociedade atual. Carlotto (1999) aponta Sarandon como a autora de maior destaque nesta corrente. (PEREIRA, 2002, páginas 36-37)
\end{abstract}

Diante do exposto pensa-se que a cultura é um fator determinante e que merece destaque por ser forte em termos de estabilidade. Pretende-se dizer que dificilmente os aspectos culturais de um indivíduo são passíveis de mudanças, principalmente aquelas enraizadas há anos. Mas que é possível as pessoas adaptarem-se as mudanças de acordo com as condições que o meio social tem a oferecer. São vários os sintomas que podem estar associados ao Burnout. Os físicos podem ser caracterizados como fadiga constante e progressiva, dores musculares ou osteomusculares, distúrbios do sono, cefaléias, enxaquecas, perturbações gastrointestinais, imunodeficiência, transtornos cardiovasculares, distúrbios do sistema respiratório, disfunções sexuais e alterações menstruais nas mulheres.

Sobre os sintomas psíquicos pode-se mencionar a falta de atenção, de concentração, alterações de memória, lentificação do pensamento, sentimento de alienação, sentimento de solidão, impaciência, sentimento de impotência, labilidade emocional, dificuldade de auto-aceitação, baixa autoestima, astenia, desânimo, disforia, depressão, desconfiança e paranóia.

Em relação aos sintomas comportamentais pode-se apontar a negligência ou escrúpulo excessivo, irritabilidade, incremento da agressividade, incapacidade para relaxar, dificuldade na aceitação de mudanças, perda de iniciativa, aumento do consumo de substâncias, comportamento de alto risco e suicídio.

Já sobre os sintomas defensivos apontam-se a tendência ao isolamento, sentimento de onipotência, perda do interesse pelo trabalho, absenteísmo, ímpetos de abandonar o trabalho, ironia e cinismo.

Todos os dados mencionados foram retirados das entrelinhas do livro Burnout: Quando o trabalho ameaça o bem-estar do trabalhador, entre as páginas 38 a 43 de Ana Maria T. Benevides Pereira, 2002. Observa-se que ações grupais podem ser reforçadoras do ego (mente) ou podem enfraquecê-lo. $O$ que se pretende afirmar é que o ambiente de trabalho pode ser algo que venha a reforçar 


\section{Desafios da psicologia no Brasil}

positivamente o estado psicológico da pessoa ou até mesmo pode abafa-lo de forma negativa. Tudo dependerá da relação de trabalho estabelecida e o tipo de vínculo/ convivência estabelecido entre os trabalhadores da mesma instituição.

Complementando:

Até o momento, não há um consenso sobre um modelo de desenvolvimento do processo no que diz respeito a esta síndrome. Diversos autores, em contextos diferentes, empregando métodos distintos, obtiveram resultados diversos (PEREIRA,2004, página 43).

Através da revisão de literatura pode-se constatar que existem estudos objetivando a adaptação e em alguns casos, a tentativa de validação e aperfeiçoamento de instrumentos a fim de rastrear sintomas relativos a esta síndrome e possivelmente, num futuro, auxílio na avaliação, para diagnóstico clínico.

Uma pessoa com síndrome de Burnout não necessariamente deve vir a denotar todos estes sintomas. O grau, o tipo e o número de manifestações apresentadas dependerá da configuração de fatores individuais (como predisposição genética, experiências socioeducacionais), fatores ambientais (locais de trabalho ou cidades com maior incidência de poluição por exemplo) e a etapa em que a pessoa se encontre no processo de desenvolvimento da síndrome.

Pode-se notar que vários destes sintomas também são característicos dos estados de estresse; no entanto, os que se referem aos distúrbios defensivos são mais freqüentemente apresentados nos processos de Burnout. (PEREIRA, 2002, páginas 4445)

Sendo assim, pode-se afirmar que os reflexos dos sintomas já mencionados interferem de forma negativa na saúde do trabalhador em seus aspectos individual, profissional e organizacional. Interferem de forma direta na qualidade do trabalho e/ou vida e no desempenho de funções e afazeres diários.

No Burnout, além destes fatores, a qualidade do trabalho é comprometida não só pela desatenção e negligência, mas especialmente pela relação entre o profissional e a pessoa a quem presta atendimento ou serviços, com o distanciamento, falta de empatia e hostilidade evidenciados. (PEREIRA, 2002, página 46) 


\section{Desafios da psicologia no Brasil}

É importante que, por parte do indivíduo, haja compreensão quanto à dinâmica da instituição, e todos os fatores e pessoas nela envolvidos, objetivando facilitar relacionamentos, propiciar novas formas de interação, conquistas e de certa forma, fazer com que se abram novas perspectivas e experiências futuras, que visem o enriquecimento pessoal e profissional.

\section{CONCLUSÃO}

Nos dias atuais as pessoas estão cada vez mais sobrecarregadas e com isso estão mais expostas a situações geradoras de estresse e desgaste emocional.

Pode-se constatar que o trabalho, quando não bem administrado pelo próprio indivíduo, pode ocasionar desgaste e adoecimento.

No contexto educacional acredita-se que docentes são expostos com maior freqüência a riscos psicossociais justamente por lidarem com esta sobrecarga de trabalho e demais assuntos correlacionados que exijam para sua produção, tempo e esforço mental.

É importante o desenvolvimento de trabalhos preventivos voltados para a questão da saúde coletiva, do trabalhador, a fim de minimizar os efeitos causados pelo desgaste físico e emocional. Com relação a esta postura, pesquisas apontam que é possível minimizar os sentimentos e os sintomas negativos os quais são considerados fortes precursores para o desenvolvimento e cronificação da Síndrome de Burnout e do Estresse.

Sob o ponto de vista psicológico, a Síndrome de Burnout pode ser considerada como uma tentativa frustrada da pessoa em lidar com situações estressantes.

Difere da Depressão porque no estado depressivo é como se a pessoa sentisse um bloqueio emocional em todas as esferas de sua vida. Seja na parte psicológica, comportamental ou social.

Por outro lado, na Síndrome de Burnout, a pessoa pode estar com dificuldade e/ou problemas na dimensão do relacionamento social, mas desempenhar bem atividades que se utilizem do estado emocional como, por exemplo, atividades desenvolvidas em grupo, atendimento a pacientes, dentre outros pontos relacionados a estes contextos.

Existem várias as estratégias possíveis a serem utilizadas como tentativas para o indivíduo procurar lidar com situações estressantes, mas cabe ressaltar que é imprescindível que a pessoa que está sentindo o sofrimento aceite o propósito. Um exemplo ilustrativo é utilizar-se do recurso do coping onde o indivíduo cria estratégias a fim de que possibilite sensação de alívio imediato para a situação estressante. 


\section{Desafios da psicologia no Brasil}

Também é cabível fazer com que a pessoa tente refazer sua vivência estressante de modo que se utilize de aproximações sucessivas frente ao estímulo estressor. Este processo chama-se experiência emocional corretiva (EEC), uma forma da pessoa reelaborar seus sentimentos e experiências frustradas, já vivenciadas e que causaram mal-estar, sofrimento e bloquearam o indivíduo como tentativa de proporcionar auxílio na resolução de problemas e tomada de atitude em seu dia a dia e relacionamento interpessoal.

Desta forma, constata-se que é importante que haja o fortalecimento do EGO (mente onde se encontram os impulsos e os desejos consciente e inconsciente) porque se acredita que pessoas estando bem conseguem possuir um maior autocontrole de suas emoções, autonomia e qualidade na produção, trabalho e desempenho de outras funções, e além do mais, acredita-se que seja possível que estas mesmas pessoas apresentem motivação mais elevada do que pessoas que não trabalham seu estado emocional.

Quanto às abordagens teóricas pertinentes ao assunto em questão, são várias. Diferentes estudos e enfoques norteiam sobre o temático estresse e Burnout, mas pode-se afirmar que Freudenberger foi o primeiro a utilizar a denominação, por volta da década de 70 e Maslach (1982) é um dos nomes mais relevantes sobre o tema.

Conclui-se que é imprescindível o desenvolvimento de projetos voltados para a saúde do trabalhador, principalmente para aquelas pessoas que atuam na área da saúde e educação por estarem propensos a maior pressão e conflitos interpessoais - fatores estes propensos ao desenvolvimento do estresse, Burnout e possivelmente, quando os sintomas são acentuados, de forma crônica, uma possível depressão.

\section{AGRADECIMENTO}

O presente trabalho foi realizado com o apoio da Coordenação de Aperfeiçoamento de Pessoal de Nível Superior Brasil (CAPES) - Código de Financiamento 001.

\section{REFERÊNCIAS}

CARLOTTO, M. S. Síndrome de burnout. Síndrome de burnout: o estresse ocupacional do professor. Canoas: Editora ULBRA, 2010. 159 páginas.

CARLOTTO, M. S. Síndrome de burnout: o estresse ocupacional do professor. Canoas: Editora ULBRA, 2010. 


\section{Desafios da psicologia no Brasil}

FERNANDES, A. (Direção) CHAMBEL, M. J \& PINTO, A. M(Orgs.). Burnout e engagement em contexto organizacional: estudos com amostras Portuguesas. Coleção Ciências Empresariais. Livros Horizonte LDA: Lisboa, 2008.

PEREIRA, A. M. T. B., Burnout: por quê? Uma introdução-. In: Ana Maria T. Benevides Pereira (Org.). Burnout: Quando o trabalho ameaça o bem estar do trabalhador.São Paulo: Casa do Psicólogo,2002. Página 14.

PEREIRA, A. M. T. B. Burnout: O processo de Adoecer pelo Trabalho. In: Ana Maria T. Benevides Pereira (Org.). Burnout: Quando o trabalho ameaça o bem estar do trabalhador. São Paulo: Casa do Psicólogo, 2002. Página 24.

PEREIRA, A. M. T. B. Burnout: O processo de Adoecer pelo Trabalho. In: Ana Maria T. Benevides Pereira (Org.). Burnout: Quando o trabalho ameaça o bem estar do trabalhador. São Paulo: Casa do Psicólogo, 2002. Página 26.

PEREIRA, A. M. T. B. Burnout: O processo de Adoecer pelo Trabalho. In: Ana Maria T. Benevides Pereira (Org.). Burnout: Quando o trabalho ameaça o bem estar do trabalhador. São Paulo: Casa do Psicólogo, 2002. Páginas 28-29.

PEREIRA, A. M. T. B. Burnout: O processo de Adoecer pelo Trabalho. In: Ana Maria T. Benevides Pereira (Org.). Burnout: Quando o trabalho ameaça o bem estar do trabalhador. São Paulo: Casa do Psicólogo, 2002. Página 29.

PEREIRA, A. M. T. B. A síndrome de Bournout. In: 1o Congresso Internacional Sobre Saúde Mental no Trabalho, 2004, Goiânia, Goiás, Anais, páginas 36-51.

In: http://www.prt18.mpt.gov.br/eventos/2004/saude_mental/anais/artigos/2.pdf. Acesso em 27 de Março de 2012. 


\section{Capítulo 55}

\section{COORDENADOR PEDAGÓGICO: MEDIADOR NO PROCESSO DE INCLUSÃO DE ALUNOS COM DEFICIÊNCIAS NO ENSINO REGULAR}

DOI: $10.37423 / 200200308$

Ana Paula de Souza Muniz (Professora de Educação Infantil da Rede Municipal de Ensino em Parintins, AM). mgpssoares@hotmail.com

Maria das Graças Pexeira Soares (Professora Doutora do curso de/Pedagogia do Instituto de Ciênciàs Sociais, Educação e Zootecnia, Campus/Parintins da Universidade Federal do Amazonas. mgpssoares@hotmail.com.
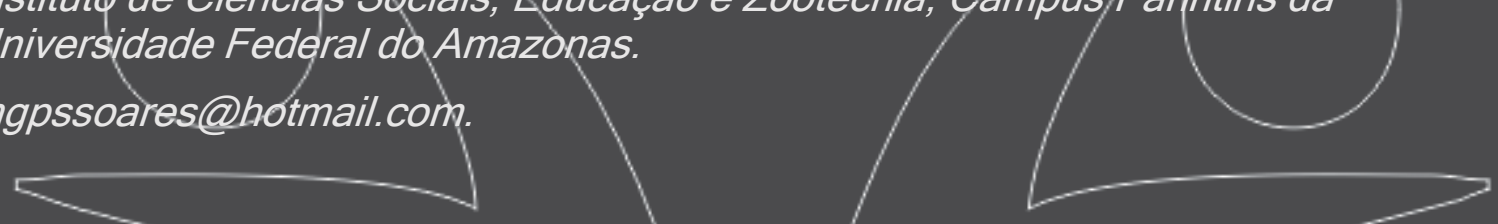

Corina Fátíma Costa Vasconcelos (Pkofessora boutora do curso de Pedagogia do Instituto de Ciências Sociais, Educaçầo e Zootecnia, Campus Parintins da Universidade Federal do Amazonas. corina.ftima@yahoo.com.bx

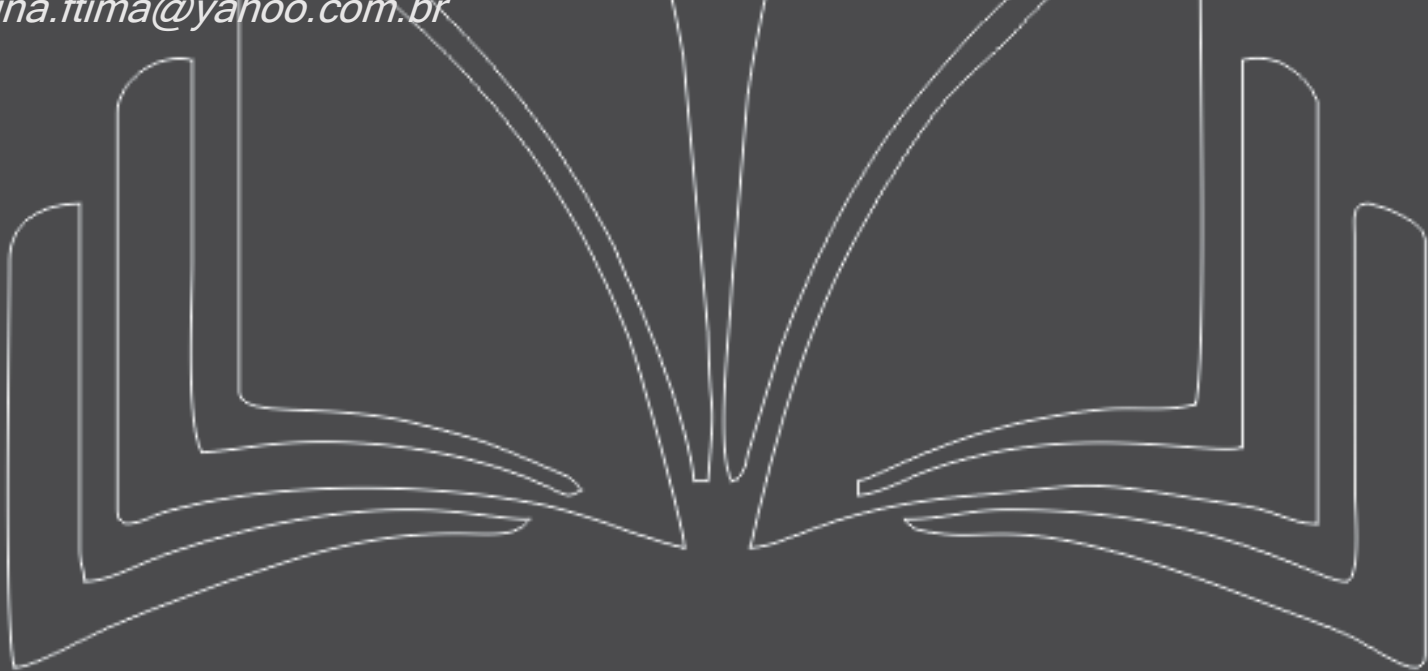




\section{Desafios da psicologia no Brasil}

\section{INTRODUÇÃO}

A educação como um direito humano fundamental, ganha cada vez mais destaque no cenário mundial. As convenções entre entidades, chefes de governos e organizações reafirmam a educação como um direito universal a partir de um conjunto de leis que preconizam uma educação para todos os alunos em condições de igualdade e respeito às diferenças.

A Declaração Mundial sobre Educação para todos (1990) e a Declaração de Salamanca (1994) declaram o direito de todos os sujeitos à educação como meio eficaz no combate às atitudes discriminatórias e construção de uma sociedade inclusiva.

A educação inclusiva é uma proposta que sugere mudanças na formação dos educadores, concepção de currículo e das práticas pedagógicas, visando o benefício acadêmico de todos os alunos, cuja proposta impulsiona a transformação das práticas tradicionais em direção a uma prática inovadora que trabalha as necessidades específicas de aprendizagem dos alunos.

Diante do exposto, esta pesquisa teve como finalidade investigar o papel do coordenador pedagógico no processo de inclusão de alunos deficientes na escola regular dos anos iniciais do Ensino Fundamental da Rede Pública de Ensino do município de Parintins - Am.

\section{EDUCAÇÃO INCLUSIVA: ASPECTOS LEGAIS}

A educação inclusiva é um movimento que compreende a educação como um direito humano e social e base para uma sociedade mais justa e igualitária possibilitando ao ser humano aprender a viver junto com o outro na diferença, ao mesmo tempo desenvolver valores mais humanos de respeito e aceitação do outro.

Para Sassaki (1997, p. 167), a "inclusão social é o processo pelo qual a sociedade e o deficiente procuram adaptar-se mutuamente tendo em vista a equiparação de oportunidades e, consequentemente, uma sociedade para todos". Esse processo está atrelado à construção de uma sociedade democrática, na qual todos conquistam sua cidadania e a diversidade é respeitada, ou seja, as diferenças de cada um são reconhecidas e aceitas.

Gaio e Meneghetti (2009) afirmam que a diferença garante a identidade entre as pessoas. Nas diferenças assinalam-se as faltas, as ausências e as possibilidades, elementos presentes na vida concreta e que constituem, por natureza, os seres humanos. É em razão da diferença que descobrimos 


\section{Desafios da psicologia no Brasil}

o quanto podemos criar alternativas novas e o quanto nesse processo é possível recriar soluções para os problemas.

A diversidade humana é inegável, vivemos em uma sociedade caracterizada pelas diversidades sociais, culturais, étnicas, religiosas e de gênero, mas a escola apesar de ser um ambiente sociocultural onde as diferenças existem, nem sempre reconheceu sua existência ou considerou-a na sua complexidade, em todos os aspectos do processo pedagógico. A convivência com os diferentes de forma harmoniosa e produtiva na escola, sempre foi um desafio, visto que esta sempre buscou desenvolver um trabalho baseado na homogeneização e na premissa de que turmas homogêneas facilitam o trabalho do professor e da aprendizagem.

Segundo as Diretrizes Curriculares Nacionais para a Educação Especial (2001), a escola inclusiva deve ser um ambiente democrático e competente para trabalhar com todos os educandos sem distinção de raça, classe, gênero ou características pessoais, baseando-se no princípio de que a diversidade deve não ser só aceita como desejada.

O processo da inclusão traz como premissa básica, propiciar a educação para todos. No entanto, sabese que a realidade da educação inclusiva ainda é bem diferente do que se propõe na legislação e requer ainda muitos debates e desafios relativos ao tema. O grande desafio da escola contemporânea é trabalhar com essa diversidade e garantir a aprendizagem a todos, de modo que todos tenham acesso a uma educação de qualidade social, que aceite as singularidades como atributo e não como obstáculo.

A educação inclusiva está fundamentada na filosofia que reconhece e valoriza a diversidade. No Brasil, a educação é assegurada na Constituição Federal do Brasil de 1988, Lei de Diretrizes e Bases da Educação Nacional - LDBEN Lei 9.394/96, Estatuto da Criança e do Adolescente - ECA Lei 8.069/90 e no Plano Nacional de Educação - Lei no 10.172/2001.

A Constituição Federal de 1988 nos Art.206 e 208 garante que todo o aluno deve ter "Igualdade de condições para o acesso e permanência na escola [...]. "Atendimento educacional especializado [...]". O ECA no Cap. IV Art.53 declara que, "a criança e o adolescente têm direito à educação, visando o pleno desenvolvimento de sua pessoa, preparo para o exercício da cidadania e qualificação para o trabalho para assegurar-Ihes: Igualdade de condições para o acesso e permanência na escola".

A LDBEN Lei № 9.394/96 no Capítulo V da Educação Especial reitera no Art.58 que a educação especial pode ser entendida "para os efeitos desta Lei, como modalidade de educação escolar, oferecida preferencialmente na rede regular de ensino, para educando portador de necessidades especiais". 


\section{Desafios da psicologia no Brasil}

O PNE, Lei no 10.172/2001 argumenta que "o grande avanço na década da educação deveria produzir a construção de uma escola inclusiva para garantir o atendimento à diversidade humana".

Portanto, a construção de um sistema educacional de qualidade social para todos, impõe uma reforma no sistema educacional, bem como políticas educacionais que promovam a qualificação permanente dos profissionais e melhores condições de trabalho.

\section{COORDENAÇÃO PEDAGÓGICA E A EDUCAÇÃO INCLUSIVA}

A educação inclusiva parte da reflexão sobre a inclusão dos diversos grupos sociais nas instituições formativas, dos impactos desta formação na construção de sua identidade, os processos de inserção no âmbito social e práticas de inclusão nos diversos contextos educativos. No entanto, a educação inclusiva envolve a reestruturação das culturas organizacionais, das políticas e das práticas de nossas escolas que, como sistemas abertos, precisam rever suas ações, até então predominantemente excludentes. Este processo vem ocorrendo gradativamente e exigindo novas discussões, estruturações e adequações.

Dentre essas transformações, destaca-se a formação do coordenador pedagógico para mediar, articular, coordenar, planejar, criar e facilitar todas as atividades relacionadas com o processo de ensino- aprendizagem, visando sempre o acesso, à permanência e a aprendizagem do aluno no ambiente escolar, independentemente de ter ou não uma deficiência.

Diante do exposto, pode-se perceber a grande responsabilidade do coordenador pedagógico na educação inclusiva, pois o sucesso do seu trabalho não depende exclusivamente da sua ação, mas de todos os sujeitos que participam ativamente do processo educativo. Dessa forma, ele deverá criar, propor, transformar e implementar novas ideias e ações em conjunto com a equipe pedagógica, com objetivo de efetivar a inclusão no âmbito escolar. Nóvoa (apud ALMEIDA e PLACCO, 2010 p. 150) argumenta "a experiência não é formadora e nem produtora. É a reflexão sobre a experiência que pode provocar a produção do saber e a formação".

\section{A MEDIAÇÃO DO COORDENADOR NA INCLUSÃO DE ALUNOS COM DEFICIÊNCIAS NA ESCOLA} REGULAR

Orsolon (2003) afirma que o coordenador pedagógico tem papel importante no estabelecimento de uma prática cotidiana escolar que leve a uma constante transformação. Para o autor o coordenador é um agente de mudança das práticas pedagógicas, mediante as articulações que realiza entre os 


\section{Desafios da psicologia no Brasil}

professores, num movimento de interações permeadas por valores, convicções, atitudes, possibilitando articulações internas para mobilizar dimensões políticas, humano-interacionais e técnicas.

Para tanto, torna-se necessário na educação de alunos com deficiência a presença de um coordenador pedagógico consciente de seu papel social, da sua formação e do trabalho coletivo, tendo em vista uma educação de qualidade para todos os sujeitos e uma ação comprometida com o desenvolvimento social, educacional e político. Os saberes deste profissional devem ir além do conhecimento teórico, pois para acompanhar o trabalho pedagógico e estimular os sujeitos envolvidos no processo educativo é preciso ter percepção e sensibilidade para identificar as necessidades dos alunos e professores, manter-se sempre atualizado, buscar novas fontes de informação e refletir constantemente sobre sua prática.

Dentre das diversas atribuições do coordenador pedagógico destaca-se o ato de acompanhar o trabalho docente por meio da mediação dos processos educativos, como agente formador, articulador e transformador, comprometido com seu papel social e político no processo de inclusão de alunos com deficiência.

A escola é um espaço privilegiado de construção de conhecimentos e desenvolvimento de valores e significados, tendo em vista a transformação da sociedade no sentido de torná-la menos desigual e mais democrática. Assim, um espaço democrático, em essência, deve viabilizar a construção de saberes, políticas e práticas inclusivas. Em se tratando da educação de alunos com deficiências físicas, múltiplas (paralisia cerebral, surdo, cegueira e etc.) ou sensoriais (auditiva e visual), mental, transtornos severos de comportamento ou condutas típicas, a escola deve desenvolver ou adaptar o currículo para atender as especifidades de cada aluno. Elaborar um planejamento para inclusão de alunos com deficiência num processo dinâmico e estruturado, a partir das observações das necessidades especificas de cada aluno, tanto no início como no decorrer do processo ensino/aprendizagem, a fim de que ocorra uma educação potencializadora de novas aprendizagens.

Desse modo, o coordenador pedagógico como mediador no processo de inclusão de alunos com deficiências deve ter instrumentos que promova a organização do processo ensino- aprendizagem, a partir do desenvolvimento de um trabalho coletivo com professores, pais e alunos em busca de estabelecer parcerias e diálogos com outros agentes para o sucesso desse processo que, todavia, não ocorre isoladamente, mas em articulação com toda a comunidade escolar e outros profissionais. 


\section{Desafios da psicologia no Brasil}

A coordenação do cotidiano escolar exige do coordenador não somente o cumprimento do planejamento curricular, mas também a articulação das relações interpessoais e dos múltiplos saberes. Batista (2003) fala desta complexa teia que se estabelece no espaço escolar e atribui ao coordenador pedagógico à função de administrá-la, o que inclui a aplicação das determinações legais. O coordenador não basta ser apenas um especialista em sua própria área, mas deve ter uma visão holística e ser um mediador entre todos os sujeitos do processo educativo.

A escola é um espaço de constante contradição e complexidade. Um espaço organizado, com grupos distintos, programas e rotinas, não é possível concebê-la sem antagonismos, os quais geram conflitos permanentes. Partindo do princípio de que sempre haverá conflitos, a autora aponta para a importância do coordenador pedagógico abandonar a busca por um grupo homogêneo, pois isso nunca ocorrerá. É imprescindível neste trabalho o apoio de diferentes profissionais para auxiliar as múltiplas tarefas que a escola exerce atualmente, uma vez que a instituição está cada vez mais dinâmica e complexa. Esta complexidade vem trazendo ao trabalho do coordenador novas atribuições escolares e a necessidade de novos saberes. Christov (apud, ALMEIDA e PLACCO, 2010 p.92) comenta "os saberes das teorias pedagógicas, os saberes do campo das relações interpessoais enredam-se no saber fazer. Compõem a sabedoria necessária ao cotidiano do coordenador pedagógico".

É papel do coordenador favorecer a construção de um ambiente escolar democrático e participativo, onde se incentive a produção do conhecimento e troca de saberes por parte da comunidade escolar, promovendo mudanças atitudinais, procedimentais e conceituais na perspectiva de favorecer o pleno desenvolvimento de todos os alunos.

\section{METODOLOGIA}

Com o objetivo de aprofundar os conhecimentos sobre o tema pesquisado, utilizou-se o enfoque da pesquisa qualitativa e o método de abordagem dialético. No que concerne o método de procedimento, foi utilizado o monográfico ou estudo de caso.

A pesquisa foi realizada em uma escola dos anos iniciais do Ensino Fundamental da Rede Estadual de Ensino da zona urbana do município de Parintins, AM. Os sujeitos dessa pesquisa foram 01 (uma) Coordenadora Pedagógica, 02 (duas) professoras. Para a coleta de dados utilizou-se a observação direta das atividades da coordenação pedagógica e entrevista semiestruturada aplicada aos educadores dos alunos com deficiência. 


\section{Desafios da psicologia no Brasil}

\section{ANÁLISE E DISCUSSÃO DOS RESULTADOS}

A observação ocorreu no período 23/10/12 a 23/11/12 a partir de um roteiro elaborado. Durante esse período buscou-se observar as atividades do coordenador pedagógico no processo de inclusão dos alunos com deficiência na escola regular.

No que tange as atribuições do coordenador pedagógico da escola foram observadas as seguintes ações: articulação de ações que viabilizem a parceria com instituições públicas ou privadas para o atendimento especializado com médicos e outros profissionais que possam contribuir no desenvolvimento dos alunos com deficiência; acompanhamento dos alunos com deficiência nas atividades realizadas na sala de recurso e nas aulas de música; atendimento individual aos pais ou responsáveis; atividades em sala de aula; orientações pedagógicas aos professores; organização de eventos culturais realizados na escola.

Percebeu-se que a coordenadora exerce a função de mediadora, articuladora, formadora, orientadora, harmonizadora e transformadora, ajuda na organização estrutural, legal e pedagógica da instituição escolar, também contribui assessorando e acompanhando os professores em suas atividades de planejamento, execução e avaliação dos processos educativos e na efetivação das ações do projeto político pedagógico da escola, levando em consideração as diferenças intelectuais, físicas, culturais e sociais presente na escola. Ações pedagógicas realizadas no ambiente escolar não se concretizam em um dia ou em uma semana, mas no decorrer das necessidades do processo educativo. A coordenadora tem uma sobrecarga de trabalho, que não atende todas as demandas do fazer pedagógico, uma vez que tem apenas uma carga horária de vinte horas semanais, observou-se a necessidade da escola de ter uma equipe multidisciplinar para contribuir com o trabalho pedagógico na perspectiva da educação inclusiva.

Para desenvolver um bom trabalho a coordenadora necessita de um horário integral para executar todas as funções da coordenação pedagógica. Observou-se que a coordenadora enfrenta muitos desafios no cotidiano escolar, principalmente a falta de apoio dos pais no acompanhamento do desenvolvimento do processo ensino- aprendizagem dos alunos com deficiência. A participação da família é um fator primordial para a educação desses alunos; outro obstáculo é a falta de especialistas na cidade para atender as necessidades específicas dos educandos 


\section{Desafios da psicologia no Brasil}

Percebe-se então que ser coordenador pedagógico não é tarefa fácil, pois envolve inúmeros fatores, pessoais, políticos, pedagógicos e administrativos, uma função complexa, que precisa de uma ação comprometida com o desenvolvimento da educação inclusiva.

Outro instrumento de coleta de dados foi a entrevista com a coordenadora e as professoras. Para identificar as professoras entrevistados serão apresentados os cognomes professora A e professora B.

A educação inclusiva pressupõe novas relações pedagógicas centradas nos modos de aprender, partindo deste princípio questionou-se à coordenadora pedagógica sobre o significado de educação inclusiva. Esse fato é evidenciado pela entrevistada como "um direito de cada pessoa ter educação, não importa como é esse direito. Ao contrário de que muitos pensam que a educação inclusiva está voltada aos deficientes, educação inclusiva é muito mais, entendo como um direito assegurado a todos os excluídos e os que estão em situação de vulnerabilidade social. A inclusão precisa da efetivação das políticas públicas para assegurar tal direito aos indígenas, negros, brancos, pobres, todos e sobretudo os que já estão incluídos no sistema de ensino, para mim a inclusão está relacionada em aprender o que a escola apresenta como necessário à vida da pessoa para o bom convívio na sociedade".

E também foi questionado às professoras sobre a concepção de educação inclusiva. A professora $A$ ressaltou "a educação inclusiva como proposta educacional que reconhece e garante o direito de todos os alunos em compartilhar um mesmo espaço escolar, sem discriminação de qualquer natureza, desde a Educação Infantil à Educação Superior, de forma a promover a aprendizagem e o desenvolvimento pessoal de todos", e a professora B declarou: "é aquela que os alunos com dificuldades são considerados capazes de aprender".

A concepção de educação inclusiva relatada pelas educadoras parte do princípio dos direitos de todos à educação e valorização da diversidade humana, fundamenta-se na política que orienta os sistemas de ensino para garantir o acesso de todos às escolas comuns da sua comunidade e o atendimento às necessidades educacionais especiais dos alunos. Questionou-se a coordenadora: Qual o papel do coordenador pedagógico no processo de inclusão de alunos com deficiência na escola regular?

Para a coordenadora este profissional tem um papel fundamental de acompanhar o processo de inclusão na escola e as atividades desenvolvidas pelos estudantes para propor alternativas para o processo de aprendizagem. E para averiguar as ações do coordenador na inclusão de alunos com deficiência, perguntou-se quais as atribuições do coordenador no processo de inclusão dos alunos com deficiência na escola regular? Ela relatou: o papel do coordenador será de acompanhar e propor atividades que favoreçam a aprendizagem. Geglio (apud ALMEIDA e PLACCO 2007, p. 116) argumenta 


\section{Desafios da psicologia no Brasil}

que o coordenador pedagógico no cotidiano escolar assume responsabilidades de caráter pedagógico e burocrático, com atividades programadas e assertivas, mas também com ações urgentes e incertas da escola, que estão além dos limites da profissão. Sobretudo, diante desse desafio de acolher e atender a todos, com suas particularidades e necessidades, este se revela um autêntico agente de inclusão.

O coordenador pedagógico deve ser consciente da importância de seu papel como articulador, transformador e formador do processo de ensino-aprendizagem, precisa estar atento às exigências da sociedade, já que tem o desafio de compreender e respeitar as diversidades humanas e sociais presentes no campo educacional.

Indagou-se a coordenadora quais as estratégias pedagógicas utilizadas na mediação do processo de inclusão de alunos com deficiência na escola regular. De acordo com a coordenadora: acompanhar os professores em sua ação, formulando e desenvolvendo metodologias que contemplem a todos os estudantes, tanto para os alunos que aprendem com facilidade, quanto para aqueles com dificuldades de aprendizagem e necessidades especiais.

Questionou-se para a coordenadora quais os desafios e benefícios da inclusão de alunos com deficiência na escola regular? Segundo a coordenadora, os desafios são muitos, a começar pela própria família quando não há uma compreensão das especificidades da criança; a escola por não compreender a inclusão e o desafio do professor para atender as necessidades do aluno. Os desafios são diversos, mas os benefícios são muitos, primeiro por trazer a criança para escola para socializarse e aprender assuntos que dificilmente aprenderia se ficasse somente em casa.

A professora A relatou: O fator que dificulta é a superlotação das salas de aula, pois fica difícil o professor trabalhar numa sala contendo 35 alunos e entre estes alunos, um surdo, que necessita de uma atenção especial. Uma sala com 36 ou até 38 alunos, contendo uma criança com diagnóstico de limitações mentais e outras que precisam de um tutoramento mais individual. Além da formação continuada da equipe escolar que é necessária e urgente, a redução do número de alunos na sala de aula. A professora B mencionou que as dificuldades são muitas, a escola não possui um planejamento direcionado para esse trabalho. Através dos relatos apresentados percebeu-se que a inclusão escolar é uma questão complexa, envolve uma série de fatores, desde a formação inicial e permanente dos educadores, do planejamento, da adequação dos materiais, recursos pedagógicos e avaliação da aprendizagem por meio de um trabalho coletivo de sensibilização e conscientização que abranja todos os sujeitos envolvidos no processo educacional. 


\section{Desafios da psicologia no Brasil}

Diante de todas as experiências relatadas e das observações realizadas percebeu-se que para se trabalhar numa perspectiva de uma escola inclusiva, devemos estar atrelados a ações coletivas e colaborativas entre família, escola, governo, pois, do contrário, esse trabalho ficará fragmentado. Ainda há um longo caminho a ser percorrido, incluir não é apenas possibilitar o acesso da criança a escola, é preciso acolher as diferenças, suscitar debates, socializar experiências e garantir a permanência e aprendizagem deste aluno no ambiente escolar propiciando o efetivo exercício de construção da cidadania. E mesmo com as dificuldades e limitações enfrentadas relatadas pelos professores, questionou-se quais os benefícios oriundos do processo de inclusão de alunos com deficiência na escola regular.

Para a professora A os benefícios são imensos, com força transformadora, a educação inclusiva aponta para uma sociedade inclusiva. O processo de inclusão proporciona a valorização de cada pessoa, a convivência dentro da diversidade humana, uma aprendizagem por meio da cooperação, da afetividade e do amor ao próximo. Para a professora B o principal benefício é a socialização dos alunos. Essa interação sócio-afetiva é muito importante para que esse aluno possa ser incluído nesse processo. A escola não prepara professores para esse processo de ensino, muita coisa ainda tem que ser feita. Para Sartoretto (apud MANTOAN 2008, p. 76), "a inclusão escolar é a possibilidade de ver, refletir, de analisar a escola sob todos seus aspectos".

Por último, perguntou-se se a formação inicial e continuada dos profissionais prepara para a educação inclusiva. Segundo os relatos da professora A: Não! É necessário que os profissionais continuem estudando por meio da formação continuada em cursos de pós-graduação; o professor é uma peça importante no processo educacional, portanto, precisa estar qualificado para educar esses alunos. A escola deve proporcionar à sua equipe, formação continuada, para fortalecer o atendimento às nossas crianças. Para a professora B: Não, o currículo de formação dos educadores tem que ser olhado com mais atenção para preparar os futuros professores para a educação inclusiva. É essencial que mesmo diante dos problemas ocorridos na escola, o professor tenha consciência da relevância do seu trabalho, o que falta para esses profissionais, segundo Mittler (2003, p. 184), são [...] oportunidades para refletir sobre as propostas de mudanças que mexem com seus valores e com suas convicções [...]. A oportunidade de refletir mencionada pelo autor deve começar nos cursos de formação inicial dos educadores. 


\section{Desafios da psicologia no Brasil}

Ainda é comum ouvir professores justificarem que não foram preparados para trabalhar com alunos com deficiência, posicionamentos afirmados pelos docentes entrevistados, que para conhecer as especificidades dos alunos deficientes foram necessários estudos complementares.

Considerando a escola um espaço de formação para a cidadania e para a construção de valores é necessário propor ações para promover reflexões, recursos para tratar as questões e singularidades da inclusão escolar. Freitas (apud, MEC, 2007) fala que a formação do professor não tem sido suficiente para garantir o desenvolvimento das capacidades imprescindíveis para as crianças e jovens, nem para o sucesso escolar, tampouco para a plena participação social no mundo atual.

\section{CONSIDERAÇÕES FINAIS}

Este trabalho possibilitou uma reflexão sobre o papel do coordenador pedagógico na educação inclusiva, destacando as suas atribuições no acesso, permanência e aprendizagem do aluno com deficiência na escola regular e os desafios encontrados no desenvolvimento desse processo.

A coordenação dos processos educativos na perspectiva de inclusão não é tarefa fácil, implica uma série de fatores levando à escola repensar seu papel político e social para a construção de uma sociedade igualitária que respeite as diferenças e promova o desenvolvimento integral de todos os alunos, independentemente de condição física, intelectual, social, religiosa, econômica, entre outras.

Diante desse cenário da educação, destaca-se a função do coordenador pedagógico no cotidiano escolar com a finalidade de promover ações que propicie uma educação inclusiva de qualidade social, onde o coordenador exerça a função de mediador para enfrentar os constantes desafios do contexto escolar. Vale ressaltar a necessidade de uma equipe multidisciplinar e do apoio de todos os sujeitos para a efetivação desse processo.

É visível nessa pesquisa o posicionamento das professoras acerca da relevância da educação inclusiva, mas ressaltam a necessidade de uma formação inicial e continuada aos educadores e melhores condições de trabalho. Tais observações evidenciam a precisão de rever a matriz curricular dos cursos de formação de educadores e da necessidade de uma formação permanente.

\section{REFERÊNCIAS}

ALMEIDA, Laurinda R.; PLACCO, Vera Ma N. de S. O coordenador pedagógico e o atendimento a diversidade. São Paulo: Edições Loyola, 2010. 


\section{Desafios da psicologia no Brasil}

; Laurinda R.; PLACCO, Vera Ma N. de S. O coordenador pedagógico e questões da contemporaneidade. São Paulo: Edições Loyola, 2007.

BATISTA, Sylvia Helena Souza da Silva. Coordenar, avaliar, formar: discutindo conjugacoespossiveis. In: ALMEIDA, Laurinda Ramalho, PLACCO, Vera Maria Nigro de Souza (orgs). O coordenador pedagógico espaço de mudança. São Paulo, Edições Loyola, 2003.

BRASIL. Constituição da República Federativa do Brasil, Brasília: imprensa Oficial, 1988.

- Declaração Mundial sobre Educação para Todos: plano de ação para satisfazer as necessidades básicas de aprendizagem UNESCO, Jomtiem/Tailandia, 1990.

. Estatuto da Criança e do Adolescente no Brasil, Lei 8.069 de 13 de julho de 1990.

- Ministério da Educação Secretaria da Educação Especial. Diretrizes Nacionais para Educação especial na Educação Básica. Secretaria de educação especial - MEC/ SEESP 2001.

- Ministério da Educação e Cultura, Declaração de Salamanca e linha de ação sobre necessidades educativas especiais. Brasília: UNESCO, 1994.

. Ministério da Educação. Leis de Diretrizes e Bases da Educação Nacional, LDBN. Lei №. 9.394/96, de 20 de dezembro 1996.

. Ministério da Educação. Plano Nacional de Educação - Lei no 10.172/2001.

GAIO, Roberta, MENEGHETTI, Rosa G. Krob (Orgs) Caminho pedagógico da educação especial: 5. ed. Petrópolis, RJ: Vozes, 2009.

MANTOAN, Maria Tereza Eglér (Org.). O desafio das diferenças nas escolas. Petrópolis, RJ: Vozes, 2008.

MITTLER, Peter. Educação Inclusiva. Contextos sociais. Tradução de Windyz Brazão Ferreira. Porto Alegre: Armend, 2003.

ORSOLON, Luzia Angelina Marinho. Coordenador/formador como um dos agentes de transformação da/na escola. In: ALMEIDA, Laurinda Ramalho, PLACCO, Vera Maria Nigro de Souza (orgs). O coordenador pedagógico espaço de mudança. São Paulo, Edições Loyola, 2003.

SASSAKI, Romeu Kazumi. Inclusão: construindo uma Sociedade para Todos. Rio de Janeiro: WVA, 1997. 


\section{Capítulo 56}

\section{CONCEPÇÃO E ATUAÇÃO DE PSICÓLOGOS EM SECRETARIAS DE EDUCAÇÃO DE SÃO PAULO ${ }^{1}$}

DOI: $10.37423 / 200200310$

Marilene Proença Rebello de Souzan (Professora Titular do Instituto de Psicologia da Universidade de São Paulo (USP).

marileneproenca@gmail.com.

Ana Karina Amoxim Checchia (Professora do curso de Psicologia da Universidade Paulista (UNIP-SP) e professora contratada da Faculdade de Edulcação-da Universidade de SãoPaulo(USP). Email: anakarina.ak.ac@gmail.com.

Aline Morais Mizytani Goimes (Mestre em Psicologia Escolar pelo Instituto de Psicologia da Universidade de São Paulo (USP).

alinemizu@gmail.com...

Jane Teresinha Domingues Cotrin (Professora Associada do Departamento de Psicologia da Universidade Federal de Mato Grosso (UFMT). janecotrin@gmail.com.

Juliana Sano de Almeida Lara (Mestre em Psicologila Escolar pelo Instituto de Psiçologia da Universidade de SãoRaulo (USP).

juliana.sano@gmail.com.

Marcelo Domingues Roman-fRrofessor do Departamento-de Políticas Públicas e Saùde Coletiva da Universidade Federal de \$ão Patho (UNIEESP - Baixada Santista).

marcelodroman@gmail.com.

Roseli Fernandes Lins Caldas (Professora do curso de Psicologia da Universidade Presbiteriana Mackenzie.roseli.caldas@uol.com.br. 


\section{Desafios da psicologia no Brasil}

\section{INTRODUÇÃO}

A Psicologia Escolar e Educacional tem desenvolvido, nos últimos vinte anos, importante discussão em relação à formação/atuação do psicólogo no campo educacional, em busca de perspectivas críticas que visem conceber o fenômeno educacional nas dimensões pedagógica, institucional, relacional, social e política, superando, assim, modelos tradicionais de atuação na área, marcadamente calcados na avaliação e atendimento clínico individualizantes.

As primeiras críticas no campo da Psicologia a este perfil profissional do psicólogo e às concepções adaptacionistas da Psicologia surgiram particularmente, no Brasil, na década de 1980, destacando-se a Tese de Doutorado de Maria Helena Souza Patto², publicada em 1984, no livro intitulado Psicologia e Ideologia: uma introdução crítica à Psicologia Escolar.

A partir então, compreender a atuação psicológica no campo educacional em uma perspectiva crítica passou a ser objeto de estudo de vários pesquisadores brasileiros. Trabalhos de pesquisa e análise da produção científica no Estado de São Paulo realizados por Tanamachi $(1992,1997,2002)$ revelam tendências da área, temáticas abordadas, concepções teórico-metodológicas presentes nas produções acadêmicas, sendo que parte significativa da produção de 1984 a 2001 está centrada nessa perspectiva. $^{3}$

As novas bases partem da necessidade de se conhecer a realidade escolar, explicitando os processos que acontecem intramuros, no dia a dia do fazer docente. Assim, estudar a escola que temos, e não a escola que idealizamos, é um dos pontos fundamentais dessa perspectiva (EZPELETA; ROCKWELL, 1986; ROCKWELL, 2009). Além disso, a prática crítica deve procurar analisar a produção da queixa escolar e o processo de subjetivação e objetivação da escolarização, buscando compreender os fenômenos por meio de suas múltiplas determinações e utilizando como método a reflexão e a análise dos processos (TANAMACHI; MEIRA, 2003a).

Tais discussões têm gerado muitas publicações no campo acadêmico ${ }^{4}$ e oferecem importantes subsídios, tanto no sentido de desvelar os determinantes sociais e históricos que conformam o (des)encontro entre a Psicologia e a Educação, quanto no sentido de reafirmar a possibilidade da construção de perspectivas mais adequadas no campo da pesquisa e da atuação profissional. 


\section{Desafios da psicologia no Brasil}

Dessa forma, torna-se necessário avaliar se a discussão acadêmica tem efetivamente influenciado a prática profissional e, sobretudo, compreender como psicólogos que atuam na área da educação têm se apropriado dessa discussão em suas práticas concretas.

Diante disso, o presente trabalho origina-se da pesquisa intitulada " $\mathrm{A}$ atuação do psicólogo na rede pública de Educação frente à demanda escolar: concepções, práticas e inovações" ${ }^{5}$, cujo objetivo consistiu em identificar e analisar concepções e práticas desenvolvidas pelos psicólogos da rede pública frente às queixas escolares oriundas do sistema educacional, visando compreender em que medida apresentam elementos pertinentes às discussões recentes na área de Psicologia Escolar e Educacional em busca de um ensino de qualidade para todos. Esta pesquisa, realizada no período entre 2006 e 2010, envolveu pesquisadores dos estados de São Paulo, Rondônia, Acre, Minas Gerais, Bahia, Santa Catarina e Paraná, utilizando os procedimentos: análise documental da produção bibliográfica sobre a atuação do psicólogo na Educação; elaboração e aplicação de questionários; realização de entrevistas com psicólogos que evidenciaram nos questionários indícios de uma atuação coerente com os recentes avanços teórico-metodológicos da área.

Neste texto, será apresentada a análise das entrevistas realizadas em nove municípios do Estado de São Paulo, a partir de três eixos centrais: descrição dos Serviços de Psicologia nas Secretarias de Educação, atuação dos psicólogos escolares e concepção teórica dos entrevistados.

Para a realização desta etapa da pesquisa, foram selecionados 9 dos municípios contatados, a partir dos dados coletados por meio dos questionários. Adotamos como critério de seleção dos municípios para a entrevista a presença de indicativos de uma atuação dos psicólogos em uma perspectiva crítica, conforme critérios apontados pela literatura, e que contemplasse os avanços teórico-metodológicos da área de Psicologia Escolar e Educacional. Para identificar um trabalho como crítico, Tanamachi (2000) considerou se a base teórica adotada seguia os pressupostos do pensamento crítico e o modo como foram apropriados, e se o trabalho procurava entender os fenômenos a partir de suas múltiplas determinações. Meira (2000) compreende que o conceito de crítica deve estar pautado em uma reflexão dialética e comprometido com a denúncia da degradação humana. Segundo a autora, a Psicologia Escolar e Educacional em uma perspectiva crítica deve se preocupar com a efetivação do processo de democratização na Educação, contribuir com ações educativas que façam a escola exercer sua função emancipatória e privilegiar uma gestão escolar participante. 


\section{Desafios da psicologia no Brasil}

É importante salientar que compreendemos que não existe uma prática puramente crítica, mas sim práticas compostas tanto por elementos críticos, que representam inovações, quanto por elementos não críticos, correspondentes a uma atuação que tradicionalmente centrou o foco da queixa escolar no indivíduo - geralmente no aluno e em sua família - desconsiderando as relações institucionais e a multiplicidade de determinações sociais e históricas que a produzem.

\section{CONSTITUIÇÃO DOS SERVIÇOS DE PSICOLOGIA NAS SECRETARIAS MUNICIPAIS DE EDUCAÇÃO}

A maioria dos serviços em que os psicólogos entrevistados estão inseridos surgiu a partir de 2000. Chamou a atenção o fato dos serviços terem sido criados e se estruturarem de forma tão diversa: por iniciativa de um grupo de profissionais (psicólogos e/ou pedagogos) que estava inserido na rede; por iniciativa do secretário de educação; pela necessidade de se adaptar à política de inclusão escolar; pela pressão dos pais de crianças portadoras de deficiências físicas; por iniciativa de uma psicóloga, que observava a grande demanda vinda da educação para a saúde. Assim, observaram-se tanto movimentos individualizados ou coletivos, mas que partiram da reflexão e envolvimento direto dos profissionais ou da comunidade, quanto ações de nível macro-político. Além disso, enquanto alguns serviços se constituíram em núcleos com departamentos específicos para cada nível de ensino e com equipes multidisciplinares, outros concentraram o trabalho em torno de um único profissional.

Em relação à forma de contratação do psicólogo, todos disseram ter ingressado através de concurso público, entretanto, alguns são contratados pela Secretaria de Saúde e outros fazem parte do quadro da prefeitura e naquele momento estavam lotados na Educação. Embora todos atuem como psicólogos, a denominação do cargo variou: psicólogo, psicólogo escolar, professor, supervisor de ensino; assim, nem sempre a via de acesso à secretaria era direta, o que demonstra que o espaço da psicologia na educação ainda é bastante instável.

Na maioria dos municípios entrevistados (6), os psicólogos relataram trabalhar 40 horas semanais. Também encontramos psicólogos com regime de 20 horas ou de 30 horas. Houve 3 casos de municípios em que dentro da mesma equipe, os psicólogos tinham formas de contrato e cargas horárias diferentes. Em geral, os que têm uma carga horária menor avaliaram como positiva a possibilidade de terem tempo para trabalharem em outros lugares e investirem na sua formação acadêmica. Por outro lado, também apareceram queixas em relação à carga horária reduzida, por impossibilitar dar conta da demanda. 


\section{Desafios da psicologia no Brasil}

Em apenas um dos municípios existe plano de carreira para o psicólogo, que foi incluído no plano de carreira do magistério após muita reivindicação. Em todos os outros não há qualquer tipo de perspectiva de crescimento profissional previamente estabelecido. Os critérios e prazos para aumento de salário são bem variáveis: alguns consideram o bom desempenho, outros a obtenção de títulos e realização de cursos ou o tempo de serviço. Há tanto regime estatutário como CLT (Consolidação das Leis de Trabalho). Foram freqüentes queixas sobre baixa remuneração e precárias condições de trabalho.

Na maioria dos municípios observou-se que os psicólogos trabalham em conjunto com outros profissionais, entre eles: fonoaudiólogos, fisioterapeutas, assistentes sociais, terapeutas ocupacionais e principalmente pedagogos, formando, assim, equipes multidisciplinares dentro das secretarias de Educação ou apenas parcerias; mas em ambos os casos observou-se uma preocupação em desenvolver um trabalho mais ampliado, articulando toda a rede envolvida com o contexto educacional.

Notou-se que nem sempre a quantidade de escolas do município é proporcional ao número de psicólogos; assim, há cidades pequenas com grandes equipes de psicólogos e cidades grandes com apenas um psicólogo.

A maioria dos serviços está sujeita a mudanças de gestão. Assim, em muitas falas dos entrevistados foi possível notar uma insegurança quanto ao futuro do trabalho que é desenvolvido e a necessidade de reafirmar frequentemente a sua relevância.

É interessante destacar que nos municípios pequenos, os psicólogos têm a possibilidade de ter um contato bastante próximo com o secretário ou até mesmo com o prefeito, facilitando a superação de entraves burocráticos. Por outro lado, em outros municípios aparecem dificuldades em relação à comunicação com os demais serviços da rede municipal, o que acaba fragmentando o trabalho.

\section{ATUAÇÃO DOS PSICÓLOGOS ENTREVISTADOS}

De modo geral, o trabalho de psicólogos vinculados às secretarias de educação é demandado prioritariamente pelas escolas da respectiva rede municipal de ensino. Porém, de acordo com a natureza da demanda, também pode ser demandado por outros órgãos ou agentes, como o Conselho Tutelar ou órgãos da Secretaria de Saúde. Essa demanda pode surgir por meio da convivência direta de psicólogos com o dia-a-dia das escolas - a partir da observação de práticas educativas, participação 


\section{Desafios da psicologia no Brasil}

em reuniões pedagógicas e contato regular com educadores - ou por meio de telefonemas, e-mails e pedidos endereçados diretamente aos serviços.

As demandas oriundas das escolas são geralmente formuladas por professores, mas também pela direção e por outros agentes escolares, como orientadores educacionais e coordenadores pedagógicos. Grande parte delas centra-se em casos individuais de alunos. São principalmente pedidos de avaliação psicológica para verificação da existência de deficiências mentais e para ajuste de comportamentos indesejáveis (indisciplina escolar e agressividade). Essas demandas fazem parte do fluxo de encaminhamento de alunos para atendimento educacional especializado, salas de recursos e de recuperação de ciclo. Há, nesse sentido, um esforço de vários psicólogos entrevistados em tentar mudar o olhar e o entendimento do professor sobre o papel do psicólogo na escola. Assim, embora eles relatem que ainda haja muitos pedidos da escola para que sejam feitas avaliações e encaminhamento para atendimento clínico de crianças "com problemas", tem havido um forte movimento na direção da reflexão conjunta com os professores para repensar a produção do fracasso escolar.

Além destas, há demandas de cunho mais coletivo ou institucional, como o trabalho com determinada classe, a discussão de determinados temas com alunos, pais e/ou educadores e formação de educadores e dirigentes. Os entrevistados também indicaram que embora os professores venham com a intenção de buscar "receitas" durante as formações, as reuniões e cursos oferecidos podem se constituir enquanto um espaço para reflexão e questionamento da sua prática e concepções.

Parte significativa dos entrevistados declarou trabalhar especificamente com educação especial ou inclusão escolar, apontando outras demandas além das discriminadas acima, tais como: inserção e acompanhamento escolar de crianças e adolescentes portadores de necessidades educacionais especiais - demanda geralmente encaminhada pelo Conselho Tutelar -, formação de classes especiais e seleção de professores especializados.

Entre as demandas apresentadas pelo Conselho Tutelar e órgãos da Secretaria da Saúde estão, além da inclusão escolar, a avaliação e acompanhamento de vítimas de violência, de crianças expostas a condições de extrema vulnerabilidade social e de alunos medicados com psicotrópicos. Também foram relatadas demandas para atuação em questões que se relacionam com a participação da comunidade nos órgãos de controle social, como os conselhos de educação, de defesa da mulher e de orçamento participativo. 


\section{Desafios da psicologia no Brasil}

A maior parte dos trabalhos é realizada no interior das escolas. Entrevistados mencionaram que podem ser desenvolvidos projetos que seguem um planejamento específico, com objetivos determinados de acordo com demandas antes identificadas. Desta forma, psicólogos podem permanecer durante certo tempo na escola para conhecer sua realidade, conversar com a equipe e assim levantar as necessidades da escola. No caso de serviços em que as demandas não surgem diretamente do contato regular com as escolas, mas são encaminhadas pelos canais instituídos, são organizadas conversas para esclarecimento dos problemas e então se decide quais encaminhamentos devem ser feitos dentro e fora da escola. Para isto, os profissionais necessitam de contatos com a rede de serviços locais, que inclui secretaria de saúde, de assistência social, conselho tutelar, promotoria, ONGs e outras entidades. Nesse trabalho, são freqüentes os contatos com as famílias, buscando ampliar, do ponto de vista da família, algumas questões colocadas pela análise da demanda.

Há projetos em que o foco de trabalho é o professor, em atividades de formação cujos temas são elaborados a partir de demandas das escolas e/ou sugestões da equipe. Essa formação se dá nas reuniões pedagógicas regulares ou em horários fora da jornada de trabalho - noite ou sábados -, sob a forma de cursos específicos, como braile e libras, contando com a participação de formadores externos. Além da coordenação ou participação em reuniões pedagógicas ou cursos de formação, os profissionais podem comparecer a reuniões de pais e também atuar junto a diretores e coordenadores, entre outros.

Para alguns psicólogos, o centro do trabalho deve ser o gestor escolar. Ou seja, o foco de sua intervenção está na orientação de diretores de escola, realizando orientação pedagógica e administrativa, além de supervisionar e mediar relações entre os diretores e professores, ou, de forma mais ampla, entre diretores e a comunidade escolar. $\mathrm{O}$ trabalho com diretores envolve a orientação para elaboração do projeto pedagógico, incluindo-se a discussão sobre o embasamento teórico utilizado.

Vários psicólogos informaram que realizam atendimento individual ou em grupo com crianças encaminhadas, participam de atividades em que se discutem temas como drogas e sexualidade ou realizam ações específicas voltadas para o combate à evasão escolar. A maioria dos trabalhos envolve alunos, educadores e pais. A forma como cada profissional vai realizar estes grupos pode variar: alguns planejam encontros quinzenais, outros semanais, de uma hora cada; podem ser na sala de aula, na biblioteca ou em outro espaço. O material utilizado também varia: os citados foram vídeo, material 


\section{Desafios da psicologia no Brasil}

gráfico e dinâmicas de grupo. Ao final do ano, geralmente é feita uma avaliação do projeto a partir da qual são apontadas falhas e reconhecidos os objetivos atingidos.

Em alguns municípios foram criados centros de atendimento utilizados, sobretudo, como apoio à inclusão escolar. Nesses centros, alunos encaminhados são avaliados e encaminhados para os serviços educacionais ou de saúde mais apropriados às necessidades de cada caso. Os psicólogos evidenciaram uma preocupação com o rigor com que alunos devem ser encaminhados para atendimento educacional especializado, bem como para médicos que freqüentemente lançam mão de psicotrópicos para controle do comportamento, humor ou estado de atenção. Há, enfim, um explícito esforço para reverter o grande número de encaminhamentos para esses serviços ou atendimentos. Como exemplo, há o relato de uma psicóloga que trabalha com Educação Inclusiva e destacou elementos de uma atuação psicológica que se distingue do modelo tradicional, ancorado na realização de diagnósticos e aplicação de testes psicológicos. Afirmou que seu trabalho centra-se no processo de escolarização do aluno e nas relações entre professor, aluno, escola e família, além de atentar para as concepções e os preconceitos desses participantes do contexto escolar, em relação à deficiência. Entrevistados explicitaram, ainda, críticas à homogeneização e padronização presentes no contexto escolar. Esse aspecto se tornou mais presente nos discursos sobre Educação Inclusiva, em que psicólogos afirmaram que na escola não se sabe lidar com as diferenças e questionaram práticas pedagógicas que contemplam apenas os alunos considerados "normais". A dimensão segregadora da escola também foi apontada ao se mencionar que o aluno é considerado "problemático", caso não se enquadre na padronização imposta. Diante disso, uma psicóloga destacou a importância de se atentar para os recursos e potencial dos alunos, em oposição à ênfase atribuída às faltas ou limitações.

De maneira geral, o foco da atuação do psicólogo se dá no âmbito institucional, no processo de escolarização, assim nomeado pelos entrevistados. Nessa perspectiva, não excluem ações mais individualizadas junto à criança encaminhada e às famílias, mas expandem seu raio de ação ao professor e outros profissionais da escola e fora dela. Vários psicólogos mencionaram que nesse trabalho institucional procuram potencializar as ações dos diversos atores envolvidos no processo educacional, tendo como objetivo tirar o foco dos alunos e centrando-se na mediação das situações e na participação de sujeitos que podem, de alguma forma, ajudar a atender a demanda. Por isto, as conversas e a participação nas reuniões têm como objetivo responsabilizar os vários sujeitos. Neste contexto, as famílias são freqüentemente chamadas, e nestes encontros busca-se trazê-las como aliadas do processo de escolarização. 


\section{Desafios da psicologia no Brasil}

Em relação à Educação Inclusiva, compareceu no discurso dos entrevistados a importância da "educação para todos", com ênfase na qualidade da educação como meio de desenvolvimento e socialização de todos os alunos, inclusive aqueles com necessidades educacionais especiais. Psicólogas de um município acrescentaram a necessidade de que a escola esteja comprometida em atender a diversidade, buscando formas de lidar com as diferenças e de trabalhar com os alunos na própria escola, ao invés de se isentar desta responsabilidade ao encaminhar tais alunos a especialistas. Além disso, afirmaram que o acesso de alunos com necessidades educacionais especiais à Educação está garantido por lei e cabe à Educação propiciar condições adequadas para que os alunos se desenvolvam, com garantia da qualidade do ensino.

Um dos psicólogos que trabalha com Educação Inclusiva enfatizou que a intervenção envolve as relações no interior do contexto escolar, de forma que essas se transformem para possibilitar processos de escolarização de boa qualidade. Parte-se, dessa forma, do princípio de que a inclusão de alunos com necessidades educacionais especiais nas escolas regulares deve vir acompanhada de transformações na escola, introduzindo adaptações materiais (acessibilidade física, de mobiliário, recursos pedagógicos etc.) e imateriais (nas relações humanas e nos métodos de ensino). Além disso, certos casos requerem recursos auxiliares, tanto na área de educação especial quanto de saúde, o que indica a necessidade de articulação intersetorial e interprofissional.

Ao analisarmos as práticas que, de acordo com os psicólogos entrevistados, alcançaram os objetivos propostos e aquelas que não os alcançaram, encontramos dois eixos de descrição: parte das práticas centra-se em casos específicos e ações pontuais e outra parte em atuações de caráter mais geral, que envolvem um número maior de contextos e articulações entre secretarias, programas e participantes. Entre as primeiras estão a constituição de um centro de apoio à educação inclusiva e a transferência de $90 \%$ de alunos da classe especial para classes regulares de ensino. Entre as segundas, destacam-se ações de combate à violência envolvendo a educação infantil.

No âmbito da política de inclusão da pessoa com deficiência, uma das experiências consideradas como bem sucedida refere-se à inclusão no mercado de trabalho. Com relação a ações que não conseguiram repercutir positivamente na rede de educação são citados casos de crianças com deficiências que são considerados cristalizados, demandando formas de atuação mais específicas em que seja possível a articulação com educadores e outros profissionais que se proponham, de fato, a acompanhar estes alunos. É mencionada também a realização de curso de formação em alfabetização que não acarretou 


\section{Desafios da psicologia no Brasil}

mudanças em sala de aula. A fim de enfrentar tais dificuldades, foi apontada a necessidade de formação continuada dos psicólogos e membros da equipe de trabalho, com destaque para o trabalho de supervisão como um instrumento importante de atualização e de compreensão da prática profissional. É sabido que o processo de autocrítica e reconstrução do trabalho deve ser ininterrupto e, para tanto, entrevistados apontaram como decisiva a realização de assessorias e cursos externos.

Embora haja grandes diferenças entre os municípios quanto às condições de trabalho do psicólogo, as limitações em muito coincidem. Um dos entrevistados considera que a Secretaria da Educação impõe uma série de limitações, tais como: falta de plano de carreira, burocratização do trabalho, excesso de escolas a serem supervisionadas, desvio de função, baixa remuneração, excesso de trabalho, falta de formação continuada. Outra equipe informa que freqüentemente têm que se ocupar com atividades burocráticas ou acompanhamento de cursos que pouco ou nada têm a ver com o foco do trabalho da equipe. Relata também que determinadas práticas oficiais parecem excluí-los dos processos de decisão, retirando-Ihes a autonomia, a possibilidade de ações coletivas e fazendo-os sentirem-se solitários. Entretanto, os psicólogos consideraram que não há, de forma geral, limitações criadas por diferentes concepções, no interior na Secretaria de Educação, sobre o seu trabalho. Mas há sempre um temor em relação à mudança de gestão, pois o fato de vários deles não ocuparem um cargo de psicólogo escolar torna-os vulneráveis a serem remanejados para outros setores, como, por exemplo, para a saúde.

Apesar das dificuldades e tensões acima relacionadas, um dos principais aspectos apontados pelas equipes e psicólogos está no fato de terem conquistado, no plano da Secretaria de Educação, a mudança de foco do trabalho de um atendimento individual, do aluno, para uma atuação institucional e centrada na formação. Mas essa mudança de concepção também precisa ser aceita pelos educadores. Algumas equipes mencionaram um visível esforço por parte dos profissionais mais antigos e até da própria coordenação para mudar esta visão tradicional de que o psicólogo só atende e faz avaliação psicológica. Para isso, são fundamentais as reuniões de equipe e supervisões. A partir deste movimento, também buscam sensibilizar os profissionais da escola e mostrar que o trabalho deve ser diferente.

No campo da Educação Inclusiva, ainda foram apontados vários desafios, dentre eles destacam-se: a reversão da tendência a encaminhar alunos para salas especiais após avaliação psicológica e a não transformação de problemas educacionais em questões médicas, a serem indevidamente tratadas 


\section{Desafios da psicologia no Brasil}

com medicamentos, a exemplo do que ocorre com alunos diagnosticados com TDAH. Para isso, é preciso que o psicólogo torne-se cada vez mais capaz de sensibilizar educadores para a crítica e para a reflexão permanente acerca da própria prática.

\section{CONCEPÇÃO TEÓRICA DOS ENTREVISTADOS}

Ao longo das entrevistas, os psicólogos citaram os seguintes autores cujas obras norteiam seu trabalho: Foucault, Vigotski, Paulo Freire e Marx, além de Maria Teresa Eglér Mantoan e autores da Psicologia Escolar como Marilene Proença, Marisa Meira, Marilda Facci, Adriana Marcondes Machado e Yara Sayão. Além disso, houve referências a conhecimentos de desenvolvimento infantil, teorias psicodinâmicas, psicanálise, teoria sistêmica, Psicologia Social, Filosofia e Educação.

De modo geral, os entrevistados revelaram elementos que configuram sua concepção de Psicologia e Psicologia da Educação ao afirmarem que o psicólogo escolar deve apresentar um olhar crítico em sua atuação, que não deve se pautar em um atendimento clínico tradicional ou no encaminhamento de alunos para a área da Saúde e, sim, no enfrentamento das questões no âmbito escolar. Nesse sentido, segundo os entrevistados, o foco da atuação do psicólogo escolar centra-se nas relações que compõem o contexto educacional e influenciam o processo de ensino-aprendizagem, bem como no funcionamento institucional escolar.

A relevância de trabalhar com a formação de professores de forma reflexiva sobre as relações que configuram o contexto escolar foi apontada pelos entrevistados ao afirmarem que o foco da atuação do psicólogo escolar consiste no trabalho com os professores, visando contribuir para o fortalecimento do papel dos educadores na escola e apropriação de seu trabalho, bem como para a transformação de seu olhar em relação aos alunos, atentando para seus recursos e potenciais. A função do psicólogo como mediador entre os participantes do contexto escolar foi enfatizada pelos entrevistados, que destacaram a importância de se considerar todos os participantes envolvidos no contexto educacional. Também atribuíram ao psicólogo escolar a função de reflexão, sistematização, desconstrução e reconstrução.

Diante disso, deve-se ressaltar que foi possível identificar no discurso de alguns entrevistados uma concepção ancorada na constituição histórico-cultural dos fenômenos humanos, nos momentos em que criticaram o olhar do psicólogo voltado para questões individuais ou biológicas, enquanto destacaram a necessidade de atentar para fatores educacionais, institucionais e sociais. 


\section{Desafios da psicologia no Brasil}

Um dos elementos que compõem o questionamento e a reflexão propiciados pelo psicólogo consiste na crítica à medicalização na Educação e à patologização no contexto escolar, conforme apontaram alguns entrevistados.

A crítica à medicalização foi explicitada por um psicólogo que questiona o fato de inúmeras crianças saudáveis serem medicadas em função de queixas escolares, muitas vezes, como um meio de controle do comportamento. Diante disso, destacou a necessidade de se discutir, informar e refletir com os profissionais da escola sobre o processo de medicalização, denunciando, inclusive, a influência da indústria farmacêutica nesse processo. Foi evidenciada a necessidade premente de crítica, por parte do psicólogo, à patologização no contexto escolar e à redução de questões educacionais a fatores genéticos.

A relevância de se romper com rótulos pré-estabelecidos e diagnósticos atribuídos aos alunos, bem como de problematizá-los com os professores, também foi apontada por um psicólogo de outro município. No discurso dos entrevistados, comparecem tanto a referência específica à necessidade de "desconstrução" de certos diagnósticos - como a dislexia e o TDAH -, quanto uma crítica à realização tradicional da avaliação psicológica, de um modo geral.

\section{CONCLUSÃO}

Conforme descrito na introdução desse texto, foram entrevistados, nesta pesquisa, psicólogos que haviam evidenciado nos questionários (em uma etapa anterior às entrevistas), indícios de uma atuação coerente com pressupostos teórico-metodológicos de uma perspectiva crítica em Psicologia Escolar e Educacional, que vem sendo proferida no meio acadêmico nos últimos anos.

De modo geral, foi possível identificar no discurso desses psicólogos entrevistados, que atuam em nove municípios da Secretaria da Educação no estado de São Paulo, uma coerência entre tais pressupostos teóricos e sua atuação profissional, nos momentos em que se referem: ao foco de intervenção em âmbito institucional no processo de escolarização e nas relações que compõem o contexto escolar, em oposição ao atendimento clínico tradicional centrado no aluno e/ou família; à função do psicólogo como mediador entre os participantes do processo educacional; ao trabalho de formação dos educadores (incluindo-se espaços de discussão com professores e gestores) e à crítica à medicalização na Educação e patologização no contexto escolar. 


\section{Desafios da psicologia no Brasil}

Deve-se ressaltar que condições adversas de trabalho, tais como a baixa remuneração, burocratização do trabalho, falta de plano de carreira, excesso de trabalho, desvio de função, mudanças de gestão e falta de formação contínua consistem em obstáculos enfrentados por esses profissionais que se deparam com o desafio de efetivar esse tipo de intervenção psicológica na rede pública educacional paulista.

\section{REFERÊNCIAS}

Ezpeleta, J. \& Rockwell, J. (1986). Pesquisa Participante. São Paulo: Cortez.

Freller, C. C. (2001). Histórias de indisciplina escolar: o trabalho de um psicólogo numa perspectiva winnicottiana. São Paulo, Casa do Psicólogo.

Machado, A. M. \& Proença, M. (Orgs). (2004). Psicologia Escolar: em busca de novos rumos. São Paulo: Casa do Psicólogo.

Meira, M. E. M. \& Antunes, M. A. M. (Orgs). (2003a). Psicologia Escolar: Práticas Críticas. Ed. Casa do Psicólogo: São Paulo.

Meira, M. E. M. \& Antunes, M. A. M. (Orgs). (2003b). Psicologia Escolar: Teorias Críticas. Ed. Casa do Psicólogo: São Paulo.

Meira, M. E. M. Psicologia Escolar: pensamento crítico e práticas profissionais. In Tanamachi, E. R., Proença, M. \& Rocha, M. (Orgs). (2002). Psicologia e Educação: desafios teórico-práticos. São Paulo: Casa do Psicólogo.

Meira, M. E. M \& Tanamachi, E. R. (2003) A atuação do psicólogo como expressão do pensamento crítico em Psicologia e Educação. In Meira, M. E. M. \& Antunes, M. A. M. (Orgs.). Psicologia Escolar: Práticas críticas. São Paulo: Casa do Psicólogo.

Patto, M. H. S. (1984). Psicologia e Ideologia. São Paulo: T.A. Queiroz.

. (2000). Mutações do cativeiro: escrito de Psicologia e Política. São Paulo: Hacker

Editores/Edusp.

. (2005). Exercícios de indignação: escritos de Educação e Psicologia. São Paulo:

Casa do Psicólogo.

Rockwell, E. (2009). La experiência etnográfica. Paidós: Argentina.

Souza, B. P. (Org.). (2007). Orientação à queixa escolar. São Paulo: Casa do Psicólogo, 2007.

Souza, MPR de; Checchia, AKA; Gomes, A.M.M; Cotrin, J.T.D.; Lara, J.S.A.; Roman, M.D; Caldas, R.F.L. (2012) Atuação de psicólogos em Secretarias de Educação de São Paulo. In: Anais do X CONPE Congresso Nacional de Psicologia Escolar e Educacional da Abrapee. Disponível em

https://abrapee.files.wordpress.com/2012/02/conpe-trabalhos-completos-anais_x-conpe-final.pdf. Acesso em 27 de fevereiro de 2020. 


\section{Desafios da psicologia no Brasil}

Souza, M.P.R.; Silva, S.M.C \& Yamamoto, K. (orgs) (2014). Atuação do psicólogo da Educação Básica: concepções, práticas e desafio. Uberlândia: EDUFU.

Tanamachi, E., Rocha, M. \& Proença, M. (Orgs.). (2000). Psicologia e Educação: desafios teóricopráticos. São Paulo: Casa do Psicólogo.

Tanamachi, E. R. (1992). Psicologia Escolar: Tendências e avanços da Psicologia na educação escolar. Dissertação de Mestrado, Universidade Estadual Paulista, Marília-SP.

. (1997). Visão crítica de Educação e de Psicologia: elementos para a construção de uma visão crítica de Psicologia Escolar. Tese de Doutorado, Universidade Estadual Paulista, Marília-SP.

. (2002). Mediações teórico-práticas de uma Visão Crítica em Psicologia Escolar. In Tanamachi, E. R.; Proença, M. \& Rocha, M. (Orgs.) Psicologia e Educação: desafios teórico-práticos. São Paulo: Casa do Psicólogo.

Viégas, L. \& Angelucci, C. B. (Orgs). (2006). Políticas Públicas em Educação: uma análise crítica a partir da psicologia escolar. São Paulo, Casa do Psicólogo. 


\section{Desafios da psicologia no Brasil}

\section{NOTAS}

Nota 1

Agradecemos ao CNPq e à FAPESP pelo apoio para realização desta pesquisa. Este texto foi publicado originalmente nos Anais do X CONPE - Congresso Nacional de Psicologia Escolar e Educacional da Abrapee, realizado em 2011 (Souza, M.P.R; Checchia. A.K.A et.al, 2012).

Nota 2

Trata-se da Tese de Doutorado intitulada Psicologia e ideologia: reflexões sobre a psicologia escolar, defendida no Instituto de Psicologia da Universidade de São Paulo, em 1981, sob a orientação da Profa. Dra. Ecléa Bosi.

Nota3

Tanamachi publica resumo deste levantamento no capítulo intitulado "Mediações Teórico-Práticas de uma visão crítica em Psicologia Escolar" do livro organizado pela autora e por Proença e Rocha, Psicologia e Educação: desafios teórico-práticos. 2. ed. São Paulo, Casa do Psicólogo, 2002.

Nota 4

Entre elas: Patto (2000; 2005); Tanamachi, Meira, Rocha (2000); Freller (2001); Meira, Antunes (2003a; 2003b); Machado, Proença (2004); Angellucci, Viégas (2006); Souza (2007).

Nota 5

Pesquisa publicada como livro com o título Atuação do psicólogo da Educação Básica: concepções, práticas e desafios (SOUZA; SILVA \& YAMAMOTO, 2014) 


\section{Capítulo 57}

\section{DESAFIOS DA AVALIAÇÃO PSICOLÓGICA PARA PORTE DE ARMA DE FOGO}

DOI: $10.37423 / 200200312$

Marcelo Augusto Resende

psiresende@gmail.com

RESUMO: No contexto atual em que impera a violência e a insegurança, muitas pessoas buscam se prevenir comprando uma arma de fogo para proteger a si mesmo,-sua-família, seus amigos seu patrimônio. Percepe-se que o posicionamento das pessoas pode se tornar favorável se elas são colocądas frente a determinadas situações/de violência. As legislações que regulam sobre o uso de armamento foram sendó modificadas com o passar dos anos. Atualmente exige-se do candiòdato, civil qu militar, que deseja usar uma arma de foge, que ele seja submetido a ùmąa avaliação psicológica. Esta ávaliação tem por finalídade verificar se a pessoa possui características compatíveis para o trabalho armado ou- posse e manuseio pelos civis. Cabe ao psicólogo prestar esta funçẩo avaliativa levandó em consideração à própria capacitação profissional e os preceitos da ética. Muitos sâo os desafios viyenciados pelos psicólogos nesta atividade como: credenciamento/junto à Polícia Federal; escolha de instrumentos psicológicos pertinentes â Instrução Normativa n 78/2014; capacita ção para aplicação, correçẩo e interpretação dos resultadós, com elaboração de síntese e laudo conclusivo; remuneração-adequada ao servico/prestado; e devolutiva aos candidat $\phi$ s. 0 psicólogo devidamente capacitado, àtualiządo, ético éfento-aos fatores-que podem estar envolvidos na vida do candidato ao porte de arma, tem condições de dake seù parecer com segurança e embasamento científico. A prática revela desafios a serem enfrentados è esforços devem ser empregados para minimizar os problemas nesta área de atuação. 


\section{Desafios da psicologia no Brasil}

\section{INTRODUÇÃO}

No contexto atual em que impera a violência e a insegurança, muitas pessoas buscam se prevenir comprando uma arma de fogo para proteger a si mesmo, sua família e seu patrimônio. Em pesquisa realizada por um jornal de grande circulação na cidade de Belo Horizonte/MG (MIRANDA, 2018), buscou-se verificar o que a população pensava sobre o assunto. Dos 648 entrevistados, foram a favor do porte de arma 51,4\% dos homens e 33,3\% das mulheres. Em relação à situação sócio-econômica, 55\% de pessoas de classes sociais A e B são favoráveis ao direito da população se armar, enquanto que nas classes C, D e E o percentual é de 38,7\%. Em relação à idade: de 16 a 34 anos, 40,2\%; de 35 a 44 anos, 42,1\%; e de 45 ou mais, 43,3\%. Pode-se observar que a opinião dos pesquisados quanto a portar uma arma de fogo tende a ter mais aceitação pelas pessoas do sexo masculino, de classe econômica mais elevada e de idade mais avançada.

Os entrevistados que foram contra a liberação das armas justificaram suas respostas dizendo que: "isso não reduziria a violência", "o brasileiro tem a mania de fazer justiça com as próprias mãos, já que a justiça é lenta, e a liberação seria caótica", "ficaria preocupado se soubesse que os meus vizinhos estão armados" e que "qualquer briga boba poderia terminar em morte". Por outro lado, os participantes que responderam a favor do porte de arma disseram que: "se eu visse minha família em risco, eu não pensaria duas vezes antes de atirar", "eu apertaria o gatilho se minha filha estivesse sendo violentada por um bandido", "os criminosos se sentiriam menos confortáveis para realizar crimes se presumissem que seus potenciais alvos estão armados", e que "se eu pudesse andar armado me sentiria mais seguro para trabalhar como taxista", entre outras justificativas.

Ao ser questionado em que situação de violência você teria coragem de atirar em um bandido, os entrevistados responderam em mais de uma situação, como pode ser constatado a seguir: assalto a residência $(56,3 \%)$, estupro de alguém próximo $(50,4 \%)$, sequestro de familiar $(43,3 \%)$, assalto na rua (36,6\%), agressão física a alguém próximo $(27,2 \%)$, ameaça em briga de trânsito $(7,2 \%)$ e ameaça em briga de bar (6,2\%). Percebe-se que o posicionamento das pessoas pode mudar se elas são colocadas frente a determinadas situações de violência, fazendo com que o porte de arma seja uma saída para se defender ou proteger familiares e amigos.

O conceito de portar arma de fogo, segundo Jesus (2002), está relacionado com a ação de transportar pessoalmente a arma nas mãos, roupas, bolsa, maleta, sacolas, meios de transporte como automóveis, barcos e até no arreio do cavalo, entre outros, de maneira a permitir seu pronto uso, demonstrando o requisito da ofensividade. Não se exige o contato físico com a arma, basta que esteja junto da pessoa, 


\section{Desafios da psicologia no Brasil}

possibilitando a utilização imediata. O porte de arma só se concretiza se a pessoa o faz fora de casa, não sendo considerado "porte" o transporte da arma no interior da residência.

Para portar arma de fogo, afirma Sznick (1997), é preciso ter licença de autoridade policial. As legislações que regulam sobre o uso de armamento foram sendo modificadas com o passar dos anos. O artigo 14 da Lei no 10826 (BRASIL, [2003]/2018) afirma que portar, deter, adquirir, fornecer, receber, ter em depósito, transportar, ceder, ainda que gratuitamente, emprestar, remeter, empregar, manter sob sua guarda ou ocultar arma de fogo, acessório ou munição, de uso permitido, sem autorização e em desacordo com determinação legal ou regulamentar, terá como pena a reclusão de 02 (dois) a 04 (quatro) anos, e multa. O parágrafo único esclarece que o crime previsto neste artigo é inafiançável. Exemplo recente foi a prisão do médium "João de Deus" em Abadiânia/GO, que além das acusações de estupro de vulneráveis, mantinha em seu poder várias armas de fogo sem a devida autorização.

\section{A AVALIAÇÃO PSICOLÓGICA PARA CONCESSÃO DE PORTE DE ARMA DE FOGO}

O Sistema Nacional de Armas (SINARM), do Ministério da Justiça (BRASIL, [1997]/2018), através da lei 9437 de 20/02/97, tornou obrigatória a avaliação psicológica para o candidato que desejar obter porte de arma de fogo, objetivando diminuir o número de ocorrências de má utilização desta arma por pessoas despreparadas ou inabilitadas. A lei federal 10.826, conhecida como Estatuto do Desarmamento (BRASIL, [2003]/2018), foi criada com o objetivo de manter um maior controle sobre as armas de fogo no Brasil. Tornou proibido o seu uso pela população, exceto por agentes de segurança e casos funcionais, como agentes de inteligência, auditores fiscais e cidadãos maiores de 25 anos, que comprovem idoneidade e motivação justificável para ter uma arma, conforme legislação da Polícia Federal (2014).

A avaliação psicológica para concessão do porte de arma de fogo, segundo o Conselho Federal de Psicologia (CFP, [2008]/2018), tem por finalidade verificar se a pessoa possui características compatíveis para o trabalho armado ou posse e manuseio pelos civis. Cabe ao psicólogo prestar esta função avaliativa levando em consideração a própria capacitação profissional e os preceitos da ética.

Esse processo avaliativo pretende, mais do que predizer o risco de sofrer ou produzir conflitos ou acidentes, identificar as dimensões psicológicas relevantes para um manejo adequado do porte e manuseio do armamento. Toledo, Montoro e Civera (2005) enfatizam que a cultura da segurança se efetiva por meio de ações preventivas, não bastando ações interventivas posteriores a um inadequado desempenho do uso da arma de fogo. Uma vez disparada, a arma já causou danos a terceiros ou contra 


\section{Desafios da psicologia no Brasil}

si mesmo. Deve-se tomar os devidos cuidados para quem será concedido o direito de portar uma arma de fogo.

No Brasil, todas as pessoas que buscam se armar, seja no meio civil ou militar, tem que se submeter a uma avaliação psicológica para verificação de sua aptidão para porte e manuseio de uma arma de fogo, segundo o CFP (2018). Na prestação desta avaliação, o Código de Ética da Psicologia (CFP, 2005) estabelece princípios e normas sobre a prática do psicólogo, que deve se pautar pelo respeito ao ser humano e a seus direitos fundamentais. Cabe ao psicólogo atuar com responsabilidade, por meio do contínuo aprimoramento profissional, e assumir responsabilidade somente por atividades para as quais esteja capacitado pessoal, teórica e tecnicamente; podendo lançar mão de ferramentas, como testes psicológicos de uso privativo dos profissionais da psicologia.

A Instrução Normativa no 78 (POLíCIA FEDERAL, 2014) descreve em seu anexo V, a relação dos indicadores psicológicos do portador de arma de fogo. São eles: atenção necessária (concentrada e difusa), memória (auditiva e visual) e indicadores psicológicos necessários (adaptação, autocrítica, autoestima, autoimagem, controle, decisão, empatia, equilíbrio, estabilidade, flexibilidade, maturidade, prudência, segurança e senso crítico. São considerados indicadores psicológicos restritivos: conflito, depressão, dissimulação, distúrbio, exibicionismo, explosividade, frustração, hostilidade, imaturidade, imprevisibilidade, indecisão, influenciabilidade, insegurança, instabilidade, irritabilidade, negativismo, obsessividade, oposição, perturbação, pessimismo, transtorno e vulnerabilidade.

A aptidão psicológica deverá ser atestada em laudo conclusivo por psicólogo da própria Polícia Federal ou por esta credenciada. A instrução normativa 78 , de 10/02/2014, estabeleceu ainda uma bateria mínima de testes na aferição das características de personalidade e habilidades específicas dos usuários de arma de fogo: um teste projetivo, um expressivo, um de memória, um de atenção difusa e concentrada, além da entrevista semi-estruturada. (POLÍCIA FEDERAL, 2014). Nota-se que a referida instrução não determina qual teste deve ser utilizado, mas estipula algumas áreas essenciais para serem avaliadas como: personalidade, memória, atenção e contexto sócio-histórico. Isso possibilita que o psicólogo escolha as técnicas que tem maior capacitação e experiência, possibilitando identificar pontos fortes e fraquezas que irão embasar o seu parecer de aptidão. 


\section{Desafios da psicologia no Brasil}

\section{DESAFIOS DA AVALIAÇÃO NO CONTEXTO DE PORTE DE ARMA DE FOGO}

A avaliação psicológica para concessão de porte de arma de fogo apresenta diversos desafios ao psicólogo que trabalha ou pretende trabalhar nesta área. Uma questão inicial dos profissionais é saber como se faz o credenciamento para oferecer este serviço. Segundo a Polícia Federal, o psicólogo deve apresentar alguns requisitos quando abrir o edital, divulgado por esta instituição, a partir do preenchimento de um formulário próprio. Além deste, é preciso apresentar: I. Foto 3x4 recente; II. Original e cópia, ou cópia autenticada de documento de identidade e do CPF (poderá ser apresentada a carteira do Conselho de Psicologia); III. Comprovante de inscrição ativa e regular no Conselho Regional de Psicologia e certidão negativa de infrações éticas do respectivo Conselho; IV. Documentos que comprovem que dispõe de ambiente e mobiliário adequado para a aplicação dos testes (planta baixa/croquis e fotografias); V. Original e cópia, ou cópia autenticada dos documentos que autorizam o funcionamento do local onde serão aplicados os testes (Alvará de Localização e Funcionamento e Alvará da Vigilância Sanitária); VI. Comprovante de que possui pelo menos dois anos de efetivo exercício na profissão de psicólogo; VII. Certificado que ateste sua aptidão para aplicação dos instrumentos psicológicos previstos nos incisos I e II do art. 5o da IN 78/2014 - DG/PF; e VIII. Comprovação de idoneidade, com a apresentação das certidões negativas de antecedentes criminais fornecidas pela Justiça Federal, Estadual, Militar e Eleitoral e de declaração de não estar respondendo a inquérito policial ou a processo criminal, que poderão ser fornecidas por meios eletrônicos. O local de trabalho será vistoriado pela Polícia Federal, devendo contar com ambiente e equipamentos adequados para aplicação dos testes, composto de banheiro, sala de espera e sala de aplicação individual de testes, com o mínimo de quatro metros quadrados, ou sala para aplicação coletiva de testes, onde sua capacidade de uso permita o espaço mínimo de dois metros quadrados por candidato, equipada com os materiais necessários à execução das atividades e isolada acusticamente. (POLÍCIA FEDERAL, 2018). Constata-se que é exigida uma série de requisitos, não sendo viabilizado o credenciamento a qualquer psicólogo.

Uma vez credenciado, o psicólogo passará por uma fiscalização pelas psicólogas da Polícia Federal no período de validade do credenciamento, que é de quatro anos, para verificar sua capacitação na realização deste trabalho e se o profissional está atuando conforme as instruções e orientações da PF e CFP. Será verificado se: realiza a completa avaliação do teste; mantêm atualizados os conhecimentos relativos ao teste; utiliza material original na testagem; utiliza manuais atualizados e referendados pelo CFP; mantêm os protocolos (testes) dos candidatos arquivados na clínica ou consultório; observa o nível de escolaridade do candidato para aplicação dos testes; anota a parte, os dados qualitativos e 


\section{Desafios da psicologia no Brasil}

quantitativos de cada instrumento com a respectiva síntese; não anota nada nos testes dos candidatos, somente medidas indicadas nos manuais dos mesmos; o candidato assinou e datou todas as folhas utilizadas dos instrumentos; e inseriu junto com o material do candidato um laudo de toda a avaliação psicológica realizada. Esta fiscalização torna-se imprescindível para manter uma boa qualidade técnica dos psicólogos credenciados, sendo oportunidade para orientações e troca de informações entre os profissionais. O problema é que apenas uma pequena quantidade de casos é fiscalizada, permitindo que vários outros passem despercebidos.

Na prática, muitos psicólogos credenciados não estão devidamente capacitados para aplicação, correção, interpretação e integração dos dados obtidos em diversas técnicas utilizadas neste tipo de avaliação. Isso decorre, muitas vezes, da própria deficiência dos cursos de graduação e de curta duração de capacitação em avaliação psicológica. Alguns profissionais não fazem as correções conforme o previsto no manual técnico, realizando correções superficiais. Algumas clínicas com demandas muito grandes, realizam aplicações coletivas, tornando o tempo de correção dos testes bem limitado e favorecendo as popularmente conhecidas "correções no olho". Um dos testes em que é muito frequente tal procedimento é o teste Palográfico.

A escolha dos testes a serem utilizados na bateria também é fonte de preocupação. Soube de uma credenciada, que ela utilizava apenas o teste de Rorschach em suas avaliações. Disse que o teste era muito completo e por meio dele era capaz de verificar se a pessoa era ou não apta a portar arma de fogo. De fato, o citado teste demonstra muitas qualidades quantitativas e qualitativas, mas não se pode basear um parecer de aptidão apenas em um instrumento, além disso, contraria o prescrito na Instrução Normativa no 48 (POLÍCIA FEDERAL, 2014), que estipula uma bateria contendo, no mínimo, seis técnicas psicológicas (entrevista, expressivo, projetivo, memória, atenção difusa e concentrada). Outra psicóloga, em um congresso científico nacional, relatou usar o teste do desenho da casa, árvore e pessoa (HTP) em aplicações coletivas para concessão de porte de arma de fogo. Esta escolha é equivocada, uma vez que o HTP é uma técnica individual. Tais fatos demonstram que não se pode aplicar qualquer técnica ou de qualquer maneira, devendo o profissional estar devidamente capacitado e atualizado em relação à prática que pretende trabalhar. Além disso, os testes devem estar considerados favoráveis pelo Sistema de Avaliação dos Testes Psicológicos (SATEPSI) e devem ser usados para o contexto e propósito que foram criados, segundo o CFP $(2013,2018)$. Aqui cabe uma ressalva quanto a IN 78, pois ela descreve a utilização de seis técnicas, mas não limita o psicólogo a usar outras, se necessário for. Caso o candidato ao armamento apresente indícios de déficit intelectual, deve ser aplicado um teste de inteligência para eliminar as possíveis suspeitas. 


\section{Desafios da psicologia no Brasil}

Outra dificuldade detectada entre os profissionais é a elaboração de documentos. Alguns não sabem diferenciar o que é uma síntese e um laudo. Isso demonstra uma deficiência na formação e na atualização das resoluções do CFP (2008), que orienta como fazer os documentos advindos da prática psicológica. Síntese é o resultado alcançado em uma técnica específica, enquanto o laudo é o resultado de diversas técnicas utilizadas numa avaliação psicológica, compilando as principais características de personalidade e demais fatores avaliados, como inteligência, memória e atenção, entre outros. No caso específico da avaliação no âmbito do porte de arma, a PF criou um modelo específico de laudo para que o credenciado enviasse o resultado de forma objetiva e conclusiva, sem descrição de detalhes. Isso, no entanto, não isenta o psicólogo de elaborar um laudo completo do caso avaliado, que deverá ser anexado e guardado em local sigiloso, juntamente com todo o material do candidato ao porte.

A remuneração tem sido outro desafio encontrado pelos psicólogos em sua prática. A instrução normativa no 48 estipula que o preço a ser cobrado por este tipo de avaliação não pode exceder o valor médio dos honorários profissionais cobrados para realização de avaliação psicológica para o manuseio de arma de fogo constante da tabela do Conselho Federal de Psicologia. Segundo a referida tabela (CFP, 2018), o preço médio para este tipo de avaliação é de $R \$ 468,12$ (quatrocentos e sessenta e oito reais e doze centavos). Infelizmente, este preço está muito além da realidade praticada pelos psicólogos. Uma média de preço usada pelos credenciados está em torno de $\mathrm{R} \$ 200$ a $\mathrm{R} \$ 250,00$ (duzentos a duzentos e cinquenta reais). Não é incomum o interessado na avaliação dizer que já encontrou por preço mais barato, como $\mathrm{R} \$ 80,00$ (oitenta reais). Tal valor é cobrado em clínicas que utilizam a aplicação coletiva e podem, desta forma, oferecer preços mais competitivos. Além disso, oferecem disponibilidades de tempo maiores, oferecendo quase que uma avaliação instantânea à demanda feita, tipo um "self-service psicológico": você quer, você tem. Isso acaba inviabilizando quem trabalha em consultório, com aplicação individual, que precisa agendar a avaliação com antecedência e cobrar um preço que seja compatível com os gastos e serviço realizado. A perversão do mercado abre espaço para que psicólogos menos criteriosos realizem avaliações menos consistentes e em desacordo com o prescrito pela PF, CFP e o código de ética da Psicologia.

A devolutiva tem sido outro ponto que levanta muito questionamento por parte dos psicólogos. Toda pessoa que passa por um processo de avaliação psicológica tem o direito a uma entrevista de devolução de seus resultados, segundo o CFP (2005). O problema está justamente nos casos que não foram aptos ao porte de arma. Muitos candidatos não aceitam o resultado e tem condutas inadequadas com o psicólogo, chegando, em algumas situações, a ameaçá-lo ou suborná-lo. Existe 


\section{Desafios da psicologia no Brasil}

uma falsa ideia de que se pagou pelo serviço, deve ser aprovado. O credenciado não pode ficar intimidado ou seduzido a dar um parecer favorável. Ao mesmo tempo, tem que buscar uma postura ética e profissional para revelar ao sujeito as razões que o impede de neste momento ter ou manusear

um armamento. É preciso que a pessoa tome consciência dos fatores de contra indicação para que possa tratá-los adequadamente e quem sabe no futuro poder se armar. Caso contrário, irá peregrinar de consultório em consultório, de clínica em clínica, até conseguir alguém que lhe dê o parecer de aptidão.

\section{CONSIDERAÇÕES FINAIS}

Diante de tantos desafios que atravessam a prática do psicólogo que trabalha com avaliação psicológica para concessão do porte de arma de fogo, é fundamental uma reflexão sobre o papel e a função deste profissional. Armar ou desarmar alguém é de extrema responsabilidade. Imagine que essa pessoa possa ser um psicótico, um bandido, um sequestrador, um irresponsável, um desleixado, um inseguro, um homicida ou um suicida. Que uso fará da arma? Deixará em qualquer lugar, podendo ficar acessível ao uso pelos filhos ou amigos? Eliminará o demônio que acredita estar encarnado? Ficará na dúvida se deve ou não atirar ao ser ameaçado de morte? Usará para benefícios escusos ou ter poder sobre os outros? Será vítima da própria arma?

Existe um ditado que diz: "quem vê cara, não vê coração". Não se pode basear uma avaliação apenas na imagem que vemos de alguém. Pode até ser que a imagem reflita aquilo que a pessoa é de fato. Mas os psicólogos têm um saber para além das aparências, afinal elas podem enganar. E é aí que se pode fazer a diferença. Ao realizar uma avaliação psicológica consistente, bem embasada, é possível distinguir os que podem e os que não podem estar armados. É de extrema relevância social armar apenas os que apresentarem requisitos para tal.

O psicólogo devidamente capacitado, atualizado, ético e atento aos fatores que podem estar envolvidos na vida do candidato ao porte de arma, tem o dever de dar o parecer de aptidão se julgar que o mesmo demonstrou condições psicológicas e capacidade para portar e manusear uma arma de fogo. Da mesma forma, negar o porte de qualquer pessoa que não apresente tais requisitos. A prática revela vários desafios a serem enfrentados e esforços devem ser empregados para minimizar os problemas nesta área de atuação. 


\section{Desafios da psicologia no Brasil}

\section{REFERÊNCIAS:}

BRASIL. Presidência da República. Casa Civil. Subchefia para assuntos Jurídicos. Lei no 9437/1997. [Revogado pela lei no 10826, de 22.12.2003]. Disponível

em: http://www.planalto.gov.br/ccivil_03/Leis/L9437.htm. Acessado em: 22 ago. 2018.

BRASIL. Presidência da República. Casa Civil. Subchefia para assuntos Jurídicos. Lei no 10826/ 2003. Disponível em:

http://www.planalto.gov.br/ccivil_03/Leis/L10826.htm. Acessado em: 22 ago. 2018.

CONSELHO FEDERAL DE PSICOLOGIA. Resolução no 002/2003. Define e regulamenta o uso, $a$ elaboração e a comercialização de testes psicológicos. Disponível

em: https://site.cfp.org.br/legislacao/resolucoes-do-cfp/ Acessado em: 15 jul. 2018.

CONSELHO FEDERAL DE PSICOLOGIA. Resolução no 007/2003. Manual de Elaboração de Documentos Escritos produzidos pelo psicólogo. Disponível

em: https://site.cfp.org.br/legislacao/resolucoes-do-cfp/ Acessado em: 15 jul. 2018.

CONSELHO FEDERAL DE PSICOLOGIA. Código de ética profissional do psicólogo. Brasília: CFP, 2005.

CONSELHO FEDERAL DE PSICOLOGIA. Resolução no 018/2008. Avaliação psicológica para concessão de registro e/ou porte de arma de fogo. Disponível

em: https://site.cfp.org.br/legislacao/resolucoes-do-cfp/ Acessado em: 10 jun. 2018.

CONSELHO FEDERAL DE PSICOLOGIA. Cartilha Avaliação Psicológica. Brasília: CFP, 2013.

CONSELHO FEDERAL DE PSICOLOGIA. Sistema de Avaliação de Testes Psicológicos (SATEPSI). Disponível em: http://www2.pol.org.br/satepsi/sistema/admin.cfm?lista1=sim. Acessado em: 22 set. 2018.

CONSELHO FEDERAL DE PSICOLOGIA. Tabela de honorários da Psicologia. Disponível em: https://site.cfp.org.br/servicos/tabela-de-honorarios/. Acessado em: 26 dez. 2018.

JESUS, D. Crimes de porte de arma de fogo e assemelhados. São Paulo: Saraiva, 2002.

MIRANDA, B. Maioria dos mineiros se diz contra liberar armas. Jornal O tempo. Belo Horizonte, p. 4, 26 de mar. 2018.

POLÍCIA FEDERAL. Instrução normativa $n^{0.78 / 2014-D G / D P F, ~(10 ~ d e ~ f e v e r e i r o ~ d e ~ 2014) . ~ D i s p o n i ́ v e l ~ e m: ~}$ http://www.dpf.gov.br. Acessado em: 22 ago. 2018.

POLÍCIA FEDERAL. Edital de credenciamento de psicólogos. Disponível

em:http://www.pf.gov.br/servicos-pf/armas/credenciamento-psicologos/editais-decredenciamento/edital_psicologo_2018-mg.pdf/view. Acessado em: 26 dez. 2018. 


\section{Desafios da psicologia no Brasil}

TOLEDO, F.; MONTORO, L.; CIVERA, C. La psicología aplicada a la selección de aspirantes a la tenencia y uso de armas de fuego en España. Revista Interamericana de Psicología/Interamerican Journal of Psychology, 39(1), 2005, 117-126. Disponível

em: http://www.redalyc.org/articulo.oa?id=28439112. Acessado em: 01 out. 2018.

SZNICK, V. Crime de porte de arma. São Paulo: Livraria e Editora Universitária de Direito Ltda., 1997

\section{REFERÊNCIAS SOBRE O AUTOR:}

Mestre e Doutor pela UFMG, Professor Adjunto da PUC MINAS São Gabriel, Tenente Coronel PM QOS psicólogo da reserva, Coordenador e professor da pós-graduação em Avaliação Psicológica do IEC/MG, Membro da Comissão de Avaliação Psicológica do CRP 04 e Membro da Diretoria da Sociedade de Avaliação Psicológica de MG (SAPSI/MG). 


\title{
Capítulo 58
}

\section{O REBAIXAMENTO COMO FATOR DE PRESTÍGIO SOCIAL}

\author{
DOI: $10.37423 / 200200316$
}

Renata Ferreira Munhoz (Pós-Doutora e Doutora em Letras pela FFLCHIUSP). renatafmunhoz@gmail.com

RESUMO: Este trabalho baseia-se na tese de Doutorado, intitulada "Eilologia e discurso na correspóndência oficial do Morgado de Mateus: edição de documentos administrativos e estudo das marcas de avalliatividade". Trata-se da análise da construçąo e manutenção do ethos do governador e capitắo general de São Paulo, nó período de 1765 a 1775, por meio de seu discurso oficial. São anâtisados fragmentos textuais retirados de cartas que compuseram a documentação pública enviada desşa capitania aos governantes fierarquicamente superiores em Portugal. Dentre as diversas características do discurso do período, será estudado o aspecto da "vassalagem" enquanto/prática de rébaixamento e menosprezo da própria persona. 0 recurso de inferiorizar-se e exaltar o\%utro (hierarquicantente superior), bastante empregado no período sętẹcentista, além da evidente função de apresentar-se submisso ao sistema monárquico vigente, permite, embora paradoxalmente, a elevaçầo da estima do ethos do sujeito em seu meio social. A ahálise do discurso veiculado no corpus será embasada na teoria do Sistema de Avaliatividade,desenvolvida por Martin e White (2005), a fim de se conceberem as mareas textuais que exemplificam-a ideotogia-coeva, bem como as esferas contextuais-que motivaram a sujeiçẫo como garantia de prestigio-social. Pretende-se, portanto, verificar a intersubjetividade que legitimou o poder no século XVHH e sua repercussão atual. 


\section{Desafios da psicologia no Brasil}

Palavras-chave: Ethos; Filologia; Análise do Discurso; Manuscritas setecentistas; Avaliatividade. 


\section{Desafios da psicologia no Brasil}

\section{INTRODUÇÃO}

Este artigo intenciona analisar as estratégias discursivas empregadas pelo Morgado de Mateus em seu discurso oficial com a finalidade de demonstrar submissão pessoal e exaltar os seus superiores na hierarquia do governo monárquico coevo. Para tanto, estudam-se a seguir fragmentos textuais retirados de quatro cartas manuscritas enviadas pelo Morgado de Mateus (Dom Luís Antônio de Sousa Botelho Mourão) em seu período de governo, de 1765 a 1775, como governador e capitão-general de São Paulo sobre assuntos variados que envolviam a prática da governança da capitania. Todos os documentos manuscritos analisados foram enviados de São Paulo a Portugal, para o Conde de Oeiras, Sebastião José de Carvalho e Melo (posteriormente, o Marquês de Pombal). Foram selecionados por conterem o mesmo tom de distanciamento e respeito em relação ao interlocutor, embora sejam divergentes quanto ao conteúdo temático de que tratam. Como elementos passíveis de análise com o aporte da Teoria da Avaliatividade, serão apresentados alguns itens da esfera do discurso, portadores da ideologia da exaltação do interlocutor em detrimento da manutenção do ethos autoral.

O conceito de ethos é aqui entendido como a imagem que o autor constrói de si em seu discurso para exercer uma influência em seu interlocutor. Em análise do discurso, esse termo emprestado da retórica antiga foi retomado por Kerbrat-Orecchioni (1980) como a imagem que os interlocutores fazem de si no processo de troca dentro dos parâmetros da subjetividade da linguagem.

A metodologia empregada para desenvolver a análise adota como base a edição textual fidedignamente proposta pela Filologia, por meio da transcrição semidiplomática do original manuscrito a partir de sua versão fac-similar. Nessa etapa, empregaram-se as "Normas para Transcrição de Documentos Manuscritos", propostas durante o 2‥ Seminário "Para a História do Português do Brasil", realizado em Campos do Jordão, em maio de 1998, disponíveis em Cambraia et al (2001, p. 13). Embora a ortografia do período contenha marcas pessoais do escriba e seja mantida de forma genuína pela edição semidiplomática, optou-se pela atualização da linguagem para facilitar a leitura dos trechos citados.

A título de ilustração, será apresentada a carta III como modelo em sua imagem fac-similar, acompanhado da respectiva transcrição. Vale ressaltar que, muito embora se apresente a seguir a versão atualizada dos fragmentos, a edição semidiplomática, comumente empregada nos trabalhos da área de Filologia, facilita o estabelecimento do texto, uma vez que apresenta, por exemplo, o desenvolvimento das abreviaturas.

Como cartas oficiais, referentes à administração oficial da capitania, de autoria intelectual do Morgado de Mateus (por ele ditados aos secretários e, posteriormente, assinados por seu próprio punho), 


\section{Desafios da psicologia no Brasil}

apresentam a tentativa de padronização do discurso com base na estrutura formal da espécie textual. Apesar disso, o aspecto da submissão evidencia a existência da intersubjetividade incutida nos elementos discursivos veiculados nessa documentação.

\section{AS CARTAS}

Foram elencados quatro documentos manuscritos da espécie documental 'carta', catalogados em Arruda (2000), para comporem a análise deste estudo. Todos são datados dos dez anos que compõem o período de governo do Morgado de Mateus (de 1765 a 1775), têm os mesmos interlocutores e a mesma data tópica, a capitania de São Paulo, com exceção da carta I, produzida na Vila de Santos, onde o governador iniciou sua estadia no Brasil, antes de tomar posse efetivamente em São Paulo. As quatro cartas foram produzidas pela autoria intelectual do Governador e Capitão-General da capitania de São Paulo, o Morgado de Mateus, Dom Luís Antônio de Sousa Botelho Mourão, e endereçadas ao Secretário do Reino, o Conde de Oeiras, Sebastião José de Carvalho e Melo.

Convém retomar que a carta é uma espécie documental não-diplomática, uma vez que não conta com uma fórmula padronizada de redação. No entanto, pode ser estudada como um diploma, devido aos padrões formais do período e ao objetivo que atende de corresponder "ao alto escalão da administração pública em comunicações sociais decorrentes de cargo e função públicos." (Bellotto, 2002, p. 51)

Ao longo das análises, a reprodução das cartas será fragmentária, em linguagem atualizada, e se dará entre aspas simples ", seguida da menção do número da carta de onde o trecho foi retirado. Por exemplo (C. I), quando se tratar da carta I. Por não serem reproduzidas na íntegra (apenas a carta III encontra-se reproduzida no anexo, a título de exemplo), cabe apresentar o verbete descritivo de cada uma:

I. Datada de 28 de maio de 1765, informa ao rei Dom José I das primeiras ideias do seu governo e das dificuldades que ia encontrando e transmitindo-lhes os seus agradecimentos pelo favor do cargo concedido e os seus desejos de feliz saúde.

II. Datada de 03 de julho de 1767, apresenta queixas dos insultos e impropérios de que tem sido alvo por meio de cartazes anônimos, expostos à porta das igrejas, nos quais são postas a ridículo as principais disposições de seu governo, repetindo-se o sucedido na vila de Paranaguá, fato a que se referiu em carta de 16 de janeiro de 1767. Expõe a forma honesta como executa sempre as reais ordens, e pede que lhe faça justiça no caso dos seus inimigos conseguirem que chegue ao Reino as calúnias com que pretendem depô-lo. 


\section{Desafios da psicologia no Brasil}

III. Datada de 04 de agosto de 1767, cumprimenta e reverencia o Secretário do Reino, o Conde de Oeiras, reiterando sua obediência.

IV. Datada de 18 de junho de 1774, afirma a sua amizade e informa ter entregue ao Bispo de São Paulo, Dom Frei Manuel da Ressurreição, o colégio onde estava morando. Pede que lhe envie o que achar mais justo sobre as questões de seu governo, a fim de poder desempenhar corretamente a sua função para o real serviço.

\section{METODOLOGIA DE ANÁLISE}

Parte-se do conceito de que "uma teoria deve ser geral, no sentido em que ela deve pôr à nossa disposição um instrumental que nos permita reconhecer não apenas um dado objeto ou objetos já submetidos a nossa experiência, como também todos os objetos possíveis da mesma natureza suposta." (Hjelmslev, 2003, p. 19). Assim, selecionou-se a Teoria da Avaliatividade por fornecer metodologia de análise que possibilita a observação dos elementos de ordem intersubjetiva, relacionada à esfera da valoração. Criada "como um sistema interpessoal ao nível da semântica do discurso" (Martin e White, 2005, p. 33), a Teoria da Avaliatividade deriva da Linguística Sistêmico Funcional (LSF), a partir da metafunção interpessoal proposta pela gramática funcional de Halliday e Mattiessen (2004). Por representar um sistema discursivo, a Avaliatividade pressupõe a existência dos demais sistemas: "negociação, periodicidade, identificação, ideação e conjunção" (Martin e White, 2005, p. 162), embora não os estude.

Essa teoria define que a valoração pela linguagem cumpre três funções principais: atitude, gradação e engajamento. A atitude engloba o posicionamento atitudinal do autor, por meio do elogio e da censura, apresentando os seus sentimentos e julgamentos sobre o que o cerca. Essa função é subdividida em afeto (que expressa estados emocionais), em julgamento (referente a normas e valores) e apreciação (recurso de expressar gostos). A gradação é responsável por intensificar ou mitigar os significados dos dois subsistemas anteriores. Divide-se em força, que gradua as avaliações, para intensificar ou mitigar os significados; e foco, que gradua contextos não possíveis de gradação. Já o engajamento trata da adesão ou não do autor em relação aos posicionamentos de outrem.

A partir das funções elencadas, a análise será construída com base no escopo das duas primeiras: a atitude e a gradação. Intenciona-se, com isso, melhor compreender as três questões básicas postuladas pela própria Teoria da Avaliatividade: “a) como os autores constroem sua identidade para si mesmos; b) como os autores posicionam-se diante dos potenciais destinatários; c) como os autores constroem a audiência ideal para seus textos." (Martin e White, 2005, p. 40). 


\section{Desafios da psicologia no Brasil}

Além disso, adotaram-se os pressupostos teóricos referentes à construção do discurso político (Charaudeau, 2013, 2014) e à manutenção do poder (Dijk, 2012), a fim de se observarem "os modos em que se utilizam as formas linguísticas em diversas expressões e manipulações do poder" (Meyer, 2003, p. 31). Cria-se, no nível discursivo, o conceito de identidade do autor, no sentido de ser o sujeito, enquanto "primado da mediação reflexiva sobre a posição imediata do sujeito, tal qual se exprime na primeira pessoa do singular: 'eu penso', 'eu sou'” (Charaudeau e Maingueneau, 2008), entendido a partir do princípio da alteridade.

Desse modo, a metodologia de análise parte do pressuposto de que há em toda formulação discursiva um ponto de vista codificado, veiculado no texto de forma explícita ou implícita. Por meio do detalhamento do sistema com o aporte das ferramentas teóricas elencadas, pretende-se analisar os aspectos referentes à intersubjetividade contida nos manuscritos setecentistas.

\section{ESFERA DO LAUDATÓRIO}

A escrita do século XVIII serviu comumente de instrumento à manutenção do princípio entendido como o de 'vassalagem', enquanto subordinação dos cidadãos frente ao governo monárquico estabelecido. Por se tratar de instrumento simbólico de poder, a produção escrita era associada ao que se entendia por 'poder oficial', aquele diretamente ligado ao Rei e aos ocupantes dos demais cargos por ele instituídos.

As produções discursivas de caráter laudatório veiculadas nas cartas visam a enaltecer as qualidades do Conde de Oeiras, colocando-o em posição superior aos demais homens, a quem Morgado de Mateus espera 'poder ter a satisfação e o gosto de aparecer todas as vezes que lhe for possível aos pés de Vossa Excelência' (C. I). O rebaixamento do autor, deve-se ao ethos de grandeza e merecimento atribuído ao interlocutor, o Conde de Oeiras, na construção discursiva do próprio Morgado de Mateus. Diante dessa superioridade, o autor recomenda que 'Deus permita acrescentar a Vossa Excelência muitos anos de vida para amparo de nós todos, pois só em Vossa Excelência esperamos todo o nosso bem e toda a nossa felicidade.' (C. IV). Eleva-se ainda mais o ethos do interlocutor ao se atribuir a dependência de seu amparo para que se tenha o bem e a felicidade. Reforça-se tal asserção com os intensificadores 'todo' e 'toda' a ampliarem o escopo dessas venturas.

Em contrapartida, o assunto tratado pela carta II demonstra o estarrecimento do autor diante da ruptura da função laudatória de louvação da escrita. Trata-se da oposição imediata do laudatório de aprovação: a produção do vitupério ou sátira, que fizeram de seu governo: 'foram pregar na porta [da igreja] uma vergonhosa sátira' (C. II). A classificação 'vergonhosa' exprime o julgamento de sanção 


\section{Desafios da psicologia no Brasil}

social, à medida que a atitude contraria a ordem oficial estabelecida ao desrespeitar o representante do governo, mas traz em si também a marca do afeto negativo. Descreve com detalhes os seus planos criticados: 'são escarnecidas as tropas, e o seu luzido fardamento, chamando-me destruidor do povo' (C. II). Ao ser considerado 'destruidor do povo', pelo fato de impor o alistamento militar dos moradores da capitania de São Paulo à formação das tropas, usa a adjetivação com a atitude de julgamento de estima social 'luzido', a fim de comprovar a distinção dessas tropas.

Na mesma sátira, é chamado de 'carreiro', ao se criticarem as lavouras que vinha instituindo como base de seu governo e criticam as a criação das 'vilas, chamando-me fidalgo da aldeia, e de meia tigela, e outros vários impropérios indignos de pôr na presença de Vossa Excelência' (C. II). Todas as ofensas remetem às suas medidas de governo e, por isso, ofendem seu ethos público, colocada por ele acima da esfera pessoal. Mas o que mais o preocupa é o fato de terem concluído a sátira 'com muitas ameaças de darem de mim conta a Vossa Excelência para que me desse carreira e me pusesse não menos que na forca.' (C. II)

Por se tratar de algo que o incomodou demais, a carta narra com detalhes o ocorrido: 'tirou logo o vigário capitular a dita sátira e a consumiu, de sorte que se não soube nada nesse dia e nos seguintes. Porém, não contentes com este excesso, passaram a fazer outro maior, pondo-me a mesma sátira dentro de uma carta fechada diante do bofete em que eu costumo despachar, e então é que a vi, e pouco depois me disseram o que já tinha sucedido de aparecer outra pregada na porta da Igreja do Recolhimento de Santa Tereza.' (C. II). Dos muitos detalhes, destacam-se os de ordem religiosa, pois a igreja era o lugar público onde se afixara a sátira e, sobretudo, revela-se a atitude de proteção do vigário, que retirou a sátira antes que outros a vissem, evitando aborrecimentos no dia festivo. Além disso, a esfera da gradação permite que a passagem narrativa ganhe cores, com a intensificação 'não contentes com este excesso, passaram a fazer outro maior', o que tangencia a afetividade.

Como bom estrategista, Morgado de Mateus tenta descobrir o autor da sátira de forma velada: 'tenho dissimulado até agora e vou fazendo toda a diligência para descobrir os cúmplices desta obra, o que até agora não tem sido possível. Se eu os puder conhecer, Ihes darei o castigo merecido' (C. II). Para descobrir os responsáveis, empenha 'toda a diligência', em que a gradação de força indica sua resolução em resolver o caso pessoal, elevado à esfera do público. Com isso, o princípio da justiça entra em voga por meio do 'merecido castigo', em que o culpado seria punido de acordo com o julgamento de sanção social em voga, em que uma sátira seria (como posteriormente de fato o foi) considerada um crime grave. 


\section{Desafios da psicologia no Brasil}

O poder de mando dos interlocutores deve-se ao fato de serem pessoas com poderes delegados pelo soberano pelo critério do 'merecimento'. O Conde de Oeiras ganhou esse título nobilitário por sua eficiente atuação na reconstrução de Lisboa após o terremoto de 1755. Já Morgado de Mateus tem o seu cargo de governado por conta de sua experiência militar de vitória no episódio "Defesa da Passagem do Rio Tua" (Bellotto, 1979, p. 14), na Campanha de 1762 em Trás-os-Montes contra os espanhóis, o que legitima sua nomeação com a patente de capitão-mor. Dessas conquistas pessoais, resulta o destaque do ethos de cada um dos interlocutores, vinculados à ligação afetiva e o contrato de fidelidade com o Rei.

Em troca de proteção e benefícios pessoais, o autor constantemente jurava fidelidade ao Rei de Portugal. Tal fidelidade incluía a promessa de cumprir as ordens e imposições do governo d'além mar, mesmo quando essas determinações contrariassem os interesses locais, o que comumente ocorria. $E$, sobretudo, gerir o governo de forma a evitar dissabores à Coroa Portuguesa: 'eu me opunha para coibir os seus efeitos, e conservar, como conservo, mediante o favor de Deus até o presente, a tranquilidade pública.' (C. II). Além das medidas em si, seu empenho é comprovado pelas afirmativas reiteradas de que 'eu sirvo com zelo e amor a Sua Majestade' (C. II) e, sobretudo da demonstração do grau de dificuldade de sua missão: 'Eu os acho muito decadentes, sem rendas, sem cultura e sem sujeitos de que me possam ajudar. Quase tudo me é necessário formar de novo' (C. I). Ao se referir à capitania de São Paulo, sempre apresenta os inúmeros problemas a serem vencidos, o que faz com que suas execuções ganhem aura de verdadeiras conquistas. Atinge, por meio dessas estratégias discursivas, a proposta de elevar o nível de conceituação de seu ethos.

\section{AS RELAÇÕES DE PODER}

Normalmente, a tramitação dos documentos administrativos cumpre etapas que podem gerar a produção de outros documentos, formando um processo: "uns são sempre ascendentes, como as cartas, outros, sempre descendentes, como a carta régia." (Bellotto, 2014, p. 398). Ao se observar que as cartas são trocadas entre as mais altas esferas do governo, na transmissão ascendente, os assuntos comumente tratam de assuntos de ordem pública, dos quais transmite apenas o necessário: 'por me parecer desnecessário cansar muito a Vossa Excelência o repeti-las' (C. IV). A estratégia de resumir informações e evitar a redundância de assuntos é também explicitada ao se valorizar o tempo do leitor 'Desculpe-me Vossa Excelência ter Ihe embaraçado tanto tempo' (C. II). Retoma-se, com isso, o princípio da legitimação do poder atribuído ao interlocutor e, como consequência, confere ao autor o mecanismo de valorização de seu bom senso. 


\section{Desafios da psicologia no Brasil}

O conceito de "poder" é baseado em uma "a noção tão complexa quanto vaga" (Dijk, 2012, p. 9). Em termos sociológicos, pode-se definir o poder como um conceito normativo que, segundo Duverger (1983, p. 152) define a situação daqueles que têm o direito de exigir que os outros se verguem às suas diretivas numa relação social, porque o sistema de normas e de valores da coletividade na qual se desenvolveu esta relação estabelece este direito. O poder por excelência é pertencente ao Rei, por ser o "portador de uma voz cuja onipotência resulta de ela não se encontrar aqui, mas em um além inacessível" (Charaudeau, 2013, p. 69) o poder da realeza é legitimado pela filiação de natureza sagrada, como herança natural da predestinação, da qual derivam os atributos e qualidades pessoais. As relações de poder no nível social manifestam-se na interação, haja vista que "o poder social é geralmente indireto e age por meio da 'mente' das pessoas, por exemplo, controlando necessárias informações de que precisam para planejar ou executar suas ações." (Dijk, 2012, p. 42). Daí a extrema necessidade de relatar todas as ações de seu governo em um diário e enviar em documentos oficiais, relatos de sua governança: 'Esta ocasião que me permite a frota e a obrigação de dar conta a Sua Majestade, que Deus guarde, das primeiras ideias do meu governo' (C. I). O princípio de reportar ações ao superior reforça a tenção constante de demonstração de poderes, em que aquele que detém menos serve-se de estratagemas que sirvam de ponto de contato e validem a relação com o outro. Daí a atribuição de seu bom relacionamento com o Conde de Oeiras, desejando 'a continuação de uma saúde muito feliz, com que nos seguremos /mediante o vigilante zelo de Vossa Excelência/ todos os aumentos, e felicidades desta Monarquia, a consolação e amparo dos que, como eu, têm em Vossa Excelência sua fortuna e toda a sua esperança' (C. III), de modo a personificar nele suas realizações. $\mathrm{Na}$ mesma diretriz, de modo muito mais amplo, atribui a ele a manutenção do próprio sistema monárquico.

Charaudeau (2013, p. 10) estabelece que o espaço público seja o lugar propício para a representação de papéis sociais. Nesse "jogo de máscaras", os interlocutores dão vida a personagens, sempre recorrendo a estratégias que os permitam a preservação da face e garantam uma interação harmônica. Diante disso, Morgado de Mateus apresenta em forma de confissão o desejo de acertar: 'Confesso, Senhor, que desejara ter presa a meu arbítrio a fortuna: para poder ter préstimo e adquirir os maiores acertos neste meu emprego' (C. I). Esse desejo, no entanto, está restrito a uma hipótese, o que o invalida e, por conseguinte, justifica suas falhas futuras.

Com base na concepção de que o discurso político serve-se de estratégias capazes de construir a identidade do político que o enuncia, verifica-se que a construção discursiva é sempre repleta de significado, o que pode ser ainda mais representativo se as entrelinhas forem consideradas. Por 


\section{Desafios da psicologia no Brasil}

exemplo, a afirmação de 'que em toda a parte possa eu ter o gosto, e a satisfação de me chegarem estas estimáveis, e desejadas notícias para alívio do meu cuidado e da minha grande saudade e desempenho dos meus votos e dos meus interesses' (C. I) pode parecer meramente de cunho afetivo. No entanto, a vital importância que se atribui ao recebimento de 'notícias' pode ser entendida como a busca do poder. Uma vez que a comunicação com o Reino ocorria unicamente por via das correspondências enviadas e recebidas, o contato com a esfera do poder se daria por intermédio dos papéis. Afinal, "o poder é tanto exercido quanto reproduzido no e pelo discurso. Sem comunicação escrita (e falada), o poder na sociedade não pode ser exercido ou legitimado" (Dijk, 2012, p. 85).

Intenciona-se, por meio do envio e espera de recebimento das correspondências oficiais, o reconhecimento social, que seria dado à distância, por meio das correspondências. Assim, constrói-se "um estado comunicativo em que as condições intersubjetivas da integridade pessoal aparecem como preenchidas" (Honneth , 2003, p. 268).

Com isso, o Morgado de Mateus serve-se da prática de constantemente registrar suas ações. Por exemplo ao agir sem a validação prévia, justifica-se: 'em muitas coisas me tenho visto duvidoso do que será mais conforme as intenções de Vossa Excelência e me resolvi segundo o que eu quisera que se me fizesse a mim em semelhante caso' (C. I). O fato de agir de acordo com o que queria receber retoma os preceitos cristãos, detentores de prestígio social, o que justificaria o fato de porventura não ter agido de acordo com as 'intenções' do governo central.

Acima do que se pode ser feito contra a pessoa, está a preocupação do que pode ser feito com seu ethos: 'Mas eu não temo o que cá me podem fazer, temo que na presença de Vossa Excelência representem de mim algumas queixas com que Vossa Excelência venha a pôr em dúvida o meu procedimento, por isso quero prevenir a Vossa Excelência dando-Ihe esta notícia para que Vossa Excelência me faça a justiça de me ouvir, sendo servido, sobre as culpas que quiserem acumular-me os meus inimigos' (C. II) Pode-se afirmar, diante dessa asserção, que o ethos enquanto sua representação social é mais importante do que si mesmo em sua integridade física.

\section{LINGUAGEM FORMULAICA}

Embora tenham sido selecionadas apenas cartas, cuja espécie textual é de cunho não diplomático, as cartas contam com um padrão estabelecido pela "redação mais ou menos padronizada" (Bellotto, 2002, p. 77). Em detrimento da ausência de rigidez estabelecida de forma, essa padronização deve-se ao emprego reiterado dos mesmos termos em partes determinadas da redação dessas missivas. 


\section{Desafios da psicologia no Brasil}

As expressões formulaicas comumente empregadas iniciam-se no vocativo ou endereçamento, com 'Ilustríssimo e Excelentíssimo Senhor' (C. I, II, III e IV). Essa fórmula é retomada ao final das cartas, antes do fecho de cortesia, a anteceder o título do interlocutor, o 'Conde de Oeiras' (C. I, II e III) ou 'Marquês de Pombal' (C. IV). Os pronomes de tratamento, abreviados nas epístolas contém em si, além do padrão da mais alta formalidade, o aspecto da gradação de força, por meio da intensificação contida na forma do superlativo. Termos similares são usados como adjetivos 'llustríssima e Excelentíssima pessoa' (C. IV), em que o julgamento de estima social exalta o destinatário da mensagem. Inclui-se a esta a menção 'e casa de Vossa Excelência' (C. I), ao se desejar que mantenha o poder do Estado e a felicidade.

O fecho de cortesia recorrente em todas as cartas: 'de Vossa Excelência cativo e menor criado' antecede a assinatura de próprio punho do autor intelectual (Morgado de Mateus), grafada como 'Dom Luís António de Sousa', recebe o acréscimo, na carta I do termo 'Meu Senhor', situando à altura a persona do Conde de Oeiras. A escolha dos termos 'cativo' e 'criado' pressupõe a atitude de julgamento de sanção social, designando o comportamento do autor. Apesar da semântica de rebaixamento que acarretam, geram destaque ao ethos do autor. Do mesmo modo, a adjetivação do superlativo 'menor' atua como a gradação de força, que visa (mesmo que paradoxalmente) a intensificar o escopo da posição social desse governante.

No decorrer das cartas, a tratativa é constante e sempre formal, com o uso do pronome de tratamento 'Vossa Excelência'. Embora o teor quantitativo não seja o escopo deste artigo, vale mencionar que o emprego dessa fórmula para se manter o contato com o interlocutor é uma estratégia bastante empregada, cuja ocorrência soma 17 vezes ao longo das três páginas da carta I, tanto como pronome de tratamento quanto como possessivo 'de Vossa Excelência'. Do mesmo modo, aparece 16 vezes na carta II; 11, na carta IV; e 6 vezes na carta III, que está redigida em apenas uma página, diferente das demais, com três.

A fórmula 'Deus guarde a Vossa Excelência', empregada para o fechamento das correspondências, inclui a esfera do religioso católico ao discurso, tornando legítimas as intenções anteriormente apresentadas. A esfera ideológica do religioso católico está bastante internalizada nas correspondências oficiais setecentistas, o que explica o fato de ser "difícil separar o brasileiro do católico: o catolicismo foi realmente o cimento de nossa unidade" (Freyre, 2007: 92). A mesma formulação é usada quando se menciona o Rei: 'Sua Majestade, que Deus guarde' (C. II). De tão usual, essa colocação de termos apresenta-se como uma espécie de epíteto na estrutura redacional das cartas. 


\section{Desafios da psicologia no Brasil}

\section{IMAGENS CONSTRUÍDAS PELA IDEOLOGIA DO REBAIXAMENTO}

A esfera discursiva assume um escopo mais tangível quando emprega a construção de imagens por meio de figuras de linguagem, sobretudo as metáforas, as figuras mais importantes. Entende-se que as metáforas podem exercer uma função persuasiva no discurso político, pois "fornecem uma analogia condensada e um julgamento de valor concentrado" (Charaudeau e Maingueneau, 2008, p. 330), atuando como um recurso de evitar a comparação declarada e normalizar o ethos, naturalizando-o ao leitor, o que contribui para a manipulação do discurso. As metáforas empregadas encontram-se introjetadas no imaginário católico, o que Ihes confere ainda mais força e destaque: 'Sabe Vossa Excelência também que aos tiros da inveja, da calúnia e da arrogância, nem a inocência de Cristo, nem a iminência do respeito pode ser isenta.' (C. II). As investidas dos que se opõem a seus planos de governo são nomeadas 'tiros', como elementos direcionados contra alguém na intenção de ferir ou matar. Contra tais investidas, nem mesmo as esferas religiosas mais altas, como a do Cristo, foram isentas.

Há também uma metáfora que, embora mais implícita, serve-se da imagem idealizada do ‘Espírito Santo', para comparar à acertada medida proposta pelo conde de se criarem tropas na capitania de São Paulo. 'He sem dúvida que só o Espírito Santo e a iluminada compreensão de Vossa Excelência podia determinar a criação destas tropas' (C. II)

Outra figura de linguagem bastante representativa é a metonímia, que consiste na "designação de um objeto pelo nome de outro, [por conta de semelhanças], seja sua existência, seja sua maneira de ser" (Charaudeau e Maingueneau, 2008, p. 332) e promove um afastamento da normalidade do que se esperava no nível discursivo, homogeneizando o conteúdo semântico do enunciado. Por exemplo, a expressão 'Vou juntamente aos pés de Vossa Excelência' (C. III) que apresenta a esfera do físico. A imagem do ato de submissão ao outro ganha a imagem do ato físico, de baixar-se aos pés do outro. Conta, portanto, com a escala da gradação, em que o ato de rebaixamento do outro frente a seu superior assume a escala máxima.

A imagem dos pés é recorrente, como a única parte do corpo em que se pode merecer o acesso, por ser a mais rente ao chão: 'Beijo reverente os pés de Vossa Excelência' (C. III); 'Busco os pés de Vossa Excelência' (C. IV). A construção discursiva de reverenciar-se aos pés do outro e levar os lábios a esses pés para Ihes beijar pressuporia a total redução do ethos. Entretanto, de maneira paradoxal, esse aparente rebaixamento constitui um recurso discursivo, e (se possível fosse) até mesmo atitudinal, para elevar a representação de si próprio perante os superiores na hierarquia monárquica. 


\section{Desafios da psicologia no Brasil}

Além dos pés, como a imagem do mais baixo na estrutura do corpo humano, apresenta-se a metonímia das mãos, como a parte que representaria a pessoa do Conde de Oeiras na execução de suas ações. Com isso, observam-se as seguintes ocorrências: 'Na poderosa mão de Vossa Excelência que humildemente beijo, me encomendo a mim mesmo, a meus filhos e a toda a minha casa' (C. I); 'Por isso me valho da poderosa mão de Vossa Excelência' (C. II). O epíteto 'poderosa mão' contém a carga semântica do afeto de polaridade positiva, mas, sobretudo, a do julgamento de estima social. Essa estima social, por se tratar da mão daquele que pode cuidar da família e das propriedades, ascencionase à esfera da sanção social. Diante disso, o Conde seria, a exemplo do Rei, o executor dos desígnios divinos, aquele que deteria o poder temporal.

\section{(DES)CONSTRUÇÃO DO ETHOS}

Um estratégia discursiva recorrente é a da aparente desconstrução do ethos, por meio da negação dos valores pessoais, no intuito de provar as características socialmente ideadas de humildade e de subserviência. Ao se negar o conjunto das qualidades pessoais, intenciona-se que o interlocutor verifique a incoerência desse rebaixamento extremo e adote a atitude oposta: a de exaltar as qualidades negadas por esse autor. Nessa medida, as negações seriam marcas linguísticas de ordem paradoxal, visando à aprovação do superior. O fragmento 'o grande dito com que o mesmo Senhor e Vossa Excelência me honraram em se fiar de mim, sem eu ter merecimentos' (C. I) aponta essa estratégia, uma vez que o autor nega o seu merecimento. Essa negativa contradiz o universo da verdade, haja vista os méritos pessoais que conduziram a sua nomeação, na tentativa de manipular a reação do interlocutor.

Outra assertiva de rebaixamento está contida no fragmento: 'Vossa Excelência será servido dar nestas matérias as providências que lhe parecem mais justas, ilustrando com as suas sábias instruções o meu entendimento' (C. IV), em que sua inteligência é subestimada em relação à do Conde, na mesma linha de construção discursiva que a da negação anterior.

Embora exalte os atributos do seu interlocutor, em detrimento dos seus próprios, o Morgado de Mateus afirma que 'ninguém melhor do que Vossa Excelência sabe, que eu, que me posso enganar com as paixões e com o amor próprio' (C. II). Ao se preocupar com o fato de poder exaltar suas qualidades, reitera a ideia de que sua postura de rebaixamento seria sincera e não um mecanismo de promoção do ethos. Serve-se de um elemento típico da manipulação, que é o de "comunicar crenças implicitamente, isto é, sem realmente afirmá-las e, portanto, com pouca chance de serem questionadas." (Dijk, 2012, p. 123) 


\section{Desafios da psicologia no Brasil}

Deliberadamente, coloca o bem do seu governo acima de sua própria pessoa: 'Não desejo outra ventura, nem outro despacho mais do que alcançar que os meus cuidados, as minhas diligências, e os meus desvelos em que não descanso, possam vir a servir de algum aumento a estes Estados.' (C. I). Mostra-se sempre desinteressado do que possa Ihe ser útil pessoalmente, visando ao bem do seu serviço.

Ao assumir os erros, redime-se ao alegar não ter errado de forma premeditada: ‘Peço encarecidamente a Vossa Excelência me perdoe em tudo o que possa ter desacertado; porque asseguro muito muito a Vossa Excelência que me parece não terá sido nem com dolo, nem por interesse.' (C. I). O fato de poder errar fica diluído pela justificativa de não se ter errado por querer prejudicar, nem por interesses pessoais. A humildade é usada como recurso para justificar e, sobretudo, para redimir os erros. De acordo com a dogmática católica (adotada de forma evidente pelos interlocutores) da absolvição dos pecados mediante o arrependimento, o fato de reconhecer os erros seria o bastante para serem perdoados, especialmente quando se comprova que não houve intenção de errar.

Novamente em busca da reação de causar estranhamento no leitor a fim de que ele conclua por si a falta de consistência da assertiva, afirma que tem vícios: 'atacando não os meus vícios /que era o que deveriam fazer/ mas as disposições principais do meu governo, em que executo as reais ordens de Sua Majestade' (C. II). Assegura, dessa maneira, que se sentiria menos ofendido se suas falhas de conduta fossem criticadas ao invés do seu trabalho, como foi feito.

Opõe-se, constantemente, aos corruptores da ordem, contrários ao governo, afinal "nem a reta administração da justiça se pode praticar, sem levantar o ódio dos maus: estes são os que ofendem, que os bons não obram desta sorte, senão o bem e a caridade' (C. II). Por meio desse postulado, implicitamente situa a si mesmo no grupo dos 'bons' e, por conseguinte, divulga a proposta de que seus atos estariam ligados ao 'bem' e à 'caridade'.

Emprega o recurso da gradação de força ao intensificar com o adjetivo 'indefectível' o julgamento de estima social de 'clemência', no fragmento 'e da indefectível clemência de Sua Majestade, que Deus guarde, para que me não falte a graça do mesmo Senhor porque sem ela nem as grandezas, quanto mais a minha humildade, pode conservar-se, e melhor me fora não viver.' (C. II). Apresenta a hipótese de que nem mesmo os detentores de grandezas poderiam suportar a ausência de 'graça' do Rei. Verbaliza, em acréscimo, deter a característica da humildade, como um julgamento de estima social de polaridade negativa, mais uma vez de modo a rebaixar-se. 


\section{Desafios da psicologia no Brasil}

\section{ESTRATÉGIAS DELIBERADAS DE VASSALAGEM}

Nas relações pessoais, que refletiam as relações políticas do período, estava implícito o 'contrato de vassalagem'. Esse contrato chegou a ser um documento escrito com direitos e obrigações dos vassalos em relação a seus senhorios no período feudal e estendeu-se ao longo dos séculos aos moradores de algumas colônias. Mesmo sem a existência literal de contratos vassálicos entre os governantes, as nomeações já podem ser consideradas como tal. Afinal, os governantes mantinham conduta de submissão às ordens reais, responsáveis por sua nomeação, baseada nos critérios pessoais de confiança e de amizade, do qual derivava a constante possibilidade de destituição. Daí os governantes manterem em evidência o princípio de fidelidade ao Rei e, com isso, o constante realce de seu ethos: ‘e do modo possível rendo a Vossa Excelência as graças pelos especiais benefícios que a grandeza de Vossa Excelência está dispendendo continuamente comigo, e com a minha casa' (C. IV). Os benefícios recebidos são considerados o bastante para o emprego vocabular de itens como 'criados', 'súditos', que demonstram a submissão e obediência total ao superior em nome do Rei.

A obrigação perante o soberano reflete-se de forma explícita: 'Dispense, meu Senhor, a grandeza de Vossa Excelência que a um criado tão afetivo, e tão infinitamente obrigado a Vossa Excelência como eu sou' (C. I), ou até mesmo de maneira implícita, por meio da prática do enaltecimento pessoal: 'Desejo muito que a preciosíssima saúde de Vossa Excelência se conserve sempre feliz para meu amparo. Que a amabilíssima família da ilustríssima e excelentíssima casa de Vossa Excelência goze da mesma perfeita disposição' (C. I), em que se desejava a manutenção da prosperidade ao interlocutor. O reconhecimento da valoração social do conde ganha instância máxima no seguinte trecho: 'a todos Vossa Excelência como pai e autor que é de tudo o que somos, nos ampare e sustente e favoreça como pode' (C. I). A construção do imaginário de paternidade associa o governo monárquico ao da religião católica, em que todas as possibilidades provêm do pai.

A postura para se 'protestar a minha fiel obediência e reverente escravidão' (C. III) seria a de reverência do vassalo frente ao soberano, em que, humildemente, punha as mãos juntas dentro das mãos do senhor como forma de simbolizar a submissão ao controle do outro. Esse gesto, nomeado hominaticum no latim, tornou-se homenatge em um dialeto da língua francesa e resultou no termo 'homenagem'. Assim, prestava-se homenagem por meio das cartas: 'o meu reverente obséquio, a suma veneração com que de toda a parte adoto o respeito de Vossa Excelência e a viva memória que sempre tenho das recomendações de Vossa Excelência dos seus impreteríveis preceitos, e das inumeráveis mercês com que Vossa Excelência me tem engrandecido' (C. I). Sentindo-se agraciado pelas concessões recebidas, agradece de maneira a seus superiores de maneira expressa e deseja que 


\section{Desafios da psicologia no Brasil}

'Deus, Nosso Senhor, guarde a Vossa Excelência para meu amparo' (C. II), incluindo-se como beneficiário da proteção divina, embora abaixo de seu superior.

\section{CONSIDERAÇÕES FINAIS}

O presente artigo intencionou observar o discurso oficial setecentista produzido pelo governador Morgado de Mateus em cartas enviadas a Portugal, no que diz respeito às práticas que aparentemente denotam rebaixamento e menosprezo do seu ethos. Para tanto, foram apresentadas as estratégias de enaltecimento do Conde de Oeiras enquanto interlocutor e representante do Rei e as relações de poder contidas na intersubjetividade dessa relação de direcionamento ascendente. Apresentaram-se alguns exemplos da produção de imagens construídas pelo universo ideológico da vassalagem. Em acréscimo, observaram-se a construção e manutenção do ethos do governador e capitão-general de São Paulo por meio da materialidade discursiva do rebaixamento e de estratégias da "vassalagem". No conjunto das quatro cartas apresentadas por meio de fragmentos, dessa maneira, observa-se a prática comum no período setecentista de inferiorizar-se e exaltar o outro, a fim de que o outro, de forma solidária, fizesse o mesmo. Ao ter ações e comportamento elogiados pelo interlocutor, sobretudo por se tratar do grande detentor de poder, o Conde de Oeiras, o Morgado de Mateus garantiria um estatuto de destaque ao seu ethos.

Observando-se as formas como o poder é “exercido, manifestado, descrito, disfarçado ou legitimado" (Dijk, 2012, p. 39) no discurso político escrito na segunda metade do século XVIII, nota-se que o discurso setecentista grafado nas cartas ultrapassa a proposta de meramente comunicar as ocorrências locais e solicitar orientações. Esse discurso pressupunha o cuidado com a manutenção de seu ethos por parte do autor e, em última instância, conduzia à legitimação do poder das autoridades políticas europeias no Brasil colonial. Observa-se, com isso, que o poder social não apenas aparece 'nos' ou 'por meio dos' discursos, mas também que é relevante como força societal 'por detrás' dos discursos, conforme Dijk (2012, p. 32).

Com base no pressuposto de que "a maioria das ideologias são formadas discursivamente" (Dijk, 2012, p. 33), objetivou-se analisar o discurso veiculado nas cartas administrativas do Morgado de Mateus em suas estruturas cognitivas e sociais. Tal análise visou, portanto, retratar, mesmo que sucintamente, como se dava a construção das identidades e as relações de poder setecentistas, a fim de se ampliar o conhecimento da realidade e do imaginário daquele período. 


\section{Desafios da psicologia no Brasil}

\section{REFERÊNCIAS BIBLIOGRÁFICAS}

Arruda, J. J. de A. (2000). Documentos manuscritos avulsos da Capitania de São Paulo - Catálogo 1 (1644 - 1830). São Paulo, SP: EDUSC.

Bellotto, H. L. (2014). Arquivo, estudos e reflexões. Belo Horizonte, MG: Editora UFMG.

. (2002). Arquivística. Objetos, princípios e rumos. São Paulo, SP: Associação de Arquivistas de São Paulo.

(1979). O Morgado de Mateus, governador de São Paulo. Coimbra, PT: Coimbra editora.

Cambraia, C. N. \& Cunha, A. G. da \& Megale, H. (2001). A Carta de Pero Vaz de Caminha. São Paulo, SP: Humanitas,

Calfee, R. C., \& Valencia, R. R. (1991). APA guide to preparing manuscripts for journal publication. Washington, DC: American Psychological Association.

Charaudeau, P. (2013). Discurso político. São Paulo: Editora Contexto. Trad. Fabiana Komesu e Dilson Ferreira da Cruz. 2a ed. 2013.

Contexto.

\& Maingueneau, D. (2008). Dicionário de análise do discurso. São Paulo, SP: Editora

Dijk, T. A. van. (2012) Discurso e Poder. Judith Hoffnagel e Karina Falcone (org). São Paulo, SP: Editora Contexto.

Duverger, M. (1983). Sociologia da política. Coimbra: Livraria Almedina.

Freyre, G. (2007). Casa grande \& Senzala - formação da família brasileira sob o regime da economia patriarcal. Editora Global. Recife, PE, 2007.

Halliday, M. A. K. \& Matthiessen, C. M. I. M. (2004). An Introduction to Functional Grammar. 3a ed. London, EN: Edward Arnold.

Hjelmslev, L. (2003). Prolegômenos a uma teoria da linguagem. São Paulo, SP: Perspectiva.

Honneth, A. (2003). Luta por reconhecimento: a gramática moral dos conflitos sociais. São Paulo, SP: Editora 34.

Kerbrat-Orecchioni, C. (1980). L'énonciation de la subjectivité dans le langage. Paris, FR: Armand Colin.

Martin, James, \& White, Peter. (2005). The language of evaluation: Appraisal in English. Basingstoke, AUS: Palgrave Macmillan.

Meyer, M. (2003). Métodos de Análisis Crítico del Discurso. Barcelona, ES: Gedisa. 


\section{Desafios da psicologia no Brasil}

Anexo - Carta III

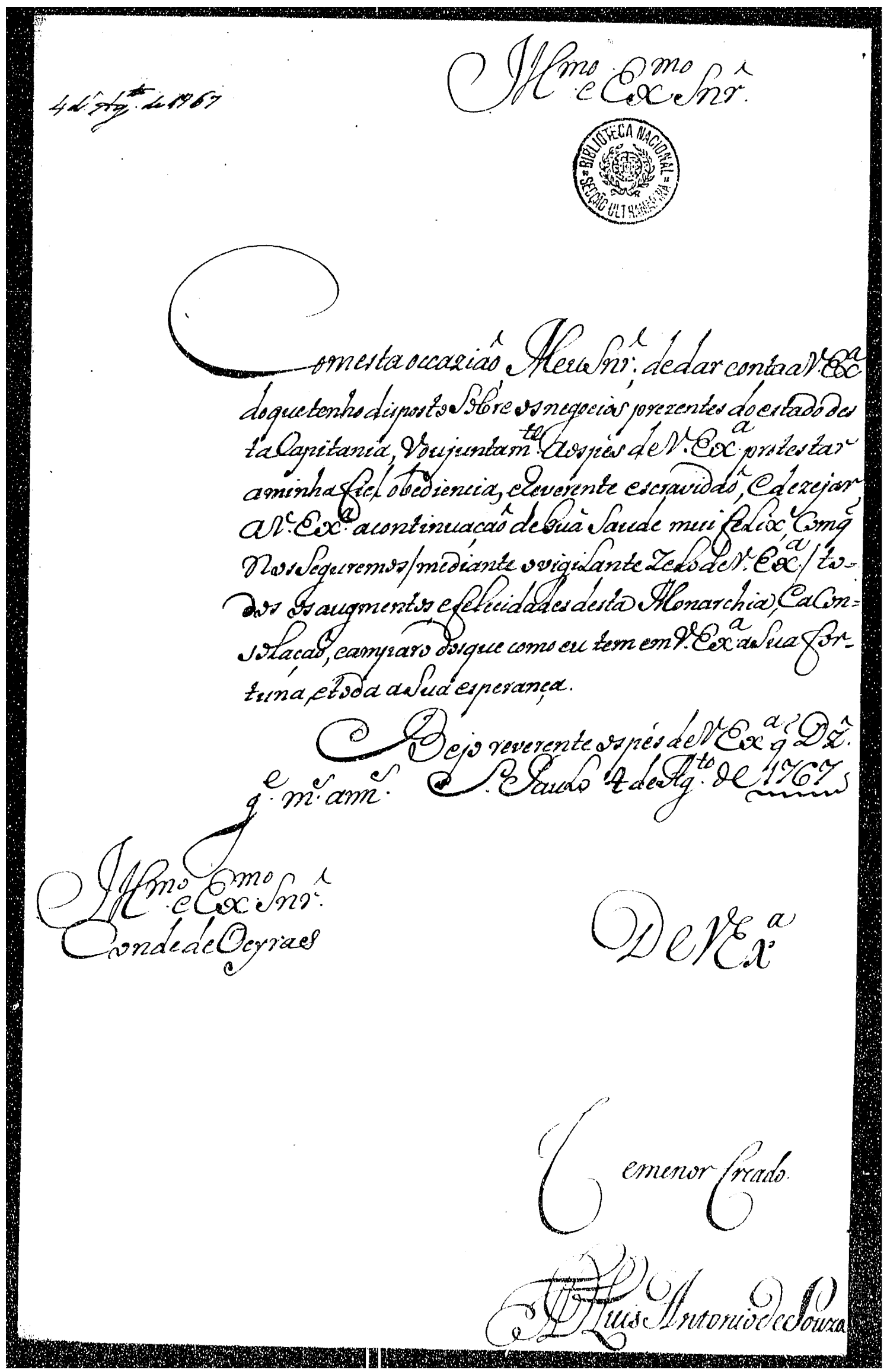

Illustríssimo e Excelentíssimo Senhor 


\section{Desafios da psicologia no Brasil}

Com esta occaziaõ Meu Senhor; dedar conta a Vossa Excelência Doque tenho disposto Sobre os negocios prezentes do estado destaCapitania, Voujuntamente Aos pés deVossaExcelência protestar a minha fiel obediencia, ereverente escravidaõ, E dezejar a Vossa Excelência a continuaçaõ dehuâ Saude mui felix, Com que Nos Seguremos/mediante o vigiLante Zelo deVossaExcelência/ to=dos os augmentos, efelicidades desta Monarchia, EaCon-soLaçaõ, eamparo dosque como eu tem em VossaExcelência sSua for-tuna, etoda aSua esperança.

Bejo reverente os pés deVossaExcelência que Deoz guarde muitos annos. Saõ PauLo 4 de Agosto de 1767.

Illustríssimo e Excelentíssimo Senhor

Conde de Oeyras

De VossaExcelência

Cativo emenor Creado.

DomLuis AntoniodeSouza 


\section{Capítulo 59}

\section{A SAÚDE DO TRABALHADOR BANCÁRIO: (DES)VELANDO O RETORNO AO TRABALHO APÓS AFASTAMENTO POR DOENÇA}

DOI: $10.37423 / 200200319$

Luana Carolina Bellan Posser (Universidade Estadual do Centro Oeste UNICENTRO - Irati, PR, Brasil).

luana.cbposser@gmail.com

Marielli Ramos Pinheiro (Universidade Estadual do Centro Oeste - UNICENTRO Irati, PR, Brasil). marielli.rp@gmail.com

RESUMO: O trabalho vem sofrendo grandes transformações devido à globalização, às inovaçỗes tecnológicas, às novas formas de gestão e organização. A relação do homem com o trabalho é, muitas vezzes, contraditória, polis enquahto pessoas sofrem pela falta de emprego, outras sofrem por trabailharem excessivamente e sob pressão. Partindo desse pressuposto, realizou-se uma pesquisa qualitativa a partir de entrevistas semiestruturadas-com bancários que sofreram afastamento por motivos de saúde e/retornaram ao trabalho, a fim de compreender o significado que esses atribuem às possíveis mudanças em sua vida łaboral e pessoal ao retornarem ao trabalho. Posteriormenté, fizemos a análise de conteúdo e os resultados mostraram uma continuidade de pressóes por produtividade e cumprimento de metas no ambiente de trabalho-após o retorno ao/trabalho, além da falta de um programa de prevenção e reinserção-dos trabalbadores nesse ambiente.

Palaqvas-chave: psicologia do trabalho; lesão por esforço repetitivo/doença ôsteomuscular relacionadas ao trabalho; depressão. 


\section{Desafios da psicologia no Brasil}

\section{INTRODUÇÃO}

Acompanhamos grandes transformações no mundo do trabalho devido à globalização, às inovações tecnológicas, às novas formas de gestão e organização, fazendo com que sua natureza se modifique constantemente. A relação do homem com o trabalho é, muitas vezes, contraditória, pois enquanto algumas pessoas padecem pela falta de emprego, outras sofrem por trabalharem excessivamente e sob pressão. Em consequência disso, os trabalhadores passam a enfrentar dificuldades para perceber, refletir e agir em benefício de sua saúde.

O trabalho exerce uma função importante na sociedade, visto que a partir dele os indivíduos possuem relacionamentos com outras pessoas, se sentem úteis e têm um objetivo de vida. Apresenta também grande representatividade na vida do ser humano, pois produz desde grandes satisfações até grandes preocupações (MORIN, 2001).

As influências dessas características atuais do trabalho sobre a saúde do trabalhador pode ocorrer devido a vários fatores e situações, entre os quais: as formas pelas quais o trabalho se organiza, as políticas de gerenciamento que desconsideram limites físicos e psíquicos dos trabalhadores, pressões por produtividade, alcance de metas em curtos prazos, a obsessão pela eficácia, entre outros fatores que causam repercussões na saúde dos trabalhadores, propiciando a anulação da subjetividade dos mesmos para que a produção não seja prejudicada e as metas sejam cumpridas (DEJOURS, 1992).

Mesmo aqueles que apresentam uma situação aparentemente privilegiada, com vínculos estáveis, experienciam a insegurança, a competitividade e uma precariedade do trabalho, o que SeligmannSilva et al (2010) nomeiam como "precariedade subjetiva", sendo esse um dos aspectos presentes no trabalho contemporâneo "a todos os assalariados, em nome da autonomia e da responsabilização, gerir inúmeras disfunções que não Ihes proporcionam os recursos necessários para fazer frente às exigências de seu trabalho, ao mesmo em que intensificam de forma espetacular os ritmos de trabalho" (LINHART, 2009, p. 2).

Nesse sentido, as organizações criam um lugar propício ao sofrimento, à violência física e psicológica, ao tédio e aos problemas de saúde graves (DEJOURS, 1992). A organização do trabalho, motivada pela divisão de tarefas, tem um papel significativo nos riscos ao equilíbrio psíquico e na saúde mental dos trabalhadores (DEJOURS, 1993). Essa preocupação tem grande importância para os estudos relacionados à saúde do trabalhador, os quais serão citados a seguir. 


\section{Desafios da psicologia no Brasil}

Estudos realizados pelo Instituto Americano de Estresse apontam para um índice de $80 \%$ dos acidentes de trabalho nos Estados Unidos tendo o estresse como uns dos fatores mais agravantes, conforme menciona Atkinson, citado por Zanelli (2010). Porém, de acordo com Richardson e Rothstein (2008), esse fenômeno não é somente americano, outras regiões do mundo também vêm mostrando um crescente nos números de trabalhadores com estresse ocupacional.

No Brasil, esse fato é evidenciado nas pesquisas sobre a saúde, a qualidade de vida e o bem-estar do trabalhador. Em um estudo sobre estresse no Brasil, Lipp (1996) relata que, em 1996, o estresse advindo de cargos de nível executivo e diretivo representava um índice de 40\%, já em 2004, Lipp (2005) mostrou que o índice de estresse subiu para $49 \%$.

Entre empregados que não exercem cargos executivos e diretivos, mas que trabalham em escritórios, o índice de estresse foi de $35 \%$.

Segundo o Sindicato dos Bancários (2009), em reportagem à revista Caros Amigos, o Brasil teve um aumento significativo no número de trabalhadores afastados por doenças ocupacionais, relacionadas com estresse e depressão. De acordo com o INSS (Ministério da Previdência Social), em 2009 foram cerca de 13.000 casos de afastamento. O NTEP (Nexo Técnico Epidemiológico Previdenciário) observa um aumento das LER/DORT, ou seja, lesão por esforço repetitivo e doenças osteomuscular relacionada ao trabalho, respectivamente, entre os trabalhadores.

Esses índices tornam-se preocupantes, pois, de acordo com Lipp (2005), entre as ocupações de trabalho mais agravantes estão os bancários em segundo lugar, atrás apenas de policiais, controladores de voo e juízes. Langlieb e Kahn, citados por Zanelli (2010), evidenciam que as situações de ansiedade e depressão no trabalho vêm causando grandes consequências como, por exemplo: ausência no trabalho, queda de produtividade, afastamentos, sofrimento e surgimento de doenças físicas e mentais.

O afastamento por motivo de doença torna-se algo presente na vida dos bancários, de acordo com o que aponta a pesquisa realizada pelo Laboratório de Saúde do Trabalhador da Universidade de Brasília (2002), os bancários são trabalhadores que mais se afastam por causa de doenças mentais, sendo que dessas, 55\% são por doenças depressivas. De acordo com dados do INSS, em 2013, houve um índice de 21.144 registros de afastamento de bancários, desses, $27 \%$ são decorrentes de LER/DORT e outros $26 \%$ de transtornos mentais e comportamentais, como estresse, depressão e síndrome do pânico. Percebemos que as consequências em bancários vão além de aspectos físicos, mas também sintomas psicológicos e problemas mentais. 


\section{Desafios da psicologia no Brasil}

Estudos na área da Psicologia do Trabalho têm demonstrado que o excesso de trabalho tem causado consequências negativas para os trabalhadores, tanto em sua vida laboral quanto pessoal. De acordo com Zanelli (2010), mesmo que nos últimos dois séculos os trabalhadores venham lutando por melhores condições de trabalho, essas mesmas condições vêm agravando o nível de estresse e causando danos à saúde. O trabalho vem exigindo resultados capazes de prejudicar e causar danos à saúde daqueles que não conseguem lidar com pressões por produtividade e alcance de metas. Diante dessas transformações, esses indivíduos afetados buscam readaptações físicas e psicológicas a partir de afastamentos.

Segundo Castro-Silva (2006) em seu estudo realizado com bancários, após o período de afastamento, os trabalhadores passam a retomar as suas atividades laborais, mesmo ainda não estando recuperados e lutando por manter a produtividade e suas metas. Após o retorno, a organização do trabalho continua a demonstrar presença de pressão por metas e grande quantidade de tarefas a serem realizadas. Desta forma, percebemos que não há mudanças reais após o retorno do funcionário a sua vida laboral, não existindo uma ação que identifique os fatores organizacionais para que haja um melhoramento da qualidade de vida desses funcionários. Os mesmos retornam ao trabalho para evitar represálias e perdas salariais.

A partir dos dados apresentados e das considerações acerca das preocupações com a saúde do trabalhador, em que os sofrimentos e danos à saúde são marcados pelo adoecimento, gerando incapacidades, desde problemas físicos até aos mentais caracterizados por um processo patológico, buscamos investigar os trabalhadores bancários envolvidos nesse conjunto de doenças.

Portanto, julgamos importante realizar um estudo sobre a situação de bancários que sofreram afastamento por motivo de saúde e retornaram ao seu emprego após esse período e também por uma falta de pesquisas acadêmicas recentes voltadas para essa questão e, assim, investigar e compreender se houveram possíveis mudanças em sua vida laboral e pessoal. Salientamos que o que apresentaremos neste texto é fruto de uma pesquisa realizada durante a graduação em psicologia para o trabalho de conclusão de curso.

A seguir serão descritos os procedimentos metodológicos adotados para a realização da pesquisa.

\section{METODOLOGIA}

Segundo Minayo (2010), a metodologia deve incluir concepções teóricas da abordagem, os instrumentos a serem utilizados e a criatividade do pesquisador. Richardson (1985) define o método 


\section{Desafios da psicologia no Brasil}

de pesquisa como sendo a escolha dos procedimentos sistemáticos e da descrição e exploração dos fenômenos.

Considerando essa definição, esta pesquisa foi realizada a partir do método qualitativo, devido a este oferecer uma melhor compreensão dos significados dos fenômenos, ou seja, possibilitou a pesquisadora ir a campo buscar entender o fenômeno a partir da perspectiva das pessoas que estavam inseridas nele, sempre levando em consideração os pontos de vistas mais relevantes (GODOY, 1995).

De acordo com Minayo (2010), a pesquisa qualitativa se caracteriza por se preocupar com as ciências sociais em um nível de realidade que não é quantificado, levando em consideração o universo dos valores, crenças, significados e outros aspectos das relações. O método qualitativo baseia-se em conceitos, hipóteses, métodos e técnicas que se dão a partir de três etapas: a fase exploratória, o trabalho de campo e a análise e tratamento dos dados.

Em um primeiro momento, recorremos à agência do INSS de Irati/PR a fim de realizar um levantamento e verificar os casos de afastamento bancário. Entretanto, os registros não apresentaram as informações necessárias para a realização da pesquisa, pois não existia uma separação dos afastamentos por área de atuação.

Então, a partir de conversas informais e idas aos bancos para a apresentação deste trabalho aos gerentes, é que pudemos ter o contato com os trabalhadores que sofreram afastamento e já haviam retornado ao trabalho.

A pesquisa contou com 3 trabalhadoras de duas agências bancárias privadas, na região Centro-Sul do Paraná, que passaram por afastamento devido a problemas de saúde relacionados ao trabalho, no período de 2008 a 2015. As mesmas passaram por um período de afastamento maior que 15 dias.

Para a realização desta pesquisa foi utilizada como instrumento a entrevista semiestruturada, a qual se caracteriza por combinar perguntas abertas e fechadas. Nela, o entrevistado pode discorrer sobre o assunto livremente, mas sempre de acordo com as perguntas realizadas. A entrevistadora seguiu questões previamente definidas, fazendo com que o contexto parecesse uma conversa informal. Ela possibilitou à entrevistadora retomar ao assunto quando a participante dispersava. Esse tipo de entrevista é muito utilizado quando se pretende delimitar a quantidade de informações e obter um maior direcionamento para o tema proposto (BONI \& QUARESMA, 2005).

As primeiras perguntas foram direcionadas à coleta dos dados sociodemográficos, em que constaram: gênero, estado civil, número de filhos, idade do entrevistado e tempo de serviço no banco. A segunda 


\section{Desafios da psicologia no Brasil}

parte abordou os impactos da doença, realização de tratamento, tempo de afastamento, busca de ajuda junto a profissionais, descrição de seu trabalho, relação entre colegas e chefes, hábitos cotidianos, alimentação, relação familiar, entre outras questões relacionadas ao seu afastamento.

O tempo para cada entrevista foi de aproximadamente uma hora e trinta minutos. As mesmas foram gravadas em áudio e posteriormente transcritas, sendo acordado com as participantes o compromisso ético em manter sigilo e identidade das mesmas.

O local para a realização da entrevista foi decidido de acordo com a disponibilidade das entrevistadas, sendo que as mesmas preferiram realizá-las no seu próprio local de trabalho, após o encerramento do expediente. Posterior à realização das entrevistas, essas foram transcritas na íntegra e em sequência a sua organização. A análise do material coletado foi feita a partir da análise de conteúdo, que de acordo com Minayo (2010) é a expressão mais usada para o tratamento de dados em uma pesquisa qualitativa. Bardin (2006, p. 42) a define como

Um conjunto de técnicas de análise de comunicação visando obter, por procedimentos sistemáticas e objetivos de descrição do conteúdo das mensagens, indicadores (quantitativos ou não) que permitam a inferência de conhecimentos relativos às condições de produção/recepção destas mensagens.

De acordo com Nunes et al (2008, p. 3), "na análise do conteúdo, o texto é um meio de expressão do sujeito, onde o analista busca categorizar as unidades de texto (palavras ou frases) que se repetem, inferindo uma expressão que as representem". Logo, a análise de conteúdo é uma técnica de pesquisa que trabalha com a palavra e que permite produzir conclusões de um determinado conteúdo a partir do contexto social em que está inserido.

Posteriormente a transcrição, foi realizada a leitura do material. Em um primeiro momento, foram grifadas as partes que julgamos relevantes para o estudo e em seguida foram transcritas as frases, assim dando origem as categorias, que são: afastamento do trabalho, ambiente e rotina de trabalho, apoio familiar e de colegas e retorno ao trabalho.

\section{RESULTADOS}

Os resultados encontrados foram analisados a partir das categorias, sendo reflexo da realização de três entrevistas, onde os dados sociodemográficos das participantes estão presentes no Quadro 1. As participantes são apresentadas por nomes fictícios para melhor entendimento ao longo da análise.

Quadro 1: Dados sociodemográficos das participantes da pesquisa 


\section{Desafios da psicologia no Brasil}

\begin{tabular}{|c|c|c|c|}
\hline Participantes & Letícia & Solange & Sandra \\
\hline Idade & 48 anos & 34 anos & 40 anos \\
\hline Estado civil & Casada & Casada & Casada \\
\hline Filho(s) & 2 & - & 1 \\
\hline Formação & Administração & Contábeis & Administração \\
\hline Tempo de serviço & 17 anos & 8 anos & 10 anos \\
\hline Tempo de afastamento & 2 anos & 2 semanas & 4 meses \\
\hline
\end{tabular}

Fonte: elaborado pelas autoras

Em termos sociodemográficos, fica nítido que todas as trabalhadoras entrevistadas que passaram pelo processo de afastamento são do sexo feminino, sendo todas casadas, duas com filhos e apresentando uma razoável diferença de idade entre as mesmas.

\section{O AFASTAMENTO DO TRABALHO}

As participantes da pesquisa possuem entre 8 a 17 anos de serviço no banco, com afastamento entre 2 semanas a 2 anos, sendo Letícia e Solange afastadas por LER/DORT e Sandra por depressão.

Heloani e Capitão (2003) constatam que doenças como LER/DORT, onde até século passado eram restritas a certas funções empresarias, vêm se tornando cada vez mais comum, fazendo com que muitos trabalhadores fiquem impossibilitados de praticar suas atividades. Ainda segundo os autores, essas doenças não são facilmente detectadas e relacionadas ao trabalho, afetando, sobretudo trabalhadoras do sexo feminino com idade entre 18 e 35 anos.

Além da LER/DORT, a depressão também vem sendo motivo de afastamento de bancários. De acordo com Cenci (2004), a depressão é mais evidenciada em contextos onde organizações, como bancos, são altamente racionalizadas e têm as metas e a produtividade no topo de seus objetivos. Em casos de trabalhadores bancários, o sofrimento psíquico pode não aparecer explicitamente, porém, está presente e sua origem pode ser devido ao individualismo, a competitividade e o estresse no ambiente de trabalho. Isso confirma que doenças como LER/DORT e depressão estão entre as que mais causam afastamentos de bancários.

A partir do discurso das entrevistadas, percebemos que Letícia e Sandra apresentaram um sofrimento intenso, tanto físico quanto psíquico, até mesmo de isolamento 


\title{
Desafios da psicologia no Brasil
}

\begin{abstract}
"fui entrando em depressão aos poucos, já não dormia direito, delirava a noite inteira com as coisas que eu tinha que fazer, tinha que produzir, tinha que entregar até que um dia eu me dei conta que eu estava acabada, já não comia direito, não dormia, estava com muita olheira, cansada, a minha relação em casa estava ficando ruim, não sentia mais vontade de conversar com ninguém, só queria ficar trancada no meu quarto, minha produção caiu muito, não sentia mais vontade de fazer as coisas, foi aí que percebi que estava me afundando dentro de mim mesma" (Sandra).
\end{abstract}

Letícia e Sandra manifestaram um sofrimento intenso, por decorrência de todo o processo de pressão e do sentimento de inutilidade por não poder trabalhar. Sandra relata que perdeu o foco nas tarefas, não apresentava vontade de trabalhar e se relacionar com os membros da família, fazendo o uso de medicamentos como calmantes e antidepressivos. As outras participantes também utilizaram de medicamentos e da automedicação, como relaxantes musculares, confirmando assim a afirmação de Oliver et al (2011) em que, de início, os trabalhadores recorrem ao uso de medicamentos, e quando o caso se agrava, como nos casos apresentados, são obrigados a recorrer ao afastamento.

Em todos os casos, as participantes tiveram acompanhamento de fisioterapeuta, no caso de Letícia e Solange, e acompanhamento psicológico, no caso de Sandra. Isso foi considerado fator fundamental para a recuperação.

\section{AMBIENTE E ROTINA DE TRABALHO}

As participantes da pesquisa relataram vários fatores laborais que podem contribuir para o desenvolvimento de doenças físicas e mentais, entre eles: rotina e tarefas repetitivas, muitas horas sentadas na mesma posição e sentindo desconfortos, excesso de trabalho, pressão das chefias e clientes, ausência de pausas, ambiente estressante e competição entre os colegas de trabalho, "ficar o dia inteiro sentada aqui, no final do dia dói o corpo, as costas, o braço e as pernas que eu quase nunca movimento" (Solange).

Nas entrevistas, ficaram perceptíveis as exigências por produtividade e alcance de metas, muitas delas consideradas ambiciosas e com a incerteza de que poderão ser cumpridas, "eles parecem que não entendem que a gente também tem limites, e quando consigo cumprir a meta, aí eles vêm com mais meta, já que eu consegui a anterior eles acham que podem aumentar sem ao menos me perguntar o que eu acho" (Sandra), assim, de acordo com Sardá et al (2004), não levando em consideração os limites biopsicológicos dos trabalhadores.

Existe também a pressão por parte dos clientes, "muitos já chegam dando de dedo na nossa cara, culpando a gente, brigando, gritando" (Sandra), tornando comuns os maus tratos e desacatos dos 


\section{Desafios da psicologia no Brasil}

mesmos, querendo receber as prioridades de atendimento e que seus problemas sejam resolvidos de imediato.

A sobrecarga laboral gera um estado de estresse e tensão no dia a dia das trabalhadoras, causando apreensão por não conseguirem terminar seu trabalho. De acordo com Carnoy, citado por Oliver et al (2011), existe uma nova visão do trabalho, onde o trabalhador ideal é aquele que tem os interesses e a produção em primeiro lugar, ou seja, é aquele que não dorme, não come, não tem socialização fora de seu ambiente de trabalho.

Observando as entrevistas, o que fica claro é que todas trazem em primeiro lugar questões referentes a cobranças e metas por parte das chefias, até mesmo Letícia e Solange que tiveram problemas físicos relataram primeiro os seus problemas com as metas, chefias e clientes e somente depois seus problemas de LER/DORT.

E o ambiente de trabalho veio a confirmar os estudos que mostram as configurações dos bancos atualmente, dando um destaque para a grande competitividade e a pressão por produtividade. Podemos observar também que o tratamento dos gerentes, conforme relatado pelas entrevistadas, é igual a outras organizações, sempre reforçando o alcance por altos desempenhos e o cumprimento de metas.

\section{APOIO FAMILIAR E DE COLEGAS}

As participantes revelaram que seus relacionamentos com colegas de profissão e com as chefias continuaram os mesmos, antes e depois do afastamento, e que muitos deles as ajudaram no processo de recuperação e retorno ao trabalho, mostrando empatia com a situação em que se encontravam.

Entretanto, Letícia e Sandra relatam existir alguns colegas que não têm essa mesma compreensão, alguns não aceitam e não acreditam em suas doenças, têm comportamentos individualistas, "Tenho alguns que são meus amigos aqui dentro e entenderam a minha situação, me apoiaram, até porque já tinha colegas que se afastaram também, mas outros eu sinto que acham que é frescura e que estava criando coisas para me afastar" (Sandra). De acordo com Oliver et al (2011), esse comportamento de colegas de trabalho mostra que, muitas vezes, não há o respeito devido de quem não viveu a doença, não levando em consideração os limites de atuação de quem foi afastado.

Já no que diz respeito à família, todas relataram que tiveram total apoio. Mesmo quando estavam em momentos delicados, seus maridos e filhos as ajudavam e incentivaram, "Minha relação com a minha família sempre foi muito boa, eles sempre me apoiam" (Letícia). 


\section{Desafios da psicologia no Brasil}

Em um dos casos, Sandra relata que durante seu processo de afastamento teve dificuldades de estabelecer relacionamento com seus familiares, principalmente com seu filho e marido, mostrando desinteresse e impaciência diante das situações familiares, afetando assim a relação familiar. Oliver et al (2011) revelaram que os bancários têm a compreensão de que sua doença está afetando suas relações dentro e fora do trabalho, porém, eles não conseguem se mover na direção da ação efetiva que pudesse contornar a situação.

É perceptível a dificuldade desses trabalhadores em fazer uma separação entre ambiente laboral e familiar e suas consequências, sendo impossível que esses passassem pelo sofrimento sem envolver seus familiares aos problemas do trabalho. Constatamos, então, que os membros da família também sofrem com o processo de afastamento e que ela exerce um fator importante para a recuperação e retorno ao trabalho. Além das consequências das relações, existiram também os problemas com alimentação e práticas cotidianas que foram comprometidas.

\section{RETORNO AO TRABALHO}

Após o afastamento, as trabalhadoras retornaram ao trabalho, relatando que não observaram grandes mudanças em relação aos aspectos de ambiente de trabalho, a rotina, a ergonomia e a pressão.

As mudanças que apresentaram parecem ter sido por parte delas, principalmente por parte de Sandra, que apresentou uma maior conscientização sobre seus problemas, talvez pelo fato dela fazer psicoterapia, expondo suas opiniões e lidando melhor com a pressão das chefias, "eu não senti mudanças não, continuam me cobrando, dando metas... antes eu engolia as coisas e guardava pra mim, agora não, eu consigo me impor um pouco mais e lidar melhor com a pressão" (Sandra).

Já Letícia e Solange tentaram fazer adaptações de postura e a disposição do computador, do teclado e da cadeira por conta própria e de acordo com as suas necessidades, "posição do computador e do teclado possibilitam a gente a apoiar os braços na mesa, mas foi só isso, eles não dão muita importância pro que acontece" (Letícia). Porém, em relação à pressão por produtividade e por metas, estas continuam em seus ambientes de trabalho.

Após o afastamento e retorno ao trabalho, é perceptível uma dificuldade em atribuir ao trabalho o processo de adoecimento, apresentando também dificuldades em apontar a importância de melhorar o ambiente de trabalho para elas e para os demais trabalhadores, "para falar bem a verdade, eu não senti mudanças não, continuam me cobrando, dando metas" (Sandra). 


\section{Desafios da psicologia no Brasil}

Outro ponto importante a ser destacado é que mesmo retornando ao trabalho após ficarem afastadas devido a uma doença laboral, as preocupações com seus desempenhos e as cobranças continuaram. Esse fenômeno mostra também o quanto os bancos não estão preparados para receber os funcionários afastados, não existindo um programa de reinserção ao trabalho, e nem se preocupam em realizar um trabalho preventivo com os demais trabalhadores.

\section{CONCLUSÃO}

Podemos dizer que os objetivos da pesquisa foram alcançados, pois compreendemos o significado que os bancários atribuem às possíveis mudanças em sua vida laboral e pessoal ao retornarem ao trabalho após o período de afastamento por motivos de saúde relacionados ao trabalho, bem como investigamos como os mesmos executam suas atividades antes e depois do afastamento e os significados atribuídos ao seu afastamento.

A partir da experiência, concluímos que as agências bancárias vivem em paradigma, pois não levam em consideração os limites de seus funcionários, esquecendo que são seres humanos passíveis de falhas. Além disso, desconsideram o fato de o corpo humano ser um sistema complexo e delicado, muitas vezes suscetível ao desgaste devido as grandes pressões colocadas a ele.

Em relação às causas do afastamento, percebemos que existem diferentes formas de significado que os indivíduos atribuem as suas doenças, suas condições de trabalho e de relacionamento, mas mesmo aquelas que sofreram por problemas físicos, trazem sempre em primeiro lugar os problemas de relacionamento com gestores devido a grande pressão pela produtividade e alcance de metas.

É perceptível também que, após o afastamento das trabalhadoras participantes da pesquisa, não houve um enfrentamento efetivo para que as condições de trabalho melhorassem e nem mudanças por parte dos superiores, mas houve um movimento das próprias funcionárias para tentar, de alguma forma, melhorar o ambiente de trabalho, seja na mudança de postura do corpo, seja no enfrentamento sobre as metas a serem cumpridas. Desse modo, tentando alterar o ritmo de desempenho das tarefas, tornando-se mais preocupadas com seu estado físico e emocional, mostrando uma maior resistência às pressões e frustações do trabalho quando comparadas antes do afastamento.

A partir das entrevistas, foi perceptível que os bancos pesquisados demostram uma postura de não dar atenção às emoções e às doenças decorrentes das precárias condições de trabalho em que suas funcionárias foram expostas. Acreditamos que uma escuta dos trabalhadores por parte dos superiores 


\section{Desafios da psicologia no Brasil}

e dos gestores de recursos humanos possa despertar iniciativas de intervenção, as quais minimizem os danos causados aos bancários que retomam às suas atividades, no sentido de dar uma nova significação a sua profissão. Assim, daria amparo ao trabalhador e traria possibilidades de melhorias da organização.

Acreditamos, assim, que essa pesquisa serve de inspiração para que outras possam surgir e que principalmente possa trazer contribuições para os gestores, e que esses possam repensar a forma como um ambiente bancário, permeado por pressões e cobranças, afeta a vida de milhares de funcionários. Bem como a necessidade de empoderamento por parte dos trabalhadores, em que eles possam perceber-se nesse espaço, possibilitando uma consciência coletiva para que os problemas apresentados possam ser repensados.

Acima de tudo para aqueles que sofreram afastamento devido a doenças relacionadas ao trabalho, juntamente com os gestores e clientes, consigam pensar coletivamente em formas de preveni-las para que casos como esses não venham a se repetir. E também pensar em formas de reintroduzir esses funcionários ao seu trabalho, melhorando o ambiente de trabalho para receber novamente esses trabalhadores.

\section{REFERÊNCIAS}

BARDIN, L. Análise de conteúdo. Lisboa: Edições 70, 2006.

BONI, V.; QUARESMA, S. J. Aprendendo a entrevistar: como fazer entrevistas em ciências sociais. Revista eletrônica dos pós-graduandos em sociologia política da UFSC, Santa Catarina, v.2, n.1, p.6880, jan/jul. 2005.

CASTRO-SILVA, L.M. Casos de afastamento por LER/DORT e retorno ao trabalho bancário: uma análise psicodinâmica. 2006. 111 f. Dissertação (Mestrado em Psicologia) - Instituto de Psicologia, Universidade de Brasília, Brasília, 2006.

CENCI, C.M.B. Depressão e contexto de trabalho. Aletheia, n.19, p.31-44, jan/jun.2004.

DEJOURS, C. A loucura do trabalho: estudo de psicopatologia do trabalho. 5.ed. São Paulo: Cortez, 1992.

DEJOURS, C. Uma visão do sofrimento humano nas organizações. São Paulo: Atlas, 1993.

GODOY, A.S. Uma revisão histórica dos principais autores e obras que refletem esta metodologia de pesquisa em ciências sociais. Revista de Administração de Empresas, São Paulo, v.35, n.2, p. 57-63, mar/abr.1995.

HELOANI, J.R.; CAPITÃO, C.G. Saúde mental e psicopatologia do trabalho. Revista São Paulo em Perspectiva, v.17, n.2, p.102-108, 2003. 


\section{Desafios da psicologia no Brasil}

LINHART, D. Modernisation et précarisation de la vie au travail. Papeles del CEIC, v. 1, n. 43, p.1-19, 2009. Disponível em: <http://www.identidadcolectiva.es/pdf/43.pdf>. Acesso em: 03 jun.2014.

LIPP, M.E.N. Pesquisas sobre stress no Brasil: saúde, ocupações e grupos de risco. Campinas: Papirus, 1996.

LIPP, M.E.N. Stress no trabalho: implicações para a pessoa e para a empresa. In: NUNES SOBRINHO, F.P.; NASSARALLA, I. Pedagogia institucional: fatores humanos nas organizações. Rio de Janeiro: ZIT Editora, 2005.

MINAYO, M.C.S. Pesquisa social: teoria, método e criatividade. 29. ed. Petrópolis, RJ: Vozes, 2010.

MORIN, E.M. Os sentidos do trabalho. Revista de Administração de Empresas, São Paulo, v. 41, n. 3, p. 8-19, 2001.

NUNES, A.V.L.; et al. Análise de conteúdo: olhar da técnica sobre o preconceito racial no Brasil. Psicologia, o portal dos psicólogos. 2008. Disponível

em: <http://www.psicologia.pt/artigos/textos/A0443.pdf>. Acesso em: 26 set.2014.

OLIVER, M.; et al. Trabalhadores afastados por transtornos mentais e de comportamento: o retorno ao ambiente de trabalho e suas consequências na vida laboral e pessoal de alguns bancários. RAC, Curitiba, v.15, n.6, p.993-1015, nov/dez.2011.

RICHARDSON, R.J. Pesquisa social: métodos e técnicas. São Paulo: Atlas, 1985.

RICHARDSON, K.M.; ROTHSTEIN, H.R. Effects of occupational stress management intervention programs: a meta-analysis. Journal of Occupational Health Psychology, v.13, n.1, 2008.

SARDÁ, J.J.; LEGAL,J.E.; JABLONSKI, J.S. Estresse: conceitos, métodos, medidas e possibilidades de intervenções. São Paulo: Casa do Psicólogo, 2004.

SELIGMANN-SILVA, E.; et al. O mundo contemporâneo do trabalho e a saúde mental do trabalhador. Revista brasileira de Saúde Ocupacional, São Paulo, v. 35, n. 122, p. 187-191, 2010.

SINDICATO DOS BANCÁRIOS. 2009. Cresce o número de trabalhadores afastados por transtornos mentais e comportamentais. Disponível em: <http://www.bancarios.com.br>. Acesso em: 03 jun. 2014.

ZANELLI, J.C. Estresse nas organizações de trabalho: compreensão e intervenção baseadas em evidências. Porto Alegre: Artmed, 2010. 


\section{Capítulo 60}

\section{UMA OBSERVAÇÃO PSICOLÓGICA DOS VÍNCULOS DA EDUCADORA DE CRECHE ${ }^{1}$}

\section{DOI: $10.37423 / 200200323$}

Liliana Pereira Lima (Psicóloga, doutora em Educação, mestre em Psicologia Escolar e do Desenvolvimento Humano e professora da Universidade Nove de Julho).

\section{lilianapereiralima58@gmail.com}

RESUMO: Introduçầo- 0 trabalho é resultado de pesquisa supervisionada de estágio de alunos do segundo ano da graduação em Psicologia e trata dos vínculos que a educadora de creche (estabelece com crianças, pequenas e os significados que representam de sua identidade profissional. o éstudo épautado no enfoque educacional social-crítico para a formação de psicólogos e edycadores. Objetivo- Visa/verificar, em uma creche paulistana de caráter filantrtrópico, a hipótese de que as educadoras da instituição apresentam suas identidades mais voltadas para o papel maternall do que de fato para o de educadoras. Método- O público-alvo foi a de quatro educadoras no total, duras trabalhàndo com crianças de 2 a 3 anos e duas trabalhando com crianças de 3 a 4 anos de idade. Deu-secom coleta de dados na creche por meio de uma entrevista com cada/educadora, acesso ap planejamento semanaT, além de observações semanąis de suas atividades com as crianças por uma dưpla de estagiários. Discussão/resultados Observa-se, nos/dois grupos, a confirmação da hipótese inicial: as educadoras demonstram seu papel confundindo-se com o das auxiliares, mais identificadas como cuidadoras.
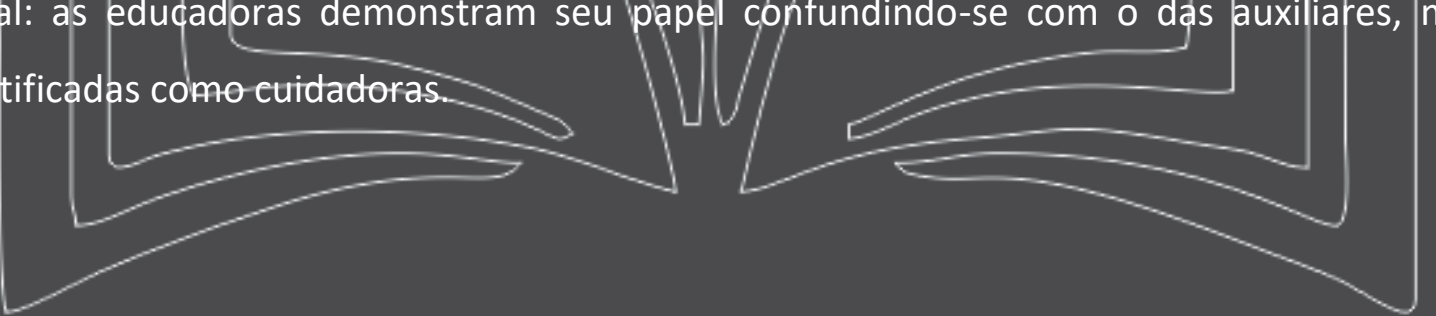


\section{Desafios da psicologia no Brasil}

Não está evidenciado, em suas ações, o papel pedagógico de promoção da socialização; não estão claros os objetivos do planejamento, cujo registro por escrito não condiz com a prática; demonstram atitudes de envolvimento afetivo ora sem paciência, ora superprotegendo, e em diversos momentos guiadas pelo senso-comum, estigmatizando e discriminando as crianças. Estar neste papel é um lugar de passagem em seu projeto de vida, segundo as entrevistas. Relevamos a importância de temas como este na formação de psicólogos para a construção de ações psicoeducativas com educadores, em especial com educadoras de crianças pequenas que demonstram não ter consciência do seu importante papel que é a contribuição para a construção das subjetividades.

Palavras- chave: ações psicoeducativas na creche; psicologia e educação infantil; a identidade da educadora da primeira infância. 


\section{Desafios da psicologia no Brasil}

\section{BREVE INTRODUÇÃO}

Em um primeiro momento, não podemos deixar de contextualizar o papel da creche na nossa cultura ao longo da história. As preocupações pedagógicas com relação à creche advém da sua inserção na constituição de 1988, que significa um marco oficial de mudanças sociais já em andamento ao longo das últimas décadas: a inserção da mulher no mercado de trabalho e o novo olhar para a educação infantil que transcende o cuidar, tendo a merecida importância segundo as teorias pedagógicas, psicológicas e psicanalíticas que muito contribuíram para esta área do saber.

Tendo em vista o contexto histórico da educação no Brasil, este estudo visa verificar, em uma creche paulistana de caráter filantrópico, a hipótese de que o caráter assistencialista de cuidador 'maternal' ainda, nos tempos atuais, na prática cotidiana, não deu lugar ao profissional da educação infantil. Desta forma, as educadoras de crianças pequenas na instituição ainda apresentam suas identidades mais voltadas para o papel maternal do que de fato para o de educadoras-profissionais da educação.

\section{UM BREVE HISTÓRICO DA EDUCAÇÃO INFANTIL}

Retomemos a história da creche desenhando uma linha do tempo bastante simplificada, tendo como referência Kramer e Jobim e Souza (1987).

O início do séc. XX é marcado por significativas mudanças sociais: a industrialização e consequente urbanização. Apontam-se novas necessidades advindas de um novo modo de vida. Grupos filantrópicos compostos por médicos, sanitaristas e religiosos dão origem à instituição creche, com os primeiros projetos de atendimento às crianças de famílias operárias das camadas populares. 0 trabalho feminino industrial fora do domicílio passou a demandar guarda diária e cuidados básicos de seus filhos pequenos, papel assumido pela creche de então. Esse papel assistencialista significou uma resposta a problemas sociais tais como abandono, mortalidade infantil, desnutrição.

Os anos 1920 são marcados pelo pronunciamento do setor público ao proclamar a necessidade de "preparar a criança de hoje para ser o homem de amanhã", fortalecendo o Estado. A criança é vista como a "matriz do homem e redentora da pátria". As políticas públicas têm uma concepção abstrata de infância, voltada ao trabalho puramente assistencialista e de forma muito vaga, pouco efetiva: o discurso oficial de cada um dos Ministérios da Saúde, Assistência Social e Educação jogava a responsabilidade sempre para o outro, pela precariedade das condições de vida das classes desfavorecidas no tocante à saúde, nutrição, educação, família, etc. Dessa forma, a viabilização de ações voltadas à criança ficava comprometida. E o problema da criança desassistida já se mostrava 


\section{Desafios da psicologia no Brasil}

como um problema muito maior, estrutural, de ordem social.

Os anos 1940 trazem o papel normativo do Ministério da Educação e Saúde com o Departamento Nacional da Criança, reconhecendo a creche como o "mal necessário" no combate à mortalidade infantil e "criadeiras" sem condições e infra - estrutura.

Os anos 1950 inauguram as classes anexas de pré-primário aos estabelecimentos de ensino. Temos o início dos jardins de infância - atendimento a crianças de quatro a seis anos de idade. O profissional, da área de saúde ou assistencial, passa a ser da educação: entra em cena o PROFESSOR normalista, cuja tarefa é educar e socializar. Para a escola 'maternal', a 'educadora' tem como papel as funções maternais e de cuidado e higiene.

No final dos anos 1970 temos a expansão das creches e pré-escolas: um novo perfil demográfico traz uma demanda social crescente do atendimento dessas instituições. Mais mulheres ingressam no mercado de trabalho, muitas com trabalho leigo e sub remunerado e o papel da mulher na sociedade, de forma geral, começa a tomar novo corpo com o movimento feminista. O resultado do atendimento às crianças é de qualidade pobre, já que a leitura assistencialista voltada a esse trabalho obedece à lógica de que o trabalho de atendimento para pobres é pobre.

O marco significativo para a história da educação infantil dá-se em 1988, com a Constituição Federal que garante atendimento em creches e pré - escolas às crianças de zero a seis anos, promulgando o artigo 208, que assinala : "direito da criança, opção da família e obrigação do Estado".

Em 1996 temos a Lei de Diretrizes e Bases, que promulga a educação para crianças de zero a seis anos como primeira etapa da educação básica, com o artigo 21, que garante o desenvolvimento integral da criança e a obrigatoriedade de qualificação mínima do profissional de educação infantil com pelo menos a conclusão do nível médio.

\section{POLÍTICA E EDUCAÇÃO}

Apesar do marco oficial da creche como "direito da criança, opção da família e obrigação do Estado", a transformação social é um processo bastante lento, já que a representação social que ainda se faz da creche é ainda retrógrada, arraigada de crenças que não a consideram direito da criança, mas uma espécie de pena a que tem que se submeter, tampouco opção da família, que se sente obrigada, com muito pesar, a "abandonar o filho indefeso" na instituição, e menos ainda "obrigação do Estado", já que a cultura submissa e despolitizada não permite esta visão. 


\section{Desafios da psicologia no Brasil}

Sekkel (1988), comenta: "Tanto no caso da esmola como no trabalho assistencial a idéia do favor, da boa ação, está presente. Isso já coloca o pobre numa situação que não é de direito, mas de dívida". Esta fala está ligada à idéia do valor cultural presente em nossa sociedade que é o assistencialismo, como parte da ideologia política econômica que faz manter condições de desigualdade social. Não há interesse, por parte dos poderes políticos, em investir onde o resultado não é visível concretamente e de forma imediata. O investimento na educação deveria ser contínuo e os resultados são evidenciados a médio ou longo prazo; mudam-se as políticas, e não se pensa política como investimento no humano, na comunidade. Nossa cultura carrega o mito do desvalor da educação, de uma forma geral, e mais ainda da educação infantil, que é desvalorizada dentro da área da educação. O desvalor se estende para o próprio sujeito que se vê em dívida com a assistência que recebe ; o conceito que tem de si mesmo faz com que encare sua condição como sendo natural, e o pior, as más condições de vida são atribuídas à sua própria natureza, à sua "incapacidade natural”. Essa naturalização, atribuída à natureza humana, que não permite questionar as condições humanas, faz parte da ideologia política do Estado. Aproveitando aqui para situar o significado que pretendemos dar ao conceito de ideologia, citamos Bock (1999, p.24 - 25), sob a perspectiva crítica sócio - histórica:

\footnotetext{
A idéia de natureza humana tem um caráter ideológico, pois camufla a determinação social do homem. $O$ homem é pensado de forma descolada de sua realidade social, realidade essa que o constitui e lhe dá sentido. As teorias que têm a idéia de natureza humana como seu fundamento se tornam, assim, com esse trabalho de ocultamento da realidade, teorias ideológicas... "Ideologia é um conceito complexo e cheio de significados. Utilizamos, aqui, o termo no seu sentido marxista,. Ideologia, para Marx, é um termo crítico, que implica ilusão e mistificação da realidade, construída pela classe dominante, e que se torna idéia dominante na sociedade.
}

A idéia de ser 'pobre' engloba um conceito de pobreza muito mais amplo que pobreza material, ou condições de carência material. O ser pobre passa a significar ser menos capaz, ser naturalmente deficiente de capacidade intelectiva e humana, ser naturalmente mais fraco, portanto justifica - se a submissão. Na sociedade capitalista, em que o valor do sujeito é medido pelo tamanho de suas posses ou de sua conta bancária, a carência do ter coisas é vista como carência do ser alguém. Atualmente, com condições de vida de muita precariedade, estar desempregado passa a ter significado de deixar de existir, para ser ninguém. Se não ter lugar na sociedade pressupõe o sentimento de não existência, tampouco há lugar para a educação de seus filhos. 


\section{Desafios da psicologia no Brasil}

Demo (1996) conceitua de forma bastante clara o que chama de 'pobreza política'. Como nos mostra o autor, pobreza política é pobreza de consciência política, ou seja, consciência da própria opressão. O mesmo autor cita:

Não estamos habituados a considerar como pobre a pessoa privada de sua cidadania, ou seja, que vive em estado de manipulação, ou destituída da consciência de sua opressão, ou coibida de se organizar em defesa de seus direitos..."'"continua sendo um vez o tecnocrático marcante, inclusive da assim Nova República, a política social assistencialista, que distribui algumas migalhas materiais em troca da desmobilização política das massas e dos movimentos sociais.

\section{A MÃE E A EDUCAÇÃO INFANTIL NO IMAGINÁRIO SOCIAL}

Nossa cultura, ainda submersa em crenças sobre o papel da mãe e o papel da instituição de educação infantil, sofre um processo a longo prazo de transformação. Ainda acreditamos que a mãe tem papel exclusivo nos cuidados e afeto com a criança pequena, e dividí-los com a instituição significa abandonar o papel de "boa mãe", inevitavelmente a mãe, ou o responsável pela criança, sente-se culpado por este "abandono", que para ele representa o abandono do próprio filho. Muitas vezes, o olhar da mãe implica em acreditar que a creche é pura extensão dos cuidados maternais, não tendo clareza do significado pedagógico de ampliação dos horizontes da criança para seu desenvolvimento integral e integrado.

Implicações psicossociais da mulher contemporânea mãe-profissional-mulher são inúmeras e de uma complexidade grande que dá significados e repercussões na sua relação com a criança e com a instituição responsável pela educação infantil. A mulher da atualidade conquistou um papel significativo no mercado de trabalho e maior reconhecimento e igualdade perante o mundo masculino. Acontece que esse espaço conquistado obedeceu ao modelo masculino de incessante produtividade, ilimitada competitividade. Dessa foma, as exigências e pressões também são as mesmas, assim como o estresse diário e todos os prejuízos acarretados. Além do que, por mais conquistas realizadas, a grande maioria das mulheres mantém a função das tarefas domésticas, cumprindo dupla ou tripla jornada de trabalho, fora e dentro de casa, principalmente grande parte da população que não tem condições de ter alguém que auxilie nas tarefas domésticas.

Com todas as dificuldades, para a grande parte da população e especificamente a feminina, o 


\section{Desafios da psicologia no Brasil}

significado do trabalho está longe de ser o de realização pessoal e profissional, mas tem sido o de sacrifício. O ideal seria realmente poder estar em casa, cuidando tão somente das tarefas domésticas e dos filhos. Dessa maneira, a representação que a mãe terá da creche será o "mal necessário"; se ela não está feliz fora de casa, o filho também não poderá.

As fantasias psicológicas dos adultos que convivem com a criança são das mais diversas, provindas de sentimentos construídos no quadro social de abandono, dó, culpa, rivalidade, medo, insegurança. Todos estes sentimentos são transmitidos para as crianças, que por sua vez acabam refletindo - os na sua relação com a instituição.

O desvalor histórico da educação infantil encontra-se arraigado ainda também na própria instituição, muitas vezes de forma velada. $\mathrm{O}$ assistencialismo como mote do trabalho educacional acarreta a falta de preparo e competência para lidar com questões como a adaptação da criança. O desvalor do papel da educação infantil encontra-se arraigado, muitas vezes, na subjetividade do profissional da área: como mostrarei as vantagens do ingresso da criança na creche se também não acredito nelas? Se, como educador, não consigo ter clareza do meu papel e também alimento sentimentos de dó, resignação e culpa? Se o projeto pedagógico não está bem delineado, eventuais problemas com as crianças que poderiam ser resolvidos na instituição são levados à família, chamada a responder por eles, e por sua vez vê-se muitas vezes incapaz para tal, porque precisa de orientação para a qual a instituição está também incapacitada. De um lado, a culpa de muitas mães tende a aumentar, acreditando que realmente o filho está abandonado; para outras tantas, que comodamente colocaram na instituição a total substituição das funções maternas e da educação familiar, seguem insatisfeitas com as expectativas não atendidas.

\section{MÉTODO}

O estudo está pautado por meio de coleta de dados realizada por quatro duplas de estagiários do curso de graduação em psicologia, pesquisa de campo supervisionada pela pesquisadora que elabora este trabalho.

Tratou-se de cinco observações semanais, não participativas, de atividades com quatro educadoras de crianças de 2 a 3 anos e de 3 a 4 anos de idade. Duas duplas observaram, cada uma, atividades com uma educadora de crianças de 2 a 3 anos, e outras duas duplas, cada uma observou atividades com uma educadora de crianças de 3 a 4 anos.

O público-alvo foi o de quatro educadoras no total, com suas respectivas auxiliares. Além das 


\section{Desafios da psicologia no Brasil}

observações não participativas, deu-se coleta de dados com uma entrevista com cada educadora e acesso ao planejamento semanal.

\section{DISCUSSÃO / RESULTADOS}

\section{ENTREVISTAS COM EDUCADORAS DA FAIXA ETÁRIA 2-3 ANOS DE IDADE}

Tivemos resultados semelhantes para ambas as faixas etárias.

Para a faixa etária dos 2 anos de idade, percebeu-se que, tanto a professora quanto a auxiliar apresentaram atitudes pouco profissionais, atitudes de mãe, com relação aos menores. Uma, a auxiliar, apresenta atitudes como mais carinhosa; e a outra demonstra atitudes de mãe muito estressada que se ocupa de muitos filhos ao mesmo tempo.

Um dos maiores problemas das educadoras é a atribuição que dão às crianças de naturalização de comportamentos, ao atribuírem causas sociais como se fossem naturais, além dos estigmas e estereótipos dados aos menores, como em expressões: "Ele morde..."; "Ele é assim mesmo..."; "Ela é chorona..."; "Ela é sempre cheirosa...".

Vivemos numa cultura impregnada de preconceitos e estereótipos, mas o problema dos educadores, no papel de grande responsabilidade, é que, a partir do momento que estigmatizam os indivíduos , colaboram para a perpetuação das formas de ser, com a força do poder que seu papel representa.

Percebe-se a atenção especial que as educadoras dão para as crianças mais ativas e desinibidas no meio escolar, e até por tal motivo são as que se destacam mais em público; esquecem as tidas como quietas, fazendo com que essas crianças sejam estigmatizadas, assim desvalorizando a timidez.

Essa timidez muitas vezes é vista como uma marca de personalidade do sujeito. Marcas essas, que podem ser dadas por um professor na infância, por exemplo, e subjetivadas pelo indivíduo para o resto de sua vida, pois a pessoa aceita como é vista e acredita de fato, que faz parte de um número de pessoas com essa certa personalidade determinada pelo outro. Ao correlacionarmos esses fatos, abordamos a questão da individualização (o sujeito pensa que é o problema e é tido como tal) e da naturalização (quando se atribuem causas sociais como se fossem naturais, aqui no caso, da natureza humana). E ainda nesse contexto fazemos uma distinção entre responsabilidade e culpa, pois a primeira implica na capacidade de responder por seus próprios atos, que gera a maturidade, e a segunda, quando o sujeito aponta o outro como culpado de certas situações. 


\section{Desafios da psicologia no Brasil}

\section{ENTREVISTAS COM EDUCADORAS DA FAIXA ETÁRIA 3-4 ANOS DE IDADE.}

Para a faixa etária dos 3 a 4 anos de idade, nota-se uma preocupação com o desenvolvimento de um plano pedagógico por parte da educadora que visa instalar comportamentos adequados nas crianças, promovendo o respeito entre elas. No entanto, assim como observado no grupo da outra faixa etária, nota-se que a profissional não consegue separar o papel de mãe e educadora e sua autoridade fica prejudicada. Percebe-se, mais uma vez, atitudes de individualização do problema na busca por definir, estigmatizar, estereotipar e condenar o sujeito, eximindo-se assim da responsabilidade para com a sua formação; a culpa é sempre do outro.

Nota-se que há, por parte das educadoras, preferências por determinadas crianças, as mais limpinhas e choronas estão sempre no colo das educadoras por longo período. Neste grupo as educadoras são mal preparadas para realizar um trabalho tão sério de desenvolvimento e cuidado com as crianças.

Atitudes da diretora e da coordenadora demonstram despreparo para lidar com algumas atitudes das crianças, ou ainda orientar as professoras, assim como estas consideram as atitudes das crianças como naturais, sem investigar as suas origens, sem contextualizar a problemática.

\section{RESULTADOS GERAIS DAS ENTREVISTAS}

Quanto aos resultados das entrevistas realizadas, pode-se concluir, a partir das respostas obtidas, que o discurso da educadora comprova a temática do presente trabalho. Várias respostas emitidas reforçam a idéia da figura materna presente no papel de professora. Obtém-se a resposta unânime das educadoras quanto ao se sentirem "mães" das crianças: "Não há como não me sentir mãe das crianças pequenas, não é possível separar o papel de mãe e de professora".

Um dos fatos mais marcantes das entrevistas, foi o conhecimento sobre a falta de interação entre educadoras e mãe dos alunos, além de coordenação/diretoria e educadores. O contato não se dá de forma direta entre pais e educadores e sim por meio da coordenação que é responsável por resolver os problemas impedindo este contato direto.

É de suma importância uma boa integração com professores e familiares, para o estabelecimento de um vínculo saudável para a família conhecer melhor o ambiente da creche e a rotina de seus filhos, gerando assim confiança nas pessoas que cuidam de seus filhos, para que ocorra a adaptação dos alunos. 


\section{Desafios da psicologia no Brasil}

Outro problema encontrado, são as divergências entre coordenação/diretoria educadoras, que sempre tem como conseqüência à má qualidade educacional infantil.

A professora também é estigmatizada; ela se vê da mesma forma que a estigmatizam. Se a professora se intitula de tal forma, determina um autoconceito, fazendo também que passem a rotular seus alunos. $O$ estigma que elas se atribuem e igualmente direcionando ao seus alunos, não colabora para uma transformação, não possibilitando a oportunidade de mudanças para a obtenção de sua autonomia no contato com os pais das crianças, por exemplo.

Observa-se o fenômeno da cristalização e naturalização nas relações humanas, de acordo com Machado e Proença (2008), no espaço institucional. Constroem-se subjetividades nos processos de subjetivações e objetivações: internalizam-se características objetivadas como definições dos sujeitos que, estigmatizados, carregam marcas que se perpetuam em suas subjetividades.

A frase dita pela profissional: "Estamos aqui para limpar bunda de criança!", demonstra além de uma visão assistencialista, uma falta de preparo em lidar com crianças pequenas, e uma certa frustração em relação à sua função. Fica nítida que sua atividade como educadora não implica em consciência da importância de seu papel relacionado ao desenvolvimento infantil.

Percebe-se, no decorrer das entrevistas, muita insegurança em relação a determinados apontamentos quando referidos à coordenação, devido às limitações impostas. As educadoras demonstram não possuir autonomia para realizar atividades fora do planejamento para o desenvolvimento das crianças, só realizando o que os superiores determinam como de acordo.

Existe um desejo de mudança por parte das educadoras, que alegam não poder opinar e nem trazer idéias novas, estão lá apenas para seguir as ordens.

\section{ANÁLISE GERAL DO PLANEJAMENTO E SUA APLICAÇÃO}

O planejamento da instituição é fora de propósito, algumas das atividades são feitas apenas para ocupar o tempo da criança; não há demonstração de preocupação de fato com as questões educacionais.

Algumas atividades descritas no planejamento semanal das professoras são descritas apenas pelo local, como "brinquedoteca", ou "sala de TV", "parque", ou ainda pelo material: "brinquedos diversos", "músicas". Mesmo que descritos os objetivos, muitas vezes, como "psicomotricidade", 


\section{Desafios da psicologia no Brasil}

"socialização" e "linguagem oral", estes não ficam visíveis durante as atividades e na relação do grupo e deste com as educadoras.

Não se obsevou a realização das atividades propostas no planejamento semanal, assim como também na segunda observação não houve a atividade no parque, mesmo com o tempo muito ensolarado.

Acreditamos que, conforme estudos epistemológicos de Wallon (2005), embora as crianças sejam pequenas, é de vital importância, para a construção de todas as dimensões da pessoa completa (afetiva/emocional/cognitiva/motora), a inserção de atividades que incluam movimento, como a dança, por exemplo, para que a criança se familiarize com a imagem do próprio corpo, ou mesmo explore as possibilidades de gestos, ritmos corporais e expressões em brincadeiras motoras. E não apenas, como várias vezes observado, ficarem correndo em um espaço relativamente pequeno para a quantidade de crianças no local, enquanto que algumas permanecem no colo do adulto o tempo todo.

As brincadeiras poderiam ser melhor dirigidas, afinal, a atividade lúdica dentro de uma proposta educacional é que irá propiciar que elas façam suas associações com outras atividades do cotidiano, além de desenvolverem autonomia e a própria identidade.

Outra coisa que não foi observado no planejamento semanal e tampouco no espaço da instituição, foi a exploração do meio ambiente, aliada à interatividade do grupo. É no contato com a natureza que a criança pode vivenciar valores humanos, ao explorar o ambiente, manifestando curiosidade e interesse pelo mundo social, natural e cultural; além de valorizar a importância da preservação das espécies e da qualidade de vida.

\section{CONCLUSÃO}

As educadoras pesquisadas são mulheres que ingressaram na vida educacional por vários motivos. São pessoas dotadas de sentimentos, sonhos e frustrações, além de fazerem parte de uma cultura. Na sua infância aprenderam a executar o papel de mãe com seus cuidadores e, ao se tornar jovens, tiveram a oportunidade de por em prática o que aprenderam de acordo com o que seu grupo social atribui como verdade. Ao se tornarem professoras, levam representações e manifestações que sua formação e mundo social construiram em seu imaginário.

Fica nítido, nas entrevistas realizadas, que o papel de educadoras está presente de forma efêmera na vida delas como mulheres; seu lugar nesta instituição é um lugar de passagem. 


\section{Desafios da psicologia no Brasil}

Consideramos importante dentro deste estudo ressaltar a necessidade e importância no preparo do profissional atuante na área da educação infantil em instituição de ensino, pois não há ação consciente da educadora junto ao trabalho desenvolvido e com isso perde-se o verdadeiro valor do papel desempenhado.

Confirma-se nossa hipótese inicial, que aponta o papel maternal mais acentuado na professora da educação infantil. Além do que, observa-se, na prática do cotidiano com as crianças pequenas, a indiferenciação dos papéis da professora e da auxiliar. As duas são cuidadoras.

Por não existir a separação entre o papel do educador e a figura da mãe, o desenvolvimento das crianças fica prejudicado, pois falta motivação e atividades educacionais dirigidas a fim de explorar e incentivar o desenvolvimento infantil.

Fica evidente a complexidade da figura materna no trabalho pedagógico. A observação psicológica nesse contexto muito contribuiu para mostrar a necessidade de futuras pesquisas e trabalhos psicoeducativos de promoção de saúde no contexto educacional.

Faz-se importante enfatizar a idéia de atividade no contexto social e histórico dos sujeitos - sua práxis - que remete ao processo intencional e consciente para a apropriação de conceitos construídos pela coletividade e que promove as responsabilidades em cada papel desempenhado. Este passa a ser significativo.

\section{REFERÊNCIAS BIBLIOGRÁFICAS}

Alves, R.(1999). Entre a ciência e a sapiência-o dilema da educação. São Paulo: Loyola.

Cambi, F. (1999). História da pedagogia. 3ạed. São Paulo: Unesp.

Bock, A. M. B. (1999). As aventuras do barão de munchhausen na psicologia. São Paulo: Cortez, 1999.

Crochik, J. L. (1997). Preconceito, indivíduo e cultura. 2ª ed. São Paulo: Robe.

Demo, P. (1996). Pobreza Política - polêmicas do nosso tempo. Campinas: Autores Associados.

Grinspun, M. P. S. Z.(2001). A orientação educacional-conflito de paradigmas e alternativas para a escola. 3aed. São Paulo: Cortez.

Kramer, S. e Jobim e Souza, S. (1987). Avanços, retrocessos e impasses da política e educação préescolar no Brasil. X Reunião anual da ANPED: Salvador, BA.

Leontiev, A. N. (1978). O desenvolvimento do psiquismo. Lisboa: Livros Horizonte.

Leontiev, A.N., Vygostsky, L.S. e Luria, A.R. (2007). Psicologia e Pedagogia - Bases Psicológicas da Aprendizagem e do Desenvolvimento. 4aed. São Paulo: Centauro. 


\section{Desafios da psicologia no Brasil}

Luria, A. R.(1990). Desenvolvimento cognitivo: seus fundamentos sociais e culturais. São Paulo: Ícone.

Machado, A. M. e Proença, M. ((2008). As crianças excluídas da escola: um alerta para a psicologia. Em Machado, A. M. e Proença, M. (orgs). Psicologia Escolar: em busca de novos rumos. 8ªed. São Paulo: Casa do Psicólogo.

Meira, M. (2007). Psicologia histórico-cultural- contribuições para o encontro enrre a subjetividade e a educação. São Paulo: Casa do Psicólogo.

Molon, S. I. (2003). Subjetividade e constituição do sujeito em Vygotsky. 2ª ed. Petrópolis: Vozes.

Meira, M. E. M. e Facci, M. G. D. (orgs). (2007). Psicologia Histórico-Cultural-Contribuições para o encontro entre a subjetividade e a educação. São Paulo: Casa do Psicólogo.

Oliveira, M, K., Souza, D. T. R. e Rego, T. C. (orgs). (2002). Psicologia, educação e as temáticas da vida contemporânea. São Paulo: Moderna.

Piaget,, J. (1994). O juízo moral na criança. São Paulo: Summus.

(2003). A construção do real na criança. São Paulo: Ática.

Sekkel, M. C. (1998). Reflexões sobre a experiência com a educação infantil: possibilidades de uma educação contra a violência na primeira infância. Instituto de Psicologia da Universidade de São Paulo. São Paulo-SP.

Sisto, F. F, Oliveira, F. C. e Fini, L. D. T. (2000). Leituras de Psicologia para formação de professores. 2ª ed. Petrópolis: Vozes.

Vitória,T. e Rosseti-Ferreira, M. C. (1993). Processos de adaptação na creche. Cad. Pesq.: São Paulo, n.86, p.55-64.

Vygotsky, L. S. (1984). A formação social da mente. São Paulo: Martins Fontes. (2003). O desenvolvimento Psicólogico na Infância. 3ạed. São Paulo: Martins Fontes.

Vygotsky, L. S., Luria, A.R. e Leontiev, A.N. (2001). Linguagem, desenvolvimento e aprendizagem. 7ạed. São Paulo: Ícone.

Wallon H. A evolução psicológica da criança. (2005). Lisboa: Edições 70. 


\section{Desafios da psicologia no Brasil}

\section{NOTAS}

Nota 1

Trabalho publicado nos anais do X Congresso Nacional de Psicologia Escolar e Educacional-Julho/2011. 


\section{Capítulo 61}

\section{JACAREZINHO-APARECIDA DE BICICLETA: A PRÁTICA DO \\ CICLOTURISMO PARA UMA VIDA SOCIAL COM QUALIDADE}

DOI: $10.37423 / 200200325$

Leandro Dri Manfiolete Troncoso. Bacharelado em Educação Física, Universidade Estadual de Londrina (UEL) e Mestre em Ciências da Motricidade, área Pedagogia da Motricidade Humana, Universidade Estadual Paulista "Júlio de Mesquita Filho" (UNESP)

RESUMO: O objetivo deste ąrtigo foi de compreender as relaçốes entre cicloturìismo, saúde e qualidade de vida a partir da perspectiva de cicloturistas. Participaram do estudo 32 pessoas, 30 homens e 2 mulheres entre 20 e 60 anos. Como gritério de inclusäo, todos ós sujeitos participaram da viagem 'Jacarezinho-Aparecida de bike' com grupo Ciclistas de Maria da cidade de Jacarezinho, estado do Paraná Para a coléta de dados, foram utilizadas as técnicas de entrevista semiestruturada e da observação participante. Para a interpretação dos dados, foi empregada a técnica de análise de conteúdo temático. Emergiram três unidades de significado: aspectos físicos e de estilo de vida, motivação pessoal e interaçã $\phi$ social. A partir da temática qualidade de vida que permeou a totálidade dos discursos, considero o cicloturismo um objeto de estudo interdisciplinar.

Palavras-chave: bicicleta, cicloturismo, saúde, qualidade de vida.

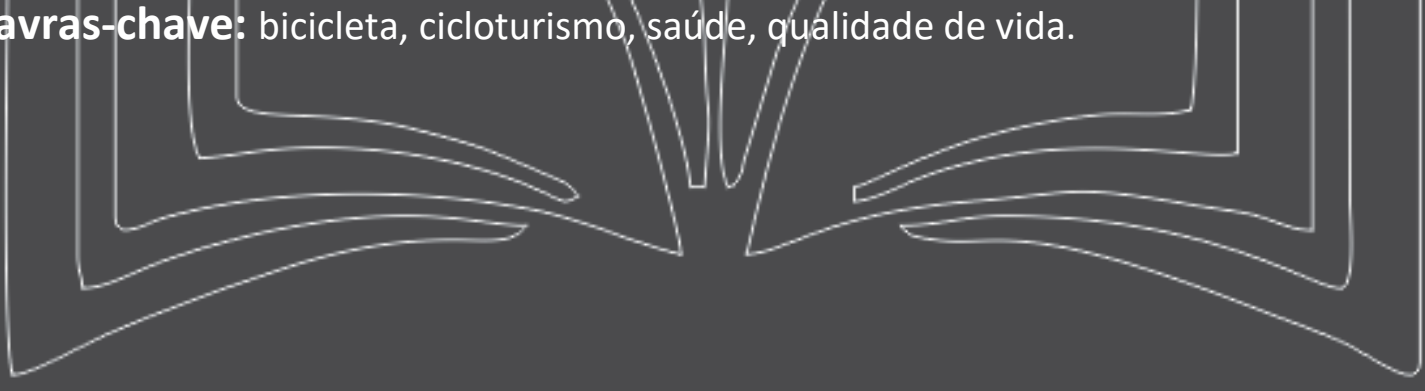




\section{Desafios da psicologia no Brasil}

\section{INTRODUÇÃO}

Tendo como foco a ampliação das possibilidades de vivência em ambiente social, o objetivo deste trabalho é conhecer e registrar a interface das relações entre cicloturismo e qualidade de vida, a partir da perspectiva dos praticantes. Levando em conta que as relações sociais são a base das atividades desenvolvidas em todos os segmentos da sociedade, a proposta do estudo será de contribuir para uma reflexão sobre o "corpo que pedala" no contexto da motricidade humana, compreendendo o ciclista como membro integrante de um universo sociocultural situado historicamente.

$\mathrm{O}$ ato de pedalar faz parte do cotidiano de muitas pessoas e pode ser incorporado como hábito para a promoção da saúde e, até mesmo, de lazer, considerando os aspectos físicos, psicológicos e sociais envolvidos nesta atividade. Isto faz com que andar de bicicleta esteja inserido em diversos contextos socioculturais. Pedalar envolve uma destreza que exige do ciclista interação corpo-bicicleta, o que se dá por meio de uma sucessão constante de movimentos que permite o deslocamento rápido, seguro e agradável. Trata-se de uma técnica corporal, isto é, uma maneira pela qual os indivíduos utilizam seus corpos, cuja habilidade é apreendida conforme os padrões culturais de cada sociedade, para realizar determinada atividade.

Percebe-se que o ser humano faz uso da bicicleta para diversas finalidades. Pode ser utilizada como transporte no espaço urbano; para fins desportivos como o "Ciclismo de Estrada", o "BMX" e o mountain bike nas modalidades "Cross Country" e "Downhill"; como prática de atividade física em academias denominada "Spinning" e, entre outras modalidades, além do simples pedalar no domingo, pode servir com o intuito de realizar viagens entre cidades, estados ou países, atividade denominada cicloturismo. Para Roldan (2000) o cicloturismo é uma prática onde a questão do tempo é definida a partir do lugar que o ciclista percorrerá. Independente de sexo ou idade podendo ser praticado sozinho ou em grupo, pedalar no meio urbano ou rural, em qualquer época e período e com ou sem equipamentos auxiliares ${ }^{1}$. Segundo o autor, o objetivo da atividade é de conhecer lugares utilizando a bicicleta como meio de locomoção, diferenciando-se de outras atividades não competitivas pelas dimensões espaciais, cronológicas e de planejamento.

No Brasil, trata-se de um fenômeno relativamente novo e, por isso, são encontradas poucas informações sobre a temática, porém, tem ocorrido um aumento no número de informações nos últimos anos. A guisa de exemplo, numa pesquisa realizada no sitio de busca Google na internet, foram 


\section{Desafios da psicologia no Brasil}

encontrados aproximadamente 447.000 páginas brasileiras que, abordavam de alguma forma o tema cicloturismo.

A bicicleta sempre fez parte da minha vida como transporte. O interesse de se investigar o ciclismo começou no terceiro ano da faculdade de Bacharelado em Educação

Física na UEL com o estudo das AFAN (Atividades Físicas de Aventura na Natureza), relacionado aos praticantes de mountain bike e senti a necessidade de vivenciar a atividade. Foi nesse contexto que realizei a primeira viagem de bicicleta. Saí de Londrina, estado do Paraná, no dia 18 de dezembro de 2008, com um amigo, mas como ele teve de parar no primeiro dia, cheguei sozinho à Piracicaba, estado de São Paulo, cinco dias depois. Perpassando as cidades dos dois estados, fiquei três dias pedalando durante a noite, um dia de descanso e, no último dia, pedalando com a luz do sol cheguei ao destino dando-se por concluído o meu primeiro cicloturismo. O quadro da bicicleta estava rachado próximo ao pé-de-vela, um pneu furou duas vezes ao longo da viagem, mas tive a absoluta certeza de que outras viagens seriam inevitáveis. Utilizo como retrato o interesse na época pelo cicloturismo que foi quando realizei a segunda "cicloviagem", no ano seguinte, com um amigo onde visitamos a cachoeira Salto do Rio do Tigre na cidade de São Jerônimo da Serra - PR. O curioso desta viagem se deu na volta quando nos deparamos com um ciclista pedalando numa bicicleta toda colorida. Tratava-se de Lavoisier Richard, que, naquele momento treinava para seu desafio e nos contou sobre o Break on Through Project - Hard Bike Tour ${ }^{2}$. No mesmo ano, ao finalizar a graduação retornei novamente para Piracicaba de bicicleta, mas agora, hospedando na casa de outras pessoas. As condições foram às mesmas, porém, senti diferença em relação ao meu corpo, pois enquanto na primeira vez foi um sofrimento pedalar, desta vez percebi melhor os lugares por onde passei, creio eu, por estar melhor preparado dado o tempo disponível para percorrer distâncias maiores com maior frequência. No mesmo ano, ao finalizar a graduação retornei novamente para Piracicaba de bicicleta, mas agora, hospedando na casa de outras pessoas. As condições foram às mesmas, porém, senti diferença em relação ao meu corpo, pois enquanto na primeira vez foi um sofrimento pedalar, desta vez percebi melhor os lugares por onde passei, creio eu, por estar melhor preparado dado o tempo disponível para percorrer distâncias maiores com maior frequência.

Com o ingresso na pós-graduação em 2012, publiquei artigo baseado em meu Trabalho de Conclusão de Curso, que buscava compreender os sentidos da aderência ao mountain bike na relação ser 


\section{Desafios da psicologia no Brasil}

humano-natureza $^{3}$. Partiu daí o interesse em investigar o cicloturismo. Nesse mesmo ano realizei a viagem "Jacarezinho-Aparecida de bike" com

o grupo Ciclistas de Maria a qual se seguiu outra viagem no ano seguinte, em 2013. Foi considerando estas experiências que a pesquisa se estruturou no sentido de compreender o cicloturismo sob o contexto sociocultural desse grupo.

Considerando esses fatores, o caminho a ser percorrido será o de realizar uma discussão sobre a condição do ciclista relativa aos aspectos físicos e estilo de vida, motivação pessoal e interação social. Para a área de Educação Física, tal interesse se justifica pelo ciclismo ser uma atividade que pode ser incorporada como prática de atividade física e, ao mesmo tempo, como estilo de vida para o praticante, tamanho o potencial desta prática corporal como alternativa às atividades físicas habituais. Para tanto, o presente trabalho subdivide-se em três momentos. O primeiro refere-se a uma descrição sobre os Ciclistas de Maria, grupo ao qual foram coletadas as informações da pesquisa. O segundo momento refere-se aos "Procedimentos Metodológicos" delineando a abordagem utilizada para coleta e análise dos dados. No terceiro momento, "A Qualidade de Vida e o Corpo que Pedala" são discutidos os termos chave do estudo e, no último momento, as "Considerações Finais".

\section{CICLISTAS DE MARIA}

O grupo Ciclistas de Maria reúne ciclistas que praticam cicloturismo nas rodovias na região do Vale do Rio Paranapanema, divisor natural dos territórios dos Estados de São Paulo e Paraná. O grupo tem sede na cidade de Jacarezinho, no estado do Paraná mais especificamente na "Vidativa Sports", academia de natação e bicicletaria. Idealizado por um dos membros líder do grupo Claudio Henrique Cavazzani que, com mais dois amigos, no ano de 2001, decidiram pedalar da cidade até a Estância Turística de Aparecida - SP, capital Mariana do Brasil, surgindo daí a viagem "Jacarezinho-Aparecida de bike".

Com um percurso de aproximadamente 680 quilômetros, o evento ocorre há treze anos sempre durante o feriado de Corpus Christi. Até a nona edição da viagem, devido ao menor número de pessoas e maior experiência dos envolvidos, a viagem era realizada em três dias, porém, com o aumento no número de novos praticantes, o trajeto começou a ser realizado em quatro dias. No trajeto, os ciclistas pedalam por rodovias asfaltadas saindo de Jacarezinho pela rodovia Transbrasiliana (BR-153) para Ourinhos e, a partir daí, cruzam o território do estado de São Paulo no sentido oeste-leste. Saindo 


\section{Desafios da psicologia no Brasil}

desta rodovia, pedalam sentido a rodovia Orlando Quagliato (SP-327) até a cidade de Santa Cruz do Rio Pardo, para chegar até a Castelo Branco (SP-280), parando, no primeiro dia, na cidade de Itatinga. No segundo dia, os ciclistas continuam por esta mesma rodovia de manhã e, à tarde, pedalam sentido rodovia do Açúcar (SP-308) e rodovia Santos Dummond (SP-75), parando, para descanso, na cidade de Indaiatuba. No terceiro dia, após passar ao lado do Aeroporto de Viracopos na cidade de Campinas, o grupo passa rapidamente pela rodovia Anhanguera (SP-330) e atravessa uma rotatória, seguindo pela rodovia Dom Pedro (SP-65) até a cidade de Jacareí, onde param. No segundo ano que viajei a parada se deu 20 quilômetros antes, na cidade de Igaratá, em um hotel às margens da represa do Rio Jaguari. No quarto e último dia, depois de pedalar certa distância pela rodovia Carvalho Pinto (SP-070), o grupo passa a percorrer a última e mais perigosa rodovia do trajeto, a Dutra (BR-116), na cidade de Taubaté. Antes de pedalar o trecho final, o grupo faz uma parada ao lado da "tradicional placa" que indica a distância de 46 quilômetros até Aparecida. Após o trecho percorrido na rodovia mais movimentada do país, o grupo se reúne em um viaduto próximo à cidade afim de que todos cheguem juntos no complexo da Basílica de Nossa Senhora Aparecida. Em seguida, os ciclistas se encontram com os familiares que viajaram para recepcioná-los na chegada e, quando todos já se cumprimentaram, se forma um grande círculo para rezarem.

Depois de se alimentar, o grupo descansa o restante do dia. À noite, no jantar de confraternização, cada ciclista recebe um certificado de conclusão da viagem e, no ato da entrega, cada um tem o seu momento para discursar sobre a trajetória percorrida. No domingo pela manhã, o grupo assiste a missa de Corpus Christi na basílica; logo após saem para visitar a cidade, almoçam e no começo da tarde retornam de ônibus. Dois detalhes pertinentes ao contexto da viagem merecem atenção. O primeiro detalhe se deve a mudança do percurso. Nas primeiras viagens, os Ciclistas de Maria cruzavam a Marginal do Tietê na cidade de São Paulo, mas devido ao risco de acidentes com veículos motorizados, o trajeto foi modificado passando agora pelo interior do estado. O segundo detalhe é derivado desta mudança. Quando a viagem era realizada em três dias, os ciclistas não paravam no santuário da Mãe e Rainha Schoenstatt na cidade de Atibaia-SP, porém, a organização decidiu aumentar um dia na viagem para almoçar e participar de uma missa de agradecimento no local (Figura 22). Sobre o santuário, o Movimento Apostólico Internacional de Schoenstatt é um movimento católico mariano fundado em 1914, na cidade de Schonstatt -Alemanha. Atualmente existem 195 santuários espalhados pelo mundo, sendo 22 no Brasil e, dentre estes, está o de Atibaia, considerado o maior do Brasil e o de Jacarezinho, cidade do grupo Ciclistas de Maria. 


\title{
Desafios da psicologia no Brasil
}

Um fato relevante da pesquisa é o aumento do número de participantes ao longo dessas viagens. Até a oitava edição do evento, o número de ciclistas não passava de dez, porém, em 2010 subiu para treze e, em 2011, vinte e dois ciclistas participaram da viagem. Devido ao maior número de pessoas, houve a modificação referida no percurso e na organização, com a implantação do carro e moto de apoio acompanhando os ciclistas. Após esta alteração, em 2012, o número saltou para vinte e nove ciclistas e, em 2013, trinta e quatro pessoas participaram da viagem. Para cada vez que o ciclista participou da viagem, ganha uma camiseta personalizada com o logo dos Ciclistas de Maria.

Um membro líder do grupo comenta sobre o aumento na procura pela viagem quando assume a bicicletaria na qual formou-se um lugar de encontro gerando mais visibilidade à prática do cicloturismo na região:

\begin{abstract}
Quando montamos a loja há dois anos, virou um ponto de encontro aonde às pessoas vinham procurar um local para começar a pedalar sobre algumas sugestões e recomendações e logo acabavam adquirindo sua bicicleta e equipamento e começa a andar junto com a gente. É também um ponto de saída para os treinos e viagens, ponto de encontro para vir conversar e referência do ciclismo e cicloturismo na região, de locais de mais de $100 \mathrm{~km}$ procuram a loja para adquirir seu equipamento, recomendação ou até mesmo uma orientação vinda de longe para conversar conosco.
\end{abstract}

Nas primeiras viagens, a organização era limitada ao ponto dos ciclistas terem de levar seus pertences no bagageiro da bicicleta durante a viagem e não terem pontos específicos para alimentação e descanso. Com a abertura do espaço, foi estabelecido um lugar para discussão sobre a viagem e, percebendo a demanda, o líder do grupo e dono da bicicletaria começou a pensar numa logística apropriada para a viagem. A partir disso, é ofertado para cada ciclista um pacote de serviços que, dentre os custos, consta de hotel, alimentação, uniforme e o carro de apoio para levar as bagagens e peças de manutenção das bicicletas. Este formato fez com que a pessoa se preocupe apenas em pedalar, detalhe que na visão dele, mudou a forma da viagem trazendo mais segurança para o grupo:

Nesses doze anos mudou muito. Por exemplo, saíamos daqui e não sabia onde ia parar, pedalava $230 \mathrm{~km}$ a $280 \mathrm{~km}$, variando o ano e local de parada, até chegar à próxima cidade, que a gente prezava em não andar a noite, como prezamos hoje em relação à segurança, não tinha local definido para parar e com isso, criaram-se diversas situações que a gente chegava à cidade e não tinha lugar para dormir, não achava hotel, encontrava local tarde da noite, não achava lugar para jantar e a viagem, nesses doze anos foi cada vez mais se organizando. Começamos em três ciclistas e nessa última viagem em 2013, estávamos com trinta e quatro ciclistas, mais de sessenta pessoas já realizaram esta viagem e, percebemos que quanto maior o número de ciclistas, alguns cuidados tiveram de ser tomados como a reserva de hotéis, o meio de locomoção no retorno como o ônibus ser locado para o retorno nosso, a reserva de restaurantes, tudo isso teve de ser criado, como também o carro e moto de 


\section{Desafios da psicologia no Brasil}

apoio. Teve de ser criada esta segurança porque se percebia que o grupo não era mais homogêneo que era no começo, que eram pessoas bem treinadas com o objetivo de fazer toda a viagem juntos no mesmo ritmo, do primeiro ao último integrante que chegava. Hoje, percebe no grupo que há vários níveis de treinamento, então o primeiro do grupo a chegar ao local de destino chega muitas vezes duas a quatro horas antes do último ciclista chegar. Só que para isso, o aparato de segurança tem de ser feito do primeiro ao último ciclista, então por isso contamos com carro e moto de apoio, reservas prédefinidas. Vimos que nesses doze anos, muita coisa mudou, ou se torna um grupo mais organizado com os equipamentos de segurança melhor, todo mundo uniformizado, mas o objetivo continua o mesmo de chegar a Aparecida, só que a forma de chegar se deu de forma diferente de antigamente.

Com o aumento no número de adeptos, a viagem não é mais feita apenas por um grupo homogêneo como era antes, mas foi desmembrada em vários pequenos grupos e, para garantir que todos estarão sendo acompanhados foi implantado o apoio motorizado que melhorou as condições de segurança para os ciclistas. Para acompanhá-los como apoio é escolhido um dos integrantes do grupo que participava da viagem quando era realizada sem o carro de apoio. Um desses apoios comenta sobre a diferença entre ir pedalando e, agora, oferecendo segurança para os que estão pedalando:

Pela experiência de eu já ter ido, uma pessoa no apoio que nunca foi pedalando, talvez não tenha a mesma visão que eu tenho, eu consigo visualizar o estado físico de cada um durante a viagem e eu sei pela experiência de já ter ido e sofrido durante a viagem, eu sei os pontos onde as pessoas irão precisar do apoio, consigo saber a quilometragem que vão precisar do apoio, consigo pela fisionomia dos ciclistas saber como eles estão se vai precisar já ou daqui a pouco. Por exemplo, quando estou atrás, paro e vejo o último, pela fisionomia dele, eu sei se posso adiantar e o quanto eu posso adiantar, ou se eu tenho que ficar próximo dele porque daqui a pouco ele vai precisar de mim e os pontos da viagem, o trecho que força mais e exige do atleta e daí vem o lado da experiência de estrada e do cuidado com o transito.

Este cuidado de acompanhar todos do grupo, ajudando no momento que o ciclista precisar, foi uma medida primordial para que aumentasse o número de adeptos. Isto porque deste modo ninguém fica para trás, pois todos devem chegar ao final do dia no destino proposto. 569 Em relação às atividades, como o feriado geralmente ocorre no mês do junho, três meses antes o grupo começa a se reunir duas vezes durante a semana para pedalar, com saída próxima das $17 \mathrm{~h} 30 \mathrm{~min}$ em frente à mesma igreja de partida da viagem. A distância dos trajetos varia em aproximadamente 60 quilômetros com duração de três horas, o que facilita a inserção dos iniciantes que almejam um dia chegar a Aparecida de bicicleta. Aos finais de semana são realizados os pedais longos, que variam de 100 a 150 quilômetros de distância com duração média de sete horas, conforme o trajeto escolhido. Com saída às 06h30min em frente à mesma igreja de partida da viagem para Aparecida, estas pedaladas são, geralmente, praticadas pelos mais experientes, mas algumas vezes, os iniciantes se arriscam a pedalar e quem 


\section{Desafios da psicologia no Brasil}

mantém a aderência, se sente confiante e preparado para fazer a viagem. Na maioria das vezes, o destino das pedaladas são as estradas de asfalto, porém, algumas vezes, saem para pedalar por caminhos de terra. Esta característica se deve muito pela viagem ser percorrida na estrada de asfalto, mas também ao tempo e pela velocidade e distância que se consegue percorrer. Os encontros do grupo não ficam restritos apenas às pedaladas rotineiras. Quando o grupo começa a se encontrar para pedalar, uma vez por mês eles se reúnem para assistir à missa e, após, discutem sobre a logística e organização, fazendo, ao final, um almoço de confraternização. Esses encontros são realizados para discutir os detalhes da viagem. Às vezes, alguns dos integrantes do grupo também realizam encontros, com churrasco, em suas próprias casas para conversarem mais e se conhecerem melhor, depois do "pedal longo".

\section{PROCEDIMENTOS METODOLÓGICOS}

Esta pesquisa é de natureza qualitativa. Conforme Minayo (2010, p. 57), pesquisas qualitativas se aplicam ao estudo da história, das relações, das representações, das crenças, das percepções e das opiniões, produtos das interpretações que os humanos fazem a respeito de como vivem, constroem seus artefatos e a si mesmos, sentem e pensam. A escolha pelos sujeitos fez-se de maneira intencional, porém, de acordo com o interesse de ambos: colaborador e pesquisador. Foram abordados trinta e dois indivíduos, trinta homens e duas mulheres, na faixa etária entre vinte e sessenta anos.

O critério de inclusão foi ter realizado, pelo menos uma vez, a viagem "Jacarezinho-Aparecida de bike". Na volta da segunda viagem que participei no ano de 2013, por estar praticamente todo o grupo reunido, decidi como momento oportuno para conscientizá-los sobre a investigação e que, necessitava fazer uma entrevista gravada com aqueles que estivessem dispostos a participar, dando-Ihes liberdade a possíveis dúvidas e questionamentos. Os participantes das entrevistas foram os ciclistas que o pesquisador teve contato nas duas viagens que participou. Antes da realização das entrevistas realizadas na "Vidativa Sports", foi solicitado para cada sujeito assinar o TCLE - Termo de Consentimento Livre e Esclarecido, aprovado pelo CEP - Comitê de Ética e Pesquisa com Seres Humanos, Instituto de Biociências de Rio Claro (IBRC-UNESP). Aos que moravam nas cidades de Ourinhos - SP e Santa Cruz do Rio Pardo - SP e em Ribeirão do Pinhal - PR foi agendado um dia para a realização das entrevistas e, como de praxe, o pesquisador se dirigiu até eles de bicicleta. Em relação a coleta de dados, foi empregada a técnica de entrevista semiestruturada em que o entrevistado teve a possibilidade de discorrer sobre o tema em questão, mas sem se prender à indagação formulada. 


\section{Desafios da psicologia no Brasil}

Este tipo de abordagem permite maior liberdade aos entrevistados para seguirem a linha de seus próprios pensamentos e experiências, orientados por questões-chave, tendo por objetivo captar informações sobre sentidos, significados, motivações, sensações e valores relativos ao tempo de vivência atrelado à prática (MYNAIO, 2010). Nesse tipo de pesquisa, segundo Triviños (2007), o pesquisador deve assumir no momento da entrevista, uma postura com o colaborador de uma conversação com um propósito definido, ou seja, deve-se tornar a conversa como uma forma de interação social mais próxima da realidade valorizando o uso da palavra, símbolo ou signo por meio da qual os atores sociais constroem procurando dar sentido a realidade que os cerca.

Foram três meses acompanhando o grupo antes da segunda viagem que participei, seja no espaço de encontros dos ciclistas na 'Vidativa Sports', como também pedalando todo final de semana e, rotineiramente, uma vez durante a semana, em pedaladas próximas às redondezas da cidade. Um momento importante no contato com o grupo foi o cicloturismo pelo "Caminho da Fé", que resultou em um relato de experiência ${ }^{4}$.

Depois de gravados os dados, fez-se a transcrição do material coletado. Para a análise dos dados obtidos, utilizamos a Análise de Conteúdo, definida como um conjunto de técnicas que visa obter indicadores que permitam a inferência de conhecimentos relativos às condições de produção/recepção destas mensagens (BARDIN, 1979, p. 42). Dentre as modalidades dessa análise, o estudo optou pela temática, por ser segundo Minayo (2010) a mais simples e apropriada para a investigação qualitativa em saúde. Emergiram três categorias para análise: aspectos físicos e estilo de vida, motivação pessoal e interação social. As informações obtidas colaboraram para a compreensão de várias outras questões associadas ao cicloturismo, um objeto de estudo mais amplo.

\section{A QUALIDADE DE VIDA E O CORPO QUE PEDALA}

Neste terceiro momento do trabalho, são apresentadas reflexões que emergiram a partir dos discursos, a fim de aprofundar o conhecimento sobre o tema. Porém, antes de abordar as categorias que foram selecionadas para análise, é necessária uma contextualização sobre a "qualidade de vida" e o "corpo que pedala", visto que estes dois termos permeiam os discursos, independente das categorias analíticas.

De acordo com Minayo et. al. (2000), qualidade de vida é uma noção eminentemente humana, aproximada ao grau de satisfação encontrado na vida familiar, amorosa, social e ambiental, que pressupõe a capacidade de efetuar uma síntese cultural de todos os elementos que determinada 


\section{Desafios da psicologia no Brasil}

sociedade considera seu padrão de conforto e bem-estar. Gonçalves (2004) entende o conceito de qualidade de vida como a percepção subjetiva do processo de produção, circulação e consumo de bens e riquezas, ou seja, é a forma pela qual cada pessoa vive seu dia-a-dia. Para Nahas (2001) qualidade de vida é a condição humana derivada do conjunto de parâmetros individuais e socioambientais, que caracterizam a forma como vive o ser humano. Não existe um único conceito sobre qualidade de vida, mas se podem estabelecer elementos para pensar nessa noção enquanto fruto de indicadores sociais ou individuais, a partir da percepção que os sujeitos constroem em seu meio (BARBOSA, 1998).

Quanto à análise semântica, tem-se que o termo "Qualidade", num sentido filosófico, refere-se a um caráter do objeto, que a princípio nada diz sobre ele, suas propriedades ou possibilidades sendo que caracterizar algo pela sua qualidade é estipular um nível bom ou ruim a ele, porém, essa atribuição é subjetiva, de acordo com o referencial e os elementos considerados (BETTI, 2002). Uma boa percepção de qualidade de vida dependerá das possibilidades que tenham as pessoas de satisfazer adequadamente suas necessidades fundamentais, ou seja, uma boa ou má percepção sobre a vida é relativa à qualidade do ambiente em que se encontra o sujeito, ao oferecimento de condições de realização e de satisfação das necessidades básicas que a própria sociedade estipula como essenciais, e que o interessado toma e deseja, ou não, como verdade para sua própria vida (ALMEIDA et. al., 2012, p.38).

A condição de qualidade de vida está ligada à área da saúde. As intervenções nesse campo se dão em alterações e melhorias do estilo de vida das pessoas (MINAYO et. al., 2000). O esporte ligado à qualidade de vida é considerado um dos grandes desafios atuais dos programas de promoção à saúde, cabendo ao educador físico o encargo de que essa proposição alcance sua finalidade (KREBS, 2002). Para Czeresnia e Freitas (2009), o que caracteriza a promoção da saúde é os determinantes gerais que influenciam nas condições de saúde como produto de um amplo número de fatores relacionados com a qualidade de vida. Dentre estes fatores, inclui-se o padrão adequado de alimentação, nutrição, habitação, saneamento, boas condições de trabalho, oportunidade de educação ao longo da vida, ambiente físico limpo, apoio social para famílias e indivíduos e um estilo de vida responsável adequado com os cuidados de saúde. Segundo Matsudo (2011) o ato de pedalar como promoção da saúde é uma forma de movimento do corpo que gera benefícios não apenas no âmbito físico, mas também no psicológico e social possibilitando o encontro e a socialização com outras pessoas e que contribui em diversos aspectos para o acesso à qualidade de vida. 


\section{Desafios da psicologia no Brasil}

Muito se tem vinculado na mídia sobre a relação da bicicleta com a saúde. O tema é tão importante que o secretário-geral da Organização das Nações Unidas (ONU), Ban Ki-moon, considerado o advogado da bicicleta, espera que esta cultura continue crescendo nas cidades. A entidade entende que a mobilidade é uma questão central da agenda atual e que, já traçou o uso da bicicleta como promoção à saúde no mundo, tanto pela necessidade de redução de poluentes no ambiente das cidades devido à elevada motorização, como também pela redução de indivíduos portadores de doenças crônicodegenerativas que a sua utilização como meio de transporte pode representar a médio e longo prazo (DETRAN-RS, s/d).

A qualidade de vida está ligada a noção de corpo. Por isso, no campo da educação física dá-se certa ênfase a esta discussão. Acompanhando este substantivo, imprime-se uma série de adjetivos como saudável, natural, holístico, moderno, consciente, inteiro, prazeroso, gordo, magro, entre outros (GREINER, 2005). Para aqueles que trabalham com o corpo humano no contexto do exercício físico e lidam com os adjetivos incutidos a esta palavra, é importante uma reflexão sobre o tema.

De acordo com a etimologia da palavra, o substantivo corpo nasceu do latim corpus e corporis e pertence à mesma família de corpulência e incorporar; corpus designava o corpo morto, o cadáver, em oposição à alma ou anima. Assim, nasceu uma divisão que atravessou séculos e culturas, separando o material do mental, o corpo morto do corpo vivo. Nesse caso, a noção de corpo teria a ver com o que é sólido, tangível, sensível e, sobretudo banhado pela luz, portanto visível e com forma. Como o corpo abrangeria muitos elementos acabou designando, ainda, tudo que está reunido, uma "corporação". Assim, o corpo poderia ser entendido também como corpo de uma doutrina ou corpo da lógica. Já a carne ou o carnal (em grego sarx e em latim caro) implicaria em keiro, da palavra grega que significa cortar, destacar (GREINER, 2005, p. 17).

Um filósofo em particular exemplifica esta separação marcando a passagem da Idade Média para a Moderna e que, ainda influência a atuação do profissional de educação física é René Descartes. Ao estudar o pensamento do autor, conhecemos o dualismo cartesiano, cuja premissa é a separação entre corpo e alma. Este pensador que viveu no século XVII, é considerado o pai da filosofia moderna devido às grandes contribuições realizadas por ele no mundo científico (ARANHA \& MARTINS, 2003). Esta dualidade histórica reflete na relação corpo/bicicleta, no campo da Educação Física, e impede a maior compreensão da abrangência do fenômeno do ciclismo como parte de uma cultura de movimento. Para Velozo (2010) grande parte das pesquisas sobre o tema na literatura da Educação Física brasileira, estão relacionadas à racionalização do corpo e do movimento tendo como interesse principal a otimização no desempenho do ciclista. Segundo Kunz e Trebels (2006), as pesquisas na 


\section{Desafios da psicologia no Brasil}

área, geralmente estão baseadas em um paradigma reducionista, limitando-se a verificar e analisar os mecanismos fisiológicos, porém, a importância do pesquisador em reconhecer que o homem é um ser a um só tempo biológico e cultural, é primordial, pois os domínios operacionais (fisiológico) e relacionais (cultural) estão emaranhados por essência.

Considerando esses argumentos, interpomos uma nova perspectiva de entender a situação: a relação do "corpo que pedala". O 'corpo da bicicleta' se unifica com o corpo do seu condutor na composição de uma verdadeira dança conjunta e estrutural. Nesse caso, o ciclista se põe a prova a uma série de competências práticas e perceptivas que o permitem pedalar com segurança, dispondo no momento que está em cima da bicicleta, formas de conduta necessárias para adequar-se a diferentes situações, como a imprudência de motoristas, a travessia de um local movimentado, as condições adversas do clima, o som ambiente que se torna importante recurso para o indivíduo conduzir a bicicleta, como alguns que pedalam ouvindo música e outros o utilizam como espelho retrovisor de um automóvel, orientando-se, assim, melhor no trânsito. A bicicleta proporciona uma relação com o corpo de forma única. Podemos comparar o caminhar com o andar de bicicleta. Enquanto andar a pé é uma sucessão de desequilíbrios e equilíbrios, já que quando é dado um passo o corpo se desequilibra para aquele lado, e, para recuperar o equilíbrio, novo passo é dado com a outra perna e assim sucessivamente, andar de bicicleta parece o oposto disto, pois enquanto a pessoa está em cima da bicicleta e seu corpo desequilibra para um lado, o movimento necessário para retomar o equilíbrio é, justamente, inclinar a bicicleta para o próprio lado, exatamente no sentido oposto ao da correção do desequilíbrio do andar natural (GUIMARÃES, 2009). Quando se está andando a pé e a pessoa desequilibra, é necessário parar para recuperar o equilíbrio. Na bicicleta, é, novamente, ao contrário. Ao andar de bicicleta, quando a pessoa começa a perder o equilíbrio, é preciso acelerar as pedaladas para obter mais velocidade e buscar novamente o equilíbrio. Parece até uma ação antinatural virar a bicicleta para o lado que está inclinado ou para recuperar o equilíbrio ao aumentar a velocidade, mas isto ocorre devido à aplicação do princípio do movimento giroscópico ${ }^{5}$, mas o fato é que o ato parece fácil tanto que, a maioria das pessoas começa a andar de bicicleta desde a infância (GUIMARÃES, 2009). Com a exposição cada vez maior na mídia sobre os usos da bicicleta pela sociedade nos momentos de lazer, no âmbito esportivo ou, até mesmo, no contexto da mobilidade urbana, a utilização deste equipamento tem proporcionado uma "redescoberta do corpo" por quem a usufrui:

As descobertas do corpo possuem uma história secular e vasta, pontuada pelos avanços e limites do conhecimento humano. Pois se o corpo não cessa de ser descoberto, é preciso não perder de vista a provisoriedade de cada conhecimento produzido a seu respeito: constantemente redescoberto, nunca, 


\section{Desafios da psicologia no Brasil}

porém, completamente revelado! Cada tentativa feita para conhecer o funcionamento do corpo, incluindo os seus significados biológicos e culturais, é desencadeadora de esclarecimentos e de dúvidas inusitadas a seu respeito. Da medicina dos humores à biotecnologia contemporânea, passando pela invenção de regimes, cirurgias, cosméticos e técnicas disciplinares, o conhecimento do corpo é por excelência histórico, relacionada aos receios e sonhos de cada época, cultura e grupo social (SANT'ANNA, 2000, p.237).

Embora as descobertas do corpo não sejam uma novidade da atualidade, foram no decorrer dos últimos quarenta anos do século XX que elas ganharam uma importância inusitada. Após os movimentos sociais da década de 60 , o corpo foi redescoberto na arte, na política, na ciência e na mídia, provocando um verdadeiro “corporeismo" nas sociedades ocidentais (SANT'ANNA, 2000).

Na década de 80, algumas questões se aliaram a outras redescobertas do corpo. Pregava-se a necessidade de estimular o físico no lazer e nos esportes sem esquecer-se de aliar o prazer ao pragmatismo. É quando o estilo esportivo conquistou as ruas e as moradias de milhares de pessoas que não eram atletas profissionais. Havia, enfim, a tentativa de acelerar os deslocamentos do corpo e de generalizar o estilo esportivo que prega a autonomia como norma e a conquista de novos recordes como meta. Para a autora, nos anos 90 novas redescobertas e críticas são formuladas. Nos grandes centros urbanos, houve uma aceleração do processo de diminuição das condições mínimas de lazer e de saúde, sendo assim redescobrir o corpo começava a soar muito menos como moda ou um signo da modernidade, e muito mais como necessidade básica e opção para garantia de um mínimo de qualidade de vida (SANT'ANNA, 2000).

A bicicleta representa, a partir do ato de pedalar, uma atividade mais natural do que possa parecer, pois realiza de modo completo a simbiose 'homem-máquina', condição primordial que caracteriza o homem moderno. Seja como instrumento de trabalho, como meio de locomoção das grandes metrópoles às pequenas vilas ou como esporte praticado por um grande número de adeptos amadores, andar de bicicleta evoluiu gradativamente desde sua criação e foi incorporado às práticas culturais da modernidade, ocupando hoje posição de destaque (SCHETINO, 2008). Esta posição devese à versatilidade na qual a bicicleta pode se encaixar na vida das pessoas, até mesmo como lazer para viajar. O cicloturismo no Brasil se apresenta como um fenômeno com enorme potencial de crescimento seja para as localidades que ganham com mais turistas como para o praticante que sente os efeitos no corpo que pedala. 


\section{Desafios da psicologia no Brasil}

\section{Considerações finais}

O registro das relações entre cicloturismo e qualidade de vida, objetivo deste trabalho, possibilitou que fossem elencadas três categorias de análise, que, apesar de sobreporem em alguns aspectos, buscaram entender o contexto geral do tema, sob a perspectiva dos praticantes. As principais contribuições para uma reflexão sobre o "corpo que pedala" no contexto da motricidade humana foram a respeito da importância do cicloturismo para a qualidade de vida. A abordagem utilizada para o grupo "Ciclistas de Maria" possibilitou que aspectos físicos e estilo de vida, motivação pessoal e interação social fossem discutidos. Apesar das pessoas falarem sobre consciência ambiental em andar de bicicleta, nos discursos não foi notado este fator. Um fato que contribuiu para essa discussão foi que o grupo é interessante do ponto de vista sociocultural, por fazer um trajeto relativamente longo se dirigindo para um lugar sagrado da religião católica no nosso país e, além disso, ao longo dos anos o número de praticantes aumentou de forma significativa. Com relação aos aspectos físicos e estilo de vida, a prática do cicloturismo esteve ligada, entre outras coisas, à saúde e lazer. A educação para um estilo de vida ativo é uma das tarefas fundamentais que o profissional de Educação Física deve cumprir, pois se o objetivo é fazer com que o indivíduo venha a incluir o hábito de atividade física em sua vida, é fundamental fazer com que estas pessoas sintam prazer em se movimentar e que, ao longo do tempo, desenvolvam certo grau de habilidade motora, o que lhes dará a capacidade e motivação para a prática de atividade física (NAHAS, 2006). Um ponto bastante comentado sobre o cicloturismo foi o compartilhamento de emoções distintas, que pode gerar um significado para aqueles que pedalam e se reúnem para conversar sobre a compra de equipamentos, competições, lugares a serem visitados e ações correlatas. Estas reuniões conferem ao indivíduo o sentido de pertencimento ao grupo por meio de ideais, atitudes e comportamentos distintos criados a partir de uma série de códigos e valores que os caracterizam enquanto grupo. Esses aspectos aparecem como motivação e interesse na interação social. A utilização da bicicleta pelo ciclista no tempo livre representa uma oportunidade de distanciamento dos problemas cotidianos, pois ele tem que se concentrar naquele momento no ato de pedalar e no trânsito da via. É notório que esse gesto é um tipo de movimento de grande importância para a promoção da saúde, porém, pouco estudado em nosso país. O primeiro passo para uma possível mudança é a inclusão da disciplina de ciclismo no currículo dos cursos de Educação Física e áreas correlatas. Em nível governamental, é necessário colocar em prática uma política cicloviária ampla e urgente para os municípios com alta densidade populacional, o que acarretará mais pessoas pedalando e, consequentemente, mais difusão do cicloturismo. Isto se deve à criação e formação de 


\section{Desafios da psicologia no Brasil}

um ambiente viário mais favorável ao uso da bicicleta, já que o risco de acidentes com veículos motores é o maior empecilho no cicloturismo. Em relação à intervenção profissional, o cicloturismo se estende para uma gama de oportunidades a serem desenvolvidas pelo educador físico. Dentre várias possibilidades, podemos destacar, por exemplo, a criação de clubes de ciclismo e agências de turismo que promovam viagens de bicicleta, ou até mesmo, nas escolas, a promoção da conscientização para o uso benéfico da bicicleta, considerando que nesses espaços podem ser formados futuros cidadãos ciclistas. A bicicleta chega ao século XXI como uma resposta aos pedidos de mudança, pois atende ao chamado de uma vida mais saudável porque antes de tudo, ela nos ensina a estar em harmonia com o tempo e o espaço, fazendo descobrir a realidade em um mundo invadido pelas imagens. "O ciclismo é um humanismo", símbolo de um projeto urbano que talvez possa reconciliar a sociedade consigo mesma (AUGÉ, 2009). A bicicleta se tornou um significante cultural que começa a unir pessoas de diferentes estratos, pois sinaliza uma sensibilidade que representa uma interação mais humana e um ambiente urbano que favoreça a autopropulsão (CARLSSON, 2014).

Acredito na importância da continuidade de pesquisas que evidenciem novas perspectivas sobre o tema qualidade de vida no contexto sociocultural, pois se torna relevante o entendimento e aprendizado sobre novas formas de relacionamento, como no caso o cicloturismo, possibilitando a difusão desse conhecimento afim de que beneficiem mais pessoas das ressonâncias positivas advindas de experiências significativas como essa, fazendo com isso nos faz questionar sobre o mundo em que vivemos. Portanto, a partir da bibliografia, da minha vivência como praticante e pesquisador sobre a atividade e dos discursos dos sujeitos, o objetivo foi entrelaçar estas três formas de conhecimento, no caso, a teoria com a práxis, dentro de um contexto social.

\section{REFERÊNCIAS}

ALMEIDA, MAB. Qualidade de vida: definição, conceitos e interfaces com outras áreas de pesquisa. (Orgs.) ALMEIDA, MAB; GUTIERREZ, G. L.; MARQUES, R.: São Paulo: Escola de Artes, Ciências e Humanidades (EACH/USP), 2012.

ARANHA, MLA \& MARTINS, MHP. Filosofando: introdução à filosofia. São Paulo: Editorial Moderna, 2003.

AUGÉ, M. Elogio de la Bicicleta. Barcelona Editorial Gedisa S.A, 2009.

BARBOSA, SRCS. Qualidade de vida e ambiente: uma temática em construção. In: A temática ambiental e a pluralidade do Ciclo de Seminários do NEPAM. BARBOSA, SRCS (org.). Campinas: Editora UNICAMP, 1998. 


\section{Desafios da psicologia no Brasil}

BARDIN, L. Análise de Conteúdo. Lisboa: Edições 70, 1979.

BETTI, M. Esporte Espetáculo e Mídias: Implicações para a Qualidade de Vida. In: Esporte como fator de Qualidade de Vida. MOREIRA, WW \& SIMÕES, R. (Orgs). Piracicaba: Editora UNIMEP, 2002.

CARLSSON, C. Nowtopia: iniciativas que estão construindo o futuro hoje. Porto Alegre: Tomo Editorial, 2014.

CZERESNIA, D. \& FREITAS, CM. Promoção da Saúde: Conceitos, Reflexões e Tendências. Rio de Janeiro: Editora FIOCRUZ, 2009.

DETRAN-RS. Acesso em: 24/06/2014. Disponível

em: http://www.detran.rs.gov.br/uploads/1402062951Ciclistas_2013_atualizado.pdf.

GONÇALVES, A. Em busca do diálogo do controle social sobre o estilo de vida. In: VILARTA, R. (Org.) Qualidade de Vida e políticas públicas: saúde, lazer e atividade física. Campinas: Editora IPES, 2004.

GREINER, C. O Corpo: pistas para estudos indisciplinares. São Paulo: Editora Annablume, 2005.

GUIMARÃES, A. T. R. O Princípio da Bicicleta: revisitando a mudança organizacional. Revista Capital Científico, v.7, n.1 2009. Acesso em: 5 set. 2014. Disponível

em: https://revistas.unicentro.br/index.php/capitalcientifico/article/view/836

KREBS, R. J. Esporte, meio ambiente e qualidade de vida: um entrejogo mediado pela perspectiva ecológica. In: Esporte como Fator de Qualidade de Vida. MOREIRA, WW \& SIMÕES, R. (Orgs.). Piracicaba: Editora UNIMEP, 2002.

KUNZ, E. \& TREBELS, AH. Educação Física Crítico-Emancipatória - Com uma perspectiva da pedagogia alemã do esporte. Ijuí: Editora UNIJUI, 2006.

MATSUDO, S. M. Envelhecimento e atividade física. Londrina: Editora Midiograf, 2011.

MINAYO, MCS; HARTZ, ZMA; BUSS, PM. Qualidade de vida e saúde: um debate necessário. Ciência \& Saúde Coletiva, v.5, n.1, pp.7-18, 2000. Acesso em: 28 jul. 2014. Disponível

em: http://www.scielo.br/scielo.php?pid=S1413-81232000000100002\&script=sci_abstract\&tlng=pt

MINAYO, M. C. S. O Desafio do conhecimento: pesquisa qualitativa em saúde. São Paulo: Editora Hucitec, 2010.

NAHAS, MV; BARROS, MVG; FRANCALACCI, VL. O pentáculo do bem-estar: base conceitual para avaliação do estilo de vida de indivíduos ou grupos. Revista Brasileira de Atividade Física e Saúde, v.5, n.2, pp. 48-59, 2001. Acesso em: 15 ago. 2014. Disponível

em: http://rbafs.org.br/RBAFS/article/view/1002

NAHAS, M. V. Atividade Física, Saúde e Qualidade de Vida: Conceitos e Sugestões para um Estilo de Vida Ativo. Londrina: Editora Midiograf, 2006. 


\section{Desafios da psicologia no Brasil}

SANT'ANNA, DB. As infinitas descobertas do corpo. Cadernos Pagu, v.14, pp.235-249, 2000. Acesso em: 12 set. 2014. Disponível

em: https://periodicos.sbu.unicamp.br/ojs/index.php/cadpagu/article/view/8635354

SCHETINO, A. M. Pedalando na modernidade: a bicicleta e o ciclismo na transição do século XIX para o século XX. Rio de Janeiro: Editora Apicuri, 2008.

VELOZO, E. L. Ciclismo e Cultura: anotações sobre o uso da bicicleta. In: Anais do V Congresso Sulbrasileiro de Ciências do Esporte. Itajaí: Editora UNIVALI, 2010. 


\section{NOTAS}

\section{Nota 1}

Há duas modalidades de cicloturismo: de forma autônoma e com suporte. Viajar com autonomia, o cicloturista leva consigo tudo o que precisa na viagem, normalmente nas bolsas específicas para bicicleta chamadas alforjes. Na modalidade com suporte, geralmente é contratado o serviço de apoio motorizado para levar as bagagens, fazendo com que não seja necessário leva-las na bicicleta (ROLDAN, 2000).

\section{Nota 2}

Manfiolete, LD \& Aguiar, CM. Break on Through Project: relato de experiência sobre a viagem Hard Bike Tour no contexto do cicloturismo. EFDeportes.com, Revista Digital. Buenos Aires - Argentina, Año 16, № 162, Noviembre de 2011. Acesso em: 23 jun. 2014. Disponível

em: https://www.efdeportes.com/efd162/hard-bike-tour-no-cicloturismo.htm

Nota 3

Manfiolete, LD \& Aguiar, CM. Sentidos da aderência ao mountain bike na relação ser-humano natureza. Revista ALESDE, Curitiba-PR; v.2, n.1, 2012. Acesso em: 16 ago. 2014. Disponível em: https://revistas.ufpr.br/alesde/article/view/24777

\section{Nota 4}

Manfiolete, LD \& Aguiar, CM. Os Ciclistas de Maria e o Caminho da Fé. EFDeportes.com, Revista

Digital. Buenos Aires, Argentina, Año 18, № 181, Junio de 2013. Acesso em: 3 ago. 2014. Disponível em: https://www.efdeportes.com/efd181/os-ciclistas-de-maria-e-o-caminho-da-fe.htm

\section{Nota 5}

O movimento giroscópico é caracterizado pelo equilíbrio do condutor em cima da bicicleta quando a velocidade de movimento mantém uma relação linear do guidão com as rodas, ou seja, quando o ciclista aumenta a cadência da pedalada, ele se movimenta numa direção retilínea ao passo que se ele quiser realizar uma curva, ele precisa diminuir a velocidade para depois realiza-la, haja vista os velódromos serem inclinados para que os ciclistas não precisarem diminuir a velocidade. Como exemplo, boa parte das quedas de um ciclista iniciante, se dão no instante de frear e mudar a trajetória, tamanha a adaptação do corpo que pedala para adequar a este movimento. 


\section{Capítulo 62}

\section{EFEITO ANTIDEPRESSIVO DA RIPARINA IV EM MODELO DE ESTRESSE CRÔNICO EM CAMUNDONGOS}

DOI: $10.37423 / 200200326$

Raquell de Castro Chaves

Auriana Serra Vasconcelos Mallmann

Natália Ferreira Qliveira

Danusio Pinheiro Sartori

Alyne Mara Rodrigues de Càrvalho

Leonardo Freire Yasconcelos

José Maria Barbosa Filho

Francisca Cléa Florenço de Sousa

um dos principais fatores causais. Ną depressão, sugere-se que a alta concentração de cortisol contribua diretamente para a patologia desta doença. Baseado nisso, o estudo tem como objetivo ayaliar o potencial efeito antidèpressivo/da Riparina IV (Rip IV) em camundongos submetidos ao medelo de estresse crônico por/administração repetida de corticosterona. Camundongos swiss fêmeas foram selecciobados em quatro grupos: controle (Ctrl), corticosterona fEort), Riparina IV (Cort + Ripl IV) effuvoxamina (Cort+_Flü). 


\section{Desafios da psicologia no Brasil}

Os três grupos últimos grupos receberam, por via subcutânea (sc) corticosterona (20 mg / kg) durante vinte e um dias, enquanto o grupo controle recebeu apenas veículo. Após o décimo quarto dia, os grupos receberam as drogas teste: riparina IV, fluvoxamina ou água destilada, por gavagem, uma hora após as injeções subcutâneas. Após o tratamento final, os animais foram expostos a modelos comportamentais como teste do nado forçado (TNF), teste de suspensão da cauda (TSC), teste de campo aberto (TCA), labirinto em cruz elevado (LCE) e teste de preferência por sacarose (PSS). O hipocampo também foi removido para a determinação dos níveis de BDNF. O tratamento com corticosterona alterou todos os parâmetros nos testes comportamentais, levando a um comportamento do tipo depressivo e ansioso. A Riparina IV e a fluvoxamina exibem efeito antidepressivo no TNF, TSC e TPSS. No LCE e TCA, o tratamento apresentou efeito ansiolítico sem alteração da atividade locomotora. A administração de corticosterona diminuiu os níveis de BDNF e o Riparin IV foi capaz de restabelecê-los, indicando que seu efeito antidepressivo pode estar relacionado à capacidade de melhorar a neurogênese do hipocampo. Esses achados sugerem que a Riparina IV melhora os sintomas depressivos e ansiosos após o estresse crônico e pode ser uma nova alternativa de tratamento para pacientes com depressão.

Palavras-chave: riparina; administração de corticosterona; estresse crônico; depressão. 


\section{Desafios da psicologia no Brasil}

\section{INTRODUÇÃO}

A depressão é um distúrbio crônico e complexo, com enorme impacto na sociedade, e é associada a um alto comprometimento funcional e morbimortalidade. A prevalência de distúrbios depressivos é alta e ainda está aumentando. Estudos confirmaram que as mulheres são mais vulneráveis que os homens, além de ser mais frequente em jovens e idosos (SILVA et al., 2014; WORLD HEALTH ORGANIZATION, 2017). Segundo a

Organização Mundial da Saúde (OMS), estima-se que até 2020 a depressão seja o segundo principal fardo global de doenças.

Sintomas depressivos incluem o humor deprimido, irritabilidade, falta de concentração, retardo ou agitação psicomotora, anedonia (diminuição da capacidade de sentir prazer), e anormalidades no apetite e sono (AMERICAN PSYCHIATRIC ASSOCIATION, 2014; ANISMAN; MATHESON, 2005). Os transtornos de ansiedade têm co-morbidade substancial com a depressão e podem combinar , além de sintomas depressivos regulares, medo do futuro, hipervigilância, aumento da frequência cardíaca e pressão arterial (GREGUS et al., 2005; GRILLO, 2016; MILLER; HEN, 2015).

A maioria dos tipos de depressão ocorre de forma idiopática, entretanto alguns fatores de risco poderiam desencadear sintomas depressivos, tais como alguns tipos de câncer, anormalidades endócrinas, efeitos secundários a medicamentos, eventos de vida estressantes, entre muitos outros (WAGER-SMITH; MARKOU, 2011). O estresse se apresenta como um importante fator causal de muitos transtornos mentais e sugere-se que a hipersecreção de cortisol contribui diretamente para a patologia da ansiedade e depressão (DU; PANG, 2015; ROHLEDER; WOLF; WOLF, 2010; SKÓRZEWSKA et al., 2006).

Durante a depressão, distúrbios do sistema límbico podem resultar em alterações no eixo hipotálamohipófise-adrenal (HHA), onde o hipocampo está envolvido no controle da retroalimentação negativa dos níveis de glicocorticoides (GOGOS; VAN DEN BUUSE; ROSSELL, 2009; KRISHNAN; NESTLER, 2008; SCHOENFELD; CAMERON, 2015; STERNER; KALYNCHUK, 2010; WARNER-SCHMIDT;DUMAN, 2006).

Esta inibição parece ser dependente da integridade do hipocampo. Vários estudos relataram que pacientes depressivos exibiram reduções volumétricas no hipocampo (CHATTARJ et al., 2015; LORENZETTI et al., 2009) e, em roedores, a neurogênese hipocampal foi reduzida em condições de estresse e aumentada após vários tipos de tratamentos antidepressivos (MILLER; HEN, 2015; SAHAY; 


\section{Desafios da psicologia no Brasil}

HEN, 2007; WARNER- SCHMIDT; DUMAN, 2006). As alterações neurotróficas observados no hipocampo de pacientes com depressão podem ser atribuídas, em parte, às reduções no fator neurotrófico derivado do cérebro (BDNF) (AUTRY; MONTEGGIA, 2012).

A Riparina IV é uma alcamida sintética análoga aos compostos naturais encontrados no fruto verde da Aniba riparia (Nees) Mez, as riparinas I, II e III (Figura 1) (BARBOSA-FILHO; DA SILVA; BHATTACHARYYA, 1990). Estudos anteriores realizados por Dias (2012) e Nascimento et al. (2016) evidenciaram que a Riparina IV apresenta uma atividade antinociceptiva e anti-inflamatória em vários modelos de nocicepção em roedores.

Figura 1. Estrutura química da riparina IV e seus análogos
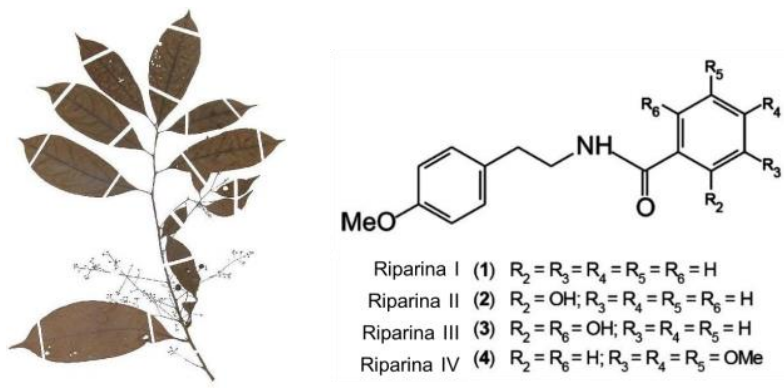

Legenda: Aniba riparia (Nees) Mez, conhecida popularmente no Brasil como "louro", "louro-faia" ou "pau-rosa". Do fruto verde foram identificadas e isoladas as riparinas I, II e III por Barbosa-Filho et al. (1990). A riparina IV foi posteriormente sintetizada através de modificações estruturais pelos mesmos pesquisadores.

Devido à semelhança com a estrutura química de tiramina, uma amina simpatomimética, e os efeitos centrais observados nas riparinas I, II e III, torna-se relevante investigar o potencial farmacológico da Riparin IV em modelos de ansiedade e depressão. Com base nesses achados, o objetivo deste estudo é avaliar o potencial efeito antidepressivo da Riparina IV em camundongos submetidos a um modelo de estresse crônico induzido pela administração de corticosterona.

\section{MATERIAIS E MÉTODOS}

\subsection{ANIMAIS}

Camundongos Swiss fêmeas foram utilizados neste estudo. Os animais foram mantidos em um ciclo claro / escuro de 12/12 h, com acesso a água e alimentos ad libitum, distribuídos aleatoriamente em 


\section{Desafios da psicologia no Brasil}

grupos experimentais especificados. Todas as experiências foram realizadas à temperatura ambiente de $23 \pm 2^{\circ} \mathrm{C}$ e foram realizadas entre as 12:00 e as 16:00 $\mathrm{h}$. Os experimentos foram realizados após o consentimento do Comitê de Ética do Departamento de Fisiologia e Farmacologia da Universidade Federal do Ceará (protocolo n 112/2014).

\subsection{DROGAS}

A corticosterona (Sigma ${ }^{\circledR}$, St Louis, MO, EUA) foi dissolvida em uma solução salina a $0,9 \%$, contendo 0,1\% de polissorbato (Tween ${ }^{\circledR}$ ) 80 (VETEC ${ }^{\text {TM }}$, EUA) e 0,1\% de dimetilsulfóxido (DMSO) (VETEC ${ }^{\text {TM }}$, EUA) e foi administrada na dose de $20 \mathrm{mg} / \mathrm{kg}$, por via subcutânea (SC).

A Riparina IV foi fornecida pelo Laboratório de Tecnologia Farmacêutica da Universidade Federal da Paraíba, Brasil. A Riparina IV foi emulsionada com Tween ${ }^{\circledR} 80$ a $2 \%$ e administrada em doses intragástricas (gavagem oral; VO) de $50 \mathrm{mg} / \mathrm{kg}$. A fluvoxamina (Abott ${ }^{\circledR}$, New Jersey, EUA ), na dose de $50 \mathrm{mg} / \mathrm{kg}$, foi dissolvida em água destilada e administrada por gavagem.

\subsection{PROCEDIMENTO EXPERIMENTAL}

O desenho do estudo foi baseado em um modelo de depressão envolvendo administração exógena de corticosterona (ZHAO et al., 2008), onde injeções repetidas de corticosterona aumentam o comportamento semelhante à depressão em camundongos a partir de uma semana.

Os animais foram divididos em quatro grupos experimentais ( $\mathrm{n}=10$ animais/grupo, em média): (1) controle; (2) corticosterona (Cort); (3) corticosterona

+ Riparina IV (Cort + Rip IV) e (4) corticosterona + fluvoxamina (Cort + Flu). Nos grupos (1), (2) e (3) foram administrados por via subcutânea (SC) com $20 \mathrm{mg} / \mathrm{kg}$ de corticosterona em veículo salino por 21 dias, enquanto no grupo controle foi administrado apenas o veículo salino. Nos últimos sete dias de tratamento, a cada grupo foi administrada as drogas testes: Riparina IV (50 mg/kg) (grupo 3), fluvoxamina $\left(50 \mathrm{mg} / \mathrm{kg}\right.$ ) (grupo 4 ) ou veículo oral (2\% Tween ${ }^{\circledR} 80$ dissolviso em água destilada) (grupos 1 e 2), por gavagem, com uma $1 \mathrm{~h}$ de intervalo entre as injeções de corticosterona (Figura 2).

Os testes comportamentais foram registradas sessenta minutos após a última administração das drogas e o hipocampo foi removido para avaliação dos níveis de BDNF.

Figura 2. Visão geral esquemática do protocolo experimental. 


\section{Desafios da psicologia no Brasil}

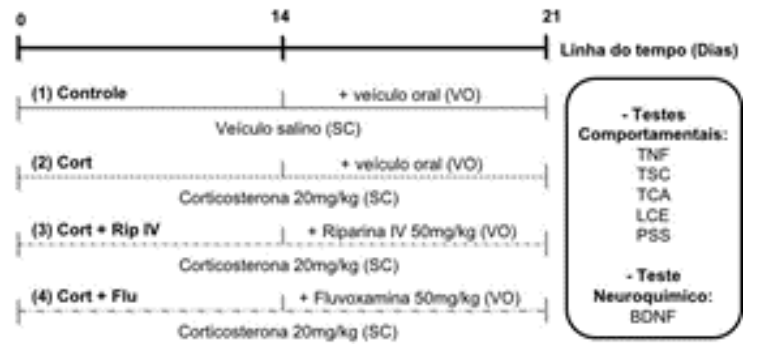

Legenda: SC: via subcutânea; VO: por gavagem oral; TNF: teste do nado forçado; TSC: Teste de suspensão da cauda; TCA: teste de campo aberto; LCE: teste de labirinto em cruz elevado; PSS: teste de preferência pela solução de sacarose; BDNF: Fator neurotrófico derivado do cérebro. Veículo salino: salina fisiológica $(\mathrm{NaCl} 0,9 \%)+0,1 \%$ Tween ${ }^{\circledR} 80+0,1 \%$ DMSO; Veículo oral: $2 \%$ Tween ${ }^{\circledR} 80+$ água destilada.

\subsection{TESTES COMPORTAMENTAIS}

\subsubsection{TESTE DO NADO FORÇADO}

O procedimento utilizado foi baseado no descrito por Porsolt, Bertin e Jalfre (1977) com modificações mínimas. Os camundongos foram colocados individualmente no tanque de cilindros cheios de água $\left(25^{\circ} \mathrm{C} \pm 1^{\circ} \mathrm{C}\right)$ a uma profundidade de $25 \mathrm{~cm}$, dimensões que os camundongos não conseguem tocar no fundo do tanque, com os pés ou a cauda, durante o teste do nado. Foi registrado, durante 5 minutos, o tempo de imobilidade, sendo considerado imóvel quando o animal permaneceu flutuando passivamente, com a ausência de qualquer movimento, exceto os necessários para manter a cabeça fora da água. Um aumento na duração da imobilidade é indicativo de comportamento do tipo depressivo (YANKELEVITCH-YAHAV et al., 2015).

\subsubsection{TESTE DA SUSPENSÃO DA CAUDA}

O procedimento seguido neste estudo foi descrito anteriormente por Steru et al. (1985), onde os camundongos foram suspensos a $50 \mathrm{~cm}$ acima do chão por fita adesiva colocada na ponta da cauda. O tempo de imobilidade foi medido usando um cronômetro por um observador durante um período de seis minutos.

\subsubsection{TESTE DO CAMPO ABERTO}

O teste foi realizado em isolamento acústico em câmara climatizada sob pouca luz. 0 aparelho utilizado foi um cubo de acrílico transparente com piso preto $(30 \times 30 \times 15 \mathrm{~cm})$ e dividido em 


\section{Desafios da psicologia no Brasil}

nove quadrantes iguais. Após 60 minutos de tratamento, os animais foram colocados no quadrante central para iniciar o teste. $\mathrm{O}$ resultado medido durante o teste de 5 minutos foi: número de cruzamento entre os quadrantes (crossing), número de vezes que o animal fica ereto sobre as patas traseiras (rearing) e número de movimento de autolimpeza (grooming), conforme figura 3 (ARCHER, 1973).

Figura 3. Movimentos de grooming e rearing em roedores.

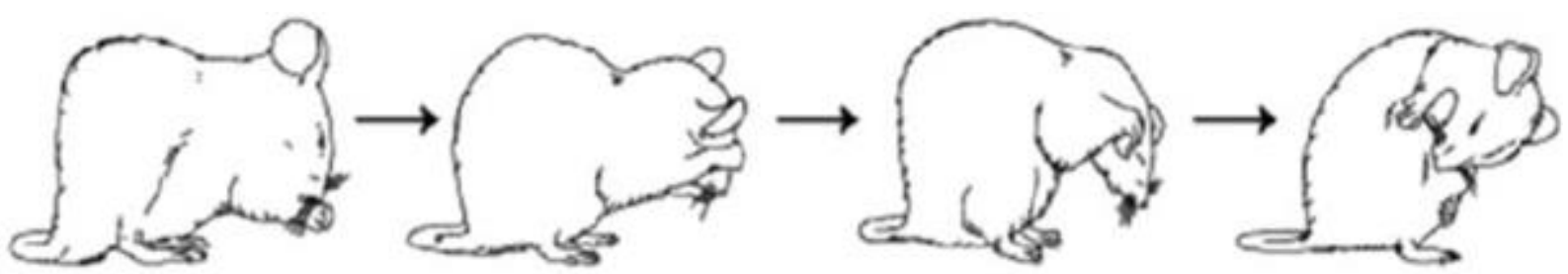

Fases do movimento do grooming em roedores

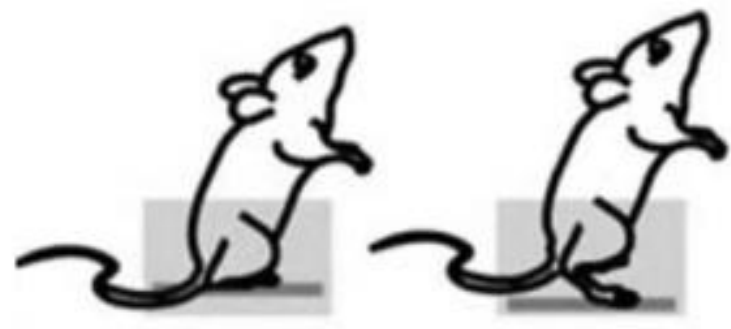

Movimento rearing em roedores

\subsubsection{TESTE DO LABIRINTO EM CRUZ ELEVADO}

O labirinto em cruz elevado foi realizado com o objetivo de avaliar os efeitos do "padrão exploratório" sobre o comportamento de risco e ansiedade dos animais. Consiste em um aparato na forma de cruz com quatro braços perpendiculares um ao outro, conforme descrito por Handley and Mithani (1984). Sessenta minutos após tratamento oral, o animal foi colocado no centro do labirinto de frente para um dos braços fechados, e observado durante $5 \mathrm{~min}$, de acordo com os seguintes parâmetros: número de entradas nos para os braços abertos e fechados e o tempo de permanência em cada um deles. 0 critério para a visita ao braço foi considerado apenas quando o animal moveu decisivamente todos os seus quatro membros em um braço. Os resultados foram expressos em relação ao braços abertos, conforme as fórmulas abaixo: 


\section{Desafios da psicologia no Brasil}

Número de entrada nos braços abertos $(\%)=n^{\circ}$ de entrada nos braços abertos $\times 100$

$\mathrm{n}^{\circ}$ de entrada nos braços abertos + fechados

Tempo de permanência nos braços abertos $(\%)=$ tempo de gasto nos braços abertos $\times 100$

tempo gasto nos braços abertos + fechados

\subsubsection{TESTE DE PREFERÊNCIA PELA SOLUÇÃO DE SACAROSE}

A preferência pela solução de sacarose é considerada um índice de anedonia (WANG et al., 2014). O teste foi realizado como descrito anteriormente por Strekalova et al. (2004), com pequenas modificações. Neste modelo, ao animal é dada a livre escolha entre duas soluções para beber: água ou uma solução de sacarose. Geralmente, os camundongos mostram uma clara preferência pela água adocicada, enquanto os animais deprimidos demonstram menos interesse. Antes do teste, no 19 을 dia do experimento, os camundongos foram habituados a solução de sacarose a $2 \%$ ( $p / v$ ), colocando dois frascos de solução de sacarose a $2 \%$ em cada gaiola. No $20^{\circ}$ dia, a solução de sacarose nas duas garrafas foi substituída por água. Depois de adaptação, para realização do teste propriamente dito, os camundongos foram alojados em gaiolas individuais durante dezoito horas e tiveram acesso livre a dois frascos idênticos, um preenchido com uma solução de sacarose a $2 \%$ e outro cheio com água. Após dezoito horas, o consumo de sacarose e água foi registrado e a preferência pela sacarose foi calculada pela seguinte fórmula:

Preferência de sacarose $(\%)=$ consumo de sacarose $\times 100$

consumo de água + consumo de sacarose

\subsection{TESTE NEUROQUÍMICO}

\subsubsection{BDNF}

Após vinte e um dias de tratamento, os animais foram sacrificados por decapitação para remoção dos crânios. Os hipocampos foram dissecados e armazenados em um freezer a $-80^{\circ} \mathrm{C}$ para posterior análise bioquímica. O conteúdo da proteína BDNF foi medido usando um kit de ELISA (R\&D Systems Inc, Minneapolis, Minnesota) de acordo com as instruções do fabricante. A quantidade de BDNF foi determinada por absorbância em $450 \mathrm{~nm}$ e expressa em pg/ g de tecido. A curva padrão demonstra uma relação direta entre densidade óptica e concentração de BDNF. 


\section{Desafios da psicologia no Brasil}

\subsection{ANÁLISE ESTATÍSTICA}

Os dados foram analisados com o GraphPad Prism 7.0 a (San Diego, CA, EUA). Inicialmente, os resultados foram submetidos ao teste de Shapiro-Wilk, para verificar a normalidade da amostra. A análise estatística foi realizada usando o teste de análise de variância (ANOVA), seguido do teste de Student Newman Keuls (post hoc). Em todas as análises estatísticas, os valores foram representados pela Média \pm Erro Padrão da Média (EPM) com valores significativos quando $p<0,05$.

\section{RESULTADOS}

Os camundongos foram tratados com injeções subcutâneas de corticosterona numa dose de $20 \mathrm{mg} / \mathrm{kg}$, diariamente, e vigésimo primeiro dia os efeitos comportamentais foram avaliadas no por meio do teste do nado forçado (TNF), teste de suspensão da cauda (TSC), teste de preferência pela solução de sacarose (PSS), labirinto em cruz elevado (LCE) e teste de campo aberto (TCA).

Os resultados mostraram que a administração exógena de corticosterona durante vinte e um dias podem produzir comportamento do tipo depressivo, como observado nos testes do nado forçado e suspensão da cauda (Figura 4). A administração de Riparina IV ou fluvoxamina por 7 dias diminuiu o tempo de imobilidade em comparação à administração de corticosterona sozinha $(p<0,0001)$.

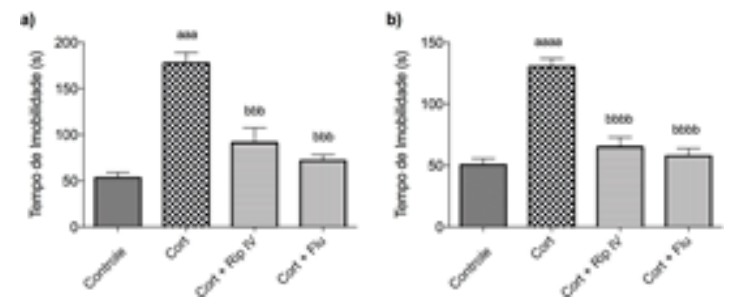

Figura 4. Análise do tempo de imobilidade no teste do nado forçado (a) e no teste de suspensão da cauda (b) após administração crônica de corticosterona (20 mg / kg) e 7 dias de administração oral das drogas testadas Riparina IV (50 mg / kg) ou fluvoxamina (50 mg/kg). Os dados são expressos como média \pm EPM do tempo de imobilidade ( $n=10$ por grupo). A análise estatística foi realizada por oneway ANOVA, seguida de Student Newman Keuls. Valores significativos: aaa $p<0,001$; aaaa $p<0,0001$ vs controle; bbb $p$

$<0,001 ;$ bbbb $p<0,0001$ vs grupo Cort.

Também foi avaliado o efeito da Riparina IV no campo aberto e labirinto em cruz elevado, dois testes sensíveis para avaliar comportamento ansioso-símile (KORTE; DE BOER, 2003). No TCA, os grupos 


\section{Desafios da psicologia no Brasil}

tratados com Riparina IV e fluvoxamina diminuíram o número de rearings e groomings em comparação ao grupo Cort. Não foi observada alteração no número de cruzamentos (Figura 5).

a)

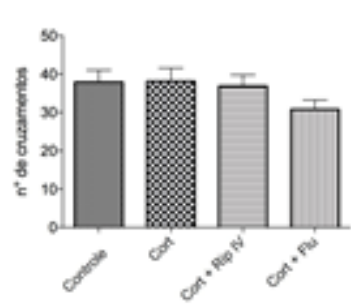

b)

c)

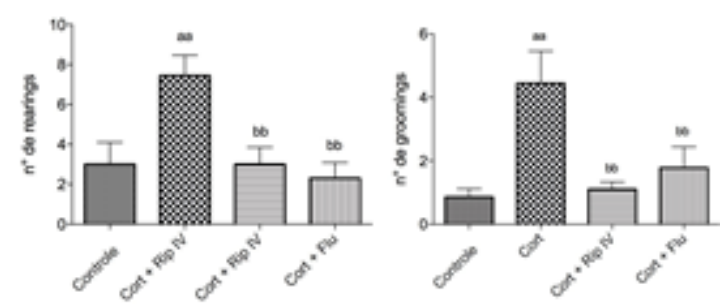

Figura 5. Número de cruzamentos (a), rearings (b) e groomings (c) de animais no teste de campo aberto após administração crônica de corticosterona (20 mg / kg) e 7 dias de administração oral das drogas testadas Riparina IV (50 mg / kg) ou fluvoxamina (50 mg/kg). Os dados são expressos como média \pm EPM durante 5 minutos de teste ( $n=10$ por grupo). A análise estatística foi realizada por one-way ANOVA, seguida de Student Newman Keuls . Valores significativos: aa $p<0,01$ vs controle; bb $p<0,01$ vs grupo Cort.

No teste do labirinto em cruz elevado (LCE) , o número de entradas e o tempo de permanência nos braços abertos foram tomados como índices de ansiedade. O tratamento aumentou significativamente o número e o tempo gasto nos braços abertos em comparação com o grupo Cort. Comparando o percentual de tempo gasto nos braços abertos em relação aos braços fechados, os animais tratados com Riparina IV ( $p<0,0001)$ e fluvoxamina $(p<0,01)$ permaneceram, significativamente, mais tempo nos braços abertos que os grupos Cort e controle (Figura 6).

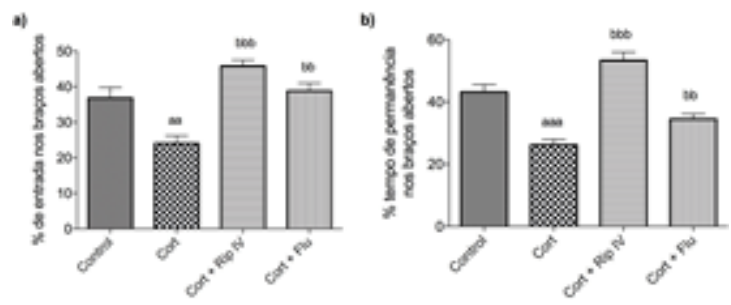

Figura 6. Análise da percentagem do número de entradas e o tempo de permanência nos braços abertos de animais submetidos ao teste do labirinto em cruz elevado após administração crônica de 


\section{Desafios da psicologia no Brasil}

corticosterona (20 mg/kg) e 7 dias de administração oral das drogas testadas Riparina IV (50 mg/kg) ou fluvoxamina ( $50 \mathrm{mg} / \mathrm{kg}$ ). Os dados são expressos como média \pm EPM durante 5 minutos de teste ( $\mathrm{n}$ = 10 por grupo). A análise estatística foi realizada por one-way ANOVA, seguida de Student Newman Keuls. Valores significativos: aa $p<0,01$; aaa $p<0,001$ vs controle; bb $p<0,01$; bbb $p$

$<0,001$ vs grupo Cort.

Na avaliação do parâmetro de preferência pela solução de sacarose

(Figura 7), o grupo tratado com Cort teve um menor consumo de sacarose quando comparado aos outros grupos $(p<0,001)$, enquanto o tratamento com Riparina IV $(p<0,01)$ e fluvoxamina $(p<0,0001)$ foi capaz de recuperar a preferência pela soluçãoadocicada após a administração exógena de corticosterona.

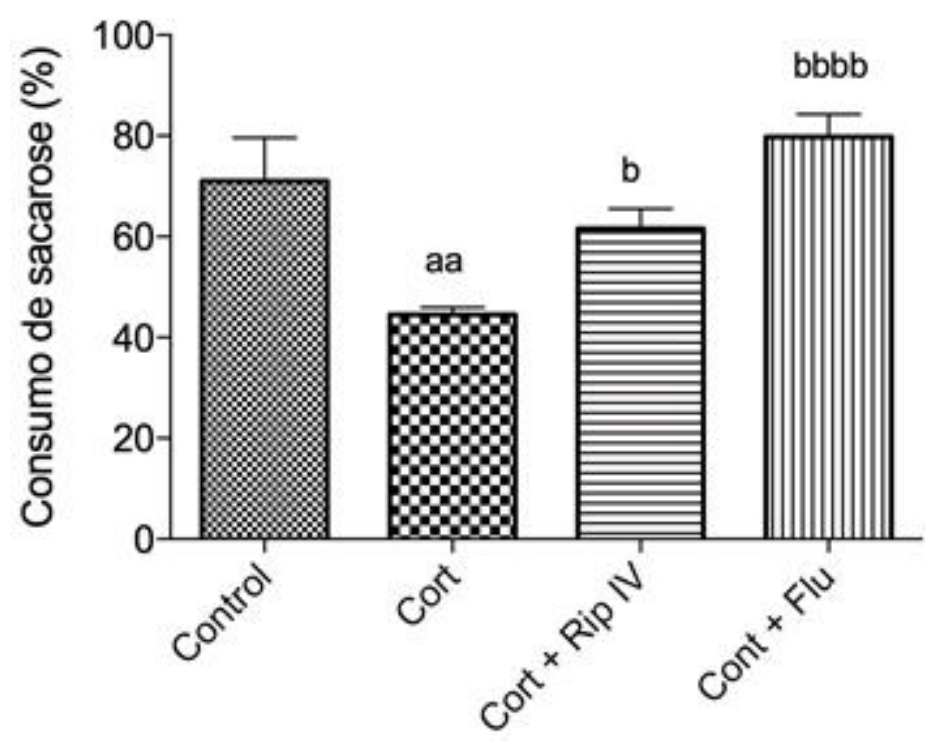

Figure 7. Análise da percentagem do consumo de solução de sacarose após administração crônica de corticosterona ( $20 \mathrm{mg} / \mathrm{kg}$ ) e 7 dias de administração oral das drogas testadas Riparina IV (50 mg/kg) ou fluvoxamina (50 mg/kg). Os dados são expressos como média

\pm EPM ( $n=10$ por grupo). A análise estatística foi realizada por one-way ANOVA, seguida de Student Newman Keuls. Valores significativos: aa $p<0,01$ vs controle; $b p$

$<0,05$ e bbbb $p<0,0001$ vs grupo Cort.

No teste neuroquímico, a figura 8 mostra o efeito do tratamento com a Riparin IV e a fluvoxamina nos níveis de BDNF no hipocampo. A administração de corticosterona diminuiu significativamente os níveis 


\section{Desafios da psicologia no Brasil}

de BDNF no hipocampo de camundongos, em comparação ao grupo controle. O tratamento com riparina IV e fluvoxamina aumentou significativamente os níveis de BDNF quando comparado aos animais estressados.

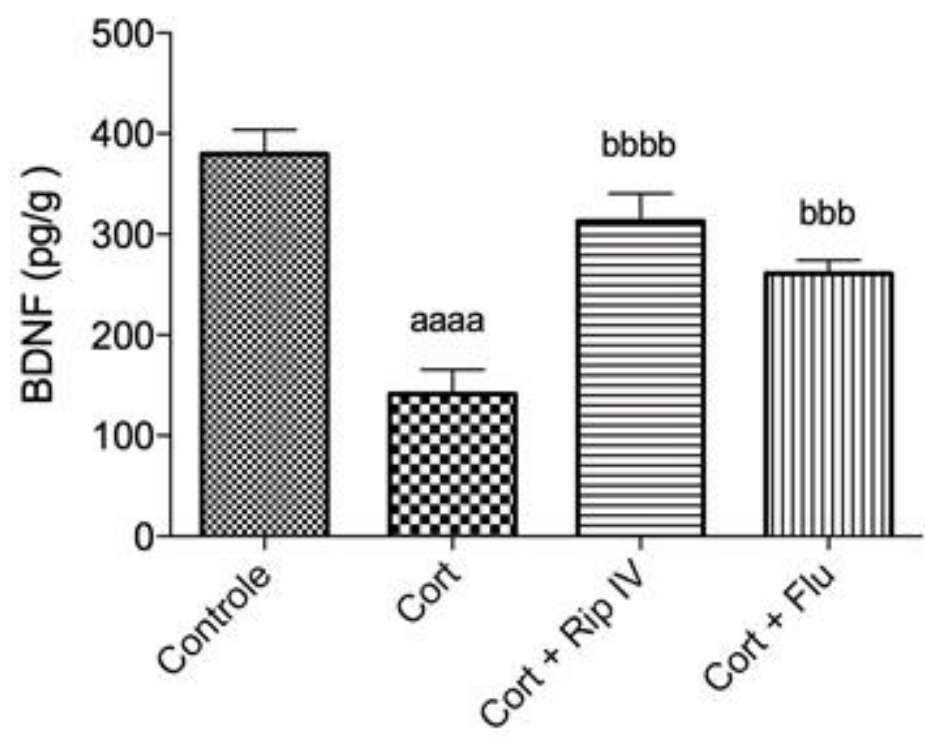

Figure 8: Níveis de proteína do fator neurotrófico derivado do cérebro (BDNF) no hipocampo de animais após administração crônica de corticosterona $(20 \mathrm{mg} / \mathrm{kg}$ ) e 7 dias de administração oral das drogas testadas Riparina IV (50 mg/kg) ou fluvoxamina $(50 \mathrm{mg} / \mathrm{kg})$. Os dados são expressos como média \pm EPM ( $n=8$ por grupo). A análise estatística foi realizada por one-way ANOVA, seguida de Student Newman Keuls. Valores significativos: aaaa $p<0,0001$ vs controle; bbb $p<0,001$ e bbbb $p$ $<0,0001$ vs grupo Cort.

\section{DISCUSSÃO}

O estresse induzido pela administração repetida de corticosterona foi escolhido para induzir depressão crônica, pois pode controlar o aumento dos glicocorticoides circulantes, diferente de outros modelos de estresse, como o estresse crônico moderado e o estresse de contenção (GREGUS et al., 2005; HERRERA-PÉREZ et al., 2016). Os animais podem diferir na resposta ao estresse (qualidade e quantidade) e na estimulação do eixo HHA e isto pode resultar em diferentes níveis de corticosterona entre diferentes animais expostos ao mesmo estressor, que por sua vez pode levar a um aumento da variabilidade experimental (MARKS; FOURNIER; KALYNCHUK, 2009; ZHAO et al., 2008).

Os modelos animais de depressão são tipicamente baseados na exposição de animais sob uma condição estressante (uma situação real ou potencialmente perigosa) e no uso de um teste específico para medir reações comportamentais e fisiológicas. Os teste do nado forçado e 


\section{Desafios da psicologia no Brasil}

suspensão da cauda são dois dos modelos mais amplamente utilizados para a avaliação do comportamento do tipo depressivo em camundongos (BAI et al., 2018; BERGNER et al., 2016; CAN et al., 2012; KRISHNAN; NESTLER, 2011) e são altamente sensíveis a todas as principais classes de medicamentos e tratamentos antidepressivos, incluindo inibidores da MAO, tricíclicos, inibidores de recaptação da serotonina, antidepressivos atípicos e choque eletroconvulsivo(CASTAGNÉ et al., 2011). O aumento do comportamento de imobilidade no TNF e no TSC é considerado um indicador de desamparo e é amplamente utilizado para investigar os efeitos agudos e crônicos dos antidepressivos (BERGNER et al., 2010).

A depressão é uma das principais causas de incapacidade para homens e mulheres, no entanto, o ônus da depressão é duas a três vezes mais comum em mulheres do que em homens (WORLD HEALTH ORGANIZATION, 2017) e o sexo feminino é considerado um fator de risco para depressão resistente ao tratamento (KORNSTEIN; SCHNEIDER, 2001). Ainda não está claro se essa diferença de sexo na fisiopatologia e no tratamento da depressão é causada por aspectos culturais ou se baseia em diferenças biológicas entre os sexos. Uma das principais hipóteses é que as mulheres são mais sensíveis nos hormônios relacionados ao eixo hipotálamo-hipófise-adrenal (HHA) do que os homens(ALBERT, 2015; DESANTIS et al., 2011; PALANZA, 2001).

De fato, a administração de estrogênio em mulheres ovariectomizadas aumenta a secreção de corticosterona após exposição ao estresse (HERMAN et al., 2003; SOARES, 2017). Nesse sentido, Cheslack-Postava et al. (2015) indicaram que as mulheres que utilizam contraceptivos orais mostraram taxas de depressão e ansiedade reduzida em comparação com as mulheres que não utilizaram. Tomados em conjunto, estes estudos sugerem que o controle do ciclo estrogênico pode ter um importante efeito (possivelmente protetor) sobre a precipitação de distúrbios depressivos e que a diminuição de estrogênio pode aumentar o risco para a depressão. Além disso, estudos pré-clínicos recentes conduzidos por nosso grupo foram realizados utilizando fêmeas (CHAVES et al., 2019; LOPES et al., 2018; SILVA et al., 2013, 2016; SOUSA

et al., 2015; VASCONCELOS et al., 2015) . Assim, nossos resultados estão alinhados com os encontrados na literatura que mostram a precipitação de comportamentos depressivos em roedores induzidos por estresse crônico.

Níveis altos de cortisol também podem estar associados à depressão psicótica, onde pessoas com depressão severa também podem desenvolver sintomas psicóticos (alucinações e/ou delírios), mais 


\section{Desafios da psicologia no Brasil}

comumente relacionados com pensamentos negativos e de culpa, mau humor, ideação suicida e comprometimento neuropsicológico. Este subtipo de depressão se revela difícil de tratar e a farmacoterapia inclui a combinação de antidepressivos e antipsicóticos associados a muitos efeitos adverso (BAJOR; TICLEA; OSSER, 2011; FURUSE; HASHIMOTO, 2009; IIJIMA et al., 2010).

Estudos clínicos comprovaram que a monoterapia com fluvoxamina, um inibidor seletivo da recaptação de serotonina (ISRS), foi eficaz contra os sintomas depressivos e psicóticos desse distúrbio (FURUSE; HASHIMOTO, 2009). Zanardi e colaboradores (2000) realizaram um estudo duplo-cego comparando fluvoxamina e venlafaxina em monoterapia por seis semanas. Em 28 pacientes hospitalizados diagnosticados com depressão maior com características psicóticas graves, a fluvoxamina mostrou eficácia como tratamento da depressão psicótica. Estes resultados motivaram a escolha da fluvoxamina como o medicamento de referência para este trabalho. Além disso, estudos realizados em nosso laboratório mostraram o efeito da fluvoxamina nesse modelo (LOPES et al., 2018; VASCONCELOS et al., 2015).

A resposta ao estresse tem o objetivo de manter a estabilidade ou a homeostase do organismo. A ativação prolongada dessa resposta pode causar estados patológicos ou exacerbar estados mórbidos preexistentes ou latentes, como obesidade e doenças cardiovasculares (PEREIRA-FIGUEIREDO et al., 2017; ROHLEDER; WOLF; WOLF, 2010). Eventos estressantes também estão subjacentes a vários processos fisiopatológicos associados a transtornos do humor, como depressão unipolar ou bipolar, bem como transtorno de estresse pós-traumático (MORRIS; COMPAS; GARBER, 2012) ou ansiedade (KIYOHARA; YOSHIMASU, 2009).

Mais de metade das pessoas com depressão também são diagnosticados com um transtorno de ansiedade (WU; FANG, 2014) e foi crucial avaliar o efeito ansiolítico da Riparina IV. O teste de campo aberto é utilizado para medir não apenas comportamentos semelhantes à ansiedade, como também hiperatividade ou mesmo sedação (PRUT; BELZUNG, 2003). Nossos resultados mostram que o tratamento com corticosterona, Riparina IV e fluvoxamina não alteram a atividade locomotora e exploratória em animais. Contudo, a administração crônica de corticosterona aumentou o grooming e o rearing, aumentados em caso de ansiedade, e o tratamento com a droga testada diminuiu significativamente esses parâmetros, demonstrando também um efeito ansiolítico. 


\section{Desafios da psicologia no Brasil}

De acordo com van Erp et al. (1994) e Kalueff e Tuohimaa (2004), o estresse pode induzir o grooming em roedores e esse comportamento inato pode estar relacionado ao eixo endócrino hipotálamohipófise-adrenal. A Riparina IV foi capaz de diminuir o grooming, sugerindo que o tratamento pode alterar a homeostase do cortisol. O tratamento com Riparina IV foi capaz de diminuir o tempo de imobilidade do camundongo causado pelo estresse crônico e também preservou a atividade locomotora no campo aberto, sugerindo que seu efeito antidepressivo nesse modelo preditivo é específico e não está relacionado ao aumento da atividade motora dos animais.

Em modelos animais, os resultados encontrados por lijima at al. (2010) mostraram uma conclusão diferente. Os ratos receberam injeções de corticosterona (20 mg/kg, por via subcutânea), uma vez ao dia por 21 dias consecutivos antes do teste do nado forçado. Um dia antes do teste comportamental, os animais receberam fluvoxamina ( $3 \mathrm{mg} / \mathrm{kg})$, imipramina (10 mg/kg) e uma combinação de risperidona $(0,1 \mathrm{mg} / \mathrm{kg})$ e fluvoxamina $(3,0 \mathrm{mg} / \mathrm{kg})$. O tratamento agudo com fluvoxamina e imipramina como monoterapia não diminuíram o tempo de imobilidade, mas a combinação do drogas antidepressivas e antipsicóticas causaram essa redução no tempo de imobilidade quando administrados apenas uma vez. Nossas descobertas comportamentais mostram que fluvoxamina reverte os sintomas de estresse associados com a depressão e ansiedade em doses maiores (50mg / kg) e após vários dias de administração.

Resultados de vários estudos anteriores indicaram que tratamentos repetidos com corticosterona podem influenciar o comportamento dos roedores e induzir sintomas depressivos (LUSSIER et al., 2013; MARKS; FOURNIER; KALYNCHUK, 2009; MURRAY; SMITH; HUTSON, 2008; SILVA et al., 2016; SKÓRZEWSKA et al., 2014;

ZHAO et al., 2008, 2009), incluindo anedonia (BAl et al., 2018; CAPIBARIBE et al., 2019; GUPTA; RADHAKRISHNAN; KURHE, 2015; LEVINSTEIN; SAMUELS,

2014; LI et al., 2015; LOPES et al., 2018; PIZZAGALLI, 2014; VASCONCELOS et al.,

2015). A anedonia é um sintoma chave de todas as formas de depressão e pode influenciar muitos de seus sintomas (AMERICAN PSYCHIATRIC ASSOCIATION, 2014; BOGDAN; PIZZAGALLI, 2006). A redução da capacidade de experimentar prazer causada por eventos estressantes tende a ser de longa duração e é operacionalmente definida pela diminuição da preferência por soluções adocicadas (STREKALOVA et al., 2004). 


\section{Desafios da psicologia no Brasil}

A anedonia surge de interações disfuncionais entre o estresse e os sistemas de recompensa cerebral, relacionadas à disfunção nas vias de dopamina mesolímbicas (PIZZAGALLI, 2014). Essas informações corroboram com a capacidade do Riparina IV, em estudos agudos, de causar alterações nos sistemas monoaminérgicos, incluindo níveis aumentados de dopamina com envolvimento dos receptores D1 e D2 (SARTORI et al., 2020). A administração de corticosterona levou a uma redução do consumo de sacarose e um tratamento de sete dias com Rip IV normalizou a ingestão de sacarose semelhante à fluvoxamina. Esse achado é muito relevante porque alguns tipos de medicamentos antidepressivos e ansiolíticos são ineficazes na reversão da anedonia crônica induzida pelo estresse (PATEL, 2016; TREADWAY; ZALD, 2011; WILLNER; MUSCAT; PAPP, 1992).

O fator neurotrófico derivado do cérebro (BDNF) é um membro da família de fatores de crescimento do nervo. O BDNF, sinalizando na via mesolímbica, desempenha um papel no mecanismo de sobrevivência no sistema nervoso central, como neurogênese, crescimento neuronal, diferenciação celular e sobrevivência de neurônios. Esse tipo de neurotrofina também influencia a conectividade dendrítica e a neuroplasticidade (BANERJEE et al., 2014; BRAMHAM; MESSAOUDI, 2005; CASTRÉN; RANTAMÄKI, 2010a).

No entanto, sob estresse, o gene do BDNF é reprimido, levando a atrofia e possível apoptose de neurônios no hipocampo. Esses eventos, por sua vez, levam à depressão e à suscetibilidade à anedonia social seguida de estresse social (HUANG; LIN, 2015; KIYOHARA; YOSHIMASU, 2009; KUPFERBERG; BICKS; HASLER, 2016). Além

disso, o hipocampo é particularmente suscetível aos efeitos prejudiciais do estresse prolongado evidenciados pela diminuição da neurogênese e da expressão do mRNA do receptor de glicocorticoide (GR) hipocampais (IHARA et al., 2016; NOVKOVIC; MITTMANN; MANAHAN-VAUGHAN, 2015; STERNER; KALYNCHUK, 2010).

Essa diminuição do GR pode levar a uma estimulação do eixo HPA e aumentar os níveis séricos de glicocorticoides e criar ainda mais danos no hipocampo.

Muitos antidepressivos aumentam agudamente os níveis de monoaminas, mas, para obter sucesso na terapia, é necessário promover alterações a longo prazo, como a regulação de neurotrofinas, como o BDNF (Kozisek et al., 2008). Estudos demonstraram, em pacientes deprimidos e modelos animais de estresse, que a eficácia dos antidepressivos em causar alterações em sintomas comportamentais de 


\section{Desafios da psicologia no Brasil}

depressão depende de sua capacidade de aumentar os níveis de BDNF (BANERJEE et al., 2014; CASTRÉN; RANTAMÄKI, 2010b; DELTHEIL et al., 2008; SOUSA et al., 2015).

A literatura sugere que a administração crônica de corticosterona reduz os níveis de BDNF no hipocampo (GREGUS et al., 2005; SOUSA et al., 2015; VASCONCELOS et al., 2015; WARNER-SCHMIDT; DUMAN, 2006) e a Riparina IV mostra um efeito significativo nos níveis de BDNF, o que não é um achado regular em todo tratamento antidepressivo.

Jacobsen e Mørk (2004) encontraram diferentes alterações produzidas pelo tratamento antidepressivo nos níveis de BDNF, em que o escitalopram (ISRS) diminuiu o BDNF no hipocampo e a desipramina (antidepressivo tricíclico que inibe a recaptação da noradrenalina) não afetou o nível da proteína BDNF. Assim, o efeito antidepressivo da Riparina IV pode estar relacionado à capacidade de aumentar a neurogênese hipocampal.

Como mencionado anteriormente, o estresse crônico induzido pela corticosterona é um modelo de depressão que envolve sintomas psicóticos e se mostra um tipo persistente de depressão (LORENZETTI et al., 2009). A depressão psicótica é difícil de tratar e normalmente envolve a administração da combinação de um antidepressivo e um antipsicótico, o que aumenta o risco de efeitos adversos (HAMODA; OSSER, 2008). A evidência de que a Riparina IV poderia reverter a depressão psicótica induzida em animais como monoterapia incita sua importância no tratamento da depressão.

\section{CONCLUSÃO}

A depressão é um transtorno mental comum associado a sintomas debilitantes; também pode coexistir com outros distúrbios, como ansiedade e psicose, e afetar populações em todo o mundo. Faltam tratamentos farmacológicos eficazes e 10 a 30\% dos pacientes não respondem a tratamentos antidepressivos convencionais (AL-HARBI, 2012). O tratamento de uma depressão resistente causa impacto socioeconômico e o desenvolvimento de novas estratégias é extremamente necessário.

Modelos animais são utilizados para fornecer conhecimento da base neurobiológica de vários distúrbios, o que pode produzir opções de tratamento aprimoradas para o paciente com depressão. Revisamos os resultados de pesquisas pré-clínicas que demonstram que a Riparina IV evita os efeitos do estresse induzido pela corticosterona no comportamento. A capacidade de aumentar os níveis de BDNF também é um achado crítico e pode tornar a Riparina IV uma estratégia de tratamento potencial no futuro. 


\section{Desafios da psicologia no Brasil}

\section{REFERÊNCIAS}

AL-HARBI, K. S. Treatment-resistant depression: Therapeutic trends, challenges, and future directions. Patient Preference and Adherence, v. 6, p. 369-388, 2012.

ALBERT, P. R. Why is depression more prevalent in women? Journal of Psychiatry and Neuroscience, v. 40, n. 4, p. 219-221, 2015.

AMERICAN PSYCHIATRIC ASSOCIATION. Manual Diagnóstico e Estatístico de Transtornos Mentais DSM-5. 5a edição ed. [s.I.] Artmed, 2014.

ANISMAN, H.; MATHESON, K. Stress, depression, and anhedonia: Caveats concerning animal models. Neuroscience and Biobehavioral Reviews, v. 29, n. 4-5, p. 525-546, 2005.

ARCHER, J. Tests for emotionality in rats and mice: A review. Animal Behaviour, v. 21, n. 2, p. 205-235, 1973.

AUTRY, A. E.; MONTEGGIA, L. M. Brain-derived neurotrophic factor and neuropsychiatric disorders. Pharmacol Rev, v. 64, n. 2, p. 238-258, 2012.

BAI, Y. et al. Antidepressant effects of magnolol in a mouse model of depression induced by chronic corticosterone injection. Steroids, v. 135, n. 155, p. 73-78, 2018. BAJOR, L. A.; TICLEA, A. N.; OSSER, D. N. The Psychopharmacology Algorithm Project at the Harvard South Shore Program: An Update on Posttraumatic Stress Disorder. Harvard Review of Psychiatry, v. 19, n. 5, p. 240-258, 2011.

BANERJEE, R. et al. Chronic Administration of Bacopa Monniera Increases BDNF Protein and mRNA Expressions: A Study in Chronic Unpredictable Stress Induced Animal Model of Depression. The Psychiatry Investigation, v. 11, n. 3, p. 297-306, 2014.

BARBOSA-FILHO, J. M.; DA SILVA, E. C.; BHATTACHARYYA, J. Synthesis of

Several New Phenylethylamides of Substituted Benzoic Acids. Quimica Nova, v. 13, n. 4, p. 332-334, 1990.

BERGNER, C. L. et al. Mouse Models for Studying Depression-like States and Antidepressant Drugs. In: PROETZEL, G.; WILES, M. (Eds.). . Mouse Models for Drug Discovery. Methods in Molecular Biology (Methods and Protocols). [s.l.] Humana Press, 2010. v. 602p. 267-282.

BERGNER, C. L. et al. Mouse Models for Studying Depression-Like States and Antidepressant Drugs. In: PROETZEL, G.; WILES, M. V. (Eds.). . Mouse Models for Drug Discovery: Methods and Protocol, Methods in Molecular Biology. New York, NY: Humana Press, 2016. v. 1438p. 255- BOGDAN, R.; PIZZAGALLI, D. A. Acute Stress Reduces Reward Responsiveness: Implications for Depression. Biological Psychiatry, v. 60, n. 10, p. 1147-1154, 2006. BRAMHAM, C. R.; MESSAOUDI, E. BDNF function in adult synaptic plasticity: The synaptic consolidation hypothesis. Progress in Neurobiology, v. 76, $n$. 2, p. 99-125, 2005.

CAN, A. et al. The mouse forced swim test. Journal of visualized experiments : JoVE, n. 59, p. e3638, 2012. 


\section{Desafios da psicologia no Brasil}

CAPIBARIBE, V. C. C. et al. Thymol reverses depression-like behaviour and upregulates hippocampal BDNF levels in chronic corticosterone-induced depression model in female mice. Journal of Pharmacy and Pharmacology, v. 71, n. 12, p.

1774-1783, 2019.

CASTAGNÉ, V. et al. Rodent models of depression: forced swim and tail suspension behavioral despair tests in rats and mice. Current Protocols in Pharmacology, v. Unit 5.8, p. Unit 8.10A, abr. 2011.

CASTRÉN, E.; RANTAMÄKI, T. Role of brain-derived neurotrophic factor in the aetiology of depression: Implications for pharmacological treatment. CNS Drugs, v. 24, n. 1, p. 1-7, 2010a.

CASTRÉN, E.; RANTAMÄKI, T. The role of BDNF and its receptors in depression and antidepressant drug action: Reactivation of developmental plasticity.

Developmental Neurobiology, v. 70, n. 5, p. 289-297, 2010 b.

CHATTARJI, S. et al. Neighborhood matters: Divergent patterns of stress-induced plasticity across the brain. Nature Neuroscience, v. 18, n. 10, p. 1364-1375, 2015. CHAVES, R. DE C. et al. Reversal effect of Riparin IV in depression and anxiety caused by corticosterone chronic administration in mice. Pharmacology Biochemistry and Behavior, v. 180, p. 44-51, 2019.

CHESLACK-POSTAVA, $K$. et al. Oral contraceptive use and psychiatric disorders in a nationally representative sample of women. Archives of Women's Mental Health, v. 18, n. 1, p. 103-111, fev. 2015.

DELTHEIL, T. et al. Consequences of changes in BDNF levels on serotonin neurotransmission, 5-HT transporter expression and function: Studies in adult mice hippocampus. Pharmacology Biochemistry and Behavior, v. 90, n. 2, p. 174-183, 2008.

DESANTIS, S. M. et al. Gender differences in the effect of early life trauma on hypothalamic-pituitaryadrenal axis functioning. Depression and Anxiety, v. 28, n. 5, p. 383-392, 1 maio 2011.

DIAS, M. L. Atividade antinociceptiva da riparina IV: participação dos receptores TRPV1, TRPM8, receptores glutamatérgicos e do óxido nítrico. Fortaleza: Universidade Federal do Ceará, 2012.

DU, X.; PANG, T. Y. Is dysregulation of the HPA-axis a core pathophysiology mediating co-morbid depression in neurodegenerative diseases? Frontiers in Psychiatry, v. 6, n. MAR, p. 1-33, 2015.

FURUSE, T.; HASHIMOTO, K. Fluvoxamine monotherapy for psychotic depression: the potential role of sigma-1 receptors. Annals of General Psychiatry, v. 8, p. 26, 2009.

GOGOS, A.; VAN DEN BUUSE, M.; ROSSELL, S. Gender differences in prepulse inhibition (PPI) in bipolar disorder: men have reduced PPI, women have increased PPI. The International Journal of Neuropsychopharmacology, v. 12, n. 09, p. 1249, 2009.

GREGUS, A. et al. Effect of repeated corticosterone injections and restraint stress on anxiety and depression-like behavior in male rats. Behavioural Brain Research, v.156, n. 1, p. 105-114, 2005. 


\section{Desafios da psicologia no Brasil}

GRILLO, L. A Possible Role of Anhedonia as Common Substrate for Depression and Anxiety. Depression Research and Treatment, v. 2016, p. 8 pages, 2016.

GUPTA, D.; RADHAKRISHNAN, M.; KURHE, Y. Effect of a novel 5-HT3 receptor antagonist 4i, in corticosterone-induced depression-like behavior and oxidative stress in mice. Steroids, v. 96, p. 95102, 2015.

HAMODA, H. M.; OSSER, D. N. The Psychopharmacology Algorithm Project at the Harvard South Shore Program: An Update on Psychotic Depression. Harvard Review of Psychiatry, v. 16, n. 4, p. 235-247, jul. 2008.

HANDLEY, S. L.; MITHANI, S. Effects of alpha-adrenoceptor agonists and antagonists in a mazeexploration model of 'fear'-motivated behaviour. Naunyn- Schmiedeberg's Archives of Pharmacology, v. 327, n. 1, p. 1-5, ago. 1984.

HERMAN, J. P. et al. Central mechanisms of stress integration: Hierarchical circuitry controlling hypothalamo-pituitary-adrenocortical responsiveness. Frontiers in Neuroendocrinology, v. 24, n. 3, p. 151-180, 2003.

HERRERA-PÉREZ, J. J. et al. Young-Adult Male Rats' Vulnerability to Chronic Mild Stress Is Reflected by Anxious-Like instead of Depressive-Like Behaviors.

Neuroscience Journal, v. 2016, p. 1-12, 2016.

HUANG, T. L.; LIN, C. C. Advances in Biomarkers of Major Depressive Disorder. In: MAKOWSKI, G. S. (Ed.). . Advances in Clinical Chemistry. 1. ed. [s.I.] Elsevier Inc., 2015. v. 68p. 177-204.

IHARA, K. et al. Serum BDNF levels before and after the development of mood disorders: a case-control study in a population cohort. Translational Psychiatry, v. 6, n. 4, p. e782, 2016.

IIJIMA, M. et al. Pharmacological characterization of repeated corticosterone injection- induced depression model in rats. Brain Research, v. 1359, p. 75-80, 2010.

JACOBSEN, J. P. R.; M $\varnothing$ RK, A. The effect of escitalopram, desipramine, electroconvulsive seizures and lithium on brain-derived neurotrophic factor mRNA and protein expression in the rat brain and the correlation to 5-HT and 5-HIAA levels.

Brain Research, v. 1024, n. 1-2, p. 183-192, 2004.

KALUEFF, A. V.; TUOHIMAA, P. Grooming analysis algorithm for neurobehavioural stress research. Brain Research Protocols, v. 13, n. 3, p. 151-158, 2004.

KIYOHARA, C.; YOSHIMASU, K. Molecular epidemiology of major depressive disorder. Environmental Health and Preventive Medicine, v. 14, n. 2, p. 71-87, 2009.

KORNSTEIN, S. G.; SCHNEIDER, R. K. Clinical features of treatment-resistant depression. The Journal of Clinical Psychiatry, v. 62, n. 16, p. 18-25, 2001.

KORTE, S. M.; DE BOER, S. F. A robust animal model of state anxiety: Fear- potentiated behaviour in the elevated plus-maze. European Journal of Pharmacology, v. 463, n. 1-3, p. 163-175, 2003. 


\section{Desafios da psicologia no Brasil}

KRISHNAN, V.; NESTLER, E. J. The molecular neurobiology of depression. Nature, v. 455, n. 7215, p. 894-902, 2008.

KRISHNAN, V.; NESTLER, E. J. Animal models of depression: molecular perspectives. Current Topics in Behavioral Neurosciences, v. 7, p. 121-47, 2011. KUPFERBERG, A.; BICKS, L.; HASLER, G. Social functioning in major depressive disorder. Neuroscience and Biobehavioral Reviews, v. Volume 69, n. October 2016, p. 313-332, 2016.

LEVINSTEIN, M. R.; SAMUELS, B. A. Mechanisms underlying the antidepressant response and treatment resistance. Frontiers in behavioral neuroscience, v. 8, n. June, p. 208, 2014.

LI, Y. C. et al. Baicalin decreases SGK1 expression in the hippocampus and reverses depressive-like behaviors induced by corticosterone. Neuroscience, v. 311, p. 130-137, 2015.

LOPES, I. S. et al. Riparin II ameliorates corticosterone-induced depressive-like behavior in mice: Role of antioxidant and neurotrophic mechanisms. Neurochemistry International, v. 120, p. 33-42, 2018.

LORENZETTI, V. et al. Structural brain abnormalities in major depressive disorder: A selective review of recent MRI studies. Journal of Affective Disorders, v. 117, n. 1-2, p. 1-17, 2009.

LUSSIER, A. L. et al. The progressive development of depression-like behavior in corticosterone-treated rats is paralleled by slowed granule cell maturation and decreased reelin expression in the adult dentate gyrus. Neuropharmacology, v. 71, p. 174-183, 2013.

MARKS, W.; FOURNIER, N. M.; KALYNCHUK, L. E. Repeated exposure to corticosterone increases depression-like behavior in two different versions of the forced swim test without altering nonspecific locomotor activity or muscle strength.

Physiology \& Behavior, v. 98, n. 1-2, p. 67-72, 2009.

MILLER, B. R.; HEN, R. The current state of the neurogenic theory of depression and anxiety. Current Opinion in Neurobiology, v. 30, p. 51-58, 2015.

MORRIS, M. C.; COMPAS, B. E.; GARBER, J. Relations among posttraumatic stress disorder, comorbid major depression, and HPA function: A systematic review and meta- analysis. Clinical Psychology Review, v. 32, n. 4, p. 301-315, 2012.

MURRAY, F.; SMITH, D. W.; HUTSON, P. H. Chronic low dose corticosterone exposure decreased hippocampal cell proliferation, volume and induced anxiety and depression like behaviours in mice. European Journal of Pharmacology, v. 583, n. 1, p. 115-127, 2008.

NASCIMENTO, O. A. et al. Pharmacological Properties of Riparin IV in Models of Pain and Inflammation. Molecules (Basel, Switzerland), v. 21, n. 12, p. 1-14, 2016. NOVKOVIC, T.; MITTMANN, T.; MANAHANVAUGHAN, D. BDNF contributes to

the facilitation of hippocampal synaptic plasticity and learning enabled by environmental enrichment. Hippocampus, v. 16, 2015.

PALANZA, P. Animal models of anxiety and depression: how are females different? 


\section{Desafios da psicologia no Brasil}

Neuroscience and Biobehavioural Reviews, v. 25, n. 3, p. 219-233, 2001. PATEL, P. The Efficacy of Antidepressants in Alleviating Anhedonia in Depressed Patients. Undergraduate Honors Thesis Collection, v. 350, 2016.

PEREIRA-FIGUEIREDO, I. et al. Long-Term Sertraline Intake Reverses the Behavioral Changes Induced by Prenatal Stress in Rats in a Sex-Dependent Way. Frontiers in Behavioral Neuroscience, v. 11, n. May, p. 1-11, 2017.

PIZZAGALLI, D. A. Depression, stress, and anhedonia: toward a synthesis and integrated model. Annual Review of Clinical Psychology, v. 10, p. 393-423, 2014. PORSOLT, R. D.; BERTIN, A.; JALFRE, M. Behavioral despair in mice: a primary screening test for antidepressants. Archives Internationales de Pharmacodynamie et de Thérapie, v. 229, n. 2, p. 327-36, out. 1977.

PRUT, L.; BELZUNG, C. The open field as a paradigm to measure the effects of drugs on anxiety-like behaviors: a review. European Journal of Pharmacology, v. 463, n. 1, p. 3-33, 2003.

ROHLEDER, N.; WOLF, J. M.; WOLF, O. T. Glucocorticoid sensitivity of cognitive and inflammatory processes in depression and posttraumatic stress disorder.

Neuroscience and Biobehavioral Reviews, v. 35, n. 1, p. 104-114, 2010. SAHAY, A.; HEN, R. Adult hippocampal neurogenesis in depression. Nature

Neuroscience, v. 10, n. 9, p. 1110-1115, 2007.

SARTORI, D. P. et al. Involvement of monoaminergic targets in the antidepressant- and anxiolytic-like effects of the synthetic alkamide Riparin IV: elucidation of further mechanisms through pharmacological, neurochemistry and computational approaches. Behavioural Brain Research, v. 4328, n. 19, p. 112487, 2020.

SCHOENFELD, T. J.; CAMERON, H. A. Adult neurogenesis and mental illness.

Neuropsychopharmacology Reviews, v. 40, n. 1, p. 113-128, 2015.

SILVA, M. C. C. et al. Augmentation therapy with alpha-lipoic acid and desvenlafaxine: A future target for treatment of depression? Naunyn-Schmiedeberg's Archives of Pharmacology, v. 386, n. 8, p. 685695, 2013.

SILVA, M. C. C. et al. Evidence for protective effect of lipoic acid and desvenlafaxine on oxidative stress in a model depression in mice. Progress in Neuro- Psychopharmacology and Biological Psychiatry, $v$. 64, p. 142-148, 2016.

SILVA, M. T. et al. Prevalence of depression morbidity among Brazilian adults : a systematic review and meta-analysis. Revista Brasileira de Psiquiatria, v. 36, n. 3, p. 262-270, 2014.

SKÓRZEWSKA, A. et al. The effects of acute and chronic administration of corticosterone on rat behavior in two models of fear responses, plasma corticosterone concentration, and c-Fos expression in the brain structures. Pharmacology Biochemistry and Behavior, v. 85, n. 3, p. 522-534, 2006. 


\section{Desafios da psicologia no Brasil}

SKÓRZEWSKA, A. et al. The effect of chronic administration of corticosterone on anxiety- and depression-like behavior and the expression of GABA-A receptor alpha-2 subunits in brain structures of low- and high-anxiety rats. Hormones and Behavior, v. 65, n. 1, p. 6-13, 2014.

SOARES, C. N. Depression and Menopause: Current Knowledge and Clinical Recommendations for a Critical Window. Psychiatric Clinics of North America, v. 40, n. 2, p. 239-254, 1 jun. 2017.

SOUSA, C. N. S. DE et al. Reversal of corticosterone-induced BDNF alterations by the natural antioxidant alpha-lipoic acid alone and combined with desvenlafaxine: Emphasis on the neurotrophic hypothesis of depression. Psychiatry Research, v. 230, n. 2, p. 211-219, 2015.

STERNER, E. Y.; KALYNCHUK, L. E. Behavioral and neurobiological consequences of prolonged glucocorticoid exposure in rats: Relevance to depression. Progress in Neuro-Psychopharmacology and Biological Psychiatry, v. 34, n. 5, p. 777-790, 2010.

STERU, L. et al. The tail suspension test: a new method for screening antidepressants in mice. Psychopharmacology, v. 85, n. 3, p. 367-70, 1985.

STREKALOVA, T. et al. Stress-induced anhedonia in mice is associated with deficits in forced swimming and exploration. Neuropsychopharmacology, v. 29, n. 11, p.

2007-2017, nov. 2004.

TREADWAY, M. T.; ZALD, D. H. Reconsidering Anhedonia in Depression: Lessons from Translational Neuroscience. Neuroscience and Biobehavioral Reviews, v. 35, n. 3, p. 537-555, 2011.

VAN ERP, A. M. M. et al. Effect of environmental stressors on time course, variability and form of selfgrooming in the rat: Handling, social contact, defeat, novelty, restraint and fur moistening. Behavioural Brain Research, v. 65, n. 1, p. 47-55, 1994.

VASCONCELOS, A. S. et al. Subchronic administration of riparin III induces antidepressive-like effects and increases BDNF levels in the mouse hippocampus. Fundamental and Clinical Pharmacology, v. 29, n. 4, p. 394-403, 2015.

WAGER-SMITH, K.; MARKOU, A. Depression: A repair response to stress-induced neuronal microdamage that can grade into a chronic neuroinflammatory condition?

Neuroscience and Biobehavioral Reviews, v. 35, n. 3, p. 742-764, 2011.

WANG, Z.-J. et al. Correlations between depression behaviors and sleep parameters after repeated corticosterone injections in rats. Acta Pharmacologica Sinica, v. 35, p. 879-888, jul. 2014.

WARNER-SCHMIDT, J. L.; DUMAN, R. S. Hippocampal neurogenesis: Opposing effects of stress and antidepressant treatment. Hippocampus, v. 16, n. 3, p. 239-249, 2006.

WILLNER, P.; MUSCAT, R.; PAPP, M. Chronic mild stress-induced anhedonia: A realistic animal model of depression. Neuroscience \& Biobehavioral Reviews, v. 16, n. 4, p. 525-534, 1992.

WORLD HEALTH ORGANIZATION. Depression and Other Common Mental Disorders: Global Health Estimates. Geneva: World Health Organization, 2017. WU, Z.; FANG, Y. Comorbidity of depressive and 


\section{Desafios da psicologia no Brasil}

anxiety disorders: challenges in diagnosis and assessment. Shanghai Archives of Psychiatry, v. 26, n. 4, p. 227-231, 2014.

YANKELEVITCH-YAHAV, R. et al. The Forced Swim Test as a Model of Depressive-like Behavior. Journal of Visualized Experiments : JoVE, v. 97, n. e52587, p. 1-7, 2015.

ZANARDI, R. et al. Venlafaxine Versus Fluvoxamine in the Treatment of Delusional Depression: A Pilot Double-Blind Controlled Study. The Journal of Clinical Psychiatry, v. 61, n. 1, p. 26-29, 2000.

ZHAO, Y. et al. A mouse model of depression induced by repeated corticosterone injections. European Journal of Pharmacology, v. 581, n. 1-2, p. 113-120, 2008. ZHAO, Y. et al. The varying effects of shortterm and long-term corticosterone injections on depression-like behavior in mice. Brain Research, $v$. 1261, n. 1999, p. 82-90, 2009. 


\section{Capítulo 63}

\section{MÃO E COGNIÇAO: RETIRADA DOS SUBTESTES}

\section{EXECUTIVOS/MOTORES NO WISC-IV ${ }^{1}$}

DOI: $10.37423 / 200200327$

Maria A. Ramim (Estudante do curso de Pós-Graduação Lato-Sensu em Neuropsicologia e Reabilitação Cognitiva da Universidade de Vila Velha).

\section{ramim78@uQt.com.br.}

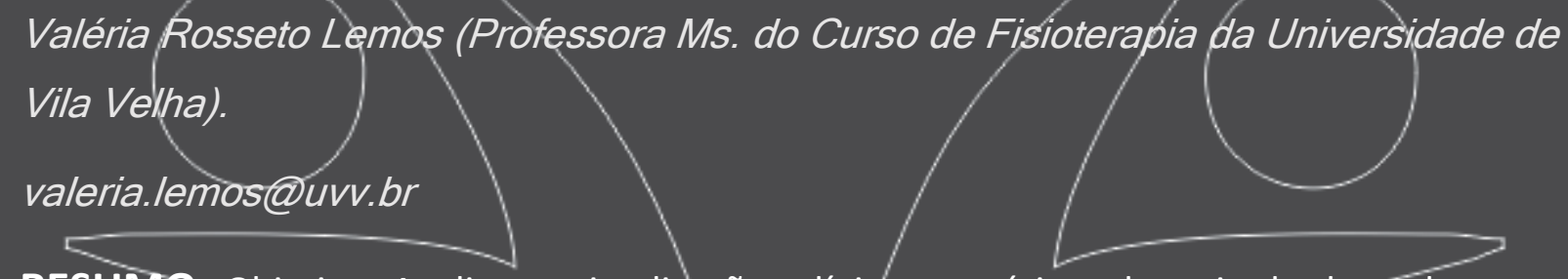

RESUMO:-Qbjetivo: Analisar as implicąções clínicas e teóricas da retirada dos subtestes: arranjo de figuras, armar objetos e labirintos do WISC-IV. Método: Pesquisa de revisão bibliográfica. Resultados: Apurou-se paralelismo/funcional e fisiologico do aparato motor e cognitivo em todo o percurso do processamento; disfunções no substrato motor e na integração sensório-motora, em distúrbios avaliados pelo WISC; e a impossibilidade de conclưir por meio de estudos comparattivos se há implícações clínicas quanto a retirâda dos subtestes. Discussão: As variáveis que se interagem no processamento do complexo perceptivo apontam para mostrar a importância dos inputs sensoriais na aferição da resposta motora. Situação avessa ao-que se delineia $\oint$ atual W4SC-W. Conclusão: Em função do construto teórico que associa cognição e resposta motora e por haver poùcos trabalhos comparativos-com as duas últimas versões do WISC é oportuno a realizaçã de trabalhos experimentais para melhor compreensão clínica da retirada dos subtestes. 


\section{Desafios da psicologia no Brasil}

PALAVRAS-CHAVE: Subtest Picture Arrangement; Subtest Object Assembly; Subtest Mazes; Elimination; differences of Wisc-III and Wisc-IV. 


\section{Desafios da psicologia no Brasil}

\section{INTRODUÇÃO}

A Escala de Inteligência Wechsler para Crianças, atualmente em sua 4oe edição, (WISC - IV), é um dos testes de inteligência mais utilizados em avaliações clínicas de crianças com dificuldade de aprendizagem (Canivez, 2014, Styck e Watkins, 2014), lesão cerebral traumática (Rackley, et. al., 2012), para estimar a inteligência dos distúrbios do espectro autista (Nader, et. al., 2014), Transtorno de Déficit de Atenção e Hiperatividade - TDAH (Styck e Watkins, 2014), evolução de uma reabilitação neuropsicológica (Bardoni, et. al. 2013), funcionamento cognitivo de epiléticos (Lopes, et. al. 2013), classificação da deficiência intelectual (Koriakin. et.al. 2013), integridade funcional do cérebro e atraso no desenvolvimento (Houskeeper, 2011). Além de que está ligada ao próprio surgimento da testagem psicológica moderna (Urbina, 2007).

No início do século XX, especificamente, em 1905, Alfred Binet (1857) e Theodore Simon (1872) publicaram o primeiro instrumento, de caráter preliminar, para mensurar a inteligência global sendo denominado de escala Binet-Simon (Freitas-Magalhães, 2013). Ao contrário da escala Stanford-Binet, o primeiro teste de inteligência criado por David Wechsler, o W-B I, publicado em 1939, percussor dos atuais: WISC-IV - para as idades de 6 a 16 anos e 11 meses; WAIS-IV (no Brasil ainda não validado, em vigor o WAIS-III) - para idades de 16 a 90 anos e 11 meses e; WPPSI-III - para as idades de 3 a 7 anos e 3 meses, era uma escala baseada no formato de testes já existentes, como a própria escala StanfordBinet, mas com conteúdo diferente, constituída por pontos e subtestes e, não uma escala por idade, organizada em 6 subtestes verbais e 5 de execução (desempenho) e com os itens organizados em ordem crescente de dificuldade (Cohen et. al., 2014).

Então, quando o WISC foi publicado pela primeira vez em 1949, como uma extensão do W-B, ele incorporou também itens do W-B-II, criado em 1942, porém sem ter sido padronizado e publicado (Cohen, et. al. 2014). A primeira versão apontava dois tipos de problemas. Primeiro, nas padronizações, alguns estereótipos de gênero e aspectos culturais ignorados. E, segundo, o manual era considerado obscuro e induzia a ambiguidades em sua administração e pontuação (Cohen, et. al. 2014). Em 1974, foi publicada uma nova versão revista, denominada WISC-R visando sanar os problemas de normatização e culturais apresentados na primeira versão. Além disso, modificaram alguns termos linguísticos, por exemplo a troca da palavra cigarro por barra de chocolate e alternância na administração dos testes verbal e de execução (Cohen, et. al. 2014). Em 1991 foi publicado o WISCIII oriundo da revisão do WISC-R. Essa nova versão atualizou e melhorou os itens e as normas do teste 


\section{Desafios da psicologia no Brasil}

(Cohen, et. al. 2014). Isto é, no subteste de aritmética adicionaram itens mais simples para avaliar a capacidade de contagem no início e foi incorporado ao final enunciados mais difíceis; introduziram o subteste procurar símbolos como resultado de pesquisas que o indicavam como bom preditor do controle da atenção e distração (Cohen, et. al. 2014).

Posteriormente, como resultado de um programa de pesquisa de 5 anos, abrangendo o desenvolvimento conceitual quanto a montagem e a avaliação final, em 2003 foi publicado o WISC-IV. Cohen, et. al. (2014) argumentam que o WISC-IV foi dinamizado pelo modelo de Inteligência CattelHorn-Carrol - CHC. Este modelo foi proposto por McGrew e Flanagan em 1998 integrando as teorias Gf-Gc - inteligência fluída e cristalizada, iniciada por Cattell (1941-1971) que integrou as noções monista e pluralista e, na sequência, aprimorada por um de seus estudantes: Horn (1991) e; os Três Estratos - estrato I: capacidades específicas, estrato II: capacidades gerais, entre estas a Inteligência fluida e cristalizada e, estrato III. Esse modelo é baseado numa visão multidimensional dos seguintes fatores ligados ao funcionamento cognitivo: linguagem, raciocínio, memória, percepção visual, recepção auditiva, produção de ideias, velocidade cognitiva, conhecimento e rendimento acadêmico (Primi, R. 2003). No caso do WISC, os subtestes informação, semelhanças, vocabulário e compreensão são medidas de fatores específicos da inteligência cristalizada; o subteste aritmética do fator conhecimento quantitativo; o subteste dígitos mede o fator memória de curto prazo; o subteste, arranjo de figuras, armar objetos (excluídos no WISC-IV), cubos e completar figuras medem o processamento visual, em termos de padronização realizada para o teste, mas são capazes de fornecer paralelamente dados quanto aos outros canais que não o visual; os subtestes código e procurar símbolos são medidas específicas de velocidade de processamento (Primi, R. 2003). Logo, no WISC-IV o QI total estaria presentes os fatores de inteligência cristalizada (Gc), processamento visual (Gv) e velocidade de processamento (Gs). A ultima versão do teste também traz 7 modificações técnicas: I mudanças de terminologia: 1) de "resistência a distração" para "memória de trabalho" - MT ou "memória operacional" - OP, 2) de "organização perceptual" para "raciocínio perceptual" - RP; II simplificação do modelo hierárquico fatorial: 1) extinção do QI verbal - QIV e QI executivo - QIE, 2) o QIV ficou assimilado ao índice de compreensão verbal e o QIE equiparou-se ao índice de RP, 3) ficou mantido os fatores de compreensão verbal - CV e velocidade de processamento - VP; III - modificações de ordem práticas, segundo Vidal et. al (2011): 1) eliminação dos subtestes arranjo de figuras, armar objetos e labirintos, 2) foram acrescentados sequência de números e letras, raciocínio matricial (ambos adaptados do WAIS-III) e os novos subtestes - raciocínio com palavras, conceitos em imagens 


\section{Desafios da psicologia no Brasil}

e cancelamento; IV - estrutura: enquanto no WISC-III aplicavam-se 10 subtestes e eram obtidos 3 QIs, ou aplicavam-se 12 e eram obtidos, além dos QIs, 4 índices fatorias, no WISC-IV: 1) os 4 índices são obtidos com os 10 subtestes principais, 2) os outros 5 subtestes são suplementares, servem como substitutos em caso de algum não ser aplicável, por exemplo, por dificuldades sensoriais ou motoras: a) a compreensão verbal é avaliada pelos subtestes (semelhança, compreensão e vocabulários) os suplementares desse item são (informação e raciocínio com palavras), b) a memória operacional é avaliado pelo subtestes (dígitos, sequência de números e letras) e o suplementar é o de aritmética, c) o raciocínio perceptual é avaliado pelo subtestes (cubos, raciocínio matricial e conceitos de figuras) o suplementar é completar figuras, d) a velocidade de processamento é avaliado pelos subtestes (código e procurar figuras) o suplementar é cancelamento; $V$ - tempo: 1) abreviou o tempo de aplicação, 2) simplificou a administração dos itens 3 ) criou escores de processos que oferecem informações mais específicas sobre processos cognitivos envolvidos na realização das tarefas de alguns subtestes (cubos sem bônus de tempo, dígitos na ordem direta e na ordem inversa - para representar um reconhecimento de que certas culturas valorizam tarefas de velocidades mais do que outras e cancelamento aleatório e estruturado); VI - estatística: 1) média 10 e desvio padrão 3 e; VII apresentação do material: modificação visual e de portabilidade (Vidal, et. al. 2011). Outros avanços são as amostras de 2.200 indivíduos estratificadas por idades e representativas ao senso de 2000 do EUA e suas variáveis fundamentais, revisão qualitativa e quantitativa (metodologia de análise de viés TRI) e, comprovação de solidez psicométrica (Cohen, 2014). Para Cohen (2014) o WISC-IV, publicado em 2003, dispensou a dicotomia até então presente nas edições anteriores entre os subtestes verbal e de execução.

Logo, historicamente, as diversas mudanças implementadas nas 4 edições do WISC levaram em consideração os avanços científicos, predominantemente, quanto ao Ql total, a forma de apresentação em termos de conteúdo e, da estatística, por meio da psicometria, e muito pouco foi agregado quanto aos outros avanços conceituais ligados a neuropsicologia, em especial, as teorias de processamento da informação: entrada, representação, processamento e saídas; que estão atrelados ao mecanismo global de avaliação. Muito embora uma das críticas dirigidas ao WISC-III era a ineficiência em avaliar áreas importantes da inteligência fluída, capacidade, armazenamento e recuperação da memória de longo prazo e o processamento auditivo (Primi, R. 2003). Em contrapartida, ainda no arcabouço crítico, apresentava um excesso de subtestes para avaliar o processamento visual e a inteligência cristalizada, além de um ajuntamento designado de resistência 


\section{Desafios da psicologia no Brasil}

a distração não muito claro, por ser questionável quanto ser ou não um fator cognitivo (Primi, R. 2003). Entretanto, Primi (2003) argumenta que "o WISC-IV não resolveu esses problemas por razões econômicas descomprometidas com os avanços científicos" (Primi, R. p. 70, 2003) e vêm se negando a fazer mudanças úteis para torná-lo um instrumento condizente com as atuais teorias da inteligência, principalmente quanto ao QI total.

\section{MATERIAL E MÉTODOS}

Tipo de pesquisa: A pesquisa foi de bibliográfica qualitativa e de natureza aplicada

Tratamento dos dados: A seleção dos artigos foi feita por meio de sistematização da coleta de informações em planilha; identificação dos problemas metodológicos que possam inviabilizar o uso do artigo na revisão; comparação com outros estudos. O procedimento para análise dos dados foi executada a partir do levantamento bibliográfico, leitura e análise dos estudos selecionadas na base de dados Pubmed de acordo com os descritores selecionados. A análise foi feita comparando e confrontando os objetivos elencados com os dados apurados nos estudos selecionados a fim de confirmar ou rejeitar a hipótese da pesquisa, bem como o problema de pesquisa.

Método: Bibliográfica, qualitativa e de natureza aplicada, com a finalidade de gerar conhecimentos para aplicação prática dirigidos à solução de problemas específicos.

Tipo de estudo: Pesquisa qualitativa, orientada pelo questionamento da pesquisa, identificação em artigos científicos sobre a retirada dos subtestes: arranjo de figuras, armar objetos e labirintos no WISC-IV, seleção de material pertinente, análise qualitativa se a ênfase do canal perceptivo visual, na entrada das informações, em detrimento de canais mais concretos e sensórios-motores, são capazes de interferir na avaliação clínica de diversos distúrbios que apresentam modalidades de captação sensorial e perceptual atípicas.

Fonte de dados: Artigos publicados na base de dados Pubmed com os temas: Subtest Picture Arrangement; Subtest Object Assembly; Subtest Mazes; Elimination; differences of Wisc-III and WiscIV, cognitive psychology, mental processing.

\section{RESULTADOS}

A fim de analisar se há implicações téoricas e clínicas quanto à retirada dos subtestes que requerem manipulação motora: arranjo de figuras, armar objetos e labirintos do WISC-IV e às suas substituições 


\section{Desafios da psicologia no Brasil}

por subtestes que enfatizam a percepção visual é que se buscou apurar a variabilidade do processamento sensorial requerida pelos seres humanos. Bem como, apresentar a componente motora disfuncional em distúrbios frequentemente avaliados pelo WISC (tabelas I, II, III, IV e V). Assim como apontar se há evidências quanto a eficiência avaliativa em grupos clínicos com a nova versão, por meio de 7 estudos comparativos entre as versões III e IV (tabela VI).

Por conseguinte, a percepção é a habilidade de extrair informação do contato com um estímulo, sendo dependente do aprendizado e da maturação, ou seja, é necessário aprender a usar os órgãos sensoriais e a atribuir significado às sensações (Gibson, 1969). E para extrair essa informação o aparato perceptivo é dividido em etapas, aqui simplificadas em input sensorial, processamento, output sensorial. Sendo o input a entrada sensorial dos sentidos ambientais e corporais, que acompanhadas do processamento/integração e do output sensorial permitem a identificação e a organização dos estímulos e conduz a uma resposta, normalmente motora (Shimizu, et.al. 2012).

Outra característica, são as duas modalidades de processamento sensorial. A primeira inclui os sentidos ambientais: visão, audição, olfato e paladar. A segunda, os sentidos corporais: tato, sistema vestibular e propriocepção (Anzalone e Lane 2012). O processamento da informação implica em vários mecanismos de entrada do tipo bottom-up e de saída/entrada do tipo top-down. Esses mecanismos de processamento da informação juntos contribuem para uma resposta adequada do sistema nervoso central. Nesta premissa, os sentidos funcionam por receptores sensoriais que captam estímulos do meio (interno/externo) e os canalizam ao cérebro para que sejam processados, organizados e interpretados. A qualidade da avaliação do processamento cortical do que é visto e do que é manipulado são diferentes. Isto significa que o aspecto intencional, top-down, que envolve, por exemplo, a manipulação dos subtestes arranjo de figuras, armar objetos e labirintos são afetadas de forma direta pelo foco da atenção. Situação diferente ao que ocorre nos outros subtestes do WISC-IV que requerem o uso predominante da via visual, a exceção é o subteste cubos, que ainda permanece na nova versão, assim como os que foram retirados, não pode ser executado sem ser foco da atenção do observador. Isto porque o teste não permite a automatização da tarefa. Os outros testes que requerem essencialmente a via visual, o estímulo pode ficar retido em sua etapa inicial (identificação) e não chegar às etapas posteriores dessa via, ou seja, do processamento com resposta concatenada ao estímulo. Uma vez que, o avaliador não tem controle sobre a manutenção e da modulação da atenção ao estímulo visual, já que às representações das etapas posteriores são dependentes do foco 


\section{Desafios da psicologia no Brasil}

atentivo. Logo, de maneira geral a percepção é holistica, mas se existe a manipulação, um comportamento analítico é necessário para uma reposta eficaz (Sternberg, 2008. p.147).

Outro aspecto fundamental desses três subtestes: arranjo de figuras, armar objetos e labirintos é que eles estão associados a integração sensório-motora. Isto é, a capacidade do sistema nervoso central SNC de reunir informações captadas pelos sentidos, com objetivo de assistir e aprimorar a execução de atos motores (Velasques, et. al. 2010). A integração de informações de múltiplos canais sensoriais atrelada a uma resposta motora coordenada é sensível, em termos comportamentais, à transtornos hipercinéticos, como o TDAH², além de disfunções executivas (Shimizu, et.al. 2012, Velasques, et. al. 2010). Assim sendo, mesmo que essas características motoras nunca tenham sido validadas e padronizadas nas diversas revisões pelos quais se passou o WISC elas eram quesito de análise por meio da sensibilidade do avaliador que oportunamente, utiliza-se das sutilezas que os testes permitem na avaliações, para além das funções para as quais foram padronizados e validados.

Assim, as variáveis que se interagem no processamento do complexo perceptivo apontam para mostrar a importância dos inputs sensoriais na aferição da resposta em virtude qualidade do fluxo funcional perceptivo, inclusive pelo seu retorno motor em termos de resposta desse processamento.

Além do mais, os 20 estudos das tabelas I, II, III, IV e V, filtrados na base de dados Pub-med com os descritores específicos utilizados no mecanismos de busca: ADHD, intellectual disabilities, brain injury, neurological sequalae, neurological disease, perception sensory e neuropsychology, apresentam como os canais de captação sensorial e a resposta motora, ou seja, a dinâmica bottom-up e top-down, manifestam-se de maneira disfuncionais em distúrbios que são avaliados comumente pelo WISC, dando suporte no diagnóstico clínico e diferencial e, mesmo, na condução da reabilitação do indivíduo.

Tabela I: Estudos que discriminam as funções motoras disfuncionais em TDAH: 


\section{Desafios da psicologia no Brasil}

\begin{tabular}{|c|c|c|c|c|}
\hline FONTE & TIPO DE ESTUDO & OBJETIVO & $\begin{array}{l}\text { TRANSTORNO } \\
\text { / DISFUNÇÕES }\end{array}$ & RESULTADO DO ESTUDO \\
\hline $\begin{array}{l}\text { Goldsm } \\
\text { ith } \mathrm{HH} \\
\text { et. al. } \\
2006\end{array}$ & $\begin{array}{l}\text { Experimental, com } \\
\text { amostra de } 1.394 \\
\text { crianças gêmeas }\end{array}$ & $\begin{array}{l}\text { Apurar a percepção } \\
\text { tátil e auditiva }\end{array}$ & TDAH & $\begin{array}{l}\text { Comportamentos defensivos } \\
\text { para estimulação tátil (mais } \\
\text { frequente em meninas) e } \\
\text { auditiva. }\end{array}$ \\
\hline $\begin{array}{l}\text { Wang J. } \\
\text { et. al. } \\
2003\end{array}$ & $\begin{array}{l}\text { Experimental, } 80 \\
\text { crianças com TDAH e } \\
80 \text { controles pareados } \\
\text { por idade e sexo. }\end{array}$ & $\begin{array}{l}\text { Explorar o caráter } \\
\text { da função de } \\
\text { equilibrio. }\end{array}$ & TDAH & $\begin{array}{l}\text { Crianças com TDAH tem pouca } \\
\text { estabilidade, integração } \\
\text { sensorial e visual anormal, } \\
\text { déficits somatossensorial e na } \\
\text { função vestibular. }\end{array}$ \\
\hline $\begin{array}{l}\text { Bédard } \\
\text { AC. et. } \\
\text { al. } 2010\end{array}$ & $\begin{array}{l}\text { Experimental } \\
\text { longitudinal, com } 98 \\
\text { participantes com } \\
\text { diagnóstico de TDAH } \\
\text { na infância e } \\
\text { reavaliados } 10 \text { anos } \\
\text { depois e } 85 \text { controles } \\
\text { pareados. }\end{array}$ & $\begin{array}{l}\text { Examinar inibição } \\
\text { motora } r \text { e } \\
\text { perceptual numa } \\
\text { amostra } \\
\text { longitudinal em } \\
\text { individuos } \\
\text { diagnosticados } \\
\text { com TDAH. }\end{array}$ & TDAH & $\begin{array}{l}\text { Os resultados são consistentes } \\
\text { com as teorias que postulam o } \\
\text { estado de regulação, mas não } \\
\text { com os déficits de controle } \\
\text { inibitório e sugerem que a } \\
\text { melhora do controle inibitório } \\
\text { perceptual pode está associada } \\
\text { com um melhor resultado para o } \\
\text { TDAH. }\end{array}$ \\
\hline
\end{tabular}

Tabela II: Estudos que discriminam as funções motoras disfuncionais em síndromes e doença:

\begin{tabular}{|c|c|c|c|c|}
\hline FONTE & TIPO DE ESTUDO & OBJETIVO & $\begin{array}{l}\text { TRANSTORNO } \\
\text { / DISFUNÇÕES }\end{array}$ & RESULTADO DO ESTUDO \\
\hline $\begin{array}{l}\text { Baker S. } \\
\text { et. al. } \\
2011\end{array}$ & $\begin{array}{l}\text { Experimental, } 40 \\
\text { meninos entre } 7-13 \\
\text { anos com a Síndrome } \\
\text { do X Frágil e } 40 \\
\text { meninos }\end{array}$ & $\begin{array}{l}\text { Avaliar a memória } \\
\text { de trabalho em } \\
\text { meninos com a } \\
\text { Sindrome do } \mathrm{X} \\
\text { frágil. }\end{array}$ & $\begin{array}{l}\text { Síndrome do X } \\
\text { Frágil }\end{array}$ & $\begin{array}{l}\text { Déficit generalizado na memória } \\
\text { de trabalho visoespaciais, com } \\
\text { prejuízo desproporcional } \\
\text { específico na alça fonológica. }\end{array}$ \\
\hline
\end{tabular}




\section{Desafios da psicologia no Brasil}

\begin{tabular}{|c|c|c|c|c|}
\hline & $\begin{array}{l}\text { desenvolvimento } \\
\text { típico. }\end{array}$ & & & \\
\hline $\begin{array}{l}\text { Groen } \\
\text { MA, et. } \\
\text { al. } 2008\end{array}$ & $\begin{array}{l}\text { Experimental, } \\
\text { comparação entre } \\
\text { crianças com } \\
\text { síndrome de Down e } \\
\text { com desenvolvimento } \\
\text { típico. }\end{array}$ & $\begin{array}{lr}\text { Explorar } & \text { a } \\
\text { associação } & \text { entre } \\
\text { capacidade } & \text { de } \\
\text { linguagem } & \mathrm{e} \\
\text { preferência } & \text { da } \\
\text { mão. } & \\
\end{array}$ & $\begin{array}{l}\text { Sindrome de } \\
\text { Down }\end{array}$ & $\begin{array}{l}\text { As crianças com síndrome de } \\
\text { Down que mostraram maior } \\
\text { preferência pela mão dominante } \\
\text { ou mais consistente tinham } \\
\text { melhores competências } \\
\text { linguisticas e de memória. }\end{array}$ \\
\hline $\begin{array}{l}\text { Vicari S. } \\
2006\end{array}$ & $\begin{array}{l}\text { Revisão da literatura } \\
\text { quanto as habilidades } \\
\text { motoras, linguísticas e } \\
\text { cognitivas em crianças } \\
\text { com síndrome de } \\
\text { Down. }\end{array}$ & $\begin{array}{l}\text { Apresentar } \\
\text { evidências que } \\
\text { apoiam a hipótese } \\
\text { de que indivíduos } \\
\text { com síndrome de } \\
\text { Down apresentam } \\
\text { desenvolvimento } \\
\text { motor e perfil } \\
\text { neuropsicológico } \\
\text { peculiar com } \\
\text { algumas } \\
\text { habilidades mais } \\
\text { preservadas } \\
\text { enquanto outras } \\
\text { mais disfuncionais. }\end{array}$ & $\begin{array}{l}\text { Sindrome de } \\
\text { Down. }\end{array}$ & $\begin{array}{l}\text { Apresentam um perfil peculiar } \\
\text { no desenvolvimento motor e } \\
\text { neuropsicológico, com algumas } \\
\text { habilidades mais preservadas e } \\
\text { outras mais disfuncionais. }\end{array}$ \\
\hline $\begin{array}{l}\text { Cornish } \\
\text { KM. et. } \\
\text { al. } 1999\end{array}$ & $\begin{array}{l}\text { Experimental com } \\
\text { dois grupos: (I - } \\
\text { portadores da } \\
\text { síndrome do X frágil } \\
\text { (mutação no FMR-1) e } \\
\text { II - grupo controle } \\
\text { composto por dois } \\
\text { subgrupos: I - com } \\
\text { deficiência de de } \\
\text { aprendizagem } \\
\text { (síndrome de Down) II } \\
\text { - com desempenho } \\
\text { escolar tradicional. }\end{array}$ & $\begin{array}{lrr}\begin{array}{lr}\text { Avaliar } \\
\text { desempenho }\end{array} & \\
\text { espacial } & & \text { em } \\
\text { meninos } & \text { com } \\
\text { síndrome } & \text { do } & \mathrm{X} \\
\text { frágil. } & & \end{array}$ & $\begin{array}{l}\text { Síndrome do } \mathrm{X} \\
\text { frágil. }\end{array}$ & $\begin{array}{l}\text { Desempenho vulnerável em } \\
\text { habilidades visuo-construtivas e } \\
\text { visuo-motoras no grupo } \\
\text { portador da síndrome do X frágil. }\end{array}$ \\
\hline $\begin{array}{l}\text { Battagli } \\
\text { a D. et. } \\
\text { al. } 2013\end{array}$ & $\begin{array}{l}\text { Experimental, com } \\
\text { grupos de } 9 \text { crianças } \\
\text { com Síndrome de } \\
\text { Dravet e outro grupo }\end{array}$ & 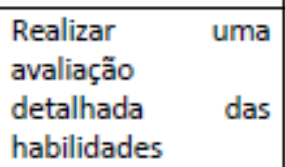 & $\begin{array}{lr}\text { Sindrome } & \text { de } \\
\text { Dravet } & \text { e } \\
\text { epilepsia. } & \end{array}$ & $\begin{array}{l}\text { Padrão de dificuldades } \\
\text { cognitivas em pacientes com } \\
\text { síndrome de Dravet é } \\
\text { consistente com oquér relatado }\end{array}$ \\
\hline
\end{tabular}




\section{Desafios da psicologia no Brasil}

\begin{tabular}{|c|c|c|c|c|}
\hline & & $\begin{array}{l}\text { Dravet para } \\
\text { estabelecer um padrão } \\
\text { de ligação cerebelar. }\end{array}$ & & $\begin{array}{l}\text { cerebelar, podendo ter uma etiologia } \\
\text { cerebelar, pelo menos como co-fator. }\end{array}$ \\
\hline $\begin{array}{l}\text { Brinckman } \\
\text { DD. et. al. } \\
2013\end{array}$ & $\begin{array}{l}\text { Experimental com } 42 \\
\text { pacientes com diagnóstico } \\
\text { clinico de sindrome de } \\
\text { Bardet-Biedl com idades } \\
\text { entre 2-61. }\end{array}$ & $\begin{array}{l}\text { Estudar as } \\
\text { caracteristicas } \\
\text { cognitivas, sensoriais } \\
\text { e psicossociais em } \\
\text { pacientes com } \\
\text { sindrome de Bardet- } \\
\text { Biedl. }\end{array}$ & $\begin{array}{l}\text { Sindrome de } \\
\text { Bardet-Biedl }\end{array}$ & $\begin{array}{l}\text { Função motora fina prejudicada e } \\
\text { redução do olfato, além de déficits nas } \\
\text { habilidades sociais e QI reduzido. }\end{array}$ \\
\hline $\begin{array}{l}\text { Foti F. et. } \\
\text { al. } 2011\end{array}$ & $\begin{array}{l}\text { Experimental com } \\
\text { individuos com sindrome } \\
\text { de Prader-Willi (PWS) } \\
\text { comparados com } \\
\text { desempenho } \\
\text { individuos com sindrome } \\
\text { de Williams (WS). }\end{array}$ & $\begin{array}{l}\text { Investigar as } \\
\text { habilidades espaciais } \\
\text { na PWS. }\end{array}$ & $\begin{array}{l}\text { Sindrome de } \\
\text { Prader-Willi. }\end{array}$ & $\begin{array}{l}\text { Os déficits espaciais observados em } \\
\text { individuos com PWS podem ser } \\
\text { relacionados ao mau funcionamento } \\
\text { do processamento da integração } \\
\text { motora e espacial. }\end{array}$ \\
\hline $\begin{array}{l}\text { Say M. et. } \\
\text { al. } 2011\end{array}$ & $\begin{array}{l}\text { Experimental longitudinal } \\
\text { com } 239 \text { individuos com } \\
\text { expansão CAG HD e } 122 \\
\text { controles. }\end{array}$ & $\begin{array}{l}\text { Documentar os } \\
\text { déficits de integração } \\
\text { visuomotor na doença } \\
\text { de Huntington antes de } \\
\text { seu inicio clinico. }\end{array}$ & $\begin{array}{l}\text { Doença de } \\
\text { Huntington. }\end{array}$ & $\begin{array}{l}\text { Déficits de integração visuomotor são } \\
\text { evidentes muitos anos antes da } \\
\text { manifestação clinica da doença. }\end{array}$ \\
\hline $\begin{array}{l}\text { Zabel TA } \\
\text { et. al. } 2010\end{array}$ & $\begin{array}{l}\text { Estudo de caso com } 4 \\
\text { pacientes. }\end{array}$ & $\begin{array}{l}\text { Apresentar } 4 \text { casos de } \\
\text { individuos entre } 8-9 \\
\text { anos. }\end{array}$ & $\begin{array}{l}\text { Sindrome de } \\
\text { Sturge-Weber }\end{array}$ & $\begin{array}{l}\text { Requer uma ampla avaliação de base } \\
\text { para apurar as diversas combinações } \\
\text { disfuncionais perceptuais, linguisticas } \\
\text { e executivas e intervenção } \\
\text { individualizada. }\end{array}$ \\
\hline
\end{tabular}

Tabela III: Estudos que discriminam as funções motoras disfuncionais em grupos de riscos e variações no próprio desenvolvimento típico:

\begin{tabular}{|c|c|c|c|c|}
\hline FONTE & TIPO DE ESTUDO & OBJETIVO & $\begin{array}{l}\text { TRANSTORNO } \\
\text { / DISFUNÇÕES }\end{array}$ & RESULTADO DO ESTUDO \\
\hline $\begin{array}{l}\text { Nava E. } \\
\text { e } \\
\text { Pavani } \\
\text { F. } 2013\end{array}$ & 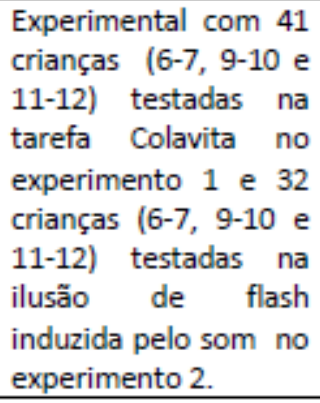 & $\begin{array}{l}\text { Apurar as } \\
\text { mudanças de } \\
\text { dominância } \\
\text { sensorial durante a } \\
\text { infância. }\end{array}$ & $\begin{array}{l}\text { Desenvolvime } \\
\text { nto } \\
\text { perceptivo- } \\
\text { sensorial }\end{array}$ & $\begin{array}{l}\text { O domínio auditivo persiste até } \\
\text { aos } 6 \text { anos, mas muda para o } \\
\text { domínio visual durante os } \\
\text { primeiros anos escolares. }\end{array}$ \\
\hline $\begin{array}{l}\text { Geldof } \\
\text { CF. et. } \\
\text { al. } 2014\end{array}$ & $\begin{array}{l}\text { 116 crianças com } 5 \\
\text { anos, nascidas muito } \\
\text { abaixo do } \\
\text { peso/prematuro, e } 73 \\
\text { crianças nascidas } \\
\begin{array}{l}\text { dentro do prazo } \\
\text { normal. }\end{array}\end{array}$ & $\begin{array}{l}\text { Examinar funções } \\
\text { sensoriais, } \\
\text { perceptivo-visual e } \\
\text { associações entre } \\
\text { disfunções visuais e } \\
\text { inteligência. }\end{array}$ & Grupo de risco & 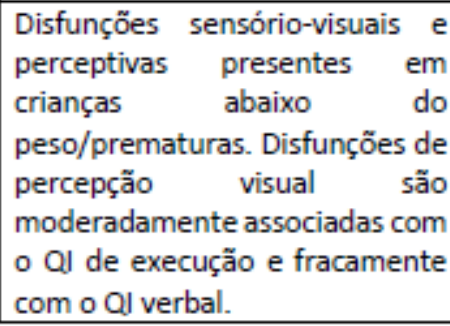 \\
\hline
\end{tabular}

Tabela IV: Estudos que discriminam as funções motoras disfuncionais em grupos com lesões traumáticas: 


\section{Desafios da psicologia no Brasil}

\begin{tabular}{|c|c|c|c|c|}
\hline FONTE & TIPO DE ESTUDO & OBJETIVO & $\begin{array}{l}\text { TRANSTORNO } \\
\text { / DISFUNÇÕES }\end{array}$ & RESULTADO DO ESTUDO \\
\hline $\begin{array}{l}\text { Sutton } \\
\text { GP. et. } \\
\text { al. } 2011\end{array}$ & $\begin{array}{l}\text { Experimental com } 123 \\
\text { crianças com TCE e } 65 \\
\text { com TDAH. }\end{array}$ & $\begin{array}{l}\text { Avaliar as } \\
\text { propriedades } \\
\text { psicométricas das } \\
\text { habilidades de } \\
\text { visuoconstrução } \\
\text { em crianças e } \\
\text { adolescentes com } \\
\text { TCE e TDAH. }\end{array}$ & TCE e TDAH & 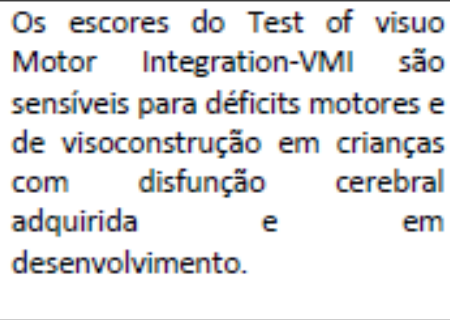 \\
\hline
\end{tabular}

\begin{tabular}{|c|c|c|c|c|}
\hline $\begin{array}{l}\text { Bologni } \\
\text { ni N. et. } \\
\text { al. } 2013\end{array}$ & Revisão & $\begin{array}{l}\text { Estudo teórico } \\
\text { quanto } \\
\text { investigação } \\
\text { neuropsicológica } \\
\text { dos fenômenos } \\
\text { multissensoriais. }\end{array}$ & Lesão cerebral & $\begin{array}{l}\text { O estudo apresenta: 1) lesão } \\
\text { cerebral pode perturbar a } \\
\text { capacidade de integrar } \\
\text { informações multisessoriais, 2) } \\
\text { induzir experiências } \\
\text { multissensoriais anormais, } 3 \text { ) a } \\
\text { plasticidade cruzada representa } \\
\text { a tentativa de reconectar os } \\
\text { sentidos e 4) fenômenos } \\
\text { multissensoriais são mediados } \\
\text { por redes cerebrais em grande } \\
\text { escala. }\end{array}$ \\
\hline $\begin{array}{l}\text { Recla } \\
\text { M. et. } \\
\text { al. } 2013\end{array}$ & $\begin{array}{l}\text { Experimental com } 118 \\
\text { pacientes com TCE } \\
\text { divididos em } 3 \text { grupos } \\
\text { de acordo com a } \\
\text { gravidade do caso. }\end{array}$ & $\begin{array}{lr}\text { Examinar } & 0 \\
\text { cognitivo } & \text { perfil } \\
\text { adaptativo } & \text { de } \\
\text { crianças em idade } \\
\text { escolar com TCE } \\
\text { grave. }\end{array}$ & $\begin{array}{l}\text { Traumatismo } \\
\text { crânio- } \\
\text { encefálico } \\
\text { TCE grave. }\end{array}$ & $\begin{array}{l}\text { Após } 12 \text { meses do quadro de TCE } \\
\text { grave } 11,9 \% \text { apresentavam } \\
\text { déficits motores e linguísticos. }\end{array}$ \\
\hline $\begin{array}{l}\text { Hattian } \\
\text { gadi } \mathrm{N} \text {. } \\
\text { et. al } \\
2005\end{array}$ & $\begin{array}{l}\text { Estudo de caso de uma } \\
\text { perturbação na } \\
\text { percepção. }\end{array}$ & $\begin{array}{l}\text { Mostrar um caso } \\
\text { incomum } r \text { de } \\
\text { agnosia auditiva } \\
\text { quanto aos } \\
\text { mecanismos de } \\
\text { lesão, idade e } \\
\text { localização do dano } \\
\text { neurológico. }\end{array}$ & $\begin{array}{l}\text { Agnosia } \\
\text { auditiva }\end{array}$ & $\begin{array}{l}\text { O estudo demonstra que a } \\
\text { agnosia auditiva pode aparecer } \\
\text { após uma lesão cerebral } \\
\text { traumática em criança e ilustra a } \\
\text { necessidade de avaliação } \\
\text { criteriosa e maior variedade de } \\
\text { estímulos auditivos para } \\
\text { caracterizar plenamente a } \\
\text { disfunção. }\end{array}$ \\
\hline
\end{tabular}

Tabela V: Estudos que discriminam as funções motoras disfuncionais em grupos com deficiências intelectual e educacional:

\begin{tabular}{|c|c|c|c|c|}
\hline FONTE & TIPO DE ESTUDO & OBJETIVO & $\begin{array}{l}\text { TRANSTORNO } \\
\text { / DISFUNÇÕES }\end{array}$ & RESULTADO DO ESTUDO \\
\hline $\begin{array}{l}\text { Napalk } \\
\text { ov DA. } \\
\text { et. al. } \\
1994\end{array}$ & $\begin{array}{lr}\text { Experimental com } \\
\text { crianças de } \\
\text { desenvolvimento } \\
\text { típico e com } \\
\text { deficiência } \\
\text { educacional. }\end{array}$ & $\begin{array}{l}\text { Estudar os } \\
\text { mecanismos } \\
\text { psicofisiológico de } \\
\text { controle do estado } \\
\text { funcional por meio } \\
\text { do RRG, testes } \\
\text { neuropsicológicos }\end{array}$ & $\begin{array}{l}\text { Deficiência } \\
\text { educacional }\end{array}$ & $\begin{array}{l}\text { Índice de atenção e produção em } \\
\text { intervelo de tempo } \\
\text { estatisticamente inferior ao do } \\
\text { grupo controle. }\end{array}$ \\
\hline
\end{tabular}




\section{Desafios da psicologia no Brasil}

\begin{tabular}{|l|l|l|l|l|}
\hline & & $\begin{array}{l}\text { e frequência } \\
\text { cardiaca. }\end{array}$ & \\
\hline $\begin{array}{l}\text { Muñoz- } \\
\text { Ruata, } \\
\text { et.al. } \\
2010\end{array}$ & $\begin{array}{l}\text { Experimental com } 69 \\
\text { individuos com } \\
\text { deficiência intelectual } \\
\text { leve heterogênea de } \\
\text { discriminação ativa de } \\
\text { figura geométricas. }\end{array}$ & $\begin{array}{l}\text { Avaliar a influência } \\
\text { na cognição dos } \\
\text { transtornos } \\
\text { perceptivos. }\end{array}$ & $\begin{array}{l}\text { Deficiência } \\
\text { intelectual leve }\end{array}$ & $\begin{array}{l}\text { Alteração perceptiva observada } \\
\text { em individuos com deficiência } \\
\text { intelectual correlacionada a } \\
\text { áreas sensoriais alteradas, mas } \\
\text { também numa falha na } \\
\text { participação frontal de } \\
\text { processos perceptivos } \\
\text { concebidas como elaborações } \\
\text { dentro do circuito percepção- } \\
\text { ação. }\end{array}$ \\
\hline
\end{tabular}

Em suma, a menos que o profissional recorra a instrumentos complementares, o WISC-IV perdeu a oportunidade de validar e agregar no rol da avaliação neuropsicológica a variável motora por meio dos subtestes retirados. Eles eram recursos úteis, mesmo que, informalmente, que o avaliador tinha como aliado, já durante a aplicação do teste em disfunções em que o substrato motor e a integração sensório-motora também se mostrava alteradas, como o TDAH (Goldsmith HH et. al. 2006; Wang J. et. al. 2003; Sutton GP. et. al. 2011; Bédard AC. et. al. 2010), Sindrome do X Frágil (Baker S. et. al. 2011 e Cornish KM. et. al. 1999), grupo de risco - crianças pré-maturas (Geldof CF et. al. 2014), deficiência intelectual leve (Muñoz Ruata, et. al. 2010), Síndrome de Down (Groen MA. et. al. 2008 e Vicário S. $2006^{3}$ ), deficiência educacional (Napalkiv DA. et. al. 1994), Síndrome de Dravet e epilepsia (Battaglia D. et. al. 2013), agnosia auditiva (Hattiangadi N. et. al. 2005), lesão cerebral (Bolognini N. et. al. 2013), desenvolvimento perceptivo-sensorial (Nava E. e Pavani F. $2013^{4}$ ), Síndrome de Bardet-Biedl (Brinckman DD. et. al. 2013), traumatismo crânio-encefálico - TCE (Recla M. et. al. 2013 e Sutton GP. et. al. 2011), Síndrome de Prader-Willi (Foti F. et. al. 2011), doença de Huntington (Say MJ et. al. 2011) e para finalizar, Síndrome de Sturge-Weber (Zabel TA et. al. 2010).

Em contrapartida, apesar de a publicação americana do WISC-IV ter sido em 2003 e já terem se passado, com isso, 12 anos, ainda existem poucos estudos publicados na base de dados Pubmed em língua inglesa, comparando as duas versões com grupos clínicos. A seleção dos 7 estudos foi feita com os descritores "WISC-III and WISC-IV".

Tabela VI: Relação de estudos comparando a versão III e IV do WISC:

\begin{tabular}{|l|l|l|l|l|}
\hline FONTE & TIPO DE ESTUDO & $\begin{array}{c}\text { OBJETIVO DO } \\
\text { ESTUDO }\end{array}$ & $\begin{array}{c}\text { TRANSTORN } \\
\text { O / } \\
\text { DISFUNÇÕES }\end{array}$ & RESULTADO DO ESTUDO \\
\hline $\begin{array}{l}\text { Nader } \\
\begin{array}{l}\text { AM et. } \\
\text { al } 2014\end{array}\end{array}$ & $\begin{array}{l}\text { Experimental com 25 } \\
\text { crianças autistas e 22 } \\
\text { crianças }\end{array}$ & $\begin{array}{l}\text { Avaliar se o WISC- } \\
\text { IV subestima a a } \\
\text { inteligência autista. }\end{array}$ & Autismo & $\begin{array}{l}\text { As crianças autistas } \\
\text { apresentaram uma desigualdade } \\
\text { distinta no perfil de índice do }\end{array}$ \\
\hline
\end{tabular}




\section{Desafios da psicologia no Brasil}

\begin{tabular}{|c|c|c|c|c|}
\hline & $\begin{array}{l}\text { desenvolvimento } \\
\text { típico. }\end{array}$ & & & $\begin{array}{l}\text { WISC-IV com um pico no novo } \\
\text { índice de raciocínio perceptivo. }\end{array}$ \\
\hline $\begin{array}{l}\text { Allen } \\
\text { DN et. } \\
\text { al. } 2014\end{array}$ & $\begin{array}{lll}\text { Analise } & \text { de } & \text { dois } \\
\text { estudos. } & & \\
\end{array}$ & $\begin{array}{l}\text { Relatar dois estudos } \\
\text { que examinaram a } \\
\text { sensibilidade das } \\
\text { escalas de avaliação } \\
\text { intelectual } \\
\text { Reynolds (RIAS), } \\
\text { WISC-III e IV em } \\
\text { jovens com TCE } \\
\text { moderado e grave. }\end{array}$ & $\begin{array}{l}\text { Lesão cerebral } \\
\text { traumática } \\
\text { grave } \\
\text { moderada } \quad \text { - } \\
\text { TCE. }\end{array}$ & $\begin{array}{l}\text { A comparação entre as } 3 \text { escalas } \\
\text { não revelou diferenças } \\
\text { significativas entre as medidas } \\
\text { sobre o QI verbal, não verbal e } \\
\text { índice de composição/ escala } \\
\text { geral. }\end{array}$ \\
\hline $\begin{array}{l}\text { Rackle } \\
\text { y C. et. } \\
\text { al. } 2012\end{array}$ & Experimental & $\begin{array}{ll}\text { Avaliar } & \text { as } \\
\text { propriedades } & \\
\text { psicométricas } & \text { do } \\
\text { WISC-IV. } & \end{array}$ & $\begin{array}{l}\text { Crianças com } \\
\text { TCE. }\end{array}$ & $\begin{array}{l}\text { O estudo é consistente com dois } \\
\text { estudos anteriores que } \\
\text { apresentam evidência para perfis } \\
\text { diferentes entre o WISC-III e } \\
\text { WISC-IV na avaliação do TCE } \\
\text { infantil. }\end{array}$ \\
\hline $\begin{array}{l}\text { Allen } \\
\text { DN et. } \\
\text { al. } 2010\end{array}$ & $\begin{array}{l}\text { Experimental com } 61 \\
\text { crianças com TCE. }\end{array}$ & $\begin{array}{l}\text { Avaliar } \quad 0 \\
\text { desempenho de } \\
\text { crianças com TCE } \\
\text { nas escalas WISC- } \\
\text { III e WISC-IV. }\end{array}$ & $\begin{array}{l}\text { Crianças com } \\
\text { TCE. }\end{array}$ & $\begin{array}{l}\text { Os resultados indicam diferenças } \\
\text { substanciais entre o WISC-III e o } \\
\text { WISC IV nos perfis de crianças } \\
\text { com TCE. }\end{array}$ \\
\hline $\begin{array}{l}\text { Launey } \\
\text { KB. et. } \\
\text { al. } 2007\end{array}$ & \begin{tabular}{lr}
\multicolumn{2}{|l}{ Experimental com 35} \\
alunos & classificados \\
com & deficiência \\
intelectual.
\end{tabular} & $\begin{array}{l}\text { Apurar a validade } \\
\text { entre o WISC-III e } \\
\text { WISC-IV. }\end{array}$ & $\begin{array}{l}\text { Deficiência } \\
\text { intelectual }\end{array}$ & $\begin{array}{l}\text { Os escores de QIs da escala } \\
\text { completa do WISC-III } \\
\text { correlacionaram em } 0,91 \text { com os } \\
\text { escores de QIs da escala } \\
\text { completa do WISC-IV. Das } \\
\text { decisões de elegibilidade previa, } \\
80 \% \text { foram confirmadas pelos } \\
\text { escores do WISC-IV. }\end{array}$ \\
\hline $\begin{array}{l}\text { Mayes } \\
\text { SD e } \\
\text { Calhou } \\
\text { n SL } \\
2008\end{array}$ & $\begin{array}{l}\text { Estudo comparativo } \\
\text { entre o WISC-III e } \\
\text { WISC-IV. }\end{array}$ & $\begin{array}{l}\text { Avaliar se o WISC- } \\
\text { IV é mais eficiente } \\
\text { do que o WISC-III } \\
\text { no processo de } \\
\text { avaliação das } \\
\text { funções afetadas. }\end{array}$ & $\begin{array}{l}\text { Autismo de } \\
\text { alto } \\
\text { funcionamento }\end{array}$ & $\begin{array}{l}\text { O WISC-IV demonstrou-se } \\
\text { melhor em relação o WISC-III } \\
\text { para captura do raciocínio visual, } \\
\text { além de identificar fraquezas na } \\
\text { velocidade de processamento, } \\
\text { atenção e grafomotora. }\end{array}$ \\
\hline $\begin{array}{l}\text { Mayes } \\
\text { SD e } \\
\text { Calhou } \\
\text { n SL } \\
2004\end{array}$ & $\begin{array}{l}\text { Experimental para } \\
\text { validar a sensibilidade } \\
\text { de dos subtestes do } \\
\text { WISC-III para } \\
\text { diagnóstico. }\end{array}$ & $\begin{array}{lr}\text { Apontar perfis } \\
\text { clínicos ruteis } \\
\text { apurados nos } \\
\text { subtestes quanto as } \\
\text { possibilidades } \\
\text { diagnóstico. }\end{array}$ & $\begin{array}{l}\text { Autismo, } \\
\text { TDAH, lesão } \\
\text { cerebral e } \\
\text { dificuldade de } \\
\text { aprendizagem. }\end{array}$ & $\begin{array}{l}\text { Os perfis são clinicamente úteis } \\
\text { porque eles podem alertar os } \\
\text { clínicos para certas } \\
\text { possibilidades diagnósticas ao } \\
\text { revelar pontos fortes e fracos que } \\
\text { têm implicações para a } \\
\text { intervenção e esses perfis estão } \\
\text { de acordo com os dados } \\
\text { preliminares do WISC-IV. }\end{array}$ \\
\hline
\end{tabular}

Em conformidade com a análise entre os estudos podemos separá-los em 5 grupos clínicos: autismo, TCE, deficiência intelectual, TDAH e dificuldade de aprendizagem. No entanto, talvez pelo número 


\section{Desafios da psicologia no Brasil}

reduzido de trabalhos publicados comparando grupos clínicos com as duas versões e o desinteresse por causa do tempo transcorrido para publicação de mais trabalhos, os resultados são pouco conclusivos e ineficientes para evidenciarem se há implicações clínicas quanto à retirada dos três subtestes: arranjo de figuras, armar objetos e labirintos. Nesse caso, caberia uma pesquisa experimental para apurar se a retirada deles prejudicou a avaliação qualitativa em disfunções/transtornos que apresentam sequelas motoras. Lembrando que a variável motora não era validada pelo WISC-III o que já é um empecilho para a metodologia.

\section{DISCUSSÃO}

Realmente, a avaliação de indivíduos com déficits motores e sensoriais é realizada pela neuropsicologia levando-se em conta o estudo de caso do paciente por meio do rastreio da suspeita clínica, definição do grau de deteriorização e diferenciação entre lesões focais e difusas, bem como a função neurológica afetada: músculo, tônus, reflexos, sensibilidade, recepção. Consequentemente, há a necessidade de seleção de testes, muitas vezes não específicos, por falta deles, para a avaliação neuropsicológica das funções gerais em pacientes com distúrbios motores e sensoriais (PereaBartolomé, 2000).

Todavia, tanto pelo rastreio teórico, como pela demonstração do viés motor afetado em distúrbios/transtorno avaliados pelo WISC na clínica (tabelas I, II, III, IV e V) pode-se inferir que a retirada dos subtestes fez com que o teste perdesse em qualidade instrumental e o pior, desperdiçouse assim a oportunidade de retornar para um teste de avaliação da inteligência a variável psicomotora, como parte do arcabouço do estrato cognitivo/comportamental humano que há muito já não corrobora da cisão corpo/mente, apesar de continuar dividido pela linguagem como aponta Searle (1997). Entretanto, com o enfoque dado no WISC ao fato G parece que ele continua compactuando desse postulado superado.

Contraditoriamente, ao que se vê hoje, quando da preferência quase exclusiva da via visual e auditiva na captação da informação nos testes de inteligência, o primeiro teste de inteligência desenvolvido por Francis Galton era um teste sensoriomotor (Flanagan e Kaufman, 2004). Esse foi criado na crença de que a inteligência é desenvolvida através do recebimento das informações por meio dos sentidos e, logo, aqueles indivíduos com melhor desenvolvimento sensorial se correlacionariam com maior escore de inteligência. 


\section{Desafios da psicologia no Brasil}

Em contrapartida, o WISC que é um teste de aplicação clínica apareceu como um avanço em relação a Escala Binet e outros semelhantes por combinar medidas verbais e de desempenho, em vez de confiar exclusivamente em testes que avaliavam habilidades verbais. $O$ desempenho é um substrato importante para a avaliação e diagnóstico, mas ainda assim, como vimos nos 20 estudos das tabelas I, II, III, IV e V, ao retirar os subtestes que requeriam a manipulação empobreceu-o como instrumentos de cunho clínico para diagnóstico de patologias/transtornos/distúrbios tão sensíveis a variável motora. Não obstante, o motivo alegado para a retirada desses testes foi exatamente por seu quesito motor. Houskeeper (2011) alega que esses subtestes catalogados no índice de organização perceptiva, dificultavam determinar se a baixa pontuação estava relacionada a inteligência ou a deficiência motora (Houskeeper, 2011).

Esse equivoco de negligenciar os canais de retorno perceptivos, de cunho motor, depauperou o WISC teoricamente e, logo clinicamente. A atenção, por exemplo, sem a qual não é possível aferir nenhum índice de inteligência vem sendo estudada intensivamente por suas características motoras por compartilha fisiologicamente os mesmos canais motores de percepção e, de integração visual e auditiva, a partir da teoria pré-motora da atenção de Rizzolatti et. al. (1987).

Primi (2003) aponta que os subtestes complementares do WISC-IV ( I - compreensão verbal: subtestes informação e raciocínio com palavras; II - memória de trabalho/operacional: aritmética; III - raciocínio perceptual: completar figuras; e, IV - velocidade de processamento: cancelamento) são substitutos válidos para ser aplicados a indivíduos que apresentem dificuldades sensoriais ou motoras, ou seja, buscou-se testes visuais para compensar a dificuldade motora ou sensorial. Contudo, a escolha dos testes compensatórios parecem ignorar o intercâmbio entre a cognição, as funções sensoriais e motoras.

Por outro lado, Dupré (1925), no primeiro quarto do século XX, já correlacionava as perturbações de ordem cognitiva e motoras como um paralelismo e argumentava naquela época que a correspondência entre elas "constituem verdadeiros casais psicomotores", Wallon (1968) ia além, ao relatar que mais do que um paralelismo, o que existe é uma ligação associativa na proximidade das células corticais e cognitivas. E nos últimos anos, trabalhos em fisiologia funcional confirmam um compartilhamento de redes neurais por funções motoras e cognitivas (Hutton, SB. 2008; Rayner, K. 1998; Liu, C,-L et. al. 2010; Miyamoto, N. T. 2010; Dockstader, C. 2010; entre outros). 


\section{Desafios da psicologia no Brasil}

Dentro das características validadas na versão anterior para os três subtestes retirados, não há como negar a interferência sensorial de manipulação no escore de avaliação do subtestes, pois os sentidos buscam eficiência funcional por meio de vários órgãos de maneira integrada. A percepção de um estímulo não depende exclusivamente do sentido da visão, audição, tato, paladar. Os sentidos funcionam juntos e se completam. Logo, os estímulos são localizados, manipulados, ouvidos, saboreados de forma idêntica. Embora, alguns estudos apontem que a informação fora da modalidade visual pode mudar o que se vê, por exemplo, sons adequadamente cronometrados podem mudar qualitativamente a percepção visual. De modo que, de maneira geral, a ativação sensorial é interativa, no que tange o processamento neural. Sinais de entrada sensorial é apenas uma parte do que impulsiona os impulsos sensoriais, pois eles são associativos, ou seja, um processamento anterior pode influenciar um processamento posterior (Lupyan e Ward, 2013). Por outro lado, a integração sensório-motora pode ser melhor investigada quando se manipula um estimulo e se observa a resposta motora (Schöner, 1991).

Resumindo, mediante essa interferência considerada qualitativa quando há integração intersensorial e considerando a importância motora para aquisição, aprimoramento, identificação e refinamento do acoplamento da informação sensorial na ação motora o teste parece ter perdido em qualidade clínica por negligenciar estudos que permitiriam validar a sua interferência motora considerada negativa por Houskeeper (2011) para avaliação do escore de inteligência.

O principal debate teórico que norteou as revisões do WISC é em torno da definição de inteligência e como o teste poderia agregar os avanços teóricos de forma mais eficiente. Para tanto, como já dito, o WISC-IV é permeado pela teoria da inteligência CHC. Esse modelo é composto por 7 habilidades primárias que compreendem g: as categorias de inteligência fluída, cristalizada e memória de curto prazo, processamento de visual, processamento auditivo, armazenamento e recuperação de longo prazo e velocidade de processamento visual (Houskeeper, 2011).

Por conseguinte, os subtestes do WISC-IV foram classificados por Flanagan (2007), conforme o modelo CHC. Nesta classificação os subtestes enquadrados como de inteligência fluída que se referem as habilidades de raciocínio utilizadas para realizar novas tarefas que ainda não foram automatizadas, como a formação de conceitos, padrão de percepção, raciocínio inferencial, resolução de problemas, raciocínio indutivo e dedutivo são os de: raciocínio matricial, conceitos de imagem, aritmética (o subteste cubo não foi incluído nesta categoria, por considerar o aspecto enfático do processamento 


\section{Desafios da psicologia no Brasil}

espacial e visual). A inteligência cristalizada definida como a amplitude e profundidade do conhecimento verbal adquiridos por meio da cultura, educação e outras experiências de aprendizagem, ou seja, é o conhecimento lexical e de informação geral, está representada por meio dos subtestes: semelhanças, vocabulário, raciocínio de palavras, compreensão e informação. Quanto a memória de curto prazo, que se refere a capacidade de utilizar a informação alguns segundos depois após o contato com o estímulo incluem os subtestes: dígitos, aritmética, sequenciamento de letra e números. A quarta capacidade cognitiva avaliada é o processamento visual - a capacidade de perceber, analisar, organizar e gerar padrões relacionados aos estímulos visuais, medida pelo subteste cubos, ou seja, o propósito é medir a capacidade específica das relações espaciais. A velocidade de processamento que se refere as habilidades de rapidez e eficiência com a qual o indivíduo percebe e responde a uma informação, isto é, a rapidez mental, capacidade de executar fluentemente tarefas cognitivas de forma automática, especialmente quando sob pressão, além de manter a atenção em foco e a concentração, estão incluídos os subtestes símbolos, cancelamento e codificação. No processamento visual entram os subtestes cubos e completar figuras. O processamento auditivo que apura a capacidade de perceber, analisar, organizar e gerar padrões a partir de estímulos auditivos no WISC-IV não há subtestes capazes de processar essa modalidade sensorial, assim como o armazenamento e recuperação da memória de longo prazo.

Enfim, apesar do WISC-IV apresentar avanços em termos teóricos em relação ao seu antecessor, ainda mostra-se alienado a concepção do fator $G$ de inteligência. Esse, historicamente, conduziu as suas revisões de caráter doutrinário e, em 2003, num reducionismo permeado pela falta de flexibilidade cognitiva, corta com a 'navalha de Occam' os três subtestes mais sensíveis a avaliação motora por considerá-lo um empecilho ao invés de aliado a ser validado quanto a essa variável e atender de forma mais ampla, como o teste se propõe, a demanda clínica.

Contudo, por mais que o rastreio entre a comparação com as duas versões do WISC em grupos clínicos tenha sido inconclusivas, por carência de estudos voltados para o preterimento da temática psicomotora num teste de inteligência, o mesmo não se observar nos trabalhos de Wallon, Sherrington, Conel, Herbert e Piaget, todos citados por Fonseca (1996). Aliás, para esses autores o ato motor desempenha o papel fundamental na estruturação cortical e está na base da representação e da manipulação tátil. A inteligência é uma adaptação e assimilação e neste contexto o movimento é primordial, pois é por ele que se estrutura a inteligência sensório-motora (prática), a qual, organizando 


\section{Desafios da psicologia no Brasil}

atos, assimila os comportamentos motores das diversas situações oferecidas pelo meio, com isso, é possível o esboço da inteligência reflexiva ou gnósica (Fonseca, 1996).

Logo, a retirada dos subtestes arranjo de figuras, armar objetos e labirintos do WISC-IV tem implicações clínicas, pois dos 15 subtestes validados no instrumento de avaliação, o único que ainda requer manipulação motora, sem uso de lápis, é o cubo. Todavia, ele é mais sofisticado em termos de abstração do que os que foram retirados e muitas vezes o teste é interrompido em fase muito precoce em determinados grupos clínicos, para possibilitar a avaliação dos déficits de execução motora.

\section{CONCLUSÃO}

As variáveis que se interagem no processamento do complexo perceptivo apontam para mostrar a importância dos inputs sensoriais na aferição da resposta em virtude da qualidade do fluxo funcional perceptivo, inclusive pelo seu retorno motor em termos de resposta desse processamento. Situação avessa ao que se delineia o atual WISC-IV. Nele, a entrada do estímulo é dada por via visual (input), como já dito, com exceção o subteste cubos, e a resposta desse processamento é verbal, sem exigir execução motora. Em suma, a menos que o profissional recorra a instrumentos complementares, o WISC-IV perdeu a oportunidade de validar e agregar no rol da avaliação neuropsicológica a variável motora por meio do subtestes retirados. Eles eram recursos úteis, mesmo que informalmente, que o avaliador tinha como aliado já durante a aplicação do teste em disfunções em que o substrato motor e a integração sensório motora também se mostrava alteradas (tabelas I, II, III, IV e V), como o TDAH, Sindrome do X Frágil, grupo de risco - crianças pré-maturas, deficiência intelectual leve, Síndrome de Down, deficiência educacional, Síndrome de Dravet e epilepsia, agnosia auditiva, lesão cerebral, desenvolvimento perceptivo-sensorial, Síndrome de Bardet-Biedl, traumatismo crânio-encefálico TCE, Síndrome de Prader-Willi, doença de Huntington e para finalizar Síndrome de Sturge-Weber.

Enfim, todo o arcabouço teórico apresenta tanto em termos fisiológicos como funcionais o viés motor atrelado a cognição. E, por mais que o WISC-IV tenha apresentado avanços em termos teóricos em relação ao seu antecessor, ainda mostra-se alienado a concepção do fator $G$ de inteligência. No entanto, não é possível afirmar por meio de estudos comparativos entre as versões do WISC-III e WISCIV, em grupos clínicos, (tabela IV) se há implicações clínicas quanto a retirada dos três subtestes: arranjo de figuras, armar objetos e labirintos. Nesse caso, caberia uma pesquisa experimental para responder a essa indagação via comparação entre as duas versões. 


\section{Desafios da psicologia no Brasil}

\section{REFERÊNCIAS BIBLIOGRÁFICAS}

ALLEN DN. et. al. Validity of the RIAS for assessing children with traumatic brain injury: sensitivity to TBI and comparability to the WISC-III and WISC-IV. Applied Neuropsychology. Child. 2014; 3 (2):8393.

ALLEN DN. et. al. WISC-IV profiles in children with traumatic brain injury: similarities to and differences from the WISC-III. Psychological Assessment. 2010 Mar; 22 (1): 57-64.

ANZALONE, Marie E. e LANE, Shelly. Sensory Processing Disorders. In_Lane, SJ \& Bundy, AC (2012) Kids can be kids: a childhood occupations approach. F.A. Davis.

BARDONI A. et. al. Evolutio of the cognitive profile in school-aged patients with severe TBI during the first 2 years of neurorehabiltation. Brain Injury, 2013; 27 (12): 1395-401.

BAKER S. et. al. Working memory subsystems and task complexity in young boys with Fragile $\mathrm{X}$ Syndrome. Journal of Intellectual Disability Research: JIDR. 2011 Jan; 55(1): 19-29.

BATTAGLIA D. et. al. Cognitive declive in Dravet syndrome: is there a cerebellar role? Epilepy research. 2013 Sep; 106 (1-2):211-21.

BÉRDARD AC. et. al. Perceptual and motor inhibtion in adolescents/young adults with childhooddiagnosed ADHD. Neuropsychology. 2010 Jul; 24 (4): 424-34.

BENNETTO L. et.al. Profile of cognitive functioning in wowen with the fragile $X$ mutation. Neuropsychology. 2001 Apr; 15 (2): 290-9.

BOLOGNINI N. et. al. Multisensory processing after a brain demage: clues on post-injury crossmodal plasticity from neuropsychology. Neurosciense and Biobehavioral Reviews. 2013 Mar; 37 (3): 269-78.

BRINCKMAN DD. et. al. Cognitive, sensory, and psychosocial characteristics in patients with BardetBiedl syndrome. American Journal of Medical Genetics. Part A. 2013 Dec; 161A (12): 2964-71.

CANIVEZ, G.L. Construct validity of the WISC-IV with a referred sample: direct versus indirect hierarchical structures. Sch Psychol Q. 2014 Mar;29(1):38-51.

COHEN, Ronald Jay, et. al. Testagem e Avaliação Psicológica. Porto Alegre: Artmed. $8^{\circ}$ ed. 2014. p. 330 339.

CORNISH KM. et. al. Spatial cognition in males with Fragile-X syndrome: evidence for a neuropsychological phenotype. Cortex. 1999 Apr; 35(2):263-71.

DOCKSTADER, C. et. al. Cortical dynamics of selective attention to somatosensory events. Neuroimage 49 (2010) 1777-1785.

DUPRÈ, E. Pathologie de l'imagination et de lemotivé. Payot. 1925.

FLANAGAN, DA, et. al. Essentials of cross-battery assessment. Hoboken: New Jersey. 2o ed. 2007.

FONSECA, Vitor da. A importância das obras de Wallon e de Piaget no estudo da gênese da psicomotricidade. In Psicomotricidade. 4 ed. Martins Fontes: São Paulo. 1996. p. 17-33 


\section{Desafios da psicologia no Brasil}

FOTI F. et. al. Spatial competences in Prader-Wili syndrome: a radial arm maze study. Behavior Genetics. 2011 May; 41 (3): 445-56.

FREITAS-MAGALHÃES, A. F-M emotional intelligence scale (F-MEIS). In Psicologia das emoções. Porto-Portugal: Edição do Autor. 3ํed. Revisada. 2013.

GELDOF CJ.et. al. Visual sensory and perceptive functioning in 5-year-old very preterm/very-low birthweight children. Developmental Medicine and Child Neurology. 2014 Sep; 56 (9):862-8.

GIBSON, E. J. Principles of perceptual learning and development. New York: Appleton-Century Crofts. 1969.

GOLDSMITH HH. et. al. A population-based twin study of parentally reported tactile and auditory defensiveness in young children. Journal of Abnormal Child Psychology. 2006 Jun; 34 (3): 393-407.

GROEN MA. et. al. Weak hand preference in children with down sydrome is associated with language deficits. Developmental Psychobiology. 2008 Apr; 50 (3): 242-50.

HATTIANGADI N. et. al. Characteristics of auditory agnosia in a child with severe traumatic brain injury: a case report. Brain and Language. 2005 Jan; 92 (1): 12-25.

HOUSKEEPER, Jaime L. WISC-IV matrix reasoning and picture concepts Subtestes: does the use of verbal mediation confound measurement of fluid reasoning? (Doctoral dissertation, Pacifitc University).Retrieved fromhttp://commons.pacificu.edu/212.

HUTTON, S. B. Cognitive control of saccadic eye movements, Brain and Cognition, Volume 68, Issue 3, December 2008, Pages 327-340.

L. Picq e P. Vayer. Educação psicomotora e retardo mental. Editora Manole: São Paulo. 4ำed. 1985.

LAUNEY KB. et. al. Concurrent validity of the WISC-IV in eligibility decisions for students with educable mental disabilities. Psychological Reports. 2007 Jun; 100 (3 Pt 2): 1165-70.

LOPES AF. et. al. Intellectual functioning in children with epilepsy: frontal lobe epilepsy, childhood absence epilepsy and benign epilepsy with centro-temporal spikes. Seizure. 2013, Dec; 22 (10) 86-92.

LIU, C.-L. et. al. Antisaccade Cost Is Modulated by Contextual Experience of Location Probability. Cereb Cortex, November 8, 2010.

LUPYAN, Gary e WARD, Emily J. Language can boost otherwise unseen objects into visual awareness. Proceedings of the National Academy of Sciences of the United States of America. 2013 Aug 27; 110 (35) 14196-201.

KORIAKIN TA. et. al. Classification of intellectual disability using the Wechsler Intelligence Scale For Children: full scale IQ or general abilities index? Developmental Medicine and Child Neurology. 2013; sep; 55 (9): 840-5.

MAYES SD e CALHOUN SL. WISC-IV e WIAT-II profiles in children with high-functioning autism. Journal of Autism and Developmental Disorders. 2008 Mar; 38 (3): 428-39. 


\section{Desafios da psicologia no Brasil}

MAYES SD e CALHOUN SL. Similarities and differences in Wechsler Intelligence Scale for Children-Third Edition (WISC-III) profiles: support for subtest analysis in clinical referrals. The Clinical Neuropsychologist. 2004 Dec; 18 (4): 559-72.

MIYAMOTO, Nelson T. Latency and accuracy of motor response to visual stimuli in stress. 2010. $116 \mathrm{f}$. Tese (Doutorado em Fisiologia Humana) - Instituto de Ciências Biomédicas, Universidade de São Paulo. 2010.

MUÑOZ-RUATA, J. et. al. Visual perception and frontal lobe in intellectual disabilities: a study with evoked potentials and neuropsychology. Journal of Intellectual Disability Research (Impact Factor: 2.41). 10/2010; 54(12):1116-29.

NADER, A.M. et.al. Does WISC-IV underestimate the inteligence of autistic children? J Autism Dev Disord. 2014 Oct 12.

NAPALKOV DA. et. al. The characteristics of the autonomic reactions of healthy adolescents and of those with lowered intellectual productivity. Zhurnal Vysshei nervnoi deiatelnosti imeni I P Pavlova. 1994 Jun-Oct; 44 (4-5): 674-81.

NAVA E. e PAVANI F. Changes in sensory dominance during childhood: coverging evidence from the colavita effect and the sound-induced flash ilusion. Child Development. 2013 Mar-Apr; 84 (2): 604-16.

NEUFELD, Carmem Beatriz. et. al. Bases epistemológicas da psicologia cognitiva experimental. Psicologia: Teoria e Pesquisa. Jan-Mar 2011, vol. 27 n.1 pp.103-112.

PEREA-BARTOLOMÉ MV. Neuropsychological evaluation of patients with perceptual and/or motor deficits. Revista de Neurologia. 2000 Mar 1-15; 30(5): 468-73.

PRIMI, R. Inteligência: avanços nos modelos teóricos e nos instrumentos de medida. Revista Avaliação Psicológica. V. 2 N.1 Porto Alegre Jun. 2003.

RACKLEY, C.et. al. Generalizability of WISC-IV index and subtest score profiles in children with traumatic brain injury. Child Neuropsychol. 2012;18(5):512-9.

RAYNER, K. (1998). Eye movements in reading and information processing: 20 years of research. Psychological Bulletin, 124(3), 372-422.

RECLA M. et. al. Cognitive and adaptive functioning after severe TBI in school-aged children. Brain Injury. 2013; 27 (7-8):862-71.

SAY MJ. et. al. Visuomotor integration deficits precede clinical onset in Huntington's disease. Neuropsychologia. 2011 Jan; 49 (2): 264-70.

SCHÖNBERGER AR. et. al. Joint principles of motor and cognitive dysfunction in Parkinson's disease. Neuropsychologia. 2013 Jul; 51 (8): 1417-25.

SCHÖNER, G. Dynamics theory of action-perception patterns: the "moving room" paradigm. Biological Cybernetics, Berlim, v. 64, p. 455-462, 1991.

SEARLE, John R. A Redescoberta da mente. São Paulo: Martins Fontes, 1997. 


\section{Desafios da psicologia no Brasil}

SHIMIZU, Vitoria Tiemi. et. al. Processamento sensorial na criança com TDAH: uma revisão da literatura. Revista de Psicopedagogia. vol. 29, n.․ 89. São Paulo. 2012.

SUTTON GP. et. al. Berry-Buktenica Developmental Test of Visual-Motor Integration performance in children with traumatic brain injury and attention-deficit/hyperactivity disorder. Psychological Assessment. 2011 Sep; 23 (3): 805-9.

STERNBERG, R. J. Psicologia Cognitiva. Porto Alegre: Artmed, 2008.

STYCK KM. e WATKINS MW. Structural validity of the WISC-IV for students with ADHD. Journal Of Attention Disordens. 2014 Oct. 7.

STYCK KM. e WATKINS MW. Structural validity of WISC-IV for students with learning disabilities. Journal of Learning Disabilities. 2014 jun 23.

WANG J. et. al. A case-control study on balance function of attention deficit hyperactivity disorder (ADHD) children. Jornaol of Peking University. 2003 Jun 19; 35(3) 280-3.

URBINA, Suzana. Histórico da testagem psicológica. In__ Fundamentos de testagem psicológica. Porto Alegre: Artmed. 2007. P. 18-24.

VELASQUES, Bruna. et. al. Integração sensório-motora e psicopatologia. Revista Mente e Cérebro. Junho. 2010. p. 55-55.

VICARI S. Motor development and neuropsychological patterns in persons with Down syndrome. Behavior Genetics. 2006 May; 36(3):355-64.

VIDAL, Francisco Antonio Soto, et. al. A quarta edição do WISC americano. Revista Avaliação Psicológica, vol. 10 n.ำ. Itatiba, agosto 2011.

ZABEL TA. et. al. Neuropsychological features and risk factors in children with Sturge-Weber sydrome: for case reports. The Clinical Neuropsychologist. 2010; 24 (5): 841-59.

WALLON, H. A evolução psicológica da criança. São Paulo: Edições 70. 1968.

WECHSLER, D. Escala de Inteligência Wechsler para crianças - Terceira Edição (WISC-III) Manual. Casa do Psicológo: NCA Pearson. 1991. 


\section{Desafios da psicologia no Brasil}

\section{NOTAS}

Nota 1

Trabalho apresentado como requisto para conclusão do curso de Pós-Graduação Lato-Sensu em Neuropsicologia e Reabilitação Cognitiva da Universidade de Vila Velha - ES

Nota 2

O cerebelo funcionalmente trabalha junto ao córtex motor no planejamento do próximo movimento, controle motor dos músculos axiais e no mapeamento dos movimentos.

\section{Nota 3}

O estudo referenda informações importantes para o processo de avaliação para dar suporte principalmente quanto a condução da reabilitação por apresentar as peculiaridades do desenvolvimento motor e neuropsicológico da síndrome.

\section{Nota 4}

O estudo foi incluído por coadunar com o tema da pesquisa em termos teóricos, que de todo, a ênfase dada ao canal visual nos testes neuropsicológicos pode ser reportada ao domínio visual a partir da primeira infância. 


\section{Capítulo 64}

\section{A ANÁLISE DE ERROS EM MATEMÁTICA: ELEMENTOS PARA A FORMAÇÃO DOCENTE}

DOI: $10.37423 / 200200328$

Juliane do Nassimento - Universidade Estadual Paulista - UNESPIFCF ju_nsc@hotmail.com

Maria Raquel Miotto Morelatti - Universidade Estadual Paulista UNESPFFCT mraquelm@fct.unesp.br

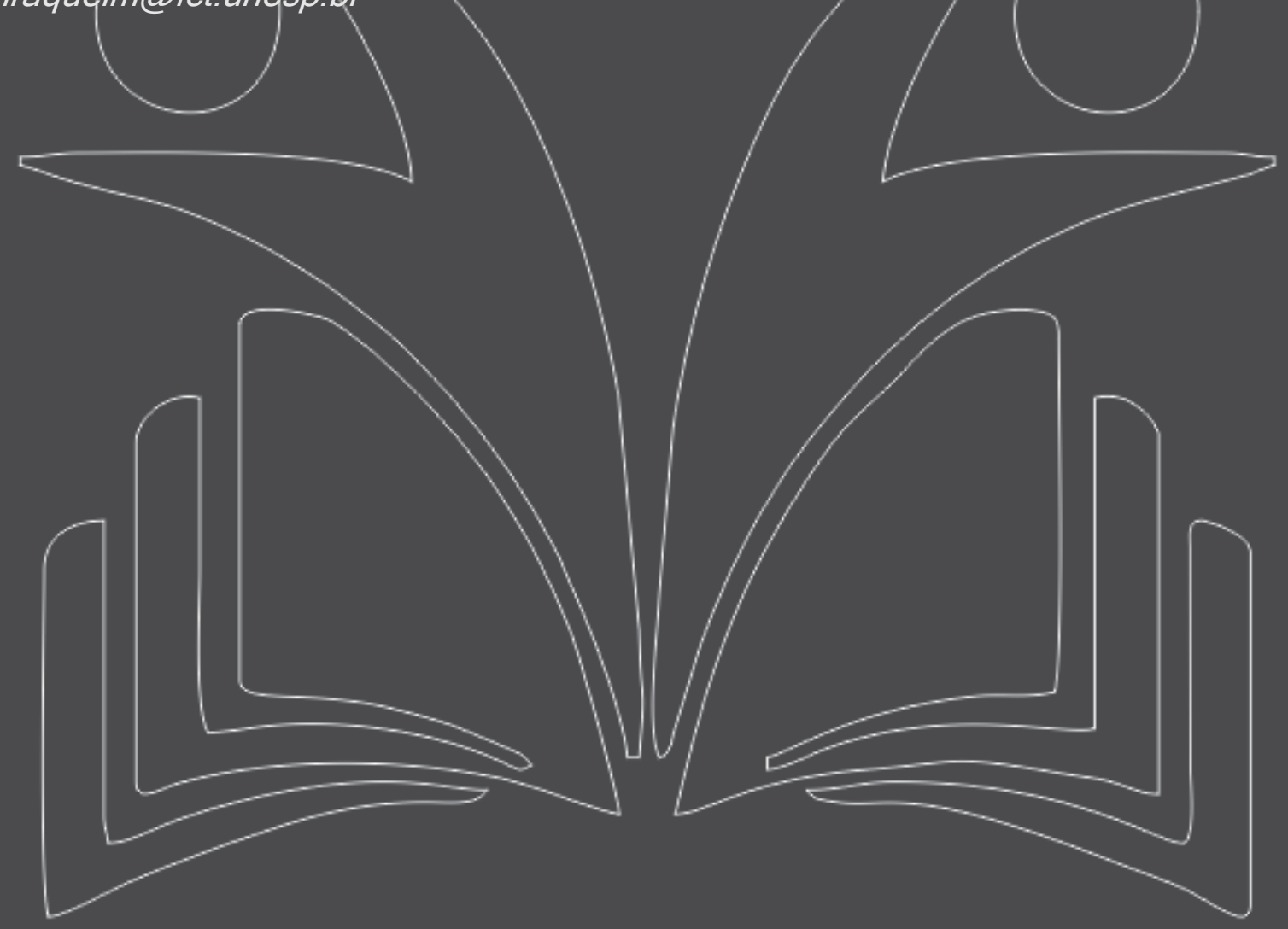




\section{Desafios da psicologia no Brasil}

\section{INTRODUÇÃO}

Na correção de provas, testes e trabalhos em Matemática é comum o apontamento dos erros e dos acertos obtidos pelos alunos. Os erros acabam sendo considerados sob o ponto de vista negativo e os acertos pelo ponto de vista positivo. Contudo, há que se considerar que nem sempre os acertos são garantia de que o aluno aprendeu e tampouco mostram o que realmente eles sabem (CURY, 2008). Nessa ótica, os erros também não evidenciam apenas o que os alunos não sabem, pelo contrário, eles fornecem pistas sobre como os alunos aprendem e compreendem determinado conteúdo.

A concepção de erro ao longo da história da educação foi sempre vista sob o aspecto negativo. Assim, é importante considerar que tal mudança aconteceu somente após a segunda metade do século XX, em que este deixou de ter uma conotação negativa para o ensino, dando origem a uma nova abordagem na qual o papel do erro passou então a ser discutido. As contribuições da teoria de Piaget para a reconsideração do papel do erro no processo de ensino e aprendizagem foram significativas e possibilitaram repensar e reconsiderar o aprendizado da matemática. Nessa perspectiva, o erro deixa de ser simplesmente casual e, passa a ser considerado como parte do processo de construção do conhecimento (TEIXEIRA, 2004). Para a autora, essa nova abordagem trouxe compreensões sobre a aprendizagem de conteúdos matemáticos pelos alunos e suas dificuldades, bem como a descoberta da existência de certos obstáculos na aprendizagem de conceitos matemáticos. Esses obstáculos podem ser tanto de caráter epistemológico quanto obstáculos provenientes da forma de ensinar ou mesmo estar atrelado a certas limitações no desenvolvimento do aluno. Assim, para este trabalho destacamos os erros epistemológicos que, por sua vez, constituem os erros de concepções que os alunos têm em relação a um determinado conceito e/ou conhecimento.

Levando em consideração que o erro permeia todo o processo de ensino e aprendizagem e, portanto, exerce um importante papel nesse processo, enfatizamos a necessidade de tomar como objeto de análise as produções dos alunos em Matemática, buscando compreender a natureza do erro e, suas contribuições para aprendizagem de conceitos matemáticos.

Partindo do ponto de vista que a atividade de análise de produções dos alunos em Matemática pode se constituir em um importante momento de aprendizagem para o professor, pois possibilita a ele compreender como os alunos se apropriam de um determinado conhecimento matemático (CURY, 2008), apresentamos neste trabalho uma análise dos erros cometidos pelos alunos durante o processo de elaboração de suas escritas numéricas. Cabe salientar, que tal análise foi tomada como objeto de 


\section{Desafios da psicologia no Brasil}

discussão em um dos encontros do curso de formação continuada em Matemática, realizado em serviço, com professores que atuavam em um projeto de recuperação de ciclo.

\section{PROCEDIMENTOS DE COLETA DOS DADOS}

O estudo fez parte de uma pesquisa de mestrado que teve como objeto de estudo a implantação do projeto PIC (Projeto Intensivo de $\mathrm{Ciclo}^{1}$ ) , no município de Pompeia/SP. A pesquisa foi realizada com professores que atuavam em turmas de 40 e 50 ano PIC e alunos do $5 ㅇ$ ano do ensino fundamental de duas escolas municipais de Pompeia que participavam do projeto de recuperação. Para a coleta de dados, primeiramente foram aplicados a 37 alunos, em março do presente ano, uma avaliação diagnóstica com o objetivo de fazer um levantamento dos conhecimentos desses alunos em relação à Matemática, identificando dessa forma, suas dificuldades e suas necessidades de aprendizagem.

Tal avaliação foi composta por 14 questões que englobavam os quatro eixos da Matemática propostos pelos PCN: Números e Operações, Espaço e Forma, Grandezas e Medidas e Tratamento da Informação. O instrumento foi organizado tomando como base o material do PIC de 4ㅇaㅇ ano (3a série) volume 1 (SÃO PAULO, 2009), o Guia do professor de 3o ano (2a série) do Ler e Escrever volume 1 (SÃO PAULO, 2010) e a prova do Saresp de 3 ano de 2010. Foram escolhidas atividades do material do PIC para compor a avaliação, uma vez que, os alunos que cursavam o 5o ano PIC, já tinham passado por um processo de recuperação no ano anterior, participando do mesmo projeto. Também selecionamos algumas questões da prova do Saresp de 3으 ano por se aproximar dos conteúdos que foram trabalhados com os alunos no 4 을 ano e pela necessidade de avaliar alguns conteúdos que não foram contemplados no material.

Para analisar os conhecimentos dos alunos sobre a numeração, elaboramos uma atividade de ditado de números com base no material do professor de 3ㅇa ano do Ler e Escrever. Essa questão propiciou reflexões interessantes sobre o modo como as crianças pensam a escrita numérica e os erros que cometem no processo de elaboração do sistema de numeração e, sobre a qual centramos o nosso olhar neste trabalho. Além do instrumento de avaliação, a pesquisa também compreendeu a análise do processo de formação em Matemática para os professores que atuavam no 4ํ e 5ㅇanos PIC. Essa formação foi realizada em serviço, durante os Horários de Trabalho Pedagógico Coletivo (HTPC). Os encontros de formação em Matemática ocorreram quinzenalmente sob a responsabilidade da pesquisadora com duração de 1 h30 min. 


\section{Desafios da psicologia no Brasil}

Tal processo de formação tomou como ponto de partida a discussão dos erros apresentados pelos alunos na avaliação diagnóstica. O objetivo foi levar os professores a compreender os conhecimentos que as crianças elaboram e as dificuldades que enfrentam no processo de construção de conceitos matemáticos a fim de que pudessem criar situações didáticas e intervir de forma adequada para promover a aprendizagem dos alunos.

\section{OS ERROS APRESENTADOS PELOS ALUNOS DURANTE O PROCESSO DE CONSTRUÇÃO DE ESCRITAS}

\section{NUMÉRICAS}

A primeira atividade da avaliação consistiu em um ditado de números, cujo objetivo era verificar as escritas numéricas dos alunos, buscando identificar os números que eles já escreviam convencionalmente e os que ainda precisavam aprender. Foram ditados seis números aos alunos, compreendendo números com dezenas, centenas e unidade de milhar. Os números ditados foram: 63 - 2029 - $307-1238-583-3000$, respectivamente. A escolha por esses números tomou como base o Guia do Professor de 3 ano do material do Ler e Escrever (SÃO PAULO, 2010) que apresenta sugestões e orientações para a realização de sondagens em relação às escritas numéricas.

Dos 37 alunos que realizaram a prova, constatamos que apenas 8 (22\%) dominavam a escrita convencional de números com dezenas, centenas e milhar. Dos 29 restantes, 8 (22\%) dominavam a escrita convencional de números com centenas, 16

(43\%) dominavam a escrita de apenas números com dezenas e 5 (13\%) que ainda não escreviam números convencionalmente.

Os erros cometidos pelos alunos que não escreviam convencionalmente números com dezenas, centenas e unidades de milhar nos levaram a refletir sobre os conhecimentos que elaboram sobre a numeração escrita ao passo que contribuiu também para a realização de um diagnóstico sobre o que já sabiam a respeito da numeração e o que ainda precisavam aprender.

Analisando os erros cometidos pelos alunos, verificamos que os que escreveram convencionalmente números com dezenas apresentaram respostas do tipo:

Figura 1. Escritas numéricas (sujeito 28)
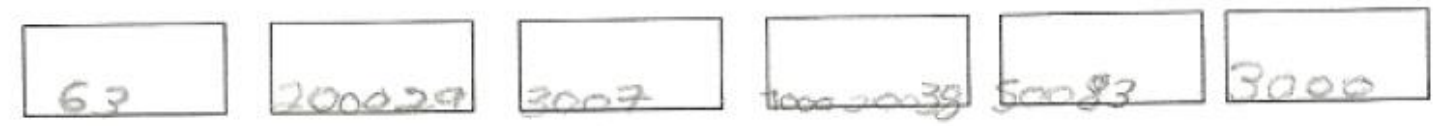


\section{Desafios da psicologia no Brasil}

Fonte: Dados das autoras.

Figura 2. Escritas numéricas (sujeito 1)
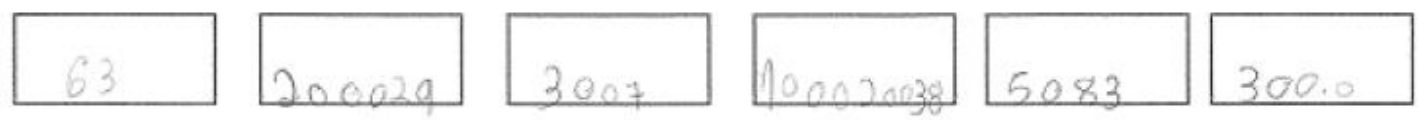

Fonte: Dados das autoras.

Figura 3. Escritas numéricas (sujeito 9)
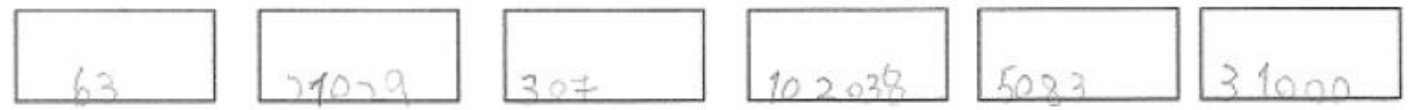

Fonte: Dados das autoras.

Figura 4. Escritas numéricas (sujeito 22)
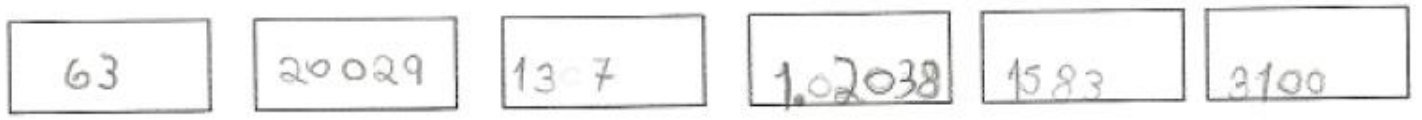

Fonte: Dados das autoras.

As escritas revelam que as crianças se apoiam na numeração falada para escrever números cuja escrita convencional desconhece. A escrita apresentada nas figuras 1 e 2 são representativas desse tipo de conhecimento elaborado por elas. Nelas, assim como nas figuras 3 e 4, é possível perceber claramente a escrita dos números que os alunos já dominam, e que nesses casos se restringem aos números compostos por dois algarismos.

As escritas apresentadas nas figuras 3 e 4 embora também estejam associadas à numeração falada revelam outras formas de se pensar à escrita dos números. Na figura 3 é possível perceber que a criança representa o número mil em 1238 como 10 e em 2029 como 210. Assim, 1000 para ela é 10 e 2000 é 210, isto é, dois dez. Também é verificável esse mesmo raciocínio na escrita de -31000 (3000), em 200 que representa como 20 e em 500, que aparece como 50. Na figura 4 a escrita do número 1238 é igual a do sujeito da figura 3. Esses sujeitos também elaboram o mesmo pensamento para a escrita do número 3000, com a diferença que o sujeito da figura 4 considera a escrita do número mil como -100. Isso também aparece na escrita do 2000, que é representado por ele como 200 . Tal fato indica por um lado, que possivelmente esse sujeito não conhece que a escrita do número mil possui três zeros e, por outro, pode significar também um avanço em relação ao conhecimento de valor 


\section{Desafios da psicologia no Brasil}

posicional, uma vez que utiliza uma menor quantidade de algarismos para escrever os números, o que também é verificável no sujeito da figura 3.

Já os alunos que escrevem convencionalmente números com centenas, foram frequentes respostas como:

Figura 5. Escritas numéricas (sujeito 7)
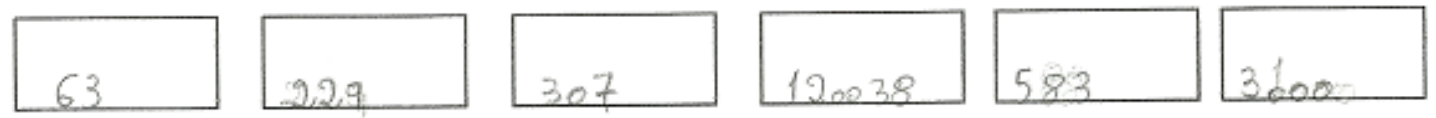

Fonte: Dados das autoras.

Figura 6. Escritas numéricas (sujeito 14)
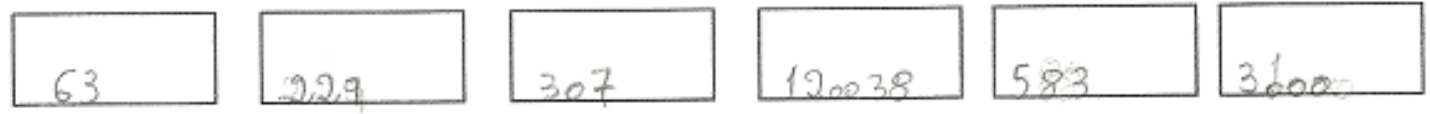

Fonte: Dados das autoras.

É possível perceber o avanço em relação à compreensão das escritas dos números, quando comparamos essas escritas com as anteriores. As escritas representadas nas figuras 5 e 6 mostram que as crianças já escreviam convencionalmente números com três algarismos, como em 307 e 583, porém se apoiavam novamente à numeração falada quando precisavam escrever números com milhar. Esse é o caso do sujeito da figura 5 que escreve 1200 para 1238 e o sujeito da figura 6 que escreve 200 para 2000 e 100 para 1000, mostrando que as crianças ainda que saibam escrever alguns números convencionalmente recorrem sempre aos conhecimentos sobre a numeração falada para escrever números que desconhecem a escrita convencional.

Identificamos também um grupo de alunos que pelas respostas dadas, revelavam não dominar a escrita convencional dos números de dois, três e quatro algarismos.

Figura 7. Escritas numéricas (sujeito 30)
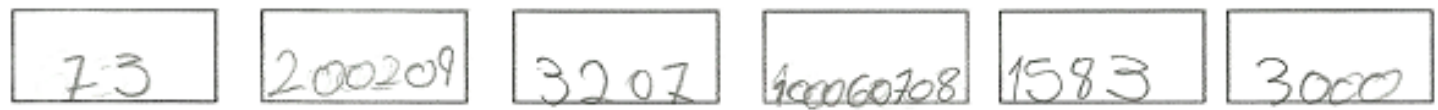

Fonte: Dados das autoras. 


\section{Desafios da psicologia no Brasil}

Figura 8. Escritas numéricas (sujeito 17)
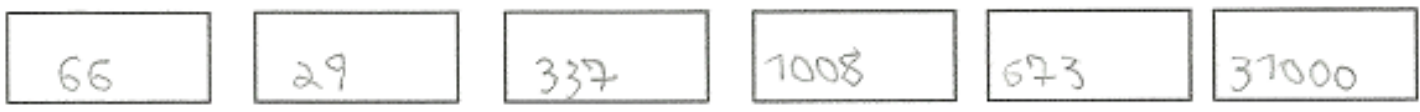

Fonte: Dados das autoras.

Embora as escritas representadas na figura 7 e 8 estabeleçam relação com os números ditados, notase que o sujeito da figura 7 apresenta uma escrita representativa da fala para o número 29 (209) e para o número 38 (que representa como 708), além de apresentar uma escrita que não estabelece relação com o número ditado como na escrita de 100060708 (1238). Apesar da escrita do número 63 estar incorreta, seu erro é considerado válido na medida em que a sonoridade entre as palavras sessenta e setenta é muito próxima.

No caso do sujeito da figura 8 verifica-se que sua escrita tem mais relação com o final dos números ditados, como aparecem nas escritas do número 2029, que o sujeito representa apenas como 29; 1238 que aparece como 1008 e 583 representado por 673.

As variações e alternâncias presentes nas escritas desses alunos reportam para o fato de não dominarem nem escritas de números com dois algarismos, pois, é possível perceber o não reconhecimento de algumas dezenas por parte dos sujeitos, como no número 38 (representado por 708 na figura 7) e em 83 (representado por 73 na figura 8).

A compreensão para as escritas numéricas produzidas pelos alunos encontra fundamentação nas pesquisas de Lerner e Sadovsky (1996). Essas pesquisas mostraram que as crianças não se apropriam da escrita convencional dos números seguindo a ordem da série numérica. Isto significa que as crianças não aprendem primeiro o 1, 2, 3, ..., 11, 12, 13, ...,21, 22, 23, etc. Elas se apropriam primeiramente da escritas denominadas de "nós", isto é, das dezenas, centenas, unidades de milhar exatas “(...) e só depois elaboram a escrita dos números que se posicionam nos intervalos desses nós" (p. 87). Esse fato é perceptível na escrita do número 3000, pois a maioria das crianças conseguiu representar essa escrita, mesmo não escrevendo ainda convencionalmente números com milhar. Algumas, associando com a fala como em "31000" e "3100", "300", "300.0" e outras apresentando uma escrita mais próxima da convencional para esse número. Notamos ainda que a escrita do número três mil foi mais fácil para a maioria das crianças ao tomarmos como referência a escrita do número 2029 e 1238, como podemos observar nas escritas dos sujeitos 17 (figura 8) e 30 (figura 7). 


\section{Desafios da psicologia no Brasil}

Nesse sentido, as crianças constroem o conhecimento a respeito da numeração escrita a partir dos conhecimentos sobre a numeração falada e sobre a escrita convencional dos números exatos, também chamados de números rasos (MORENO, 2006). Para escrever números, cuja, a escrita convencional desconhece, as crianças fazem uso desses conhecimentos e misturam os símbolos que conhecem, seguindo a ordem indicada pela numeração falada. Ao escrever números como 15, as crianças representam "105", isto é, 10 e 5. Já para escrita de 1254, as crianças costumam utilizar a seguinte representação "1000200504". Pelo fato da criança, basear-se na hipótese de que a numeração escrita corresponde à numeração falada, acaba produzindo escritas numéricas não convencionais, isso se deve ao fato da numeração falada não ser posicional. A escrita do número mil duzentos e cinquenta e quatro é: 1254, se por outro lado, a numeração falada correspondesse à numeração escrita, então deveríamos falar "um, dois, cinco e quatro".

Outro ponto fundamental é que na numeração escrita estão envolvidas propriedades das operações. Essas propriedades, por sua vez, também são enunciadas na numeração falada, por exemplo, no número 3460, temos $3 \times 1000+4 \times 100+6 \times 10$, portanto, nela estão envolvidas situações de multiplicação e de soma que aparecem combinadas. Contudo, essas propriedades constituem um obstáculo à compreensão do sistema de numeração, uma vez que uma mudança provocada na enunciação das palavras produz também uma mudança na operação aritmética envolvida, por exemplo, sete mil é 7 x 1000, já mil e sete é $1000+7$.

Ao produzir escritas numéricas, as crianças podem apresentar variações, entre elas, escrever convencionalmente números com dezenas, como, 18, 23, 56, mas associar a escrita dos números com a numeração falada para escrever números com centenas $(10018,30023,60056)$, ou mesmo escrever convencionalmente números com dois e três algarismos, mas apresentar uma escrita correspondente à numeração falada para escrever números com milhares (1000125, 500043). Essas variações ainda existem em números que possuem mesma quantidade de algarismos, por exemplo, as crianças produzem escritas convencionais para números como 154, mas ao escrever novecentos e oitenta e seis, registram -90086, demonstrando que a generalização ainda não foi aplicada a todas as centenas. Escritas convencionais e não convencionais podem, assim, aparecer dentro de uma mesma centena, dezena ou unidades de milhar. Para Lerner e Sadovsky (1996):

(...) a relação numeração falada/numeração escrita não é unidirecional: assim como a numeração extraída da numeração falada intervém na conceitualização da escrita numérica, reciprocamente os conhecimentos elaborados a respeito da escrita dos números incidem nos juízos comparativos referentes à numeração falada. (p. 96). 


\section{Desafios da psicologia no Brasil}

A análise das escritas dos alunos do 5 ano PIC revelou que a maioria delas não dominava a numeração convencional. Tal fato permitiu identificar em um primeiro momento que esses alunos precisavam se apropriar de um sistema convencional de escrita dos números, isto é, apropriar-se das características e propriedades do sistema de numeração decimal. Esse conhecimento é fundamental para o avanço em relação à numeração. Mediante a análise desses dados apresentamos os seguintes questionamentos: qual a importância desse diagnóstico para o professor? Porque é importante saber o conhecimento dos alunos a respeito da numeração?

\section{ANÁLISE DOS ERROS NO PROCESSO DE FORMAÇÃO}

Com o objetivo de levar os professores a refletir sobre essas questões, consideramos a importância de tomar as escritas numéricas dos alunos como ponto de partida para as discussões a respeito de como os alunos aprendem os números, que hipóteses elaboram e como o professor pode trabalhar com a numeração em sala de aula, durante o processo de formação em Matemática. Assim, os objetivos do primeiro encontro com as professoras do PIC foram:

- analisar escritas numéricas;

- discutir a importância do diagnóstico em Matemática;

- reconhecer a importância de saber o que pensam as crianças sobre os números;

- analisar situações didáticas que ajudam as crianças a refletir sobre as escritas numéricas.

As análises das escritas numéricas de crianças do 5ㅇan ano PIC foram ponto de partida para o inicio das discussões. Foi apresentada às professoras uma amostra de seis escritas numéricas, sendo três de cada sala. Fizemos a leitura dessas escritas e à medida que as professoras iam observando o modo como cada criança tinha escrito os números aproveitavam para fazer os comentários. Na análise da escrita do sujeito 9 (fig. 3) surgiram algumas discussões interessantes:

"eu nunca vi assim, já tinha visto do outro jeito (e mostrou a escrita do sujeito 1 - fig. 2), mas assim não" (Professora A).

"é mais fácil os alunos avançarem nesse caso" (apontando para a escrita do sujeito 1 - fig. 2) (Professora A).

"aqui dá pra ver que eles entendem o valor de cada algarismo, é mais fácil" (apontando para a escrita do sujeito 1 - fig. 2 ) (Professora B).

"eles já sabem a decomposição dos números" (Professora C). 


\section{Desafios da psicologia no Brasil}

A escrita do sujeito 9 intrigou as professoras pelo fato dessa escrita não ser o "modelo" que elas conheciam sobre escrita representativa da fala como no caso dos sujeitos 1 (fig. 2) e 28 (fig. 1). Apesar da escrita do sujeito 9 representar uma evolução em relação a dos sujeitos 1 e 28, por apresentar uma menor quantidade de algarismos, as professoras a consideraram mais difícil de avançar. Tal fato revela ainda uma dificuldade em compreender os conhecimentos que são elaborados pelas crianças e como esses conhecimentos vão progredindo. Durante a análise das escritas, surgiu o seguinte comentário:

\footnotetext{
"eu sempre peço para eles escreverem 2011 na data e eles ainda escrevem o 2029 errado" (Professora B).

"mas é porque é uma cópia, ele não construiu". (Professora A).
}

A fala das duas professoras revela como cada uma delas concebe a aprendizagem dos alunos. A professora B tem uma concepção sobre aprendizagem que se aproxima mais da repetição e da cópia. Basta que a criança observe como se escrevem os números para que ela aprenda a escrevê-los. Em oposição a essa visão, a professora A concebe a aprendizagem mais como um processo de construção do que simplesmente uma mera reprodução. A riqueza reside nas discussões que surgem entre as professoras e o contraponto entre diferentes visões, contribuindo para que a professora B reveja suas concepções sobre como as crianças aprendem.

A análise das escritas dos alunos seguiu com a discussão sobre as hipóteses que eles elaboram a respeito da numeração escrita. Para tanto, realizamos a leitura de um quadro sobre as hipóteses das crianças elaborado com base nas pesquisas de Lerner e Sadovsky (1996), e que foi retirado do Guia do professor de 3으 ano (SÃO PAULO, 2010). A leitura do quadro propiciou reflexões para o grupo, no sentido de articular teoria e prática, uma vez, que as professoras puderam constatar a partir das amostras de escritas das crianças que elas se apoiam nos conhecimentos sobre a numeração falada para produzir suas escritas numéricas e, que, portanto, acabam por produzir escritas não convencionais, dando origem ao erro.

Durante a leitura do quadro ouviam-se comentários que demonstravam como as professoras estavam surpresas: "[...] é verdade, está aqui"; "[...] é isso mesmo"; "[...] o processo é o mesmo". Com o objetivo de fazer com que as professoras percebessem além dos erros de caráter epistemológico, o que as 


\section{Desafios da psicologia no Brasil}

crianças já sabiam sobre a numeração, a intervenção nesse momento foi fundamental para propiciar tal processo:

Pesquisadora: "O que essas crianças já sabem sobre a numeração escrita?"

Professora C: "é, [...], elas já tem alguns conhecimentos sobre a numeração [...]."

Pesquisadora: "Que conhecimentos?"

Professora A: "por exemplo, aqui (apontando para a escrita do sujeito 28 - fig. 1) ela já sabe como se escreve o 2000 e o 29."

Pesquisadora: "o que dá pra perceber? Que números eles já escrevem convencionalmente?"

Professora B: "[...] os com dezena."

Professora C: "olha [...], a maioria escreve certo o 29, 38, 83, o 63 [...]."

Logo após a discussão das análises das escritas dos alunos surgiu um novo diálogo entre as professoras:

"E aí? E como fazer para passar desse nível? Essa é a minha dúvida." (Professora A)

"Sabe aquelas fichas numeradas que nós trabalhamos? Elas são ótimas para trabalhar isso daqui. Com as fichas os alunos vão sobrepondo os números e fica fácil perceber o valor posicional e trabalhar a decomposição." (Professora C).

Esse é um dos momentos interessantes da discussão. A professora A expõe a sua dúvida e preocupação sobre como ensinar para que os alunos passem para a escrita convencional dos números. E a professora C, então apresenta uma sugestão, partindo da sua experiência com as fichas sobrepostas. A ficha sobreposta é um recurso didático que possibilita trabalhar com a relação numeração falada/escrita, permite a associação entre o modo como falamos os números (aditivamente) e o modo como escrevemos (posicionalmente). Essas fichas foram trabalhadas com as professoras em um dos encontros realizados com a pesquisadora no ano de 2010. A pesquisadora levou para o encontro as fichas sobrepostas e discutiu com as professoras as diferentes possibilidades de utilizá-las como recurso didático para trabalhar a numeração. Assim, a fala da professora $C$ revelou a incorporação desse recurso no seu trabalho em sala de aula. Isso só foi possível porque essa professora utilizou esse material e testou suas possibilidades, o que a levou a considerá-lo um recurso importante para o ensino do sistema de numeração, evidenciando também uma mudança na sua prática de ensino. 


\section{Desafios da psicologia no Brasil}

\section{CONSIDERAÇÕES FINAIS}

A análise dos erros cometidos pelas crianças durante o processo de elaboração de suas escritas numéricas propiciou importantes discussões e reflexões para os professores no momento da formação. Essas reflexões ocorreram no sentido de levar os professores a compreender os conhecimentos que elas elaboram a respeito da numeração e, que acabam gerando o erro (quando as crianças produzem escritas não convencionais). Tal fato possibilitou também, que os professores elaborassem um novo olhar sobre as produções dos alunos. Nessas produções o erro deixou de ser visto apenas sob o aspecto negativo e passou a ser concebido como parte do processo de aprendizagem.

Cabe salientar que as produções dos alunos quando tomadas como objeto de discussão no processo de formação contribuiu para a contraposição entre as professoras sobre diferentes concepções de ensino e aprendizagem, ao passo que favoreceu também a troca de experiências entre elas. Tal fato corrobora com o pensamento de D’Ambrósio (2005) que considera que o professor precisa "desempacotar" o seu conhecimento formal da Matemática para poder compreender as construções realizadas pelos alunos e fazer uma análise delas. Esse desempacotamento torna-se possível quando o professor analisa e compreende as produções dos alunos. Assim para a autora, a análise do trabalho das crianças serve como catalisador para o desenvolvimento de conceitos e ideias matemáticas. “Oferece uma oportunidade de questionar as limitações de uma compreensão puramente voltada aos procedimentos do conteúdo matemático" (D`AMBRÓSIO, 1995, p. 22).

Ao investigar erros em Matemática e observar como os alunos resolvem um determinado problema ou situação matemática, o professor reflete sobre processos de aprendizagem e também de ensino, na medida em que passa a buscar possíveis metodologias para implementar em suas práticas, com o objetivo de ajudar os alunos a avançarem a partir do momento que detectam as suas dificuldades (CURY, 2008). Tal fato contribui, dessa forma, para que haja uma mudança na prática dos professores e, nos seus modos de pensar e conceber a matemática em sala de aula.

\section{REFERÊNCIAS}

CURY, H. N. (2008). Análise de erros: o que podemos aprender com as respostas dos alunos. (1a ed.) (1a reimp.). Belo Horizonte: Autêntica.

D'AMBROSIO, B. S. (2005). Conteúdo e metodologia na formação de professores. In: FIORENTINI, D.; NACARATO, A. M. (Orgs.) Cultura, formação e desenvolvimento profissional de professores que ensinam matemática: investigando e teorizando a partir da prática. (pp. 20-32). São Paulo: Musa. 


\section{Desafios da psicologia no Brasil}

LERNER, D. e SADOVSKY, P. (1996). O sistema de numeração: um problema didático. In: Parra, C. e Saiz, I. (org). Didática da matemática: reflexões psicopedagógicas. Porto Alegre, Artes Médicas.

MORENO, B. R. (2006). O ensino do número e do sistema de numeração na educação infantil e na 1á série. In: PANIZZA, M. (org) Ensinar Matemática na Educação Infantil e nas Séries Iniciais: análises e propostas. Porto Alegre: Artmed.

SÃO PAULO (Estado). Secretaria da Educação. (2009). Ler e Escrever: PIC - Projeto Intensivo no Ciclo; material do aluno - 3a série. São Paulo: FDE, v.1.

. Secretaria da Educação. (2010). Ler e Escrever: guia de planejamento e orientações didáticas; professor - 2a série; adaptação do material original,Cláudia Rosenberg Aratangy, Rosalinda Soares ribeiro de Vasconcelos. (3a ed.). São Paulo: FDE, v. 1.

TEIXEIRA, L. R. M. (2004). Dificuldades e Erros na Aprendizagem da Matemática. In: Encontro Paulista de Educação Matemática - EPEM, 7, 2004. USP/SP. Anais do VII EPEM, São Paulo: SBEM. 


\section{Desafios da psicologia no Brasil}

\section{NOTAS}

\section{Nota 1}

O PIC foi um projeto elaborado pela rede estadual de ensino de São Paulo, implantado no município por meio de uma parceria com a rede estadual. 


\section{Capítulo 65}

\section{EFEITO ANTIDEPRESSIVO DA RIPARINA III EM CAMUNDONGOS SUBMETIDOS AO MODELO DE ESTRESSE CRÔNICO PELA ADMINISTRAÇÃO DE CORTICOSTERONA}

DOI: $10.37423 / 200200332$

Auriana Serra Vasconcelos Mallmann

Raquell de Castro Chaves

Natália ferreira de Oliveira

Danusio Pinheiro Sartori, Alyne Mara Rodrigues de Carvalho Eduardo José Jucá Mallmann Stanley Juan Chavez Gutierrez Francisca Clea Florenço de Sousa
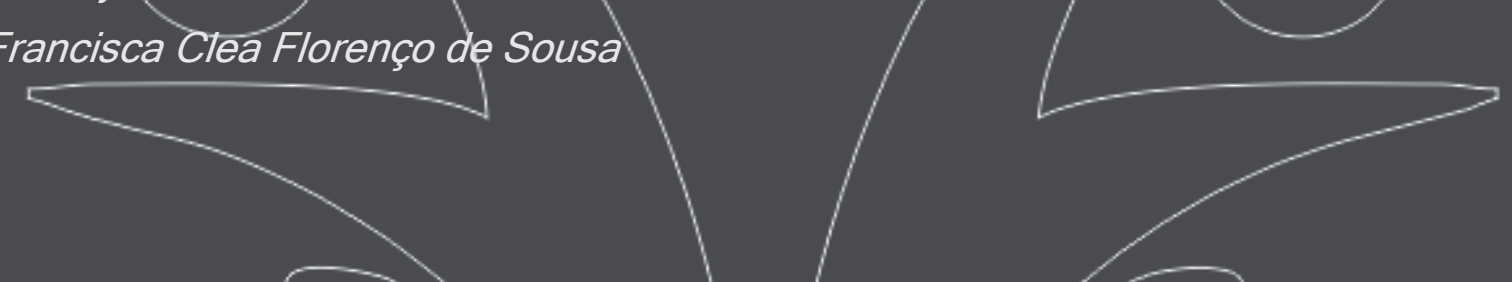

Resumo: Depressão maìr é um transtorno de humor grave, eomum, crônico e recorrente. Acreditase que sua etiologia seja resultado de anormalidades que interagem com fatores genéticos e ambientais, sendo o estresse o principal fator ambiental descrito. A riparina III (Rip III), işlada do fruto verde de Aniba riparia, é yma um/composto bioativo que já apreséentou ação sobre o sistema nervoso central, cọm atividade/ansiolítica e antidepressiva. Portanto, o objetivo do presente trabalho é investigar o/ potencial antidepressivo da Rip III em camundongos submetidos a corticosterona (Cort).

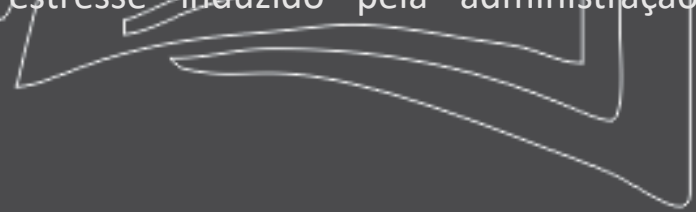




\section{Desafios da psicologia no Brasil}

Foram utilizados camundongos swiss, fêmeas. Cada animal recebeu uma injeção subcutânea (SC) de Cort $20 \mathrm{mg} / \mathrm{kg}$, ou de veículo, durante 22 (vinte e dois) dias. A partir do 14음 dia de tratamento em diante, os animais receberam respectivamente a administração oral de veículo, Rip III ou fluvoxamina (Flu), durante oito dias. Testes comportamentais foram registrados. Em seguida, os animais foram sacrificados para dissecação do hipocampo e dosagem de BDNF. Os resultados mostraram que foi possível induzir depressão com corticosterona e que Rip III e Flu foram capazes de reverter as alterações comportamentais nos testes de nado forçado, anedonia, plus maze, campo aberto, sem alterar a atividade locomotora. Além disso, a administração dessas drogas restaurou níveis de BDNF no hipocampo. Portanto, este trabalho permitiu inferir que a Rip III é uma droga eficaz na reversão e prevenção nesse modelo. Este estudo abre perspectivas para continuidade, no sentido de elucidar as vias com as quais ela está envolvida, contribuindo como mais uma possível droga com potencial para ser utilizada no tratamento da depressão.

Palavras-chave: Riparina III, Corticosterona, Depressão, Testes comportamentais, BDNF. 


\section{Desafios da psicologia no Brasil}

\section{INTRODUÇÃO}

A depressão maior (DM) é um grave distúrbio de humor que tem sido relatada como a principal causa de incapacidade no mundo, sendo um dos principais contribuintes para o ônus global da doença (WHO, 2019). DM afeta pessoas de todas as origens, idades e sexos. O sexo feminino apresenta maior risco de desenvolver depressão. Além disso, é considerado um fator de risco para depressão resistente ao tratamento. Essas taxas aumentadas de distúrbios afetivos em mulheres podem estar relacionadas a processos específicos de gênero, como maiores variações nos hormônios reprodutivos ao longo da vida e maior sensibilidade ao aumento da catecolamina associado à consolidação da memória emocional. No entanto, até o momento, os mecanismos específicos subjacentes às diferenças sexuais na fisiopatologia e no tratamento da depressão ainda são indeterminados. Portanto, estudos préclínicos recentes em depressão foram conduzidos favorecendo o uso de animais fêmeas.

A etiologia da doença é multifatorial e algumas teorias, como a teoria do estresse psicossocial e os hormônios do estresse, tentam explicar o fenômeno. O estresse humano pode colaborar para a patogênese da depressão e também pode influenciar a gravidade e a recorrência dessa doença debilitante.

A ligação entre estresse e depressão foi inicialmente pensada a partir de observações de hiperatividade do eixo hipotálamo-hipófise-adrenal (HPA), níveis elevados de cortisol e interrupção da ritmicidade do cortisol em pacientes deprimidos. Posteriormente, observou-se que pacientes com níveis elevados de glicocorticóides como resultado da doença de Cushing ou terapia com glicocorticóides sintéticos desenvolvem sintomas psiquiátricos e cognitivos consistentes com os observados na DM. Estudos indicam que a hiperatividade do eixo HPA nessa doença pode ser induzida pelo comprometimento dos mecanismos de inibição de feedback. A resposta normal à supressão de cortisol está ausente em cerca de metade dos pacientes mais gravemente deprimidos.

Em roedores, vários achados indicaram que injeções repetidas de corticosterona (Cort) induzem aspectos neuroquímicos da depressão, incluindo efeitos na neurogênese hipocampal e no metabolismo de monoaminas cerebrais. Além disso, foram verificados comportamentos semelhantes à depressão. Pelo Teste do Nado Forçado (TNF) Foi possível concluir que esse modelo animal é válido para o estudo da etiologia da depressão e para a avaliação da eficácia dos antidepressivos. Além disso, tem sido sugerido como um modelo animal de depressão resistente ao tratamento. 


\section{Desafios da psicologia no Brasil}

A depressão resistente continua sendo um grande desafio para a psiquiatria, pois muitos indivíduos não experimentam alívio dos sintomas do tratamento. O estudo STAR*D do Instituto Nacional de Saúde Mental, o maior e mais longo estudo já realizado para avaliar o tratamento da depressão, constatou que apenas aproximadamente um terço dos pacientes responderam ao tratamento inicial e aproximadamente um terço dos pacientes não exibia resposta clínica após o tratamento com vários medicamentos diferentes.

Nesse contexto, os produtos naturais têm grande potencial como fonte de novos medicamentos. Recentemente, propriedades ansiolíticas e antidepressivas foram demonstradas em modelos animais agudos através do uso de Riparin III (Rip III), uma alcamida isolada da planta Aniba riparia. Neste estudo, o efeito semelhante ao antidepressivo do tratamento com Rip III foi ainda avaliado em um modelo de depressão de camundongos fêmeas induzido por Cort.

Assim, nosso objetivo com o presente estudo foi usar o modelo animal de depressão induzido por Cort em camundongas fêmeas para determinar os efeitos antidepressivos do Rip III.

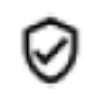

\section{MÉTODOS}

\section{ANIMAIS}

Foram utilizados camundongos swiss, fêmeas, pesando entre 22 e 26 g, provenientes do Biotério Central do Departamento de Fisiologia e Farmacologia, da Faculdade de Medicina, da Universidade Federal do Ceará. Os animais foram mantidos em gaiolas de plástico, com ciclo claro/escuro alternado de doze horas, com luzes acesas às seis horas, recebendo ração padrão, tipo Purina, e água ad libitum. Os protocolos experimentais seguiram os princípios éticos na experimentação animal e foram realizados após aprovação do comitê de ética com protoloco 13.2014,

\section{DROGAS}

Todas as substâncias a seguir foram administradas num volume de $0,1 \mathrm{~mL} / 10 \mathrm{~g}$ de peso corporal. Cort (20 mg/kg, por via subcutânea (sc), Sigma, St. Louis, MO, EUA) foi dissolvida em solução salina, contendo 0,1\% de dimetilsulfóxido (DMSO) e 0,1\% deTween 80 . Rip III (50 mg/kg, via oral (vo), Laboratório de Tecnologia Farmacêutica, João Pessoa-PB, Brasil) foi dissolvida em 2\% de Tween 80 e 


\section{Desafios da psicologia no Brasil}

diluídas em água destilada. A escolha da dose utilizada foi determinada por meio de curva doseresposta realizada por Melo (2012). Flu (50 mg/kg, via oral) foi diluída em água destilada.

\section{PROCEDIMENTO EXPERIMENTAL}

Os animais foram divididos em quatro grupos experimentais ( $n=12$ animais /grupo, em média): grupo controle (veículo 1: solução salina contendo 0,1\% de dimetilsulfóxido e 0,1\% Tween-80, SC, por 14 ou 21 dias e veículo 2: água destilada emulsionado com 2\% de Tween-80, PO, por 8 dias), grupo estressado (Cort, 20mg / kg, SC, por 14 dias ou 21 dias), grupo Rip III (50 mg / kg, PO, por 8 dias) e Grupo Flu (50 mg / kg, PO, por 8 dias).

No presente estudo, simulamos o tratamento crônico de episódios do tipo depressivo. Resumidamente, cada grupo de animais recebeu uma injeção diária de Cort de $20 \mathrm{mg} / \mathrm{kg}$ ou veículo 1 (SC) por 22 dias. A partir do 14을 dia de tratamento, os animais dos grupos tratados também receberam uma administração diária do veículo 2 (VO), Rip III (50 mg / kg) ou Flu (50 mg / kg) por oito dias, com intervalo de 1 hora entre os tratamentos. Ao final do tratamento, testes comportamentais foram realizados. Apos, os animais foram sacrificados e o hipocampo foi dissecado para análise neuroquímica (Zhao, 2008).

\section{TESTES COMPORTAMENTAIS}

\section{TESTE DE NADO FORÇADO}

Esse teste foi utilizado para avaliar a indução do estresse por corticosterona e o potencial antidepressivo da riparina III. Foi realizado de acordo com o modelo de Porsolt et al. (1977) com poucas modificações. Os animais foram colocados no cilindro com água, e a duração total da imobilidade (em segundos) foi registrada durante cinco minutos por um observador cego ao tratamento dado a cada animal. O camundongo foi considerado imóvel quando ele permaneceu flutuando passivamente em posição vertical, podendo fazer até leves movimentos para manter a cabeça fora d'água.

\section{TESTE DE PREFERÊNCIA PELA SOLUÇÃO DE SACAROSE}

A anedonia foi avaliada por meio do teste de preferência pela solução de sacarose. $O$ teste foi realizado como descrito por Strekalova e Steinbusch (2010) com 


\section{Desafios da psicologia no Brasil}

pequenas modificações. Antes do teste, os camundongos foram treinados para se adaptar a uma solução de sacarose $(2 \%, v / v)$ por intermédio da colocação de dois frascos de uma solução de sacarose em cada gaiola, durante dezoito horas; em seguida, foram expostas aos animais duas garrafas, contendo água, durante $18 \mathrm{~h}$. Por fim, durante o mesmo período de tempo, os animais receberam a opção de uma garrafa de água e outra de sacarose. O teste foi realizado no período da noite sem privação de comida. Ao final do teste, foram determinados o consumo de água e a porcentagem de preferência pela solução de sacarose a qual foi calculada pela seguinte fórmula:

Preferência de sacarose $(\%)=$ consumo de sacarose $\mathrm{x} 100$

\section{consumo de água + consumo de sacarose}

\section{CAMPO ABERTO}

Esse teste foi utilizado para avaliar a atividade locomotora, tendência exploratória e ansiedade do animal. O aparato para realização deste teste é feito de acrílico (ou seja, paredes transparentes e piso preto, $30 \times 30 \times 15 \mathrm{~cm}$ ) e dividido em nove quadrados de área igual. Cada camundongo foi colocado no centro do aparato e, ao longo de um período de seis minutos, foram registados os seguintes parâmetros: número de quadrados cruzados ou crossings (ou seja, a atividade locomotora), o número de groomings (ou seja, gesto de limpeza com patas, pegando no corpo e púbis com a boca e as ações face-lavagem), e número de rearings (ou seja, o animal de pé sobre as patas traseiras). Antes da introdução de cada animal para a área, o aparato foi limpo com álcool 10\% para eliminar possível viés devido aos odores que poderiam permanecer nas superfícies dos animais anteriores (ARCHER, 1973).

\section{LABIRINTO EM CRUZ ELEVADO OU PLUS MAZE}

Esse é um modelo utilizado para avaliação da atividade ansiolítica de uma substância. O modelo Plus Maze ou Labirinto em Cruz Elevado (LCE) (LISTER, 1987) consiste em dois braços abertos opostos (50 x $10 \mathrm{~cm}$ cada um) e dois fechados (50 x $10 \times 30 \mathrm{~cm})$, também opostos, em forma de cruz. Os braços abertos e fechados estão conectados por uma plataforma central $(10 \times 10 \mathrm{~cm})$. A plataforma, as paredes laterais dos braços fechados são confeccionadas em acrílico transparente e o chão em acrílico 


\section{Desafios da psicologia no Brasil}

preto. O aparelho está elevado a uma altura de $50 \mathrm{~cm}$ do nível do chão. Para o teste, os camundongos foram colocados no centro do aparelho com a cabeça voltada para um dos braços fechados e o seu comportamento foi observado por cinco minutos. O padrão de medida da ansiedade foi a proporção de tempo total gasto nos braços abertos. O número de entradas nos braços abertos e fechados também foi utilizado como medida de atividade ou tendência exploratória.

\section{TESTE NEUROQUÍMICO}

\section{DISSECAÇÃO DO HIPOCAMPO}

Após o sacrifício por guilhotina, os animais tiveram os encéfalos rapidamente retirados e colocados sobre papel alumínio numa placa de petri com gelo para dissecação do hipocampo, com posterior preparo dos homogenatos cerebrais para detecção dos níveis de BDNF. O córtex pré-frontal foi rebatido para os lados, expondo parte do hipocampo que, com divulsionamento, foi descolado e retirado.

Ao final da dissecação, as áreas foram colocadas em eppendorfs devidamente identificados, pesados e conservados a $-70^{\circ} \mathrm{C}$ para uso posterior.

\section{ANÁLISE DE BDNF}

As concentrações de BDNF em hipocampos foram medidos por anti-BDNF-ELISA sanduíche, de acordo com as instruções do fabricante (Chemicon, EUA). Resumidamente, os hipocampos de camundongos foram homogeneizados em solução tampão de fosfato (PBS) com $1 \mathrm{mM}$ de fluoreto de fenilmetilsulfonilo (PMSF) 1 mM e etileno-glicol tetraaceticacid (EGTA). As placas de microtitulação de 96 poços (de fundo plano) foram revestidas durante 24 horas com as amostras preparadas em 1: 2 , em um diluente e a curva-padrão variou de 7,8 a 500 pg / ml de BDNF. As placas foram então lavadas quatro vezes com o diluente de amostra. Um anticorpo monoclonal de coelho anti-FNEC diluído 1:1000 em diluente da amostra, em seguida, foi adicionado a cada poço e incubou-se durante três horas à temperatura ambiente. Depois da lavagem, um conjugado de peroxidase com anticorpos anticoelho (diluído a 1: 1000) foi adicionado a cada poço e incubou-se à temperatura ambiente durante uma hora. Após a adição de estreptavidina-enzima, substrato e solução de paragem, a quantidade de BDNF foi determinada por absorbância em $450 \mathrm{~nm}$ e expressa como pg de proteína por g de tecido. A curva-padrão demonstra uma relação direta entre a densidade óptica e concentração 


\section{Desafios da psicologia no Brasil}

BDNF. A proteína total foi medida pelo método de Lowry, utilizando albumina de soro bovino como padrão (FREY et al., 2006).

\section{RESULTADOS}

O presente estudo demonstrou que a administração de Rip III foi capaz de reverter as alterações comportamentais induzidas pela administração repetida de CORT.

\section{Testes Comportamentais}

\section{NADO FORÇADO}

Por intermédio do TNF foi possível verificar a indução da depressão por corticosterona por meios do aumento do tempo de imobilidade (Gráfico 1) com o decorrer dos dias de tratamento. Além disso, conforme se verifica no Gráfico 2, ficou demonstrado que o tratamento com Rip III ( $50 \mathrm{mg} / \mathrm{kg}$, VO) e Flu $(50 \mathrm{mg} / \mathrm{kg}, \mathrm{VO})$ foram capazes de reverter e prevenir a depressão pelo aumento do tempo de imobilidade no TNF.

Gráfico 1 - Efeito da administração crônica de corticosterona na indução da depressão por meio do tempo de imobilidade no TNF.

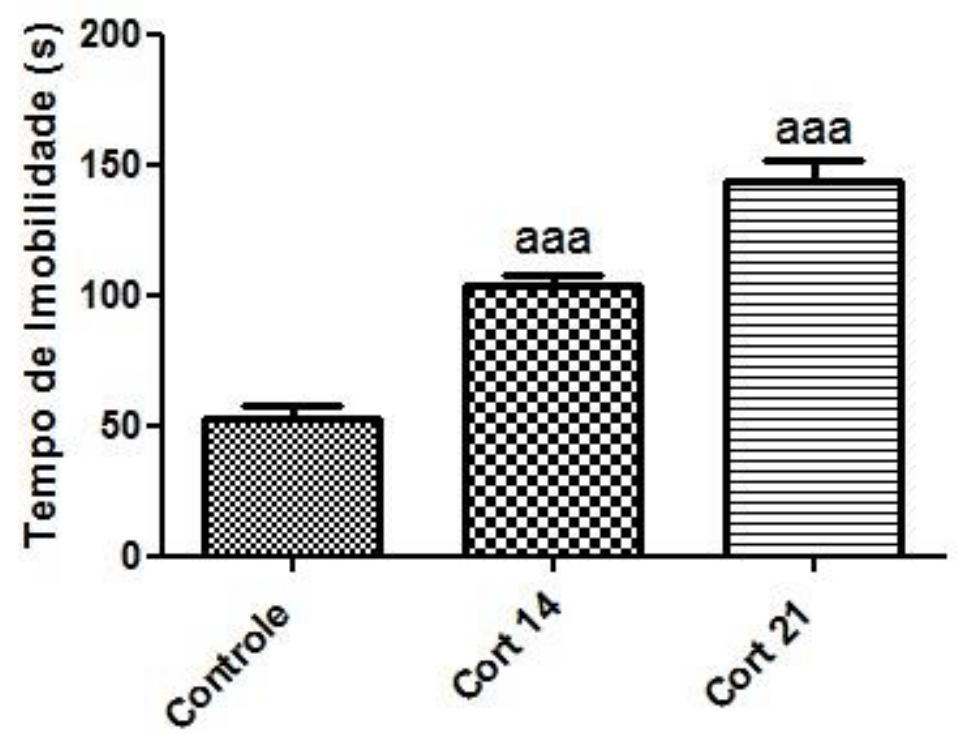

Os resultados são expressos como a média \pm EPM de $n=10-15$ animais/grupo. A análise estatística foi determinada por one-way ANOVA, seguido pelo teste de Student-Newman-Keuls. Valores significativos: aaap $<0,001$ vs controle. 


\section{Desafios da psicologia no Brasil}

Gráfico 2 - Efeito da Riparina III (50 mg/ $\mathrm{kg}$ ) e Fluvoxamina $(50 \mathrm{mg} / \mathrm{kg})$, via oral, no tempo de imobilidade em camundongos no teste de nado forçado

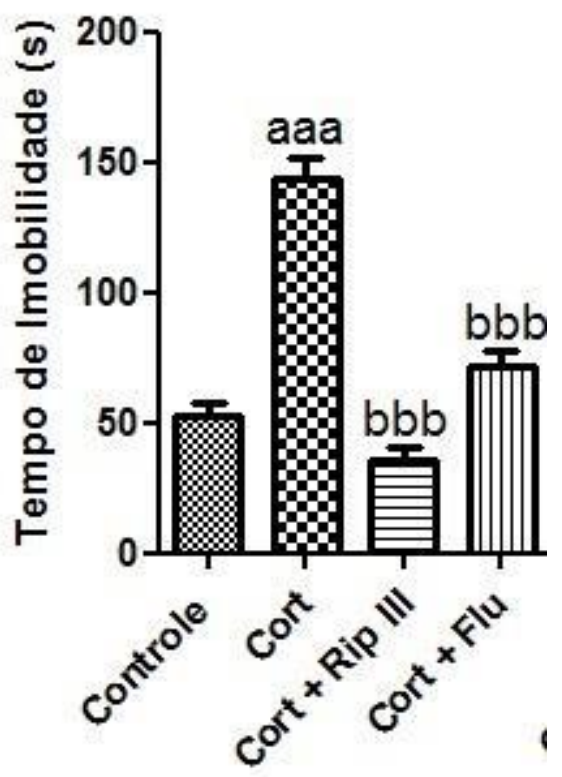

Os resultados são expressos como a média \pm EPM de $n=10-15$ animais/grupo. A análise estatística foi determinada por one-way ANOVA, seguido pelo teste de Student-Newman-Keuls. Valores significativos: aaap $<0,001$ vs controle.

\section{ANEDONIA}

O teste de preferência pela solução de sacarose, utilizado para avaliar anedonia, demonstrou que Rip III (50mg/kg, VO) e Flu (50mg/kg, VO) foram capazes de restaurar a preferência pela solução de sacarose, quando comparada a água, em animais submetidos ao tratamento com Cort, entretanto não foram capazes de preveni-la (Gráfico 4).

Gráfico 4 - Efeito da Riparina III (50mg/ $\mathrm{kg}$ ) e Fluvoxamina $(50 \mathrm{mg} / \mathrm{kg})$, via oral, na porcentagem de preferência pela solução de sacarose no teste de anedonia. 


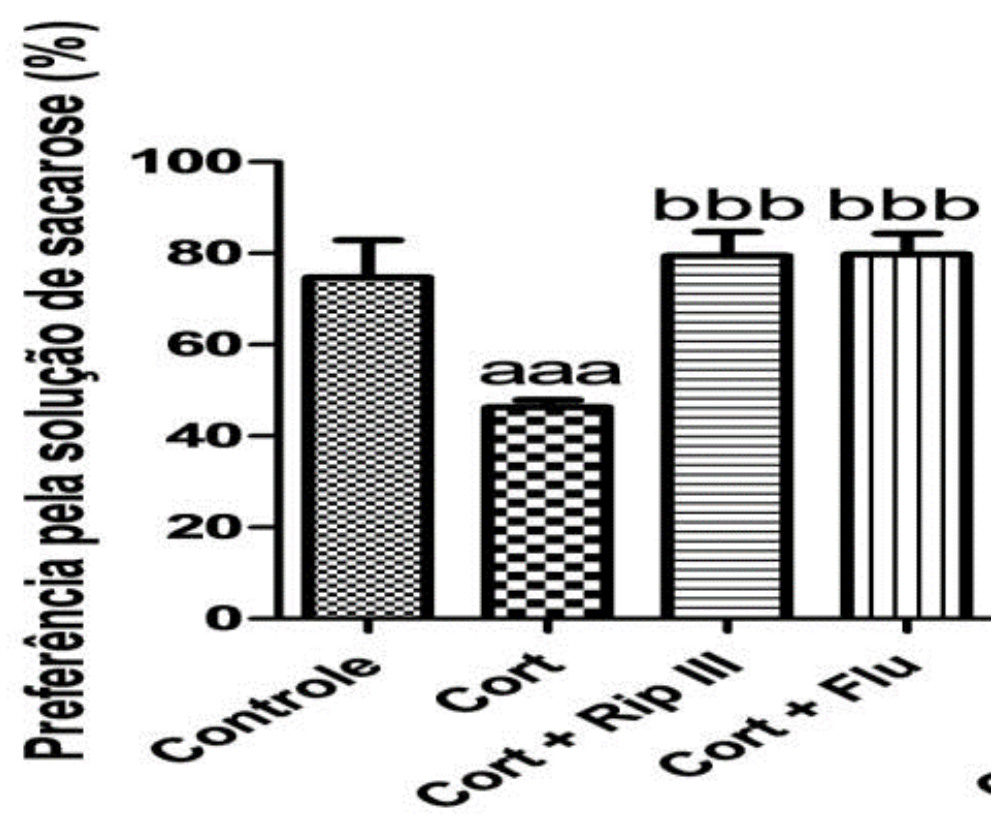

Os resultados são expressos como a média \pm EPM de $n=10-15$ animais/grupo. A análise estatística foi determinada por one-way ANOVA, seguido pelo teste de Student-Newman-Keuls. Valores significativos: aaap $<0,001$ vs controle.

\section{CAMPO ABERTO}

Foi realizado o teste do campo aberto no intuito de observar a atividade locomotora e parâmetros de ansiedade dos animais. Os resultados (da Tabela 1) mostraram que não houve diferença estatisticamente significante entre os grupos no número de cruzamentos (crossings). Pode-se observar que houve aumento no número de rearings, e este foi revertido e prevenido pelo tratamento com Rip III (50mg/kg, VO) e Flu (50mg/kg, VO). Considernado o número de groomings, foi observada eficácia da Rip III apenas no tratamento de prevenção.

Tabela 1 - Efeitos de Veículo, Cort, Flu ou Rip III isolada no campo aberto ou associada a esse campo. 


\section{Desafios da psicologia no Brasil}

\begin{tabular}{cccc}
\hline GRUPO & $\begin{array}{c}\text { NÚMERO DE } \\
\text { CRUZAMENTOS }\end{array}$ & REARING & GROOMING \\
\hline Veículo 7 dias & $39,42 \pm 3,474$ & $6,333 \pm 0,9796$ & $2,500 \pm 0,3794$ \\
\hline Rip III 50 mg 7 & $35,00 \pm 2,601$ & $5,455 \pm 1,461$ & $1,909 \pm 0,3682$ \\
dias & & $3,500 \pm 0,8724$ & $1,900 \pm 0,2333$ \\
\hline Flu 50mg 7 dias & $36,00 \pm 1,106$ & $7,333 \pm 1,202$ & $2,400 \pm 0,4989$ \\
\hline Veículo 14 dias & $37,80 \pm 1,467$ & $5,737 \pm 1,288$ & $2,765 \pm 0,3590$ \\
\hline Veículo 21 dias & $36,67 \pm 3,693$ & $12,10 \pm 1,748^{\mathrm{a}}$ & $4,800 \pm 0,3266^{\mathrm{a}}$ \\
\hline CORT 14 dias & $35,00 \pm 1,880$ & $10,35 \pm 2,181^{\mathrm{a}}$ & $3,444 \pm 0,5842$ \\
\hline CORT 21 dias & $39,80 \pm 4,141$ & $10,88 \pm 5,915$ & $10,88 \pm 2.091^{\mathrm{bb}}$ \\
\hline Rip III + Cort 14 & $35,13 \pm 4,194$ & & \\
dias & & $4,389 \pm 1,487^{\mathrm{b}}$ & $2,000 \pm 0,3524$ \\
\hline CORT + Rip III & $32,60 \pm 3,455$ & & \\
21 dias & & $2,882 \pm 0,8175^{\mathrm{bb}}$ & $2,353 \pm 0,2836^{\mathrm{b}}$ \\
\hline CORT + Flu 21 & $28,18 \pm 2,565$ & & \\
\hline dias & & & \\
\hline
\end{tabular}

Os resultados são expressos como a média \pm EPM de $n=10-15$ animais/grupo. A análise estatística foi determinada por one-way ANOVA, seguido pelo teste de Student-Newman-Keuls. Valores significativos: aaap $<0,001$, aap $<0,01$ e ap $<0,05$ vs controle ou controle 14 e bbbp $<0,001, b b p<0,01$ e bp $<0,05$ vs cort ou cort 14 .

\section{ANÁLISE DO BDNF}

Grafico 5 - Efeito da Rip III na reversão e prevenção dos níveis de BDNF em camundongos expostos à administração crônica de corticosterona. 


\section{Desafios da psicologia no Brasil}

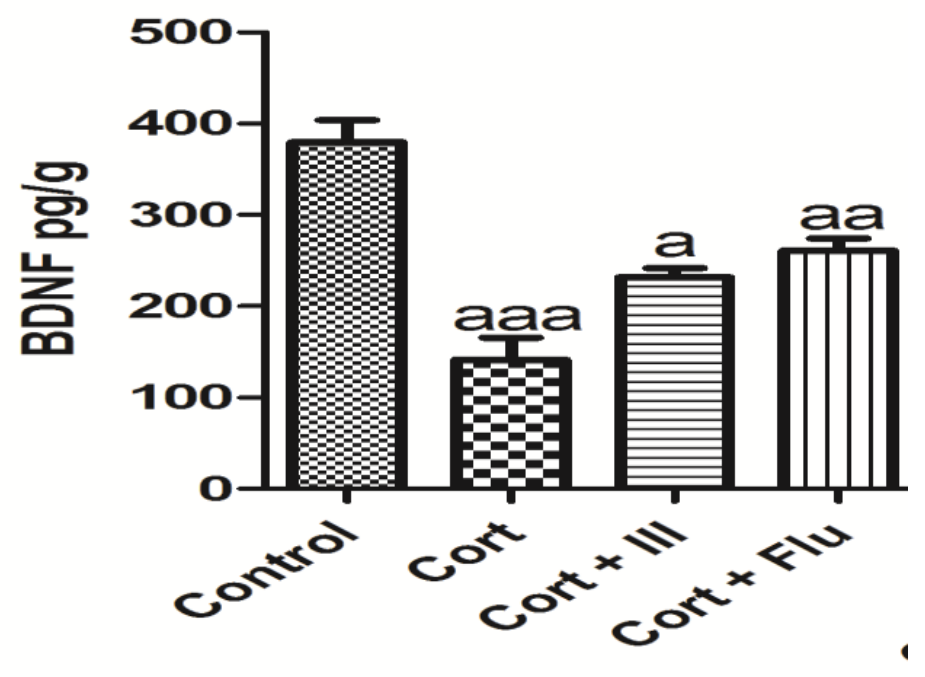

Os resultados são expressos como a média \pm EPM de $n=10-15$ animais/grupo. A análise estatística foi determinada por one-way ANOVA, seguido pelo teste de Student-Newman-Keuls. Valores significativos: aaap $<0,001$, aap $<0,01$ e ap $<0,05$ vs controle ou controle 14 e $b b b p<0,001, b b p<0,01$ e bp<0,05 vs cort ou cort 14.

\section{DISCUSSÃO}

Por meio desse trabalho, ficou evidenciada a eficácia do modelo de estresse induzido por Cort, demonstrando que o estresse e a depressão são fenômenos interrelacionados. Diversas linhas de pesquisa indicam que os animais os quais passam por estresse crônico exibem frequentemente respostas diminuídas ou suprimidas do HPA após reexposição ao mesmo estressor (ZHAO, 2008). No presente trabalho, essa habituação foi comprovada no teste de nado forçado de 14 dias, quando se observou a redução no tempo de imobilidade. Lijima et al (2010) e Zhao et al (2008) também demonstraram semelhantes resultados através de estresse de imobilização.

Além disso, demonstrou-se também a eficácia da Rip III, já que sua administração foi capaz de reverter alterações comportamentais induzidas pela aplicação repetida de corticosterona, um modelo animal de depressão que produz comportamento depressivo, como observado pela diminuição da ingestão de sacarose e pelo aumento do tempo de imobilidade dos animais no teste de nado forçado.

Para o rastreio de drogas com potencial antidepressivo, o teste mais utilizado é o nado forçado (CRYAN et al., 2002;. ZHAO et al., 2008), já que o aumento do comportamento passivo como a imobilidade e a diminuição do comportamento ativo como o nado são indicativos de comportamentos depressivos. 


\section{Desafios da psicologia no Brasil}

Além disso, esse teste é considerado válido, porque todas as formas de tratamento que são eficazes em humanos, incluindo os antidepressivos típicos e atípicos, bem como a terapia por eletrochoque são eficazes em diminuir o tempo de imobilidade (PORSOLT et al., 1978; CRYAN et al., 2005). De acordo com os resultados, Rip III apresentou atividade antidepressiva no modelo de depressão induzido por Cort, como observado em ambos os modelos e corroborando os resultados de um modelo de estresse agudo em estudos anteriores no laboratório (SOUSA, 2004; MELO, 2011).

Em pacientes deprimidos, um dos sintomas observado é a anedonia. O termo "anedonia" é caracterizado pela perda de interesse ou prazer, que são critérios necessários (em associação com humor deprimido) para o diagnóstico de depressão (KENDLER, MUÑOZ, MURPHY, 2010; GAILLARD, GURION, LIORCA, 2013) e está associado com a disfunção do sistema de recompensa do cérebro (KEEDWELL et al., 2005). Associado com o TNF, pode-se avaliar a anedonia, utilizando o teste de preferência pela solução de sacarose (GRONLI et al., 2004). Os resultados obtidos de anedonia mostraram que houve uma diminuição na ingestão de sacarose após doses repetidas de Cort, no entanto, o tratamento com Rip III e Flu foram capazes de reverter essa situação, já que houve um alto consumo de sacarose, quando comparado ao consumo de água. Esse resultado é surpreendente se for considerado que, em geral, os fármacos tratam os sintomas depressivos como um todo (DI GIANNANTONIO, MARTINOTTI, 2012), mas a anedonia permanece como um sintoma difícil de tratar e a farmacoterapia de primeira linha existente nem sempre é suficiente para corrigir (MCCABE, COWEN, HARMER, 2009; FRANCO-CHAVES et al., 2013).

Por meio do número de cruzamentos no teste campo aberto ficou demonstrado que nem a Rip III, Flu ou Cort são drogas que alteram a atividade locomotora dos animais. Esse resultado exclui a possibilidade de que, nos testes em que se utiliza como parâmetro o tempo de imobilidade, os animais estejam respondendo devido a uma ação sedativa ou estimulante, visto que no TNF e TSC, o tratamento com Cort aumenta o tempo de imobilidade dos animais, enquanto Rip III e Flu diminuem.

Além da avaliação da atividade locomotora, o teste de campo aberto, também pode dar indícios a respeito do estado emocional do animal. É considerado, por exemplo, que a atividade locomotora do animal no centro do campo aberto é uma medida mais seletiva de ansiedade (CRUZ, LANDEIRAFERNANDEZ, 2014). Outros parâmetros como o número de groomings e rearings também são analisados. Desse modo, percebeu-se que a administração de corticosterona promoveu um aumento no número de rearings e groomings no teste de campo aberto. Grooming é um comportamento 


\section{Desafios da psicologia no Brasil}

observado em muitas espécies, incluindo ratos. É considerado uma adaptação de uma situação de estresse e pode ser revertido com o uso de drogas ansiolíticas. O tratamento com Rip III e Flu foi capaz de reverter o aumento desses dois parâmetros, entretanto o pré-tratamento evitou o surgimento apenas de groomings.

Antigamente, a depressão era explicada apenas pela teoria monoaminérgica. Atualmente a literatura descreve a hipótese das neurotrofinas na depressão. Esta, já demonstrada pelos modelos animais, sugere que há uma redução dos níveis de BDNF em indivíduos com depressão e que a reversão dessa situação podia ser associada a uma ação antidepressiva, o que já foi demonstrado pelos modelos animais (DUMAN, MONTEGGIA, 2006).

Muitos estudos têm sugerido que a sinalização do receptor de BDNF-TrkB é necessário para a ação de drogas antidepressivas comuns (CASTRÉN, VÕIKAR, RANTAMAKI, 2007). Os resultados desta pesquisa mostraram que a administração de corticosterona reduziu os níveis de BDNF no hipocampo e que a administração de Rip III e Flu auxilia na inversão desta situação, indicando que a ação antidepressiva da Rip III pode estar associada à produção de fatores neurotróficos.

Os resultados apresentados, como já descrito, são muito promissores com relação ao potencial antidepressivo da riparina, e este efeito vem acompanhado da capacidade prevenir e/ou reverter vários sintomas associados à depressão, como ansiedade, perda da interação social, anedonia, déficit cognitivo. Digno de nota, também o importante papel da Rip III em reverter a diminuição da concentração de BDNF, induzida por corticosterona, sugerindo que sua ação antidepressiva pode estar relacionada à produção de fatores neurotróficos. Esses achados comportamentais e neuroquímicos abrem perpectivas para que mais estudos possam ser implementados, visando a evidenciar ainda mais a eficácia da riparina III e explicar com maior riqueza de detalhes as possíveis vias em que essa substância está envolvida.

\section{REFERÊNCIAS}

Ago Y., Yano K., Araki R., Hiramatsu N., Kita Y., Kawasaky T., Onoe H., Chaki S., Nakazato A., Hashimoto H., Baba A., Takuma K., Matsuda T. Metabotropic glutamate 2/3 receptor antagonists improve behavioral and prefrontal dopaminergic alterations in the chronic corticosterone-induced depression model in mice. Neuropharmacology. (2013) 65 29-38.

Altemus M. Sex differences in depression and anxiety disorders: potential biological determinants. Horm. Behav. (2006) 50 534-538. 


\section{Desafios da psicologia no Brasil}

Antonijevic I.A., Murck H., Frieboes R.M., Uhr M., Steiger A. On the role of menopause for sleependocrine alterations associated with major depression. Psychoneuroendocrinology. (2003) 28 401418.

Archer J. Tests for emotionality in rats and mice: a review. Anim Behav. (1973) 21 205-235.

Brown E.S., Varghese F.P., McEwen B.S. Association of depression with medical illness: does cortisol play a role? Biological Psychiatry. (2004) 55 1-9.

Carrier N., Kabbaj M. Sex differences in the antidepressant-like effects of ketamine. Neuropharmacol. (2013) 19 3-8.

Carroll B.J., Cassidy F., Naftollowtiz D., Tatham N.E., Wilson W.H., Iranmanesh A., Liu P.Y., Veldhuis J.D. Pathophysiology of hypercortisolism in depression. Acta Psychiatr Scand Suppl. (2007) 433 90-103.

Castrén E., Võikar V., Rantamäki T. Role of neurotrophic factors in depression. Curr. Opin. Pharmacol. (2007) 7 18-21.

Cruz, A. P. M.; Landeira-fernandez, J. Modelos animais de ansiedade e o estudo experimental de drogas serotonérgicas. Seção III, Cap. 13.

Cryan, J. F.; Page, M. E.; Lucki, I. Noradrenergic lesions differentially alter the antidepressant-like effects of reboxetine in a modified forced swim test. E-European Journal of Pharmacology. (2002) 436, 197-205.

Cryan J.F.; Valentino, R.J.; Lucki I. Assessing substrates underlying the behavioral effects of antidepressants using the modified rat forced swimming test. Neurosci Biobehav Rev. (2005), 547569.

Di Giannantonio, M.; Martinotti, G. Anhedonia and major depression: the role of agomelatine. Eur. Neuropsychopharmacol. (2012) 22 505-510.

Dinan L. Phytoecdysteroids in Kochia scoparia (burning bush). Journal of Chromatography A. (1994) 658 69-76.

Duman R. S., Monteggia L M. A neurotrophic model for stress-related mood disorders. Biol Psychiatry (2006) 59 1116-1127.

Ferrari A.J., Charlson F.J., Norman R.E., Flaxman A.D., Patten S.B., Vos T., Whiteford H.A. The epidemiological modeling of major depressive disorder: application for the global burden of disease study 2010. Plos one. (2013) 8 Franco-Chaves, J.A.; Mateus, C.F.; Luckenbaugh, D.A., Martinez, P.E.; Mallinger, A.G.; Zarate JR, C.A. Combining a dopamine agonist and selective serotonin reuptake

inhibitor for the treatment of depression: a double-blind, randomized pilot study. J. Affect Disord. (2013) 149 319-325.

Frey B.N., Andreazza A.C., Ceresér K.M.M., Martins M.R., Valvassori S.S., Réus G.Z., Quevedo J., Kapczinski F. Effects of mood stabilizers on hippocampus BDNF levels in an animal model of mania. Life Sciences. (2006) 79 281-286. 


\section{Desafios da psicologia no Brasil}

Gaillard, R.; Gourion.D.; Liorca P.M. L'anhédonie dans la depression. L'Encéphale. (2013) 39 296-305.

Holsboer F. The Corticosteroid Receptor Hypothesis of Depression. Neuropsychopharmacology. (2000) 23 477-501.

Inoue T., Koyama T. Effects of acute and chronic administration of high dose corticosterone and dexamethasone on regional brain dopamine and serotonin metabolism in rats. Prog. Neuropsychopharmacol. Biol. Psychiatry (1996) 20 147-156.

Keedwell, P.A.; Andrew, C.; Williams, S.C.R.; Brammer, M.J.; Phillips, M.L.The Neural Correlates of Anhedonia in Major Depressive Disorder. Biol psychiatry (2005) 58 843-853.

Kendler, K.S.; Munõz, R.A.; Murphy, G. The development of the Feighner criteria: a historical perspective. Am J Psychiatry, (2010) 167 134-142.

Kornstein S.G., Schneider R.K.Clinical features of treatment resistant depression. J Clin Psychiatry (2001) 16 18-25.

Lijima M., Ito A., Kurosu S., Chaki, S. Pharmacological characterization of repeated corticosterone injection-induced depression model in rats. Brain research (2010) 1359 75-80.

Lister R.G. The use of a plus-maze to measure anxiety in the mouse. Psychopharmacology (1987) 92 180-185.

Mao Q., Huang Z., Ipa S, Xiana Y., Che C. Peony glycosides reverse the effects of corticosterone on behavior and brain BDNF expression in rats. Behavioural Brain Research (2012) 227 305- 309.

Mccabe C., Cowen P.J., Harmer C.J. Neural representation of reward in recovered depressed patients.Psychopharmacology (2009) 205 667-677.

Melo, C.T.V. Investigação do efeito antidepressivo da riparia III: alterações comportamentais, neuroquímicas e avaliação do estresse oxidativo. 2012. Tese (doutorado). - Universidade Federal do Ceará, Centro de Ciências da Saúde, Faculdade de Medicina, Departamento de Fisiologia e Farmacologia, Programa de Pós-Graduação em Farmacologia, Doutorado em Farmacologia, Fortaleza, 2012. National Institute of Mental Health (NIMH). Questions and Answers about the NIMH Sequenced Treatment Alternatives to Relieve Depression (STAR*D) Study - All Medication Levels (2006).

Pariante C.M., Miller A.H. Glucocorticoid receptors in major depression: relevance to pathophysiology and treatment. Biological Psychiatry. (2001) 49 391-404.

Pitta S., Augustine B.B., Kasala E.R., Sulakhiya K., Ravindranath V., Lahkar M. Honokiol reverses depressive-like behavior and decrease in brain BDNF levels induced by chronic corticosterone injections in mice. Pharmacognosy Journal (2013) 5 211-215.

Porsolt, R.D., Bertin, A., Jalfre, M. Behavioral despair in mice: a primary screening test for antidepressants. Arch. Int. Pharmacodyn. Ther. (1977) 229 327-336.

Rai D., Zitko P., Jones K., Lynch J., Araya R. Country- and individual-level socioeconomic determinants of depression: multilevel cross-national comparison. Br J Psychiatry (2013) 24 195-203. 


\section{Desafios da psicologia no Brasil}

Reus V.I.R., Miner, C. Evidence for physiological effects of hypercortisolemia in psychiatric patients. Psychiatry Research. (1985) 14 47-56.

Silva M.C.C., Sousa C.N.S., Sampaio L.R.L., Ximenes N.C., Araujo P.V.P., Silva J.C., Oliveira S.L., Sousa F.C.F., Macêdo D.S., Vasconcelos S.M.M. Augmentation therapy with alpha-lipoic acid and desvenlafaxine: A future target for treatment of depression? Naunyn-Schmiedeberg's Arch. Pharmacol. (2013) 386 685-695.

Sterner E. Y., Kalynchuk L.E. Behavioral and neurobiological consequences of prolonged glucocorticoid exposure in rats: Relevance to depression. Progress in Neuro-Psychopharmacology and Biological Psychiatry. (2010) 34 777-790. Sousa F.C., Melo C.T., Monteiro A.P., Lima V.T., Gutierrez S.J., Pereira B.A., Barbosa-Filho, J.M., Vasconcelos, S.M., Fonteles, M.F., Viana, G.S. Antianxiety and antidepressant effects of riparin III from Aniba riparia (Nees) Mez (Lauraceae) in mice. Pharmacol. Biochem. Behav. (2004) 78 27-33.

Strekalova T., Steinbuch H.W.M. Measuring behavior in mice with chronic stress depression paradigm. Progress in Neuro-Psychopharmacology and Biological Psychiatry. (2010) 34 348-361.

Ye L., Hu Z., Du G., Zhang J., Dong Q., Fu F., Tian J. Antidepressant-like effects of the extract from Cimicifuga foetida L. J Ethnopharmacol. (2012) 144 683-691.

ZHAO, Y.; SHEN, J.; SU, H. U. I. et al. Chronic corticosterone injections induce a decrease of ATP levels and sustained activation of AMP-activated protein kinase in hippocampal tissues of male mice. Brain Research. (2008), 148-156. 


\section{Capítulo 66}

O TRABALHO PEDAGÓGICO DOS PROFESSORES DE PRIMEIRO ANO DO ENSINO FUNDAMENTAL

DOI: $10.37423 / 200300334$

Daniele Ramos de Oliveira

unespdaniele@gmail.com

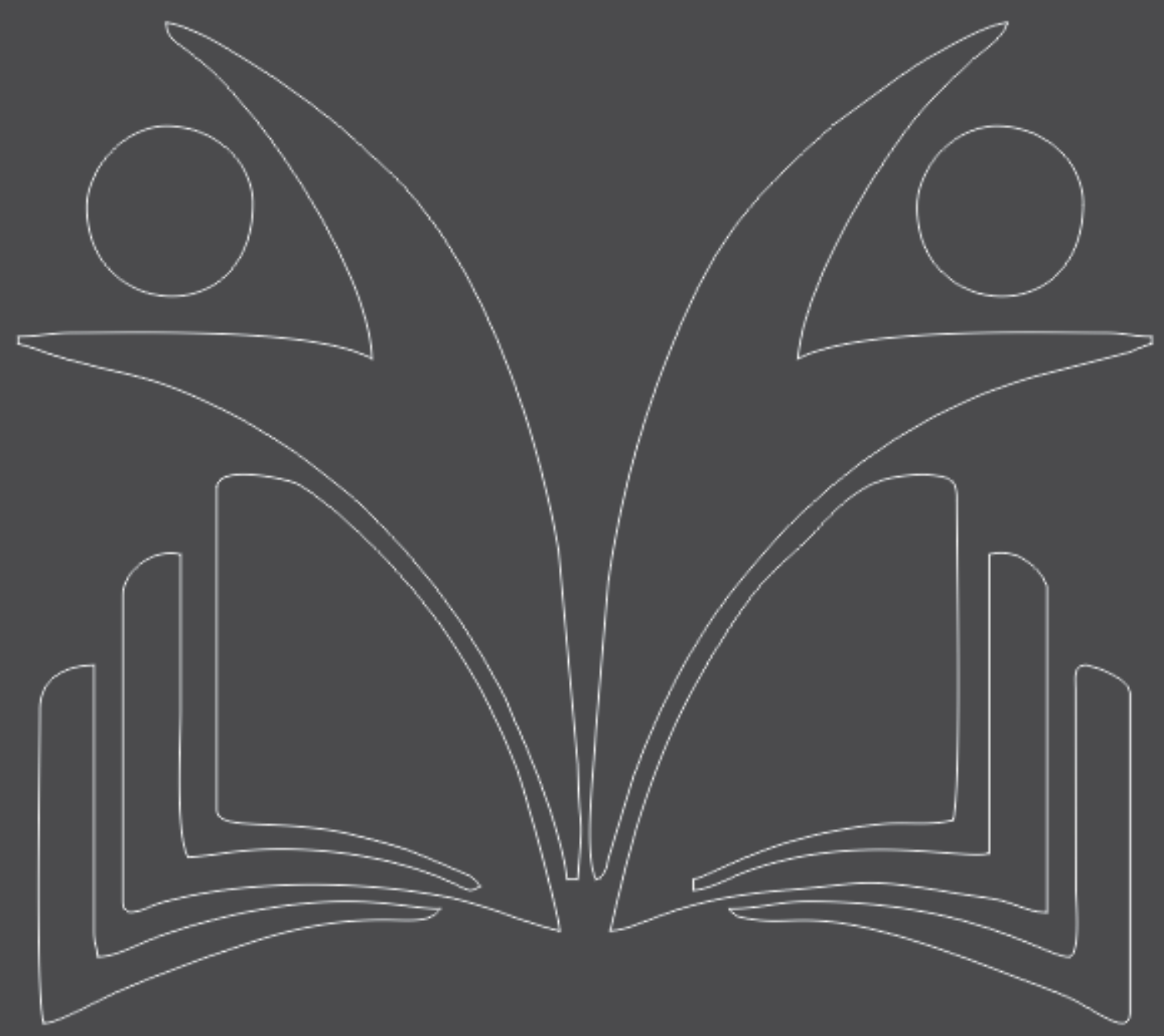




\section{Desafios da psicologia no Brasil}

\section{INTRODUÇÃO}

Desde 2006 o Ensino Fundamental tem sofrido alterações em sua organização nas diversas escolas de todo o país a partir da Lei 11.274/06 (BRASIL, 2006a), segundo a qual a idade para ingresso obrigatório nessa etapa de ensino passaria dos sete para os seis anos e os sistemas deveriam ampliar em mais um ano a duração do Ensino Fundamental, prevendo-se como limite para o ajuste necessário o ano de 2010. Assim, a lei no 11.274, de 2006 alterou a redação do artigo 32 da Lei de Diretrizes e Bases da Educação Nacional (LDBEN/96) que passou a vigorar do seguinte modo: “O Ensino Fundamental obrigatório, com duração de 9 (nove) anos, gratuito na escola pública, iniciando-se aos 6 (seis) anos de idade, terá por objetivo a formação básica do cidadão (...)” (BRASIL, 1996).

A partir de 2009 o município de Marília-SP passou a organizar o Ensino Fundamental mediante o ciclo de nove anos. A proposta curricular para o primeiro ano do Ensino Fundamental foi formulada pela equipe pedagógica da Secretaria Municipal de Educação no segundo semestre de 2008. Para implantação da proposta foi realizado um curso de capacitação ${ }^{1}$ para os professores responsáveis pelas turmas de primeiro ano e coordenadores das escolas de Ensino Fundamental.

Embora na Lei 11.274 (BRASIL, 2006) o prazo proposto para mudança nacional fosse até 2010, a resolução estadual de São Paulo no 98, de 23 de dezembro de 2008, instituiu em seu artigo 2 que o Ensino Fundamental teria, em 2009, sua organização curricular desenvolvida em regime de progressão continuada, estruturada em nove anos, constituída por dois segmentos de ensino: anos iniciais, correspondendo ao ensino do primeiro ao quinto ano e anos finais, correspondendo ao ensino do sexto ao nono ano. No entanto, de acordo com a resolução, as unidades escolares estaduais dariam início à implantação da organização do Ensino Fundamental de nove anos de forma gradativa e contínua e, excepcionalmente, em 2009, esta ocorreria a partir do segundo ano, correspondente à primeira série do Ensino Fundamental de oito séries (SÃO PAULO, 2008). Com isso, os municípios do estado de São Paulo que ainda não tinham realizado as alterações em seu sistema de ensino, tiveram que antecipar a implantação do novo ciclo para assumir também as turmas de primeiros anos das escolas estaduais.

Em 2009, a Secretaria Municipal da Educação de Marília assumiu a demanda de alunos do primeiro ano do Ensino Fundamental do Sistema Estadual de Ensino e, com isso, remodelou sua infraestrutura para poder atendê-los, ocupando salas e demais dependências de oito escolas municipais de Educação Infantil. Em 2010, o Sistema Estadual de Ensino passou a atender todos os anos do Ensino 


\section{Desafios da psicologia no Brasil}

Fundamental, portanto, no município de Marília não há mais turmas do primeiroano ocupando o espaço físico de escolas de Educação Infantil.

De acordo com Valiengo (2008), do ponto de vista político-pedagógico, estamos vivendo um momento na sociedade brasileira denominado redução da infância caracterizado pelo fato de as crianças, cada vez mais cedo, deixarem de serem crianças

[...] ao colocar de lado as brincadeiras, os relacionamentos com seus pares em fazeres lúdicos e interpretativos da realidade [...] para então se tornar aluna e executar tarefas direcionadas ao ensino sistemático da leitura e da escrita, mas não com seus usos ativos e motivadores de aprendizagens [...] (p.9).

Uma das comprovações desse momento histórico é ampliação do Ensino Fundamental para nove anos em âmbito nacional e a conseqüente diminuição da Educação Infantil (VALIENGO, 2008). A pesquisa de mestrado, em parte aqui sintetizada, se insere na tentativa de contribuir com estudos e pesquisas sobre a ampliação do Ensino Fundamental, fato recente no Brasil que merece destaque devido às implicações que tem trazido tanto para as crianças que freqüentam a Educação Infantil quanto para os alunos do Ensino Fundamental no Brasil. O tema é relativamente novo, pois apesar de estar sinalizado na LDBEN/96 e ter se transformado em meta em 2001 por meio da Lei 10.172, somente em 2005 e 2006, a ampliação do Ensino Fundamental, a iniciar-se aos seis anos de idade, passou a se efetivar em âmbito nacional por meio da promulgação das Leis no 11. 114/2005 e no 11.274/2006. (ARAÚJO, 2008).

Constituir-se como docente responsável por crianças de seis anos nessa nova configuração do sistema de ensino tem sido um desafio a ser enfrentado. Estudos (BRUNETTI, 2007, MOYÁ, 2009, VALIENGO, 2008, MORO, 2009) revelam que as propostas tem se caracterizado mais por arranjos materiais do que propriamente por uma reformulação pedagógica para atender às necessidades reais dessa faixa etária em diferentes contextos regionais do Brasil. Na organização da rotina educativa reincide a desconsideração do valor de atividades essenciais às aprendizagens infantis, tais como a brincadeira, os jogos de construção, o desenho, a dança, a pintura e a modelagem. A ênfase do trabalho pedagógico tem recaído nas atividades relacionadas a uma pretensa aquisição da escrita.

Os resultados de pesquisas (ARAÚJO, 2008; BRUNETTI, 2007; MORO, 2009) têm apontado ainda para a necessidade de maior preparação teórico-metodológica dos professores que assumem o primeiro 


\section{Desafios da psicologia no Brasil}

ano do Ensino Fundamental. No entanto, a formação oferecida tem o foco exclusivamente nos processos relativos à alfabetização. Dessa forma, é possível inferir que uma das possíveis conseqüência sejam professoras responsáveis pela educação e desenvolvimento das crianças de seis anos no Ensino Fundamental que desconhecem as especificidades das aprendizagens infantis nessa faixa etária, relegando a proposta de formação integral. Perante a incerteza quanto às mudanças, as professoras têm evidenciado sentimentos de angústia e frustração. Entretanto, de acordo com Kramer (2006), a inclusão das crianças de seis anos no Ensino Fundamental requer diálogo entre os níveis de ensino; entre os municípios; dentro da escola e entre as escolas.

Sendo assim, os principais problemas apontados pelas pesquisas acadêmicas sobre Ensino Fundamental de nove anos são: a falta de apoio pedagógico às professoras, o desconhecimento por parte delas dos documentos oficiais que orientam o trabalho com as crianças de seis anos; a necessidade de fundamentação teórica articulada a prática educativa mais consistente acerca do desenvolvimento infantil nessa faixa etária e a estruturação do trabalho pedagógico em função da centralidade na alfabetização, o

que acentua a preocupação com a dificuldade em acolher as culturas e linguagens infantis. (ARAÚJO, 2008, BRUNETTI, 2007; MORO, 2009, VALIENGO, 2008).

Por todas as razões apontadas, foi desenvolvida uma pesquisa de mestrado, a qual aqui será apresentado um recorte dos resultados obtidos, com os seguintes objetivos: investigar se as características do trabalho pedagógico desenvolvido pelos professores com as crianças do primeiro ano do Ensino Fundamental do município de Marília-SP são as mesmas apontadas pela literatura científica até o momento ou se apresentam características singulares, explicitando-as; caracterizar o que motiva as dificuldades e tendências detectadas entre os professores participantes do estudo; compreender se as dificuldades e tendências do trabalho desenvolvido por esses professores são consideradas pela equipe da Secretaria Municipal da Educação ao proporem ações formativas; investigar se há correlação entre as ações de formação continuada e a manutenção ou superação das dificuldades e tendências pedagógicas demonstradas pelos professores e analisar as necessidades formativas dos docentes de primeiro ano a partir de duas perspectivas: dos próprios docentes e dos gestores das escolas onde esses atuam. Diante disso, a pergunta norteadora da pesquisa é: qual a correlação entre as características do trabalho pedagógico desenvolvido pelos professores de primeiro 


\section{Desafios da psicologia no Brasil}

ano do Ensino Fundamental e os aspectos presentes e ausentes nas ações de formação continuada que a equipe da Secretaria Municipal da Educação tem desenvolvido?

Para fins deste texto, apresentaremos a análise dos resultados obtidos até o momento concernente as características do trabalho pedagógico desenvolvido pelos professores de primeiro ano do Ensino Fundamental do município de Marília-SP.

\section{PROCEDIMENTOS METODOLÓGICOS}

O município escolhido para o desenvolvimento da pesquisa foi Marília-SP, conforme já mencionado, devido a três fatores: o município estar em fase de implantação do primeiro ano do Ensino Fundamental em todas as escolas sob sua responsabilidade, iniciada em 2009; a pesquisadora principal ter sido professora de escola municipal na cidade referida, o que possibilitou acompanhar as ações da Secretaria Municipal de Educação em relação a ampliação do Ensino Fundamental e obter acesso facilitado em escolas e outras dependências necessárias para obtenção de dados; todos os professores que atuam no primeiro ano já serem concursados e contratados em regime efetivo para atuar nesse nível de ensino, não sendo provenientes da Educação Infantil.

Nesse sentido, o município de Marília-SP se apresenta como um caso particular provido de características que auxiliarão a elucidar os objetivos propostos para esta pesquisa. É o que Stake (1995) apud André (2005) denomina de estudo de caso instrumental, segundo o qual o foco não é o caso em si, mas "[...] os insights que o estudo exaustivo de uma unidade podem trazer para o entendimento dos modos de apropriação das reformas pelos atores escolares." (ANDRÉ, 2005, p.20)

Para atingir todos os objetivos propostos para a pesquisa e já elucidados, foi feito uso da triangulação, que consiste na combinação de dois ou mais pontos de vista, fontes de dados, abordagens teóricas ou métodos de recolha de dados numa mesma pesquisa de forma a obter como resultado final um retrato mais fidedigno da realidade ou uma compreensão mais completa do fenômeno a ser analisado.

Os informantes ou sujeitos da pesquisa são constituídos por três grupos: os professores de primeiro ano do Ensino Fundamental; os gestores (diretores e coordenadores) das escolas onde atuam esses professores e os gestores e/ou formadores ${ }^{2}$ responsáveis pelas ações formativas propiciadas aos professores do primeiro ano do Ensino Fundamental no âmbito da Secretaria Municipal de Educação. 


\section{Desafios da psicologia no Brasil}

Diante disso, a pesquisa tem sido desenvolvida por meio dos seguintes procedimentos: mapeamento bibliográfico sobre o tema, pesquisa documental e aplicação de questionários e entrevistas junto aos sujeitos participantes. O recorte estabelecido para este texto diz respeito a análise da parte dos questionários aplicados aos professores e gestores das escolas que trata do trabalho pedagógico desenvolvido com crianças de seis anos.

Os aplicados com professores de primeiro ano do Ensino Fundamental em exercício, constituídos por uma amostra de 47 profissionais que aceitarem participar da pesquisa e de uma amostra de 9 gestores $^{3}$ das escolas onde atuam esses professores em dezembro de 2010. A intenção inicial era aplicar os questionários com todos os 76 professores de primeiro ano do município, porém nem todos aceitaram respondê-lo. Dessa forma, foi necessário trabalhar com uma amostra. Amostra esta que parece ser representativa do universo inicial, pois consiste em $62 \%$ do total. Com o objetivo de não atrapalhar a rotina dos professores com as crianças do primeiro ano do Ensino Fundamental, foi feita a opção de aplicar os questionários nas últimas semanas do ano letivo, momento em que costuma diminuir a freqüência de alunos e de tarefas a serem realizadas pelos docentes.

Os questionários foram elaborados com base no questionário do SAEB e Prova Brasil - 2007 do MEC e nas entrevistas presentes nas dissertações e teses sobre Ensino Fundamental de nove anos.

O questionário dos professores foi organizado com 43 questões, divididas em três partes: caracterização do sujeito; trabalho pedagógico e formação continuada. A parte sobre trabalho pedagógico foi composta de 11 questões, sendo 6 questões fechadas, de múltipla escolha, 3 questões abertas, de múltipla escolha e 2 discursivas, que versavam sobre o uso de livros didáticos, proposta curricular do município, as dificuldades de organização do trabalho pedagógico com as crianças de primeiro ano, a influência das avaliações nacionais, estaduais e municipais nas escolhas para organização das aulas e as características do trabalho com crianças de seis anos.

O questionário dos gestores foi organizado com 27 questões e divididos da mesma maneira que o questionário dos professores, em três partes: caracterização do sujeito; trabalho pedagógico e formação continuada. A parte sobre trabalho pedagógico foi organizada mediante 10 questões, assim como a de formação continuada. Conforme já mencionado, neste texto será apresentada somente a análise inicial referente a trabalho pedagógico a partir da análise das respostas dadas pelos professores e gestores. 


\section{Desafios da psicologia no Brasil}

A análise de dados tem estado presente em todas as etapas do trabalho, porém será feita de forma mais sistematizada ao final da obtenção de dados, momento em que será realizada a classificação e organização desses, com a finalidade de estabelecer relações que possibilitem interpretações para a realidade pesquisada. O procedimento para a análise dos dados obtidos consiste numa análise de conteúdo do tipo categorial temática, que segundo Bardin (1979):

Funciona por operações de desmembramento do texto em unidades, em categorias segundo reagrupamentos analógicos. Entre diferentes possibilidades de categorização, a investigação dos temas, a análise temática, é rápida e eficaz na condição de se aplicar a discursos directos (significações manifestas) e simples. (p.153, grifos do autor)

O procedimento de análise será utilizado a partir de categorização prévia e de indicadores qualitativos e quantitativos estabelecidos em função dos objetivos e do objeto de pesquisa. Embora este seja um dos procedimentos adotados, em conformidade às qualidades do estudo de caso, a forma de análise dos dados não está absolutamente pronta, havendo necessidade de que a pesquisadora se baseie em sua própria sensibilidade, capacidades e habilidades pessoais.

\section{DISCUSSÃO DOS RESULTADOS}

De acordo com o MEC (2006), ao organizar o trabalho pedagógico com crianças de seis anos no Ensino Fundamental de nove anos é preciso atentar para duas dimensões: o desenvolvimento das diversas expressões da criança, incluindo a leitura e escrita, e o lúdico como um dos princípios para a prática pedagógica. Entretanto, conforme explica Bonfim (2010), apesar de os documentos oficiais do Ministério de Educação destacarem a inserção da ludicidade e da dimensão artístico- cultural no Ensino Fundamental, não esclarecem aos educadores como efetivá-las na prática pedagógica.

Nesse sentido, os professores de primeiro ano do Ensino Fundamental de nove anos de Marília foram questionados sobre qual seria a principal característica do trabalho pedagógico com crianças de seis anos do primeiro ano do Ensino Fundamental. Os dados revelaram que 60\% deles percebem a ludicidade como uma das principais características do trabalho pedagógico com crianças de seis anos. Desse grupo, 55\% citaram o aspecto lúdico sem vinculá-lo ao desenvolvimento de conteúdos curriculares e $45 \%$ consideraram que o aspecto lúdico deve estar atrelado aos conteúdos curriculares, ou seja, os conteúdos são trabalhados de forma lúdica ou desenvolve-se o aspecto lúdico com a criança e a partir dele realiza-se a sistematização dos conteúdos. Dos oito gestores participantes da pesquisa, 


\section{Desafios da psicologia no Brasil}

seis deles também responderam que a principal característica do trabalho pedagógico com o primeiro ano do Ensino Fundamental é a ludicidade.

Os dados delineiam uma realidade percebida também por Marega (2010). De acordo com a autora, as escolas tentam organizar "[..] o momento da brincadeira e o momento do estudo de forma separada, ou então, tentam conciliar o estudo com uma brincadeira e então, o brincar torna-se pretexto para ensinar algo." (MAREGA, 2010, p.72). Para a autora, porém, em ambas as formas existe confusão de como agir com as crianças de seis anos no Ensino Fundamental. O brincar quando utilizado como um instrumento para o ensino de conteúdos (jogos pedagógicos para aprender as letras, amarelinha para aprender a contar, músicas para memorizar informações, entre outras) passa a ser caracterizado como um recurso e perde o caráter lúdico, assumindo outras funções. Bonfim (2010) também afirma ter presenciado diversos momentos em que ocorreu a didatização de atividades que deveriam se apresentar como propostas mais livres e espontâneas: “[...] pintar para aprender as cores; dramatizar para decorar um texto; cantar para manter a ordem, direcionar a próxima atividade ou, simplesmente, animar as datas comemorativas; dançar para automatizar os movimentos corporais $[\ldots]^{\prime \prime}(p .108)$.

Os professores de primeiro ano do Ensino Fundamental e gestores das escolas que participaram desta pesquisa demonstraram por meio das respostas ao questionário reconhecer a importância da ludicidade para criança de primeiro ano. Embora grande parcela dos professores investigados (45\%) tenha relacionado o lúdico ao desenvolvimento dos conteúdos, a maioria (55\%) apontou a ludicidade sem estabelecer essa relação. Entretanto, é preciso lembrar que no questionário não era perguntado como os professores trabalham o aspecto lúdico em sala de aula. Talvez, se houvesse essa pergunta, a parcela de professores que relacionariam o aspecto lúdico com os conteúdos seria maior, uma vez que as recentes pesquisas (MAREGA, 2010, BONFIM, 2010, SCHMITZ, 2008) têm apontado essa percepção por parte dos professores.

Rocha (2007) auxilia nessa reflexão ao lembrar que as pesquisas evidenciam que nos contextos de educação das crianças pré-escolares, há fortes tendências de antagonismo entre a valorização do brincar em nível de discurso e o modo como essa atividade é tratada nas práticas cotidianas. Diante da implantação do Ensino Fundamental de nove anos, a autora destaca o risco de desaparecimento da atividade lúdica, e, de modo especial, dos jogos de faz-de-conta, dados os modos de funcionamento mais comuns das circunstâncias escolares na contemporaneidade. 


\section{Desafios da psicologia no Brasil}

A esse respeito Marega (2010) aponta que por meio da aprendizagem de novos conteúdos, a brincadeira de faz-de-conta poderia ser enriquecida, aproximando assim a atividade de estudo da atividade lúdica. A autora realizou um experimento com crianças de uma turma de primeiro ano do Ensino Fundamental de Maringá-PR, de modo a investigar como a brincadeira ocorreria após proporcionar às crianças o contato com conteúdos relacionados ao meio de transporte. Entretanto, mesmo proporcionando conteúdos antes das brincadeiras, as crianças não conseguiram assumir os papéis com propriedade e a autora acredita que isso ocorreu devido ao pouco tempo que foi desenvolvida a proposta, o que não permitiu que tivessem mais experiências sobre o assunto. Apesar disso, considera que durante o ano letivo seja possível desenvolver conteúdos com o tempo suficiente para proporcionar um faz-de-conta produtivo no primeiro ano do Ensino Fundamental.

Se, de fato, os professores de primeiro ano do Ensino Fundamental compreendem a importância do lúdico, conforme demonstram os dados dos questionários, e, apesar das intenções desses responsáveis pelas crianças, nem sempre isso se faz presente no cotidiano das escolas. Seria possível pensar que os contextos de gestão municipal e gestão das próprias escolas, onde estão inseridos, não propicie o alcance desse objetivo. A brincadeira muitas vezes é evitada pelos professores do Ensino Fundamental porque estes reconhecem que, conforme lembra Barbosa (2009), o silêncio e a falta de movimentos por parte dos alunos são vistos por outros atores do contexto escolar como uma qualidade docente. Barbosa (2009) constatou que as professoras que mantinham suas turmas de primeiro ano dessa maneira eram tidas na escola como boas professoras, sob a justificativa de dominarem muito bem a sala de aula.

As famílias também podem contribuir para a diminuição do trabalho lúdico no Ensino Fundamental, uma vez que, de forma geral, preferem que as escolas privilegiem as práticas tradicionais por acreditarem que por meio delas o processo de ensino e aprendizagem ocorra de maneira mais significativa e que no Ensino Fundamental seus filhos sejam alfabetizados, aprendam a ler, escrever e contar (BARBOSA, 2009; FONTES, 2009). Ao mesmo tempo, os discursos das famílias são produzidos a partir de "[...] opiniões e crenças admitidas no seio de uma determinada sociedade ou de grupos sociais a que se impõem aos demais, principalmente a escola, pois há um argumento transmitido com muita força nessa direção e as famílias o reproduzem." (FONTES, 2009, p.124) Nesse sentido, um diálogo entre professores e famílias poderia auxiliar nesse processo. 


\section{Desafios da psicologia no Brasil}

Além disso, há ainda outro aspecto importante vinculado a esse a ser considerado: as influências históricas de uma forma de conceber o Ensino Fundamental, em que o espaço e tempo são destinados para o desenvolvimento da linguagem escrita, numa organização do ensino compartimentado em disciplinas, sisudo e silencioso. Barbosa (2009) percebeu que apesar de as professoras que investigou terem afirmado utilizar muito jogos e brincadeiras no ensino de seus alunos de seis anos, isso raramente ocorreu. Para ela, as professoras acabam reproduzindo aspectos das escolas que viveram suas infâncias, como o autoritarismo e a preocupação excessiva em alfabetizar.

Compreendemos não ser fácil manter atitudes e ações contrárias às práticas já enraizadas dentro da rotina escolar. Acreditamos que nenhum professor é capaz de lidar sozinho com todas as dificuldades existentes no espaço escolar e que todos intercalam momentos de dificuldade e sucesso, de avanços e retrocessos, mais adequados ou inapropriados para o desenvolvimento de determinados objetivos com seus alunos. Entretanto, para que os professores não passem somente a reproduzir aquilo que vivenciaram enquanto alunos em suas práticas pedagógicas são necessários conhecimentos, constituídos com base em reflexões sobre as vivências cotidianas e que permitam aos professores instrumentos teórico-metodológicos para produzir um ensino coerente às necessidades de aprendizagem de seus alunos atuais.

A alfabetização foi o segundo aspecto mais apontado (23\%) pelos professores investigados como principal característica do trabalho pedagógico desenvolvido com crianças de seis anos no Ensino Fundamental. Desse grupo de professores, 64\% citaram a alfabetização associando-a a ludicidade ou ao desenvolvimento de aptidões necessárias para a alfabetização de uma forma lúdica e 36\% desses sujeitos citaram a alfabetização sem mencionar o lúdico, associando outros aspectos como adaptação, socialização, paciência e arte. Embora a maioria tenha citado a alfabetização associando-a ao lúdico, não há exemplos de como isso seria realizado. No entanto, nessa resposta parece prevalecer novamente a percepção do brincar como instrumento para o ensino de conteúdos.

Nesse contexto, cabe ressaltar a pesquisa de Araújo (2007), que buscou compreender os sentidos que os professores de primeiro ano do Ensino Fundamental da Rede Municipal de Ensino de Juiz de ForaMG estavam construindo para a inclusão das crianças de seis anos nesse nível de ensino. $A$ autora constatou que os professores têm construído sentidos a partir de um imaginário pedagógico construído ao longo de suas práticas educativas em escolas de Educação Infantil e Ensino Fundamental, reconhecendo que o papel do primeiro ano é o de alfabetizar. Parece, portanto, estar 


\section{Desafios da psicologia no Brasil}

implícita nessas posturas a idéia de que só há um momento para ser alfabetizado e, historicamente, essa função reconhecida como sendo da primeira série do Ensino Fundamental agora passaria a ser transposta para o primeiro ano.

Concordamos com Capuchinho (2007), apesar de essa não ser a perspectiva apontada pelos gestores das escolas que participaram desta pesquisa, que no entendimento de muitos professores, gestores e pais, as crianças de seis anos deveriam se adaptar ao modelo anterior. Contudo, conforme aponta o MEC (2009), o alvo que se quer atingir com a ampliação do Ensino Fundamental é exatamente a formulação de uma nova proposta para a iniciação desse nível de ensino. Capuchinho (2007) verificou que as professoras de turmas de primeiro ano do Ensino Fundamental possuem uma enorme preocupação em alfabetizar a criança "[...] como se a inclusão dela no Ensino Fundamental representasse apenas uma alfabetização mais precoce, a antecipação de um ano e não a extensão para mais um ano." (CAPUCHINHO, 2007, p.100).

Embora o MEC (2009) ressalte que não se deve restringir o desenvolvimento das crianças de seis anos à exclusividade da alfabetização no primeiro ano do Ensino Fundamental, sendo importante que o trabalho pedagógico assegure o estudo das diversas expressões e de todas as áreas do conhecimento, Araújo (2007) compreende que dentre os vários objetivos da ampliação do ensino fundamental, o foco realmente está na alfabetização.

Esse foco tem sido o maior gerador de angústias, ansiedades, medos e dúvidas, mas também tem sido o maior motivador para a instabilidade produtiva, levando as professoras a desligarem os "[..,] pilotos automáticos e a buscarem melhores formas de pilotar, com mais compreensão, segurança e conhecimento. Este, possivelmente, será o maior desafio das professoras frente aos impactos da nova organização do ensino." (ARAÚJO, 2007, p.95).

Nesse sentido, se os docentes das turmas de primeiro ano do Ensino Fundamental não foram suficientemente esclarecidos sobre a alfabetização, isso pode trazer como conseqüência a centralidade desse processo no trabalho pedagógico com crianças de seis anos, como parece estar ocorrendo de acordo com as pesquisas já mencionadas, de modo a explicitar a contradição entre o discurso documentado por parte do MEC (2009) e as práticas escolares. (MORO, 2009; BONFIM, 2010).

Além disso, 7\% dos professores consideraram como principal característica do trabalho pedagógico com crianças de seis anos no primeiro ano do Ensino Fundamental trabalhar os conteúdos que partam 


\section{Desafios da psicologia no Brasil}

do interesse do aluno, contemplando suas necessidades e a individualidade de cada um, condizentes com a construção de seus conhecimentos, o que denota uma visão romântica da educação.

Outro grupo constituído por $7 \%$ dos sujeitos respondeu que o trabalho pedagógico desenvolvido com as crianças de seis anos no Ensino Fundamental tem como principal característica se constituir como um trabalho intermediário que acolha o aluno da Educação Infantil e ao mesmo tempo atenda as expectativas do Ensino Fundamental; ter muita paciência, acreditar na capacidade destes alunos e ter uma estrutura física melhor (como as escolas de Educação Infantil). Esse grupo de professores demonstra se preocupar em realizar um trabalho pedagógico que tenha como preocupação central a criança e seu desenvolvimento, além de estar de acordo com as orientações do MEC (2009) que incentivam os sistemas de ensino a procurar minimizar as diferenças entre o último ano da Educação Infantil e o primeiro ano do Ensino Fundamental.

Além desses, $4 \%$ consideraram como principal característica do trabalho pedagógico no primeiro ano do Ensino Fundamental trabalhar conceitos priorizando a infância, explorando o levantamento de hipóteses e ao máximo a leitura de livros infantis, músicas e -material concretoll. No entanto, não fica claro como seria o trabalho com conceitos que priorizasse a infância para esses professores, tampouco o conceito de material concreto.

Ao serem questionados se sentiam dificuldades na organização do trabalho pedagógico e na prática cotidiana com as crianças de primeiro ano, $87 \%$ dos professores dessas turmas responderam não ter sentido nenhuma dificuldade e $13 \%$ responderam ter sentido dificuldades no planejamento de propostas para a faixa etária. Como exemplos das dificuldades no planejamento de propostas para essa faixa etária citaram a escolha de atividades referentes aos conteúdos de matemática porque embora saibam que devem trabalhar com o conceito, não sabem como organizar o trabalho pedagógico; as diferenças no nível de escrita da turma; a falta de clareza na proposta curricular apresentada pela Secretaria Municipal de Educação e a escassez de material didático para esse ano escolar, apesar da existência da Proposta Curricular Municipal.

Além disso, 4\% desses professores afirmaram ter sentido dificuldade, além de planejar propostas, também de relacionamento com essa faixa etária. De acordo com esses professores, as dificuldades de relacionamento consistem na dependência que essa faixa etária exige nas realizações das atividades e no fato das crianças de primeiro ano serem imaturas, chorarem muito e não aceitarem ouvir não. Esses professores denotam falta de conhecimentos sobre o desenvolvimento infantil e 


\section{Desafios da psicologia no Brasil}

sensibilidade para perceber quando a criança não está bem e necessita de ajuda, o que não consiste numa tarefa fácil e que por vezes culmina na comunicação com a família.

A maioria dos gestores das escolas investigados afirmou não ter percebido dificuldades nos professores de primeiro ano do Ensino Fundamental para planejamento de propostas pedagógicas ou de relacionamento com essa faixa etária. Somente dois gestores afirmaram ter percebido dificuldades nos docentes de sua escola para planejar propostas de ensino que envolvesse o lúdico. Interessante notar que apesar de somente $13 \%$ dos professores terem apontado ter sentido alguma dificuldade na organização do trabalho pedagógico e na prática cotidiana com as crianças de primeiro ano, quando questionados se eles percebiam dificuldades por parte das crianças essa porcentagem aumentou relativamente para quase metade dos professores participantes (38\%). Sendo assim, é possível perceber que a maioria dos professores investigados que percebem dificuldades de aprendizagem e desenvolvimento nas crianças de primeiro ano do Ensino Fundamental não compreendem que essas dificuldades possam ter relação com as dificuldades deles em organizar o trabalho pedagógico para atendê-las. Como forma de compreender a quais fatores os professores investigados atribuíam essas dificuldades das crianças para aprender foi dada uma lista de possíveis causas que pudessem de alguma forma explicá-las, considerando a situação atual das escolas. Essas causas foram propositadamente divididas em quatro grupos: relacionadas ao exercício profissional do professor; às características físicas e psicológicas dos alunos, principalmente comportamentais; aos deveres e características das famílias e aos aspectos de estrutura e organização da escola.

A ênfase das respostas dos professores recaiu sobre dois aspectos que se inter- relacionam: a criança e sua família. Os professores concordaram que as dificuldades de aprendizagem percebidas por eles nas crianças de seis anos no Ensino fundamental decorrem do excesso de faltas dos alunos, de problemas fonológicos e psicológicos e de graves problemas de comportamento. De acordo com eles, os alunos, por serem muito novos, têm dificuldades para realizar atividades de estudo desvinculadas das brincadeiras e são indisciplinados, pois são muito agitados nessa faixa etária. As dificuldades de aprendizagem também são percebidas como relacionadas à falta de assistência e acompanhamento da família nos deveres de casa e pesquisas dos alunos e às dificuldades familiares (brigas entre os pais, pais que não gostam dos filhos, famílias desestruturadas, violência sexual, prisão dos pais, etc).

Ademais, os professores (53\%) investigados concordaram que as dificuldades dos alunos também ocorrem, além dos motivos já citados, devido à carência de infra-estrutura física e/ou pedagógica da 


\section{Desafios da psicologia no Brasil}

escola. Os gestores das escolas investigadas afirmaram que para receber os alunos de seis anos no Ensino Fundamental foram realizadas pequenas reformas, com a criação de quiosques, tanques de areia e trocas de carteiras e cadeiras em algumas salas por outras mais adaptadas a altura dos alunos. No entanto, do ponto de vista dos professores isso não parece ter sido suficiente para atendimento das necessidades das crianças de seis anos.

Cabe ressaltar que os aspectos que criticavam de alguma forma o exercício profissional docente não foram enumerados pela maioria dos professores como motivos para as dificuldades das crianças de primeiro ano. Como, por exemplo, que essas dificuldades dos alunos estariam relacionadas à falta de compreensão por parte dos professores de como organizar o trabalho pedagógico com essa nova turma do Ensino Fundamental; à sobrecarga de trabalho dos professores, dificultando o planejamento e o preparo das aulas; o não cumprimento do conteúdo curricular ou ainda encontram-se na escola, que oferece poucas oportunidades de desenvolvimento das capacidades intelectuais do aluno.

\section{CONSIDERAÇÕES FINAIS}

A apresentação e discussão de resultados parciais permitem dizer que a formação continuada oferecida pelo município aos professores de primeiro ano do Ensino Fundamental parece ter sido suficiente para subsidiar um discurso por parte dos professores investigados sobre a importância da ludicidade e do respeito à infância. Mas ao mesmo tempo os docentes investigados mostraram-se hesitantes ao notarem como os principais problemas para as dificuldades de aprendizagem dos alunos, o fato de não se envolverem em atividades desvinculadas das brincadeiras, assim como características da família da criança.

Diante disso, as características do trabalho pedagógico desenvolvido pelos professores investigados parecem se assemelhar aquelas apontadas pela literatura científica até o momento, ou seja, no âmbito discursivo os professores afirmam ser o lúdico a principal característica do trabalho pedagógico com as crianças de seis anos no Ensino Fundamental, mas no cotidiano da sala de aula parecem perceber isso como um problema para o desenvolvimento do ensino.

A partir da análise realizada, finalizamos com a síntese dos três principais motivos que podem caracterizar essa tendência detectada entre os professores participantes de estudo a seguir:

- $\quad$ os contextos de gestão municipal e gestão das próprias escolas, onde estão inseridos, não propicia o alcance do lúdico nas práticas pedagógicas porque muitas vezes os professores 


\section{Desafios da psicologia no Brasil}

reconhecem que o silêncio e a falta de movimentos por parte dos alunos são vistos por outros atores do contexto escolar como uma qualidade docente;

- as famílias também podem contribuir para a diminuição do trabalho lúdico nessa etapa de ensino, uma vez que, de forma geral, preferem que as escolas privilegiem as práticas tradicionais por acreditarem que por meio delas o processo de ensino e aprendizagem ocorra de maneira mais significativa, já que para muitos deles os objetivos do Ensino Fundamental se resumem a ler, escrever e contar;

- $\quad$ as influências históricas de uma forma de conceber o Ensino Fundamental, em que o espaço e tempo são destinados para o desenvolvimento da linguagem escrita, numa organização do ensino compartimentado em disciplinas, sisudo e silencioso que as professoras acabam reproduzindo por terem vivenciado em suas infâncias e a formação recebida não ter sido suficiente para modificar essas concepções e promover subsídios teórico-metodológicos para uma prática diferente.

\section{REFERÊNCIAS}

ANDRÉ, M. E. D. A. (2005) Estudo de caso em Pesquisa e Avaliação Educacional. Brasília: Líber Livro Editora.

ARAÚJO, R. C. B. F. (2008) Construindo sentidos para a inclusão das crianças de seis anos de idade no ensino fundamental de nove anos: um diálogo com professores. Dissertação de Mestrado, Curso de Pós-graduação em Educação, Universidade Federal de Juiz de Fora. Juiz de Fora, MG.

BARBOSA, M. S. P. (2009). A implementação do 10 ano no ensino fundamental de nove anos: estudo de uma experiência. Dissertação de Mestrado, Curso de Pós-graduação em Educação, Universidade Católica Dom Bosco. Campo Grande, MS.

BARDIN, L. (1979). Análise de conteúdo. Trad. Luis Antero Reto e Augusto Pinheiro. Lisboa: Edições 70.

BONFIM, P. V. (2010). A criança de seis anos no ensino fundamental: uni- duni-tê...corporeidade e ludicidade - mais que uma rima, um porquê...Dissertação de Mestrado, Curso de Pós-graduação em Educação, Universidade Federal de São João Del Rei. São João Del Rei, MG.

BRASIL. Lei n. 9.394, de 20 de dezembro de 1996. (1996) Estabelece as diretrizes e bases da educação nacional. Diário Oficial da União, Brasília, DF, 23 dez. 1996.

BRASIL. Lei n. 11.274, de 6 de fevereiro de 2006. (2006) Altera a redação dos artigos 29, 30,32 e 87 da Lei n. 9.394, de 20 de dezembro de 1996, que estabelece as diretrizes e bases da educação nacional, dispondo sobre a duração de 9 (nove) anos para o ensino fundamental, com matrícula obrigatória a partir dos 6 (seis) anos de idade. Diário Oficial da União, Brasília, DF, 7, fev., 2006. 


\section{Desafios da psicologia no Brasil}

BRUNETTI, G. C. (2007) O trabalho docente face ao atendimento da faixa etária de 6 anos no Ensino Fundamental: um estudo a partir das manifestações de um grupo de professoras alfabetizadoras no município de Araraquara. Dissertação de Mestrado em Educação, Universidade Estadual Paulista. Araraquara, SP.

CAPUCHINHO, A. (2007) Os Sentidos e significados produzidos pelo professor sobre o ensino fundamental de nove anos. Dissertação de Mestrado, Curso de Pós-graduação em Educação, Pontifícia Universidade Católica. São Paulo, SP.

FONTES, V. L. (2009) A escola de 9 anos, características e impactos por meio de representações parentais: um estudo na Rede Municipal de Ensino de Araraquara. Dissertação de Mestrado, Curso de Pós-graduação em Educação, Pontifícia Universidade Católica. São Paulo, SP.

MAREGA, A. M. P. (2010). A criança de seis anos na escola: transição da atividade lúdica para a atividade de estudo. Dissertação de Mestrado, Curso de Pós- graduação em Educação, Universidade Estadual de Maringá. Maringá, PR.

MORO, C. S. (2009). Ensino Fundamental de 9 anos: o que dizem as professoras do $1 .^{\circ}$ ano. Tese de Doutorado, Curso de Pós-graduação em Educação, Universidade Federal do Paraná. Curitiba, PR.

MOYÁ, D. J. L. (2009). A criança de seis anos de idade no Ensino Fundamental de nove anos: práticas e perspectivas no primeiro ano. Dissertação de Mestrado, Curso de Pós-graduação em Educação, Universidade Estadual de Maringá. Maringá, PR.

SCHIMTZ, L. L. (2008). Entre a educação infantil e o ensino fundamental: uma análise das vivências espaço-temporais das infâncias. Dissertação de Mestrado, Curso de Pós-graduação em Educação, Universidade Regional do Noroeste do Estado do Rio Grande do Sul. Ijuí, RS.

VALIENGO, A. (2008). Educação Infantil e Ensino Fundamental:bases orientadoras à aquisição da leitura e da escrita e o problema da antecipação da escolaridade. Dissertação de Mestrado, Curso de Pós-graduação em Educação, Universidade Estadual Paulista. Marília, SP. 


\section{Desafios da psicologia no Brasil}

\section{NOTAS}

Nota 1

Este curso foi ministrado pela equipe pedagógica da Educação Básica da Secretaria Municipal de Educação, das $7 \mathrm{~h}$ às $12 \mathrm{~h}$, de 3 a 6 de fevereiro de 2009, totalizando 20 horas, na semana anterior ao recebimento das crianças de seis anos nos primeiros anos do Ensino Fundamental.

Nota 2

No caso da Secretaria Municipal de Educação o papel de gestor e formador se confundem às vezes, pois diversos cursos organizados pela Secretaria têm como ministrantes os gestores dessa instância.

\section{Nota 3}

São considerados gestores das escolas municipais de Ensino Fundamental de Marília: diretores, vicediretores e coordenadores pedagógicos. O questionário deveria ser respondido por pelo menos um gestor de cada escola, não havendo necessidade que os três gestores respondam ao questionário, uma vez que a aplicação foi realizada com o objetivo de permitir um segundo olhar sobre o trabalho pedagógico desenvolvido pelos professores de primeiro ano do Ensino Fundamental. 


\section{Capítulo 67}

O USO/ABUSO DE ÁLCOOL ENTRE JOVENS INDÍGENAS: ESTUDO DE UMA COMUNIDADE KAINGANG NO PARANÁ

DOI: $10.37423 / 200300337$

Paulo Caldas Ribeiro Ramon

pauloribeiro1987@gmail.com

Luane Maciel Freire

Iuanemfreire@gmail.com

Rosângela Célia Faustino

rofaustino@terra.com.br

Resumo. e presente trabà)ho aborda a temática do ýso abusjvo de álcool por populações indígenas no Estado do-Paraná cuja população é de 9.150 indivídtros (dados estimados em 2010/2011) provvenientes de três etnias diferentes (Guarani, Kaingang e Xetá), habitantes de 29 Terras Indígenas demarcadas e 3 não demarcadas. De acordo com a FUNASA - Fundação Nacional da Saúde, instituição responsável pela saúde indígena, o suicídio e o alcoolismo são as maiores moléstias que acometem a população indígena. Nos anos de 2థ01/2006 foram realizadas conferências, com a partíạpação das comunidades, sobre a temática do alcoolismo, nas quais as propostas estavam na projibição da entyada de bebida alcoólica nas aldèias e conscientização sobre os malefícios da ingestão de álcool. Os grupos indígenas desenvolveram algumas estratẹgias (aconselhamentos, privação dá liberdade, expulsões, consentimentos em algumas situações) para enfrentar este problema que e considerado muito grave pelas lideranças. Algumas escotas indígenas tềm-tentado um trabalho preventivo abringo espaço para o diáłogo e a reflexão junto à comunidade, porém são iniciativas incipientes diante da gravidade do problema. 


\section{Desafios da psicologia no Brasil}

A presente pesquisa realizou-se no âmbito do projeto "O esporte/lazer em Comunidades Indígenas no Paraná" 2009/2010 financiado pela Rede Cedes e Ministério do Esporte. Observou-se a gravidade do problema bem como a ausência de diagnósticos que contribuam com a formulação de estratégias para seu enfrentamento.

Palavras-Chave: Indígenas no Paraná; Jovens; Uso/Abuso de álcool. 


\section{Desafios da psicologia no Brasil}

\section{INTRODUÇÃO}

O presente trabalho aborda a temática da problemática do Uso/Abuso de álcool entre o povo Kaingang em uma Terra Indígena (T.I.) no vale do rio Ivaí no Paraná. Estado cuja a população indígena é de 9.150 indivíduos (dados estimados em 2010/2011) de três etnias diferentes (Guarani, Kaingang e Xetá), espalhados ao longo de 29 Terras Indígenas demarcadas e 3 em processo de demarcação. Trazendo assim uma análise referente a coleta de dados realizada no ano de 2011 na execução do projeto de pesquisa "O Impacto do Programa Bolsa Família na melhoria do acesso à educação e aprendizagem em comunidades indígenas Kaingang e Guarani no Estado do Paraná" ${ }^{1}$. A localização da respectiva população será mantida no anonimato, escolha que se justifica em razão das exigências requisitadas pelo cacique perante a discriminação que acomete a comunidade em relação ao assunto supracitado.

Para a presente discussão recorremos a etnohistória, nesta evidencia-se as constantes lutas das populações pela manutenção de seus territórios e viveres (MOTA, 2003; TOMMASINO, 1995; TOMMASINO, FERNANDES, 2003). Atualmente os Kaingang têm uma população estimada de 29 mil habitantes, ocupando do estado de São Paulo ao Rio Grande do Sul vivendo em Terras Indígenas e Aldeias Urbanas, demarcadas ou em processo de demarcação. Sendo a etnia mais populosa da região sul, linguisticamente são pertencentes ao tronco Macro Jê .

Conforme Mota (2003) consta que a presença dos grupos Kaingang no vale do rio Ivaí está relacionada com a expansão das fazendas de gado nos Campos Gerais e na região de Guarapuava ocorridas desde o início do século XIX, o que compeliu os Kaingang a irem se instalando nas matas das serras desta região, além de sofrerem com a pressão da sociedade envolvente chegadas neste período para ocupar esses territórios. No início do século XX, distintas localidades do atual estado do Paraná passaram pelo processo de colonização de povos estrangeiros, como alemães, poloneses e ucranianos, além de ocupação por agrupamentos não Apesar do governo disponibilizar parcelas de terras aos povos indígenas no Paraná não as regulamentou, o que indicou a redução considerável dos seus territórios. Em meados do século $X X$, os Kaingang situados no vale do rio Ivaí sofreram mais uma vez com a diminuição das suas terras, no momento em que o governo do Estado determinou com a União em subtrair grande parte das áreas indígenas da região em proveito de fazendeiros, imigrantes e colonos que já haviam tomado posses destas terras. (MOTA, 2003).

Neste contexto, as companhias colonizadoras de capital estrangeiro já haviam ocupado grande parte do Paraná, o que obrigou os Kaingang a viver em Postos Indígenas demarcados pelo Estado, 


\section{Desafios da psicologia no Brasil}

circunstância em que o SPI - Serviço de Proteção ao índio, acabou sendo encarregado em gerenciar os conflitos entre fazendeiros, políticos locais e os índios. Toda essa conjuntura de ocupação de outros grupos populacionais no Estado, findou com a mobilidade das populações indígenas em seus territórios tradicionais, estabelecendo-os em regiões limitadas e consequente dependência desses povos ao poder público. (FAUSTINO, 2006).

Portanto o problema de crescente redução territorial que acometeu os povos indígenas que habitam o Estado do Paraná impactou na produção dos seus viveres, antes organizados por meio de grupos familiares em grandes extensões de terra, o que possibilitava o manejo ecológico do território, o acesso a farta e diversificada alimentação proveniente da caça, pesca e coleta (mel, frutas, pinhões, raízes, plantas). Dentre as práticas Kaingang destaca-se o ritual do kikikoi, que consistia em um rito destinado aos mortos, o qual expressava a cosmovisão e organização societária, que contava com a ingestão de uma bebida fermentada a base de mel, com baixa graduação alcoólica e regulada pelas práticas sociais.

Entretanto na atualidade, a violenta pilhagem de seus territórios resultou na dependência dos organismos estatais, e escassas condições de manutenção de hábitos, inclusive a proibição de prática tradicionais (neste caso do Kiki) e da língua materna. As políticas indigenistas passam a introduzir alambiques, processo este que gerou o consumo de bebidas destiladas de maior graduação alcoólica, a partir do séc. XIX (AMOROSO, 1998). Tais circunstâncias históricas reverberam na problemática do uso e abuso de álcool que aflige o povo Kaingang, traz severas consequências que implicam no aumento da violência e vulnerabilidade, seguido de comportamentos de riscos compreendendo uma das maiores mazelas que acomete grande parte dos indígenas.

No trabalho de campo realizado 2011 levantou-se genéricos dados a respeito da gravidade do consumo de álcool desta população indígenas, situação que os afeta de modo abrangente, bem como dados etnográficos dos condicionantes em uma T.I., e algumas possibilidades de intervenção. Foram constatados que apesar de impactar boa parte dos indivíduos, há uma predominância dos jovens, dificultando ainda mais a relação com a sociedade não indígena, dada a baixa escolaridade, pouco acesso a empregos e renda, concomitante a práticas de assédio, provenientes dos meios de comunicação de massa, ao consumo.

Frente a tal conjuntura tem-se o objetivo de apresentar o tema do uso/abuso de álcool em uma comunidade indígena Kaingang no Paraná, partimos para a análise dos condicionantes históricos e sociais que circunscrevem tal situação, procurando superar visões estereotipadas e preconceituosas 


\section{Desafios da psicologia no Brasil}

muito presentes no imaginário ocidental, que em sua maioria levam a culpabilização individual e exclusão. A ação histórica dos Kaingang também é evidenciada a partir do uso que os caciques e lideranças fazem da escola como um local privilegiado para medidas profiláticas, abertura esta que também permite a atuação do psicólogo e profissionais da saúde e educação para o enfrentamento de tal problemática.

Destarte esta reflexão apresenta uma breve contextualização histórica acerca do processo de desterritorialização do povo Kaingang que impactou diretamente em seus modos de vida, posteriormente demonstramos dados acerca da relação do consumo de álcool com povos indígenas, com considerações de indígenas e não-indígenas imersos na temática, na sequência são descritos dados de campo que evidenciam a condição na T.I. e algumas medidas profiláticas que foram implementadas pelos próprios indígenas a fim de conter tal disseminação, e neste contexto a instituição escolar se mostrou fecunda para tal ação, dada a abrangência e possível ação comunitária.

\section{BREVE HISTÓRICO}

No início do século XX, por meio da Lei no 853/1909, o governo do Paraná decretou uma porção de terras aos índios Kaingang na margem direita do rio Ivaí. O Art. 1ำ da Lei determinara que: "[...]o governo do Estado fará medir e demarcar as áreas de terras reservadas em tempos aos índios, em vários pontos do Estado, por decreto do executivo." (MOTA, 2003, p. 93). A análise desta legislação feita pelo autor, levou-o a concluir que o governo republicano ainda mantinha a ideia de agrupar os índios para "catequizá-los" e "civilizá-los", seguindo os preceitos desde o período imperial e colonial em todo o país.

Tal estudo demonstra que a partir de 1912, diferentes regiões do Paraná passaram a receber diversos grupos de colonizadores estrangeiros, entre esses, alemães, poloneses e ucranianos, que fundaram colônias ou núcleos de povoação. Além dos estrangeiros, os territórios foram sendo ocupados por contingentes de populações não índias oriundas da região de Guarapuava.

Os desdobramentos envolvem um conjunto de conflitos provenientes deste processo, em 1912 o governo do Paraná, mesmo tendo destinado parcelas de terras aos indígenas não as regulamentou efetivamente o que gerou uma série de disputas. Exemplo disso é o "[...]sangrento episódio da guerra de Pitanga envolvendo os Kaingang e outras populações da região". (MOTA, 2003, p.97). A partir deste acontecimento foi elaborado um novo decreto, em 1924, no qual se demarcaram as Terras Indígenas no vale do Ivaí. Contudo, o novo "desenho" dos territórios Kaingang, significou uma diminuição substancial de áreas, anteriormente destinadas aos indígenas. 


\section{Desafios da psicologia no Brasil}

Anos depois os Kaingang desta região sofreram novamente violenta subtração de suas terras quando, em 1949, o governo do Estado firmou com a União um acordo que diminuiu consideravelmente as extensões da grande maioria das áreas indígenas do Estado em benefício de fazendeiros, colonos e imigrantes que haviam já se apropriado destas terras. Sob a justificativa de "reestruturação" das áreas indígenas, esse acordo expropriou cerca de 90\% dos territórios Kaingang demarcados em decretos anteriores.

\footnotetext{
Todos os decretos anteriores foram revogados e as terras indígenas sofreram uma grande redução nas suas extensões. No dia 29 de janeiro de 1951 foi lavrada a escritura que transferiu as terras expropriadas para a Fundação Paranaense de Colonização e Imigração. O SPI ficou responsável pela demarcação das novas áreas que só foram escrituradas em 1955. (MOTA, 2003, p. 103)
}

Conforme Faustino (2006), neste período, grande parte do Paraná já havia sido “colonizado", inclusive o norte do Estado já estava dividido em lotes e cidades "pólos" planejadas pelas companhias colonizadoras de capital estrangeiro. Devido a este "projeto de desenvolvimento", a expansão das fazendas de café que promoveram a devastação da fauna e flora, os Kaingang foram obrigados a residir nos Postos Indígenas demarcados pelo Estado restando ao SPI - Serviço de Proteção ao índio, o papel de administrar os conflitos e atender aos inúmeros problemas surgidos entre.

Nos períodos seguintes teve início a chegada de novos grupos de populações imigrantes (poloneses, italianos, alemães, ucranianos, libaneses) e nacionais (paulistas, mineiros, nordestinos, gaúchos, catarinenses), incentivada pela propaganda de atração para venda, feitas pelas companhias colonizadoras e governo do Estado. Esta entrada em massa de novos grupos populacionais colocou fim à mobilidade das populações indígenas em seus antigos territórios, fixando-os em áreas restritas e institucionalizando a dependência destes povos ao poder público Faustino (2006).

Esta historicidade fica evidente em Mota (2008) em seu livro “As Guerras dos Índios Kaingang” destaca que os solos férteis ocupados pelos Kaingang no séc. XIX eram apresentados a partir da década de 30 como terras desconhecidas e inabitadas, desta forma, muitos relatores e a própria mídia da época considerava o solo fértil um "Vazio Demográfico" que ocupava a região Norte e Central, estimulando assim desconhecidos a se aventurarem em uma terra na qual não, erroneamente se propagava que havia população, no entanto os fatos evidenciados posteriormente foram de intensas trocas, guerras e sequestros. 


\section{Desafios da psicologia no Brasil}

Desde os primeiros anos da chegada dos europeus aos territórios indígenas no sul do Brasil já percebemos as relações interculturais dentro de um gradiente que vai da amizade a e da troca de produtos até o extremo desse gradiente com mortes, raptos e outras formas de violência. A partir das donatarias e do 10 Governo Geral, o processo de ocupação das terras e do aprisionamento indígena para o trabalho nas fazendas faz eclodir a era dos conflitos e da resistência indígena. (MOTA 2009 p. 115.)

No que tange ao uso de bebidas neste contexto, Kohatsu e Oliveira (1999) abordaram ao abordar a temática do alcoolismo em uma Terra Indígena Kaingang de características culturais e linguísticas muito similares, às que observamos e destacam:

(...) a semelhança de outras etnias, a introdução da bebida alcoólica dentro da aldeia do Apucaraninha, tem sua origem na época do contato. (...) bebidas fermentadas eram fabricadas e consumidas durante festas religiosas e profanas, em rituais e comemorações, sendo restritas a estas ocasiões. A introdução de alambiques dentro da reserva foi uma estratégia para dominação e apropriação de terras e bens das comunidades indígenas, e causou mudanças drásticas no modo de beber, gerando os problemas enfrentados na atualidade. (KOHATSU e OLIVEIRA, 1999 p. 191)

\section{COMPREENDENDO O PROBLEMA.}

As conceituações tradicionais acerca do uso/abuso e dependência alcoólica consideraram o consumo de álcool em três formas básicas: uso, abuso e dependência ${ }^{2}$ (Marques e Ribeiro, 2002). Tal conceituação é uma classificação predominantemente médica que demonstra limitações quanto ao termo "alcoolismo" ou alcoolista, sobretudo aplicados na temática indígena, pois não se trata de um fenômeno unicamente médico e individual (embora tenha consequências também individuais) mas trata-se de uma problemática social, cultural e antropológica. (GUIMARÃES, GRUBITS, 2007; SOUZA, GARNELO, 2006; LANGDON, 2005).

No âmbito da Medicina, o alcoolismo apresenta-se como uma soma de problemas relacionados ao consumo excessivo e prolongado do álcool ou ainda um vício de ingestão excessiva e regular de bebidas alcoólicas com consequências decorrentes. Não tendo uma definição simples ou absoluta, o alcoolismo pode ser compreendido como um conjunto de diagnósticos. Nesse conjunto existe a dependência, a abstinência, o abuso (uso excessivo, porém não continuado) e a intoxicação por álcool (embriaguez) (SOUZA; GARNELO, 2006). 


\section{Desafios da psicologia no Brasil}

Em uma análise para além da individualização do problema, consideramos que nem toda a ingestão de bebida alcoólica por si é prejudicial, com base no estudo de Langdon (2005) existem diferentes modos de beber, e nem todos estão diretamente relacionados com danos à saúde e/ou comportamentos negativos, no caso dos povos indígenas existe uma infinidade de rituais que, a partir do uso de bebidas fermentadas, potencializam as relações sociais, no caso dos índios Kaingang este fato se demonstrava no ritual Kiki-koi.

A partir de um enfoque antropológico, diferentemente da medicina e da psicologia clássica, o alcoolismo não pode ser compreendido como algo universal, mas sim consequência das relações socioculturais, nas palavras de Langdon (2005, p. 104)

As conseqüências desta perspectiva são múltiplas: exige que reexaminemos nosso entendimento de alcoolismo como doença; que reconheçamos os diversos estilos de beber entre os diferentes povos indígenas e, também, entre os vários grupos de um mesmo povo; e, que as estratégias para contornar o problema sejam baseadas na participação da comunidade e em todas as fases de pesquisa e ações práticas.

Portanto para compreendermos a situação em uma perspectiva ampla, as políticas pública da época também foram importantes, durante os anos de 1999 -2010 vigorou a FUNASA - Fundação Nacional da Saúde, esta foi responsável pela saúde Indígena, tal instituição se fez presente com postos de Saúde nas T.I. .Nos anos de 2001-2006 foram realizadas conferências sobre a temática do alcoolismo, nas quais as propostas implementavam a proibição da entrada de bebida alcoólica nas aldeias e conscientização dos malefícios da ingestão de álcool, dado que o suicídio e o alcoolismo são considerados as maiores moléstias que acometem a população indígena.

No período de vigência da FUNASA (1999-2011), além das conferências em âmbito nacional, não foram identificados tratamentos ou medida preventivas específicas junto a população indígena, sendo que, as alternativas encontradas pelo corpo técnico são escassas. Em especial na T.I. analisada, os casos são mais agudos eram encaminhados para os CAPS-AD (Centro de Atenção Psicossocial Anti-Drogas), pois nas cidades que envolvem as aldeias não foram identificadas nenhuma forma de tratamento e/ou intervenção.

Deste modo os encaminhamentos eram realizados para as cidades Pólos no Estado, como Londrina (Região-Norte), Palmas (Região-Sul), Guarapuava (Região-Central), havendo uma grande resistência por parte dos indígenas internados em irem ou permanecerem nestes. Na época questões observadas referente a esta "resistência" ao tratamento remetia-se para a própria cultura (não querem se afastar 


\section{Desafios da psicologia no Brasil}

da comunidade onde se sentem protegidos), além das dificuldades inerentes do tratamento nãoindígena (principalmente o preconceito ou julgamentos de valor), dificuldades lingüísticas, hábitos alimentares dentre outros estranhamentos presentes na medicina tradicional somavam-se ao rol de vicissitudes encontradas pelos indígenas.

Um dos exemplos mais agudos do despreparo da sociedade envolvente foi o trágico caso de "Dingo" ou "Yuno" (apelidos pelos quais este indígena era conhecido em sua aldeia). Por transitar sem documentos de identificação, foi encaminhado ao Hospital Psiquiátrico de Maringá-PR no ano de 2010, quando encontrado estava em condição transeunte e em embriaguez pelas ruas e avenidas movimentadas de Maringá-PR. O tratamento e a identificação foram muito difíceis principalmente pela barreira lingüística, e só fora conseguida após intervenção de uma estudante indígena de enfermagem da Universidade Estadual de Maringá, pertencente a etnia Kaingang. Portanto há um conjunto de fatores que circunscrevem a complexidade do tema, sendo claro que explicações monocausais não permitem a apreensão e o desafio histórico posto aos povos e profissionais da área.

\section{ETNOGRAFIA DO PROBLEMA.}

No âmbito dos dois projetos de pesquisa mencionados, por meio de observações e entrevistas abertas com as comunidades, caciques (lideranças políticas) e profissionais da Saúde, um conjunto de fatores que sintetizam parcialmente a relação de consumo de álcool nas Terras Indígenas no Paraná.

“Para você entender bem ... o álcool é o crack do índio." (Liderança Guarani em relato a partir de uma conversa oportunizada no II Campeonato de Futebol Indígena no dia 23 de Abril de 2011).

"Aqui é bom trabalhar, mas é difícil, eles bebem e geralmente os homens não pedem ajuda. Eles são ariscos mesmo sabe? não querem pedir ajuda. perdem o controle com a bebida. vão bebendo, bebendo...até cair, daí os encaminhamentos são difíceis, além de haver poucas vagas nas regionais, eles tem um choque cultural muito grande." (Enfermeira não-indígena da FUNASA, de uma Terra localizada na região centro-norte do Estado coletado em 24/05/2010)

"Sabe... aqui na aldeia temos um problema grave, é muito grande e espalhada, temos muita influência do branco aqui...você deve saber né? O Kiki (bebida fermentada de mel que deu nome ao ritual dos mortos Kaingang, eles já bebiam antes de entrar em contato com o branco, só que agora é pior, eles bebem de tudo, cerveja... inclusive muita pinga." (Relato de enfermeira da T.I. em questão coletado em 05/02/2011) 
"Não liga não! Estou bebendo só um pouquinho só, é que faz parte da minha cultura!" Relato de um indígena Kaingang em estado eufórico devido ao uso de álcool, coletado no II Campeonato de Futebol Indígena, ao referir-se a um "trago", termo utilizado na língua fog (dos brancos) para designar bebidas (geralmente destiladas). A estas bebidas os Kaingang usam o termo goiô koreg (goiô significa água e koreg tudo que é ruim para os Kaingang). (UEM, Maringá, II Campeonato de Futebol Indígena dia 23/03/2010)

Além desses depoimentos, coletados em diferentes espaços e situações, os dados apresentados a seguir foram registrados em nosso Caderno de Campo pessoal elaborado ao longo do ano de 2011, encontrando-se assim em caráter descritivo, e não em forma de entrevista como os relatos acima expostos, e desta maneira manteremos o anonimato dos envolvidos e da cidade em questão:

Nos dias 05/04/2011 observamos a presença de indígenas embriagados pelas ruas de um município em questão no Estado do Paraná adjacente à Terra Indígena em que fazíamos a pesquisa de campo. Havia muitos indígenas notoriamente embriagados e caídos ao longo da estrada. Geralmente bebem cachaça e destilados misturados à Vermout, Pinga, Vodka, Groselha, suco de saquinho, guaraná, ou tubaína. Em um recipiente só (geralmente garrafa PET), com esse tipo de bebida, passam o dia todo alcoolizados e notoriamente desprovidos de coordenação motora. Muitos exalam cheiro muito forte de pinga, mas diferente do cheiro dos alcoolistas não índios, um cheiro um pouco mais ácido e doce. Não é possível saber se o odor diferenciado é decorrente da diferente metabolização ou das misturas." (CADERNO DE CAMPO PESSOAL, 2011 s. p.)

Outro excerto que destacamos:

Na volta do primeiro dia de trabalho, quando íamos ao hotel, vimos mais alguns indígenas embriagados pelas ruas da cidade. Observamos que algumas casas, logo na entrada da T.I., servem de bares. Embora estivessem fechadas, os vizinhos informaram que ali se vende cerveja Nos recipientes de lixo da aldeia há muitas garrafas de destilados dos mais diversos, entre eles pingas, conhaques e batidas. Destas batidas, a maioria é de garrafa de plástico, pelo rótulo observamos ser das mais fortes e adoçadas. A suposição é de que, possivelmente, servem para disfarçar o gosto ácido das pingas normais. (DIÁRIO DE CAMPO PESSOAL, 2011 s. p.)

Quanto à catalogação de bebidas encontradas em campo, fora possível destacar Conhaques, Aguardentes em geral, Cervejas de Latinha e de Garrafa, Garrafas de Vodca, Vermout. Havendo assim clara predominância de uma marca em específico (T. B.), de uma destilaria do próprio município do entorno, com uma graduação alcoólica de 29 GLo .Sobre o consumo de álcool no interior da aldeia:

$\mathrm{Na}$ tarde do dia seguinte, fomos a algumas casas que acompanham o sentido do rio e das Araucárias, então vi mais alguns indígenas embriagados. Bebiam 


\section{Desafios da psicologia no Brasil}

latinhas de cerveja e corotinhos (garrafas pequenas e atarracadas de pinga) dos quais geralmente escondiam quando aparecíamos nas casas, mas desta vez haviam me chamado para conversar, estavam nas proximidades do campo de futebol, mas infelizmente não consegui aplicar o questionário ${ }^{4}$, primeiramente por que estavam em estado de embriaguez aguda e acrescido a isto, meu entendimento da língua indígena deixa muito a desejar. Quando o motorista chegou fomos embora. Quase atropelamos um indígena que estava dormindo no mato, ao lado da estrada que liga a aldeia à cidade, com os pés para fora. Já caia o dia e muitos estavam embriagados ao longo da estrada. Registrei uns 30 homens (entre jovens, adultos e crianças) perambulando pela estrada que nos pediram carona e dinheiro. DIÁRIO DE CAMPO PESSOAL, 2011 s. p.

Como destacado por Oliveira (2001) o consumo alcoólico não se restringe aos jovens, maiores ou menores de idade, estando presente na aldeia, abrange homens e mulheres de todas as faixas etárias:

(...) Assim fizemos mais uns questionários, fomos no final indagados, eu disse Bom Dia, Ele - 'Rapé! Nós temos nossa língua! Vocês as suas! E eu a minha!'. Estava notoriamente bravo e me fitava com seu hálito etílico característico (...) Conversamos um pouco sem muito sucesso, muitos indígenas estavam bebendo mas alguns chamavam mais a atenção e notoriamente faziam questão de me cumprimentar, ao longo da estrada vi um jovem de seus 15 anos que estava alcoolizado desde o dia anterior, mas nessa manhã ele não agüentava mais caminhar, estava de cócoras na estrada de terra, enquanto cambaleava conversava com seu pai e sua mãe, que segundo Intérprete que nos acompanhou, diziam para ele levantar e ir para casa e parar de beber, mas ele insistentemente mantinha a garrafa de Corotinho em mãos, até que seu pai também retirou uma outra garrafa da jaqueta, o jovem animou-se e com mais outro, entraram na mata, na volta para o almoço pude ver o Jovem que estava de cócoras na estrada, agora estava caído em um caminho na mata. (...) Também havia um menino de aparência de uns 12 anos que estava com o hálito etílico jogando bola com os mais novos, aproximei-me pelo futebol e comecei a brincar e tirar fotos das crianças, quando este jovem se aproximou pude sentir seu hálito etílico, depois, juntando os fatos notei que ele estava na casa de um indígena que faz artesanato pois sua mulher o abandonou (segundo seus próprios relatos) e muitos homens estavam lá bebendo, entre eles este jovem rapaz. DIÁRIO DE CAMPO PESSOAL, 2011 s. p.

Sem solução para a questão, os caciques buscaram alternativas, na época a primeira consistiu na não proibição de ingestão de bebida na aldeia, pois as lideranças anteriores haviam instaurado o modelo proibicionista na T.I. A alegação do cacique na época foi que tal medida havia sido discutida com a comunidade e aplicada para evitar que perambulem pelas ruas e desta forma sejam atropelados, outra alegação da comunidade foi que ao permitir essa prática, se evitaria os conflitos e constrangimentos com os não-índios da e na cidade.

No relato abaixo evidencia-se algumas diretrizes próprias tomadas pelas lideranças frente ao consumo de bebida e aos divórcios constantes. 


\section{Desafios da psicologia no Brasil}

(...) anteriormente, quando o outro era cacique havia tipo de uma ditadura. Os homens não podiam namorar, as mulheres não podiam sair de casa, mas hoje ele já liberou todos. Liberou para beber também, e tudo que eles quiserem... mas antes tem que falar e avisar os caciques ou outras lideranças. DIÁRIO DE CAMPO PESSOAL, 2011 s. p.

Esta primeira medida da "liberação" trouxe certos resultados na época, pois os problemas eram resolvidos pelas lideranças de modo interno, evitou-se atropelamentos que eram frequentes, em linha gerais, aproximou-se o problema para a resolução, situação esta que permitiu novos desdobramentos.

\section{MODOS DE BEBER}

Os estudos de Oliveira (2001) apontaram elementos que contribuíram na investigação entre bebidas alcoólicas e os Kaingang. A autora destacou que, em cada cultura o uso alcoólico varia quantitativamente e qualitativamente. No caso dos Kaingang afirmou que há uma clara ruptura do sentido, ou seja, inicialmente a bebida utilizada por estes povos era o Kiki fermentado de mel, geralmente servido em um grande cocho, na ocasião era celebrada a festa dos mortos. Sobre a confecção das bebidas fermentadas o relato do viajante Koenigswald ${ }^{5}$ em 1908 é deveras elucidativo e coaduna com a transformação sócio histórica que analisamos:

Os Coroados amam bebidas embriagantes. As muitas festas que celebram são impensáveis sem bebidas alcoólicas. Para sua fabricação, trituram o milho num tipo de pilão e o preparam com água morna em recipientes de madeira, onde permanece por vários dias, sendo remexido periodicamente, submetido a forte fermentação. Com o término da fermentação, a bebida, denominada Goya-fá, está pronta para ser consumida. Para dar palatabilidade a essa bebida azeda e amarga, os índios a misturam ao mel aromático das abelhas silvestres, do qual resulta o Quequi, bebida adocicada, de forte poder embriagante. Uma terceira bebida, Goya-kupri, é obtida também do milho, que é hidratado, mastigado pelas mulheres e levado à fermentação em recipientes de barro, tornando-se consumível após 24 horas, sendo de paladar bastante agradável. (KOENIGSWALD, 1908, p.45)

A descrição acima indica a confecção da bebida fermentada, medida esta realizada antecedente da redução territorial, havia a execução do principal ritual Kaingang, no qual participavam as metades clânicas (TOMMASINO, 1995), presença de diversos rezadores Kuiãs e comunidade, as rezas se destinavam para encaminhar os mortos se estendiam horas e dias até que o Kiki fosse todo consumido em volta ao fogo. 


\section{Desafios da psicologia no Brasil}

Estendendo nosso estudo sobre outra etnia indígena numerosa, é possível identificar um fato muito similar ocorrido com os Bororo (pertencentes ao mesmo tronco linguístico Jê) do estado do Mato Grosso do Sul, sendo o álcool uma clara forma de domínio por parte da sociedade envolvente:

Os Bororo 'se entregaram' não só no sentido militar, mas também amorosamente, no sentido relacional, do vínculo que vai estabelecer-se com a sociedade dominante daí por diante. Eles acreditaram, fizeram um voto de confiança nas promessas e nas alianças que, sabemos, foram todas abandonadas posteriormente. A 'pacificação' conseguida nos Bororo pelas autoridades civís, militares e religiosas (processo que os índios chamam mais honestamente de "amansamento"), seguida do desapontamento, foi tudo tão maciço (e cronologicamente associado ao álcool), que produz uma mudança permanente na própria personalidade étnica ou modal (cf. Devereux, 1972), aparecendo características de dependência extrema, exigência de provisão e atenção, e ressentimento profundo.(QUILES 1999 p. 182)

E ainda no caso dos Bororo, Quiles (1999, p.17) destaca que o consumo de álcool promoveu uma condição de passividade e domínio em na relação com a sociedade envolvente, e com o uso do álcool aguça-se o que o próprio autor chamaria de recuperação da força perdida, ou seja, fatos esquecidos ou negligenciados pelo Bororo são relembrados com o uso alcoólico, como destaca:

E aí temos outra função do álcool para a personalidade Bororo atual: através dele, recuperam a força perdida, a agressividade para se defender (ou se vingar). São inúmeros os testemunhos de que Bororo bebe para "ganhar coragem", pois a expressão "falta de coragem" abrange tudo o que queremos significar como a repressão de toda agressividade. (QUILES, 1999, p. 184)

Observamos assim que ambas etnias tem histórias muito similares na inserção de alambiques nas aldeias como forma de controle. Diferentemente do caso dos Bororo, os Kaingang possuem uma beligerância firmada nos anos de relação com os fog, não-índios. São vastos os relatos de pioneiros em Mota (2009), que muito sofreram com a resistência que os Kaingang empreenderam para defender seus territórios. Já Oliveira (2001) traz a luz um ocorrido que nos chamou atenção:

Em 1990, um triste retrato desta situação foi descrita por eles sobre a ocorrência de uma briga entre um grupo de homens e mulheres Kaingáng que bebiam numa venda acerca da aldeia. Depois de se embriagarem houve um desentendimento que culminou com a morte de dois Kaingáng a golpes de foice. Vale lembrar que a forma utilizada para tal fim foi exatamente a mesma que usavam tradicionalmente quando guerreavam com seus inimigos. (OLIVEIRA 2001 p.. 118) 


\section{Desafios da psicologia no Brasil}

Oliveira (2001) apresentou a questão beligerante, bem como a ingestão de álcool como fator agravante da violência:

Parece portanto, que formas de violência entre os Kaingáng, mesmo tendo características ligadas as conquistas, tem raízes em sua tradição de tempos imemoriais. A agressividade e violência eram práticas estimuladas entre os Kaingáng para se tornarem guerreiros. Atualmente a violência é transportada para um contexto onde o alcoolismo se impõe. Parece crer que assim como a (re) organização e reelaboração de práticas tradicionais como festas, danças, jogos, etc., a violência e agressividade também foram reorganizados e hoje são inseridos no âmbito doméstico e social e não são mais usadas as guerras e sim decorrentes da ingestão de bebidas alcóolicas. (OLIVEIRA 2001 p. 121)

Destaca também uma considerável dimensão lúdica proporcionada pelo uso de bebidas, como também pudemos notar sua maior incidência em bailes e eventos festivos.

É preciso também refletir sobre o lado lúdico que a bebida proporciona ou proporcionou a eles, conforme já mencionamos desde o passado antigo até a atualidade. Não podemos desconsiderar esta realidade ainda que pese toda a problemática e transtornos causados pela bebida. (OLIVEIRA 2001 p. 122)

Em decorrência dos estudos existentes sobre o tema e das observações feitas, pode-se perceber a gravidade, profundidade e complexidade do uso de álcool em comunidades indígenas. Os próprios caciques, embora não verbalizassem, por possivelmente quererem preservar a comunidade contra o preconceito do "alcoolismo", tem esta compreensão, uma vez que buscaram a relação estabelecida com a Universidade como uma saída sem que esta seja representada apenas pela coerção, proibição e castigos.

\section{MEDIDAS PROFILÁTICAS}

No que se refere às medidas preventivas, podemos destacar que na ocasião as lideranças estavam buscando uma maneira de intervir, tentaram parcerias com a prefeitura (muitas vezes sem sucesso), equipe pedagógica das escolas, professores, profissionais de saúde e, e neste caso com a Universidade. As observações e registros possibilitam destacar algumas medidas tomadas, dentre elas tanto a liberação moderada como a repressão nos casos de abuso, "exagero" no consumo de álcool, brigas, espancamentos etc. Todas as aldeias Kaingang tem um espaço, uma construção muito rudimentar de alvenaria ou madeira, chamada de cadeia (sem banheiros, camas, cobertores ou qualquer outra 


\section{Desafios da psicologia no Brasil}

estrutura, geralmente serve de morada de 2 a 3 dias, de acordo com o grau da infração cometida pelo indígena). Observamos que estas cadeias são demasiadamente próximas da escola, situando-se no centro da aldeia. Tal fato fora justificado por uma liderança Kaingang, quando perguntada, como sendo importante para que as crianças aprendam o que não se deve fazer.

Em uma das Terras, um professor indígena que ingerira grande quantidade de bebida, espancou sua esposa e por isso foi preso pela polícia indígena (um tipo de liderança de apoio ao cacique), a mando do cacique que é seu tio. No dia seguinte, no horário de sua aula foi solto e dirigiu-se diretamente à escola para ministrar sua aula, retornando depois para terminar de cumprir sua "pena".

A nosso ver, estes fatos têm significados profundos que devem ser analisados cuidadosamente, concomitantes com o estudo da cultura Kaingang para que se possa ter uma melhor compreensão sobre o significado do alto índice de alcoolismo entre as comunidades.

Entretanto, uma medida observada fora uma intervenção direta realizada em uma das maiores aldeias do Paraná. A pedido do cacique foram chamados filhos, esposas e pais de alcoolistas para que assim fossem contar suas vivências na escola. Acredita-se que o impacto proveniente dos relatos dramáticos, diretamente sobre os mais jovens poderá coibir futuros bebedores.

A escola se mostra muito propícia em desenvolver medidas preventivas, conforme a descrita acima, podemos notar a manutenção da dinâmica Kaingang na escola, como destaca Faustino (2010):

Essa educação tradicional é responsabilidade da comunidade e disseminada através da oralidade, de modo coletivo. A educação está pautada no fazer diário, e há aplicabilidade nessa aquisição de conhecimento, como o trabalho na roça, o trabalho em casa, o trabalho com o artesanato, o cuidar dos irmãos mais novos, ou o respeitar uma orientação dada pelos adultos. (FAUSTINO 2010 p. 218)

Mesmo havendo possibilidade preventiva, ainda faz-se necessária a atenção para medidas que ocorram na escola, dado que mesmo muitas vezes sendo estruturadas, ainda apresentam carências como a defasagem na formação de professores, de material didático adequado, de projetos coletivos que contem com o envolvimento da liderança indígena, equipe pedagógica, professores e comunidade de forma geral.

Ainda não há entre os Kaingang no Paraná a compreensão plena sobre o papel da aprendizagem escolar, da aquisição do conhecimento sistematizado como uma forma de desenvolver funções intelectuais superiores (memória, percepção, sentimentos, capacidade de análise e síntese), pois essas, entre o grupo, são desenvolvidas por meio de outras estratégias. (FAUSTINO 2010 p. 218) 


\section{Desafios da psicologia no Brasil}

\section{CONSIDERAÇÕES FINAIS}

Apesar de confinados em pequenas áreas, a literatura sobre o tema é unânime em evidenciar que os Kaingang nem se "aculturaram" como previa o projeto do Estado e nem foram subsumidos ou integrados pela sociedade envolvente. Ao contrário, se mantiveram como populações diferenciadas, conseguiram preservar a língua materna (todos os Kaingang no Paraná falam ou conhecem com profundidade sua língua materna. Em muitas Terras, a usam em todas as situações cotidianas e, mesmo sendo bilíngües, só usam o português nos contatos com não-índios) e parte de suas tradições. Em decorrência de algumas políticas públicas, tais como o Bolsa Família, Leite das Crianças, Casa da Família Indígena e outras, a população indígena do Estado voltou a apresentar grande crescimento demográfico, adquiriram maior visibilidade e passaram a recolocar a questão da terra (a perda de seus territórios), da saúde e da educação como pontos principais de suas lutas.

Em nossas observações, evidenciam-se alguns elementos, primeiramente e de maneira óbvia o alcoolismo se mostra como problema grave, que possivelmente veio se agravando desde a implementação de alambiques e posteriormente frente uma certa negligência por parte do poder público, da FUNASA que não interveio na questão de forma eficiente.

Ao longo da história, os Kaingang resistiram e foram agentes de sua história. Incorporam muitos elementos em contato com a cultura dos colonizadores, descartaram muitos porém o alcoolismo parece ter sido incorporado fortemente às tradições e, desta forma, representam um grande problema social para as aldeias. Assim, mostram-se imperativos estudos que transitem nas mais diversas áreas do conhecimento. Dada a complexidade da temática, somente uma abordagem crítica e abrangente poderá contribuir para a compreensão e transformação desta e de tantas outras patologias que acometem principalmente as populações vulneráveis economicamente como é o caso dos indígenas no Paraná.

Em relação à escola, independentemente do papel que assume na dinâmica social Kaingang, é instituição privilegiada para a apropriação do legado cultural e historicamente acumulado pela humanidade, sendo assim, torna-se um direito de todos, sejam deficientes, etnicamente "desfavorecidos", e também se mostra para as comunidades, como a pesquisa permitiu-nos observar, como um eixo confiável para o desenvolvimento de medidas preventivas consideráveis em relação ao alcoolismo. 


\section{Desafios da psicologia no Brasil}

\section{REFERENCIAS BIBLIOGRÁFICAS}

Benites, A. As narrativas de representantes indígenas sobre o uso de bebidas

alcoólicas dentro das áreas indígenas.In: Seminário sobre alcoolismo e DST / Aids

entre os povos indígenas. 2001.

Blog Dependência Química, UNIAD (unidade de pesquisa em álcool e drogas) disponível em<http://www.uniad.org.br/index.php?option=com_content\&view=article\&id=3976:sem-falarportugues-indigena-passa-um-ano-internado-em-hospital-psiquiatrico\&catid=29:dependenciaquimica-noticias\&Itemid=94> Acessado em 12/05/2011

Faustino, R. C. (2010) Aprendizagem escolar entre os Kaingang no estado do Paraná: questões sobre língua, alfabetização e letramento. Práxis Educativa (Brasil), vol. 5, núm. pp. 213-219

Mota, L. T.(2009) As guerras dos índios kaingang: a história épica dos índios kaingang no paraná (17691924). 2a ed revisada e ampliada. Maringá : EDUEM.

Mota, L.T. et al (2000). As cidades e os povos indígenas: mitologias e visões. Maringá: EDUEM.

Mota, L. T. (2000) As colônias indígenas no Paraná provincial. Curitiba: Aos Quatro Ventos.

MOTA, L.T. et al (2003) . Diagnóstico etno-ambiental da Terra Indígena Ivaí - PR. Programa Interdisciplinar de Estudos de Populações. Maringá/UEM/LAAE.

Oliveira, M \& Kohatsu, M.(1999) - Relatório de atividades do programa de atendimento aos kaingáng do P.I.Apucaraninha/ano de 1999. Londrina (PR) Relatório consolidado da 1a Oficina Macrorregional de Estratégias de Prevenção e Controle das DST/AIDS para as Populações Indígenas das Regiões Sul Sudeste e Mato Grosso do Sul. Londrina.

Oliveira, M. (2001). Alcoolismo entre os kaingáng: do sagrado e lúdico à dependência.seminário sobre alcoolismo e DST/AIDS entre os povos indígenas.Brasília: Ministério da Saúde/ Secretaria de Políticas de Saúde/ Coordenação Nacional de DST e AIDS. pp.99-125.

Quiles M. L.(1999) A mansidão de fogo: aspectos etnopsicológicos entre o comportamento alcoólico entre os bororo. trabalho apresentado no seminário sobre alcoolismo e vulnerabilidade às DST/AIDS entre os Povos Indígenas. Londrina.

Souza, R. L.(2004) O uso de drogas e tabacos em ritos religiosos e na sociedade brasileira:uma análise comparativa Sæculum - REVISTA DE HISTÓRIA [11]; João Pessoa, ago./ dez.

Tommazino, K. (1995) A história dos Kaingang da Bacia do Tibagi: uma sociedade Jê Meridional em movimento. Tese de Doutorado. Departamento de Antropologia. Universidade de São Paulo. São Paulo. 


\section{Desafios da psicologia no Brasil}

\section{NOTAS}

\section{Notas 1}

Juntamente com os Xokleng, em Santa Catarina, constituem o chamado tronco linguístico Jê Meridional ou Jê do Sul.

\section{Nota 2}

Sendo que a primeira se caracteriza pela ingestão de uma pequena quantidade de álcool na qual não trará comportamentos de risco, mas que impreterivelmente, trará algum dano/prejuízo ao consumidor, seja âmbito biológico, social ou psicológico. Já no Abuso há um claro déficit cognitivo caracterizado por estados de Euforia e conseqüente Depressão, geralmente após algumas horas de uso, em momentos de Euforia o comportamento agressivo pode ser exacerbado diminuindo consideravelmente a tolerância a frustrações trazendo assim muitos danos sociais como acidentes de carro e brigas. No caso da dependência alcoólica, $90 \%$ a $70 \%$ dos dependentes apresentam a SAA (Síndrome de Abstinência Alcoólica), sendo que para se caracterizar a dependência há necessário que haja um enquadramento específico no CID e DSM.

\section{Nota 3}

No ano de 2010 a FUNASA deixa de atender os indígenas, passando a ser gerida pela SESAI, Secretaria Especial de Saúde Indígena.

\section{Nota 4}

Questionário este sobre a política do Bolsa Família.

\section{Nota 5}

Texto traduzido por Werner Paulo Oesterle intitulado Os Coroados no sul do Brasil. 


\section{Capítulo 68}

\section{ALTERAÇÕES NEUROPSICOLÓGICAS CAUSADAS PELA INGESTÃO DO CHÁ DA AYAHUASCA E A OBSERVAÇÃO DO EFEITO EM UM BEBÊ}

DOI: $10.37423 / 200300380$

Gésica Borges Bergamini (Neuropsicóloga, Mestra em Psicologia). gpensemagro@gmail.com

Dalila Maitê Rosà Sena (Pedagoga, Mestra em Administração e Gestão Educacional). dalila_maite@hotmail.com

Resump: o chá conhẹcido como Ayahuasca, é feito com a (utilização do cipó Banisteriopsiscaapi, da família Malpighiaceae, nativa da Amazộnia e dos Andes-e também a planta da família Rubiaceae, PsycotriaViridis. Foi realizada revisão de literatura com objetivo de compreender as alterações neuropsicólógicas calusadas devido ao uso da Ayahuasca. Para tal, este estudo analisou 18 pesquisas experpimentąis e 7 relatos literários e/ou de experiências. Tendo como critério de inclusăo os estudos que foram realizados no Brasil e com autorização da União do Vegetal - ordem religipsa que possui autorização para distribuiçấo, èstudo e uso do chá no Brasil. Os efeitos observadós na exposição à ayahuasca podem ser exemplificados na área somática por náuseas, vômitos, tremores, tøńturas, debilidade, contratura muscular, hiperreflexia, dores generalizadas, taquicardia. Nœ plano psíquico, verificam-se profundas e rápidas alteraçŏes dos estados emocionais: p indivíduo vai da depressãoà-euforia em poucos segundos. Pânico, apatia, alteraçồes na memória e wo pensamento, despersonalização e hipersugestabitidade, medo, insônia e señsaçấo de morte iminente-também podem ser observados.

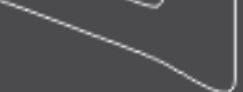




\section{Desafios da psicologia no Brasil}

No plano perceptivo-sensorial observam-se distorções de tempo e espaço, estranhas sensações corporais, alterações nas percepções de formas, cores, sons, sinestesias e alucinações com alterações auditivas, olfativas e visuais. A ingestão do chá da ayahuasca provoca estados alterados de consciência, alterando as emoções e a percepção da realidade. Além disso, as mudanças na percepção podem gerar crises decorrentes dos conteúdos que o indivíduo possui como: história pessoal, experiências, grau de vulnerabilidade física e emocional. Nesta pesquisa apresentaremos a alteração comportamental observada em um bebê sob o efeito da ayahuasca, filho de pais de religião oaskeira, a mãe fez uso da ayahuasca durante toda a gestação, inclusive no momento do parto.

Palavras-Chave: Ayahuasca, Alterações Neuropsicológicas, Amazônia, Vegetal. 


\section{Desafios da psicologia no Brasil}

\section{INTRODUÇÃO}

A ayahuasca é uma bebida psicoativa originalmente utilizada em rituais de tribos indígenas da região amazônica. A ayahuasca consiste, geralmente, na cocção de duas plantas: o caule da Banisteriopsiscaapi e as folhas da Psychotriaviridis (Callaway \& Grob, 1998; Santos et al., 2006). O consumo da bebida oferece aumento nas concentrações de serotonina e torna biodisponível a DMT por via oral (o DMT é o componente usual da ayahuasca), causando ação alucinógena (Callaway \& Grob, 1998). O tempo de início dos efeitos do chá é de aproximadamente uma hora após a ingestão. Esses efeitos duram aproximadamente quatro horas (Brito, 2004).

As concentrações de alcaloides na bebida ayahuasca são maiores que as concentrações encontradas nas plantas utilizadas para seu preparo. As diferenças nas concentrações e proporções dos alcaloides encontrados nos chás de ayahuasca estão provavelmente relacionadas com o método de preparação, a quantidade e proporção das plantas empregadas em seu preparo (Mckenna, 2004).

Em estudo observou-se os efeitos subjetivos, através da Escala de HRS (Hallucinogen Rating Scale), que permite medir níveis de alucinação. A duração desses efeitos foi coincidente com os níveis de alcaloides presentes no plasma, variando entre visualização de imagens coloridas com olhos fechados, modificação dos processos perceptivos, cognitivos e afetivos (Callaway et al., 1999).

Os efeitos observados na exposição à ayahuasca podem ser exemplificados na área somática por náuseas, vômitos, tremores, tonturas, debilidade, contratura muscular, hiperreflexia, dores generalizadas, taquicardia (Callaway \& Grob, 1998). No plano psíquico, verificam-se profundas e rápidas alterações dos estados emocionais: o indivíduo vai da depressão à euforia em poucos segundos. Pânico, apatia, alterações na memória e no pensamento, despersonalização e hipersugestabilidade, medo, insônia e sensação de morte iminente também podem ser observados. No plano perceptivo-sensorial observam-se distorções de tempo e espaço, estranhas sensações corporais, alterações nas percepções de formas, cores, sons, sinestesias e alucinações com alterações auditivas, olfativas e visuais (Shannon, 2003).

Esse estudo tem como finalidade apresentar uma síntese dos principais aspectos médico-científicos do chá ayahuasca relacionado à saúde humana, apresentou-se consenso na literatura de que a atividade psicoativa primária da bebida decorra da atuação sinérgica dos alcalóides das duas plantas, 


\section{Desafios da psicologia no Brasil}

na qual o efeito de inibição reversível sobre a MAO-A das betacarbolinas permite que a DMT seja ativa por via oral. (Castello \& Brito 1999; Mckenna 1984; Rivier \& Lindgren, 1972).

Os efeitos de ordem psíquica afetam as percepções da realidade, alterando assim as sensações vivenciadas. Alguns efeitos são descritos sendo: alteração na percepção da passagem do tempo, medo de perda do controle e do contato com a realidade, alterações na expressão emocional variando do êxtase ao desespero, sensação de medo exacerbado, alterações perceptuais onde alucinações e sinestesias são comuns, "insights", surtos psicóticos, inefabilidade e sensação da alma se desprendendo do corpo bem como contato com locais e seres sobrenaturais. (DE SOUZA, 2011)

O estado psicótico ou surto psicótico possuem fatores genéticos que podem ser desencadeados pela utilização do chá, visto que o sujeito irá experienciar diversas sensações de cunho psicodélico, podendo provocar alucinações, êxtase, narcose onírica, visões do próprio self, entre outros. Contudo, os efeitos físicos provocados por esta droga são: vômitos, náuseas, aumentos leves da pressão arterial, midríase, contração motora, sonolência entre outros (DE SOUZA, 2011).

\section{METODOLOGIA}

Tratou-se de uma pesquisa de revisão bibliográfica cuja trajetória metodológica percorrida foi a de leituras exploratórias. Para a concretização do levantamento bibliográfico realizou-se leituras e compreensões da literatura já existente presente em livros do acervo pessoal e também buscas em bases de indexação de resumos de revistas e periódicos eletrônicos consideradas referências na produção de estudos na área da saúde, como Scientific Electronic Library Online (SCIELO) e Literatura Latino-Americana e do Caribe em Ciências da Saúde (LILACS), usando como descritores diversas combinações de palavras chaves como: efeitos neurobiológicos, alterações psicológicas, Amazônia.

Após a classificação do material bibliográfico, foi realizada a leitura exploratória, obtendo assim uma visão global do material, considerando o interesse ou não à pesquisa. Os estudos selecionados permitiram definir qual material bibliográfico realmente era relevante à pesquisa, sendo então selecionados e citados no transcorrer da pesquisa.

\section{O USO DA AYAHUASCA NO BRASIL}

O Brasil é o único país onde se desenvolveu o uso ritualístico em populações não-indígenas, centrados em rituais religiosos que buscam uma forma de facilitação do autoconhecimento e introspecção. 0 


\section{Desafios da psicologia no Brasil}

uso da ayahuasca é amparado por lei, foi reconhecido como pratica legal no Brasil pelo Conselho Nacional Antidrogas, em Resolução de 04 de novembro de 2004 (Pires et al, 2010).

Santo Daime, a União do Vegetal (UVD) e a Barquinha são os grupos que mais se destacam por fazerem ingestão da ayahuasca (Labate, 2004). O culto daimista foi um marco rompedor da antiga tradição de consumo da bebida sem contexto por parte das tribos indígenas para uma nova forma, contextualizada e bem definida, com objetivos e regras estipuladas.

McKenna (2004) realizou levantamento de referências de estudos com o chá e concluiu que a ayahuasca possui características que indicam que ela pode apresentar potencial terapêutico: o uso da mesma por tribos remotas a um período de tempo bastante longo e também o fato de apresentar histórico positivo de recuperação no tratamento de indivíduos usuários de álcool e outras substancias de abuso.

\subsection{ALTERAÇÕES NEUROPSICOLÓGICAS}

A ingestão do chá da ayahuasca provoca estados alterados de consciência, alterando as emoções e a percepção da realidade. Além disso, as mudanças na percepção podem gerar crises decorrentes dos conteúdos que o indivíduo possui como: história pessoal, experiências, grau de vulnerabilidade física e emocional (DE SOUZA, 2011).

Doering-Silveira et al. (2005) avaliaram neuropsicologicamente adolescentes $(n=84)$ que usavam ayahuasca no contexto religioso, comparando-os com adolescentes que nunca fizeram uso de ayahuasca (grupo controle). A avaliação neuropsicológica inclui testes de velocidade de atenção, pesquisa visual, velocidade psicomotora, habilidade verbal e visual, flexibilidade mental e memória. Os resultados mostraram não haver diferença entre os dois grupos para os parâmetros avaliados.

Outro estudo realizou-se uma avaliação psiquiátrica, verificando-se escalas de depressão, ansiedade, uso de álcool e problemas de atenção em adolescentes $(n=80)$ que usavam ayahuasca em comparação a um grupo de adolescentes que não usava (controle). A avaliação mostrou diferenças mínimas entre os grupos, havendo uma tendência a menores sintomas de ansiedade e menor déficit de atenção no grupo que usava ayahuasca (Doering-Silveira et al, 2005).

Estudos relacionados às informações sobre o uso de álcool podem ter sido prejudicados uma vez que a UDV proíbe que seus membros usem qualquer substância psicoativa. Entretanto, os outros 


\section{Desafios da psicologia no Brasil}

parâmetros avaliados como agressão e a procura pela novidade diminuíram significativamente no grupo de usuários de ayahuasca quando comparados com grupo controle e também quando comparados com resultados de outro estudo realizado com usuários de LSD - ácido lisérgico (Halpern \& Pope, 1999).

Em relação aos estudos de toxidade aguda e crônica da exposição à ayahuasca por humanos, Grob et al. (1996) não verificaram evidências de efeitos adversos graves em voluntários que usavam ayahuasca em cerimônias religiosas. Neste contexto, o chá é consumido regularmente por homens e mulheres na faixa de idade dos 13 aos 90 anos. A avaliação psicológica de usuários de longo prazo não encontrou evidências de prejuízos nas atividades mentais. Funções cognitivas, fluência verbal, habilidade matemática, motivação bem-estar emocional e personalidade foram alguns dos parâmetros avaliados no estudo. De fato, tem sido repostado que vários usuários regulares de ayahuasca com idade aproximada de 80 anos e que fizeram uso desde sua adolescência, permaneceram com acuidade mental e vigor físico preservados (Callaway et al., 1999).

Em Manaus - na Amazônia brasileira - pesquisadores de dez instituições de três países, liderados pelos cientistas americanos Mckenna e Grob, conduziram um estudo-piloto multifacetado que avaliou aspectos farmacológicos, clínicos e de saúde mental em quinze membros experientes da UDV, comparando-os a um grupo-controle de indivíduos sem experiência prévia com a bebida (Grob 1996; Mckenna 1998; Mckenna 2002). Os entrevistados no estudo (Projeto Hoasca) relataram que a experiência com o chá mudou o rumo de suas vidas. Ao ingerir o chá viam imagens de seu futuro, que era de catástrofes e ruína, caso eles não mudassem seus comportamentos, a partir dessas visualizações e de agora pertencer a um grupo religioso abandonavam o uso de substâncias alcoólicas e de drogas. Grob e seus colaboradores (1996) verificaram que todos eles descontinuaram o uso daquelas substâncias, sem recorrências, pouco tempo depois do início do uso regular do chá (De Rios, 2003; Grob 1996).

Em estudo sobre as alterações neurofuncionais após a ingestão de Ayahuasca foram realizados dois estudos com voluntários saudáveis. No primeiro foi avaliado alterações do FSC, através de SPECT, em dez voluntários sem o uso da ayahuasca. No segundo, dez usuários ritualísticos foram submetidos a duas sessões nas quais foram avaliadas a fluência verbal com as letras " $F$ ", " $A$ " e "S". Em uma das sessões, os voluntários ingeriram o chá (150ml). Não houve grandes diferenças comportamentais 


\section{Desafios da psicologia no Brasil}

entre os experimentos, com alterações sensoperceptivas, porém sem perda do contato com a realidade.

No estudo com RMF foi observada diminuição de áreas relacionadas à linguagem, diminuição da lateralização hemisférica fisiológica durante o teste. Essas alterações foram anteriormente relacionadas com transtornos psicóticos e com estados alterados de consciência induzidos por substâncias. A modulação cerebral relacionada à Ayahuasca é útil no estudo da neurobiologia das psicoses, embora haja diferenças entre estas e o estado induzido pela substância (PINTO, 2010).

O estudo neurobiológico das psicoses há muito tempo é discutido no meio acadêmico. Em um estudo microbiológico, comportamental e histomorfológico avaliou brevemente isso com os Rattus norvegicus, ratos geralmente utilizados em treinamentos de Psicologia Experimental, foram usados na pesquisa que visava avaliar as possíveis consequências/reações da ingestão da Ayahuasca. Os 16 ratos foram divididos em dois grupos, o grupo controle tinha uma tendência menor a pressionar a barra dos que ingeriram Ayahuasca. Porém numa perspectiva comportamental não houve grandes diferenças (SANTOS, 2004).

A primeira investigação empírica do tipo cognitivo-psicológico realizada sobre a experiência da ayahuasca, mas especificamente das visões ou mirações, realizada em diferentes contextos onde se examinou 12 conjuntos de dados relativos às visões, incluindo a própria experiência do autor. As visões variam de acordo com a atitude dos bebedores, pois geralmente são associadas a insights pessoais havendo uma recorrência de cobras, jacarés, demônios, deuses, cidades paisagens diversas, experiência extra-corporal e clarividências (SHANON, 2003).

\subsection{NEUROBIOLOGIA DA AYAHUASCA}

A União do Vegetal é uma instituição religiosa onde são realizados rituais com o uso da ayahuasca em encontros quinzenais entre seus membros. Tal instituição utiliza o cipó Banisteriopsis caapi, da família Malpighiaceae, nativa da Amazônia e dos Andes e também a planta da família Rubiaceae, Psycotria Viridis. A composição química do caapi, segundo McKenna et al. (1998 apud Costa; Figueiredo; Cazenave, 2005, p.4) consiste em alcalóides $\beta$-carbolinas inibidoras de monoaminoxidase (MAO), sendo as mais encontradas: harmina, harmalina, tetra-hidro-harmalina - tal qual a variância de suas concentrações são de $0.05 \%$ a $1.95 \%$. Além destes, encontra-se na Psycotria Viridis, a Ndimetiltriptamina ou DMT, substância que age junto aos receptores de serotonina, com concentrações 


\section{Desafios da psicologia no Brasil}

que variam de $0.1 \%$ a $0.66 \%$. No chá de ayahuasca as $\beta$-carbolinas inibem o MAO, protegendo o DMT da mesma.

As propriedades alucinógenas das $\beta$-carbolinas contribuem para a atividade da Ayahuasca. Estas auxiliam na chegada do DMT ao cérebro, através da inibição de MAO, produzindo diminuição na desanimação intestinal do DMT, auxiliando na chegada deste ao cérebro, mesmo ingerido via oral. Os efeitos sedativos primários de altas doses de $\beta$-carbolinas são resultantes do bloqueio da desanimação da serotonina (Cazenave, 1996 apud Costa et al., 2005, p. 5). Além disso, segundo Cazenave et al. (2005) as $\beta$-carbolinas produzem aumento nos níveis de serotonina, dopamina, norepinefrina e epinefrina no cérebro. Por outro lado, temos a ação do N-dimetiltrptamina ou DMT, que segundo McKenna et al.:

O dimetiltriptamina (DMT) é um potente alucinógeno quando usado por via parenteral na dosagem de 25 mg. Sua ação é agonista dos receptores 5-HT1a, 1b, 1d e do 5-HT2a e 2c. Porém, por via oral, ele é inativado através da desaminação sofrida pela ação da enzima MAO intestinal e hepática. Os efeitos aparecem de 30 a 45 minutos, aproximadamente, e podem durar até quatro horas. (MACKENNA et al., 1998, apud Costa et al., 2005, p.5)

O mecanismo endógeno da serotonina no organismo, segundo Katzung (1998 apud Cazenave; Figueiredo; Costa. 2005, p. 4) ocorre com a 5-hidroxitriptamina (5-HT) distribuída amplamente nos tecidos animais, sendo na glândula pineal, atuante como precursora da melatonina, um hormônio estimulador do melanócitos. Além disso, $90 \%$ da serotonina é encontrada nas células do trato gastrintestinal (TGI). Entretanto, no sangue a serotonina é encontrada nas plaquetas, onde estas são capazes de concentrar a amina por meio de um mecanismo transportador ativo. Logo, são observadas nos núcleos da rafe no tronco cerebral, onde existem neurônios triptaminérgicos que conseguem sintetizar, armazenar e liberar a serotonina como transmissor.

As ações dos neurônios serotoninérgicos estão relacionadas com funções do organismo como sono, humor, regulação da temperatura, percepção da dor e regulação da pressão arterial. (KATZUNG, 1998, apud Costa et al., 2005, p.5). Contudo, outras funções são exercidas por este neurotransmissor, sendo especificadas abaixo:

A serotonina exerce muitas ações mediadas por receptores na membrana celular. O receptor 5-HT1a tem distribuição pelos núcleos da rafe e hipocampo, diminuindo o AMP cíclico e levando à 


\section{Desafios da psicologia no Brasil}

hiperpolarização da membrana causada pelo aumento da condutância de K+. O receptor 5-HT1b aparece no globo pálido e gânglios da base e sua estimulação leva à diminuição do AMPc. O receptor 5-HT1c ocorre no coróide e hipocampo gerando também, aumento do IP3 nesses locais. (KATZUNG, 1998, apud Costa et al., 2005, p.5).

Embora, sejam diversas as funcionalidades de ação da serotonina no organismo humano, também encontram-se atividades desta no sistema cardiovascular, segundo Katzung (1998, apud Costa et al., 2005, p. 5): contração do músculo liso, vaso constrição potente, vasodilatação e agregação plaquetária - além de estimular o peristaltismo, contração na musculatura lisa e aumento do tônus na região do trato gastrintestinal (TGI). Sendo assim, é evidente uma relação entre as $\beta$-carbolinas juntamente com o DMT para serem obtidos os efeitos da Ayahuasca. (Cazenave et al, 2005)

Tais substâncias levam o indivíduo a um estado alterado de consciência, provocando efeitos subjetivos como visões, delírios semelhantes aos sonhos, sensação de vigilância e estimulação, sendo comum, segundo Cazenave (2000 apud Costa et al., 2005, p. 5) a ocorrência de hipertensão, palpitação, taquicardia, tremores, midríase, euforia e excitação agressiva, além de náuseas, vômitos que estão associadas à ação do receptor 5-HT2.

No artigo de Costa et al, (2005) é feito uma contextualização do uso do Chá da Ayahuasca no Brasil e sobre o seu preparo com a infusão do cipó Banisteriopsiscaapie as folhas do arbusto Psycotriaviridis e que o efeito do chá se deve aos alcaloides encontrados nas plantas usadas na sua preparação. Destaca os efeitos observados após a ingestão da beberagem que podem-se citar como alucinações, hipertensão, taquicardia, náuseas, vômitos e diarreia. O cipó B. Caapi possui em sua composição alcalóides $\beta$-carbolinas inibidoras da MAO, sendo que os de maior concentração são: harmina, harmalina, tetra-hidro-harmalina. A concentração desses alcaloides varia de 0,05\% a 1,95\%.

A as folhas da planta PsychotriaViridisé composta pelo alcalóide derivado indólicoN, Ndimetiltriptamina (DMT) em concentração de 0,1\% a 0,66\% que age sobre os receptores da serotonina. Os principais efeitos subjetivos da ayahuasca são visões com os olhos fechados, delírios semelhantes a sonhos, sensações de vigilância e estimulação. Também pode ocorrer hipertensão, palpitação, taquicardia, tremores, midríase, euforia e excitação agressiva. Náuseas, vômito e diarreias também são comuns devido à ação do receptor 5-HT. Podem ocorrer ilusões visuais, auditivas e olfativas considerando também alterações na volição, percepção, cognição e afetividade. Essa pesquisa foi realizada com relato de voluntários. As autoras alertam a respeito da ingestão de alimentos com 


\section{Desafios da psicologia no Brasil}

tiramina antes de uso do chá, pois estes alimentos, como o queijo, podem conter níveis de tiramina que é uma molécula metabolizada pela MAO, podendo atingir níveis tóxicos devido à inativação da enzima causada pelo chá.

Callaway et al (2002) expõe o histórico do uso da beberagem da Ayahuasca e destaca aspectos interessantes da história da humanidade num pressuposto curioso o qual o corpo humano possui em seu organismo substâncias que podem fornecer o que se pode chamar de "estados alterados da consciência". No artigo ele quantifica os princípios ativos e suas variações após a exposição a respeito da serotonina como neurotransmissor e agentes psicoativos, essas variações como a de alcalóides observadas a partir de amostras B. Caapi e as variações de DMT nas amostras de P. Viridis, além da variação de alcalóides na ayahuasca contemporânea. $O$ autor também destaca o preparo que tem um caráter notável, pois mantém a presença dos alcalóides harmala que servem como inibidores da enzima MAO. Os efeitos de uma dose típica podem durar de 8 a 12 horas. Assim sendo a beberagem composta inteiramente de B. Caapi, segundo Callaway (2002), é psicoativa em decorrência de sua neuroatividade. Além dos efeitos psicoativos esse tipo de beberagem, segundo o autor, pode ser usada como purgante e às vezes na remoção de parasitas intestinais. Observou que após a ingestão do chá da ayahuasca náuseas e vômitos ocorrem com frequência, isso se deve provavelmente ao aumento crescente dos níveis de serotonina no cérebro resultando na estimulação excessiva do nervo pneumogástrico.

Através de suas observações Calaway (2002) percebeu que após 60, 90 e 120 minutos do uso do chá as respostas neuroendócrinas de níveis básicos se intensificaram significativamente em seus voluntários, apresentando concentrações máximas de cortisol e também da prolactina. Após 360 minutos essas medidas retornaram aos seus níveis básicos. Também ocorreram respostas anatômicas como o aumento de diâmetro da pupila para $3.7 \mathrm{~mm}$ indo para $4.8 \mathrm{~mm}$ entre 40 e 180 minutos voltando ao normal 6 horas após a ingestão da ayahuasca. Notou-se também o aumento da respiração após 90 minutos de 22 respirações por minuto e oscilou no decorrer da sessão (podendo questionar se pelo efeito da ayahuasca, pois o autor destaca que essas medidas foram tiradas enquanto os voluntários também dançavam), observou-se também a temperatura oral aumentou ligeiramente, mas nada excessivo.

\section{ESTUDO DE CASO}

A ingestão do chá da ayahuasca provoca estados alterados de consciência, alterando as 


\section{Desafios da psicologia no Brasil}

emoções e a percepção da realidade. Além disso, as mudanças na percepção podem gerar

crises decorrentes dos conteúdos que o indivíduo possui como: história pessoal, experiências, grau de vulnerabilidade física e emocional. Realizou-se a observação e analise da ação do chá ayahuasca em um bebê de 9 meses, através da observação participativa. Analisando os padrões de alteração do comportamento do bebê do momento da ingestão até o tempo de 4 horas após a ingestão. Observação o tempo de reação da substância e comportamentos atípicos presentes no bebê. Realizouse um comparativo da conduta comportamental do bebê relatado pela progenitora sem o efeito do chá.

Foi ofertado para o sujeito uma colher de sobremesa da substância em ritual religioso, a substância foi ofertada pelo dirigente, o responsável pelo momento religioso com a autorização dos pais, conforme orienta a legislação da própria instituição. Em 15 minutos após a ingestão o bebê apresentou inquietação motora, gritos e balbucios repetidos e em alto tom. Após 60 minutos o bebê apresentou diminuição da agitação e iniciou o choro.

Neste momento a mãe o amamentou com formula láctea e no período da amamentação ele adormeceu. Após 1 h23 minutos o bebê acordou chorando e assim permaneceu por mais 36 minutos. Nos próximos 46 minutos o bebê permaneceu calmo, engatinhou pelo local sob supervisão da mãe e não teve nenhuma outra reação.

A mão do bebê fez uso da ayahuasca durante toda a gestação e no momento do parto. Até os 9 meses ele já ingeriu a substância 4 vezes, aos 25 dias, 3 meses, 5 meses e 9 meses. A progenitora relatou que o comportamento observado não é típico do mesmo, pois dorme geralmente 4 horas seguidas, não balbucia de forma prolixa e em alto tom. O choro de forma continua também somente é perceptível quando o bebê faz uso da substancia.

Não há estudos controlados sobre o efeito da ayahuasca e suas consequências devido ao uso na primeira infância. O centro religioso assegura que o uso desde o nascimento é inofensivo a saúde e de acordo com a crença dos usuários o uso do chá na primeira infância, incluindo nos primeiros dias de vida, traz aprimoramento no desenvolvimento.

A ayahuasca e permitido pela legislação brasileira em uso somente de caráter religioso. 


\section{Desafios da psicologia no Brasil}

Os pais que participam dessa religião e fazem uso possuem o costume de ofertá-la as crianças com regularidade. É necessário um estudo longitudinal para observar possíveis efeitos e consequências do uso continuo nessas crianças que entram em contato com a substância de forma precoce.

\section{CONCLUSÃO}

Desta forma, a ingestão do chá ayahuasca provoca estados alterados de consciência, alterando as emoções e a percepção da realidade. Essas alterações da percepção podem gerar crises decorrentes dos conteúdos que o indivíduo possuir como: história pessoal, experiências, grau de vulnerabilidade física e emocional (DE SOUZA, 2011).

As substâncias levam o indivíduo a um estado alterado de consciência, provocando efeitos subjetivos como visões, delírios semelhantes aos sonhos, sensação de vigilância e estimulação, sendo comum, segundo Cazenave (2000 apud Costa et al., 2005, p. 5) a ocorrência de hipertensão, palpitação, taquicardia, tremores, midríase, euforia e excitação agressiva, além de náuseas, vômitos que estão associadas à ação do receptor 5-HT2.

\section{DIVULGAÇÃO}

Este artigo é inédito e não está sendo considerado para qualquer outra publicação. O(s) autor(es) e revisores não relataram qualquer conflito de interesse durante a sua avaliação.

\section{REFERÊNCIAS}

BARBOSA PC, GIGLIO JS, DALGALARRONDO P. Altered states of consciousness and short-term psychological after-effects induced by the first time ritual use of ayahuasca in an urban context in Brazil. J Psychoactive Drugs. 2005 Jun;37(2):193-201.

BOUSO JC, FÁBREGAS JM, ANTONIJOAN RM, RODRÍGUEZ-FORNELLS A, RIBA J. Acute effects of ayahuasca on neuropsychological performance: differences in executive function between experienced and occasional users. Psychopharmacology (Berl). 2013 Dec;230(3):415-24. doi: 10.1007/s00213-013-3167-9. Epub 2013 Jun 21.

BOUSO JC, GONZÁLEZ D, FONDEVILA S, CUTCHET M, FERNÁNDEZ X, RIBEIRO BARBOSA PC, ALCÁZARCÓRCOLES MÁ, ARAÚJO WS, BARBANOJ MJ, FÁBREGAS JM, RIBA J. Personality, psychopathology, life attitudes and neuropsychological performance among ritual users of Ayahuasca: a longitudinal study. PLoS One. 2012;7(8):e42421. doi: 10.1371/journal.pone.0042421. Epub 2012 Aug 8.

CALLAWAY, Jace. Fitoquímica e Neurofarmacologia da Ayahuasca. In METZNER, Ralph. Ayahuasca: Alucinógenos, Consciência e o Espirito da Natureza. Rio de Janeiro. Ed. Gryphus. 2002. 


\section{Desafios da psicologia no Brasil}

CAZENAVE, S.O.S. - Banisteriopsis caapi: ação alucinógena e uso ritual, Rev. Psiq. Clín. 27; (1), 2000, pp. 1-6.

COSTA, M.C.M.; FIGUEIREDO, M.C.; CAZENAVE, S.O.S. Ayahuasca: Uma abordagem toxicológica do uso ritualístico. Revista de Psiquiatria Clínica, São Paulo, v. 32 n. 6 p.310-318, 2005.

DOERING-SILVEIRA E, LOPEZ E, GROB CS, DE RIOS MD, ALONSO LK, TACLA C, SHIRAKAWA I, BERTOLUCCI PH, DA SILVEIRA DX. Ayahuasca in adolescence: a neuropsychological assessment. J Psychoactive Drugs. 2005 Jun;37(2):123-8.

DOS SANTOS, Rafael Guimarães. AYAHUASCA: neuroquímica e farmacologia. SMAD, Rev. Eletrônica Saúde Mental Álcool Drog. (Ed. port.) [online]. 2007, vol.3, n.1, pp. 00-00. ISSN 1806-6976.

KATSZUNG, B.G. - Farmacologia Básica e Clínica. 6a edição, Guanabara Koogan, Rio de Janeiro, 1998, pp 204-6.

MCKENNA, D.J.; CALLAWAY, J.C.; GROB, CS. - The Scientific Investigation of Ayahuasca: A Review of Past and Current Research. The Heffer Review of Psychedelic Reseach, Volume 1, 1998.

PEREIRA, O. C. de C. Considerações médico-científicas a respeito do chá hoasca e sua inofensividade à saúde. 2012. Disponível em: www.neip.info.

PINTO, J. P. Estudo sobre alterações neurofuncionais após ingestão de ayahuasca. Universidade de São Paulo, Ribeirão Preto, 2010.

PIRES, A.P.S.; OLIVEIRA, C.D.R.; YONAMINE, M. Ayahuasca: uma revisão dos aspectos farmacológicos e toxicológicos. Revista de Ciências Farmacêuticas Básica e Aplicada, 2010; 31(1):15-23

SANTOS, R. G. dos. AYAHUASCA: chá de uso religioso Estudo microbiológico, observações comportamentais e estudo histomorfológico de cérebro em Murídeos. Centro Universitário de Brasília - UniCEUB, 2004.

SHANON, Benny. Os conteúdos das visões da ayahuasca. Mana [online]. 2003, vol.9, n.2, pp. 109-152. ISSN 0104-9313. 